\title{
Hanford Site Groundwater Monitoring for Fiscal Year 1998
}

\section{Editor}

M. J. Hartman

\author{
D. B. Barnett \\ C. J. Chou \\ P. E. Dresel \\ B. M. Gillespie \\ H. Hampt \\ D. G. Horton \\ V. G. Johnson \\ J. W. Lindberg . \\ J. P. McDonald \\ R. B. Mercer \\ D. A. Myers
}

S. H. Narbutovskih
D. R. Newcomer
R. E. Peterson
R. Randall
S. P. Reidel
J. T. Rieger
V. J. Rohay
R. J. Serne
D. S. Sklarew
D. L. Stewart
L. C. Swanson

M.D. Sweeney

C. J. Thompson

P. D. Thome

E. C. Thornton

W. D. Webber

R. L. Weiss

B. A. Williams

M. D. Williams

S. K. Wurstner

February 1999

Prepared by personnel from

Pacific Northwest National Laboratory, CH2M Hill Hanford, Inc., and

IT Corporation for the U.S. Department of Energy under Contract DE-AC06-76RLO 1830 


\title{
DISCLAIMER
}

This report was prepared as an account of work sponsored by an agency of the United States Government. Reference herein to any specific commercial product, process, or service by trade name, trademark, manufacturer, or otherwise does not necessarily constitute or imply its endorsement, recommendation, or favoring by the United States Government or any agency thereof, or Battelle Memorial Institute.

\author{
PACIFIC NORTHWEST NATIONAL LABORATORY \\ operated by \\ BATTELLE \\ for the \\ UNITED STATES DEPARTMENT OF ENERGY \\ under Contract DE-AC06-76RLO 1830
}

Printed in the United States of America

Available to DOE and DOE contractors from the

Office of Scientific and Technical Information, P.O. Box 62, Oak Ridge, TN 37831;

prices available from (615) 576-8401.

Available to the public from the National Technical Information Service, U.S. Department of Commerce, 5285 Port Royal Rd., Springfield, VA 22161

This document was printed on recycled paper. 


\section{DISCLAIMER}

This report was prepared as an account of work sponsored by an agency of the United States Government. Neither the United States Government nor any agency thereof, nor any of their employees, make any warranty, express or implied, or assumes any legal liability or responsibility for the accuracy, completeness, or usefulness of any information, apparatus, product, or process disclosed, or represents that its use would not infringe privately owned rights. Reference herein to any specific commercial product, process, or service by trade name, trademark, manufacturer, or otherwise does not necessarily constitute or imply its endorsement, recommendation, or favoring by the United States Government or any agency thereof. The views and opinions of authors expressed herein do not necessarily state or reflect those of the United States Government or any agency thereof. 


\section{DISCLAIMER}

Portions of this document may be illegible in electronic image products. Images are produced from the best available original document. 


\begin{abstract}
This report presents the results of groundwater and vadose-zone monitoring and remediation for fiscal year (FY) 1998 on the Hanford Site, Washington.

Soil-vapor extraction in the 200-West Area removed $777 \mathrm{~kg}$ of carbon tetrachloride in FY 1998, for a total of $75,490 \mathrm{~kg}$ removed since remediation began in 1992. Spectral gamma logging and evaluation of historical gross gamma logs near tank farms and liquid-disposal sites in the 200 Areas provided information on movement of contaminants in the vadose zone.
\end{abstract}

Water-level monitoring was performed to evaluate groundwater-flow directions, to track changes in water levels, and to relate such changes to evolving disposal practices. Water levels over most of the Hanford Site continued to decline between June 1997 and June 1998.

The most widespread radiological contaminant plumes in groundwater were tritium and iodine-129. Concentrations of technetium-99, uranium, strontium-90, and carbon-14 also exceeded drinking water standards in smaller plumes. Plutonium and cesium-137 exceeded standards only near the 216-B-5 injection well. Derived concentration guide levels specified in U.S. Department of Energy Order 5400.5 were exceeded for tritium, uranium, strontium-90, and plutonium in small plumes or single wells. One well completed in the basalt-confined aquifer beneath the 200-East Area exceeded the drinking water standard for technetium-99.

Nitrate is the most extensive chemical contaminant. Carbon tetrachloride, chloroform, chromium, cis-1,2-dichloroethylene, fluoride, and trichloroethylene also were present in smaller areas at levels above their maximum contaminant levels. Cyanide concentrations were elevated in one area but were below the maximum contaminant level. Tetrachloroethylene exceeded its maximum contaminant level in several wells in the 300 Area for the first time since the 1980s. Metals such as aluminum, cadmium, iron, manganese, and nickel exceeded their maximum contaminant levels in filtered samples from numerous wells; they are believed to represent natural components of groundwater.

Resource Conservation and Recovery Act of 1976 groundwater monitoring continued at 25 waste management areas during FY 1998: 17 under detection programs and data indicate that they are not adversely affecting groundwater, 6 under interim-status groundwater-quality-assessment programs to assess possible contamination, and 2 under final-status corrective-action programs.

Groundwater remediation in the 100 Areas continued to reduce the amount of strontium-90 (100-N) and chromium (100-K, D, and $\mathrm{H}$ ) reaching the Columbia River. Two systems in the 200-West Area operated to prevent the spread of carbon tetrachloride and technetium/uranium plumes. Groundwater monitoring continued at these sites and at other sites where there is no active remediation.

A three-dimensional, numerical groundwater model was applied to simulate radionuclide movement from sources in the 200 Areas following site closure in 2050. Contaminants will continue to move toward the southeast and north (through Gable Gap), but the areas with levels exceeding drinking water standards will diminish.

Inquiries regarding this report may be directed to Ms. Mary J. Hartman or Dr. P. Evan Dresel, Pacific Northwest National Laboratory, P.O. Box 999, Richland, Washington 99352 or by electronic mail to mary.hartman@pnl.gov or evan.dresel@pnl.gov. 


\section{.}




\section{Summary}

This report summarizes the results of fiscal year (FY) 1998 groundwater and vadose-zone monitoring and remediation activities on the Hanford Site. This report is designed to provide a comprehensive interpretation of current groundwater conditions on the site and in adjacent areas, including a description of site hydrogeology, groundwater flow, and groundwater-contaminant distribution. This report fulfills reporting requirements of the Resource Conservation and Recovery Act of 1976 (RCRA), specific Washington Administrative Codes, and the Atomic Energy Act of 1954 as implemented by U.S. Department of Energy (DOE) orders. This report also summarizes results of groundwater monitoring conducted to assess the effects of remediation or interim measures conducted in accordance with the Comprehensive Environmental Response, Compensation, and Liability Act of 1980 (CERCLA).

The uppermost aquifer beneath most of the Hanford Site is unconfined and is composed of unconsolidated to semiconsolidated sediments deposited on the basalt bedrock. In some areas, deeper parts of the aquifer are locally confined by layers of silt and clay. Confined aquifers occur within the underlying basalt flows and associated sedimentary interbeds. Groundwater in the unconfined aquifer system generally moves from recharge areas along the western boundary of the site to the east and north toward the Columbia River, which is the major discharge area. This natural flow pattern was altered by the formation of groundwater mounds created by the discharge of large volumes of wastewater at disposal facilities. These mounds are declining, and groundwater flow is gradually returning to earlier patterns.

Water levels are monitored across the Hanford Site and to the east and north of the Columbia River. The purpose of these measurements is to monitor changes in water-table elevations that affect the direction and velocity of groundwater flow and transport of contaminants, and to assess impacts of the changes on monitoring networks. A site water-table map for June 1998 was constructed and used to infer groundwater-flow directions. Water levels over most of the site declined during FY. 1998, continuing the trend caused by reduction in liquid effluent disposal. Water levels are also measured in wells completed in the upper basalt-confined aquifer. Several areas showed declines in the confined-aquifer potentiometric surface associated with declines in the water table of the overlying unconfined aquifer.

\section{Vadose Zone}

Radioactive and hazardous wastes in the soil column from past intentional liquid waste disposals, unplanned leaks, and underground tanks at the Hanford Site are potential sources of continuing/future groundwater contamination. The continued infiltration of vadose-zone contamination to groundwater depends on contaminant chemistry, stratigraphy, and drainage of water through the vadose zone.

Soil-vapor extraction continued in the 200-ZP-2 Operable Unit as a CERCLA expedited response action to remove the carbon tetrachloride source from the vadose zone. The mix of extraction wells was changed periodically during FY 1998 to improve performance based on a 1997 rebound study. In FY $1998,777 \mathrm{~kg}$ of carbon tetrachloride were removed, totaling $75,490 \mathrm{~kg}$ since remediation began in 1992. 
In 1998, results from 1997 spectral gamma logging of boreholes surrounding the B-BX-BY singleshell tank farm in the 200-East Area became available. The logging was to detect changes in the distribution of man-made radionuclides in the sediments associated with liquid waste-disposal facilities adjacent to the tank farm. Spectral gamma logging also was performed at boreholes around the Plutonium Finishing Plant liquid-disposal facilities to ascertain any changes in subsurface radionuclide distribution since last logging. Also, baseline characterization logging of all drywells in the BX, C, S, and TY tank farms was completed and the results reported in 1998. In addition, 10 new groundwatermonitoring wells were installed and logged by spectral gamma-ray methods. Historical gross gamma logs from boreholes near SX, BX, BY, and TY tank farms were analyzed to locate mobile radionuclides.

Directional well drilling was tested at two sites. The holes were completed, but boulder gravels at one site presented difficulties in drilling and sampling. Control of drilling fluids also presented an obstacle that must be overcome before using this technique to address vadose-zone contamination.

Sediment samples from new vadose-zone or groundwater wells were collected and analyzed for contaminants and physical properties. A vadose-zone borehole near the SX tank farm was extended to groundwater, and sediments were analyzed for radionuclides. Cesium-137 contamination decreased with depth and was undetectable at the water table.

\section{Groundwater Monitoring of RCRA Treatment, Storage, and Disposal Units}

RCRA groundwater monitoring continued at 25 waste management areas. At the end of FY 1998, 17 were being monitored under detection programs and do not appear to be adversely affecting groundwater. The others were monitored under assessment or corrective-action programs. The following summarizes the highlights of RCRA monitoring during FY 1998.

Four single-shell tank waste management areas were monitored under interim-status assessment investigations. Contamination from chemically similar sources such as nearby cribs made it difficult to determine whether the waste management areas (tank farms, transfer lines, diversion boxes) were the source, but the assessment investigations indicate they were. The T and TX-TY single-shell tank farms (200-West Area) have been monitored under an assessment program since 1993 because of elevated specific conductance. An assessment report concluded that the tanks or associated structures probably have contaminated the groundwater with technetium-99. Waste Management Area S-SX (200-West Area) began an assessment program in FY 1996 and appears to have contaminated the groundwater with technetium-99, nitrate, and hexavalent chromium. Waste Management Area B-BX-BY (200-East Area) appears to have.contaminated the groundwater with technetium-99.

The $183-\mathrm{H}$ solar evaporation basins (100-H Area) and the $316-5$ process trenches ( 300 Area) were monitored under final-status regulations during FY 1998. The 183-H basins have contaminated the groundwater with technetium-99, uranium, nitrate, and chromium at levels exceeding applicable concentration limits. Corrective action is being addressed by the CERCLA program, and an interim remedial action (pump-and-treat system) for chromium continued operation in FY 1998. Groundwater monitoring to meet RCRA requirements is continuing during the remediation. 
The 316-5 process trenches and other nearby sources contaminated groundwater with cis-1,2dichloroethylene, trichloroethylene, and uranium at levels above their respective concentration limits. However, the corrective-action monitoring plan has not been approved, and monitoring is continuing under the compliance plan. Natural attenuation of the contaminants is the corrective action chosen in the CERCLA record of decision. Groundwater monitoring is continuing in accordance with RCRA to monitor the decline in contaminant concentrations.

\section{Groundwater Contamination}

Monitoring wells were sampled during FY 1998 to satisfy requirements of RCRA, CERCLA, Washington Administrative Code, and DOE orders. Approximately 750 wells were sampled during the period.

The extent of major radionuclides at levels above the interim drinking water standards (DWSs) is shown in Figure S.1. Tritium, iodine-129, technetium-99, and strontium-90 were present at levels above the U.S. Environmental Protection Agency (EPA) or State of Washington interim DWSs, and uranium exceeded the EPA's proposed maximum contaminant level (MCL). Minor radiological contamination above the DWS included carbon-14 (100-K Area), cesium-137, and plutonium (200-East Area near the 216-B-5 injection well). Derived concentration guide (DCG) ${ }^{1}$ levels were exceeded for strontium-90 in the 100-K, 100-N, and 200-East Areas (near the 216-B-5 injection well), and near the former Gable Mountain Pond. The DCG for uranium was exceeded near U Plant. The DCG for tritium was exceeded in one well near cribs that received effluent from the Plutonium-Uranium Extraction (PUREX) Plant, and in another well near Waste Management Area TX-TY. The DCG for plutonium was exceeded in one well in the 200-East Area (near the 216-B-5 injection well). Cobalt-60 levels exceeded the $100-\mathrm{pCi} / \mathrm{L}$ interim DWS in recent years but were below the DWS in FY 1998. Results for individual constituents are summarized below.

The extent of major chemical constituents at levels above the primary MCLs is shown in Figure S.2. Nitrate, carbon tetrachloride, and trichloroethylene were the most widespread. Chloroform, cis-1,2dichloroethylene, cyanide, fluoride, chromium, and other metals also were present at levels above their MCLs. Tetrachloroethylene exceeded its 5- $\mu \mathrm{g} / \mathrm{L}$ MCL in the 300 Area in FY 1998 for the first time since the 1980s. Results for individual constituents are summarized below.

The area of Hanford contaminant plumes with concentrations exceeding an MCL or DWS was estimated to be $\sim 245$ million $\mathrm{m}^{2}$ in FY 1998. This equates to a volume of $\sim 1.4$ billion $\mathrm{m}^{3}$, which is the same as FY 1997. The volume estimate has a high uncertainty because of a lack of knowledge of the vertical extent of contaminant plumes. Plume thickness is estimated to be $20 \mathrm{~m}$, except in the 100,300 , and Richland North Areas, where it is estimated to be $5 \mathrm{~m}$. The porosity of the aquifer is not wellcharacterized; for the purpose of the calculation, the porosity was assumed to be $30 \%$. The estimate did not include water in the vadose zone.

1 The DCG is based on a 100-mrem/yr exposure standard and is the amount of an individual radionuclide that would lead to that dose through ingestion under specified intake scenarios. 


\section{Tritium}

Tritium was present in many Hanford Site waste streams discharged to the soil column and is the most mobile and most widely distributed radionuclide onsite.

Tritium activities at greater than the 20,000-pCi/L interim DWS were detected in FY 1998 in portions of the 100,200, 400, and 600 Areas. The highest tritium activities in the 200-East Area (exceeding the 2,000,000-pCi/L DCG in one well) continued to be found in wells near cribs that received effluent from the PUREX Plant. Tritium increased suddenly in a 200-West Area well near Waste Management Area TX-TY, exceeding the DCG for the first time in FY 1998.

Tritium in the 400 and 600 Areas can be related to migration from sources in the other operational areas. In particular, tritium migration from sources in the 200-East Area near the PUREX Plant affected that part of the 600 Area downgradient to the east and southeast, the $400 \mathrm{Area}$, and the 300 Area. This plume discharges to the Columbia River along a stretch that extends from the Old Hanford Townsite to the 300 Area. A smaller plume between the 200-East and 200-West Areas has its source near the 200-West Area's Reduction-Oxidation (REDOX) Plant. This plume is moving relatively slowly because the aquifer has a relatively low permeability and the hydraulic gradient has decreased.

Portions of the 600 Area north of Gable Mountain and Gable Butte are contaminated with tritium at levels below the DWS. The sources appear to be the 100 and 200-East Areas.

\section{Iodine-129}

The presence of iodine-129, a moderately low-yield fission product, in groundwater is significant because of its relatively low, 1-pCi/L interim DWS; its long-term releases from nuclear fuel-processing facilities; and its long half-life (16,000,000 years). However, iodine-129's relatively low-fission yield and long half-life limit its activity in Hanford Site groundwater. Iodine-129 is transported in groundwater as the anionic species, which is very mobile. Wastes containing iodine-129 were historically disposed of in the 200 Areas. Extensive plumes at levels above the interim DWS are found in the 200 Areas and in downgradient portions of the 600 Area. The major plume extends toward the southeast from the 200-East Area. A smaller arm of the plume is moving toward the north between Gable Mountain and Gable Butte:

\section{Technetium-99}

Technetium-99 is produced as a high-yield fission product and is present in waste streams associated with fuel processing. Technetium is transported in groundwater as a negatively charged species that is highly mobile. Technetium tends to be associated with uranium through the fuel-processing system, but uranium is less mobile in groundwater on the Hanford Site. Technetium- 99 activities $>900 \mathrm{pCi} / \mathrm{L}$ (interim DWS) continued to be observed in the 100-H Area downgradient of the 183-H solar evaporation basins, where fuel-fabrication waste leaked to the ground. The highest technetium-99 activities (annual average of $14,000 \mathrm{pCi} / \mathrm{L}$ ) were observed in FY 1998 in wells in the 200-West Area, where the largest plume is associated with U Plant, and the plume is migrating to the east into the 600 Area. A groundwater pump-and-treat system is operating near U Plant to contain the plume. Equally high activities were 
observed in a well near Waste Management Area T. Technetium-99 is also elevated in wells monitored for the B-BX-BY, S-SX, and TX-TY single-shell tank farms. These sites are undergoing RCRA assessment investigations.

Elevated technetium-99 levels apparently associated with the BY cribs (200-East Area) continued to be observed in FY 1998. A well formerly used for groundwater extraction in treatability testing that contained up to $9,910 \mathrm{pCi} / \mathrm{L}$ of technetium-99 in 1995 contained only $398 \mathrm{pCi} / \mathrm{L}$ in FY 1998. The maximum average annual level of technetium-99 detected in the area north of the 200-East Area in FY 1998 was $2,200 \mathrm{pCi} / \mathrm{L}$.

A well completed in the confined aquifer near the BY cribs had technetium-99 at levels above the 900-pCi/L DWS in FY 1998 (average of $1,500 \mathrm{pCi} / \mathrm{L}$, which is within the historical range). The well also had elevated cobalt- 60 and cyanide, though levels were less than the applicable standards.

\section{Uranium}

There are numerous potential sources of uranium release on the Hanford Site, including fuel fabrication, fuel processing, and uranium recovery from separations activities. Uranium mobility is dependent on Eh, $\mathrm{pH}$, and the presence of carbonate; its migration is slower than that of tritium and technetium-99. At the $\mathrm{Eh} / \mathrm{pH}$ conditions found in the unconfined aquifer, U(VI) is the most mobile state.

The EPA proposed a 20- $\mu \mathrm{g} / \mathrm{L} \mathrm{MCL}$ for uranium. Uranium was detected at concentrations above this proposed MCL in the 100-H, 200, and 300 Areas. One well in the 100-F Area that exceeded the standard in previous years was not sampled in FY 1998. Contamination in the 100-H and 200-East Areas is very localized. The highest concentrations detected in FY 1998 (exceeding the DCG) were in the 200-West Area near the 216-U-1 and 216-U-2 cribs, and this plume extends into the 600 Area to the east. Like technetium-99, this plume is being contained by a pump-and-treat system.

Another area of elevated uranium concentrations is observed in the 300 Area, downgradient of the 316-5 process trenches and ponds. Uranium contamination appears to be moving from the vicinity of the process trenches toward the southeast. An expedited response action was performed on the trenches in mid-1991 to reduce the uranium source in that area. Use of the trenches for disposal of cooling water was resumed after the expedited response action was completed. Uranium levels decreased sharply after the expedited response action but rose again after 1994, when discharges and associated dilution ceased.

\section{Strontium-90}

Strontium-90 is produced as a high-yield fission product and is, therefore, present in waste streams associated with fuel processing; it was released also by fuel-element failures during reactor operations. Strontium-90 is of concern because of its moderately long half-life (28.8 years), its potential for concentrating in bone tissue, and the relatively high energy of the beta decay from its yttrium- 90 radioactive decay product. In FY 1998, strontium-90 activities exceeded the 8-pCi/L interim DWS in wells in all of the 100 and 200 Areas and near the former Gable Mountain Pond. Strontium-90 exceeded the 1,000-pCi/L DCG in wells in the 100-K, 100-N, and 200-East Areas and near the former Gable Mountain Pond. 
The most widespread, high strontium-90 activities (greater than the DCG) continued to be observed in the $100-\mathrm{N}$ Area. The overall extent of the $100-\mathrm{N}$ Area strontium-90 plume is not increasing perceptibly. A pump-and-treat system operates in the 100-N Area to reduce the flux of strontium-90 to the Columbia River.

\section{Carbon-14}

Carbon-14 exceeded the 2,000-pCi/L interim DWS in two small plumes near waste-disposal facilities adjacent to the $\mathrm{K}$-West and K-East Reactor buildings. The maximum average activity in FY 1998 was $33,000 \mathrm{pCi} / \mathrm{L}$.

\section{Cobalt-60}

Cobalt- 60 is a neutron activation product typically associated with wastes generated by the processing of irradiated fuel or with reactor-cooling water. Cobalt- 60 is predominantly present as a divalent cation that is strongly adsorbed onto onsite sediments and is rarely observed in groundwater unless complexed by other chemicals. North of the 200-East Area, in an area that is affected by waste disposed to the BY cribs, wells consistently show the presence of detectable cobalt-60, but levels have declined because of its relatively short half-life (5.3 years). In FY 1998, the maximum annual average cobalt-60 detected in this vicinity remained below the 100 -pCi/L interim DWS. Cobalt- 60 in this area appears to be highly mobile, probably because of the presence of a soluble cobalt-cyanide (or ferrocyanide) complex associated with the plume originating in the BY cribs.

Very low levels of cobalt- 60 have been detected in groundwater downgradient of the PUREX Plant as far as the Old Hanford Townsite in the past. This indicates that cobalt- 60 may have been mobilized by a complexing agent other than cyanide in some Hanford Site wastes. Levels have been below detection limits in FY 1997 and FY 1998.

\section{Cesium-137}

Cesium-137 is produced as a high-yield fission product, is present in waste streams associated with fuel processing, and has been released in reactor areas by fuel-element failures. The activity of cesium-137 in FY 1998 reached 2,200 pCi/L in a well near the 216-B-5 injection well, which is in line with the historical trend for the well. The interim DWS for cesium- 137 is $200 \mathrm{pCi} / \mathrm{L}$.

Cesium-137 is a potential contaminant of concern at the S and SX single-shell tank farms because it was detected in vadose-zone sediments in FY 1996. Low activities of cesium-137 continued to be detected in one groundwater well in this area, but it appears that the contamination is dominantly sorbed to particulate matter and does not seem to be a significant groundwater contaminant.

\section{Plutonium}

Plutonium was present in waste streams associated with fuel processing. The DCG for plutonium-239 is $30 \mathrm{pCi} / \mathrm{L}$. There is no explicit interim DWS for plutonium-239; however, the gross alpha MCL of $15 \mathrm{pCi} / \mathrm{L}$ is applicable. Alternatively, if the $\mathrm{DCG}$ (which is based on a 100 -mrem dose standard) is 
converted to the 4-mrem dose equivalent used for the interim DWS, $1.2 \mathrm{pCi} / \mathrm{L}$ would be the relevant guideline. Plutonium generally binds strongly to sediments, so its mobility in groundwater is limited.

The only significant detection of plutonium in FY 1998, as in previous years, was associated with the 216-B-5 injection well in the 200-East Area. The maximum plutonium-239/-240 activity detected near this injection well in FY 1998 was $63 \mathrm{pCi} / \mathrm{L}$. There was no significant difference in activities from filtered and unfiltered samples. Plutonium had been detected at low levels in the past in a well $150 \mathrm{~m}$ northwest of this injection well, but was below the detection limit in FY 1997 and FY 1998.

\section{Nitrate}

Nitrate contamination in the unconfined aquifer system reflects the extensive use of nitric acid in decontamination and chemical-processing operations. Like tritium, nitrate was present in many waste streams and is mobile in groundwater. Additional sources of nitrate are located offsite to the south and west.

Nitrate was measured at concentrations greater than the MCL ( $45 \mathrm{mg} / \mathrm{L}$ as the $\mathrm{NO}_{3}^{-}$ion) in wells in all operational areas. Although elevated nitrate levels were found throughout the extensive plume that emanates from the vicinity of the PUREX Plant in the 200-East Area, only proportionally small areas contained nitrate at levels above the MCL. Extensive nitrate contamination extends into the 600 Area from the vicinity of U Plant in the 200-West Area. A large nitrate plume in the 200-West Area is located near T Plant, while smaller amounts of contamination are found near the Plutonium Finishing and REDOX Plants. Two relatively small areas greater than the MCL are observed near the 400 Area and the Washington Public Power Supply System. Nitrate contamination in the Richland North Area apparently has a source off the Hanford Site.

\section{Chromium}

A major source for chromium was the sodium dichromate used as a corrosion inhibitor in cooling water for reactors in the 100 Areas. Chromium was also used for decontamination in the 100,200 , and 300 Areas and for oxidation-state control in the REDOX Plant processes in the 200-West Area. Chromium was elevated in each of the 100 Areas, but the major plumes exceeding the $100-\mu \mathrm{g} / \mathrm{L}$ MCL are related to operations in the $100-\mathrm{K}, 100-\mathrm{D}$, and 100-H Areas and portions of the 600 Area between. Hexavalent chromium was detected in the Columbia River substrate adjacent to these areas and is a hazard to some aquatic life. Therefore, interim actions are under way to pump and treat groundwater in these areas to reduce the amount of chromium reaching the river. The chromium plumes are not welldefined in the area east of the 100-K Area, the southwestern 100-D Area, and in the area between the $100-\mathrm{D}$ and $100-\mathrm{H}$ Areas.

Chromium concentrations were also found at levels above the $100-\mu \mathrm{g} / \mathrm{L}$ MCL near T Plant and the 216-S-10 pond and ditch in the 200-West Area. Chromium continued to exceed the MCL in one well south of the 200-East Area. Other wells in the area also have elevated chromium, though levels are below the MCL. The source of this plume was not established. 


\section{Carbon Tetrachloride}

Carbon tetrachloride contamination was found in FY 1998, as in previous years, to be above the $5-\mu \mathrm{g} / \mathrm{L}$ MCL beneath much of the 200 -West Area. The plume extends beyond the area boundary and forms the most widespread organic contaminant plume onsite. The contamination is principally from waste-disposal operations associated with the Plutonium Finishing Plant, where it was used in plutonium processing. Concentrations in the central part of the plume remained above $2,000 \mu \mathrm{g} / \mathrm{L}$ in FY 1998. A groundwater pump-and-treat system is operating in this area to prevent further movement of the central portion of the plume. There appears to be a shift in the maximum concentrations toward the pumping wells, and the treated water is displacing the plume in the vicinity of the injection wells, located west of the area. The total area of the carbon tetrachloride plume at the top of the unconfined aquifer in FY 1998 (5- $\mu \mathrm{g} / \mathrm{L}$ contour) was $\sim 11.4 \mathrm{~km}^{2}$, compared to $\sim 11.3 \mathrm{~km}^{2}$ in FY 1997. In some areas, concentrations of carbon tetrachloride decrease with depth, but data collected in recent years indicate that in other areas carbon tetrachloride is present at higher concentrations deeper in the suprabasalt sediments than at the water table. Therefore, the extent of the plume at the water table may not reflect the extent in deeper parts of the aquifer.

\section{Chloroform}

The 200-West Area chloroform plume is associated with the carbon tetrachloride plume and is believed to be a degradation product of carbon tetrachloride. The MCL for chloroform is $100 \mu \mathrm{g} / \mathrm{L}$ (total trihalomethanes).

\section{Trichloroethylene}

Trichloroethylene (TCE) was commonly used on the Hanford Site in the 1960s and 1970s as a degreasing compound. TCE was detected at concentrations greater than the 5- $\mu \mathrm{g} / \mathrm{L} \mathrm{MCL}$ in FY 1998 in wells in the 100-K, 100-F and adjacent upgradient 600 Areas, 200-West, 300, and Richland North Areas. Concentrations of TCE were also detected in wells near the Solid Waste Landfill but were below the MCL.

Concentrations of TCE exceeded the MCL in the 200-West Area to the west of T Plant and to the east of U Plant. It was not detected near the REDOX Plant in FY 1998, unlike previous years. Some TCE at levels above the MCL is also associated with the carbon tetrachloride plume near the Plutonium Finishing Plant.

The 5- $\mu \mathrm{g} / \mathrm{L}$ MCL for TCE was exceeded in two of the point-of-compliance wells for the 1100-EM-1 Operable Unit and in other wells near Siemens Power Corporation and Horn Rapids Landfill. The plume appears to be moving toward the northeast.

\section{cis-1,2-Dichloroethylene}

Concentrations of cis-1,2-dichloroethylene continued to increase in a well that monitors the bottom of the unconfined aquifer near the 316-5 process trenches in the 300 Area. The average cis-1,2dichloroethylene concentration in this well in FY 1998 was $156 \mu \mathrm{g} / \mathrm{L}(\mathrm{MCL}=70 \mu \mathrm{g} / \mathrm{L})$. The source of this constituent is believed to be anaerobic biodegradation of TCE. 


\section{Tetrachloroethylene}

A plume of tetrachloroethylene was detected in the 300 Area in FY 1998. Concentrations exceeding the 5- $\mu \mathrm{g} / \mathrm{L} \mathrm{MCL}$ appeared simultaneously in six wells downgradient of the $316-5$ process trenches in May 1998. Concentrations increased in July (maximum of $38 \mu \mathrm{g} / \mathrm{L}$ ), and decreased again by September as the plume appeared to be moving downgradient.

\section{Cyanide}

A cyanide plume is present north of the 200-East Area and is believed to have originated from wastes containing ferrocyanide that were disposed in the BY cribs. Wells containing cyanide often contain concentrations of several radionuclides, including cobalt- 60 . Cobalt- 60 appears to be chemically complexed and mobilized by cyanide or ferrocyanide. The maximum average annual concentration of cyanide detected in FY 1998 was $333 \mu \mathrm{g} / \mathrm{L}$, exceeding the $200-\mu \mathrm{g} / \mathrm{L}$ MCL.

\section{Fluoride}

Fluoride was detected at the primary 4-mg/L MCL in a small plume near the T Plant waste-disposal facilities (200-West Area). Three wells in the Richland North Area also exceeded the MCL, and the contamination is believed to come from an offsite source.

\section{Ingestion Dose and Risk Estimates}

Results of groundwater monitoring are compared to the DWSs for individual radiological constituents. These interim DWSs use the methodology set out in 40 CFR 141, 40 CFR 142, and 40 CFR 143 to estimate the concentration in water that could result in a potential radiological dose of $4 \mathrm{mrem} / \mathrm{yr}$ from consumption of each individual constituent. Similarly, DCGs provide estimates of activities that could result in a 100-mrem/yr dose as defined in DOE Order 5400.5. However, the potential dose is actually the sum of the doses from the individual constituents. An estimate of this cumulative dose, which could result from consumption of groundwater from different onsite locations, can be calculated from the extent of contamination.

Figure S.3 shows the cumulative dose estimates from ingestion of groundwater from the unconfined aquifer system on the Hanford Site. These estimates were made by summing the interpolated carbon-14, strontium-90, technetium-99, iodine-129, cesium-137, plutonium, tritium, and uranium activities in groundwater. The automatic interpolation process sometimes resulted in peak grid values that were lower than the measured maximum values because it averaged in other lower values. In these cases, the value at the grid node closest to the measured peak value was increased to match the measured peak. Factors to convert activities to ingestion dose equivalents were taken from DOE Order 5400.5. The dose presented in Figure S.3 represents the cumulative dose equivalent from all major radionuclides in Hanford Site groundwater.

The dose estimates presented in Figure S.3 show that areas above the $100-\mathrm{mrem} / \mathrm{yr}$ dose standard are restricted to localized parts of the 100-K, 100-N, and 200 Areas. Areas above $4 \mathrm{mrem} / \mathrm{yr}$ are more restricted than the area above the interim DWS for individual constituents because the dose map used 
more recent conversion factors than those used in calculating the interim DWSs. Dose estimates for portions of the 100, 200,300, and 600 Areas exceed $4 \mathrm{mrem} / \mathrm{yr}$.

Figure S.4 illustrates the estimated lifetime incremental cancer risk that would be experienced by a person drinking water contaminated with chemicals and radionuclides at concentrations that have been measured in groundwater across the Hanford Site. Cancer-risk estimates weré made by summing interpolated groundwater concentrations of the radionuclides listed above plus carbon tetrachloride, chloroform, trichloroethylene, cis-1,2-dichloroethylene, nitrate, and hexavalent chromium. The calculation assumes that a person weighing $70 \mathrm{~kg}$ consumes $2 \mathrm{~L}$ of groundwater every day for 30 years (DOE/RL-91-45, Rev. 3; IRIS 1997). Cancer risks exceeding 0.0001 are present in portions of the $100,200,300$, and 600 Areas, and this contour closely resembles the cumulative dose map (see Figure S.3). An additional area of cancer risk $>0.0001$ is observed in the 200-West Area, a result of the carbon tetrachloride plume.

Figure S.5 shows the estimated hazard quotient that would be experienced by an individual drinking water contaminated with chemicals at concentrations that have been measured in groundwater across the Hanford Site. The hazard quotient relates the potential human health hazards associated with exposure to noncarcinogenic substances or carcinogenic substances with systemic toxicities other than cancer (in Hanford Site groundwater, these include nitrate, hexavalent chromium, uranium, and strontium). The calculation assumes that a person weighing $70 \mathrm{~kg}$ consumes $2 \mathrm{~L}$ of groundwater every day for 30 years (DOE/RL-91-45, Rev. 3; IRIS 1997). The only part of the Hanford Site with a $>5$ hazard quotient is a small portion of the 200-West Area. Hazard quotients $>0.3$ are present in all of the operational areas and in parts of the 600 Area, primarily those areas with nitrate contamination.

\section{Groundwater Modeling}

Numerical simulations of groundwater flow and contaminant movement are used to predict future conditions and to assess the effects of remediation systems. One sitewide model and several local-scale models were applied to the Hanford Site in FY 1998.

The sitewide three-dimensional model was used during FY 1998 to support the composite analysis of the Hanford Site. The composite analysis involved simulation of future transport of radioactive contaminants from all sources expected to exist on the Hanford Site following site closure. Site closure was assumed to occur in 2050 , followed by a 1,000 -year compliance period.

Over an 300-year period following site closure and the elimination of wastewater discharges to the ground at the Hanford Site, the water table is predicted by the model to decline significantly and return to near pre-Hanford Site conditions. Over this period, the water table is predicted to drop as much as $11 \mathrm{~m}$ beneath the 200-West Area near the 216-U-10 pond and 7 to $8 \mathrm{~m}$ beneath the 200-East Area near 216-B-3 pond.

Other groundwater models were applied in the design and evaluation of pump-and-treat activities aimed at remediation of contaminated groundwater in the 100 and 200-West Areas. These models were used to describe the capture and injection zones for extraction and injection wells, respectively, and to estimate the area affected by the pump-and-treat operations at different times. 


\section{Groundwater Remediation}

Groundwater remediation conducted in accordance with CERCLA was performed at the following sites:

- 100-KR-4 Operable Unit - An interim action to address chromium contamination near the 116-K-2 trench was initiated in FY 1997 and continued in FY 1998. Groundwater is extracted from six wells between the trench and the river, treated to remove chromium, and injected into wells upgradient of the trench. Significant portions of the plume are being captured and the mass of chromium in the aquifer is being reduced.

- 100-NR-2 Operable Unit - Groundwater continued in FY 1998 to be extracted from wells near the 1301-N liquid waste-disposal facility, treated to remove strontium-90, and injected into wells near the 1325-N liquid waste-disposal facility. The extraction wells create a hydraulic barrier to reduce the volume of contaminated groundwater reaching the river.

- 100-D Area chromium hot spot - A demonstration of in situ redox manipulation technology con- . tinued in FY 1998 in the 100-D Area to determine the feasibility of using the technology to reduce hexavalent chromium in groundwater. The project's goal is to create a permeable treatment zone in the subsurface where chemical-reducing agents will turn the highly soluble hexavalent chromium to an insoluble state. Groundwater chemistry in the treatment zone shows dramatic effects of the reduction. It is too soon to see the effects on groundwater farther downgradient.

- 100-HR-3 Operable Unit, 100-D Area - An interim action pump-and-treat system was put into operation in FY 1997 and continued in FY 1998. The system removes chromium-contaminated groundwater from wells near the river and pipes it to the $100-\mathrm{H}$ Area for treatment and injection. The hydraulic effects of groundwater extraction result in containment of the plume along $\sim 400 \mathrm{~m}$ of shoreline.

- 100-HR-3 Operable Unit, 100-H Area - An interim action pump-and-treat system began to operate in FY 1997 and continued in FY 1998. The system removes chromium from wells around the 183-H solar evaporation basins, treats it to remove chromium, and injects the water into wells in the southwestern part of the area. Most of the plume is being captured, but a portion continues to pass between the extraction wells into the river.

- 200-UP-1 Operable Unit - An interim action pump-and-treat system, designed to contain and treat the elevated technetium-99 and uranium, continued to operate in FY 1998. The most notable success in FY 1998 was the reduction of technetium-99 to below the remediation goal of $9,000 \mathrm{pCi} / \mathrm{L}$ in all but 2 wells. Uranium concentrations remained above the remediation goal of $480 \mu \mathrm{g} / \mathrm{L}$ in almost all wells, even after treatment of $338,300,000 \mathrm{~L}$ and 3 years of operation.

- 200-ZP-1 Operable Unit - An interim action pump-and-treat system continued to operate to prevent further movement of carbon tetrachloride, chloroform, and trichloroethylene from the highconcentration portion of the carbon tetrachloride plume and to reduce contaminant mass. Treatment of the contaminated water resulted in the removal of $1,212 \mathrm{~kg}$ of carbon tetrachloride in FY 1998. Since initiation of pump-and-treat operations (August 1994) through September 1998, >614,800,000 L 
of water have been treated, resulting in removal of $2,099 \mathrm{~kg}$ of carbon tetrachloride. The system is containing and capturing the high-concentration portion of the plume.

\section{Well Installation, Maintenance, and Decommissioning}

Ten new wells were installed for RCRA groundwater monitoring in FY 1998. Seven of these replaced wells that are going dry because of a declining water table. The other three wells supplemented assessment or detection networks to maintain adequate monitoring coverage.

Approximately 190 well-maintenance activities were carried out during FY 1998. These activities included well or pump repair, cleaning, and maintenance.

The schedule for well decommissioning is driven by potential risk for a well to provide a contaminant pathway to deeper zones and the long-range environmental restoration schedule. In general, areas adjacent to the Columbia River are to be remediated first. In FY 1998, 28 Hanford Site wells were decommissioned. They were located in the 100, 200, and 600 Areas, and north of the Columbia River. 


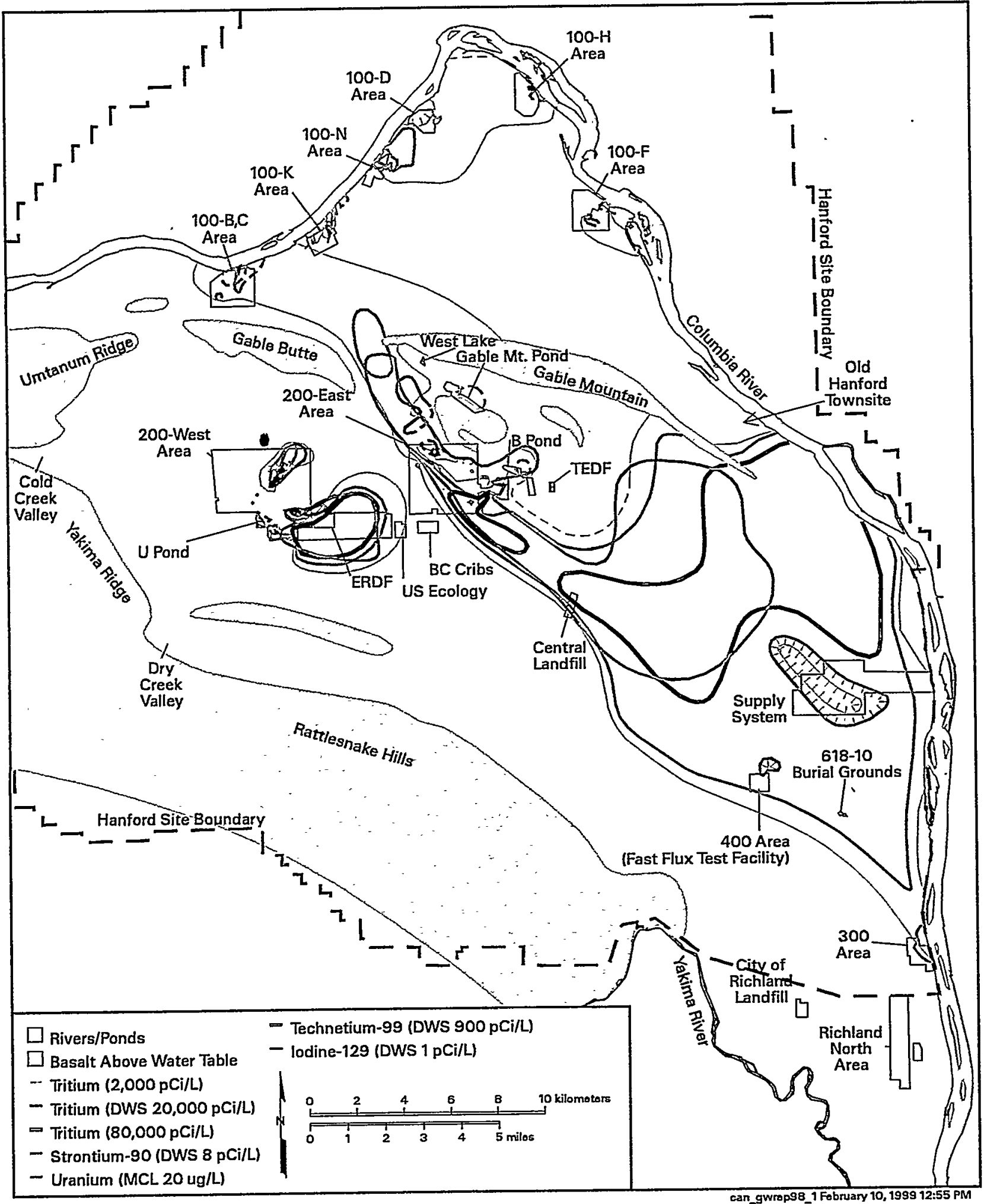

Figure S.1. Distribution of Major Radionuclides in Groundwater at Activities Above Maximum Contaminant Levels or Interim Drinking Water Standards, Fiscal Year 1998 


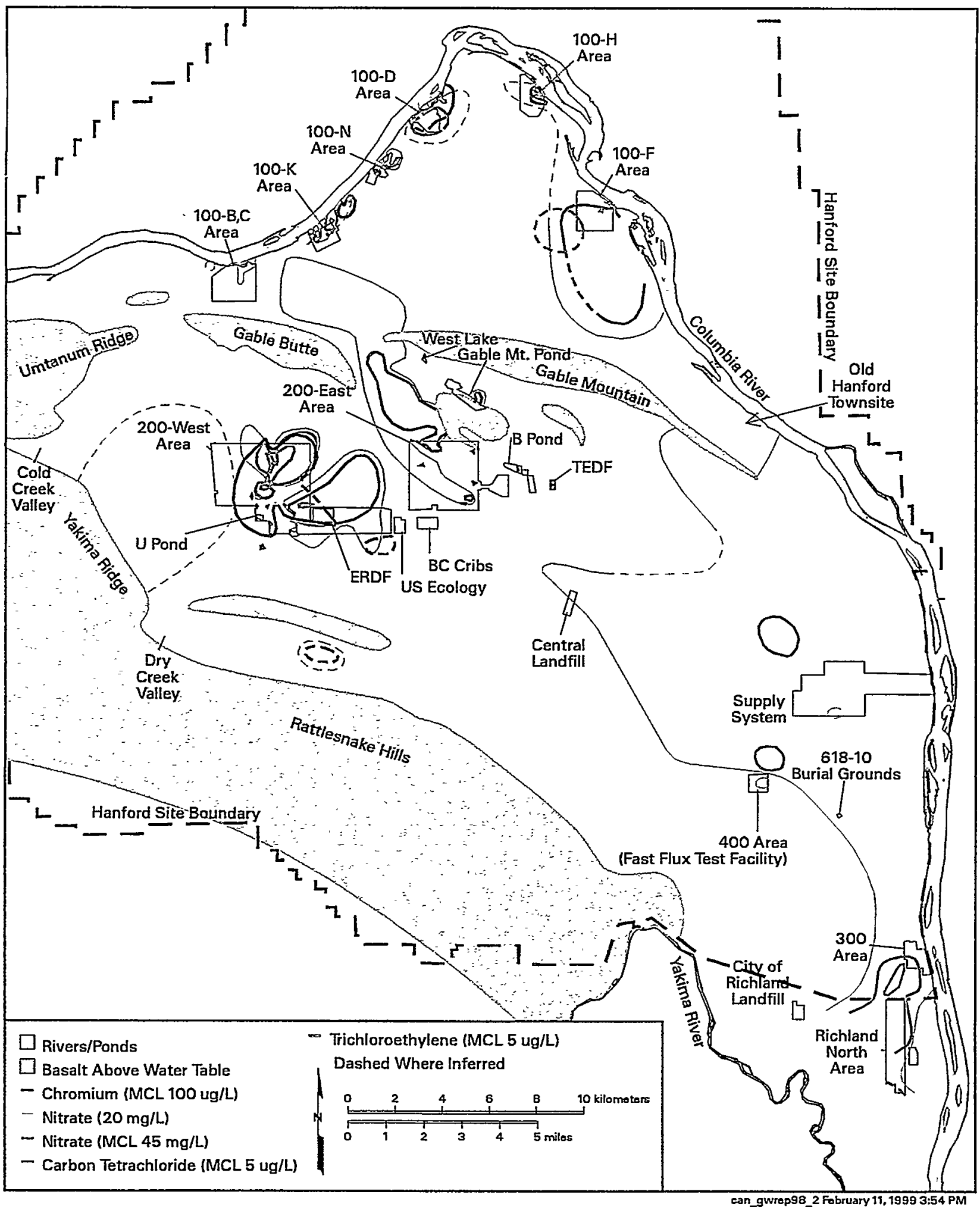

Figure S.2. Distribution of Major Hazardous Chemicals in Groundwater at Concentrations Above Maximum Contaminant Levels, Fiscal Year 1998 


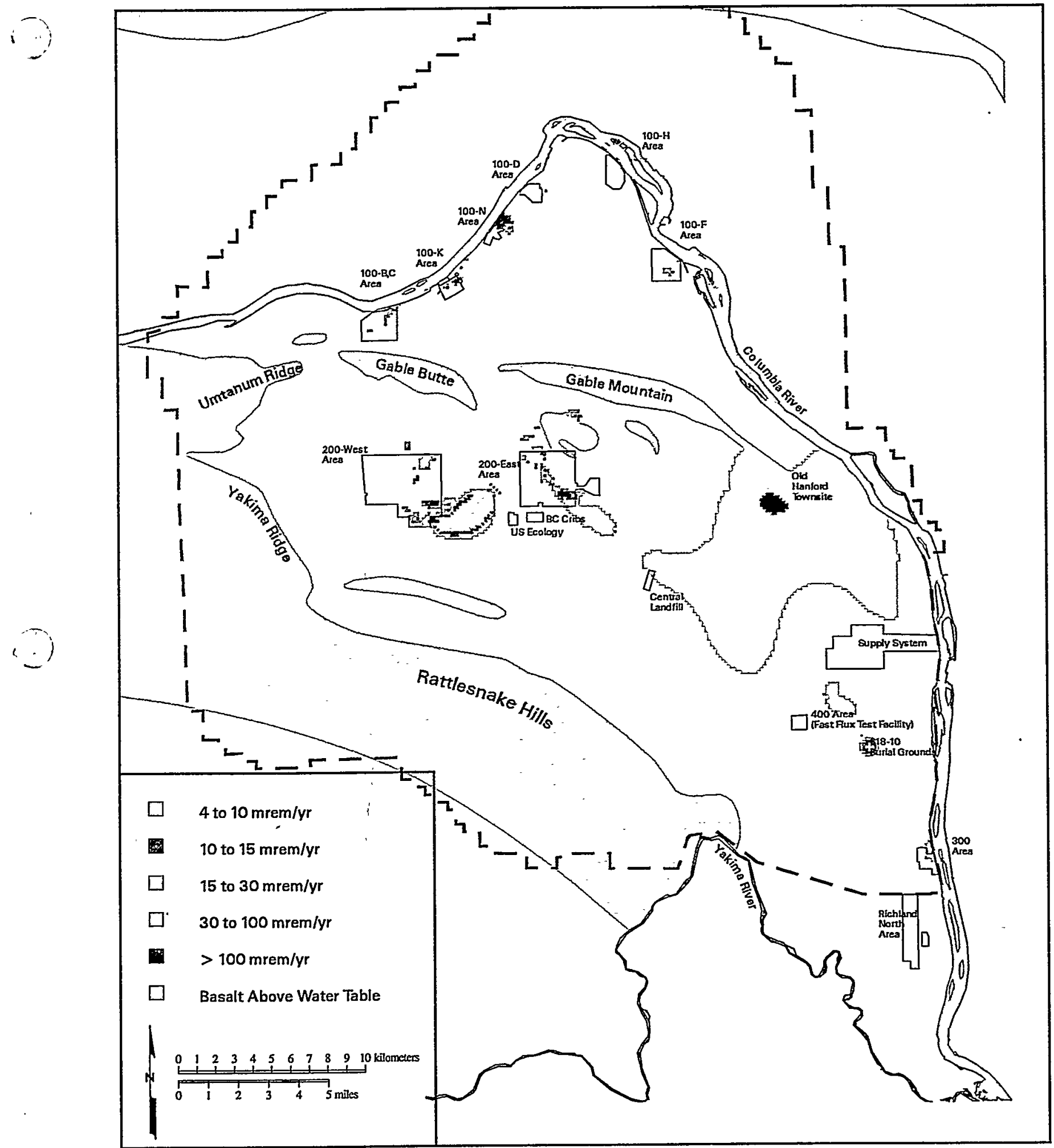

pdt69014.eps February 22, 1999

Figure S.3. Potential Dose Estimates from Ingestion of Groundwater, Fiscal Year 1998 


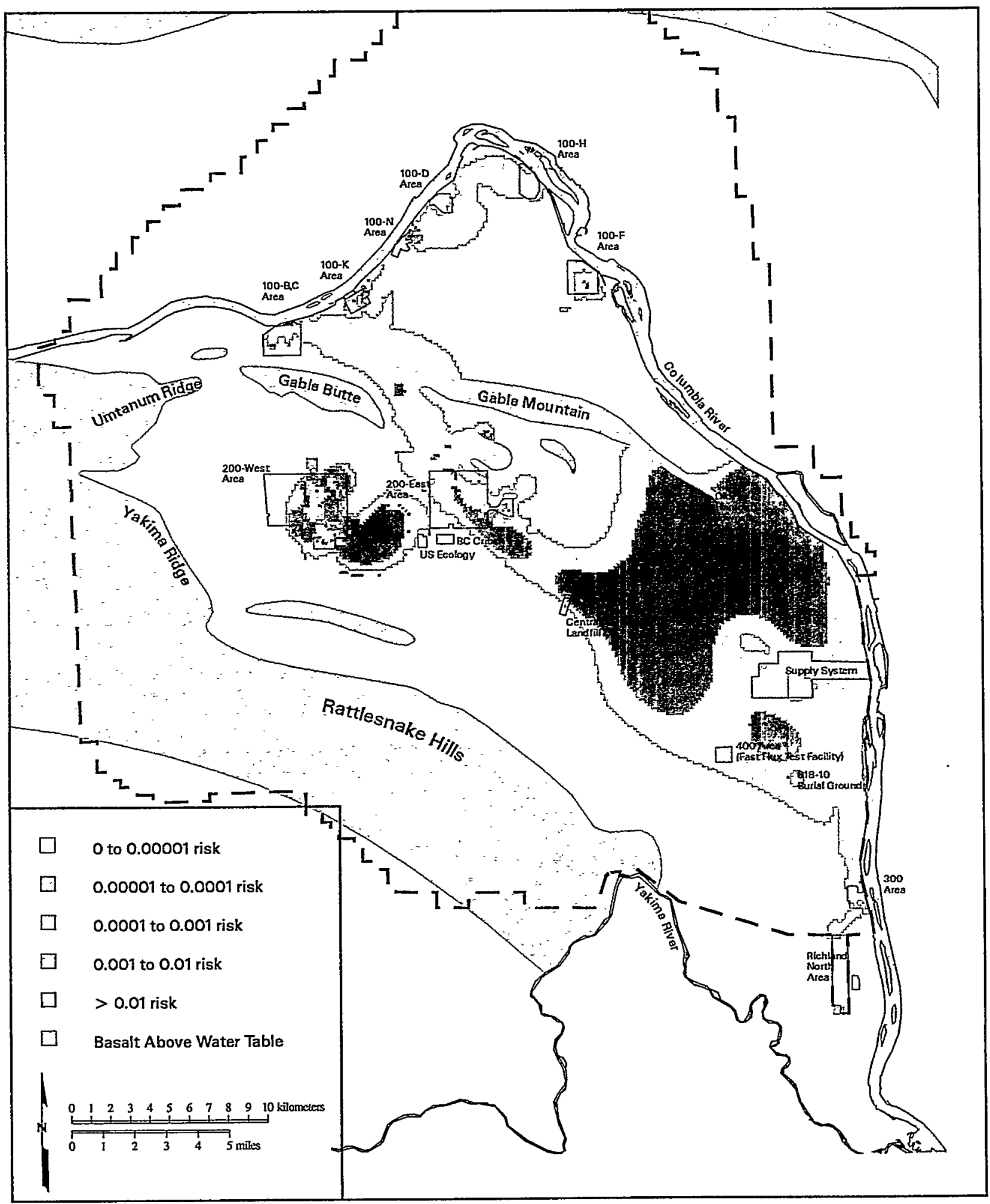

pd199015.eps February 22, 1999

Figure S.4. Cancer-Risk Estimates from Ingestion of Groundwater, Fiscal Year 1998 


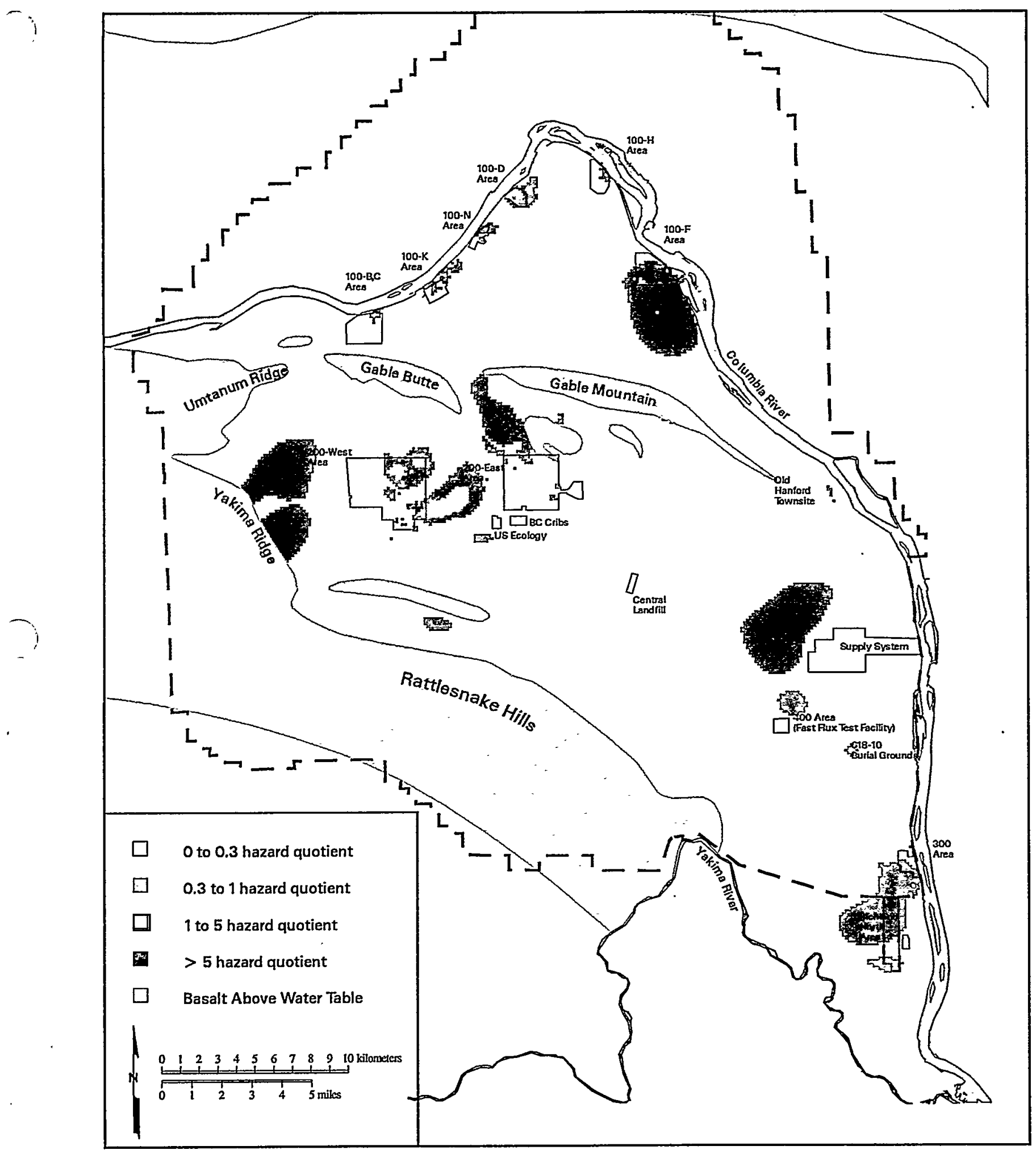

pd199016.eps February 22, 1999

Figure S.5. Hazard Quotient Estimates from Ingestion of Groundwater, Fiscal Year 1998 



\section{Acknowledgments}

This report represents the efforts of dozens of individuals who contribute to the Hanford GroundwaterMonitoring Project: planners, schedulers, samplers, laboratory technicians, data management staff, site scientists, editors, text processors, and staff in graphics and duplicating.

Ron Smith and Stuart Luttrell, Pacific Northwest National Laboratory (PNNL), managed the Hanford Groundwater Monitoring Project and the Groundwater Monitoring Task, respectively. Dot Stewart managed the monumental tasks of sampling and analysis, quality control, and data management. Staff of PNNL, Bechtel Hanford, Inc. (BHI), and Waste Management Federal Services of Hanford, Inc. scheduled and coordinated sampling and measured water levels. Data management teams at PNNL and BHI made sure new and historical data were at our fingertips. Bill McMahon (CH2MHill Hanford, Inc.) provided transducer data. Bob Riley (PNNL) provided peer review.

The production of the vast number of figures in this report was the responsibility of the following individuals - their skill is appreciated very much: Mickie Chamness, David Lanigan, John McDonald, Chris Newbill, JoAnne Rieger, and Denise Sauer (PNNL); Deborah Liddell (Lockheed Martin Hanford Corporation); Bill McMahon and Buddy Bentz (CH2M Hill Hanford, Inc.).

The cover for this year's report was designed by Jane Winslow, WinSome Design, Richland, Washington. The inset figures were provided by PNNL and BHI.

Duplication of this report was provided by PNNL's ROB and 337 Building Duplicating crews.

Last, and certainly not least, is our editor, Bev Johnston. She is commended for her "stick-to-itiveness," for her keeping us on track, and for her full candy dish. Also, she made us smile when we didn't feel like it. To our text processor, Kathy Neiderhiser, goes our special thanks for deciphering our tiny writing in the tiny spaces and her wonderful disposition about a report this large. 



\section{Contents}

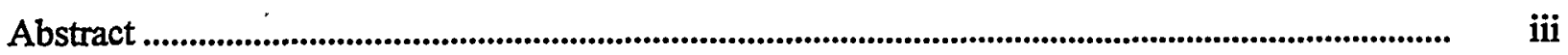

Summary .............................................................................................................................................

Acknowledgments ........................................................................................................................................... xxiii

1.0 Introduction ..................................................................................................................................

$1.1 \quad$ Purpose .................................................................................................................................

1.2 Organization ....................................................................................................................

1.3 Related Reports ........................................................................................................... 1.2

1.4 Groundwater/Vadose Zone Integration Project.................................................................. 1.3

2.0 Groundwater-Monitoring Requirements ............................................................................................ 2.1

2.1 Environmental Monitoring................................................................................................. 2.2

2.2 Groundwater Protection ................................................................................................... 2.2

2.2.1 General Environmental Protection Program ........................................................ 2.2

2.2.2 Radiation Protection of the Public and the Environment ...................................... 2.3

2.3 Hanford Federal Facility Agreement and Consent Order ................................................... 2.3

2.4 Applicable Federal Regulations ......................................................................................... 2.3

2.4.1 Comprehensive Environmental Response, Compensation, and Liability Act of 1980/Superfund Amendments and Reauthorization Act of 1986.............. 2.4

2.4.2 Resource Conservation and Recovery Act of 1976................................................ 2.5

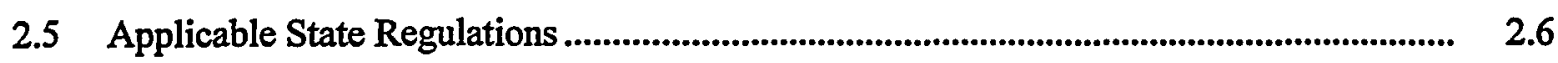

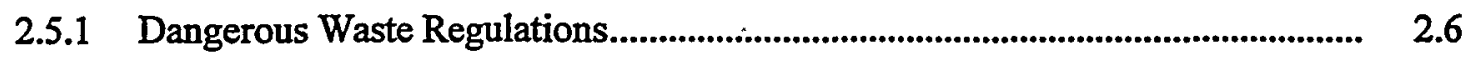

2.5.2 State Waste Discharge Program ....................................................................... 2.6

2.5.3 Minimum Functional Standards for Solid Waste Handling ................................... 2.7

2.5.4 Model Toxics Control Act - Cleanup ................................................................... 2.7

2.6 Regulatory Authority Interface ..................................................................................... 2.7

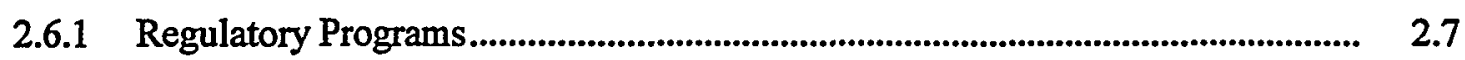

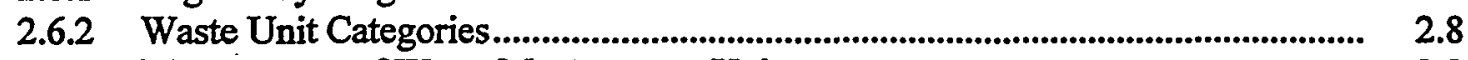

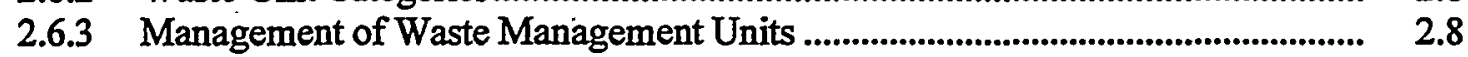

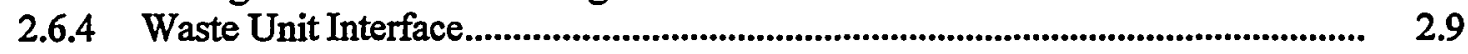


3.0 Hydrogeologic Setting

3.1 Geologic Setting

3.1.1 Columbia River Basalt Group ........................................................................ 3.2

3.1.2 Ringold Formation ........................................................................................... 3.2

3.1.3 Plio-Pleistocene Unit and Early Palouse Soil .............................................................. 3.3

3.1.4 Hanford Formation and Pre-Missoula Gravels..................................................... 3.4

3.1.5 Holocene Surficial Deposits ........................................................................... 3.4

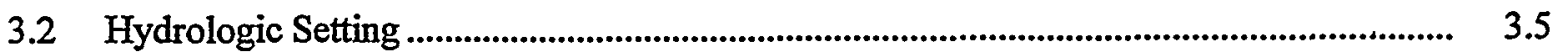

3.2.1 Unconfined Aquifer System Recharge and Discharge.......................................... 3.5

3.2.2 Unconfined Aquifer System Hydraulic Properties................................................. 3.6

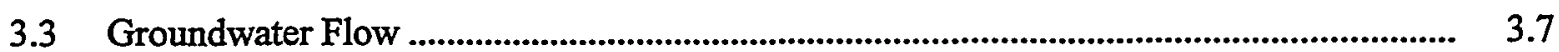

3.3.1 Hanford Site Groundwater-Level Monitoring ..................................................... 3.8

3.3.1.1 Monitoring Network............................................................................ 3.8

3.3.1.2 Data-Collection Methods .................................................................. 3.9

3.3.1.3 Data Quality .................................................................................... 3.9

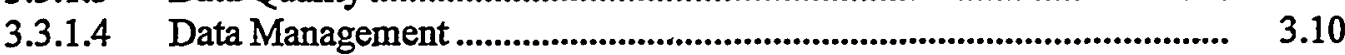

3.3.2 Unconfịned Aquifer......................................................................................... 3.11

3.3.2.1 Interpretive Techniques................................................................... 3.11

3.3.2.2 Regional Groundwater Flow .............................................................. 3.13

3.3.2.3 Historical Changes in Water Levels..................................................... 3.14

3.3.2.4 Changes from June 1997 to June 1998.................................................. 3.15

3.3.3 Upper Basalt-Confined Aquifer System ......................................................... 3.16

3.4 Hydrogeology of Upper Cold Creek and Dry Creek Valleys ......................................... 3.18

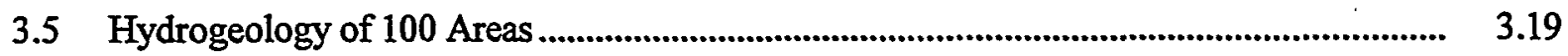

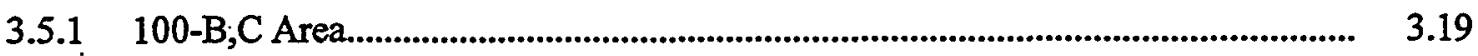

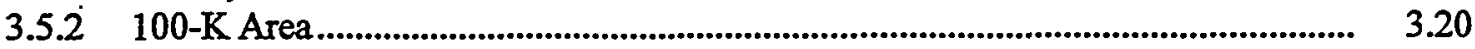

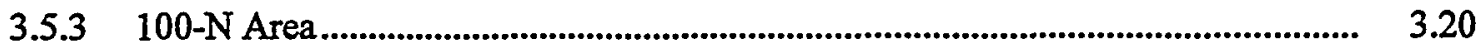

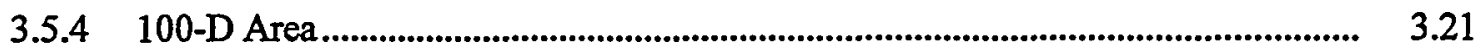

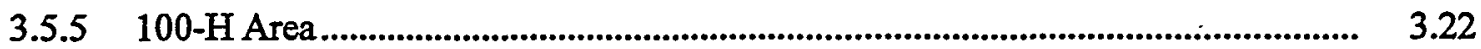

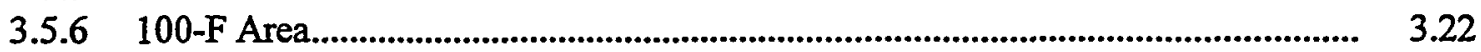

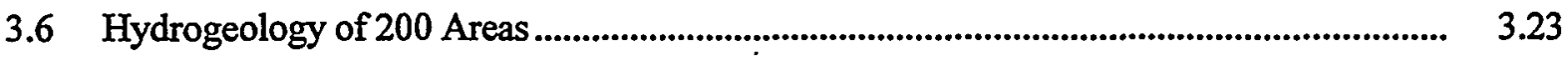

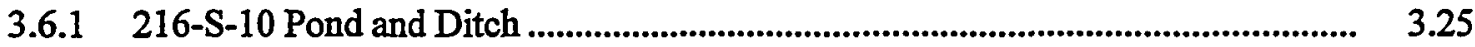

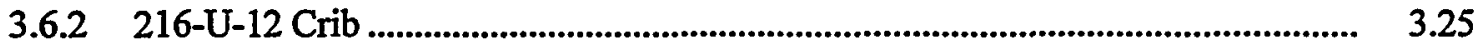

3.6.3 200-West Area Single-Shell Tank Farms........................................................ 3.25

3.6.3.1 Waste Management Areas S-SX and U Single-Shell Tank Farms ...... $\quad 3.25$

3.6.3.2 Waste Management Areas T and TX-TY Single-Shell Tank Farms.... $\quad 3.26$

3.6.4 200-West Area Low-Level Burial Grounds ......................................................... 3.27

3.6.5 216-A-10, 216-A-36B, and 216-A-37-1 Cribs ................................................ 3.28

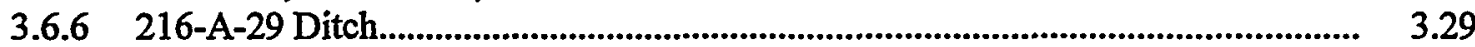


3.6.7 216-B-3 Pond ...................................................................................................... 3.29

3.6.8 216-B-63 Trench ................................................................................................ $\quad 3.30$

3.6.9 200-East Area Single-Shell Tank Farms ........................................................... 3.31

3.6.9.1 Waste Management Area A-AX Single-Shell Tank Farms ................ $\quad 3.31$

3.6.9.2 Waste Management Area B-BX-BY Single-Shell Tank Farms........... 3.32

3.6.9.3 Waste Management Area C Single-Shell Tank Farm .......................... 3.33

3.6.10 200-East Area Low-Level Burial Grounds............................................................... 3.34

3.6.11. Liquid Effluent-Retention Facility .................................................................. 3.34

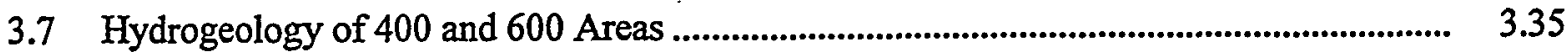

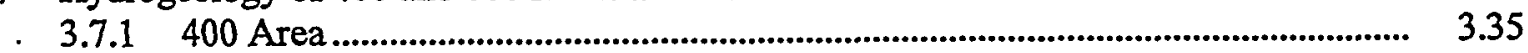

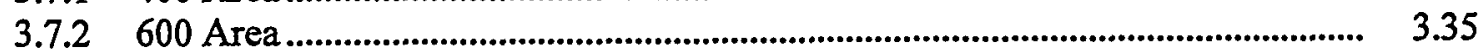

3.8 Hydrogeology of 300 and Richland North Areas............................................................... 3.37

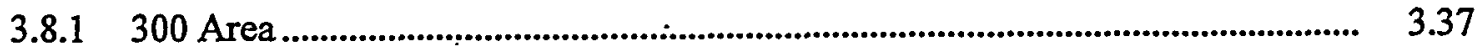

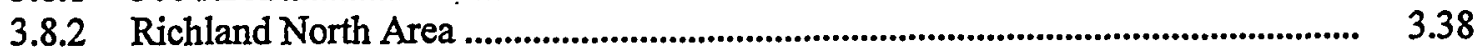

3.9 Hydrogeology of Areas East and North of Columbia River ........................................... 3.39

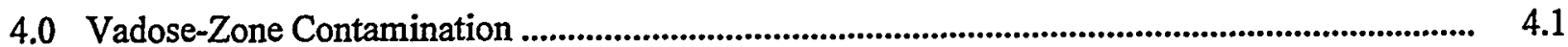

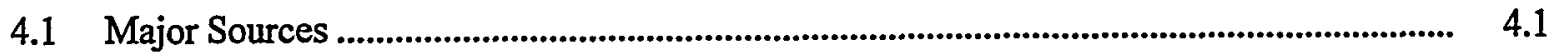

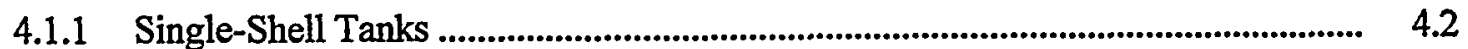

4.1.2 Plutonium Finishing Plant................................................................................... 4.3

4.1.3 Other Past-Practice Liquid-Disposal Facilities ......................................................... 4.5

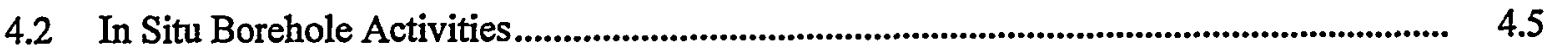

4.2.1 Spectral Gamma-Logging Methods .................................................................. 4.6

4.2.2 Monitoring Networks ......................................................................................... 4.7

4.2.2.1 Soil-Column-Disposal Sites ................................................................. 4.7

4.2.2.2 New RCRA-Compliant Groundwater Wells......................................... 4.7

4.2.2.3 Single-Shell Tanks .............................................................................. 4.7

4.2.3 Borehole Spectral Gamma Logging ...................................................................... 4.8

4.2.3.1 WMA B-BX-BY Assessment - Soil-Column-Disposal Sites in 200-East Area.................................................................................. 4.8

4.2.3.2 Plutonium Finishing Plant Liquid-Disposal Facilities ......................... 4.9

4.2.3.3 Single-Shell Tank Farms...................................................................... 4.12

4.2.3.4 Other Borehole Geophysical Logging............................................... 4.17

4.3 Historical Gross Gamma-Ray Log-Time Series ........................................................... 4.18

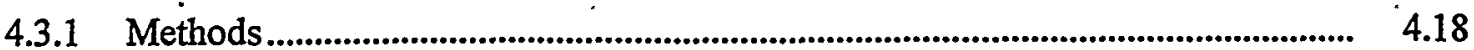

4.3.1.1 Stack Plot ........................................................................................ 4.19

4.3.1.2 Clean Plot......................................................................................... 4.19

4.3.1.3 Radiation Zone Plot............................................................................ 4.19

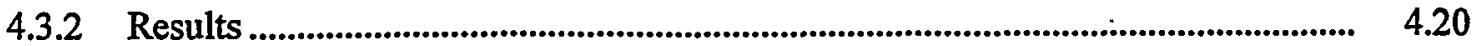




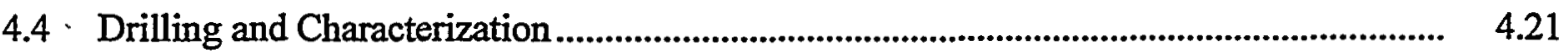

4.4.1 Directional Drilling ............................................................................................ 4.21

4.4.2 Immobilized Low-Activity Waste Site................................................................. 4.21

4.4.2.1 Drilling of Borehole 299-E17-21 ..................................................... 4.21

4.4.2.2 Hydrologic Characterization .............................................................. 4.23

4.4.2.3 Specific Distribution Coefficient Data................................................. 4.23

4.4.2.4 - Uranium(VI) Distribution Coefficient at Unsaturated Moisture

Conditions ........................................................................................... 4.25

4.4.3 TWRS Phase I Demonstration Site Vadose-Zone Characterization ...................... 4.26

4.4.4 New RCRA Well Sediment Characterization ......................................................... 4.27

4.4.5 Borehole 41-09-39 Extension to Groundwater........................................................ 4.27

4.4.6 200 Areas Assessment........................................................................................ 4.29

4.4.7 Tank AX-104 Vadose-Zone Characterization Technology Demonstration ........... 4.31

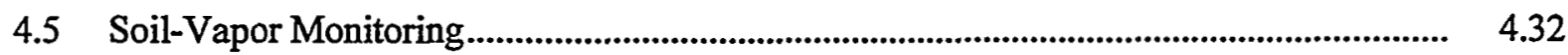

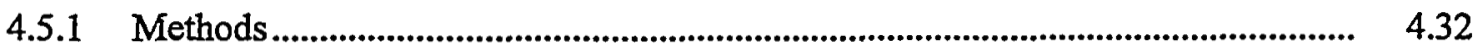

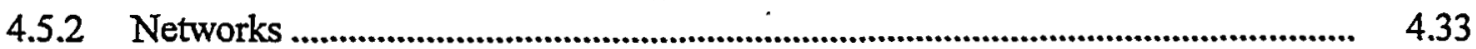

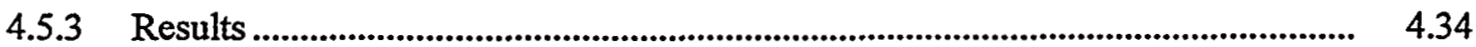

4.5.3.1 Soil-Vapor Remediation.................................................................. 4.34

4.5.3.2 Soil-Vapor Monitoring..................................................................... 4.35

4.5.4 Carbon Tetrachloride Migration................................................................... 4.36

5.0 Contaminant Evaluation and Compliance............................................................................... 5.1

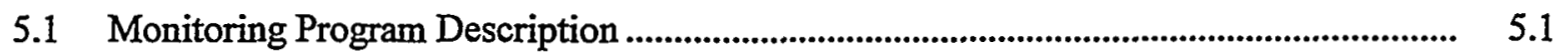

5.1.1 Monitoring Network ........................................................................................... 5.1

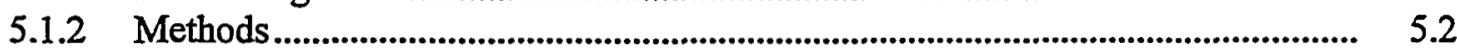

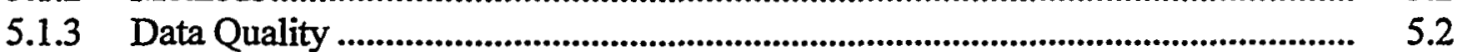

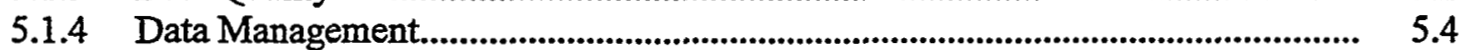

5.1.5 Interpretive Techniques.................................................................................... 5.4

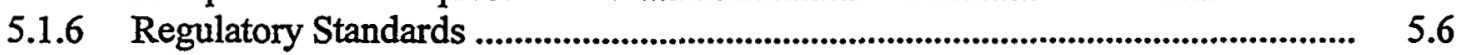

5.2 Hanford Site Groundwater Contamination Overview.................................................... 5.7

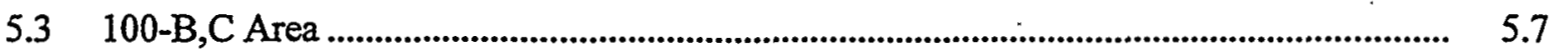

5.3.1 Facilities and Operable Units ....................................................................... 5.7

5.3.2 Compliance Issues ...................................................................................... 5.9

5.3.3 Extent of Contamination ............................................................................. 5.9

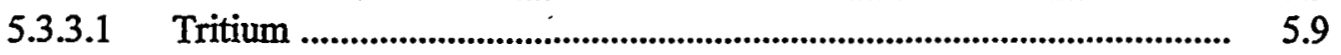

5.3.3.2 Strontium-90 ......................................................................... 5.10

5.3.3.3 Chromium ................................................................................. 5.10

5.3.3.4 Nitrate............................................................................................ 5.10

5.3.3.5 Water Quality at Shoreline-Monitoring Locations............................. 5.11 
5.4.1 Facilities and Operable Units ...................................................................... 5.11

5.4.2 Compliance Issues............................................................................................ 5.13

5.4.2.1 Monitoring at $\mathrm{KE}$ and KW Fuel-Storage Basins................................. 5.13

5.4.2.2 CERCLA Interim Action .................................................................... 5.13

5.4.2.3 100-KR-4 Operable Unit Remedial Investigation.................................. 5.13

5.4.2.4 Drinking Water Standards and Derived Concentration Guides ........... $\quad 5.13$

5.4.3 Extent of Contamination ................................................................................. 5.14

5.4.3.1 K-West and K-East Reactors ............................................................ 5.14

5.4.3.2 116-K-2 Liquid Waste-Disposal Trench .............................................. 5.16

5.4.3.3 Water Quality at Shoreline-Monitoring Locations................................ 5.17

5.4 .4 Groundwater Remediation ............................................................................ 5.18

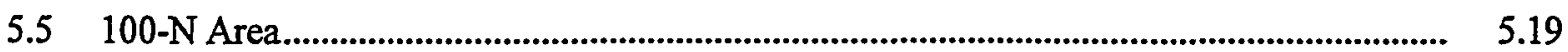

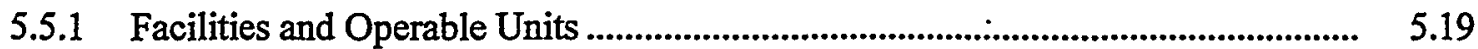

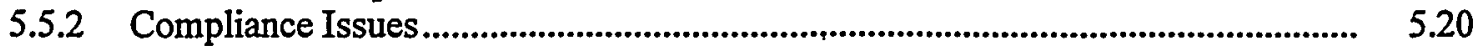

5.5.2.1 1301-N and 1325-N Liquid Waste-Disposal Facilities ........................ 5.20

5.5.2.2 1324-N Surface Impoundment/1324-NA Percolation Pond ................. 5.21

5.5.2.3 N Springs Expedited Response Action ................................................. 5.21

5.5.2.4 100-NR-2 Operable Unit Remedial Investigation................................. 5.22

5.5.2.5 Drinking Water Standards and Derived Concentration Guides ........... $\quad 5.23$

5.5.2.6 Pollution Permit ......................................................................................... 5.23

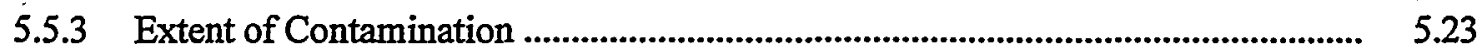

5.5.3.1 1301-N and 1325-N Liquid Waste-Disposal Facilities ......................... 5.23

5.5.3.2 1324-N Surface Impoundment/1324-NA Percolation Pond ................. 5.26

5.5.3.3 Other Groundwater Contamination Indicators ...................................... 5.26

5.5.3.4 Water Quality at Shoreline-Monitoring Locations................................. 5.28

5.5.4 Groundwater Remediation ............................................................................ 5.29

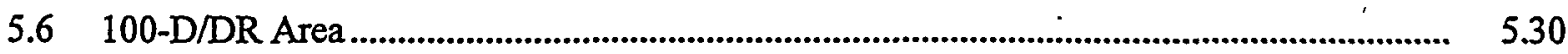

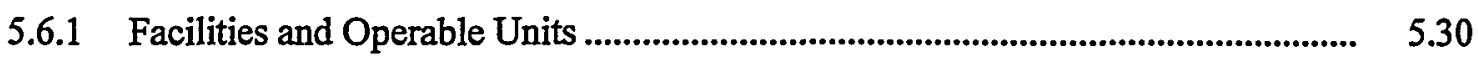

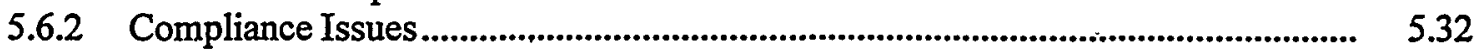

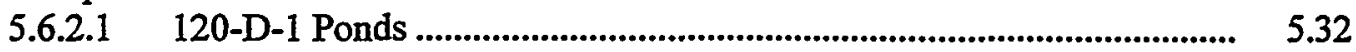

5.6.2.2 CERCLA Interim Action ............................................................. 5.32

5.6.2.3 100-HR-3 Operable Unit Remedial Investigation................................. 5.32

5.6.2.4 Drinking Water Standards and Derived Concentration Guides ........... $\quad 5.33$

5.6.3 Extent of Contamination .................................................................................... 5.33

5.6.3.1 D and DR Reactors........................................................................... 5.33

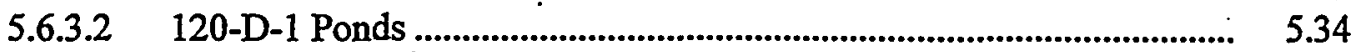

5.6.3.3 100-D Area Chromium Hot Spot ........................................................ 5.35

5.6.3.4 Water Quality at Shoreline-Monitoring Locations............................... 5.35

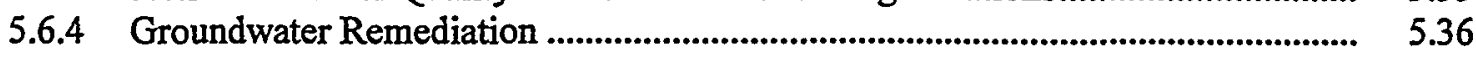

5.6.4.1 Effects of Pilot-Scale Pump-and-Treat System.................................... 5.36

5.6.4.2 CERCLA Interim Action ................................................................... 5.36

5.6.4.3 In Situ Redox Manipulation Technology Demonstration ..................... 5.37 
$5.7 \quad$ 100-H Area.......................................................................................................... 5.39

5.7.1 Facilities and Operable Units .............................................................................. 5.39

5.7.2 Compliance Issues......................................................................................... 5.40

5.7.2.1 183-H Solar Evaporation Basins ........................................................... 5.40

5.7.2.2 CERCLA Interim Action .................................................................. 5.40

5.7.2.3 100-HR-3 Operable Unit Remedial Investigation................................. 5.41

5.7.2.4 Drinking Water Standards and Derived Concentration Guides ........... $\quad 5.41$

5.7.3 Extent of Contamination ........................................................................................ 5.41

5.7.3.1 183-H Solar Evaporation Basins ............................................................. 5.41

5.7.3.2 Other Sources of Contamination .......................................................... 5.43

5.7.3.3 Water Quality at Shoreline-Monitoring Locations................................ 5.44

5.7.4 Groundwater Remediation .................................................................................... 5.45

$5.8 \quad 100-F$ Area ................................................................................................................... 5.46

5.8.1 Facilities and Operable Units ................................................................................ $\quad 5.46$

5.8.2 Compliance Issues............................................................................................. $\quad 5.47$

5.8.3 Extent of Contamination ............................................................................... 5.47

5.8.3.1 Tritium ............................................................................................... 5.48

5.8.3.2 Uranium ......................................................................................... 5.48

5.8.3.3 Strontium-90 ...................................................................................... 5.48

5.8.3.4 Nitrate............................................................................................ 5.48

5.8.3.5 Chromium ...................................................................................... 5.48

5.8.3.6 Trichloroethylene ............................................................................. 5.49

5.8.3.7 Water Quality at Shoreline-Monitoring Locations................................ $\quad 5.49$

$5.9 \quad 200$-West Area .................................................................................................................. 5.49

5.9.1 Facilities and Operable Units ........................................................................... $\quad 5.50$

5.9.1.1 T Plant ................................................................................................ 5.50

5.9.1.2 REDOX Plant....................................................................................... 5.51

5.9.1.3 U Plant.............................................................................................. 5.51

5.9.1.4 Plutonium Finishing Plant................................................................ 5.51

5.9.1.5 RCRA Facilities .................................................................................. 5.52

5.9.1.6 Other Facilities ................................................................................ 5.54

5.9.1.7 Operable Units ................................................................................ 5.54

5.9.2 Compliance Issues ............................................................................................... 5.55

5.9.2.1 Waste Management Areas T and TX-TY Single-Shell Tank Farms.... $\quad 5.55$

5.9.2.2 Waste Management Area S-SX Single-Shell Tank Farms.................... 5.56

5.9.2.3 Waste Management Area U Single-Shell Tank Farm ........................... 5.56

5.9.2.4 216-U-12 Crib ........................................................................... 5.57

5.9.2.5 216-S-10 Pond and Ditch ................................................................... 5.57

5.9.2.6 Low-Level Waste Management Area 3 ............................................... 5.58

5.9.2.7 Low-Level Waste Management Area 4 ............................................... 5.58

5.9.2.8 State-Approved Land-Disposal Site..................................................... $\quad 5.58$

5.9.2.9 Environmental Restoration Disposal Facility .................................... 5.59

5.9.2.10 Drinking Water Standards and Derived Concentration Guides ........... $\quad 5.59$

5.9.3 Extent of Contamination .......................................................................................... 5.59

5.9.3.1 T Plant .................................................................................................. 5.60 
5.9.3.2 REDOX Plant............................................................................. 5.63

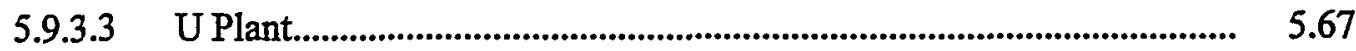

5.9.3.4 Plutonium Finishing Plant................................................................. 5.69

5.9.3.5 Low-Level Waste Management Area 3 .............................................. 5.73

5.9.3.6 Low-Level Waste Management Area 4 ................................................ 5.73

5.9.3.7 State-Approved Land-Disposal Site...................................................... 5.73

5.9.4 Summary of Remediation Effects ................................................................................. 5.74

5.9.4.1 200-UP-1 Operable Unit .................................................................. 5.74

5.9.4.2 200-ZP-1 Operable Unit....................................................................... 5.76

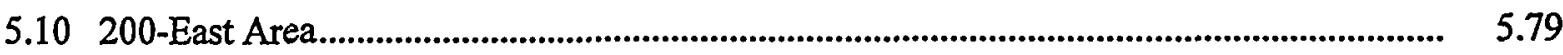

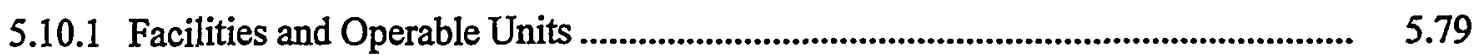

5.10.1.1 B Plant........................................................................................... 5.79

5.10.1.2 PUREX Plant ................................................................................ 5.80

5.10.1.3 RCRA-Regulated PUREX Cribs........................................................ $\quad 5.80$

5.10.1.4 216-A-29 Ditch ................................................................................. 5.82

5.10.1.5 216-B-3 Pond ............................................................................... 5.82

5.10.1.6 200 Areas Treated Effluent-Disposal Facility..................................... 5.83

5.10.1.7 216-B-63 Trench .......................................................................... 5.83

5.10.1.8 Single-Shell Tank Farms................................................................ 5.83

5.10.1.9 Low-Level Waste Management Areas............................................. 5.84

5.10.1.10 Liquid Effluent-Retention Facility .................................................. 5.84

5.10.1.11 Operable Units ............................................................................... $\quad 5.85$

5.10 .2 Compliance Issues........................................................................................... 5.86

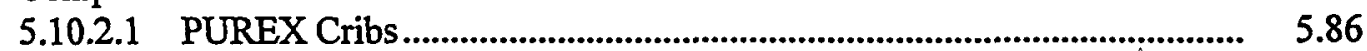

5.10.2.2 216-A-29 Ditch ......................................................................... 5.86

5.10.2.3 216-B-3 Pond ..................................................................................... 5.87

5.10.2.4 200 Areas Treated Effluent-Disposal Facility...................................... 5.88

5.10.2.5 216-B-63 Trench ................................................................................. 5.88

5.10.2.6 Single-Shell Tank Farms................................................................. 5.89

5.10.2.7 Low-Level Waste Management Area 1 .............................................. $\quad 5.90$

5.10.2.8 Low-Level Waste Management Area 2 ............................................ $\quad 5.90$

5.10.2.9 Liquid Effluent-Retention Facility .................................................... 5.90

5.10.2.10 Drinking Water Standards and Derived Concentration Guides ........... $\quad 5.90$

5.10.3 Extent of Contamination ................................................................................ 5.91

5.10.3.1 B Plant Area ............................................................................. 5.91

5.10.3.2 PUREX Plant Area......................................................................... 5.96

5.10.3.3 Low-Level Waste Management Area 1 .............................................. 5.100

5.10.3.4 Low-Level Waste Management Area 2 ............................................... 5.100

5.10.3.5 Liquid Effluent-Retention Facility .................................................... 5.101

5.10.3.6 Contamination Within Lower Portion of Ringold Formation .............. 5. 5.101

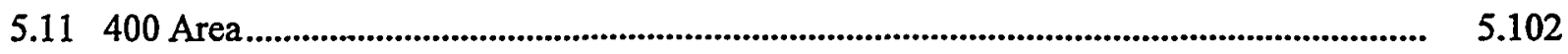

5.11 .1 Facilities ............................................................................................................... 5.102

5.11.1.1 Process Ponds....................................................................................... 5.102

5.11.1.2 Water-Supply Wells .......................................................................... 5.102

5.11.2 Compliance Issues .................................................................................................... 5.103

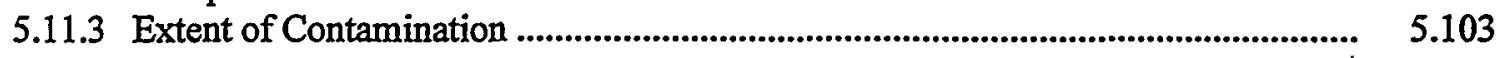




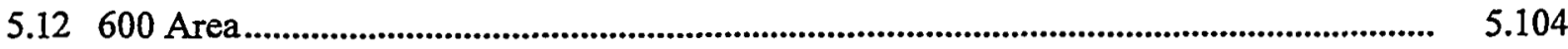

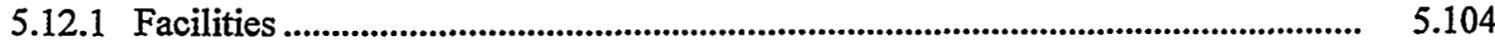

5.12.1.1 Solid Waste Landfill ........................................................................ 5.104

5.12.1.2 Nonradioactive Dangerous Waste Landfill .......................................... 5.104

5.12.1.3 Other Facilities...................................................................................... 5.104

5.12.2 Compliance Issues .......................................................................................... 5.105

5.12.2.1 Solid Waste Landfill ........................................................................... 5.105

5.12.2.2 Nonradioactive Dangerous Waste Landfill ........................................ 5.105

5.12.2.3 Drinking Water Standards and Derived Concentration Guides ........... $\quad 5.106$

5.12.3 Extent of Contamination .................................................................................... 5.106

5.12.3.1 Solid Waste Landfill ........................................................................ 5.106

5.12.3.2 Nonradioactive Dangerous Waste Landfill ........................................ 5.108

5.12.3.3 Other Facilities ................................................................................. 5.109

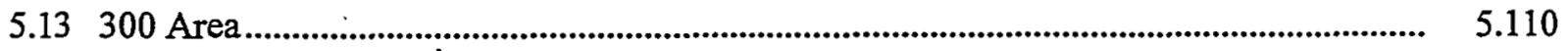

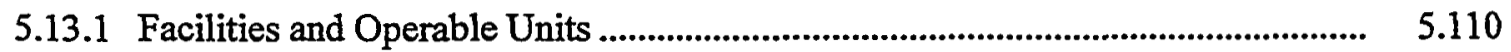

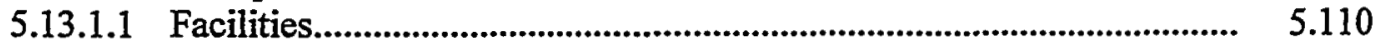

5.13.1.2 Operable Units................................................................................. 5.111

5.13 .2 Compliance Issues ................................................................................................ 5.112

5.13.2.1 316-5 Process Trenches........................................................................ 5.112

5.13.2.2 300-FF-1 and 300-FF-5 Operable Units Remedial Actions................. 5.113

5.13.2.3 Drinking Water Standards and Derived Concentration Guides ........... $\quad 5.113$

5.13.3 Extent of Contamination .................................................................................. 5.113

5.13.3.1 Uranium .............................................................................................. 5.114

5.13.3.2 Strontium-90 ........................................................................... 5.114

5.13.3.3 Trichloroethylene, cis-1,2-Dichloroethylene, and
Tetrachloroethylene......................................................................... 5.115

5.13.3.4 Iron and Manganese ................................................................................ 5.116

5.13.3.5 Other Constituents................................................................................. 5.116

5.14 Richland North Area .......................................................................................................... 5.116

5.14.1 Facilities and Operable Units .................................................................................. 5.116

5.14.2 Compliance Issues .................................................................................................... 5.117

5.14.2.1 Operable Unit Remedial Investigation .................................................. 5.117

5.14.2.2 Drinking Water Standards and Derived Concentration Guides ........... 5.117

5.14.3 Extent of Contamination ....................................................................................... 5.117

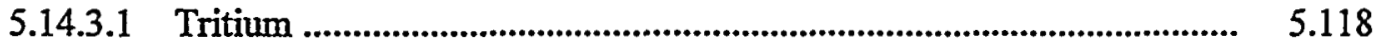

5.14.3.2 Nitrate.................................................................................... 5.118

5.14.3.3 Trichloroethylene ......................................................................... 5.119

5.14.3.4 Gross Alpha and Uranium............................................................. 5.119

5.14.3.5 Other Constituents....................................................................... 5.120

5.15 Radiological and Chemical Monitoring for the Upper Basalt-Confined Aquifer .............. $\quad 5.120$

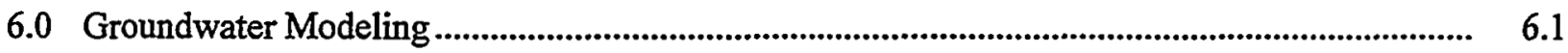

6.1 Sitewide, Three-Dimensional, Groundwater-Flow and -Transport Model ...................... $\quad 6.2$ 


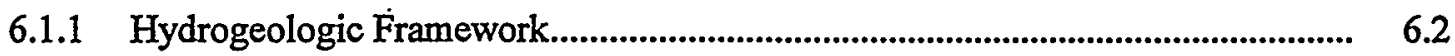

6.1.2 Recharge and Flow-System Boundaries.............................................................. 6.3

6.1.3 Hydraulic and Transport Properties.................................................................. 6.4

6.1.4 CFEST Flow Model Implementation and Calibration ........................................ 6.4

6.1.5 Groundwater-Flow Model Results .................................................................. 6.5

6.1.6 Groundwater-Transport Model Implementation ................................................ 6.5

6.1.7 Groundwater-Transport Model Results .......................................................... 6.6

6.2 Modeling to Support Pump-and-Treat Operations....................................................... 6.6

6.2.1 Model Results for 200-UP-1 Operable Unit................................................................. 6.7

6.2.2 Model Results for 200-ZP-1 Operable Unit ......................................................... 6.7

7.0 Well Installation, Maintenance, and Decommissioning.......................................................

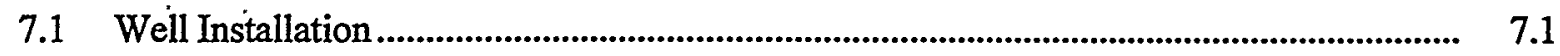

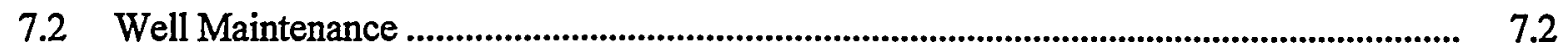

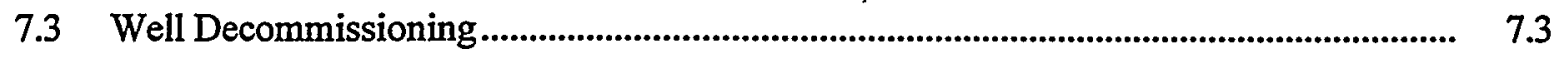

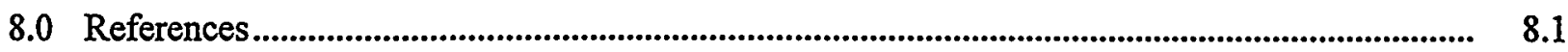

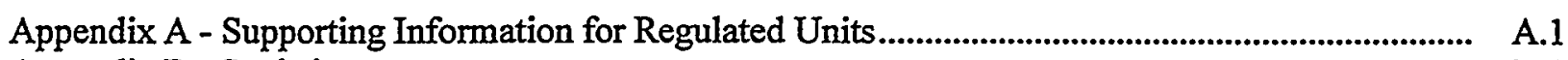

Appendix B - Statistics............................................................................................................................... B.1

Appendix C - Analytical Methods.......................................................................................................... C.1

Appendix D - Quality Assurance and Quality Control................................................................. D.1

Computer Disk Contents

Historical Bibliography (formatted in ASCII)

Selected Water-Level Measurements from Unconfined Aquifer System Wells (formatted in delimited ASCII text file)

Chemical and Radiological Data (formatted in delimited ASCII text file) 


\section{Tables}

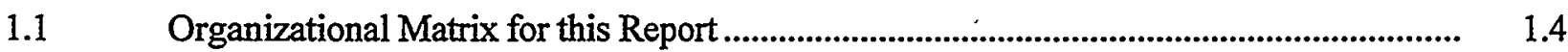

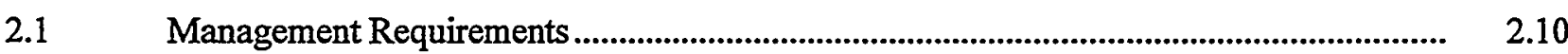

2.2 Groundwater Operable Unit Monitoring Status ....................................................... 2.11

2.3 RCRA Interim- and Final-Status Groundwater-Monitoring Projects, as of

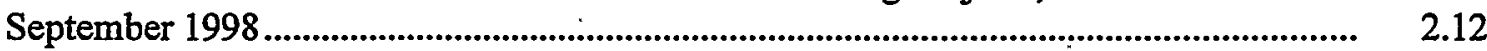

3.3-1 Estimates of Groundwater-Flow Rates at RCRA Facilities ............................................

4.4-1 Conservative and Best Estimates of Distribution Coefficient Values of Layers 1, 2, and 3

4.4-2 Conservative and Best Estimates of Distribution Coefficient Values for Hanford

Formation

4.4-3 Comparison of Maximum Man-Made Radionuclide Activities Detected at 216-B-2-2 Ditch

4.5-1 Carbon Tetrachloride Inventory in Primary Disposal Sites.

5.1-1 Maximum Contaminant Levels and Interim Drinking Water Standards.

5.123

5.1-2 Derived Concentration Guides and 4-mrem Effective Dose Equivalent Concentrations for Drinking Water

5.6-1 Summary of Groundwater Chemistry in Redox Manipulation Technology

Demonstration

5.9-1 Quantity of Groundwater Treated and Contaminant Mass Removed Since Startup of 200-UP-1 Operable Unit Pump-and-Treat Operations.

5.9-2 Volume of Groundwater Treated and Carbon Tetrachloride Mass Removed Since Startup of 200-ZP-1 Operable Unit Operations.

5.9-3 Concentrations for Each Phase III Extraction Well and Influent Tank at 200-ZP-1 Operable Unit.

5.12-1 Ranges of Chlorinated Hydrocarbon Concentrations in Groundwater at Solid Waste Landfill, December 1997 to August 1998.

6.1 Major Hydrogeologic Units Used in Sitewide Three-Dimensional Model ....................... 6.8

6.2 Aquifer-Transport Properties Used in Hanford Site Composite Analysis.......................... 6.9

Well Installation Summary, Fiscal Year 1998............................................................. 


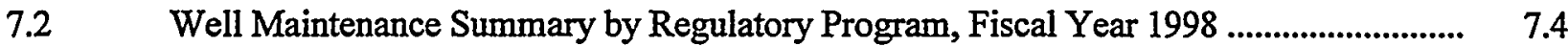

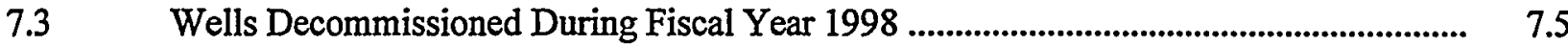

\section{Figures}

S.1 Distribution of Major Radionuclides in Groundwater at Concentrations Above Maximum Contaminant Levels or Interim Drinking Water Standards, Fiscal

Year 1998

xvii

S.2 Distribution of Major Hazardous Chemicals in Groundwater at Concentrations Above Maximum Contaminant Levels, Fiscal Year 1998

xviii

S.3 Potential Dose Estimates from Ingestion of Groundwater, Fiscal Year 1998..................... xix

S.4 Cancer Risk Estimates from Ingestion of Groundwater, Fiscal Year 1998........................

S.5 Hazard Quotient Estimates from Ingestion of Groundwater, Fiscal Year 1998................. xxi

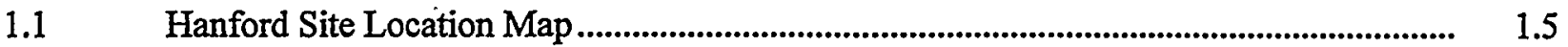

1.2 Location of Groundwater-Monitoring Wells Sampled, Fiscal Year 1998 ......................... $\quad 1.6$

2.1 Relationship Between Environmental Protection Programs and Plans ............................. 2.15

3.1-1 Pasco Basin Surface Geology and Structural Features..................................................... 3.45

3.1-2 Comparison of Generalized Hydrogeologic and Geologic Stratigraphy ........................... 3.46

3.1-3 Hydrogeologic Units Present at the Water Table, June 1998 ........................................... 3.47

3.1-4 Hanford Site Geologic Cross-Section ............................................................................ 3.48

3.2-1 Estimated Annual Recharge from Infiltration of Precipitation and Irrigation.................... $\quad 3.49$

3.2-2 Transmissivity Distribution from Model Calibration ............................................................. 3.50

3.2-3 Saturated Thickness of Unconfined Aquifer System .........................................................

3.3-1 Hanford Site and Outlying Areas Water-Table Map, June 1998.......................................... 3.52

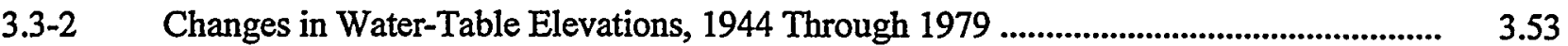

3.3-3 Annual Volumes of Major Liquid Effluent Streams Discharged to Hanford Site Soil Column and Net Recharge at City of Richland's North Well Field 
3.3-4 Active Discharge Sites

3.3-5 Changes in Water-Table Elevations, 1979 Through 1995

3.3-6 Changes in Water-Table Elevations Between June 1997 and June 1998 ........................... 3.57

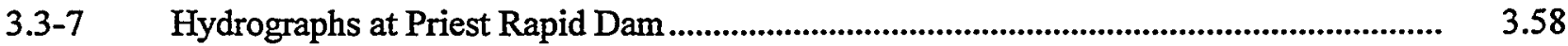

3.3-8 Potentiometric Map of Upper Basalt-Confined Aquifer System, June 1998 .................... 3.59

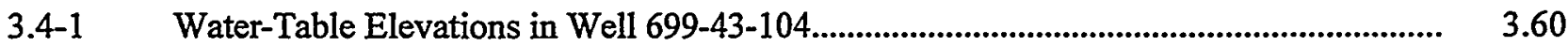

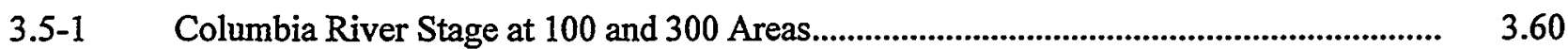

3.5-2 Water-Table Elevations in Wells Monitoring 100-N Area ..............................................

3.5-3 Water-Table Map for 100-N Area, September 1998 .................................................... 3.62

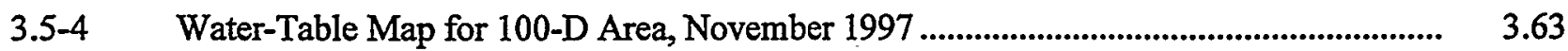

3.5-5 . Water-Table Elevations in Wells Monitoring 120-D-1 Ponds ......................................... 3.64

3.5-6 Water-Table Elevations in Wells Monitoring 183-H Solar Evaporation Basins................ 3.64

3.5-7 Water-Table Map for 100-H Area, November 1997 ..................................................... 3.65

3.6-1 Water-Table Elevations in Wells Monitoring 216-S-10 Pond and Ditch.......................... 3.66

3.6-2 Water-Table Elevations in Wells Monitoring 216-U-12 Crib........................................ 3.66

3.6-3 Water-Table Elevations Near Waste Management Area S-SX ......................................... 3.67

3.6-4 Water-Table Elevations in Wells Monitoring Waste Management Area U ........................ 3.67

3.6-5 Water-Table Elevations in Wells Monitoring Waste Management Area T ...................... 3.68

3.6-6 Water-Table Elevations in Wells Monitoring Waste Management Area TX-TY .............. 3.68

3.6-7 Water-Table Elevations in Wells Monitoring 216-A-29 Ditch ....................................... 3.69

3.6-8 Water-Table Elevations in Wells Monitoring 216-B-3 Pond .......................................... 3.69

3.6-9 Water-Table Elevations in Wells Monitoring 216-B-63 Trench......................................... 3.70

3.6-10 Water-Table Elevations in Wells Monitoring Liquid Effluent-Retention Facility............. $\quad 3.70$

3.7-1 Water-Table Map for Nonradioactive Dangerous Waste Landfill/Solid Waste Landfill, June 1998 
3.7-2 Water-Table Elevations in Wells Monitoring Nonradioactive Dangerous Waste

Landfill

3.7-3 Water-Table Elevations in Wells Monitoring Solid Waste Landfill

3.8-1 Water-Table Elevation-Contour Map of 300 and Richland North Areas, June 1998, and Hydrographs of Selected Wells

3.8-2 Water-Table Elevations in Richland North Area Well-699-S31-1

3.8-3 Water-Table Elevations in Siemens Power Corporation Well GM-2 .

4.1-1 Major 200 Areas Vadose-Zone-Contamination Sites..

4.2-1 Comparison of Cesium-137 and Protactinium-233 Activities Versus Depth from 1991

and 1998 Log Data in Borehole 299-W18-159

4.2-2 Comparison of Protactinium-233 Activities Versus Depth from 1998 and 1993 Log

Data in Borehole 299-W18-175

4.2-3 Comparison of Protactinium-233 and Plutonium-239 Activities Versus Depth from 1993 and 1998 Log Data in Borehole 299-W18-179

4.2-4 Plan View of BX Tank Farm, Showing Borehole Locations

4.2-5 Selected Spectral Gamma-Ray Logs of Radionuclides Around Boreholes in

BX Tank Farm

4.2-6 Plan View of C Tank Farm, Showing Borehole Locations

4.2-7. Selected Spectral Gamma-Ray Logs of Radionuclides Around Boreholes in

$C$ Tank Farm

4.2-8 Plan View of S Tank Farm, Showing Borehole Locations.

4.2-9 Selected Spectral Gamma-Ray Logs of Radionuclides Around Boreholes in

$S$ Tank Farm

4.2-10 Plan View of TY Tank Farm, Showing Borehole Locations

4.2-11 Selected Spectral Gamma-Ray Logs of Radionuclides Around Boreholes in

TY Tank Farm

4.2-12 Portion of Three Geophysical Logs from Borehole 299-W14-14...

4.3-1 Example Stack Plot Used to View Overall Trends in Gross Gamma-Ray Data

Through Time

4.3-2 Example of Clean Plot Borehole for Entire History of Electronic Data. 
4.3-3 Example of Radiation Zone Plot

4.4-1 Distribution of Cesium-137 and Technetium-99 in the Vadose-Zone Sediments from Depth and the Water-Extractable Nitrate Concentrations from Borehole 41-09-39

4.4-2 Iocation of the 216-B-2 Ditch System

4.4-3 (a) Cone Penetrometer (b) Cone Penetrometer Tip.

4.5-1 Location of Wells and Deep Soil-Vapor-Monitoring Probes at the Carbon

Tetrachloride Vapor-Extraction Site

4.5-2 Location Map of Shallow Soil-Vapor-Monitoring Probes at the Carbon Tetrachloride Vapor-Extraction Site.

4.5-3 Time-Series Concentration of Carbon Tetrachloride in Soil Vapor Extracted from the 216-Z-1A/-12/-18 Well Fields

4.5-4 Conceptual Model of Carbon Tetrachloride and Wastewater Migration Beneath 216-Z-9 Trench

5.1-1 Wells Sampled During Fiscal Year 1998

5.2-1 Average Tritium Activities, Top of Unconfined Aquifer:

5.2-2 Average Nitrate Concentrations, Top of Unconfined Aquifer

5.2-3 Average Iodine-129 Activities, Top of Unconfined Aquifer.

5.2-4 Groundwater Operable Units.

5.3-1 Tritium Activities in Wells 199-B3-1 and 199-B3-47.

5.3-2 Average Strontium-90 Activities in 100-B,C Area, Top of Unconfined Aquifer

5.4-1 Tritium Activities in Well 199-K-27 Monitoring K-East Fuel-Storage Basin

5.4-2 Tritium Activities in Well 199-K-109A Monitoring K-East Fuel Storage Basin

5.4-3 Effects of Water-Level Changes on Tritium Activity, 100-K Area, Top of Unconfined Aquifer.

5.4-4 Average Carbon-14 Activities in 100-K Area, Top of Unconfined Aquifer

5.4-5 Carbon-14 Versus Tritium in Wells Monitoring K-West and K-East Fuel-Storage Basins

5.4-6 Average Strontium-90 Activities in 100-K Area, Top of Unconfined Aquifer 
5.4-8 Filtered Chromium Concentrations in Wells 199-K-107A and 199-K-108A

Monitoring $\mathrm{K}$-West Fuel-Storage Basin.

5.4-9 Average Filtered Chromium Concentrations in 100-K Area, Top of Unconfined Aquifer..

5.4-10 Filtered Chromium Concentrations in Wells 199-K-20 and 199-K-117A Near 116-K-2 Trench

5.5-1 Tritium Activities in Wells 199-N-32, 199-N-74, and 199-N-76.

5.5-2 Average Strontium-90 Activities in 100-N Area, Top of Unconfined Aquifer..

5.5-3 Strontium-9.0 Activity in Extraction Wells 199-N-75, 199-N-103A, 199-N-105A, and $199-\mathrm{N}-106 \mathrm{~A}$

5.5-4 Strontium-90 Activity in Well 199-N-67 Monitoring 1301-N Liquid Waste-

Disposal Facility

5.5-5 Specific Conductance in Wells Monitoring 1301-N Liquid Waste-Disposal Facility ...

5.5-6 Specific Conductance in Wells Monitoring 1325-N Liquid Waste-Disposal Facility ..

5.5-7 Specific Conductance in 100-N Area, Top of Unconfined Aquifer

5.5-8 Specific Conductance in Wells Monitoring 1324-N/NA Facilities

5.5-9 Total Organic Carbon in Wells Monitoring 1324-N/NA Facilities.

5.5-10 Nitrate Concentrations in Wells Monitoring 100-N Area

5.5-11 Nitrate Concentrations in Wells Near 1301-N Facility

5.5-12 Manganese Concentrations in Well 199-N-16

5.6-1 Average Filtered Chromium Concentrations in 100-D and 100-H Areas, Top of Unconfined Aquifer

5.6-2 Chromium Concentrations in Wells Monitoring 120-D-1 Ponds..

5.6-3 Chromium Concentrations in Extraction Wells 199-D8-53 and 199-D8-54A.

5.6-4 Tritium Activities in Well 199-D5-17.

5.6-5 Tritium Activities in Well 199-D2-6.

5.6-6 Specific Conductance in Wells Monitoring 120-D-1 Ponds 
5.6-8 In Situ Redox Manipulation Test Site Well Locations................................................. 5.155

5.6-9 Chromium Concentrations in Well 199-D4-1 ................................................................ 5.156

5.7-1 Average Uranium Concentrations in 100-H Area, Top of Unconfined Aquifer ................. $\quad 5.157$

5.7-2 Filtered Chromium Concentrations in Wells Monitoring 183-H Solar Evaporation

Basins

5.7-3 Chromium Concentrations in Two Wells South of 183-H Solar Evaporation Basins........ $\quad 5.158$

5.7-4 Average Strontium-90 Activities in 100-H Area, Top of Unconfined Aquifer.................. 5.159

5.7-5 Chromium Concentrations in Wells 199-H3-1 and 699-97-43 ....................................... 5.160

5.7-6 Chromium Concentrations in Wells 199-H3-2A and 199-H3-2C.................................... 5:160.

5.7-7 Nitrate Concentrations in Wells 199-H3-2A, 199-H3-2C, and 699-97-43 ....................... 5.161

5.8-1 Average Strontium-90 Activities in 100-F Area, Top of Unconfined Aquifer ................. 5.162

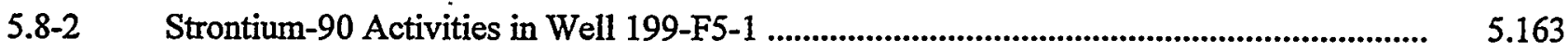

5.8-3 Nitrate Concentrations in Wells 199-F8-1 and 699-71-30 ............................................ 5.163

5.8-4 Trichloroethylene Concentrations in Wells 199-F7-1 and 699-77-36.............................. 5.164

5.9-1 Tritium Activities in Well 299-W14-2 Monitoring Waste Management Area TX-TY ..... $\quad 5.164$

5.9-2 Tritium, Nitrate, and Technetium-99 in Well 299-W11-27 Monitoring Waste • Management Area T .................................................................................................... 5.165

5.9-3 Average Technetium-99 Activities in 200-West Area, Top of Unconfined Aquifer ......... 5.166

5.9-4 Technetium-99 Activities in Well 299-W14-12 Monitoring Waste Management Area TX-TY

5.9-5 Average Uranium Concentrations in 200-West Area, Top of Unconfined Aquifer........... $\quad 5.168$

5.9-6 Average Filtered Chromium Concentrations in 200-West Area Near T Plant, Top of Unconfined Aquifer

5.9-7 Average Carbon Tetrachloride Concentrations in 200-West Area, Top of Unconfined Aquifer.

5.9-8 Average Trichloroethylene Concentrations in Northern 200-West Area .......................... 5.171

5.9-9 Specific Conductance in Selected Wells Monitoring Waste Management Area T............ 5.172 
5.9-10 Specific Conductance in Selected Wells Monitoring Waste Management Area TX-TY

5.9-11 Tritium Activities in Wells 699-40-62 and 699-36-61A, East of the 200-West Area........

5.9-12 Tritium Activities in Wells Monitoring Waste Management Area S-SX and

Surrounding Areas.

5.9-13 Tritium Activities in Downgradient Wells Monitoring Waste Management Area S-SX.

5.9-14 Average Chromium Concentrations in Wells Monitoring 216-S-10 Pond and Ditch,

Top of Unconfined Aquifer

5.9-15 Time-Series Plot of Technetium-99, Nitrate, and Chromium in Wells Monitoring

Waste Management Area S-SX.

5.9-16 Technetium-99 Activity and Chemical Concentration Trends in Well 299-W22-45

Monitoring Waste Management Area S-SX.

5.9-17 Gross Alpha Activities in Wells Monitoring 216-S-10 Pond and Ditch

5.9-18 Uranium Concentrations in Well 299-W19-3 Monitoring 216-U-1 and 216-U-2 Cribs....

5.9-19 Specific Conductance in Wells Monitoring 216-U-12 Crib.

5.9-20 Tritium Activities in Wells Monitoring 216-U-12 Crib

5.9-21 Carbon Tetrachloride Concentrations in Wells Monitoring 200-West Area, Top of

Unconfined Aquifer.

5.9-22 Carbon Tetrachloride Concentrations in Well 299-W15-16 Near Plutonium

Finishing Plant.

5.9-23 Carbon Tetrachloride Concentrations in 200-West Area at $>10 \mathrm{~m}$ Below Water Table....

5.9-24 Carbon Tetrachloride Concentrations in Wells 699-48-77C and 699-48-77D

Monitoring State-Approved Land-Disposal Site.

5.9-25 Vertical Distribution of Carbon Tetrachloride in Wells 299-W10-24, 299-W14-14, and 299-W11-32

5.9-26 Average Chloroform Concentrations in 200-West Area, Top of Unconfined Aquifer ......

5.9-27 Technetium-99, Uranium, Nitrate, and Carbon Tetrachloride in 200-UP-1 Operable Unit Extraction Well 299-W19-39

5.9-28 200-UP-1 Operable Unit Technetium-99 Measurements, Top of Unconfined Aquifer..... 
5.9-30 200-UP-1 Operable Unit Capture Area, September 1998

5.9-31 Carbon Tetrachloride Concentrations at 200-ZP-1 Operable Unit Extraction Wells.........

5.9-32 Carbon Tetrachloride Concentrations at 200-ZP-1 Operable Unit Extraction Wells..........

5.9-33 Carbon Tetrachloride 200-ZP-1 Operable Unit Plume Map, September 1998, Top of Unconfined Aquifer

5.9-34 Carbon Tetrachloride 200-ZP-1 Operable Unit Baseline Plume Map, June 1996, Top of Unconfined Aquifer

5.9-35 200-ZP-1 Operable Unit Pump-and-Treat Capture-Zone Analysis

5.10-1 Average Technetium-99 Activities in 200-East Area, Top of Unconfined Aquifer.

5.10-2 Average Strontium-90 Activities in 200-East Area, Top of Unconfined Aquifer

5.10-3 Technetium-99 Activities in Key Wells on East Side of Waste Management

Area B-BX-BY

5.10-4 Technetium-99 Activities in Key Wells North and West of Waste Management

Area B-BX-BY.

5.10-5(a) Nitrate Concentrations in Wells East of Waste Management Area B-BX-BY

5.10-5(b) Nitrate Concentrations at Wells North and Along West Side of Waste Management Area B-BX-BY

5.10-6 Uranium Activities in Wells North and East of Waste Management Area B-BX-BY.......

5.10-7 Comparison of Technetium-99 Versus Uranium in Well 299-E33-41

5.10-8 Uranium Concentrations in Wells West of Waste Management Area B-BX-BY

5.10-9 Cobalt-60 Activities in Wells North of Waste Management Area B-BX-BY

5.10-10 Cyanide Concentrations in Wells Monitoring Waste Management Area B-BX-BY

5.10-11 Tritium Activities in Well 699-40-1

5.10-12 Tritium Activities in Well 699-24-33

5.10-13 Iodine-129 Activities in Well 299-E17-9.

5.10-14 Comparison of Nitrate Versus Technetium-99 in Well 299-E25-46, Waste Management Area A-AX

5.10-15 Comparison of Chromium, Manganese, and Nickel in Well 299-E24-19, Waste Management Area A-AX 
5.10-16 Technetium-99 Activities in Wells 299-E27-13 and 299-E27-14, Waste

Management Area C.

5.10-17 Sulfate Concentrations in Selected Wells Monitoring 216-A-29 Ditch

5.10-18 Specific Conductance in Selected Wells Monitoring 216-A-29 Ditch

5.10-19 Nitrate Concentrations in Selected Wells Monitoring 216-B-3 Pond

5.10-20 Contaminant Concentrations in Well 299-E34-7

5.10-21 Calcium Concentrations in Selected Wells Monitoring Liquid Effluent-Retention Facility.

5.10-22 Magnesium Concentrations in Selected Wells Monitoring Liquid Effluent-

Retention Facility

5.10-23 Sulfate Concentrations in Selected Wells Monitoring Liquid Effluent-Retention Facility

5.10-24 Groundwater-Monitoring Results for Selected Constituents in Ringold Formation Unit A, 200-East Area

5.11-1 Average Nitrate Concentrations in 400 Area Wells

5.11-2 Nitrate Concentrations in 600 Area Wells Near 400 Area

5.11-3 Nitrite Concentrations in 600 Area Wells Near 400 Area

5.11-4 Average Tritium Activities in 400 Area Wells.

5.11-5 Comparison of Tritium Activities in 400 Area Drinking Water System.

5.12-1 Strontium-90 Activities in Well 699-53-47B

5.12-2 Uranium Concentrations in Well 699-S6-E4A.

5.12-3 Average Filtered Chromium Concentrations in Central Plateau South of 200-East

Area, Top of Unconfined Aquifer

5.13-1 Tritium Concentrations in Unconfined Aquifer-Monitoring Wells in 300 Area and Richland North Area

5.13-2 Average Uranium Concentrations in the 300 Area, Top of Unconfined Aquifer.

5.13-3 Uranium Concentrations in Well 399-1-17A

5.13-4 Trichloroethylene Concentrations in Well 399-1-16B .............................................. 5.216

5.13-5 cis-1,2-Dichloroethylene Concentrations in Well 399-1-16B, 300 Area ........................... 5.217 
5.13-6 Tetrachloroethylene Concentrations in Well 399-1-17A, 300 Area

5.13-7 Tetrachloroethylene Concentrations in 300 Area, August 1998, Top of Unconfined Aquifer.

5.14-1 Average Trichloroethylene Concentrations for the 300 and Richland North Areas,

Top of Unconfined Aquifer

5.15-1 Hanford Site Map Showing Upper Basalt-Confined Aquifer Wells

5.15-2 Highest Results for Tritium Detected in Upper Basalt-Confined Aquifer-

Monitoring Wells

5.15-3 Highest Results for Selected Radionuclides Detected in Upper Basalt-Confined

Aquifer-Monitoring Wells

5.15-4 Highest Results for Nitrate Detected in Upper Basalt-Confined Aquifer-Monitoring

Wells.

6.1 Surface Grid and Boundary Conditions for Three-Dimensional CFEST Model

6.2 Refined CFEST Surface Grid Used for Composite Analysis Transport Modeling.

6.3 Water Table Elevations Predicted for 2350 Compared to the Inferred 1944 Water

Table.

6.4 Predicted Tritium Plume from the 200 Areas for 1997

6.5 Predicted Tritium Plume from the 200 Areas for 2050

6.14

6.6

Predicted Iodine-129 Plume from the 200 Areas for 2049

6.15

6.7 Predicted Technetium-99 Plume from the 200 Areas for 2049

6.8 Predicted Uranium Plume from the 200 Areas for 2049

6.9 Predicted Strontium-90 Plume from the 200 Areas for 2049

6.10 Predicted Carbon-14 Plume from the 200 Areas for 2049

6.11 Predicted Chlorine-36 Plume from the 200 Areas for 2049

6.12 Predicted Selenium-79 Plume from the 200 Areas for 2049

7.1 Classification of Wells for Decommissioning

Plate 1 Locations of Hanford Site Monitoring Wells Pocket

Plate 2 Hanford Site Water-Table Map, June 1998

Pocket 
Plate 3 FY 1998 Average Tritium Concentrations ........................................................................ Pocket

Plate 4 FY 1998 Average Nitrate Concentrations ......................................................................... Pocket

Plate 5 FY 1998 Average Iodine-129 Concentrations.................................................................... Pocket 


\title{
1.0 Introduction
}

\author{
M. J. Hartman, B. H. Ford
}

\subsection{Purpose}

Groundwater monitoring is conducted on the Hanford Site to meet the requirements of the Resource Conservation and Recovery Act of 1976 (RCRA); Comprehensive Environmental Response, Compensation, and Liability Act of 1980 (CERCLA); U.S. Department of Energy (DOE) orders; and the Washington Administrative Code. Interpretations based on results of monitoring are presented in this Hanford Site Groundwater Monitoring for Fiscal Year 1998.

The interpretations contained in this report primarily rely on data from samples collected between October 1, 1997 and September 30, 1998. Data received from the laboratory after November 11, 1998 may not have been considered in the interpretations.

This report is designed to meet the following objectives:

- provide a comprehensive interpretation of current groundwater conditions on the Hanford Site and adjacent areas (Figure 1.1), including a description of hydrogeology, flow, and contaminant distribution

- meet the reporting requirements of RCRA, DOE orders, and Washington Administrative Code

- summarize the results of groundwater monitoring conducted to assess the effects of remediation or interim measures conducted under CERCLA

- describe the results of vadose-zone monitoring

- summarize the installation, maintenance, and decommissioning of Hanford Site monitoring wells.

The Groundwater Monitoring Project is conducted for DOE by Pacific Northwest National Labora-

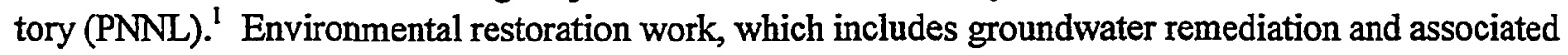
monitoring of pumping wells, is the responsibility of Bechtel Hanford, Inc. The distribution of monitoring wells used for these programs is illustrated in Figure 1.2. Vadose-zone monitoring is the responsibility of Fluor Daniel Hanford, Inc.

${ }^{1}$ PNNL is operated by Battelle for DOE. 


\subsection{Organization}

This report is organized by primary subject areas and geographic region (Table 1.1). Chapter 2.0 defines the DOE groundwater-protection program and associated requirements for groundwater monitoring. Chapter 3.0 describes the hydrogeologic setting of the Hanford Site and groundwater-flow patterns. Chapter 4.0 presents the results of vadose-zone studies and monitoring. Chapter 5.0 describes contaminant distribution, organized by the constituents of concern in each geographic area. Chapter 6.0 presents the results of groundwater modeling, and Chapter 7.0 summarizes well installation, maintenance, and decommissioning activities. Chapter 8.0 gives the references cited in the text. Additional references are provided in an historical bibliography on the computer diskette included with this report.

Supporting information is organized in appendixes, and groundwater data are included on the computer diskette. Large plate maps are included in the back of this report that show the wells used for monitoring, the Hanford Site water table, and the distribution of widespread groundwater contaminants (tritium, nitrate, and iodine-129) in the uppermost aquifer.

The organization of this report is designed for the reader interested in groundwater and vadose-zone activities at the Hanford Site. Readers interested in results related to specific regulatory requirements will find required elements in several chapters. Appendix A is designed to guide the reader interested primarily in the RCRA program.

\subsection{Related Reports}

Other reports and databases relating to Hanford Site groundwater in fiscal year 1998 include the following:

- Hanford Site Environmental Report for Calendar Year 1997 (PNNL-11795) - This annual report summarizes environmental data, describes environmental management performance, and reports the status of compliance with environmental regulations. Topics include effluent monitoring, surfacewater and sediment surveillance, soil and vegetation sampling, vadose and groundwater monitoring, radiological surveys, air surveillance, and fish and wildlife surveillance.

- Hanford Environmental Information System (HEIS) - This is the main environmental database for the Hanford Site that stores groundwater chemistry and water-level data, as well as other environmental data (e.g., soil chemistry, survey data).

- Quarterly data transmittals - Letters are transmitted quarterly by DOE to the State of Washington Department of Ecology after groundwater data collected for the RCRA program have been verified and evaluated. These letters describe changes or highlights of the quarter with reference to HEIS for the analytical results.

- Fiscal Year 1998 Annual Summary Report for the 200-UP-1, 200-ZP-1, and 100-NR-2 Pump-andTreat Operations and Operable Units (DOE/RL-99-02) - This report describes results of remediation and monitoring in three groundwater operable units. 
- 100-KR-4 and 100-HR-3 Operable Units Interim Action Performance Evaluation Report (DOE/RL97-96) - This report assesses the effectiveness of pump-and-treat systems for chromium in the 100-K, 100-D, and 100-H Areas.

\subsection{Groundwater/Vadose Zone Integration Project}

In late 1997, DOE established the Hanford Site Groundwater/Vadose Zone Integration Project (integration project) to fulfill its commitment to ensure the protection of water resources, the Columbia River environment, river-dependent life, and users of the Columbia River resources. The integration project will

- integrate Hanford Site groundwater/vadose-related work scope

- predict current and future impacts resulting from contaminants that have been (or are predicted to be) released to the soil column at the Hanford Site

- provide sound science and technology for site decisions and actions

- promote the open and honest involvement of tribal nations, regulators, and stakeholders so that project outcomes reflect expressed interests and values

- establish an independent technical peer review.

Bechtel Hanford, Inc. was assigned the responsibility for managing the integration of groundwater/vadose activities. Other major Hanford Site participants are Fluor Daniel Hanford, Inc. and PNNL.

To accomplish its mission, the integration project is establishing a technical foundation for predicting the transport of contaminants through the vadose zone, the groundwater, and the Columbia River to receptors (i.e., affected organisms). The integration project is employing a systems approach to develop and assemble the scientific understanding, data, and capability required to evaluate the cumulative impacts of Hanford Site operations, as well as proposed corrective actions and remediation alternatives for regional water resources and receptors. This approach involves an iterative process for establishing an understanding of the system (a conceptual model), developing and exercising a system-assessment capability (models, analytical tools, data needed for effects assessments), and defining uncertainties and requirements for science and data to fill identified gaps.

The integration project divides. its work into eight technical elements: inventory, vadose zone, groundwater, river, risk, monitoring, regulatory path, and remediation options. The relationships between elements are coordinated through the system assessment. The work scope for these technical elements is specifically defined in the Groundwater/Vadose Zone Integration Project Specification (DOE/RL-98-48, Draft C). 


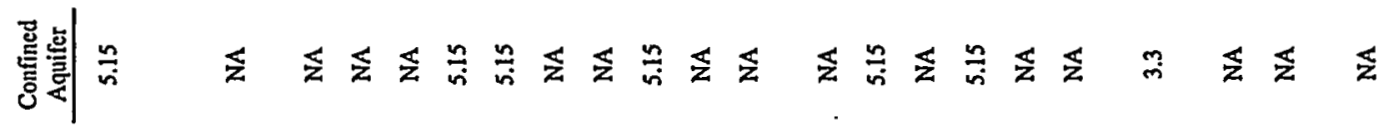

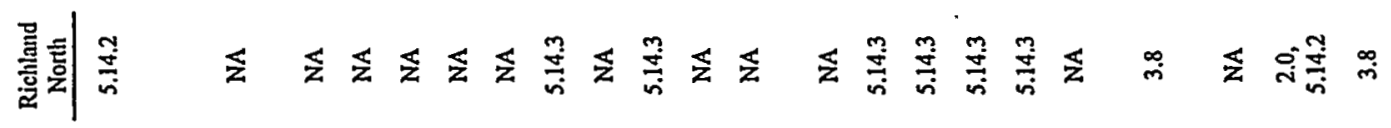

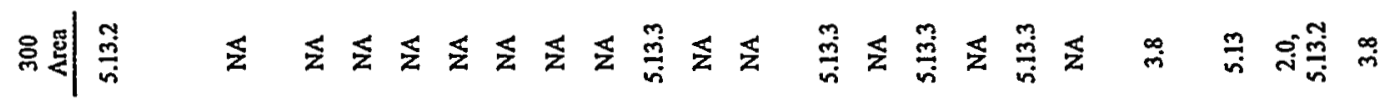
8)

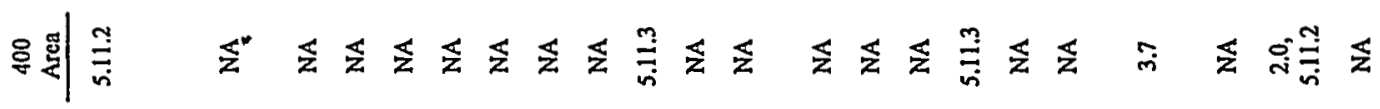

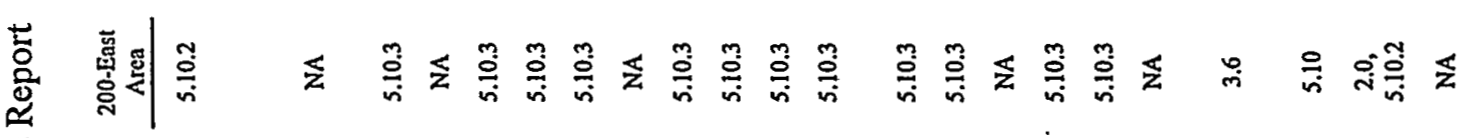
总

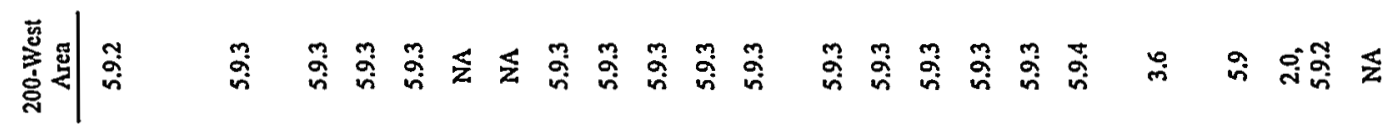

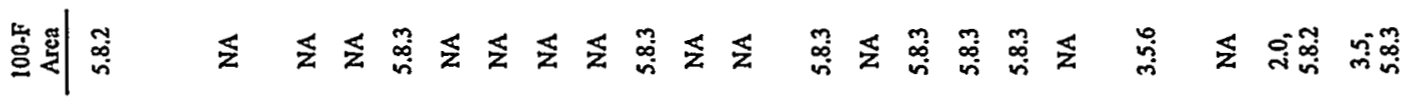

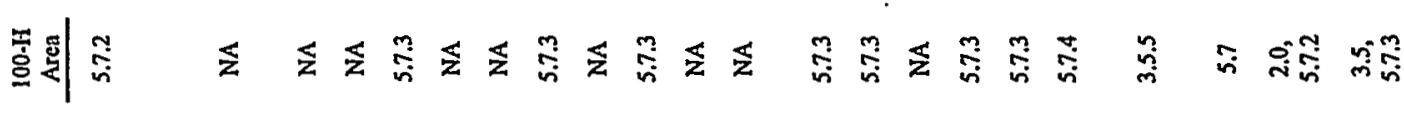

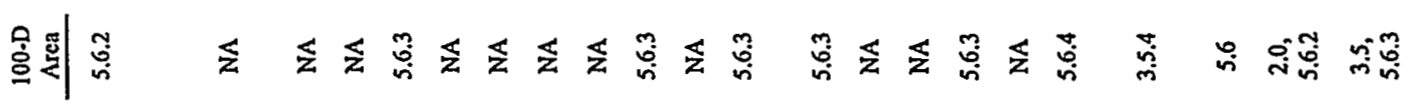

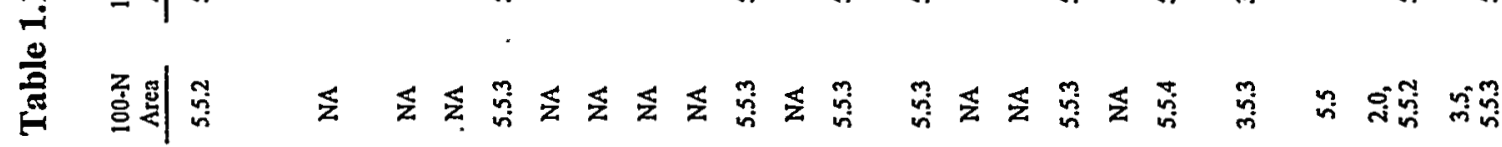

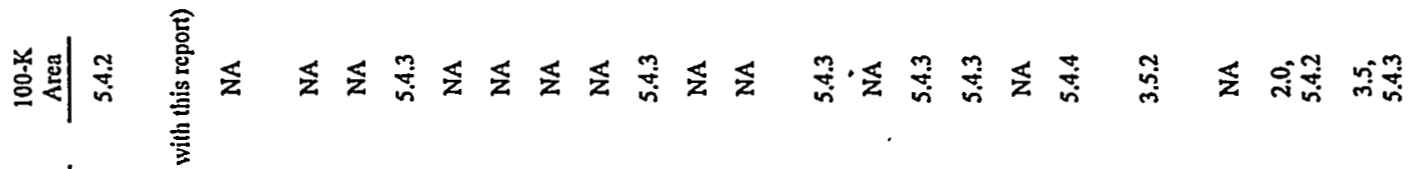

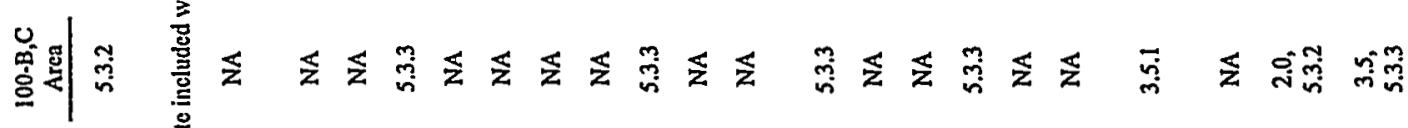

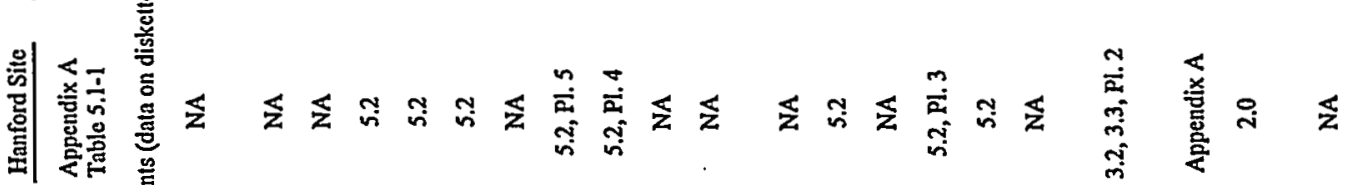
Hit

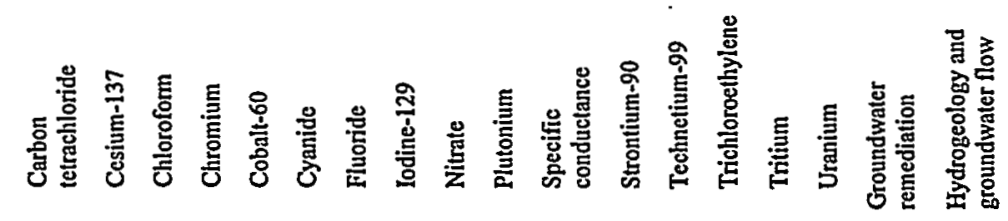




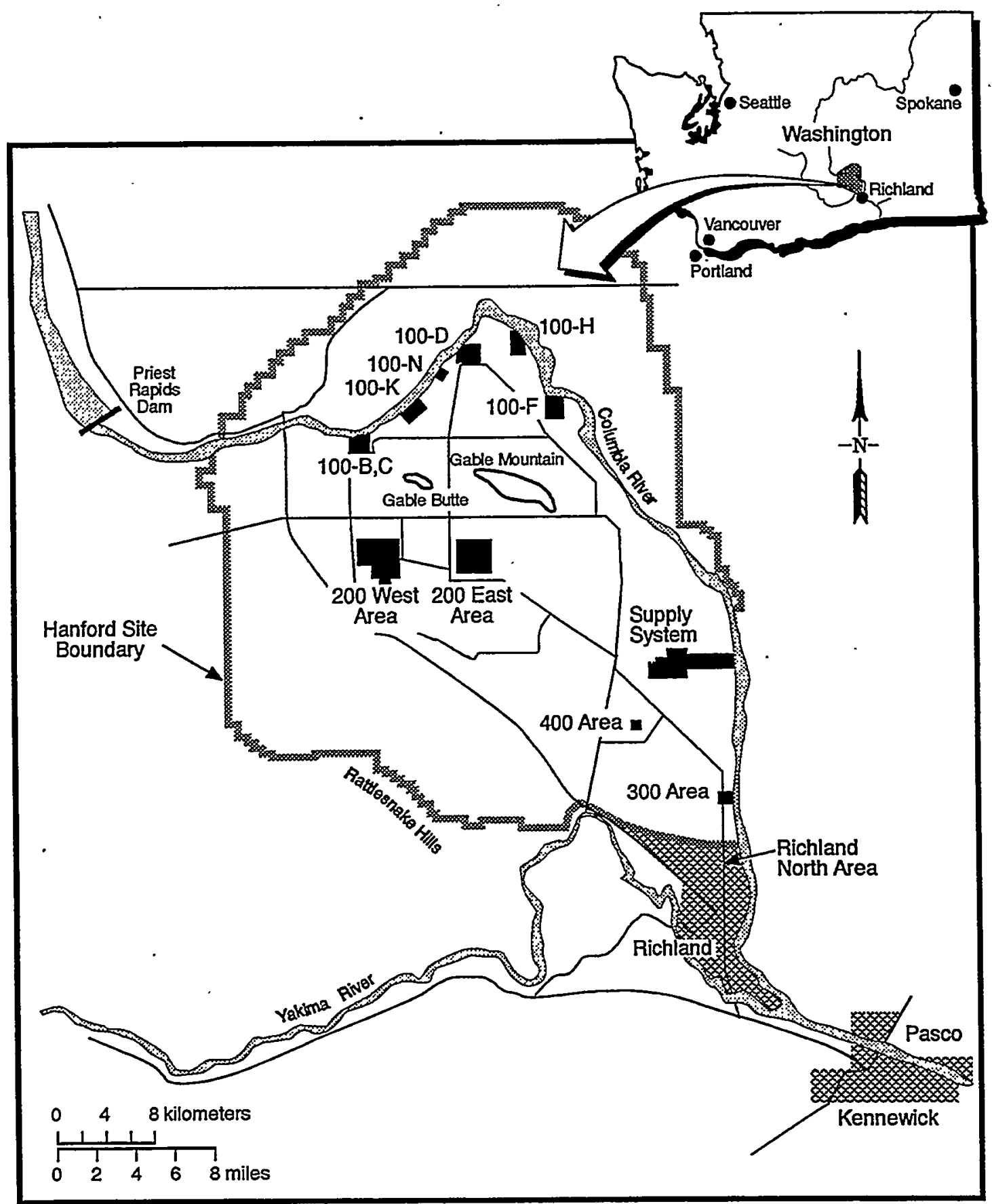

Figure 1.1. Hanford Site Location Map

RG98120214.10 


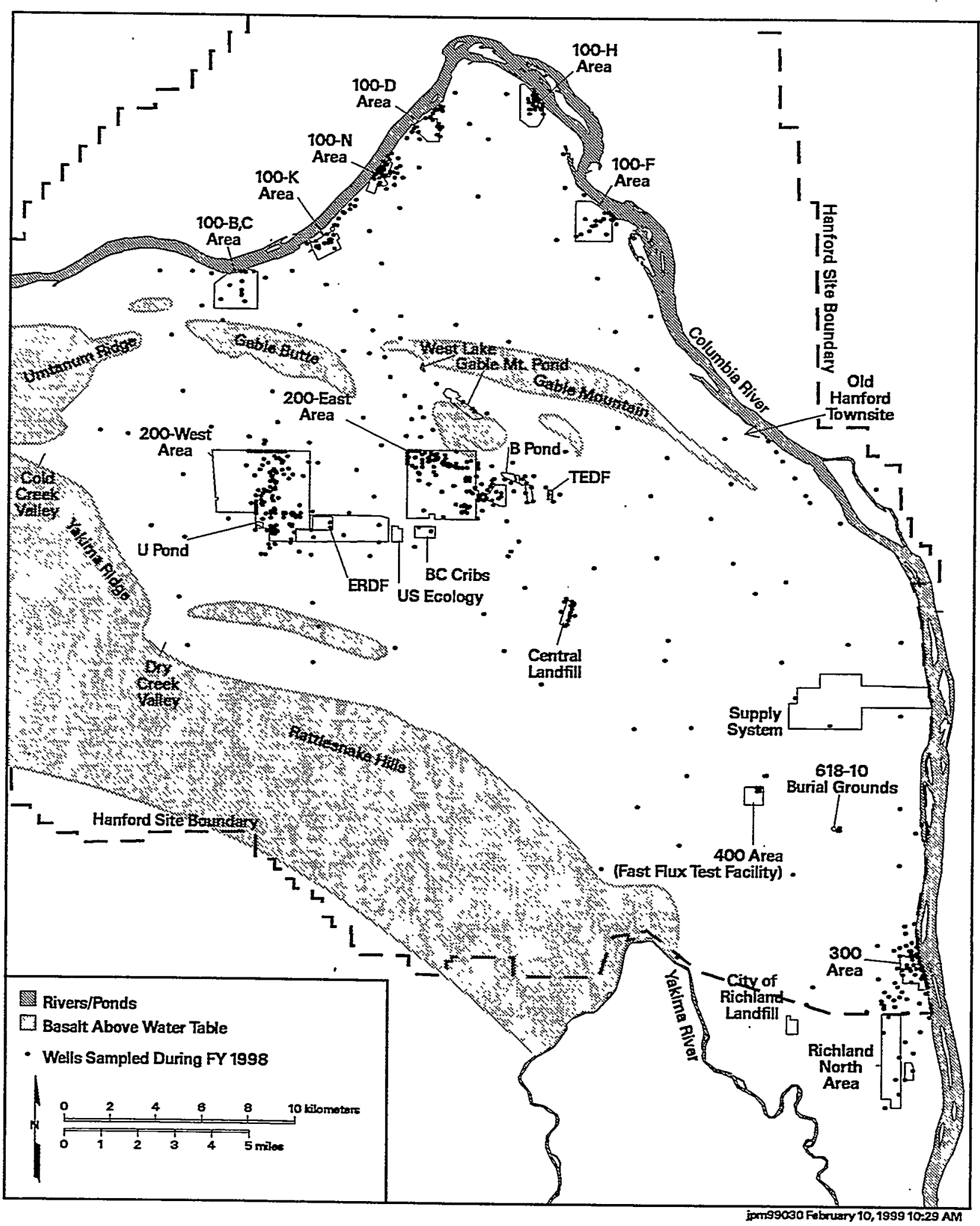

Figure 1.2. Location of Groundwater-Monitoring Wells Sampled, Fiscal Year 1998 


\title{
2.0 Groundwater-Monitoring Requirements
}

\author{
B. A. Williams
}

This chapter describes the regulatory framework that governs the monitoring of the Hanford Site's groundwater. That framework consists of various federal and state regulations, orders, and agreements. Pursuant to those regulations, orders, and agreements, the groundwater monitoring performed at the Hanford Site during fiscal year 1998 is in compliance. The Hanford federal facility agreement and consent order (more commonly known as the Tri-Party Agreement; Ecology et al. 1989) provides the legal and procedural basis for cleanup and regulatory compliance at the numerous hazardous waste sites at Hanford. The Tri-Party Agreement is the vehicle for coordination and groundwater-monitoring and -remediation activities under the Resource Conservation and Recovery Act of 1976 (RCRA) and the Comprehensive Environmental Response, Compensation, and Liability Act of 1980 (CERCLA).

Under the Atomic Energy Act of 1954, as amended, the U.S. Department of Energy (DOE) is obligated "...to regulate its own activities so as to provide radiation protection for both workers and public."

The environmental standards and regulations applicable for groundwater protection/management and environmental monitoring are described in DOE Order 5400.1. These environmental protection standards are categorized as 1) those imposed by federal regulations, 2) those imposed by state and local regulations, and 3) those imposed by DOE directives. The objectives of DOE's groundwater-protection and environmental monitoring projects (as defined in DOE Order 5400.1) are to demonstrate compliance with regulations imposed by applicable federal, state, and local agencies; to confirm adherence to DOE environmental protection policies; and to support environmental management decisions.

The Hanford Site's environmental monitoring plan (DOE/RL-91-50, Rev. 2) and the groundwaterprotection management plan (DOE/RL-89-12, Rev. 2) summarize the groundwater- and programintegration activities and regulatory-reporting requirements for those activities. These plans integrate the following:

- near-field monitoring at active or inactive waste treatment, storage, or disposal (TSD) facilities to comply with RCRA, applicable State of Washington regulations, and operational monitoring required at nuclear facilities and untreated liquid waste-disposal sites

- sitewide and offsite monitoring of contaminant migration required by DOE Order 5400.1

- site-specific groundwater monitoring to support groundwater remediation projects under CERCLA.

The following sections discuss the specific requirements in more detail. 


\subsection{Environmental Monitoring}

Groundwater monitoring is a critical element of DOE's environmental monitoring project at the Hanford Site because an unconfined aquifer and a system of deeper confined aquifers underlie the site. Groundwater from the unconfined aquifer that enters the Columbia River provides one of the most significant pathways for transporting contaminants offsite.

Because the Hanford Site has multiple, extensive, and unique groundwater-pollution problems, DOE has integrated groundwater monitoring to ensure protection of the public and the environment while improving the efficiency of monitoring operations. The environmental monitoring plan (DOE/RL-91-50, Rev. 2) documents the various elements of the groundwater-monitoring project currently operating at the Hanford Site. As required by DOE Order 5400.1, the plan addresses the high-priority elements of Environmental Regulatory Guide for Radiological Effluent Monitoring and Environmental Surveillance (DOE/EH-0173T). The relationship of the environmental monitoring plan to DOE Order 5400.1 and to the various groundwater-monitoring projects and -reporting requirements is shown in Figure 2.1.

\subsection{Groundwater Protection}

DOE/RL-89-12, Rev. 2 provides a framework for coordinating the existing onsite groundwaterprotection activities conducted by DOE's contractors, establishes the policy and strategies for groundwater protection/management at the Hanford Site, and proposes an implementation plan to meet goals (and milestones). These goals include 1) improving coordination between the federal and state regulations applicable to groundwater activities, 2) maintaining/achieving regulatory compliance of all groundwater activities), and 3) achieving cost-effective groundwater program administration. The relationship of DOE/RL-89-12, Rev. 2 to DOE Order 5400.1 and to the various groundwater-monitoring, remedial activities, and reporting requirements is shown in Figure 2.1.

\subsubsection{General Environmental Protection Program}

Groundwater-monitoring projects are established under DOE Order 5400.1 to meet the requirements of 1) DOE Order 5400.5, which deals with radiation protection of the public and the environment and 2) federal and state regulations. DOE Order 5400.1 requires that groundwater-monitoring projects be designed and implemented in accordance with the Code of Federal Regulations (40 CFR 264 or 40 CFR 265, Subpart F). DOE Order 5820.2, which deals with radioactive waste management, is also covered under the 5400.1-series requirements. The groundwater-monitoring requirements for federal and state regulations are presented in Sections 2.4 and 2.5, respectively.

Because of the Hanford Site's unique groundwater-pollution problems, radiation protection of the public and the environment is an integral part of the Hanford Groundwater Monitoring Project. The requirements for radiation management are found in DOE Order 5820.2, established to satisfy the groundwater-monitoring objectives listed above. The objectives of the DOE orders relative to groundwater monitoring include the following:

- verify compliance with other applicable regulations

- characterize and define hydrogeologic, physical, and chemical trends in the groundwater system 
- establish groundwater quality baselines

- provide continuing assessment of monitoring and remediation activities

- identify new and quantify existing groundwater contamination and quality problems.

The Hanford Groundwater Monitoring Project assesses radionuclides and other hazardous effluentdisposal impacts of non-RCRA facilities on groundwater quality and monitors and documents the overall distribution and movement of radionuclides and other hazardous contaminants in groundwater beneath and adjacent to the Hanford Site in accordance with DOE Orders 5400.1 and 5400.5.

\subsubsection{Radiation Protection of the Public and the Environment.}

Standards and requirements are established in DOE Order 5400.5 for DOE and its contractors to operate the facilities and conduct the activities so that radiation exposure to the public is maintained within the limits established in the order (e.g., public dose limits and derived concentration guides for air and water) and to control radioactive contamination through the management of real and personal property. In addition, it is DOE's objective to protect the environment from radioactive contamination to the extent practical.

\subsection{Hanford Federal Facility Agreement and Consent Order}

A key element to Hanford Site compliance is the Tri-Party Agreement (Ecology et al. 1989). Compliance and waste-cleanup timetables and implementation milestones are established in the Tri-Party Agreement to ensure that cleanup progresses and to enforce environmental protection. Tri-Party Agreement Milestone M-13-81A established DOE/RL-89-12, Rev. 2 as the vehicle to be used to coordinate groundwater-protection and remedial-action efforts and to manage the Hanford Site groundwater resource. The Tri-Party Agreement is a contract between the U.S. Environmental Protection Agency (EPA), State of Washington Department of Ecology (Ecology), and DOE for achieving compliance (enforceable by law) with the remedial-action provisions of CERCLA and the TSD unit regulation and corrective-action provisions of RCRA.

This annual report contains the results of applicable groundwater-protection, -cleanup, and -monitoring activities as scheduled in the Tri-Party Agreement action plan. Table 2.1 provides a general listing of those applicable major milestones. Details for each milestone are described in the Tri-Party Agreement.

\subsection{Applicable Federal Regulations}

This section describes the federal regulations that govern groundwater monitoring, remedial investigation, and remediation. The institutional and regulatory interfaces are defined by the Tri-Party Agreement (Ecology et al. 1989) and are outlined in Section 2.6. 


\subsubsection{Comprehensive Environmental Response, Compensation, and Liability Act of 1980/ Superfund Amendments and Reauthorization Act of 1986}

These Acts establish a federal program that authorizes waste cleanup at inactive sites. The Hanford Site was listed on the National Priorities List (Appendix B of 40 CFR 300) based on the EPA's hazardranking system that subdivided the Hanford Site into four National Priorities List sites: 100, 200, 300, and 1100 Areas. Preliminary assessments revealed $\sim 1,400$ known waste management units wherein hazardous substances may, have been disposed. The four listed sites were further divided into 74 source and 10 groundwater operable units (i.e., a grouping of individual waste units based primarily on geographic area and common waste sources).

The groundwater operable units currently being studied were selected as a result of Tri-Party Agreement negotiations (Ecology et al. 1989). Table 2.2 defines the current status of groundwater operable unit monitoring according to Tri-Party Agreement priority, and also defines the Tri-Party Agreement regulatory unit designation and lead regulatory agency responsible for the operable unit (described more fully in Section 2.6).

The Hanford Past-Practices Strategy (DOE/RL-91-40) provides the framework for streamlining corrective actions through the use of limited field investigations, expedited response actions, and interim remedial measures. The bias-for-action principles of the strategy were vigorously pursued in accelerating the groundwater-remediation project through the investigative phases and into pilot-scale treatability studies, both of which gathered important data necessary to begin full-scale remediation activities through implementation of interim remedial measures.

The interim actions consist primarily of hydraulic containment actions using pump-and-treat technologies and are designed to halt the continued migration of the most-contaminated portions of the plumes into the Columbia River or out of aquifers underlying the 100 and 200 Areas. DOE plans to continue the interim remedial measures already under way and to supplement and expand the system, where needed, to meet remediation objectives.

The Hanford Sitewide Groundwater Remediation Strategy (DOE/RL-94-95, Rev. 1) establishes an overall goal of restoring groundwater to its beneficial uses in terms of protecting human health and the environment and its use as a natural resource. In recognition of the Hanford Future Site Uses Working Group (Drummond 1992) and public values, the strategy establishes that the sitewide approach to groundwater cleanup is to remediate the major plumes found in the reactor areas and to contain the spread and reduce the mass of the major plumes found in the 200 Areas. This remediation strategy is documented in DOE/RL-89-12, Rev. 2 and DOE/RL-94-95, Rev. 1.

The scope of this decision process encompasses all contaminated groundwater (CERCLA and/or RCRA past-practice projects) at the Hanford Site. Currently, five pump-and-treat projects in five groundwater operable units address the following contaminants:

- 100-HR-3 Operable Unit - hexavalent chromium in the 100-D and 100-H Areas

- 100-KR-4 Operable Unit - hexavalent chromium

- 100-NR-2 Operable Unit-strontium-90 
- 200-UP-1 Operable Unit - technetium-99 and uranium

- 200-ZP-1 Operable Unit - carbon tetrachloride (and associated organics).

These pump-and-treat systems are discussed more fully in Chapter 5.0.

Groundwater monitoring is performed at operable units to evaluate the pump-and-treat performance or for contaminant monitoring (i.e., no active groundwater remediation). Individual requirements as defined by CERCLA are described in the work plans and/or records of decision. See Table 2.2 for the sites that are currently under contaminant or performance monitoring.

Under the EPA's interpretation of CERCLA, contaminated groundwater generally must be cleaned up to meet maximum contaminant levels or goals established under the Safe Drinking Water Act of 1974 if the groundwater, prior to contamination, could have been used at some future date as a drinking water source. Using the EPA's groundwater classification as well as Ecology's highest beneficial use assumption in Washington Administrative Code (WAC) 173-340-720, almost all Hanford Site groundwater is, by definition, a potential future source of drinking water. The classification is based on the quality characteristics of the groundwater and not those related to land-use designations, which are tied to the source or surface operable unit remediation. These cleanup levels are identified in the applicable operable unit's record of decision (ROD 1995, 1996a, 1996b, 1997) or action memorandum (Ecology and EPA 1994).

. Certain areas of the Hanford Site may require restrictions to groundwater use. The Hanford Future Site Uses Working Group, supported by DOE, Ecology, and EPA, recognizes that contaminated soils and groundwater beneath the 200 Areas plateau will be difficult to clean up and may not be able to achieve cleanup levels/requirements. The group has recommended that the water beneath the 200 Areas plateau be excluded from use and managed to limit or restrict access by the public (Drummond 1992).

\subsubsection{Resource Conservation and Recovery Act of 1976}

Regulatory standards for the generation, transportation, storage, treatment, and disposal of hazardous wastes are established in RCRA and relate to ongoing waste management and permitting at those facilities. Ecology and EPA designated the Hanford Site as a single RCRA facility with over 60 individual liquid and solid waste TSD units. The Tri-Party Agreement (Ecology et al. 1989) recognized that all of the TSD units cannot be permitted simultaneously and set up a schedule for submitting unit-specific Part B RCRA/dangerous waste permit applications and closure plans to Ecology and EPA. Twenty-five TSD waste management areas required groundwater monitoring in fiscal year 1998 to determine if operations are impacting the uppermost aquifer or to assess the nature, extent, and rate of contaminant migration.

The RCRA groundwater-monitoring requirements for the 25 active waste management areas fall into one of two categories: interim status or final status. A permitted or closed RCRA TSD unit requires final-status groundwater monitoring as specified in 40 CFR 264. Nonpermitted RCRA units require interim-status groundwater monitoring as specified in 40 CFR 265. Ecology was authorized by the EPA to implement its dangerous waste program in lieu of the EPA's. Ecology's interim-status TSD requirements, established in WAC 173-303-400, invoke 40 CFR 265 that governs RCRA groundwatermonitoring activities. RCRA final-status TSD sites follow. WAC 173-303-645, which specifies the groundwater-monitoring requirements. Table 2.3 provides a list of the 25 active RCRA sites requiring 
groundwater monitoring and the status of each. The 120-D-1 ponds closure plan, scheduled for clean closure in 1998, is expected to be finalized and approved during FY 1999.

This annual report also includes groundwater results for the Environmental Restoration Disposal Facility. This facility is a landfill authorized under CERCLA that is constructed to meet final-status RCRA technical requirements (40 CFR 264). The facility is not a RCRA TSD unit but utilizes a four-well, RCRA-style, groundwater-monitoring network and conducts monitoring in accordance with WAC 173-303-645 as outlined in BHI-00079.

RCRA groundwater monitoring is conducted under one of three possible phases: 1) indicator parameter/detection, 2) assessment (or final-status compliance), and 3) corrective action (via administrative order [for interim-status sites] or during final status). Initially, a detection-level program is developed to determine and monitor the impact of facility operations on the groundwater. If the detection-monitoring results indicate a statistical increase in the concentrations of key indicator parameters or dangerous waste constituents in the groundwater, then an assessment (or final-status compliance) phase of monitoring and investigation is initiated. If the source of the contaminants is determined to be the TSD unit and those concentrations exceed maximum contaminant levels (i.e., concentration limits) as defined in the monitoring program plan or permit, then Ecology may require corrective action to reduce the contaminant hazards to the public and environment. Table 2.3 also indicates when the site is scheduled for incorporation under the site permit. The comparisons and details of these three phases of groundwater monitoring and the specific requirements of the interim- and final-status groundwatermonitoring projects are provided in Appendix B.

The Hanford Groundwater Monitoring Project is currently applying EPA's data quality objectives process (EPA/600/R-96/055) to develop strategies that will allow the use of technically improved and more site-responsible methodology (e.g., in the areas of network design, sampling and analysis, statistical analysis) while maintaining RCRA groundwater compliance. This process will improve the overall efficiency of monitoring groundwater at multiple facilities/projects and create a more cost-effective, flexible approach because it will be less restrictive than the current interim-status groundwater requirements.

\subsection{Applicable State Regulations}

\subsubsection{Dangerous Waste Regulations}

As stated in Section 2.4.2, Ecology was authorized by EPA to implement state groundwater regulations. WAC 173-303-400 and -600 provide the requirements for interim- and final-status TSD units. The state interim-status regulations invoke the EPA regulations ( 40 CFR 265) that govern the RCRA groundwater-monitoring activities. RCRA final-status TSD units follow WAC 173-303-645, which specifies the groundwater-monitoring requirements for operating or closed facilities.

\subsubsection{State Waste Discharge Program}

Non-RCRA TSD units are regulated by DOE orders and the Tri-Party Agreement (Ecology et al. 1989). These consist primarily of soil-column-disposal facilities that receive treated effluent derived from liquid waste that was associated with nuclear material processing, refining, and waste-treatment activities. 
An agreement was reached in December 1991 to regulate these non-RCRA TSD units and to include all miscellaneous waste streams and/or any new waste streams discharged to the groundwater under the waste-discharge permit system defined in WAC 173-216. All major discharges of untreated wastewater were terminated in June 1995.

Groundwater monitoring is conducted at three of the WAC 173-216 permit sites: $4608 \mathrm{~B} / \mathrm{C}$ ponds (also called the 400 Area process ponds), 200 Areas Treated Effluent-Disposal Facility, and the 616-A crib (also called State-Approved Land-Disposal Site or SALDS) (Ecology 1995a, 1995b, 1996). The StateApproved Land-Disposal Site receives treated effluent from the 200 Areas Effluent-Treatment Facility. Monitoring and reporting requirements for the latter two facilities are specified in the monitoring plans (DOE/RL-89-12, Rev 2; WHC-SD-C018H-PLN-004, Rev. 1).

\subsubsection{Minimum Functional Standards for Solid Waste Handling}

The Solid Waste Landfill is a disposal facility that is not a RCRA hazardous waste site and is not addressed under the Tri-Party Agreement (Ecology et al. 1989). WAC 173-304 regulates the current operations of this landfill. A permit application was submitted to the Benton-Franklin District Health Department in 1991 (DOE/RL-90-38, Rev. 0). Responsibility for the site was subsequently assumed by Ecology (DOE/RL-90-38, Rev. 1). Groundwater-monitoring activities conducted at this landfill comply with requirements stipulated in WAC 173-304-490. WAC 173-304 requires that data for specific groundwater parameters be reported annually. This requirement is fulfilled by the data and interpretations included in this report.

\subsubsection{Model Toxics Control Act - Cleanup}

Through WAC 173-340, Ecology defined straightforward standards that govern the decisions for hazardous waste cleanup. These standards are designed to direct and expedite cleanup at hazardous waste sites that come under the scope of the Superfund Amendments and Reauthorization Act of 1986 and under RCRA corrective-action responsibilities. The funding for this type of waste cleanup is through a state tax on disposal of hazardous substances.

\subsection{Regulatory Authority Interface}

\subsubsection{Regulatory Programs}

The RCRA, CERCLA, and WAC regulations and DOE orders overlap in many areas with respect to groundwater monitoring, remedial investigations, and remediation. The following sections clarify how, through the Tri-Party Agreement (Ecology et al. 1989), these programs must interface to achieve integration and to minimize redundancy during implementation of groundwater projects.

The EPA and Ecology have selected a lead regulatory agency approach to minimize duplication of . effort and to maximize productivity. Either the EPA or Ecology will be the lead regulatory agency for each operable unit, TSD group/unit, or milestone. Currently assigned lead regulatory agency designations for groundwater operable units were listed in Table 2.2. 


\subsubsection{Waste Unit Categories}

There are three waste unit categories and related regulatory authorities addressed in the Tri-Party Agreement action plan: RCRA TSD, RCRA past-practice, and CERCLA past-practice.

The TSD units requiring groundwater monitoring are listed in Table 2.3. TSD units are defined as units receiving a RCRA permit (i.e., based on the nature of waste and timing of disposal) for either operation or postclosure care and must be closed to meet WAC 173-303-610 and the Hazardous and Solid Waste Amendments of 1984. These units shall remain classified as RCRA TSD units, rather than CERCLA units, even if they are investigated in conjunction with CERCLA units. All TSD units that undergo closure, irrespective of permit status, must be closed pursuant to the authorized regulations in WAC 173-303-610.

The RCRA and CERCLA past-practice units are waste management units wherein hazardous substances from sources (other than TSD units) have been disposed, as addressed by CERCLA, regardless of date of receipt at the units.

\subsubsection{Management of Waste Management Units}

Since the Hanford Site was placed on the National Priorities List (Appendix B of 40 CFR 300), Ecology, EPA, and DOE agreed that the units managed as RCRA past-practice units shall address all CERCLA hazardous substances for the purposes of corrective action. An agreement was also made that all of the waste regulated by WAC 173-303 (RCRA) will be addressed as part of any CERCLA response action or RCRA corrective action.

Section 121 of CERCLA requires that remedial actions attain a degree of cleanup that meets applicable or relevant and appropriate federal and state environmental requirements (ARARs). Based on this, the Tri-Party Agreement (Ecology et al. 1989) requires that 1) all state-only hazardous wastes will be addressed under CERCLA and 2) RCRA standards for cleanup or TSD requirements (for applicable RCRA TSD units) will be met under a CERCLA action. This eliminates many discrepancies between the two programs and lessens the significance of whether an operable unit is placed in one program or the other.

All inactive units within an operable unit are designated as either RCRA or CERCLA past-practice. This designation ensures that only one past-practice program is applied at each operable unit. The corrective action process selected for each operable unit must be sufficiently comprehensive to satisfy the technical requirements of both statutory authorities and the respective regulations.

The authority in CERCLA will be used for operable units that consist primarily of past-practice units (i.e., no TSD units or relatively insignificant units). The CERCLA authority will also be used for pastpractice units in which remediation of CERCLA-only materials is the majority of work to be done in that operable unit. The RCRA past-practice authority generally is used for operable units that contain significant TSD units and/or lower-priority past-practice units. Currently assigned RCRA and CERCLA pastpractice designations were shown in Table 2.2. 


\subsubsection{Waste Unit Interface}

There are several cases where TSD units are closely associated with past-practice units, both geographically or through similar processes and waste streams. A procedure to coordinate the TSD unit closure or permitting activity with the past-practice investigation and remediation activity is necessary to prevent overlap and duplication of work, thereby economically and efficiently addressing the contamination. Based on the discussion in Section 2.6.3, selected TSD groups/units were assigned to corresponding operable units and the information necessary for performing RCRA closure/postclosure within an operable unit is provided in various RCRA facility investigation/corrective measure reports. The initial work plan contains a sampling and analysis plan for the associated RCRA units and outlines the manner in which RCRA closure/postclosure requirements are met in the work plan and subsequent documents. The selected closure/postclosure method and associated design details, submitted as part of the corrective measure report, must 1) meet RCRA standards and requirements, 2) be consistent with requirements specified in the sitewide RCRA permit (Ecology 1994), and 3) be coordinated with the recommended remedial action for the associated operable unit. Each remedial facility investigation/ corrective measure document must be structured such that RCRA closure/ postclosure requirements can be readily identified for a separate review/approval process and so the RCRA closure/postclosure requirements can be incorporated into the RCRA permit.

It was agreed by Ecology, EPA, and DOE that past-practice authority may provide the most efficient means for addressing mixed waste contamination plumes originating from a combination of TSD and past-practice units. However, to ensure that TSD units within the operable units are brought into compliance with RCRA and state hazardous waste regulations, Ecology intends that all response or corrective actions, excluding situations where there is an imminent threat to the public health or environment, will be conducted in a manner that ensures compliance with the technical requirements of the Revised Code of Washington 70.105, Hazardous Waste Management. The DOE Richland Operations Office has assigned the maintenance of RCRA and state groundwater-monitoring compliance at TSDs within the operable units to the Hanford Groundwater Monitoring Project. 
Table 2.1. Management Requirements

Hanford Site Groundwater Program

\author{
Tri-Party Agreement (TPA) \\ Milestones $^{(a)}$
}

Regulations/Orders

Resource Conservation and Recovery Act of 1976 (RCRA)

RCRA/TSD unit monitoring

M-20-00

$\mathrm{M}-24-00$
40 CFR 264

40 CFR 265

40 CFR 257

WAC $173-303-400,-645$

Comprehensive Environmental Response, Compensation, and Liability Act of 1980 (CERCLA)

CERCLA operable unit remedial assessment monitoring

M-15-00

M-16-00

Atomic Energy Act of 1954

Sitewide environmental surveillance and operational monitoring

Liquid Effluent-Disposal Facilities

Facility-specific monitoring

M-17-00b

State-Approved LandDisposal Site

200 Areas Treated EffluentDisposal Facility

400 Area process ponds

\section{Liquid Effyent-Disposal Facilities}

DOE Orders 5400.1, 5400.5, and 5820.2

40 CFR 300

WAC 173-216

SWDP Permit ST-4500 (b)

SWDP Permit ST-4502 (b)

WAC 173-216

SWDP Permit ST $-4501^{(b)}$

(a) TPA M-20-00 - Submit Part B permit applications or closure/postclosure plans for all RCRA TSD units.

TPA M-24-00 - Install RCRA groundwater-monitoring wells at the rate of up to 50/year (after 1990) as scheduled in interim milestones until all land disposal units and single-shell tanks are determined to have RCRA-compliant monitoring systems.

TPA M-15-00 - Complete remedial investigation/feasibility study (or RCRA facility investigation/corrective measure study) process for all operable units.

TPA M-16-00 - Complete remedial actions for all non-tank farm operable units.

TPA M-17-00b - Complete implementation of best available technology/all known available and reasonable methods of prevention, control, and treatment for all Phase II liquid effluent streams at the Hanford Site.

(b) Ecology (1995b, 1995a, 1996, respectively).

CFR = Code of Federal Regulations.

DOE = U.S. Department of Energy.

SWDP $=$ State Waste Discharge Permit.

TSD = Treatment, storage, and disposal (units).

WAC = Washington Administrative Code 
Table 2.2. Groundwater Operable Unit Monitoring Status

\begin{tabular}{|c|c|c|c|c|}
\hline $\begin{array}{l}\text { Tri-Party } \\
\text { Agreement } \\
\text { Priority }\left({ }^{(2)}\right. \\
\end{array}$ & $\begin{array}{l}\text { Groundwater } \\
\text { Operable Unit }\end{array}$ & Monitoring Status & $\begin{array}{l}\text { Regulatory Unit } \\
\text { Designation }\end{array}$ & $\begin{array}{c}\text { Lead Regulatory } \\
\text { Agency }\end{array}$ \\
\hline 1 & 1100-EM-1 & Contaminant monitoring & $\begin{array}{l}\text { CERCLA } \\
\text { past practice }\end{array}$ & EPA \\
\hline $2 \mathrm{~A}$ & $300-F F-5$ & Contaminant monitoring & $\begin{array}{l}\text { CERCLA } \\
\text { past practice }\end{array}$ & EPA \\
\hline $4 \mathrm{~A}$ & 100-HR-3 & $\begin{array}{l}\text { Performance monitoring for } \\
\text { pump-and-treat interim } \\
\text { action. }\end{array}$ & $\begin{array}{l}\text { RCRA } \\
\text { past practice }\end{array}$ & Ecology \\
\hline $6 \mathrm{~A}$ & $100-B C-5$ & Contaminant monitoring & $\begin{array}{l}\text { CERCLA } \\
\text { past practice }\end{array}$ & EPA \\
\hline $7 \mathrm{~A}$ & $100-K R-4$ & $\begin{array}{l}\text { Performance monitoring for } \\
\text { pump-and-treat interim } \\
\text { action }\end{array}$ & $\begin{array}{l}\text { CERCLA } \\
\text { past practice }\end{array}$ & EPA \\
\hline 9 & $100-N R-2$ & $\begin{array}{l}\text { Performance monitoring for } \\
\text { pump-and-treat interim } \\
\text { action }\end{array}$ & $\begin{array}{l}\text { RCRA } \\
\text { past practice }\end{array}$ & Ecology \\
\hline $10 \mathrm{~A}$ & 100-FR-3 & Contaminant monitoring & $\begin{array}{l}\text { CERCLA } \\
\text { past practice }\end{array}$ & EPA \\
\hline 13 & 200-BP-5 & Contaminant monitoring & $\begin{array}{l}\text { CERCLA } \\
\text { past practice }\end{array}$ & EPA \\
\hline $20 \mathrm{~A}$ & 200-UP-1 & $\begin{array}{l}\text { Performance monitoring for } \\
\text { pump-and-treat interim } \\
\text { action }\end{array}$ & $\begin{array}{l}\text { RCRA } \\
\text { past practice }\end{array}$ & Ecology \\
\hline $20 \mathrm{~A}$ & $200-Z P-1$ & $\begin{array}{l}\text { Performance monitoring for } \\
\text { pump-and-treat interim } \\
\text { action }\end{array}$ & $\begin{array}{l}\text { CERCLA } \\
\text { past practice }\end{array}$ & EPA \\
\hline $20 \mathrm{~B}$ & 200-PO-1 & Contaminant monitoring & $\begin{array}{l}\text { RCRA } \\
\text { past practice }\end{array}$ & Ecology \\
\hline
\end{tabular}

(a) Listed from highest to lowest.

CERCLA = Comprehensive Environmental Response, Compensation, and Liability Act of 1980.

Ecology = State of Washington Department of Ecology.

$\mathrm{EPA} \quad=$ U.S. Environmental Protection Agency.

RCRA = Resource Conservation and Recovery Act of 1976. 


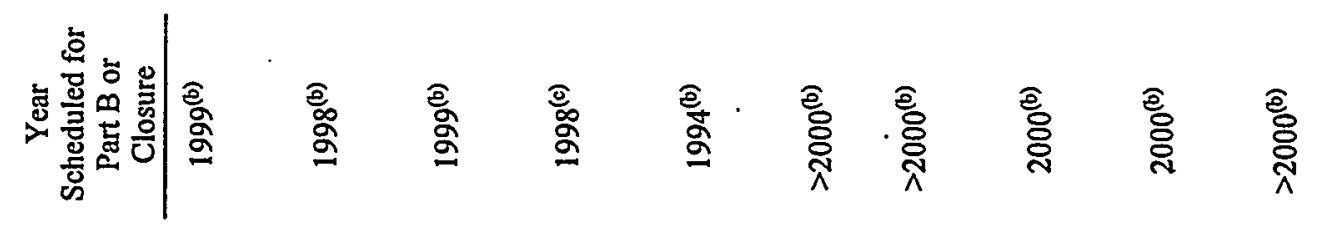

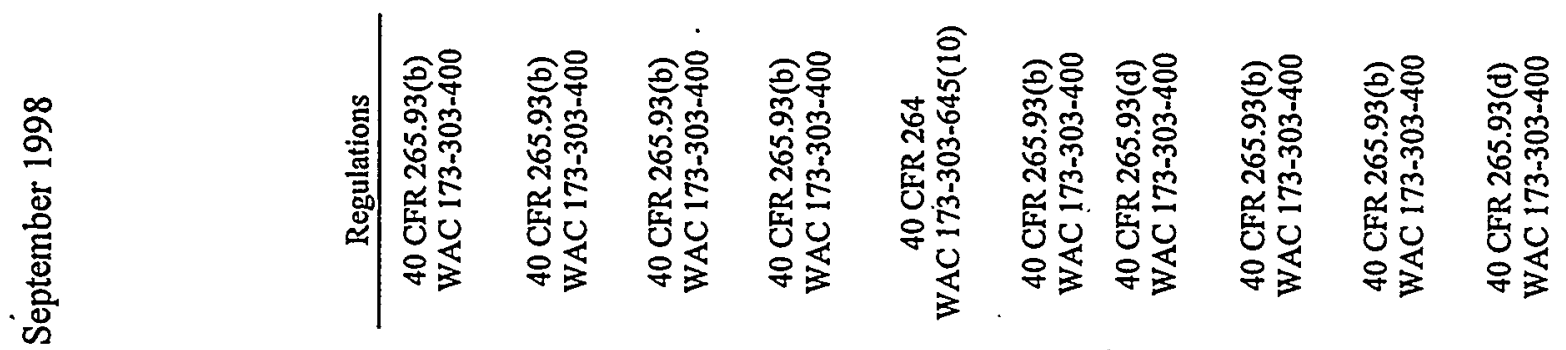

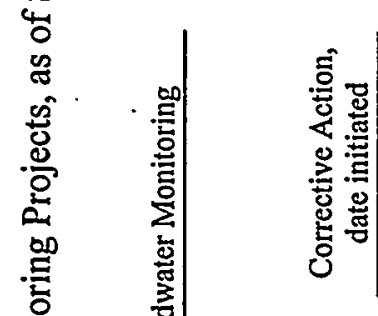

$\frac{\infty}{2}$

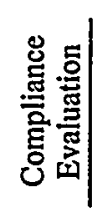

$\frac{2}{x}$

$\frac{5}{x}$

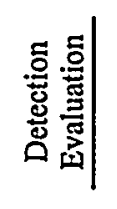

社

兽

家

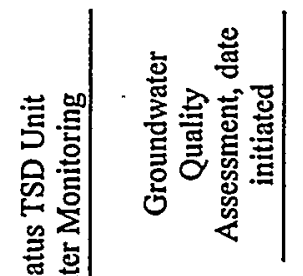

$\underset{\longleftarrow}{\longleftarrow}$

总

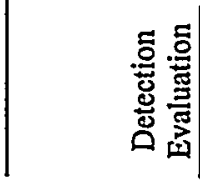

竞总苛

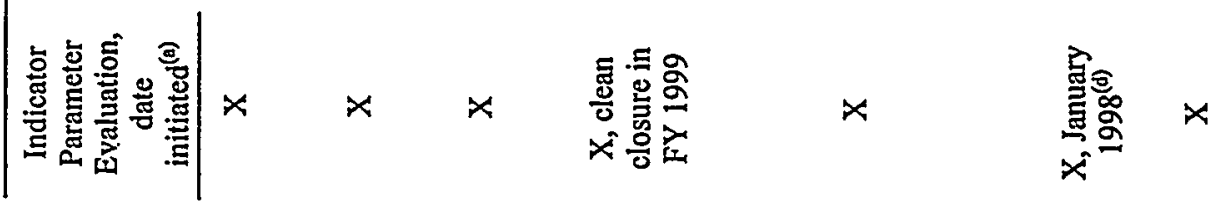

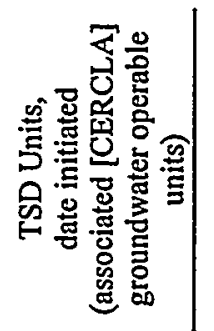

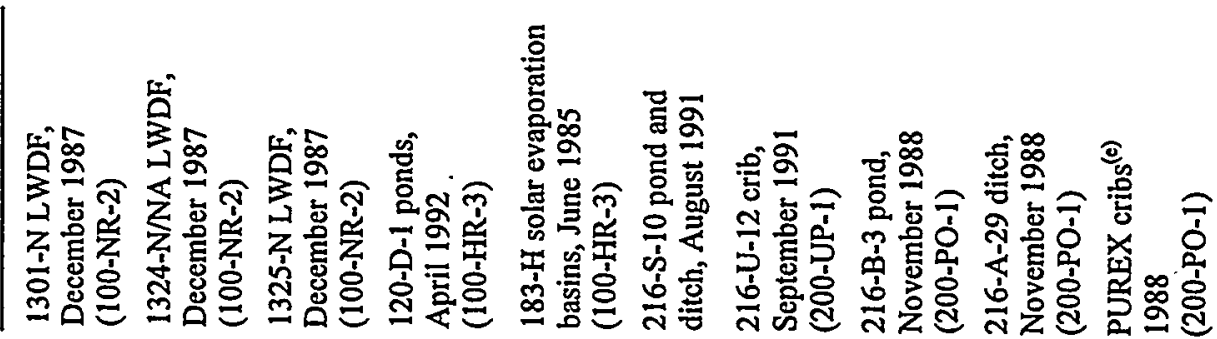




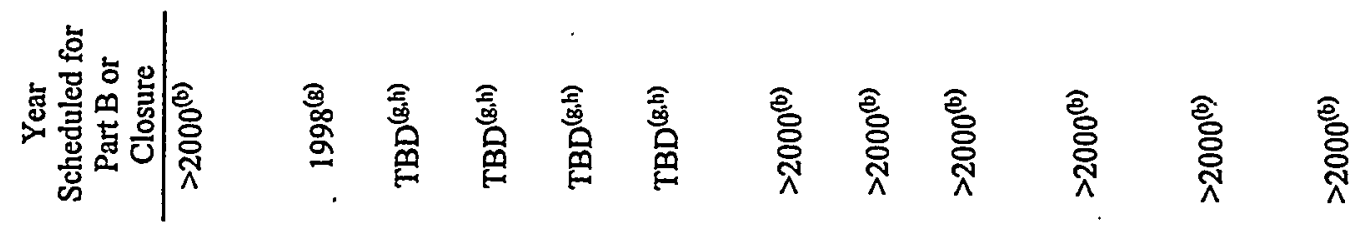

\begin{tabular}{|c|c|c|c|c|}
\hline 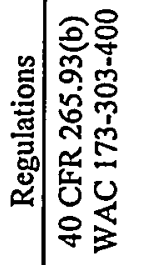 & 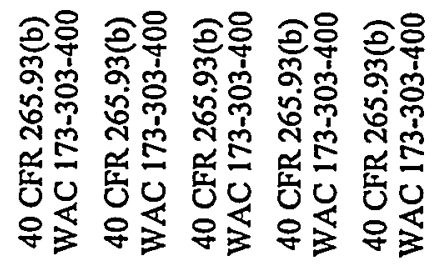 & 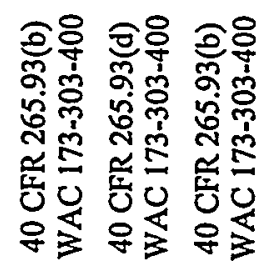 & 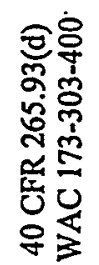 & 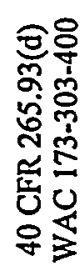 \\
\hline
\end{tabular}
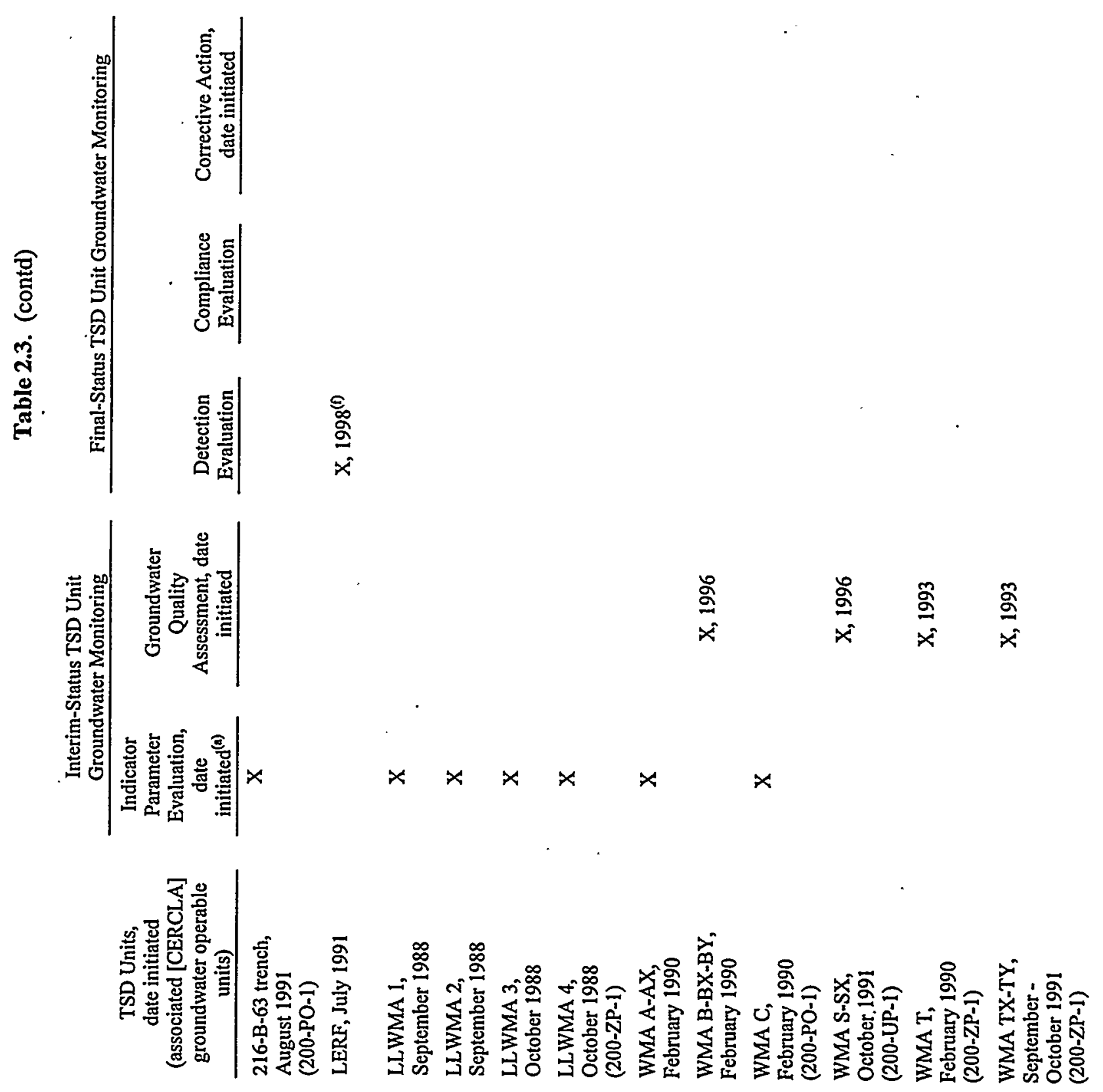


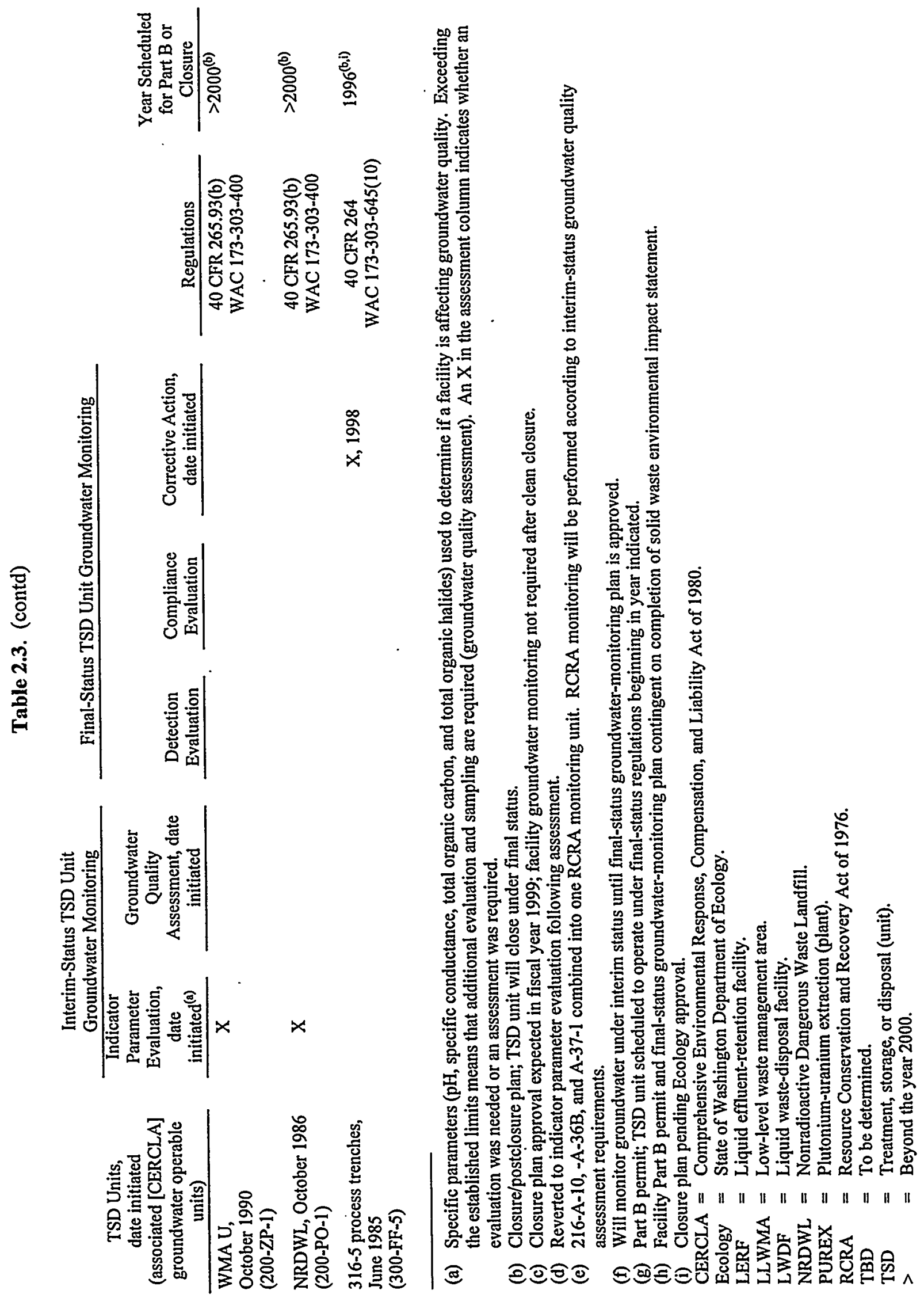




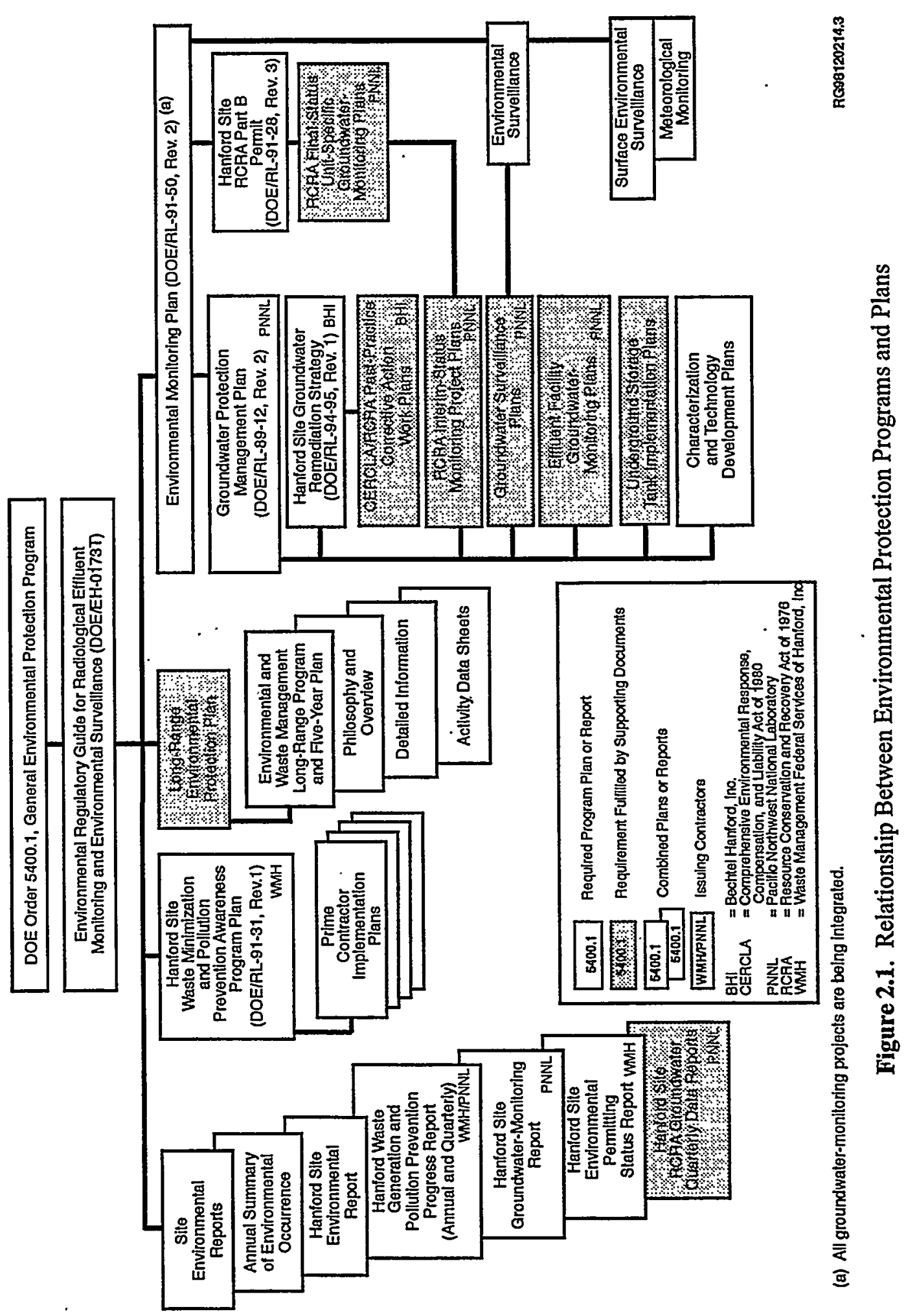




\subsection{Hydrogeologic Setting}

Understanding the groundwater-flow system is important in assessing the potential for contaminants to migrate from the site through the groundwater pathway. To understand this system, the geology and hydrology of the Hanford Site must be discerned because they control the movement of contaminants in groundwater. The hydrogeologic information is also used in the determination of the designs and locations of the monitoring wells and provides the basis for numerical modeling of groundwater flow and contaminant-plume migration.

This chapter provides an overview of the hydrogeology of the Hanford Site and describes groundwater flow within the unconfined and upper basalt-confined aquifers. The geology and hydrology of the Hanford Site are provided in Sections 3.1 and 3.2, respectively. Descriptions of regional flow in the unconfined aquifer and upper basalt-confined aquifer systems are given in Section 3.3. A description of the hydrogeology, including flow in the unconfined aquifer within specific areas in and adjacent to the Hanford Site, is provided in Sections 3.4 through 3.9. Water-level data for fiscal year (FY) 1998 are presented in electronic form on the diskette included with this report.

\subsection{Geologic Setting \\ S. P. Reidel}

The Hanford Site lies in the Columbia Plateau, a broad plain situated between the Cascade Range to the west and the Rocky Mountains to the east. The Columbia Plateau was formed by a thick sequence of Miocene-Age tholeiitic basalt flows, called the Columbia River Basalt Group, that erupted from fissures in north-central and northeastern Oregon, eastern Washington, and western Idaho (Swanson et al. 1979). The Columbia Plateau is often called the Columbia Basin because it forms a broad lowland surrounded by mountains. In the central and western sections of the Columbia Plateau, where the Hanford Site is located, the Columbia River Basalt Group is underlain by continental sedimentary rocks from earlier in the Tertiary Period.

The basalt and sedimentary rocks have been folded and faulted over the past 17 million years, creating bróad structural and topographic basins separated by asymmetric anticlinal ridges. Sediments up to $518 \mathrm{~m}$ in thickness accumulated in some of these basins. Basalt flows are exposed along the anticlinal ridges, where they have been uplifted as much as $1,097 \mathrm{~m}$ above the surrounding area. Overlying the basalts in the synclinal basins are sediments of the late Miocene, Pliocene, and Pleistocene Ages. The Hanford Site lies within one of the larger basins, the Pasco Basin, that is bounded on the north by the Saddle Mountains and on the south by Rattlesnake Mountain and the Rattlesnake Hills. The Yakima and Umtanum Ridges trend into the basin and subdivide it into a series of anticlinal ridges and synclinal basins. The largest syncline, the Cold Creek syncline, lies between Umtanum and Yakima Ridges and is the principal structural basin containing the U.S. Department of Energy's waste management areas (WMAs). Figure 3.1-1 shows the surface geology and major structural features of the Pasco Basin. The geology of the Hanford Site is described in detail in DOE/RW-0164. 
Figure 3.1-2 shows the stratigraphic units underlying the Hanford Site. These include, in ascending order, the Columbia River Basalt Group, Ringold Formation, Plio-Pleistocene unit (including the early Palouse soil), and Hanford formation. A regionally discontinuous veneer of Holocene alluvium, colluvium, and/or eolian sediments overlies the principal geologic units. The hydrogeologic and geologic stratigraphic columns in Figure 3.1-2 show differences in stratigraphy, primarily within the Hanford and Ringold Formations. The geologic column on the right defines the lithostratigraphic units, based on mapping and physical properties of the sediments, modified from BHI-00184. The hydrogeologic column on the left defines hydrostratigraphic units based on hydraulic properties (PNL-8971). The various stratigraphic units found within the Hanford Site boundaries are described below.

\subsubsection{Columbia River Basalt Group}

There are a minimum of 50 basalt flows beneath the Hanford Site with a combined thickness of $>3,000 \mathrm{~m}$ (DOE/RW-0164). The most recent, laterally extensive basalt flow underlying the Hanford Site is the Elephant Mountain Member of the Saddle Mountains Basalt. However, the younger Ice Harbor Member is found in the southern part of the site (DOE/RW-0164). Sandwiched between various basalt flows are sedimentary interbeds, collectively called the Ellensburg Formation, which include fluvial and lacustrine sediments consisting of mud, sand, and gravel deposited between volcanic eruptions. Along with the porous basalt flow tops and bottoms, these sediments form basalt-confined aquifers that extend across the Pasco Basin. The Rattlesnake Ridge interbed is the uppermost laterally extensive hydrogeologic unit of these sedimentary interbeds.

\subsubsection{Ringold Formation}

The Pliocene-Age Ringold Formation sediments overlie the basalts and are overlain by late Plioceneand Pleistocene-Age deposits. Ringold Formation sediments consist of a heterogeneous mix of variably cemented and compacted gravel, sand, silt, and clay deposited by the ancestral Columbia and Snake Rivers (Fecht et al. 1987; Reidel et al. 1994; WHC-SD-EN-EE-004). The depositional system was a braided stream channel with the two rivers joining in the area of the present White Bluffs. The deposits at the Hanford Site represent an eastward shift of the Columbia River from the west side of the Hanford Site to the east side. The Columbia River first flowed across the west side of the Hanford Site (where Dry Creek is now), crossing through the Rattlesnake Hills. The river eventually shifted to a course that took it through the gap between Gable Mountain and Gable Butte and south across the present 200-East Area.

Traditionally, the Ringold Formation in the Pasco Basin is divided into several informal units. In ascending order, these units are the 1) gravel, sand, and paleosols of the basal unit; 2) clay and silt of the lower unit; 3) sand and gravel of the middle unit; 4) mud and lesser sand of the upper unit; and 5) basaltic detritus of the fanglomerate unit (DOE/RW-0164, Newcomb 1958, Newcomb et al. 1972, RHO-BWI-ST-4, RHO-ST-23, SD-BWI-DP-039). Ringold strata also. have been divided on the basis of facies types (RHO-BWI-ST-14) and fining upward sequences (Puget Sound Power and Light Company 1982). The Ringold sediment facies have been described on the basis of lithology, stratification, and pedogenic alteration (WHC-SD-EN-TI-012, BHI-00184). More recently, the facies types identified include the following:

- fluvial gravel facies - These consist of matrix-supported granule to cobble gravels with a sandy silt matrix and intercalated sands and muds. The facies were deposited in a gravelly fluvial braidplain characterized by wide, shallow, shifting channels. 
- fluvial sand facies - These consist of cross-bedded and cross-laminated sands that are intercalated with lenticular silty sands, clays, and thin gravels. Fining upward sequences are common. Strata comprising the association were deposited in wide, shallow channels.

- overbank facies - These consist of laminated to massive silt, silty fine-grained sand, and paleosols containing variable amounts of pedogenic calcium carbonate. Overbank deposits occur as thin lenticular interbeds in the gravels and sands and as thick, laterally continuous sequences. These sediments record deposition in proximal levee to more distal floodplain conditions.

- lacustrine facies - These are characterized by plane laminated to massive clay with thin silt and silty sand interbeds displaying some soft-sediment deformation. Deposits coarsen downward. Ștrata were deposited in a lake under standing water to deltaic conditions.

- alluvial fan facies - These are characterized by massive to crudely stratified, weathered to unweathered basaltic detritus. These deposits generally are found around the periphery of the basin and record deposition by debris flows in alluvial fan settings and in sidestreams draining into the Pasco Basin.

As described and illustrated in the geologic column on the right side of Figure 3.1-2, the upper part of the Ringold Formation is composed of interbedded fluvial sand and overbank facies, which are overlain by mud-dominated lacustrine facies (BHI-00184, WHC-SD-EN-EE-004). The lower part of the Ringold Formation contains five separate stratigraphic intervals dominated by the fluvial gravel facies. These gravels, designated Units A, B, C, D, and E, are separated by intervals containing deposits typical of the overbank and lacustrine facies. The lowermost of the fine-grained sequence units, overlying Unit $A$, is designated the lower mud sequence. The lithofacies defined in WHC-SD-EN-EE-004 were regrouped into nine hydrogeologic units to support development of a layered, three-dimensional, groundwater-flow and -transport model (PNL-8971, PNL-10195, PNL-10886). A comparison of these units with the stratigraphic column of BHI-00184 is shown in Figure 3.1-2. Additional information on the definition of hydrogeologic units for the groundwater-flow model is provided in Chapter 6.0.

\subsubsection{Plio-Pleistocene Unit and Early Palouse Soil}

The laterally discontinuous Plio-Pleistocene unit unconformably overlies the Ringold Formation and is found only in the western part of the Hanford Site (DOE/RW-0164). This unit consists of sidestream alluvial deposits and buried soil horizons with significant caliche in some areas and is generally above the current water table (Slate 1996).

The Pleistocene-Aged early Palouse soil is a buried eolian unit that overlies part of the Plio-Pleistocene unit. Because of the difficulty in distinguishing the early Palouse soil from the Plio-Pleistocene unit, these two are commonly grouped together and called the Plio-Pleistocene unit. The early Palouse soil consists of up to $20 \mathrm{~m}$ of massive, brown-yellow, and compact, loess-like silt and minor fine-grained sand (DOE/RW-0164, RHO-ST-23). The early Palouse soil is found only in the vicinity of the 200-West Area. The early Palouse soil and the fine-grained and caliche portions of the Plio-Pleistocene unit, both of which are found in the 200-West Area, form a low-permeability layer that significantly affects migration of water through the vadose zone. 


\subsubsection{Hanford Formation and Pre-Missoula Gravels}

The informally named Hanford formation consists of deposits from a series of Pleistocene-Age cataclysmic floods. The floods occurred when ice dams gave way, releasing water from Lake Missoula, a large glacial lake that formed in the Clark Fork River valley. Flood episodes may have occurred as many as 40 times, with the released water spreading across eastern Washington. The floodwaters collected in the Pasco Basin and formed Lake Lewis, which is estimated to have drained in about a week through the gap in the Horse Heaven Hills, called Wallula Gap (Allison 1933). Three principal types of deposits were left behind by the floods: 1) high-energy deposits, consisting of gravel; 2) low-energy, slackwater deposits, consisting of rhythmically bedded silt and sand of the Touchet Beds; and 3) coarse- to fine-sand deposits, representing an energy transition environment. Fluvial pre-Missoula (flood) gravels underlie the Hanford formation gravel deposits in the central part of the Hanford Site. The pre-Missoula deposits are difficult to distinguish from the Hanford gravels, so they are usually grouped together.

The Hanford formation is divided into a variety of sediment types, facies, or lithologic packages. Reports dealing with the Hanford formation (WHC-MR-0391, WHC-SD-EN-EE-004) recognized three basic facies: gravel, sand, and silt dominated. These facies generally correspond to the coarse gravels, laminated sands, and graded rhythmites, respectively (Baker et al. 1991, DOE/RW-0164, WHC-SD-ERTI-003). The Hanford formation ranges in thickness from $<1$ to $>100 \mathrm{~m}$.

Gravel-dominated strata consist of coarse-grained sand and granule to boulder gravel that display massive bedding, plane to low-angle bedding, and large-scale cross-bedding in outcrop. Matrix commonly is lacking from the gravels, giving them an open-framework appearance: The sand-dominated facies consists of fine- to coarse-grained sand and granules that display plane lamination and bedding and, less commonly, plane and trough cross-bedding in outcrop. Small pebbles and pebbly interbeds $(<20 \mathrm{~cm}$ thick) may be encountered. The silt-dominated facies consists of silt and fine- to coarse-grained sand that form normally graded rhythmites. Plane lamination and ripple cross-lamination are common in outcrop.

Figure 3.1-3 is a map view of the hydrogeologic units that were intersected by the water table during 1998. The figure shows that the water table lies within the Hanford formation over most of the eastern and northern parts of the Hanford Site. The Hanford formation lies entirely above the water table in the western part of the site and in some other localized areas. Figure 3.1-4 shows a geologic cross-section of the Hanford Site and the location of the water table between Cold Creek Valley and the Columbia River in 1998. This cross-section represents A-A' on the map in Figure 3.1-3 and shows that the saturated sediments of the Hanford formation represent a small portion of the total saturated sediments above basalt.

\subsubsection{Holocene Surficial Deposits}

Holocene surficial deposits, consisting of silt, sand, and gravel, form a thin $(<5-\mathrm{m})$ veneer across much of the Hanford Site. In the 200-West Area and southern part of the 200-East Area, these deposits consist dominantly of laterally discontinuous sheets of wind-blown silt and fine-grained sand. They are generally found above the water table. 


\subsection{Hydrologic Setting}

\section{P. D. Thorne}

This section provides general information on the Hanford Site groundwater-flow system. Additional details concerning hydrogeologic conditions at each of the Resource Conservation and Recovery Act of 1976 (RCRA) sites is provided in the following sections.

Groundwater is present in both unconfined and confined aquifers at the Hanford Site. The unconfined aquifer is generally located in the unconsolidated to semiconsolidated Ringold and Hanford formations that overlie the basalt bedrock. In some areas, low-permeability mud layers form aquitards that create confined hydraulic conditions in the underlying sediments. Although they are extensive in some locations, these aquitards are not continuous across the Hanford Site and, thus, the entire suprabasalt aquifer is hydraulically connected on a sitewide scale. Consequently, from a regional perspective, the entire suprabasalt aquifer is referred to as the unconfined aquifer system in this report. The following discussion focuses on the Hanford Site unconfined aquifer system because, as the uppermost system, it is most likely to be affected by contaminants released from Hanford Site sources. Monitoring data confirm that almost all of the groundwater contamination is found within the upper part of the unconfined aquifer system. From a local perspective, the unconfined aquifer is referred to as the saturated zone above lowpermeability mud units for some areas (e.g., 200-West Area and most of the 100 Areas).

The saturated thickness of the unconfined aquifer system is $>180 \mathrm{~m}$ in areas near the Central Landfill, west of the 200-West Area, and north of Gable Butte near the 100-B,C and 100-K Areas, but pinches out along the flanks of the basalt ridges. Depth to the water table ranges from $<1 \mathrm{~m}$ near the Columbia River to $>100 \mathrm{~m}$ near the 200 Areas. Perched water-table conditions have been encountered in sediments above the unconfined aquifer system in the 200-West Area (PNL-8597, WHC-MR-0206) and in irrigated offsite areas east of the Columbia River (RHO-BWI!-C-56).

Groundwater in the unconfined aquifer system generally flows from recharge areas in elevated regions near the western boundary of the Hanford Site toward the Columbia River (discussed more fully in Sections 3.3 and 3.4), which is a discharge zone for the unconfined aquifer on both sides of the river. The Yakima River lies southwest of the Hanford Site and is generally regarded as a source of recharge to the unconfined aquifer system between the southern part of the site and the Richland North Area.

A sequence of basalt-confined aquifers is present within the Columbia River Basalt Group beneath the Hanford Site. These aquifers are composed of sedimentary interbeds and the relatively permeable tops of basalt flows. The dense interior sections of the basalt flows form confining layers. Groundwater in the basalt-confined aquifers also generally flows from elevated regions at the edge of the Pasco Basin toward the Columbia River (PNL-10817). However, the discharge zone locations are also influenced by geologic structures that increase the vertical permeability of the confining basalt layers. Additional information on the upper basalt-çonfined aquifer system is available in DOE/RW-0164, PNL-10158, and PNL-10817.

\subsubsection{Unconfined Aquifer System Recharge and Discharge}

Natural recharge to the unconfined aquifer system occurs from infiltration of runoff from elevated regions along the western boundary of the Hanford Site, infiltration of springwater and upwelling of 
groundwater that originates from the basalt-confined aquifer system, and infiltration of precipitation falling across the Hanford Site. Some recharge also takes place along the Yakima River. Recharge from precipitation is highly variable, both spatially and temporally, ranging from near zero to $>100 \mathrm{~mm} / \mathrm{yr}$, depending on climate, vegetation, and soil texture (Gee et al. 1992, PNL-10285). Recharge from precipitation is highest in coarse-textured soils with little or no vegetation, which is the case for most of the industrial areas on the site. A map showing estimated average natural recharge based on distributions of soil and vegetation types is shown in Figure 3.2-1 (PNL-10285). Some artificial recharge as a result of irrigation occurs in the upper Cold Creek Valley in the western part of the site and in agricultural areas south of the site.

Since the start of Hanford Site operations in the mid-1940s, artificial recharge from wastewaterdisposal facilities has been several times greater than the estimated recharge from natural sources. This caused an increase in the water-table elevation over most of the Hanford Site and the formation of groundwater mounds beneath major wastewater-disposal facilities. However, beginning in 1988, all production activities on the Hanford Site have closed, resulting in a decrease in wastewater disposal and subsequent decreases in water-table elevation over much of the site. As the Hanford Site's mission changed to include environmental cleanup and restoration and through the efforts of the Waste Minimization and Pollution Prevention Program (DOE/RL-91-31, Rev. 1), the volume of wastewater discharged to the soil column has been greatly reduced. For example, $\sim 34$ billion $\mathrm{L}$ of liquid effluents were discharged to the soil column in 1985, 14 billion L were discharged to the soil column in 1990, and $\sim 2.3$ billion $L$ were discharged to the soil column in 1997 (HNF-EP-0527-6). The reduction of wastewater discharge to the ground was accompanied by elimination of many discharge sites, including the 216-B-3 pond (B Pond) in the 200-East Area (decommissioned in 1997), the 216-U-10 pond (U Pond) in the 200-West Area (decommissioned in 1985), Gable Mountain Pond north of the 200-East Area (decommissioned in 1984-1988), and by diversion of waste streams to permitted facilities.

Permitted discharge sites actively releasing liquid effluent to the ground in FY 1998 include the following (see discussion in Section 3.3.2.3):

- 200 Areas Treated Effluent-Disposal Facility

- 616-A crib (also called the State-Approved Land-Disposal Site)

- $4608 \mathrm{~B} / \mathrm{C}$ ponds (also called the 400 Area process ponds)

- 124-N-10 sanitary sewage lagoon

- 130-N-1 (183-N) filter backwash pond.

\subsubsection{Unconfined Aquifer System Hydraulic Properties}

Aquifer hydraulic properties, including hydraulic conductivity, specific yield, and effective porosity, are needed to calculate groundwater- and contaminant-travel times and to conduct flow and transport modeling. 
Hydraulic property data for the unconfined aquifer system are derived mainly from well-pumping and slug tests and, in a few cases, laboratory permeameter tests of sediment samples. These results were documented in dozens of published and unpublished reports over the past 50 years. A summary of available data for the unconfined aquifer system is provided in DOE/RW-0164, and an updated summary is provided in PNL-8337 together with an evaluation of selected pumping test analyses. Additional tests were conducted to support several specific Hanford Site projects. Examples are presented in BHI-00917, PNL-8332, PNL-8971, PNL-10195, PNL-10422, PNL-10633, WHC-SD-C018H-RPT-003, WHC-SDEN-DP-052, WHC-SD-EN-TI-052, and WHC-SD-EN-TI-294.

The distribution of unconfined aquifer transmissivity, which is the product of the vertically averaged horizontal hydraulic conductivity and the aquifer thickness, is shown in Figure 3.2-2. This distribution was determined from the results of well-pumping tests combined with a flow-model calibration procedure (PNNL-11801). The model calibration is discussed in more detail in Chapter 6.0. In Figure 3.2-2, the zone of high transmissivity that extends from northwest to southeast across the site generally corresponds with the main flow channel of the catastrophic proglacial floods that deposited the Hanford formation gravels. Thickness of the unconfined aquifer system, which includes all the saturated sediments above basalt, is shown in Figure 3.2-3. Where they are found below the water table, the Hanford formation gravels make up the most-permeable zones of the unconfined aquifer system. The hydraulic conductivity of these sediments is generally 10 to 100 times greater than the hydraulic conductivity of Ringold Formation gravels. In some areas of the Hanford Site, including the 200-West Area, the water table is below the bottom of the Hanford formation (see Figures 3.1-3 and 3.1-4). The aquifer transmissivity in these areas is generally much lower than the transmissivity in areas where Hanford formation sediments are saturated.

For an unconfined aquifer, specific yield is approximately equal to effective porosity, which is important in calculating contaminant travè times. Aquifer specific yield, which is a measure of the volume of water released from aquifer storage in response to a change in the water-table elevation, is more difficult to measure than hydraulic conductivity and generally requires relatively long-duration aquifer-pumping tests with observation wells (PNL-8539) or slug tests with observation wells (PNL-10835, Spane 1996). Even for these tests, the calculated specific yield is subject to errors that result from nonideal test conditions, such as aquifer heterogeneity, anisotropy, and partially penetrating wells (PNL-8539). Specific yield values calculated from several multiple well tests are listed in PNL-10886. These results range from 0.02 to 0.38 and have a mean of 0.15 .

\subsection{Groundwater Flow}

\section{J. P. McDonald, W. D. Webber}

This section describes groundwater flow in the unconfined aquifer system and the upper basaltconfined aquifer system beneath the Hanford Site. Regional flow patterns in the unconfined aquifer system are the primary focus because this aquifer is the most likely pathway for offsite migration of contaminants in groundwater. The dynamics of the groundwater-flow system discussed in this section are used to determine flow directions, to support interpretation of plume distribution (Chapter 5.0), and to support modeling of flow and contaminant transport (Chapter 6.0). 


\subsubsection{Hanford Site Groundwater-Level Monitoring}

Water-level data are used to delineate groundwater-flow patterns and to evaluate flow-system dynamics in the unconfined aquifer system and the upper basalt-confined aquifer system. Water levels are measured in June of each year in selected wells completed in the unconfined aquifer system beneath the Hanford Site and outlying areas. The purpose of these measurements is to monitor changes in watertable elevations that affect the direction and linear velocity of flow and transport of contaminants. More frequent measurements are made at selected wells to monitor temporal variations. The June measurements are used to produce an annual water-table map of the Hanford Site. Water-table maps of the unconfined aquifer system have been prepared semiannually or annually since 1944 (see Water-Table Maps in the Historical Bibliography provided on the diskette included with this report). Groundwater flow within the unconfined aquifer system is discussed in Section 3.3.2.2.

Groundwater-monitoring plans for individual RCRA sites specify requirements for water-level monitoring. These data aid in determining the direction of flow beneath the RCRA units and in determining if the monitoring network is adequate. Water-level-measurement frequency varies from monthly to annually, depending on such factors as the hydraulic gradient beneath the site and the temporal variability of water levels. Flow beneath specific RCRA units is discussed in Sections 3.5 through 3.8.

Groundwater-monitoring plans for individual Comprehensive Environmental Response, Compensation, and Liability Act of 1980 (CERCLA) sites specify requirements for water-level monitoring. These data aid in determining the direction of flow beneath the CERCLA sites and the area affected by withdrawal and/or injection associated with pump-and-treat operations. Water-level-measurement frequency varies from hourly to annually, depending on the local gradient, temporal variability of water levels, and site requirements.

Water levels are also measured in the upper basalt-confined aquifer system to monitor changes in the potentiometric surface. These changes can affect the direction, flow rate, and potential for hydraulic communication with the overlying unconfined aquifer system. Groundwater flow within the upper basaltconfined aquifer system is discussed in Section 3.3.3.

In addition to the water-level measurements described above, where possible, water levels are measured prior to each groundwater-sampling event.

\subsubsection{Monitoring Network}

Locations of Hanford Site groundwater-monitoring wells in which a water-level measurement or sample has been collected during the FY 1994 through FY 1998 period are shown in Plate 1. Wells monitored north and east of the Columbia River that are numbered by the U.S. Geological Survey's wellnumbering system are not shown in Plate 1 but can be located by well name, which includes the township, range, and section numbers. These wells are shown in Plate 1 of PNL-8122.

During June 1998, water levels were measured in $>600$ wells completed in the unconfined aquifer system on the Hanford Site, south and west of the Columbia River, in 33 Bureau of Reclamation wells 
north and east of the Columbia River, and in 38 wells completed within the upper basalt-confined aquifer system. Monitoring wells used to measure water levels for the water-table map were selected using the following criteria:

- open interval does not extend $>10 \mathrm{~m}$ below the water table and does not monitor a perched zone - well location and elevation are accurately known.

Exceptions were made where no alternative wells existed and vertical gradients were small relative to horizontal gradients. For example, no wells in the B Pond-monitoring network are completed in the upper part of the aquifer where the water table lies above the Ringold lower mud unit. Therefore, wells completed below this unit were used. In some areas, not all wells that met these criteria were selected because an adequate number of nearby wells exist.

In addition to water levels measured during June in wells across the Hanford Site, water levels were measured more frequently and at more closely spaced wells in the vicinity of the Hanford Site operational facilities, groundwater-remediation sites, and the Richland North Area. These data are used to evaluate local flow patterns associated with those areas. Artificial recharge to the unconfined aquifer system in many of these areas has resulted in groundwater mounding that influences flow, as discussed in Sections 3.5 through 3.8 .

\subsubsection{Data-Collection Methods}

Procedures developed in accordance with the techniques described in American Society for Testing and Materials (1988), Garber and Koopman (1968), OSWER 9950.1, and U.S. Geological Survey (1977) were followed to measure water levels in piezometers and wells across the Hanford Site. Water levels were measured with steel tapes or laminated steel electric sounding tapes that were standardized by comparison to a calibrated steel tape. Only those standardized tapes that deviated from the calibrated steel tape by $<0.03 \mathrm{~m}$ over a length of at least $85 \mathrm{~m}$ were used.

A few wells completed in the upper basalt-confined aquifer system along the Columbia River are under flowing artesian conditions; where the potentiometric surface is above the top of the well or piezometer. For these wells, which are pressure sealed from the atmosphere, a pressure gauge or transducer is used to measure the equivalent head above the top of the surveyed reference point.

Pressure transducers and data loggers were used to measure and record heads automatically over discrete time intervals in a few wells where water levels change rapidly (e.g., near the Columbia River and near extraction or withdrawal wells). Pressure transducers and data loggers were also used to measure river stage to provide spatial and temporal control as it relates to groundwater levels near the river. River'stage-monitoring stations, which support CERCLA activities, are located at the $100-\mathrm{B}, \mathrm{C}, 100-\mathrm{H}, 100-\mathrm{N}$, $100-\mathrm{F}$, and 300 Areas. The data-logger systems generally record pressure head at 1-h intervals.

\subsubsection{Data Quality}

The procedures developed for determining water levels were designed to ensure the integrity and representativeness of the data. Interpretation of water-level data assumes that the measurements are 
temporally and spatially representative. However, various sources of error and uncertainty that limit the accuracy of the data and affect their representativeness include the following:

- temporal variations in the water table or potentiometric surface caused by natural external stresses (e.g., changes in river stage, barometric pressure fluctuations, earth tides, recharge) or anthropogenic activities (e.g., wastewater disposal to the ground)

- vertical gradients associated with the length and depth of the screened interval

- well deviations from vertical

- errors in surveyed elevations of measuring points

- limits of measuring equipment precision and accuracy

- limits to the degree in which the reference datum represents a surface of equal gravitational potential.

To reduce the effect of seasonal and other long-term water-level changes, water-level measurements for the site water-table map were made within a 1-month period (June 1998). The most significant shortterm water-level changes measured within this period were in wells influenced by fluctuations in Columbia River stage. These short-term water-level fluctuations in wells introduce transient effects in representing the water-table surface adjacent to the river. Therefore, the water-table-elevation contours adjacent to the river have a lower confidence in representing a point-in-time water-table surface for June 1998 than other contours.

The effect of open-interval depth below the water table on water levels depends on the vertical gradient in a given area. For the scale and contouring interval of the site map and of most local maps, any well screened within $10 \mathrm{~m}$ of the water table is assumed to be acceptable (see Section 3.3.1.1). The remaining sources of error listed above generally are only significant in areas of very low horizontal gradients (e.g., the 200-East Area). In some of these areas, water-level data alone are insufficient to determine the direction of groundwater flow, and other information (e.g., contaminant-plume configuration, regional flow patterns) must also be considered.

Water-level data were screened for outliers (obvious errors and extreme data) before producing the water-table maps presented in this report. Outliers are not plotted on the water-table or potentiometric surface maps shown in this report but are included in the data tables provided on the diskette included with this report. Outliers were generally included on the water-level-trend plots; however, outliers beyond the limits of the plot scale were removed. Data collected from data-logger and pressuretransducer systems were compared to manual measurements to evaluate and correct for transducer drift.

\subsubsection{Data Management}

The Hanford Environmental Information System (HEIS) database is used to store and maintain manual hydraulic head measurements. In FY 1997, 3,040 hydraulic head measurements were entered into this database. As of the end of FY 1998, many of the manual measurements taken had not been 
entered into HEIS because of the reconfiguration of the hydraulic head table associated with conversion to a new vertical datum. During this transition, some FY 1998 data were stored in project databases.

\subsubsection{Unconfined Aquifer}

June 1998 water-level measurements were used to construct contour maps that show the elevation of the potentiometric surface for the unconfined aquifer system, which is referred to as the water table. The water-table map primarily represents groundwater-head conditions in the upper part of the unconfined aquifer system. Assuming isotropic hydraulic conductivities, uniform fluid density, and no vertical flow, the direction of flow is perpendicular to contours of equal potentiometric surface elevation. Potentiometric surface maps can be used to

- identify the recharge and discharge areas

- evaluate the influence of wastewater discharges on groundwater flow

- evaluate the interaction between groundwater and surfacewater bodies

- assess the interaction between aquifers or between hydrogeologic units within an aquifer

- determine the hydraulic gradient and average linear velocity of flow

- provide information required to calibrate groundwater-flow and contaminant-transport models

- improve the design of the monitoring well network.

\subsubsection{Interpretive Techniques}

Water-level elevation is determined by taking the surveyed elevation of a reference point on the well casing and subtracting the depth to water measured from that point. Water-level elevations are reported using the North American Vertical Datum of 1988 (NAVD88) (DOE/RL-94-111). Previous versions of the Hanford Site water-table map reported elevations using the National Geodetic Vertical Datum of 1929 (NGVD29). NAVD88 elevations are $1 \mathrm{~m}$ higher than NGVD29 elevations in the vicinity of the Hanford Site. Many of the wells used to construct the water-table map were surveyed earlier and have referencepoint elevations in NGVD29. Elevations were converted to NAVD88 using a software package called Corpscon (version 5.11, U.S. Army Corps of Engineers 1997), which makes use of the VERTCON software program (version 2.0) developed by the National Geodetic Survey. The error associated with conversion to the NAVD88 datum using the Corpscon software is $\pm 1 \mathrm{~cm}$.

The areas where basalt occurs above the water table, which do not change significantly from year to year, were identified by comparing the top-of-basalt surface with the June 1997 water-table surface. The area where the Ringold lower mud unit occurs above the water table was identified near B Pond for FY 1998.

Maps showing the June 1998 water-table-elevation contours for the unconfined aquifer system are presented in Plate 2. A contour interval of $2 \mathrm{~m}$ is used to show regional water-table features on the Hanford Site. To show more detail, the inset maps (i.e., operational areas) use a contour interval of $0.5 \mathrm{~m}$. Selected FY 1998 water-level data, including the measured depth to water, reference-point elevation, and calculated water-table elevation for each well are provided on the diskette included with this report. 
The contour map was constructed by preparing a water-level-elevation grid to represent the watertable surface for the Hanford Site. Contours were derived using the computer program EarthVision TM (Dynamic Graphics Inc., Alameda, California). Preparation of the water-table-elevation grid using EarthVision ${ }^{\mathrm{TM}}$ includes the following:

- selection of data (see Sections 3.3.1.1 and 3.3.1.3)

- calculation of the water-level elevation for June 1998 at each selected well

- calculation of simulated, mean, river-stage elevations for June 1998 along the Hanford Reach of the Columbia River

- determination of grid boundary and break lines

- computer-automated gridding of selected water-level elevations

- manual editing of the grid using utilities supplied in the EarthVision ${ }^{\mathrm{TM}}$ software.

Editing of the water-level-elevation grid is done to add control where data distribution is insufficient for automated gridding. When editing is complete, contour lines are generated from the grid. Contour lines are then posted with the water-level elevations and reviewed. Final editing of the contour lines is done where the grid resolution was insufficient to represent local water-table features.

Because water-table elevations north and east of the Columbia River are much greater than on the Hanford Site and water-level changes are small relative to the regional water-table gradient, water-level measurements are not collected in all offsite monitoring wells each year. The June 1998 map of watertable elevations for the Hanford Site and outlying areas is presented in Figure 3.3-1. The contour intervals are $2 \mathrm{~m}$ on the Hanford Site west and south of the Columbia River. A 50-m contour interval was used north and east of the river because the water-table gradients are much steeper. Contours of the water-table surface north and east of the Columbia River were constructed based on June 1997 and June 1998 water-level measurements. Changes in the elevation of the water-table surface in this area is strongly controlled by recharge from canal seepage and applied irrigation (Drost et al. 1997). The water table in some parts of Franklin County has risen by $>150 \mathrm{~m}$ since 1948, when the South Columbia Basin Irrigation District began operation. However, trend plots indicate that water levels in most wells in this area have reached a state of equilibrium (Drost et al. 1997) and, thus, do not change significantly, relative to the water-table gradient, from year to year.

The RCRA regulations require an annual determination of the direction and rate of groundwater or contaminant movement for sites in assessment- or compliance-level monitoring (40 CFR 265.94[b][2], WAC 173-303-645[10][e]). For most of the RCRA sites described in this chapter, the rate of flow is estimated using a form of the Darcy equation

$$
\mathrm{v}=\mathrm{Ki} / \mathrm{n}_{\mathrm{e}}
$$


where $\mathrm{v}=$ average linear groundwater velocity, $\mathrm{m} / \mathrm{d}$

$\mathrm{K}=$ hydraulic conductivity, $\mathrm{m} / \mathrm{d}$

$\mathrm{i}=$ hydraulic gradient

$\mathrm{n}_{\mathrm{e}}=$ effective porosity.

Representative values of hydraulic conductivity, effective porosity, and current (FY 1998) hydraulic gradient were used for each site. Values of hydraulic conductivity were taken from published hydrologic test results that best represent the uppermost part of the unconfined aquifer system. The value for effective porosity was chosen within the range of values (i.e., 0.1 to 0.3 ) typical for unconfined aquifer conditions (Bear 1979). The hydraulic gradient was estimated from the wells monitoring the RCRA facility. However, for some sites where the slope of the water table is too gentle, the hydraulic gradient was uncertain; thus, it was estimated from the regional water-table contours.

Estimates of groundwater-flow rates and directions for the RCRA facilities are presented in Table 3.3-1. In some cases, other methods were used to estimate groundwater- or contaminant-flow rates and direction, including the migration of contaminant plumes or numerical flow modeling. Contaminantplume maps were used to estimate flow directions to confirm or provide better confidence than flow directions determined by the water-table contours. Flow meters have been used in the past, but are not currently used on a regular basis.

\subsubsection{Regional Groundwater Flow}

The June 1998 water-table map for the Hanford Site is shown in Figure 3.3-1 and Plate 2. Figure 3.3-1 also shows the water table north and east of the Columbia River. The water table for the unconfined aquifer system beneath the Hanford Site is generally located in the unconsolidated to semiconsolidated sediments of the Ringold and Hanford formations (see Figure 3.1-3). The Ringold and Hanford formations have vastly different estimates of hydrologic properties (see Section 3.2.2). Steep gradients in the western region of the Hanford Site are due to groundwater recharge at the western edge of the Pasco Basin, to lower hydraulic conductivities than in the eastern region of the site, and to a change in the aquifer thickness from west to east. Possible sources of recharge include infiltration of rain and snowmelt at higher elevations, primarily in the Cold Creek and Dry Creek Valleys, as well as irrigation of offsite agricultural land in the Cold Creek Valley. Steep gradients north and east of the Columbia River are attributed to recharge associated with irrigation of agricultural land. Regionally, water-table elevations decrease while approaching the Columbia River from either side, indicating that groundwater flow converges and ultimately discharges at the river.

Wastewater discharge to the ground associated with Hanford Site operations resulted in groundwater mounding and significantly affected the flow system on the Hanford Site. Past discharges at U Pond and smaller discharges to other 200-West Area disposal facilities are apparent from the shape of the contours passing through the 200-West Area. The steep gradient just east of the 200-West Area results partially from this mounding and partially from the relatively low transmissivity (from low hydraulic conductivity and aquifer thinning) of the aquifer in this area. The hydraulic gradient decreases abruptly between the 200-West and 200-East Areas, corresponding to an increase in transmissivity caused by the presence of the highly permeable Hanford formation sediments below the water table. The steep gradient in the gap 
between Umtanum Ridge and Gable Butte results partially from recharge coming from Cold Creek Valley, mounding in the 200-West Area, and restriction of the unconfined aquifer system by the underlying basalt to a thin, narrow zone in the gap.

The water table in the central portion of the Hanford Site south of Gable Mountain is relatively flat, except for the groundwater mound around B Pond, where process cooling water and other liquid wastes were discharged to the ground up until FY 1997. The presence of highly permeable sediments of the Hanford formation below the water table results in a relatively flat water table in spite of the large discharges in past years. The presence of low-permeable sediments of the Ringold Formation is a controlling factor in the development of the mound around B Pond. For the past several years, the annual volumes of discharges to the soil column resulting from 200-East Area operations have been significantly higher than discharges from 200-West Area operations (discussed in Section 3.3.2.3).

A local groundwater mound exists $\sim 2 \mathrm{~km}$ north of Gable Mountain (between Gable Mountain and the 100-F Area). Jenkins (1922) reported the area of elevated groundwater levels, which have persisted to the present, long before the Hanford Site was established. Data suggest that this mound is associated with a subsurface topographic "high" of low-permeability sediments (primarily clay) of the Ringold Formation. One possible source of recharge is conveyance losses associated with past seasonal irrigation use of the Hanford Canal that traversed the groundwater mound area between 1908 and 1943. Other potential sources of recharge include upwelling from the upper basalt-confined aquifer system and infiltration from surface runoff. The slow dissipation of the recharge water is attributed to the presence of a significant thickness of clay in the Ringold Formation sediments. There is insufficient information to distinguish whether the groundwater in this area is locally perched or is part of the regional, unconfined flow system.

The elevation of the water table in the region between the Yakima and Columbia Rivers is lower than the Yakima River stage elevation, which is $\sim 122 \mathrm{~m}$ above mean sea level at Wanawish (formerly Horn Rapids) Dam. This implies that infiltration from the Yakima River recharges the unconfined aquifer system in this area. During the summer, leakage from the Horn Rapids Ditch and Columbia Canal, which originate from the Yakima River at Wanawish Dam, and irrigation in offsite areas east of the Yakima River may also recharge the unconfined aquifer system in this area. Operation of the City of Richland's North Well Field recharge ponds results in a groundwater mound in the Richland North Area.

\subsubsection{Historical Changes in Water Levels}

This section describes changes in the water table from 1944 to 1979 and 1979 to 1995.1944 was chosen to illustrate the water table before it was affected by Hanford Site effluent discharges and irrigation practices in the upper Cold Creek Valley. 1979 is representative of maximum, steady volumes of effluent discharge. 1995 marks the reduction and consolidation of many waste streams and their diversion to new treatment and disposal sites.

Between 1944 and 1979, water-table elevations at the Hanford Site increased in most areas, with the greatest increases occurring near facilities where wastewater was discharged to the ground (Figure 3.3-2). Groundwater mounds associated with wastewater discharge to the ground formed in the 100,200 , and 300 Areas and in parts of the 600 Area. The two most prominent formed near U Pond in the 200-West Area and near B Pond in the 200-East Area. Figure 3.3-3 shows the volume of wastewater discharged to ground in each of the major Hanford Site operational areas and net recharge (infiltration less pumping) at 
the City of Richland's North Well Field recharge ponds from 1944 through 1997. This figure does not include large volumes of water discharged at the 100 Areas in the 1940s, 1950s, and 1960s. Figure 3.3-3 indicates that, in the past, the largest volumes discharged to the soil column occurred in the 200-East and 200-West Areas, which corresponds to the two most prominent groundwater mounds. These mounds altered the natural flow pattern of the unconfined aquifer system. Water levels in the unconfined aquifer system changed continually during Hanford Site operations because of variations in the volume and location of wastewater discharged to the ground. Consequently, the movement of groundwater and its associated constituents also changed with time. Figure 3.3-4 shows the locations of the active discharge sites that released liquid effluent to the ground in FY 1998.

Reduced wastewater discharge to the soil column resulted in declining water levels for most of the Hanford Site. Figure 3.3-5 indicates that the greatest water-level-elevation decline from 1979 through 1995 occurred in the 200-West Area near U Pond. Water-table-change maps and a discussion for June 1995 to June 1996 and June 1996 to June 1997 are presented in Section 5.3 of PNNL-11470 and Section 3.3 of PNNL-11793, respectively. The trend of declining water levels in most areas of the Hanford Site continued from June 1995 through June 1997. The Columbia River stage was unusually high throughout most of 1996 and 1997, resulting in a rising water table near the river from bank-storage effects.

\subsubsection{Changes from June 1997 to June 1998}

Figure 3.3-6 shows a contour map of the change in the water table from June 1997 to June 1998 . The water table declined over much of the Hanford Site during this period. The Columbia River stage, which was higher than normal during the past 2 years, returned to more normal conditions during 1998: This is graphically illustrated by the Columbia River hydrographs at Priest Rapids Dam upstream of the Hanford Site (Figure 3.3-7). The hydrographs show that the daily average flows during most of 1996 and 1997 were equal to or greater than the maximum daily average for the previous 6 years (1990 through 1995), which is equivalent to normal flows. Daily average flow in 1998 returned to levels similar to the 19901995 period.

The return to normal river flows resulted in declining water levels in much of the adjacent aquifer along the river. The largest declines occurred in the 300 Area (up to $2.9 \mathrm{~m}$ ), in the vicinity of the Old Hanford Townsite (up to $2.6 \mathrm{~m}$ ), and west of the 100-B,C Area (up to $2.0 \mathrm{~m}$ ), and are associated with areas of high transmissivity in the adjacent aquifer (see Figure 3.2-2). The smallest declines along the river occurred in the $100-\mathrm{F}$ Area $(0.1$ to $0.8 \mathrm{~m}$ ), which is a region of relatively low transmissivity.

Other significant water-level declines occurred east of the 200-East Area beneath B Pond and in the central portion of the 200-West Area. The decline beneath B Pond (up to $2.4 \mathrm{~m}$ ) is attributed to the total cessation of effluent discharges to this facility in August 1997. The declines in the 200-West Area are due to residual effects from a groundwater mound associated with effluent discharges to cribs, trenches, and ponds in the past. The maximum decline in the 200-West Area $(1.5 \mathrm{~m})$ is a local effect associated with extraction at pump-and-treat wells. Water-level decreases in the remaining areas of the Hanford Site are the result of the general reduction of wastewater disposed to ground throughout the 200-East and 200-West Areas, consistent with long-term trends. 
The water table increased in selected regions of the Hanford Site from June 1997 to June 1998. The largest increase in water levels ( 1.3 m) occurred in well 699-43-104 in Cold Creek Valley (discussed in Section 3.4). This signifies an increased level of recharge to the unconfined aquifer from Cold Creek Valley, but it is not known if this is due to natural runoff or a change in offsite irrigation practices. Water-table increases are also observed beneath the 616-A crib (also known as the State-Approved LandDisposal Site) just north of the 200 -West Area (up to $0.8 \mathrm{~m}$ ) and with pump-and-treat injection wells also in the 200-West Area (0.5 m). The State-Approved Land-Disposal Site began operation in December 1995 and receives tritium-bearing wastewater from the 200 Areas Effluent-Treatment Facility.

Other water-table elevation increases occurred along the Rattlesnake Hills (up to $0.2 \mathrm{~m}$ ), east of the Yakima River near the southern boundary (up to $0.4 \mathrm{~m}$ ), in a region north of the Washington Public Power Supply System (up to $0.2 \mathrm{~m}$ ), and within the region bounded by the 100 Areas and Gable Mountain (up to $0.5 \mathrm{~m}$ ). The increase along the Rattlesnake Hills is due most likely to increased recharge from precipitation. The other increases are primarily the result of lingering bank-storage effects from the higher-than-normal Columbia River stage during 1996 and 1997.

\subsubsection{Upper Basalt-Confined Aquifer System}

The upper basalt-confined aquifer system is defined as the groundwater occurring within basalt fractures and joints, interflow contacts, and intercalated sedimentary interbeds within the upper Saddle Mountains Basalt (see Figure 3.1-2). The thickest and most widespread sedimentary unit is the Rattlesnake Ridge Interbed. Groundwater is confined by the dense, low-permeability, interior portions of basalt flows and by Ringold Formation silt and clay units overlying the basalts.

In 1993, hydraulic head distribution and flow dynamics of the upper basalt-confined aquifer system were evaluated and reported in PNL-8869, which identified the following prominent hydrologic features:

- a broad recharge mound extending northeastward from Yakima Ridge in the 200-West Area

- a small recharge mound (now subsiding) immediately east of the 200-East Area in the vicinity of B Pond

- a subsurface hydrogeologic barrier (i.e., an impediment to groundwater flow), believed to be related to faulting, near the mouth of Cold Creek Valley

- a region of low hydraulic head (potential discharge) in the Umtanum Ridge-Gable Mountain structural area

- a region of high hydraulic head to the north and east of the Columbia River associated with recharge attributed to agricultural activities.

Recharge to the upper basalt-confined aquifer system is believed to result from precipitation and surfacewater infiltration where the basalt and interbeds are exposed at ground surface. Recharge also may occur through the unconfined aquifer system where a downward hydraulic gradient exists between the unconfined and upper basalt-confined aquifers. Hydraulic communication with overlying and underlying aquifers is believed to cause the region of low hydraulic head found in the Umtanum Ridge-Gable 
Mountain structural area (these relationships are given in more detail in PNL-8869). Maps of the upper basalt-confined and unconfined aquifer potentiometric surfaces indicate that a downward hydraulic gradient from the unconfined aquifer to the upper basalt-confined aquifer occurs in the western portion of the Hanford Site, in the vicinity of the B Pond recharge mound, as well as in the regions north and east of the Columbia River (PNL-6313, PNL-8869, PNL-10082, PNNL-11470, PNNL-12067, WHC-EP-0142-3, WHC-EP-0142-4, WHC-EP-0394-3). In the vicinity of B Pond, however, a recent acceleration in head decline within the unconfined aquifer system (see Section 3.3.2.4) may soon lead to a reversal in the vertical hydraulic gradient between the unconfined and upper basalt-confined aquifer systems in this region. In other areas of the Hanford Site, the hydraulic gradient is upward from the upper basalt-confined aquifer to the unconfined aquifer system.

Figure 3.3-8, constructed by manual contouring, presents a regional approximation of the potentiometric surface for the upper basalt-confined aquifer system based on water-level measurements taken during June 1998. Measurements in the Rattlesnake Ridge Interbed were primarily used to construct this map, though additional measurements in the upper Saddle Mountains Basalt were used for general contouring. The datum used was NAVD88, which is $\sim 1 \mathrm{~m}$ higher than the NGVD29 datum used in previous versions of this map (e.g., PNL-8869, PNL-10817, PNNL-11793) (see Section 3.3.2.1).

With some exceptions, the major potentiometric map features shown in Figure 3.3-8 are nearly the same as those exhibited for 1996, as reported in Section 5.5 of PNNL-11470 and Section 3.10 of PNNL-11793. The potentiometric map indicates that, south of the Umtanum Ridge-Gable Mountain structural area, groundwater flows from west to east across the site toward the Columbia River, which represents the regional discharge area for groundwater-flow systems. In the region northeast of Gable Mountain, the potentiometric contours suggest that groundwater flows southwest and discharges primarily to underlying confined aquifer systems in the Umtanum Ridge-Gable Mountain structural area (PNL-8869). This increased hydraulic head region is associated with recharge from agricultural activities north and east of the Columbia River and has been observed for deeper, confined aquifer systems. Therefore, the Columbia River does not represent a major discharge area for upper basalt-confined groundwater in the northern portion of the Hanford Site.

Water levels in almost all wells monitoring the upper basalt-confined aquifer system declined from June 1997 to June 1998. The greatest declines occurred near the B Pond (well 699-42-40C) and in the eastern portion of the site (wells 699-26-15C and 699-42-E9B). However, water levels in well 699-42-E9B are known to be affected by stage fluctuations in the Columbia River. The river stage was higher than normal during 1996 and 1997 but returned to normal during 1998, thus accounting for the water-level decline in well 699-42-E9B. For this reason, short-term water-level fluctuations in this well and in other wells near the river (i.e., 199-H4-2 and 399-5-2) mask long-term trends in the upper basalt-confined aquifer system. Water levels in confined aquifer wells near the northern boundary of the 200-East Area and immediately east of the 200-East Area near B Pond continue to show a decline; falling in the range of 0.1 to $0.7 \mathrm{~m}$ from June 1997 to June 1998 . Water levels in confined aquifer wells near the 200-West Area also continue to show a decline of $\sim 0.1$ to $0.4 \mathrm{~m} / \mathrm{yr}$. Water levels in wells located between Gable Mountain and the northern boundary of the 200-East Area fell $\sim 0.1$ to $0.3 \mathrm{~m}$ from June 1997 to June 1998. These declines are a response to curtailed effluent-disposal activities in the 200 Areas and are consistent with water-level declines in the overlying unconfined aquifer system. 


\subsection{Hydrogeology of Upper Cold Creek and Dry Creek Valleys}

\section{R. Newcomer, S. P. Reidel}

The upper Cold Creek Valley is a narrow valley that lies between Umtanum Ridge to the north and Yakima Ridge to the south (see Plate 1). The valley is controlled by the Yakima Ridge fault, a thrust fault along the north side of Yakima Ridge. A thin veneer of sediments overlies the basalt bedrock in the upper valley. Springs along the valley floor are fault controlled and provide recharge to Cold Creek and the unconfined aquifer. To the east where the valley widens, the veneer of sediments above the basalt thickens into the Cold Creek depression. Upper Cold Creek sediments are primarily alluvia; farther east, the basalt is overlain by the Ringold and Hanford formations. Sporadic flash flooding in upper Cold Creek has resulted in debris flows at the surface on the western part of the Hanford Site.

Dry Creek Valley lies between the Rattlesnake Hills-Snively Basin area to the south and Yakima Ridge to the north (see Plate 1). The upper portion of Dry Creek flows on a thin veneer of alluvium overlying Columbia River basalts; farther east, these sediments increase in thickness into the Cold Creek depression. Suprabasalt sediments consist of the Ringold Formation; the Hanford formation Touchet Beds; alluvial fan deposits shed off the Rattlesnake Hills; and a thick, $\sim 10-\mathrm{m}$ deposit of post-Missoula flood alluvium. The suprabasalt sediments have been incised $10 \mathrm{~m}$ in the past 10,000 years by Dry Creek. Dry Creek emerges from the sediments as a spring (Rattlesnake Spring) and flows east for several kilometers until it disappears beneath the Hanford formation. Secondary streams supplied by spring lines along faults on the Rattlesnake Hills provide water for Dry Creek.

The water table in the western part of the Hanford Site may have responded to irrigation practices in the upper Cold Creek Valley (PNL-5506). Figure 3.4-1 shows a hydrograph of well 699-43-104 downgradient from the irrigated fields in upper Cold Creek Valley. The hydrograph indicates that the water table declined steadily between 1988 and 1997 and then increased in 1997 and 1998 (also see Figure 3.3-6). The water-level decline between 1988 and 1997 may have been caused by decreased recharge, resulting from changes in irrigation practices at Ste. Michelle Vineyards upgradient of the site. Between 1982 and 1983, the vineyards converted their irrigation system from sprinkler to drip, which reduced consumption between $40 \%$ and $50 \%$ (PNL-7498). Declining water levels in the unconfined aquifer also may have been associated with decreases in the hydraulic heads of the underlying confined aquifers in this area. It is estimated that the hydraulic heads in the upper basalt-confined aquifer dropped $>55 \mathrm{~m}$ in the Cold Creek Valley since the early 1900s (DOE/RW-0164). Thus, the upward gradient from the confined to the unconfined aquifer is not as strong as it once was. Well construction may also be a factor. Well 699-43-104 was open originally to both the unconfined and the upper basalt-confined aquifers (1957 to 1978). In 1978, a cement plug was placed in the well but was removed sometime before 1994. In 1994, a cement plug was placed in the bottom of the well casing to isolate the basalt section and prevent aquifer intercommunication (PNL-10195). In 1998, the water level rose $1.5 \mathrm{~m}$. At this time, it is uncertain what the causative factors are for this recent increase in water level.

The relationship of the water table to the top of the basalt surface in upper Dry Creek Valley was evaluated for this report. Based on an elevation contour map of the top of basalt and the June 1998 waterlevel data from two wells in this area, it was inferred that groundwater exists above the basalt surface in a small saddle at the western end of the Yakima Ridge extension (see Plate 2). 


\subsection{Hydrogeology of 100 Areas}

\section{J. Hartman, J. W. Lindberg, M. D. Sweeney}

The 100 Areas include six separate areas where retired plutonium-production reactors and associated support facilities are located. The hydrogeology of these areas is somewhat unique because of their location along the Columbia River in the northern part of the Hanford Site. The unconfined aquifer in the $100-\mathrm{B}, \mathrm{C}, 100-\mathrm{K}, 100-\mathrm{N}$, and 100-D Areas is composed of either the Unit E Ringold gravels or Unit E combined with the Hanford gravels, depending on the location of the water table (BHI-00917). In the 100-H and 100-F Areas, Ringold Unit E gravel is missing and the Hanford formation lies directly on the paleosol/overbank deposits of the Ringold Formation. In most of the 100 Areas, this unit forms a local aquitard, and the Ringold gravels below this mud are locally confined. Additional information on the hydrogeology of the 100 Areas is presented in BHI-00917, WHC-SD-EN-TI-023, and WHC-SDEN-TI-294.

The water table in the 100 Areas is shallower than in the more-elevated central regions of the Hanford Site. The depth to groundwater ranges from $<1 \mathrm{~m}$ adjacent to the river to $>30 \mathrm{~m}$ farther inland. Groundwater flow is generally toward the river in these areas, particularly during low-river stage. However, in some areas along the river (e.g., west of 100-B,C Area), flow appears to approximately parallel the river during most of the year. This may reflect the influence of buried river-channel deposits.

In FY 1998, the greatest groundwater-level changes in the 100 Areas were in response to Columbia River stage (see Figure 3.3-6). Changes in Columbia River stage also cause periodic reversals in the direction of flow immediately adjacent to the river. River stage was high in the spring and summer of 1998, as shown in the river-stage hydrographs constructed from pressure transducer data for the 100-B,C, $100-\mathrm{N}, 100-\mathrm{H}$, and 100-F Areas (Figure 3.5-1). When the river stage is higher than the water table in the adjacent aquifer, water moves into the banks of the river, resulting in bank storage. When the river stage drops, water moves back toward the river, often appearing as riverbank seepage. The distance that water moves into the aquifer from the river depends on the magnitude and duration in river stage above groundwater elevation and the hydraulic properties of the intervening aquifer. The reversal of flow adjacent to the river also causes a pressure pulse in the aquifer that affects water levels in wells up to several hundred meters inland. Thus, the estimates of groundwater gradients and flow rates for each of the 100 Areas discussed below, which are based on discrete water-level measurements, are reflective of temporal effects of river-stage fluctuations and not of more long-term effects. The effects of bank storage on contaminant transport in the 100 Areas are discussed in Chapter 5.0.

\subsubsection{0-B,C Area}

The stratigraphy beneath the 100-B,C Area consists of the Ringold and Hanford formations. The thickness of the Hanford formation is uncertain because the contact between it and the underlying Ringold Formation is not well defined. The Hanford formation, a gravel-dominated sequence with sandy and silty intervals, was reported to range from $\sim 14 \mathrm{~m}$ thick near the Columbia River to $>30 \mathrm{~m}$ thick in the southern part of the area (Newcomb et al. 1972, WHC-SD-EN-TI-133). The Ringold Formation includes Unit $\mathrm{E}$ and the underlying paleosols and overbank deposits (BHI-00917, WHC-SD-EN-TI-133). Unit E, which varies in thickness across the 100-B,C Area, is dominated by silty, sandy gravel with subordinate sand- and silt-dominated interbeds. 
The unconfined aquifer beneath the 100-B,C Area lies within silt, sand, and gravels belonging primarily to the Ringold Formation and is $-34 \mathrm{~m}$ thick. The upper portion of the unconfined aquifer lies locally within the lowermost Hanford formation. The top of the paleosols and overbank deposits of the Ringold Formation form the bottom of the unconfined aquifer. The depth to the water table varies from $<1 \mathrm{~m}$ near the river to $>30 \mathrm{~m}$ farther inland. Local confined aquifers lie within the Ringold Formation between the paleosol/overbank deposits and the top of the basalt.

The direction of groundwater flow within the unconfined aquifer was northeast toward the Columbia River in June 1998 (see Plate 2). During that time, the groundwater gradient was estimated to be 0.0004 . Hydraulic conductivity of the unconfined aquifer in the 100-B,C Area ranges from 4.3 to $17 \mathrm{~m} / \mathrm{d}$ (BHI00917). Using this range for hydraulic conductivity, the 0.0004 gradient, and an effective porosity of 0.1 to 0.3 , the flow rate ranges from 0.006 to $0.07 \mathrm{~m} / \mathrm{d}$.

\subsubsection{0-K Area}

Geologic units beneath the 100-K Area from the surface downward include eolian silty sand, Hanford formation (sandy gravel, gravelly sands, sand), Ringold Formation Unit E (sandy gravel, gravelly sand), and Ringold Formation paleosols and overbank deposits (silt, sandy silt) (WHC-SD-EN-TI-155). The water table is at $\sim 22 \mathrm{~m}$ below ground surface near the 105-KE and 105-KW Reactor buildings, within Unit E. Locally, the bottom of the unconfined aquifer is the top of the paleosols and overbank deposits at $\sim 49 \mathrm{~m}$ below ground surface (WHC-SD-EN-TI-294).

Groundwater in the unconfined aquifer generally flows from the southeast to northwest toward the river in the 100-K Area. However, the flow direction occasionally changes when the river stage is high. In FY 1998, the high-river stage in late spring and early summer (May - July) caused groundwater to flow northeast near the riverbank (see Plate 2). Effects of river stage on groundwater levels typically range over a 2-m rise along the riverbank and gradually decrease to a fraction of a meter at $1,000 \mathrm{~m}$ from the riverbank. The horizontal hydraulic gradient typically varies between 0.002 (high-river stage) and 0.005 (low-river stage), depending on Columbia River stage. Hydraulic conductivity of Ringold Formation Unit E ranges from 0.98 to $44 \mathrm{~m} / \mathrm{d}$ (BHI-00917, WHC-SD-EN-TI-294). Using a geometric mean of $.6 .1 \mathrm{~m} / \mathrm{d}$ for hydraulic conductivity, the 0.003 to 0.005 gradient, and an effective porosity of 0.1 to 0.3 , the flow rate ranges from 0.06 to $0.3 \mathrm{~m} / \mathrm{d}$.

A pump-and-treat system continued to operate in the 100-K Area during FY 1998 to remove hexavalent chromium from the groundwater (DOE/RL-97-96). Because extracted groundwater is treated and reinjected into the aquifer, the areal hydraulic response is not widespread, and effects are local to the immediate vicinity of the $116-K-2$ trench (see Plate 2 ). Detailed water-table maps are included in DOE/RL-97-96.

\subsubsection{0-N Area}

- The 100-N Area is the most recently active of the reactor areas and includes three RCRA-regulated liquid.waste-disposal facilities that affected groundwater flow (1301-N, 1324-N/NA, and 1325-N; see Plate 1). All of the wells monitoring these facilities are completed at shallow depths, but deep boreholes drilled for characterization in the 1970 s provided information on stratigraphy. 
The unsaturated zone in the 100-N Area lies in the Hanford formation and the upper part of the Ringold Formation. The unconfined aquifer is contained in the sands and gravels of Ringold Formation Unit $\mathrm{E}$. The depth to the water table in the $100-\mathrm{N}$ Area varies from $<1 \mathrm{~m}$ near the Columbia River to $\sim 21 \mathrm{~m}$ farther inland. The base of the unconfined aquifer is a clay-rich unit $12 \mathrm{~m}$ beneath the water table. One well is completed in a thin sand unit within this clay. Although no wells are completed in sandy units deeper in the Ringold Formation, information from deep boreholes near the 100-N Area indicates that these units may also act as local confined aquifers. Basalt lies at a depth of $\sim 150 \mathrm{~m}$ below ground surface. The hydrogeology of the 100-N Area is described in more detail in WHC-SD-EN-EV-027.

When the major liquid-waste-disposal units in the 100-N Area were active, the water table in the entire area was elevated by up to $7 \mathrm{~m}$ (Figure 3.5-2). Discharge to all the facilities ceased by 1991, resulting in a sharp water-table decline in the early 1990s. By 1994, effects from facility discharge on the water table stabilized.

Groundwater normally flows toward the northwest (toward the river) beneath the 1301-N and 1324-N/NA facilities and toward the north beneath the 1325-N facility (Figure 3.5-3). Estimated flow rates ranged between 0.02 to $1.6 \mathrm{~m} / \mathrm{d}$ during low-river stage (see Table 3.3-1). High-river stage in June 1998 affected the gradient, creating a potential for groundwater to flow toward the northeast, approximately parallel to the river (see Plate 2).

A pump-and-treat system continued to operate in the 100-N Area during FY 1998. Water was extracted from wells near the 1301-N facility and reinjected into a well or wells near the $1325-\mathrm{N}$ facility (see Plate 1). The effects of withdrawal and injection on the water table are not evident on Figure 3.5-2 and Plate 2.

Vertical gradients are not well known in the 100-N Area. Wells adjacent to the Columbia River show an upward gradient in the unconfined aquifer (WHC-SD-EN-EV-027). Farther inland, there is no significant difference in head between wells completed at the water table and wells completed at the base of the aquifer, which are $\sim 6 \mathrm{~m}$ deeper. Limited data prevent a clear comparison of vertical heads in the unconfined and shallowest, locally confined, Ringold Formation aquifers.

\subsubsection{0-D Area}

The unsaturated zone in the 100-D Area lies in the Hanford formation and the upper portion of the Ringold Formation. The unconfined aquifer is a sand and gravel unit, $\sim 3$ to $9 \mathrm{~m}$ thick, which corresponds to Ringold Unit E. Depth to the water table varies from $<1 \mathrm{~m}$ near the river to $\sim 25 \mathrm{~m}$ farther inland. The base of the aquifer is a fine-grained overbank interval, which is $\sim 15 \mathrm{~m}$ thick. The deeper Ringold Formation is believed to comprise more layers of clay, silt, and sand based on interpolations between wells elsewhere in the 100 Areas. The depth to basalt is inferred to be $125 \mathrm{~m}$ (DOE/RL-92-71, Rev. 2).

Groundwater in the unconfined aquifer beneath the 100-D Area generally flows toward the north and northwest (Figure 3.5-4). However, high-river stage resulted in a potential for flow toward the northeast in June 1998 (see Plate 2).

The 120-D-1 ponds are a small RCRA site that was formerly used for disposal of effluent from a water-treatment plant in the 100-D Area. Water levels in the wells that monitor these ponds respond to 
changes in river stage (Figure 3.5-5). During times of high-river stage, the heads in the downgradient wells, as defined in the RCRA groundwater-monitoring plan, are higher than in well 199-D5-13, defined as an upgradient well (WHC-SD-EN-AP-048). Estimated flow rates ranged between 0.0052 and $0.52 \mathrm{~m} / \mathrm{d}$ during low-river stage (see Table 3.3-1).

A pump-and-treat system for the remediation of a chromium plume in the 100-D Area began in the summer of 1997 and continued in FY 1998. Water was extracted from wells in the northern part of the area near the river (see Plate 1), treated, and reinjected in the 100-H Area. The effects of withdrawal on the water table are not evident on Figure 3.5-4 and Plate 2.

An upward vertical gradient was estimated to range from 0.007 to 0.02 between wells 199-D8-54A and 199-D8-54B in 1993 (Section 3.3 in DOE/RL-93-88). Well 199-D8-54A is completed across the water table, and well 199-D8-54B is completed $22.6 \mathrm{~m}$ deeper than well 199-D8-54A in a thin layer of silty sand that is confined beneath $15 \mathrm{~m}$ of clay. Well 199-D8-54A is now an extraction well, increasing the upward gradient in the vicinity.

\subsubsection{0-H Area}

The unsaturated zone and the unconfined aquifer in the 100-H Area lie entirely in unconsolidated sands and gravels of the Hanford formation. Depth to the water table ranges from $<1 \mathrm{~m}$ near the river to $\sim 12 \mathrm{~m}$ farther inland. The saturated portion of the Hanford formation ranges in thickness from 2 to $6 \mathrm{~m}$ (Peterson and Connelly 1992). Hydraulic conductivity is high, ranging up to $1,800 \mathrm{~m} / \mathrm{d}$ (PNL-6728). This hydrogeologic unit is underlain by the more-consolidated fluvial sands and overbank deposits of the Ringold Formation, which have much lower hydraulic conductivity. Ringold gravels below this unit are locally confined. Depth to basalt is $\sim 96 \mathrm{~m}$. A comprehensive description of 100-H Area stratigraphy is presented in WHC-SD-EN-TI-132.

The 183-H solar evaporation basins were used to treat and dispose RCRA waste during the 1970s and 1980s. Water levels in wells that monitor the basins fluctuate in response to changes in river stage (Figure 3.5-6). The general direction of groundwater flow beneath the basins under normal river-stage conditions is toward the east (toward the Columbia River) (Figure 3.5-7). High-river stage in June 1998 influenced flow in the area, creating a potential for flow toward the southwest (see Plate 2). Estimates of flow rates during FY 1998 ranged between 0.18 and $5.0 \mathrm{~m} / \mathrm{d}$ during low-river stage (see Table 3.3-1).

A pump-and-treat system for the remediation of a chromium plume in the 100-H Area began in the summer of 1997 and continued during FY 1998. Water was extracted from five wells, treated, and reinjected into three wells in the southwestern part of the area (see Plate 1). The effects of withdrawal and injection on the water table are not evident on Plate 2 and Figure 3.5-7.

\subsubsection{0-F Area}

The unsaturated zone and unconfined aquifer in the 100-F Area lie in the Hanford formation (BHI-00917). The unconfined aquifer in the 100-F Area lies within unconsolidated sediments in the lower part of the Hanford formation. Sandy gravel and silty sandy gravel dominate these sediments. Underlying the Hanford formation are the Ringold paleosols and overbank deposits, which are dominated by silt and clay with sandy interbeds. The top of the paleosol/overbank deposits locally forms the bottom 
of the unconfined aquifer in the 100-F Area. The thickness of the unconfined aquifer ranges up to a maximum of $9 \mathrm{~m}$. Depth to the water table ranges from $<1 \mathrm{~m}$ near the river to $\sim 14 \mathrm{~m}$ farther inland. The depth to the top of the basalt is estimated to be $\sim 110 \mathrm{~m}$ below ground surface.

River-stage fluctuations dominate groundwater flow beneath the 100-F Area. The general direction of unconfined flow beneath the 100-F Area under normal river-stage conditions is east toward the Columbia River (BHI-00917). However, a plume of nitrate-contaminated groundwater, originating from the 100-F Area, indicates a southeast flow direction. In October 1997, when the river stage was relatively low, the gradient between wells $199-\mathrm{F} 8-3$ and $199-\mathrm{F} 5-3$ was $~ 0.0015$. Hydraulic conductivity of the Hanford formation in the 100-F Area ranges from 9.1 to $69 \mathrm{~m} / \mathrm{d}$ (BHI-00917). Using this range for hydraulic conductivity, the 0.0015 gradient, and an estimated effective porosity of 0.2 , the flow rate ranges from 0.07 to $0.5 \mathrm{~m} / \mathrm{d}$. There were only a few water-level measurements made in the $100-\mathrm{F}$ Area in June 1998, so the water table map (see Plate 2) is highly speculative. However, as in past years, there appeared to be a reversed gradient from the river into the aquifer during June, when the river was high.

\subsection{Hydrogeology of 200 Areas \\ J. W. Lindberg, B. A. Williams, R. B. Mercer, M. D. Sweeney, D. B. Barnett, S. M. Narbutovskih}

The 200-East and 200-West Areas, jointly referred to as the separations areas, are located on the central plateau of the Hanford Site. The geology and hydrology of these areas have been extensively studied because they contain major sources of groundwater contamination; RHO-ST-23 describes the geology and RHO-ST-42 describes the hydrology. The hydrogeology of these areas was described in WHC-SDEN-TI-019 and WHC-SD-EN-TI-014, respectively. These documents provide references to many other studies conducted to support specific projects. The stratigraphy in the 200-East Area is currently being updated and the results will be available in FY 1999.

The unconfined aquifer in the 200-West Area lies almost entirely in Ringold Unit E gravels, the saturated thickness of which varies from $\sim 65$ to $>150 \mathrm{~m}$. The Ringold lower mud unit, the top of which defines the base of the unconfined aquifer in much of the 200-West Area, is absent in an area north of the 200-West Area (WHC-SD-EN-TI-014). Where the lower mud unit is absent, the top of the basalt defines the bottom of the unconfined aquifer. A semiconfined suprabasalt aquifer lies in Ringold Unit $A$ gravels between the lower mud unit and the basalt. The depth to the water table in the 200-West Area varies from $\sim 50$ to $>100 \mathrm{~m}$.

In the 200-West Area, groundwater flows from the basalt ridges and Cold Creek Valley to the west of the Hanford Site and flows out primarily to the north and east (see Plate 2). Residual effects from the groundwater mound associated with the former U Pond and other 200-West Area discharge facilities continue to dominate the water table in the 200-West Area. Water levels declined $\sim 0.5$ to $\sim 1 \mathrm{~m}$ over much of the 200-West Area between June 1997 and June 1998 (see Figure 3.3-6).

Local effects from a pump-and-treat system and a liquid effluent discharge site are superimposed on the regional water-table decline in the 200-West Area. The water-table map in Plate 2 indicates that groundwater withdrawal and injection at pump-and-treat wells have altered the water-table configuration 
in the vicinity of the Plutonium Finishing Plant. North of the 200-West Area, a small groundwater mound has developed as a result of release of liquid effluent to the State-Approved Land Disposal Site.

The 200-East Area is located on the southern flank of the Gable Mountain anticlinal structure (see Figure 3.1-1). Sediments lying on this structure in the 200-East Area include the Hanford and Ringold Formations. In most of the 200-East Area, the aquifer transmissivity is generally high because the unconfined aquifer lies within gravels of these formations (WHC-SD-EN-TI-019). However, the water table has dropped below the bottom of the Hanford formation in part of the 200-East Area during the last few years. This has decreased the aquifer transmissivity in this area and altered groundwater-flow patterns. In some areas of the 200-East and B Pond areas, lower permeability units of the Ringold Formation extend above the water table. The depth to the water table in the 200-East Area varies from $\sim 65$ to $100 \mathrm{~m}$. The thickness of the saturated zone above the top of the basalt varies from $0 \mathrm{~m}$ in the north to $\sim 80 \mathrm{~m}$ in the south.

In the 200-East Area, groundwater flows primarily in two general directions: to the northwest through Gable Gap (located between Gable Mountain and Gable Butte) and to the southeast toward the Columbia River (see Plate 2). These flow directions are based on contaminant-plume maps and waterlevel elevation data. However, the location of the divide between flow to the northwest and flow to the southeast is not discernible because the water table in the 200-East Area is nearly flat. The very gently sloping water table corresponds to a high transmissivity zone that extends through the 200-East Area (see Figure 3.2-2).

Groundwater flow at the former B Pond continues to show a radial pattern (see Plate 2). This radial pattern is attributed to a groundwater mound that developed when wastewater discharge was released to B Pond in the past. Hydrogeologic conditions are controlling factors in the magnitude and extent of the groundwater mound at $\mathrm{B}$ Pond. The aquifer at B Pond lies primarily within the Ringold Formation, which has significantly lower transmissivity than the Hanford formation.

In the B Pond area, groundwater levels dropped as much as $\sim 2 \mathrm{~m}$ between June 1997 and June 1998 (see Figure 3.3-6). This decline in water level is attributed primarily to discontinued discharges to $B$ Pond. As a result of the discontinued discharges, the water table has fallen below the top of the Ringold formation lower mud unit over much of the B Pond area over the last several years, as illustrated on Plate 2. Water-level elevations in this area represent potentials of the aquifer contained in the Ringold Unit A gravels. The aquifer in this unit is considered semiconfined to confined.

A downward hydraulic gradient between the unconfined aquifer and the upper basalt-confined aquifer occurs at B Pond as a result of the groundwater mound. However, recent geochemical and hydrologic evidence suggests that an upward-directed gradient is possibly becoming reestablished between the upper basalt-confined aquifer and the overlying unconfined aquifer near the former B Pond (PNNL-11986). An area of increased intercommunication between the unconfined aquifer and the upper basalt-confined aquifer was identified in the area north of the 200-East Area based on chemical and hydraulic head evidence (PNL-6313, RHO-RE-ST-12 P). The increased communication is likely caused by local erosion of the upper basalt-confining layer in this area (RHO-RE-ST-12 P).

The water-level declines in the 200-West and 200-East Areas affected the integrity of the monitoring well network for some of the RCRA facilities. For some monitoring wells, the head dropped below the 
bottom of the well screens. In other monitoring wells, the head is low and is expected to drop below the bottom of the well screens within the next few years, assuming the rate of water-level decline continues. The monitoring well network for these RCRA facilities is discussed in the following sections.

\subsubsection{6-S-10 Pond and Ditch}

The stratigraphic section at the $216-S-10$ pond and ditch is similar to that at the $216-U-12$ crib and includes the Hanford formation, the Plio-Pleistocene unit, and the Ringold Formation (WHC-SD-ENDP-052).

The water table is in the lower part of the upper Ringold unit at a depth of $\sim 70 \mathrm{~m}$ and is declining at $\sim 0.45 \mathrm{~m} / \mathrm{yr}$ (Figure 3.6-1). During the operation of U Pond, the groundwater-flow direction at this facility was toward the southeast to east-southeast because of the influence of the large groundwater mound emanating from U Pond. Now that the wastewater discharges have ceased to U Pond, water levels are declining, and the flow in the vicinity of this facility is returning to its prior direction (i.e., from west to east). The flow rate is estimated to be 0.05 to $2.3 \mathrm{~m} / \mathrm{d}$ (see Table $3.3-1$ ).

\subsubsection{6-U-12 Crib}

The unsaturated sediments beneath the 216-U-12 crib are composed of unconsolidated sandy gravel and sand of the Hanford formation, sandy silt and silt of the Plio-Pleistocene unit, and silty sandy gravel to gravelly sand of Ringold Unit $\mathrm{E}$. The unconfined aquifer is within the silty sandy gravels of lower Ringold Unit $E$ and is $\sim 53 \mathrm{~m}$ thick. The depth to the water table is $\sim 75 \mathrm{~m}$ below ground surface. The top of the Ringold lower mud unit locally defines the base of the unconfined aquifer beneath the crib. Details of the stratigraphy beneath the crib may be found in WHC-SD-EN-AP-108.

Water levels declined an average of $0.61 \mathrm{~m}$ during FY 1998 under this crib (Figure 3.6-2), just slightly less than in FY 1997. The water table beneath this crib during June 1998 is illustrated in Plate 2, indicating that the groundwater flow is still toward the east-southeast. While the direction of flow beneath the crib is relatively unchanged from FY 1997 to FY 1998, the average flow rate has been slowly decreasing as a result of a slight flattening of the water table in the vicinity of the crib. The average gradient in FY 1998 was 0.0015 . The flow-rate estimate for June 1998 is 0.03 to $0.1 \mathrm{~m} / \mathrm{d}$ (see Table 3.3-1). .

\subsubsection{0-West Area Single-Shell Tank Farms}

In general, the single-shell tank WMAs in the 200-West Area are underlain by the Hanford and Ringold Formations. Groundwater-monitoring wells in these WMAs are screened primarily in Ringold Unit $\mathrm{E}$ gravels, which contain the water table in these areas. A description of the stratigraphy beneath these tank farms may be found in Section 4.1.3 of DOE/RL-93-88, which also contains numerous crosssections through the 200-West Area. Details of the stratigraphy beneath these tank farms may be found in WHC-SD-EN-AP-012, Rev. 0 and Rev. 1.

\subsubsection{Waste Management Areas S-SX and U Single-Shell Tank Farms}

The unsaturated sediments beneath WMAs S-SX and U are composed of the unconsolidated glacial flood deposits of the Hanford formation, the silts and sands of the Plio-Pleistocene unit, and the sands and 
gravels of Ringold Unit $\mathrm{E}$. The depths to the water table are $\sim 64$ and $\sim 68 \mathrm{~m}$ below ground surface at WMAs S-SX and U, respectively. The unconfined aquifer beneath these WMAs is contained entirely within the sands and gravels of Ringold Unit $E$ and is $\sim 65$ and $\sim 70 \mathrm{~m}$ thick, respectively. On a local scale, the top of the Ringold lower mud unit defines the base of the unconfined aquifer.

The strongest influence on groundwater levels and flow directions beneath these WMAs has historically been the groundwater mound beneath $U$ Pond. Water-table elevations in the vicinity of these WMAs have fallen rapidly since the decommissioning of $U$ Pond in 1985 . The water-table elevation dropped nearly $8 \mathrm{~m}$ between 1984 and the present. Hydrographs in Figure 3.6-3 illustrate the water-level declines and elevation relationships between wells monitoring WMA S-SX. The hydraulic gradient beneath WMA S-SX has decreased with time, and water-table elevations declined $\sim 0.5 \mathrm{~m}$ during FY 1998.

The current direction of groundwater flow beneath WMA S-SX is toward the east to southeast (see Plate 2). The flow-rate estimate ranges from 0.002 to $0.4 \mathrm{~m} / \mathrm{d}$ (see Table 3.3-1). The estimates of hydraulic conductivity used to calculate these flow rates are believed to represent the lower range of hydraulic conductivity expected for Ringold Unit $E$; therefore, these flow rates should be considered lower limits (Section 4.11 in DOE/RL-96-01).

The groundwater-flow direction under WMA U in FY 1998 was toward the east to northeast (see Plate 2). The direction of flow in the northern part of the WMA may be northward because of the influence of extraction wells to the north; however, this influence is not clear on the water-table map (see Plate 2). Figure 3.6-4 shows hydrographs for monitoring wells in the southwestern and southeastern corners of WMA U, respectively. Large volumes of liquid waste were discharged to the 216-U-14 ditch in 1993, causing a reversal in flow directions between 1993 and 1995, which is evident in the hydrographs. Subsequently, flow reverted to an east-southeast direction. More recently, as a result of the 200-ZP-1 Operable Unit pump-and-treat operation, the flow direction has swung around toward the northeast. In FY 1998, water levels beneath the WMA declined $\sim 0.7 \mathrm{~m}$, and the gradient across the WMA appears to have increased slightly (see Figure 3.6-4).

Flow-rate estimates within the unconfined aquifer beneath WMA U range from 0.03 to $0.5 \mathrm{~m} / \mathrm{d}$ (see Table 3.3-1).

\subsubsection{Waste Management Areas T and TX-TY Single-Shell Tank Farms}

The unsaturated sediments beneath WMAs $\mathrm{T}$ and TX-TY are composed of the unconsolidated glacial flood deposits of the Hanford formation, the silts and sands of the Plio-Pleistocene unit, and the sands and gravels of Ringold Unit E. The depths to the water table are $\sim 71$ and $\sim 66 \mathrm{~m}$ below ground surface at WMAs T and TX-TY, respectively. The unconfined aquifer beneath these WMAs is contained entirely within the sands and gravels of Ringold Unit $E$ and is $\sim 60 \mathrm{~m}$ thick. On a local scale, the top of the Ringold lower mud unit defines the base of the unconfined aquifer.

The groundwater-flow direction beneath WMAs T and TX-TY was primarily to the north when the groundwater mound developed beneath U Pond. As the mound began to decline following decommissioning of U Pond in 1985, the flow direction began shifting eastward. In FY 1998, the flow direction was toward the east beneath WMA T and the northern part of WMA TX-TY (see Plate 2). Flow 
directions beneath the southern part of WMA TX-TY are most affected by groundwater withdrawal for remediation of the 200-ZP-1 Operable Unit. The flow direction in this part of the WMA is south or southwest toward the groundwater-withdrawal wells. At WMA T, the hydraulic gradient is 0.0014 , and the estimated flow rate is 0.05 to $0.14 \mathrm{~m} / \mathrm{d}$ (see Table 3.3-1). The gradient beneath the northern half of WMA TX-TY is 0.0008 , and the flow rate is estimated to range from 0.04 to $0.43 \mathrm{~m} / \mathrm{d}$ (see Table $3.3-1$ ).

Water-level-elevation trends for wells monitoring WMAs T and TX-TY are presented in Figures 3.6-5 and 3.6-6, respectively. The rate of water-level decline increased sharply in 1995 when discharges of effluent ceased in the 200-West Area. The rate of decline changed from $\sim 0.2$ to $\sim 1.2$ and $\sim 0.3$ to $\sim 1.3 \mathrm{~m} / \mathrm{yr}$ at WMAs T and TX-TY, respectively. However, the hydraulic gradient at WMA TX-TY decreased at that time, while at WMA $T$ it did not. Groundwater withdrawal at the 200-ZP-1 Operable Unit has caused water levels in the upgradient well to fall below water levels in some downgradient wells (see Figure 3.6-6). The rate of water-level decline has slowed somewhat in the last year and averaged $\sim 0.6 \mathrm{~m} / \mathrm{yr}$ at both WMAs in FY 1998 .

\subsubsection{0-West Area Low-Level Burial Grounds}

Burial grounds 218-W-3A, 218-W-3AE, and 218-W-5 make up Low-Level Waste Management Area 3 (LLWMA 3) in the north-central portion of the 200-West Area (see Plate 1). LLWMA 4 is in the south-central portion of the 200-West Area and comprises burial grounds 218-W-4B and 218-W-4C. LLWMA 5 in the north-central portion of the 200-West Area has not been monitored for groundwater since FY 1996 because the burial ground never received waste.

The 200-West Area burial grounds (LLWMA 3 and 4) are underlain by the Ringold and Hanford formations. The unconfined aquifer is entirely within Ringold Unit $\mathrm{E}$. There are indications that the aquifer is locally semiconfined in the northern portions of LLWMA 3 (WHC-SD-EN-DP-049). The depths to the water table are $\sim 67$ and 64 to $74 \mathrm{~m}$ below ground surface at LLWMAs 3 and 4 , respectively. The saturated thickness is $\sim 62$ to $\sim 75 \mathrm{~m}$ beneath LLWMA 3 and $\sim 62$ to $\sim 72 \mathrm{~m}$ beneath LLWMA 4 . At LLWMA 3, because of stratigraphic discontinuity, either the top of the Ringold lower mud unit or the top of the basalt defines the base of the unconfined aquifer.

The groundwater-flow direction beneath LLWMA 3 is to the northeast (see Plate 2). The eastward component is increasing with time, as expected, resulting from the decreased liquid disposal in the 200-West Area. The flow rate beneath LLWMA 3 is estimated to be 0.0001 to $0.13 \mathrm{~m} / \mathrm{d}$ (see Table 3.3-1).

Water-level data from the wells that monitor the base of the unconfined aquifer beneath LLWMA 3 indicate that the vertical gradient in this area is downward. Water-level elevations in a shallow, upgradient well are generally $0.15 \mathrm{~m}$ greater than in a deep well, for a downward gradient of 0.0026 .

The groundwater-flow direction beneath LLWMA 4 is primarily from west to east. Groundwater flow was from east to west as recently as 1995 . The estimated flow rate beneath LLWMA 4 is 0.2 to $0.6 \mathrm{~m} / \mathrm{d}$ (see Table 3.3-1). The 200-ZP-1 Operable Unit pump-and-treat project is affecting the flow regime beneath LLWMA 4, with withdrawal occurring to the east and injection to the west of the facility. 
The vertical groundwater gradient in the unconfined aquifer beneath LLWMA 4 appears to be downward. Two sets of paired wells monitor the upper and lower portions of the confined aquifer and data therefrom indicate a very slight upward gradient at this time. However, the head differences are well within the margin of error $(0.02 \mathrm{~m})$ for water-level measurements. The other paired set of wells shows a downward differential of $0.23 \mathrm{~m}$, for a downward gradient of 0.003 .

\subsubsection{6-A-10, 216-A-36B, and 216-A-37-1 Cribs}

These cribs (also known as the plutonium-uranium extraction [PUREX] cribs) are in the southeastern portion of the 200-East Area (see Plate 1). The ground surface is relatively flat, but slopes gently toward the north. Elevation of the ground surface ranges from $\sim 220 \mathrm{~m}$ near the $216-\mathrm{A}-10$ and $216-\mathrm{A}-36 \mathrm{~B}$ cribs to $205 \mathrm{~m}$ near the $216-\mathrm{A}-37-1 \mathrm{crib}$.

The general stratigraphy in the vicinity of these cribs includes, from the surface downward, a discontinuous and thin veneer of Holocene-Age eolian sand, the Hanford formation, and the Ringold Formation (PNNL-11523). The Hanford formation consists predominantly of sand, but contains substantial percentages of gravel in the lowermost and uppermost portions of the unit. The Ringold Formation contains thick layers of river gravel intercalated with sequences of overbank silts and fine-grained paleosols.

Although the stratigraphy at all three crib sites contains the general stratigraphic sections described above, there are differences between the 216-A-10 and 216-A-36B cribs and the area near the 216-A-37-1 crib. To the southwest near the 216-A-10 and 216-A-36B cribs, the Ringold Formation contains three mappable units, including coarse-grained fluvial Units A and E (WHC-SD-EN-TI-012) that are separated with the fine-grained lower mud unit. However, in the vicinity of the 216-A-37-1 crib (northeast), the lower mud unit and Unit $\mathrm{E}$ are missing. There, the Hanford formation rests directly on Ringold Unit $\mathrm{A}$.

Near the 216-A-10 and 216-A-36B cribs, the unconfined aquifer is in the saturated portion of Ringold Unit $E$. The water table lies at $\sim 122 \mathrm{~m}$ above mean sea level. The base of the unconfined aquifer is the top of the lower mud unit at $\sim 100 \mathrm{~m}$ above mean sea level. Monitoring wells are screened entirely in the unconfined aquifer. Below the lower mud unit, Ringold Unit $A$ forms a locally confined aquifer, which is $\sim 24 \mathrm{~m}$ thick. Near the 216-A-37-1 crib, the unconfined aquifer is within the lowest portion of the Hanford formation or the upper part of the Ringold Formation (Unit A). The lower mud unit is not present, so the saturated zone is entirely unconfined to the base of the Ringold Formation at $\sim 85 \mathrm{~m}$ above mean sea level. Therefore, the thickness of the unconfined aquifer system near the $216-\mathrm{A}-37-1 \mathrm{crib}$ is $\sim 37 \mathrm{~m}$.

Groundwater-flow direction in the area northeast of the PUREX cribs, interpreted from water-table maps, is predominantly from the northeast to the southwest because of the influence of $B$ Pond, where the flow is radially outward. However, to the west and northwest, the water table is extremely flat, making estimates of flow direction and rate unreliable. Estimates from contaminant-plume maps suggest that the flow direction in the area west and northwest of the PUREX cribs is to the southeast. Therefore, based on contaminant-distribution patterns, groundwater from the B Pond area most likely joins groundwater from the western and northwestern 200-East Area and flows toward the south and southeast. The flow rate beneath the $216-\mathrm{A}-10$ and $216-\mathrm{A}-36 \mathrm{~B}$ cribs is estimated to be between $\sim 0.4$ and $\sim 53 \mathrm{~m} / \mathrm{d}$. Flow-rate estimates beneath the $216-\mathrm{A}-37-1$ crib range from $\sim 0.01$ to $\sim 0.1 \mathrm{~m} / \mathrm{d}$ (see Table 3.3-1). 


\subsubsection{6-A-29 Ditch}

The stratigraphy underlying the 216-A-29 ditch consists of the Hanford and Ringold Formations. The Hanford formation, $\sim 85 \mathrm{~m}$ thick, is predominantly composed of loose, sandy, pebble-cobble gravel and a gravelly sand with a thick layer of sand and/or muddy sand. The sand-dominated facies occurs between sequences of gravel-dominated facies west to east along the margin of the ditch (WHC-SD-EN-TI-019, WHC-SD-EN-TI-071). Where this occurs, the Hanford formation is subdivided into an upper gravel sequence, a sandy sequence, and a lower gravel sequence. The top gravel unit is discontinuous north and south of the ditch. Sediments of the Ringold Formation consist of Units A and E gravel and sand sequences and the lower mud unit (WHC-SD-EN-TI-019, WHC-SD-EN-TI-071, WHC-SD-EN-TI-290). The unconfined aquifer beneath the ditch lies mainly within the gravelly sediments of Ringold Unit A. The saturated thickness ranges between $\sim 2 \mathrm{~m}$ at the discharge (lower) end of the ditch to $\sim 24 \mathrm{~m}$ at the head (upper) end. The depth to the water table is $\sim 76 \mathrm{~m}$ below ground surface.

The direction of groundwater flow beneath the ditch is west-southwest at $\sim \mathrm{S} 60^{\circ} \mathrm{W}$, based on tritiumand nitrate-plume maps (Plates 3 and 4, respectively) and on water-level elevations in the monitoring wells. The tritium-plume map (see Plate 3 ) shows that the flow direction swings to the southeast as groundwater flows to the southeastern corner of the 200-East Area. The calculated gradient is $\sim 0.0005$ for the entire length of the ditch and yielded a flow rate of $\sim 0.03$ to $\sim 0.09 \mathrm{~m} / \mathrm{d}$ (see Table 3.3-1).

The water table beneath the ditch has steadily declined since discharges to the $\mathrm{B}$ Pond system were terminated. Figure 3.6-7 shows the water levels are continuing to decline in wells monitoring the head and discharge ends of the ditch. The change in water-table elevation resulted in a flattened water table at the headend of the ditch and a drop in gradient at the discharge end.

\subsubsection{6-B-3 Pond}

The Hanford formation consists of silty sand to sand and gravel. The vadose zone under most of the facility is composed of Hanford formation sediments. The shallowest aquifer beneath B Pond occurs primarily within sediments of the Ringold Formation. Ringold Formation sediments here consist of Unit A gravel and the lower mud unit, which is discontinuous in the northern portion of this area. The water table is generally near the contact between the Hanford and Ringold Formations, and the aquifer is locally confined, especially to the south and southeast of the facility. Depths to the water table range from $\sim 30$ m northeast to $\sim 73 \mathrm{~m}$ southwest of the main pond.

Groundwater has historically flowed radially outward from a recharge mound, the apex of which is located in the vicinity of the 216-B-3B expansion pond. Large volumes of wastewater recharging the aquifer created the mound and significantly altering the original flow pattern of the area. In the past, the mound was even more extensive than at present because of larger volumes of effluent discharge to the system. As the rate of effluent discharge decreased, water levels in wells generally declined with time, and the mound is now becoming less discernible as a hydrologic feature. Only as recently as 1998 did the configuration of this feature change significantly. As a result, the groundwater-flow direction at the main pond has changed from west to southwest (see Plate 2).

Groundwater levels at B Pond declined $2.4 \mathrm{~m}$ between June 1997 and June 1998. The composite hydrograph in Figure 3.6-8 illustrates the typical patterns of water-level declines in B Pond wells. For 
most wells, the rate of decline accelerated in 1997 and then decreased abruptly, as shown by the trend in well 699-43-43. However, the water-level decline in a few wells maintained a steady rate, as shown by the trend for well 699-44-39B. These declines in water level are primarily attributed to the cessation of discharges to B Pond between 1994 and 1997.

The projected life of wells at the Hanford Site was modeled (PNL-10196) using the Coupled Fluid, Energy, and Solute Transport (CFEST) model (BMI/ONWI-660). In the B Pond-monitoring network, 7 wells were predicted to be dry before the year 2000. Most of the wells projected to be dry are near the main pond. In fact, all wells in the network currently containing the least amount of water in the casing coincide with those predicted to go dry. Four of these wells $(699-42-41,699-43-40,699-43-42 \mathrm{~J}$, and 699-43-43) are now considered dry, for practical purposes.

Estimates of groundwater-flow rates near the B Pond system are mostly based on numerical modeling, hydraulic conductivity and effective porosity estimates, and by the tracking of tritium migration from the 200-East Area operations to the Columbia River (PNL-6328, PNNL-11604, PNWD-1974 HEDR). Based on June 1998 water-level measurements, the horizontal component of the hydraulic gradient near $B$ Pond is estimated at -0.008 near the former location of the main pond but considerably less elsewhere within the boundary of the facility (see Plate 2). The average horizontal flow rate determined by these methods is estimated to range from 0.03 to $51 \mathrm{~m} / \mathrm{d}$ (see Table 3.3-1). This wide range of estimated flow rates reflects the contrast between hydraulic conductivities of the Hanford and Ringold Formations. It can be assumed that these flow-rate estimates have diminished somewhat with the removal of most of the head source (groundwater mound).

The vertical hydraulic gradient was calculated for two well pairs in the network, representing deep and shallow completions. Both pairs indicate a downward hydraulic gradient. Because the screens in each of these wells are open to several meters of aquifer thickness, potentiometric measurements used for the calculations should be considered approximations. The well pairs and the calculated approximate vertical hydraulic gradients for June 1998 are, respectively, 699-43-41E/699-43-41G, 0.08 and 699-43-42J/ 699-42-42B, 0.29. Compared with FY 1997, the downward vertical hydraulic gradient in FY 1998 decreased between well pairs 699-43-41E/G but increased significantly between wells 699-43-42J/ 699-42-42B.

\subsubsection{6-B-63 Trench}

The stratigraphy beneath the 216-B-63 trench consists of the Hanford formation and the Elephant Mountain Member of the Saddle Mountains Basalt. The Ringold Formation is absent beneath this trench; however, some remnants of reworked Ringold Formation sediments may be incorporated into the Hanford formation. The Hanford formation consists of unconsolidated pebble to boulder gravel, fine- to coarsegrained sand, and silt. These deposits are divided into the gravel-, sand-, and silt-dominated facies, respectively (WHC-SD-EN-TI-008, WHC-SD-EN-TI-012). The unconfined aquifer underlying the trench occurs within the lower 3.4 to $6.1 \mathrm{~m}$ of the Hanford formation. The depth to water is $\sim 73 \mathrm{~m}$ below ground surface, and the top of the basalt forms the base of the unconfined aquifer.

The water table under the trench is nearly flat. Based on regional flow patterns, the groundwater direction under the trench is generally from east to west. Flow paths constructed on a water-table map of the regional area indicate that B Pond to the east is the primary source of recharge beneath the trench. 
The gradient was estimated to be in the range of $\sim 0.00005$ and $\sim 0.0003$, using measured water levels from wells monitoring the trench. The flow rate was estimated to be between $\sim 0.03$ and $\sim 0.2 \mathrm{~m} / \mathrm{d}$ (see Table 3.3-1).

Groundwater levels beneath the trench are strongly affected by the dissipating B Pond mound. Figure 3.6-9 shows that water levels in the wells monitoring the trench continued to decline in FY 1998.

\subsubsection{0-East Area Single-Shell Tank Farms}

The single-shell tank farms in the 200-East Area are underlain by the Hanford and Ringold Formations. The Hanford formation beneath these tank farms consists of the gravel-dominated facies, sanddominated facies, and basal interbedded sand and gravel facies. The underlying Ringold Formation includes primarily the lower half of the formation, informally referred to as the Wooded Island member. Two units are found under these tank farms: Unit A, consisting of uncemented to partially cemented pebble to cobble gravels, and at places, the lower mud. Generally, backfill at the tank farms consists of excavated material removed during facility construction. A general description of the stratigraphy beneath these tank farms may be found in DOE/RL-93-99, Rev. 1. Details on the stratigraphy under each of the 200-East Area tank farms can be found in WHC-SD-EN-AP-012, Rev. 1 and WHC-SD-ENTA-004.

The water-table mound beneath B Pond is the controlling influence on the rate and direction of groundwater flow at these tank farms. The discharges to B Pond created the mound that reversed the preHanford flow direction from a west-to-east flow to an east-to-west flow across the northern part of the 200-East Area. As the size of the B Pond mound dissipates, the water table at the tank farms decreased, becoming essentially flat. This results in ambiguities in determination of the local flow directions. Consequently long-term flow paths were, in the past, determined by the migration of contaminant plumes from the area near the PUREX Plant and from the BY cribs in the northern part of the 200-East Area. However, eventually, the flow direction should change back to its natural direction based on basin recharge. Because of the flat water table, it may become necessary to use a different method of flow determination than relying on gradient information and the direction of contaminant transport. The general stratigraphy and current hydrologic information for the three WMAs in the 200-East Area are presented and discussed in the following sections.

\subsubsection{Waste Management Area A-AX Single-Shell Tank Farms}

In addition to the backfill that ranges from 14 to $17 \mathrm{~m}$ thick, there are two main suprabasalt units underlying WMA A-AX. The unsaturated portions of these sediments vary between $\sim 81$ and $90 \mathrm{~m}$ thick. These sediments consist predominantly of interbedded gravel and sand near the surface, extending to $4.6 \mathrm{~m}$ below the base of the backfill followed by a transitional section of interbedded gravel and sand facies. The frequency of gravel beds decreases downward and to the south. These beds are underlain by a well-stratified sand that contains localized interbeds of the gravel and silt facies, extending 4.6 to $12 \mathrm{~m}$. Next, there are 39 to $43 \mathrm{~m}$ of sand-dominated facies. Below this is the basal Hanford formation that consists of interbedded sand and gravel facies similar to those found close to the surface. The top of the basalt defines the base of the unconfined aquifer. 
In the north, erosional remnants of the lower mud unit of the Ringold Formation may be present below the Hanford formation. But as the Ringold Formation slopes to the south where the lower mud is not present, the Hanford formation overlies partially cemented gravels of the lower Ringold Formation.

The saturated aquifer thickness beneath this WMA is estimated to be $27 \mathrm{~m}$. The water table lies in the Ringold Formation, primarily in the partially cemented sandy gravel of Unit A. The direction of groundwater flow based on contours of the regional water table (see Plate 2) was estimated to be westsouthwest, with a flow rate between $\sim 0.005$ and $\sim 0.07 \mathrm{~m} / \mathrm{d}$ (see Table 3.3-1).

Water-table elevations in the monitoring wells are not consistent with the direction of flow based on regional water-table contours. For example, the water-level elevations in wells 299-E24-20 and 299-E25-46, defined as downgradient wells according to the RCRA groundwater-monitoring plan, were consistently higher over time than those in well 299-E25-41, defined as an upgradient well (WHC-SDEN-AP-012, Rev. 1). The maximum difference in the water-table elevations across this WMA was $0.15 \mathrm{~m}$. These discrepancies in water-level elevations cannot be attributed to measurement error because measurement error is random and would not likely yield consistently higher water-level elevations over time. The cause of this discrepancy may be the result of survey error and is currently under investigation.

The elevation of the water table continues to decline because of reduced discharges to cribs, trenches, and ponds. The annual decrease was from 0.13 to $0.15 \mathrm{~m}$ from June 1997 and June 1998. The previous year, the total decline was $\sim 0.22 \mathrm{~m}$. These water-level declines are not great, compared to the $3-$ to $5-\mathrm{m}$ water column in the network wells. Assuming the rate of decline does not increase, the network wells will be usable for monitoring for at least the next 5 years.

\subsubsection{Waste Management Area B-BX-BY Single-Shell Tank Farms}

The unsaturated sediments beneath WMA B-BX-BY are $\sim 73$ to $80 \mathrm{~m}$ thick. Below the tanks, the Hanford formation sediments consist of 3- to 6-m-thick interbedded gravel and sand facies, which contain dominant lenticular, downward-thinning, gravel beds. These are underlain by 37 to $46 \mathrm{~m}$ of wellstratified, coarse to fine-grained sands that contain laterally discontinuous silt interbeds. Gravel beds are present locally. Thin intervals of the Hanford formation gravels contain the water table in the northern part of the site. In the southern part of the WMA, the Hanford formation is underlain by unconsolidated cobble to boulder gravel. Based on a reevaluation during the WMA B-BX-BY assessment, these sediments are reworked Ringold Unit A redeposited as part of the Hanford formation. This unit contains the water table in the southern two-thirds of the site (WHC-SD-EN-TA-004). The presence and thickness of each unit within the unconfined aquifer depend on the location. The saturated aquifer thickness beneath this WMA ranges from 1.9 to $3.7 \mathrm{~m}$. The top of the basalt defines the base of the unconfined aquifer.

As with WMA A-AX, determining the groundwater-flow direction using water-level measurements at this site is difficult because the water table is nearly flat. Water-level data based on the NAVD88 datum are currently being evaluated for the WMA B-BX-BY assessment. The maximum difference in watertable elevations across the site was $0.12 \mathrm{~m}$, calculated between wells 299-E33-33 and 299-E33-13. Water-level elevations in some of the wells are not consistent with a north-trending flow pattern as suggested by regional plume maps. For example, the water-level elevations in wells 299-E33-41 and 299-E33-42, defined as downgradient wells in the RCRA groundwater-monitoring plan, are consistently higher than those in well 299-E33-33, defined as an upgradient well (WHC-SD-EN-AP-012, Rev. 1). 
These discrepancies in water-level elevations cannot be attributed to measurement error, which is random and not likely to yield consistently higher water levels over time.

In the past, it has been assumed that the general groundwater-flow direction is to the northwest based on the regional nitrate- and technetium-99-plume maps (see Plate 4 and Figure 5.10-1, respectively). However, water-level data are scheduled to be evaluated and refined in FY 1999 in support of the RCRA assessment of this site to better determine the local flow direction. The flow rate beneath WMA B-BX-BY was estimated to be between $\sim 0.07$ and $\sim 0.2 \mathrm{~m} / \mathrm{d}$, a slight increase from FY 1997 (see Table 3.3-1).

The water table continues to decline in this region as the B Pond mound dissipates. The annual decrease in water levels ranged from 0.11 to $0.16 \mathrm{~m}$, which is slightly less than reported in FY 1997. These declines are small compared to the height of the water columns in the network wells. Water columns in network wells range from a maximum of $3.7 \mathrm{~m}$ in well 299-E33-43 to $1.9 \mathrm{~m}$ in well 299-E33-42. Assuming the rate of decline does not increase, the network wells will be usable for at least the next 5 years.

\subsubsection{Waste Management Area C Single-Shell Tank Farm}

The unsaturated sediments beneath WMA $\mathrm{C}$ range between $\sim 71$ and $82 \mathrm{~m}$ thick. The unconsolidated sediment rests on the Elephant Mountain Member of the Saddle Mountains Basalt and consists of $\sim 6 \mathrm{~m}$ of gravelly muddy sand. Above this lies $15 \mathrm{~m}$ of muddy sandy gravel. Although this unit may represent the lowermost Hanford formation (WHC-SD-EN-AP-012, Rev. 1), more recent work suggests that this basal unit may be part of Ringold Unit A (WHC-SD-EN-TA-004). The water table lies within these gravels, and the aquifer is estimated to be $\sim 13.8 \mathrm{~m}$ thick.

Above this gravel, extending to the surface, is a relatively thick $(\sim 1.1 \mathrm{~m})$ sand sequence with intercalated sands, some sandy gravels, and gravelly sands associated with the sand-dominated facies of the Hanford formation. The upper layer consists of $\sim 20 \mathrm{~m}$ of gravel-dominated facies, described as a sandy gravel to a.gravely sand.

The groundwater-flow direction, based on regional water-table contours, is generally toward the southwest (see Plate 2). This is generally consistent with water-elevation data from the monitoring wells. Well 299-E27-7, along the WMA's northeastern edge, is upgradient from the other monitoring wells. The flow rate is estimated at 0.01 to $0.11 \mathrm{~m} / \mathrm{d}$ (see Table 3.3-1), with the maximum difference in water-table elevations across the site in June $1998(0.15 \mathrm{~m})$, the same as last year.

The elevation of the water table continues to decline, reflecting the reduction in discharges to cribs, trenches, and ponds. Decreases in the water-table elevations range from 0.13 to $0.19 \mathrm{~m}$ between June 1997 and June 1998. These declines are not great compared to the height of the water columns in the network wells that vary from 2.7 to $15.6 \mathrm{~m}$. Assuming the rate of decline does not increase, the network wells will be usable for monitoring for at least the next 5 years. 


\subsubsection{0-East Area Low-Level Burial Grounds}

LLWMA 1 is located in the northwestern corner of the 200-East Area (see Plate 1). All of the 218-E-10 burial ground is included in this LLWMA. LLWMA 2 is located in the northeastern corner of the 200-East Area and includes all of burial ground 218-E-12B.

The burial ground in LLWMA 1 is underlain by the Hanford and Ringold Formations, and the burial ground in LLWMA 2 is underlain by the Hanford formation. The unconfined aquifer beneath LLWMA 1 is contained in sands and gravels of the Hanford formation and in sediments of the Ringold lower mud unit and Ringold Unit A. The unconfined aquifer beneath LLWMA 2 is contained in the sands and gravels of the Hanford formation, which directly overlie the basalt. The top of the basalt defines the base of the unconfined aquifer beneath LLWMAs 1 and 2. The depth to the water table ranges between 71 and $87 \mathrm{~m}$ below ground surface at LLWMA 1 and 57 and $74 \mathrm{~m}$ below ground surface at LLWMA 2. The aquifer thickness ranges from $\sim 3$ to $\sim 8 \mathrm{~m}$ beneath LLWMA 1 and from 0 to $\sim 2 \mathrm{~m}$ beneath LLWMA 2 .

Determining the groundwater-flow direction in the area of LLWMA 1, using only water-level data from the monitoring wells, is unreliable because the gradient in this area is extremely low. A better estimate of the flow direction can be inferred from contaminant-plume maps (e.g., Plates 3 and 4). The contamination distribution suggests that the general direction of flow is to the northwest beneath LLWMA 1. An estimate of the flow rate beneath LLWMA 1 was calculated to be $0.5 \mathrm{~m} / \mathrm{d}$ or less (see Table 3.3-1). The flow rate is uncertain because the hydraulic gradient is extremely low, on the order of 0.00006 or less. The hydraulic gradient was determined from water-table contours of the regional flow system.

As with LLWMA 1, water-level data from LLWMA 2 monitoring wells cannot be used to determine the groundwater-flow direction because the gradient is extremely low. The flow direction in this area is primarily from east to west based on water-table contours of the regional flow system. The basalt high north and east of LLWMA 2 and the continued presence of the B Pond groundwater mound affect flow. The flow rate beneath LLWMA 2 is estimated to be $\sim 0.8 \mathrm{~m} / \mathrm{d}$ (see Table 3.3-1). This estimate is uncertain because the gradient beneath LLWMA 2 is low, on the order of $\sim 0.00004$.

\subsubsection{Liquid Effluent-Retention Facility}

The stratigraphy beneath this facility is primarily composed of gravel-dominated sediments of the Hanford formation with occasional interbedded fine-grained zones. Isolated erosional remnants of Ringold Unit A exist locally between the Hanford formation and the underlying basalt bedrock (WHC-SD-EN-TI-012, WHC-SD-EN-TI-019, WHC-SD-EN-TI-071, WHC-SD-EN-TI-290). Thin (few meters or less) pockets of Ringold Formation occur to the south (i.e., well 299-E25-9).

The unconfined aquifer beneath this facility is predominantly composed of sediments of the Hanford formation. The thickness of the unconfined aquifer beneath this facility is thin, ranging from 0.2 to $2.1 \mathrm{~m}$. The depth to the water table is $\sim 59.5$ to $61.0 \mathrm{~m}$ below ground surface. The top of the basalt defines the base of the unconfined aquifer.

The direction of groundwater flow beneath the facility is generally to the southwest based on the regional water-table contours (see Plate 2). . However, using only water-level data from wells monitoring 
the facility, the local flow direction is generally to the west. The gradient is 0.002 and reflects the effects from the western flank of the $B$ Pond groundwater mound to the east. The flow rate is estimated to range from 0.04 to $2.4 \mathrm{~m} / \mathrm{d}$ (see Table 3.3-1).

Figure 3.6-10 shows the water-level trends for wells monitoring this facility. In general, the trends indicate that the water table continues to decline in response to a decline in the B Pond mound.

\subsection{Hydrogeology of 400 and 600 Areas J. W. Lindberg}

The 400 Area is located in the south-central portion of the Hanford Site (see Figure 1.1 and Plate 1). The Fast Flux Test Facility and its associated facilities, including the $4608 \mathrm{~B} / \mathrm{C}$ ponds and water-supply wells, are in the 400 Area. The 600 Area includes all of the Hanford Site that is not within other designated operational areas. Facilities in the 600 Area include the Nonradioactive Dangerous Waste Landfill (NRDWL) and the Solid Waste Landfill (SWL), also known collectively as the Central Landfill. These landfills are in the central part of the Hanford Site southeast of the 200-East Area (see Plate 1).

\subsubsection{Area}

At the 400 Area, the Hanford formation consists mainly of the sand-dominated facies. The water table is located near the contact of the Hanford and Ringold Formations, which is $\sim 49 \mathrm{~m}$ below ground surface (WHC-EP-0587). The depth to the water table in the 400 Area varies from -45 to $50 \mathrm{~m}$. Hanford formation sediments dominate groundwater flow in the 400 Area because of their relatively high permeability compared to that of sediments in the Ringold Formation. The Ringold Formation consists, in ascending order, of fluvial gravels and overbank and lacustrine silt and clay, silty sands, sandy gravels, and gravelly sands. The saturated aquifer thickness is $\sim 140 \mathrm{~m}$. The top of the basalt is at a depth of $\sim 185 \mathrm{~m}$. Additional details concerning the geology and the construction of wells near the 400 Area facilities are provided in WHC-EP-0587.

The Hanford Site water-table map (see Plate 2) shows the groundwater-level contours for the 400 Area. The water-table map indicates that flow is generally from west to east across the 400 Area.

\subsubsection{Area}

The NRDWL and SWL are underlain by $180 \mathrm{~m}$ of Hanford and Ringold Formation sediments. The Hanford formation beneath these landfills consists of sands and gravels, dominated by sands near the surface and gravels in the deeper portions of the formation. Thin, discontinuous, silt layers, as well as clastic dikes, are common in the upper part of the formation (WHC-EP-0021). The Ringold Formation consists of the upper Ringold; Ringold Units A, B, C, and E; and Ringold lower mud. The upper Ringold contains a thin, silt-rich layer that may be locally confining (WHC-EP-0021). Ringold Unit E lies below the Hanford formation at a depth of $\sim 70 \mathrm{~m}$, except where remnants of the upper Ringold are present. The upper Ringold has been eroded away over parts of the central Hanford Site. The Ringold lower mud is relatively continuous in this area and acts as a local confining unit to Ringold Unit $A$ that overlies the basalt. Additional details concerning the geology and the construction of wells near these facilities are provided in WHC-EP-0021 and PNL-6852. 
The water table in the central Hanford Site, where the NRDWL and SWL are located, is in the Hanford formation gravels (see Figure 3.1-3). At the NRDWL and SWL, the depth to the water table varies from $\sim 38$ to $41 \mathrm{~m}$ below ground surface. The saturated thickness above the top of the basalt is $\sim 140 \mathrm{~m}$.

A map of the water table (and supporting data) in the vicinity of the NRDWL and SWL based on June 1998 data is presented in Figure 3.7-1 (also see Plate 2). This map indicates low hydraulic gradients in the vicinity. The low gradients are attributed to a zone of very high transmissivities beneath the landfills that extends to the northwest beneath the 200-East Area (see Figure 3.2-2). Transmissivity is high beneath the landfills because the unconfined aquifer lies within the main flow channel of the catastrophic floods that deposited the Hanford formation gravels. Groundwater flows into this highly transmissive zone from the B Pond groundwater mound to the north and from the former U Pond area and Cold Creek recharge area to the west.

Groundwater input from the B Pond mound strongly affects the water-table elevations over a wide area, including the vicinity of these landfills. Figures 3.7-2 and 3.7-3 show that water-table elevations beneath the NRDWL and SWL have dropped $>1.8$ and $1.7 \mathrm{~m}$, respectively, since December 1988. These declines were primarily the result of decreased discharge to B Pond. The rate of decline slightly increased in FY 1997 and FY 1998 after nearly all discharges to B Pond were terminated in FY 1997.

The movement of tritium and nitrate plumes and the measurement of water levels infer groundwaterflow directions beneath the NRDWL and SWL. The tritium and nitrate plumes (see Plates 3 and 4, respectively), which originate in the 200-East Area and pass beneath the landfills, indicate that the principal direction of flow is 125 degrees east of north (Section 17.0 in DOE/RL-91-03), a direction that has remained relatively constant since 1990 . Flow directions based on water-level elevations range between $\sim 96$ and $\sim 139$ degrees east of north. These directions are uncertain because of the low gradient, as indicated by the small differences in elevations between hydrographs (see Figure 3.7-3). The difference in water-table elevations across the area of the landfills ranges from 0.01 to $0.1 \mathrm{~m}$.

The rate of groundwater flow beneath the landfills is uncertain based exclusively on water-level data because the hydraulic gradient is very low. On the basis of site-specific hydrologic testing and the observed hydraulic gradients, the flow rate was estimated to be on the order of 1.2 to $1.8 \mathrm{~m} / \mathrm{d}$ (see Table 3.3-1). However, indicators of flow rate from recent plume movement and tracer tests yield values that range from 6 to $>30 \mathrm{~m} / \mathrm{d}$ (see Table 3.3-1). The flow rate was estimated by the recent decrease in tritium and nitrate concentrations across the landfills. Tritium and nitrate, which have upgradient sources, exhibit nearly identical time-concentration variation in certain upgradient and downgradient well pairs with quarterly sampling. This correspondence indicates that the time required for the contaminants to traverse the site is on the order of 3 months. This traverse time indicates a transport rate of $\sim 6 \mathrm{~m} / \mathrm{d}$. Flow-rate estimates $>30 \mathrm{~m} / \mathrm{d}$ were determined from tracer test results in 1959 (HW-60601); however, the hydraulic gradient was higher than that determined from tritium- and nitrate-concentration variations.

At the NRDWL, two well pairs (699-25-33A/699-25-34A and 699-26-35A/699-26-35C) sample the top of the unconfined aquifer and the top of the Ringold Formation. The lack of a detectable head difference in each of the well pairs indicates that the vertical gradient within the upper portion of the aquifer is negligible. 


\subsection{Hydrogeology of $\mathbf{3 0 0}$ and Richland North Areas}

\section{J. W. Lindberg, D. R. Newcomer}

The 300 and Richland North Areas are located in the southern part of the Hanford Site and vicinity (see Figure 1.1). The 300 Area is adjacent to the Columbia River and was the site of reactor fuelfabrication facilities and research-and-development functions. The Richland North Area is an informal designation for the southernmost part of the Hanford Site and northern part of the City of Richland.

\subsubsection{Area}

The unconfined aquifer in the 300 Area consists of Hanford formation gravels and sands and Ringold Formation gravels and sands with varying amounts of silt and clay (WHC-SD-EN-TI-052). The water table is within the Hanford formation in most of the 300 Area. West and north of the 300 Area, the water table is in Ringold Unit E (see Unit 5 on Figures 3.1-2 and 3.1-3), below the bottom of the Hanford formation. Channeling in the top of the Ringold Formation (PNL-2949, WHC-SD-EN-TI-052) is a factor in controlling groundwater movement in the unconfined aquifer. The Ringold lower mud unit is found below the unconfined Ringold gravels and forms a local confining unit for thin, Ringold, gravel deposits that lie directly above the basalt. The depth to the water table beneath the 300 Area ranges from $<1 \mathrm{~m}$ near the Columbia River to $\sim 18 \mathrm{~m}$ farther inland. Detailed information on the hydrogeology of the 300 Area is provided in WHC-SD-EN-TI-052.

At the 316-5 process trenches (RCRA site), the Hanford formation is 9 to $12 \mathrm{~m}$ thick and is composed of gravelly sand and sandy gravel. The Ringold Formation is $\sim 40 \mathrm{~m}$ thick and comprises two major facies groups. The upper half is interbedded sandy gravels, gravelly sands, and silty sands of Unit $E$. The lower half is composed of sandy and clayey silt of the Ringold lower mud unit, which overlies basalt at this location. The water table at the process trenches is close to the position of the Hanford-Ringold Formation contact.

The primary influence on groundwater-elevation changes in the 300 Area is the fluctuation in Columbia River stage (see Figures 3.5-1 and 3.8-1). Changes in Columbia River-stage elevation can be correlated to changes in water-level elevations at wells as far as $\sim 360 \mathrm{~m}$ from the river (PNL-8580). In FY 1997, river stage was slightly elevated during the winter and early spring, but in June rose to $>3.5 \mathrm{~m}$ higher than a typical river stage in June. This unusually high-river stage caused the highest water levels ever recorded in wells near the 316-5 process trenches. During FY 1998, river stages were typical of an average year (104- to $106-\mathrm{m}$ elevation).

Groundwater-flow directions in the 300 Area vary in response to the rise and fall of river stage. During low to average stages, groundwater in the unconfined aquifer converges at the 300 Area from the northwest and southwest, flows beneath the 300 Area in a west-to-east or northwest-to-southeast direction, and eventually discharges to the river (see Figure 3.8-1). During high-river stages, when the water table rises well above the Hanford-Ringold Formation contact, groundwater temporarily flows in a southwestern to southern direction. In the immediate vicinity of the 316-5 process trenches, the flow direction was primarily to the southeast during FY 1998. During low to average stage, flow in the vicinity of these trenches is generally to the southeast or east (see Section 6.1 in DOE/RL-96-01). 
The flow rate in the top of the unconfined aquifer was $\sim 31 \mathrm{~m} / \mathrm{d}$ near the process trenches based on data from tetrachloroethylene spills that occurred in 1982 and 1984 while the trenches were in use (DOE/RL-89-14) (see Table 3.3-1). Because the trenches artificially recharged groundwater, the water table was steeper when this estimate was made than it is now. The gradient, and hence flow rate, decreased after discharge to the trenches ceased. Flow-rate estimates in FY 1998, based on hydraulic gradients, were 0.35 to $105 \mathrm{~m} / \mathrm{d}$ to the southeast in June 1998 (see Table 3.3-1). The high-flow rates reflect higher hydraulic conductivity of the Hanford formation and the low-flow rates reflect lower hydraulic conductivity of the Ringold Formation.

There is an upward vertical gradient between the unconfined aquifer above the Ringold lower mud unit and the gravels beneath the lower mud unit. In June 1998, the head in well 399-1-17C was $9.4 \mathrm{~m}$ higher than in well 399-1-17A. Well 399-1-17C is screened $42 \mathrm{~m}$ deeper than 399-1-17A; thus, flow is upward, with a vertical gradient of 0.22 . Confined aquifers within the basalt also display higher hydraulic heads than the overlying unconfined aquifer, indicating an upward vertical gradient.

\subsubsection{Richland North Area}

The Richland North Area is located in the southern part of the Hanford Site (see Figure 1.1 and Plate 1), and though not formally defined, includes the former 1100 and 3000 Areas, that part of the 600 Area south of the 300 Area, and parts of nearby Richland between the Yakima and Columbia Rivers.

The unconfined aquifer beneath the Richland North Area occurs within the predominant sands and gravels of the Hanford and Ringold Formations. The depth to water ranges from $<2 \mathrm{~m}$ along the riverbank and adjacent to the Horn Rapids Business Center to $30 \mathrm{~m}$ beneath the Richland Landfill. Aquifer thickness varies, ranging from $\sim 7$ to $32 \mathrm{~m}$. Silty clays overlying the Saddle Mountains Basalt form the aquifer base. Silt and clay lenses in the eastern part of the Richland North Area may result in local, semiconfined to confined conditions within the aquifer. Perched water is found locally in north Richland during the summer irrigation season. Additional details on the hydrogeology of the Richland North Area can be found in DOE/RL-90-18 and PNL-10094.

Figure 3.8-1 shows the June 1998 water-table elevations and illustrates water-level-elevation trends for selected areas of the Richland North Area. Groundwater beneath the Richland North Area generally flows from west to east between the Yakima and Columbia Rivers. The contours indicate that, in the vicinity of the 300 Area, groundwater converges from the northwest, west, and southwest and discharges to the Columbia River. South of the former 1100 Area, flow is to the southeast. This flow field is the result of at least the following regional and local influences:

- net recharge to the City of Richland's North Well Field

- agricultural irrigation and infiltration between the Yakima River and the 1100 Area

- fluctuations in the Columbia River stage

- recharge from the Yakima River.

The City of Richland's North Well Field, in the south-central portion of the Richland North Area, is the primary influence on groundwater-elevation changes in this area. The well field serves as the City of Richland's secondary drinking water-supply system. This system consists of a settling basin and two recharge basins that recharge the unconfined aquifer with water from the Columbia River. Water is then 
pumped from the aquifer via the well field and dispensed to city lines for use. The well field is used primarily when the city's filtration plant is shut down for annual maintenance (January) and during peak water use in the summer months.

Historical data indicate that the ratio of recharge to discharge at this well field has varied from $2: 1$ to 4:1 (PNL-10094). Because of this net recharge, groundwater levels rose in this area and their elevations vary accordingly with the volume of recharge. Groundwater levels immediately west of the well field illustrate this effect (see Figure 3.8-1). Operation of the well field impacts water-table elevations in wells throughout the Richland North Area. In the past, wells as far as $1.6 \mathrm{~km}$ to the north and south of the well field have been identified with water-level changes corresponding to the net recharge to the aquifer (e.g., well 699-S32-E13A). Hydrographs for wells nearest the well field have the highest correlation. The amplitude of water-level response decreases with distance from the well field, decreasing more rapidly to the west and east than to the north and south (PNL-10094).

Irrigation of $\sim 1 \mathrm{~km}^{2}$ of agricultural fields began in 1989 in the area between the Yakima River and the former 1100 Area. The total irrigated land was expanded to $30 \mathrm{~km}^{2}$ by 1991 . Irrigation water has been supplied by the Columbia River and by shallow irrigation wells that are located near wells 699-S42E8A and 699-S42-E8B. Increasing water levels have been observed to the north of these fields along the southern boundary of the Hanford Site as a result of the irrigation (Figure 3.8-2). The water level in this area has risen $\sim 1.4 \mathrm{~m}$ since 1989. An additional $2 \mathrm{~km}^{2}$ of irrigated land were added in 1997, immediately west of Siemens Power Corporation. Continuous monitoring was initiated in two Siemens Power Corporation wells in July 1997 to assess local water-level changes and impacts on groundwater-flow direction. The general trend for both wells, as represented by a well adjacent to the fields, clearly indicates irrigation ceasing in September 1997 and beginning again in May 1998 (Figure 3.8-3).

\subsection{Hydrogeology of Areas East and North of Columbia River D. R. Newcomer, S. P. Reidel}

The Wahluke Slope is that area extending from Umtanum Ridge and the Columbia River north to the Saddle Mountains. The south flank of the Saddle Mountains anticline controls the gentle south slope. The Wahluke syncline lies between Umtanum Ridge and the Saddle Mountains. The principal rock units on the Wahluke Slope are the Columbia River Basalt Group, the Ringold Formation, and the Hanford formation. All three units thin onto the Saddle Mountains. Ringold Formation sediments consist principally of alluvial fan material shed from the Saddle Mountains as the mountains were uplifted; these gravels are intercalated to the south with Columbia River sediments of Ringold age. The Hanford formation consists of gravel deposits near the river and finer slackwater Touchet Bed sediments along the flanks of the Saddle Mountains.

The Columbia River east of the Hanford Site marks the western edge of the Palouse Slope. The Palouse Slope consists of gently west-dipping basalt flows overlying rocks that make up the Paleozoic North American craton. Along the eastern boundary of the Hanford Site, the Ringold Formation and Hanford formation overlie the basalt bedrock. The Ringold Formation consists of ancestral Columbia River and Salmon/Clearwater River gravels that are, in turn, overlain by finer silts, sands, and lake deposits. The Hanford formation consists of gravels and Touchet Bed deposits near the Columbia River 
but, farther east, the gravels give way to only Touchet Bed deposits. At $\sim 15 \mathrm{~km}$ east of the Hanford Site, both the Ringold and Hanford formation deposits pinch out, and basalt bedrock is either exposed at the surface or covered by a thin deposit of loess.

Water-level elevations north and east of the Columbia River are much greater than on the Hanford Site. As indicated in Figure 3.3-1, the water-table elevation to the east of the Columbia River is currently from 50 to $150 \mathrm{~m}$ higher than the water-table elevation on the Hanford Site. Groundwater flow in the unconfined aquifer system north and east of the Columbia River follows the bedrock structure and is toward the Columbia River. The water-table configuration in these areas is heavily influenced by recharge from irrigation with Columbia River water. The irrigated areas are part of the South Columbia Basin Irrigation District. Recharge to the unconfined aquifer system in this area is caused by leakage from canals, wasteways, and ponds and by seepage from irrigated fields (Ebbert et al. 1991). Pumping from wells that tap the unconfined aquifer system is mostly for domestic, stock, and irrigation purposes but yield is commonly low (Bauer et al. 1985). For this reason, pumping from the unconfined aquifer system in this area has little influence on the configuration of the regional water-table surface.

The water-table map (see Figure 3.3-1) shows a steep hydraulic gradient along the eastern bank of the Columbia River east of Gable Mountain in the area known as White Bluffs. A similar steep gradient is exhibited in the area east of the river and north of the 300 Area. These steep gradients represent a series of springs and seepage faces along the bluffs, where groundwater flow intersects the ground surface. Groundwater flow in these areas is controlled primarily by low-permeability zones (i.e., caliche) near the top of the bluffs and other low-permeability horizons in the upper Ringold Formation.

Water-table maps by the U.S. Geological Survey (Drost et al. 1989, 1993, 1997; Ebbert et al. 1995) indicate that the elevation of the water table north of the Columbia River, extending from Wahluke Slope southeast to Columbia Flat, is controlled primarily by the topography of the land surface and the underlying basalt. Comparison of water-level data indicates that the water-table elevation in this area did not change significantly between 1989 and FY 1998. Water-table-elevation contours in the nonirrigated portion of Wahluke Slope north of the Columbia River are inferred because data are limited (i.e., there are few wells for measuring water levels). The sources of information used to infer the contours include the elevation of water in ponds and seeps in the Saddle Mountain National Wildlife Refuge, which is across the Columbia River from the $100-\mathrm{N}$ and $100-\mathrm{K}$ Areas. These data, used in conjunction with topographic elevations, indicate that the 150-m contour extends south and east of the ponds (see Figure 3.3-1). Along. the northeastern border of the Hanford Site, contour flexures are inferred from topographic elevations. 

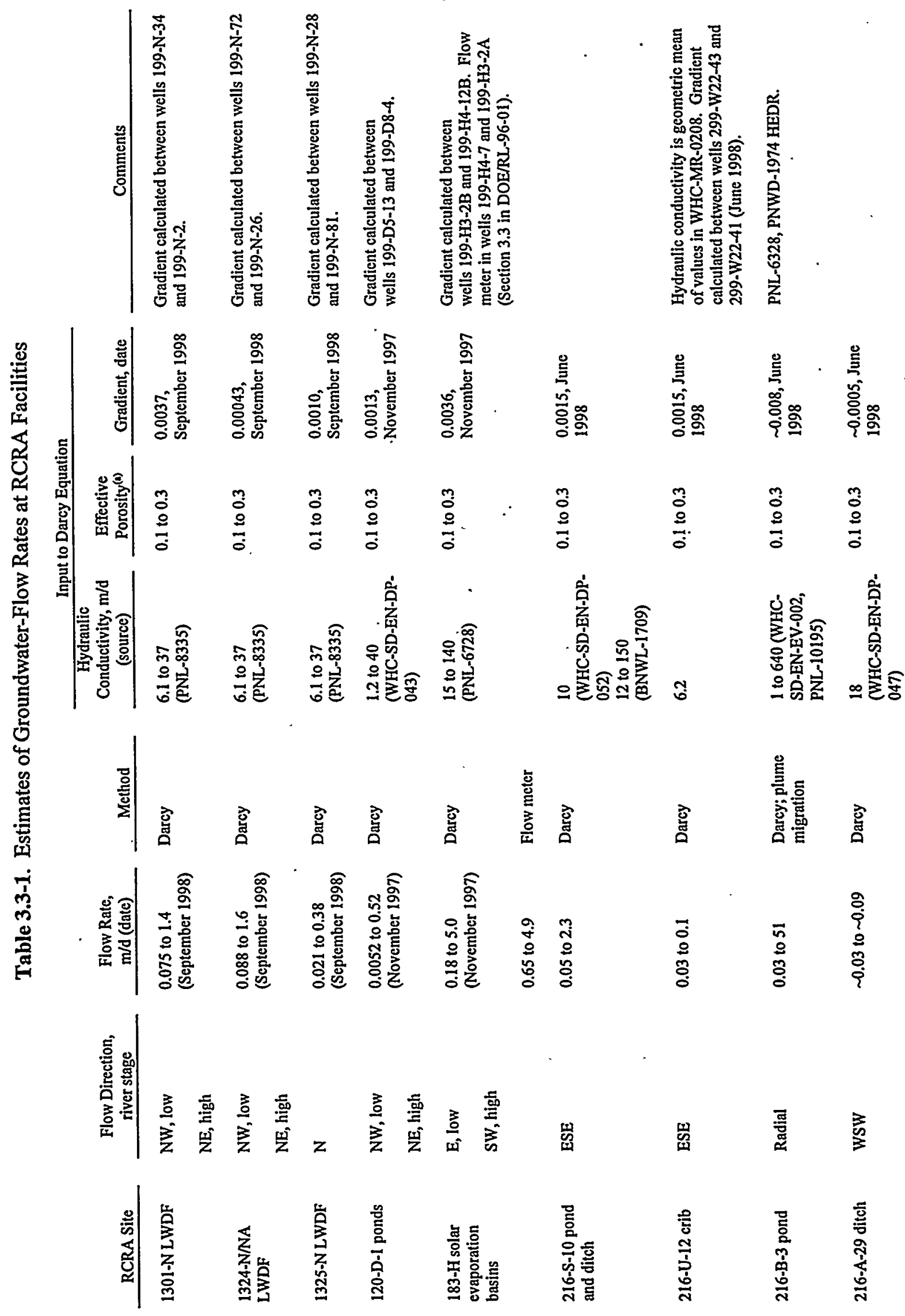

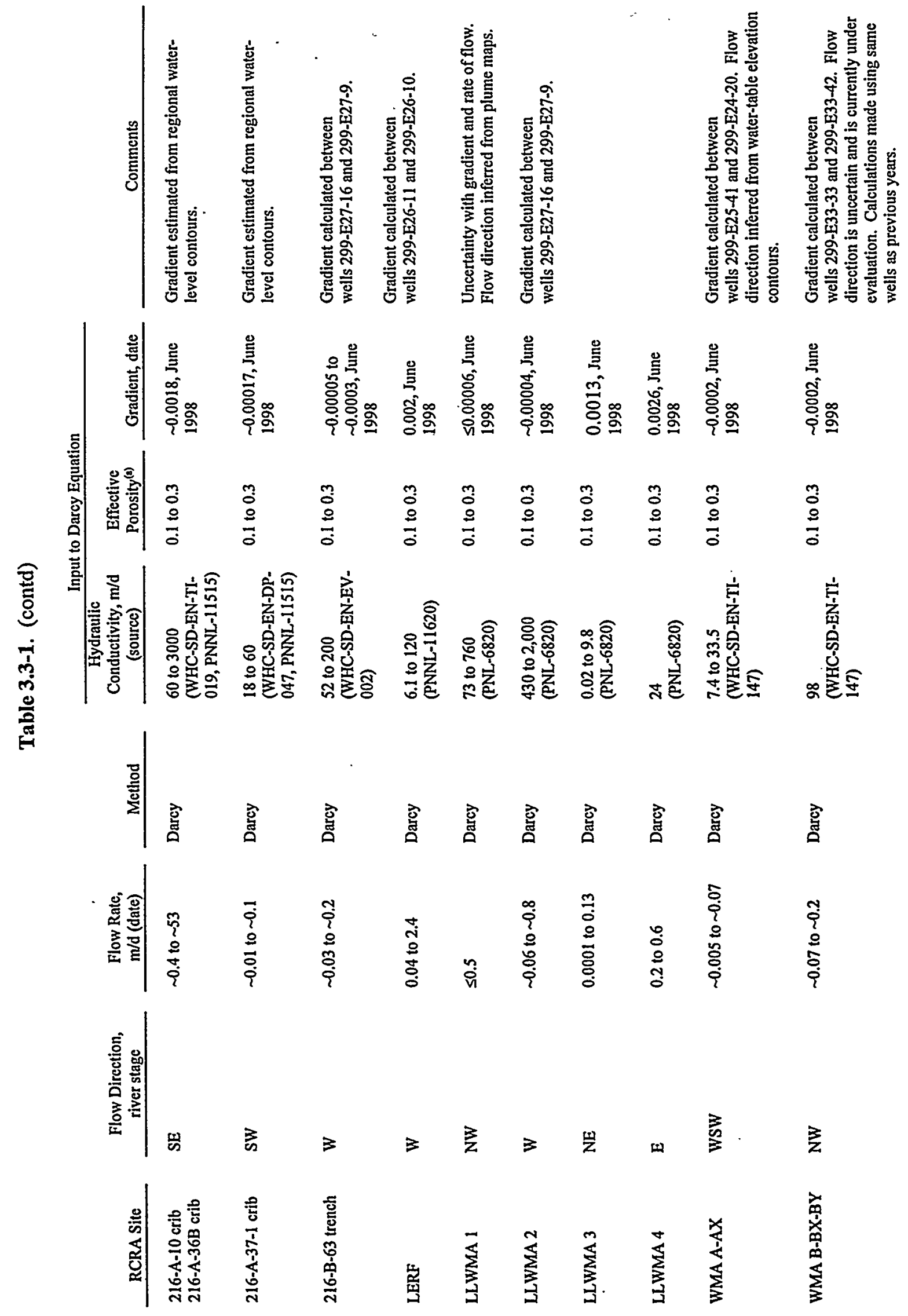

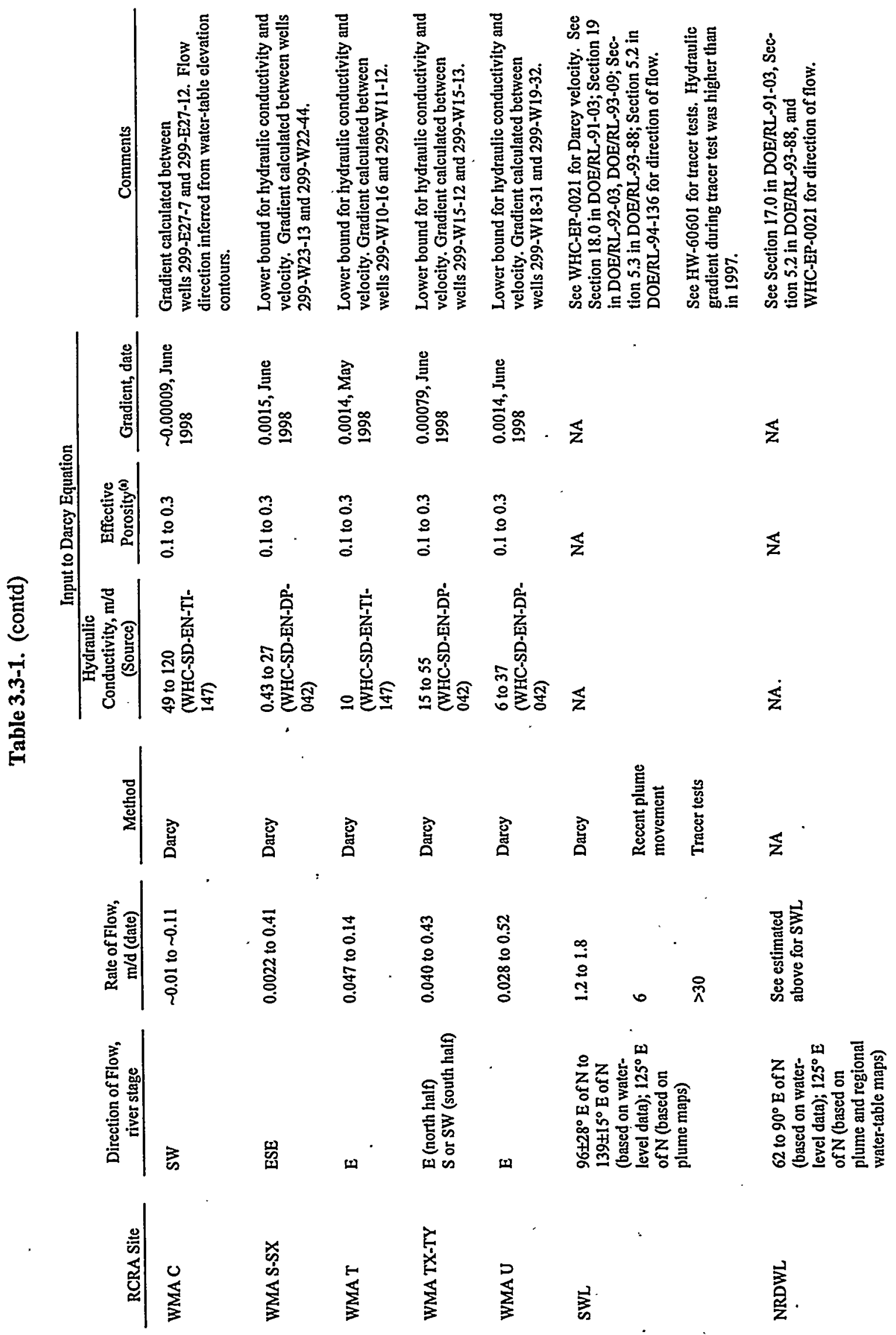


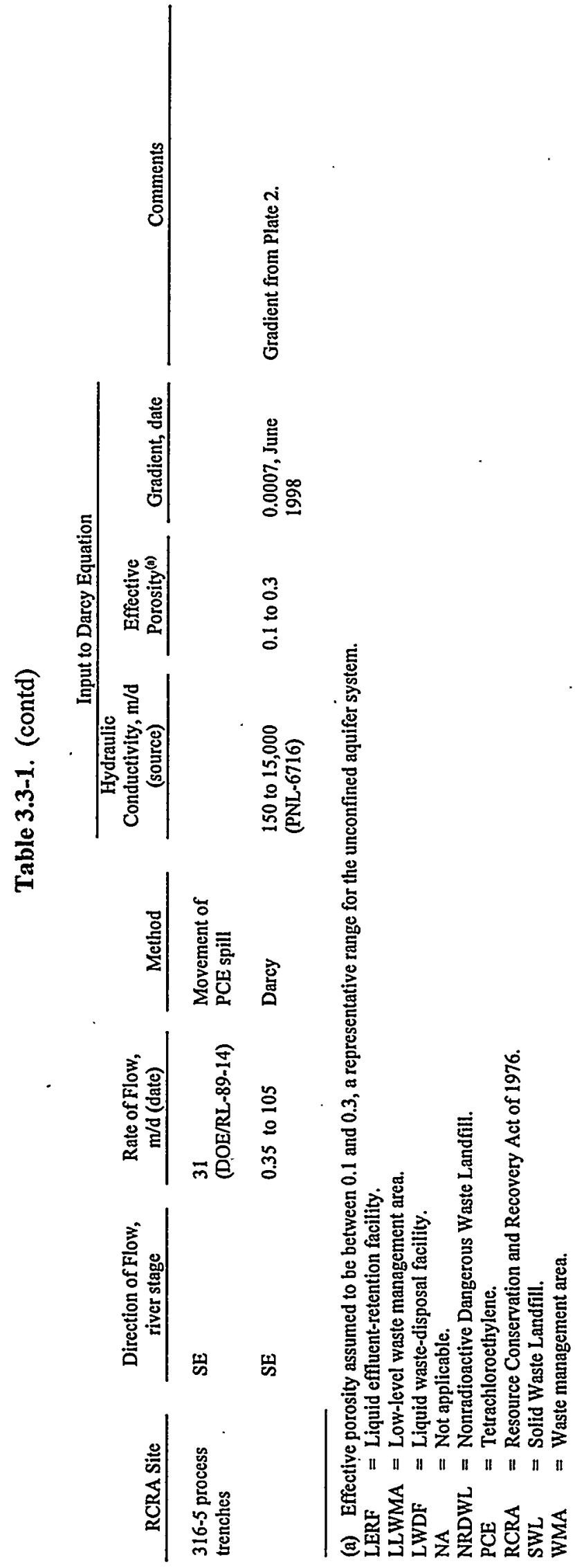




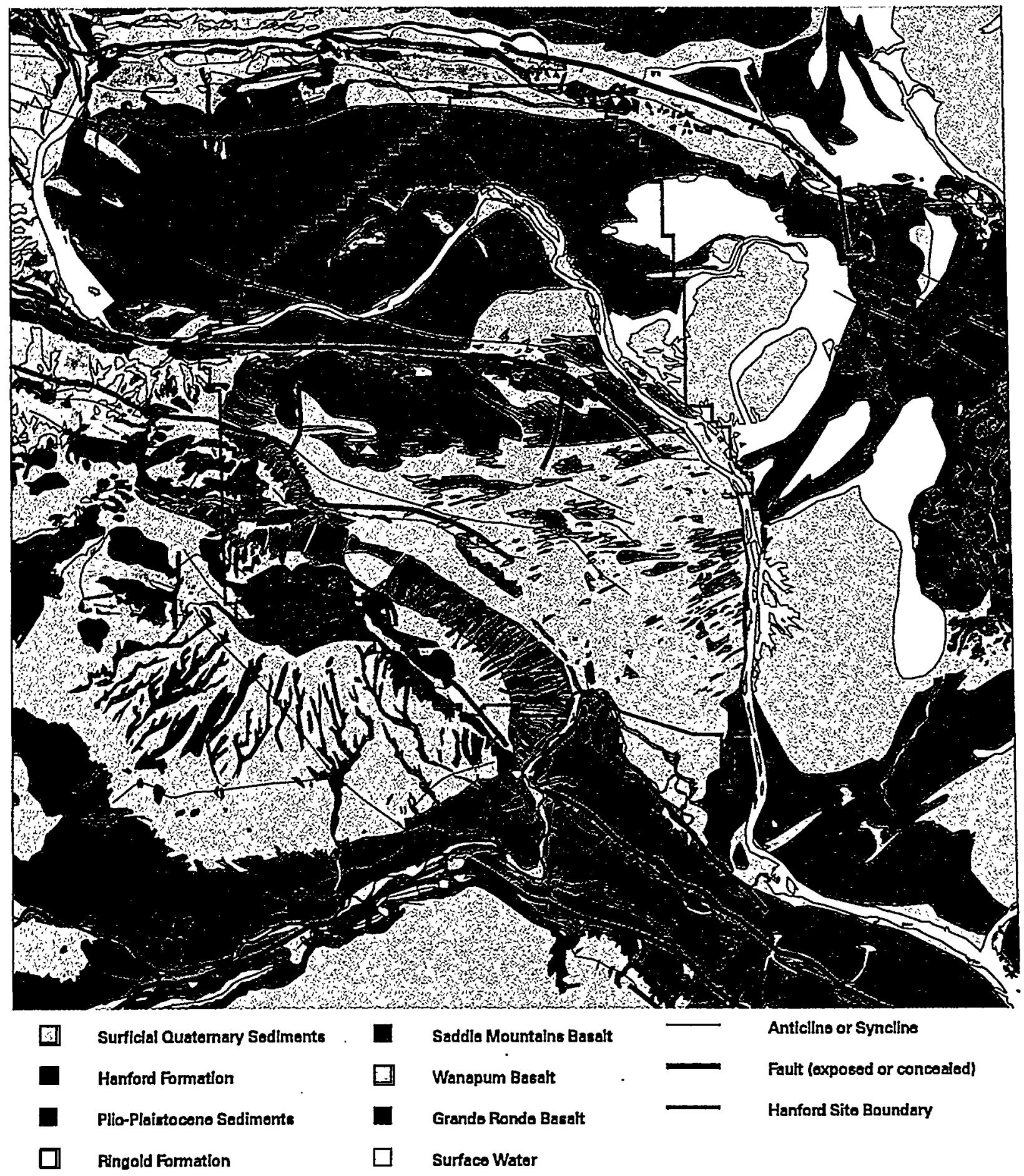

012345678810 kllomotart

$0 \begin{array}{lllll}0 & 3 & 4 & \end{array}$

skw98001.ppa January 26, 1989

Figure 3.1-1. Pasco Basin Surface Geology and Structural Features

(after Reidel and Fecht 1994a, 1994b) 


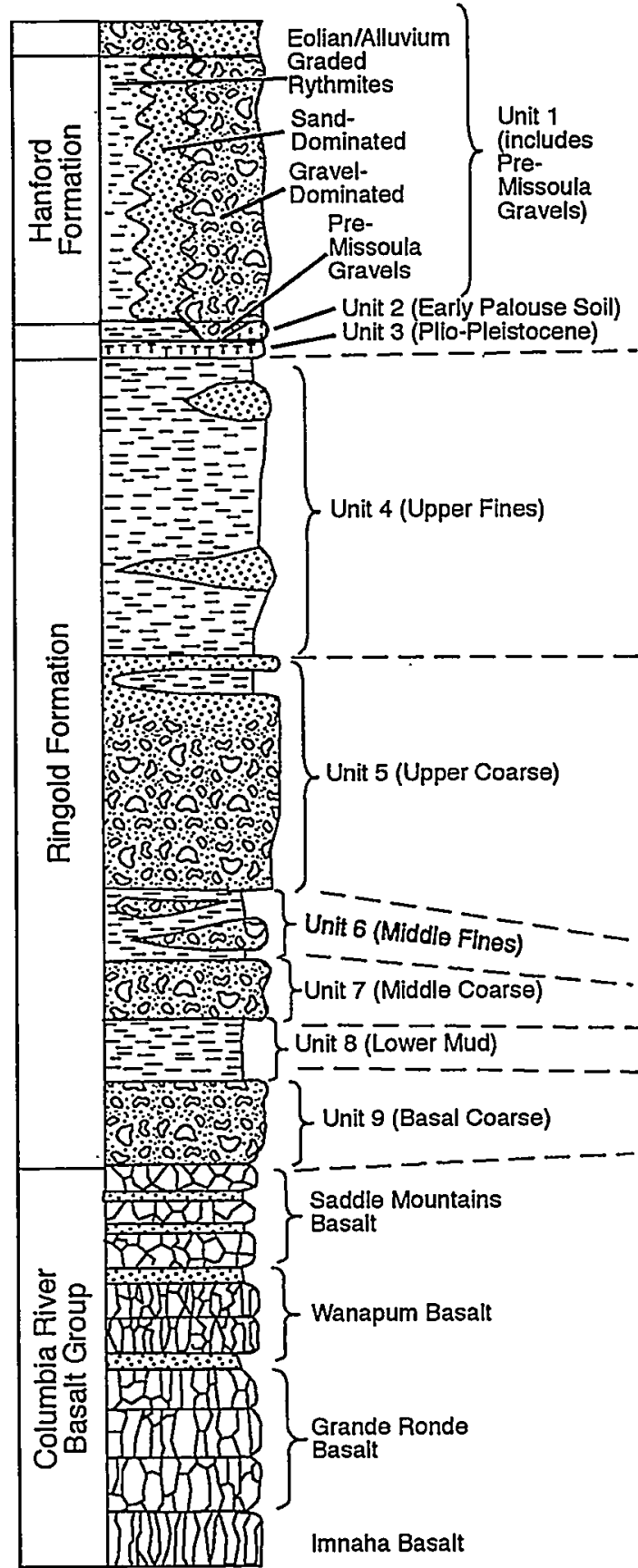

From PNL-8971

\begin{abstract}
Not to Scale
\end{abstract}

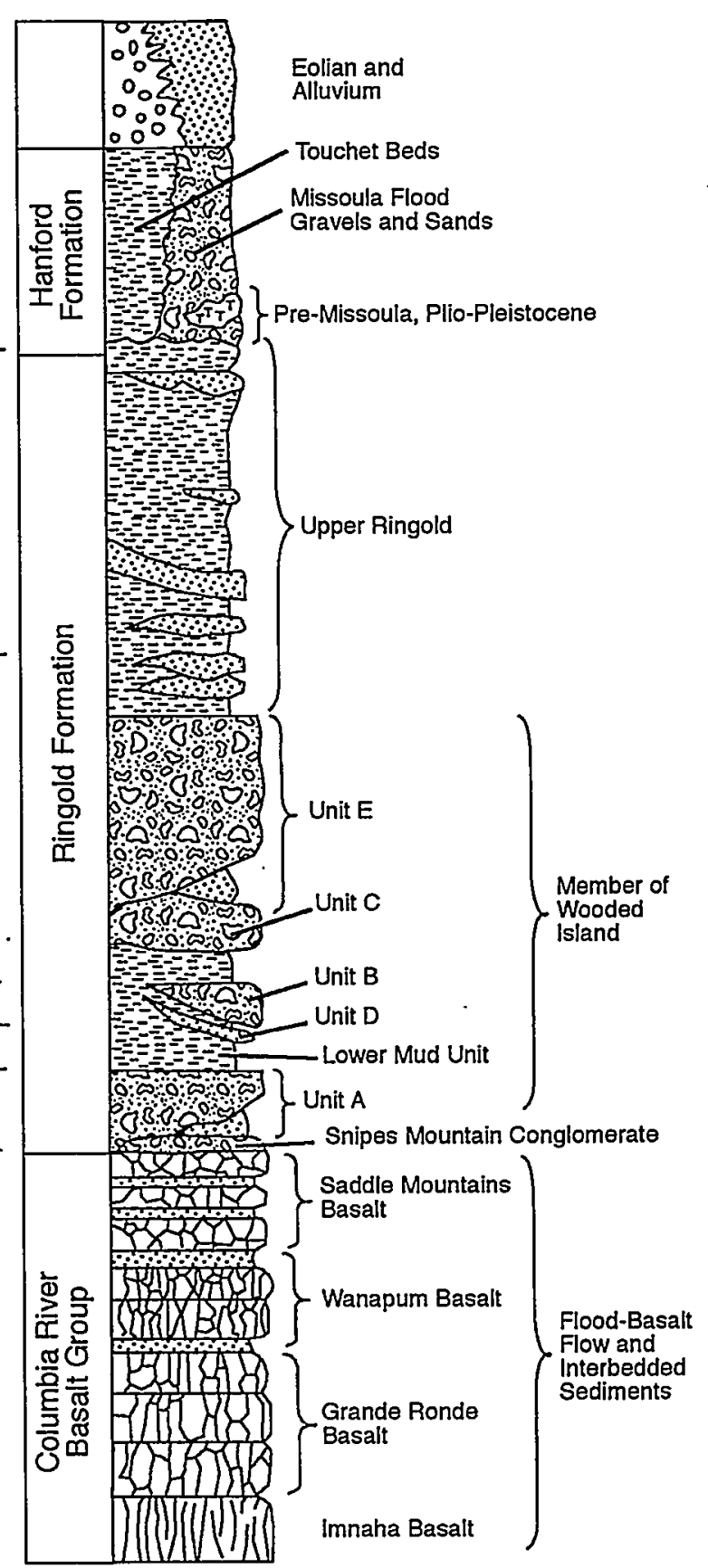

After BHI-00184

RG98120214.14

Figure 3.1-2. Comparison of Generalized Hydrogeologic and Geologic Stratigraphy 


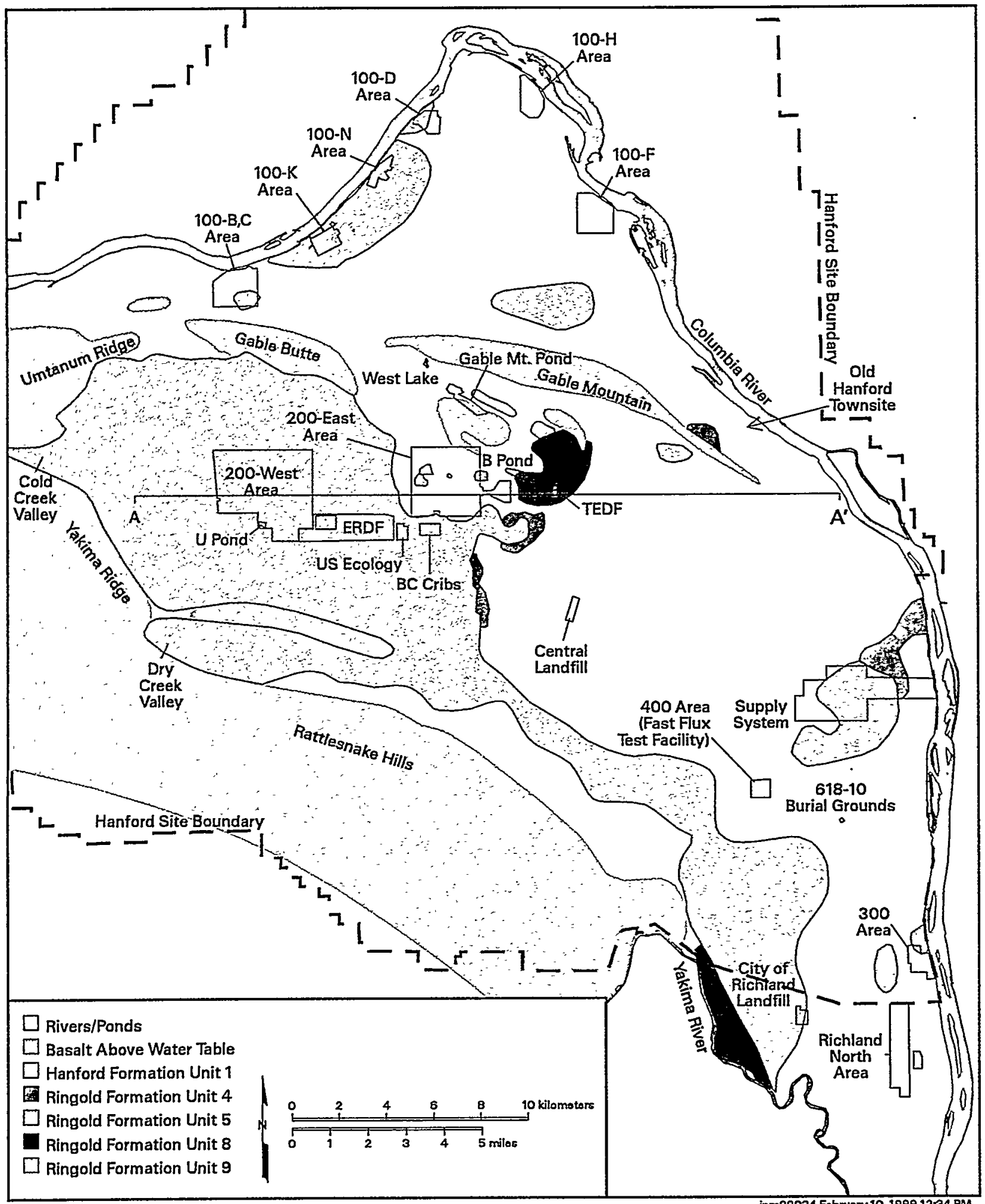

Figure 3.1-3. Hydrogeologic Units Present at Water Table, June 1998 

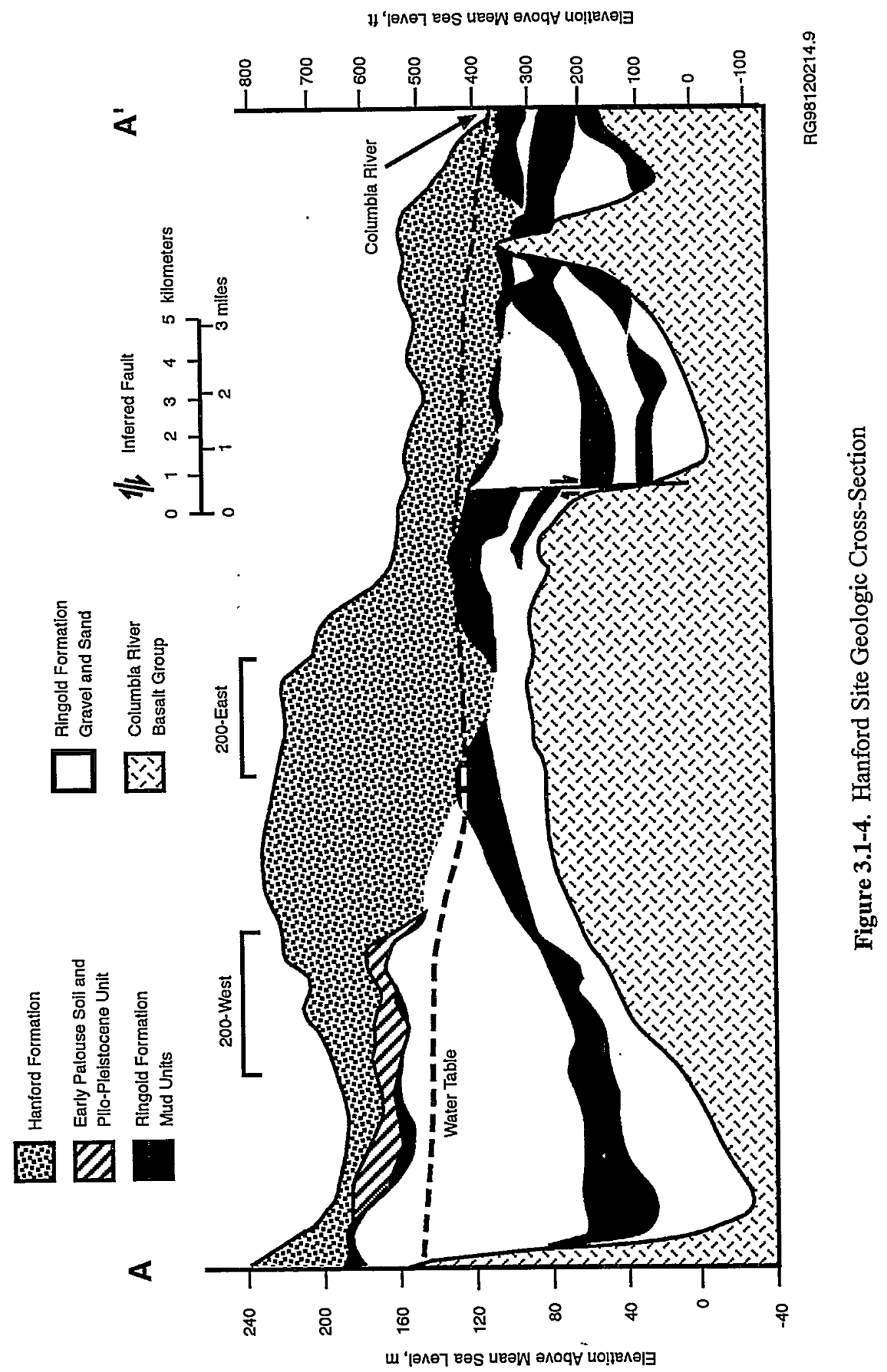


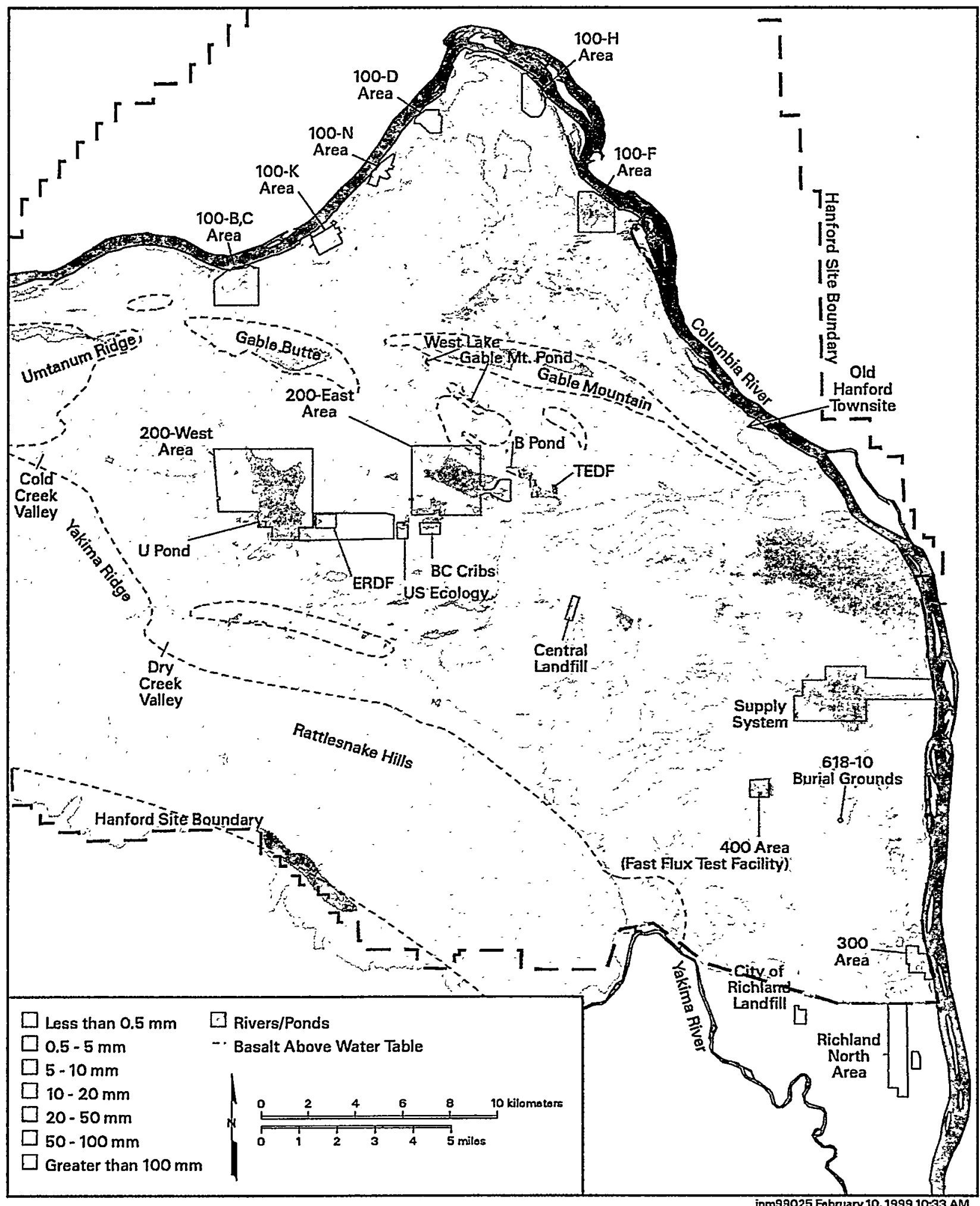

Figure 3.2-1. Estimated Annual Recharge from Infiltration of Precipitation and Irrigation (from PNL-10285) 


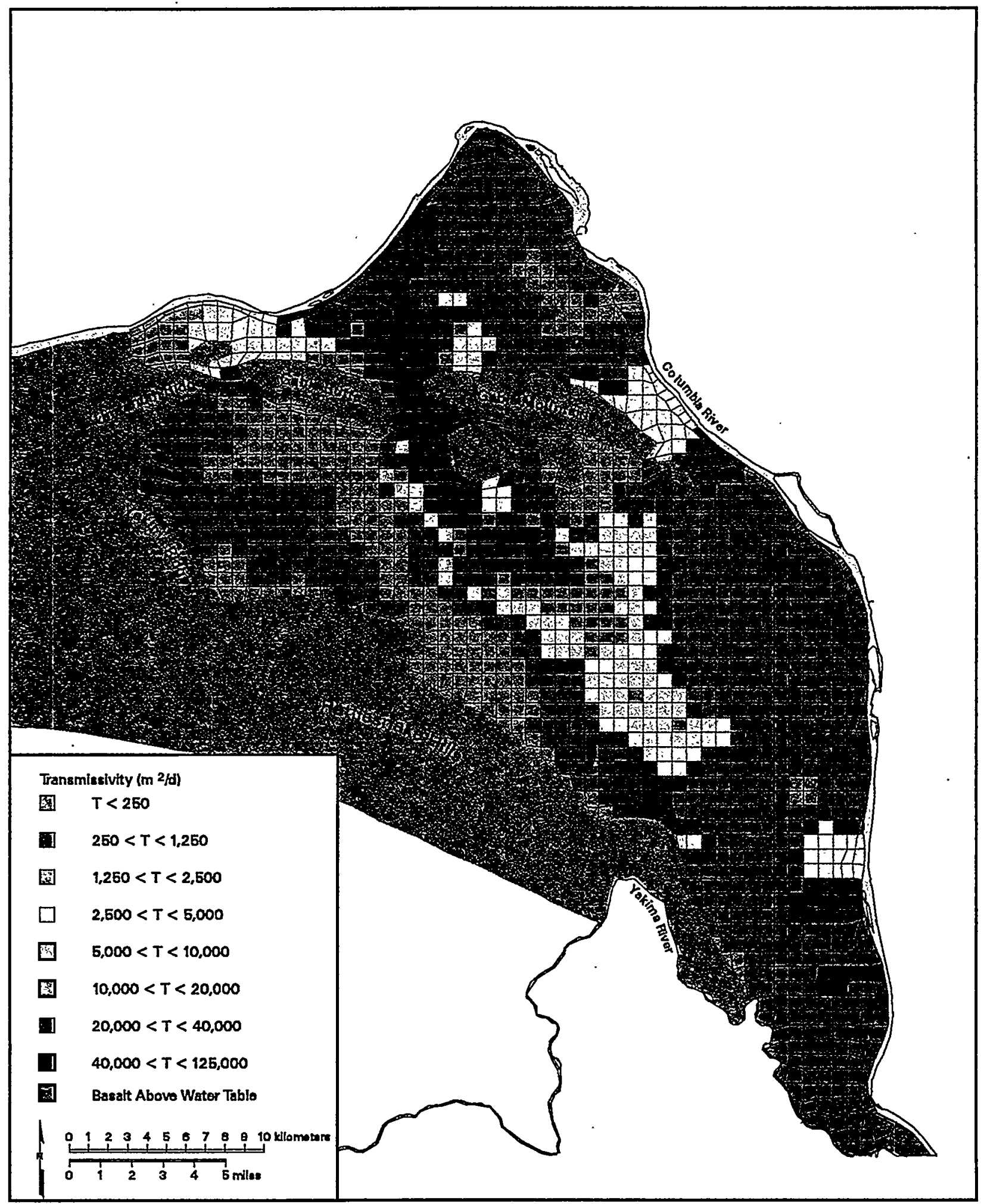

skw98002.sps January 25, 1998

Figure 3.2-2. Transmissivity Distribution from Model Calibration 


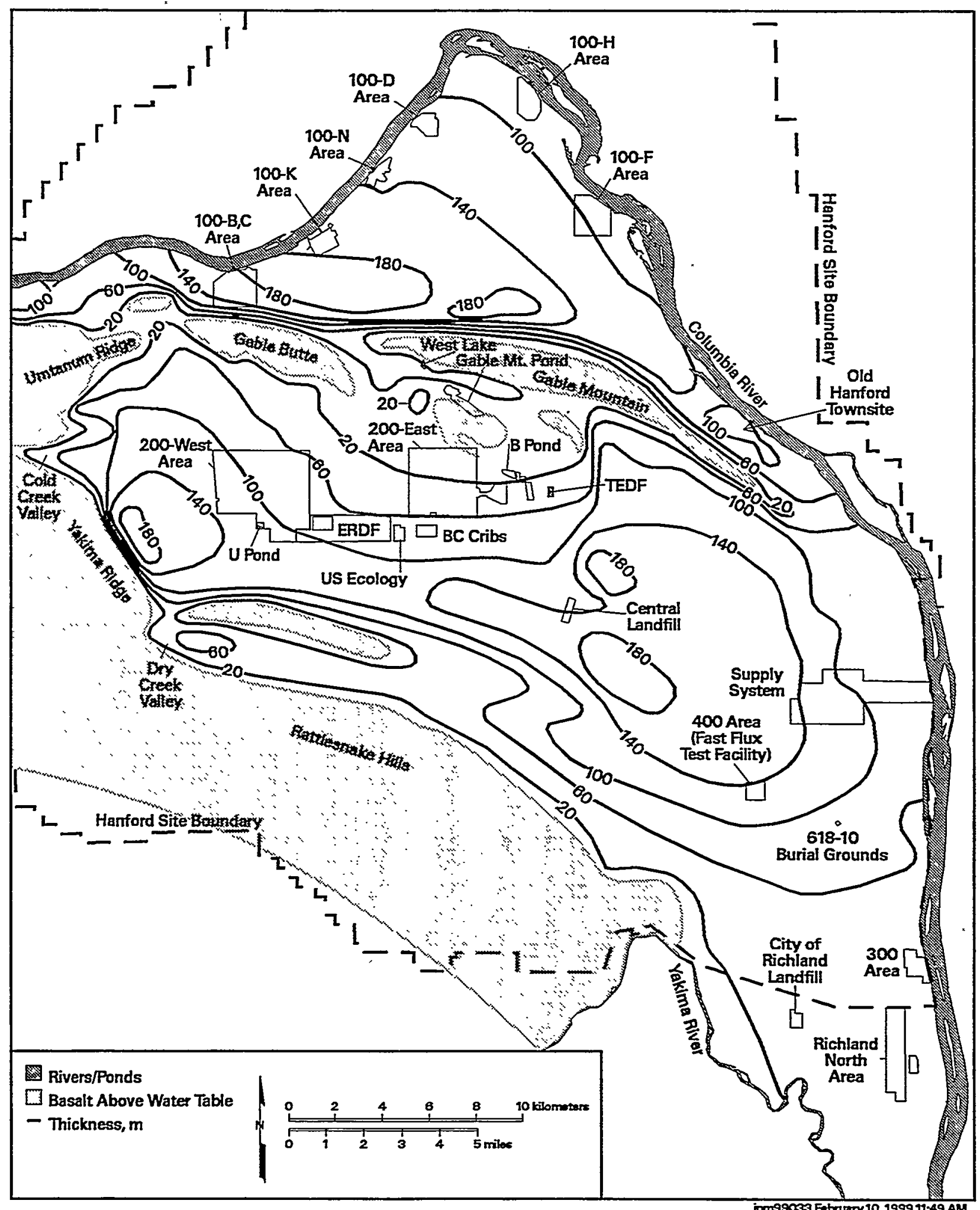

Figure 3.2-3. Saturated Thickness of Unconfined Aquifer System 


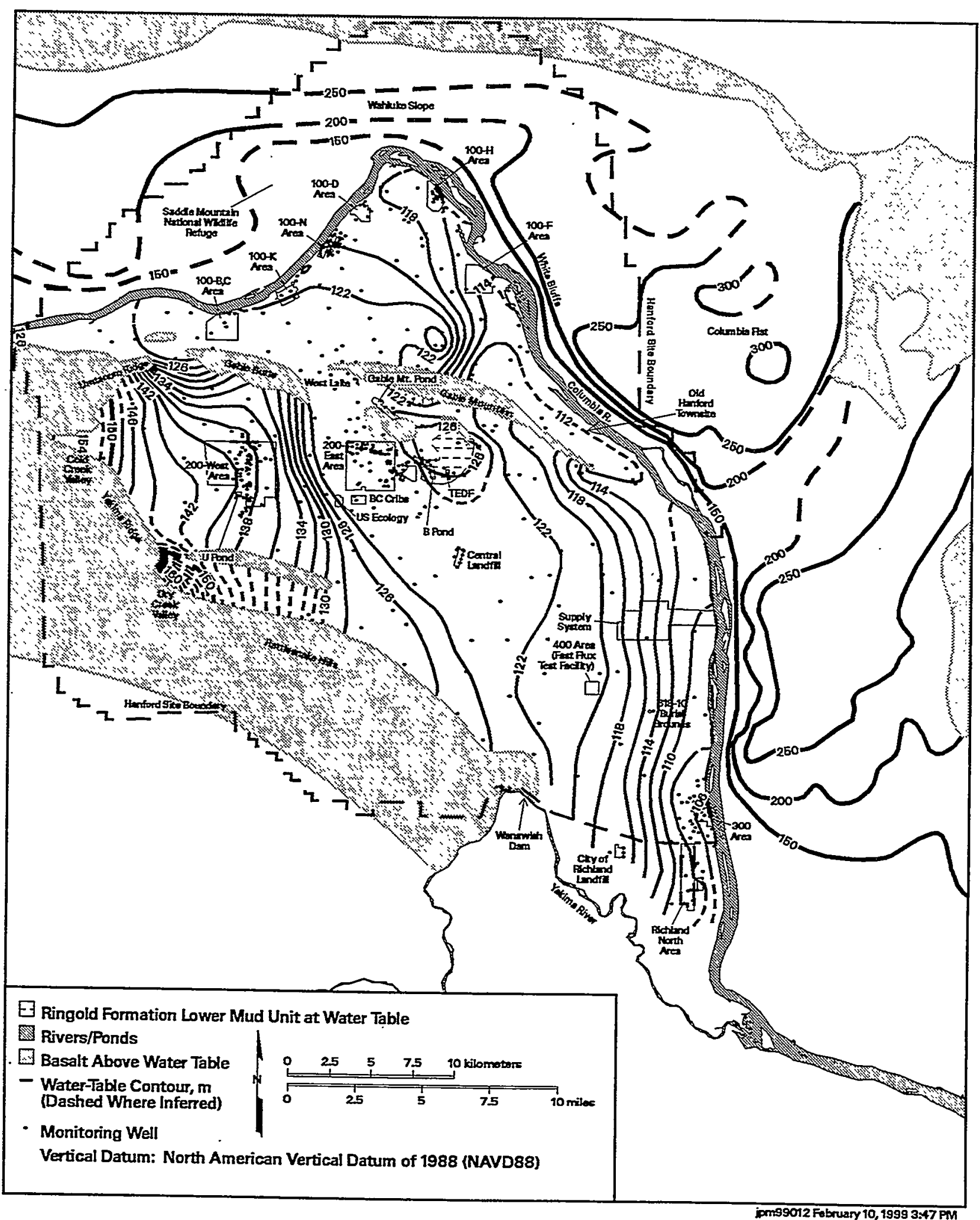

Figure 3.3-1. Hanford Site and Outlying Areas Water-Table Map, June 1998 


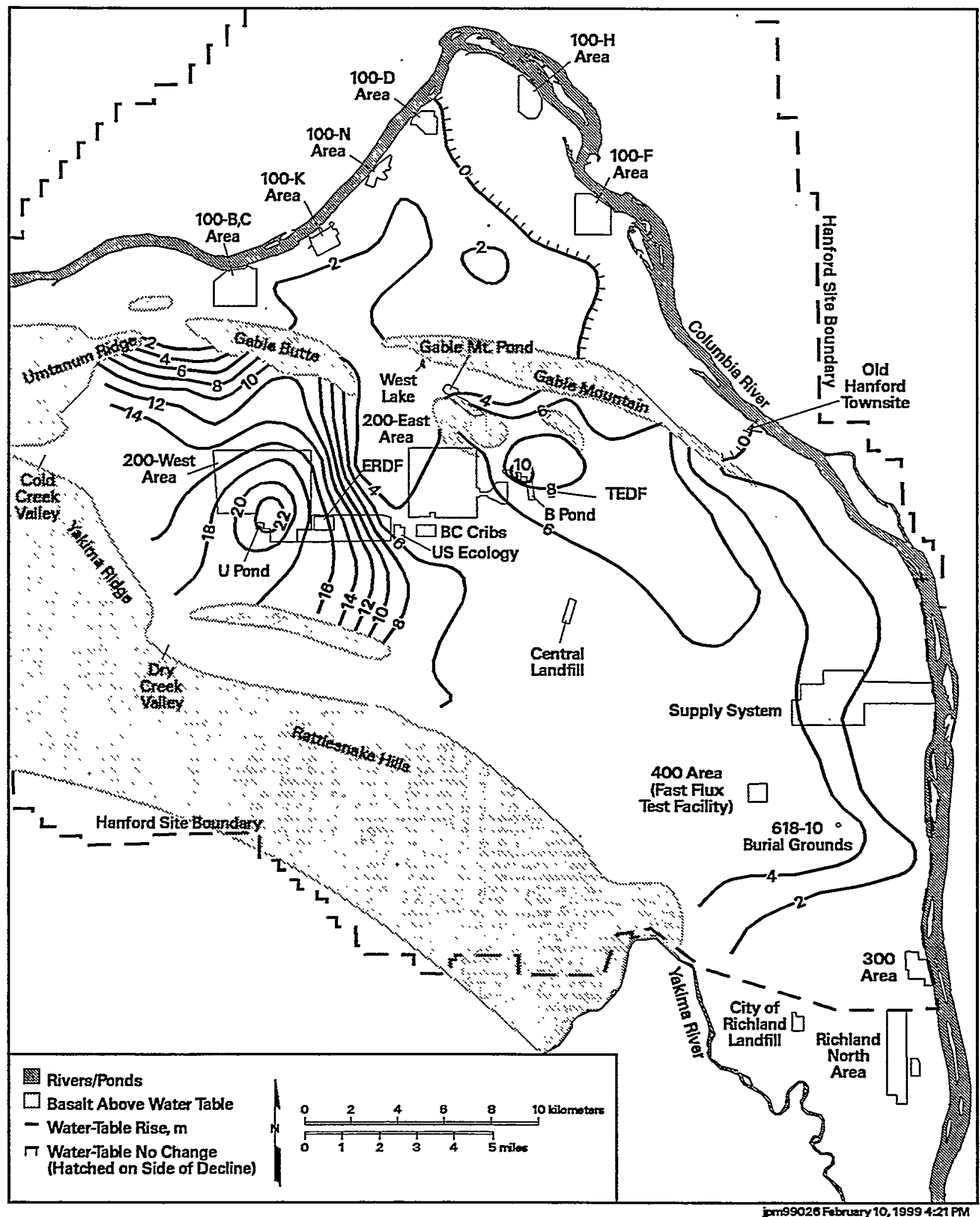

Figure 3.3-2. Changes in Water-Table Elevations, 1944 Through 1979 


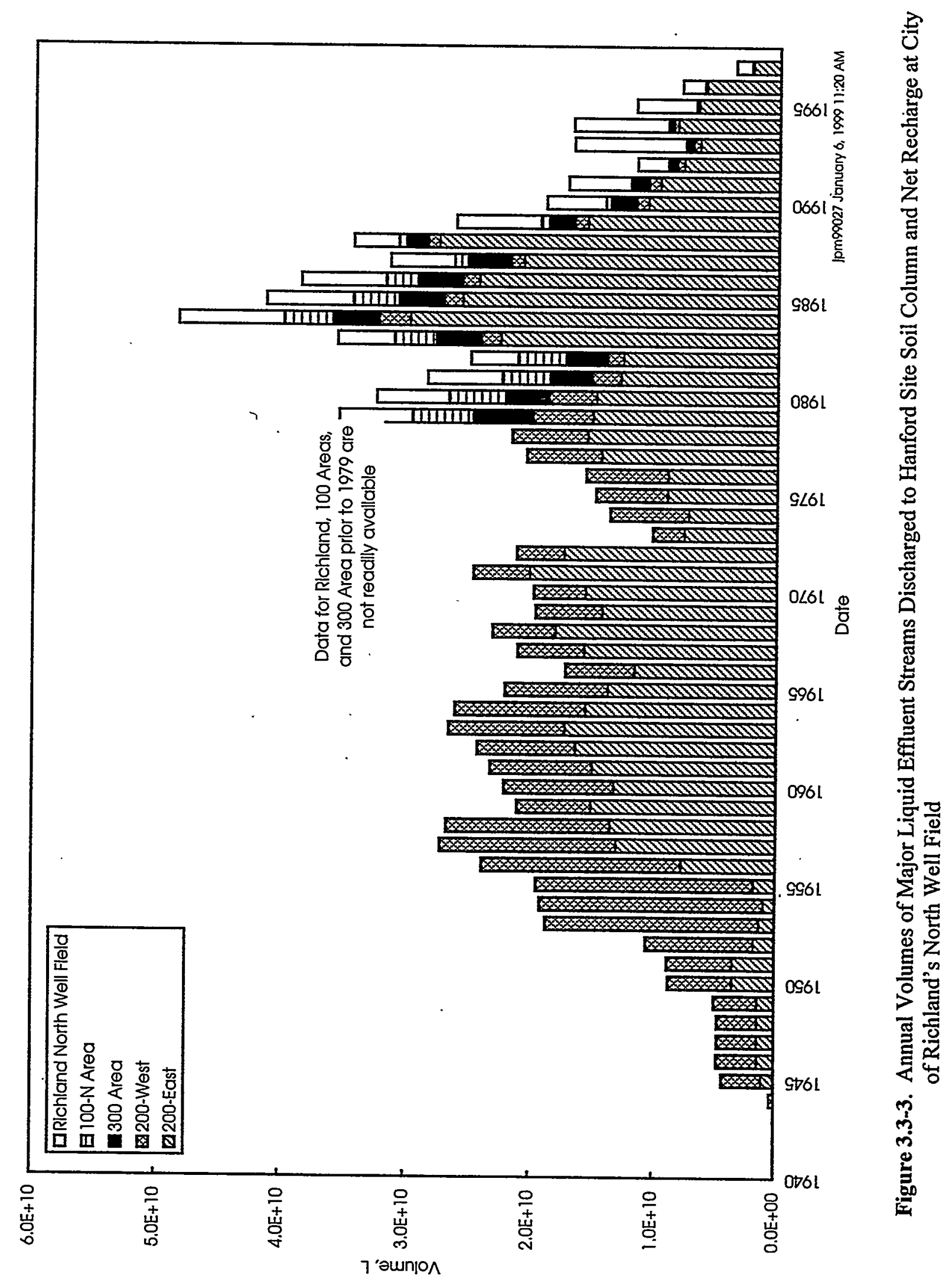




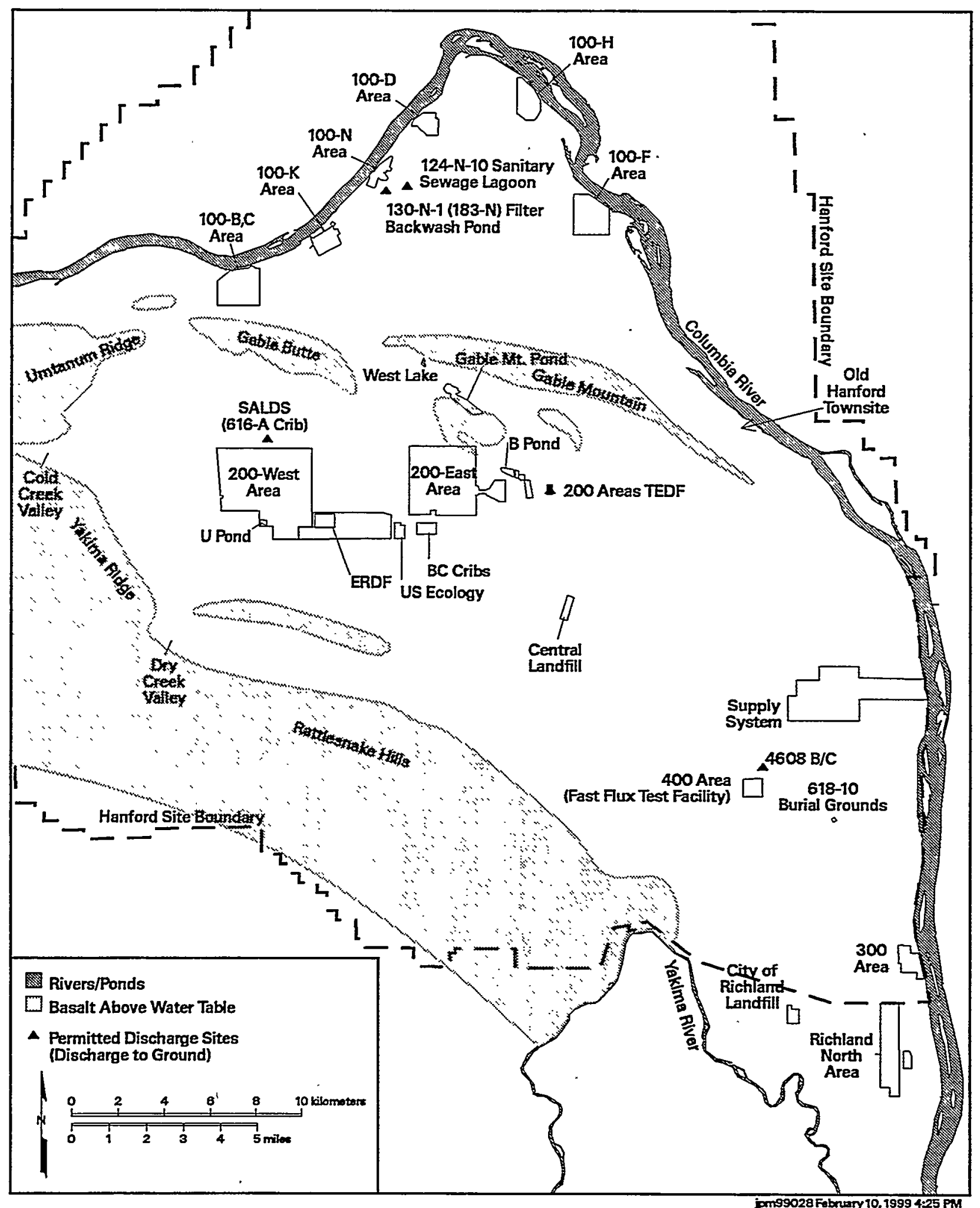

Figure 3.3-4. Active Discharge Sites 


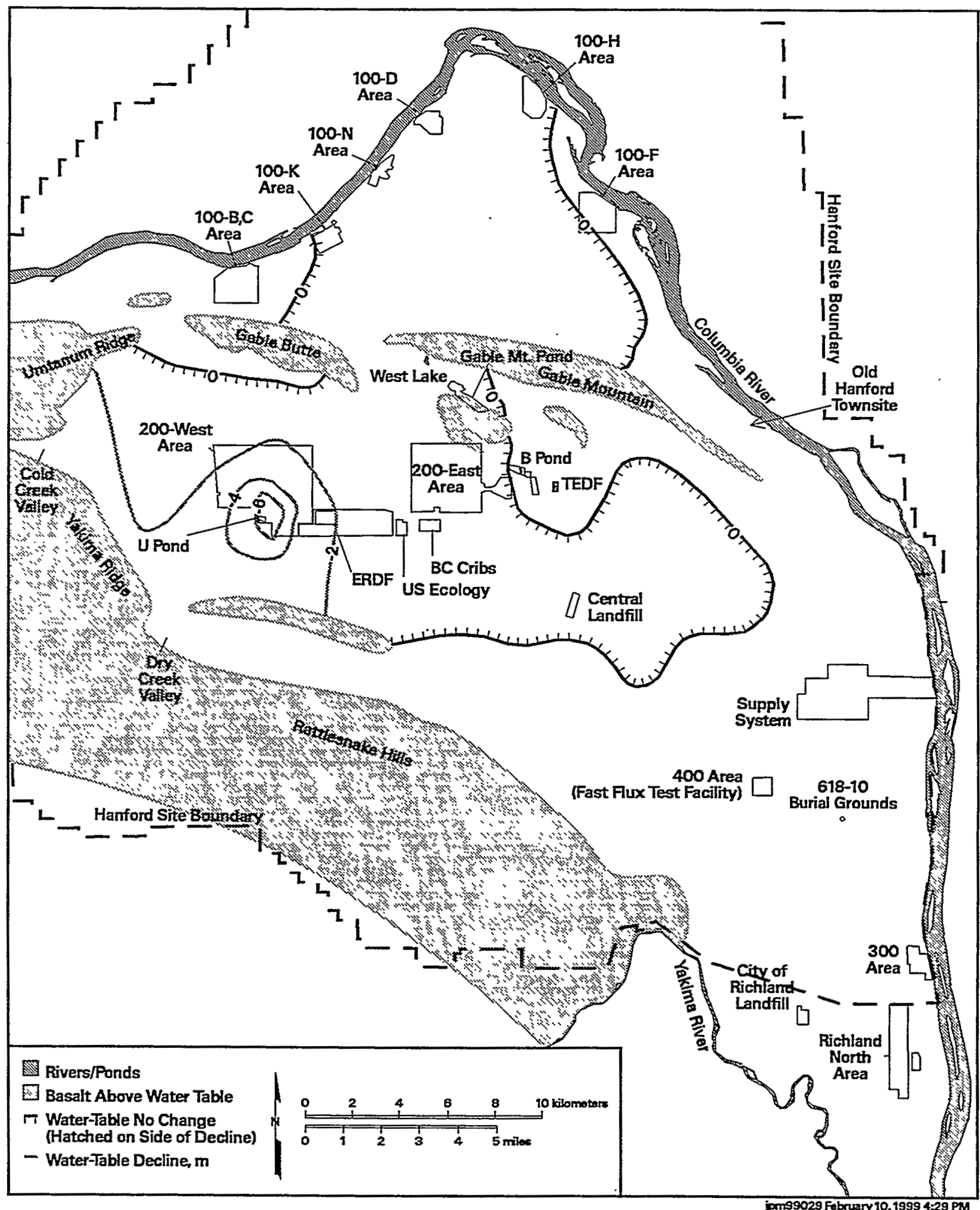

Figure 3.3-5. Changes in Water-Table Elevations, 1979 Through 1995 


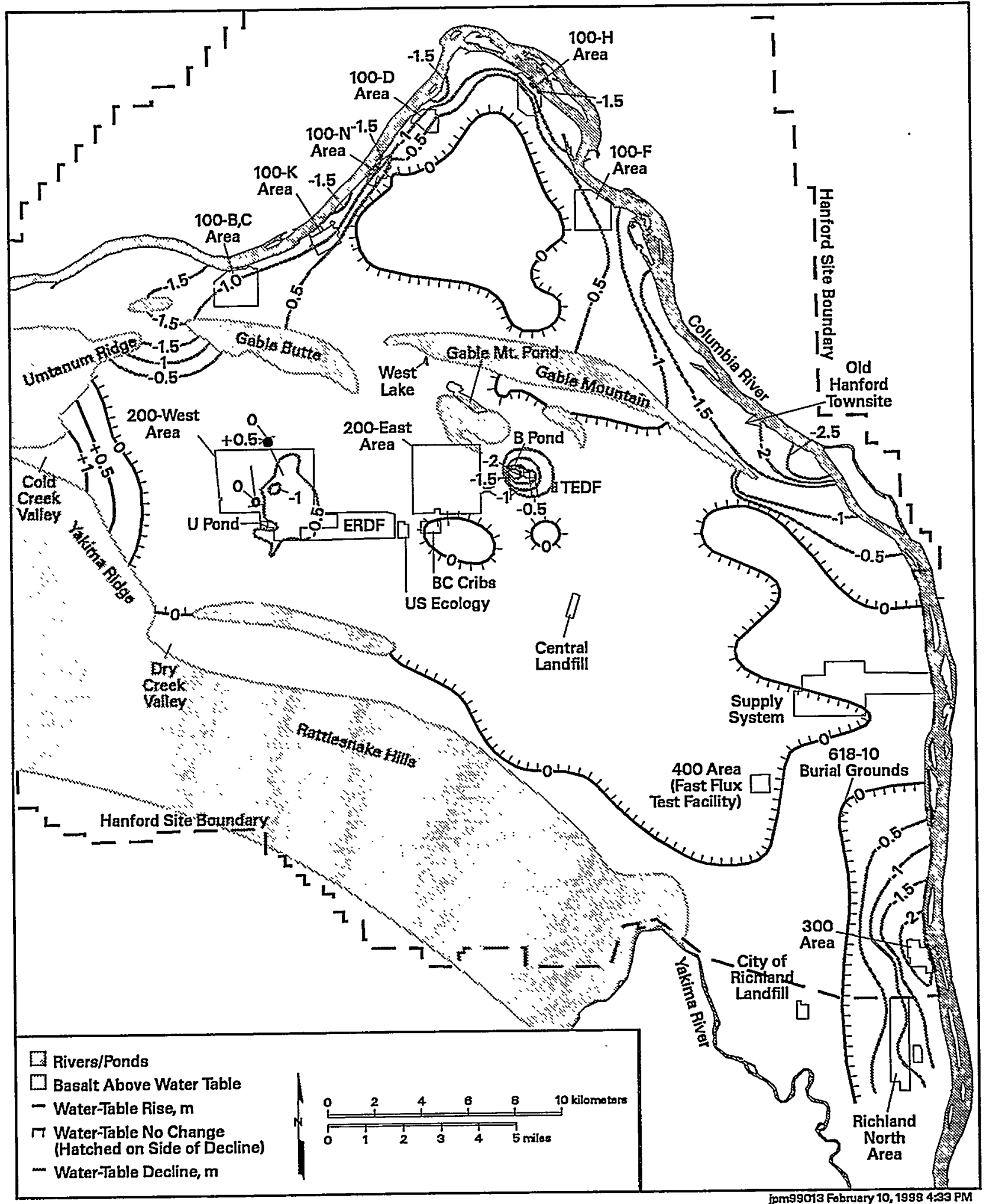

Figure 3.3-6. Changes in Water-Table Elevations Between June 1997 and June 1998 


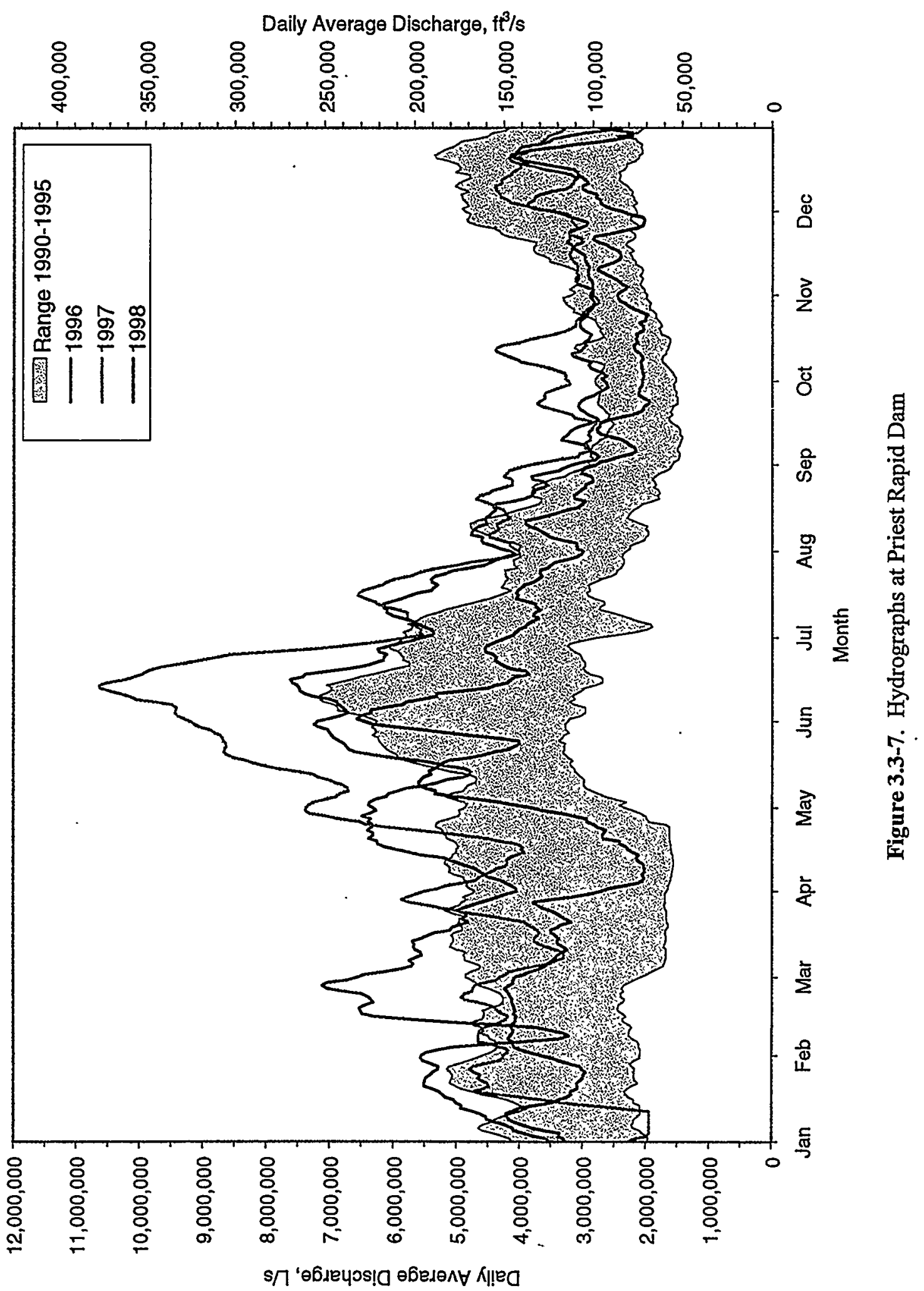




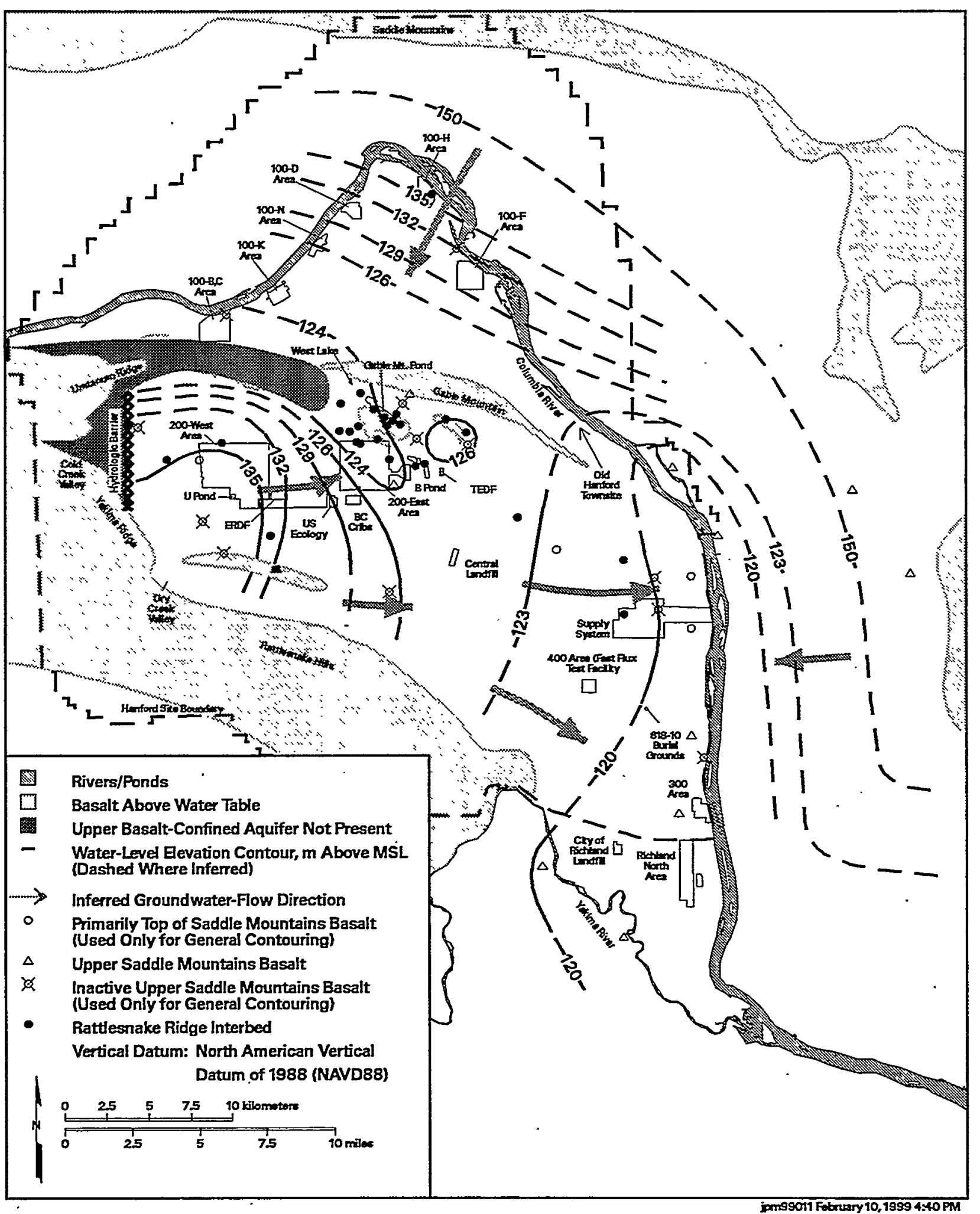

Figure 3.3-8. Potentiometric Map of Upper Basalt-Confined Aquifer System, June 1998 


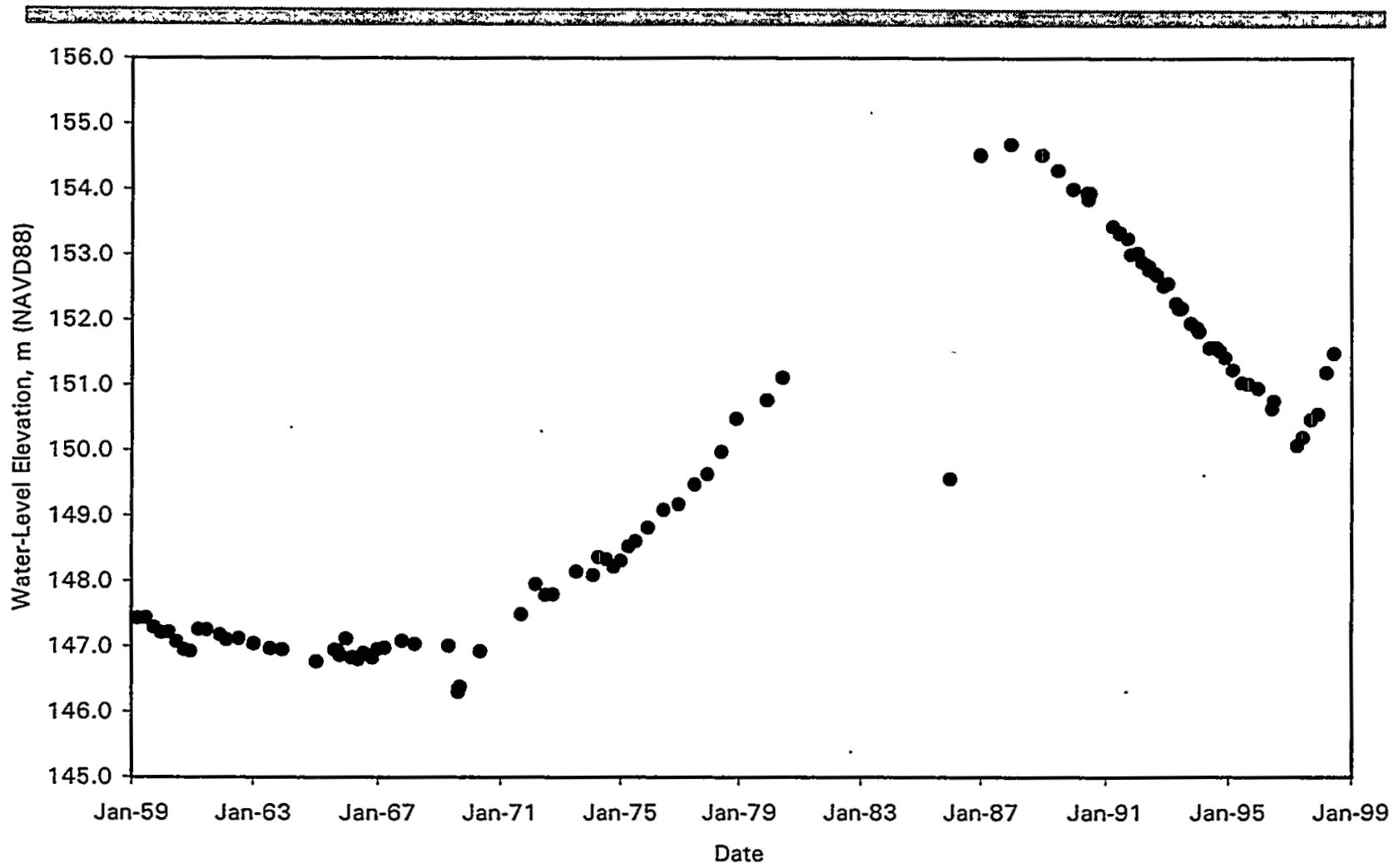

Figure 3.4-1. Water-Table Elevations in Well 699-43-104

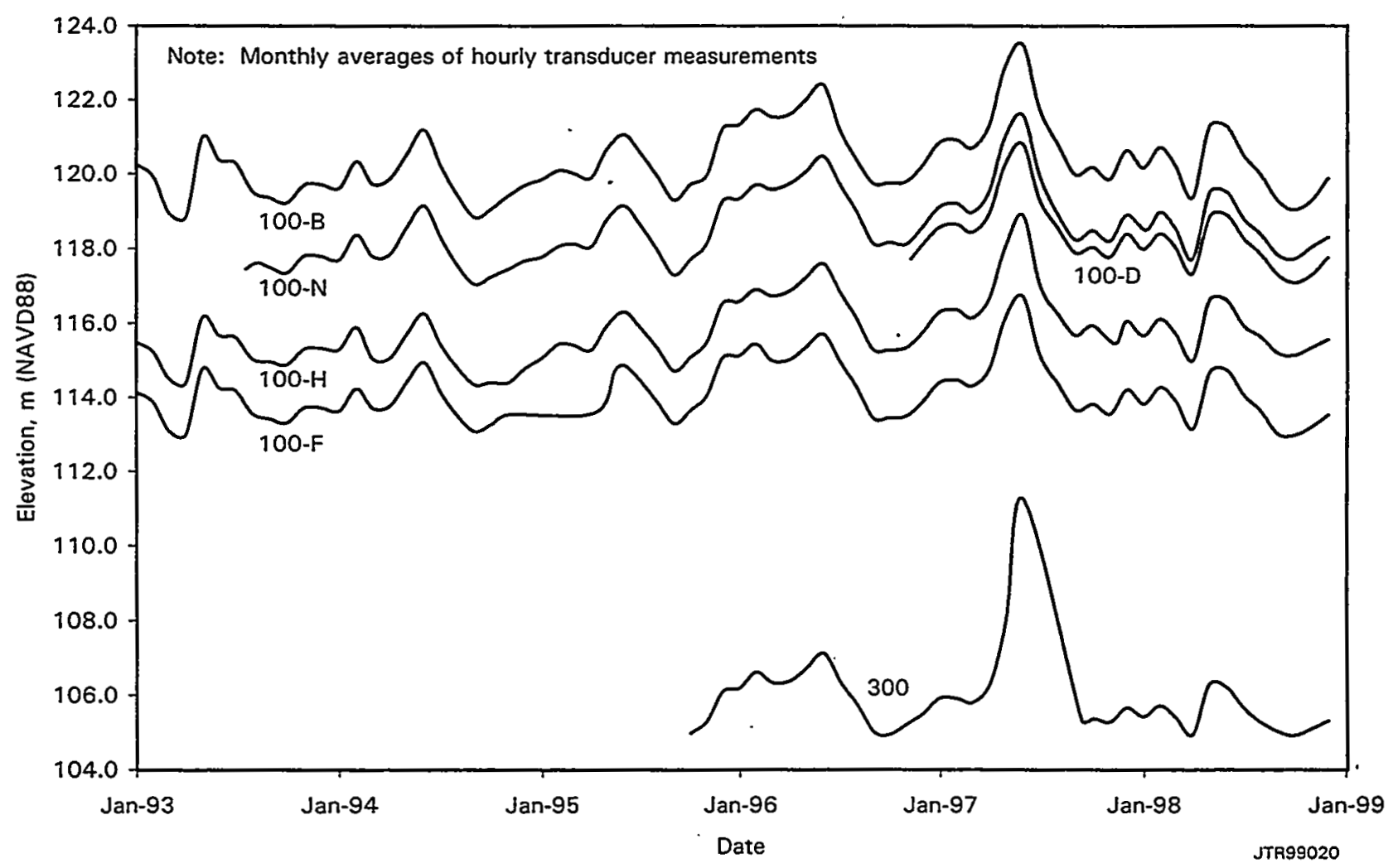

Figure 3.5-1. Columbia River Stage at 100 and 300 Areas 

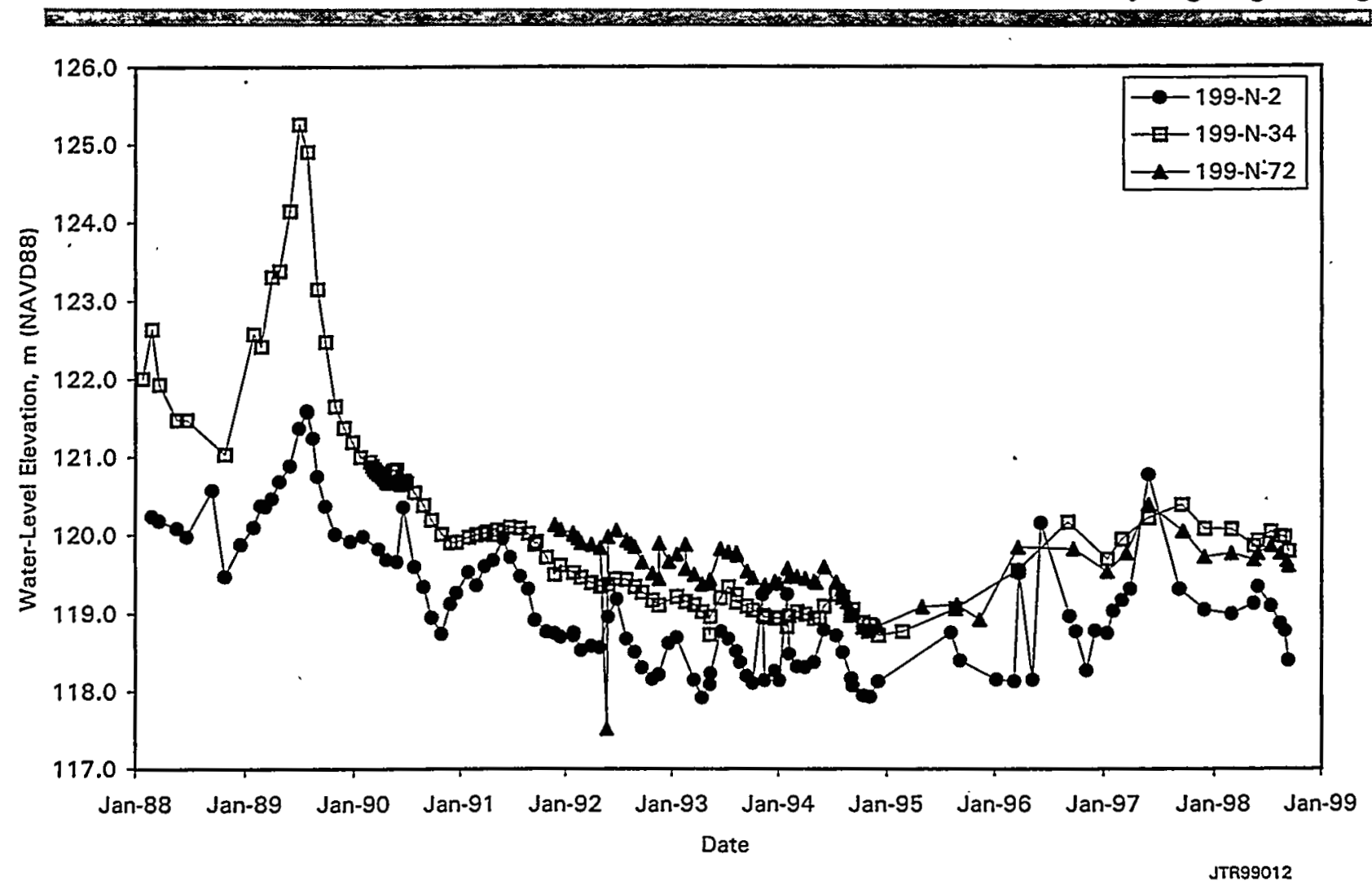

Figure 3.5-2. Water-Table Elevations in Wells Monitoring 100-N Area 


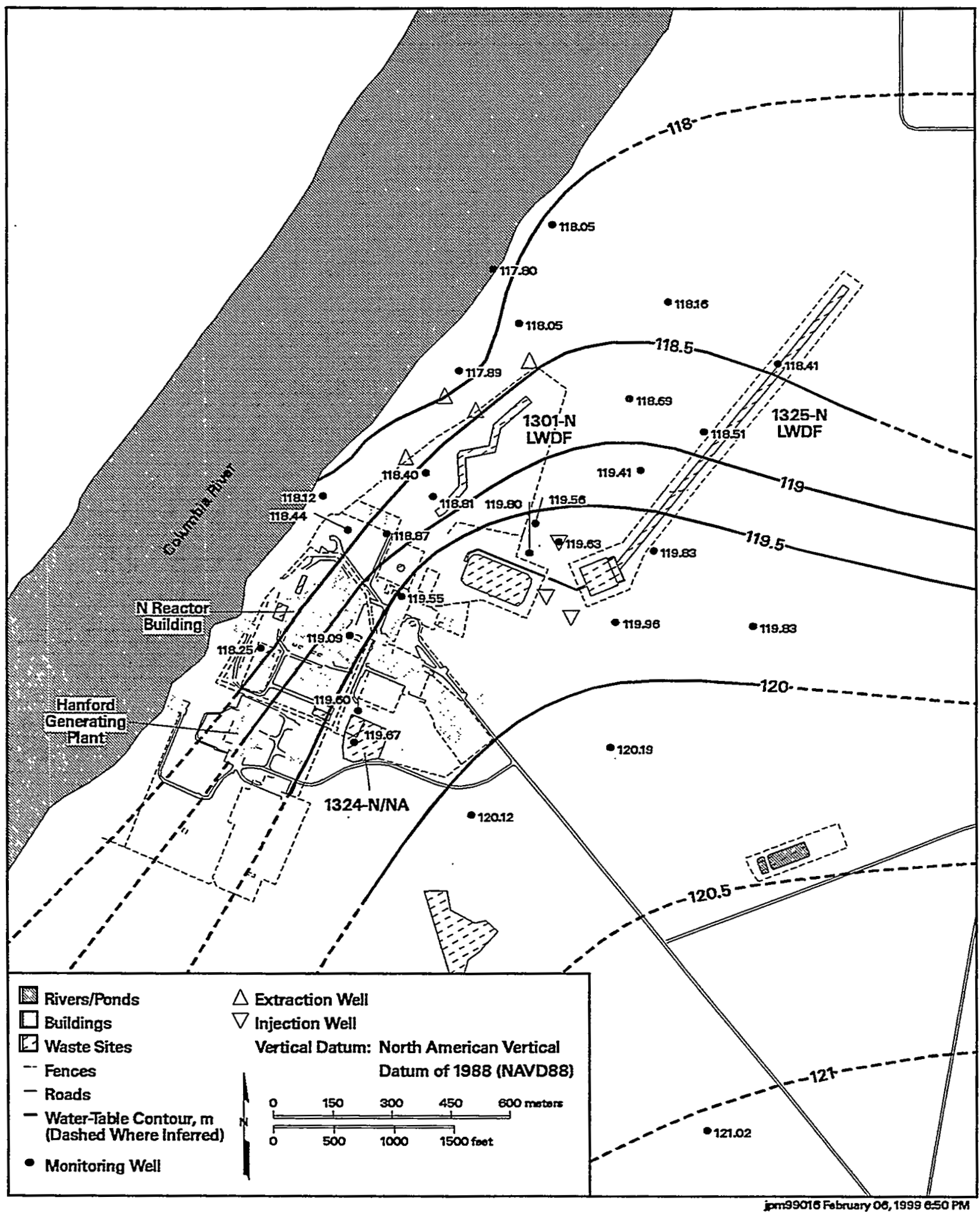

Figure 3.5-3. Water-Table Map for 100-N Area, September 1998 


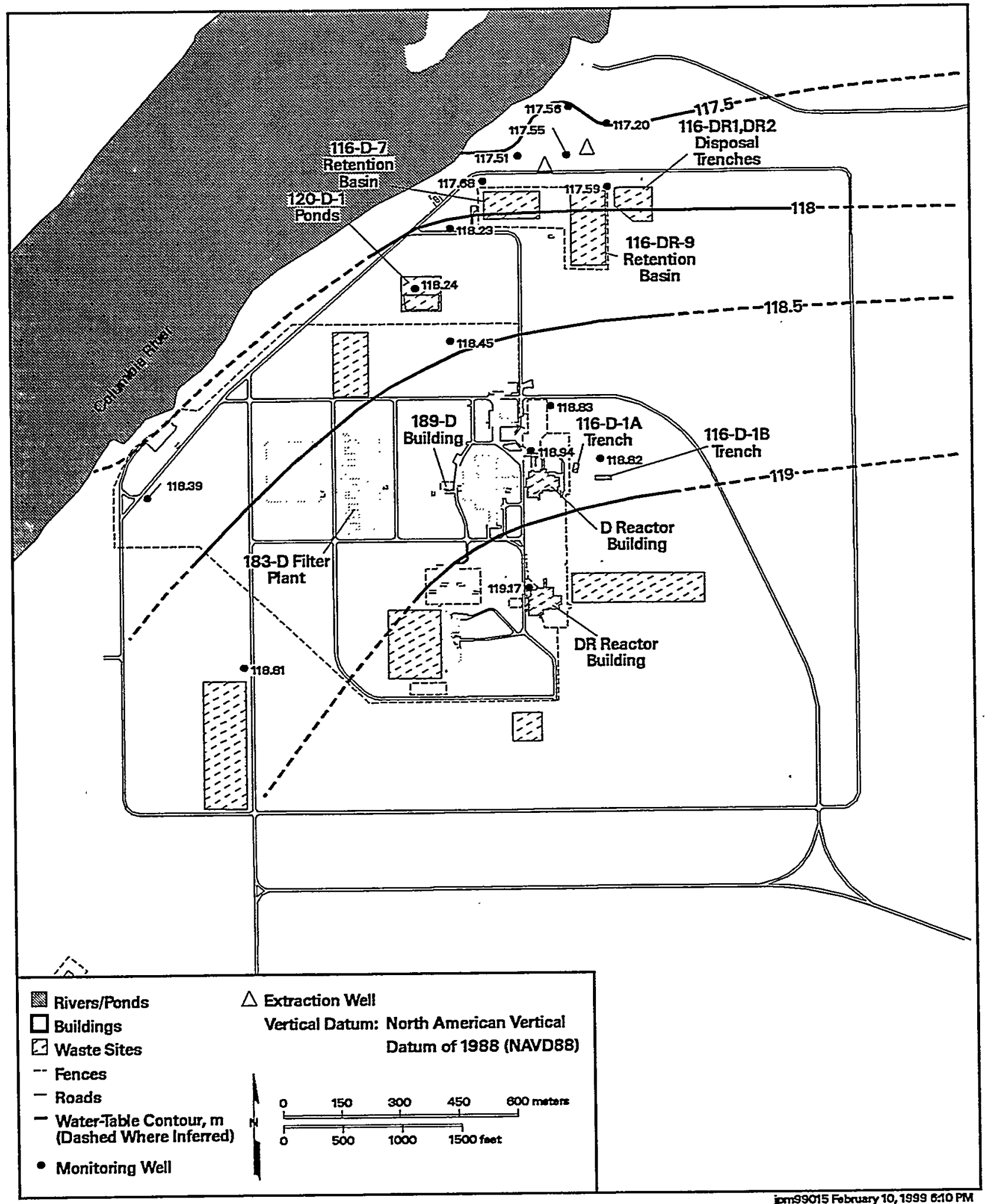

Figure 3.5-4. Water-Table Map for 100-D Area, November 1997 


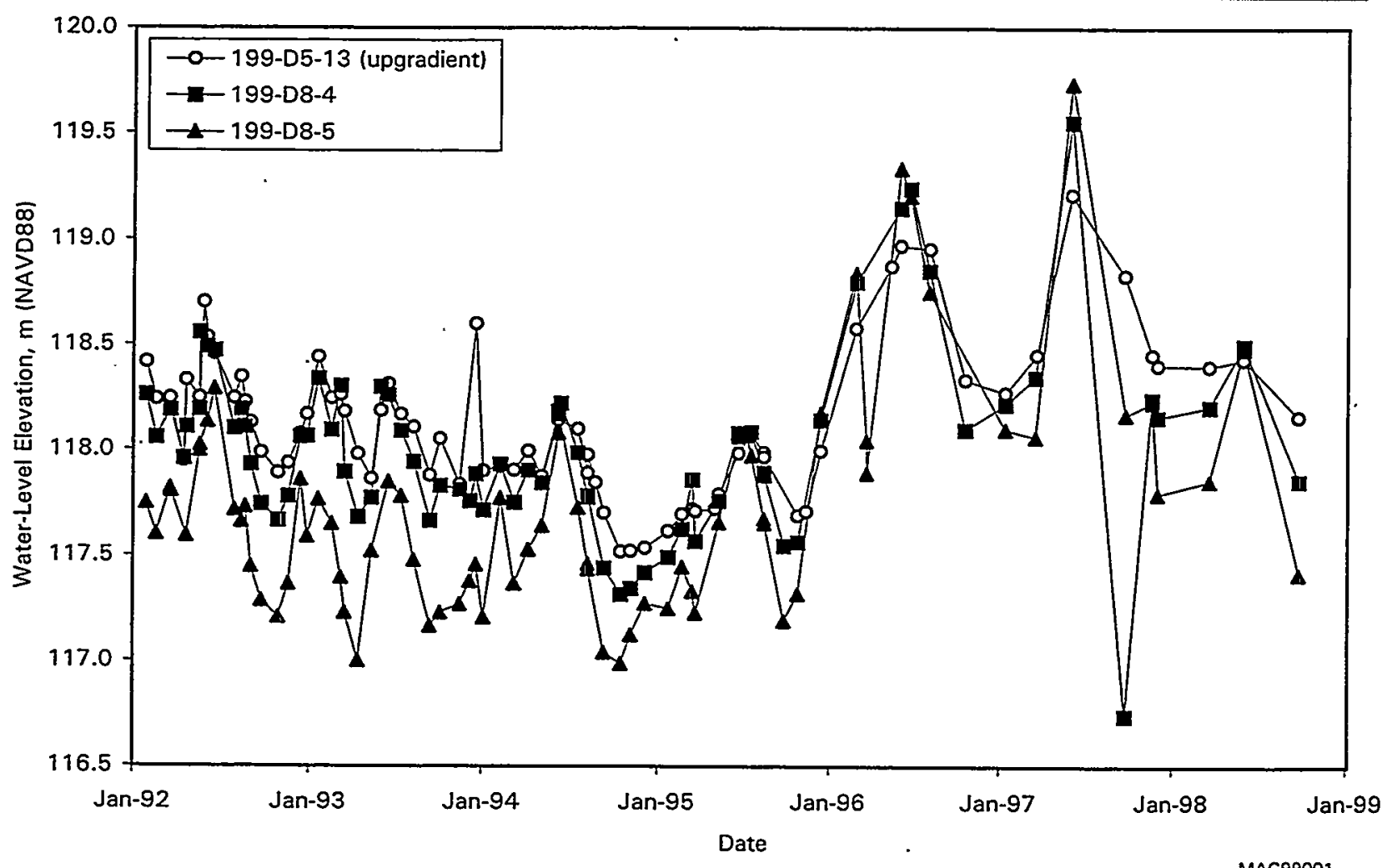

Figure 3.5-5. Water-Table Elevations in Wells Monitoring 120-D-1 Ponds

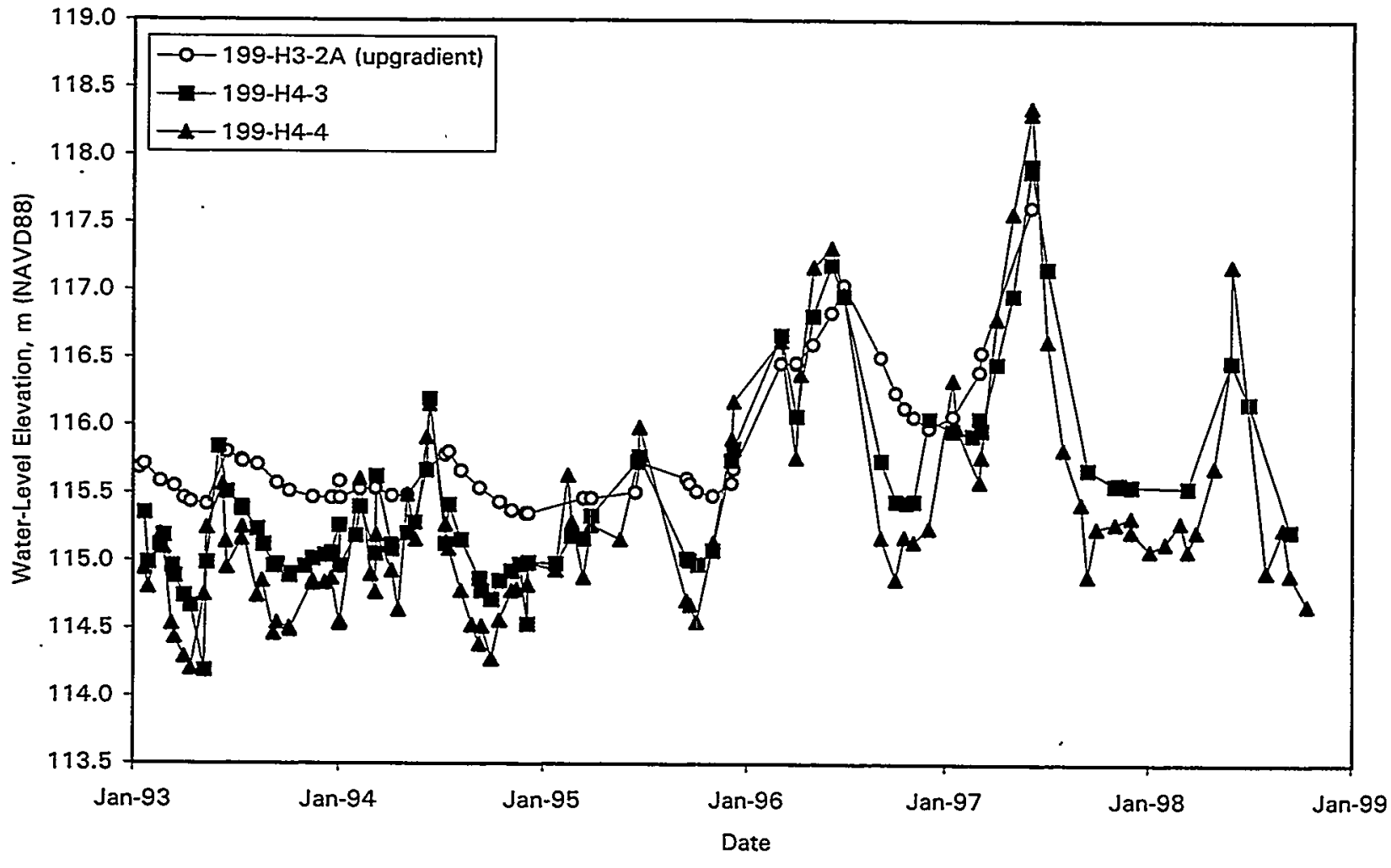

Figure 3.5-6. Water-Table Elevations in Wells Monitoring 183-H Solar Evaporation Basins 


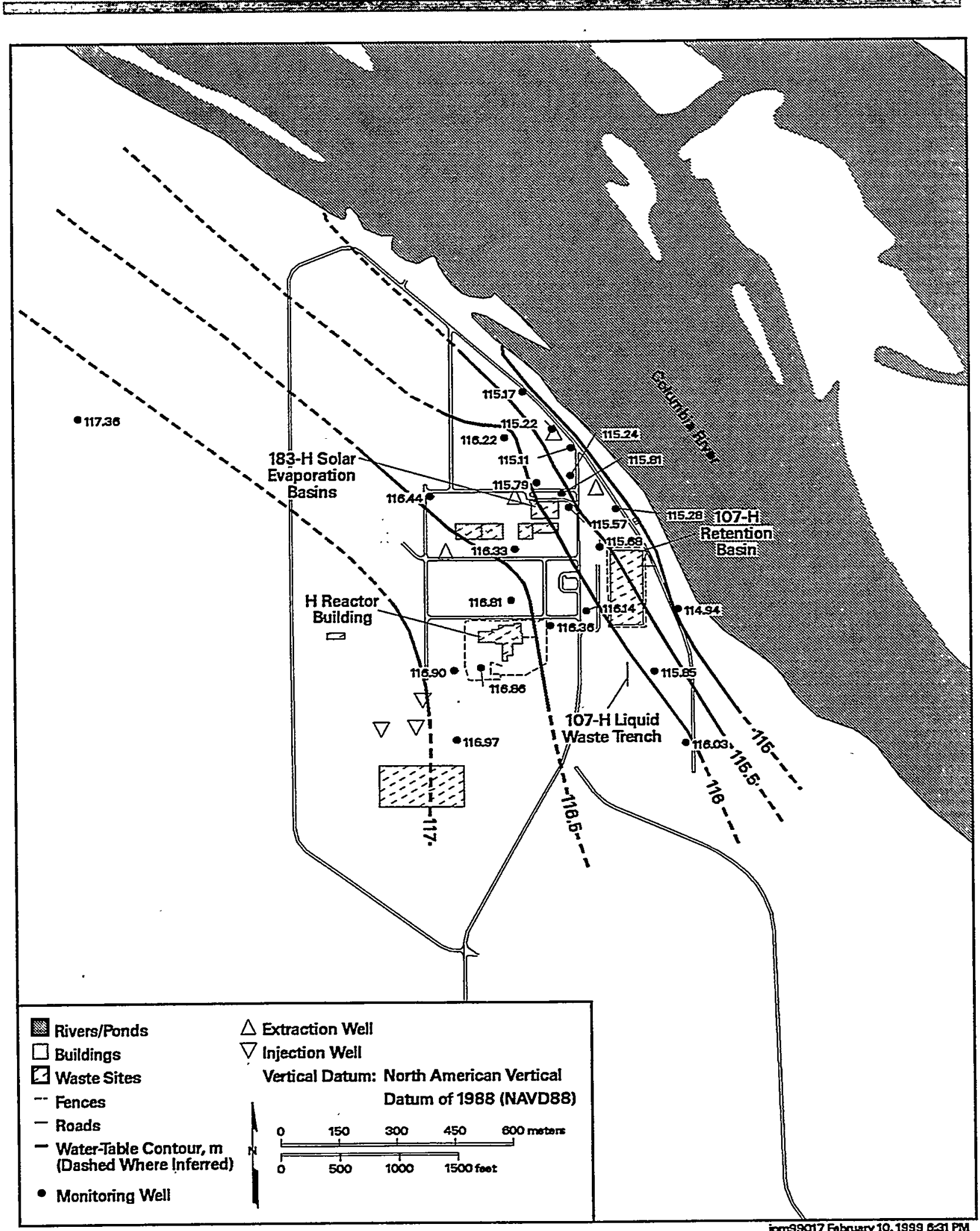

Figure 3.5-7. Water-Table Map for 100-H Area, November 1997 


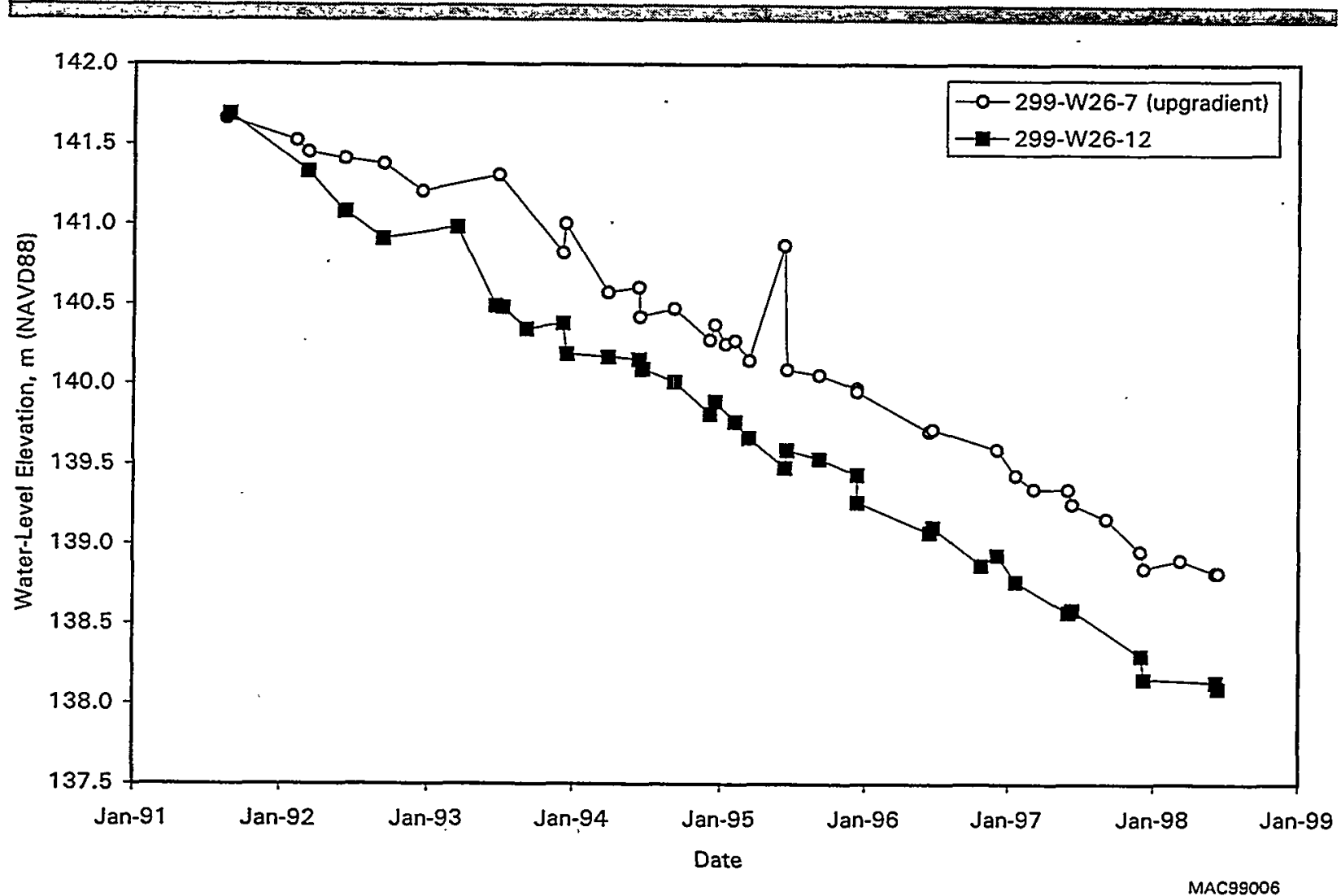

Figure 3.6-1. Water-Table Elevations in Wells Monitoring 216-S-10 Pond and Ditch

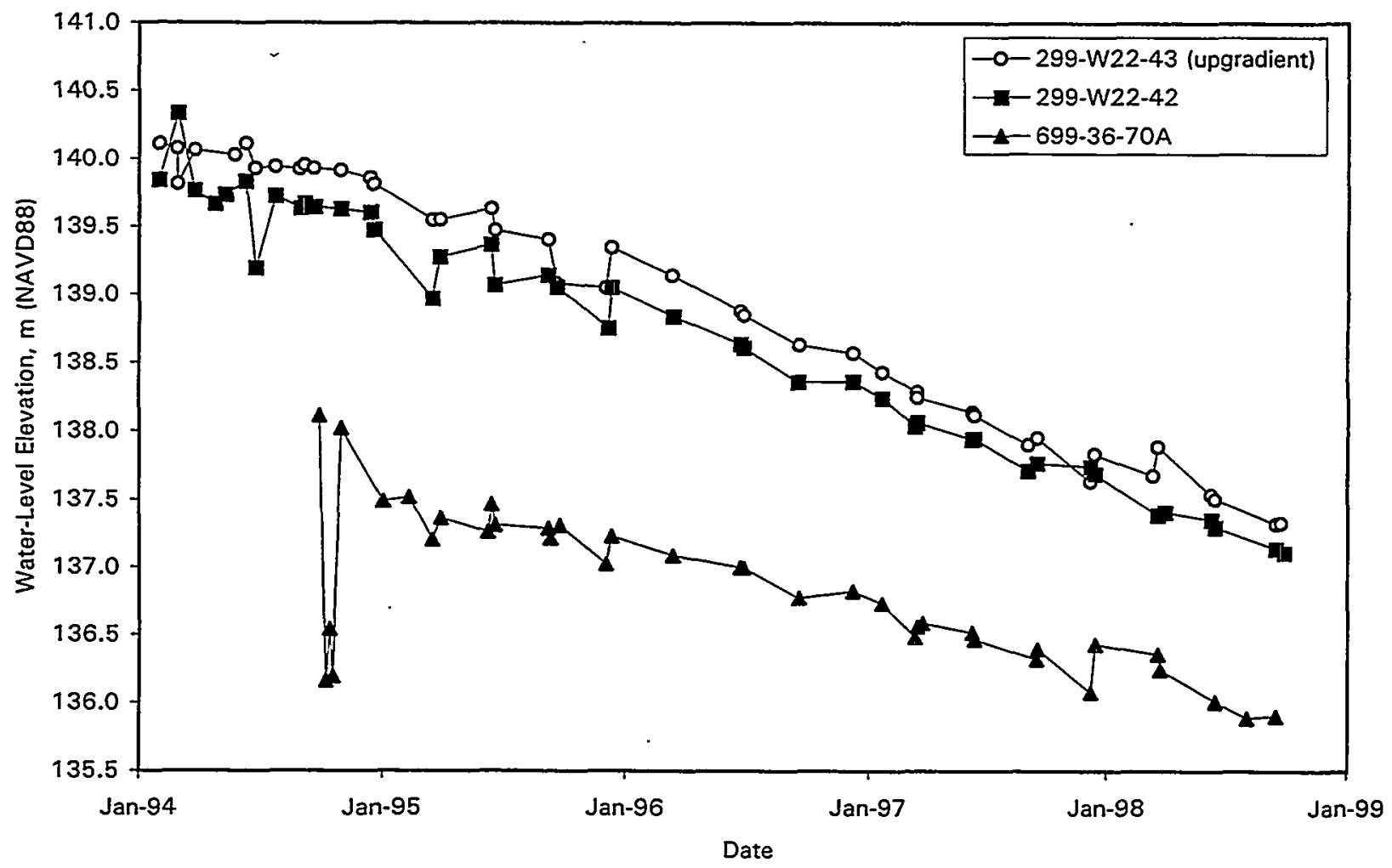

Figure 3.6-2. Water-Table Elevations in Wells Monitoring 216-U-12 Crib 


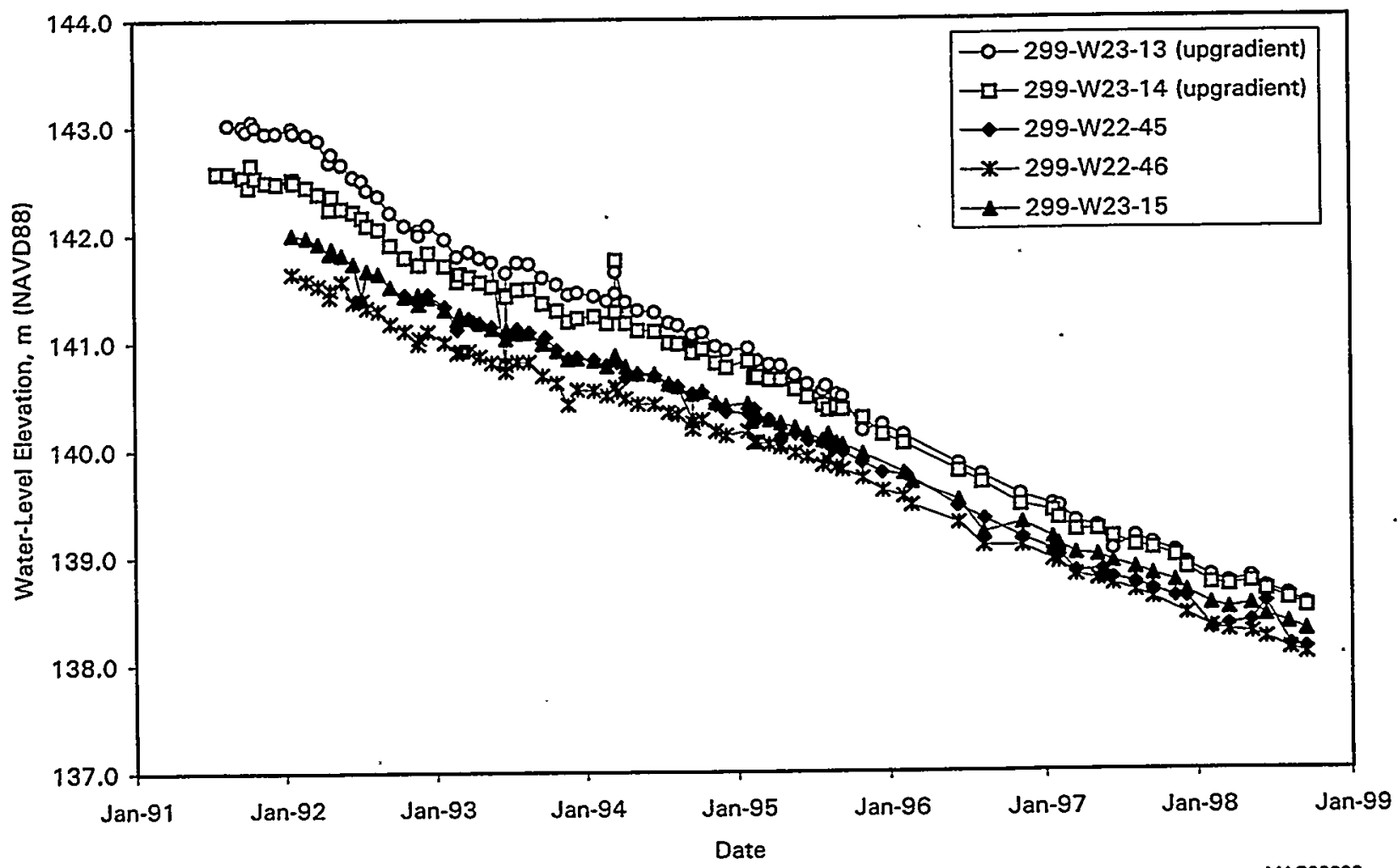

Figure 3.6-3. Water-Table Elevations Near Waste Management Area S-SX

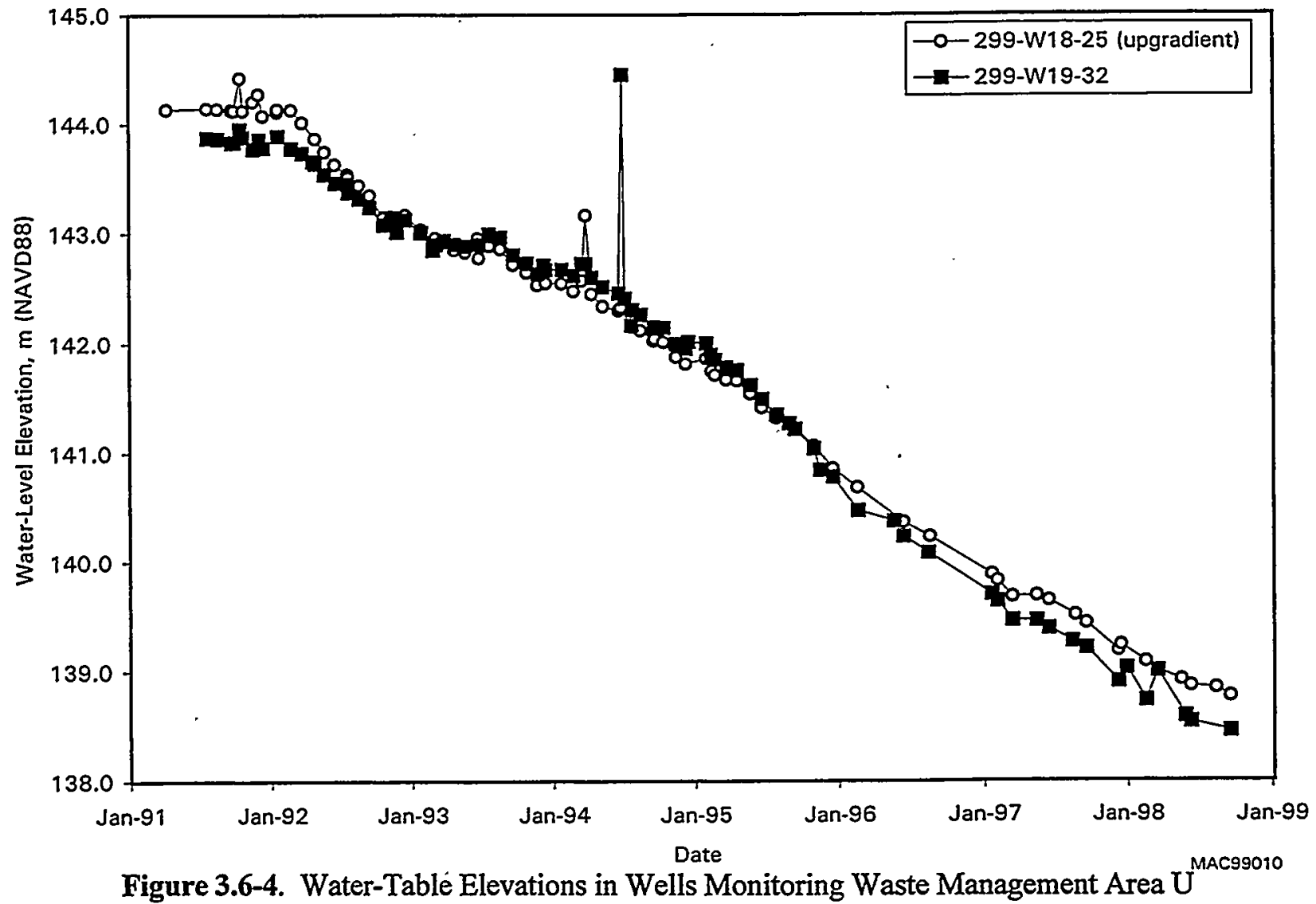




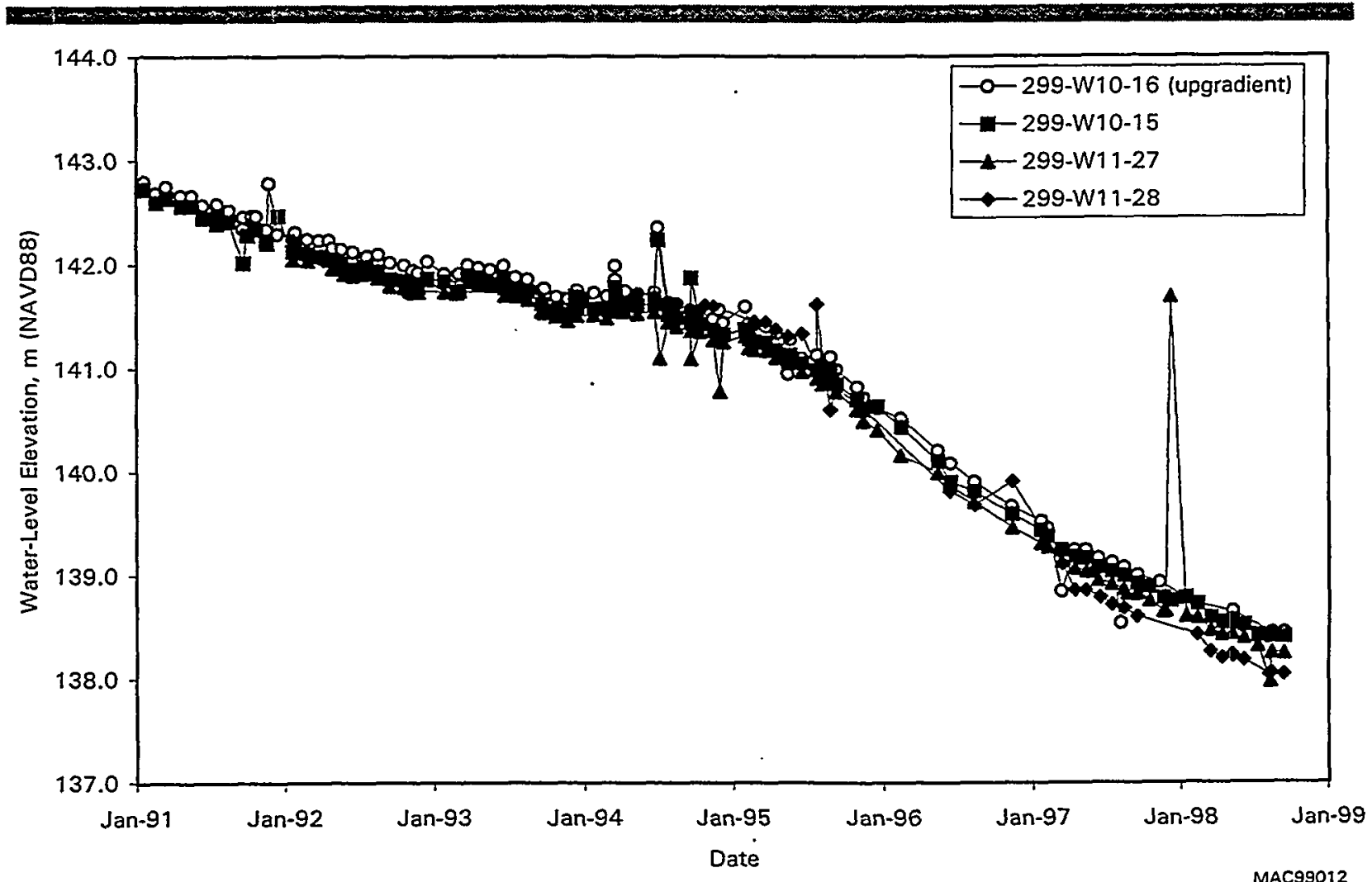

Figure 3.6-5. Water-Table Elevations in Wells Monitoring Waste Management Area $T$

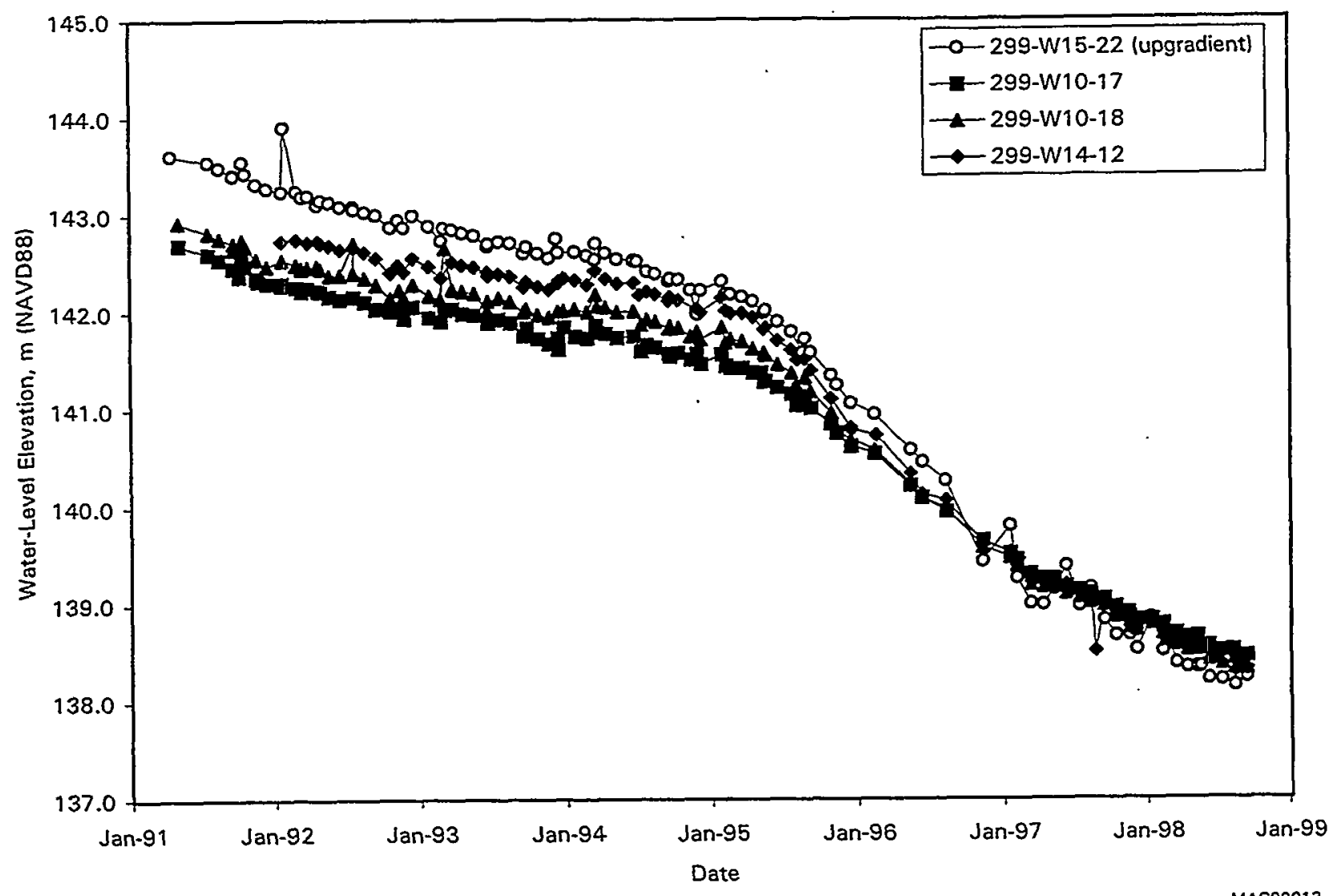

Figure 3.6-6. Water-Table Elevations in Wells Monitoring Waste Management Area TX-TY 


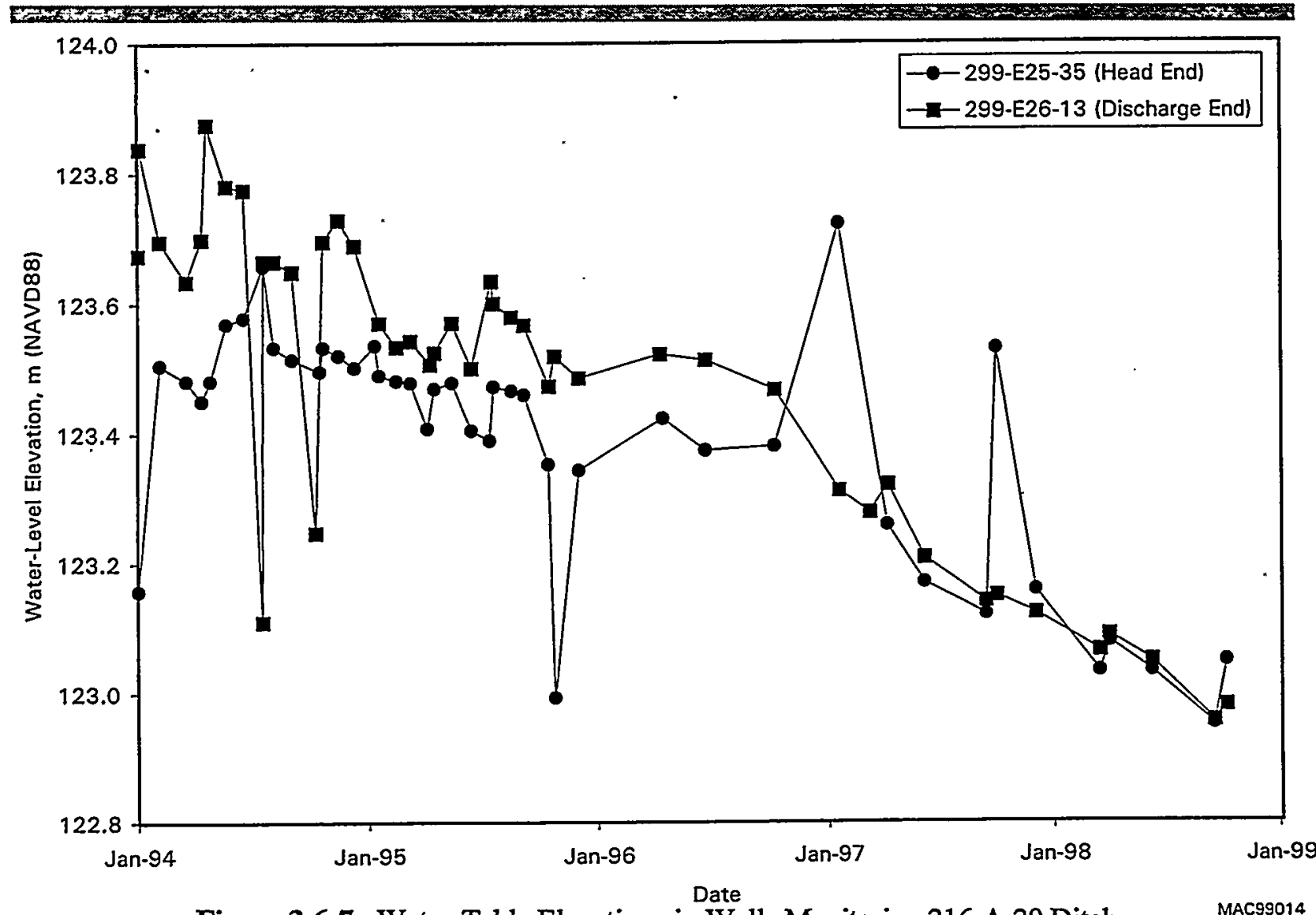

Figure 3.6-7. Water-Table Elevations in Wells Monitoring 216-A-29 Ditch

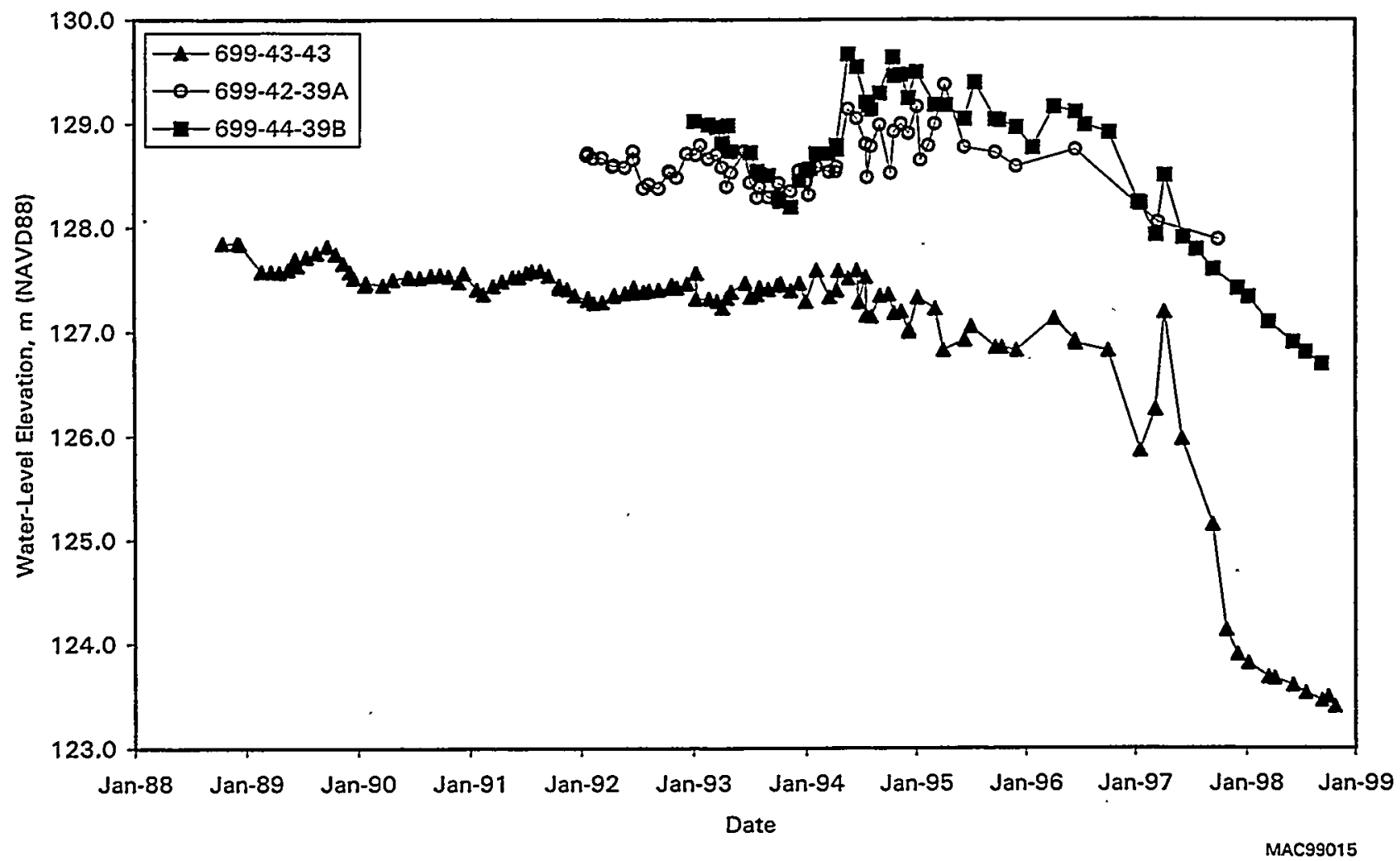

Figure 3.6-8. Water-Table Elevations in Wells Monitoring 216-B-3 Pond 


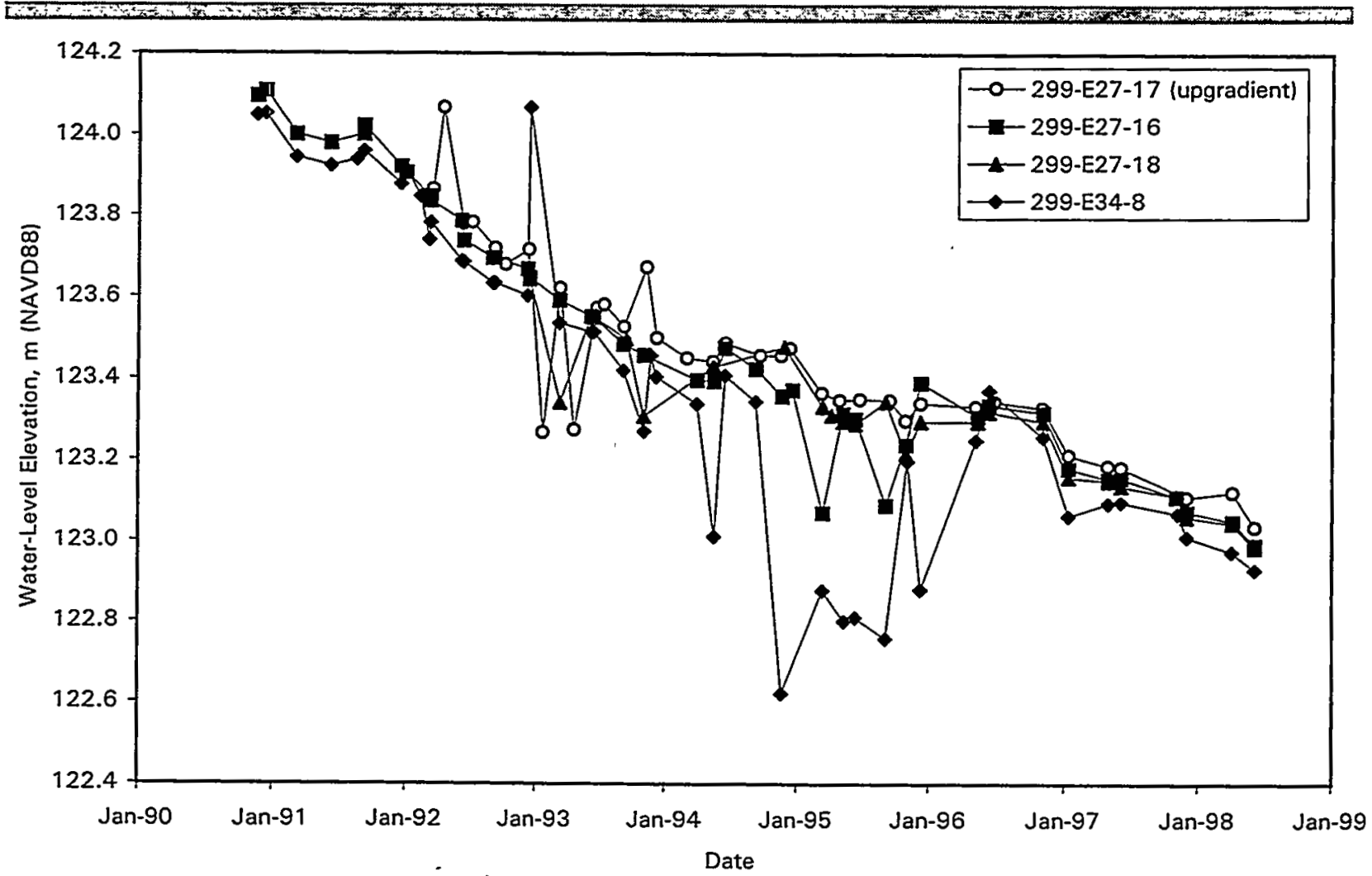

Figure 3.6-9. Water-Table Elevations in Wells Monitoring 216-B-63 Trench

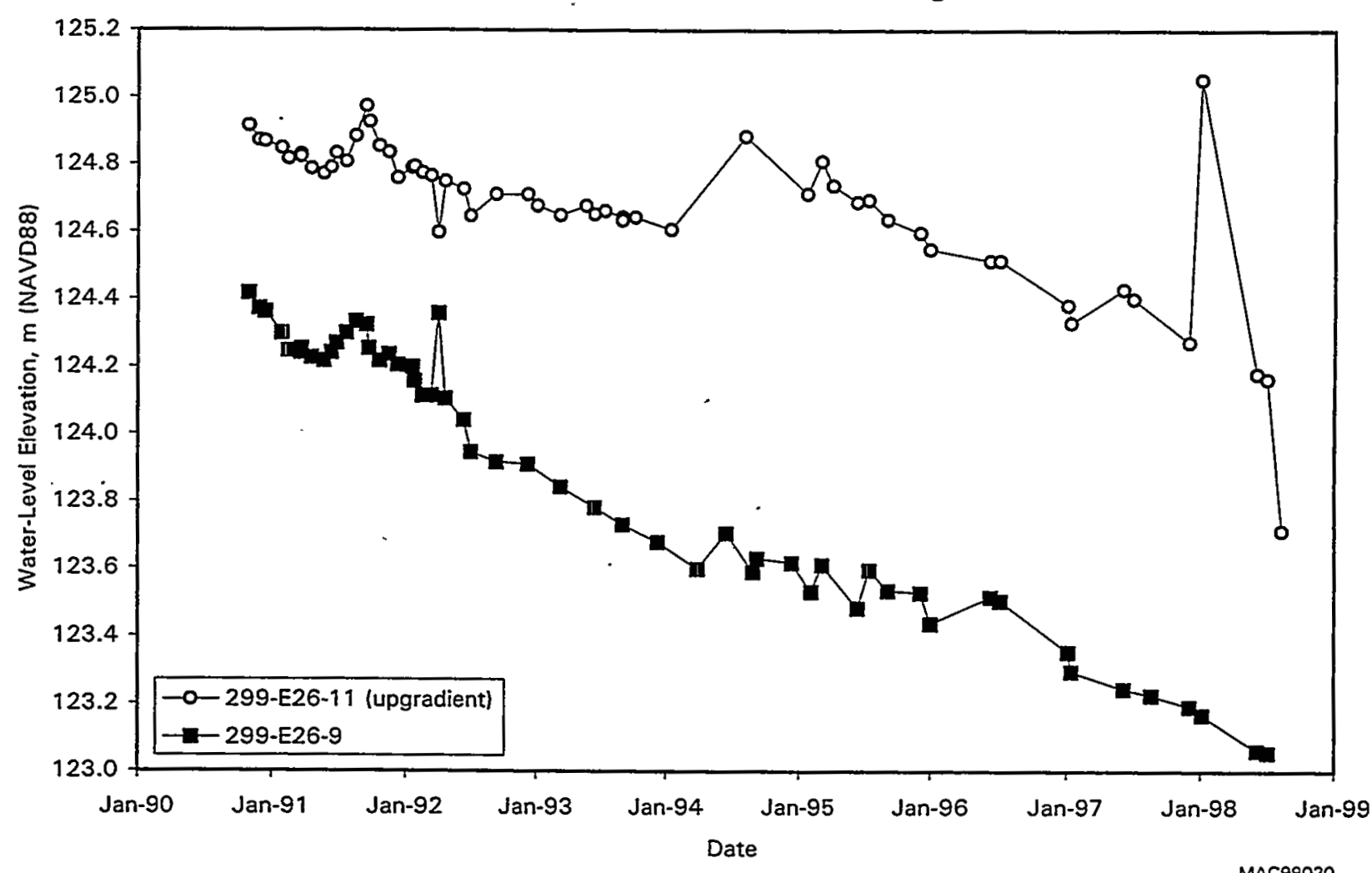

Figure 3.6-10. Water-Table Elevations in Wells Monitoring Liquid Effluent-Retention Facility 


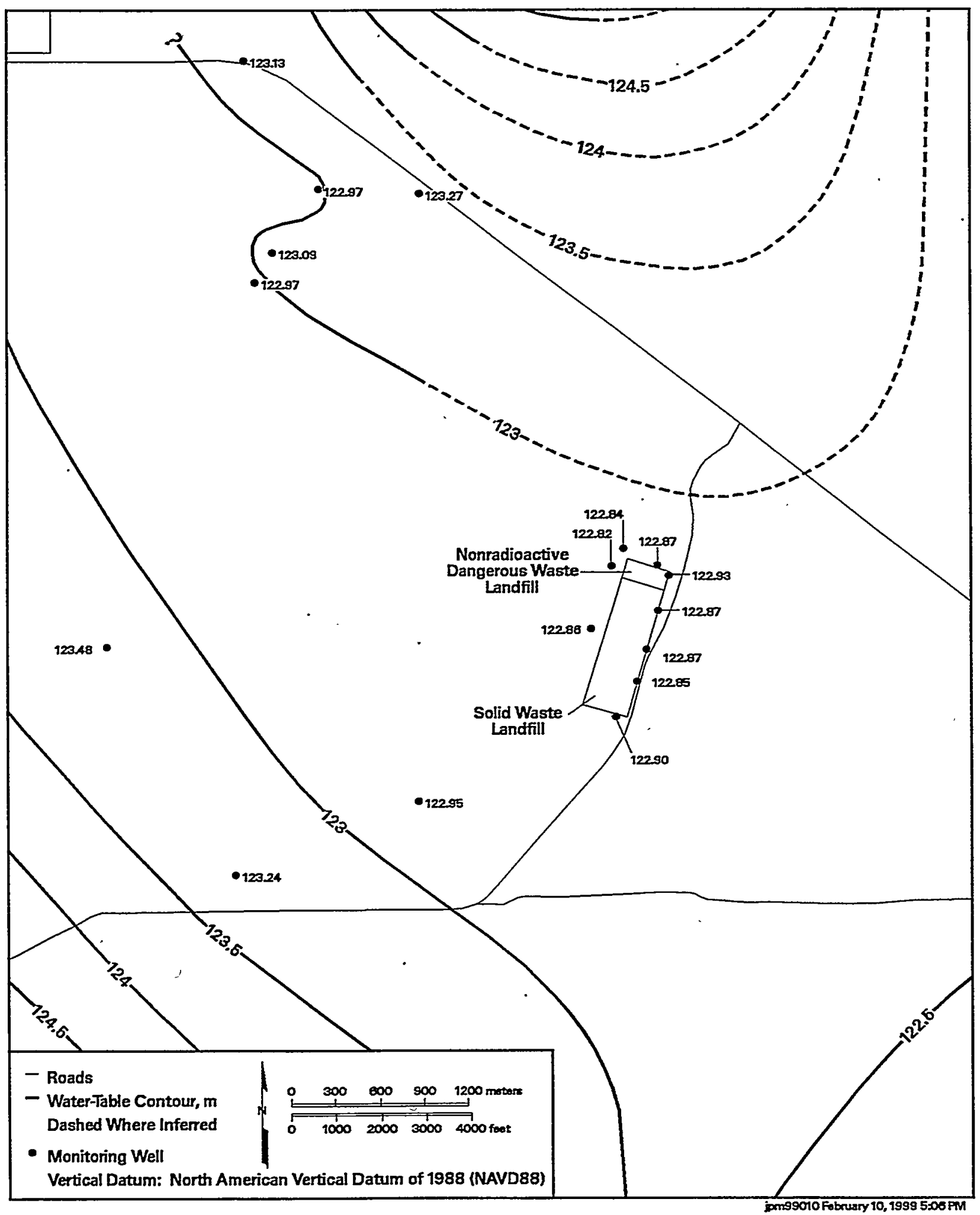

Figure 3.7-1. Water-Table Map for Nonradioactive Dangeroús Waste Landfill/Solid Waste Landfill, June 1998 


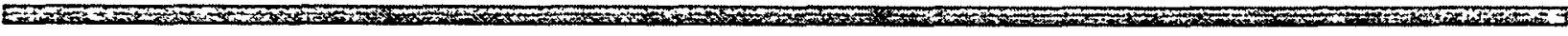

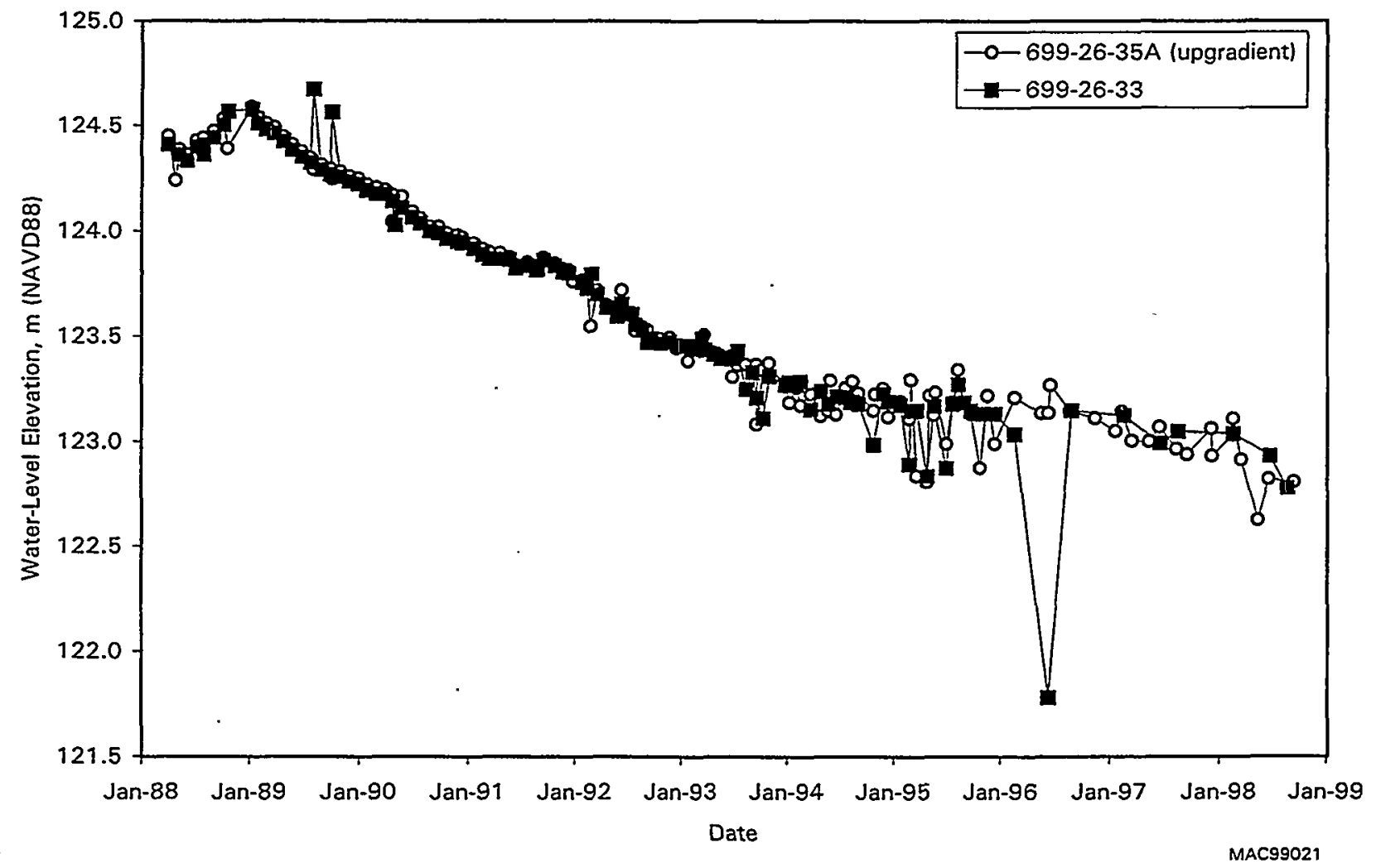

Figure 3.7-2. Water-Table Elevations in Wells Monitoring Nonradioactive Dangerous Waste Landfill

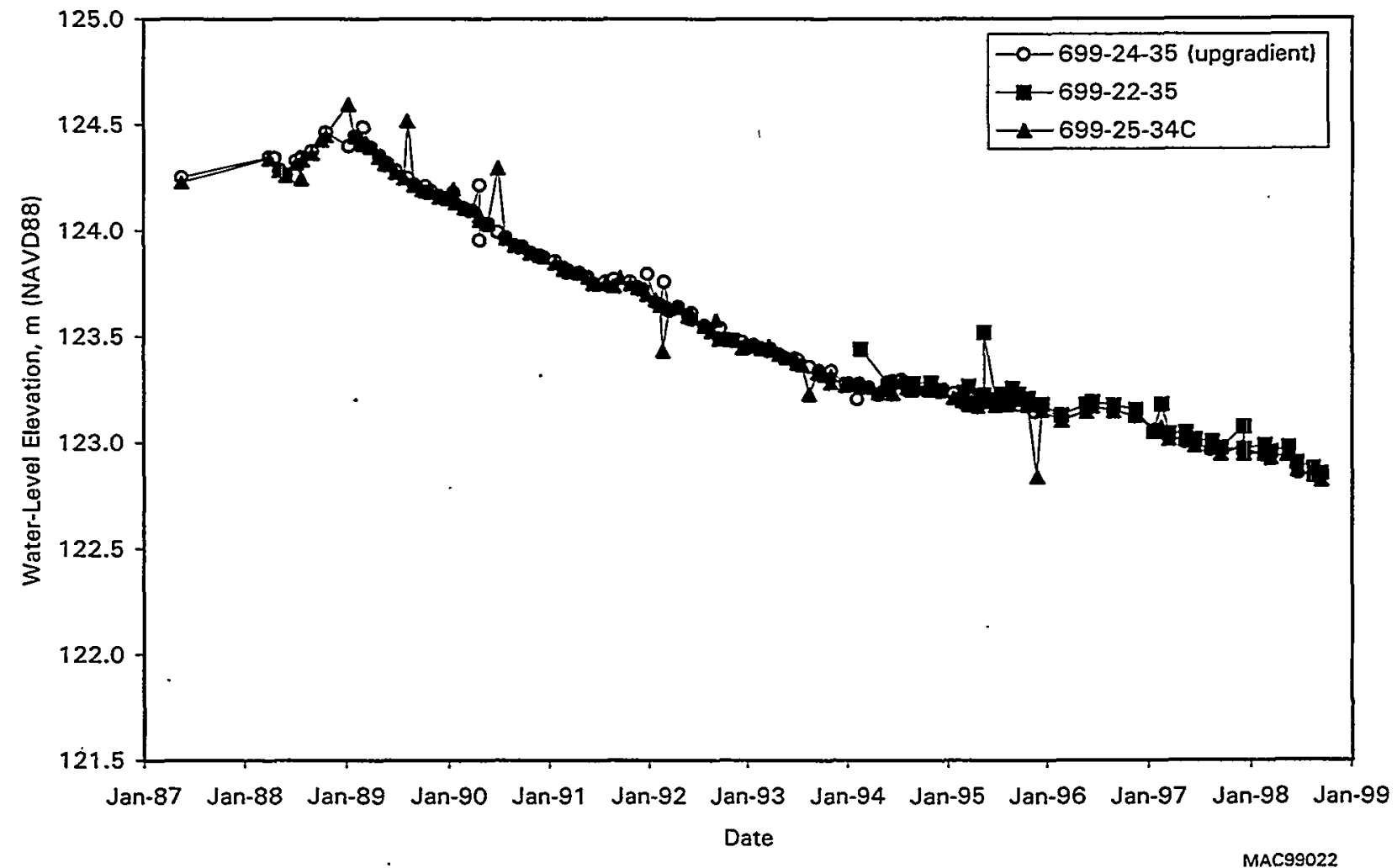

Figure 3.7-3. Water-Table Elevations in Wells Monitoring Solid Waste Landfill 


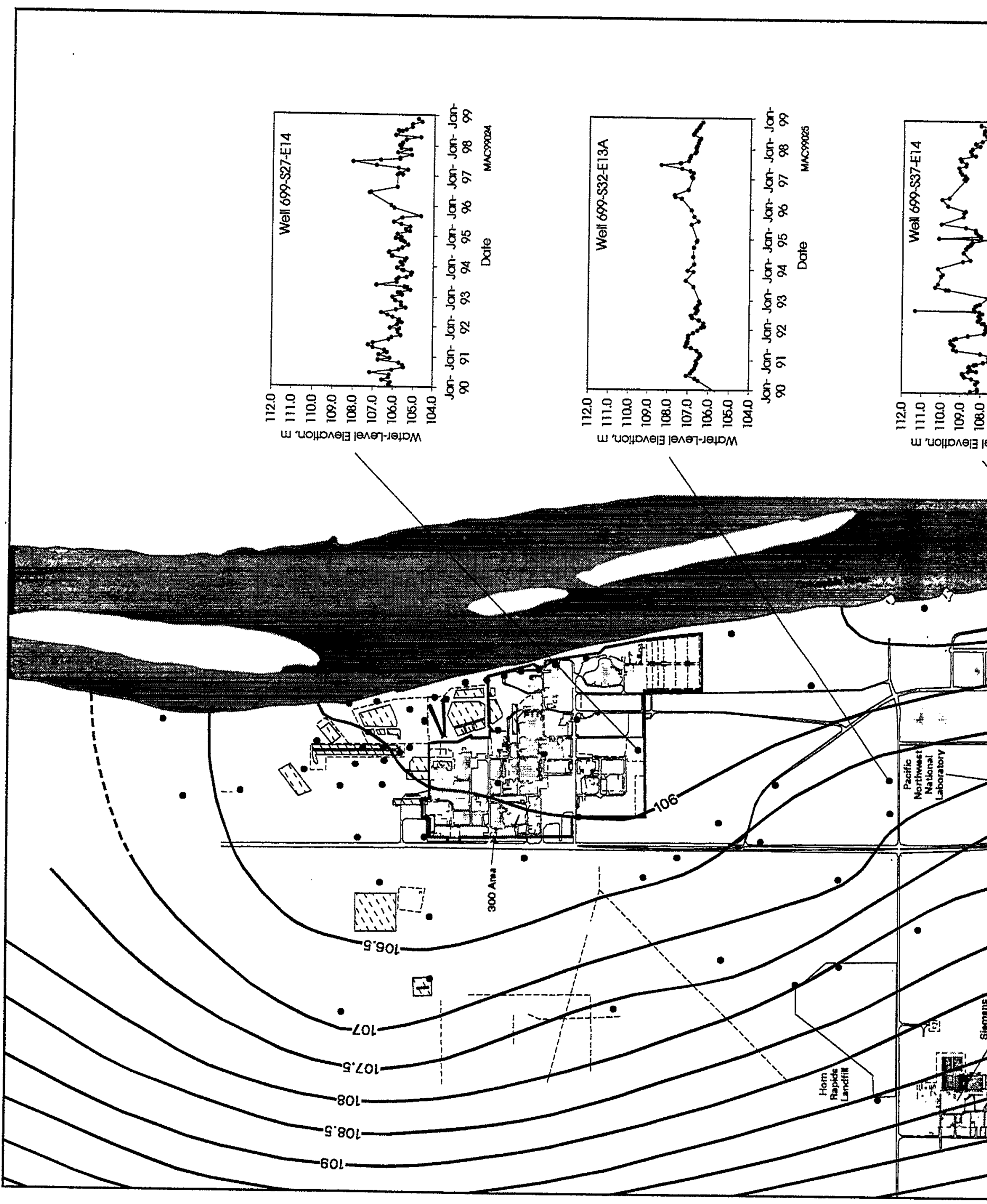




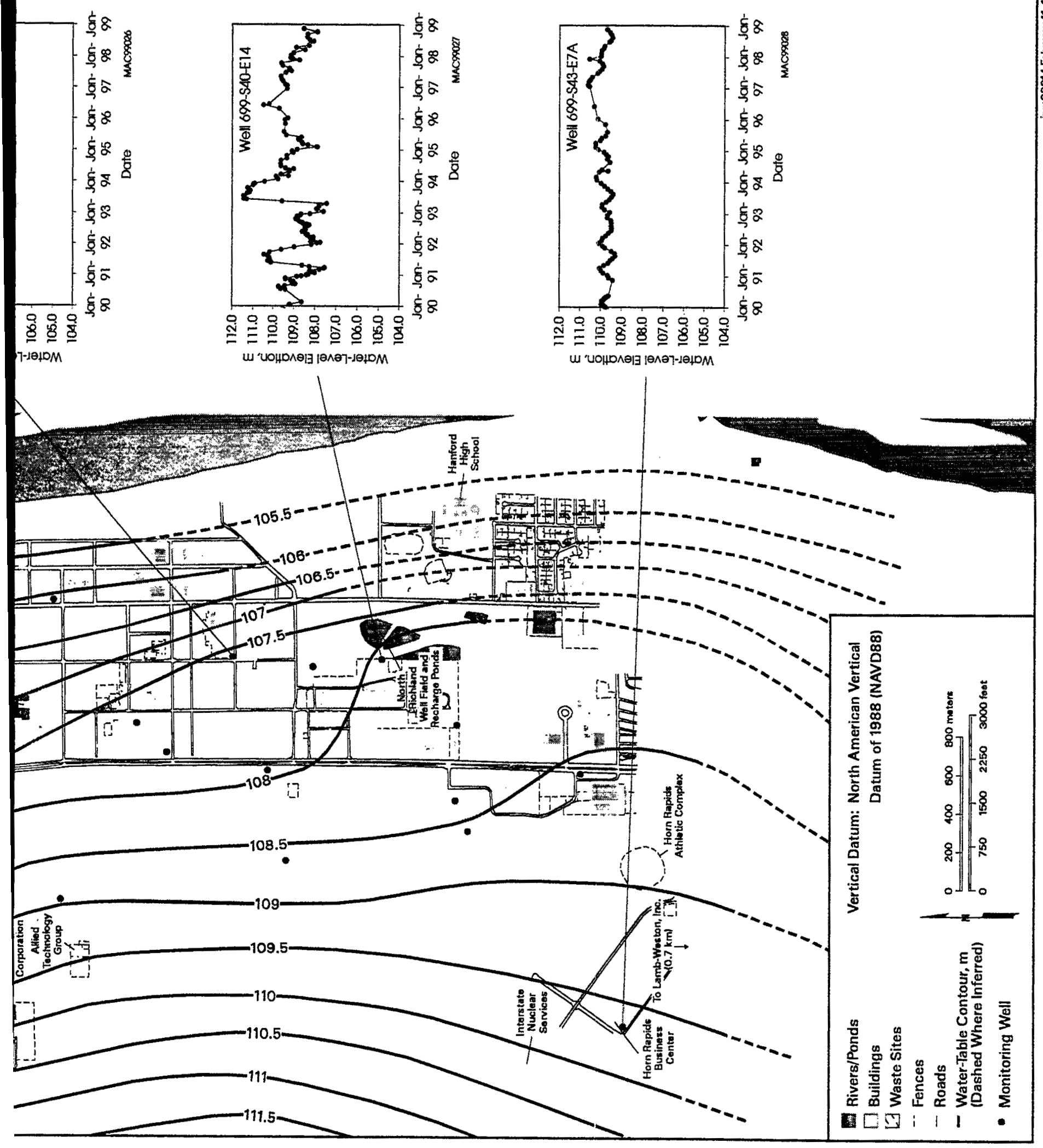




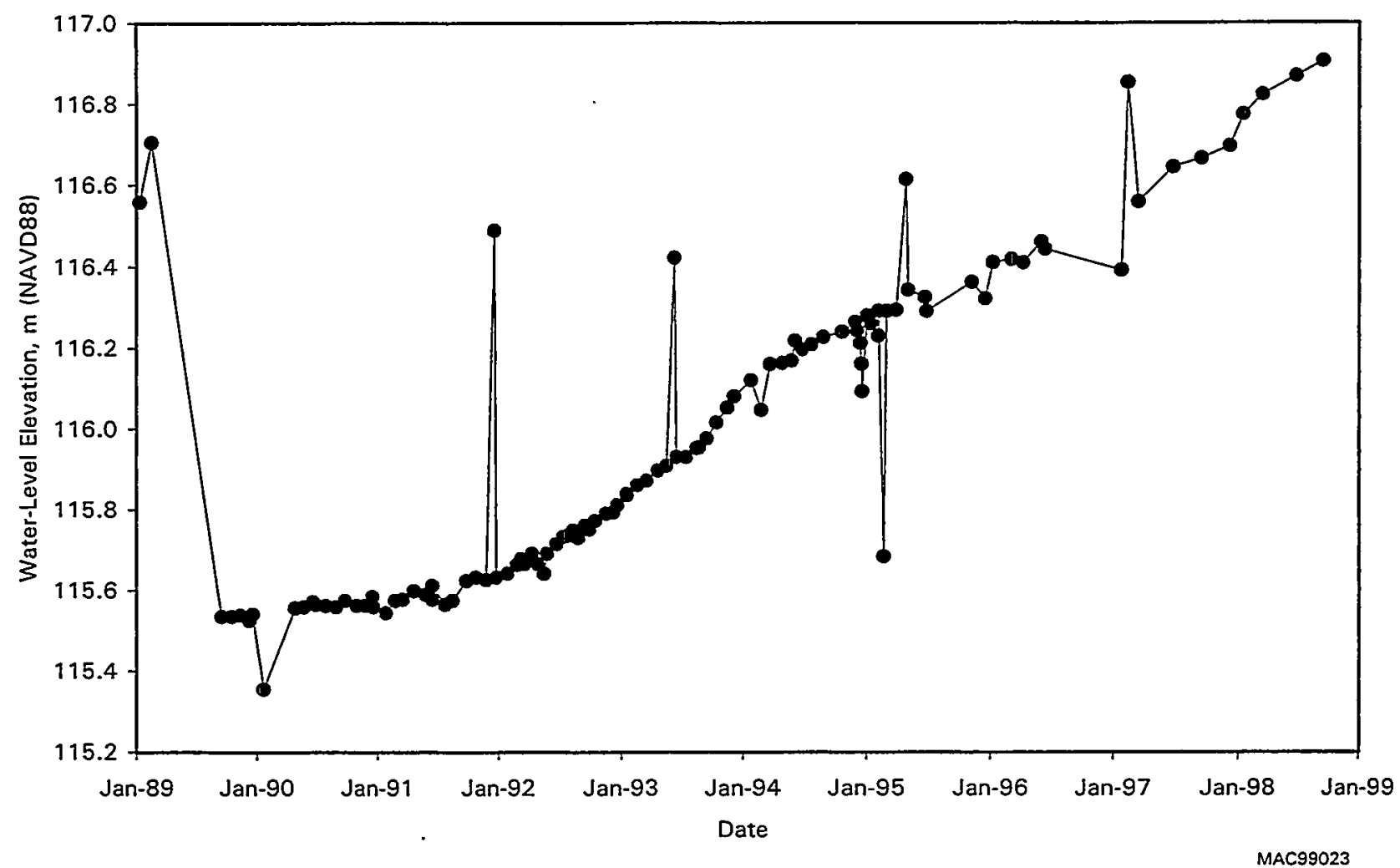

Figure 3.8-2. Water-Table Elevations in Richland North Area Well 699-S31-1

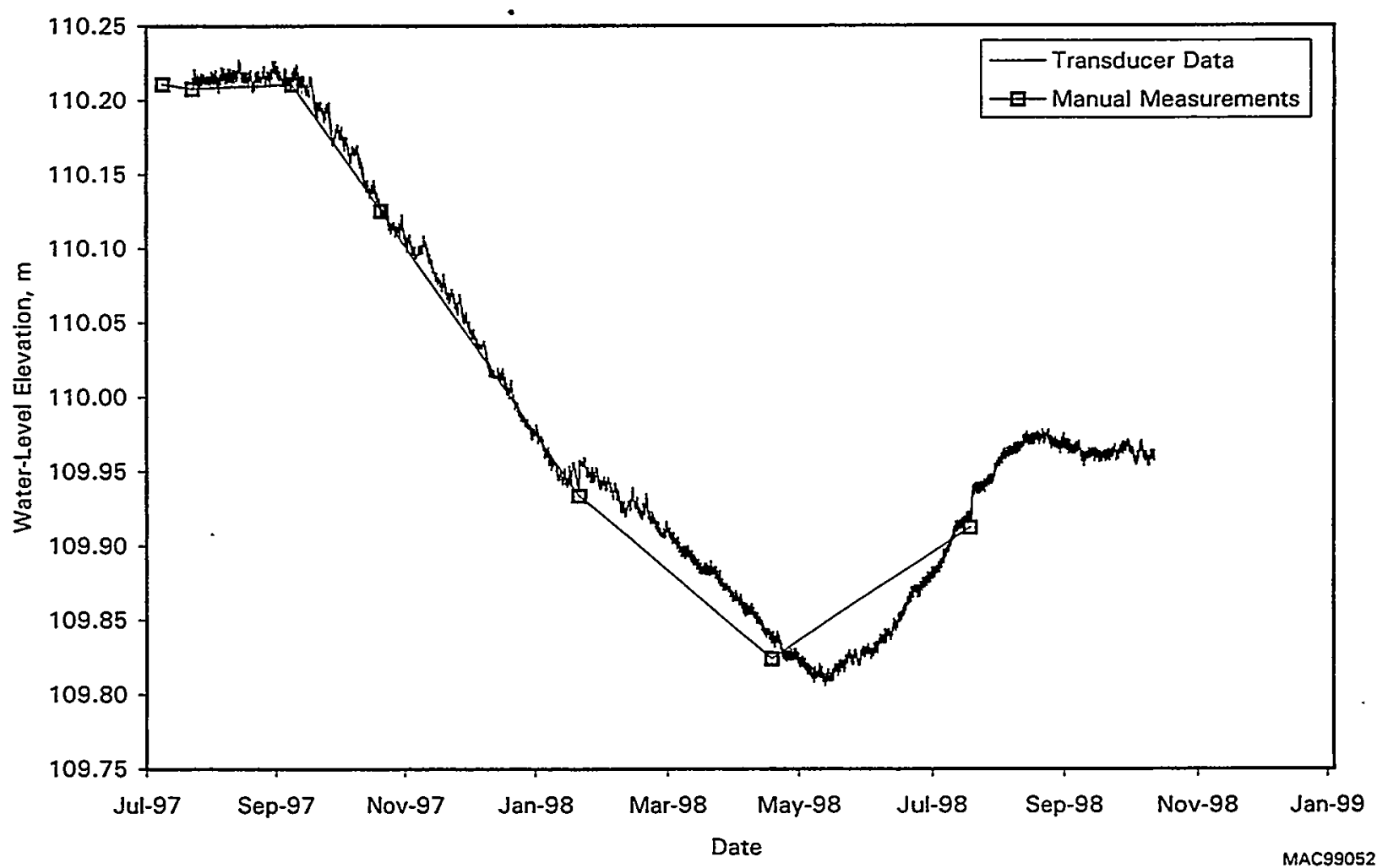

Figure 3.8-3. Water-Table Elevations in Siemens Power Corporation Well GM-2 


\subsection{Vadose-Zone Contamination}

Radioactive and hazardous wastes in the soil column from past intentional liquid waste disposals, unplanned leaks, solid waste burial grounds, and underground tanks at the Hanford Site are potential sources of continuing/future groundwater contamination. Subsurface source characterization and vadosezone monitoring, using spectral gamma-ray logging, soil-vapor monitoring, and sediment sampling and characterization were conducted during fiscal year (FY) 1998. This chapter summarizes major findings from these efforts, focused primarily on vadose-zone soil contamination associated with past single-shell tank leaks at several tank farms (i.e., waste management areas [WMAs]) and the Plutonium Finishing Plant liquid waste-disposal sites (i.e., major subsurface sources of carbon tetrachloride and transuranics [TRUs]) and characterization efforts associated with several new boreholes in support of the Immobilized Low-Activity Waste disposal site performance assessment, remedial action/closure decisions, and Resource Conservation and Recovery Act of 1976 (RCRA) groundwater monitoring. An overview of the major soil-column sources of groundwater contamination is provided as background for the more detailed description of activities at these specific sites. The interpretation of monitoring and characterization results is presented in the sections that follow.

This chapter discusses evidence for breakthrough, or transport, of residual soil-column contaminants to groundwater and possible driving forces. Much of the evidence for continuing impacts on groundwater from vadose-zone contamination is discussed in Chapter 5.0. The evaluation depends, to a large degree, on a synthesis of vadose-zone- and groundwater-monitoring data to present a comprehensive picture of contaminant fate and transport. The significant vadose-zone results are summarized here but the bulk of the data synthesis on impacts to groundwater is presented and discussed in Chapter 5.0.

\subsection{Major Sources}

\section{R. J. Serne, V. J. Rohay, D. G. Horton}

The major vadose-zone sediment sources of known or potential groundwater contamination are a result of the treatment, storage, and disposal of liquid wastes produced during 1) once-through cooling water from plutonium-production reactors and cooling water from the now inactive 100-N Reactor; 2) initial, or first-decontamination-cycle, chemical dissolution of irradiated nuclear fuel elements; and 3) subsequent plutonium-refining or -finishing steps. Large volumes of low-activity aqueous waste were intentionally discharged to soil-column-disposal sites from these operations, as well as from intermediate processing and waste-handling steps. Also, leaks from fuel-storage basins in the 100-K Area and from now inactive single-shell tanks resulted in radioactive waste in the soil column. Subsurface disposal and storage sites with the largest contaminant inventories are found in the 200 Areas and are shown in Figure 4.1-1. Waste characteristics and soil-column disposal-site conditions for these potential sources of groundwater contamination are discussed below. 


\subsubsection{Single-Shell Tanks}

Liquid waste from the nitric acid dissolution of the irradiated nuclear fuel and initial separation steps typically contained radionuclides at activities $>100 \mathrm{mCi} / \mathrm{L}$ and very high total salt concentrations $(>100 \mathrm{~g} / \mathrm{L})$. The primary chemical waste components were nitrate, chromium, fluoride, chloride, phosphate, and sodium. The relative amounts varied considerably, depending on the separation process. Detailed descriptions of these complex and variable mixtures are given in LA-UR-94-2657, Rev. 2, and LA-UR-96-858.

After the initial plutonium-separation step, the highly acidic first-cycle waste was neutralized with sodium hydroxide and transferred to underground single-shell storage tanks. A high pH was maintained by overaddition of sodium hydroxide, causing many chemical and radioactive constituents to precipitate and settle to the bottom of the tanks. Typically, the tank liquor flowed, or cascaded, through a series of tanks to remove most of the particulate phases. Early in the Hanford Site's production history when the bismuth phosphate process was used, the supernatant from the third tank in the cascade was discharged intentionally to soil-column-disposal sites.

Over 450,000,000 L of liquid waste that cascaded through underground storage tanks were discharged to the vadose zone via cribs, trenches, and french drains (WHC-MR-0227). The estimated total quantity of radioactivity in these cascaded wastes was $65,000 \mathrm{Ci}$ (decayed through December 1989).

Because of the large volumes discharged, the entire soil column beneath many disposal sites in the 200 Areas became saturated, and breakthrough of mobile contaminants (e.g., tritium, iodine-129, technetium-99, nitrate, chromium, fluoride) from the soil column to groundwater occurred. Although the disposal of cascaded tank wastes was terminated over 30 years ago, the residual liquid held in soil-pore spaces following drainage of free liquid at these sites can continue to be a long-term source of groundwater contamination, especially if a source of moisture is available to transport the mobile waste constituents (e.g., enhanced natural infiltration resulting from unfavorable topography and/or coarse gravel covers present at some inactive disposal facilities, removal of vegetation, leaking water lines).

Leakage from single-shell tanks can also be a source of groundwater contamination under certain conditions (see Sections 5.9.3 and 5.10.3). The estimated total volume of such sources is, however, small $(<4,000,000 \mathrm{~L})$ compared to the intentional soil-column-disposal volume $(450,000,000 \mathrm{~L})$ of very similar waste. However, there is growing evidence that downward movement of moisture and associated mobile contaminants from small-volume leaks $(\sim 100,000 \mathrm{~L})$ may be greater than previously thought (see Sections 5.9.3 and 5.10.3). Small leak sources can also be mobilized if a driving force and/or a preferential vertical pathway is present to transport the contaminants through the vadose zone to groundwater. The role of ground-cover type, or enhanced natural infiltration, and preferential pathways is, thus, a crucial issue in the tank-farm areas. A treatability demonstration, consisting of a surface covering to limit infiltration, was initiated at the 216-B-57 crib a few years ago. Similar engineered covers are being considered for some single-shell tank farms to reduce infiltration.

In FY 1998, boreholes in the BX, C, S, and TY single-shell tank farms were monitored by downhole, spectral gamma-ray spectroscopy methods. Also, time-series analyses of historic gross gamma-ray logs from boreholes in these single-shell tank farms were made to ascertain the current distribution of radionuclide contamination in the vadose zone beneath those facilities. Also, borehole 41-09-39 in the SX tank 
farm was extended from 39.6 to $68.6 \mathrm{~m}$ in depth. Nearly continuous core was recovered from this borehole, and many samples were characterized in detail for radionuclide and chemical content.

\subsubsection{Plutonium Finishing Plant}

The spent process solutions from the Plutonium Finishing Plant contained carbon tetrachloride, nitric acid, and isotopes of plutonium and americium (TRU waste). Liquid waste discharges to cribs and trenches in the Plutonium Finishing Plant area resulted in the accumulation of an estimated $20,000 \mathrm{Ci}$ of plutonium-239 and americium-241 in the underlying soil column (DOE/RL-91-32, Draft B; WHC-EP-0674): Based on relative hazard (e.g., dividing curie quantities of plutonium-239 and americium-241 by the appropriate health/risk standard), the Plutonium Finishing Plant liquid wastedisposal sites are some of the most significant sources of radioactive contamination in the vadose zone at the Hanford Site.

TRU activities up to $25,000,000 \mathrm{pCi} / \mathrm{g}$ are inferred from spectral gamma logging, and grab samples of shallow sediment (upper $6 \mathrm{~m}$ ) were found to contain $>100,000 \mathrm{pCi} / \mathrm{g}$ (maximum of 4,300,000 pCi/g plutonium-239/-240) immediately below the 216-Z-1A tile field distributor pipes. This high-activity, shallow zone has been attributed to particulate plutonium dioxide that was filtered out by the fine sediments. The estimated volume of soil in this zone is $45,000 \mathrm{~m}^{3}$. The area immediately beneath the tile field that contained the high-activity zone did not extend over the entire drain field. See RHO-ST-17 for details. The distribution of the $>100,000-\mathrm{pCi} / \mathrm{g}$ sediment was limited to the headend area and around the primary distribution line (center). There were also isolated volumes of sediment deeper in the profile (extending to depths of 20 to $30 \mathrm{~m}$ ) that contained similar high TRU activities. An estimate of the volume of this deeper, high-contamination sediment is $\sim 2,000 \mathrm{~m}^{3}$, but more detailed characterization would be needed to confirm this estimate, which is based on 16 boreholes.

The dissolved TRU (in either an aqueous and/or an organic phase) that was disposed was more widely distributed across the footprint of the disposal facility and with depth. The volume of soil with TRU $>100 \mathrm{pCi} / \mathrm{g}$ (definition of soil that must be removed, packaged, and sent to the Waste Isolation Pilot Plant, Carlsbad, New Mexico) is very large; again, based on the 16 boreholes.

Similar conditions exist at the 216-Z-9 and -18 facilities, which received the same waste stream as the 216-Z-1A tile field. A characterization was done at the 216-Z-9 trench (ARH-2207, ARH-2915), in which soil samples were obtained from shallow drill holes and analyzed for plutonium. Those samples, however, were all obtained from $\leq 3 \mathrm{~m}$ in depth; therefore, little can be said about the TRU distribution beneath the trench. In 1977 and 1978, an attempt was made to remove much of the TRU-contaminated soil at shallow depths beneath the 216-Z-9 trench (RHO-ST-21). However, low $(<10 \mathrm{pCi} / \mathrm{L})$ plutonium239/-240 and americium-241 activities were detected in one groundwater-monitoring well (299-W15-8) adjacent to the 216-Z-9 trench on two sampling dates (May 7, 1990 and November 13, 1991). The well went dry sometime after January 1992 and can no longer be sampled. Whether these analytical results are representative of the aquifer or were influenced by well construction (no annular seal) is not determinable, but future sampling at nearby wells should include careful analyses for these TRUs.

Well 299-W15-8 was logged by gross gamma and spectral gamma methods in 1992 and 1993. The data showed detectable, but relatively low, activities of plutonium-239 in the sediment around this well. The logging data confirmed the presence of TRUs to depths down to $\sim 33 \mathrm{~m}(\sim 175,000 \mathrm{pCi} / \mathrm{g})$, such that 
detection of plutonium in the groundwater for a brief period may be plausible. At shallower depths comparable to the depth of the crib bottom $(15.5 \mathrm{~m})$, the maximum plutonium activity in soil was $300,000 \mathrm{pCi} / \mathrm{g}$. The interior of the casing of well $299-\mathrm{W} 15-8$ became contaminated with alpha-emitting contaminants when it was perforated for the vapor-extraction project in 1995 and can no longer be used for gamma logging. If the isotopes were confirmed in the groundwater, it would take more detailed vadose-zone-sediment study to determine whether the TRUs traveled through the vadose zone to groundwater or migrated along the outside of the well casing.

Unlike the acidic waste streams sent to the $216-Z-1 A,-9$ and -18 facilities, the waste stream sent to the 216-Z-12 crib was neutral-basic process, analytical laboratory, and development laboratory wastes that included 25,000 g of plutonium (DOE/RL-91-58). Prior to disposal, the waste stream was adjusted to a pH of 8 to 10 . Not only did the $\mathrm{pH}$ of the waste stream differ, so did the organic content. The processes that generated waste sent to the $216-Z-12$ crib did not use the large volumes of organic compounds that were part of the waste streams sent to the 216-Z-1A, -9 , and -18 facilities. However, sufficient carbon tetrachloride is present beneath the $216-Z-12$ crib to include it in the vapor-extraction project.

Soil characterization at the $216-Z-12$ crib (RHO-ST-44) took place in the early 1980s. The results showed that plutonium activity was highest $(1,000,000$ to $5,000,000 \mathrm{pCi} / \mathrm{g})$ immediately beneath the crib bottom. Plutonium activity decreases rapidly with depth, such that activity, $3 \mathrm{~m}$ below the crib, was $<1,000 \mathrm{pCi} / \mathrm{g}$ and at $10 \mathrm{~m}$ below the crib was $<1 \mathrm{pCi} / \mathrm{g}$. Plutonium activity increased to a few tens of picocuries at 30 to $36 \mathrm{~m}$ below the crib, where it is probably associated with a silt unit of greater sorption capacity (RHO-ST-44).

In FY 1998, 21 boreholes were logged by spectral gamma-ray spectroscopy methods to determine the current distribution of TRU beneath the 216-Z-1A, -9 , and -12 facilities. The results of that logging are summarized in Section 4.2.3.2.

In addition to TRUs, the $216-\mathrm{Z}-1 \mathrm{~A},-9$, and -18 facilities received 570,000 to $920,000 \mathrm{~kg}$ of carbon tetrachloride (as both dissolved and separate liquid phases) between 1955 and 1973 (WHC-SD-EN-TI248). The discharged contaminated liquid wastes were apparently intended to remain in the soil column; however, carbon tetrachloride was discovered in groundwater near the Plutonium Finishing Plant in the mid-1980s and was later found to be widespread in the 200-West Area. In December 1990, planning began for an expedited response action, which started operation in 1992, to reduce the carbon tetrachloride vadose-zone source in the 200 -West Area based on concerns that the carbon tetrachloride was continuing to spread to the groundwater. If left unchecked, the carbon tetrachloride would significantly increase the extent of groundwater contamination because of downward migration through the vadose zone as a dense, nonaqueous-phase liquid; as an aqueous phase dissolved in natural recharge water; and/or as a vapor phase. Once in groundwater, the dense, nonaqueous-phase liquid dissolves slowly, and its status in the vadose zone and groundwater is the subject of ongoing remediation and characterization efforts (BHI-00720, Rev. 2).

In FY 1998, soil-vapor extraction to remove carbon tetrachloride continued. Also, to assess the effects of nonoperation of the soil-vapor-extraction system, monitoring was undertaken between October 1997 and March 1998. The results of these projects are summarized in Section 4.5. 


\subsubsection{Other Past-Practice Liquid-Disposal Facilities}

The Hanford Site has more than 800 past-practice liquid-disposal facilities. Radioactive liquid waste was discharged to the vadose zone through reverse wells, French drains, cribs, and tile fields. Along the Columbia River in the vicinity of the nine (now inactive and closed) reactors, once-through cooling waters were routinely disposed into cribs and trenches. The disposed cooling waters contained low levels of fission and neutron activation products and very low levels of some chemicals and actinides. Of biggest concern is the impacts of tritium, strontium-90, nitrate, and chromium to groundwater. Strontium-90 is present in groundwater seeping out of the banks of the river at the 100-N Area. Removal of strontium-90 has been ongoing for several years using pump-and-treat operations (see Section 5.5.4 in PNNL-11793 and Section 5.5.4 in this report). Also, chromium is actively being remediated at the $100-\mathrm{K}, 100-\mathrm{D} / \mathrm{DR}$, and 100-H Areas (see Sections 5.4.4, 5.6.4, and 5.7.4 in PNNL-11793 and Sections 5.4.4, 5.6.4, and 5.7.4 in this report).

Leakage from fuel-storage basins in the 100-K Area also contributes potentially significant inventories of fission products and TRUs to the soil column (WHC-SD-EN-AP-174). Thus, both past-practice sites and fuel-storage-basin leakage are potential vadose-zone sources.

Even though disposal of untreated wastewater to the ground stopped in 1995 (WHC-EP-0573-4), contaminant movement can still occur in the soil column beneath past-practice sites. Vadose-zone monitoring/characterization is one approach to evaluating the status of possible leaks or remobilization of contaminants caused by enhanced natural or artificial infiltration. The objectives of vadose-zone monitoring/characterization are to document the location of the contamination, to determine the moisture and contaminant movement in the soil column, and to assess the effectiveness of remedial actions. FY 1998 activities involved in situ borehole spectral gamma logging, soil-vapor sampling and analysis, and characterization of sediments obtained through drive-barrel and split-spoon sampling at new boreholes. New boreholes where vadose-zone characterization occurred include 299-E17-21 at the Immobilized Low-Activity Waste disposal site, 299-E33-333 at the 216-B-2-2 ditch, the extension of 41-09-39 to groundwater at the SX tank farm, as well as less-extensive characterization efforts at several other new RCRA wells and boreholes. Ten new RCRA wells were emplaced in FY 1998. Also, an extensive characterization was completed in mid-1998 at the Tank Waste Remediation System (TWRS) Phase I demonstration site east of the 200-East Area. The FY 1998 vadose-zone-monitoring activities are described in following subsections.

\subsection{In Situ Borehole Activities}

\section{G. Horton, R. J. Serne}

The objectives of vadose-zone borehole monitoring are to document the amount, location, and movement of contamination and moisture in the soil column. The most frequently used borehole-monitoring methods at the Hanford Site are gamma-ray and moisture logging. Borehole spectral gamma-ray logging is an in situ measurement of subsurface gamma-emitting radionuclides obtained through cased groundwater-monitoring wells and vadose-zone boreholes. The detector, or sensor, is a crystal of sodium iodide or germanium and associated electronics. Photons emitted from radionuclides in the formation interact with the detector material, resulting in electronic pulses transmitted to the surface via electrical cables to a digital data-storage system. By periodically recording detector response at various depths, 
changes over time can be documented. This general type of logging (in particular, gross gamma logging as opposed to spectral gamma logging) has been conducted at the Hanford Site for $>25$ years by slowly raising and lowering the detector inside existing cased monitoring wells in the vicinity of disposal facilities.

Neutron-source logging is an in situ measurement of subsurface moisture (hydrogen) content. The moisture can be the result of natural precipitation or be present in the soil from liquid waste discharge or leaks from tanks or pipelines. A neutron source is lowered into the borehole, where the neutrons collide with nuclei in the formation. With each collision, the neutrons lose some energy, with the greatest energy loss occurring when the neutrons strike a hydrogen nucleus. The slowed neutrons deflected back to the tool are counted by detectors, and the resulting electronic pulses are transmitted to the surface via electrical cables to a digital data-storage system. Borehole-construction materials are accounted for during tool calibration and data analysis. By periodically recording detector response at various depths, changes in moisture content over time can be documented. This type of logging is not used as often as gamma-ray logging at the Hanford Site but some neutron moisture logging was done in FY 1998.

\subsubsection{Spectral Gamma-Logging Methods}

Two organizations performed borehole-logging surveys at the Hanford Site in FY 1998. MACTECERS conducted single-shell tank vadose-zone characterization (C, BX, S, and TY tank farms) and Waste Management Federal Services, Inc., Northwest Operations (WMNW) conducted vadose-zone monitoring at several past-practice, soil-column-disposal facilities (BY cribs and trenches and Plutonium Finishing Plant liquid disposal facilities). WMNW also performed logging surveys on several new and existing wells for the Hanford Groundwater Monitoring Project. The equipment, calibration, and operating procedures were equivalent for the systems used by both logging organizations, except for administrative and procedural controls for data acquisition and handling as indicated in the following subsections.

The WMNW logging equipment used at past-practice sites was calibrated at the Hanford Site. The calibration facilities were constructed for long-term stability and designed to represent subsurface conditions (PNL-9958, PNL-10801). The detection systems were calibrated in these facilities, and corrections were established for differences between the calibration facilities and Hanford Site boreholeconstruction conditions (WHC-SD-EN-TI-292, WHC-SD-EN-TI-306). Procedures in WMNW-CM-004 (Sections 17.0 and 18.0) governed the subsurface geophysical surveys and the analysis of the resulting raw data. Logging results, including raw and interpreted data, were loaded into a Pacific Northwest National Laboratory database for storage.

The MACTEC-ERS spectral gamma-ray borehole-logging measurements in the WMAs (tank farms) were conducted in accordance with P-GJPO-1786. Depth profiles, or logs, of radionuclide activities in all boreholes surrounding a tank were produced and stored electronically. The logs were correlated with tank farm gross gamma-ray log data and historical information about each tank, and a tank summary data report was prepared for each tank characterized. The individual tank reports documented the results of the logging in relation to tank-leak history. An interpretive summary tank farm report was prepared for each tank farm to provide a complete assessment and correlation of all vadose-zone-contamination data at a particular tank farm. These data were used to identify sources and to determine the nature and extent of the contamination. 
The MACTEC-ERS logging systems used in the tank farms were calibrated following GJPO-HAN-1. The base calibration was performed using the facilities in Grand Junction, Colorado, and is reported in GJPO-HAN-1. The field calibrations are published biannually, most recently in GJPO-HAN-3.

Data were recorded by the logging system in accordance with procedures outlined in P-GJPO-1783, Rev. 1 and managed as outlined in MAC-VZCP-1.7.10-1, Rev. 2. Details on other aspects of the project are provided in MAC-VZCP-1.7.3, Rev. 1; MAC-VZCP 1.7.9, Rev. 1; MAC-VZCP-1.7.4, Rev. 1; MAC-VZCP-1.7.10-2, Rev. 1; and MAC-VZCP-1.7.2, Rev. 1.

\subsubsection{Monitoring Networks}

Three types of monitoring structures were logged in FY 1998: 1) older, vadose-zone boreholes and groundwater-monitoring wells in and near past-practice sites; 2) new RCRA-compliant groundwater monitoring wells; and 3) single-shell tank farm vadose-zone borehole networks.

\subsubsection{Soil-Column-Disposal Sites}

Older, existing, groundwater-monitoring wells and vadose-zone boreholes adjacent to past-practice sites were constructed to a variety of specifications. Depending on when the boreholes were drilled and their purpose, casing diameter, number of casings, presence or absence of borehole seals, and seal material may or may not be well documented. In addition, changes to wells, such as extension or cutting of the casing and retrofitted annular seals, may have been made subsequent to borehole construction.

Existing wells and boreholes were logged on an as-is basis after an extensive fitness-for-logging evaluation. Corrections for varying borehole diameters, casing thickness, and borehole fluids were taken into account prior to interpreting the raw counts obtained as a function of depth in these monitoring structures. In addition, a concern. with any of the older boreholes is the degree to which contaminants may have migrated down the inside or outside of the borehole casing. At many past-practice disposal facilities, relatively large numbers of boreholes were installed for earlier characterization purposes (1970s). These older boreholes allow some assessment of contaminant migration over time by comparing current depth profiles with the previous logs. In a few cases, downward migration has been corroborated using actual sediment characterization.

\subsubsection{New RCRA-Compliant Groundwater Wells}

New groundwater-monitoring wells are constructed to specifications in WAC 173-160. The new FY 1998 RCRA wells were logged within the temporary casing. Thus, many of the problems encountered in older wells (e.g., unknown casing thickness, unspecified thicknesses for annular seals) were not encountered in the new RCRA wells, so that more exact corrections for borehole-construction materials could be made.

\subsubsection{Single-Shell Tanks}

The tank farm vadose-zone-monitoring networks consist of 5 to 7 steel-cased, 15.2- to 20.3-cm-dia. dry wells (i.e., boreholes) arranged around the perimeter of each tank. Illustrations of four tank farms are provided in Section 4.2.3.3. The dry-well depths range from $\sim 23$ to $46 \mathrm{~m}$ below ground surface. As with 
the analyses done at the soil-column-disposal sites, analysis of logging data from tank farms included corrections for varying borehole diameters, casing thickness, and fluids. Most of the single-shell tankmonitoring networks were installed in the late 1960s and early to mid-1970s. In addition, some tank farms included lateral lines that ran horizontally beneath the tanks to detect leakage from the tanks and to track movement over time.

Borehole designations within the tank farm are of the form $x x-y y-z z$, where $x x$ refers to the numerical tank farm designation, yy refers to the tank number (06 is tank 106), and zz refers to the clock position of the borehole relative to the tank, where $120^{\prime}$ clock is north. A borehole with the designation 41-09-04 is at the 4 o'clock position of tank 109-SX. A borehole with the designation 41-00-08 is in the SX tank farm, is not directly associated with any tank, and is at the approximate 8 o'clock position on the tank farm perimeter.

\subsubsection{Borehole Spectral Gamma Logging}

Logging was conducted at several facilities during FY 1998. The results of the logging in the 200-East Area; at the Plutonium Finishing Plant liquid-disposal facilities; at the C, BX, S, and TY singleshell tank farms; and at other locations are given in this section.

\subsubsection{WMA B-BX-BY Assessment - Soil-Column-Disposal Sites in 200-East Area}

Several groundwater-monitoring wells or vadose-zone boreholes near various inactive liquid-disposal facilities (e.g., 216-B-35 to -41 trenches; 216-B-43 to -50 cribs; 216-B-57 crib; 216-B-7A -7B, and -8 cribs; 216-B-11A and -11B reverse wells; 216-B-8 tile field) adjacent to WMA B-BX-BY were logged by WMNW in support of a RCRA groundwater assessment. Sixteen wells were logged in August and September 1997 with a 35\% high-purity germanium spectral gamma detector. The casing in one of the wells (299-E33-33) was bent, and the detector would not pass through the total depth of the well. The specific wells and the complete results of the surveys are described in Section 6.2.4 of PNNL-11795 and are summarized below. All depths referred to in this section are relative to the top of the casing.

Of the 16 gamma-ray logs obtained outside WMA B-BX-BY, 4 suggest that gamma-emitting radionuclides may have been redistributed in the surrounding sediments over the last 10 years (wells 299-E33-05, -18, -38, and -41). The evidence is questionable in some of those wells, and the significance of redistribution varies. The following summarizes apparent changes in radionuclide distribution that occurred. For results from other wells, see Section 6.2.4 in PNNL-11795.

Two wells (299-E33-05 and -38) in the BY crib area showed small changes (a few picocuries per gram) of cobalt-60 in the sediment profiles. The changes occurred between 1991 and 1994 in the first well and between 1991 and 1995 in the second well. There has been little indication of further movement based on the 1997 logs of these two wells. The cobalt-60 movement in well 299-E33-05 appeared to be horizontal, migrating laterally in a fine-grained zone between 33.2 and $34.7 \mathrm{~m}$. The cobalt- 60 migration in well 299-E33-38 may have been downward between 37.2 and $42.1 \mathrm{~m}$, but migrating amounts are insignificant ( $1 \mathrm{pCi} / \mathrm{g})$. The lithology at the depths of these changes beneath the BY cribs is a thick ( $\sim 30$ to 35-m) sequence of slightly gravelly sands, sands, and silty sands of the Hanford formation (Qfs of Reidel and Fecht 1994a, 1994b). The sequence contains several discontinuous silt lenses and calcareous horizons. 
Two wells (299-E33-18 and -41) showed migration of uranium-235 and uranium-238. In well 299-E33-18, the uranium-238 activity changed from "not detected" in September 1992 to $400 \mathrm{pCi} / \mathrm{g}$ when logged in September 1997. Uranium movement occurred above the water table between 70.7 and $75.9 \mathrm{~m}$. The water table is at $76.5 \mathrm{~m}$ in this well. Results from groundwater samples from this well indicate rising uranium activities, possibly beginning in 1993 and extending to 1997. See Section 5.10.3 for a discussion of uranium in groundwater near WMA B-BX-BY.

In well 299-E33-41, uranium-238 appears to have increased from 200 to $1,000 \mathrm{pCi} / \mathrm{g}$ between 1991 (when the well was installed) and September 1997 in a deep zone between 67.1 and $73.2 \mathrm{~m}$. Also, comparison of the current and past logs suggests that the peak activity and the entire plume of uranium have migrated 1.2 to $6.1 \mathrm{~m}$ deeper into the soil column. However, the well casing and seal were changed between the two logging events, complicating the comparison of data. See Section 5.10.3 for a discussion of the possible sources of recent elevated levels of uranium and technetium in groundwater at this well.

\subsubsection{Plutonium Finishing Plant Liquid-Disposal Facilities}

During FY 1998, WMNW logged, by spectral gamma-ray methods, 21 boreholes at the 216-Z-1A, -9 , and -12 liquid waste-disposal facilities associated with the Plutonium Finishing Plant.

The 21 boreholes were selected for logging after a review was made of driller's logs, boreholeconstruction reports, as-builts, and documentation of alterations subsequent to the borehole's original construction. Data were acquired with a high-purity germanium detector. Dead-time corrections adjusted counting times for losses in high count-rate conditions (Koizumi et al. 1994).

Generally, boreholes of $15 \mathrm{~m}$ 'or less total depth were logged at 15.2-cm increments for $200 \mathrm{~s}$ per depth reading. Boreholes $>15 \mathrm{~m}$ total depth were first logged at $47 \mathrm{~s}$ per $15.2-\mathrm{cm}$ increment. Full analysis of the first $\log$ was used to determine a re-log section of the most critical depths. The re-log section was logged at $200 \mathrm{~s}$ per $15.2-\mathrm{cm}$ increment. Logging speeds were controlled by the data acquisition computer.

It was initially thought that all previous laboratory data from the 216-Z-1A, -9 and -12 characterizations and logging activities could be used as the baseline for the FY 1998 logging. However, comparisons of newly acquired logging data with historical laboratory analytical data were very difficult because of the differences in the analytical methods. Thus, most comparisons were made with previously collected spectral gamma-ray logs.

Results. All borehole logs and a full discussion of the logging results at the 216-Z-1A, -9 and -12 facilities can be found in PNNL-11978. The discussion below summarizes those results. All depths referred to in this section are relative to ground surface.

Cesium-137, protactinium-233, plutonium-239, and americium-241 were identified in the logs from the $216-Z-1 A$ and -12 facilities. The maximum activities found at the $216-Z-1 A$ tile field were in borehole 299-W18-159, which is located along the centerline/central distributor pipe of the tile field (cesium-137,23 pCi/g at $3.3 \mathrm{~m}$; protactinium-233, $63 \mathrm{pCi} / \mathrm{g}$ at $16.5 \mathrm{~m}$; plutonium-239, 25,000 nCi/g at $3.3 \mathrm{~m}$; americium-241, 2,500 nCi/g at $4.3 \mathrm{~m}$ ). The distributor pipes are at $\sim 4.6 \mathrm{~m}$ (RHO-ST-17). High count rates exceeded dead-time accuracy from 1.5 to $4.3 \mathrm{~m}$. The difference between the maximum 
activities found from laboratory results obtained from discrete samples (RHO-ST-17) and the logging results (PNNL-11978) at borehole 299-W18-159 probably are the result, in part, of differences in the two analytical methods, coupled with the potential for discrete particulate plutonium-dioxide at the level of the distributor pipe.

The deepest depth at which contamination was found at the 216-Z-1A tile field was in borehole 299-W18-175, which is located along the centerline/central distributor pipe, where protactinium-233 was $\sim 21 \mathrm{pCi} / \mathrm{g}$ at $30 \mathrm{~m}$, plutonium-239 was near $28 \mathrm{nCi} / \mathrm{g}$ at $30 \mathrm{~m}$, and americium- 241 was near $80 \mathrm{nCi} / \mathrm{g}$ at $30 \mathrm{~m}$ (the americium-241 value is relative as a result of interferences). Significant activities ( $\geq 100 \mathrm{nCi} / \mathrm{g}$ ) of plutonium-239 were found as deep as $16 \mathrm{~m}$ in one borehole and $\sim 14 \mathrm{~m}$ in another. Significant activities ( $\geq 100 \mathrm{nCi} / \mathrm{g})$ of americium-241 were found as deep as 15 to $18 \mathrm{~m}$ in two boreholes. Whereas the shallow, high-activity zone can be attributed, in part, to particulate plutonium-dioxide that was filtered out of the effluent by the sediments, the deeper, more widely distributed zones of contamination probably resulted from dissolved TRU in aqueous and/or organic phases.

The only man-made radionuclide identified at the $216-\mathrm{Z}-9$ trench was cesium-137, at $<1 \mathrm{pCi} / \mathrm{g}$ near the surface in borehole 299-W15-95. However, only four wells were logged, and radionuclide contamination almost certainly exists beneath the trench.

At the 216-Z-12 crib, boreholes 299-W18-181, -182, and -185 showed the highest activities of manmade radionuclides in the boreholes logged. The maximum plutonium-239 activity was $3,000 \mathrm{nCi} / \mathrm{g}$ at $7 \mathrm{~m}$ in borehole $299-\mathrm{W} 18-181$. The maximum americium-241 activity was $2,100 \mathrm{nCi} / \mathrm{g}$ at $7 \mathrm{~m}$ in borehole 299-W18-182. The maximum cesium-137 activity was $900 \mathrm{pCi} / \mathrm{g}$ at $5.8 \mathrm{~m}$ in borehole 299-W18179. The distributor pipe is $\sim 5.2 \mathrm{~m}$ below ground surface. The deepest contamination was found $\sim 10$ to $11 \mathrm{~m}$ under borehole 299-W18-181, where plutonium-239 was $\sim 110 \mathrm{nCi} / \mathrm{g}$, americium-241 was $\sim 40 \mathrm{nCi} / \mathrm{g}$, and cesium-137 was $\sim 6 \mathrm{pCi} / \mathrm{g}$. These boreholes all lie along the central distributor pipe near the headend of the crib. Protactinium-233 was the only man-made radionuclide found in boreholes peripheral to the crib.

Comparisons of log data collected in FY 1998 with data from past logging events suggested that some changes have occurred in radionuclide activity around two boreholes in the 216-Z-1A tile field and around one borehole in the $216-Z-12$ crib.

In borehole 299-W18-159 at the 216-Z-1A tile field, there is an apparent decrease in protactinium233 activity to $\sim 1 / 3$ of 1991 values between 13.4 and $15 \mathrm{~m}$, with no apparent change above or below that zone. This suggests a lateral, not a vertical, change in protactinium-233 activity. Also, between 13 and $16 \mathrm{~m}$, cesium-137 activity decreased by a factor of $\sim 3$, compared to the $1991 \log$ (Figure 4.2-1).

In borehole 299-W18-175 at the 216-Z-1A tile field, a 51\% increase in protactinium-233 activity was found between 6 and $16 \mathrm{~m}$ and a $22 \%$ increase between 28 and $29 \mathrm{~m}$ when compared to activities from the $1993 \log$ (Figure 4.2-2). Also in this borehole, there was an increase in the intensity of the americium-241 $60-\mathrm{keV}$ photopeak but no change in the intensity of the americium-241 208-keV photopeak at $12.5-\mathrm{m}$ depth when compared with the $1993 \mathrm{log}$ data. This suggested either a decrease in the casing thickness (corrosion?), leading to less attenuation of the less-energetic photon or small amounts of americium-241 inside the borehole casing. 
Only borehole 299-W18-179 at the 216-Z-12 crib suggested that there were changes in subsurface distribution of radionuclides since the last logging in 1993. Protactinium-233 showed an apparent $16 \%$ increase, and plutonium-239 showed an apparent $123 \%$ increase over the $4.6-$ to $5.5-\mathrm{m}$ depth interval (Figure 4.2-3). This depth is within the trench backfill material. The zone between 4.9 and $5.5 \mathrm{~m}$ exceeded dead-time-correction limits for both the 1993 and 1998 datasets. However, the system used in 1993 would have overestimated the activities, and the system used in 1998 would have underestimated the activities so that the apparent increases are in opposition to the dead-time effects. The conclusion was a significant increase occurred over the last 5 years in the activities of protactinium-233 and plutonium-239 (between 4.6 and $5.5 \mathrm{~m}$ ) around the borehole.

There is significance to the occurrence and the changes in protactinium-233 activity found in the three boreholes. Protactinium-233 has a 27-day half-life, so its occurrence must be supported by a long-lived parent isotope. Alpha decay of neptunium-237, with a half-life of $2,200,000$ years, is the most probable parent for protactinium-233. One probable origin for the neptunium-237 is alpha decay of americium-241, which was a significant contaminant in the waste stream sent to the Plutonium Finishing Plant cribs. A second possible origin for neptunium-237 is uranium-238 $(n, 2 n)$ uranium-237, which beta decays to 'neptunium-237. Regardless of the origin of the neptunium-237, it is considered to be rather mobile in oxic environments (see PNL-10379, SUP. 1). Thus, the changes in activity of protactinium-233 probably reflect movement of neptunium-237, and the distribution of protactinium-233 can be considered a surrogate for neptunium-237.

Finally, the FY 1998 logging found large amounts of TRUs around boreholes 299-W18-149 and 299-W18-159 that produced a large neutron flux, resulting in activation of elements in the soil column and in the borehole casing. This phenomenon was not investigated further.

Migration of TRUs. The mobility of TRUs as organometallic complexes in the acidic waste streams discharged to the past-practice disposal facilities near the Plutonium Finishing Plant were discussed in Section 4.4.5 of PNNL-11793 and Johnson and Hodges (1997). The mechanism suggested by Johnson and Hodges might account for the distribution of high-activity TRUs to the $20-$ to $30-\mathrm{m}$ depth in the 216-Z-1A tile field as found in earlier soil-column characterizations (RHO-ST-17). It is also suggested that the TRUs could be adsorbed by the soil column after degradation of the organic complexing agents, resulting in stabilization of the contaminants. Alternatively, other soil-chemical reactions may have occurred (RHO-ST-17, NUREG/CR-6124). The 216-Z-1A, -9, and -12 facilities were logged in FY 1998 to determine whether recent TRU movement had occurred beneath those facilities as a result, in part, of infiltration of natural precipitation. The surface of the $216-Z-1 A$ tile field is $\sim 2 \mathrm{~m}$ below the surrounding grade and is covered with gravel. Thus, infiltration at this facility is expected to be enhanced.

In 1993, the Grand Junction Projects Office logging team produced prompt fission neutron logs of four boreholes at $216-Z-1 A$ and one each at 216-Z-9 and -12. The prompt fission neutron tool measures undifferentiated, fissionable isotopes (primarily uranium-235, plutonium-239, and plutonium-241) and gives actual activities per gram. The tool was calibrated to uranium-235 in the calibration boreholes at Grand Junction and Hanford. Activities were reported as "apparent Pu-239 (nCi/g)." The conversion from uranium-235 to plutonium-239 was computed from numerical simulation of the ratio of neutron production from uranium-235 and plutonium-239. The results of the prompt fission neutron logging were not published, but a draft report states that all the boreholes at the 216-Z-1A tile field and one borehole at the 216-Z-12 crib showed large activities of fissionable isotopes. Two of the boreholes at $216-Z-1 \mathrm{~A}$ had 
been logged previously with the prompt fission neutron tool in 1978 and again in 1984. The distribution of contaminants as seen from the $1993 \mathrm{log}$, agreed well with the previous logs, indicating that fissionable radionuclides, including plutonium, had not moved substantially over the span of 15 years at the two boreholes. The general conclusion is that TRUs were relatively mobile at the time of discharge to the 216-Z-1A tile field but have been fairly stable since.

The FY 1998 logging found that the subsurface distribution of plutonium had changed around only one borehole (299-W18-179) at the 216-Z-12 crib. The reason for the apparent redistribution of plutonium around the borehole is not known. "Particulate" plutonium, with discrete 2- to $24-\mu \mathrm{m}$ particle sizes ( $>79 \mathrm{wt} \%$ plutonium dioxide) at and immediately below the distribution pipe at 216-Z-1A was documented in Price and Ames (1976). Borehole 299-W18-179 is at the extreme headend of the crib; the depth at which plutonium appeared to have redistributed is at the level of the distributor pipe. Although it is possible that particulate plutonium has been remobilized at the $5-\mathrm{m}$ depth around the borehole, further investigation is needed to determine both the nature and the reasons for plutonium remobilization.

Comparing the distribution of TRUs beneath the 216-Z-1A and -12 facilities shows a much deeper penetration of TRUs beneath the tile field. This agrees with past characterizations at the two facilities (RHO-ST-17, RHO-ST-44) and can be explained by either the acidic disposal or the organometallic complexation process described by Johnson and Hodges (1997). Unlike the acidic, organics-containing waste stream disposed to the $216-Z-1 A$ tile field, the waste stream sent to the $216-Z-12$ crib was neutral to basic and contained little organic-complexing agents (though sufficient carbon tetrachloride was found beneath the crib to include it in the vapor-extraction project). The initial mobility of TRU is expected to be greater in the former waste stream than in the latter. After the disposal occurred, both the acidic and organic complexes are expected to diminish via soil $\mathrm{pH}$ neutralization and biodegradation processes, and TRUs, especially americium and plutonium, would be expected to adsorb strongly to the Hanford Site sediments. There has been no obvious increased americium or plutonium migration deeper into the sediment profile at this disposal facility, but the protactinium-233 distribution may be interpreted as showing some migration of neptunium-237.

\subsubsection{Single-Shell Tank Farms}

Spectral gamma logging of vadose-zone-monitoring boreholes were completed in the BX, C, S, and TY single-shell tank farms in FY 1998. A comprehensive report was published for each of these tank farms (GJO-98-40-TAR, GJO-HAN-19; GJO-98-39-TAR, GJO-HAN-18; GJO-97-31-TAR, GJOHAN-17; GJO-97-30-TAR, GJO-HAN-16, respectively) from which the following summaries are taken. All depths in this section are relative to the top of the casing.

During borehole logging, the spectra collected in some intervals were distorted because of high dead times (i.e., the minimum time that must separate two counting events so that each event can be counted as a separate event) caused by high gamma-ray activity in those intervals. The intervals of borehole logs where high dead time caused spectral distortion and radionuclide activities could not be quantified are marked "high dead time" on the spectral gamma-ray figures in this section. In regions of very high dead time (i.e., very high gamma-ray activity), the detector became saturated, and no spectra could be collected. Intervals where the detector became saturated are marked "detector saturated" on the logs. 
BX Tank Farm. In FY 1998, the tank farm summary report on spectral gamma logging of the 74 boreholes surrounding the 12 single-shell tanks in the BX tank farm was completed (GJO-98-40-TAR, GJO-HAN-19). Figure 4.2-4 shows the configuration of tanks within the farm and the location of associated boreholes. Most of the boreholes are 30 or $46 \mathrm{~m}$ deep. The logging in BX tank farm found cobalt- 60 , antimony-125, cesium-137, europium-152, europium-154, uranium-235, and uranium-238 to be the major gamma-emitting contaminants. Interpretation of the logging results supports the designation of tanks BX-101, $-102,-108,-110$, and -111 as leakers, though in some cases mixing of leak plumes and leaks from pipelines complicates assignment of vadose-zone contamination with specific leaks (GJO-9840-TAR, GJO-HAN-19). Figure 4.2-5 shows selected logs from boreholes in the BX tank farm. All logs can be found in GJO-98-40-TAR, GJO-HAN-19.

The logging at the BX tank farm showed evidence of much surface and near-surface contamination from unplanned spills and pipeline leaks. Most of this contamination is from cesium-137, but other radioisotopes observed include cobalt-60, europium-152, and europium-154. Most of the boreholes are completed at $30 \mathrm{~m}$. Contamination at the bottom of some of the boreholes was interpreted to be casing related (GJO-98-40-TAR, GJO-HAN-19) such as contaminated mud attached to the casing, particulate drag down, or water leakage down the interior or exterior walls of the casing.

Extensive, deep, vadose-zone contamination was found east of tanks BX-101 and -102, where cobalt-60, antimony-125, cesium-137, europium-152, europium-154, uranium-235, and uranium-238 were all identified in the subsurface. However, uranium-235 and uranium-238 dominate the plume in this area, with activities of uranium-238 approaching $1,000 \mathrm{pCi} / \mathrm{g}$ in boreholes $21-27-07,-08$, and -09 . Uranium-235 and uranium-238 were detected in borehole 21-27-08 almost continuously from $\sim 28 \mathrm{~m}$ to the bottom of the borehole at $\sim 45 \mathrm{~m}$ and almost continuously in borehole 21-27-07 from $\sim 22 \mathrm{~m}$ to the bottom of the borehole at $\sim 42 \mathrm{~m}$. The depth to which man-made uranium contamination extends is not known because deeper boreholes in the immediate vicinity are not available. Activities decrease to the northeast, east, and southwest from tanks BX-101 and -102. Logs from boreholes 21-27-01 (also known as well 299-E33-141) and 21-27-02 (see Figure 4.2-5) show minimal contamination to their limited depth. Associated with the uranium are significant quantities of cobalt-60, antimony-125, and cesium-137 in some boreholes, but the extent of significant amounts of these is less than that of uranium.

Logs from boreholes west of tanks BX-101 and -102 are shallower than the 21-27-series boreholes east of the tanks and do not show the presence of any man-made radioisotope, except cesium-137. Most of the identified cesium-137 activity west of the tanks is at or near the surface.

A second area of widespread subsurface contamination exists in the southwestern portion of the tank farm between tanks BX-107 and -110 and between BX-108 and -111 .

Cesium-137 dominates vadose-zone contamination in the southwestern part of the tank farm. The greatest cesium-137 activities are in boreholes near tanks BX-107 and -110 (21-07-06, 21-10-03, and 21-10-05), where activities exceeding $1,000 \mathrm{pCi} / \mathrm{g}$ are common (see Figure 4.2-5). In two boreholes between tanks BX-108 and -111 (21-11-03 and -04), cesium-137 also exceeds 1,000 pCi/g. Zones of high dead time exist in all of these boreholes. Logs from boreholes west of tanks BX-110 and -111 show considerably less subsurface contamination. Cobalt- $60(\sim 1 \mathrm{pCi} / \mathrm{g})$ is found in one borehole (21-00-21) between $\sim 15$ and $18 \mathrm{~m}$. 
Cesium-137 around boreholes between tanks BX-108 and -111 has a maximum at $\sim 12$ to $14 \mathrm{~m}$, corresponding to the base of the tank farm. A second maximum exists in borehole 21-11-03 at 20 to $21 \mathrm{~m}$. Farther south near tanks BX-107 and -110, cesium-137 exhibits several maxima, but the interpretation of the data is made difficult by several vertical zones in which dead time was excessive and where contamination may be associated with movement along the casing either during or after drilling (GJO-98-40TAR, GJO-HAN-19). Activities $>1,000 \mathrm{pCi} / \mathrm{g}$ were found at the deepest levels logged $(30 \mathrm{~m})$ in borehole 21-07-06 (see Figure 4.2-5) and in lesser amounts near the bottom of several other boreholes. Thus, the deepest penetration of contamination in this area is not known. Cobalt-60 at the 1- to $2-\mathrm{pCi} / \mathrm{g}$ level is found associated with the cesium- 137 in a few boreholes in this area, and uranium-235 is found in one borehole (21-10-05) at $\sim 20$ to $70 \mathrm{pCi} / \mathrm{g}$.

Borehole 21-06-05 is not associated with either of the plumes in the southwestern or southeastern parts of the BX tank farm. This borehole is at the southeastern edge of tank BX-106. Cesium-137 contamination up to $\sim 600$ to $700 \mathrm{pCi} / \mathrm{g}$ is found at $\sim 12 \mathrm{~m}$, which is the approximate base of the tank. Lesser amounts of antimony-125 ( $\sim 3 \mathrm{pCi} / \mathrm{g}$ maximum), uranium-235 ( $\sim \mathrm{pCi} / \mathrm{g}$ maximum), and uranium-238 $(\sim 100 \mathrm{pCi} / \mathrm{g}$ maximum) also occur at depths within $\sim 3 \mathrm{~m}$ of the bottom of the tank. The depth of this contamination suggests that tank BX-106, not currently designated a leaker, may have leaked in the past (GJO-98-40-TAR, GJO-HAN-19). The only other significant contamination in the area is an isolated occurrence of uranium-235 ( $10 \mathrm{pCi} / \mathrm{g})$ at $23 \mathrm{~m}$ in borehole 21-03-07.

A discussion of groundwater contamination in the vicinity of the BX tank farm can be found in Section 5.10.3.

C Single-Shell Tank Farm. In FY 1998, the tank farm summary report on spectral gamma logging of the 70 boreholes surrounding the 12 single-shell tanks in the $C$ tank farm was completed (GJO-98-39TAR, GJO-HAN-18). Figure 4.2-6 shows the configuration of tanks within the farm and the location of associated boreholes.

Tanks C-101, -110 , and -111 are currently classified as assumed leakers and are estimated to have leaked $\sim 110,000 \mathrm{~L}$ of liquid. The spectral gamma-logging data corroborate leakage of radionuclides from tanks C-101 and -110 into the surrounding sediments, though the amount of contamination around tank $\mathrm{C}-110$ is not great. There is no indication in the spectral gamma data, or in historical gross gamma data, to indicate that tank C-111 leaked (GJO-98-39-TAR, GJO-HAN-18). Figure 4.2-7 shows selected logs from boreholes in $\mathrm{C}$ tank farm. Logs from all boreholes can be found in GJO-98-39-TAR, GJO-HAN-18.

The best indication that tank C-101 leaked is found in boreholes 30-01-06 and -09 (see Figure 4.2-7), where significant cesium-137 (up to $\sim 600 \mathrm{pCi} / \mathrm{g}$ in borehole 30-01-09) is found at or slightly above the base of the tank, which is $\sim 11 \mathrm{~m})$.

The borehole logs show that contamination associated with assumed leaking tanks C-110 and -111 is much less significant than elsewhere in the tank farm. The greatest activity in the area is in borehole 30-10-02, located between the two tanks. Contamination in borehole 30-08-12 is attributed to a possible origin from tanks C-108 or -110 (GJO-98-39-TAR, GJO-HAN-18).

There are two areas in the $C$ tank farm that show more significant contamination than that associated with the assumed leakers. Several boreholes between tanks C-104 and -105 exhibit $>10 \mathrm{pCi} / \mathrm{g}$ 
cesium-137 between $\sim 12$ and $18 \mathrm{~m}$, with the highest activity (500 to $600 \mathrm{pCi} / \mathrm{g}$ ) in borehole 30-04-03 at a shallower depth near 7.3 m (see Figure 4.2-7). Borehole 30-05-07 has the greatest cesium-137 activity, but the detector saturation, or high dead time, occurred between $\sim 10.6$ and $19 \mathrm{~m}$. Several other boreholes in this area have cesium-137 activity $<2$ to $3 \mathrm{pCi} / \mathrm{g}$. Cobalt-60, generally near 1 to $10 \mathrm{pCi} / \mathrm{g}$, is associated with the cesium-137 in six of the boreholes between tanks C-104 and -105 . This area of contamination has been associated with a leak, or leaks, from the cascade line connections between the two tanks (GJO-98-39-TAR, GJO-HAN-18). Contamination in this area appears localized and does not show up in all boreholes. For example, boreholes 30-04-03, 30-05-05, and - 07 show the greatest activities of both cobalt-60 and cesium-137, whereas the boreholes nearest them (30-04-02 and 30-05-06) do not show zones of activity $\geq 1 \mathrm{pCi} / \mathrm{g}$ below the base of the tanks (see Figure 4.2-7).

A second area with significant contamination exists between tanks C-108 and -109, though the levels of contamination are not as great as they are in the area of tanks C-104 and -105. Borehole 30-08-02 (see Figure 4.2-7) shows the greatest activity. Except for borehole 30-08-02, activities (not associated with surface sources) are $1 \mathrm{pCi} / \mathrm{g}$ cobalt- 60 and $\leq 10 \mathrm{pCi} / \mathrm{g}$ cesium- 137 . Also, the greatest activity of europium-154 ( 2 to $3 \mathrm{pCi} / \mathrm{g}$ ) found in the $\mathrm{C}$ tank farm occurs in this area at borehole 30-08-02 coincident with the cesium-137 maximum. The source for contamination in this area cannot be positively identified.

The logging at $\mathrm{C}$ tank farm showed evidence of much surface and near-surface contamination from unplanned spills and pipeline leaks. Most of the surface contamination is due to cesium-137 but other radioisotopes observed include cobalt-60 and europium-154.

For a discussion of groundwater contamination in the vicinity of $\mathrm{C}$ tank farm, see Section 5.10.3.

241-S Tank Farm. In FY 1998, the tank farm summary report on spectral gamma logging of the 68 boreholes surrounding the 12 single-shell tanks in S tank farm was completed (GJO-97-31-TAR, GJO-HAN-17). Figure 4.2-8 shows the configuration of tanks within the farm and the location of associated boreholes. Interpretation of the logging results supports the designation of tank S-104 as a leaker. Figure 4.2-9 shows selected logs from $S$ tank farm. All available borehole logs can be found in GJO-97-31-TAR; GJO-HAN-17.

Cesium- 137 and cobalt- 60 were identified as vadose-zone contaminants. Europium-154 was found in one borehole within $2 \mathrm{~m}$ of the surface and is probably associated with a surface spill. Contamination at and near the surface is found throughout $S$ tank farm but not as great as at some other tank farms.

Contamination deeper in the vadose zone is concentrated in two areas. One of these areas is north, east, and southeast of tank S-102. The logs show that cesium-137 is the most abundant contaminant in this area and is found in several boreholes in quantities exceeding $1 \mathrm{pCi} / \mathrm{g}$ down to $\sim 15$ to $18 \mathrm{~m}$. The maximum activity at these depths is $\sim 80 \mathrm{pCi} / \mathrm{g}$ in borehole $40-02-03$ north of tank S-102. Borehole 40-02-08 is the only other borehole with cesium- 137 activities $>10 \mathrm{pCi} / \mathrm{g}$ at $15 \mathrm{~m}$ or more in depth (see. Figure 4.2-9). The contamination near tank S-102 is interpreted to have resulted from surface spills (GJO-97-31-TAR, GJO-HAN-17).

Cobalt-60, with an activity of $\geq 1 \mathrm{pCi} / \mathrm{g}$, is found in one borehole (40-03-05). Contamination in this area has been attributed to surface spills and leaking pipelines (GJO-97-31-TAR, GJO-HAN-17). 
The second area in S tank farm with relatively deep vadose-zone contamination is near tank S-104. Contamination below the base of tank S-104 is found in several boreholes. Cesium-137 was the only identified radioisotope associated with tank S-104. Borehole 40-04-05 shows the most extensive contamination, with cesium-137 activities near $1,000 \mathrm{pCi} / \mathrm{g}$ at $15 \mathrm{~m}$ and declining with depth to $1 \mathrm{pCi} / \mathrm{g}$ at $29 \mathrm{~m}$. Maximum activity in other boreholes in the area is between 1 and $10 \mathrm{pCi} / \mathrm{g}$ at depths of $<18 \mathrm{~m}$.

For a discussion of groundwater contamination in the vicinity of $\mathrm{S}$ tank farms, see Section 5.9.3.

TY Tank Farm. In FY 1998, the tank farm summary report on spectral gamma logging of the 22 boreholes surrounding the 6 single-shell tanks in TY tank farm was completed (GJO-97-30-TAR, GJO-HAN-16). Figure 4.2-10 shows the configuration of tanks within the farm and the location of associated boreholes. All tanks, except TY-102, are designated assumed leakers. For much of the contamination in this tank farm, the most recent logging cannot determine exactly which tanks may be the source because of the small number of boreholes and their shallow completion depths. Interpretation of the logging results suggests that tank TY-102, currently designated as sound, may have contributed to vadose-zone contamination in the past (GJO-97-30-TAR, GJO-HAN-16). Figure 4.2-11 shows selected logs from the TY tank farm. All available borehole logs can be found in GJO-97-30-TAR, GJO-HAN-16.

Cesium-137 and cobalt- 60 were identified as vadose-zone contaminants. Europium-154 was found in one borehole within $2 \mathrm{~m}$ of the surface and is interpreted to be the result of a surface spill. Cesium-137 contamination at and near the surface is found throughout the TY tank farm.

Significant cesium-137 activity ( $\geq 10 \mathrm{pCi} / \mathrm{g}$ ) was found in three boreholes at or below the depth of the base of the tanks. In borehole $52-02-11$, cesium-137 up to 50 to $60 \mathrm{pCi} / \mathrm{g}$ was identified between $\sim 12$ to $14 \mathrm{~m}$, corresponding to the level of the base of the adjacent tank (TY-102). Contamination is not found shallower in the borehole, suggesting that tank TY-102 may be the source.

Logging in borehole $52-03-03$ east of tank TY-103 encountered $>8,000 \mathrm{pCi} / \mathrm{g}$ of cesium-137, the activity at which the detector saturates, between 14 and $15 \mathrm{~m}$, corresponding to the base of the tank that is probably the source for this contamination. In borehole 52-05-07 south of tank TY-105, cesium-137 at $\sim 30 \mathrm{pCi} / \mathrm{g}$ was identified between 15 and $17 \mathrm{~m}$; activity decreased to $\sim 1 \mathrm{pCi} / \mathrm{g}$ with increasing depth to $\sim 23 \mathrm{~m}$. The lack of contamination from the surface to $15 \mathrm{~m}$ suggests that the adjacent tank may be the source for the contamination; however, the borehole is perforated between 12 and $30 \mathrm{~m}$ and contamination may have spread as a result (GJO-97-30-TAR, GJO-HAN-16).

Significant cobalt-60 activity ( $\geq 1 \mathrm{pCi} / \mathrm{g}$ ) was found in three boreholes adjacent to tanks TY-103, -105 , and -106 . The greatest activity was found in borehole 52-03-06, between tanks TY-103 and -105, where cobalt-60 increases (but not steadily) from $\sim 1 \mathrm{pCi} / \mathrm{g}$ at $17 \mathrm{~m}$ to $\sim 30 \mathrm{pCi} / \mathrm{g}$ at $30 \mathrm{~m}$ (the maximum depth logged). The cobalt- 60 is most likely from a tank leak, but because of the location of the borehole, a specific tank source cannot be identified.

The other two boreholes with significant cobalt-60 are in the southern part of the tank farm. Borehole 52-05-07 shows between 1 and $10 \mathrm{pCi} / \mathrm{g}$ cobalt-60 between $\sim 17$ and $29 \mathrm{~m}$. Borehole 52-06-05 shows between 1 and $3 \mathrm{pCi} / \mathrm{g}$ cobalt- 60 between $\sim 19$ and 22 and between 42 and $45 \mathrm{~m}$. The deepest penetration 
of cobalt-60 in the area of these boreholes is not known because the contamination is found to the total depths logged. However, in borehole 52-06-07, southwest of tank TY-106, cobalt-60 (0.1 to $1 \mathrm{pCi} / \mathrm{g})$ was found between 61 and $65 \mathrm{~m}$ (see Figure 4.2-11).

For a discussion of groundwater contamination in the vicinity of TY tank farm, see Section 5.9.3.

\subsubsection{Other Borehole Geophysical Logging}

Hydrostratigraphic Interpretation. Six groundwater wells were logged in FY 1998 for gross gamma-ray signature using a sodium iodide detector. The wells logged were 299-E24-7, 299-E24-8, 299-E25-28, 299-E27-1, 299-E28-26, and 699-49-33. The purpose of the logging was to obtain hydrostratigraphic information in support of ongoing geohydrologic interpretations supporting the conceptual model of the 200-East Area that will be published in FY 1999. Although detection of man-made radionuclides was not the purpose of the logging, no man-made radionuclides were discernible from the results.

New RCRA. Groundwater Wells. Ten new RCRA-compliant groundwater-monitoring wells were geophysically logged in FY 1998 (see Plate 1 for well locations). These wells were logged within temporary casing. Wells 299-W10-23 and -24 were drilled at WMA T. Both wells were logged by spectral gamma-ray methods, using a 35\% high-purity germanium detector. Only the results for well 299-W10-24 were available in FY 1998. The well is in a surface contamination zone, and the log showed cesium-137 to be present near the surface at activities of $\leq 3 \mathrm{pCi} / \mathrm{g}$ and at intermittent depths to the bottom of the well at activities of $<0.3 \mathrm{pCi} / \mathrm{g}$.

Wells 299-W10-26, 299-W14-13, 299-W14-14, and 299-W15-40 were drilled at WMA TX-TY. Only the results for well 299-W14-14 were available in FY 1998. Well 299-W14-14 was logged by spectral gamma-ray methods, using both $35 \%$ high-purity germanium and sodium iodide detectors, and by neutron probe for moisture content. Three spectral gamma logs were obtained to determine the 1) presence or absence of man-made radionuclides (the well is in a surface contamination zone, and cesium-137 was identified at $\sim 1.5 \mathrm{~m}$ with a maximum activity of $7 \mathrm{pCi} / \mathrm{g}$ ); 2) lithologic information for stratigraphic purposes; and 3) effects of logging rate on the quality of the logs used for lithologic interpretations. The high-purity germanium detector was used to $\log$ the well at a rate of $197 \mathrm{~s} / \mathrm{m}(60 \mathrm{~s} / \mathrm{ft})$ and at a rate of $656 \mathrm{~s} / \mathrm{m}(200 \mathrm{~s} / \mathrm{ft})$; the sodium iodide detector was used at $197 \mathrm{~s} / \mathrm{m}(60 \mathrm{~s} / \mathrm{ft})$. Figure $4.2-12$ shows a comparison of the three different logs. Essentially, the gross gamma logs from all three logging runs are identical, indicating that no gain in log quality is obtained by using the slower logging rate. Comparison of the gross gamma logs with the geologist's log is ongoing and will be published in FY 1999.

One well (299-E33-44) was drilled at WMA B-BX-BY and was logged by spectral gamma-ray methods using both high-purity germanium and sodium iodide detectors and by neutron probe for moisture content. The high-purity germanium log identified cesium- 137 between 0.15 and $0.9 \mathrm{~m}$ at $\leq 3 \mathrm{pCi} / \mathrm{g}$ and at intermittent depths to the bottom of the well at $<0.3 \mathrm{pCi} / \mathrm{g}$. Lithologic information from the logs is currently being incorporated into interpretations of the subsurface at the WMA. 
Three other wells (299-W19-41, 299-W19-42, and 299-W22-79) were drilled and logged by spectral gamma methods using a $35 \%$ high-purity germanium detector but the results were not available in FY 1998.

\subsection{Historical Gross Gamma-Ray Log-Time Series}

\section{R. Randall, D. A. Myers, D. G. Horton}

The single-shell tank farm borehole logging-surveillance program was established as one of several methods used to identify leaking tanks and operated until 1994. In 1975, borehole logging within this program was upgraded to a digital system. Under the upgraded program, gross gamma-ray logs were captured in digital form and reviewed to identify large leaks of radioactive liquid from the underground tanks. In FY 1998, WMNW and Three Rivers Scientific reanalyzed the January 1975 through 1993/1994 gross gamma-ray logs to note the presence of mobile radionuclides in the subsurface not targeted under the original program. During FY 1998, the tank data for BX, BY, SX, and TY tank farms were reanalyzed. The results of the analyses for the BX, BY, and SX tank farms were available in FY 1998, and only those for the SX tank farm data were published (WMNW/TRS-ES-VZMA-002). The remaining results will be published in FY 1999.

This section summarizes the methods of analysis and the general observations for the borehole data analyzed during FY 1998.

\subsubsection{Methods}

The strategy for analysis of the surveillance log data was to preserve as much of the raw data as possible by limiting the amount of processing. Data were analyzed through a series of iterations, each iteration resulting in a more definitive view of the data. All historical log surveys for one borehole were analyzed as a group for each radioactive zone in a well, allowing statements to be made about the stability of any given contaminated interval.

Integral to the analysis of the gross gamma-ray data was the use of information provided by the spectral gamma-logging system (DOE/ID/12584-268, GJPO-HAN-4). The spectral gamma-logging system employs a high-resolution germanium detector to obtain data that lead to the identity and depth of radioactive isotopes. Knowledge of the isotopes present in the subsurface was invaluable in the interpretation of the tank farm surveillance logs. By integrating the spectral gamma-logging data with historical surveillance data, the behavior of radionuclides in the vadose zone over time was examined. The analysis performed on the gross gamma-ray data makes evident the usefulness of the historical data for the purpose of evaluating the presence of gamma-emitting radionuclides in the vadose zone beneath the tank farms.

Data were represented graphically to illustrate trends in subsurface contamination. Three presentation formats were used throughout the analysis and compilation of the data. They are the stack plot, clean plot, and radiation zone plot. Grade-thickness product calculations were used to enhance the statistical precision and to reduce depth-control errors in the log data. 


\subsubsection{Stack Plot}

An example of a stack plot is shown in Figure 4.3-1. The plot shows gamma-ray data by depth ( $y$ axis) over the time period ( $x$ axis) of electronic data collection from a single borehole (41-00-08). The log profiles in Figure 4.3-1 represent quarterly logging events selected from more frequently collected data for most years between 1975 and 1994. Between 1980 and 1984, log data were collected approximately once per year. This example illustrates zones of anthropogenic gamma-ray activity at 20.7 and $23.8 \mathrm{~m}$. The activity at $20.7 \mathrm{~m}$ is first identifiable around 1985 and increases with survey date from that time to the end of data collection in 1993.

The stack plot and other processing output files were used to verify the entire dataset for possible influx or disappearance of contaminants that selected reviews of individual log surveys may have missed. In the above example, the zone at $20.7 \mathrm{~m}$ is a clear case of lateral contaminant migration into the region surrounding the borehole. One significant use of the stack plot is the analysis for downward movement of contamination.

\subsubsection{Clean Plot}

The standard plot presentation for a clean borehole (41-04-05) is shown in Figure 4.3-2. The plot shows the oldest gamma-ray survey acquired digitally, the average background values, and the frequency of clean values. The frequency-clean value for a given survey is the percentage of borehole depth that the count rate is at background level. The average background calculation smoothes any minor anomalies that may have occurred over the course of surveillance data acquisition.

Borehole 41-04-05 (see Figure 4.3-2) had numerous gross gamma-ray surveys collected over a 21-year period and was logged with the spectral gamma-logging system close to the end of 1995 . No observable changes in the character of the activity became apparent over the logging history of the borehole. Although spurious surveys exist in the frequency clean and the average background plots, the trend of the data is clear.

\subsubsection{Radiation Zone Plot}

The grade-thickness product is the sum of the product of count rate and depth increment over a selected depth interval. For boreholes with contamination, the grade-thickness product was plotted for zone(s) of radiation above natural background. Four auxiliary graphs were also prepared for boreholes with contamination, as illustrated in Figure 4.3-3 for borehole 41-00-08.

The chronologically first (left) and last (right) digitally recorded gamma-ray surveys are shown with the detector count rate presented at two linear scales (discernible by line widths) in counts per second as a function of depth. The date of the survey is presented above each graph.

The top-center graph shows the computed grade-thickness product (y axis) presented on a linear scale for every surveillance log run in the borehole between 1975 and 1995 ( $\mathrm{x}$ axis). The background value was first subtracted from the count rate to eliminate natural background and to view only the isotopic characteristics before producing the plot. The depth, or depth range, for which the grade-thickness product was computed is noted on the graph. The first and last gross gamma-ray surveys are included to 
show the zones analyzed. If an interval became radioactive between the start of the surveillance program (1975) and the end (1994), it appears as a difference in the character of the two surveys. In cases for which the specific isotope is known, based on spectral gamma-logging system data, a decay line was plotted. Multiple plots were generated to show the results for different zones within a borehole when appropriate. As can be seen in the grade-thickness plot for the $\sim 21-\mathrm{m}$ contaminated zone, the interval is not stable and is seen to increase even at the time data collection was terminated. Contaminated zones that are stable show excellent agreement between the trend of the grade-thickness product and the decay curve for the specific isotope. Analyses of data from the same borehole but at the $23.8 \mathrm{-m}$ contaminated zone show that the contamination is stable, where stable is determined by agreement between the decay line and the grade-thickness product.

The bottom-center graphs on Figure 4.3-3 show the frequency-clean and average background values ( $y$ axis) for each surveillance log acquired ( $x$ axis). Each result is overlaid by the root-mean-square value (1-sigma uncertainty) calculated for the background value and is shown as an error bar. Data gaps (occasional points that record as zero) and data that exceed the background threshold are not included in the frequency-clean or average background calculations.

\subsubsection{Results}

The analysis of the $74 \mathrm{BX}$ tank farm boreholes indicates that 25 were free of identifiable contamination, 27 exhibited zones of contamination interpreted to have been stable over the period of the records analyzed, 8 exhibited zones interpreted to have been increasing at the end of the record period, 8 had contamination interpreted to be from tank farm activities such as waste transfers, and 6 exhibited zones of contamination that could not be readily interpreted. A total of 20,021 records were analyzed in arriving at the above conclusions.

The analysis of the $71 \mathrm{BY}$ tank farm boreholes indicates that 5 were free of identifiable contamination, 8 were interpreted to be stable at the end of the period of record analyzed, 10 were interpreted to be unstable or increasing at the end of the record period, 43 had contamination interpreted to be from tank farm activities such as waste transfers, and 4 exhibited zones of contamination that could not be readily interpreted. There was one borehole for which there were no available data. A total of 30,882 records were analyzed in arriving at the above conclusions.

The analysis of the 98 SX tank farm boreholes indicates that 45 were free of identifiable contamination, 31 exhibited zones of contamination interpreted to have been stable over the period of records analyzed, 9 exhibited zones that are interpreted to have increasing activity at the end of the period of records analyzed, and 13 exhibited zones of contamination that could not be readily interpreted. A total of 37,210 records were analyzed in arriving at the above conclusions.

Boreholes may exhibit one or more characteristics, so the above summations reflect the most conservative status. 


\title{
4.4 Drilling and Characterization
}

\author{
D. G. Horton, D. A. Myers, R. J. Serne, V. J. Rohay
}

\subsubsection{Directional Drilling}

Tests of directional drilling were conducted at two locations on the Hanford Site during FY 1998: the Mock Tank Leak Test Facility in the central part of the 200-East Area and the Drilling Technology Test Site between the 200-East and 200-West Areas. The two sites were chosen because they offered very different lithologies to test this drilling technique. The sediments at the mock tank leak site are predominantly sands, sandy gravels, and sandy silts. The sediments at the drilling technology site included boulder gravels that are much more difficult to drill. The tests were designed to assess the capability of standard rotary mud-assisted directional drilling to successfully penetrate the sands and gravels of the Hanford formation and to test the capability of a Sandia National Laboratories' designed spectral gammaray tool to measure the distribution of gamma-emitting radionuclides as the drill bit was advanced. The ability to track and locate the drill bit to within $\pm 1.5 \mathrm{~m}$ while drilling was a major requirement for successful demonstration. The bit location was controlled to within specifications.

Two boreholes were successfully directed to vertical depths of 6.7 and $19.8 \mathrm{~m}$ and then extended horizontally for another $22.8 \mathrm{~m}$ once the target depth was attained. No problems were encountered while drilling in the sandy sequence at the mock tank leak site. The boulder gravels at the drilling technology site were more difficult to penetrate; therefore, temporary casing was required to maintain the borehole while passing through the boulder gravels. The spectral gamma-ray tool was deployed through the completed boreholes despite difficulties in joining the tool to the drill string. Both holes were completed in uncontaminated regions, denying the opportunity to test the full capability of the spectral gamma-ray tool. Also, a prototype sampling tool (drive sampler with a retractable tip) was deployed at the drilling technology site; this tool was shown to be inappropriate for the test terrain. As the tool was advanced prior to sampling, the tip was severely damaged by the cobbles and subsequently could not be retracted. Control of drilling fluid presented the greatest challenge to future deployment of the directional drilling method within the tank farms because considerable drilling mud was lost to the formation or found its way to the ground surface. The problems encountered during testing need to be overcome before the drilling method is employed as a possible tool for addressing vadose-zone contamination beneath the tank farms.

\subsubsection{Immobilized Low-Activity Waste Site}

\subsubsection{Drilling of Borehole 299-E17-21}

The TWRS program is focusing on resolving tank safety issues, planning for waste retrieval, developing waste-pretreatment and -treatment facilities, and evaluating waste-storage and -disposal needs for single-shell tank wastes. Vitrification and onsite disposal of low-activity waste from single-shell tanks are embodied in the strategy described in the Hanford Site federal facility agreement and consent order (commonly known as the Tri-Party Agreement; Ecology et al. 1989). The pretreatment and immobilization operations for both the low-activity and high-level wastes have been contracted to private 
(nongovernmental) organizations. The current plan is to dispose of immobilized low-activity tank waste in new facilities in the south-central part of the 200-East Area and in four existing vaults along the eastern side of the 200-East Area (DOE/RL-97-69).

Boreholes 299-E17-21, B8501, and B8502 were drilled in April 1998 at the southwestern corner of the Immobilized Low-Activity Waste-disposal site (see Plate 1 for location of borehole 299-E17-21) in support of the performance-assessment activities for the disposal options. Details of the geologic investigation can be found in PNNL-11957; the results are summarized here. Other tests being performed on vadose-zone sediments from these boreholes include chemical transport studies (PNNL-11966), physical properties, and estimation of recharge by environmental tracers. Some of these results are described in the sections that follow.

The boreholes were drilled using an air-lift, driven-casing method, referred to as the Becker

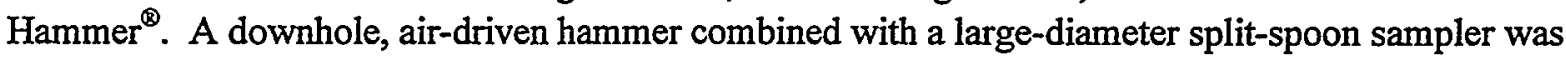
selected to obtain continuous soil samples through the vadose zone. At the onset of drilling, multiple sample-collection failures occurred because the sampling devices were not sturdy enough, as indicated by the $70 \%$ sample recovery in the upper $15 \mathrm{~m}$ of borehole 299-E17-21. Subsequent changes in technique increased sample recovery at deeper depths to an average of $95 \%$. Average sample recovery for boreholes B8501 and B8502 were $79 \%$ and $84 \%$, respectively.

Borehole 299-E17-21 was drilled to $146 \mathrm{~m}$ in April 1998. Thirty-eight split-spoon soil samples were collected, a groundwater sample was collected from $143 \mathrm{~m}$, and the entire borehole was geophysically logged. The lower $37 \mathrm{~m}$ of the borehole were then abandoned, and a groundwater-monitoring well was constructed from the 109-m depth to the surface.

Borehole B8501 was drilled in April 1998 to $15.2 \mathrm{~m}$. Fourteen split-spoon soil samples were collected; the borehole was geophysically logged and subsequently abandoned. Borehole B8502 was drilled during April 1998 to $14.3 \mathrm{~m}$. Fourteen split-spoon soil samples were collected; the borehole was geophysically logged and subsequently abandoned.

Geologic logging of the drill core showed that the vadose zone beneath the southwestern portion of the Immobilized Low-Activity Waste-disposal site consists of the upper few meters of Ringold Formation Unit E gravels overlain by the Hanford formation. A detailed description of the stratigraphy encountered . in the boreholes is given in PNNL-11957. The careful drilling and near-continuous core recovery allowed geologists to identify for the first time three paleosols (layers) in a single borehole. The three paleosols represent significant time intervals when soil development took place and are interpreted to be the tops of three Missoula flood deposits (PNNL-11957). The three flood events have been mapped at the Hanford Site (Reidel and Fecht 1994a, 1994b) but they have not been encountered in a single borehole. The detailed stratigraphy from the borehole sets a good background for the subsequent chemical transport, physical properties, and estimation of recharge tests.

All three boreholes were logged with a $35 \%$ efficiency, high-purity germanium detector to determine whether man-made, gamma-emitting radionuclides were present and to provide analysis of naturally occurring potassium-40, thorium-232, and uranium-238 for stratigraphic purposes. No man-made radionuclides were identified. The boreholes were also logged with a neutron probe to determine moisture content. The moisture logging showed higher moisture content in the upper part of the borehole, 
consistent with higher-than-normal precipitation over the past several years. Comparison of the neutron probe moisture data with the stratigraphy indicated good agreement between high-moisture zones and fine-grained stratigraphic units (PNNL-11957).

\subsubsection{Hydrologic Characterization}

Twenty intact cores from borehole 299-E17-21 were analyzed for physical and hydraulic properties in FY 1998. These data will be used to predict the movement of contaminants from the Immobilized LowActivity Waste-disposal site to the groundwater. The impacts of the contaminants reaching the groundwater will be calculated in performance-assessment activities to ascertain the suitability of the facility. In addition, these data can be used to assess remediation and closure activities at 200-East Area tank farms and specific retention basins.

The 20 cores are from the Hanford formation sandy sequence. The cores were found to be fairly uniform as were the data generated, reflecting the high percentage of medium to fine sand. The variability among the hydrologic and physical data collected was within the range reported by WHC-EP-0883 for 200 Areas sediments. This increases confidence that existing datasets are representative of the range of physical and hydrologic properties present in the uncontaminated portions of the 200 Areas and may be representative of many of the contaminated portions of the 200 Areas. What is significant and valuable is that the data give an indication of the zone directly beneath the Immobilized Low-Activity Waste-disposal site. The data represent the most complete set of physical properties (i.e., particle size, particle density, bulk density, porosity) and hydrologic properties (i.e., saturated and unsaturated hydraulic conductivity, water retention) measured on undisturbed cores (split spoon samples) at the Hanford Site. Second, the distribution coefficient $\left(\mathrm{K}_{\mathrm{d}}\right)$ measurements presented in the next section were performed on the same core material.

Two thin zones were observed with finer texture and lower hydraulic conductivities than the other 18 samples. These two thin zones could impact flow and contaminant transport by increasing lateral spreading. The results, in concert with others, will be used to formulate a vadose-zone conceptual model for the Immobilized Low-Activity Waste-disposal site. Additional boreholes are planned in future years to help verify whether the two, thin, fine-textured layers are continuous across the disposal site. An unexpected feature was the presence of a relatively thick, open-framework, gravel sequence below $76.2 \mathrm{~m}$. No physical or hydrologic data are available for this sequence. The water table was found at $100.4 \mathrm{~m}$, and thus, there are $\sim 24.4 \mathrm{~m}$ of vadose-zone gravel at the site. Plans are in place to gather samples that are as undisturbed as possible of this more-difficult-to-drill material during the future drilling activities.

\subsubsection{Specific Distribution Coefficient Data}

This section describes radionuclide $\mathrm{K}_{d}$ measurements made using the first borehole (299-E17-21) sediments collected from the Immobilized Low-Activity Waste-disposal site. Other information collected in FY 1998 at this borehole was described in Section 4.4.2.1 and PNNL-11957. The $K_{d}$ data were organized according to depth, or layers, within the Hanford formation, revealing that the Hanford formation sampled in this borehole had three geologic strata defined by three paleosols (PNNL-11957). The upper boundary of paleosol horizon 3 occurred at $1.5 \mathrm{~m}$, the upper boundary of paleosol horizon 2 at $17.7 \mathrm{~m}$, and the upper boundary of paleosol horizon 1 at $49.7 \mathrm{~m}$. The complete depths and total thicknesses of these three contiguous layers are given in Figure 2 and Table 3 of PNNL-11957. For the $K_{d}$ testing, unit 3 
resides between 1.5 and $17.7 \mathrm{~m}$ below ground surface, unit 2 between 17.7 and $49.7 \mathrm{~m}$ below ground surface, and unit 1 between 49.7 and $75.3 \mathrm{~m}$ below ground surface. Unit 3 had only 1 sample collected from within; units 2 and 1 had 10 and 9 samples collected from within, respectively. Thus, a statistical description of $\mathrm{K}_{d}$ values for unit 3 was not possible because of the lack of replication. Units 2 and 1 were described using statistics, and a Student's t-test was conducted to evaluate whether the $\mathrm{K}_{\mathrm{d}}$ values in each unit differed at the $5 \%$ level.

The $\mathrm{K}_{\mathrm{d}} \mathrm{s}$ were determined by the batch method, using a sediment:solution ratio of 1:2 for low-sorbing species and 1:30 for high-sorbing species. The sediments were preequilibrated with uncontaminated groundwater prior to contact with radiotraced groundwater for 14 days. The supernatant solution was filtered through $0.45-\mu \mathrm{m}$ membranes and the $\mathrm{K}_{d}$ calculated from the difference in radionuclide concentration between the start and end of the contact period. Adjustments for container wall adsorption and precipitation of radiotracers were made when necessary such that the $K_{d} s$ reflect only sediment adsorption.

The $K_{d}$ values of cesium, iodine, selenium, strontium, technetium, and uranium were measured in 20 sediments collected from borehole 299-E17-21, which is proximal to the disposal facility. Additionally, the $\mathrm{pH}$ and cation-exchange capacity of these sediment samples were measured. Table 4.4-1 provides the conservative and best estimates of $\mathrm{K}_{d}$ values, assuming that the Hanford formation will be divided into the three geologic units identified. Table 4.4-2 provides the conservative and best estimates of $\mathrm{K}_{d}$ values, assuming that the Hanford formation will be treated as a single modeling unit. Which of these two conceptual models will ultimately be used in future performance assessments will depend on these data as well as other characterization data to be documented in FY 1999. Presumably, if significant differences in other parameter values such as hydraulic conductivity are observed between the units, then it may be decided that introducing the added complexity of three units may be warranted. Otherwise, the most conservative estimate of the combined units will be used for the performance assessment.

The best estimate for each constituent's $\mathrm{K}_{d}$ value was the calculated median value, and the uncertainty was chosen as the standard deviation. The median was selected, as opposed to the mean, so as not to have outliers or extreme values overly influence the best estimate. The conservative estimate was based on the minimum value, except for the uranium $K_{d}$ estimate. The conservative uranium $K_{d}$ estimate was based on the second-to-lowest value $(0.5 \mathrm{~mL} / \mathrm{g})$ because of the presence of an unusually low value $(0.3 \mathrm{~mL} / \mathrm{g})$ that was not consistent with other values measured from this borehole or previously reported values (PNL-10379, SUP.1). For the radionuclide $K_{d}$ values for which there were no significant differences between the means of units 2 and 1 (i.e., for cesium, selenium, technetium, uranium), the same $K_{d}$ estimates were used in all three units. Because there was only one sample from unit $3, K_{d}$ estimates for this unit were assigned the same values as those in unit 2 . This is likely a conservative estimate of unit 3 $K_{d}$ values because they tended to be the same or greater than those of unit 2 .

Overall, the estimates appearing in these two tables are consistent with those used for past performance assessments, with some notable exceptions. The conservative $\mathrm{K}_{\mathrm{d}}$ estimates used in past performance assessments were $100 \mathrm{~mL} / \mathrm{g}$ for cesium, $3 \mathrm{~mL} / \mathrm{g}$ for iodine, $0 \mathrm{~mL} / \mathrm{g}$ for selenium, $5 \mathrm{~mL} / \mathrm{g}$ for strontium, $0 \mathrm{~mL} / \mathrm{g}$ for technetium, and $0.6 \mathrm{~mL} / \mathrm{g}$ for uranium. The new, conservative, $\mathrm{K}_{\mathrm{d}}$ estimates for technetium and uranium reported in Tables 4.4-1 and 4.4-2 are approximately the same as those used for past calculations. The older, conservative values for cesium, selenium, and strontium used in past calculations were appreciably more conservative than necessary. The conservative iodine $K_{d}$ value in this new work is 
appreciably less than that used in the most recent performance assessment ( $3 \mathrm{~mL} / \mathrm{g})(\mathrm{DOE} / \mathrm{RL}-97-69)$. The iodine $\mathrm{K}_{d}$ estimate used in the cited performance assessment was based on a literature review of $\mathrm{K}_{d}$ values measured using generic Hanford Site sediments, which revealed that the range of values was 0.7 to $15 \mathrm{~mL} / \mathrm{g}$, with an average of $3.1 \mathrm{~mL} / \mathrm{g}$ (PNNL-10379, SUP.1). The cause for the newly measured, lower, iodine $\mathrm{K}_{\mathrm{d}}$ values is not known, though the sediments used in this study clearly had appreciably lower concentrations of fine materials than the Hanford Site sediments previously used in iodine-sorption measurements. These differences in values underscore the importance of basing $\mathrm{K}_{\mathrm{d}}$ estimates for the more mobile major dose contributors on measurements using site-specific sediments. In the past, $\mathrm{K}_{\mathrm{d}}$ data were generated using generic Hanford Site sediments that were available.

Ideally, all $\mathrm{K}_{\mathrm{d}}$ experiments could be conducted using site-specific sediments because the science of geochemistry is not yet advanced enough to permit estimating the geochemical behavior of a radionuclide in one sediment based on its behavior in another sediment. However, site-specific sediments are generally expensive to collect, and the volume of material available usually is limited. The newly determined iodine $\mathrm{K}_{\mathrm{d}}$ data suggest that the most technically defensible way to quantify radionuclide sorption is through experiments conducted with site-specific sediments and pore water or waste leachate, but the new results for the other contaminants studied are quite similar to past results using generic Hanford Site sediments not proximal to the proposed Immobilized Low-Activity Waste-disposal complex.

\subsubsection{Uranium(VI) Distribution Coefficient at Unsaturated Moisture Conditions}

A series of experiments were conducted to evaluate the sorption and transport of uranium(VI) under conditions of partial moisture saturation that are relevant to arid-region burial sites and vadose-zone farfield conditions at the Hanford Site. The focus was on measuring breakthrough curves (from which $\mathrm{K}_{\mathrm{d}}$ values can be calculated) for uranium(VI) in three Hanford Site sediments that represent different texture classes at two unsaturated moisture conditions. Previous research showed that $\mathrm{K}_{\mathrm{d}}$ values measured during transport in unsaturated sediments varied with moisture saturation.

In FY 1998, it was found that uranium(VI) $\mathrm{K}_{\mathrm{d}}$ values decreased as the moisture content decreased in all three sediments evaluated, irrespective of their texture. In the medium-coarse sand, the uranium(VI) $\mathrm{K}_{\mathrm{d}}$ values decreased from 0.48 to $0.16 \mathrm{~mL} / \mathrm{g}(67 \%)$ as the moisture saturation decreased from $30 \%$ to $12 \%$ by volume. In the fine-sand sediment, the uranium(VI) $\mathrm{K}_{\mathrm{d}}$ value decreased from 1.42 to $0.39 \mathrm{~mL} / \mathrm{g}(73 \%)$ as the moisture saturation decreased from $66 \%$ to $22 \%$. In the silt/loam sediment, the uranium(VI) $\mathrm{K}_{d}$ value decreased from 4.05 to $1.81 \mathrm{~mL} / \mathrm{g}(55 \%)$ as the moisture saturation decreased from $83 \%$ to $41 \%$. The cause for this trend between moisture content and $\mathrm{K}_{\mathrm{d}}$ values is not known. It appears likely that, as sediments were desaturated, the uranium(VI) contacted fewer sorption sites. In a sense, as the moisture content decreased, the effective exchange, or sorption capacity, of the sediment also decreased because solutes did not contact the total surface area.

In addition, both conservative (nonsorbing) tracer and uranium(VI) breakthrough curves exhibited nonequilibrium characteristics, particularly at the lowest moisture condition for each sediment. At decreasing moisture saturation, the proportion of immobilized water increased in unsaturated coarse sand, fine sand, and silt/loam sediments. An approach for assessing mobile-immobile water domains was applied, and the data were well-described with a two-region transport model (see PNNL-1 1975, van Genuchten 1981, and van Genuchten and Parker 1984 for more details). Mass transfer of solutes, including uranium(VI), to regions of microporosity is limited when mobile-immobile water conditions develop. 
Immobile water domains are associated with regions of microporosity and fine-textured particles. More importantly, the parameters for dispersion, fraction of mobile water, and rate-limited mass transfer between mobile and immobile water regions were applied with reasonable success to predict uranium(VI) transport. This is an important first step for determining if observed changes in uranium(VI) $\mathrm{K}_{d}$ values can be explained by changes in the mobile and immobile water-flow regime.

An important implication of this research is that the effective exchange capacity of the sediment may be reduced for solutes undergoing transport in unsaturated, sandy sediments where immobile water domains develop. The observed decrease in $\mathrm{K}_{\mathrm{d}}$, particularly for the sandy sediments, is consistent with limited mass transfer to sorption sites in the immobile water region. The flow rates in these experiments were faster than those expected in the unsaturated vadose zone of the Immobilized Low-Activity Wastedisposal site. The linear pore-water velocity in these experiments ranged from 15 to $70 \mathrm{~cm} / \mathrm{h}^{-1}$, which may represent flow during rain events, but is certainly much faster than the average expected velocity. Slower flow rates in the field would result in increased mass transfer by diffusion. Consequently, the observed nonequilibrium for water flow may be less apparent in expected vadose-zone conditions. Even so, flow heterogeneities such as mobile-immobile water domains are observed under field conditions. The results presented here demonstrate that accounting for these heterogeneities can explain laboratoryobserved differences in sorption and transport.

\subsubsection{TWRS Phase I Demonstration Site Vadose-Zone Characterization}

The TWRS program was established to treat, store, and dispose of the tank waste in a safe manner. To that end, a final environmental impact statement (DOE/EIS-0189) identified the preferred option as vitrification of tank waste and onsite disposal. Phase I of that effort is a "proof of concept" and has been designated for private contractors to conduct the demonstration phase of the immobilization effort. In support of that demonstration, vadose-zone characterization efforts were undertaken in FY 1997 and reported in FY 1998 (HNF-2067) to assess existing conditions at the site east of the 200-East Area. This section summarizes the results of that effort pertinent to the vadose zone.

The TWRS Phase I demonstration site was delimited with a $100-\mathrm{m}$ by $100-\mathrm{m}$ grid and staked for subsequent surveys. Surface radiation surveys; surface soil sampling for hazardous and radionuclide constituents of concern; surface geophysical surveys (ground-penetrating radar and electromagnetic induction); installation of 10 thermoluminescent dosimeters; geophysical logging of 14 existing boreholes; and drilling, sampling, and logging of five new boreholes were completed.

The surface radiation surveys found no contamination above site background levels. The surface ground-penetrating radar and electromagnetic induction surveys found lateral variation in the upper $4 \mathrm{~m}$ of soil that were interpreted as variations in the shallow Holocene soils and/or Hanford formation. Three zones were described: 1) a zone of wind-blown, Holocene sand and silt that lacks stratification; 2) a zone of Holocene soils with intermittent stratification similar to what has been observed in active and inactive sand dunes; and 3) one zone of extremely complex geologic nature. The latter zone is not anthropogenic, is probably the Hanford formation, and may be related to clastic dikes.

Five boreholes were emplaced to $15 \mathrm{~m}$ in depth by the cone-penetrometer method. These boreholes were subsequently logged with high-purity germanium and neutron-neutron moisture tools. No manmade radionuclides were identified. Comparison of the moisture logs and the spectral gamma-ray logs 
allowed correlation of a geologic horizon among four of the five boreholes, interpreted to be a paleosol, that could act as a spreading horizon for infiltrating liquids.

In addition, 15 existing wells were logged by spectral gamma-ray methods and neutron-neutron moisture methods. Cesium- 137 was the only man-made radionuclide identified, and it existed at $<1 \mathrm{pCi} / \mathrm{g}$ in a few boreholes at the surface.

A preliminary statistical evaluation of analytical results from samples of surface soil indicated that the constituents of interest (americium-241, strontium-90, cesium-137, plutonium-239/-240, uranium-234/ -238 , cadmium, neodymium, silver, cobalt, barium, cerium, lead, iron, aluminum, thallium, antimony, manganese, molybdenum, nitrate, sulfate, phosphate, chloride, and fluoride) were at or near the Hanford Site-wide background levels (HNF-2067).

\subsubsection{New RCRA Well Sediment Characterization}

Section 4.2.3.4 introduced the 10 new RCRA wells constructed in FY 1998. Vadose-zone characterization of selected grab samples and undisturbed split-spoon samples was also started in FY 1998. Samples are being collected for the analysis of particle size, gravimetric moisture content, calcium carbonate content, extractable cation content and 1:1 water-extract measurements of $\mathrm{pH}$, electrical conductivity, alkalinity, and major cations and anions. Hydrologic properties such as saturated hydraulic conductivity, unsaturated hydraulic conductivity as a function of moisture content, and moisture retention may be determined on some samples. The data will be documented in FY 1999 and will be used to help refine the conceptual model of the vadose zone, to provide quantitative values for various performanceassessment calculations for the Immobilized Low-Activity Waste-disposal site, the consequences of proposed single-shell tank-sluicing operations, and the long-term environmental consequences of final single-shell tank closure.

The characterization data will also aid in delineating the sources of contaminants found in the groundwater under the various WMAs (B-BX-BY, S-SX, T, and TX-TY) as future TWRS vadose-zone studies obtain subsurface sediment samples below the tanks.

\subsubsection{Borehole 41-09-39 Extension to Groundwater}

This section documents the extension of borehole 41-09-39 in the SX single-shell tank farm. This borehole was initially driven in FY 1996 to a depth of $40.08 \mathrm{~m}$ in response to the determination that cesium-137 might reside in the soil column at depths $>30.4 \mathrm{~m}$. The closed-end casing was driven to ascertain whether the contamination was an artifact of an adjacent unsealed borehole or was disseminated in the formation. Geophysical logging of this borehole in late 1996 confirmed that cesium-137 dissemination within the formation was plausible and that contamination was still present at a depth of $40.08 \mathrm{~m}$.

Concern was raised that if relatively immobile cesium-137 was present at that depth, then moremobile, long-lived, tank-waste constituents such as technetium-99 might well be at or near the water table at $64 \mathrm{~m}$. In response to a recommendation of an expert panel brought together to address these early findings (DOE/RL-97-49), borehole 41-09-39 was extended to groundwater and samples were collected for laboratory analysis of tank-waste components. 
The closed end of the casing was removed by milling with a rotary drilling machine, and the borehole was extended by sequentially driving a split-spoon sampler into the formation ahead of the drill casing, then cleaning the bore to the depth sampled, driving the drill casing to that depth, and finally cleaning out the drill casing again. This process was then repeated with another sample being collected. The cabletool method was used to advance the bore. Geologic conditions resulted in excessive friction against the drill pipe, effectively stopping progress. The drill casing was removed from the bore, and the drill shoe was replaced to over-ream the hole, reducing friction and allowing the casing to be advanced. The overreaming casing shoe created a small annular space that may have contributed to drag down of contamination.

Vadose sediment samples were collected in a near-continuous manner. Samples were not collected when geologic conditions required that a hard tool be used, and that use rendered the returns unrepresentative. All sediment returned to the surface was preserved for potential analysis. All core was screened for gamma-emitting radionuclides and moisture content. In addition, each core section was described geologically. Samples from seven selected locations within the borehole were analyzed for radionuclides, chemical constituents, cation-exchange capacity, and particle-size distribution.

Periodic geophysical logging of the borehole was used to indicate the occurrence of drag down and to provide additional data used in selecting the seven locations for complete analysis. Gamma-logging techniques were used throughout the drilling effort. Initially, the gamma tools were operated in a total (gross) gamma mode, but as drilling proceeded, the logging mode was changed to the spectral gamma mode to indicate what gamma emitters and at what activities they were being carried along with the casing or drilling functions. On completion of the borehole, a neutron moisture log was run. Geophysical logging indicated that some contaminated material was following the casing as it was advanced. It should be noted that the indicated contaminant levels were low.

Screening analyses of the samples showed that the upper sleeves from the split-spoon sampler often exhibited low levels of contamination while lower sleeves did not. The regularity of this occurrence resulted in its being interpreted as cross-contamination, either from material carried along the outside of the casing or from material smeared along the inside of the casing that was deposited as the drill tools and samplers were inserted or extracted from the bore. Samples from the upper split-spoon sleeves were excluded from analysis when there was evidence of such possible cross-contamination.

Detailed geochemical analyses of the seven samples from this borehole showed that tank-waste constituents are predominantly held within or above the Plio-Pleistocene sediments. Nonradiological constituents (sodium, calcium, nitrate) point to the leading edge of tank-waste components being at a depth of $\sim 47 \mathrm{~m}$. This leading edge may be from natural percolation or drag down; however, the determination of which is most likely cannot be made at this time.

Analyses for cesium-137, the radionuclide originally recognized as being deeper than expected in the vadose zone, were conducted on all samples via gamma-energy analysis. Cesium-137 activity in the soils of the extended borehole was highest associated with the Plio-Pleistocene sediments at $40 \mathrm{~m}$. Activity dropped off rapidly and was at or below detection levels from $48.8 \mathrm{~m}$ to the water table at $64.3 \mathrm{~m}$.

Distribution of technetium-99, the most mobile of the long-lived radionuclides found in tank wastes, was sporadic, with most occurrences above the method detection level being above the Plio-Pleistocene 
unit. A single, deep occurrence was noted at $56.3 \mathrm{~m}$; this is the location postulated to be the highest level reached by groundwater during operation of the 216-U-10 pond (now decommissioned). It is possible that technetium-99 was brought to this sediment sample by horizontal migration from disposal facilities outside the tank farm boundaries. If the technetium source was the SX tanks, it would have been expected that near-continual detection would have been noted throughout the shallower sediments. Figure 4.4-1 shows the distribution of cesium-137 and technetium-99 in the vadose-zone sediments from depth and the water-extractable nitrate concentrations.

Desorption $K_{d}$ tests were run on sediment samples for both cesium-137 and technetium-99. These tests showed that cesium- 137 is strongly bound to the fine-grained sediments. The tests for technetium-99 showed positive values for the $K_{d}$ but the uncertainty associated with those values was significant.

. Groundwater samples were collected from 3, 0.6, and $0.02 \mathrm{~m}$ below the water table. Analyses of these samples showed technetium- 99 and tritium activities that are indicative of upgradient sources. Analyses for chromium were consistently below the method detection limit. These analyses indicate that groundwater contamination at this specific location is due to non-tank farm sources. More sampling of vadose-zone sediments under the SX tank farm at additional locations is needed to determine whether the contaminants in downgradient monitoring wells may have originated in the single-shell tanks or in nontank-related liquid discharge facilities nearby. The results of the investigation of the borehole 41-09-39 extension point to a need to ascertain the disposition and distribution of the mobile, long-lived, waste constituents in the vadose zone. The first area that should be addressed is the highly contaminated zones near the base of the SX tank farm. Complete details of the borehole extension findings can be found in HNF-2855. The geochemistry of tank wastes and the possible interactions of mobile species with sediments of the vadose zone are major gaps in the Hanford Site vadose-zone information base and for addressing tank remediation/closure.

\subsubsection{Areas Assessment}

A characterization borehole (299-E33-333; well identification number B8079) was drilled through the 216-B-2-2 ditch (Figure 4.4-2) to groundwater during late December 1997 and early January 1998. This ditch was selected for characterization based on the criteria in DOE/RL-96-81, which identified this ditch as a representative site for the 200-CW-1 Gable Mountain Pond/B Pond and Ditches Cooling Water Group (formerly the 200-BP-11 Operable Unit). The 216-B-2-2 ditch was selected as a representative site because 1) it was operationally typical of a ditch and contains a representative inventory of contaminants; 2) it is expected to contain typical to higher levels of contamination at the headend of the ditch system; and 3) it lies in the middle of the 216-B-2 ditch system, providing composite data for all three 216-B-2 ditches at depth. The 216-B-2-2 ditch received 49,700,000 L of effluent containing $147 \mathrm{Ci}$ of strontium-90 as the major contaminant (DOE/RL-96-81). The purpose of drilling the borehole was to refine the preliminary physical conceptual models of contaminant distribution and hydrogeology, to assess the nature and extent of subsurface contaminants, and to support remedial action/closure decisions for the 200-CW-1 group (BHI-01052). The characterization activities, sampling and analysis plan, and data quality objectives are described in the description of work (BHI-01052). The characterization results are found in the borehole summary report (BHI-01177).

Characterization borehole 299-E33-333 was drilled at the influent end of the 216-B-2-2 ditch because it was the location considered the most likely to have the highest concentration of contaminants along the 
ditch. The borehole was extended to a depth of $77.4 \mathrm{~m}$, which is below the water table, to investigate the extent of contamination throughout the vadose zone. The borehole was drilled using cable-tool techniques and was abandoned following characterization. Soil samples for chemical and radiological analyses and/or physical property testing were collected at 13 depths using a split-spoon sampler.

Geophysical surveys of borehole 299-E33-333 included both spectral gamma logging and neutronneutron logging (BHI-01177). Spectral gamma logging was conducted to characterize the vertical profile of gamma-emitting radionuclides in the vadose zone. Neutron-neutron logging was conducted to characterize the vertical profile of the moisture content of the vadose zone.

Volatile organic analyses were conducted on all chemical samples, with the exception of the uppermost sample from 1.2 to $1.8 \mathrm{~m}$ below ground surface, which had insufficient sample volume. Three target volatile organic contaminants (acetone, methylene chloride, toluene) were detected at estimated concentrations below the quantitation limit. One nontarget volatile organic (total xylenes) was detected at $8 \mu \mathrm{g} / \mathrm{kg}$ in the 45.7 - to $46.5-\mathrm{m}$ interval.

Semivolatile organic analyses were conducted on all chemical samples. The only polychlorinated biphenyl detected was aroclor-1260, which was found in the 2.4- to 4.7-m interval, with a maximum concentration of $9,200 \mu \mathrm{g} / \mathrm{kg}$ in the $2.4-$ to $3.2-\mathrm{m}$ interval. Two nontarget semivolatile organic contaminants (butyl benzyl phthalate, di-n-octyphthalate) were detected at estimated concentrations below the quantitation limits.

Chemical analyses for nitrate, nitrite, sulfate, ammonia, and cyanide were conducted on all samples, with one exception: cyanide was not analyzed in the uppermost sample from 1.2 to $1.8 \mathrm{~m}$ because a sufficient sample volume was not available. Cyanide was not detected in any sample. The maximum nitrate, nitrite, sulfate, and ammonia concentrations were $35.8,0.38,43.3$, and $0.533 \mathrm{mg} / \mathrm{kg}$, respectively, and all were detected in the 1.2- to 3.2-m interval. Ammonia and elevated nitrate were detected in only the uppermost sample from 1.2 to $1.8 \mathrm{~m}$.

Inorganic (metal) analyses were conducted on all chemical samples. Cadmium and tin were the only metals not detected in any samples. For 12 of the 17 target metals detected, the maximum concentration was found in the 2.4- to $4.7-\mathrm{m}$ interval.

Radiochemical analyses were conducted on all samples for both man-made and naturally occurring radionuclides. The primary man-made radionuclides detected were strontium-90, cesium-137, and europium-154 at maximum activities of $4,710,100$, and $1.29 \mathrm{pCi} / \mathrm{g}$, respectively (Table 4.4-3). The activities were one to two orders of magnitude higher in the intervals from 2.4 to 3.0 and 4.0 to $4.6 \mathrm{~m}$ than in the intervening sample interval from 3.2 to $4.0 \mathrm{~m}$. No man-made radionuclides were detected below $4.6 \mathrm{~m}$.

Based on the spectral gamma logging, cobalt-60, cesium-137, and europium-154 were detected in borehole 299-E33-333 (see Table 4.4-3). The presence of cesium-137 was detected from the ground surface to a depth of $0.7 \mathrm{~m}$ and at depths between 1.8 and $3.3 \mathrm{~m}$. The maximum cesium-137 activity was $\sim 400 \mathrm{pCi} / \mathrm{g}$ measured at a depth of $2.7 \mathrm{~m}$. Analysis of the data indicates that, within the zone of highest cesium-137 activity, the contamination is uniformly distributed in the formation as a thin, $0.15-$ to $0.3-\mathrm{m}$ thick layer (BH-01177). The presence of cobalt-60 was detected at the ground surface and at a depth of 
$0.15 \mathrm{~m}$. The maximum cobalt- 60 activity was $\sim 0.15 \mathrm{pCi} / \mathrm{g}$. The presence of europium-154 was detected at three points at depths between 2.6 and $2.9 \mathrm{~m}$ within the interval of highest cesium-137 activity. The maximum europium-154 activity was $2.0 \mathrm{pCi} / \mathrm{g}$. The spectral gamma logging and sediment radiochemical analyses agree, except that the spectral gamma logging estimates the maximum cesium- 137 activity at 400 versus $100 \mathrm{pCi} / \mathrm{g}$ for the laboratory analyses. Strontium-90, a beta emitter, was not detectable using the spectral gamma-logging instrument.

For both datasets, man-made radionuclides are found within the upper $4.6 \mathrm{~m}$ of the soil column. One zone of high activity was found at a depth of 2.4 to $3.2 \mathrm{~m}$ in both datasets. The laboratory analytical data also indicated a zone of high activity from 4.0 to $4.6 \mathrm{~m}$. The distribution of man-made radionuclides underlying the 216-B-2-2 ditch is consistent with the conceptual model developed for the 200-CW-1 group (DOE/RL-96-81). The conceptual model for this group is that the highest activity of the primary contaminants of concern (e.g., strontium-90) will be directly underlying the headend of the ditch. Furthermore, according to the conceptual model, most of the contaminants were expected to be within the uppermost gravel unit, which at this site extends to a depth of $9.1 \mathrm{~m}$. The data indicate that, in fact, the radionuclide contamination does not extend below $4.6 \mathrm{~m}$.

\subsubsection{Tank AX-104 Vadose-Zone Characterization Technology Demonstration}

The Hanford Tank Initiative Project is demonstrating cone penetrometer technology to map the location, extent, and contaminant concentration gradient of leakage-derived contaminants at tank AX-104 in the AX tank farm. The farm consists of four 3,785,000-L tanks, each $22.9 \mathrm{~m}$ in diameter. These tanks are the fifth and final generation of single-shell tanks and were designed to receive high-level waste from the Plutonium-Uranium Extraction (PUREX) Plant. Tank AX-104 is known, or suspected, to have leaked; had been sluiced to the extent practicable; and still contains highly mobile radionuclides and hazardous chemicals. This demonstration is focused on the backfill soils and vadose zone surrounding the tank. Vadose-zone-characterization information is key to reducing the existing uncertainties as to the extent of contamination, which is an important factor in calculating human health risks, and to validate/ revise conceptual models for contaminant transport through the vadose zone. This information will also support development of a basis for decisions that affect waste retrieval and operable unit closure of the single-shell tanks.

A field deployment activity to accomplish this objective using the cone penetrometer platform is planned for early FY 1999. The cone penetrometer platform will be used to deploy probes built by the U.S. Army Corps of Engineers Waterways Experiment Station and Applied Research Associates, Inc. The probes will be deployed to a maximum depth of $45.7 \mathrm{~m}$ in the soil column surrounding tank AX-104. Applied Research Associates, Inc., the Hanford Tank Initiative Project industry partner, will support field deployment during the initial demonstration.

The general functions of the cone penetrometer probes are to screen the soil column at the tank AX-104 site for selected contaminants (i.e., metals, gamma-emitting radionuclides), using X-ray 
fluorescence and gamma probes; to assess the contaminant plume boundary; and to retrieve selected samples for confirmatory laboratory analysis (Figure 4.4-3). The more specific objectives are to demonstrate the ability to perform the following:

- deploy the cone penetrometer platform, sensors, and probes in the tank farms

- screen the soil column for contaminants to guide selection of the sampling locations

- employ the reusable multisensor and soil-sampling probes

- obtain multiple soil samples during a single probe-deployment event

- detect and avoid subsurface metal objects during probe deployment

- seal penetration points on extraction of the probes.

\subsection{Soil-Vapor Monitoring}

\section{J. Rohay, D. G. Horton}

Soil-vapor extraction is being used to remove the carbon tetrachloride from the vadose zone as part of the 200-West Area expedited response action being conducted by Bechtel Hanford, Inc. The primary focus in the following subsections is on FY 1998 activities. For descriptions of past work, see BHI-00720, Rev. 2 and Section 4.4 in PNNL-11793.

To track the effectiveness of the remediation effort, measurements of soil-vapor concentrations of chlorinated hydrocarbons were made at the inlet to the soil-vapor-extraction system, at individual on-line extraction wells, and at individual off-line wells and probes throughout the soil-vapor-extraction sites during FY 1998. One soil-vapor-extraction system was operated from April through September 1998. Soil-vapor monitoring at off-line wells and probes was conducted from October 1997 through September 1998.

\subsubsection{Methods}

To maintain real-time monitoring schedules, constrain costs, and fulfill the requirements for working in a radiologically controlled area, the approach to the carbon tetrachloride remediation maximized the use of field-screening data. Since late 1993, contaminant concentrations at the soil-vapor-extraction inlets and vent stacks and at individual wells and probes have been monitored using a Type $1302^{\mathrm{TM}}$ infrared photoacoustic spectrometer (Brüel and Kjaer, Naerum, Denmark). The Brüel and Kjaer sensors are calibrated annually by the manufacturer and are periodically checked with calibrated standards in the field. The detection limit for carbon tetrachloride is 1 part per million by volume $\left(\mathrm{ppm}_{\mathrm{v}}\right)$.

Measurements made at the inlet to the extraction system represent the combined soil-vapor concentrations from all on-line wells connected to the system. A programmable logic controller samples the incoming concentrations at the inlet every $2 \mathrm{~h}$; the system technician uses these data to establish daily records of representative concentrations.

To monitor concentrations at individual on-line extraction wells, a sampling apparatus is placed in-line at the wellhead to collect a soil-vapor sample in a Tedlar ${ }^{\mathrm{TM}}$ bag (E.I. du Pont de Nemours \& Company, Wilmington, Delaware). The sample is analyzed using a Brüel and Kjaer sensor housed in a 
trailer near the extraction site. Concentrations are typically monitored monthly at individual on-line extraction wells. One "snapshot" sample is collected at each on-line extraction well.

Soil-vapor monitoring at off-line wells and probes is conducted using the sampling methods developed for the rebound study conducted in FY 1997 (BHI-01105). A low-flow (0.8-L/min) pump is used to draw soil-vapor samples from wells and probes into a 1-L Tedlar ${ }^{\mathrm{TM}}$ bag for analysis using the field Brüel and Kjaer sensor. Two purge volumes are drawn before the sample is collected. For most of the wells in which the sampling pump was used, a tube was lowered to the target depth, where the casing is perforated (i.e., open to the sediment and its pores) to minimize the volume of air to be purged. A metal filter, which is attached to the end of the tube, also served as a weight. Each sampling tube remained in the well for the duration of the monitoring period. Each well equipped with a sampling tube remained sealed at the surface throughout the monitoring period. As a test at a limited number of wells, the sampling pump was used to collect a sample at the wellhead without use of a sampling tube extended to the perforated interval. These wells were purged for either 3 or $10 \mathrm{~min}$ using the sampling pump. The wells remained sealed, and the sample pump was used to collect samples in $1-\mathrm{L}$ Tedlar ${ }^{\mathrm{TM}}$ bags for analysis using the Brüel and Kjaer sensor.

Soil-vapor samples were collected from $\sim 25$ off-line wells and probes once per month. Soil-vapor samples were analyzed primarily to monitor for carbon tetrachloride; however, the samples collected from off-line wells and probes were also analyzed for chloroform, methylene chloride, methyl ethyl ketone, and water vapor.

\subsubsection{Networks}

There are 46 drilled wells available for on-line extraction or monitoring (BHI-00720, Rev. 2) (Figure 4.5-1). Thirteen of these wells were drilled during 1992 and 1993 and were completed as vaporextraction wells with stainless-steel casing and screens; one well was drilled at a 45-degree incline. Thirty-three wells, drilled between 1954 and 1978 and completed with carbon steel casing, were adapted for vapor extraction by perforating the well casing using mechanical or jet perforators. Of the 46 wells, 17 have two screened, or perforated, open intervals isolated by downhole packers. The soil-vaporextraction system extracts simultaneously from multiple wells open either above and/or below the PlioPleistocene unit. The mix of on-line wells is adjusted periodically to optimize contaminant removal.

There are 125 subsurface monitoring probes at $>2 \mathrm{~m}$ deep. A cone penetrometer was used to install 11 extraction, or monitoring, wells and 104 subsurface monitoring probes at 33 locations. Up to five monitoring probes were installed per location at various depths. The deepest monitoring probe installed at the vapor-extraction sites is $36 \mathrm{~m}$ below ground surface. Ten stainless-steel tubes were strapped to the outside of the casing of 4 of the 13 wells during installation to enable monitoring above and below the screened intervals.

There are up to 73 shallow soil-vapor probes at depths ranging from 1.2 to $1.8 \mathrm{~m}$ (Figure $4.5-2$ ). The network was installed between 1991 and 1995. Some of the probes have since been destroyed, primarily as a result of other near-surface construction activities or prolonged exposure to weather conditions. 


\subsubsection{Results}

Based on the results of the FY 1997 rebound study (BHI-01105) and the declining rate of carbon tetrachloride removal during continuous extraction operations (BHI-00720, Rev. 2), the operating strategy for FY 1998 was modified. Rather than operating all three soil-vapor-extraction systems continuously, only the $14.2-\mathrm{m}^{3} / \mathrm{min}$ system was used for carbon tetrachloride removal during FY 1998 . The $14.2-\mathrm{m}^{3} / \mathrm{min}$ system was modified so that it could be moved between the well fields surrounding the 216-Z-1A, $-9,-12$, and -18 facilities. The $28.3-$ and $42.5-\mathrm{m}^{3} / \mathrm{min}$ soil-vapor-extraction systems were maintained in standby mode during FY 1998.

The $14.2-\mathrm{m}^{3} / \mathrm{min}$ soil-vapor-extraction system was operated from March 30 through June 30, 1998 at the combined 216-Z-1A/-12/-18 well field and from July 7 through September 30, 1998 at the 216-Z-9 well field. The system was shut down for the winter (October 1, 1997 through March 29, 1998).

For the 6 months that the system was shut down, the rebound in carbon tetrachloride concentrations was monitored at 25 nonoperational wells and probes covering both well fields. For the 3 months that the system was operated at $216-Z-1 \mathrm{~A} /-12 /-18$, carbon tetrachloride concentrations were monitored at 25 nonoperational wells and probes primarily at the 216-Z-9 well field; and for the 3 months that the system was operated at the 216-Z-9 well field, carbon tetrachloride concentrations were monitored at 25 nonoperational wells and probes primarily at the $216-Z-1 \mathrm{~A} /-12 /-18$ well field.

\subsubsection{Soil-Vapor Remediation}

Soil-vapor extraction to remove carbon tetrachloride from the vadose zone resumed March 30, 1998 at the $216-\mathrm{Z}-1 \mathrm{~A} /-12 /-18$ well field, using the $14.2-\mathrm{m}^{3} / \mathrm{min}$ system, which is on the northern side of the 216-Z-18 crib. Fifteen extraction wells distributed throughout the well field were selected to optimize both protection of groundwater and mass removal of contaminant. Initial characterization of the 15 on-line wells indicated that the system was extracting soil vapor effectively from only the closest wells and that the applied vacuum at the distant wells was insufficient to produce flow. Tests showed that the system could, however, extract soil vapor effectively from isolated, distant wells. Therefore, the mix of on-line extraction wells was periodically switched among one set of seven relatively nearby wells and various sets of four relatively distant wells. Each set included wells open near the groundwater and wells open near the less-permeable Plio-Pleistocene unit. As a result, the system was extracting from wells primarily associated with the 216-Z-18 site for the first 7 weeks (March 30 through May 17) and from wells primarily associated with the 216-Z-1A site for the following 6 weeks (May 18 through June 30). Comparison of the changes in inlet concentrations to the changes in the sets of on-line wells indicated that the higher concentrations observed from May 18 through June 30 tended to be associated with the 216-Z-1A wells (Figure 4.5-3).

Soil-vapor extraction to remove carbon tetrachloride from the vadose zone resumed July 7, 1998 at the $216-Z-9$ well field, using the $14.2-\mathrm{m}^{3} / \mathrm{min}$ system. Initial on-line wells were selected close to the 216-Z-9 trench. As extraction continued, wells farther away from the crib were brought on line. Each selection of on-line wells included wells open near the groundwater and wells open near the lesspermeable Plio-Pleistocene unit. The daily mass-removal rate increased significantly twice during the 3 months of extraction as a result of changes in extraction wells: 1) Two additional wells were brought on line on July 29,1998 . The mass-removal rate increased, despite a continued decline in concentrations, 
because the flow rate increased (see Figure 4.5-3). 2) The mix of on-line wells was changed again on September 1, 1998. The mass-removal rate increased, despite a constant flow rate, because the inlet concentrations increased (see Figure 4.5-3).

During a total of 178 days of soil-vapor extraction in FY 1998, $777 \mathrm{~kg}$ of carbon tetrachloride were removed from the vadose zone. Of this total, $254 \mathrm{~kg}$ were removed from the $216-\mathrm{Z}-1 \mathrm{~A} /-12 /-18$ well field during 91 days of operation and $523 \mathrm{~kg}$ were removed from the $216-\mathrm{Z}-9$ well field during 86 days of operation.

As of September 1998, 75,000 kg of carbon tetrachloride had been removed from the subsurface since extraction operations started in 1992 (Table 4.5-1). Since initiation, the extraction systems are estimated to have removed $7 \%$ of the residual mass at the $216-Z-1 \mathrm{~A} /-18$ well field and $22 \%$ of the mass at the 216-Z-9 well field. This estimate assumes that all of the mass that has not been lost to the atmosphere ( $21 \%$ of the original inventory) or dissolved in groundwater ( $2 \%$ of the original inventory) is still available in the vadose zone as "residual" mass (BHI-00720, Rev. 2; WHC-SD-EN-TI-101).

\subsubsection{Soil-Vapor Monitoring}

During October 1997 through March 1998, soil-vapor concentrations were monitored near the groundwater and near the ground surface to assess whether nonoperation of the soil-vapor-extraction system was allowing carbon tetrachloride to migrate out of the vadose zone. The maximum concentration detected between 1.5 and $4.5 \mathrm{~m}$ below ground surface was $1 \mathrm{ppm}_{\mathrm{v}}$; the maximum concentration detected between 7.6 and $18.3 \mathrm{~m}$ was $43 \mathrm{ppm}_{\mathrm{v}}$. Near the groundwater, at depths ranging from 56.0 to $63.4 \mathrm{~m}$, maximum concentrations ranged from 14.6 to $31.3 \mathrm{ppm}_{\mathrm{v}}$. These results, after 6 months of rebound, are similar to those obtained during the 8-month rebound study conducted in FY 1997 (BHI-01105).

During April through June 1998, soil-vapor monitoring was continued at the shallow and deep locations at the 216-Z-9 well field. Monitoring locations were added near the less-permeable Plio-Pleistocene unit at 216-Z-9 to provide an indication of concentrations that could be expected during restart of soilvapor extraction in July 1998. Concentrations detected in the near-surface and near-groundwater zones during these additional 3 months of rebound were similar to those observed during the previous 6 months. Nearer the Plio-Pleistocene layer, at depths ranging from 18.3 and $36.0 \mathrm{~m}$, maximum concentrations ranged from 0 to $630 \mathrm{ppm}_{\mathrm{v}}$. The highest concentration was detected in well 299-W15-217 (35.1 m deep), the well at which the highest concentration was detected during the FY 1997 rebound study. These results were obtained after 9 months of rebound and are similar to those obtained during the 8-month rebound study conducted in FY 1997 (BHI-01105).

During July through September 1998, soil-vapor monitoring was resumed at the 216-Z-1A and -18 sites. Monitoring was conducted in the near-surface, near-Plio-Pleistocene, and near-groundwater zones. The maximum concentration detected was $143 \mathrm{ppm}_{\mathrm{v}}$ in well 299-W18-158L (37.5 m deep) in the 216-Z-1A tile field. This result was obtained after only 3 months of rebound.

Samples were collected initially from well 299-W15-217 at the wellhead before the downhole sampling tube was installed to evaluate the effect of the sampling tube. In March and April, these wellhead samples contained 65 and $25 \mathrm{ppm}_{\mathrm{v}}$ of carbon tetrachloride, respectively. Samples collected in May and 
June, using the downhole sampling tube, contained 630 and $504 \mathrm{ppm}_{\mathrm{v}}$ of carbon tetrachloride, respectively. Other wells sampled without the sampling tube had anomalously low to nondetectable carbon tetrachloride concentrations.

Because carbon tetrachloride concentrations did not increase significantly at the shallow probes monitored in FY 1998, temporarily suspending operation of the soil-vapor-extraction system for 6 to 9 months appears to have caused minimal detectable vertical transport of carbon tetrachloride through the soil surface to the atmosphere. Because carbon tetrachloride concentrations did not increase significantly near the water table during this time, temporarily suspending operation of the soil-vapor-extraction system appears to have had no negative impact on groundwater quality.

\subsubsection{Carbon Tetrachloride Migration}

Three major pathways in the vadose zone to groundwater are possible: 1) sinking and lateral spreading of a heavier-than-air vapor phase down to the top of the aquifer; 2) transport of a liquid phase, or dense, nonaqueous-phase liquid, down through the vadose zone over time, which eventually reaches the water column, dissolves, and settles through the saturated zone to an unknown depth; and 3) transport of carbon tetrachloride dissolved in the aqueous phase either through disposal of aqueous waste or by contact between infiltrating recharge and residual, dense, nonaqueous-phase liquid (WHC-SD-EN-TI-248). A schematic representation, or conceptual model, of the subsurface behavior of carbon tetrachloride beneath the 216-Z-9 trench is shown in Figure 4.5-4.

A numerical model was developed (BHI-00459) to simulate the primary transport processes shown in Figure 4.5-4, using local stratigraphy and published input parameters for the source term and soil properties. Results of initial simulations suggested that over two-thirds of the discharged carbon tetrachloride would have been retained in the soil column and that a dense, nonaqueous-phase liquid would continue to drain slowly through the vadose zone and be transported into the underlying aquifer for years into the future. The initial modeling results indicated that the dense, nonaqueous-phase liquid dissolved in the groundwater and the depth of penetration was dependent on the groundwater-flow rate. Additional modeling is needed to assess the influence of effective porosity and groundwater velocity. Nevertheless, the modeling results support the conceptualization of the liquid-phase transport illustrated in Figure 4.5-4. The vapor-phase results were less definitive but suggested that vapor-phase transport is secondary to dense, nonaqueous-phase liquid as a groundwater contamination pathway.

Field measurements of carbon tetrachloride vapor concentrations are not completely consistent with the numerical modeling results. If a major fraction of the carbon tetrachloride originally discharged to the 216-Z-9 trench were still present in the soil column as a nonaqueous phase, a relatively high soil-vapor concentration would be expected. For example, a pure, nonaqueous, carbon tetrachloride, liquid phase in the soil-pore space should result in a maximum soil-vapor concentration of $120,000 \mathrm{ppm}_{\mathrm{v}}$ at $20^{\circ} \mathrm{C}$ (DOE/RL-91-32, Draft B). As a rule of thumb for soils saturated with an organic contaminant, standard soil-vapor extraction will produce a vapor stream containing one-tenth to one-half the expected concentration (EPA 510-R-93-001). Therefore, vapor-extraction concentrations $>12,000 \mathrm{ppm}_{\mathrm{v}}$ of carbon tetrachloride would indicate that the soil near the extraction well is saturated with nonaqueous-phase liquid.

During initial extraction operations at the 216-Z-9 well field, soil-vapor carbon tetrachloride concentrations extracted from wells open above the Plio-Pleistocene unit were $>12,000 \mathrm{ppm}_{\mathrm{v}}$, suggesting the 
presence of a nonaqueous phase. Soil vapor extracted from wells open below the Plio-Pleistocene were an order of magnitude lower and, based on the rule of thumb, would not suggest the presence of a nonaqueous-phase liquid. However, the depths and locations of the extraction wells below the PlioPleistocene may not have been optimal to detect the presence of a nonuniformly distributed contaminant, and the presence of a nonaqueous-phase liquid cannot be ruled out.

During the soil-vapor monitoring of rebound concentrations conducted in FY 1997 and FY 1998, the carbon tetrachloride vapor concentrations monitored deep within the vadose zone at the $216-Z-9$ trench did not exceed $60 \mathrm{ppm}_{\mathrm{v}}$. These low vapor concentrations do not indicate the presence of a nonaqueousphase liquid remaining in the vadose zone below the Plio-Pleistocene unit; however, these measurements were not taken directly under the 216-Z-9 trench nor at depth-discrete, narrow zones above the water table. Although carbon tetrachloride volatilizing from a residual nonaqueous-phase liquid source may have been diluted by the time the vapor reached the sampling locations, the data suggest that soil-vapor extraction may have removed much of the remaining deep, vadose-zone, nonaqueous-phase, liquid source in the area of the 216-Z-9 trench and that the continuing groundwater source may now be within the aquifer (BH-01105).

The apparent discrepancy between the numerical modeling results and the field measurements may be a result of 1) nonuniform discharge, migration, and distribution of the nonaqueous-phase carbon tetrachloride; 2) nonoptimal locations for monitoring; 3) nonequilibrium partitioning of carbon tetrachloride within the vadose zone; 4) discharge of carbon tetrachloride organic liquid mixtures rather than pure phase liquids; and/or 5) vadose-zone geologic heterogeneities and geostructural dips.

Vertical and areal distribution of dissolved carbon tetrachloride discussed in Section 5.9.3.4 is consistent with a dense, nonaqueous-phase, liquid-transport mechanism. If the numerical model predictions are correct, for example, slowly dissolving carbon tetrachloride distributed with depth in the aquifer should continue to emanate from the point of origin over time, with the highest concentrations at the source, and should result in dissolved carbon tetrachloride distributed with depth in the aquifer (BHI-00459). If vapor-phase transport were a primary pathway, the top of the aquifer should have the highest concentrations and should decline rapidly with depth over a 1- to 2-m interval.

The carbon tetrachloride plume map and vertical profiles discussed in Section 5.9.3.4 suggest there is a continuing groundwater source that produces somewhat uniform carbon tetrachloride concentrations with depth in the aquifer. A dense, nonaqueous-phase liquid that drained from the vadose zone into the aquifer and is slowly dissolving could produce such a pattern. One alternative explanation for the depthdistribution pattern is that a secondary source of water passing near or through an area containing a dense, nonaqueous-phase liquid and soil-vapor carbon tetrachloride could absorb this slightly soluble chlorinated hydrocarbon and carry it into the aquifer under saturated flow conditions. This would theoretically drive the contaminated water deep into the aquifer.

The continuing presence, 35 years after termination of disposal operations, of relatively high, dissolved, carbon tetrachloride concentrations in groundwater in the immediate vicinity of the 216-Z-9 trench suggests that a dense, nonaqueous-phase liquid is slowly dissolving within the aquifer. Although this liquid phase may be slowly draining from the vadose zone to groundwater, the soil-vapor concentrations monitored deep within the vadose zone during FY 1997 and FY 1998 suggest that soil-vaporextraction remediation may have removed much of the vadose-zone source and that the continuing 
groundwater source resides within the aquifer. Carbon tetrachloride concentrations in the soil vapor and underlying groundwater do not appear to be in equilibrium, and the expected direction of carbon tetrachloride migration is from the groundwater to the vadose zone (BHI-01105).

Carbon tetrachloride rebound concentrations indicate that in many areas much of the readily accessible mass has been removed during soil-vapor-extraction operations and that the supply of additional carbon tetrachloride is limited by desorption and/or diffusion from contaminant sources (e.g., lowerpermeability zones such as the lower Hanford formation silt, Plio-Pleistocene unit). Under these conditions, the removal rate of the additional carbon tetrachloride using soil-vapor extraction is controlled by the desorption and diffusion rates of the contaminant. 
Table 4.4-1. Conservative and Best Estimates of Distribution Coefficient $\left(\mathrm{K}_{\mathrm{d}}\right)$ Values of Units 1,2 , and $3^{(a)}$

Units 3 and $2 \mathrm{~K}_{\mathrm{d}}, \mathrm{mL} / \mathrm{g}$

\begin{tabular}{l} 
Radionuclide \\
\hline Cesium \\
Iodine
\end{tabular}

Selenium

Strontium

Technetium

Uranium

\begin{tabular}{c}
\hline Conservativ \\
\hline 1,370 \\
0 \\
3.8 \\
12.0 \\
0.0 \\
0.5
\end{tabular}

0.5

Best
$2,050 \pm 440$
$0 \pm 0$

$6.7 \pm 1.9$

$14.3 \pm 1.6$

$0 \pm 0$

$0.6 \pm 0.1$
Unit $1 \mathrm{~K}_{\mathrm{d}} \mathrm{mL} / \mathrm{g}$

\begin{tabular}{|c|c|}
\hline Conservative & Best \\
\hline 1,370 & $2,050 \pm 440$ \\
\hline 0 & $0.1 \pm 0.1$ \\
\hline 3.8 & $6.7 \pm 1.9$ \\
\hline 12.0 & $16.5 \pm 1.9$ \\
\hline 0.0 & $0 \pm 0$ \\
\hline 0.5 & $0.6 \pm 0.1$ \\
\hline
\end{tabular}

(a) Different $K_{d}$ values were assigned to each unit when statistical analyses determined that they differed at the $5 \%$ level of confidence. Otherwise, the same $\mathrm{K}_{d}$ values were assigned for all three units. Conservative estimates were based on the minimum value, and the best estimates were based on the median \pm standard deviation.

Table 4.4-2. Conservative and Best Estimates of Distribution Coefficient $\left(K_{d}\right)$ Values for Hanford Formation

\begin{tabular}{lccc}
\multicolumn{1}{c}{ Radionuclide } & Conservative $\mathrm{K}_{\mathrm{d}}$ Value, $^{(\mathrm{a})} \mathrm{mL} / \mathrm{g}$ & & Best $\mathrm{K}_{\mathrm{d}} \mathrm{Value}^{(\mathrm{b})} \mathrm{mL} / \mathrm{g}$ \\
\cline { 1 - 1 } Cesium & 1,370 & & $2,030 \pm 597$ \\
Iodine & 0 & $0 \pm 0$ \\
Selenium & 3.8 & $6.7 \pm 1.9$ \\
Strontium & 12.0 & $14.3 \pm 1.6$ \\
Technetium & 0.0 & $0.6 \pm 0$ \\
Uranium & 0.5 & & 0.1
\end{tabular}

(a) Conservative $K_{d}$ value estimates are based on the lowest value for each radionuclide (except uranium, which used the second-lowest measured $\mathrm{K}_{d}$ value; see explanation in text).

(b) Best $\mathrm{K}_{\mathrm{d}}$ value estimates are the median \pm standard deviation from the 20 samples studied. 
Table 4.4-3. Comparison of Maximum Man-Made Radionuclide Activities Detected at 216-B-2-2 Ditch

\begin{tabular}{lccc}
\multicolumn{1}{c}{ Radionuclide } & $\begin{array}{c}\text { Maximum Laboratory } \\
\text { Analytical Result, pCi/g }\end{array}$ & & $\begin{array}{c}\text { Maximum Spectral Gamma- } \\
\text { Logging Result, pCi/g }\end{array}$ \\
\cline { 1 - 1 } Strontium-90 & 4,710 & 100 & Not detectable by this method \\
Cesium-137 & 1.29 & 400 \\
Europium-154 & Not detected & 2.0 \\
Cobalt-60 & & 0.15
\end{tabular}

(a) A sample was not collected at the depth ( 0 to $0.3 \mathrm{~m}$ below ground surface) at which spectral gamma logging detected cobalt- 60

Table 4.5-1. Carbon Tetrachloride Inventory in Primary Disposal Sites

\begin{tabular}{|c|c|c|c|}
\hline Well Field & $\begin{array}{c}\text { Estimated Mass } \\
\text { Discharged } 1955 \text { to } \\
1973,{ }^{(\mathrm{a})} \mathrm{kg}\end{array}$ & $\begin{array}{c}\text { Estimated Mass Lost to } \\
\text { Atmosphere } 1955 \text { to } \\
1990,{ }^{(b)} \mathrm{kg}\end{array}$ & $\begin{array}{c}\text { Mass Removed Using } \\
\text { Soil-Vapor Extraction } \\
1992 \text { to } 1998,{ }^{(c)} \mathrm{kg}\end{array}$ \\
\hline $216-Z-1 A$ & 270,000 & 56,700 & $22,983^{(\mathrm{d})}$ \\
\hline $216-Z-9$ & 130,000 to 480,000 & 27,300 to 100,800 & 52,507 \\
\hline $216-Z-18$ & 170,000 & 35,700 & \\
\hline Total & 570,000 to 920,000 & 119,700 to 196,800 & 75,490 \\
\hline
\end{tabular}

(a) Based on DOE/RL-91-32, Draft B.

(b) Based on WHC-SD-EN-TI-101.

(c) Based on BHI-00720, Rev. 2.

(d) Includes mass removed from 216-Z-18 site; reported as a combined value because the well fields overlap. 


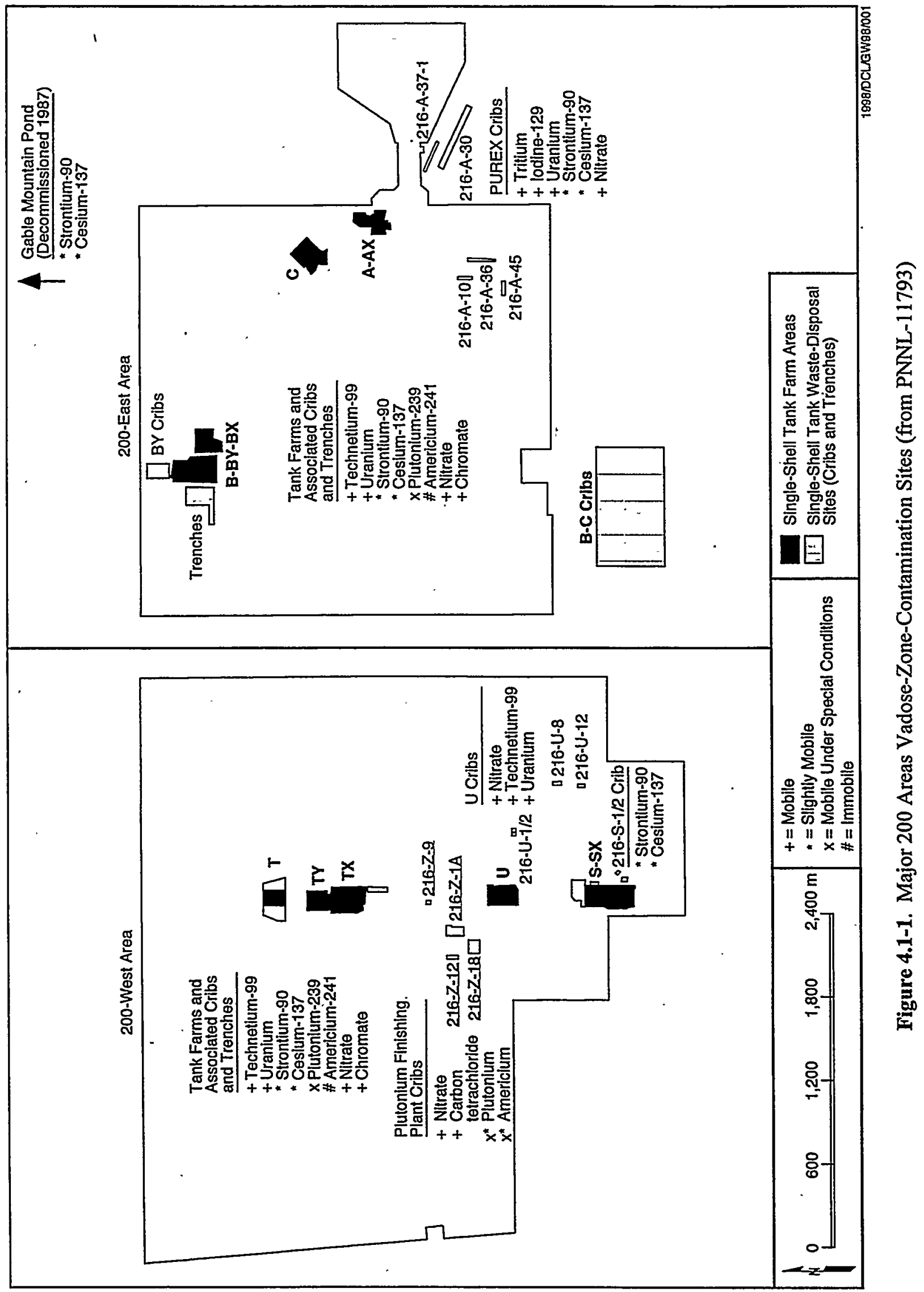



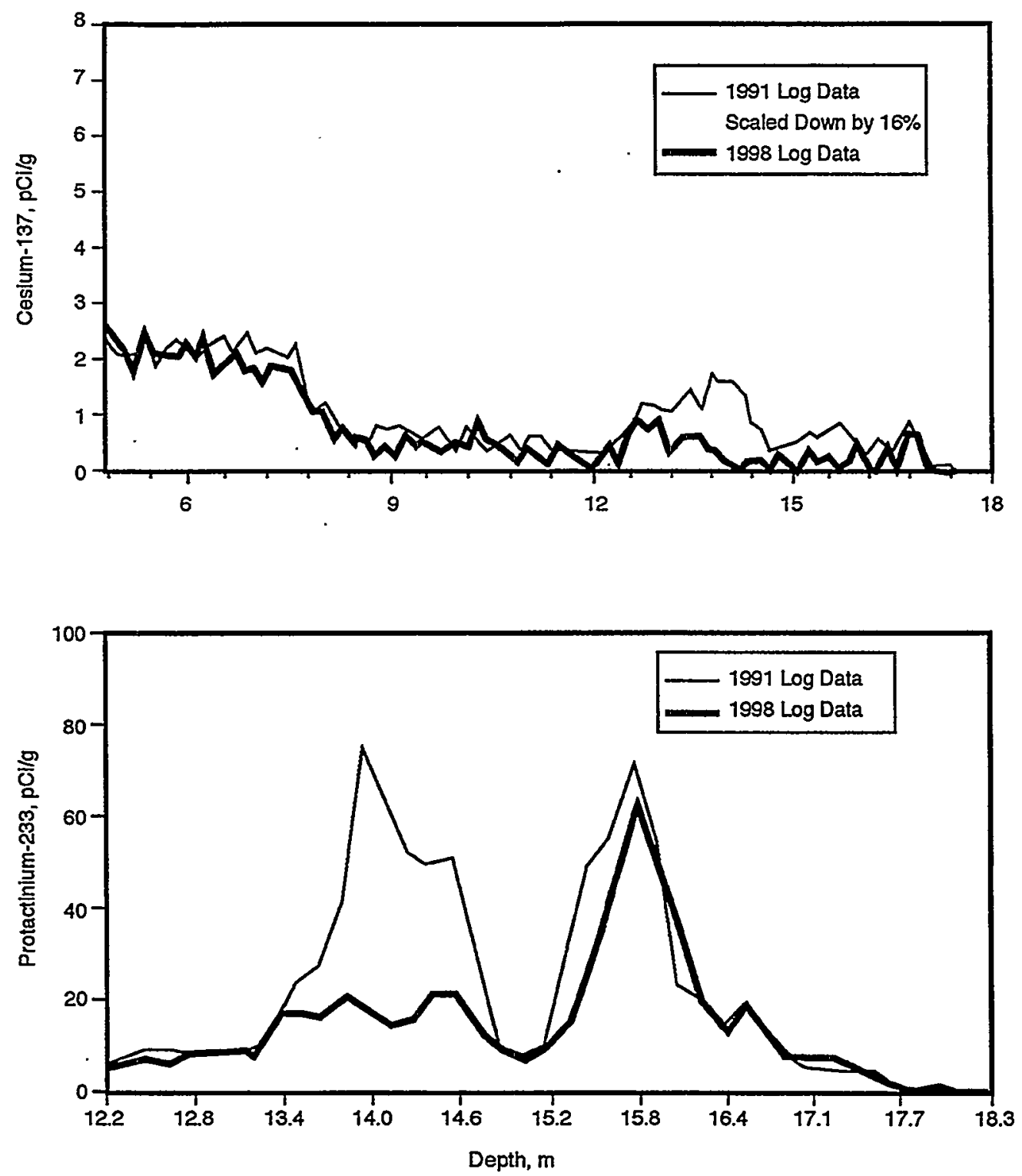

RG98120214.23

Figure 4.2-1. Comparison of Cesium-137 and Protactinium-233 Activities Versus Depth from 1991 and 1998 Log Data in Borehole 299-W18-159 (after PNNL-11978) 


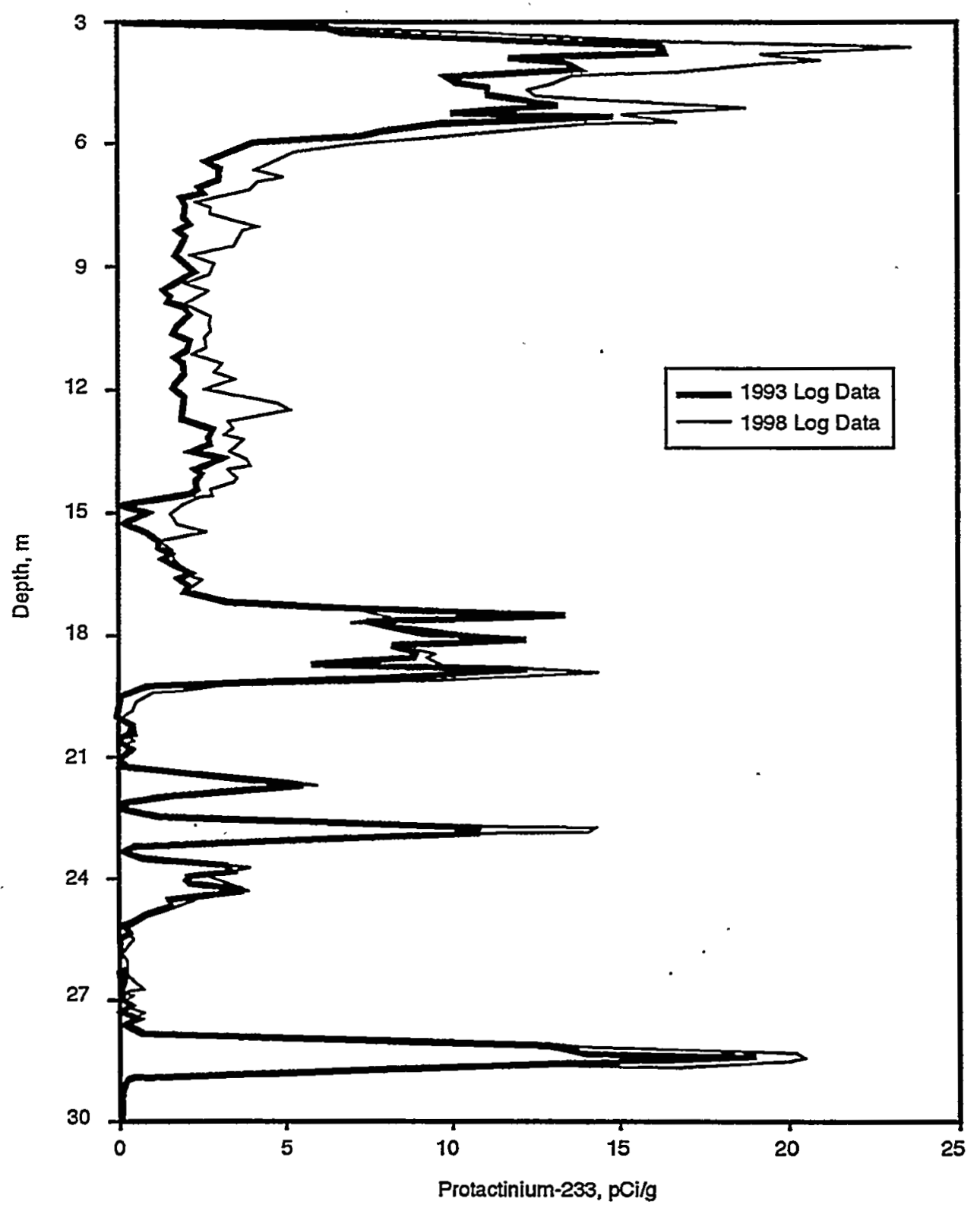

RG98120214.26

Figure 4.2-2. Comparison of Protactinium-233 Activity Versus Depth from 1998 and 1993 Log Data in Borehole 299-W18-175 (after PNNL-1 1978) 

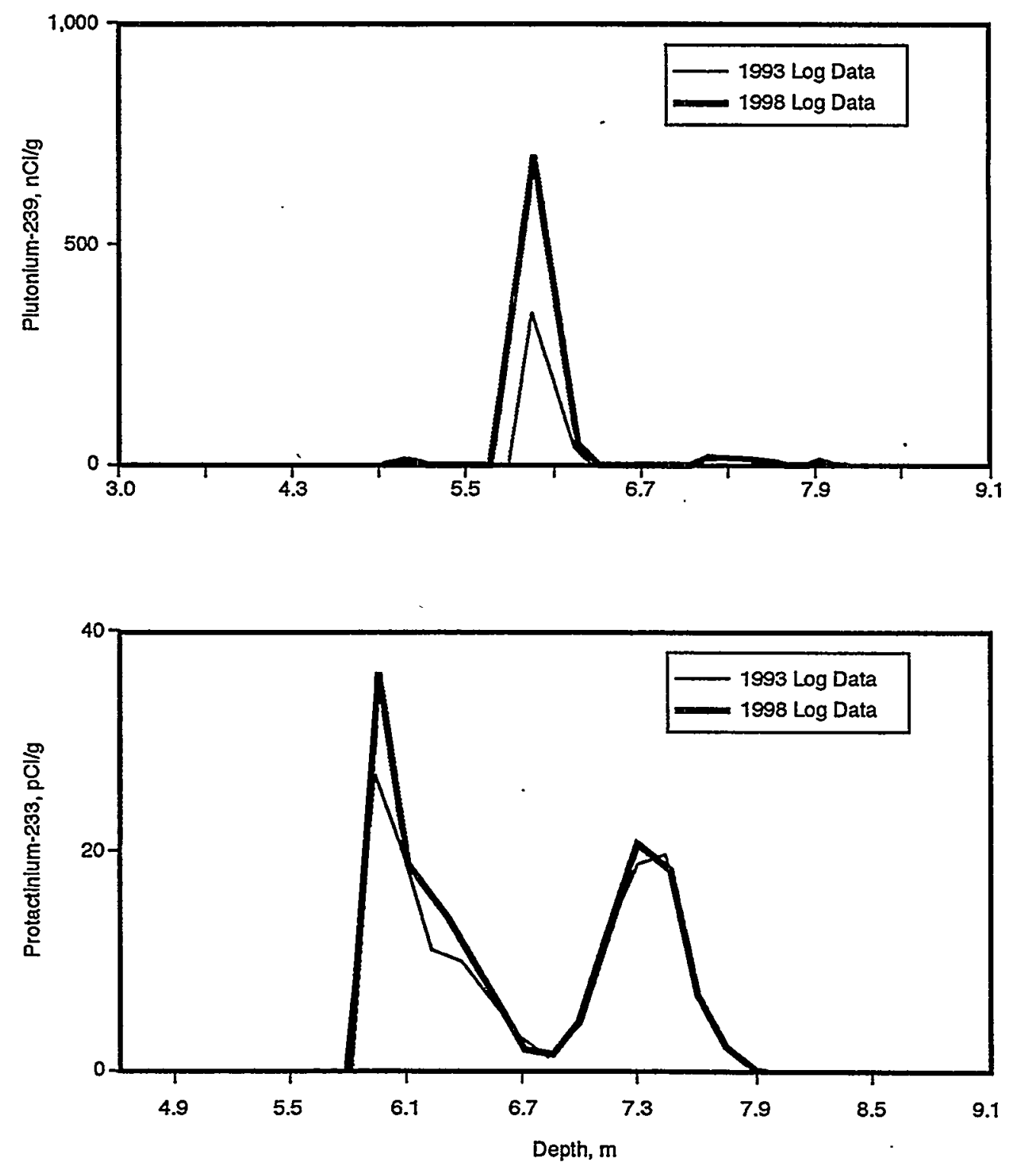

Figure 4.2-3. Compàrison of Protactinium-233 and Plutonium-239 Activities Versus Depth from 1993 and 1998 Log Data in Borehole 299-W18-179 (after PNNL-11978) 


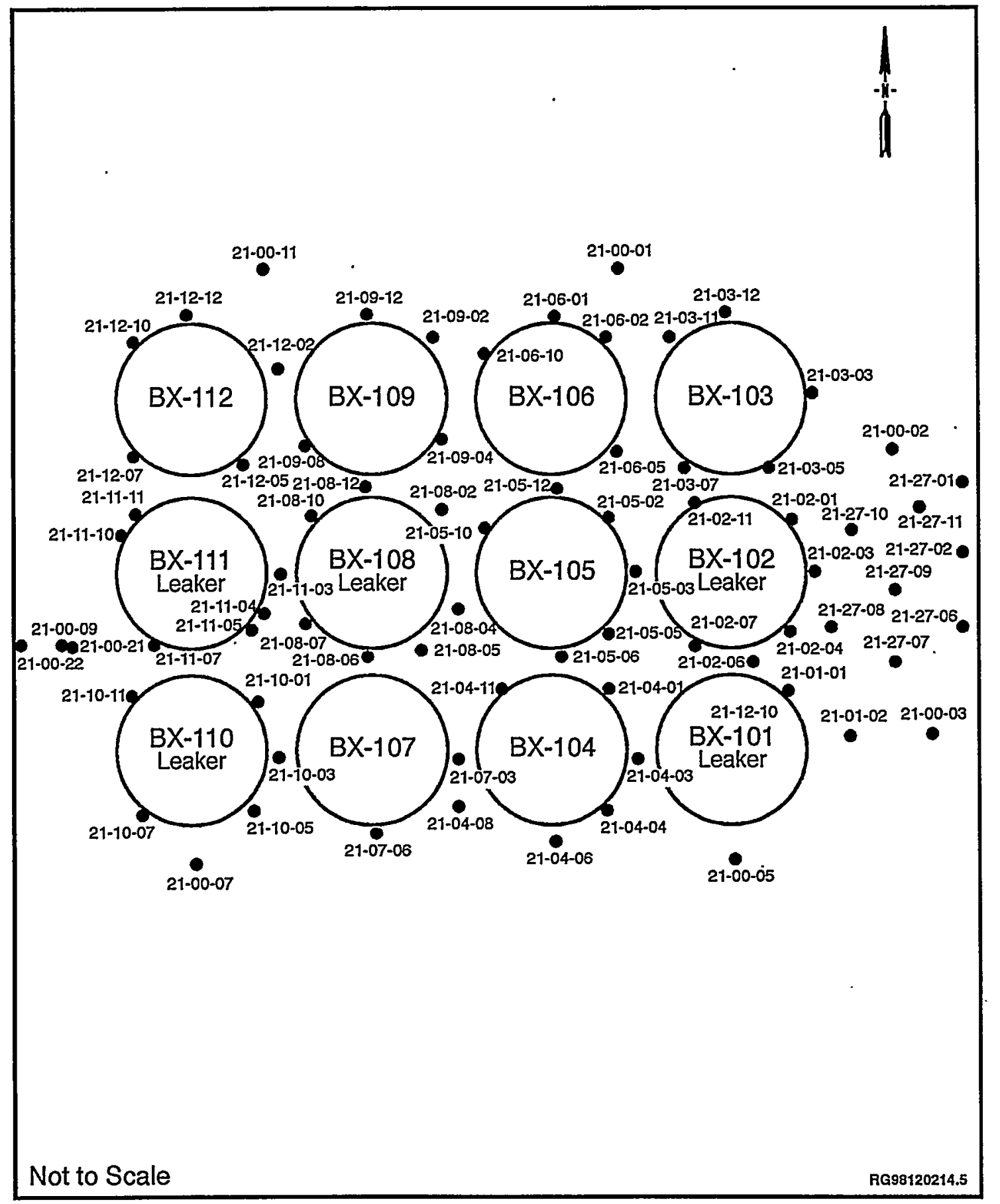

Figure 4.2-4. Plan View of BX Tank Farm, Showing Borehole Locations (after GJO-98-40-TAR, GJO-HAN-9) 


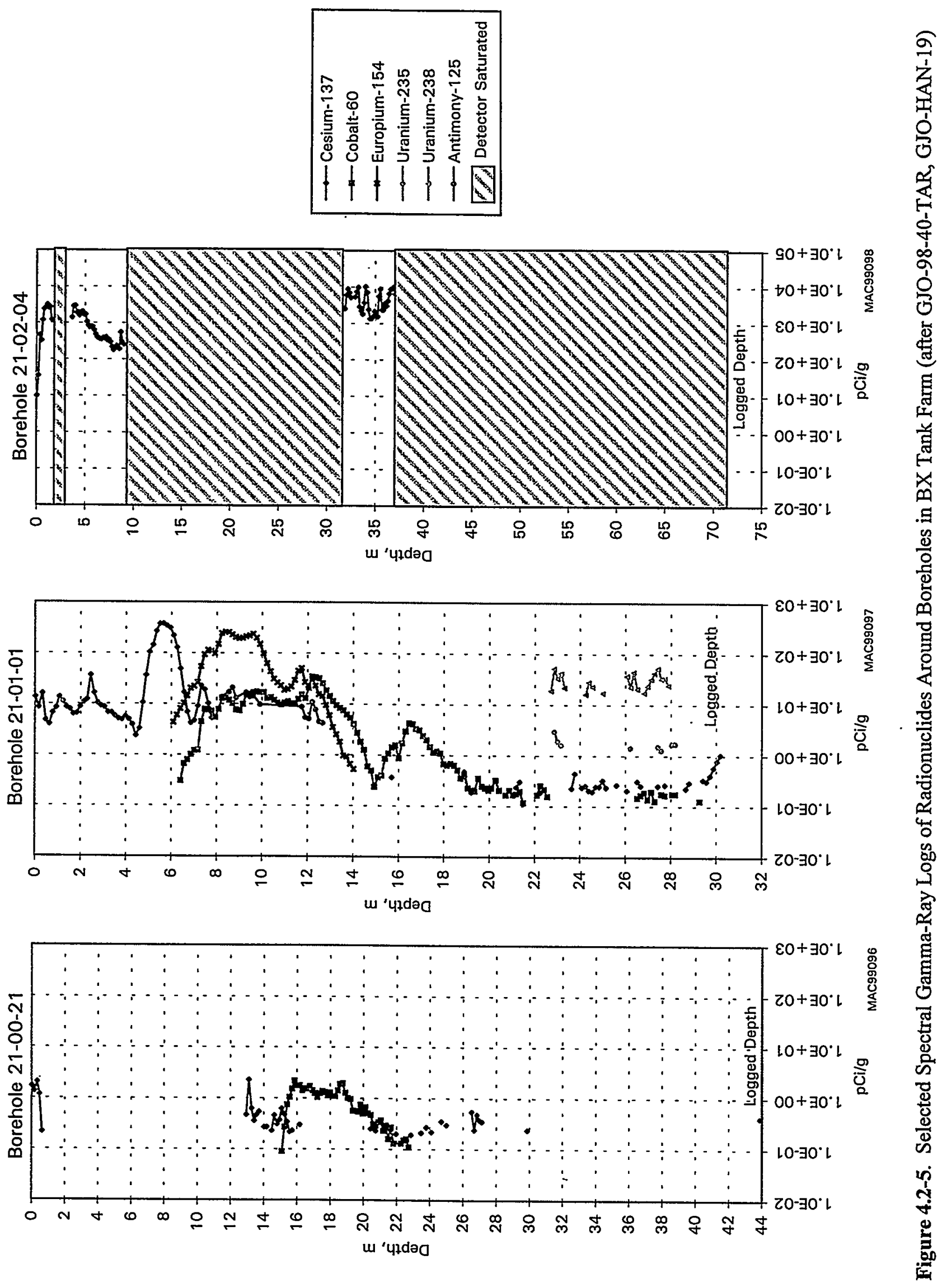



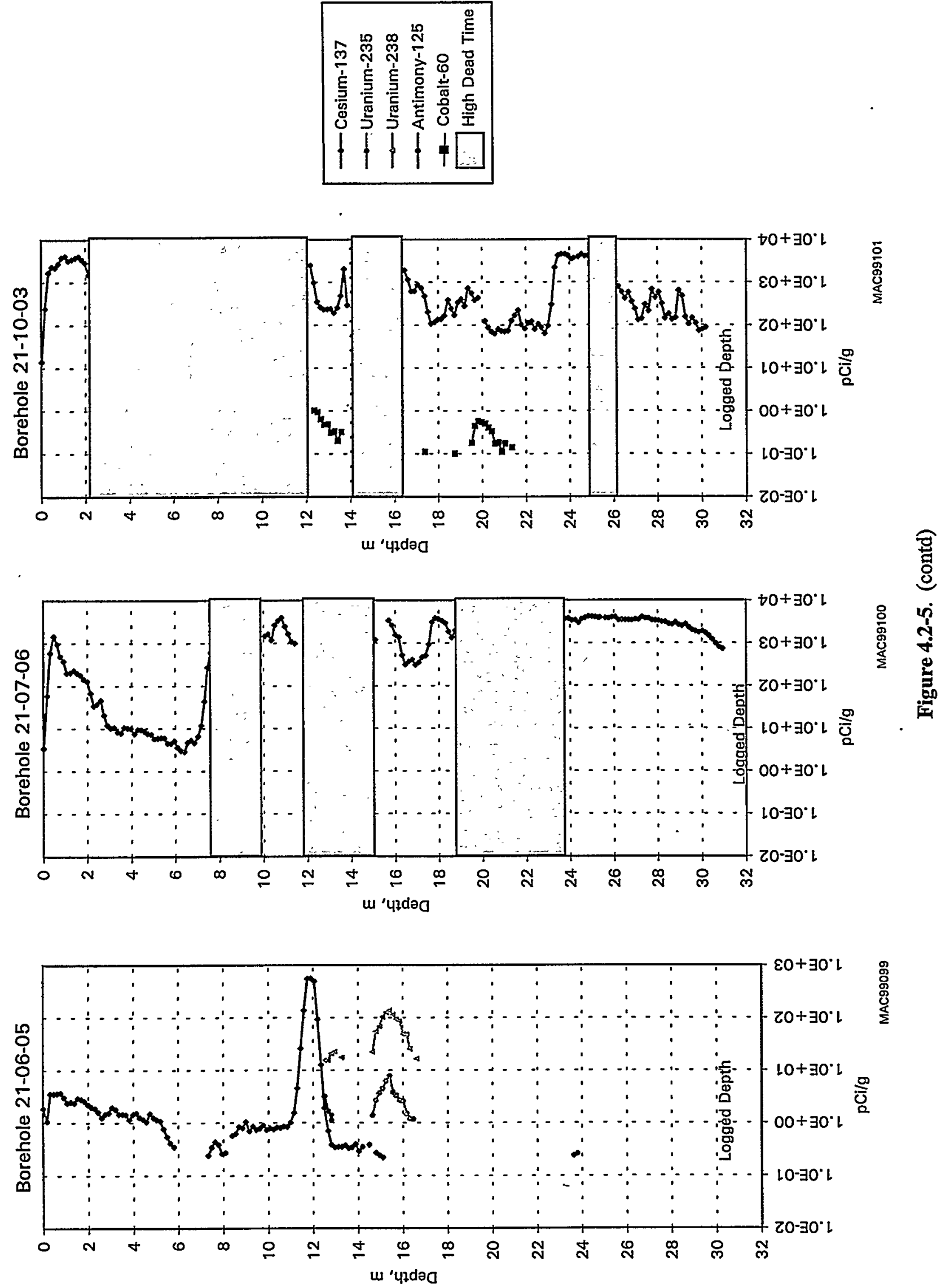

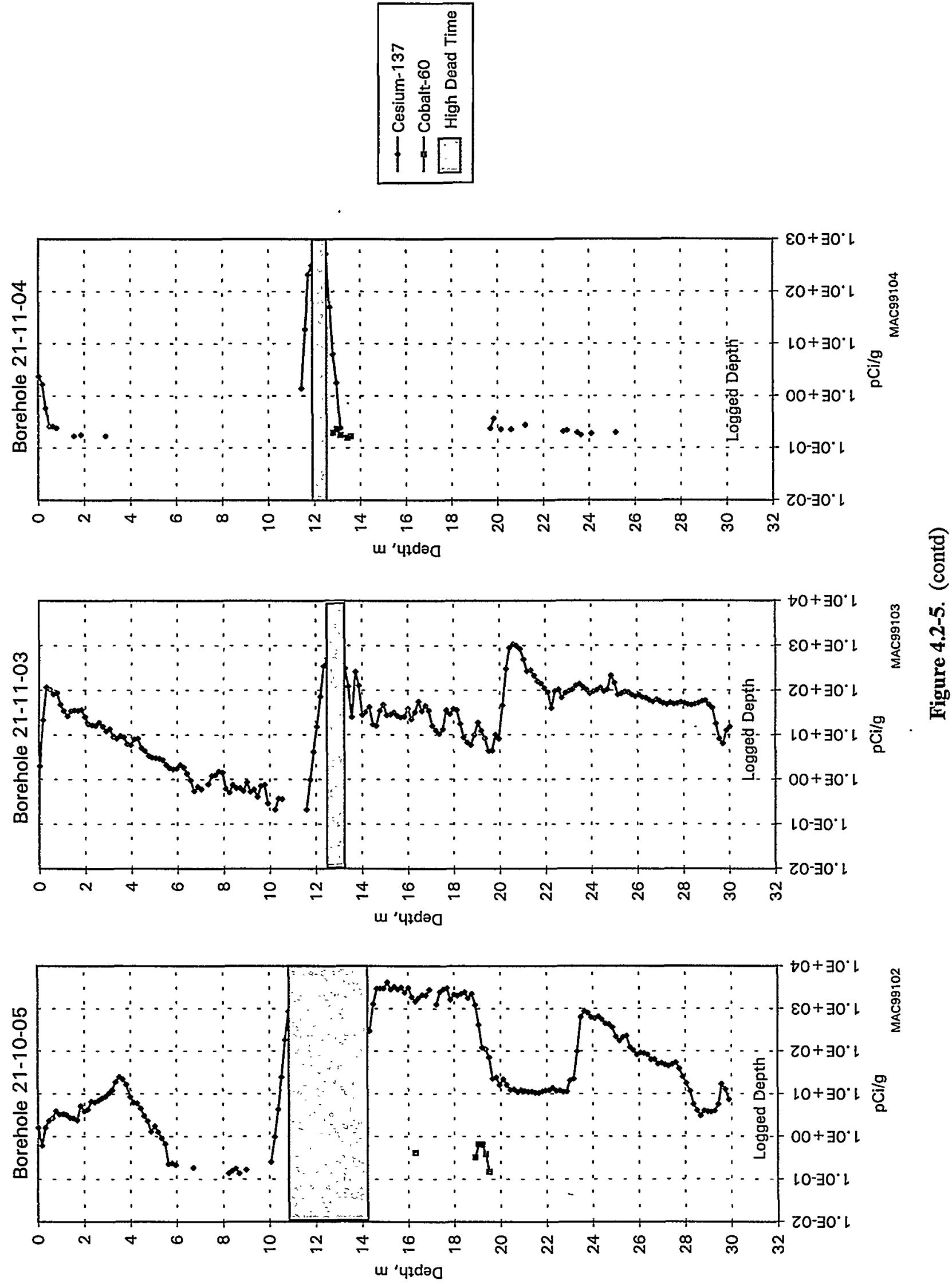

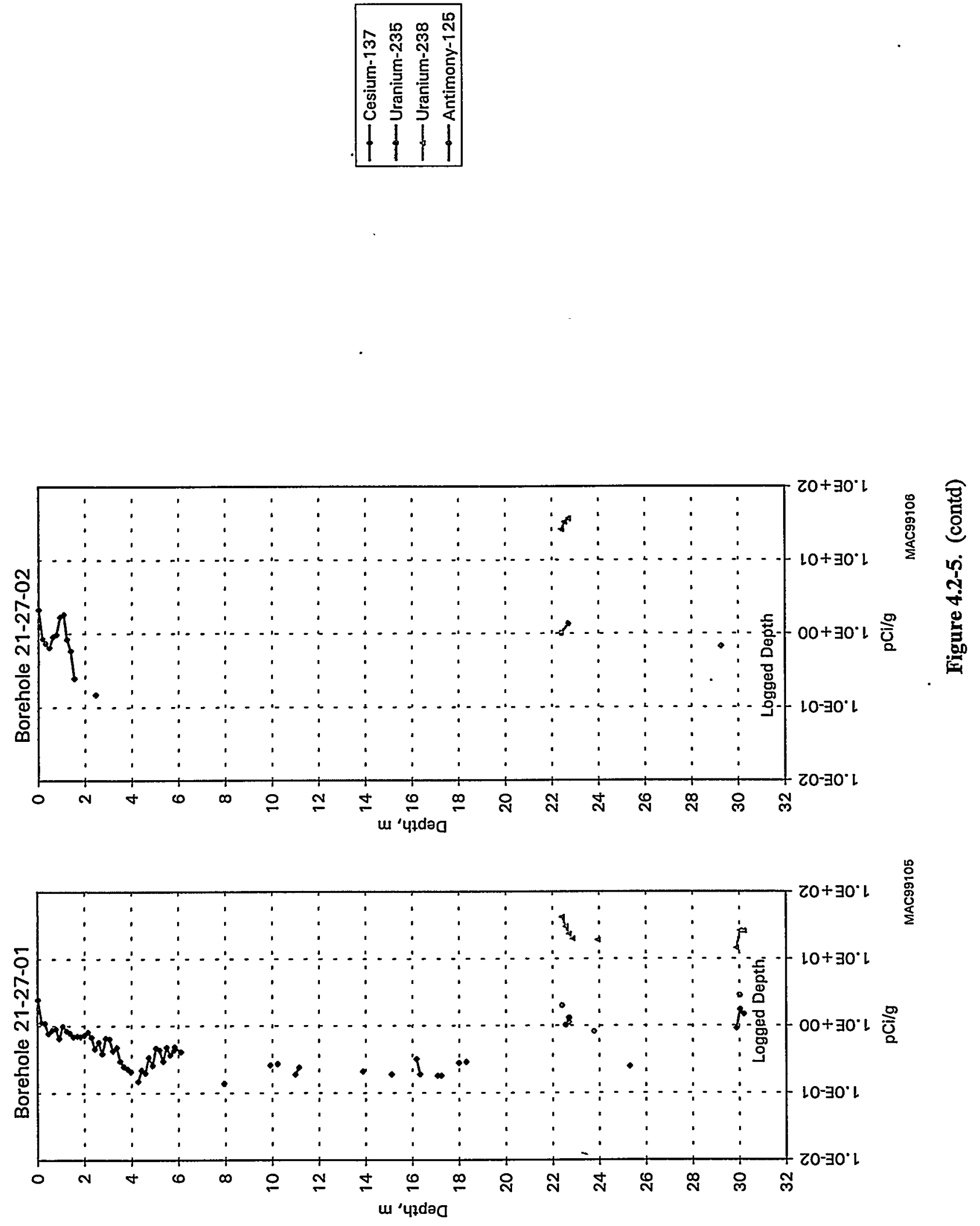

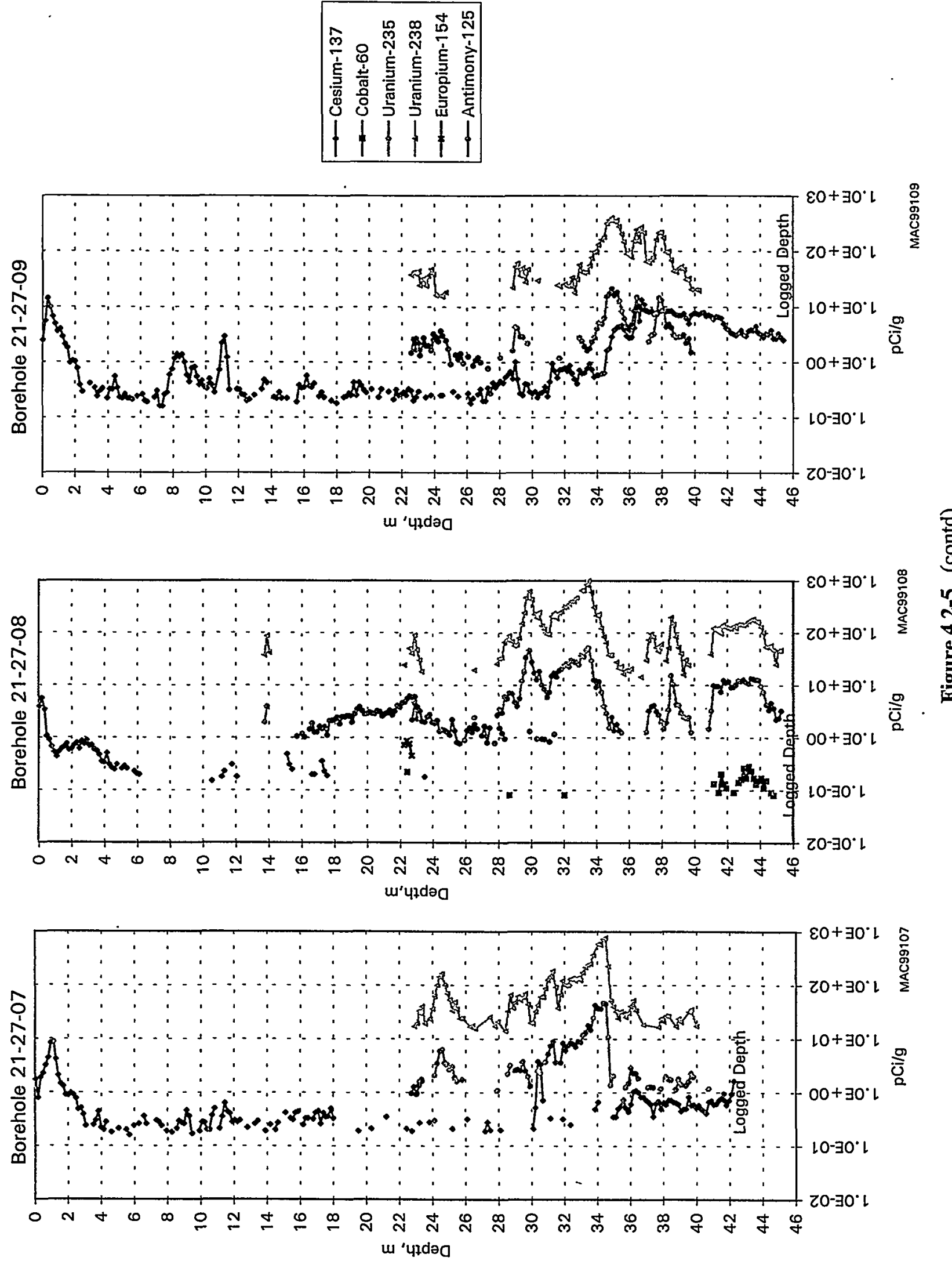


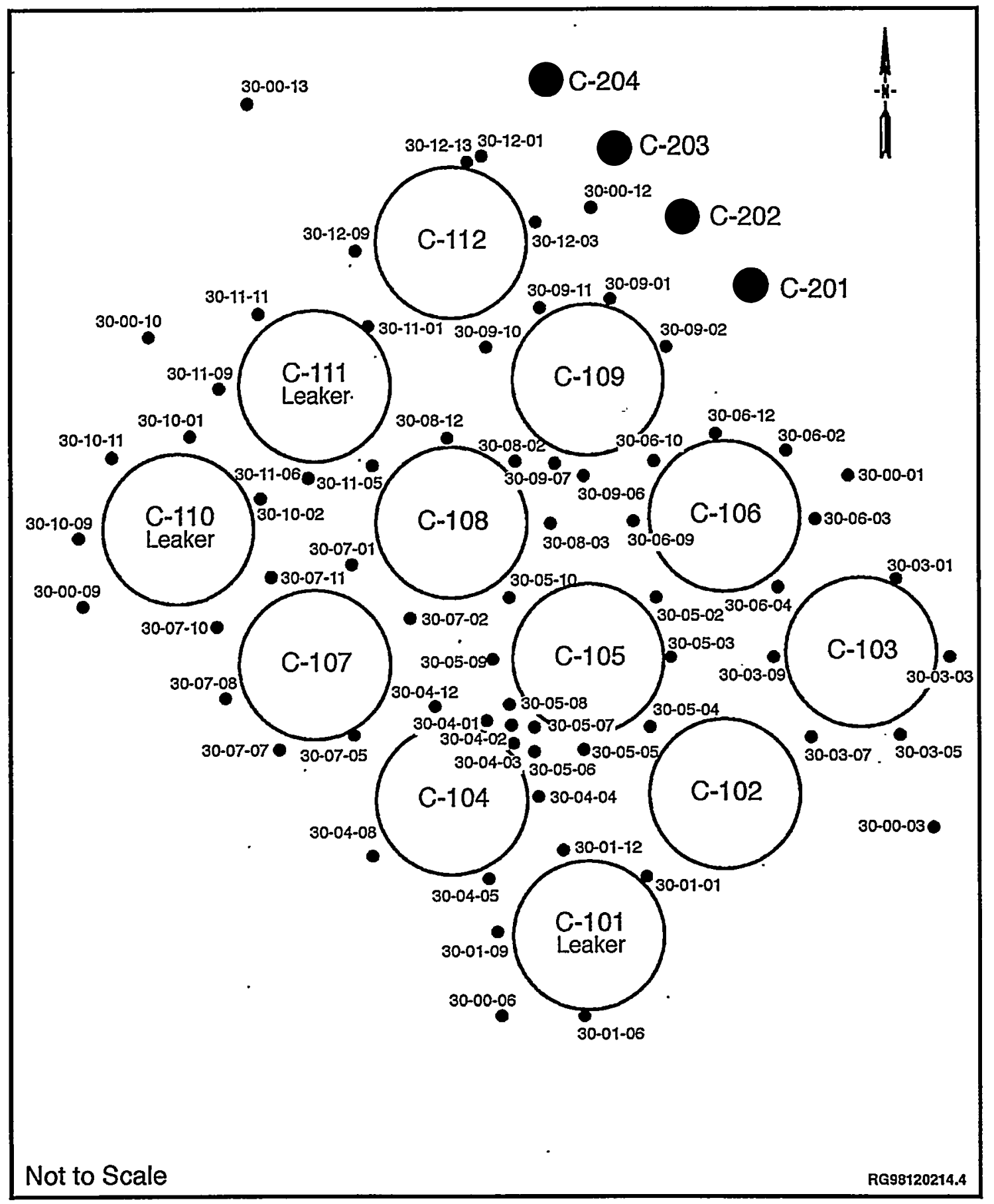

Figure 4.2-6. Plan View of C Tank Farm, Showing Borehole Locations (after GJO-98-39-TAR, GJO-HAN-18) 

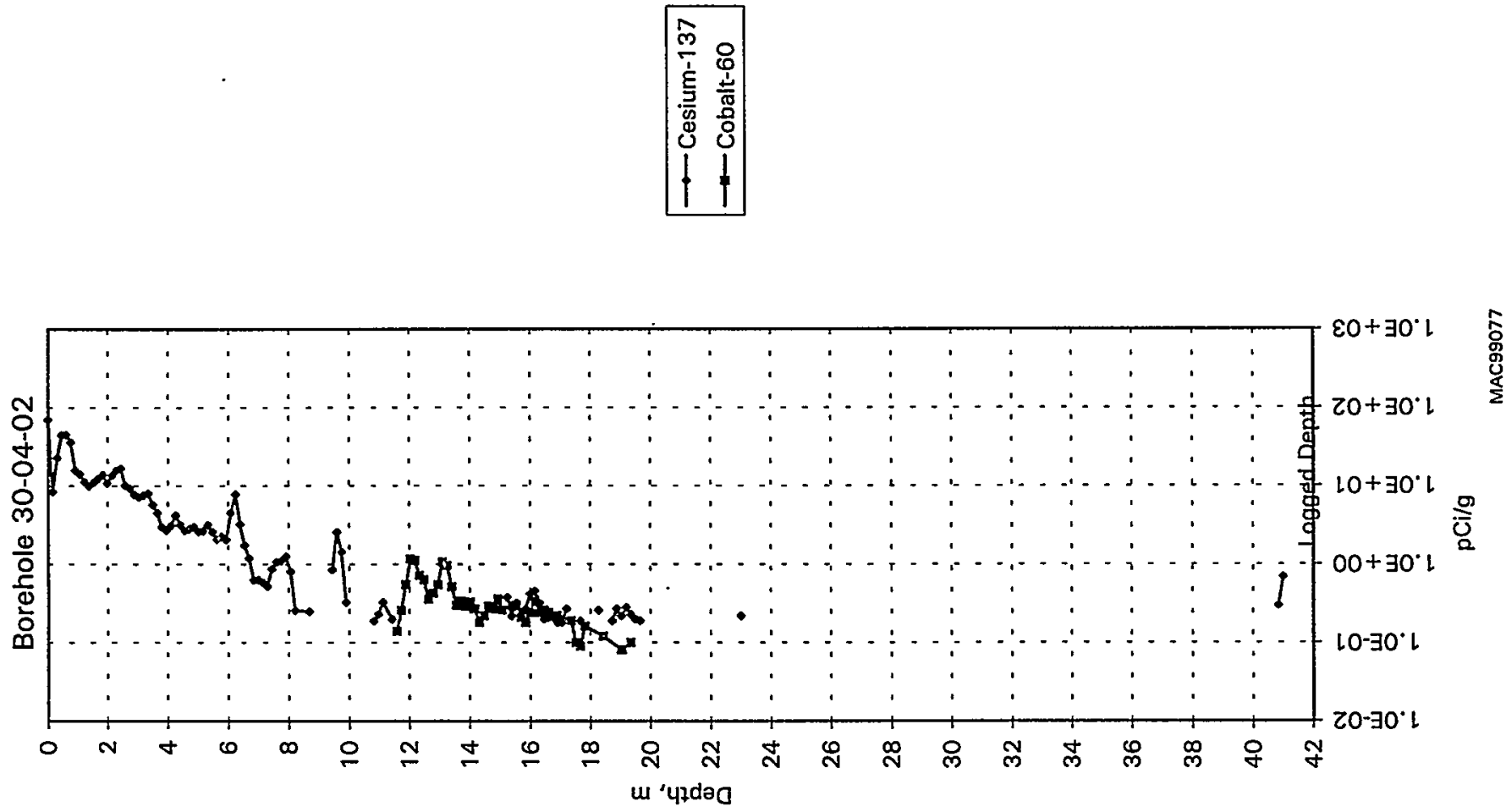

.

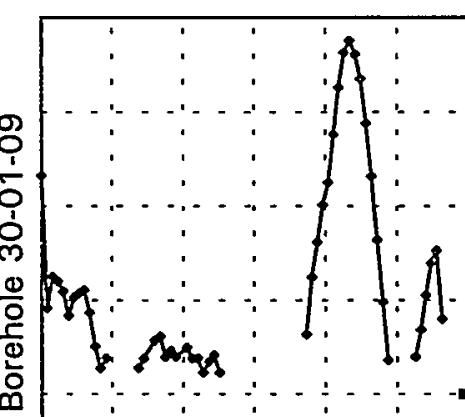

$\varepsilon 0+\exists 0^{\circ}$ 

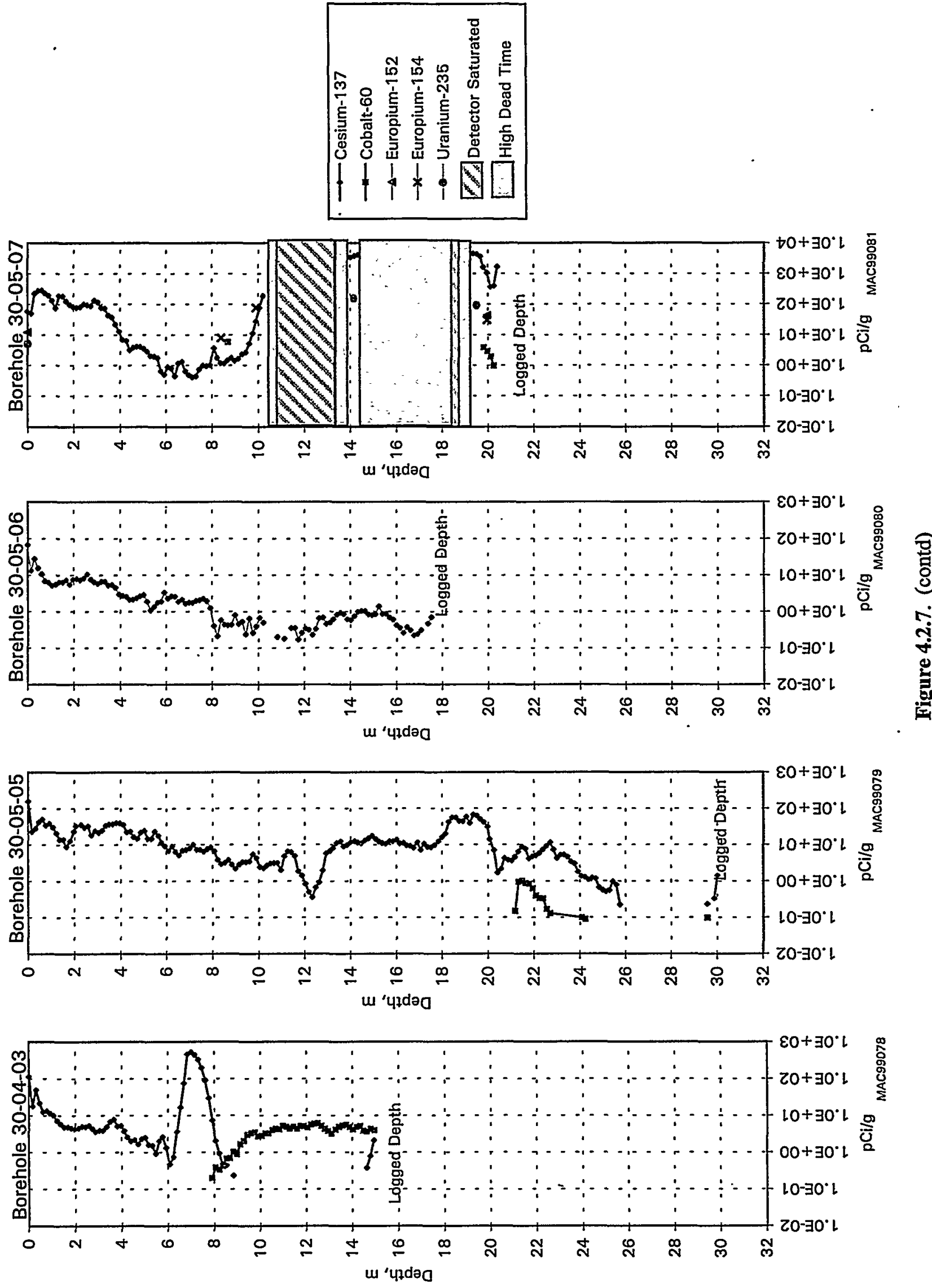

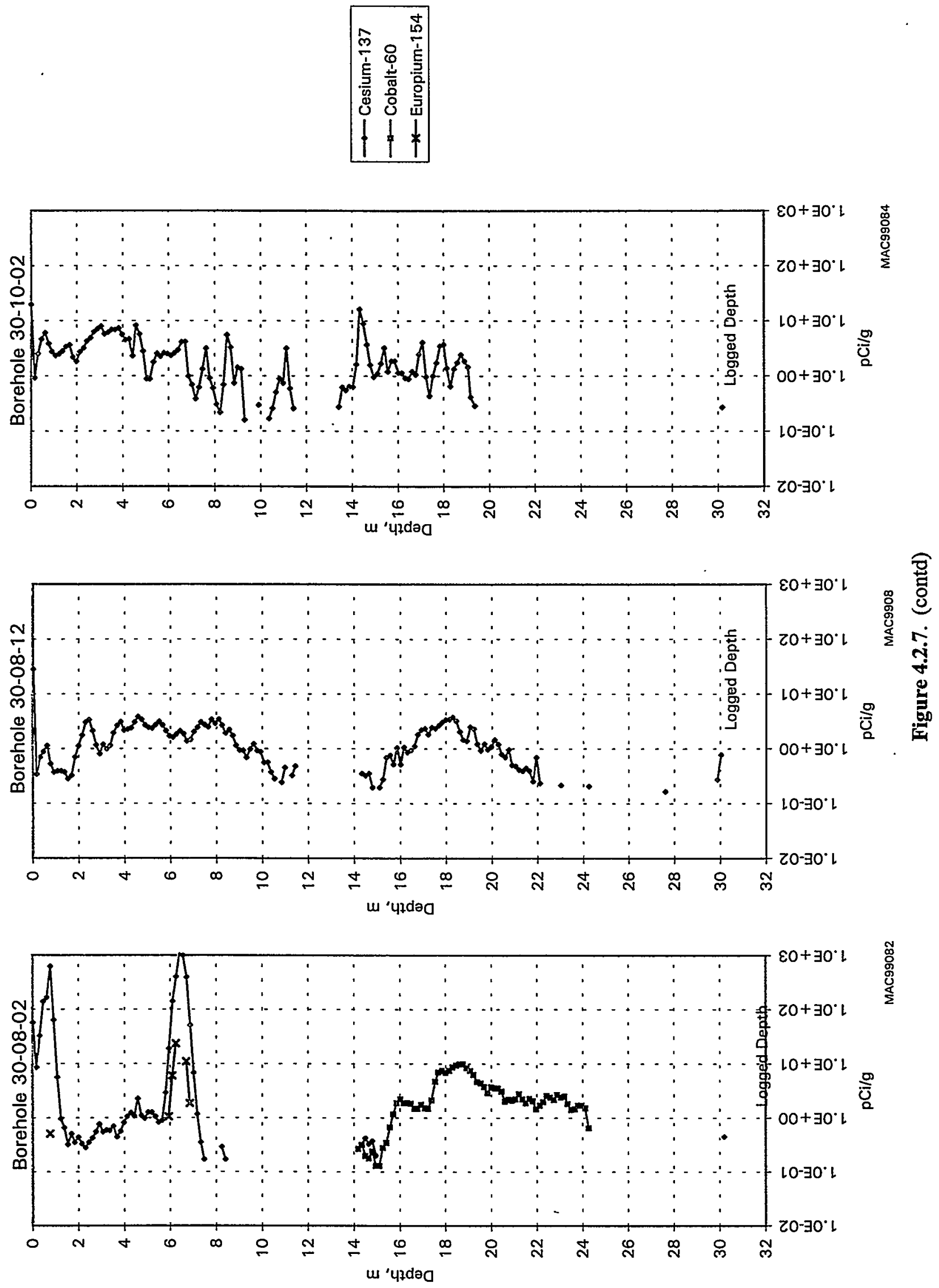


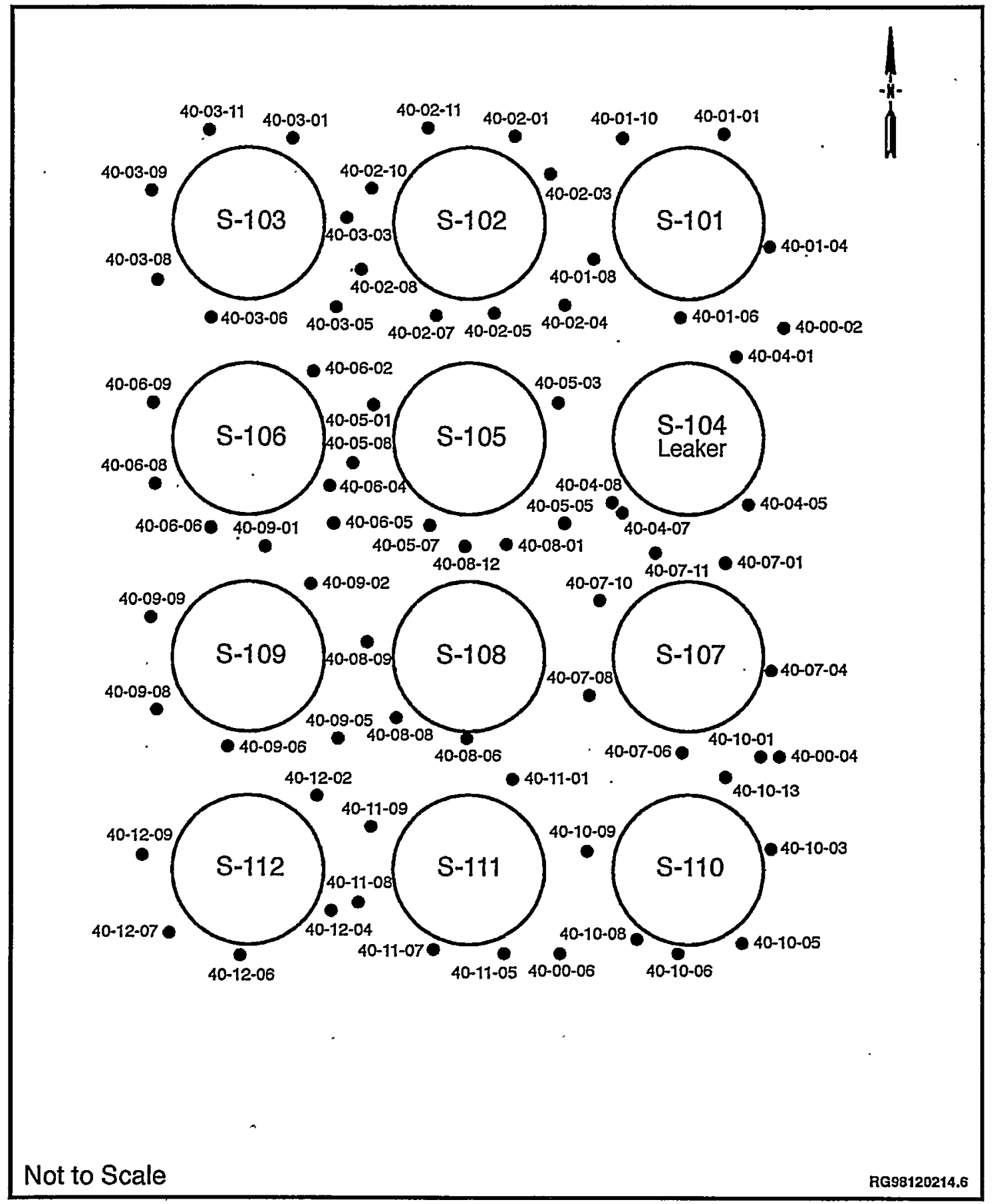

Figure 4.2-8. Plan View of S Tank Farm, Showing Borehole Locations (after GJO-97-31-TAR, GJO-HAN-17) 


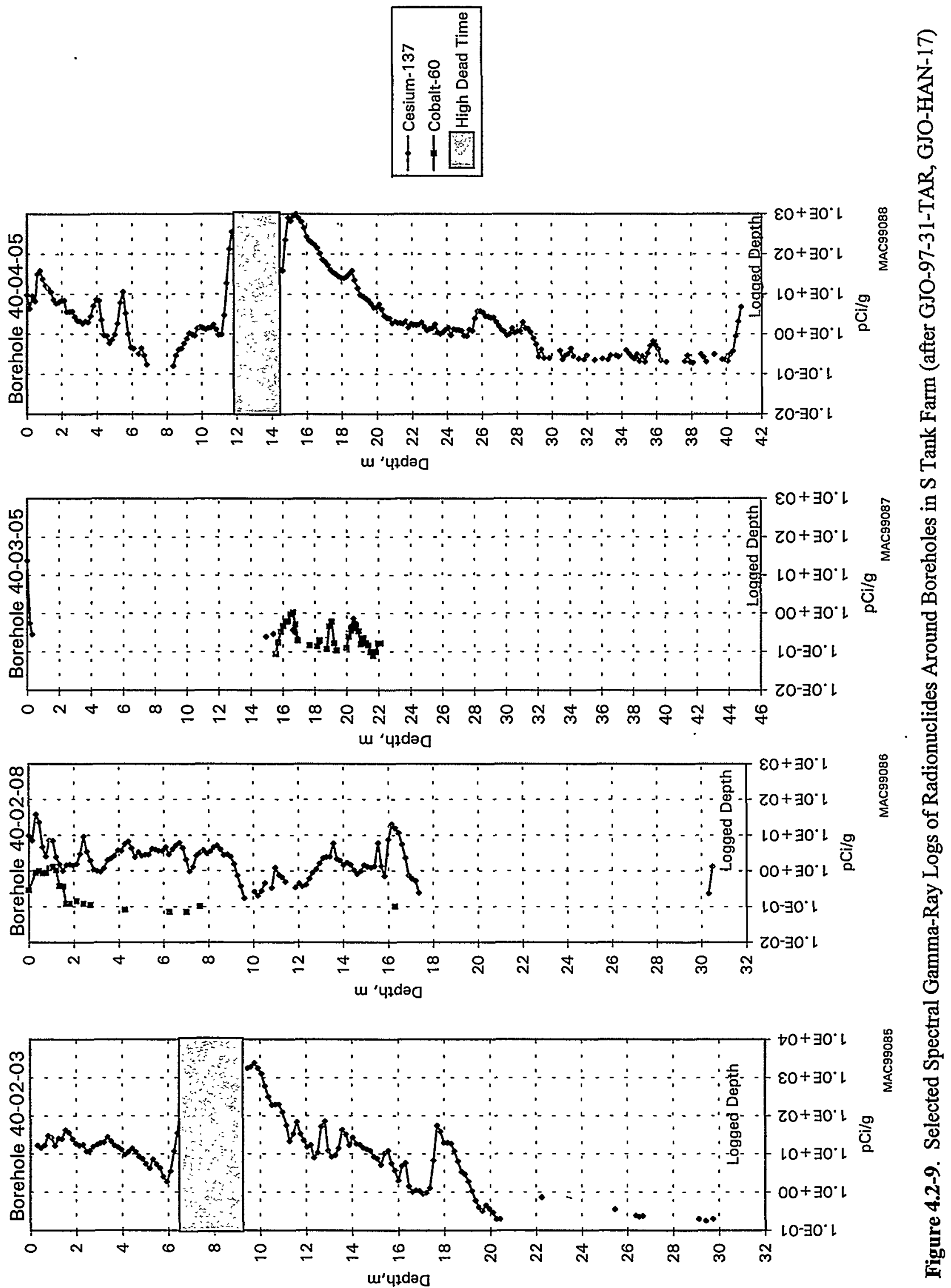




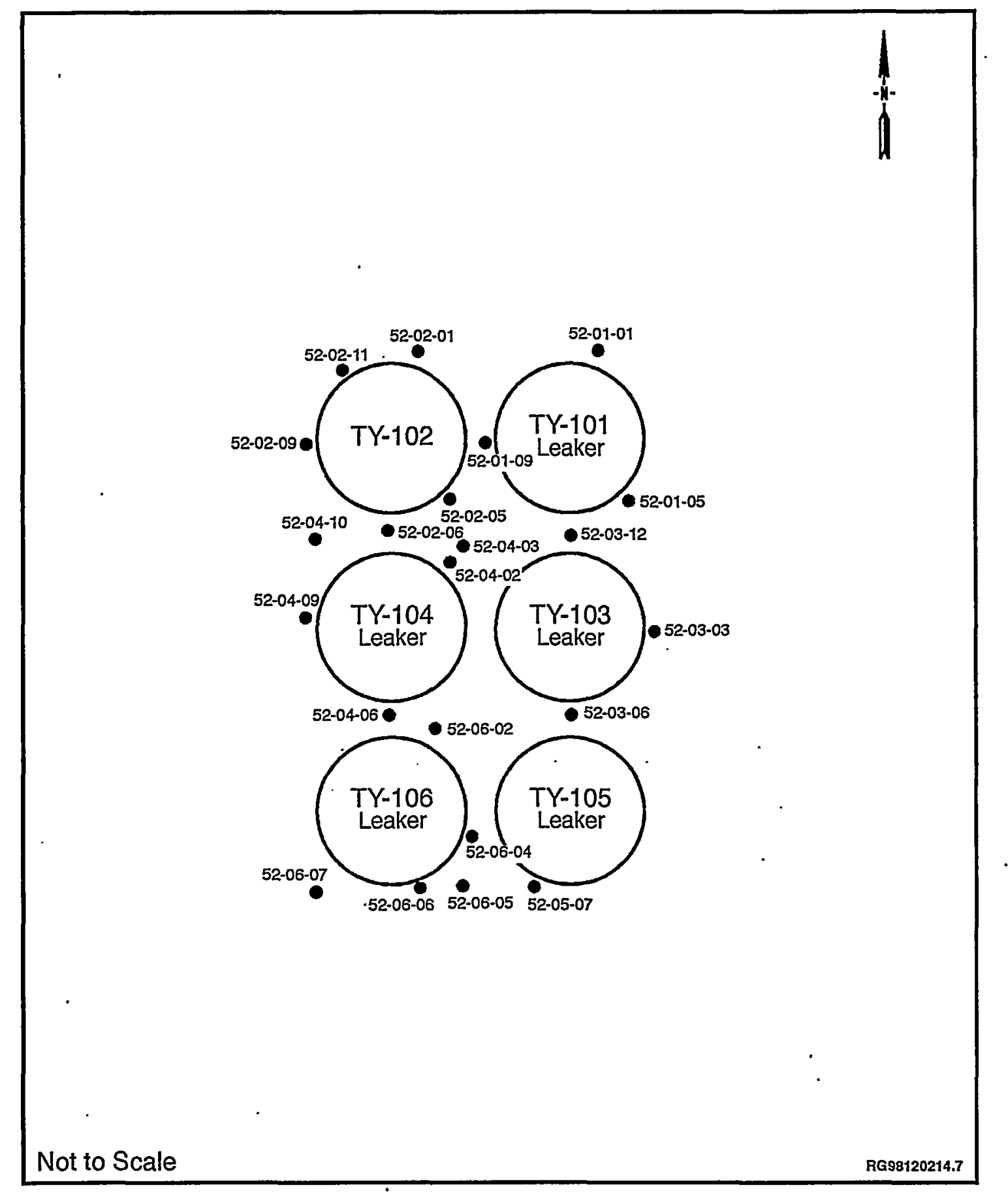

Figure 4.2-10. Plan View of TY Tank Farm, Showing Borehole Locations (after GJO-97-30-TAR, GJO-HAN-16) 


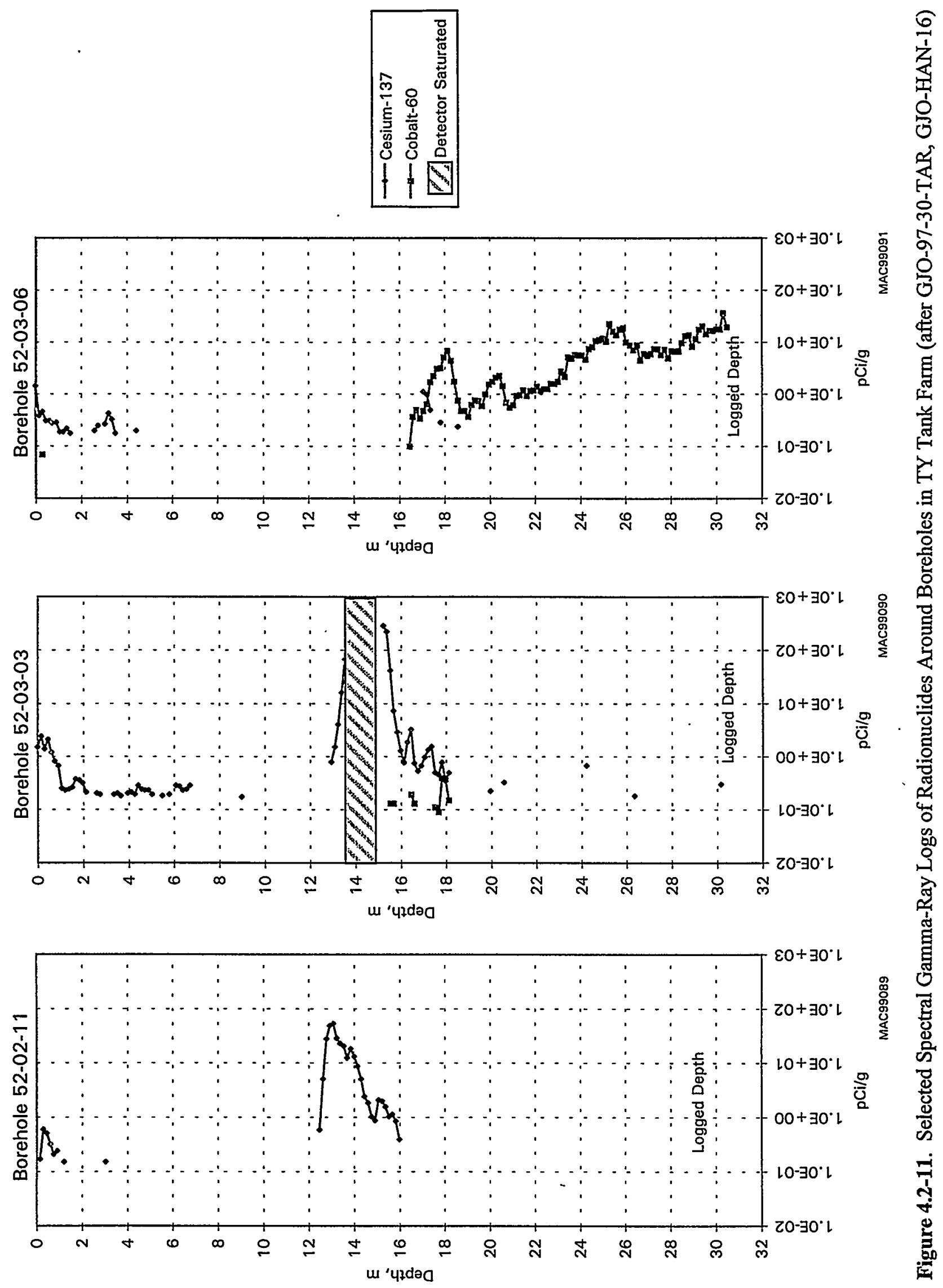



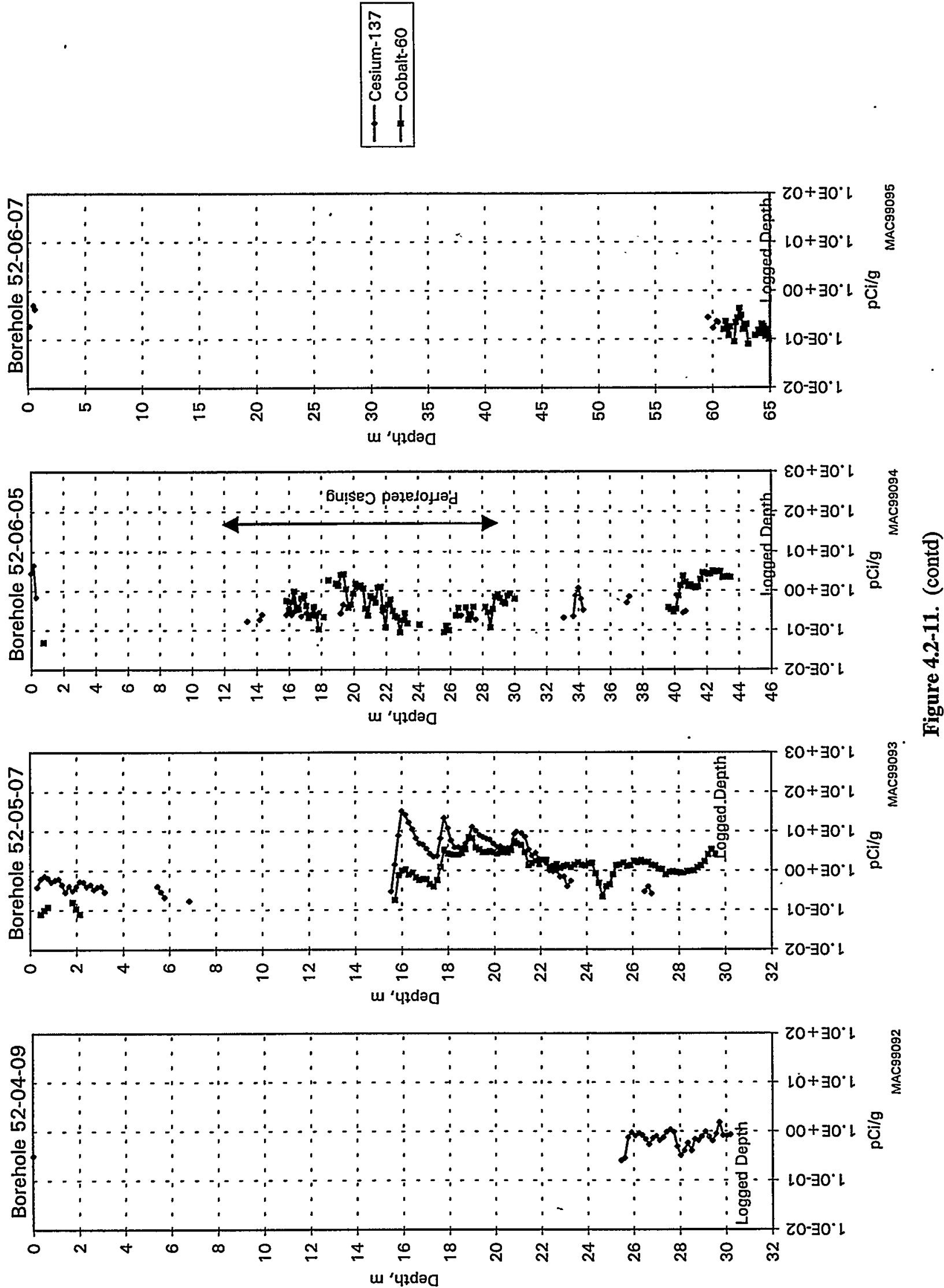


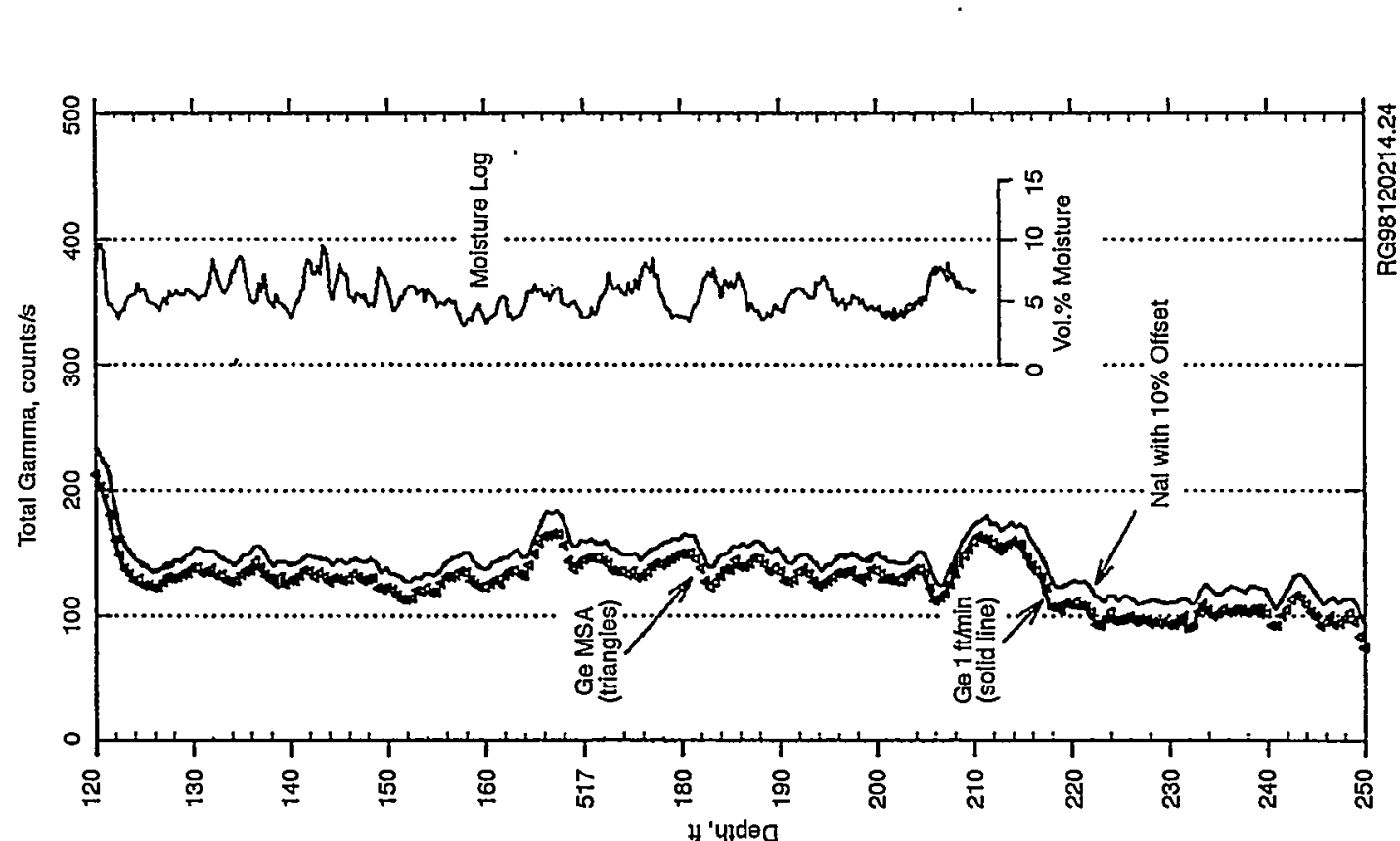

氖导

灵

再 8

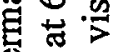

品

窝槵

它

\&

㝵

造空

$\theta$

鸟焉

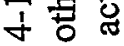

害

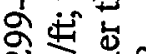

फे क्ष

응유웜유.

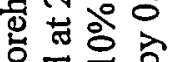

肂合

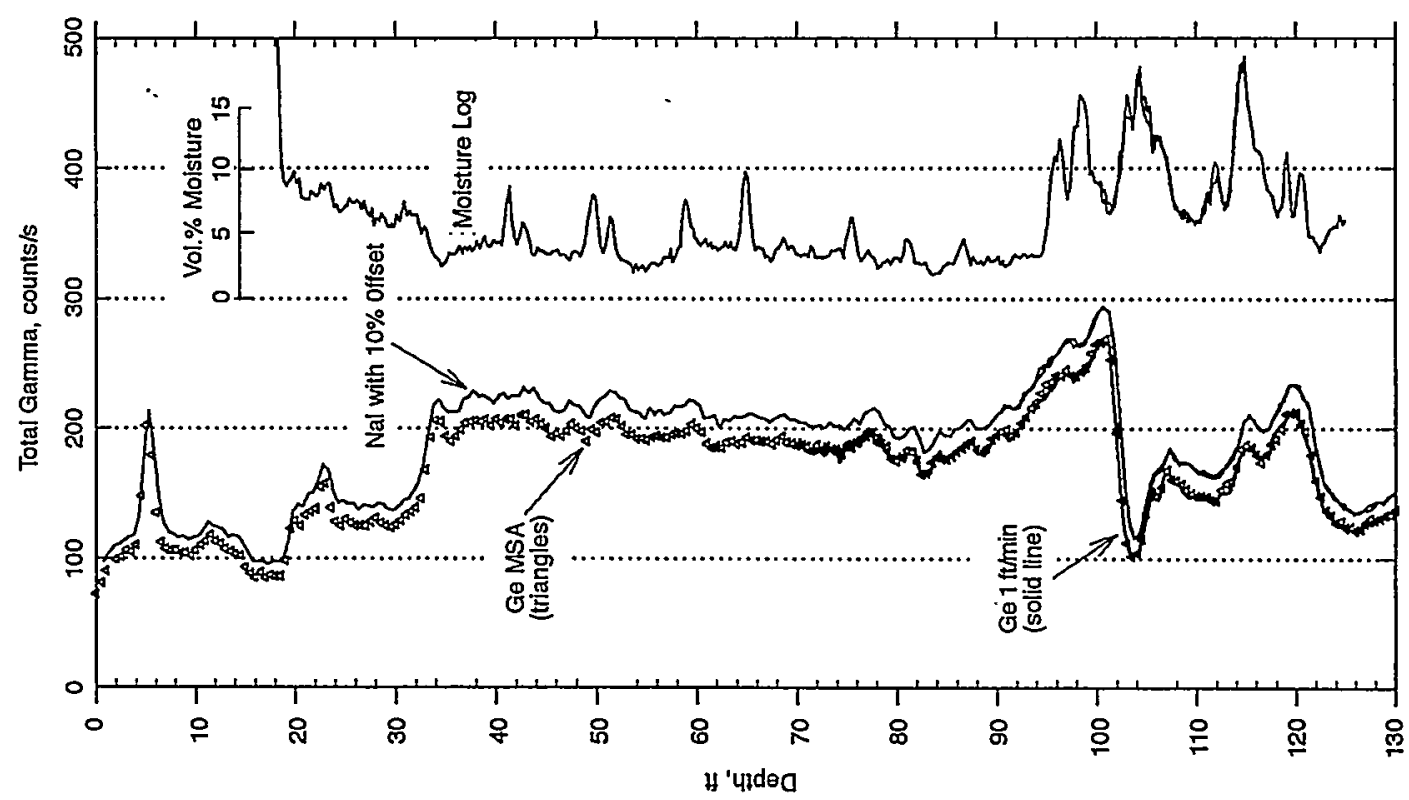

늘 울

路递

on

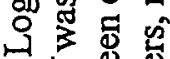

的要

它要

동영

远西

0.

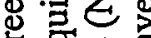

녕용

岁 定.웅

고불

题总署

ปั่ 


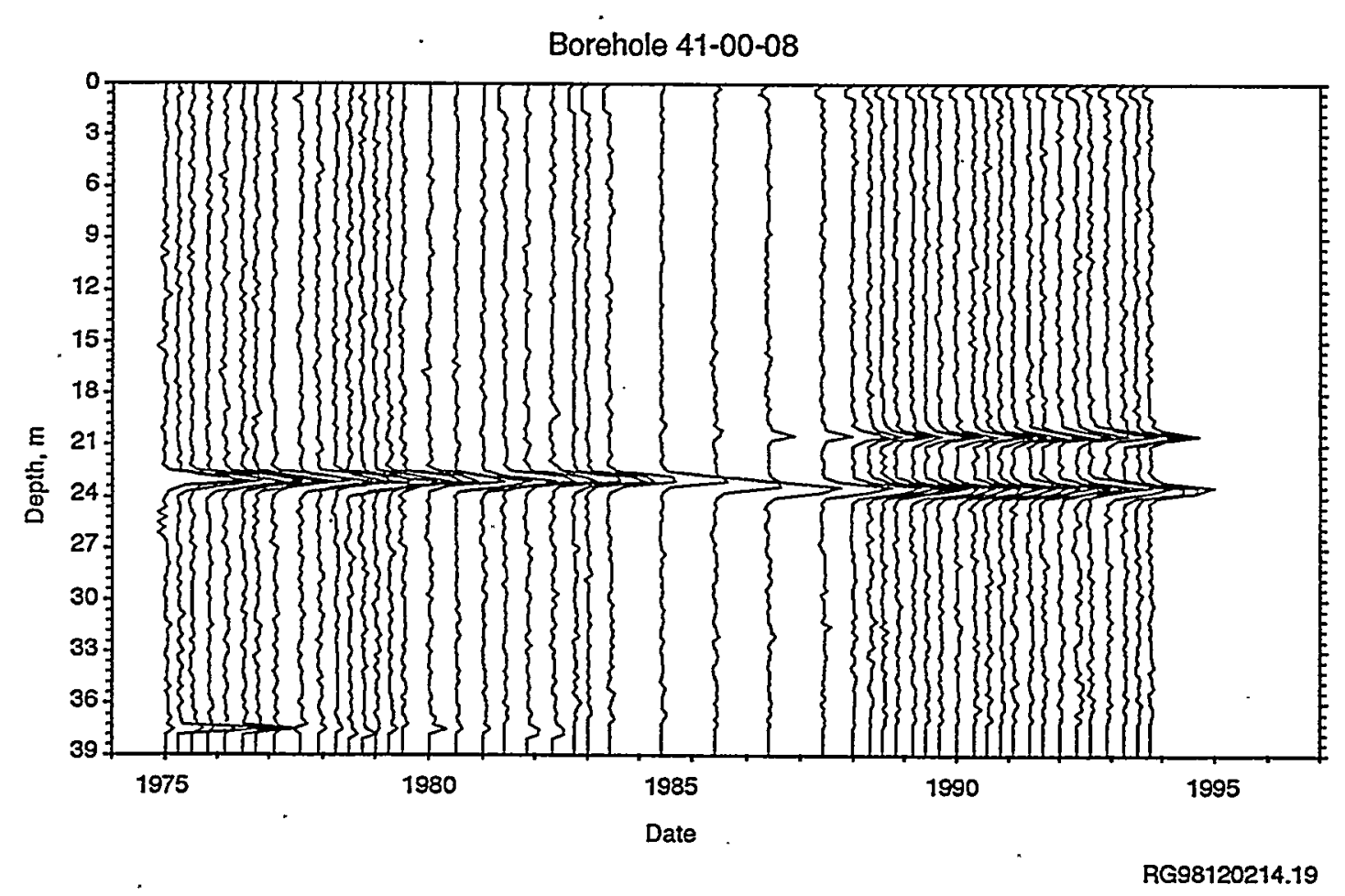

Figure 4.3-1. Example Stack Plot Used to View Overall Trends in Gross Gamma-Ray Data Through Time 


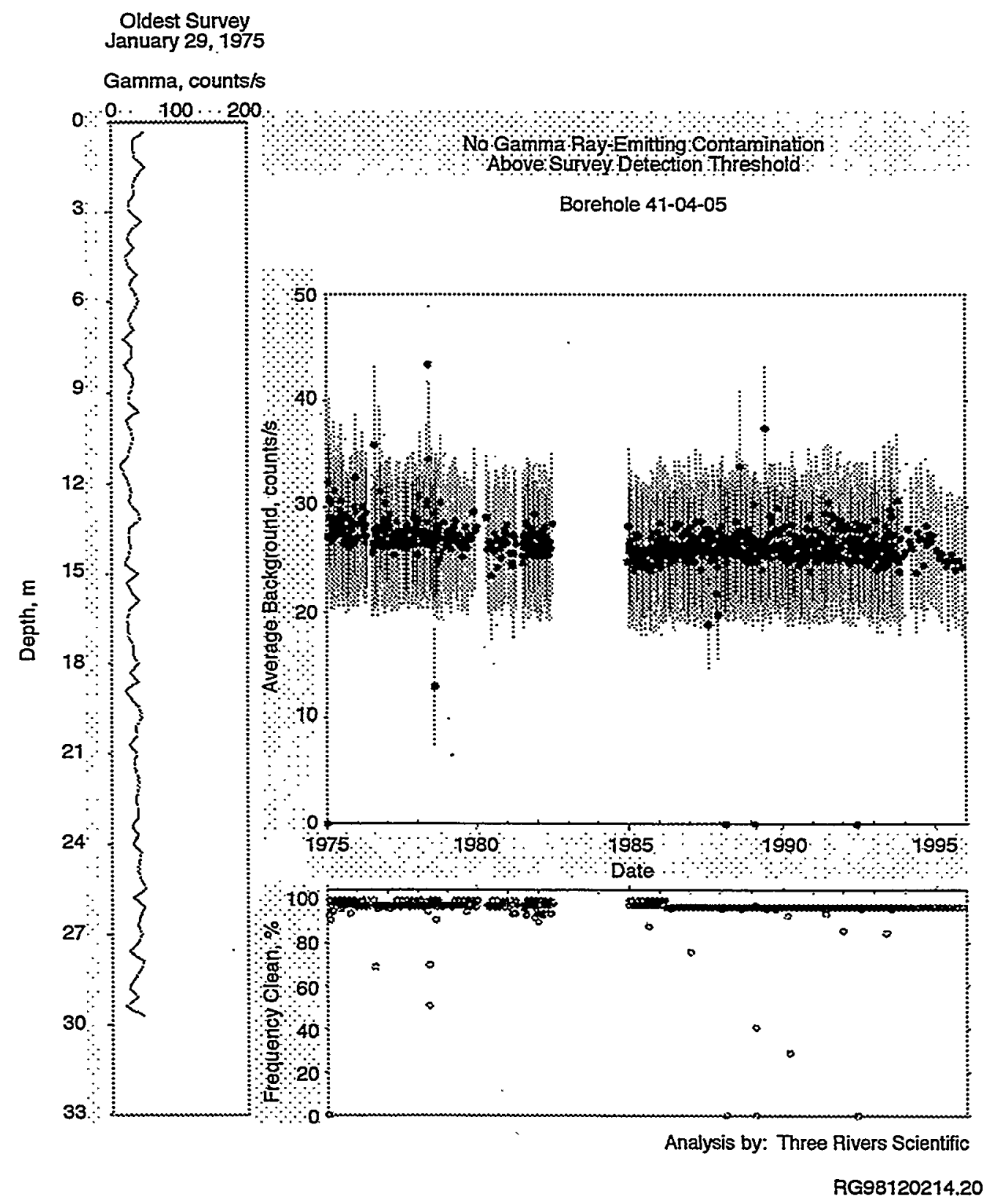

Figure 4.3-2. Example of Clean Plot Borehole (natural background) for Entire History of Electronic Data 

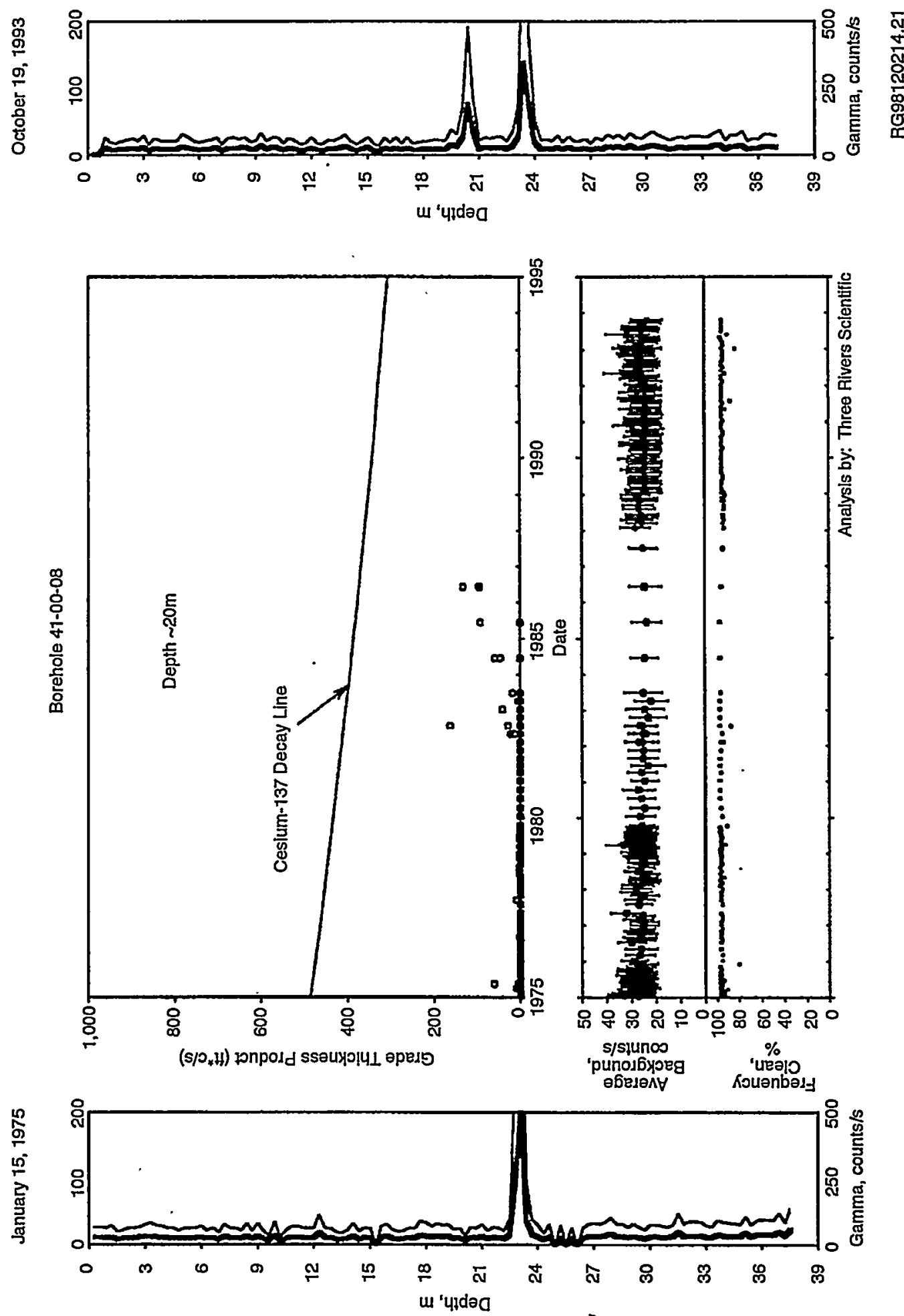

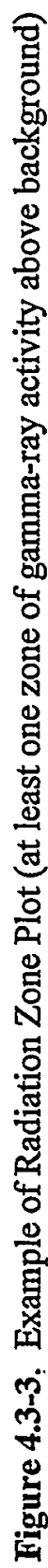




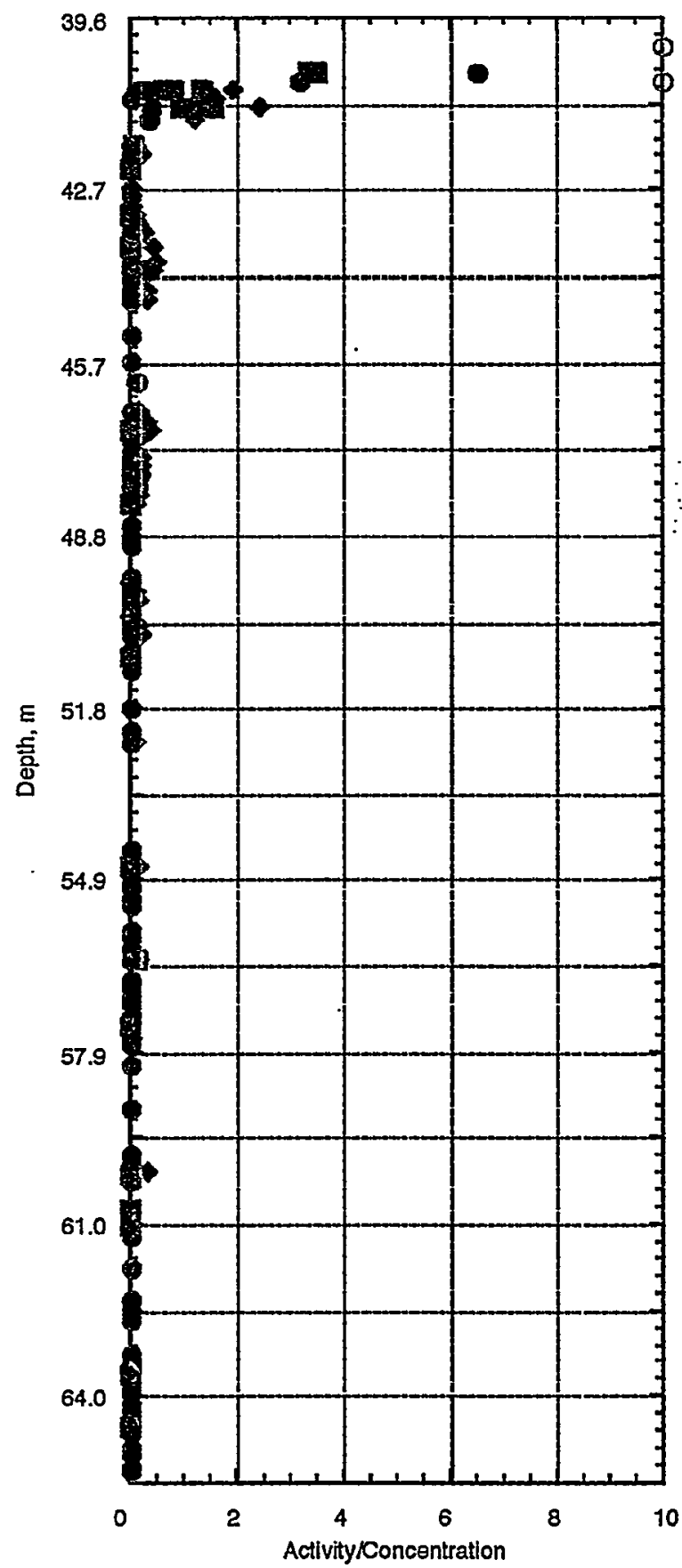

Cesium-137 x 10,000, pci/g $O$ Cesium-137 Off Scale, pCilg Technetlum-99 $\times 100, \mathrm{pCl} / \mathrm{g}$

Nitrate $\times 1,000, \mathrm{ppm}$

RG98120214.18

Figure 4.4-1. Distribution of Cesium-137 and Technetium-99 in the Vadose-Zone Sediments from Depth and the Water-Extractable Nitrate Concentrations from Borehole 41-09-39 


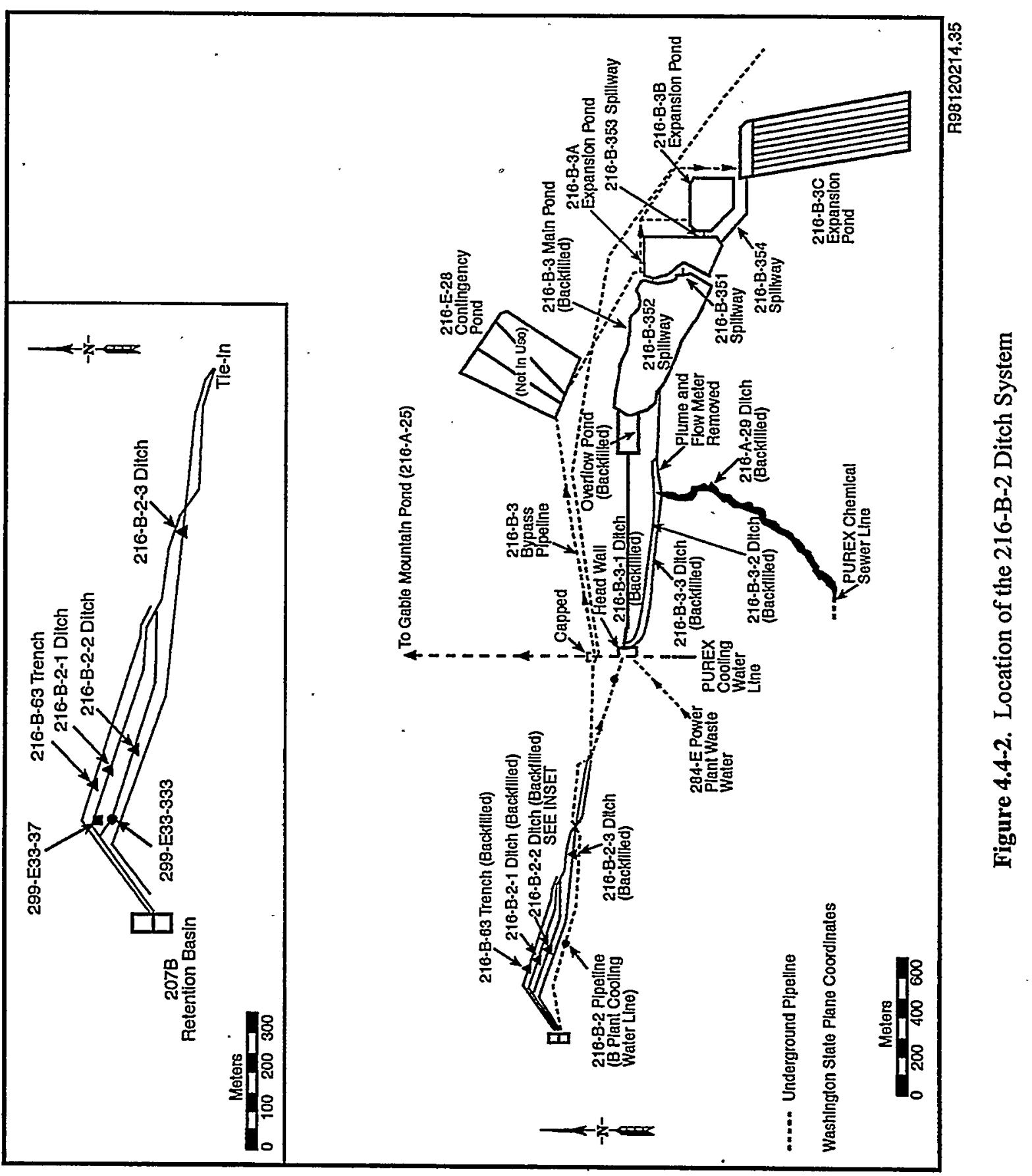




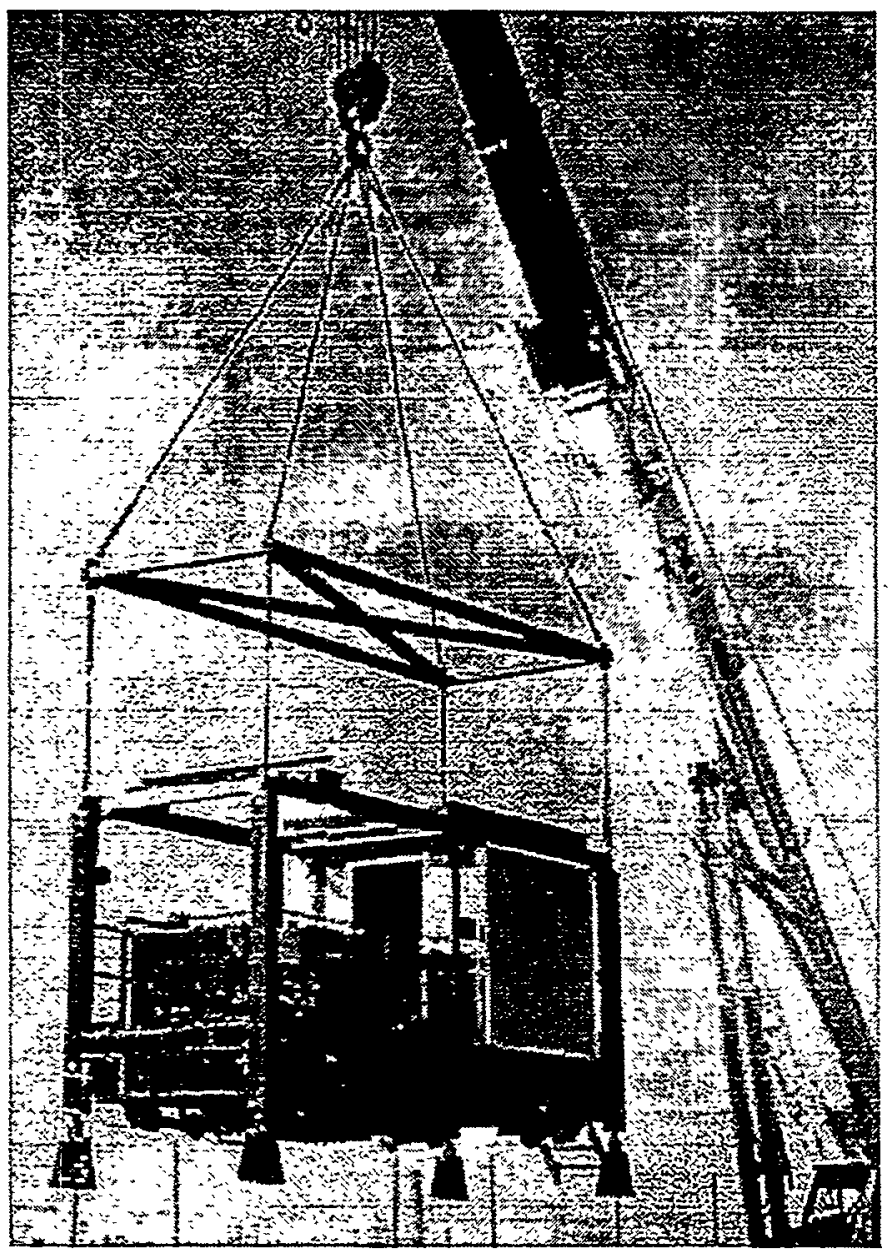

(a)

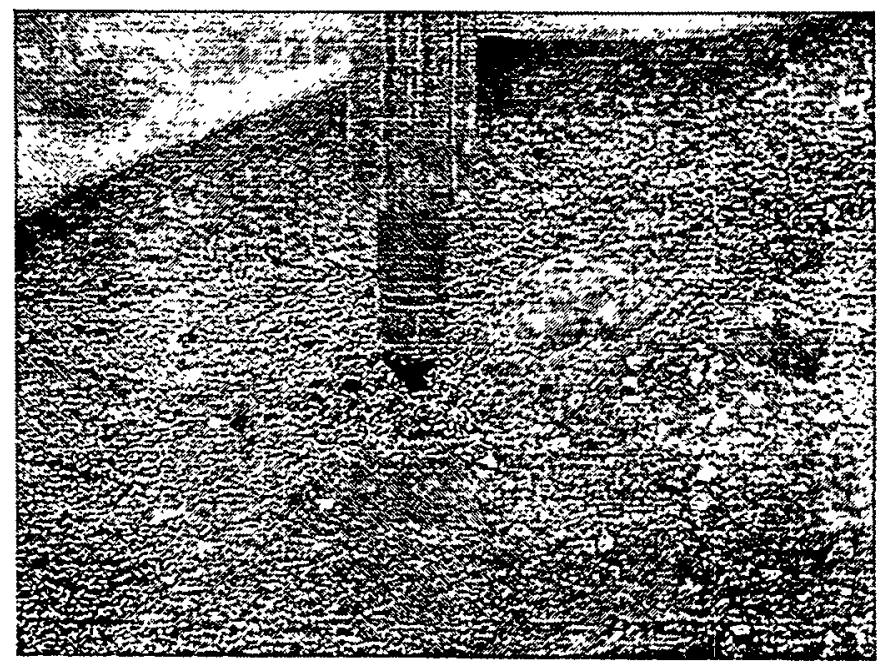

(b)

Figure 4.4-3. (a) Cone Penetrometer (b) Cone Penetrometer Tip 


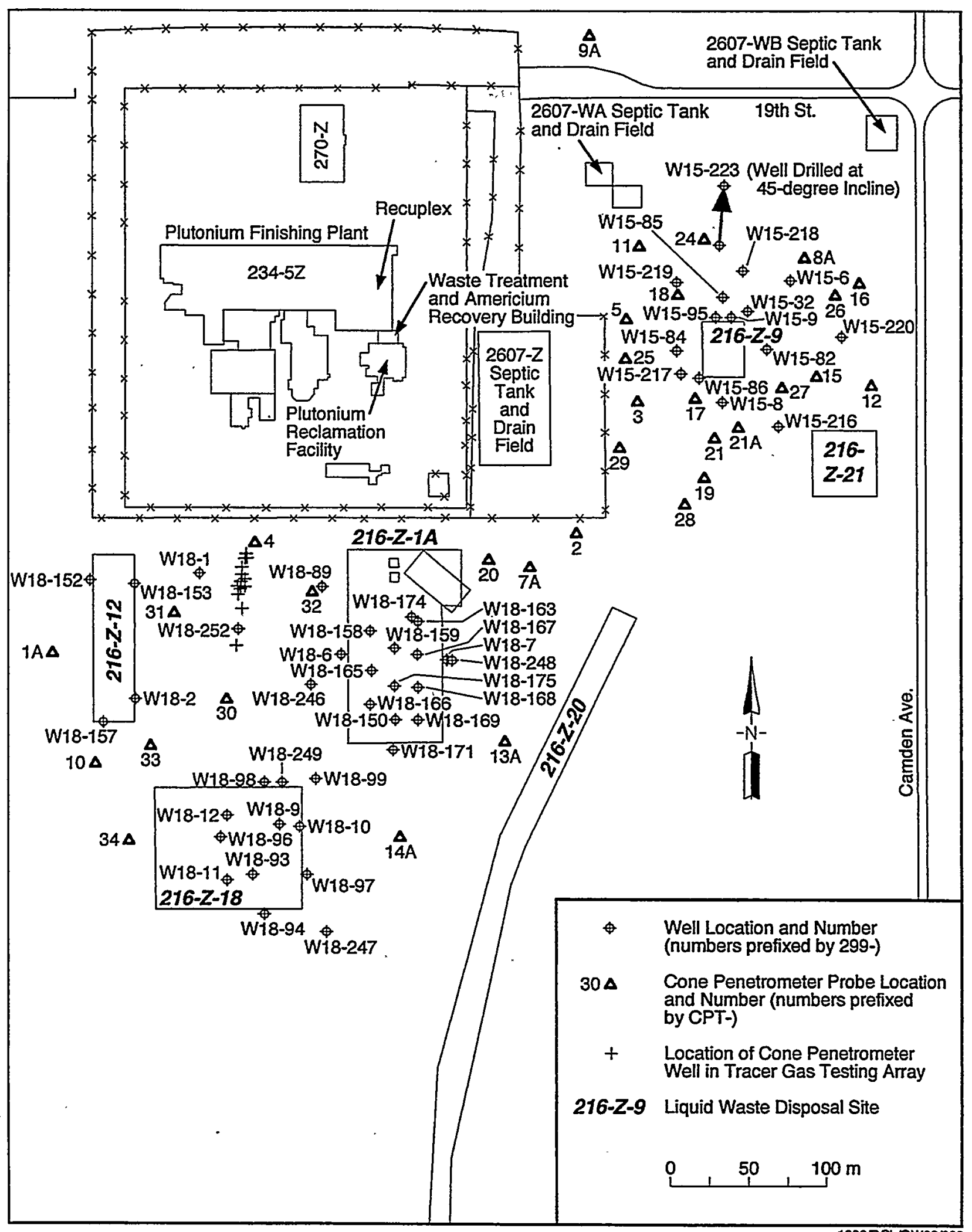

1998DCLGW981002

Figure 4.5-1. Location of Wells and Deep Soil-Vapor-Monitoring Probes at the Carbon Tetrachloride Vapor-Extraction Site 


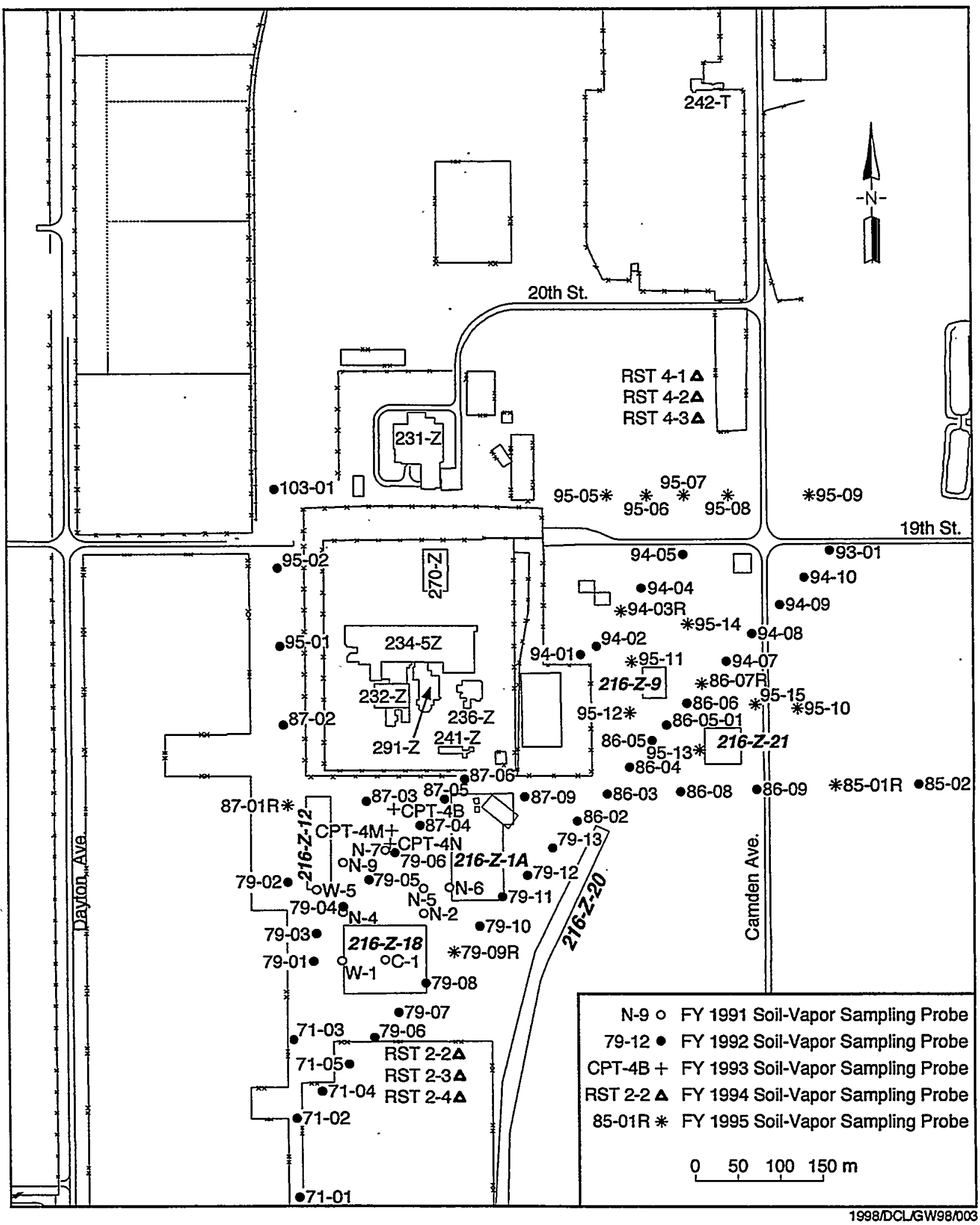

Figure 4.5-2. Location Map of Shallow Soil-Vapor-Monitoring Probes at the Carbon Tetrachloride Vapor-Extraction Site 


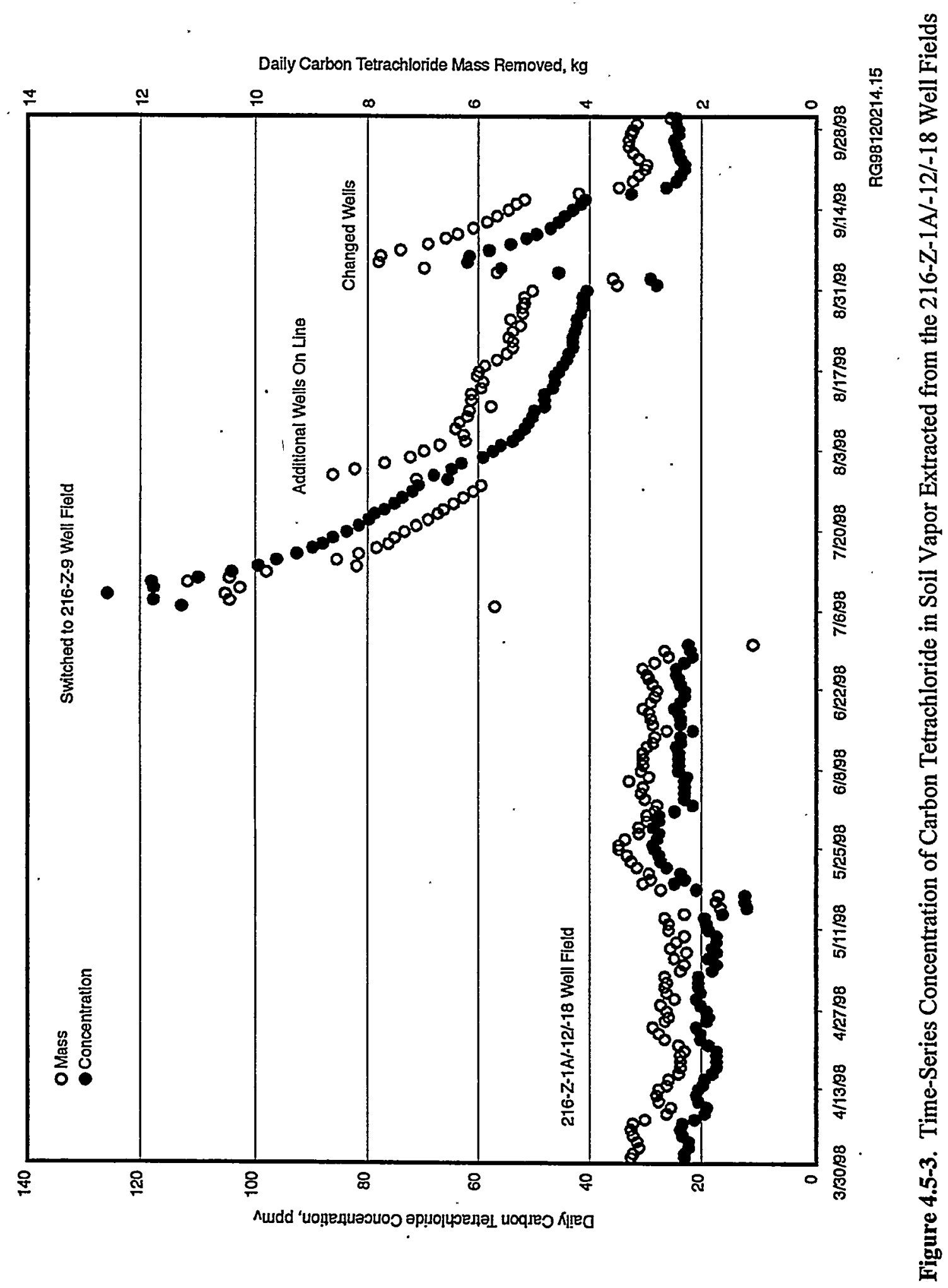




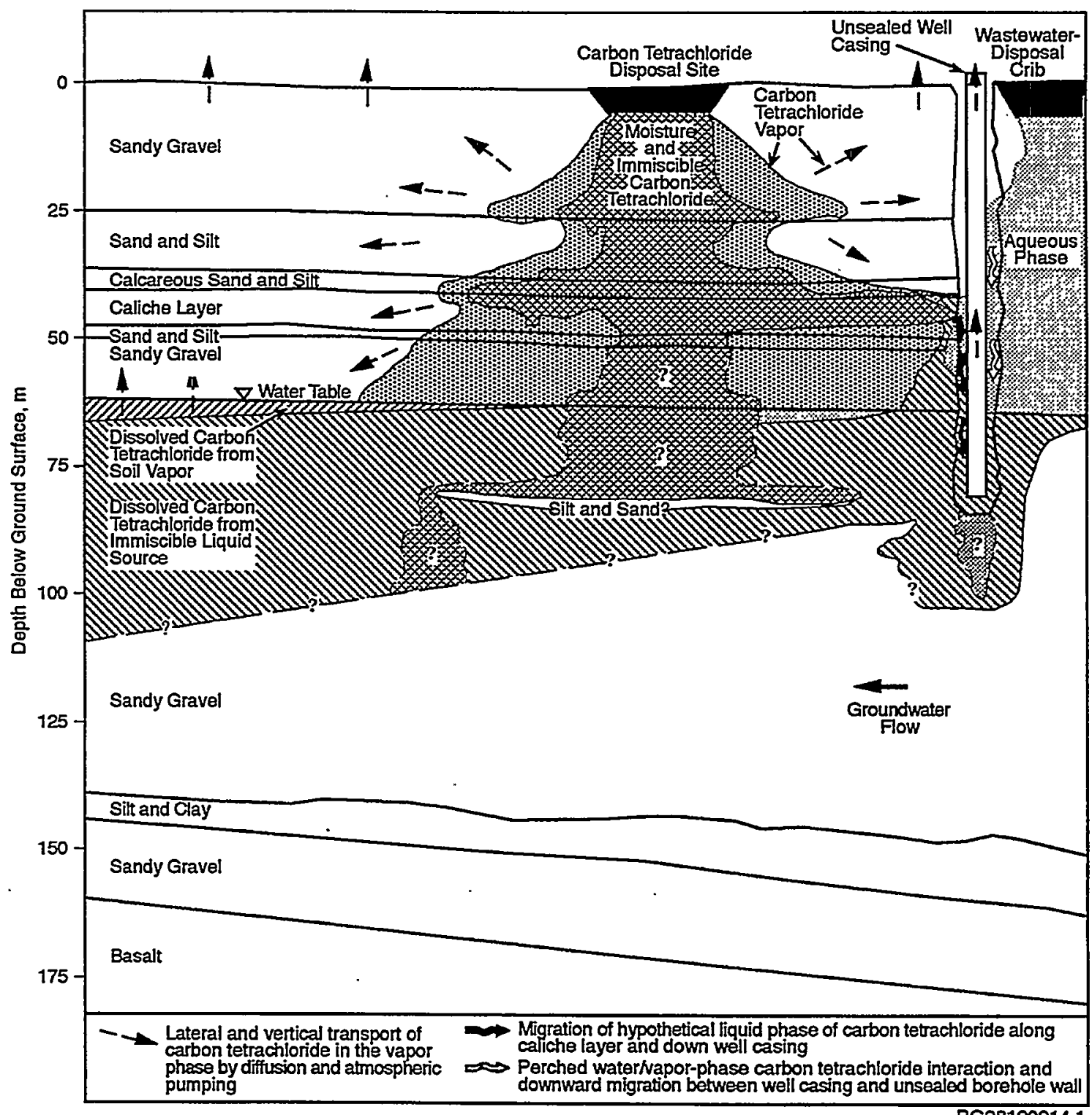

Figure 4.5-4. Conceptual Model of Carbon Tetrachloride and Wastewater Migration Beneath 216-Z-9 Trench 


\subsection{Contaminant Evaluation and Compliance}

Groundwater contamination at the Hanford Site is associated with a number of sources within its active and inactive operational areas. This chapter groups sources and potential sources of groundwater contamination by operational area in geographic (north to south, west to east) order. The results of the monitoring program and the evaluation of current contamination are discussed, as much as possible, in relation to source areas. In some cases, several potential sources such as cribs, trenches, or other disposal facilities may contribute to a particular groundwater plume, and their contributions cannot be readily distinguished. Therefore, they are discussed together. Monitoring of specific storage and disposal facilities, such as Resource Conservation and Recovery Act of 1976 (RCRA) treatment, storage, and disposal units, is reported within the sections on the operational areas. The status of groundwater remediation under RCRA or the Comprehensive Environmental Response, Compensation, and Liability Act of 1980 (CERCLA) is discussed in the relevant sections. Additional discussions are included for the potential receptors in the Richland North and 400 Areas and for the uppermost basalt-confined aquifer system.

\subsection{Monitoring Program Description P. E. Dresel, M. J. Hartman, B. M. Gillespie}

Groundwater monitoring at the Hanford Site during fiscal year (FY) 1998 was performed to track changes in the extent of existing contamination, to identify any new impacts of contamination on groundwater, to provide data needed to support groundwater remediation, and to evaluate the effectiveness of remedial activities. The selections of wells, constituents, and sampling frequencies are based on knowledge of waste-disposal practices and inventories (PNL-6456), regulatory requirements (e.g., RCRA, CERCLA), proximity to disposal areas, contaminant mobility, and site hydrogeology.

\subsubsection{Monitoring Network}

During FY 1998, 747 wells were sampled for radiological and chemical constituents as part of the various Hanford Site groundwater investigations (Figure 5.1-1). Of the wells sampled, 382 were sampled once, 170 were sampled twice, 31 were sampled three times, 97 were sampled four times, and 67 were sampled more frequently. Well locations for the Hanford Site are shown in Plate 1. A number of wells are sampled to meet RCRA- or CERCLA-specific requirements. More detailed maps of well locations are included in this chapter where necessary and in Appendix A for RCRA units and other sites regulated under the Washington Administrative Code (WAC).

A groundwater-monitoring plan for each RCRA unit describes the site hydrogeology, well networks, constituents, sampling and analytical methods, and sampling frequency. Well networks and constituents analyzed for each RCRA unit and for facilities regulated under WAC 173-216 and 173-304 are listed in Appendix A. References to groundwater-monitoring plans or assessment plans are also included in Appendix A. Monitoring networks for CERCLA are defined in records of decision or federal facility agreement and consent order change control forms. 
Most of the monitoring wells on the Hanford Site are completed near the top of the unconfined aquifer system. Most of the wells monitored to meet RCRA and CERCLA requirements are constructed to meet WAC 173-160 (e.g., stainless steel casing and screen, sand pack, full annular seal). Other wells, instailed before the adoption of WAC requirements, were usually constructed of carbon steel casing, often with perforated casing rather than well screens, and may have no annular seal.

An integrated groundwater-monitoring plan for the Hanford Groundwater Monitoring Project was released in FY 1998 (PNNL-11989). The plan documents well and constituent lists for monitoring required by the Atomic Energy Act of 1954 and its implementing orders; includes other, established monitoring plans by reference; and appends a master well/constituent/frequency matrix for the entire project. Sampling frequencies for monitoring major plumes were decreased in many wells from annual to every 3 years, beginning in FY 1999. The location and shapes of the plumes do not change much from year to year, and the reduction allows resources to be allocated to other objectives. Wells in key areas of interest (e.g., near the Columbia River or the City of Richland, adjacent to waste sites) will continue to be monitored annually or more frequently.

\subsubsection{Methods}

Methods for chemical analysis of groundwater samples conform to the U.S. Environmental Protection Agency's (EPA's) Test Methods for Evaluating Solid Wastes: Physical/Chemical Methods, 3rd ed. (SW-846); Methods for Chemical Analysis of Water and Wastes (EPA-600/4-79-020), or other EPA methods, and the Annual Book of ASTM Standards (American Society for Testing and Materials 1986). The methods used for analysis of radiochemical constituents were developed by the analyzing laboratory and are recognized as acceptable within the technical radiochemical industry. Analytical methods used by the laboratories are described in Appendix C.

Groundwater was sampled by employees and subcontractors of Pacific Northwest National Laboratory (PNNL) and Bechtel Hanford, Inc. (BHI) during FY 1998. Samplers followed their company's documented procedures for sampling, recordkeeping, field measurements, and sample shipment. The procedures were equivalent in most aspects. Most samples for metals were filtered in the field to remove particulate matter not representative of dissolved metals, and most other samples were unfiltered.

\subsubsection{Data Quality}

The chemical composition of groundwater at any location fluctuates with time because of differences in the contaminant source, recharge, and/or flow field. The range of this fluctuation can be estimated by taking many samples, but there is a practical limit to the number that can be taken. Comparison of results through time and location helps in interpreting the natural variability.

Sampling techniques are designed to provide a sample that is reasonably representative of the aquifer concentration when the sample is taken. However, there are limitations to the ability to collect representative samples or even to define precisely the volume of aquifer that is represented in the sample. Proper well construction, well purging, sample preservation, and, in some instances, filtering are used to help ensure that samples are consistent and representative. Careful sample-labeling protocols, chain-ofcustody control and documentation, and bottle preparation prevent many gross errors in sample results. 
Duplicate samples and field blanks help in assessing the sampling procedure. The majority of the analytical results have been found to be suitable for the intended purposes. Appendix D gives more specific discussions on quality assurance/quality control.

Uncertainties are also inherent in laboratory analysis of samples. Gross errors can be introduced in the laboratory as well as during sampling, including transcription errors, calculation errors, mislabeling of results, instrument malfunction, and other errors that result from failing to follow established procedures. Often, these gross errors can be recognized because unreasonably high or unreasonably low values result. Data-review procedures are used to identify and correct gross errors.

Random errors are unavoidably introduced in the analytical procedures. Usually, there are too few replicate analyses to assess the overall random error. Instruments for analyzing radioactive constituents count the amount of ionizing radiation at a detector, and background counts are subtracted. The nature of radioactive decay and the instrument design result in a random counting error, which is reported with the analytical result. Generally, sample results that are less than the counting error are an indication that the constituent was not detected. The counting methods may also result in the reporting of results that are less than zero. Although they are physically impossible, the negative values are useful for some statistical analyses.

Systematic errors may result from inaccurate instrument calibration, improper standard or sample preparation, chemical interferences in analytical techniques, or faulty sampling methodology and sample handling. Sample and laboratory protocols, therefore, were designed to minimize systematic errors. The laboratories participate in interlaboratory comparisons, including analysis of blind samples prepared by . the EPA. The contracted laboratories compared favorably with other laboratories, indicating that the level of systematic error from many sources is small enough to be acceptable.

Hanford Groundwater Monitoring Project data undergo a validation/verification process according to a documented procedure. In addition to the quality assurance/quality control checks mentioned above, data are screened by scientists familiar with the hydrogeology of the unit, compared to historical trends or spatial patterns, and flagged if they are not representative.

The following potentially significant data quality issues were identified in FY 1998. Details are provided in Appendix D.

- Some probes used to measure specific conductance in the field were found to be faulty, producing low results. The probes were taken out of use, and the suspect data were flagged. Procedural changes are being made to avoid this type of problem in the future.

- Volatile organic constituents, total dissolved solids, and alkalinity were detected in field blanks at significant levels. It is unclear whether the samples were contaminated in the field or in the laboratory, or whether the problem was in the analysis. Investigation of this problem is continuing.

- Metals (inductively coupled-plasma method) in field blanks was a problem in FY 1997, and mitigating actions were taken. The number of flagged results decreased in FY 1998. 
- Results of double blind standards were beyond acceptable limits for total organic carbon, total organic halides, and gross beta during the second and third quarters of FY 1998. These problems are being investigated and additional blind standards will be analyzed by several laboratories.

\subsubsection{Data Management}

Results of groundwater sampling and analysis are made accessible in the Hanford Environmental Information System (HEIS) database. This database currently resides on a Sun SPARC 20 UNIX-based multiprocessor computer. The database software is ORACLE ${ }^{\circledR}$ (Oracle Corporation, Redwood Shores, California). Analytical results from all groundwater-monitoring programs are stored in this common database, with the exception of some data collected for limited special projects that may not be directly comparable to standard data. The data are made available to federal and state regulators for retrieval.

The HEIS programmers and HEIS data owners, including the groundwater projects, ensure database integrity and data consistency through membership in the onsite HEIS configuration control board and other ad hoc groups. The majority of data are loaded into the database from electronic files provided by the analytical laboratories. This minimizes data-entry errors and reduces the cost of data management.

\subsubsection{Interpretive Techniques}

Overall sample uncertainty may be factored into data evaluation by considering the concentration trend in a given well over time. This often helps identify gross errors, and long-term trends can be distinguished from short-term variability. The interpretation of concentration trends depends on an understanding of chemical properties as well as site hydrogeology. The trend analysis, in turn, aids in refining the conceptual model of the chemical transport.

Trend plots in this report generally include all the available data, including those points flagged as suspect, unless the suspect points are beyond the scale of the plot. For $\mathrm{pH}$ and specific conductance, only field measurements are plotted. Replicate values are averaged by sample date, with outliers removed.

The plume maps presented in this report are diagrams of the interpretation of the groundwater chemistry at the Hanford Site based on data from all sampling programs. Most of the maps represent concentrations of contaminants at or near the water table. Although analytical data are available only for specific points where wells were sampled, contours are drawn to join the approximate locations of equal chemical concentration or radionuclide activity. The contour maps are, necessarily, simplified representations of plume geometry given the map scale, lack of detailed information, variations in well completion, and the fact that plume depth and vertical extent cannot be fully represented in a two-dimensional map. Thus, the contours shown do not honor all data values at individual wells. The contours show the extent of contamination at levels of regulatory concern, such as maximum contaminant levels (MCLs), interim drinking water standards (DWSs), or derived concentration guides (DCGs). Additional contours are shown at levels that illustrate additional features of the contaminant distribution, such as zones of high concentration or areas impacted at levels less than the interim DWSs or MCLs. Figures meeting these requirements are best prepared by using irregular contour intervals. In addition, groundwater contaminants are often found at values ranging over several orders of magnitude - often over short distances. In these cases, logarithmically increasing contour intervals or irregular intervals must be used to preserve the information about the distribution at both low and high concentrations. 
Plume maps in this report were prepared using averages of FY 1998 samples from each well. Average values for radionuclides were calculated using reported values, including the negative values that may be reported when the sample measurement is less than the instrument background correction. Values for chemical constituents below detection limits were considered to be zero in calculating averages. In a few instances, data believed to represent gross errors in sample collection or analysis were removed from the dataset before averaging. In addition, results that were reported as less than detection but at higher than normal detection levels were removed from the dataset. This occurred when samples were diluted to bring another constituent into range and when certain samples were analyzed to meet specific needs of individual projects that did not require the same reporting levels. The average values are posted in the contour plots, allowing comparison of the contour interpretation to the input dataset. As discussed above, not all posted values are in agreement with the contours presented. In some locations, contours are shown around areas having no supporting sample data from FY 1998. These contours are based on data from past monitoring. The wells may have been dropped from sampling as a result of changing sampling programs and budgets or other sampling problems.

Particular onsite situations lead to difficulties in using plume contour maps to display the extent of contamination. Rapid increases or highly variable activities of technetium- 99 and other constituents have been observed near several of the RCRA single-shell tank waste management areas. The average values do not reflect the trends in these wells. In areas of pump-and-treat remediation, particularly where injection wells are used, the contour maps do not completely reflect the dynamics of the flow field. Average values tend to smooth out the trends induced by remediation activities.

Nitrate data are reported most commonly as nitrate or as nitrogen. The latter have been converted to nitrate for trend plots, maps, and text discussion, but are reported in their original units on the data diskette included with this report.

Total chromium in filtered samples is assumed to be hexavalent, the most soluble state. In some cases, analyses were performed specifically for hexavalent chromium; both types of data are included in plots and maps in this report.

Some of the strontium- 90 data discussed in the text and plotted in the figures are actually combined strontium-89 and strontium-90. All of the strontium detected is assumed to be strontium-90 because strontium-89 has a much shorter half-life ( 50.5 days, compared to 29 years for strontium-90) and has decayed to undetectable levels since reactor operations ceased.

Monitoring at sites governed by RCRA interim-status regulations requires a comparison between upgradient and downgradient levels of selected indicator parameters to determine if the facility has potentially impacted groundwater quality. Initial background monitoring was completed at all RCRA facilities having groundwater-monitoring requirements. The statistical methods applied in RCRA interim-status monitoring are discussed in Appendix B. The results of the statistical analyses are presented in Appendix B but conclusions with regard to specific facilities are summarized in this chapter.

Two facilities on the Hanford Site were monitored under RCRA final-status regulations in FY 1998 (the 183-H solar evaporation basins and the 316-5 process trenches). The statistical methods used for the final-status monitoring are also discussed in Appendix B, and the conclusions from the statistical interpretations are included in this chapter. 
One CERCLA operable unit (1100-EM-1) was subject to groundwater monitoring under a final record of decision (ROD 1993) during FY 1998. This record of decision requires monitoring of trichloroethylene at point-of-compliance wells. The comparison to standards at the point of compliance is discussed in Section 5.14.2.

\subsubsection{Regulatory Standards}

Contaminant concentrations in this report are compared to various regulatory standards that may apply under different programs. These standards include the following:

- MCLs are federally or state-enforceable standards for drinking water supplies. Although MCLs only apply at the point of consumption of the water, they provide a useful indicator of the potential impact of groundwater contamination if water usage were to change. In addition to primary MCLs, secondary MCLs are set on aesthetic criteria, such as taste, rather than on health criteria. Under the Model Toxics Control Act - Cleanup regulations (WAC 173-340), the State of Washington claims the right to require corrective actions in some instances where water supplies exceed secondary standards. Selected MCLs are shown in Table 5.1-1.

- interim DWSs - Specific MCLs have not been set for most radionuclides; however, the MCL for gross alpha measurements, excluding uranium and radium, is $15 \mathrm{pCi} / \mathrm{L}$. For beta particles and photon activity, the MCL is set at a 4-mrem/yr effective dose. The method of calculating the 4-mrem/yr effective dose equivalent for individual radionuclides used in the interim DWSs generally results in lower activities that produce higher doses than result from calculations using more current information. The interim DWSs will serve the purpose of providing a measure of potential impacts from groundwater contamination. Interim DWSs for selected radionuclides are shown in Table 5.1-1.

- DCGs are standards set for protection of the public from radionuclides resulting from U.S. Department of Energy (DOE) activities. The DCG is based on a $100-\mathrm{mrem} / \mathrm{yr}$ exposure standard and is the amount of an individual radionuclide that would lead to that dose through ingestion under specified intake scenarios. Because the effective dose equivalent calculations for the DCG use more current methodology, the results are not completely consistent with the interim DWSs. Selected DCGs and the 4-mrem/yr effective dose equivalent are shown in Table 5.1-2.

- Standards for groundwater quality (WAC 173-200) were established to provide for the protection of the environment, human health, and existing and future beneficial uses of groundwater. These standards apply to the Solid Waste Landfill, which is regulated under WAC 173-304.

- Regulations in the Model Toxics Control Act - Cleanup (WAC 173-340) may be applicable for sites undergoing remediation. In many cases, these levels are more stringent than MCLs or DWSs.

- Concentration limits may be set in a facility's operating permit or record of decision. These limits are listed in the remainder of this chapter where they are applicable.

Wells monitored for RCRA that exceeded MCLs or DWSs are listed in Appendix A. 


\subsection{Hanford Site Groundwater Contamination Overview}

\section{P. E. Dresel}

Tritium, nitrate, and iodine-129 are the most widespread contaminants associated with past Hanford Site operations. Their distribution in the upper part of the unconfined aquifer system is shown in Plates 3 , 4 , and 5, respectively and Figures 5.2-1, 5.2-2, and 5.2-3. Available data indicate that the vast majority of the onsite contamination remains near the water table, but information on the depth of the contaminant plumes is lacking for much of the site. Figures for other constituent distributions are presented for specific areas as needed. Chromium contamination is widespread in several of the 100 Areas and extends into the surrounding 600 Area, as discussed below. Strontium-90 plumes in the 100 Areas exhibit very high activities in some cases but are of relatively smaller extent. Other extensive contaminant plumes include carbon tetrachloride and associated chloroform and trichloroethylene in the 200-West Area, chromium in the 600 Area south of the 200 Areas, technetium-99 and uranium that extend eastward from the 200-West Area, and technetium-99 with minor amounts of cyanide and cobalt-60 northeast of the 200-East Area. Several other constituents are detected outside the boundaries of the operational areas but the contamination is clearly linked to operations in the specific areas and is discussed with the source areas. A few smaller sources within the 600 Area are discussed in Section 5.12. Contamination in the upper basalt-confined aquifer is discussed in Section 5.15. All analytical results for FY 1998 are included on the data diskette included with this report.

Waste sites are grouped into source operable units, and the groundwater beneath the sites is divided into groundwater operable units. Groundwater operable unit boundaries are illustrated in Figure 5.2-4.

A number of onsite facilities have specific RCRA-monitoring requirements. The results of monitoring at these facilities are integrated into the following discussions, and specific RCRA-reporting requirements, such as indicator parameter evaluations, are included as needed. Appendix A summarizes analytical results for wells monitoring RCRA- and state-permitted facilities that exceeded MCLs or interim DWSs. Statistical evaluations for RCRA-monitoring requirements are discussed in Appendix B.

\subsection{0-B,C Area}

\section{D. Sweeney, M. J. Hartman, R. E. Peterson}

The 100-B,C Area is the farthest upstream reactor area along the Columbia River. B Reactor was placed into service in 1944 and operated until 1968. C Reactor operated from 1952 to 1969. The B and $\mathrm{C}$ Reactors used a single-pass system for cooling water (i.e., cooling water passed through the reactor and was discharged to the Columbia River).

\subsubsection{Facilities and Operable Units}

No facilities or waste-disposal sites are currently operating in the 100-B,C Area. The facilities noted below, which are associated with former reactor operations, are being decommissioned and remediated in accordance with CERCLA. A description of reactor operations and associated hazardous waste sites is presented in WHC-SD-EN-TI-220, prepared to support environmental restoration. 
For CERCLA environmental restoration activities, the 100-B,C Area is divided into two source operable units that contain hazardous waste sites at or near the surface (100-BC-1 and 100-BC-2). A single groundwater operable unit (100-BC-5) addresses contamination at and below the water table and extends from beneath the source operable units laterally to adjacent areas where contamination may pose a risk to human and ecological receptors. For the 100 Areas, the lateral boundary is generally considered to be where Hanford Site groundwater meets Columbia River water. This interface occurs along the riverbanks and within the riverbed substrate.

High-priority waste sites in the 100-BC-1 Operable Unit include retention basins used for reactorcoolant water, liquid waste-disposal trenches, and associated effluent pipelines. High-priority sites in the 100-BC-2 Operable Unit include liquid waste-disposal sites near the reactor buildings and solid wasteburial grounds. Descriptions of high-priority waste sites are presented in the proposed plans for remediation activities in each of these source operable units (DOE/RL-94-99; DOE/RL-95-66, Draft A).

The 100-BC-5 Operable Unit encompasses the groundwater underlying the 100-B,C Area (see Figure 5.2-4). The groundwater was contaminated by liquid effluent disposal associated with past reactor operations. Most of the waste site sources for this contamination ceased operating by the late 1960s. A significant amount of contamination carried by the groundwater discharged into the Columbia River. A conceptual site model for groundwater contamination at this operable unit is included in BHI-00917.

The 116-B-11 and 116-C-5 retention basins are located in the northern part of the 100-B,C Area. They received enormous volumes of reactor-coolant effluent that contained radionuclides and metals. They held the effluent for a short time to allow thermal cooling and radionuclide decay before the effluent was discharged to the Columbia River. The basins developed significant leaks, creating a mound on the underlying water table that enhanced the spread of contamination.

The 116-B-1 and 116-C-1 liquid waste-disposal trenches received highly radioactive coolant effluent that resulted when a reactor fuel element failed. The effluent was held briefly in the retention basins and was then diverted to the nearby liquid waste-disposal trenches instead of to the river. The trenches were unlined and intended as soil-column-disposal sites because the natural soils were known to retain several radionuclides of concern.

Relatively small soil-column-disposal facilities such as cribs, trenches, and French drains were located near the reactor buildings. Contaminated water and sludges from fuel-storage basins at each reactor were disposed to trenches.

Solid wastes from reactors, including piping and equipment, were disposed in unlined trenches, buried metal culverts, or buried concrete pipes.

Remedial action excavation of waste sites in the 100-B,C Area continued in FY 1998. Remedial actions consisted of removing and stockpiling clean overburden soil and removing contaminated soils for disposal at the Environmental Restoration Disposal Facility. Dust-control water was applied when necessary while the excavations were open. There may have been a potential for this water to mobilize 
vadose-zone contamination and carry it into the underlying groundwater, which is $\sim 11$ to $14 \mathrm{~m}$ below the surface. All of the waste sites excavated during the year were located in the northeastern $100-B, C$ Area:

- 116-C-1 liquid waste-disposal trench - Excavation began in July 1996 and was completed in October 1997; maximum depth was $5 \mathrm{~m}$.

- 116-C-5 retention basin - Excavation began in September 1996 and was completed in about December 1998; maximum depth was $5.6 \mathrm{~m}$.

- 116-B-11 retention basin (and associated sludge pits) - Excavation took place between January and December 1998; maximum depth was $4.6 \mathrm{~m}$.

\subsubsection{Compliance Issues}

The 100-B,C Area is monitored in accordance with CERCLA and DOE Orders 5400.1 and 5400.5. The CERCLA well network and constituent list are documented in Federal Facility Agreement and Consent Order Change Control Form No. M-15-96-07, dated July 31, 1996. Sampling schedules and analyte selection are coordinated to meet the requirements of both regulations.

Monitoring wells in the 100-B,C Area are sampled biannually to quarterly. Tritium and strontium-90 exceeded their interim DWSs locally. Chromium and nitrate exceeded the MCL in two wells. No radiological contaminants were detected at levels above the DCGs.

\subsubsection{Extent of Contamination}

The most notable contaminants in the 100-B,C Area are tritium and strontium-90. Groundwater is also contaminated locally with chromium and nitrate at levels above their MCLs. These contaminants were introduced from leaking retention basins, cribs, and trenches and, in some cases, from sources upgradient of the area.

\subsubsection{Tritium}

Tritium was manufactured in B and C Reactors (DOE/RL-90-08, WHC-MR-0425). Separation of tritium produced between 1949 and 1952 in the 100-B,C and other reactor areas was performed in the 108-B building. Liquid wastes from the tritium-recovery process were discharged to the $116-\mathrm{B}-5 \mathrm{crib}$. Also, high-level liquid tritium wastes were disposed to the 118-B-6 burial ground (DOE/RL-90-08).

Tritium activity increased in many of the 100-B,C wells in FY 1998. Most of the wells exceeding the 20,000-pCi/L interim DWS are located near the river and are associated with past disposal practices at the 116-B-11 and 116-C-5 retention basins and the 116-B-1 and 116-C-1 trenches (Figure 5.3-1). The tritium activity in well $199-\mathrm{B} 3-1$ increased from an average of $8,500 \mathrm{pCi} / \mathrm{L}$ in 1997 to $70,100 \mathrm{pCi} / \mathrm{L}$ in January 1998 and 44,000 pCi/L in July 1998. The activities reported for well 199-B3-47 showed similar increases, rising from $25,400 \mathrm{pCi} / \mathrm{L}$ in 1997 to $88,100 \mathrm{pCi} / \mathrm{L}$ in January 1998 and $83,900 \mathrm{pCi} / \mathrm{L}$ in July 1998. These wells are located near waste sites that were excavated and remediated in 1997 and 1998 . It is possible that groundwater recharge was increased because of the application of dust-control water or 
natural precipitation collecting in the pits. The increased recharge may have remobilized tritium-bearing water in the vadose zone. If that was the case, levels are expected to decrease in the future because remediation has been completed.

The remaining wells with high tritium activities are either near known waste sites such as the 116-B-5 crib or are in areas that have not been previously identified as having a potential tritium source. Tritium continues to be elevated in well $199-\mathrm{B} 5-2$, but has dropped to $21,500 \mathrm{pCi} / \mathrm{L}$, just above the $20,000-\mathrm{pCi} / \mathrm{L}$ DWS. Well 199-B8-6, located near the 105-B burial ground, had tritium activities well below the DWS in early 1997 but increased to $91,900 \mathrm{pCi} / \mathrm{L}$ in January 1998. Well 199-B5-1 is not located near any specific facility but also showed a marked increase in tritium. The January 1998 sampling produced a result of 27,000 pCi/L, which was nearly double the FY 1997 result and 10 times the pre-1996 levels.

\subsubsection{Strontium-90}

The highest strontium-90 activities in the 100-B,C Area continued to be found in wells near the 116-B-1 and 116-C-1 liquid waste-disposal trenches. The 116-B-11 and 116-C-5 retention basins and liquid waste-disposal sites near the B Reactor building also appear to have contributed strontium to groundwater. Groundwater with strontium -90 activity $>8 \mathrm{pCi} / \mathrm{L}$ (interim DWS) extends from the $B$ Reactor building downgradient to the retention basins, liquid waste-disposal trenches, and Columbia River (Figure 5.3-2).

Most of the FY 1998 data were in the same range as previous data, except for a spike in activity in well 199-B3-46. The activity rose from $48.4 \mathrm{pCi} / \mathrm{L}$ in 1995 to $170 \mathrm{pCi} / \mathrm{L}$ in January 1998 . Subsequent activities ranged from 56 to $135 \mathrm{pCi} / \mathrm{L}$. This well is adjacent to the $116-\mathrm{C}-1$ trench, which was excavated and remediated in the period 1996 through 1997. It is possible that increased recharge through the excavation site remobilized or desorbed strontium- 90 contamination in the vadose zone and carried it to groundwater.

\subsubsection{Chromium}

Chromium was introduced to the soil column and groundwater from cooling water that leaked from retention basins and pipes or was disposed in trenches and cribs. In FY 1998, chromium exceeded the $100-\mu \mathrm{g} / \mathrm{L}$ MCL in two wells: $199-\mathrm{B} 5-1$ and 199-B3-47. Well 199-B5-1 monitors an area downgradient of former water-treatment facilities, where sodium dichromate may have leaked from storage tanks and transfer facilities. Total chromium and hexavalent chromium in filtered samples exceeded the $\mathrm{MCL}$ in all samples from this well in FY 1998. The maximum value for the year was $140 \mu \mathrm{g} / \mathrm{L}$ in January 1998 (hexavalent chromium). Well 199-B3-47, located near the river downgradient of the retention basins, had one value of chromium above the MCL but the average was below the MCL. Chromium appears to show a long-term increase in both of these wells, though high variability in the data and in sampling frequencies obscures the trends.

\subsubsection{Nitrate}

There is a plume of slightly elevated nitrate in the northeastern part of the 100-B,C Area (see Plate 4). Two wells exceeded the $45-\mathrm{mg} / \mathrm{L} \mathrm{MCL}$ in FY 1998. In well 199-B3-1, nitrate declined to $49 \mathrm{mg} / \mathrm{L}$ in 
January 1998, compared to the FY 1997 concentration of $93 \mathrm{mg} / \mathrm{L}$. The other well showing an exceedance (199-B3-47) reported a concentration of $47 \mathrm{mg} / \mathrm{L}$ in January 1998. This was only a slight increase from the FY 1997 concentration of $43 \mathrm{mg} / \mathrm{L}$.

West of 100-B,C Area near the river, two wells showed sharp increases in nitrate concentration: 199-B2-13 rose from $4.7 \mathrm{mg} / \mathrm{L}$ in FY 1997 to $36 \mathrm{mg} / \mathrm{L}$ in January 1998 and 699-72-92 reached $49 \mathrm{mg} / \mathrm{L}$ in October 1997. The cause of the increase is unknown. Nitrate in other 100-B,C Area wells remained in the same range as in recent years.

\subsubsection{Water Quality at Shoreline-Monitoring Locations}

Aquifer-Sampling Tube Results. During the fall of 1997, aquifer-sampling tubes were installed along the 100 Areas' low-river-stage shoreline at $~ 600-\mathrm{m}$ intervals (BHI-01153). Initial water samples from the tubes were obtained during the installation activity and were analyzed for chemical and radiological contamination indicators. The highest concentrations observed along the 100-B,C Area shoreline were as follows: hexavalent chromium $(41 \mu \mathrm{g} / \mathrm{L})$, nitrate $(3,200 \mu \mathrm{g} / \mathrm{L})$, gross beta $(42 \mathrm{pCi} / \mathrm{L})$, and tritium $(47,100 \mu \mathrm{g} / \mathrm{L})$. These results are consistent with groundwater-contamination characteristics as inferred from monitoring well data. The aquifer-sampling tubes were sampled again during the fall of 1998 and analytical results should become available in early 1999.

Riverbank Seepage Results. Samples were collected from two riverbank seepage sites along the 100-B,C Area shoreline during late October 1997. The highest observed contamination indicator concentrations were as follows: chromium $(13.9 \mu \mathrm{g} / \mathrm{L}$, filtered sample), nitrate $(17,400 \mu \mathrm{g} / \mathrm{L})$, gross beta . $(23: 6 \mathrm{pCi} / \mathrm{L})$, and tritium $(11,700 \mathrm{pCi} / \mathrm{L})$.

\subsection{0-K Area}

\section{R. E. Peterson, M. J. Hartman}

The 100-K Area contains two former plutonium-production reactors. The K-West Reactor operated between 1955 and 1970; the K-East Reactor operated between 1955 and 1971. Prior to construction of $\mathrm{N}$ Reactor, K-East and K-West were the largest of the production reactors. A description of operations and associated hazardous waste sites for the 100-K Area is presented in WHC-SD-EN-TI-239, prepared to support environmental restoration. A pump-and-treat system to remove chromium from groundwater between the 116-K-2 liquid waste-disposal trench (i.e., 100-K mile-long trench) is currently in operation.

\subsubsection{Facilities and Operable Units}

Existing facilities, hazardous waste sites, monitoring wells, and other general features for the 100-K Area are shown in Plate 1. Principal facilities that remain are the reactor complexes and the former water-treatment plant basins, one of which (183-KE) was recently used for a fish-rearing project. Fish-rearing activities ended in the fall of 1998 , and the basins will revert to water-treatment usage.

The K-West and K-East fuel-storage basins in the reactor buildings are functioning facilities that hold irradiated fuel rods from $\mathrm{N}$ Reactor. They represent one of the most significant cleanup challenges on the 
Hanford Site. Leakage of large amounts of radiologically contaminated water occurred in the past from the $\mathrm{K}$-East basin, and the underlying soil column contains a significant inventory of radionuclides.

Each reactor had a liquid waste-disposal facility that is a potential source for currently observed groundwater contamination. The 116-KW-2 and 116-KE-3 injection wells/drain fields were used to receive storage-basin effluent from the sub-basin drainage-collection systems (WHC-SD-EN-TI-239). The facilities consist of drain fields, containing perforated well casing that extends to below the water table. Radionuclides are likely to have accumulated on the soil column beneath these drain fields, and contamination was probably introduced directly to groundwater via the well casings.

Two other important contaminant sources near the reactor buildings are the 116-KW-1 and 116-KE-1 cribs, which received condensate from processing of various inert gases in the reactors. Irradiation of reactor atmosphere gases resulted in tritium and carbon-14 in the condensate that was disposed to the cribs. Approximately $200 \mathrm{Ci}$ of tritium and $200 \mathrm{Ci}$ of carbon-14 were discharged to these cribs during reactor operations.

The 116-K-2 liquid waste-disposal trench is located to the northeast of the K-East Reactor facilities and was designed as a soil-column liquid effluent-disposal facility and operated between 1955 and 1971 . $116-\mathrm{K}-2$ is the largest radioactive liquid waste trench in the 100 Areas and received significant quantities of chemical wastes. Solutions containing chromium that were discharged to the trench were primarily decontamination solutions and leakage of routine coolant water from the retention basin and floor drains in the $\mathrm{K}$-West and $\mathrm{K}$-East Reactor buildings. Solutions contributing the greatest amount of radionuclides were decontamination solutions, shielding water from the fuel-storage basins, and coolant water that contained debris from fuel-element failures.

Coolant for these reactors was piped to the $116-\mathrm{KW}-3$ and $116-\mathrm{KE}-4$ water-retention basins, which were steel tanks located $\sim 300 \mathrm{~m}$ from the Columbia River. Thermal cooling and decay of short-lived radionuclides occurred in these tanks. The coolant was then discharged into the river via large-diameter outfall pipes. Significant leakage of coolant water occurred from the retention basins to the ground, as well as to the 116-K-2 liquid waste-disposal trench via faulty valves and associated piping.

The area immediately south of the 183-KE water-treatment plant was the receiving facility for makeup chemicals. Tank-car loads of sodium dichromate and other chemicals were transferred to other locations from this point. During transfers, spillage of highly concentrated solutions occurred and drained into the soil. A similar chemical-receiving area existed behind the $183-\mathrm{KW}$ water-treatment plant.

For CERCLA environmental restoration purposes, the 100-K Area is divided into several operable units. The 100-KR-1 and 100-KR-2 Operable Units address waste sites, spill/leakage locations, and facilities that may act as sources of hazardous materials. The 100-KR-1 Operable Unit addresses source sites nearest the river and includes the former reactor-coolant-water-retention basins and liquid wastedisposal trenches. The 100-KR-2 Operable Unit addresses source sites farther inland and includes the reactor complexes and water-treatment plants.

The 100-KR-4 Operable Unit addresses groundwater that underlies the 100-K Area. This operable unit also addresses adjacent groundwater and surfacewater (i.e., the river) that may be impacted by 
contaminated groundwater from 100-K Area operations. Riverbank seepage, riverbed sediment porewater, and sediments contacted by contaminated groundwater from the 100-K Area are included in the operable unit.

\subsubsection{Compliance Issues}

Regulatory compliance issues related to groundwater in the 100-K Area include monitoring associated with the fuel-storage basins and CERCLA environmental restoration activities.

\subsubsection{Monitoring at KW and KE Fuel-Storage Basins}

Groundwater monitoring is being conducted around these facilities to ensure compliance with requirements for nuclear fuel- and waste-storage facilities (DOE Order 5400.1 [V] $9 \mathrm{~b}$ ). The regulatory basis for monitoring these facilities is further described in the Hanford Site environmental monitoring plan (DOE/RL-91-50, Rev. 2). The implementation of these monitoring and reporting requirements is contained in WHC-SD-EN-AP-174.

\subsubsection{CERCLA Interim Action}

In April 1996, a decision was made to proceed with accelerated groundwater-remediation activities in the 100-K Area (ROD 1996b). Hexavalent chromium in groundwater that discharges into the Columbia River was viewed to pose significant risk to aquatic organisms. A groundwater-extraction-well network was designed that would intercept a chromium plume that is located between the 116-K-2 liquid wastedisposal trench and the river (DOE/RL-96-84). The extracted groundwater is passed through ion-exchange columns where hexavalent chromium is removed. The treated effluent is then returned to the aquifer.

In addition to reducing the amount of hexavalent chromium that is entering the river along the $100-\mathrm{K}$ Area shoreline, the interim-action pump-and-treat system is intended to produce data on the efficiency of the method and effectiveness for aquifer restoration. These data are being collected under the remedial design report and remedial action work plan (DOE/RL-96-84). The first performanceevaluation report for the system was released in April 1998 (DOE/RL-97-96).

\subsubsection{100-KR-4 Operable Unit Remedial Investigation}

Characterization of groundwater contamination is being conducted as the CERCLA interim action proceeds. The groundwater-monitoring schedule consists predominantly of annual sampling of wells, with analyses for anions, metals, and radiological indicators (BHI-00916). The list of wells, frequency of sampling, and analyses to be performed are described in National Priorities List Agreement/Change Control Form No. 108, dated November 20, 1996.

\subsubsection{Drinking Water Standards and Derived Concentration Guides}

In FY 1998, wells downgradient of the K-West and K-East Reactors exceeded the DWSs for tritium, strontium-90 (and gross beta), carbon-14, and nitrate. Chromium exceeded the $100-\mu \mathrm{g} / \mathrm{L}$ MCL near the $\mathrm{K}$-East Reactor and the 116-K-2 liquid waste-disposal trench. Trichloroethylene exceeded the 5- $\mu \mathrm{g} / \mathrm{L}$ MCL near the K-West Reactor. Two wells upgradient of K-East Reactor exceeded the $0.1 \mathrm{mg} / \mathrm{L}$ MCL for 
nickel. Single samples exceeded the MCLs for cadmium and thallium in filtered samples from wells 199-K-34 and 199-K-36, respectively. Strontium-90 exceeded the 1,000-pCi/L DCG in well 199-K-109A near the K-East Reactor.

\subsubsection{Extent of Contamination}

The geographic distribution of the groundwater contaminants found in the 100-K Area is described in this section. The description is organized by facilities and/or waste sites that are potential sources for contaminants that have reached the groundwater. Contaminants of concern for the 100-KR-4 Operable Unit are described in a conceptual site model report (BHI-00778). Subsequent updates to the conceptual site models are documented in internal reports, and are summarized in this and previous annual groundwater reports (e.g., Section 5.4 in PNNL-11793). Performance evaluation for the groundwater pump-andtreat remediation activity to address chromium contamination is described in periodic performanceevaluation reports. The most recent report is for the period between startup and January 1998 (DOE/RL97-96); a second report is scheduled for April 1999. Results for monitoring the fuel-storage basins are reported periodically (e.g., PNNL-12023).

\subsubsection{K-West and K-East Reactors}

Various liquid waste-disposal facilities associated with each reactor complex have contributed various radionuclides and chemical contaminants to groundwater. Also, leakage from the fuel-storage basins has been a significant source of groundwater contamination. The principal contaminants of concern from these sources are described in PNNL-12023 and are summarized below.

Tritium. Tritium is elevated downgradient of the $\mathrm{K}$-West and $\mathrm{K}$-East Reactors and related facilities (see Plate 3). The K-East plume has higher activities, and levels greater than the 20,000-pCi/L DWS are observed at least $900 \mathrm{~m}$ downgradient. The orientation of the tritium plumes indicates that the long-term flow direction is primarily toward the river, with downstream movement along the shoreline.

Well 199-K-27 is located immediately downgradient from a formerly leaking construction joint in the K-East basins. The tritium trend in well 199-K-27 illustrates the expected time-activity history in a downgradient monitoring well during and following a leak event (Figure 5.4-1). The relatively long, exponential decline is consistent with the slow drainage through the vadose zone that followed termination of a leak and subsequent dispersion in groundwater.

Groundwater at well 199-K-109A is believed to reflect influences of both the K-East basin and the 116-KE-3 injection well/drain field. A sharp peak in tritium was observed in this well in late 1997 (Figure 5.4-2). Leak-rate calculations and other operational data indicate there was no new leak in the $\mathrm{K}$-East basin, and tritium levels returned to normal in early 1998. The short duration of the peak indicates it was probably not related to the 1996-1997 increase in the water table, but could have been caused by another source of surfacewater infiltration. Disposal of fuel-storage-basin drainage to the injection well/ drain field in the past may have resulted in a significant inventory of tritium, strontium-90, and other fission products and transuranics above the current water table. The unsealed casing of the injection well could act as a conduit for infiltration of surfacewater through the residual vadose-zone contamination. 
The high-river stage in 1996-1997 is believed to be causing a shift in plume movement toward the northeast. This northeastward shift is not evident on the scale of the entire 100-K Area (e.g., Plate 3) but appears to show up in several wells near the tritium sources. Wells 199-K-30, 199-K-106A, and 199-K-109A all show high-tritium activities until late 1995 when they declined sharply (Figure 5.4-3). As shown by the inset hydrograph for well 199-K-30, this is when water levels began to increase.

Another possible explanation for the recent tritium decline in these wells is contaminant stratification in the wells or in the aquifer. If the contamination is highest near the top of the aquifer, then increasing water levels farther above the pump intakes could result in samples with lower tritium activities. However, that mechanism probably would cause tritium to vary rapidly with water-level changes. Instead, tritium levels have remained low for long periods of time, which is more consistent with a change in horizontal groundwater flow as described above.

Tritium is also elevated in a small area north of the $\mathrm{K}$-East Reactor and close to the river. Extraction well 199-K-120A shows the highest activities, which are $\sim 90,000 \mathrm{pCi} / \mathrm{L}$. Well $199-\mathrm{K}-18$, located nearby, provides a longer record for tritium in this area; activities are increasing gradually and have exceeded the DWS since 1995. Although somewhat speculative, the source for the tritium may be prior leaks from the $\mathrm{K}$-East fuel-storage basin (Section 5.4 in PNNL-11793).

The facilities around the K-West Reactor are analogous to K-East. However, the 116-KW-1 condensate crib appears to be the dominant source of contamination rather than the basins and injection well.

Carbon-14. This long-lived, low-energy, beta emitter is widely distributed in the 100-K Area and exceeds the 2,000-pCi/L DWS in two plumes, as shown in Figure 5.4-4. The source of carbon-14 is the 116-KW-1 and 116-KE-1 condensate cribs (fuel-storage basin water does not contain carbon-14).

A plot of tritium versus carbon-14 for all of the wells near the $\mathrm{K}$-West and $\mathrm{K}$-East fuel-storage basins is shown in Figure 5.4-5. Most of the wells plot along the axes near the origin, but two wells (199-K-30, $\mathrm{KE}$ and 199-K-106A, KW) are distinct. The figure shows that tritium activities decreased between 1995, a year of average river stage, and subsequent years with higher-than-average river stage. The range of carbon-14 concentrations did not change significantly between 1995 and 1996-1998. Carbon-14 may exchange for nonradioactive carbon in carbonate minerals within the aquifer. This exchange process would retard the movement of carbon-14 through the aquifer. Under these conditions, carbon-14 is slower to respond to shifts in groundwater-flow direction than is tritium. As discussed above, the unusual increase in water table during 1996-1997 caused a shift in the inferred flow direction from the northnorthwest to a more northeasterly direction. Thus, a well that was located downgradient from the suspected condensate crib sources during "normal" hydrologic conditions could be missed by a plume that is shifted (clockwise) away from the well during the high-water period. Carbon-14 would be less likely to exhibit such rapid changes because of its slower rate of movement.

Strontium-90. Strontium-90 exceeds the 8-pCi/L DWS in two plumes originating near the K-West and K-East fuel-storage basins (Figure 5.4-6). As in the past, well 199-K-109A had the highest activities. The source of strontium-90 in well 199-K-109A is believed to be the 116-KE-3 injection well/drain field, located 11 to $12 \mathrm{~m}$ from the well. Strontium-90 increased sharply in September and October 1997 (up to $\sim 18,000 \mathrm{pCi} / \mathrm{L}$ ) and decreased in the remainder of FY 1998 (Figure 5.4-7). One possible explanation for the 1997 peak is that higher-than-average water levels mobilized strontium-90 that was normally in the 
vadose zone. Water levels in well 199-K-109A rose $>2 \mathrm{~m}$ between 1995 and mid-1997. Another potential explanation is that surface runoff or fire-hydrant-testing water infiltrated through the contaminated vadose-zone sediments near the well. These discharges are now directed away from this well and the adjacent waste-disposal site.

Strontium-90 is elevated above background in K-West fuel-storage basin monitoring wells 199-K-34 and 199-K-107A, but values are two orders of magnitude lower than at the K-East basin (see Figure 5.4-6). It is not known whether the source of strontium is the K-West basin, the 116-KW-2 injection well, or both.

Nitrate. Waste sources near the reactor complexes have contaminated groundwater with nitrate at levels above the $45-\mathrm{mg} / \mathrm{L} \mathrm{MCL}$ (see Plate 4). The plumes are assumed to reach the river, but there are few wells in that region. The nitrate plume extends south of the $183-\mathrm{KE}$ water-treatment plant and beneath most of the 116-K-2 liquid waste-disposal trench, but levels there are below the MCL.

Chromium. Well 199-K-36 is located at the southeastern end of the former 183-KE water-treatment plant basins, which were recently used for raising fish. In the past, this well showed wide variations in chromium concentrations, ranging from several hundred to several thousand micrograms per liter, but levels declined below the DWS in FY 1997 and FY 1998. The suspected source for the chromium is leakage/spillage of sodium dichromate stock solutions that were stored and transferred in the area near the well. The mechanism causing relatively high concentrations and widely varying concentrations remains unknown but is believed to be related to infiltration of water from the surface, with remobilization of contamination held in the vadose zone. Leakage of water from the 183-KE water treatment plant basins is a potential source of recharge.

Chromium is also elevated in wells $199-\mathrm{K}-107 \mathrm{~A}$ and $199-\mathrm{K}-108 \mathrm{~A}$, located adjacent to the $\mathrm{K}$-West Reactor building. Figure 5.4-8 shows sharp peaks in hexavalent chromium in FY 1998. A source for this chromium has not been clearly identified. Wells 199-K-34 and 199-K-106A, which are located near the two previously mentioned wells, do not show similarly elevated chromium. There are no monitoring wells located to the west of the reactor building to constrain the lateral boundaries of a potentially more widespread plume.

Trichloroethylene. Trichloroethylene has been observed at concentrations above the $5-\mu \mathrm{g} / \mathrm{L} \mathrm{MCL}$ in two 100-K Area wells (199-K-33 and 199-K-106A) located near the K-West Reactor complex. Trichloroethylene is not a widespread contaminant of concern in the $100-\mathrm{K}$ Area.

Nickel. Filtered nickel concentrations in wells 199-K-110A (upgradient of the K-East Reactor building) and 199-K-36 (upgradient of the 183-KE water-treatment plant) trended upward between 1992 and late 1996 to early 1997. Concentrations in FY 1998 were lower, but still exceeded the $0.1 \mathrm{mg} / \mathrm{L} \mathrm{MCL}$.

\subsubsection{116-K-2 Liquid Waste-Disposal Trench}

This trench received liquid effluent from a variety of reactor operations. During a fuel-element rupture, the reactor coolant was diverted from the normal retention-basin path to the trench. This effluent contained significant quantities of radionuclides. Although not originally designed for reactor-coolant effluent, the trench also received a significant proportion of routine coolant because of faulty valves in the 
retention basins. Because the trench was unlined, disposal of huge volumes of coolant, which contained chromium, caused mounding of the water table beneath the facility. The mounding created a radial dispersal pattern, thus resulting in a widespread chromium plume that extended up to $1.6 \mathrm{~km}$ inland.

Chromium. The FY 1998 distribution of chromium (filtered samples) in the 100-K Area is shown in Figure 5.4-9. Chromium contamination is the target of a pump-and-treat remediation system. The contaminant plume is approximately centered under the 116-K-2 trench and includes a broad region inland of the trench. Mounding of liquid effluent on the water table during the reactors' operating years apparently caused contaminated groundwater to be moved at least $1.6 \mathrm{~km}$ inland. Evidence for this can be seen in well 699-78-62, where chromium was detected at $\sim 100 \mu \mathrm{g} / \mathrm{L}$ in FY.1988. Concentrations subsequently declined and have been steady at $\sim 40 \mu \mathrm{g} / \mathrm{L}$ from 1993 to the present. During the years when 100-K Area facilities were operating, the water level in this well was $\sim 5 \mathrm{~m}$ higher than it is now.

Between the trench and the river, chromium concentrations are generally in the range of $150 \mu \mathrm{g} / \mathrm{L}$ or less and relatively constant or declining slightly in most wells. For wells closest to the river (e.g., 199-K-117A), the dilution caused by infiltration of river water during high stage can be readily observed (Figure 5.4-10). The lowered concentrations that occurred in mid-1997 correspond to unusually highriver conditions.

Strontium-90. Strontium-90 is observed in several wells within the chromium plume being remediated by the pump-and-treat system (see Figure 5.4-6). Activities in this area are generally $<30 \mathrm{pCi} / \mathrm{L}$.

\subsubsection{Water Quality at Shoreline-Monitoring Locations}

Aquifer-Sampling Tube Results. Aquifer-sampling tubes were installed at $\sim 300-\mathrm{m}$ intervals along the 100-K Area shoreline during the fall of 1997 (BHI-01090). These polyethylene tubes are driven into the aquifer at locations near the low-water shoreline. At each location, multiple tubes monitor several depths in the aquifer. Analyses of the water from these tubes included screening for tritium, gross beta, nitrate, and hexavalent chromium. Analytical results for initial samples from the tubes are presented in BHI-01153.

Hexavalent chromium concentrations ranged from undetected to a maximum of $81 \mu \mathrm{g} / \mathrm{L}$ at a location within the plume attributed to the $116-\mathrm{K}-2$ trench. Nitrate ranged from undetected to a maximum of $25,000 \mu \mathrm{g} / \mathrm{L}$ downgradient of the retention basins and reactor facilities. Tritium ranged from undetected . to a maximum of $5,620 \mathrm{pCi} / \mathrm{L}$ in a previously installed tube at the downstream end of the $116-\mathrm{K}-2$ trench. Tritium was not detected at tube locations adjacent to wells $199-\mathrm{K}-18$ and $199-\mathrm{K}-120 \mathrm{~A}$, which both contain elevated tritium activities.

Gross beta activity ranged from undetected to a maximum of $41.8 \mathrm{pCi} / \mathrm{L}$ at a location downgradient from the 116-K-1 crib and the 116-K-2 trench. Several analyses for strontium-90 were performed, and results were consistent with gross beta results, as expected. The highest strontium- 90 activity observed was $17.9 \mathrm{pCi} / \mathrm{L}$ in the sample that also showed the highest gross beta activity. Where gross beta is primarily caused by strontium- 90 , gross beta activity is approximately twice that of strontium- 90 .

Two analyses for carbon- 14 were performed on tube samples from locations adjacent to monitoring wells that show activities in the $10,000-\mathrm{pCi} / \mathrm{L}$ range. The maximum tube-sample result was $348 \mathrm{pCi} / \mathrm{L}$. 
Selected tubes were sampled again during mid-October to mid-November 1998; however, the analytical results were not available when this report was compiled.

Riverbank Seepage Results. Riverbank seepage is sampled annually during the late fall from two sites along the 100-K Area shoreline as part of CERCLA remedial investigations. Seepage and finegrained sedimentary materials associated with the seepage.were analyzed in late October 1997 for metals, anions, and radioactivity. At the $100-\mathrm{K}$ Area, the sampling is conducted in accordance with National Priorities List Agreement/Change Control Form No. 108, dated November 20, 1996.

The specific conductance of the fall 1997 samples ranged from 198 to $284 \mu \mathrm{S} / \mathrm{cm}$, suggesting a. significant component of river water in the seepage. (Uncontaminated groundwater is expected to have a specific conductance in the $350-$ to $400-\mu \mathrm{S} / \mathrm{cm}$ range). Hence, observed concentrations reflect the dilution of groundwater by mixing with river water before it reaches the riverbank.

Chromium ranged from undetected to a maximum of $\sim 40 \mu \mathrm{g} / \mathrm{L}$ in a seep along the segment of $100-\mathrm{K}$ Area shoreline currently being addressed by the interim-action pump-and-treat system. This concentration is consistent with information from monitoring wells and aquifer-sampling tubes. Gross beta (an indicator of strontium-90) ranged from undetected to a maximum of $20 \mathrm{pCi} / \mathrm{L}$ at a seepage site between the $100-\mathrm{B}, \mathrm{C}$ and $100-\mathrm{K}$ Areas. Tritium ranged from undetected to a maximum of $4,400 \mathrm{pCi} / \mathrm{L}$ at a seep $\sim 200 \mathrm{~m}$ downstream of well 199-K-112A. The seep lies outside the tritium plume shown on Plate 3.

\subsubsection{Groundwater Remediation}

Groundwater remediation currently under way in the 100-K Area consists of an interim-action pumpand-treat system that addresses chromium contamination in the area between the 116-K-2 liquid wastedisposal trench and the river. The well network consists of six extraction wells (199-K-113A, 199-K-115A, 199-K-116A, 199-K-118A, 199-K-119A, and 199-K-120A; see Plate 1). The treatment system for the extracted groundwater consists of two modular $426-\mathrm{L} / \mathrm{min}$ treatment trains that contain ionexchange columns filled with Dowex $21 \mathrm{~K}^{\mathrm{TM}}$ resin to remove chromium from the influent (Dow Chemical Company, Midland, Michigan). The treated effluent is injected back into the aquifer at a location upgradient of the trench, using injection wells 199-K-121A, 199-K-122A, 199-K-123A, and 199-K-124A. During FY 1998, a new extraction well was installed (199-K-125A) to replace well 199-K-118A, which had not performed well.

Performance of the system is described in the first performance-evaluation report released in April 1998 (DOE/RL-97-96) and is summarized below. The summary reflects performance of the system through January 1998.

The treatment system is effective at removing hexavalent chromium from the extracted groundwater. Performance-monitoring data indicate that the treatment system is $>92 \%$ efficient in removing chromium from the influent stream. The treated effluent, which is returned to the aquifer at a location upgradient of the target plume, contains chromium at concentrations $<10 \mu \mathrm{g} / \mathrm{L}$. 
Complete hydraulic containment of the targeted chromium plume was not fully achieved because of poor performance by one of the extraction wells (199-K-118A). A replacement extraction well (199-K-125A) was installed during 1998, which will extend the hydraulic containment of the plume.

Abnormally high water-table conditions during 1996 and 1997 caused significant changes in the characteristics of the target plume. As.a consequence, it has not been possible to evaluate accurately the influence of extracting groundwater on chromium concentrations in the aquifer. However, $\sim 9.5 \mathrm{~kg}$ of chromium were recovered from the extracted groundwater during the first 4 months of operations. The estimated annual removal rate is $\sim 28 \mathrm{~kg} / \mathrm{yr}$.

An updated summary of the pump-and-treat system and operable unit monitoring is scheduled for publication in the spring of 1999.

\section{$5.5 \quad 100-\mathrm{N}$ Area}

\section{R. E. Peterson, M. J. Hartman}

The N Reactor operated from 1963 through 1987. The Hanford Generating Plant, which used steam from N Reactor to generate electrical power for the Washington Public Power Supply System, also shut down in 1987. Decontaminating and decommissioning the facilities, as well as environmental restoration activities, are in progress. Groundwater-remediation efforts have begun, with the construction and operation of a pump-and-treat system that reduces the movement of strontium- 90 toward the river (Ecology and EPA 1994). A corrective measures study for the 100-NR-1 (surface waste sites) and 100-NR-2 (groundwater) Operable Units was prepared (DOE/RL-95-111). Plans for additional remedial actions to address contaminated soils and groundwater have been proposed (DOE/RL-96-102).

\subsubsection{Facilities and Operable Units}

Existing facilities, hazardous waste sites, monitoring wells, and other general features of the 100-N Area are shown in Plate 1. A detailed description of the operational history of the 100-N Area and its associated waste sites is presented in WHC-SD-EN-TI-251, prepared to support the environmental restoration program. The most recent summary of progress made by the pump-and-treat system is contained in the FY 1998 annual report for the 100-NR-2 Operable Unit (DOE/RL-99-02).

For CERCLA environmental restoration purposes, the 100-N Area is divided into two operable units. The 100-NR-1 Operable Unit is a source operable unit that includes liquid, sludge, and solid wastedisposal sites associated with operation of N Reactor. The 100-NR-2 Operable Unit (see Figure 5.2-4) addresses groundwater that lies beneath the waste sites and adjacent areas, its entry into the Columbia River, and river sediments that might be impacted by contaminated groundwater from 100-N Area operations.

Four RCRA units are located in the 100-N Area: 1301-N liquid waste-disposal facility, 1324-N surface impoundment, 1324-NA percolation pond, and 1325-N liquid waste-disposal facility. The 1301-N facility was the primary liquid waste-disposal facility for N Reactor from 1963 until 1985. Discharge to this facility was primarily cooling water that contained radioactive fission and activation products. Minor amounts of dangerous waste also were discharged, including hydrazine, ammonium 
hydroxide, diethylthiourea, sodium dichromate, morpholine, phosphoric acid, lead, and cadmium. The $1301-\mathrm{N}$ facility consists of a concrete basin with an unlined, zigzagging extension trench, covered with concrete panels.

The 1324-N impoundment was a treatment facility in service from May 1986 to November 1988. This facility was a double-lined pond that was used to neutralize high- and low-pH waste from a demineralization plant. There is no indication that the facility leaked during its period of use.

The 1324-NA percolation pond is an unlined pond that was used to treat waste from August 1977 to May 1986 and to dispose treated waste from May 1986 to August 1990. The effluent to both facilities contained sulfuric acid and sodium hydroxide, whose $\mathrm{pH}$ was occasionally high or low enough to be classified as a dangerous waste.

The 1325-N facility was constructed in 1983, and $N$ Reactor effluent was discharged to it and to the 1301-N facility. In 1985, discharge to 1301-N ceased, and all effluent was sent to 1325-N. All discharge to $1325-\mathrm{N}$ ceased in late 1991. The facility consists of a concrete basin with an unlined extension trench, covered with concrete panels.

\subsubsection{Compliance Issues}

This section summarizes how groundwater was monitored to comply with applicable regulations in FY 1998, including RCRA monitoring, CERCLA environmental restoration activities, and a National Pollutant Discharge Elimination System permit under the Federal Water Pollution Control Act. The results are interpreted in more detail in Section 5.5.3.

\subsubsection{1301-N and 1325-N Liquid Waste-Disposal Facilities}

These facilities are monitored in accordance with RCRA interim-status, indicator evaluation programs (40 CFR 265, WAC 173-303-400). During FY 1998, upgradient and downgradient wells were sampled twice for contamination indicator parameters $(\mathrm{pH}$, specific conductance, total organic carbon, and total organic halides) and once for groundwater-quality and site-specific parameters (see Appendix A).

Indicator parameter data from upgradient wells were statistically evaluated, and values from downgradient wells were compared to values established from the upgradient wells (see Appendix B). Indicator parameters in downgradient wells remained below the comparison values, except for total organic carbon in one downgradient well at the 1301-N facility in September 1998. The well was resampled to confirm or refute the initial exceedance but results had not been received when this report was compiled. Of the dangerous waste constituents discharged to these facilities, only nitrate was observed at levels greater than the MCL, and the sources are unclear (Section 5.5.3.3). The 1301-N and 1325-N facilities have contaminated the groundwater with tritium and strontium-90, but radionuclides are not monitored as part of the RCRA program at these facilities. Tritium and strontium-90 are discussed in Section 5.5.3.1.

High-river stage temporarily changed the groundwater.gradient and flow direction beneath the 1301-N and 1325- $\mathrm{N}$ facilities (see Section 3.5.3). However, the current well network adequately monitors the site for long-term average conditions, and there are no plans to modify the networks in FY 1999. 
The closure plan for these two facilities was revised and incorporated into a modification of the Hanford Site RCRA Permit (Ecology 1994). When the modification becomes effective in early 1999, the sites will be regulated under final-status requirements. Remedial actions will be integrated with the 100-NR-1 and 100-NR-2 Operable Units. The closure plan (DOE/RL-96-39) states that RCRA monitoring during and after closure activities will continue according to the existing interim-status monitoring plan (WHC-SD-EN-AP-038, Rev. 2).

\subsubsection{1324-N Surface Impoundment/1324-NA Percolation Pond}

These two facilities are monitored jointly in accordance with a RCRA interim-status, indicator evaluation program. During FY 1998, one upgradient and four downgradient wells were sampled twice for contamination indicator parameters and once for groundwater-quality and site-specific parameters (see Appendix A).

Indicator parameter data from the upgradient well were statistically evaluated, and values from downgradient wells were compared to values established from the upgradient well (see Appendix B). Specific conductance values in downgradient wells were above the comparison value. A groundwater-qualityassessment program (1989-1992) concluded that the 1324-NA facility introduced nondangerous constituents (e.g., sulfate, sodium) to the groundwater, raising the specific conductance (WHC-SD-EN-EV-003, Rev. 1). Recent concentrations of these constituents and specific conductance are continuing previous trends, so no additional groundwater assessment is warranted.

Total organic carbon in downgradient well 199-N-59 was above the comparison value in September 1997. The exceedance was verified by samples collected in January 1998, and an assessment plan was submitted (PNNL-11885). However, the regulator responded that an assessment was not necessary because organic waste was not discharged to the facilities and the contamination is believed to have originated at one of several nearby oil tanks or waste sites. Total organic halide and $\mathrm{pH}$ limits were not exceeded in FY 1998. Thus, the site remains in detection monitoring.

The current well network adequately monitors the 1324-N/NA facilities, and there are no plans to modify the network in FY 1999.

The closure plan for these two facilities was revised and incorporated into a modification of the Hanford Site RCRA Permit (Ecology 1994). When the modification becomes effective in early 1999, the sites will be regulated under final-status requirements. Remedial actions will be integrated with the 100-NR-1 and 100-NR-2 Operable Units. The closure plan (DOE/RL-96-39) states that RCRA monitoring during and after closure activities will continue according to the existing interim-status monitoring plan (WHC-SD-EN-AP-038, Rev. 2).

\subsubsection{N Springs Expedited Response Action}

On September 23, 1994, an action memorandum was issued to immediately initiate groundwater remedial actions at the 100-N Area (Ecology and EPA 1994). The requested remedial actions included a groundwater pump-and-treat system and a sheet pile barrier wall at N Springs. In March 1995, the regulators concurred that installation of a jointed-hinge sheet pile wall could not be achieved in the manner specified based on a construction test conducted in December 1994. 
Subsequently, a pump-and-treat system was installed as an expedited response action. The N Springs pump-and-treat system was completed by August 1995 and put into full operation by September 1995, thus meeting Milestone M-16-12D (Ecology et al. 1989). The goals of the expedited response action are to:

- reduce strontium-90 contamination flux from the groundwater to the river

- evaluate commercially available treatment options for strontium-90

- provide data necessary to set demonstrable strontium-90 groundwater cleanup standards.

Performance-monitoring requirements for the $N$ Springs expedited response action pump-and-treat system are specified in National Priorities List Agreement/Change Control Form No. 113, dated March 25, 1997. The basic requirement is to sample the process influent and effluent streams monthly for strontium-90 analysis and to place the analytical results in a database to which the regulator has access. An update to the original performance-monitoring plan (i.e., BHI-00164, Rev. 1) has recently been completed that identifies and summarizes all current groundwater monitoring being conducted in the 100-N Area (BHI-01165).

\subsubsection{100-NR-2 Operable Unit Remedial Investigation}

As the expedited response action proceeds to address strontium-90 contamination in groundwater, concurrent monitoring continues as part of the remedial investigation for the 100-NR-2 Operable Unit. Monitoring results, along with information gained by operating the pump-and-treat system, will be used to support selection of a final remediation alternative for the operable unit.

A consolidated groundwater-monitoring schedule was developed in 1995 to provide for efficient collection of groundwater data in support of several programs (BHI-00725). Based on this proposed consolidation and the existing RCRA groundwater-monitoring plan (WHC-SD-EN-AP-038, Rev. 2), Federal Facility Agreement and Consent Order Change Control Form No. M-15-96-08, was signed October 9, 1996. This agreement lists the wells and analyses to be performed to satisfy groundwatermonitoring requirements for the 100-NR-2 Operable Unit (CERCLA) and the 1301-N, 1325-N, and 1324-N/NA facilities (RCRA).

Riverbank seepage is collected and analyzed under the Sitewide Environmental Surveillance Program annually. Authority for this activity comes from DOE orders for environmental monitoring. The results are presented in an annual report (e.g., Section 4.2 in PNNL-11795). Additional groundwater and surfacewater monitoring is conducted under the Near-Facility Environmental Monitoring Program, which is also mandated primarily by DOE orders. Samples are collected from 13 near-river well casings, which have been driven into the shoreline gravels, and also from a near-river monitoring well. The monitoring is conducted to support waste-management and environmental restoration activities and to determine the effectiveness of effluent-treatment and -control practices. Results are presented annually (e.g., HNF-EP-0573-6).

Data from all these programs support characterization and performance-monitoring objectives for remediation activities within the 100 Areas groundwater operable units, including 100-NR-2. Integration of information needs and activities of the various projects are being addressed by the Groundwater/. Vadose Zone Integration Project (DOE/RL-98-48, Draft C). 


\subsubsection{Drinking Water Standards and Derived Concentration Guides}

Tritium, strontium-90, nitrate, and sulfate continued to exceed MCLs or DWSs in the 100-N Area. Filtered manganese exceeded its MCL in two wells. Filtered chromium exceeded its MCL in one well completed in a locally confined unit. Strontium- 90 was detected at up to 25 times the $1,000-\mathrm{pCi} / \mathrm{L}$ DCG in well 199-N-67.

\subsubsection{Pollution Permit}

The National Pollutant Discharge Elimination System permit requires that 100-N Area well 199-N-8T be sampled quarterly for ammonium, chromium, grease, iron, oil, and temperature. The original purpose of this sampling was to monitor the effects of effluent discharge that was associated with the 1301-N and 1325-N facilities at a near-river location. Because neither facility has been in operation since 1991, a request to remove well 199-N-8T from the permit has been submitted to the EPA; the well continues to be sampled awaiting concurrence.

\subsubsection{Extent of Contamination}

This section describes the distribution of groundwater contamination in the $100-\mathrm{N}$ Area. Contaminants of concern that have been identified for both groundwater and river protection are described in DOE/RL-95-111. Contaminants of concern for groundwater protection are tritium, strontium-90, nitrate, hexavalent chromium, petroleum hydrocarbons (dissolved and free-product phases), manganese, and sulfate. Contaminants of concern for river protection are tritium, strontium-90, and hexavalent chromium.

\subsubsection{1301-N and 1325-N Liquid Waste-Disposal Facilities}

The principal groundwater contaminants associated with these two facilities are tritium and strontium-90. A summary of contamination is discussed below.

Tritium. The distribution of tritium in the 100-N Area is shown in Plate 3. The highest activities in the plume have decreased in recent years and are currently less than $60,000 \mathrm{pCi} / \mathrm{L}$. In general, tritium activities are decreasing with time throughout the plume as a result of movement, dispersion, and radioactive decay.

Tritium activity in well 199-N-76 is fairly steady (Figure 5.5-1) and is decreasing in wells on either side of 199-N-76 (i.e., 199-N-14 and 199-N-75). Near-river wells 199-N-96A and 199-N-99A had low activities in FY 1998, though the specific conductance of samples from these wells tends to be relatively high, which argues against dilution by river water. Near-river well 199-N-46 shows fluctuating activities that do appear to be caused by river water dilution during high stage.

Farther inland near the 1325-N facility, activities are generally decreasing (see well 199-N-32 in Figure 5.5-1). Tritium is also present in upgradient wells 199-N-74, 199-N-52, and 699-87-55. The current upgradient tritium is believed to have been moved inland by mounding during $1325-\mathrm{N}$ operations. 
Strontium-90. A distribution map for strontium-90 is shown in Figure 5.5-2. The strontium-90 distribution is similar to that described for FY 1997 (Section 5.5 in PNNL-11793). Contamination is concentrated in an area between the 1301- $\mathrm{N}$ facility and the river, where activities are $>1,000 \mathrm{pCi} / \mathrm{L}$. The highest activity is near the southwestern end of the $1301-\mathrm{N}$ trench (average of $22,000 \mathrm{pCi} / \mathrm{L}$ in well 199-N-67).

The strontium- 90 activity trends in the four extraction wells that are part of the interim action are shown in Figure 5.5-3. Strontium-90 activities in extraction well 199-N-103A appear to be split into two populations: a group that indicates a variable trend of typical plume activities and a group of very low to undetected activities. Results from nearby monitoring well 199-N-76 show a similar distribution. Peaks in strontium-90 activity appear to occur in May/June, which correlate with periods of high-river stage.

The strontium-90 activity in extraction well 199-N-75 is similar to that in 199-N-103A, with the seasonal high in May and June clearly described with sampling results for FY 1996. Strontium-90 activities in nearby extraction well 199-N-105A also reveal a trend that appears to be seasonal, though the pattern is not as obvious. Note that well 199-N-105A was not used as an extraction well during FY 1998.

Extraction well 199-N-106A contains the highest strontium-90 activities of the four wells. Values in this well appear to be generally increasing with time and ranged from 4,000 to 5,000 pCi/L in FY 1998 . The wide-ranging values obtained from the well when it was first installed in October 1995 may be an artifact of well-drilling activities.

Figure 5.5-4 shows strontium-90 activity in monitoring well $199-\mathrm{N}-67$ adjacent to the $1301-\mathrm{N}$ facility. A strong seasonal trend is apparent in this well, as is a generally increasing average strontium-90 activity. Values as high as $25,000 \mathrm{pCi} / \mathrm{L}$ have been observed in the past; sample activities at the end of FY 1998 were $\sim 18,000$ pCi/L. Well 199-N-2 downgradient of 199-N-67 also shows a strong seasonal variation, though values typically are lower and range between 500 and $4,000 \mathrm{pCi} / \mathrm{L}$.

Wells $199-\mathrm{N}-5$ and 199-N-54 help identify the southwestern extent of the strontium-90 plume and contain relatively constant strontium- 90 activity in the $500-$ to $1,000-\mathrm{pCi} / \mathrm{L}$ range. The sampling of these wells is not sufficiently frequent to identify seasonal variability in activity. Nearby well 199-N-3 does show possible seasonal variation in sample activity. The most recent result from this well $(2,500 \mathrm{pCi} / \mathrm{L})$ suggests an increasing trend in activity.

Well $199-\mathrm{N}-14$ is the northernmost well within the main strontium-90 plume. This well and nearby extraction well 199-N-106A show gradually increasing activities, which may reflect migration of the plume.

Wells near the 1325-N facility also have elevated strontium-90 (see Figure 5.5-2). Levels have increased in well 199-N-81 from hundreds (in 1993) to a maximum of $1,800 \mathrm{pCi} / \mathrm{L}$ in FY 1997 and declined to an average of $1,200 \mathrm{pCi} / \mathrm{L}$ in FY 1998. Wells $199-\mathrm{N}-27$ and $199-\mathrm{N}-28$ also show increasing trends in recent years. The cause for the increases is uncertain but may be related to a higher-thanaverage water table in 1997, which saturated contaminated vadose-zone sediments and mobilized strontium-90. Adsorption and desorption of strontium-90 on $100-\mathrm{N}$ Area sediments are described in PNNL-10899. 
Chromium. Chromium contamination is not widespread in 100-N Area groundwater, though well 199-N-80, which monitors a locally confined unit in the Ringold Formation, consistently reveals concentrations in excess of the $100-\mu \mathrm{g} / \mathrm{L} \mathrm{MCL}$ in filtered samples. Results for filtered and unfiltered samples track reasonably well and are quite steady at $\sim 180 \mu \mathrm{g} / \mathrm{L}$. The source for chromium in this deep horizon is unknown.

A filtered sample from well 199-N-64, located upgradient of the 1301-N facility, contained $124 \mu \mathrm{g} / \mathrm{L}$ of chromium in FY 1998, exceeding the MCL for the first time. There are only two previous results from this well; they were both $>50 \mu \mathrm{g} / \mathrm{L}$.

Chromium was disposed of in the 1301-N crib until the early 1970s, and it was identified as a contaminant of potential concern based on soil data (Section 2.5 in DOE/RL-96-39). There are no chromium data from wells that monitored the facility in the early 1970s, and chromium was not detected in significant concentrations in wells near the crib in the 1980s. The presence of chromium in well 699-87-55, which is located east of the northern part of the 1325-N facility, illustrates the possible inland influence of past disposal from the $100-\mathrm{N}$ or $100-\mathrm{D}$ Areas.

RCRA Parameters. Specific conductance of ambient groundwater near the 1301- $\mathrm{N}$ facility is relatively low (200 to $300 \mu \mathrm{S} / \mathrm{cm}$ ) compared to typical site groundwater because the site is close to the river. Upgradient well 199-N-57 and downgradient well 199-N-3 show elevated specific conductance (Figure 5.5-5). In FY 1998, specific conductance in well 199-N-3 rose to nearly $1,100 \mu \mathrm{S} / \mathrm{cm}$, while it declined to $\sim 650 \mu \mathrm{S} / \mathrm{cm}$ in well 199-N-57. An area of high-specific-conductance groundwater that originated beneath the 1324-N/NA facilities appears to be moving northward into the area monitored by well 199-N-3. Although specific conductance in well 199-N-3 exceeds current measurements in the upgradient wells, it remains below the critical mean value (see Appendix B).

Specific conductance near the $1325-\mathrm{N}$ facility was 300 to $500 \mu \mathrm{S} / \mathrm{cm}$ during FY 1998 , and was increasing in some wells (e.g., 199-N-81; Figure 5.5-6). Effluent discharged to the 1325-N facility had low specific conductance, which affected the groundwater beneath the site. After discharges ceased in 1991, specific conductance of groundwater began increasing (e.g., well 199-N-81; see Figure 5.5-6). The 1324-NA facility also affected groundwater quality near the $1325-\mathrm{N}$ facility with elevated levels of sulfate, sodium, and specific conductance. These constituents were elevated in 1325-N upgradient well 199-N-74 in the past (see Figure 5.5-6), and a remnant of the high-conductivity water remains in three wells near the 1325-N facility (Figure 5.5-7).

Groundwater $\mathrm{pH}$ beneath the 1301-N and 1325-N facilities averaged between 7.3 and 8.3 in FY 1998 . There are no clear upward or downward trends and no significant differences between upgradient and downgradient wells. Total organic halides ranged from less than the detection limit to $\sim 12 \mu \mathrm{g} / \mathrm{L}$, with no significant differences between upgradient and downgradient wells. Total organic carbon exceeded the critical mean value in 1301-N downgradient well 199-N-3 in September 1998. The well was resampled in January 1999 to confirm or refute the exceedance; results were not available when this report was compiled. Organic constituents were not discharged to the $1301-\mathrm{N}$ facility during its period of use.

Groundwater at 1301-N and 1325-N is also analyzed for other constituents discharged to these facilities during their use. These analytes include nitrate, cadmium, and chromium (see Appendix A). 
Cadmium and chromium (in filtered samples) were not detected in significant concentrations in $1301-\mathrm{N}$ or 1325-N downgradient wells. Nitrate was elevated in some of the downgradient wells, as discussed in Section 5.5.3.3, but the sources are unclear.

\subsubsection{1324-N Surface Impoundment/1324-NA Percolation Pond}

Groundwater beneath these facilities is characterized by high specific conductance $(>1,000 \mu \mathrm{S} / \mathrm{cm})$, primarily because of high levels of nondangerous constituents such as sodium and sulfate (Figure 5.5-8; also see Figure 5.5-7).

Field $\mathrm{pH}$ in 1324-N/NA wells was between 7.7 and 8.4 during FY 1998. Total organic halides ranged from below the detection limit to $14 \mu \mathrm{g} / \mathrm{L}$, with no significant differences between upgradient and downgradient wells. Total organic carbon concentrations ranged from less than the detection limit to $\sim 3,000 \mu \mathrm{g} / \mathrm{L}$ in well 199-N-59. Total organic carbon in this well trends higher than in the other wells and exceeded the critical mean value in FY 1998 (Figure 5.5-9). The well was sampled for organic constituents in June 1998. The only significant detection was oil and grease at $27 \mathrm{mg} / \mathrm{L}$. This contamination is believed to have originated at one of several nearby storage tanks or waste sites (PNNL-11885).

Sulfate and Specific Conductance. A plume of high-sulfate groundwater emanates from the 1324-NA facility toward the Columbia River, as reflected in specific conductance (see Figure 5.5-7). The current plume beneath the facility, where sulfate concentrations were $>300 \mathrm{mg} / \mathrm{L}$ in FY 1998, apparently is a result of continued drainage from the vadose zone. Another area of high conductivity and sulfate concentrations is observed in wells north of the $N$ Reactor building. This part of the plume is a remnant of groundwater contaminated when the 1324-N/NA facilities were in use, when the underlying groundwater had sulfate concentrations $>2,000 \mathrm{mg} / \mathrm{L}$. Wells $199-\mathrm{N}-2$ and $199-\mathrm{N}-3$, located near the $1301-\mathrm{N}$ facility, both show increasing sulfate and specific conductance trends as a result of the 1324-NA plume (see Figure 5.5-5).

\subsubsection{Other Groundwater Contamination Indicators}

Petroleum Hydrocarbons. Petroleum hydrocarbons are present as dissolved and free-product phases at several locations in the 100-N Area. Areas where dissolved oil and grease have been observed in the past are identified in the corrective measure study for the 100-NR-1 and 100-NR-2 Operable Units (DOE-RL-95-111) and in the proposed plan for interim action (DOE-RL-96-102).

Floating petroleum product (i.e., diesel) has been observed in wells $199-\mathrm{N}-17$ and $199-\mathrm{N}-18$ in the past. Field samplers look for an oil sheen or odor each time they sample wells in this area of diesel contamination. During the September 1998 sampling event, oil sheen was not evident in well 199-N-54; however, oil sheens were observed in wells $199-\mathrm{N}-17$ and 199-N-18. Wells 199-N-17 and 199-N-18 are not within the capture zone of the nearest extraction well (199-N-103A) to cause concern about contaminating the treatment system with diesel.

Results for total petroleum hydrocarbons analysis were obtained for samples from five wells in the contamination area in FY 1998. Well 199-N-18 contained the only detectable amounts, with a concentration of $18 \mathrm{mg} / \mathrm{L}$. Oil and grease were detected in wells $199-\mathrm{N}-16(4.55 \mathrm{mg} / \mathrm{L}), 199-\mathrm{N}-18(13 \mathrm{mg} / \mathrm{L})$, 
and $199-\mathrm{N}-8 \mathrm{~T}$ ( 2 to $3 \mathrm{mg} / \mathrm{L}$ ); none were detected in wells $199-\mathrm{N}-17$ or $199-\mathrm{N}-54$. Oil and grease were also detected in 1324-N/NA monitoring well 199-N-59 (27 mg/L), as discussed previously.

Nitrate. This contaminant has been increasing gradually in many $100-\mathrm{N}$ Area wells, and the areas where concentrations exceed the 45-mg/L MCL (see Plate 4) grew in FY 1998. Figure 5.5-10 shows that nitrate concentrations have increased to $\sim 80 \mathrm{mg} / \mathrm{L}$ in well $199-\mathrm{N}-59$ adjacent to the $1324-\mathrm{N} / \mathrm{NA}$ facilities. Nitrate or related constituents were not discharged in significant quantities to this facility (DOE/RL-96-39). Well 199-N-26, located near the N Reactor building, currently has even higher nitrate levels than does well 199-N-59. Historical data show a spike in 1986 (see Figure 5.5-10). Well 199-N-19, located north of the reactor building, has also had high-nitrate levels, reaching $220 \mathrm{mg} / \mathrm{L}$ in FY 1996. This peak was followed by a decrease to $\sim 100 \mathrm{mg} / \mathrm{L}$ for a sample collected in March 1998 . Nitrate also declined somewhat in wells $199-\mathrm{N}-21$ and $199-\mathrm{N}-54$.

Two wells with anomalous, low-nitrate values (199-N-18 and 199-N-5; see Plate 4) appear to separate the southern part of the plume from the portion near the 1301-N facility. In well 199-N-5, nitrate decreased from $50 \mathrm{mg} / \mathrm{L}$ in FY 1986 to $0.25 \mathrm{mg} / \mathrm{L}$ in March 1998. Nitrate has been historically below detection limits in well 199-N-18, which is very unusual in the unconfined aquifer. Groundwater is not diluted by the river or leaking utility lines in this area, as evident from the specific conductance, which is $>700$ and $>1,000 \mu \mathrm{S} / \mathrm{cm}$ in wells $199-\mathrm{N}-5$ and $199-\mathrm{N}-18$, respectively. Calcium and alkalinity (bicarbonate) are high in these wells, but the reason for these chemical anomalies is unknown.

Nitrate near the 1301-N facility is also elevated and increasing, as illustrated for wells $199-\mathrm{N}-67$ and 199-N-2 in Figure 5.5-11. Nitrate averaged $120 \mathrm{mg} / \mathrm{L}$ in well 199-N-67 in FY 1998 and is highly variable. Nitrate decreased in extraction well 199-N-105A in FY 1998. In the northern 100-N Area (e.g., well 199-N-14), nitrate is generally below the MCL but again, shows a generally increasing trend. Historical data from well 199-N-2 show a spike of nitrate in 1986, a year after the 1301-N facility was shut down.

Nitrate is also increasing near the $1325-\mathrm{N}$ facility, with the highest concentrations between 50 and $60 \mathrm{mg} / \mathrm{L}$ in wells $199-\mathrm{N}-32$ and $199-\mathrm{N}-81$, respectively. Historical data reveal that nitrate was at this same range or slightly higher when the facility was in use in the mid-1980s.

The source(s) of the elevated, increasing nitrate in the 100-N Area is unknown. However, several possible explanations can be eliminated.

- The nitrate does not appear to be coming from an upgradient location because there is no apparent "front" of the plume moving with groundwater (i.e., southeast to northwest). Rather, its distribution is spotty.

- The nitrate does not appear to be coming from deeper within the aquifer. The deeper wells (199-N-80, 199-N-69, 199-N-70, 199-N-77) have lower nitrate concentrations than the adjacent shallow wells.

- The nitrate could conceivably represent drainage of nitrate-contaminated water from the vadose zone near the 1301- $\mathrm{N}$ and $1325-\mathrm{N}$ facilities, which received nitrate-bearing wastes. Historical data from 
wells near these facilities show elevated nitrate in the mid-1980s, as discussed above. However, this does not explain the elevated nitrate near the 1324-N/NA facilities or the N Reactor building.

Manganese. As reported in FY 1997 (Section 5.5.3.3 in PNNL-11793), manganese is present in high concentrations in well 199-N-16 (Figure 5.5-12). The cause for elevated manganese is unknown. There was also one high-manganese value from well 199-N-18 in March 1998 (4.47 mg/L). There were no previous data from this well to help determine whether this value is representative. The well will be sampled again in FY 1999. Background concentrations of manganese in Hanford Site groundwater range from 0.05 to $94.4 \mu \mathrm{g} / \mathrm{L}$ (Table ES-1 in DOE/RL-96-61).

Other Radionuclides. Selected 100-N Area wells were sampled for additional radionuclides in FY 1998, including cobalt-60, europium-152, europium-154, europium-155, and ruthenium-106. None were present at values above detection limits.

\subsubsection{Water Quality at Shoreline-Monitoring Locations}

Water-quality data to describe conditions near the Columbia River in the 100-N Area are available from near-river wells (199-N-8, 199-N-46, 199-N-92A, 199-N-96A, 199-N-99A), riverbank-seepage points, and N springs seep points (NS-1 through NS-13). The FY 1998 annual report for the $100-\mathrm{NR}-2$ Operable Unit (DOE/RL-99-02) provides detailed descriptions of current conditions observed at nearriver sampling locations. The following are brief.summaries.

Near-River Wells. Strontium-90 activities in wells within the core of the plume being addressed by the interim action currently range from 300 to $2,500 \mathrm{pCi} / \mathrm{L}$. Much higher activities have been observed in the past, with the highest observed in well 199-N-99A at $19,100 \mathrm{pCi} / \mathrm{L}$ in 1996 . Strontium-90 activities in near-river wells 199-N-92A and 199-N-96A, which are positioned at the down- and upstream boundaries of the plume, appear to be $\angle 10 \mathrm{pCi} / \mathrm{L}$, though there are very few results for recent years. The specific conductance at well 199-N-92A was relatively low, suggesting river dilution at this well. At well 199-N-96A, specific conductance was relative high, suggesting minimal dilution. (Specific conductance results are used to indicate the degree to which infiltrating river water influences water quality at nearriver monitoring locations.)

Riverbank Seepage. The most recent samples of riverbank seepage were collected by the Sitewide Environmental Surveillance Program and analyzed during October and November 1997 (Section 5.5.3 in PNNL-11795). Analyses included indicators for radiological and chemical contaminants. Natural riverbank seepage at the 100-N Area was obtained from a location near well 199-N-8 and revealed a tritium activity of $19,000 \mathrm{pCi} / \mathrm{L}$ and a strontium- 90 activity of $9,900 \mathrm{pCi} / \mathrm{L}$. Chemical indicators were described as slightly lower than in previous years and were consistent with information from nearby monitoring wells.

N Springs Seep Points. During historical operations of the 1301-N facility, springs were observed along the riverbank. Carbon-steel casings ("seep points") were installed along the nearby shoreline to facilitate sampling these springs. The seep points are measured annually by the Near-Facility Environmental Monitoring Program. Only a few of the seep points were accessible during the November 1997 sampling event because of high-river stage. Data from that event can be found in HNF-EP-0573-6. The samples collected from these seep points were analyzed for radioactive constituents. Seep point NS-3, 
which is located near well $199-\mathrm{N}-46$, had the highest tritium and strontium-90 values $(3,000$ and $3,200 \mathrm{pCi} / \mathrm{L}$, respectively). Unfortunately, no specific conductance measurements are available to help interpret the degree of mixing between contaminated groundwater and river water at these sampling locations.

\subsubsection{Groundwater Remediation}

A pump-and-treat system is currently operating that reduces the movement of strontium- 90 toward the Columbia River and in the process, also removes strontium- 90 from the extracted groundwater. The goals of the pump-and-treat system are to 1) reduce strontium-90 contaminant flux from the groundwater to the river, 2) evaluate commercially available treatment options for strontium-90, and 3) provide data necessary to set demonstrable strontium-90 groundwater-cleanup standards (Ecology and EPA 1994).

- The 100-NR-2 Operable Unit interim action began operation in September 1995. The system consists of an extraction well network, treatment facility, and injection well network and operates at a minimum rate of $227 \mathrm{~L} / \mathrm{min}$. The extraction.well network includes four wells between the Columbia River and the 1301- N crib (see Plate 1). These wells are used to create a hydraulic barrier between the river and crib to reduce the volume of contaminated groundwater reaching the river.

At any given time, three of the four wells are online, with contaminated groundwater being extracted and pumped to the treatment facility; the fourth well is kept in standby mode. The pumping rate for each well is established to maximize the overall hydraulic influence of the extraction-well network. The treatment facility includes an ion-adsorption system, which uses a natural zeolite (clinoptilolite) to remove strontium- 90 from the extracted groundwater. Treated water is injected upgradient of the $1301-\mathrm{N}$ crib into two wells, each receiving half of the treated water. The performance characteristics of the interim action for FY 1998 are described in the annual report for the 100-NR-2 Operable Unit (DOE/RL-99-02), from which the following summary is taken.

During FY 1998, the interim-action pump-and-treat system operated at a nominal rate of $233 \mathrm{~L} / \mathrm{min}$; - $110,100,000 \mathrm{~L}$ of water were processed. System availability for the period was $89 \%$ (hours operating/ available hours, not including outage for resin changeouts, preventive maintenance, or scheduled maintenance outages). The system was shut down every 5 to 6 weeks for resin changeout, which usually lasted 2 to 3 days. Nine clinoptilolite changeouts occurred during FY 1998.

Three extraction wells operated during FY 1998, while the fourth available well was kept in standby mode. The three operating wells had average flow rates as follows: $199-\mathrm{N}-75(59.4 \mathrm{~L} / \mathrm{min}), 199-\mathrm{N}-103 \mathrm{~A}$ (60.2 L/min), and 199- $\mathrm{N}-106 \mathrm{~A}(115 \mathrm{~L} / \mathrm{min})$. These rates are similar to those experienced during previous years.

Extraction wells were sampled once during the year and the samples were analyzed for strontium-90, with the following results: $199-\mathrm{N}-75$ (407 pCi/L), 199-N-103A (34 pCi/L); and 199-N-106A $(4,460 \mathrm{pCi} / \mathrm{L})$. The combined average influent concentration to the treatment system was $2,348 \mathrm{pCi} / \mathrm{L}$, and the average effluent concentration was $473 \mathrm{pCi} / \mathrm{L}$. The treated effluent is injected back into the aquifer via wells $199-\mathrm{N}-104 \mathrm{~A}$ and $199-\mathrm{N}-29$ near the southwestern end of the 1325-N facility. 
The following summarizes progress in meeting stated goals for the remedial action.

- The pump-and-treat operation continued to reduce the hydraulic gradient toward the river, thus reducing the strontium-90 contaminant flux from groundwater to the river. In the target plume area, the net flux of groundwater to the river was estimated to be reduced by $\sim 96 \%$ (DOE/RL-99-02).

- Evaluation of the current treatment resin option (i.e., clinoptilolite) indicated that this medium is $>90 \%$ effective at removing strontium-90 from the extracted groundwater (DOE/RL-97-34).

- Strontium-90 ( 0.10 Ci) was removed from the extracted groundwater during FY 1998, with a total of $0.29 \mathrm{Ci}$ removed since the system began operating in September 1995. An estimated 76 to $88 \mathrm{Ci}$ of strontium- 90 are believed present in the target groundwater plume and on saturated sediments (DOE/RL-95-110).

\subsection{0-D/DR Area}

\section{R. E. Peterson, M. J. Hartman, M. D. Williams}

The 100-D/DR Area contains two former plutonium-production reactors. D Reactor operated between 1944 and 1967 and DR Reactor between 1950 and 1964. Descriptions of operations and associated hazardous waste sites for the 100-D/DR Area are presented in WHC-SD-EN-TI-181, prepared to support environmental restoration program activities.

Extensive environmental restoration was under way during FY 1998 that included the removal of radiologically contaminated soil associated with reactor-coolant-water-retention basins, liquid wastedisposal trenches, and associated underground piping. The work is continuing into FY 1999. A pumpand-treat system to remove chromium from groundwater is currently operating at the northern end of the 100-D/DR Area. A test of an in situ method to reduce hexavalent chromium (toxic to aquatic organisms) to the less-toxic trivalent chromium is in progress at the southwestern corner of the area. Twelve new groundwater wells will be installed in FY 1999 to better characterize chromium contamination in this area and to provide facilities for potential future remediation activities.

\subsubsection{Facilities and Operable Units}

Existing facilities, hazardous waste sites, monitoring wells, and other general features of the 100-D/DR Area are shown in Plate 1. For CERCLA environmental restoration purposes, the 100-D/DR Area is divided into two operable units (100-DR-1 and 100-DR-2), which address hazardous waste sites at or near the ground surface. The 100-DR-1 Operable Unit contains a former liquid waste-disposal facility (the 120-D-1 ponds) that is regulated in accordance with RCRA. These ponds were constructed in 1977 for disposal of nonradioactive effluent derived from operating facilities in the 100-D/DR Area. The ponds were clean-closed in late 1998, and no RCRA groundwater monitoring will be required in the future. 
The following summaries describe principal past-practice waste sites that may have contributed to groundwater contamination. The summaries are based primarily on information presented in WHC-SDEN-TI-181.

- The 116-D-7 and 116-DR-9 retention basins are located in the northern part of the 100-D/DR Area. They received enormous volumes of reactor-coolant effluent that contained radionuclides and chromium. They held the effluent for a short time to allow thermal cooling and radionuclide decay prior to discharging the effluent to the Columbia River via outfall pipes. The basins developed significant leaks, creating a mound in the underlying water table. Mounding enhanced the spread of contamination over a broad area that potentially exceeded the reactor area boundaries.

- The 116-D-1 and 116-DR-2 liquid waste-disposal trenches received highly radioactive coolant effluent that resulted when a reactor fuel element failed. The effluent would be held briefly in the retention basins and then diverted to the nearby trenches instead of the normal discharge via river-outfall pipes. The trenches were unlined and intended as soil-column-disposal sites.

- Relatively small soil-column-disposal facilities, such as cribs and French drains, were located near the reactor buildings. Contaminated water and sludge from fuel-storage basins at each reactor were disposed to trenches and percolation ponds. Decontamination solutions, consisting of various acid solutions that picked up radionuclides and metals were also disposed to the ground near the reactors.

- Sodium dichromate, which was added to coolant water as a corrosion inhibitor, was typically transferred from railcars to storage tanks and then piped to the facilities where it was added to coolant water. Leakage and spillage of stock solution occurred at storage tanks on the northern side of the $\mathrm{D}$ Reactor building and from piping that transferred the materials to the 190-D building immediately west of the reactor. During the later period of operations, a sodium dichromate transfer station was established $\sim 300 \mathrm{~m}$ west of $\mathrm{D}$ and $\mathrm{DR}$ Reactors. Significant spillage of sodium dichromate solution and washdown waste is assumed to have occurred at this location.

Remedial action excavation of waste sites in the 100-D Area continued in FY 1998. Remedial actions consisted of removing and stockpiling clean overburden soil and removing contaminated soils for disposal at the Environmental Restoration Disposal Facility. Dust-control water was applied when necessary while the excavations were open. There may be a potential for this water to mobilize vadose-zone contamination and carry it into the underlying groundwater, which is 15 to $19 \mathrm{~m}$ below the surface. All of the waste sites excavated were located in the northern 100-D Area: .

- 116-D-7 retention basin (and an associated sludge pit) - Excavation began in March 1997 and continues into FY 1999; maximum depth was $5.6 \mathrm{~m}$.

- 116-DR-9 retention basin (and two associated sludge pits) - Excavation began in March 1997 and concluded in December 1998; maximum depth was $4.6 \mathrm{~m}$.

- Septic tile field located north of the retention basins - Excavated in January and February 1998; maximum depth was $3.4 \mathrm{~m}$. 
Groundwater underlying the 100-D/DR Area is part of the 100-HR-3 Operable Unit, which includes groundwater beneath the 100-H Area as well (see Figure 5.2-4). Groundwater operable units address groundwater beneath the reactor areas and also groundwater in adjacent areas, Columbia River water, and river sediments that might be adversely impacted by contaminated groundwater from the reactor area.

\subsubsection{Compliance Issues}

Regulatory compliance issues related to groundwater in the 100-D/DR Area involve RCRA waterquality monitoring and CERCLA environmental restoration activities. The latter includes remedial investigations and performance monitoring associated with the groundwater interim-action pump-andtreat system.

\subsubsection{120-D-1 Ponds}

This RCRA facility is monitored under an interim-status, indicator evaluation program (40 CFR 265, WAC 173-303-400). During FY 1998, one upgradient well and three downgradient wells were sampled twice for contamination indicator parameters $(\mathrm{pH}$, specific conductance, total organic carbon, and total organic halides) and groundwater quality and site-specific parameters (see Appendix A). Indicator parameter data from the upgradient well were statistically evaluated, and values from downgradient wells were compared to values established from the upgradient well (see Appendix B). $\mathrm{pH}$, specific conductance, total organic carbon, and total organic halides in downgradient wells remained below the comparison values. Mercury is the only listed waste that may have been discharged to these ponds and has not been detected in any of the downgradient monitoring wells to date.

The closure plan for the ponds (DOE/RL-92-71, Rev. 2) was revised, and the site was incorporated into the Hanford Site RCRA Permit (Ecology 1994). All dangerous wastes or dangerous waste constituents or residues associated with the operation of the ponds have been removed. Therefore, the closure plan is a demonstration of clean closure, and there are no requirements for a landfill cover, postclosure care, or further groundwater monitoring.

\subsubsection{CERCLA Interim Action}

The extraction well network in the northern region of the 100-D/DR Area continued to operate through FY 1998. Groundwater is withdrawn through wells 199-D8-53 and 199-D8-54A and piped to a treatment facility in the 100-H Area. The purpose for the interim action is to reduce the amount of hexavalent chromium that is entering the river via groundwater movement. The river bottom in this area is heavily used as spawning habitat for fall Chinook salmon. The early life stages of salmon and other aquatic organisms are vulnerable to the toxicity of hexavalent chromium. The key documents that pertain to this interim action are the record of decision to proceed (ROD 1996b) and the performance-monitoring plan (DOE/RL-96-84).

\subsubsection{100-HR-3 (D Area) Operable Unit Remedial Investigation}

Groundwater monitoring in the 100-D/DR Area wells continued during FY 1998. The list of wells to be sampled and the analyses to be performed have been agreed on and are described in National Priorities 
List Agreement/Change Control Form No. 107, dated November 20, 1996. Most wells are sampled annually, and the samples are analyzed for anions, metals, and radiological indicators.

\subsubsection{Drinking Water Standards and Derived Concentration Guides}

Nitrate and chromium exceeded the MCLs or DWSs during FY 1998 in a fairly broad area. Tritium and strontium-90 (and gross beta) exceeded their interim DWSs in a single well in the central 100-D Area; tritium contamination that migrates from the 100-N Area at levels above the DWS, is present in the southwestern 100-D Area. Manganese, nitrite, sulfate, and gross beta exceeded standards in one well affected by in situ redox manipulation. Filtered iron exceeded its $0.3 \mathrm{mg} / \mathrm{L}$ secondary MCL in one sample from well 199-D3-2, and sulfate exceeded its secondary MCL in well 199-D5-12. No radiological constituents exceeded the DCGs.

\subsubsection{Extent of Contamination}

In this section, the distribution of groundwater contamination is described in relation to facilities and/or waste sites that are sources for the contaminants. The predominant contaminants in groundwater are tritium, strontium-90, nitrate, and chromium.

\subsubsection{D and DR Reactors}

Numerous facilities, waste sites, and spillage/leakage sites are located in the vicinity of the $\mathrm{D}$ and DR Reactors. Chemical and radiological contamination was introduced to the groundwater via these reactor complexes. The most prevalent contaminant remaining today is chromium because sodium dichromate was used in reactor coolant as a corrosion inhibitor.

Chromium. The distribution of chromium in filtered groundwater samples is illustrated in Figure 5.6-1 for the 100-HR-3 Operable Unit. The distribution in 100-D Area did not change significantly in FY 1998. The area around the D Reactor building is a primary source area for chromium. Facilities to transfer and store sodium dichromate were located in this area, and leaks and spills are known to have occurred during the operating years. Because of high concentrations in wells near the reactor, the area was chosen for a pilot-scale treatability test for removing chromium, which used a pump-and-treat system. Wells 199-D5-14, 199-D5-15, and 199-D5-16 were used as extraction wells for the test, which ran between August 1994 and August 1996 and resulted in the removal of $\sim 50 \mathrm{~kg}$ of chromium (DOE/RL-95-83). Chromium levels decreased from pre-test levels (formerly up to $1,800 \mu \mathrm{g} / \mathrm{L}$; currently $<900 \mu \mathrm{g} / \mathrm{L}$ ). Although concentrations have decreased near the treatability test area, other factors may have influenced concentrations.

Chromium from the D Reactor source area migrates to the north-northwest toward the 120-D-1 ponds. Prior to cessation of use of the ponds in June 1994, clean effluent disposed to the ponds diluted contamination in the groundwater beneath them. The dilution effect is now dissipating, and contamination from upgradient sources is increasing. The effect is most dramatic for chromium in well 199-D5-13, and is also visible in other wells in the RCRA network (Figure 5.6-2).

The D Reactor plume has presumably also migrated north toward the retention basins, where chromium may have been added to the plume by leakage from the 116-D-7 and 116-DR-9 retention basins 
and 116-D-1 and 116-DR-2 liquid waste-disposal trenches. The plume in this area is being remediated by pumping from wells 199-D8-53 and 199-D8-54A. Concentration charts for those wells are shown in Figure 5.6-3. Groundwater in both of these wells shows evidence of dilution by river water during highriver stage, and the relatively lower concentrations during FY 1996 and FY 1997 are probably a consequence of the unusually high-river-discharge conditions during those years.

Nitrate. Nitrate is widely distributed in the 100-D Area at concentrations up to approximately twice the 45-mg/L DWS (see Plate 4). Many 100-D Area wells show a slightly increasing trend in nitrate concentrations during the last 2 years, the significance of which is unknown.

Tritium. Although not a principal contaminant of concern, tritium can be a good indicator of groundwater movement and other activities. For example, the trend in well 199-D5-17, which is near the DR Reactor building, shows a dramatic decrease in tritium activities (Figure 5.6-4). Nearby well 199-D5-18 was used.to inject treated effluent from the pilot scale pump-and-treat test conducted between August 1994 and August 1996. This may represent dilution caused by the injection of clean effluent. The last sample from injection well 199-D5-18 in FY 1996 also suggested a decreasing trend.

A second noteworthy change in tritium activity occurred in well 199-D2-6, which is west of the reactors and away from known liquid waste-disposal sources. Tritium abruptly increased in this well in FY 1996 and has been highly variable since then (Figure 5.6-5). Nearby well 199-D3-2 also shows high tritium activity. The tritium plume from the $100-\mathrm{N}$ Area may have reached these wells, causing the elevated values (see Plate 3). Upgradient well 699-87-55 has had very high tritium activity in the past (up to $200,000 \mathrm{pCi} / \mathrm{L}$ in 1980 ); activities are currently decreasing.

Strontium-90. Strontium-90 is not widely distributed in the 100-D/DR Area. One well (199-D5-12) has shown a relatively constant activity of $\sim 30 \mathrm{pCi} / \mathrm{L}$, which is above the $8-\mathrm{pCi} / \mathrm{L}$ interim $\mathrm{DWS}$. Groundwater in this area is presumably influenced by past disposal of radionuclide-bearing effluent from the D Reactor fuel-storage basin, which is located nearby.

Strontium-90 in the interim-action extraction wells (199-D8-53 and D8-54A), downgradient of former liquid waste-disposal facilities, show detectable strontium-90, but do not show activities in excess of the DWS. Another well in this area (199-D8-68) has had variable strontium-90 activity, ranging from below detection levels to $35 \mathrm{pCi} / \mathrm{L}$ in FY 1998. These wells are all located near waste sites that were excavated and remediated in FY 1997 and FY 1998. It is possible that groundwater recharge was increased because of the application of dust-control water or natural precipitation collecting in the pits. The increased recharge may have remobilized or desorbed strontium-90 in the vadose zone and carried it to groundwater. If that were the case, levels are expected to decrease after remediation is completed.

\subsubsection{120-D-1 Ponds}

RCRA Parameters. Groundwater chemistry in the vicinity of the $120-\mathrm{D}-1$ ponds was affected by dilution from pond discharge. The dilution effect influenced groundwater chemistry even in upgradient well 199-D5-13. After discharges to the ponds ceased in 1994, higher-conductivity groundwater from upgradient sources flowed past the well and specific conductance increased. This parameter also is 
trending upward in the downgradient wells, and the rate of increase escalated in FY 1998 (Figure 5.6-6). Chromium concentrations beneath the 100-D ponds exceeded the $100-\mu \mathrm{g} / \mathrm{L} \mathrm{MCL}$ in FY 1998 for the first time.

Groundwater $\mathrm{pH}$ is higher in the wells immediately adjacent to the ponds than in the other wells but declined slightly in FY 1998 (Figure 5.6-7). The elevated $\mathrm{pH}$ is caused by pond discharge reacting with materials in the ash that underlies the ponds (WHC-EP-0666, WHC-SD-EN-EV-033). Concentrations of total organic carbon and total organic halides are low, with no significant differences between downgradient and upgradient wells.

\subsubsection{100-D Area Chromium Hot Spot}

During the fall of 1995 , significant concentrations $(\sim 800 \mu \mathrm{g} / \mathrm{L})$ of chromium were observed in shoreline aquifer samples and in samples of porewater from riverbed sediments (BHI-00778). Five new monitoring wells were installed to characterize the plume (BHI-01131). The highest initial concentration in these wells was $2,150 \mu \mathrm{g} / \mathrm{L}$ in September 1997. Insufficient data have accumulated for these new wells to justify trend plots, though the available data confirm a significant plume in the area. A redox manipulation test is being conducted in this area to reduce hexavalent chromium within the aquifer to the less-toxic trivalent form. The redox manipulation test is discussed more fully in Section 5.6.4.3.

\subsubsection{Water Quality at Shoreline-Monitoring Locations}

Aquifer-Sampling Tube Results. Analyses of samples collected during the fall of 1997 revealed hexavalent chromium concentrations that ranged from undetected to a maximum of $603 \mu \mathrm{g} / \mathrm{L}$ at a location within the plume referred to as the 100-D Area chromium hot spot (BHI-01131). The high 1997 concentrations are consistent with those previously observed (BHI-01153). Nitrate was observed at its highest shoreline concentration at the same location, with a maximum value of $38 \mathrm{mg} / \mathrm{L}$.

In previously installed tubes that monitor the plume addressed by the interim-action pump-and-treat system, the maximum chromium concentration was $60 \mu \mathrm{g} /$; nitrate was either at a very low concentration or was undetected. Gross beta and tritium were near detection limits at both of these locations. Tritium was elevated at the upstream limit of the $100-\mathrm{D} / \mathrm{DR}$ Area, with a maximum $20,000-\mathrm{pCi} / \mathrm{L}$ activity, which is the DWS. It is believed that the origin of this tritium was liquid waste disposal at the $100-\mathrm{N}$ Area.

For the tubes newly installed in 1997 at the $100-\mathrm{D} / \mathrm{DR}$ Area, all indicator constituents were essentially undetected. The reason appears to be that the tubes were monitoring river water held in bank storage. This is suggested by the relatively low specific conductance of the samples, when compared to the specific conductance of nearby groundwater. These tubes were sampled again in the fall of 1998; results were not available for inclusion in this report.

Riverbank-Seepage Results. Specific conductance in seepage samples collected during the fall of 1997 ranged from 202 to $279 \mu \mathrm{S} / \mathrm{cm}$, suggesting an appreciable component of river water draining from bank storage. Uncontaminated groundwater in this area typically shows a specific conductance of 350 to $400 \mu \mathrm{S} / \mathrm{cm}$. Therefore, the concentrations reflect significant dilution by river water. 
Chromium ranged from $\sim 15 \mu \mathrm{g} / \mathrm{L}$ just upstream of the hot spot, on the western side of the 100-D/DR Area, to a maximum of $215 \mu \mathrm{g} / \mathrm{L}$ at the center of the hot spot. This high value is reasonable in light of the $500-$ to $800-\mu \mathrm{g} / \mathrm{L}$ range observed previously in aquifer sampling tubes and riverbed porewater samples. At seepage points near the extraction wells, chromium concentrations are in the range of 40 to $55 \mu \mathrm{g} / \mathrm{L}$, which is consistent with monitoring results from nearby wells.

Gross beta and strontium-90 activities were undetected or very close to detection limits. The results for anions (e.g., nitrate) were not available at the time this report was compiled, and tritium was not measured.

\subsubsection{Groundwater Remediation}

Groundwater-remediation activities in the 100-D/DR Area included 1) a pilot-scale test of a pumpand-treat system to address chromium; 2) an interim action to intercept a chromium plume that is encroaching on the river, using pump-and-treat methodology; and 3) a test of an in situ method to reduce hexavalent chromium to trivalent chromium, using redox manipulation methods.

\subsubsection{Effects of Pilot-Scale Pump-and-Treat System}

Chromium concentrations in the three wells (199-D5-14, 199-D5-15, 199-D5-16) used in the pilotscale treatability test (DOE/RL-95-83) appear to have stabilized in the 400 - to $600-\mu \mathrm{g} / \mathrm{L}$ range. Anomalous, low concentrations were observed in well 199-D5-15, probably caused by surface infiltration from a utility line leak in late 1996. The diluted mass of groundwater may have migrated downgradient to well 199-D5-14, where a minor decrease in concentration has recently occurred. The wells are located $\sim 120 \mathrm{~m}$ apart, and a $\sim 0.3 \mathrm{~m} / \mathrm{d}$ travel time is reasonable in this area.

\subsubsection{CERCLA Interim Action}

The first performance-evaluation report for the 100-HR-3 Operable Unit interim action was released in April 1998 (DOE/RL-97-96). The following summary is taken from that report.

- The treatment system is effective at removing hexavalent chromium from extracted groundwater; it operates at an efficiency of $>95 \%$ removal from the influent stream. The treated effluent, which is returned to the aquifer at locations upgradient of the extraction wells in the $100-\mathrm{H}$ Area, contains . $<10 \mu \mathrm{g} / \mathrm{L}$ chromium.

- The hydraulic effects of groundwater extraction result in containment of the chromium plume along $\sim 400 \mathrm{~m}$ of shoreline.

- Abnormally high-river stage during 1996 and 1997. caused considerable variability in chromium concentrations in the target plume. Because of this, it has not been possible to describe accurately the influence of the extraction operation on concentrations in the aquifer. However, $\sim 14 \mathrm{~kg}$ of chromium were removed during the first 7 months of operation. The estimated annual removal rate is $\sim 24 \mathrm{~kg}$. 


\subsubsection{In Situ Redox Manipulation Technology Demonstration}

A treatability study is currently under way at the 100-D Area chromium hot spot as part of CERCLA environmental restoration activities. The study is intended to determine the feasibility of using this technology to address hexavalent chromium contamination in groundwater. Concentrations of hexavalent chromium in this area exceed 1,000 $\mu \mathrm{g} / \mathrm{L}$ (see Section 5.6.3.3 and Figure 5.6-1). Also, elevated concentrations have been detected in samples of porewater collected from the riverbed sediments in the adjacent Columbia River (see Section 5.6.3.4 and BHI-00778).

The goal of the study is to create a permeable treatment zone in the subsurface to remediate redoxsensitive contaminants in the groundwater. The permeable treatment zone is created by reducing the ferric iron to ferrous iron within the minerals of the aquifer sediments. This reduction is accomplished by introducing chemical-reducing agents, such as sodium dithionite. After the aquifer sediments are reduced, reagent or reaction products introduced into the subsurface are withdrawn.

Redox-sensitive contaminants that can be treated by this technology include hexavalent chromium, technetium, uranium, and some chlorinated solvents (e.g., trichloroethylene). Hexavalent chromium is immobilized by reduction of the soluble chromate ion to highly insoluble chromium hydroxide or iron chromium hydroxide. This transformation is particularly advantageous because chromium is not easily reoxidized under ambient environmental conditions. Technetium and uranium can also be reduced to less-soluble forms, and chlorinated solvents can be destroyed by reductive dechlorination.

A successful proof-of-principle test of the process was conducted in 1995 at the 100-H Area. The project has been monitored since its emplacement (PNL-11372). Since the test, hexavalent chromium concentrations within the reduced zone at the $100-\mathrm{H}$ Area test site have been below the $7-\mu \mathrm{g} / \mathrm{L}$ detection limit of the measurement equipment. Prior to the test, hexavalent chromium concentrations ranged up to $65 \mu \mathrm{g} / \mathrm{L}$ in this zone. Estimates of the lifetime of the reduced zone at the 100-H Area site range from 9 to 12 years based on analysis of core samples collected from the reduced zone. The successful completion of this field experiment led to the 100-D Area treatability study.

A small-scale test section was installed during the period September 1997 to July 1998 as part of this study to assess the performance and cost of the technology as a remediation alternative. The test site is located around well 199-D4-1 and is $\sim 150 \mathrm{~m}$ inland from the Columbia River (Figure 5.6-8). The test section has overall dimensions of $46 \mathrm{~m}$ long and $15 \mathrm{~m}$ wide and was created by overlapping 5 cylindrical, reduced zones. The site contains 5 injection/withdrawal wells and 10 monitoring wells that are upgradient, within, and downgradient of the treatment zone. Some of the monitoring wells are screened across the entire aquifer and some are screened at multiple depths.

The reduced zone was created by sequentially injecting and withdrawing a chemical reagent, consisting of sodium dithionite along with potassium carbonate and potassium bicarbonate $\mathrm{pH}$ buffers, in each of the five injection/withdrawal wells. The reagent was injected into the aquifer, given time to react with the aquifer sediments, and then the unreacted reagent and reaction products removed from the aquifer by pumping from the same well used for injection. Approximately five times the injection volume was removed from the aquifer to recover a majority of the reagent and reaction products. The first injection/ withdrawal activity was conducted in September 1997 in well 199-D4-7. The remaining four emplacements were conducted from May to July 1998 in wells 199-D4-9, 199-D4-10, 199-D4-11, and 199-D4-12. 
Withdrawn water for the first injection/withdrawal test was disposed at the State-Approved LandDisposal Site. Withdrawn water for the remaining tests was disposed using a combination of the purgewater modular tanks and purging to the ground near the site in a drip irrigation system upgradient of well 199-D4-13.

Baseline hydrologic and geochemical characterizations were conducted at the test site (e.g., constantrate discharge tests, conservative tracer tests, slug-interference tests, aqueous samples for major ions and trace metals, sediment analyses) prior to the dithionite injection/withdrawal test. Baseline data will be compared with postemplacement measurements to evaluate the performance and to determine any side effects from this process. Groundwater monitoring at the site is ongoing.

Preliminary results of the treatability study, based on September and October 1998 groundwater monitoring at the site, showed that hexavalent chromium concentrations in the wells within the treatment zone (the portion of the aquifer in contact with dithionite) were below detection limits $(7 \mu \mathrm{g} / \mathrm{L})$ compared to the average pretest baseline concentrations $(-1,000 \mu \mathrm{g} / \mathrm{L})$. Well 199-D4-1, located in the treatment zone, illustrates this marked decline in chromium (Figure 5.6-9). Other effects include drops in dissolved oxygen and nitrate, and increases in aluminum, iron, manganese, and nitrite. Although iron and manganese are elevated in the treatment zone, they are not expected to be mobile downgradient from the zone because they will reoxidize (and become immobile) once they contact untreated sediment. Chromium, however, cannot be reoxidized to its hexavalent state in the natural oxidizing conditions at the 100-D Area.

Other effects of the redox manipulation test include residual effects of the injected reagent. Although much of the reacted reagent (sodium dithionite with potassium carbonate/bicarbonate as a buffer) was pumped from the test wells, some of it remained in the aquifer. Residual effects observed in well 199-D4-1 included elevated carbonate/bicarbonate, potassium, sodium, and sulfate. These constituents cause elevated specific conductance. Gross beta activity was also elevated in this well (up to $\sim 500 \mathrm{pCi} / \mathrm{L}$ in FY 1998). It is believed to be caused by potassium-40, which occurs naturally in the injected potassium carbonate/bicarbonate solution. The residual effects are not expected to persist, and they should eventually move downgradient.

Well 199-D4-1 is the only routinely sampled well affected by the test so far. However, several wells, some with multiple sampling depths, are sampled to assess the performance of the test (well locations were shown in Figure 5.6-8). Results of the September 1998 sampling of those wells are summarized in Table 5.6-1. Wells within the treatment zone clearly showed decreases in dissolved oxygen and hexavalent chromium and increases in specific conductance and sulfate. Although sufficient time has not elapsed to fully assess the downgradient effects (i.e., travel time from the treatment zone to the downgradient wells), hexavalent chromium concentrations in the downgradient wells were mostly $<30 \%$ of the pretest values and continue to decline. A full analysis of the test will be reported in FY 1999.

In addition to the downgradient monitoring wells, five sets (each with multiple depths) of Columbia River substrate porewater-sampling tubes along the shoreline downgradient of the redox manipulation site were monitored to help assess the performance and side effects of the treatability test. It is too soon to see effects at the river. 
Estimates for the longevity of the treatment zone were $23 \pm 6$ years based on laboratory analysis of the amount of available ferric iron in the sediments collected from the site during initial well installation, groundwater velocity at the site, oxidizing capacity of the groundwater, and width of the treatment zone. Core holes will be drilled during FY 1999 to collect sediment samples from the treatment zone to measure the reductive capacity of the sediment achieved by the emplacement.

Additional activities for the treatability study for FY 1999 include the installation of additional upgradient and downgradient monitoring wells at the treatability test site, the installation of additional injection/withdrawal well(s) for expansion of the treatment zone, and preparation of the final report on the results of the study. Twelve additional monitoring wells are also planned for installation in the western portion of the 100-D/DR Area to help characterize the extent of the hexavalent chromium plume for remediation design.

\subsection{0-H Area \\ R. E. Peterson, M. J. Hartman}

The 100-H Area contains one plutonium-production reactor, which operated between 1949 and 1965 . Descriptions of reactor operations and associated hazardous waste sites are presented in BHI-00127, prepared to support environmental restoration activities.

Remediation activities already completed include demolition and removal of the former 183-H solar evaporation basins (a waste-storage facility) and the underlying contaminated soils. Pumping and treating of groundwater to remove chromium are currently under way. Extensive excavation of contaminated soils beneath the 107-H retention basin and the 107-H liquid waste-disposal trench will begin in FY 1999.

\subsubsection{Facilities and Operable Units}

Existing facilities, hazardous waste sites, monitoring wells, and other general features of the 100-H Area are shown in Plate 1. For CERCLA environmental restoration purposes, the 100-H Area is divided into two source operable units (100-HR-1 and 100-HR-2) that address hazardous waste sites at or near the ground surface. The 100-HR-1 Operable Unit contains the $183-\mathrm{H}$ solar evaporation basins, a former treatment, storage, or disposal facility that is RCRA regulated. The waste discharged to the basins originated in the 300 Area fuel-fabrication facility and was predominantly acid-etch solution that had been neutralized with sodium hydroxide. The acid solutions included chromic, hydrofluoric, nitric, and sulfuric acids. The waste solutions, described as supersaturated, contained various metallic and radioactive constituents (e.g., chromium, technetium, uranium). All wastes have been removed, the facility has been demolished, and the underlying contaminated soils have been removed and replaced with clean fill. Because residual amounts of nitrate and fluoride remain in the soil, and these constituents are attributable to $183-\mathrm{H}$ wastes, groundwater monitoring continues.

The principal past-practice waste sites that may have contributed to groundwater contamination are described below. The primary information source for these descriptions is BHI-00127, the technical baseline report for the 100-H Area. 
- The 107-H retention basin is located in the eastern part of the 100-H Area adjacent to the Columbia River. The basin received enormous volumes of reactor-coolant effluent that contained radionuclides and chromium and held the effluent for a short time to allow thermal cooling and radionuclide decay prior to discharging the effluent to the river via outfall pipes. The basin leaked at rates sufficient to create a mound on the underlying water table. Mounding enhanced the spread of contamination over a broad area that potentially exceeded the reactor area boundaries.

- The 107-H liquid waste-disposal trench received highly radioactive coolant effluent that resulted when a reactor fuel element failed. The effluent would be held briefly in the retention basin and then diverted to the nearby liquid waste-disposal trench instead of the normal discharge via river-outfall pipes. The trench was unlined and intended as a soil-column-disposal site.

- Relatively small soil-column-disposal facilities, such as cribs and French drains, were located near the $\mathrm{H}$ Reactor building. Contaminated water and sludge from the fuel-storage basin, located within the reactor building, were typically disposed to nearby trenches, though the fate of the fuel-storage-basin effluents is not well-documented. Decontamination solutions, consisting of various acid solutions that picked up radionuclides and metals, were also disposed to the ground near the reactor. Decontamination solutions also contained large amounts of chromate.

Groundwater underlying the 100-H Area is part of the 100-HR-3 Operable Unit, which also includes groundwater beneath the 100-D/DR Area (see Figure 5.2-4). Groundwater operable units address groundwater beneath the reactor areas and also groundwater in adjacent areas, Columbia River water, and river sediments that might be adversely impacted by contaminated groundwater from the reactor area.

\subsubsection{Compliance Issues}

Regulatory compliance issues related to groundwater in the 100-H Area include RCRA monitoring and CERCLA environmental restoration activities.

\subsubsection{183-H Solar Evaporation Basins}

This RCRA unit began to be monitored under a final-status corrective-action program when modification C to the Hanford Site RCRA Permit (Ecology 1994) became effective in February 1998. Groundwater remediation is integrated with the 100-HR-3 Operable Unit, where remediation for chromium is under way. While the pump-and-treat system is operating, RCRA monitoring consists of annual sampling of four wells for technetium-99, uranium, nitrate, fluoride, and chromium (PNNL-11573; also see Appen$\operatorname{dix}$ A). The wells were sampled in November 1997, in anticipation of the beginning of the corrective action monitoring project, in conjunction with CERCLA sampling of the 100-H Area.

\subsubsection{CERCLA Interim Action}

The extraction and injection well networks in the 100-H Area continued to operate through FY 1998. Groundwater is withdrawn through wells 199-H3-2A, 199-H4-7, 199-H4-11, 199-H4-12A, and 199-H4-15A. The extracted groundwater is piped to a location where it is mixed with extracted groundwater piped from the $100-\mathrm{D} / \mathrm{DR}$ Area. An ion-exchange system is used to remove chromium from the 
groundwater. The treated effluent is returned to the aquifer via injection wells 199-H3-3, 199-H3-4, and 199-H3-5 in the southwestern region of the 100-H Area.

The purpose for the interim action is to reduce the amount of hexavalent chromium that is entering the river via groundwater movement. The river bottom in this area is heavily used as spawning habitat for fall Chinook salmon. The early life stages of salmon and other aquatic organisms are vulnerable to the toxicity of hexavalent chromium. The key documents that pertain to this interim action are the record of decision to proceed (ROD 1996b) and the remedial action work plan (DOE/RL-96-84).

\subsubsection{100-HR-3 Operable Unit Remedial Investigation}

Groundwater monitoring in the 100-H Area wells continued during FY 1998. The list of wells to be sampled and the analyses to be performed have been agreed on and are described in National Priorities List Agreement/Change Control Form No. 107, dated November 20, 1996. Most wells are sampled annually, and the samples are analyzed for anions, metals, and radiological indicators.

During November and December 1997, round 12 remedial investigation sampling was conducted in the 100-HR-3 Operable Unit. Aquifer-sampling tubes were installed along the 100-H Area shoreline during the September to early November 1997 period. Riverbank seepage was collected in October 1997.

\subsubsection{Drinking Water Standards and Derived Concentration Guides}

Nitrate and chromium exceeded their MCLs in FY 1998 in slightly larger portions of the 100-H Area than in recent years. Chromium also exceeded the MCL in a well completed in the middle of the unconfined aquifer system. Technetium-99 (and gross beta) and uranium (and gross alpha) continued to exceed standards in the area immediately downgradient of the $183-\mathrm{H}$ solar evaporation basins. Strontium-90 was found at levels above the 8-pCi/L interim DWS near the 107-H retention basin and 107-H liquid wastedisposal trench; the extent of this plume expanded in FY 1998. No constituents exceeded the DCGs:

\subsubsection{Extent of Contamination}

In this section, the distribution of groundwater contamination is described in relation to facilities and/ or waste sites that are sources for the contaminants. Major groundwater contaminants are technetium-99, uranium, strontium-90, nitrate, and chromium. Water-quality monitoring at the $100-\mathrm{H}$ Area shoreline is also discussed.

\subsubsection{183-H Solar Evaporation Basins}

Groundwater chemistry near these former basins is characterized by elevated levels of technetium-99, uranium, nitrate, chromium, sodium, and sulfate. All of these constituents were present in waste discharged to the basins when they were in use.

The concentrations of the waste indicators typically are highest in well 199-H4-3, located immediately downgradient of the basins. Although the concentrations have decreased several orders of magnitude in this well since the basins ceased operation, they remained above maximum contaminant levels for drinking water for most of the past fiscal year, as discussed below. 
Technetium-99 and Uranium. Levels of these radionuclides are elevated in groundwater downgradient from the basins, as shown for uranium in Figure 5.7-1. As in previous years, the plumes extend from the basins toward the Columbia River. Contaminant concentrations in well 199-H4-3 fluctuate inversely with water levels. Like chromium and nitrate, technetium-99 and uranium peaked in extraction well 199-H4-7 in FY 1997. The pump was shut down to prevent accumulation of radionuclides on the ionexchange resins. Subsequent contaminants in this well declined to levels near their historical levels. The well was restarted as an extraction well in early FY 1998, though the water from the well is routed separately through the treatment system to keep the radionuclides separate from the other nonradionuclidebearing influent stream. Contaminant levels in well 199-H4-12A, another extraction well, increased in November 1997 but decreased again in February and May 1998. Gross alpha and beta activities in wells 199-H4-5 and 199-H4-9 increased sharply in FY 1998, along with the other 183-H basin contaminants.

The highest average technetium-99 activity in FY 1998 was $1,190 \mathrm{pCi} / \mathrm{L}$ from well 199-H4-4. Well 199-H4-3 contained the maximum average uranium concentration $(159 \mu \mathrm{g} / \mathrm{L})$. Contaminant levels vary widely in wells 199-H4-3 and 199-H4-4 because of changes in the elevation of the water table. Concentrations of waste indicators are highest in well 199-H4-4 during times of lowest water level; concentrations are lowest when the water table is high.

Nitrate. The basins also contributed to a more widespread plume of nitrate (see Plate 4). Nitrate exceeds the MCL to the east and southeast of the basins. The highest FY 1998 average concentration was $730 \mathrm{mg} / \mathrm{L}$ in well 199-H4-9. This well and nearby wells 199-H4-5 and 199-H4-12A all showed sharp increases in nitrate, chromium, technetium-99, and uranium levels in November 1997. These increases could have been caused by changes in groundwater-flow patterns from extraction at wells 199-H4-15A and 199-H4-12A or residual effects of high-river stage in 1996 and 1997.

Concentrations are increasing in three of the five 100-H Area interim-action pump-and-treat extraction wells (199-H3-2A, 199-H4-7, and 199-H4-12A). The changes are similar to those in chromium, discussed below. Nitrate in well 199-H4-7 rose from $50 \mathrm{mg} / \mathrm{L}$ or lower, up to $540 \mathrm{mg} / \mathrm{L}$ in November 1997, and subsequently declined. Nitrate also increased dramatically in well 199-H4-12A; from $\sim 50$ to $\sim 200 \mathrm{mg} / \mathrm{L}$ in November 1997.

Chromium. The 183-H basins contributed to a more widespread plume of chromium (see Figure 5.6-1). Trends for three of the shallow downgradient wells are illustrated in Figure 5.7-2. Concentrations vary inversely with water-table elevation in these wells. Increases in 1997 and early 1998 in well 199-H4-7, an extraction well, may have been caused by changes in flow directions caused by groundwater extraction or high water levels in 1997. Chromium levels also rose in wells 199-H4-9, 199-H4-5, and 199-H4-12A along with the other 183-H contaminants.

Chromium concentrations increased sharply in two wells south of the basins (Figure 5.7-3). Other basin contaminants also increased in these wells. The contaminant plume apparently has been displaced southward by the high water-table conditions in 1996 and 1997.

Well 199-H4-12C is completed in a deeper part of the aquifer than the other wells nearby. Chromium remains elevated in this well $(-230 \mu \mathrm{g} / \mathrm{L})$. Other basin contaminants are not elevated, so the source of this chromium is unknown. 
Fluoride. Fluoride was detected in the vadose zone beneath the basins, making it a constituent of interest for RCRA postclosure care (DOE/RL-97-48, Draft A; PNNL-11573). Fluoride has been higher in downgradient well 199-H4-3 than in upgradient wells in the past, but upgradient and downgradient concentrations were not significantly different in FY 1997 or FY 1998. Recent and historical values are all below the 4-mg/L MCL.

\subsubsection{Other Sources of Contamination}

The 107- $\mathrm{H}$ retention basins, $107-\mathrm{H}$ trench, and disposal facilities near $\mathrm{H}$ Reactor contributed to groundwater contamination in the $100-\mathrm{H}$ Area. The most significant contaminants are tritium, strontium-90, nitrate, and chromium.

Tritium. Tritium activity in the $100-\mathrm{H}$ Area is $\sim 10,000 \mathrm{pCi} / \mathrm{L}$ and below (see Plate 3 ). Several noteworthy changes are occurring in tritium trends in the $100-\mathrm{H}$ Area. Some wells on the western boundary of the area show a distinct upward trend in activities. A cause for the change is uncertain, but it is probably not related to the elevated water table of the past 2 years because the change started earlier, and may be related to groundwater migrating into the area from the west.

An abrupt increasing trend is also noted in well 199-H3-2C. This change correlates with similar changes for other constituents (see nitrate discussion). It may represent a possible interconnection between the unconfined and semiconfined aquifers monitored by well 199-H3-2C.

Strontium-90. Evidence for past disposal of radionuclide-bearing effluent to the retention basins and waste-disposal trench is revealed by strontium-90 activities that exceed the 8-pCi/L DWS near those facilities (Figure 5.7-4). Activities have increased in recent years in wells 199-H4-11, 199-H4-16, and 199-H4-18. Two wells downgradient of the 183-H basins (199-H4-4 and H4-12A [an extraction well]) exceeded the DWS for the first time in FY 1998. Well 199-H4-12A increased to $25 \mathrm{pCi} / \mathrm{L}$ in a May 1998 result. The explanation for the increases is not clear, though remobilization of strontium- 90 from the soil column during high water-table periods may be a posșible cause.

Chromium. The distribution of chromium in the $100-\mathrm{H}$ area is characterized by a diffuse and irregular pattern, partly because of multiple sources and an aging plume that has had many years to disperse (see Figure 5.6-1). A main contributor currently is migration of groundwater across the horn of the river from 100-D Area liquid waste-disposal sources (BHI-00917). Evidence for the arrival of this contaminated groundwater is the elevated chromium found in upgradient wells 699-97-43 (Figure 5.7-5) and 699-96-43. The most recent data from well 699-97-43 show a decreasing trend, suggesting that the main plume has passed this well, thus indicating a travel time from the 100-D Area of $\sim 30$ years.

The most recent data from well 199-H3-1 on the western edge of the 100-H Area (see Figure 5.7-5) suggest that the high-concentration core of the plume may now be arriving at that well. An alternative explanation is that injection of treated effluent from the interim-action pump-and-treat system is forcing the plume northward, as postulated by the original designers of the extraction/injection well network (DOE/RL-96-84).

An increasing trend has evolved in well 199-H3-2C (adjacent to well 199-H3்-2A) and monitors a locally confined aquifer below the unconfined, contaminated aquifer. The well showed a recent increase 
in chromium concentration in FY 1997 (Figure 5.7-6) that equates to concentrations in shallower well 199-H3-2A. Chromium concentrations decreased in FY 1998 in both wells. Other quality parameters show similar changes, suggesting a possible connection between the two aquifers (i.e., downward leakage to the lower aquifer), either in the aquifers at large, or just through the well.

Nitrate. $100-\mathrm{H}$ Area groundwater is contaminated with nitrate, which exceeds the $45-\mathrm{mg} / \mathrm{L} \mathrm{MCL}$ in two areas: near the 183- $\mathrm{H}$ basins and near the $\mathrm{H}$ Reactor building and related disposal facilities (see Plate 4). Groundwater to the west of the $100-\mathrm{H}$ Area (upgradient) is also contaminated.

As in the 100-K, 100-N, and 100-D Areas, nitrate concentrations showed a general increase during the last 2 years in many 100-H Area wells and some 600 Area wells. Some of the increase appears to be caused by groundwater flowing into the 100-H Area from upgradient locations. Nitrate increased in well 699-97-43 between the 100-D and 100-H Areas and in well 199-H3-2A in the western 100-H Area in FY 1996 through FY 1998 (Figure 5.7-7). Like chromium, nitrate also increased in deep well 199-H3-2C.

Near the $\mathrm{H}$ Reactor building, most monitoring wells showed a distinct increase in nitrate concentrations. The area of the plume that exceeded the MCL appeared to have increased in FY 1998 (see Plate 4). The cause for the increase has not been determined.

\subsubsection{Water Quality at Shoreline-Monitoring Locations}

Aquifer-Sampling Tube Results. Aquifer-sampling tubes were installed along the low-water shoreline of the 100-K, 100-D, and 100-H Areas during September, October, and November 1997 (BHI01090). The tube locations are spaced $300 \mathrm{~m}$ apart, up to three tubes are installed at each location, and their openings are at various depths in the aquifer. Initial sampling results are available for tritium, gross beta, nitrate, and hexavalent chromium (BHI-01153). The tube samples showed wide variability in the relative proportions of groundwater and river water, as indicated by the specific conductance of the samples.

Tritium was slightly elevated above background (2,000- to 3,000-pCi/L range) upstream of the 100-H Area and downstream in the slough area. Gross beta activity was slightly elevated at a shoreline location adjacent to the $107-\mathrm{H}$ retention basin $(54.4-\mathrm{pCi} / \mathrm{L}$ maximum activity). A nearby well showed similar historical activities, and the source is suspected to be strontium- 90 from the retention basins. Along other stretches of shoreline, gross beta was near background levels. Nitrate concentrations also tended to be low, with the highest values observed along the shoreline upstream of the $100-\mathrm{H}$ Area. The highest concentration was $44 \mathrm{mg} / \mathrm{L}$, which is slightly below the $45-\mathrm{mg} / \mathrm{L} \mathrm{MCL}$. Hexavalent chromium concentrations were generally undetected to low, with a maximum value of $29 \mu \mathrm{g} / \mathrm{L}$ observed in the slough area immediately downstream of the 100-H Area.

Riverbank-Seepage Results. Riverbank seeps are sampled during low-river discharge, which occurs during the late summer and fall months. This is the period when seepage is least influenced by bank storage of river water and, therefore, is most representative of groundwater that discharges into the river. Most samples are analyzed for tritium, a good tracer for groundwater movement; gross alpha/gross beta activity (indicative of strontium-90, technetium-99, and uranium); anions (e.g., nitrate); and metals (e.g., chromium). With the exception of two seepage sites upstream of the 100-H Area, most samples had 
specific conductance of $\sim 200 \mu \mathrm{S} / \mathrm{cm}$, indicating dilution by river water that drained back to the river from bank storage. Uncontaminated groundwater in this area is typically in the $400-$ to $450-\mu \mathrm{S} / \mathrm{cm}$ range.

Chromium ranged from 39 to $55 \mu \mathrm{g} / \mathrm{L}$ at the sites upstream of the $100-\mathrm{H}$ Area, and these values are considered representative of undiluted groundwater. The source for the chromium along this stretch of shoreline is likely to be the 100-D/DR Area. Chromium at other sites along the 100-H Area ranged from near detection limits $(5 \mu \mathrm{g} / \mathrm{L})$ to a high of $17 \mu \mathrm{g} / \mathrm{L}$. These values are low relative to the concentrations in the plume that is approaching the river, probably because of dilution in bank storage. The anion (e.g., nitrate and fluoride) results were not available at the time this report was compiled.

Gross beta ranged from near-detection levels upstream of the $100-\mathrm{H}$ Area to a maximum of $41 \mathrm{pCi} / \mathrm{L}$ near the retention basins. This gross beta value is consistent with strontium- 90 and technetium- 99 observed in near-shore monitoring wells. Analyses for technetium-99 and strontium-90 were not performed on seepage samples. Tritium activities ranged from undetected to a maximum of $2,480 \mathrm{pCi} / \mathrm{L}$ upstream of the 100-H Area, where specific conductance indicated essentially undiluted groundwater.

\subsubsection{Groundwater Remediation}

Groundwater remediation in the 100-H Area addresses chromium contamination. An extraction-well network, ion-exchange-treatment system, and injection-well network were in place and operating during FY 1998 to reduce the movement of chromium-contaminated groundwater into the Columbia River. Performance monitoring was conducted using numerous wells throughout the 100-H Area. An evaluation of performance-monitoring data is performed quarterly and kept within the administrative record for the interim-action project.

Extraction well 199-H3-2A showed a generally decreasing chromium concentration after a temporary rise in 1995 (see Figure 5.7-6). It is premature to associate this with the pump-and-treat operation. Near the river, pumping well 199-H4-12A showed a highly variable concentration (see Figure 5.7-2) because the well is strongly influenced by the influx of river water during high-river stage. Well 199-H4-12C, which is completed in a semiconfined aquifer below the uppermost unconfined aquifer, continued to show anomalous, high chromium concentrations, but no other co-contaminants were present that would determine the source. Concentrations in this well seemed to vary with large-scale river-discharge fluctuations. This may indicate a small zone of contamination around the well screen that gets displaced inland when gradients are reversed during seasonal high-river-stage conditions.

The first performance-evaluation report for the 100-HR-3 Operable Unit interim action was released in April 1998 (DOE/RL-97-96). The following summary is taken from that report.

- The treatment system is effective in the removal of hexavalent chromium from the extracted groundwater; it operates at an efficiency of $>95 \%$ removal of chromium from the influent stream.

- Continuous hydraulic containment of the chromium plume appears to exist in the vicinity of extraction wells 199-H4-12A and 199-H4-15A. Localized containment occurs around extraction well 199-H4-11. Therefore, a portion of the target chromium plume continues to pass between the extraction wells and into the river. 
- The unusually high Columbia River discharge during 1996 and 1997 caused significant changes in the concentrations observed in monitoring wells. The explanation is primarily shifting flow directions for the plume caused by the variable water-table gradients. Consequently, it has not been possible to describe accurately the influence of the extraction and injection operation on concentrations of chromium in the aquifer.

Three options were evaluated that would increase the extent of the capture zone and improve containment of the chromium plume in the area between wells 199-H4-12A and 199-H4-11. This area includes the contaminant plume that is directly attributable to leakage/spillage of fuel-processing wastes that were placed in the 183-H solar evaporation basins. The preferred option, a new extraction well to be located approximately between existing wells 199-H4-3 and 199-H4-18, will likely be installed during FY 1999.

\subsection{0-F Area}

\section{D. Sweeney, R. E. Peterson}

The 100-F Area is located the farthest east and downstream of the other reactor areas. F Reactor operated from 1945 to 1965. Like all of the other Hanford Site reactors, except $N$ Reactor, it was cooled by a single-pass system (i.e., cooling water passed through the reactor and was discharged directly to the Columbia River).

\subsubsection{Facilities and Operable Units}

For CERCLA environmental restoration activities, the 100-F Area is divided into two source operable units (100-FR-l and 100-FR-2), which contain hazardous waste sites at or near the surface. A single groundwater operable unit (100-FR-3) addresses contamination at and below the water table, which extends from beneath the source operable units laterally to adjacent areas where contamination may pose a risk to human and ecological receptors (see Figure 5.2-4). For the 100 Areas, the lateral boundary is generally considered to be where Hanford Site groundwater meets Columbia River water. This interface occurs along the riverbanks and within the riverbed substrate.

High-priority waste sites in the 100-FR-1 Operable Unit include reactor-coolant-water-retention basins, liquid waste-disposal trenches, associated effluent pipelines, and French drains near the F Reactor building. High-priority sites in the 100-FR-2 Operable Unit are primarily burial grounds that received radioactive and mixed wastes. Descriptions of high-priority waste sites are presented in the proposed plans for remediation activities in each of these source operable units (DOE/RL-95-54, Draft B; DOE/RL-95-92, Decisional Draft).

Contamination of groundwater occurred as the result of liquid effluent disposal associated with past reactor operations and from solid wastes disposed in burial grounds. A conceptual site model for groundwater contamination in this operable unit is included in BHI-00917.

There are no active facilities or waste-disposal sites in the 100-F Area. The facilities associated with former reactor operations that may have affected groundwater (summarized below) are being 
decommissioned and remediated in accordance with CERCLA. A description of reactor operations and associated hazardous waste sites is presented in WHC-SD-EN-TI-169, prepared to support environmental restoration.

The greatest volumes of liquid wastes in the 100-F Area were associated with the 116-F-14 retention basin and pipelines that lead to the basin from the $\mathrm{F}$ Reactor building. The retention basin is located near the Columbia River in the eastem part of the 100-F Area and received enormous volumes of reactor-coolant-water effluent that contained radionuclides and sodium dichromate. The basin held the effluent for a short time to allow thermal cooling and radionuclide decay before being discharged to the Columbia River. The basin developed significant leaks, creating a mound on the underlying water table that enhanced the spread of contamination.

The 116-F-2 overflow trench, located near the 116-F-14 retention basin, received highly radioactive effluent from the basin and F Reactor. A second trench (116-F-9) is also located near the retention basin and received liquid wastes from cleaning the experimental animal laboratories. The trenches were unlined and intended as soil-column-disposal sites because the natural soils were known to retain many radionuclides.

Other prominent liquid waste-disposal sites include cribs and French drains near the F Reactor building. The 116-F-6 and 116-F-3 trenches received cooling water and sludge from F Reactor. The 116-F-1 trench received liquid waste from $\mathrm{F}$ Reactor and associated buildings. Effluent discharged to these facilities contained radionuclides and metals.

Solid waste-burial grounds are located in the southwestern part of the 100-F Area. They were used to dispose of contaminated equipment, animal wastes from the experimental animal laboratories, or coal ash and soil.

\subsubsection{Compliance Issues}

The 100-F Area is monitored in accordance with CERCLA and DOE Orders 5400.1 and 5400.5. The CERCLA monitoring network and constituent list are documented in Federal Facility Agreement and Consent Order Change Control Form No. M-15-96-06, dated July 31, 1996. Sampling schedules and analyte selection are coordinated to meet the requirements of both regulations. Wells are sampled biannually to quarterly.

The only widespread constituent of concern is nitrate. Tritium, strontium-90, chromium, and trichloroethylene also exceeded standards locally. Uranium exceeded its proposed MCL in one well in FY 1997; that well was not sampled in FY 1998. Standards for aluminum and manganese were also exceeded in a few samples, but these are naturally occurring metals in groundwater. No radiological constituents exceeded the DCGs.

\subsubsection{Extent of Contamination}

Nitrate is elevated in most of the 100-F Area monitoring wells and downgradient. Other constituents of interest include tritium, strontium-90, uranium, chromium, and trichloroethylene. 


\subsubsection{Tritium}

Tritium exceeded the 20,000-pCi/L interim DWS in only one of the sampled wells (199-F8-3) for FY 1998. Tritium activity in this well dropped from $110,000 \mathrm{pCi} / \mathrm{L}$ in 1995 to $38,500 \mathrm{pCi} / \mathrm{L}$ in FY 1998 . It is unusual to observe tritium activities this high near a solid waste-burial ground where there is no obvious liquid waste disposal nearby. Tritium activities were well below the DWS in other parts of the 100-F Area.

\subsubsection{Uranium}

One well exceeded the 20- $\mu$ g/L proposed MCL during FY 1997 (well 199-F8-1, $28 \mu \mathrm{g} / \mathrm{L}$ ), but that well was on a 2-year sampling schedule and was not sampled in FY 1998. The well was decommissioned in FY 1998. Well 199-F8-1 was located south of the F Reactor building near several solid and liquid waste-disposal facilities. Uranium in nearby wells ranged from 1.1 to $18 \mu \mathrm{g} / \mathrm{L}$, which is fairly consistent with historical trends.

\subsubsection{Strontium-90}

Strontium-90 exceeded the 8-pCi/L interim DWS in several wells in the eastern part of the $100-\mathrm{F}$ Area near the 116-F-14 basin and the 116-F-2 trench (Figure 5.8-1). The highest activities were detected in well 199-F5-3, ranging from 179 to $429 \mathrm{pCi} / \mathrm{L}$. Previous values in this well generally ranged from 100 to $300 \mathrm{pCi} / \mathrm{L}$. Strontium-90 in nearby well 199-F5-1 showed a dramatic peak early in FY 1998 (Figure 5.8-2), rising from $10.3 \mathrm{pCi} / \mathrm{L}$ in September 1997 to a duplicate average of $119 \mathrm{pCi} / \mathrm{L}$ in October 1997. Activities declined somewhat during the rest of the fiscal year, but remained above the historical trend. Well 199-F6-1 also showed a sharp increase in strontium-90, rising from $1.23 \mathrm{pCi} / \mathrm{L}$ in May 1995 to $17.6 \mathrm{pCi} / \mathrm{L}$ in an October 1997 sample. An October 1998 sample from this well measured $4.12 \mathrm{pCi} / \mathrm{L}$. The strontium-90 increases in these wells do not appear to be related to changes in water level. Wells 199-F5-44 and 199-F5-46 slightly exceeded the DWS, but levels had not changed significantly from previous years.

\subsubsection{Nitrate}

Elevated throughout most of the 100-F Area (see Plate 4), nitrate exceeded the 45-mg/L MCL in most of the monitoring wells near the $F$ Reactor building and solid waste-burial grounds, reaching the $100-\mathrm{mg} / \mathrm{L}$ level. Well 699-71-30; south of the area, showed the greatest change in concentration, with a rise from $74 \mathrm{mg} / \mathrm{L}$ in 1995 to $169 \mathrm{mg} / \mathrm{L}$ in 1998 . This indicates the plume from the $100-\mathrm{F}$ Area has moved downgradient to this well (Figure 5.8-3). Nitrate provides a good indication of contaminant movement through preferential pathways created by buried former river channels. Movement of nitrate is generally to the south and southeast from sources near the F Reactor building and the 116-F-1 trench.

\subsubsection{Chromium}

One sample from well $199-\mathrm{F} 5-46$ was the only exceedance of the $100-\mu \mathrm{g} / \mathrm{L}$ MCL for chromium in filtered samples, but the annual average for the well was below the MCL. Chromium appears to be declining and was less variable than in previous years. This well is located near the 116-F-14 retention 
basin and two waste-disposal trenches. Two other wells in this area (199-F5-6 and 199-F8-4) have slightly elevated chromium $(-20$ to $30 \mu \mathrm{g} / \mathrm{L})$, but there is no evidence of a significant plume.

\subsubsection{Trichloroethylene}

Trichloroethylene continued to be detected in the southwestern corner of the 100-F Area and in the adjacent 600 Area. Wells 199-F7-1 and 699-77-36 both exceeded the 5- $\mu$ g/L MCL in October 1997, at levels of 17 and $19 \mu \mathrm{g} / \mathrm{L}$, respectively. These values represented slight increases over FY 1997, but are part of an overall declining trend (Figure 5.8-4). A trichloroethylene field-screening investigation in soil vapor and groundwater was performed in 1995 (DOE/RL-95-99). The extent of contamination was delineated but no specific sources were identified.

One additional well exceeded the MCL in FY 1998 for the first time. A value of $6 \mu \mathrm{g} / \mathrm{L}$ was reported for an October 1997 sample from well 199-F5-45, located east of F.Reactor. The previous result (September 1997) was at the 5- $\mathrm{gg} / \mathrm{L} \mathrm{MCL}$.

\subsubsection{Water Quality at Shoreline-Monitoring Locations}

Aquifer-Sampling Tube Results. During the fall of 1997, aquifer-sampling tubes were installed along the 100 Areas low-river-stage shoreline at 600 -m intervals (BHI-01153). Initial water samples from the tubes were obtained during the installation activity and were analyzed for chemical and radiological contamination indicators. The highest concentrations observed along the 100-F Area shoreline were as follows: tritium $(1,040 \mathrm{pCi} / \mathrm{L})$, gross beta $(7.7 \mathrm{pCi} / \mathrm{L})$, nitrate $(30,000 \mu \mathrm{g} / \mathrm{L})$, and hexavalent chromium $(15 \mu \mathrm{g} / \mathrm{L})$. All of the highest concentrations were observed in tube samples from the $\mathrm{F}$ slough area. Strontium-90 and trichloroethylene were not part of the analytical suite for the initial water samples. Some of the aquifer-sampling tubes were resampled during the fall of 1998 , and analytical results should become available in early 1999.

Riverbank-Seepage Results. Samples were collected from one riverbank-seepage site along the 100-F Area shoreline during late October 1997. Observed contamination indicator concentrations were as follows: tritium $(1,240 \mathrm{pCi} / \mathrm{L})$, gross alpha $(12 \mathrm{pCi} / \mathrm{L})$, gross beta $(16.2 \mathrm{pCi} / \mathrm{L})$, nitrate $(54,900 \mu \mathrm{g} / \mathrm{L})$, and chromium $(15.9 \mu \mathrm{g} / \mathrm{L}$, filtered sample). Strontium-90 and trichloroethylene were undetected in the samples.

\subsection{0-West Area}

\section{P. E. Dresel, V. G. Johnson, R. B. Mercer, L. C. Swanson, B. A. Williams}

The 200-West Area was used historically for chemical separation and purification of plutonium and associated waste management. For reasons of safety and security, the area was established with a significant spatial separation from the 200-East Area and with some redundancy of function. Differing hydrogeology between the two sites resulted in significant dissimilarities in contaminant distribution. Four key source areas in the environs of the 200-West Area will be discussed: T Plant, ReductionOxidation (REDOX) Plant, U Plant, and Plutonium Finishing Plant (formerly known as Z Plant). 
Numerous waste-disposal and -storage facilities, including cribs, trenches, tile fields, surface impoundments, tank farms, and landfills, are located in the 200-West Area. Specific facilities that may have contributed to groundwater contamination will be discussed, as appropriate, in Section 5.9.3. However, because of the complexity of past waste-disposal operations in the 200 Areas, as well as the close spacing of the facilities, it is often difficult to determine the exact source of contamination. CERCLA groundwater-remediation activities are grouped into groundwater operable units. These units are distinct from the numerous source area operable units for facility and vadose-zone remediation.

\subsubsection{Facilities and Operable Units}

\subsubsection{T Plant}

T Plant used the bismuth phosphate process from December 1944 through August 1956 to separate plutonium from irradiated fuel (WHC-MR-0132). More recently, $T$ Plant has been used as an equipmentdecontamination facility. The waste facilities for $T$ Plant are located generally southwest of the plant and include cribs and Tank Farms T and TX-TY (also known as waste management areas [WMAs]). Wastemanagement techniques changed during the period of operations, reducing the volume of waste produced for a given amount of fuel processed. Waste-disposal practices were complex and changed, depending on available storage capacity and treatment technology. Between 1948 and 1956, the tanks were used for settling of solids from second-decontamination-cycle wastes in a cascading system. The supernatant from the last tank in the cascade was discharged to nearby cribs or specific retention trenches (WHC-MR-0227). From 1951 to 1956, cell drainage waste was discharged through the cascade with the second-cycle waste. From 1951, the 242-T evaporator was used to reduce the volume of first-decontamination-cycle wastes, though in 1953-1954, some first-cycle waste was discharged to specific retention trenches. In 1954, scavenging operations to reduce the radioactivity of first-cycle waste began (WHC-MR-0132). The scavenged supernatant was disposed to the 216-T-26 crib (WHC-MR-0132, WHC-MR-0227). Waste from the original plutonium-concentration facility in the 224- $\mathrm{T}$ building was settled in 208,000-L, 200-series, single-shell tanks before being discharged to cribs. In addition, WHC-MR-0227 indicated that, in 1954, evaporator bottoms (concentrated waste) from the 242-T evaporator were discharged to the 216-T-25 trench. Thus, some of the most radioactive liquid waste was discharged to the ground rather than being stored in tanks. The wastes discharged were closely related to tank wastes; the tanks, however, apparently retained much of the solid fraction in the waste streams. At WMA T, 6 of 12 tanks are known or suspected to have leaked; at WMA TX-TY, 13 of 24 tanks are known or suspected to have leaked.

There are a number of significant waste-discharge sites in the T Plant area. The 216-T-28 crib received large amounts of water, as well as some decontamination wastes. The large volumes of water discharged to the 216-T-28 crib, located just east of WMA TX-TY, may have enhanced migration of contaminants from nearby sources. The 216-T-19 crib and tile field are located south of WMA TX-TY and received a variety of waste streams, including condensate from the 242-T evaporator and secondcycle supernatant waste. As discussed above, the 216-T-25 trench, located west of WMA TX-TY, received evaporator bottom waste.

Contaminants found in the groundwater near T Plant include tritium, iodine-129, technetium-99, nitrate, chromium, carbon tetrachloride, chloroform, trichloroethylene, and fluoride. 


\subsubsection{REDOX Plant}

Operation of the REDOX Plant began in 1951 and continued through 1967, with its primary mission to separate plutonium from uranium and fission products using countercurrent solvent extraction, eventually replacing the bismuth phosphate process used in $T$ and $B$ Plants. The solvent-extraction process used an organic solvent (hexone) to separate plutonium from uranium fuel that had been dissolved in nitric acid. Chemical contaminants found in the groundwater near the REDOX Plant include nitrate and minor amounts of trichloroethylene. The carbon tetrachloride plume prevalent in most of the rest of the 200-West Area is largely absent near the REDOX Plant, apparently as a consequence of the lack of any local discharges of carbon tetrachloride and, possibly, some lithologic control. The main radiological contaminants in groundwater are tritium, iodine-129, technetium-99, and uranium.

Disposal facilities associated with the REDOX Plant are generally located to the west of the plant. A number of disposal facilities, including several ponds that received large amounts of water, are located south, outside the 200-West Area perimeter fence. Waste from the redox process is stored in WMA S-SX (single-shell tanks) and WMA SY (double-shell tanks). Of the 27 single-shell tanks, 11 are known or assumed to have leaked. A number of disposal facilities located around WMA S-SX received waste from REDOX Plant operations, including condensate from the self-boiling waste tanks. Leakage of piping and transfer boxes during tank-farm operations may also have released contaminants in this area. WHC-MR-0227 indicated that tank wastes were not discharged directly to the ground via pumping or cascade overflow from WMA S-SX.

\subsubsection{U Plant}

U Plant was originally designed as a plutonium-separation facility but was never used for that purpose. The plant was converted in 1952 to recover uranium from "metal waste" generated by the bismuth phosphate process that had been stored in tanks up to that time. The uranium-recovery process used tributyl phosphate solvent extraction; however, the process generated a large amount of waste to be stored in the single-shell tanks. In 1954, ferrocyanide and nickel scavenging of the waste from the uranium recovery began. Supernatant from the scavenged waste then was discharged to the ground after settling in 200-East Area single-shell tanks. Discharge was primarily to the BY cribs in the northern 200-East Area between 1954 and 1955; subsequent discharge in 1956-1958 was to the $\mathrm{BC}$ cribs and specific retention trenches located south of the 200-East Area (WHC-MR-0227). Other process waste was discharged to cribs generally south and west of $U$ Plant and radioactive waste is stored in WMA U (single-shell tank farm). Groundwater contaminants in the U Plant area include iodine-129, technetium-99, uranium, nitrate, and trichloroethylene. In contrast to many parts of the fuel-processing areas, tritium contamination near U Plant is only minor.

\subsubsection{Plutonium Finishing Plant}

Z Plant was constructed in 1949 to purify plutonium and reduce it to a metallic state. In the early 1980 s, the plant was modernized and renamed the Plutonium Finishing Plant. The mission of the plant remained essentially unchanged but liquid discharges were significantly reduced. Primary wastes associated with the plant include transuranics (primarily plutonium and americium), nitrate, carbon tetrachloride, tributyl phosphate, dibutyl phosphate, dibutylbutylphosphonate, aluminum, fluoride, and lard oil. Transuranic contaminants typically remain bound in the soil column at relatively shallow depths, 
though there are exceptions, particularly where complexants for plutonium were present in the waste stream. Alkyl phosphates were not observed in the groundwater and their fate is still relatively obscure. Lard oil is expected to remain at shallow depth in the soil because of its high viscosity. Nitrate, carbon tetrachloride, chloroform, and trichloroethylene associated with the plant's cribs produced plumes in the groundwater. Wastes were disposed to a number of nearby facilities. The $216-Z-1 \mathrm{~A}$ crib and 216-Z-9 trench are considered to be major sources of groundwater contamination.

\subsubsection{RCRA Facilities}

A number of facilities in the 200 -West Area are being monitored in accordance with RCRA. Additional detail on those facilities is warranted by the RCRA monitoring and reporting requirements.

Single-Shell Tank Farms. The single-shell tanks that are currently storing hazardous, radioactive wastes in the 200-West Area are located in WMAs S-SX, T, TX-TY, and U (see Plate 1 and Appen$\operatorname{dix}$ A). These WMAs have been designated as RCRA facilities since 1989.

Currently, the single-shell tanks are used to store mixed waste received from various chemicalprocessing facilities. These tanks were constructed between 1943 and 1964 and, depending on dimensions, each held between 1,892,500 and 3,785,000 L. WMAs $T$ and $U$ contain four, smaller, 200-series tanks that hold $208,175 \mathrm{~L}$ each. The waste in the tanks was generated by chemical processing of spent fuel rods using the tributyl phosphate, bismuth phosphate, redox, or plutonium-uranium-extraction (PUREX) processes.

The single-shell tanks received mixtures of organic and inorganic liquids that contained radionuclides, solvents, and metals originally discharged to the tanks as alkaline slurries. Waste-management operations mixed various waste streams from numerous activities generated in the processing of spent fuel rods. Thus, the original contents within each tank are difficult to determine. The situation is further complicated by subsequent chemical reactions, degradation, and decay of radionuclides. However, much recent work has been done to characterize the tank waste (e.g., LA-UR-96-3860). The radionuclide and chemical inventories of the single-shell tanks are summarized in WHC-SD-WM-TI-565, Rev. 1; waste types and historical operations at the tank farms are summarized in WHC-MR-0132. Tank wastes were, in some instances, discharged to nearby cribs, unlined specific retention trenches, unlined ditches, and French drains.

Tank wastes exist in the form of salt cake and sludge, which is left after the liquids were removed. However, there are small quantities of supernatant and interstitial liquids that could not be removed by pumping. The wastes consist predominantly of sodium hydroxide and sodium salts of nitrate, nitrite, carbonate, aluminate, chromate, and phosphate. Some hydrous oxides of iron and manganese also are present. Fission-product radionuclides, such as technetium-99, strontium-90, and cesium-137, and actinide elements, such as neptunium, plutonium, thorium, and uranium, constitute the principal radioactive components. Some of the tanks also contain ferrocyanide, fluoride, or organic complexants.

216-U-12 Crib. This crib is located $\sim 610 \mathrm{~m}$ south of U Plant (see Plate 1). The crib received U Plant wastewater from April 1960 until February 1988, when the crib was permanently retired and replaced by the 216-U-17 crib. The 216-U-12 crib will not receive additional dangerous substances and will be closed in final status pursuant to WAC 173-303-610. 
The 216-U-12 crib is an unlined, gravel-bottomed, percolation crib that has bottom dimensions of $3.05 \mathrm{~m}$ wide, $30.5 \mathrm{~m}$ long, and $4.3 \mathrm{~m}$ deep. The crib has a plastic barrier cover and is backfilled with the original excavated soil. A vitrified,clay distributor pipe buried in gravel dispersed the effluent across the bottom of the crib.

The wastewater disposed to the $216-\mathrm{U}-12$ crib contained dangerous waste and radioactive materials. Specifically, the waste was composed of effluent from U Plant and included 291-U-1 stack drainage and highly acidic process condensate from the $224-\mathrm{U}$ building. The $216-\mathrm{U}-12$ crib received this waste stream from April 1960 until 1972, when it was deactivated. The crib was reactivated in November 1981 and received U Plant waste until it was permanently retired in February 1988. An average $>150,000,000 \mathrm{~L} / \mathrm{yr}$ of effluent were disposed to this crib during its active life. Also, the crib received small amounts of radioactive waste that is known to have included nitric acid in addition to plutonium, ruthenium-106, strontium-89/-90, and uranium. In 1985, physical controls and operating procedures were modified to avoid inadvertent discharge of hazardous chemicals to the wastewater stream.

216-S-10 Pond and Ditch. This facility is located south-southwest of the 200-West Area outside the perimeter fence (see Plate 1). Initially, the facility consisted of an open, unlined ditch $\sim 1.8 \mathrm{~m}$ deep, $\sim 4 \mathrm{~m}$ wide, and $686 \mathrm{~m}$ long. An open, unlined percolation pond, constructed at the southwestern end of the 216-S-10 ditch and $\sim 2.0$ ha in size, was also active during part of the time that the ditch was receiving waste.

The ditch began receiving waste from the REDOX Plant in August 1951. The pond was excavated and placed in service in February 1954. In October 1985, the pond and portions of the ditch were decommissioned and backfilled. The remaining portion of the ditch received nondangerous, nonregulated waste from the 202-S building chemical sewer. The waste stream included cooling water, steam condensate, water-tower overflow, and drain effluent. From 1985 to October 1991, physical controls and operating procedures were modified to avoid inadvertent discharge of hazardous chemicals to the wastewater stream. The effluent stream to the 216-S-10 facility was permanently deactivated in October 1991 . The facility will not receive additional dangerous substances and will be closed in final status pursuant to WAC 173-303-610.

Releases of dangerous constituents to the 216-S-10 facility are poorly documented. Radioactive waste was reportedly disposed to the facility as a result of contaminated floor and sewer drains at the REDOX Plant. Hazardous chemical releases were documented in 1954 and 1983 and included aluminum nitrate, sodium nitrate, sodium phosphate, sodium hydroxide, sodium fluoride, sodium chloride, and potassium dichromate.

Low-Level (LL) Waste Management Areas. LLWMAs 3 and 4 are monitored in accordance with RCRA interim-status regulations and include a number of burial grounds within each area.

Burial grounds 218-W-3A, 218-W-3AE, and 218-W-5 make up LLWMA 3, located in the northcentral portion of the 200-West Area (see Plate 1 and Appendix A). These facilities cover 74.3 ha. Burial ground 218-W-3A began accepting waste in 1970 and received primarily ion-exchange resins and failed equipment (e.g., tanks, pumps, ovens, agitators, heaters, hoods, vehicles, and accessories). Burial ground 218-W-3AE began operation in 1981 and contains low-level and mixed waste, including rags, paper, 
rubber gloves, broken tools, and industrial waste. Burial ground 218-W-5 first received waste in 1986 and contains low-level and low-level-mixed waste, including lead bricks and shielding.

LLWMA 4 covers 24.4 ha in the south-central portion of the 200-West Area. Burial grounds 218-W-4B and 218-W-4C make up LLWMA 4 (see Plate 1 and Appendix A). Burial ground 218-W-4B first received waste in 1968 and contains mixed and retrievable transuranic waste in trenches and 12 caissons. One caisson is believed to contain mixed waste. Waste was first deposited in burial ground $218-\mathrm{W}-4 \mathrm{C}$ in 1978. The transuranic, mixed, and low-level wastes placed in burial ground $218-\mathrm{W}-4 \mathrm{C}$ included contaminated soil, decommissioned equipment, and remote-handled transuranic waste.

LLWMA 5, located in the north-central portion of the 200-West Area, has been eliminated from further groundwater monitoring because no waste has been disposed to this facility and there are no plans for its use (see Plate 1).

\subsubsection{Other Facilities}

State-Approved Land-Disposal Site. The 616-A crib (also known as the State-Approved LandDisposal Site) is located $\sim 500 \mathrm{~m}$ north of the 200 -West Area northern boundary (see Plate 1 ). The crib is a drain field that receives treated effluent from the 200 Areas Effluent-Treatment Facility near the northeastern boundary of the 200-East Area. The 200 Areas Effluent Treatment Facility receives liquid wastes from various Hanford Site cleanup activities. Those wastes are stored temporarily in the Liquid Effluent-Retention Facility (Section 5.10.1.10). The treated effluent, containing nominally high levels of tritium (up to $4,000,000 \mathrm{pCi} / \mathrm{L}$ ), is transported by pipeline across the 200 Areas plateau to the State-Approved Land-Disposal Site for disposal. This site is regulated by a state waste-discharge permit (Section 5.9.2.8), and began receiving effluent in 1995 .

Environmental Restoration Disposal Facility. This facility receives waste material generated by the environmental restoration program during remediation of the Hanford Site and is located southeast of the 200-West Area. The facility contains two cells and will expand on an as-needed basis to accommodate excavated soil and debris generated from remediation activities. This waste material may have elevated levels of radionuclides and/or hazardous materials. The site covers $4.1 \mathrm{~km}^{2}$, but $\sim 67$ ha were used for the initial waste cells and an additional 23 ha for the first expansion. The facility is constructed as a single, 21.3-m-deep trench, consisting of a series of two side-by-side cells each measuring $152.4 \times 152.4 \mathrm{~m}$ at the base, with a finished wall slope of three horizontal to one vertical. Current dimensions are $432.8 \mathrm{~m}$ long (north-south) by $219.5 \mathrm{~m}$ wide (east-west) at the top of the trench. The trench design includes a double liner and leachate-collection system compliant with RCRA minimum technology requirements.

\subsubsection{Operable Units}

Only two CERCLA groundwater operable units (200-UP-1 and 200-ZP-1) relate to 200-West Area contamination (see Figure 5.2-4). The 200-UP-1 Operable Unit includes the groundwater contamination originating in the southern part of the 200-West Area. Currently, technetium-99 and uranium contamination in the vicinity of U Plant are being addressed by the 200-UP-1 interim action. The 200-ZP-1 Operable Unit includes groundwater contamination originating in the northern part of the 200-West Area. 


\subsubsection{Compliance Issues}

\subsubsection{Waste Management Areas T and TX-TY Single-Shell Tank Farms}

In November 1992, WMAs T and TX-TY were placed into RCRA interim-status groundwater quality assessment monitoring because of specific conductance exceedances in downgradient wells. An assessment plan for both WMAs was prepared (WHC-SD-EN-DP-042) and an assessment report based mainly on data from FY 1997 and earlier was released in January 1998 (PNNL-11809). Since that time, assessment work has continued. The FY 1998 assessment activities included preparation of a draft plan for continuing groundwater assessment, installation of six wells, and continued groundwater monitoring.

WMA T was placed into assessment monitoring because of specific conductance exceedances in downgradient well 299-W10-15 (see Appendix A for well locations). Subsequently, in late 1995, specific conductance increased rapidly in well 299-W11-27, exceeding the critical mean for the WMA in the August 1996 sample. The increase in specific conductance was accompanied by increases in technetium-99 and other cocontaminants (Section 5.9.3.1). Assessment findings indicate that contaminants in well 299-W10-15 are a result of sources outside the WMA. There is strong evidence, however, that contaminants observed in well 299-W11-27 are a result of sources within the WMA.

WMA TX-TY was placed into assessment monitoring because of specific conductance exceedances in wells 299-W10-17 and 299-W14-12. The exceedance in well 299-W14-12 was accompanied by elevated tritium, iodine-129, technetium-99, and cobalt-60. Assessment results indicate that contaminants in well 299-W10-17 are a result of sources outside the WMA. Assessment results for well 299-W14-12 indicate that the contamination is consistent with a source within the WMA; however, upgradient sources remain a possibility. Because there is no direct evidence for upgradient sources, assessment will continue at the site.

Monitoring wells in WMAs T and TX-TY are going dry rapidly because of declining water levels. The loss of these wells is taking place much sooner than originally expected because of the rapid drop in water levels in the area following the cessation of effluent discharges in 1995. This is clearly shown by the inflection in the hydrographs presented in Figure 3.6-6. Non-RCRA well 299-W10-12 has been used, at least temporarily, as a replacement for well 299-W10-15. Two new monitoring wells were installed in FY 1998 at WMA T. One well (299-W10-23) north of the tank farm was completed at the top of the aquifer. The second well (299-W10-24) adjacent to well 299-W11-27 and drilled into Ringold Unit A, below the Ringold lower mud unit, was then completed as a monitoring well at the top of the aquifer. Water samples were collected at $\sim 15-\mathrm{m}$ intervals during drilling. Four new wells were drilled at WMA TX-TY. Well 299-W15-40 was drilled upgradient of the tank farm and downgradient of the 216-T-25 trench. Well 299-W10-26 replaced well 299-W10-18 on the northeastern side of the WMA, and well 299-W14-13 on the eastern side of the WMA replaced well 299-W14-12. Well 299-W14-14, which was also on the eastern side, was drilled to Ringold Unit A, below the Ringold lower mud unit, and then completed at the top of the aquifer. Groundwater samples were collected from the deeper zones during drilling. All wells were completed at the top of the aquifer. Plans are in place for one new monitoring well east of WMA T and one south of WMA TX-TY. 
During FY 1998, an assessment report for WMAs T and TX-TY was released (PNNL-11809). The results of the assessment report were summarized in Section 5.9.3.1 of PNNL-11793. A plan for continued assessment has been prepared in draft form. In the interim, groundwater sampling during FY 1998 continued to provide important data on the temporal trends in contaminant concentrations.

\subsubsection{Waste Management Area S-SX Single-Shell Tank Farms}

A RCRA interim-status indicator evaluation program for WMA S-SX was initiated in 1990. In May 1996, this WMA was placed into interim-status groundwater quality assessment in response to a directive from the regulator (WHC-SD-EN-AP-191). The directive cited anomalous trends in technetium-99 and elevated specific conductance in vicinity groundwater as primary reasons for the assessment. A groundwater quality assessment plan was written in response to the directive and was submitted in August 1996 (WHC-SD-EN-AP-191): A report on the findings of the first determination was submitted in 1998 (PNNL-11810). The report concluded that this WMA contributed to groundwater contamination. Accordingly, investigation of the nature and extent of the contamination is required.

The declining water table in the 200-West Area will impact three of the seven RCRA-compliant wells at WMA S-SX during FY 1999. Accordingly, drilling plans for FY 1999 include installation of two to three replacement wells and one well at a new location to improve spatial coverage. The RCRA monitoring-well-installation plans will be coordinated with the Tank Waste Remediation System RCRA facility investigation to maximize vadose-zone information at this WMA.

\subsubsection{Waste Management Area U Single-Shell Tank Farm}

The RCRA monitoring network completed in 1993 was designed on the basis of a west-to-east groundwater-flow direction. The flow reversal between mid-1993 and late-1995 resulted in flow toward the northwest (see Section 3.6.3.1), rendering both upgradient and downgradient coverage inadequate. However, by the time this reversal was recognized, groundwater flow had returned toward the southeast. Under current flow conditions, some downgradient wells may be impacted by the carbon tetrachloride plume that emanates from the vicinity of the Plutonium Finishing Plant (Section 5.9.3.4) prior to its being detected in the upgradient wells. Flow directions continue to change in this vicinity as a result of the termination of site discharges and the impacts of the 200-ZP-1 Operable Unit pump-and-treat remediation. For this reason, well 299-W18-30 was returned to the monitoring network instead of removing it, as was proposed under last year's flow conditions (Section 5.9.2.3 in PNNL-11793). Older well 299-W19-12 was added to the monitoring network to increase spatial coverage. Two new downgradient wells were drilled on the eastern side of the tank farm for initial sampling in early FY 1999; well 299-W19-42 is a replacement for well 299-W19-31, and well 299-W19-41 is a replacement for well 299-W19-32.

Sampling of wells in the WMA U RCRA monitoring network has been increased to quarterly as a result of the observation of suddenly increasing contaminant concentrations at a number of other tank farms. The increased frequency of sampling provides assurance that changes will be rapidly detected. The wells are sampled for a broader suite of constituents than specified under the RCRA interim-status requirements. 
This WMA is currently in RCRA interim-status indicator evaluation. There were several critical mean exceedances for total organic halides during FY 1998. The exceedances are a result of an upgradient carbon tetrachloride source near the Plutonium Finishing Plant and are not related to the WMA. The critical means are discussed in Appendix B.

\subsubsection{216-U-12 Crib}

RCRA groundwater monitoring began at this crib in 1991. In the January 1993 sampling event, specific conductance in two downgradient wells (299-W22-41 and 299-W22-42) significantly exceeded upgradient concentrations, promoting the initiation of RCRA interim-status groundwater quality assessment to determine if the crib affected the quality of the groundwater in the uppermost aquifer beneath it (WHC-SD-LEF-EV-001). In FY 1998, five network monitoring wells were sampled quarterly for constituents of interest (see Appendix A).

The results and findings of the assessment-monitoring program, as required by 40 CFR 265.93, are presented in PNNL-11574. The elevated levels of specific conductance in the downgradient wells are attributed to nitrate (the mobile anion released when nitric acid is diluted in water) and calcium (released from the sediments as acid is neutralized). Technetium- 99 has also been elevated in the trigger wells since monitoring began. The source of these constituents is the crib.

Based on the results of the investigation (PNNL-11574), the site must remain in interim-status assessment monitoring because of continued elevated levels of technetium-99 and nitrate. However, the objective of the assessment monitoring, rather than delineating the existing plumes, will be focused on 1) determining whether the flux of constituents into the groundwater is increasing, staying the same, or decreasing; 2) monitoring the known constituents until a near-term interim corrective action is defined; and 3) monitoring until a final-status monitoring plan is implemented for the crib.

The crib will not receive additional effluents and is scheduled, according to provisions of the Hanford Site RCRA Permit (Ecology 1994), to be closed under RCRA final-status regulations in 2003.

In addition to the groundwater-quality issues, declining water levels in the 200-West Area are affecting the ability to sample the network wells. One new well (299-W22-79) was installed in November 1998 to replace well 299-W22-42, which will be dry by calendar year end (see Plate 1). Well 299-W22-40 will also go dry during calendar year 1999 but will not be replaced because it has not detected any crib contaminants. Groundwater-decline projections indicate that, at the current rate, the other two network wells (299-W22-41, downgradient, and 299-W22-43, upgradient) will go dry within the next 1 to 2 years. Regulatory negotiations are planned in early FY 1999 to determine a compliant groundwater-monitoring approach for the crib. This approach may require additional new wells to replace one or more of the wells going dry. The revised network will utilize existing wells, if possible, to replace the old network.

\subsubsection{216-S-10 Pond and Ditch}

During FY 1998, this facility was monitored semiannually under RCRA interim-status indicator evaluation (see Appendix A). Statistical comparisons of contaminant indicators to critical mean values are shown in Appendix B. 
The current monitoring network is adequate for the monitoring objectives at this facility; however, the water table in the vicinity is dropping at an average rate of $0.53 \mathrm{~m} / \mathrm{yr}$. Upgradient well 299-W26-8 went dry and could not be sampled after January 1998. The network will remain compliant with just one upgradient well (299-W26-7). Background values for the facility were recalculated based on just one upgradient well (299-W26-7). Assuming this rate continues, within 1 year downgradient wells 299-W26-9 and 299-W26-10 will not contain enough water to be sampled with the installed pumps. A revised groundwater-monitoring network will be proposed in calendar year 1999 to maintain a compliant groundwater-monitoring approach.

Two of the downgradient wells (299-W26-10 and 299-W26-12) continue to be plagued with slightly turbid samples. Turbidity ranged as high as 108 nephelometric units (NTUs) during FY 1998. This is not believed to have serious impacts on the sample results for detection parameters.

\subsubsection{Low-Level Waste Management Area 3}

Groundwater-monitoring wells at this LLWMA are sampled semiannually (March and September) in accordance with RCRA interim-status regulations. See Appendix A for a list of monitoring wells and a constituent list. There were no exceedances of the upgradient/downgradient comparison values for any of the indicator parameters.

The overall monitoring well network continues to be adequate, and no additional wells are planned.

\subsubsection{Low-Level Waste Management Area 4}

Samples are taken semiannually for contamination indicator parameters in accordance with RCRA interim-status regulations. See Appendix A for a list of monitoring wells and a constituent list.

The groundwater-monitoring network for LLWMA 4 was revised in FY 1998 (WHC-SD-ENAP-015) to reflect the current groundwater-flow direction (predominantly west to east). The network modifications were also needed to accommodate the declining water level beneath the LLWMA. The water level in several wells dropped to the point that sampling was impracticable or the sampling method produced unreliable results (e.g., bailing without adequate purging).

The decision was also made to curtail statistical evaluation of the upgradient/downgradient comparison values until the flow regime stabilizes following the 200-ZP-1 Operable Unit pump-and-treat activities. At that time, the comparison values will be reestablished with quarterly sampling for the contamination indicator parameters. Semiannual sampling will continue for the constituents listed in Appendix A to determine when stabilization occurs and to maintain continuity in the database.

\subsubsection{State-Approved Land-Disposal Site}

Liquid effluent (essentially deionized water with tritium) from the 200 Areas Effluent-Treatment Facility is discharged to the State-Approved Land-Disposal Site (see Plate 1). These facilities are regulated by a state waste-discharge permit, promulgated by WAC 173-216. The permit was granted in June 1995, and operation began in December 1995. The permit stipulates requirements for groundwater monitoring and criteria for allowable concentrations of several constituents (WHC-SD-C018H-PLN-004, 
Rev. 1). Groundwater-monitoring requirements are specified in the discharge permit and are discussed in detail in PNNL-11665. During FY 1998, groundwater-monitoring wells immediately downgradient of the facility continued to reflect discharges of high levels of tritium to the facility. Well 699-48-77A produced a maximum result of $1,700,000 \mathrm{pCi} / \mathrm{L}$ (December 17,1997$)$. Well 699-48-77D produced the highest result thus far observed in groundwater near the facility, 2,100,000 pCi/L (April 15, 1998). These occurrences were predicted and are within the performance criteria- of the state waste=discharge permit:--Well 699-48-77C, also a nearby downgradient well, produced only relatively minor levels of tritium (up to $4,100 \mathrm{pCi} / \mathrm{L}$ in 1998 ) because it is completed deeper in the aquifer. Other monitoring wells designated to track the effects of system operation showed no evidence of tritium incursion from the facility. Elevated levels of sulfate, calcium, and related properties (e.g., specific conductance) also appear intermittently in these wells, but these constituents are derived from natural salts in the vadose zone beneath the facility (PNNL-11633, PNNL-11665). No other constituents have exceeded permit criteria.

\subsubsection{Environmental Restoration Disposal Facility}

This facility is a landfill authorized by CERCLA that is designated to meet RCRA minimum technology requirements pursuant to Subpart N, 40 CFR 264. The groundwater-monitoring network consists of one upgradient and three downgradient wells that are sampled semiannually. In addition, the facility has a leachate-collection and -removal system that helps evaluate whether the liner system is performing within design standards. The groundwater-protection plan for the Environmental Restoration Disposal Facility is published in BHI-00079 and the groundwater-monitoring sampling plan is documented in BHI-00873. The monitoring well locations and constituent list are given in Appendix A.

No impact to groundwater is expected to occur from this facility. Groundwater data collected from the monitoring network indicates that the facility is not impacting groundwater. However, there are eight existing plumes near or extending into the area of the facility: tritium, iodine-129, technetium-99, uranium, nitrate, carbon tetrachloride, trichloroethylene, and chloroform. The sources of all the contaminant plumes are upgradient of the facility, inside the 200-West Area.

\subsubsection{Drinking Water Standards and Derived Concentration Guides}

Tritium was detected at levels greater than the DCG in one sample from well 299-W14-2, located near WMA TX-TY and associated facilities. This is the first time since site operations ceased that tritium has been detected at these levels in the northern part of the 200-West Area. Total uranium analyses of samples from wells near U Plant that indicate the DCGs for uranium-234 and uranium-238 were exceeded. Tritium, iodine-129, and technetium-99 were found at levels above the interim DWSs in the 200-West Area. Uranium was found at levels above its proposed MCL. Nitrate, chromium, carbon tetrachloride, trichloroethylene, fluoride, chloroform, and nickel were detected at levels above the MCLs. Manganese was detected at levels above the secondary MCL in filtered samples. Cadmium was detected at levels above the MCL in several filtered samples, but the results do not follow the trends for the wells and are considered suspect. Nitrite is sporadically detected at levels above the MCL.

\subsubsection{Extent of Contamination}

The groundwater contamination in the 200-West Area may generally be related to the four major production plants: T, REDOX, $U$, and Plutonium Finishing Plants. The discussion below divides the 
monitoring activities according to these four major areas. LLWMA 3 and LLWMA 4 are discussed separately because RCRA detection monitoring indicates that they have not contributed to the existing contamination. The State-Approved Land-Disposal Site, a relatively new disposal facility north of the 200-West Area, is discussed separately.

\subsubsection{T Plant}

Groundwater plumes originating from the T Plant area include tritium, iodine-129, technetium-99, uranium, nitrate, and chromium. A fluoride plume is also present in the area. Carbon tetrachloride and trichloroethylene plumes, originating near the Plutonium Finishing Plant, appear to extend throughout the T Plant area. Aqueous discharges to the 216-T-19 crib may be responsible for part of the carbon tetrachloride and trichloroethylene plumes in that area (WHC-SD-EN-TI-248).

Tritium. A tritium plume covers much of the northern half of the 200-West Area and extends to the northeast (see Plate 3). In June 1998 , a tritium activity of $3,210,000 \mathrm{pCi} / \mathrm{L}$ was measured in a sample from well 299-W14-2, located east of WMA TX-TY adjacent to the 216-T-28 crib. This value, which is greater than the 2,000,0000-pCi/L DCG for tritium, is much greater than any other in the area and greater than that seen previously in this well (Figure 5.9-1). The high tritium correlates with iodine-129, which shows a similar sudden increase to $81.4 \mathrm{pCi} / \mathrm{L}$. Condensate from the 242-T evaporator is a likely source of this contamination; however, the cause for the sudden increase is unknown. Concentrations of tritium in wells 299-W15-22 and 299-W15-4, located west and south of WMA TX, declined sharply in FY 1997 and remained low in FY 1998. These wells are within the zone of hydraulic influence for the 200-ZP-1 Operable Unit pump-and-treat system, which probably caused the concentration decline. An area north of WMA T consistently shows tritium at levels much lower than the surroundings, which may be related to past discharge of relatively clean water to the 216-T-4-2 ditch (WHC-EP-0815). Discharge of water to the 216-T-4-2 ditch ceased in 1995, and contaminant concentrations in nearby wells subsequently increased. Concentrations of tritium and other contaminants, including nitrate and technetium-99, increased markedly in well 299-W11-27 in the northeastern corner of WMA T during FY 1996 and FY 1997. Concentrations declined slowly in FY 1998, but remain above pre-1996 levels (Figure 5.9-2).

Iodine-129. The extent of iodine-129 above the interim DWS in the T Plant area (see Plate 5) coincides generally with the tritium (see Plate 3 ) and technetium-99 plumes. The maximum iodine-129 activity detected in this vicinity in FY 1998 was $81.4 \mathrm{pCi} / \mathrm{L}$ in well 299-W14-2. This is considerably higher than that detected in recent years and is correlated with elevated tritium values (see above). In FY 1998, iodine-129 also increased in well 299-W14-12, located south of well 299-W14-2, east of WMA TX-TY.

Technetium-99. A technetium-99 plume is present in the T Plant area (Figure 5.9-3), but the activities are less than the DWS in most of the area. The two areas with technetium-99 greater than the DWS are near the northeastern corner of WMA $T$ and in the WMA TX-TY area. The RCRA assessment concluded that WMAs T and TX-TY were probably the sources of this technetium-99.

Technetium-99 activities increased sharply in FY 1997 in the northeastern corner of WMA T. The area where high-technetium-99 concentrations were detected increased slightly in FY 1998, but the maximum values, which continue to be found in well 299-W11-27, decreased somewhat to give an FY 1998 
average of $13,000 \mathrm{pCi} / \mathrm{L}$ (see Figure 5.9-2). Technetium-99 in well 299-W11-23, located $\sim 25 \mathrm{~m}$ east of well 299-W11-27, increased in FY 1998, reaching a maximum of 5,950 pCi/L in August 1998.

Technetium-99 has been increasing in well 299-W15-22, located in the southwestern corner of WMA TX-TY. The FY 1998 average technetium-99 activity in this well was 3,100 pCi/L. The technetium-99 activity in well 299-W14-12 is also increasing somewhat, but remains below pre-1996 levels, with an FY 1998 annual average of $2,000 \mathrm{pCi} / \mathrm{L}$ (Figure 5.9-4).

Uranium and Gross Alpha. Few analyses for uranium were performed in the vicinity of T Plant in FY 1998 because most wells showed insignificant levels in previous monitoring. Wells monitored near the single-shell tank farms for RCRA compliance are sampled for gross alpha measurements, which would show an increase if uranium contamination appeared. Because uranium is typically the source of most elevated gross alpha measurements seen at the Hanford Site, it will also be discussed in this section. Uranium was detected above the proposed MCL in only one well in the T Plant area (Figure 5.9-5). Well 299-W11-14 contained $56 \mu \mathrm{g} / \mathrm{L}$ of uranium in the single FY 1998 sample. The value is consistent with measurements for the past several years. This well is located immediately northwest of T Plant, and the source of the uranium has not been determined. One sample from well 299-W10-18, located east of WMA TX-TY, showed $27.6 \mathrm{pCi} / \mathrm{L}$ of gross alpha, but the other three quarterly samples from this well contained $<4 \mathrm{pCi} / \mathrm{L}$ gross alpha. Gross alpha was also elevated in the February 1998 sample from well 299-W15-22, located southeast of WMA TX-TY $(157 \mathrm{pCi} / \mathrm{L})$, but declined to $16.5 \mathrm{pCi} / \mathrm{L}$ in May and to values $\angle 4 \mathrm{pCi} / \mathrm{L}$ by the August sample. Flow directions in the area of well 299-W15-22 have been affected by the 200-ZP-1 Operable Unit pump-and-treat system, so the source of the elevated gross alpha is problematic. Gross alpha was elevated in the November 1997, February 1998, and August 1998 samples from well 299-W11-27 (93.3,97.9, and $44 \mathrm{pCi} / \mathrm{L}$, respectively) but declined to $<4 \mathrm{pCi} / \mathrm{L}$ in the May sample. The gross alpha measurements in this well may have been affected by the high turbidity in the samples that results from declining water levels.

Nitrate. Much of the northern part of the 200-West Area continued to contain nitrate at concentrations in excess of the $45-\mathrm{mg} / \mathrm{L} \mathrm{MCL}$ (see Plate 4). The nitrate contamination is more widespread than the tritium/iodine-129/technetium-99 plumes discussed above. It is probable that there are multiple sources of nitrate in this area. Maximum annual average concentrations in this part of the 200-West Area in FY 1998 ranged up to $310 \mathrm{mg} / \mathrm{L}$ in well 299-W14-12, located east of WMA TX-TY.

Chromium. Chromium contamination continues to be found above the $100-\mu \mathrm{g} / \mathrm{L} \mathrm{MCL}$ in the T Plant area (Figure 5.9-6). Chromium is above the MCL in filtered samples from the area near WMA T, where the maximum average annual concentration detected in FY 1998 was $150 \mu \mathrm{g} / \mathrm{L}$ in well 299-W10-4. Chromium concentrations in well 299-W11-27, which exhibited a peak in FY 1996, remained below the MCL in FY 1997 and FY 1998. This peak in chromium occurred earlier and was sharper than the peak in technetium-99. Thus, there appears to be a transient chromium pulse superimposed on a small but morepersistent plume.

Fluoride. Fluoride was detected above the 4-mg/L MCL near the T Plant waste-disposal facilities. The fluoride contamination was found in a number of wells in the vicinity of WMA $T$, with individual measurements in wells 299-W10-4 and 299-W10-12 greater than the primary MCL. However, the FY 1998 average concentration was less than the primary MCL for all wells. 
Chlorinated Hydrocarbons. Although the bulk of the carbon tetrachloride plume in the 200-West Area is known to have originated from liquid waste-disposal facilities in the vicinity of the Plutonium Finishing Plant, a second source may exist in the vicinity of T Plant. According to WHC-SD-EN-TI-248, the source could be carbon tetrachloride that was dissolved in the 242-T evaporator overhead and discharged from 1973 to 1976 to the 216-T-19 crib. The carbon tetrachloride distribution in the 200-West Area is shown in Figure 5.9-7. Carbon tetrachloride concentrations in the vicinity of T Plant are highly variable. Of particular note are relatively low carbon tetrachloride concentrations $(<500 \mu \mathrm{g} / \mathrm{L}$ but still above the 5- $\mu \mathrm{g} / \mathrm{L} \mathrm{MCL}$ ) in the vicinity of the southeastern corner of WMA TX-TY. This area is within the hydraulic influence of the 200-ZP-1 Operable Unit pump-and-treat system discussed below. Although data are sparse, there appears to be a generally low carbon tetrachloride concentration area in the eastcentral part of the 200-West Area.

Trichloroethylene is also found at levels above the MCL in the vicinity of T Plant but at levels considerably lower than carbon tetrachloride. The area of trichloroethylene greater than the MCL extends from the Plutonium Finishing Plant northeast through the T Plant vicinity (Figure 5.9-8).

WMA T RCRA Parameters. Specific conductance in well 299-W10-12, the replacement for well 299-W10-15, remained $>1,000 \mu \mathrm{S} / \mathrm{cm}$ during FY 1998 (Figure 5.9-9). The elevated specific conductance for groundwater in this well is principally a result of elevated concentrations of nitrate and sodium. Nitrate and tritium exceeded their MCL/DWS during FY 1998, as has gross beta. This contamination pattern is a result of a regional contaminant plume and not a direct result of contaminants from within WMA T.

Specific conductance in well 299-W11-27 has been declining slowly-since a peak in FY 1997 (see Figure 5.9-9). This pulse in specific conductance results from increases in nitrate, calcium, magnesium, and sulfate and was accompanied by increases in tritium, technetium-99, cobalt-60, and chromium. Technetium-99 is the major contaminant present, reaching the $21,700-\mathrm{pCi} / \mathrm{L}$ peak in $\mathrm{FY} 1997$, which is $\sim 24$ times its interim DWS. Levels were lower in FY 1998, with an annual average activity of $12,700 \mathrm{pCi} / \mathrm{L}$ (see Figure 5.9-2). Nitrate exceeded the MCL in this well in FY 1998. Cobalt-60 was also detected in some samples from this well, with a maximum activity in FY 1998 of $18.8 \mathrm{pCi} / \mathrm{L}$.

The contaminants affecting groundwater quality in well 299-W11-27 represent a very narrow plume. Well 299-W10-8 remains unaffected by the plume, while well 299-W11-23 only became impacted in FY 1998, as discussed above with regard to technetium-99. This lack of lateral dispersion, which indicates a nearby source, coupled with the observed chemistry offers strong indication that the groundwater contamination observed in well 299-W11-27 originated within WMA T.

An assessment report released in 1998 (PNNL-11809) reached the conclusion that the contaminants observed in well 299-W11-27, which peaked in concentration in FY 1997, are most likely the result of sources within WMA T. It is uncertain, however, whether the observed decreases in contaminant concentrations are a result of a transient source, declining water table, and/or changes in groundwater-flow direction.

WMA TX-TY RCRA Parameters. Specific conductance in WMA TX-TY downgradient well 299-W10-17 remained elevated (annual average of $716 \mu \mathrm{S} / \mathrm{cm}$ ) during FY 1998 (Figure 5.9-10). The 
elevated specific conductance for groundwater in this well is principally a result of elevated concentrations of nitrate and sodium. Nitrate, tritium, and gross beta exceeded their DWSs during FY 1998. This contamination pattern is a result of a regional contaminant plume.

Specific conductance in WMA TX-TY downgradient well 299-W14-12 also remained elevated (annual average of $740 \mu \mathrm{S} / \mathrm{cm}$ ) during FY 1998 (see Figure 5.9-10); the sharp decrease of the past several years having moderated. The high specific conductance in this well is principally a result of elevated nitrate, calcium, magnesium, and sulfate, which is distinctly different from the regional sodium/nitrate signature. Concentrations of all contaminants have decreased along with specific conductance; however, in FY 1998, tritium, iodine-129, technetium-99, gross beta, and nitrate increased somewhat in late FY 1998 and remain above their respective DWSs.

Well 299-W15-22, formerly the upgradient well for WMA TX-TY, showed an increase in technetium-99, nitrate, calcium, and magnesium over the past several years. In FY 1998, technetium-99 exceeded the DWS with an average activity of $3,100 \mathrm{pCi} / L$. The source for this contamination is uncertain. Flow directions in the vicinity of this well have been impacted by the 200-ZP-1 Operable Unit pump-and-treat remediation, so this well can no longer be considered hydraulically upgradient of WMA TX-TY.

\subsubsection{REDOX Plant}

Groundwater plumes originating in the vicinity of the REDOX Plant and its associated waste-storage and -disposal facilities include tritium, iodine-129, technetium-99, uranium, nitrate, chromium, and trichloroethylene at levels above the MCLs/DWSs. Strontium- 90 was detected at levels above the interim DWS in one well (299-W22-10). Two facilities in this vicinity (WMA S-SX and 216-S-10 pond and ditch) have RCRA monitoring requirements and are discussed separately. Other facilities, however, appear to have produced the major part of the groundwater contamination.

Tritium. A tritium plume extends eastward from the vicinity of the REDOX Plant in the southern part of the 200-West Area (see Plate 3). The eastern part of the plume curves to the north, but the tritium activities in the northern part of this plume are declining, as illustrated by the tritium trend plot for well 699-40-62 (Figure 5.9-11). However, concentrations continue to increase slowly at the eastern part of the plume, as shown by well 699-36-61A (see Figure 5.9-11). Tritium was found above the interim DWS upgradient of the REDOX Plant as far as the 216-S-25 crib.

The tritium plume from the 200-West Area extends to US Ecology's low-level radioactive wastedisposal facility. The maximum tritium activities $(4,565$ to $4,907 \mathrm{pCi} / \mathrm{L})$ detected in groundwater at that facility in FY 1998 were in well 699-35-59 (US Ecology well no. 13). Tritium concentrations in that well, located on the western (upgradient) side of the facility, have continued to increase over the past several years. These data were provided by US Ecology and are not included on the diskette included with this report or shown in Plate 3.

Movement of this tritium plume is expected to be slow because of the low-permeability sediments in the area and the dissipation of the groundwater mound beneath the 200-West Area since the reduction of effluent discharge. 
The source of tritium in monitoring wells in the vicinity of WMA S-SX is attributed to the pastpractice disposal sites (e.g., 216-S-4, 216-S-21, 216-S-25). Apparently, drainage of residual tritiated water from the soil column beneath these facilities supplies the elevated tritium in nearby downgradient monitoring wells 299-W23-4 and 299-W23-9 (Figure 5.9-12). Based on the time-concentration patterns shown in Figure 5.9-12, tritium in well 299-W23-14 appears to be related to the 216-S-25 crib source (based on the pattern for well 299-W23-9). The time-concentration pattern in well 299-W22-46 farther downgradient and along the projected flow path exhibits a pattern very similar to the 1984 and 1990 segment for well 299-W23-9. Using the dates for the "knee" in the tritium plots (1987 and 1997, respectively), the implied travel time between the two wells is $30 \mathrm{~m} / \mathrm{yr}$. On the other hand, tritium in well 299-W23-15 exhibits a quite different pattern. One possibility is that well 299-W23-15 was installed too late to detect the increase in tritium seen in wells 299-W23-9 and 299-W22-46. Well 299-W23-15 may also be located slightly off center of the tritium-plume flow path, leading to the somewhat more rapid decline in tritium concentrations in well 299-W23-15 when compared to the trend in 299-W23-9. Other complex tritium-concentration patterns are also observed in wells immediately north of 299-W22-46 (Figure 5.9-13) that tend to suggest either different sources or variations in flow paths and arrival times. The dynamic tritium-response patterns in monitoring wells in this area illustrate the complex interaction of tritium-release history, hydraulics, and hydrogeology.

Iodine-129. An iodine-129 plume from the 200-West Area (see Plate 5) extends into the 600 Area to the east and coincides with the tritium plume originating near the REDOX Plant (see Plate 3). This iodine-129 plume and the iodine-129 contamination originating farther north near U Plant appear to coalesce downgradient and become indistinguishable at the current level of monitoring detail. The maximum annual average iodine-129 activity detected in this plume in FY 1998 was $33 \mathrm{pCi} / \mathrm{L}$ in well 299-W22-9. The sample from this well may not be representative of typical aquifer activities because the well contained very little water and was sampled with a bailer (i.e., not purged). This well could not be sampled in FY 1997, but the FY 1996 value for iodine-129 was $66 \mathrm{pCi} / \mathrm{L}$.

Technetium-99. Technetium-99 was above the DWS in two wells located near WMA S-SX. Evidence from recent years suggests that multiple sources of technetium-99 in the tank farm are contributing to groundwater contamination (PNNL-11810). Activities of technetium-99 in well 299-W23-1, located in the SY tank farm, were highly variable, ranging from 513 to $2,890 \mathrm{pCi} / \mathrm{L}$, with an FY 1998 average of $1,300 \mathrm{pCi} / \mathrm{L}$. Technetium-99 activities in well $299-\mathrm{W} 22-46$, southeast of the SX tank farm, remained relatively high, with an FY 1998 average of $4,100 \mathrm{pCi} / \mathrm{L}$. It should be noted that past data suggest that the 216-S-13 crib may have contributed to the technetium-99 detected downgradient of WMA S-SX.

Uranium. Uranium was found above the proposed MCL to the west of the REDOX Plant (see Figure 5.9-5). The uranium contamination extends from areas upgradient of the technetium-99 plume toward the REDOX Plant. The highest uranium concentration detected in FY 1997 in the vicinity of the REDOX Plant was $150 \mu \mathrm{g} / \mathrm{L}$ in the single sample from well 299-W22-21 immediately downgradient of the 216-S-13 crib. This well, however, could not be sampled in FY 1998 because of the declining water levels. One potential alternate source of this uranium contamination is the 216-S-25 crib, which is generally upgradient of the $216-\mathrm{S}-13$ crib. Uranium concentrations in this well fluctuate considerably. Uranium concentrations detected in well 299-W23-7 within WMA SX varied from 3.25 to $90 \mu \mathrm{g} / \mathrm{L}$. This well has nearly gone dry as a result of declining water levels and shows poor hydraulic connection to the aquifer. The samples are typically turbid and, thus, may not provide an accurate representation of aquifer concentrations. 
Strontium-90. Strontium-90 was only detected at levels above the DWS in the single sample from 299-W22-10 $(29.6 \mathrm{pCi} / \mathrm{L})$. Strontium-90 activities in this well have been erratic in the past. The 216-S1 and 216-S2 cribs are a likely source of the strontium- 90 .

Nitrate. Nitrate was detected in FY 1998 above the MCL in two small plumes in the vicinity of the REDOX Plant (see Plate 4). The first plume is located near the 216-S-20 crib, which received laboratory waste from the 222-S building. Nitrate was detected above the MCL in well 299-W23-9 near the 216-S-25 crib and WMA S-SX.

Chromium. Chromium continues to be detected at levels above the MCL in well 299-W26-7, the upgradient well for the 216-S-10 pond and ditch (Figure 5.9-14). Chromium concentrations in this well have increased, reaching $576 \mu \mathrm{g} / \mathrm{L}$ in FY 1998. The source of the chromium contamination has not been determined, but it is possibly related to the 216-S-10 pond or to earlier disposal to upgradient facilities (termed the "REDOX swamp" in some early reports). There may be a relationship between the chromium observed in well 299-W26-7 and chromium detected farther downgradient, south of the 200-East Area (discussed in Section 5.12.3.3).

Trichloroethylene. A small trichloroethylene plume, with concentrations just above the MCL, has been found in past years to the east of the REDOX Plant. Trichloroethylene was not detected in this vicinity in FY 1998. The 216-S-20 crib is a likely source of the trichloroethylene plume.

WMA S-SX RCRA Parameters. Mobile tank waste co-contaminants technetium-99, nitrate, and chromium (see Figure 5.9-3, Plate 4, and Figure 5.9-14) are the primary constituents of concern for assessment purposes at WMA S-SX (PNNL-11810). Time-concentration plots of these constituents for RCRA network monitoring wells are shown in Figure 5.9-15. The primary changes during FY 1998 were increasing and then decreasing trends for the above co-contaminants in well 299-W22-46. These trends appear to be similar to those observed in well 299-W23-15 in 1992-1993. The inferred flow direction (to the east-southeast) in this area suggests the same contaminants that passed by well 299-W23-15 may now be passing well 299-W22-46.

Lower, but sharply increasing, concentrations of technetium- 99 , nitrate, and chromium also occurred in well 299-W22-45 (Figure 5.9-16). This RCRA monitoring well is not located downgradient from any obvious single-shell tank leak or spill site. The nearest upgradient sources consist of three diversion boxes (and associated transfer lines) used in the past to route tank waste to both the S and SX tank farms. Thus, past spills from transfer lines or from the diversion boxes themselves are potential sources for the increasing trends in well 299-W22-45 (see Figure 5.9-12 for locations). These and other (nontank) sources will be evaluated as part of the integrated yadose-zone/groundwater characterization effort for the RCRA facility investigation for WMA S-SX currently being negotiated.

A transient occurrence of elevated technetium-99, nitrate and chromium was also observed in an old, non-RCRA well (299-W23-1) inside the S tank farm (between tanks S-107 and S-110). Concentrations peaked in early 1998 and then declined. The maximum technetium-99 activity was $2,890 \mathrm{pCi} / \mathrm{L}$. A similar event occurred in 1986. The cause of these short-term transients has not been determined, though infiltration of surfacewater through past tank leaks or related spills is suspected of mobilizing contamination (Johnson and Chou 1998). 
Other RCRA parameters of concern include strontium-90 and cesium-137 because of the large inventories of these moderately long-lived fission products in the single-shell tanks. As in previous years, no detectable strontium- 90 or cesium-137 was observed in the RCRA monitoring wells. However, these constituents still persist in an old well (299-W23-7) between the S and SX tank farms near the eastern fenceline. A maximum cesium-137 (unfiltered) concentration of $49 \mathrm{pCi} / \mathrm{L}$ was observed in June 1998 . No detectable cesium-137 was found in filtered water collected at the same time. Also, elevated gross alpha $(247 \mathrm{pCi} / \mathrm{L})$ and uranium $(90 \mu \mathrm{g} / \mathrm{L})$ were observed in this well in September 1998 . The well can no longer be pumped, so the sample must be collected with a bailer (no purging) and results in a highly turbid (>100 NTU) sample. Because the well is apparently plugged (insufficient inflow of water for pumping/purging) and because it is poorly sealed, this well is scheduled for decommissioning. Additional isotopic analyses on filtered and unfiltered samples are planned prior to closure of the well.

Special Sampling Results. Groundwater samples were also collected from a new borehole (borehole 41-09-39 [also known as well 299-W23-234]) between tanks SX-108 and SX-109 that was extended to the water table (see Section 4.4 .5 for more information). This location is directly beneath one of the largest known single-shell tank leak sites. Accordingly, samples from this well were analyzed for many chemical and isotopic constituents (i.e., major cations and anions; nitrate and chromium [as well as other metals]; radionuclides, including tritium, iodine-129, technetium-99, uranium, cesium-137, neptunium-237, strontium-90, plutonium-239/-240, and americium-241). The only radionuclides detected were tritium and technetium-99. The detected radionuclides were present at activities less than occur in RCRA well 299-W23-14 immediately upgradient from well 299-W23-234. Except for the tritium and technetium-99, which were attributed to upgradient sources (HNF-2855), the groundwater was similar to natural background. Additional drilling in the SX tank farm is planned for the RCRA facility investigation of WMA S-SX.

216-S-10 Pond and Ditch RCRA Parameters. Groundwater quality, drinking water, or site-specific parameters did not exceed the DWSs during FY 1998, except for chromium that is discussed above. The chromium exceedance continues in well 299-W26-7 (576 $\mu \mathrm{g} / \mathrm{L}$ in the December 1997 sample) (see Figure 5.9-14).

Specific conductance ranged from 173 to $286 \mu \mathrm{S} / \mathrm{cm}$ (the critical mean is $325.6 \mu \mathrm{S} / \mathrm{cm}$ ) in wells that sample the upper portion of the unconfined aquifer system and are subject to statistical testing of indicator parameters. Total organic carbon ranged from 370 to $904 \mu \mathrm{g} / \mathrm{L}$. The laboratory limit of quantitation is $1,179 \mu \mathrm{g} / \mathrm{L}$. The range of total organic halides was 2.38 to $11.7 \mu \mathrm{g} / \mathrm{L}$. The limit of quantitation is $39.3 \mu \mathrm{g} / \mathrm{L}$.

In the past, well 299-W26-8 showed levels of gross alpha slightly elevated over other 216-S-10monitoring wells (Figure 5.9-17). The last sample taken from this well before it went dry (December 1997) had an 11.40-pCi/L gross alpha level. Well 299-W26-8 was an upgradient well, which suggests the 216-S-10 facility is probably not the source of the elevated alpha levels. The source may be the $216-U-10$ pond (U Pond [now decommissioned]), which is upgradient of the 216-S-10 facility and known to have received radioactive wastewater. 


\subsubsection{U Plant}

Uranium, technetium-99, iodine-129, nitrate, and trichoroethylene are the major plumes originating in the vicinity of U Plant and associated waste-storage and -disposal facilities. Interim-action groundwater pump-and-treat remediation is taking place in the vicinity of $U$ Plant. Because of the effects of the remediation and injection of treated water into the aquifer, the plume maps in this report are somewhat generalized in the area of system influence. This section discusses the contamination from the facilities in the vicinity of $U$ Plant, including the contamination currently being remediated in accordance with CERCLA and the specific reporting requirements for RCRA monitoring at the $216-\mathrm{U}-12 \mathrm{crib}$ and WMA U.

Uranium. The highest uranium levels in groundwater occurred near U Plant in FY 1998 in wells downgradient from the 216-U-1 and 216-U-2 cribs and adjacent to the 216-U-17 crib (see Figure 5.9-5). Uranium concentrations in wells near the 216-U-1 and 216-U-2 cribs showed a large pulse of uranium in approximately 1986. A trend plot of uranium concentrations in samples from well 299-W19-3, immediately downgradient from the cribs, is shown in Figure 5.9-18. The uranium levels in this well decreased considerably since the maximum measured in 1986 but remained at levels far greater than the proposed MCL since 1990. Concentrations in this well recently increased somewhat, reaching an FY 1998 average of $1,850 \mu \mathrm{g} / \mathrm{L}$. The maximum average annual uranium detected near U Plant in FY 1998 was $2,400 \mu \mathrm{g} / \mathrm{L}$ in a sample from well 299-W19-20 (see Figure 5.9-5). The uranium concentrations for several wells in the U Plant vicinity represent dose values greater than the DCG. Assuming natural isotopic abundance, a uranium concentration of $790 \mu \mathrm{g} / \mathrm{L}$ represents the $100-\mathrm{mrem} / \mathrm{yr}$ dose equivalent for ingestion of drinking water. The uranium plume extends into the 600 Area to the east.

Uranium distribution in the vicinity of the $216-U-17$ crib has been affected by pump-and-treat remediation (discussed in Section 5.9.4.1). The remediation system has impacted the flow directions, both through the pumping and past reinjecting of the treated groundwater upgradient of the pumping well. The effect of the reinjection is decreasing because reinjection ceased in March 1997. As expected, uranium concentrations decreased near the injection well and increased near the pumping well as the plume is drawn toward the pumping well.

Technetium-99. Technetium-99 typically followed uranium throughout much of the fuel cycle. Thus, a sizable technetium-99 plume is associated with the 216-U-1, 216-U-2, and 216-U-17 cribs in essentially the same location as the uranium plume (see Figures 5.9-3 and 5.9-5). The maximum average annual technetium-99 activity associated with this plume in FY 1998 was $14,000 \mathrm{pCi} / \mathrm{L}$, found in well 299-W19-26 (see Figure 5.9-3). The distribution of technetium-99 in this vicinity is complex, in part because of the operation of the pump-and-treat remediation system that reinjected treated water until March 1997. Technetium-99 in the vicinity of the $216-U-12$ crib exhibits a distribution similar to nitrate.

The technetium-99 distribution in the vicinity of the 216-U-17 crib has also been affected by pumpand-treat remediation. Further details are given in Section 5.9.4.1.

Technetium-99 remains slightly elevated in wells downgradient of WMA U. Levels are below the DWS but higher than upgradient wells. The highest value was in well 299-W19-31, where the annual average activity was $390 \mathrm{pCi} / \mathrm{L}$. 
Iodine-129. Iodine-129 was found above the interim DWS in the immediate vicinity of the 216-U-1 and 216-U-2 cribs (see Plate 5). The maximum average annual iodine-129 activity detected near U Plant was $4.8 \mathrm{pCi} / \mathrm{L}$ in the single sample from well $299-W 19-28$ east of the $216-U-1$ and $216-U-2$ cribs. Iodine-129 in well 699-38-70A farther south just outside the eastern fence of the 200-West Area, reached $15 \mathrm{pCi} / \mathrm{L}$ in FY 1998, but it is probable that this well has been impacted by disposal near the REDOX Plant. Downgradient, the iodine-129 plumes from U Plant operations become indistinguishable from the REDOX Plant plume (see Section 5.9.3.2).

Nitrate. Some of the highest onsite nitrate concentrations in FY 1998 continue to be found in wells east of U Plant near the 216-U-17 crib (see Plate 4). The maximum average annual concentration detected was $1,700 \mathrm{mg} / \mathrm{L}$ in well $299-W 19-26$. Elevated nitrate was observed in wells near this crib before February 1988 when the crib went into operation. The main source of the nitrate is believed to be wastes disposed to the $216-\mathrm{U}-1$ and $216-\mathrm{U}-2$ cribs. These cribs received $>1,000,000 \mathrm{~kg}$ of nitrate during their operation from 1951 to 1967 (PNL-6456). The distribution of the highest concentrations in the nitrate plume is similar to the technetium-99 plume, which would indicate a common source. The nitrate distribution near the $216-U-17$ crib is being affected by the pump-and-treat remediation discussed in Section 5.9.4.1. The pump-and-treat system initially included injection of treated water within the plume boundary. The detailed effects of the pump-and-treat system are not completely captured in Plate 4 .

Elevated nitrate concentrations are also observed farther south near the 216-U-12 crib. Nitrate concentrations downgradient of the crib continue to exceed the $45-\mathrm{mg} / \mathrm{L} \mathrm{MCL}$ and are greater than 10 times the average background value established in the upgradient well. The effluent disposed during the last years of crib operation is still believed to be seeping into the aquifer but at a slower rate than when a driving head was available. Concentration trends are expected to decline as the vadose zone drains.

Trichloroethylene. A relatively low-level trichloroethylene plume can be detected in groundwater near U Plant. The maximum average annual concentration of trichloroethylene found in FY 1998 in this plume was $13 \mu \mathrm{g} / \mathrm{L}$ in well 299-W19-35, located generally downgradient of the U Plant cribs. This plume extends to the east, beyond the 200-West Area boundary, but at levels less than the MCL in all FY 1998 samples.

WMA U RCRA Parameters. Specific conductance values in WMA U downgradient wells did not exceed the 533- $\mu \mathrm{S} / \mathrm{cm}$ critical mean in FY 1998. Total organic carbon values in downgradient wells did not exceed the upgradient/downgradient comparison value in FY 1998 (value set to the $1,179 \mu \mathrm{g} / \mathrm{L}$ limit of quantitation).

All field $\mathrm{pH}$ measurements in FY 1998 for WMA U RCRA monitoring wells fall within the range bracketed by the upper and lower comparison values (7.4 to 8.6) except one measurement of 7.11 in well 299-W19-32. Measured $\mathrm{pH}$ values for non-RCRA well 299-W19-12, also downgradient of the WMA, also fell within this range in FY 1998.

Total organic halide values up to $631 \mu \mathrm{g} / \mathrm{L}$, which are greater than the statistical comparison value of $241.3 \mu \mathrm{g} / \mathrm{L}$, were noted in well 299-W18-30 in FY 1997. Values in FY 1998 averaged less than the comparison value for this well, which is consistent with a decline in carbon tetrachloride from the levels observed in FY 1997. Total organic halides in FY 1998 exceeded the comparison value for well 
299-W19-31 for three sampling events. Increasing total organic halide values at WMA U are a result of carbon tetrachloride, and the pattern of concentration is consistent with increased encroachment by the Plutonium Finishing Plant's carbon tetrachloride plume and the return of groundwater-flow directions to an east-southeast direction.

216-U-12 Crib RCRA Parameters. The groundwater below this crib has been monitored and analyzed as part of the RCRA program since September 1991. The site-specific waste indicators selected for the crib's interim-status quality assessment monitoring include tritium, iodine-129, technetium-99, gross alpha, gross beta, and nitrate. The results and findings of Phases I and II of the assessmentmonitoring program are given in PNNL-11574. The crib is the source of elevated technetium-99 and nitrate detected in downgradient wells 299-W22-41, 299-W22-42, and 699-36-70A (see Plate 4 and Figure 5.9-3). The sources of the technetium- 99 and nitrate plumes are a commingled series of smaller plumes with sources from several cribs (216-U-1, 216-U-2, 216-U-8, and 216-U-12) in the U Plant area. Tritium and iodine-129 are detected repeatedly in several 216-U-12 crib downgradient monitoring wells, but the sources are associated with the REDOX Plant effluent disposal cribs that are upgradient of the 216-U-12 crib.

Indicator parameters (gross alpha, gross beta, $\mathrm{pH}$, specific conductance, total organic carbon, and total organic halides) are monitored at the crib as part of RCRA assessment monitoring. During FY 1998, specific conductance continued to be elevated above the $457.8-\mu \mathrm{S} / \mathrm{cm}$ critical mean value in downgradient wells 299-W22-41 and 699-36-70A. Specific conductance values in well 299-W22-42 are lower than in the past and have been fluctuating around the critical mean (Figure 5.9-19). The highest specific conductance values, averaging $\sim 654 \mu \mathrm{S} / \mathrm{cm}$, were measured in downgradient well 299-W22-41. As expected, nitrate and calcium, the greatest contributors to the elevated specific conductance (PNNL-11574), are trending similarly. Nitrate concentrations continue to be detected at levels $>45 \mathrm{mg} / \mathrm{L}$ DWG in downgradient wells 299-W22-41 and 699-36-70A. As expected, co-contaminants gross beta and technetium-99 trend with specific conductance and nitrate. Technetium-99 activities do not exceed the interim DWS, and average $\sim 75$ to $80 \mathrm{pCi} / \mathrm{L}$ in wells $299-\mathrm{W} 22-41$ and $699-36-70 \mathrm{~A}$.

Regional tritium plume activities (20,000-pCi/L interim DWG) increased in downgradient wells 299-W22-41 and 299-W22-42 in FY 1998. The most recent concentrations are 12,700 and 45,000 pCi/L, respectively. Tritium values in downgradient well 699-36-70A declined from initial values that were $>350,000 \mathrm{pCi} / \mathrm{L}$ to $<100,000 \mathrm{pCi} / \mathrm{L}$. Although tritium is a documented component of the effluent disposed to the $216-U-12$ crib, tritium results collected in upgradient well $299-W 22-23$ suggest that there more likely is an upgradient source from REDOX Plant operations (Figure 5.9-20).

\subsubsection{Plutonium Finishing Plant}

Contamination from volatile organic compounds, predominantly carbon tetrachloride, forms the major plumes discussed in this section. The Plutonium Finishing Plant was not a significant contributor to the tritium or iodine-129 plumes. Migration of plutonium contamination from the vadose zone is of concern because of the large quantities disposed in the area and the presence of organic complexing agents and/or the formation of colloids that could enhance mobility. Nitrate contamination is also present. Remediation of volatile organic compounds in groundwater and the vadose zone is being 
undertaken in this area. The only facilities near the Plutonium Finishing Plant with RCRA monitoring requirements are the burial grounds in LLWMA 4. These are not believed to contribute to groundwater contamination and are discussed separately.

Plutonium, Americium, and Neptunium. Plutonium-239/-240 and americium-241 were detected at low levels (up to 8.3 and $5.9 \mathrm{pCi} / \mathrm{L}$, respectively) in 1990 and 1991 in well 299-W15-8, which monitors the 216-Z-9 trench. This trench received a large burden of transuranic wastes from Plutonium Finishing Plant liquid effluent streams. That well has not been monitored for transuranic wastes since 1991 because the water level dropped below the well screen. A replacement for the well has been proposed for FY 1999. The origin of the transuranic contaminants in the well is unclear but may be associated with poor-quality well completion and, thus, may be very localized or may represent mobilization by complexants in the organic liquid phase (WHC-SD-EN-TI-248). Extraction well 299-W15-32, located next to the 216-Z-9 trench, has been sampled for plutonium isotopes for the last several years and for neptunium-237 and americium-241 in FY 1998, without detecting any plutonium, neptunium, or americium. However, because this well draws water from a considerable area, the samples may not be representative of contaminant activities directly under the trench.

The potential mobilization of plutonium and americium isotopes in the organic liquid phase discharged to the ground in the vicinity of the Plutonium Finishing Plant is discussed in WHC-SD-EN-TI248. A carbon tetrachloride liquid that contained tributylphosphate was used in the purification process to complex and remove plutonium from the aqueous phase. The distribution of transuranic contaminants in the vadose zone suggests an increased mobility at the time of disposal because of their transport in the nonaqueous-phase liquid or as aqueous complexes. Transport of transuranics in the vadose zone near the Plutonium Finishing Plant is discussed in Section 4.1.2. Recent logging data suggest that plutonium has not migrated deeper within the last 20 years. Thus, it appears the plutonium was only mobile at the time of emplacement and is fixed in place now.

Nitrate. The 216-Z-9 trench received an estimated $1,300,000 \mathrm{~kg}$ of nitrate-containing chemicals over the course of its operation from 1955 to 1962 . Other liquid waste-disposal facilities associated with the Plutonium Finishing Plant received smaller but significant amounts of nitrate. There is, thus, a nitrate plume originating in this area, with levels in FY 1998 that ranged up to a maximum concentration of $480 \mathrm{mg} / \mathrm{L}$ in well $299-\mathrm{W} 15-32$ (see Plate 4 ). This nitrate plume may contribute to the T Plant contamination discussed in Section 5.9.3.1.

Carbon Tetrachloride. Carbon tetrachloride contamination is present in the unconfined aquifer system beneath much of the 200-West Area and has migrated past the 200-West Area boundary (see Figure 5.9-7). The contamination is believed to be from pre-1973 waste operations associated with the Plutonium Finishing Plant. The maximum carbon tetrachloride concentration detected in the 200-West Area in FY 1998 was in extraction well 299-W15-32, where the annual average concentration was $6,600 \mu \mathrm{g} / \mathrm{L}$. Data from extraction wells are taken from project-specific data files and, thus, are not included on the diskette provided with this report. The MCL for carbon tetrachloride is $5 \mu \mathrm{g} / \mathrm{L}$. The contaminant concentrations and distribution suggest that nonaqueous-phase liquid is probably present above and below the water table. As discussed in Chapter 4.0, the major continuing source of carbon tetrachloride now appears to be below the water table. 
The carbon tetrachloride distribution in the 200-West Area groundwater changed slowly since the presence of the contaminant plume was first noted. The influence of the pump-and-treat operations, which were phased into operation starting in 1994, on the carbon tetrachloride distribution is becoming evident. There appears to be a shift in the maximum concentrations toward the pumping wells, and the treated water is displacing the plume in the vicinity of the injection wells west of the area. Figure 5.9-21 shows the carbon tetrachloride concentration trends over time for water-table wells around the plume. Concentrations in the northern part of the plume are increasing in well 299-W7-5, but remain highly variable with no apparent increase or decrease in other wells. The carbon tetrachloride concentrations in the north-central part of the plume appear to be declining (e.g., well 299-W11-7). Concentrations in well 299-W18-21, south of the disposal areas, peaked in 1994 and have declined considerably since. However, concentrations are generally increasing in the vicinity of WMA S-SX (e.g., well 299-W23-10). Concentrations in well 699-38-70, on the eastern edge of the plume, have remained relatively stable. Carbon tetrachloride concentrations in the central part of the plume remained $>2,000 \mu \mathrm{g} / \mathrm{L}$ and continued to be erratic, as shown in the trend plot (Figure 5.9-22) for well 299-W15-16. Overall, the extent of carbon tetrachloride at the water table as contoured at the $5-\mu \mathrm{g} / \mathrm{L} \mathrm{MCL}$ changed little from previous years. The apparent division into two lobes on the eastern side of the 200-West Area is based on past data from well 299-W14-10 in the eastern part of the 200-West Area as well as low concentrations measured east of WMA TX-TY. The low values currently seen just east of WMA TX-TY may be related to past discharge of water from the laundry facilities and steam plant. The data available for this area are insufficient to determine if this is the case or if, in fact, two separate lobes actually exist.

The carbon tetrachloride distribution shown in Figure 5.9-7 represents the concentrations found at or near the water table. As discussed below, the limited data on vertical distribution of carbon tetrachloride indicate that the concentrations are highest at the top of the aquifer and decline with depth at most locations, while some locations show an increasing trend with depth or a maximum in concentration at a depth of $\sim 30$ to $40 \mathrm{~m}$ below the water table. Figure 5.9-23 summarizes information on carbon tetrachloride concentrations at depths $>10 \mathrm{~m}$ below the water table. The figure includes data from wells completed in deeper zones in the aquifer and data from vertical profile measurements. The vertical profile measurements were collected using a variety of methods, including water sampling during drilling; sampling during well abandonment; sampling from older wells with long, open intervals using packers; or depthdișcrete bailing systems (e.g., Kabis sampler; Sibak Industries, Solana Beach, California). Thus, the data are not all comparable with regard to depth interval, geologic horizon, or volume of aquifer interrogated. The data indicate that the deepest samples in the northern and western parts of the 200-West Area show little carbon tetrachloride contamination. However, carbon tetrachloride is found at levels up to several thousand micrograms per liter at depths $>30 \mathrm{~m}$ below the water table in a number of wells in the central part of the 200-West Area.

Vertical contamination profiling of wells with large, open intervals and during well abandonment generally indicates gradually decreasing carbon tetrachloride contamination with depth within the 200-West Area. Vertical profiling activities were reported in BHI-00952-01, BHI-01121, and Section 5.9.3 of PNNL-11793. Of particular note were concentrations of $2,000 \mu \mathrm{g} / \mathrm{L}$ at a depth of $33.5 \mathrm{~m}$ below the water table during the decommissioning of well 299-W15-5, which was located south of the 216-Z-9 trench. In contrast, concentrations at well 299-W15-10, north of the Plutonium Finishing Plant, increased with depth, reaching $1,970 \mu \mathrm{g} / \mathrm{L}$, corresponding to a high-hydraulic conductivity zone $\sim 15 \mathrm{~m}$ below the top of the aquifer. Information on the vertical distribution of carbon tetrachloride in the 
vicinity of U Plant at greater than the MCL $(15.4 \mu \mathrm{g} / \mathrm{L})$ in a zone $>60 \mathrm{~m}$ below the water table in well 299-W19-34B is provided in BHI-00149. This contamination was found in an interval below the Ringold lower mud unit (see Unit 8 in Figure 3.1-2).

Carbon tetrachloride is detected at greater concentrations at depth within the aquifer than at the water table at two locations near the periphery of the plume. The first location is well 699-48-77C, located north of the 200-West Area, near the State-Approved Land-Disposal Site. This well is screened $\sim 21 \mathrm{~m}$ below the water table and shows gradually increasing carbon tetrachloride concentrations currently greater than the MCL (Figure 5.9-24). Concentrations in nearby well 699-48-70D, screened across the water table, have not shown carbon tetrachloride at levels above the MCL (see Figure 5.9-24). Because carbon tetrachloride was detected prior to the startup of the State-Approved Land-Disposal Site, the 200-West Area is the presumed source.

Carbon tetrachloride is consistently detected in well 299-W27-2, screened just above a clay layer, $\sim 55 \mathrm{~m}$ below the water table. The carbon tetrachloride concentration detected in this well in FY 1998 was equal to the 5- $\mathrm{g} / \mathrm{L}$ MCL. This well is adjacent to the $216-\mathrm{S}-10$ ditch south of the 200 -West Area fenceline. Carbon tetrachloride is not detected at the water table in this vicinity. Because there are few wells screened in deeper parts of the unconfined aquifer, these data suggest that the horizontal extent of carbon tetrachloride at levels greater than the MCL may be considerably greater than previously reported.

Carbon tetrachloride is also found at a depth of $\sim 58 \mathrm{~m}$ below the water table in well 299-W15-17 near the Plutonium Finishing Plant. Concentrations in this well have generally been increasing since 1997 and were greater than the MCL in FY 1998 (maximum of $12 \mu \mathrm{g} / \mathrm{L}$ in January 1998). Other wells screened at similar depths generally show carbon tetrachloride concentrations as $<1 \mu \mathrm{g} / \mathrm{L}$ or as nondetections.

Vertical profile samples were collected during drilling of two wells in the first quarter of FY 1999 and provide additional information on the vertical distribution of carbon tetrachloride (Figure 5.9-25). The first of these wells (299-W10-24) is located north of WMA T. The second (299-W14-14) is located east of WMA TX. Samples from both wells detected carbon tetrachloride through the complete drilled interval, with a maximum concentration found at 30 to $40 \mathrm{~m}$ below the water table $(1,600 \mu \mathrm{g} / \mathrm{L}$ in well 299-W10-24 and $920 \mu \mathrm{g} / \mathrm{L}$ in well 299-W14-14). Of particular significance is the detection of carbon tetrachloride in the deepest samples, which were collected below the Ringold lower mud unit. These wells were not completed at the total drilled depth but were completed as water-table wells. The data are consistent with the results from a research well (299-W11-32) that was completed with multiple screened intervals. The data from well 299-W11-32 showed an increasing trend with depth, but the well was not drilled as deep as wells 299-W10-24 and 299-W14-14 (see Figure 5.9-25).

Trichloroethylene and Chloroform. In addition to carbon tetrachloride, lesser concentrations of trichloroethylene and chloroform were found. Trichloroethylene is slightly above the MCL near the Plutonium Finishing.Plant (see Figure 5.9-8). The source is presumably disposal in the plant area, but disposal near T Plant may have also contributed to the plume. The origin of the chloroform is unknown but is suspected to be a degradation product of carbon tetrachloride. In the past, septic drainage fields operated in the area close to where the chloroform maximum was measured, so anaerobic bacterial degradation processes are indicated. The MCL for chloroform is $100 \mu \mathrm{g} / \mathrm{L}$ (total trihalomethanes), which is 20 times higher than that for carbon tetrachloride. The distribution of chloroform is shown in Figure 5.9-26. 


\subsubsection{Low-Level Waste Management Area 3}

Carbon tetrachloride and nitrate have been consistently above MCLs at LLWMA 3. The elevated values can be attributed to contaminant plumes originating to the south of this area (see Figure 5.9-7 and Plate 3). Additional plumes have been documented elsewhere in this section. Trichloroethylene has exceeded the 5- $\mu \mathrm{g} / \mathrm{L} \mathrm{MCL}$ in upgradient well 299-W10-21. There appears to be no groundwater contamination directly attributable to LLWMA 3. All indicator parameters for LLWMA 3 ( $\mathrm{pH}$, specific conductance, total organic carbon, and total organic halides) were within statistical comparison values (see Appendix B).

\subsubsection{Low-Level Waste Management Area 4}

Concentrations of carbon tetrachloride above the MCL were found in most wells in FY 1998; the elevated values are related to the known plumes discussed above. Trichloroethylene exceeded the 5- $\mathrm{gg} / \mathrm{L}$. MCL in well 299-W15-16. Total organic halide levels in the groundwater have been historically high beneath LLWMA 4 and are related to the carbon tetrachloride plume. The total organic halide levels are generally higher in wells on the east than the wells on the west of LLWMA 4.

Nitrate also exceeded the MCL in wells 299-W15-15, 299-W15-16, 299-W15-18, 299-W18-21, 299-W18-23, 299-W18-24, and 299-W18-26 in FY 1998. This is most likely related to the nitrate plume originating from the other facilities discussed previously.

There is no indication that LLWMA 4 has contributed to groundwater contamination. Flow reversal beneath LLWMA 4, caused by changing water table and pump-and-treat remediation, has severely impacted the utility of upgradient-downgradient comparisons of indicator parameters for detection monitoring. All indicator parameters for LLWMA-4 (pH, specific conductance, total organic carbon, and total organic halides) were within previously established statistical comparison values (see Appendix B). This is relatively meaningless, however, given the current flow regime.

\subsubsection{State-Approved Land-Disposal Site}

This disposal system receives treated effluent containing tritium, which is allowed to infiltrate through the soil column to the water table. Tritium was first detected in groundwater around the facility in July 1996 in upgradient well $699-48-77 \mathrm{~A}$, located $100 \mathrm{~m}$ south of the system. A tritium activity of 1,700,000 $\mathrm{pCi} / \mathrm{L}$ was determined for this well from the December 1997 sample. During FY 1998, maximum tritium results of 4,100 and $2,100,000 \mathrm{pCi} / \mathrm{L}$ were reported in nearby downgradient wells 699-48-77C and 699-48-77D, respectively. Well $699-48-77 \mathrm{C}$ is screened at $\sim 20 \mathrm{~m}$ below the water table, leading to more-dilute tritium concentrations. Hydrogeologic and hydrochemical evaluations suggest that effluent infiltrating beneath the site may be moving a limited distance southward along the relatively impermeable Plio-Pleistocene unit before reaching the water table. Concentrations of sulfate, calcium, and total dissolved solids and levels of specific conductance parallel the rise in tritium, suggesting these constituents are leached from natural soil components in the vadose zone (PNNL-11633, PNNL-11665).

Comparison of numerical groundwater models applied over the last several years indicates that earlier predictions, which show tritium from this disposal site approaching the Columbia River, were too simplified or overly robust in source assumptions (PNNL-11665). The most recent modeling indicates that 
tritium activities $>500 \mathrm{pCi} / \mathrm{L}$ will extend, at most, no farther than $\sim 1.5 \mathrm{~km}$ from the disposal site, using the most reasonable projections of operation of the 200 Areas Effluent-Treatment Facility. This extent encompasses only the wells in the current tritium-tracking network (see Appendix A).

\subsubsection{Summary of Remediation Effects}

\subsubsection{200-UP-1 Operable Unit}

The pump-and-treat system for this operable unit is located on the northern side of the $216-U-17$ crib. The system was constructed to contain the highest portion of the technetium-99 and uranium plume (ROD 1997). Secondary contaminants (nitrate and carbon tetrachloride) are also present and being removed. Early operations consisted of a 57-L/min treatability test conducted from March 1994 to September 1995. Phase I pump-and-treat operations commenced on September 25, 1995, using one extraction well and one injection well, pumping at a rate of $190 \mathrm{~L} / \mathrm{min}$. This system operated until February 7, 1997. A pumpand-treat remediation system also operated in 1985 near the $216-U-1$ and $216-U-2$ cribs to reduce elevated uranium concentrations. For a discussion of this operation, refer to WHC-EP-0133.

On February 25, 1997, an interim-action record of decision was issued (ROD 1997) that initiated Phase II for the 200-UP-1 Operable Unit pump-and-treat operations. The selected remedy consisted of pumping the highest concentration zone of the technetium-99 and uranium groundwater plumes, using the same extraction well and pumping rate as Phase I operations, and routing the groundwater to the 200 Areas Effluent-Treatment Facility. Prior to issuance of the interim action, groundwater was treated onsite using an ion-exchange medium, with treated water injected upgradient from the extraction well. Since March 1997, contaminated groundwater is pumped from the extraction well, transported in an 11-km-long transfer pipeline to the 200 Areas Effluent-Treatment Facility for treatment, and sent to the State-Approved Land-Disposal Site north of the 200-West Area for disposal.

For more detailed information about operations during FY 1998, refer to DOE/RL-99-02. The well network for 200-UP-1 is shown in Appendix A.

Contaminant Removal and Overall Effectiveness. Until rerouting of groundwater to the 200 Areas Effluent-Treatment Facility in March 1997, treatment consisted of an ion-exchange medium composed of Dowex $21 \mathrm{~K}^{\mathrm{TM}}$ resin to remove technetium-99 and uranium from the groundwater. Following ionexchange treatment, granular activated carbon was used to remove carbon tetrachloride. After treatment, groundwater was returned to the aquifer via the upgradient injection well. Nitrate was not treated prior to bringing the 200 Areas Effluent-Treatment Facility on line.

The most significant shutdown period during FY 1998 was from January 13 through February 13. During this period, the 200 .Areas Effluent-Treatment Facility was servicing other Hanford Site treatment campaigns. Although the pumping well was shut down for 30 days, it was determined that there was no impact on hydraulic containment of the contaminant plumes. As reported in DOE/RL-99-02, the pump could be shut down for 73 days before technetium-99 exits the capture zone. 
From October through September 1998, 89,000,000 L of water were transported from the pumpand-treat site to the 200 Areas Effluent-Treatment Facility at an average flow rate of $190 \mathrm{~L} / \mathrm{min}$. Greater than $100,700,000 \mathrm{~L}$ water were treated. Table 5.9-1 lists the volumes of treated water and the mass of contaminants removed per quarter since 1994.

During FY 1998, concentrations of uranium, nitrate, and carbon tetrachloride were relatively constant in extraction well 299-W19-39. However, technetium-99 activities were noted to decline slightly, especially in comparison to FY 1997. Figure 5.9-27 shows the contaminant trend plots for extraction well 299-W19-39. As observed on the technetium-99 trend plot, concentrations decreased from $3,000 \mathrm{pCi} / \mathrm{L}$ in mid-1997 to 1,800 pCi/L at the end of FY 1998 (note: the highest sustained concentrations were $\sim 6,140 \mathrm{pCi} / \mathrm{L}$ in September 1995). The average concentrations for FY 1998 for these four contaminants were

- $2,050 \mathrm{pCi} / \mathrm{L}$ technetium-99

- $265.5 \mu \mathrm{g} / \mathrm{L}$ uranium

- $63.4 \mathrm{mg} / \mathrm{L}$ nitrate

- $24 \mu \mathrm{g} / \mathrm{L}$ carbon tetrachloride.

Carbon tetrachloride concentrations were measured at the 200 Areas Effluent-Treatment Facility after transport along the 11-km cross-transfer pipeline between 200-West and 200-East Areas. Because of outgassing and loss of volatiles while in transport, the concentrations decreased from $\sim 125 \mu \mathrm{g} / \mathrm{L}$ at the $200-\mathrm{UP}-1$ site to the measured $24 \mu \mathrm{g} / \mathrm{L}$ at the 200 Areas Effluent-Treatment Facility. Given this change in concentration and the estimated volume of pumped groundwater in FY $1998(89,000,000 \mathrm{~L})$, the estimated amount of mass lost to the atmosphere was $8.9 \mathrm{~kg}$. This loss is in addition to the mass removed during treatment.

Contaminant distribution and concentrations in the monitoring wells continue to change in response to remediation operations. Plume maps that depict the distribution of technetium- 99 and uranium contamination are shown in Figures 5.9-28 and 5.9-29. These figures also outline the original baseline contaminant area targeted for remediation. The following conclusions were drawn from these plume maps and from information contained in DOE/RL-99-02.

- The extent of the high-concentration portion of the technetium-99 plume has been reduced in comparison to the original baseline area and FY 1997.

- A localized technetium-99 "hot-spot," originating upgradient of the targeted plume area appears to be moving downgradient from well 299-W19-28 through well 299-W19-29.

- Technetium activity is below the $9,000-\mathrm{pCi} / \mathrm{L}$ remediation criterion, with the exception of only two monitoring wells (299-W19-26 and 299-W19-29).

- The extent of the high-concentration portion of the uranium plume has been reduced in comparison to the original target area but not in comparison to FY 1997.

- Uranium concentrations in most monitoring wells have remained above the $480-\mu \mathrm{g} / \mathrm{L}$ remediation criterion. 
Water-Level Impact and Capture-Zone Analysis. Pumping activities and the regional water-level decline affect water levels in the area of the 200-UP-1 remediation site. Water levels declined $\sim 0.6 \mathrm{~m}$ in FY 1998, as the residual mound from the decommissioned U Pond continued to decay. One significant effect of the declining water levels is that several of the monitoring wells in the 200-UP-1 Operable Unit can be expected to go dry in FY 1999. In FY 1998, wells 299-W19-20 and 299-W19-26 were switched to a bailer-sampling method because groundwater returns could not be sustained using pumps. It is expected that similar modifications will be made to other monitoring wells in FY 1999 as water levels continue to decline.

Groundwater modeling indicates that the targeted plume is captured under the current well configuration (Figure 5.9-30). It is estimated that $90 \%$ of one pore volume has been extracted from the original high-concentration portion of the plume based on the original baseline plume map (DOE/RL-99-02). The travel markers on the figure show that much of the water captured during the past 3 years originated at the injection well. The capture zone has broadened since operation of the injection well was terminated in 1997.

Summary. Measurable progress was made in FY 1998 toward meeting the 200-UP-1 Operable Unit remedial objectives of reducing contamination in the highest concentration area of the plumes, reducing human health risks through mass removal, hydraulically containing the contaminant plume, and providing information to support a final remedy decision. The most notable success in FY 1998 was the reduction of technetium- 99 to below the $9,000-\mathrm{pCi} / \mathrm{L}$ remediation goal in all but two wells. Uranium concentrations remained above the $480-\mu \mathrm{g} / \mathrm{L}$ remediation goal in almost all wells, even after treatment of $338,300,000 \mathrm{~L}$ and 3 years of operation.

\subsubsection{200-ZP-1 Operable Unit}

The pump-and-treat system for this operable unit, located north of the Plutonium Finishing Plant, was implemented as an interim action to prevent further movement of groundwater contamination from the high-concentration portion of the carbon tetrachloride plume and to reduce contaminant mass (ROD 1995). The pump-and-treat operations and system were implemented in a three-phased approach. Phase I operations, which have been terminated, consisted of a pilot-scale treatability test that ran from August 29, 1994 to July 19, 1996. During that period, contaminated groundwater was removed from a single extraction well at a rate of $\sim 150 \mathrm{~L} / \mathrm{min}$, treated using granular activated carbon, and returned to the aquifer through an injection well. For more detailed information about operations during the treatability test, refer to DOE/RL-95-30.

Phase II operations commenced August 5, 1996 in accordance with Milestone M-16-04A (Ecology et al. 1989) and ended on August 8, 1997 for transition to Phase III operations. The well-field configuration during Phase II operations consisted of three extraction wells, pumping at a combined rate of $\sim 570 \mathrm{~L} / \mathrm{min}$, and a single injection well. Groundwater was treated using an air stripper, followed by granular activated carbon treatment of the air stream.

From August 8 to 28, 1997, well-field piping and treatment equipment were upgraded for Phase III operations, which were initiated on August 29, 1997, meeting Milestone M-16-04B (Ecology et al. 1989). The well field was expanded to six extraction wells, pumping at a combined rate of $\sim 720 \mathrm{~L} / \mathrm{min}$, and five injection wells. 
The interim-action objectives (ROD 1995) are the following:

- prevent further movement of contaminants from the highest concentration area of the plume (i.e., containing carbon tetrachloride inside the 2,000 - to $3,000-\mu \mathrm{g} / \mathrm{L}$ contour)

- reduce contamination in the area of highest carbon tetrachloride concentrations

- provide information that will lead to development of a final remedy that will be protective of human health and the environment.

The following information is summarized from DOE/RL-99-02. The 200-ZP-1 Operable Unit facilities and Phase III extraction, injection, and monitoring well locations are shown in Appendix A.

Contaminant Removal and Overall Effectiveness. The Phase III treatment system uses air stripping combined with vapor-phase, granular activated carbon technology to remove the volatile organic compounds from the contaminated groundwater. Approximately $336,200,000 \mathrm{~L}$ of contaminated groundwater were treated in FY 1998 at an average flow rate of $743 \mathrm{~L} / \mathrm{min}$. Production rates for the six extraction wells ranged from 63 to $310 \mathrm{~L} / \mathrm{min}$. The average influent concentration for the six extraction wells was $3,530 \mu \mathrm{g} / \mathrm{L}$, ranging as high as $4,400 \mu \mathrm{g} / \mathrm{L}$.

Treatment of the contaminated water resulted in the removal of $1,212 \mathrm{~kg}$ of carbon tetrachloride in FY 1998. Since initiation of pump-and-treat operations in August 1994 through September 1998, $>614,800,000 \mathrm{~L}$ of water have been treated, resulting in removal of $2,099 \mathrm{~kg}$ of carbon tetrachloride. Table 5.9-2 shows the volumes of treated water and the mass of carbon tetrachloride removed by quarter since inception of operations.

Carbon tetrachloride concentrations increased at all three of the northernmost extraction wells, but were stable or decreased slightly in the three southernmost wells (Figures 5.9-31 and 5.9-32). The lowest concentrations were at well 299-W15-37 $(230 \mu \mathrm{g} / \mathrm{L})$ in the far south. Table 5.9-3 compares average concentrations for FY 1997 and FY 1998, the mean flow rate for each extraction well, and the relative concentration changes.

The most notable change in concentration during FY 1998 was at extraction well 299-W15-33, where carbon tetrachloride concentrations increased from $\sim 5,500 \mu \mathrm{g} / \mathrm{L}$ in October 1997 to $\sim 6,500 \mu \mathrm{g} / \mathrm{L}$ by September 1998 (see Figure 5.9-31). Concentrations from this well now rival those from well 299-W15-32 (near the 216-Z-9 trench). This situation is notable because well 299-W15-33 is not located near any known disposal site, though it is situated on the northern side of the high-concentration area of the plume (originally near the $2,000-$ to $3,000-\mu \mathrm{g} / \mathrm{L}$ plume contour).

The most significant system shutdown in FY 1998 occurred during the last week of December, when it was discovered that carbon tetrachloride in the water exiting the effluent tank was exceeding $(5.2 \mu \mathrm{g} / \mathrm{L})$ the 5- $\mu \mathrm{g} / \mathrm{L}$ MCL. Normally, carbon tetrachloride concentrations are at or below the $2-\mu \mathrm{g} / \mathrm{L}$ detection limit after treatment and before injection. Prior to that time, the system appeared to be operating normally, with no indication of a possible exceedance. The effluent was immediately resampled and analyzed at $7.1 \mu \mathrm{g} / \mathrm{L}$, confirming the exceedance. Another measurement on December 26 also yielded a high value $(10 \mu \mathrm{g} / \mathrm{L})$. No other exceedances were measured during FY 1998. 
The reason for the increased concentrations and reduced air-stripping efficiency was identified as an algae buildup in the air-stripping tower. The problem was rectified, and the system eventually brought back online after cleaning the air-stripping tower and packing, adding more packing material, and modifying the air-to-water mixture ratio for the stripping tower. An independent design review of the airtreatment system concluded that the design was adequate for the given process conditions, processing parameters, and tower-packing height.

There were no significant changes in chloroform and trichloroethylene concentrations in the extraction wells for FY 1998. Chloroform concentrations ranged from 15 to $40 \mu \mathrm{g} / \mathrm{L}$, while trichloroethylene concentrations ranged from 5 to $14 \mu \mathrm{g} / \mathrm{L}$.

Contaminant distribution's and concentrations in the monitoring wells also continue to change in response to remediation. As discussed above, the influent tank concentrations increased to an average of $3,530 \mu \mathrm{g} / \mathrm{L}$, indicating that the hydraulic gradient created by the extraction wells is moving significant quantities of dissolved organic mass from the high-concentration area of the plume to the extraction wells. Figure 5.9-33 is the FY 1998 carbon tetrachloride plume map, and Figure 5.9-34 is the baseline plume map. Several conclusions can be drawn from changes in the site carbon tetrachloride plume maps (refer to DOE/RL-99-02 for additional details and discussion).

- The plume center is moving primarily in a northerly and easterly direction toward the four northernmost extraction wells.

- The concentrations of carbon tetrachloride east of the pumping wells may be decreasing, indicated by a decrease in concentrations in monitoring well 299-W14-9 (from $\sim 100 \mu \mathrm{g} / \mathrm{L}$ in mid-1997 to 20 to $40 \mu \mathrm{g} / \mathrm{L}$ at the end of FY 1998).

- The area of the $>4,000-\mu \mathrm{g} / \mathrm{L}$ contour has apparently increased in size, noted by comparing the FY 1998 plume map with the baseline plume map. Spreading of the $>4,000-\mu \mathrm{g} / \mathrm{L}$ contour is attributed to the effects of pumping.

- Concentrations of carbon tetrachloride south and east of injection well 299-W15-29 are decreasing, as demonstrated by the indentation in the $1,000-\mu \mathrm{g} / \mathrm{L}$ contour on Figure 5.9-33. This implies that injection of the treated water is moving the plume to the east and at the same time diluting the plume.

Water-Level Impact and Capture-Zone Analysis. The water-table map (see Plate 2) indicates that general groundwater flow in the vicinity of the extraction wells is still east-northeast in this area. The persistent, broad, and relatively flat mound that characterizes the water table near the remediation site is a residual groundwater feature from discharges to the decommissioned U Pond. Water levels are estimated to be declining in this area at a rate of $0.6 \mathrm{~m} / \mathrm{yr}$ (DOE/RL-99-02).

To evaluate the hydraulic effects of remediation at the observation wells, drawdown near the extraction wells and buildup near the injection wells were calculated (DOE/RL-99-02). Based on this analysis, the radius of influence near the northern extraction wells was calculated to extend beyond monitoring well 299-W15-31A. This well is located $124 \mathrm{~m}$ from well 299-W15-33 in the interior of the highconcentration area of the carbon tetrachloride plume and had a drawdown of $0.2 \mathrm{~m}$. 
In the area of injection well 299-W15-29, water-level responses were observed as far away as $366.6 \mathrm{~m}$ at well $299-W 18-39$ (0.2 $\mathrm{m}$ of buildup). These results, taken in conjunction with the changing water-table map, confirm that the hydraulic flow field is being modified in this area. For groundwater monitoring at the low-level burial grounds and other RCRA facilities, the pump-and-treat operations have changed the flow field, so detection wells may no longer be "upgradient" and "downgradient."

Based on numerical modeling results, the entire high-concentration area of the plume was contained in FY 1998 (DOE/RL-99-02). The numerical model indicates that pump-and-treat operations have resulted in the removal of one pore volume from the upper $15 \mathrm{~m}$ of the aquifer at a distance of $\sim 70$ to $80 \mathrm{~m}$ around the Phase III wells (299-W15-32, 299-W15-36 and 299-W15-37) (Figure 5.9-35). Because the Phase II wells have operated longer, their area of capture is larger, with the removal of one pore volume at a radius of $130 \mathrm{~m}$ around wells $299-\mathrm{W} 15-33$ and 299-W15-34 and $\sim 170 \mathrm{~m}$ around well 299-W15-35.

Summary. Progress was made toward achieving the remedial action objectives at the 200-ZP-1 Operable Unit in FY 1998. It is concluded that the pump-and-treat operation is successfully containing and capturing the high-concentration portion of the carbon tetrachloride plume; that contamination was reduced in the area of highest concentrations through mass removal; and that additional information was collected through hydraulic monitoring, contaminant monitoring, and treatment system operation. All of this will support development of a final remedy that will be protective of human health and the environment.

\subsection{0-East Area \\ J. W. Lindberg, D. B. Barnett, R. B. Mercer, S. M. Narbutovskih, M. D. Sweeney}

The 200-East Area was used historically for chemical separation and purification of plutonium and related waste management. For reasons of safety and security, the area was built away from the 200-West Area but with some redundancy of function. Differing hydrogeology between the two sites resulted in significant dissimilarities in the spread of contaminants in groundwater. The B and PUREX Plants were the major processing facilities in the 200-East Area. Waste-disposal facilities associated with operations included cribs, trenches, tile fields, surface impoundments, injection wells, tank farms, and landfills. Because of the complexity of past waste-disposal operations in the 200 Areas, as well as the close spacing of the facilities, it is often difficult to determine the exact source of contamination. Groundwaterremediation activities are grouped into groundwater operable units. These groundwater operable units are distinct from the numerous source area operable units for facility and vadose-zone remediation.

\subsubsection{Facilities and Operable Units}

\subsubsection{B Plant}

- Waste-disposal facilities and single-shell tanks associated with B Plant operations are generally located in the northwestern part of the 200-East Area. The waste-disposal history associated with B Plant is similar to that of T Plant (in the 200-West Area); both plants operated over a similar time period (1944. through 1956) and used the bismuth phosphate process. High-level waste tanks in the B Plant area were used for purposes similar to the tanks in the T Plant area (see Section 5.9.1.1). Between 1948 and 1956, 
the tanks were used for settling of solids from second-decontamination-cycle wastes in a cascading system. The supernatant from the last tank in the cascade was discharged to the nearby 216-B-7A, 216-B-7B, and 216-B-8 cribs (WHC-MR-0227). From 1951 to 1956, cell-drainage waste was discharged through the cascade with the second-cycle waste. From 1951 to 1956, the 242-B evaporator was used to reduce the volume of first-cycle wastes, though in 1953-1954, some first-cycle waste was discharged to specific retention trenches. Waste from the original plutonium-concentration facility in the 224-B building was settled in 208,000-L, 200-series, single-shell tanks before being discharged to cribs. In addition, in 1954, evaporator bottoms (concentrated waste) from the 242-B evaporator were discharged to the 216-B-37 trench (WHC-MR-0227). Thus, some of the most radioactive liquid waste was discharged to the ground rather than being stored in tanks. The wastes discharged were closely related to tank wastes; the tanks, however, apparently retained much of the solid fraction in the waste streams. According to WHC-MR-0132, first-cycle waste contained $~ 10 \%$ of the original fission activity and $1 \%$ of the plutonium. Second-cycle waste was lower in overall activity, containing $<0.1 \%$ of the overall fission activity and $1 \%$ of the plutonium.

The 216-B-5 injection well was operated from April 1945 to September 1946 and received radioactive wastes from B Plant activities, including some hot-cell drainage and supernatant overflow from settling tanks. The waste was injected below the water table, resulting in radiological contamination that is still apparent $>50$ years later. Radiological contaminants associated with the facility include strontium-90, cesium-137, and plutonium. These three contaminants are restricted to the immediate vicinity of the 216-B-5 injection well by their low mobility in groundwater and the extremely low hydraulic gradient in this area.

In 1954 and 1955, scavenged uranium-recovery waste supernatant, containing large amounts of ferrocyanide and other chemical and radiological components from U Plant operations, was discharged to the BY cribs and to a trench in the northern part of the 200-East Area (WHC-MR-0227). This practice was soon discontinued because of the appearance of unacceptably high levels of cobalt- 60 in the groundwater.

\subsubsection{PUREX Plant}

The PUREX Plant started operation in 1956, eventually replacing the REDOX Plant as the plutoniumseparations facility. The first PUREX operational campaign extended from 1956 to 1972 . Following an 11-year shutdown, the PUREX Plant began operations again in 1983, which ended in December 1988 when the weapons-production mission ended. A short run was started in December 1989 to stabilize material in the system. Waste from the PUREX Plant was discharged to a number of nearby cribs, ditches, and ponds. A number of these facilities have RCRA monitoring requirements.

\subsubsection{RCRA-Regulated PUREX Cribs}

Three liquid waste-disposal facilities for the PUREX Plant require groundwater monitoring in accordance with RCRA (216-A-10, 216-A-36B, and 216-A-37-1 cribs).

The 216-A-10 crib, retired from use, was a liquid waste-disposal facility for the PUREX Plant. This crib is located $\sim 122 \mathrm{~m}$ south of the PUREX Plant and $\sim 110 \mathrm{~m}$ east of the $216-\mathrm{A}-36 \mathrm{~B}$ crib (see Appendix A). This crib is $84 \mathrm{~m}$ long, has a V-shaped cross-section, and is $14 \mathrm{~m}$ deep. Several waste streams, collectively described as process distillate discharge, were disposed to this crib and were allowed 
to percolate through the soil column. The crib first received liquid waste over a 4-month period during PUREX startup in 1956. In 1961, the crib replaced the 216-A-5 crib and received PUREX effluent continuously until 1973. Periodic discharges were received in 1977, 1978, and 1981. From 1982 to 1987, effluent discharges resumed on a continual basis. Discharge between 1981 and 1987 averaged $100,000,000 \mathrm{~L} / \mathrm{yr}$. In 1987, the crib was taken out of service and replaced by the $216-\mathrm{A}-45 \mathrm{crib}$.

The process distillate waste stream to the $216-\mathrm{A}-10$ crib was characteristically acidic and contained concentrated salts. Other waste-stream constituents included aliphatic hydrocarbon compounds; organic complexants; and tritium, uranium, strontium-90, cobalt-60, cesium-134, cesium-137, plutonium, ruthenium-103, and ruthenium-106 (RHO-HS-SR-86-3-4Q LIQ P).

The 216-A-36B crib, also retired from use, was a liquid waste-disposal facility for the PUREX Plant. The crib is located $\sim 360 \mathrm{~m}$ south of the PUREX Plant and $\sim 110 \mathrm{~m}$ east of the $216-A-10 \mathrm{crib}$. The $216-\mathrm{A}-36 \mathrm{~B}$ crib is the southern end $(150 \mathrm{~m}$ ) of the crib, originally known as the $216-\mathrm{A}-36 \mathrm{crib}$ (see Appendix A). The original crib dimensions were $180 \mathrm{~m}$ long, $4 \mathrm{~m}$ wide, and $4 \mathrm{~m}$ deep. A 0.15 -m-dia. perforated distributor pipe was placed at the bottom of the crib on a $0.3-\mathrm{m}$ bed of gravel, covered with another $0.3 \mathrm{~m}$ of gravel, and backfilled to grade. Ammonia scrubber distillate waste from the PUREX Plant was discharged through the distribution pipe to the crib and allowed to percolate through the soil column.

The original 216-A-36 crib received liquid effluent from September 1965 to March 1966. A substantial inventory of radionuclides was disposed to the crib and was assumed to have infiltrated sediments near the inlet to the crib. To prevent radionuclides from reaching the water table, the northern end of the crib was used as a specific retention facility. This practice limited the amount of water discharged to the crib (RHO-HS-EV-18). To continue effluent discharges to the crib, it was divided into two sections (216-A-36A and 216-A-36B). Grout was injected into the gravel layer to form a curtain that separated the two sections. The liquid effluent-discharge point was moved to the 216-A-36B section and the 216-A-36A section was no longer used. Discharge to the 216-A-36B crib resumed in March 1966 and continued until 1972, when the crib was temporarily removed from service. The crib was placed back in service in November 1982 and continued to operate until it was permanently taken out of service again in October 1987.

Ammonia scrubber distillate discharged to the crib consisted of condensate from nuclear fueldecladding operations, in which zirconium cladding was removed from irradiated fuel by boiling in a solution of ammonium fluoride and ammonium nitrate. Other waste-stream constituents included tritium, iodine-129, uranium, strontium-90, cobalt 60, cesium-137, and ruthenium-106 (PNL-6463).

The 216-A-37-1 crib, also retired from use, was a liquid waste-disposal facility for the PUREX Plant (see Appendix A). This crib is located near the former Grout Treatment Facility, $\sim 600 \mathrm{~m}$ east of the PUREX Plant. The original crib dimensions were $213 \mathrm{~m}$ long, $3 \mathrm{~m}$ wide, and $3.4 \mathrm{~m}$ deep. A $0.25-\mathrm{m}$-dia. corrugated, galvanized, perforated distributor pipe was placed on $1 \mathrm{~m}$ of gravel fill. The distributor pipe was covered with gravel, a layer of plastic, and backfill material. Wastewater entered at the southeastern end of the crib, which is at a lower elevation than the northwestern end. This configuration favored infiltration at the southeastern end of the crib. 
The 216-A-37-1 crib first received liquid waste in March 1977 and continued until April 1989. The waste stream included process condensate from the 242-A evaporator and included the radionuclides uranium, strontium-90, cobalt-60, cesium-137, plutonium, and ruthenium-106 (RHO-HS-EV-18). The process condensate was regulated as a mixed waste because it contained radionuclides, spent halogenated and nonhalogenated solvents, and ammonia. The estimated annual quantity of dangerous waste $(49,120 \mathrm{~kg})$ represents the maximum annual output of evaporator process condensate during operating campaigns.

\subsubsection{216-A-29 Ditch}

This is an earthen ditch $2 \mathrm{~m}$ wide and $2,000 \mathrm{~m}$ long. The depth of the ditch varies from $1 \mathrm{~m}$ at the headend (southwestern end) to $5 \mathrm{~m}$ at the point of discharge. The ditch conveyed PUREX chemical waste to B Pond from 1955 to 1986 . In 1984, administrative and physical controls were implemented to avoid inadvertent discharges of hazardous waste to the ditch. All effluent sources were rerouted in July 1991, and use of this ditch for disposal was discontinued. The ditch was backfilled and revegetated for interim stabilization later that year. Prior to deactivation, the ditch received an average of 950 to $2,000 \mathrm{~L} / \mathrm{min}$ of effluent from the PUREX Plant chemical sewer. The lower range of effluent discharges continued after production was halted in 1986 because cleanout runs were performed prior to PUREX decommissioning.

The ditch received effluents that contained hazardous and radiological waste. Stratigraphic control of migrating effluents is limited to sporadic perching horizons composed of silt and other fine-grained sediments. Of primary concern for RCRA were discharges of sodium hydroxide and sulfuric acid, which occurred on a daily basis from 1955 until February 1986. These wastes were produced as a result of ionexchange regeneration at PUREX.

\subsubsection{216-B-3 Pond}

B Pond, located east of the 200-East Area, is a RCRA-regulated wastewater-disposal facility constructed to receive effluents generated by past operations in the 200-East Area. The B Pond system consists of a main pond, three expansion ponds, and contiguous portions of the 216-B-3 ditches (see Appendix A). The main pond, which began receiving effluent in 1945, was located in a natural topographic depression and was diked on the eastern margin. The pond covered 14.2 ha and had a maximum depth of $\sim 6.1 \mathrm{~m}$. Three expansion ponds (216-B-3A, 216-B-3B, and 216-B-3C) were placed in service in 1983,1984 , and 1985, respectively. The $216-\mathrm{B}-3 \mathrm{~A}$ and $216-\mathrm{B}-3 \mathrm{~B}$ expansion ponds are $\sim 4.5$ ha; the 216-B-3C expansion pond is $\sim 16.6 \mathrm{ha}$. Water discharged to these ponds infiltrated into the ground and recharged the underlying aquifer. Details of the operation of these ponds are presented in DOE/RL-89-28, Rev 2. Adjacent portions of the three ditches (no longer in use) leading to the ponds are included in the system for groundwater-monitoring purposes.

In 1994, the main pond and the 216-B-3 ditch were filled with clean soil, and all vegetation was removed from the perimeter as part of interim stabilization activities. Also in 1994, the expansion ponds were RCRA clean-closed. In April 1994, discharges to the main pond ceased, and some effluents were rerouted to the 216-B-3C expansion pond via a bypass pipeline. In 1995 , some of these streams were sent to the newly constructed 200 Areas Treated Effluent-Disposal Facility (formerly known as the W-049H 
Project). In August 1997, the remaining streams discharging to the 216-B-3C expansion pond were diverted to the 200 Areas Treated Effluent-Disposal Facility, thus ending the operation of the B Pond system.

In the past, B Plant steam condensate and chemical sewerage and PUREX Plant chemical sewerage were also discharged to the B Pond system (primarily the main pond). Potential contaminants contained within past waste streams, which may have entered the groundwater, included tritium, aluminum nitrate, potassium hydroxide, nitric acid, sulfuric acid, and other acids (DOE/RL-89-28, Rev. 2).

\subsubsection{200 Areas Treated Effluent-Disposal Facility}

This facility is a non-RCRA waste-disposal site built to provide an infiltration area for treated liquid effluent from the generating facilities in the 200 Areas. The facility is located $\sim 600 \mathrm{~m}$ east of the 216-B-3C expansion pond (see Appendix A). In operation since June 1995, the facility allows infiltration of steam condensate and other clean water to the soil column. Some of the streams formerly discharged to the 216-B-3C expansion pond were rerouted to this facility in 1995, and the remainder of the 216-B-3C expansion pond streams were diverted to this facility in August 1997.

\subsubsection{216-B-63 Trench}

This trench, in service from March 1970 to February 1992, received liquid effluent (378,540 to $1,514,160 \mathrm{~L} / \mathrm{d}$ ) from the B Plant chemical sewer. The liquid effluent was a mixture of $70 \%$ steam condensate and $30 \%$ raw water, which was disposed to the western end of the open, unlined earthen trench. Past releases to the trench included radioactive and dangerous waste. Documented hazardous discharges occurred from 1970 to October 1985 and consisted of aqueous sulfuric acid and sodium hydroxide solutions that exceeded 2.0 and $12.5 \mathrm{pH}$, respectively. Radioactive soils were dredged from the trench in August 1970 but no records of radioactive waste disposal to the trench exist. Starting in 1985, physical controls, radiation monitoring, and operating procedures were modified to avoid inadvertent discharge of chemicals or radioactive substances to the wastewater stream. Liquid effluent discharge to this trench ceased in February 1992.

\subsubsection{Single-Shell Tank Farms}

The single-shell tanks that are currently storing hazardous, radioactive wastes in the 200-East Area are located in WMAs A-AX, B-BX-BY, and C. These WMAs, which stopped receiving waste in 1980, have been designated as RCRA facilities since 1989. Currently, the single-shell tanks are used to store radioactive and mixed waste generated by chemical processing of spent fuel rods using the tributyl phosphate, bismuth phosphate, REDOX, or PUREX processes. The types of waste added to the singleshell tanks and their general composition are discussed in WHC-MR-0132.

The tanks were constructed between 1943 and 1964 and, depending on dimensions, each held between 1,892,500 and 3,785,000 L. WMAs B and C each contain four smaller, 200-series tanks that hold 208,175 L each. WMA A-AX contains 10 tanks, 5 of which are known or assumed to have leaked; WMA B-BX-BY contains 40 tanks, 20 of which are known or assumed to have leaked; and WMA C contains 16 tanks, 6 of which are known or assumed to have leaked. 
The single-shell tanks received mixtures of organic and inorganic liquids containing radionuclides, solvents, and metals that were originally discharged as alkaline slurries. Waste-management operations have mixed various waste streams from numerous processes conducted in the processing of spent fuel rods. Thus, the contents within each tank are difficult to determine. The situation is further complicated by subsequent chemical reactions, degradation, and decay of radionuclides. The radionuclide and chemical inventory of the single-shell tanks is summarized in WHC-SD-WM-TI-565, Rev. 1; historical operations at the tank farms are summarized in WHC-MR-0227 and WHC-MR-0132. In the case of WMA B-BX-BY, source determination for the single-shell tanks is further complicated because tank wastes were discharged to nearby cribs, unlined specific retention trenches, unlined ditches, French drains, and ponds.

Tank waste exists in the form of salt cake and sludge, which is the residual left after the liquids were removed. However, there are small quantities of supernatant and interstitial liquids that could not be removed by pumping. The waste chemistry consists of sodium hydroxide, sodium salts of nitrate, nitrite, carbonate, aluminate, and phosphate. Some hydrous oxides of iron and manganese also are present. Fission-product radionuclides, such as technetium-99, strontium-90, cesium-137, and actinide elements, such as uranium, thorium, plutonium, and neptunium, constitute the principal radioactive components. Some of the single-shell tanks also contain ferrocyanide or organic salts.

\subsubsection{Low-Level Waste Management Areas}

LLWMA 1 is located in the northwestern corner of the 200-East Area, is currently following interimstatus, detection-level, monitoring regulations and includes all of the 218-E-10 burial ground (see Appen$\operatorname{dix} \mathrm{A})$. This WMA is divided by an east-west access road. The southern portion of the burial ground is currently active, while the portion north of the road is for future expansion. The active area measures $22.9 \mathrm{ha}$, and the area for future expansion measures $15.3 \mathrm{ha}$, for a total area of $38.2 \mathrm{ha}$. Disposal activities began in 1960 and continue to the present. Materials placed in this facility are primarily dragoff waste, failed equipment, and mixed industrial waste from the PUREX Plant, B Plant, and N Reactor.

LLWMA 2 is currently in RCRA interim-status indicator evaluation. This WMA is located in the northeastern corner of the 200-East Area and includes all of burial ground 218-E-12B (see Appendix A). This burial ground has a total area of 70.1 ha and has been in use since 1968. The majority of the waste is in the eastern half of the burial ground and consists primarily of miscellaneous dry waste and submarine reactor compartments. Parts of two trenches contain transuranic waste.

\subsubsection{Liquid Effluent-Retention Facility}

This facility consists of three $24,600,000-\mathrm{L}$ surface impoundments (basins) on a 15.8-ha site northeast of the 200-East Area (see Appendix A). The three basins were constructed of two composite liners, a leachate-collection system between the liners, and a floating cover. The fourth basin is excavated but is not completed and will not be used.

This facility serves as temporary storage for evaporator process condensate that is subsequently treated in the 200 Areas Effluent-Treatment Facility. The 242-A evaporator is used to substantially 
reduce the quantity of waste stored in the double-shell tanks, and the effluent is discharged to cribs in the 200-East Area. The evaporator was shut down when listed waste was found in the effluent stream but was restarted on April 14, 1994.

Primary constituents detected in the effluent stream from the 242-A evaporator were ammonium, acetone, aluminum, 1-butanol, 2-butanone, tritium, strontium-90, ruthenium-106, and cesium-137. Further information of the effect on groundwater from release of this waste stream is documented in WHC-EP-0367.

The 242-A evaporator process condensate effluent, stored at the Liquid Effluent-Retention Facility, is regulated as a dangerous waste in accordance with WAC 173-303 because of the toxicity of the ammonium and the presence of listed waste constituents. A RCRA interim-status indicator evaluation system is in place at the Liquid Effluent-Retention Facility to detect any impact on groundwater quality.

\subsubsection{Operable Units}

Two groundwater operable units relate to 200-East Area contamination (200-BP-5 and 200-PO-1). The boundaries for these two operable units were defined (WHC-SD-EN-TI-019) by an east-westtrending groundwater divide across the 200-East Area (see Figure 5.2-4). The 200-BP-5 Operable Unit lies to the north of this divide, whereas the 200-PO-1 Operable Unit is south of the divide. The divide itself is caused by hydraulic interference between wastewater mounding at the 216-B-3 pond (also known as $B$ Pond) with groundwater flowing from the 200 -West Area. The geographic boundary between the two operable units extends from B Pond southwest through the PUREX tank farms and then in an east-towest direction just south of the Semiworks and $B$ Plant facilities. A number of RCRA and CERCLA source and vadose-zone units are encompassed in the operable units.

200-BP-5 Operable Unit. This operable unit contains all plumes located north of the groundwater divide. Important plumes within the unit originated from B Plant's bismuth phosphate liquid disposal and include the strontium-90/cesium-137/plutonium-239/-240 plume centered around the 216-B-5 injection well. The 200-BP-5 cobalt-60/technetium-99/cyanide/nitrate plume is centered in the area of well 699-50-53A. This latter plume was derived from liquid waste disposal to the BY cribs.

Both the 216-B-5 injection well and the BY crib plumes were the target of pump-and-treat programs in FY 1995, which successfully removed quantities of radionuclides and cyanide. Following these treatability tests, it was determined that no further action at either plume was required. The plume at the 216-B-5 injection well has a low-migration potential. Even though the BY crib plume is more mobile, it poses a small health risk and, therefore, continued treatment was deemed unnecessary. Instead, an annual groundwater-monitoring program will track migration of these plumes.

200-PO-1 Operable Unit. This operable unit is being addressed as a RCRA past-practice unit and encompasses the area south of the 200-East Area groundwater divide. The unit consists generally of plumes derived from PUREX Plant operations. Plumes of concern extend mostly to the south and east from the PUREX.Plant. This operable unit was the subject of a RCRA facility investigation/corrective measure study because remediation is being carried out in accordance with RCRA (DOE/RL-95-100, Rev. 1). The study examined existing groundwater-monitoring data for the last 10 years. 
The RCRA facility investigation report (DOE/RL-95-100, Rev. 1) evaluated three low-to-mediumconcentration, widespread plumes. These plumes of tritium, iodine-129, and nitrate cover broad areas within and southeast of the 200-East Area. A number of small plumes or sporadic detections were identified for arsenic, chromium, manganese, strontium-90, and vanadium, occurring either as one-time hits or within a very limited area.

The RCRA corrective measure study (DOE/RL-96-66), which included numerical modeling and a risk assessment, identified only the tritium and iodine-129 plumes for further evaluation. The correctiveaction evaluation considered only the no-action and institutional control alternatives because of the widespread nature of the plumes, the low concentrations over much of the plume area, and the lack of a suitable treatment technology. Also, because of its 12.3 -year half-life, tritium is expected to decay to acceptable activities in the next 50 years. No other actions are expected at this time.

\subsubsection{Compliance Issues}

\subsubsection{PUREX Cribs}

Interim-status RCRA groundwater-monitoring networks have been in place for the 216-A-10 and 216-A-36B cribs since 1988 (WHC-SD-EN-AP-170, Rev. 0-A). Groundwater-monitoring programs at these cribs were in RCRA indicator parameter evaluation status until June 30, 1997. Starting July 1 , 1997, the 216-A-10, 216-A-36B, and 216-A-37-1 cribs were combined into one groundwater quality assessment program (PNNL-11523) because they have similar hydrogeology and waste constituents. The groundwater-monitoring plan (PNNL-11523) was changed from an indicator parameter evaluation program to a groundwater quality assessment program because of contamination and the high probability that a new indicator parameter program would show that critical means are exceeded. By combining them into one RCRA groundwater-monitoring area, there would be savings in sampling and analysis costs as a result of a reduction in the number of near-field wells sampled. Groundwater-monitoring results from one downgradient well (299-E17-9) near the 216-A-36B crib show that specific conductance is significantly higher than in the corresponding upgradient well, providing additional evidence that the crib has contaminated groundwater. Prior to July 1, 1997, the 216-A-37-1 crib was monitored for the requirements of the Atomic Energy Act of 1954. Monitoring networks and analyte lists for the PUREX cribs are included in Appendix A.

Water levels are measured regularly, and the adequacy of the existing monitoring networks of the PUREX cribs is evaluated accordingly. Although water levels were decreasing prior to FY 1996, they appear to have stabilized. Therefore, there is no near-term need to replace any of the existing groundwater-monitoring wells. Furthermore, the new well network contains 11 near-field wells and 57 far-field wells, which adequately monitor the quality of groundwater in the area that contains the tritium, iodine-129, and nitrate plumes that emanate from the PUREX cribs.

\subsubsection{216-A-29 Ditch}

Since the resumption of interim-status indicator evaluation monitoring in October 1995, the 10 wells that constitute the 216-A-29 ditch-monitoring network continue to be sampled for the constituents listed in Appendix A. There were no exceedances during FY 1998 that subsequent resampling could confirm. 
Results for total organic carbon from the November 1997 sampling event exceeded the limit of quantitation, triggering a resampling of well 299-E25-48 in April 1998. The November 1997 replicate average concentration was $1,382.5 \mu \mathrm{g} / \mathrm{L}$. The resample replicate average concentration was $552.3 \mu \mathrm{g} / \mathrm{L}$, indicating the original value was an error.

Water-level measurements were taken during routine sampling events throughout the year. Although groundwater levels continue to decline regionally, there is sufficient water in network wells for groundwater-monitoring purposes.

\subsubsection{216-B-3 Pond}

Interim-status detection-level groundwater monitoring of B Pond began in 1988 and was changed to assessment status in 1990 because of elevated total organic halide levels in two downgradient wells (699-43-41E and 699-43-41F). The B Pond system continued in an assessment program until January 1998. At that time, a detection-level program was restored, as recommended in PNNL-11604 and as presented in amendments to the groundwater-monitoring plan (WHC-SD-EN-AP-013). PNNL-11604 concluded that no definable hazardous waste contamination had affected groundwater beneath the B Pond system, despite erratic low-level occurrences of elevated total organic halide (Section 5.10.3.2). No critical means were exceeded during FY 1998.

The locations of the B Pond system wells in the RCRA groundwater-monitoring network are shown in Appendix A. The maximum number of wells (25) was monitored from 1993 until late 1995. In 1995, the number of wells in the network was reduced to 14. Three of the wells no longer in the B Pond network are part of the 200 Areas Treated Effluent-Disposal Facility groundwater-monitoring network. In 1996, one of two upgradient wells (299-E18-1) was dropped from the network. This well was part of the 2101-M pond facility, which was clean-closed. The current upgradient well (299-E32-4) is shared with the still-active low-level burial grounds in the 200-East Area (see Appendix A).

Water levels in the 25 wells in the original network have generally declined during the life of the RCRA program. Exceptions to this trend occurred during the early to mid-1990s in some downgradient wells (such as wells 699-40-40A, 699-40-40B, 699-41-42) and wells around the 200 Areas Treated Effluent-Disposal Facility. During the past year, however, water levels in all wells have continued a definite downward trend (see Sections 3.6.7 and 5.10.1.5). Water levels have dropped dramatically during the past year in many wells, particularly 699-40-40A, 699-42-41, 699-43-41E, 699-43-42J, and 699-43-43. Wells 699-42-41, 699-43-40, 699-43-42J, and 699-43-43 are virtually dry. Wells in the western portion of the network (e.g., well 699-44-42) generally have fewer years of service left than those elsewhere in the network. Wells that were shared with the 200 Areas Treated Effluent-Disposal Facility, southeast of the B Pond system, appear to be the least affected by the declining water levels. The network is currently being revised to accommodate the loss of drying wells.

The redirection in 1994 of effluent discharges from the main B Pond to the 216-B-3C expansion pond probably introduced wastewater into the Hanford formation above the relatively impermeable Ringold lower mud unit. Thus, a locally perched, artificial aquifer likely exists beneath the 216-B-3C expansion pond. No monitoring wells are completed at this depth, nor have any regulatory or technical needs for such monitoring been identified. In August 1997, discharges were diverted from the 216-B-3C expansion pond to the 200 Areas Treated Effluent-Disposal Facility, thus ending all disposal activity at the B Pond 
system. As noted in Section 3.6.7, groundwater flow in the vicinity of the B Pond system is assumed to be radially away from the apex of a hydraulic mound created by past discharges.

To maintain an adequate monitoring network, several aspects of the system are considered, such as the areal distribution of wells, depth at which wells are screened, expected life of the well, and groundwater-flow direction in relation to the facility. For the B Pond system, "the facility" is determined to consist of the main pond and adjoining portions of the 216-B-3-3 ditch (see Appendix A). The three expansion ponds were RCRA clean-closed in 1994 (DOE/RL-89-28, Rev. 2). This closure is a determination that the expansion ponds are no longer considered potential sources of contamination to groundwater. Although near-surface sediments beneath the main pond have been investigated for contamination (see Section 3.6.7), the results are regarded as incomplete. Thus, the main pond, though now interim stabilized, is still considered a potential source of contamination along with adjoining portions of the 216-B-3-3 ditch. Continued groundwater monitoring will focus on this portion of the B Pond system and the potential contamination entrained in groundwater, originating from, and still in transit, near the facility.

\subsubsection{200 Areas Treated Effluent-Disposal Facility}

Groundwater sampling and analysis in the three monitoring wells at this facility (see Appendix A) are governed by a state waste-discharge permit (WAC 173-216). The constituent list and frequency of sampling are specified in the permit. Currently, the sampling frequency is quarterly but may be reduced during FY 1999. No permit criteria for constituents in groundwater were exceeded in FY 1998.

\subsubsection{216-B-63 Trench}

Groundwater monitoring continues to provide no evidence that dangerous nonradioactive constituents from the site have entered groundwater from this trench. The RCRA interim-status indicator parameters are $\mathrm{pH}$, specific conductance, total organic carbon, and total organic halides (40 CFR 265.92[b][3]). Included in the analysis list for this trench are a gamma scan, alkalinity, gross beta, and turbidity. There were no significant detections that could be attributed to this trench. The statistical analyses presented in Appendix B revealed no exceedances in $\mathrm{pH}$, specific conductance, total organic carbon, or total organic halides.

Groundwater analysis has indicated an increase in concentrations of calcium, magnesium, sodium, and sulfate in several wells. While the constituents do not exceed MCLs, they may be an indication of significant changes in groundwater chemistry.

Based on the Wilson et al. (1992) groundwater-modeling program, the existing network should provide a monitoring efficiency of $66 \%$ to $85 \%$ for this trench. The $66 \%$ monitoring efficiency results from a flow-direction azimuth of $270^{\circ}$ (toward the west), while the $85 \%$ monitoring efficiency is associated with an azimuth of $225^{\circ}$ (toward the southwest).

The current network is composed of six wells drilled specifically to monitor this trench. The network also includes five upgradient wells drilled to monitor the low-level burial grounds located just north of the trench and one upgradient well drilled to monitor WMA B-BX-BY. The network is considered adequate but will be continuously evaluated as water levels and groundwater gradients change with time. 


\subsubsection{Single-Shell Tank Farms}

WMA $B-B X-B Y$. This WMA is currently in a RCRA interim-status groundwater quality assessment program for exceedances of the specific conductance critical mean in the February 1996 sample. A firstdetermination quality assessment plan was issued in September 1996, followed by an assessment investigation. Results of the first determination were released in February 1998, and the conclusion was reached that tank waste from this WMA has reached the groundwater (PNNL-11826). Accordingly, a further determination is being conducted to investigate the nature, rate, and extent of groundwater contamination at this site. Wells are monitored at least quarterly. In some cases, wells are monitored monthly (see Appendix A).

For FY 1998, exceedances in RCRA-compliant wells occurred for iodine-129, technetium-99, uranium, and nitrate with corresponding exceedances in gross alpha and gross beta. The exceedances are listed in Appendix A. A further discussion of contaminant trends can be found in Section 5.10.3.1.

Originally, the RCRA groundwater network was designed for northwestern flow based on trends in regional plume maps. This method was used to indicate flow direction because the water table is almost flat in the immediate area of the farms. As part of the ongoing assessment, a series of steps are being taken to refine water-level measurements to allow a better determination of the approximate flow direction based on the local gradient. Although the aquifer is thin through this area, ranging from 1.9 to $3.7 \mathrm{~m}$ for RCRA-compliant wells, it is expected that these wells will be serviceable for at least 5 years.

The assessment-monitoring network has been expanded to include 12 surrounding wells; 2 of these wells are RCRA compliant. The remaining 10 are older, non-RCRA wells installed to monitor liquid effluent discharges to the soil column from past-practice waste-disposal sites. One new well (299-E33-44) was installed on the eastern side of BX tank farm in support of the assessment. The well was not sampled or surveyed during FY 1998. Two new wells are planned for FY 1999 to provide coverage on the southeastern side of the BX tank farm.

WMAs $A-A X$ and $C$. These sites are monitored semiannually under RCRA interim-status indicator evaluation. At these WMAs, groundwater samples from RCRA monitoring wells were analyzed during FY 1998 for potential contaminants, indicator parameters, and water-quality parameters. Comparison values of the indicator parameters $(\mathrm{pH}$, specific conductance, total organic carbon, and total organic halides) were not exceeded during FY 1998 (see Appendix B).

As in past years, wells at both WMAs show iodine-129 activity above the 1-pCi/L interim DWS. Chromium, manganese, and nickel exceeded MCLs at WMA A-AX in well 299-E24-19. This well has shown high chromium and nickel in the past but not as consistently as the last several years. Further discussion of these data can be found in Section 5.10.3.2.

Currently, the well networks for these two WMAs comply minimally with the required placement of groundwater-monitoring wells. However, continued observation is required as the B Pond mound dissipates. With an expected change in flow direction, both networks will require further evaluation with time. Before the groundwater flow changes to a southeastern direction, new drilling will be considered to provide coverage on the southeastern side of WMA A-AX. Groundwater-monitoring coverage for WMA $C$, though sparse, still meets the minimal regulatory requirements. 


\subsubsection{Low-Level Waste Management Area 1}

This LLWMA continued in RCRA interim-status indicator evaluation in FY 1998. Groundwater sampling was on a semiannual schedule. Appendix A contains a list of monitoring wells and analytical constituents for LLWMA 1. There were no exceedances of the upgradient/downgradient comparison values for the averages of indicator parameters in FY 1998.

The groundwater-monitoring network at LLWMA 1 continues to meet requirements. Although water levels are declining slightly, there are no plans for additional groundwater-monitoring wells at this time.

\subsubsection{Low-Level Waste Management Area 2}

This LLWMA's contaminant indicator parameters were compared semiannually to comply with RCRA interim-status indicator evaluation. Upgradient well 299-E34-7 exceeded the upgradient/ downgradient comparison value for specific conductance in both sampling events in 1998. The increase appears to be related to elevated calcium, sulfate, and nitrate. LLWMA 2 remains in detectionmonitoring status.

The monitoring network continues to satisfy the requirement for at least one upgradient and three downgradient wells and is adequate to monitor the facility. Although water levels are declining slightly, no additional monitoring wells are planned for the LLWMA 2 monitoring network.

\subsubsection{Liquid Effluent-Retention Facility}

The Liquid Effluent-Retention Facility is in a final-status detection evaluation program and is included in the Hanford Site RCRA Permit subject to final-status monitoring. Until the final-status plan is approved by the regulators, the site will continue to operate under the existing interim-status groundwater-monitoring plan (WHC-SD-EN-AP-024).

Groundwater monitoring continues to provide no evidence that dangerous, nonradioactive constituents from the site entered the groundwater from this facility. The RCRA indicator parameters are $\mathrm{pH}$, specific conductance, total organic carbon, and total organic halides (40 CFR 265.92[b][3]). Included in the analysis list for this facility are alkalinity, gamma scan, gross beta, and turbidity. The statistical analyses presented in Appendix B revealed no exceedances of critical mean values for the RCRA indicator parameters.

The current network is composed of four wells, one of which is upgradient. The network is considered adequate but will be continuously evaluated as water levels and groundwater gradients change with time. The Wilson et al. (1992) groundwater program calculated monitoring efficiency at $95.5 \%$. Although it is likely that well 299-E26-9 may be declared inoperable because of lack of water in the screened interval, no additional wells are under consideration at this time.

\subsubsection{Drinking Water Standards and Derived Concentration Guides}

Tritium was detected at levels above the 2,000,000-pCi/L DCG at one well south of the PUREX Plant. Tritium contamination at levels above the $20,000-\mathrm{pCi} / \mathrm{L}$ interim $\mathrm{DWS}$ was found throughout much 
of the 200-East Area. Strontium-90 was detected at levels over five times the $1,000-\mathrm{pCi} / \mathrm{L}$ DCG in one well near the 216-B-5 injection well. Localized strontium-90 contamination was found at levels above the 8-pCi/L interim DWS south of the PUREX Plant. Also found at levels above standards in the 200-East Area were the following: aluminum, antimony, cesium-137, cyanide, iodine-129, manganese, nitrate, pentachlorophenol, sulfate, technetium-99, total dissolved solids, and uranium.

\subsubsection{Extent of Contamination}

During site operations, considerable waste was produced in the 200-East Area and disposed to numerous facilities. The exact source of the contamination detected in the groundwater cannot always be defined with a high degree of certainty. The discussion below divides the extent of contamination into that found generally in the vicinity of B Plant and that found in the vicinity of and downgradient of the PUREX Plant. The low-level burial grounds and Liquid Effluent-Retention Facility are discussed separately. Additional detail is provided for facilities with specific RCRA monitoring requirements.

\subsubsection{B Plant Area}

With the decommissioning of Gable Mountain Pond, groundwater near B Plant began flowing northward, and a number of groundwater-contaminant plumes reappeared north of the 200-East Area boundary. Several facilities in the vicinity of $B$ Plant are notable with regard to groundwater contamination. Radiological contaminants, including substantial levels of technetium-99 as well as some cobalt-60, are found near the BY cribs. Chemical contaminants include nitrate and cyanide. Uranium contamination is also detected in limited areas. Injection of waste below the water table at the 216-B-5 injection well produced localized groundwater contamination. The waste stream apparently contained a large amount of suspended solids and some of the waste was most likely emplaced as particulate matter. The constituents detected in groundwater (strontium-90, cesium-137, and plutonium) typically have low mobilities because of their sorption to aquifer sediments. Characterization activities in the vicinity of the 216-B-5 injection well were reported in RHO-ST-37. Tritium and iodine-129 contamination is widespread in the 200-East Area, and the sources are difficult to ascertain.

Tritium. Tritium contamination is widespread throughout the northwestern part of the 200-East Area and extends northward through the gap between Gable Mountain and Gable Butte (see Plate 3). The maximum average annual tritium activity detected in this part of the 200-East Area in FY 1998 was $34,000 \mathrm{pCi} / \mathrm{L}$ in well 299-E28-2 north of the 216-B-5 injection well. In FY 1997, 46,000 pCi/L of tritium were measured in well 299-E28-27 southeast (upgradient) of LLWMA 1. Another pulse of tritium at levels above the interim DWS can be seen between Gable Mountain and Gable Butte, where the maximum average annual activity for FY 1998 was $54,000 \mathrm{pCi} / \mathrm{L}$ in well 699-61-62. The exact sources of the tritium were not determined.

Iodine-129. Iodine-129 forms another widespread contaminant plume in the 200-East Area, and the contamination also extends northward through the gap between Gable Mountain and Gable Butte (see Plate 5). The maximum average annual iodine-129 activity detected in this part of the 200-East Area in FY 1998 was $6.6 \mathrm{pCi} / \mathrm{L}$ in well 299-E33-34. The exact sources for the iodine-129 contamination, like tritium, were not determined; however, the iodine-129 activities in this vicinity do not correlate well with tritium activities. The highest iodine-129 activities are located generally eastward of the highest parts of the tritium plume. Iodine-129 activities have declined slightly in wells east (upgradient) of WMA 
B-BX-BY. The presence of iodine-129 contamination upgradient of this WMA, at similar levels found downgradient, indicates that the WMA is not the source of the iodine-129. The iodine-129 distribution is also inconsistent with a source from the BY cribs because the high activities do not correlate with technetium-99.

Technetium-99. Elevated technetium-99 levels (potentially associated with the BY cribs' plume) continued to be observed in FY 1998 (Figure 5.10-1). Because of the extremely flat water-table configuration in the northwestern part of the 200-East Area, the flow direction in the vicinity of the BY cribs is uncertain. Technetium-99 also impacts wells that monitor the northeastern corner of LLWMA 1, resulting in elevated gross beta measurements in some wells in the monitoring well network. For further disciussion of technetium-99 in the northwestern 200-East Area, see the following section entitled WMA B-BX-BY RCRA Parameters.

North of the 200-East Area boundary, well 699-50-53A was used in FY 1995 for an extraction well in treatability testing and contained up to $9,910 \mathrm{pCi} / \mathrm{L}$ of technetium-99 in FY 1995 . This well was sampled in FY 1997 for the first time after the completion of the test, and the technetium-99 activity was only $730 \mathrm{pCi} / \mathrm{L}$. In FY 1998, it was $398 \mathrm{pCi} / \mathrm{L}$. The maximum average annual technetium-99 detected in the area north of the 200-East Area in FY 1998 was 2,210 pCi/L in wells 699-49-57A. Technetium-99 activities that were less than the interim DWS were detected north of Gable Mountain and indicate that this plume is moving into and through the gap between Gable Mountain and Gable Butte.

Uranium. Uranium is sporadically detected at levels $>20 \mu \mathrm{g} / \mathrm{L}$ (proposed DWS) in a few wells in the vicinity of B Plant. The distribution of uranium contamination suggests the plumes are of limited extent and the source of this uranium is not understood.

Another apparent source of uranium is the 216-B-5 injection well. In well 299-E28-23 near the injection well, uranium had a concentration of $52 \mu \mathrm{g} / \mathrm{L}$ in December 1997, which is up from $41 \mu \mathrm{g} / \mathrm{L}$ in December 1996 and $28 \mu \mathrm{g} / \mathrm{L}$ in May 1995. For further discussion of uranium in the general vicinity of B Plant, see the following section entitled WMA B-BX-BY RCRA Parameters.

Strontium-90. There is a small strontium-90 plume around the $216-\mathrm{B}-5$ injection well (Figure 5.10-2). Concentrations of strontium-90 in FY 1998 ranged up to $9,785 \mathrm{pCi} / \mathrm{L}$ (above the 1,000-pCi/L DCG) in well 299-E28-23 (within historical range for this well). Strontium-90 increased to $169 \mathrm{pCi} / \mathrm{L}$ in well $299-\mathrm{E} 28-2$, which is $150 \mathrm{~m}$ (northwest) from the $216-\mathrm{B}-5$ injection well. This injection well received an estimated $27.9 \mathrm{Ci}$ of strontium-90 (decayed through April 1, 1986) during 1945 to 1946 when it was used for waste disposal (PNL-6456).

Cobalt-60. Wells in the area affected by waste disposed to the BY cribs have consistently shown the presence of cobalt-60 since it was first reported in 1956. Much of that discharged cobalt-60 has now decayed away because of its relatively short half-life (5.3 years). In FY 1998, the maximum average annual cobalt-60 detected in this vicinity was $26 \mathrm{pCi} / \mathrm{L}$ (below the $100-\mathrm{pCi} / \mathrm{L}$ interim $\mathrm{DWS}$ ) in well 699-49-57A. Cobalt-60 in this area appears to be highly mobile, probably because of the presence of a soluble cobalt-cyanide (or ferrocyanide) complex associated with the plume originating in the BY cribs. The presence of complexed cobalt-60 in ferrocyanide-scavenged wastes from the bismuth phosphate process was known by 1957 to result in little retention by sediments (HW-48862). Cobalt-60 is discussed further in the section WMA B-BX-BY RCRA Parameters. 
Cesium-137. Activities of cesium-137 in FY 1998 reached 2,205 pCi/L in well 299-E28-23 near the 216-B-5 injection well. The interim DWS for cesium- 137 is $200 \mathrm{pCi} / \mathrm{L}$ and the DCG is $3,000 \mathrm{pCi} / \mathrm{L}$. This is the only part of the 200-East Area where cesium-137 is reliably or significantly detected in groundwater. Occasional, extremely low activities detected in other wells appear to be the result of uncertainties inherent in radionuclide analyses.

Plutonium. The maximum plutonium-239/-240 activity detected near the 216-B-5 injection well in FY 1998 was $63 \mathrm{pCi} / \mathrm{L}$ in well 299-E28-23 (within the historical range for this well). Plutonium had been detected in FY 1996 in well 299-E28-2, 150 m northwest of the 216-B-5 injection well $(0.11 \mathrm{pCi} / \mathrm{L})$ but was below the detection level in both FY 1997 and FY 1998. It is unusual to see plutonium that far from Hanford Site sources. Colloidal transport of a small amount of plutonium may explain the results from well 299-E28-2, but the presence of mobile radiocolloids has not yet been proved. Plutonium is generally considered to bind strongly to sediments and, thus, has limited mobility in the aquifer. The DCG for plutonium-239 is $30 \mathrm{pCi} / \mathrm{L}$. There is no explicit interim DWS for plutonium-239; however, the gross alpha 15-pCi/L MCL would be applicable, at a minimum. Alternatively, if the DCG, which is based on a 100-mrem dose standard, is converted to the 4-mrem dose equivalent used for the interim DWS, $1.2 \mathrm{pCi} / \mathrm{L}$ would be the relevant guideline.

Nitrate. The plume originating from facilities in the northwestern part of the 200-East Area contains some of the highest groundwater nitrate levels on the site (see Plate 4). The maximum concentration detected in this area in FY 1998 was $400 \mathrm{mg} / \mathrm{L}$ (the MCL is $45 \mathrm{mg} / \mathrm{L}$ ) in well 299-E33-16 near the 216-B-8 crib. This plume extends northwest through the gap between Gable Mountain and Gable Butte. Nitrate near WMA B-BX-BY is discussed further below.

WMA B-BX-BY RCRA Parameters. In June 1996, this facility was placed in a groundwater quality assessment program with quarterly monitoring because of elevated specific conductance. A first determination was conducted in accordance with the RCRA interim-status regulations (40 CFR 265.93 [d]) and the results were presented in PNNL-11826. It was concluded that the WMA was, most likely, the cause of the elevated specific conductance seen in well 299-E33-41. Consequently, the WMA will continue in assessment. The pertinent groundwater contaminants related to the ongoing assessment are discussed below.

Technetium-99. There appear to be two centers (possibly two sources) of contamination in the vicinity of the WMA with slightly lower levels in between. Contaminant ratios also imply that the sources of contamination are distinct (see Figure 5.10-1). Although elevated specific conductance in well 299-E33-32 triggered the WMA into interim assessment, the focus of the first determination not only was on nitrate, but also technetium-99 and uranium found in well 299-E33-41. During FY 1998, technetium99 rose again in well 299-E33-41 from 1,480 pCi/L in October 1997 to 2,720 pCi/L in March 1998 (Figure 5.10-3). The DWS is $900 \mathrm{pCi} / \mathrm{L}$. Technetium-99 then fell to $1,180 \mathrm{pCi} / \mathrm{L}$ in August 1998 in well 199-E33-41. Currently, levels of this contaminant are rising. Other wells (299-E33-16 and 299-E33-18) near the 216-B-7A and 216-B-8 cribs also have technetium-99 above the DWS. This part of the local technetium- 99 plume is bracketed on the northeast, east, and southeast by wells 299-E33-39, 299-E33-15, 299-E33-17, 299-E33-20, 299-E33-33, and 299-E33-36, which have low values of technetium-99 ( 10 to $189 \mathrm{pCi} / \mathrm{L})$. 
The region north and west of WMA B-BX-BY saw overall increases in technetium-99 (Figure 5.10-4), creating another local center for high technetium-99. The largest increase $(7,030 \mathrm{pCi} / \mathrm{L}$ in June 1998) was found in well 299-E33-7 in the northwestern corner of the BY cribs. Corresponding increases are seen south of well 299-E33-7 and along the western side of the WMA, with the technetium-99 activity mostly decreasing in a southerly direction. However, even the most-southerly wells at the site (299-E33-43 and 299-E33-21) are showing distinct rises in technetium-99.

The rise in technetium-99 in well 299-E33-42 appears to correspond with the sharp decrease in technetium-99 in well 299-E33-13, which fell from $2,470 \mathrm{pCi} / \mathrm{L}$ in October 1997 to $800 \mathrm{pCi} / \mathrm{L}$ in August 1998. At the same time, there are no corresponding changes in wells 299-E33-41 or 299-E33-18 These observations appear to indicate that the technetium-99 observed around the 216-B-7A crib in well 299-E33-18 and 299-E33-41 is not likely to be from the same plume as that observed farther north in the BY cribs. With the uncertainties in the flow direction discussed in Section 3.6.9.2, it is premature to discern a definitive pattern to the contaminant changes.

Nitrate. Nitrate concentrations continue to rise across the site, even in the southwestern corner, which historically shows little or no change in contamination. Nitrate is generally rising in the vicinity of WMA B-BX-BY. As of August 1998, the 45,000- $\mu \mathrm{g} / \mathrm{L}$ DWS was exceeded in all but the southernmost wells, well 299-E33-39 northeast of the site, and well 299-E33-41 (Figure 5.10-5 and see Plate 4). There are locally two centers of nitrate contamination that approximately correspond with the local high values in technetium-99 seen in wells 299-E33-7 and 299-E33-16. Although the highest technetium-99 value of $7,030 \mathrm{pCi} / \mathrm{L}$ was observed at well 299-E33-7 in June 1998, the highest nitrate values are observed at well 299-E33-16 at 460,314 $\mu \mathrm{g} / \mathrm{L}$ for August 1998. This inverse relationship results in a smaller nitrate-totechnetium-99 ratio ( 38 to 46 ) for the northern region than for the eastern region (250 to 300), suggesting that the contamination is moving as two separate plumes. It should be noted that, though technetium-99 in well 299-E33-13 decreased sharply from 1997 to 1998, the nitrate continued to rise. However, the rate of increase has declined since February 1998.

Uranizm. This contaminant is found in the groundwater at WMA B-BX-BY east of the BY tank farm and in the southern part of the BY cribs (see Appendix A for location of tank farms). Uranium has a $20-\mu \mathrm{g} / \mathrm{L}$ interim DWS. During FY 1998, four wells continued to have uranium concentrations greater than the proposed DWS (Figure 5.10-6). The sources of the uranium contamination are unknown.

One significant development during FY 1998 was the unique pattern of uranium changes observed in well 299-E33-41 (Figure 5.10-7). The double, high-frequency, high-amplitude spikes observed in the technetium-99 data during FY 1997 were repeated in the uranium data for FY 1998. No other well has shown this pattern of contamination for any constituents. Based on the time difference between the second peak of technetium- 99 to uranium, it appears that uranium is traveling $\sim 6$ months behind the technetium-99. The second peak more accurately marks the peak location for technetium-99 because the sampling schedule was less than a month during this period. Because sampling was occurring approximately monthly during the time the uranium peaks moved through the groundwater at this well, a welldefined breakthrough curve was obtained. This indicates that some degree of dispersion had occurred prior to the contaminant entering the well. The rapid, sharply rising breakthrough curve indicates that contamination has a relatively short travel path in the groundwater and entered the groundwater near the well. 
Uranium levels in well 299-E33-18 have not changed appreciably from $143 \mu \mathrm{g} / \mathrm{L}$ in May 1997 to $137 \mu \mathrm{g} / \mathrm{L}$ in August 1998. Uranium concentrations remain low at the other wells on the east but are close to background levels (2.5 to $3.0 \mu \mathrm{g} / \mathrm{L}$ ) with the exception of well 299-E33-16. That well shows a slight increase in uranium from $4.87 \mu \mathrm{g} / \mathrm{L}$ in August 1997 to $6.95 \mu \mathrm{g} / \mathrm{L}$ in August 1998.

Also, contamination decreased in well 299-E33-13, the well showing the highest FY 1997 uranium concentrations (203 $\mu \mathrm{g} / \mathrm{L}$ in April 1997 to $18.4 \mu \mathrm{g} / \mathrm{L}$ in August 1998) (Figure 5.10-8). At the same time there was a decrease in contamination on the eastern side of the BY tank farm, there were small increases in uranium on the western side of the WMA. Values in well 299-E33-42 increased from background $(2.67 \mu \mathrm{g} / \mathrm{L}$ in February 1998) to $10.5 \mu \mathrm{g} / \mathrm{L}$ in September 1998. Smaller increases are observed in wells 299-E33-8, 299-E33-31, and 299-E33-32. Other changes include increases in uranium in wells 299-E33-5 and 299-E33-38, located in the southern half of the BY cribs. These wells increased from 48.7 and $30.1 \mu \mathrm{g} / \mathrm{L}$ in November 1997 to 67.9 and $58.7 \mu \mathrm{g} / \mathrm{L}$ in August 1998, both above the $20-\mu \mathrm{g} / \mathrm{L}$ DWS.

Cobalt-60 and Cyanide. Ferrocyanide waste-scavenging processes were employed during the 1950s to provide additional storage space. By removing the soluble, long-lived fission product (cesium-137) from liquid wastes, supernatants could be disposed to the ground. These liquids were enriched in excess ferrocyanide, which possibly complexed with the cobalt- 60 previously disposed to the ground, rendering the cobalt- 60 mobile. Thus, it might be expected to find cobalt with cyanide in the groundwater under the BY cribs.

Cobalt-60 has been found in three BY crib wells (299-E33-7, 299-E33-5, and 299-E33-38) above the 22- or 25-pCi/L limit of quantitation (100-pCi/L) (Figure 5.10-9). None of the wells at WMA B-BX-BY show an exceedance of the DWS. The highest cobalt-60 activity $(61.1 \mathrm{pCi} / \mathrm{L})$ was found in well 299-E33-7, the well with the highest technetium-99 and one of the greatest nitrate concentrations. Groundwater samples from several other wells in the northern part of the WMA had indications of cobalt60 with isolated values above the method detection level but below the practical limit of quantitation.

Each of the wells discussed above also had significant increases in cyanide that correlate to the cobalt-60 occurrences (Figure 5.10-10). Well 299-E33-7 had the highest levels of cyanide (347 $\mu \mathrm{g} / \mathrm{L}$ in June 1998) that also correlate with the other increases in contaminants observed at this well. There is also a reasonable correlation between cyanide changes and technetium-99 changes for well 299-E33-13. However, the level of cyanide contamination in well 299-E33-13 is much lower than at the other three wells. As stated above, detectable cobalt-60 contamination does exist at well 299-E33-13, corresponding to the lower levels of cyanide but not at quantifiable levels. Neither cyanide nor cobalt- 60 are found in the groundwater at the remaining assessment wells at WMA B-BX-BY.

Tritium. Well 299-E33-7 was added to the WMA B-BX-BY assessment network in May 1998. Prior to that time, it was monitored annually for selected constituents. The June 1998 sample showed that tritium rose to $10,500 \mathrm{pCi} / \mathrm{L}$ from $5,040 \mathrm{pCi} / \mathrm{L}$ in May 1995 . Although the increased tritium appears to correspond with the increased technetium-99, changes that may have occurred from 1995 to 1998 are unknown. 
216-B-63 Trench RCRA Parameters. Groundwater monitoring continues to provide no evidence that dangerous nonradioactive constituents entered the groundwater from this trench. The analyses included alkalinity, gamma scan, gross beta, $\mathrm{pH}$, total organic carbon, total organic halides, and turbidity.

\subsubsection{PUREX Plant Area}

Numerous disposal facilities received waste from PUREX Plant operations. In particular, numerous cribs to the south and east of the PUREX building impacted groundwater quality over a large area of the site. The most extensive and significant contaminants are tritium, iodine-129, and nitrate. Three cribs (216-A-10, 216-A-36B, and 216-A-37-1) were monitored in accordance with RCRA in FY 1998. Monitoring results are clear that the impacts to groundwater also originate from other facilities, located generally northeast and east of the plant, that are being addressed under the CERCLA/RCRA pastpractice process. The 216-A-29 ditch, B Pond, and high-level waste tanks in WMAs A-AX and C are monitored in accordance with RCRA. This section also discusses the large plumes from the vicinity of PUREX that migrated through the 600 Area as far as the Columbia River and the 300 Area.

Tritium. The highest tritium activities in the 200-East Area continued to be found in wells near cribs that received effluent from the PUREX Plant (see Plate 3). Activities of $>2,000,000 \mathrm{pCi} / \mathrm{L}$ (the DCG) were detected only in well 299-E17-9 next to the 216-A-36B crib. The maximum activity detected in this well in FY 1998 was $3,400,000 \mathrm{pCi} / \mathrm{L}$, which was also the maximum tritium activity detected in any well onsite during FY 1998. Tritium activities exceeding the 20,000-pCi/L interim DWS continued to be found in many wells affected by cribs near the PUREX Plant.

Prior to FY 1998, tritium levels measured in well 699-37-47A, near the southeastern corner of the 200-East Area and completed in 1996, averaged 15,730 pCi/L. The April 1998 level was 35,000 pCi/L, more than twice the average measured earlier. The rise in tritium in this well is due probably to the reduction in wastewater volume discharged in the vicinity of B Pond. Well 699-37-47A is very near the mixing area of groundwater from the northwest that has higher tritium activity and groundwater from the $\mathrm{B}$ Pond area that has lower tritium. As wastewater volumes in the B Pond area are reduced, the mixing area for groundwater from the two sources (near well 699-37-47A) becomes more dominated by groundwater from the northwest that has higher tritium activities.

The movement of the widespread tritium plume (see Plate 3), extending from the southeastern portion of the 200-East Area to the Columbia River, was consistent with patterns noted in Section 5.10.3.2 of PNNL-11793. Separate tritium pulses associated with the two PUREX operational periods contributed to the plume. The first pulse, which resulted from discharges during the PUREX operation from 1956 to 1972, can be detected near the Columbia River (e.g., well 699-40-1, Figure 5.10-11). Elevated tritium activities measured immediately downgradient from the 200-East Area represent the second pulse associated with the restart of operations between 1983 and 1988. The area immediately downgradient of the cribs, where activities are $>200,000 \mathrm{pCi} / \mathrm{L}$, is naturally attenuating as a result of radioactive decay and dispersion combined with the decreasing source that resulted from the termination of operations. Figure 5.10-12 clearly shows the arrival of the plume in early 1987 at well 699-24-33, near the Central Landfill, well after the passage of the plume from the earlier operation. The tritium activities in this well during passage of the first pulse were at least three times the maximum activities in the pulse from the second period. Thus, the second pulse is expected to have a significantly lower impact than the first pulse 
downgradient toward the Columbia River. The overall decline in activities throughout this plume indicate that the greatest impacts expected at the Columbia River have already occurred.

The zone of lower tritium activities near the Washington Public Power Supply System may be related to an area where Ringold Formation sediments are present at the water table. This suggests that a zone of lower hydraulic conductivity sediments is present in this area that may be diverting the bulk of the contaminant transport to the north and south.

Iodine-129. The highest iodine-129 activities observed in the 200-East Area in FY 1998 were near the PUREX Plant cribs (see Plate 5). The maximum detected iodine-129 activity in FY 1998 was $14 \mathrm{pCi} / \mathrm{L}$ in well $299-\mathrm{E} 24-16$. This well monitors the $216-\mathrm{A}-10 \mathrm{crib}$. Activities of iodine-129 in groundwater near the PUREX cribs are generally declining slowly or are stable, as shown for well 299-E17-9 (Figure 5.10-13). The iodine-129 plume extends southeast into the 600 Area and appears to coincide with the tritium and nitrate plumes (see Plates 3,4, and 5). Seep sampling along the Columbia River shoreline shows that iodine-129 is being discharged to the river near the Old Hanford Townsite but at levels lower than can be detected by the standard groundwater analytical techniques (Section 4.2 of PNNL-11472). The activities and overall extent of this plume did not change greatly from FY 1997.

Nitrate. High nitrate concentrations continued to be found near liquid waste-disposal facilities that received effluent from PUREX Plant operations. The maximum nitrate concentration detected near the PUREX Plant in FY 1998 was $178 \mathrm{mg} / \mathrm{L}$ in well 299-E17-9, which is adjacent to the 216-A-36B crib. The extent of the nitrate plume that emanates from the 200-East Area (see Plate 4) is nearly identical to that of the tritium plume. However, the area with nitrate $>45 \mathrm{mg} / \mathrm{L}$ (the $\mathrm{MCL}$ ) is considerably more restricted than the area with tritium above the interim DWS. Nitrate at levels above the MCL north of the 400 Area, within the area impacted by PUREX operations, is attributable to 400 Area disposal (discussed in Section 5.11).

Strontium-90. A single well (299-E17-14) near cribs south of the PUREX Plant revealed an activity above the interim DWS for strontium-90 (a beta emitter) in FY 1998. The maximum annual average strontium-90 activity detected in FY 1998 was 17.2 pCi/L from well 299-E17-14 next to the 216-A-36B crib. The impact is very localized because of the lower mobility of strontium- 90 compared to tritium, iodine-129, and nitrate. This result is consistent with gross beta $(68.3 \mathrm{pCi} / \mathrm{L})$ in the same well.

Cobalt-60. A review of past data for groundwater near the Old Hanford Townsite showed the presence of extremely low but detectable concentrations of cobalt-60. Data from the 1970 s and $1980 \mathrm{~s}$ indicate that cobalt- 60 was detected in wells within the area of the current tritium plume and the source was probably in the 200-East Area. However, in FY 1998, there was no detectable cobalt-60 near the Old Hanford Townsite.

Manganese. Two wells (299-E25-17 and 299-E25-19) south of the 216-A-37-1 crib show that filtered manganese concentrations downgradient of the crib are increasing. The concentration increased in early FY 1998 to. levels not reached since 1993 and continued to rise throughout the remainder of the year. In March 1998, manganese concentrations in the two wells surpassed the secondary MCL $(50 \mu \mathrm{g} / \mathrm{L})$, for a maximum of $58 \mu \mathrm{g} / \mathrm{L}$ for June 1998 in well 299-E25-19. 
PUREX Cribs RCRA Parameters. The 216-A-10, 216-A-36B, and 216-A-37-1 cribs are located in a region where several groundwater plumes contain constituents that exceed the DWSs. Examples of these exceedances include tritium, iodine-129, strontium-90, and nitrate. The similarities in effluent constituents disposed to these cribs, as well as to the 216-A-45 crib, make determining the contribution of the PUREX cribs very difficult. The data from RCRA monitoring of these facilities are integrated into the assessment of the overall extent of contamination for these constituents.

WMA A-AX RCRA Parameters. Critical mean values of the indicator parameters ( $\mathrm{pH}$, specific conductance, total organic carbon, and total organic halides) were not exceeded during FY 1998. However, there were problems with the field specific conductance values. Although the problem with faulty probes has been remedied, the data are currently flagged as suspect. Because the field specific conductance was questionable during FY 1998, nitrate was monitored closely. For a more complete discussion of this issue, see Appendix D.

In general, nitrate concentrations were low during FY 1998, ranging from $13,190 \mu \mathrm{g} / \mathrm{L}$ to $3,320 \mu \mathrm{g} / \mathrm{L}$, except in well 299-E24-20. Although nitrate levels dropped in this well during the period FY 1993 to FY 1996, values rose to a high of $37,754 \mu \mathrm{g} / \mathrm{L}$ during FY 1998. Current nitrate concentrations appear to be dropping in this well. There is no detectable technetium-99 in this well.

In FY 1998, nitrate in well 299-E25-46 increased. As can be seen in Figure 5.10-14, there is a positive correlation of nitrate to the technetium-99 high reported in FY 1997. Nitrate dropped from $13,190 \mu \mathrm{g} / \mathrm{L}$ in February 1997 to $4,236 \mu \mathrm{g} / \mathrm{L}$ in June 1998.

Although there were increases in total organic carbon in some wells above the limit of quantitation used for comparison, these data appear to be associated with a laboratory problem and are currently under review. All wells show activities of iodine- 129 above the $1-\mathrm{pCi} / \mathrm{L}$ interim $\mathrm{DWS}$, the same as in past years. The iodine-129 plume extends from north of the PUREX Plant through the groundwater underneath the WMA. For the RCRA-network wells, tritium values for FY 1998 ranged from 7,420 to $3,050 \mathrm{pCi} / \mathrm{L}$, considerably less than the $20,000-\mathrm{pCi} / \mathrm{L}$ interim $\mathrm{DWS}$.

Chromium, manganese, and nickel were seen in filtered samples from well 299-E24-19 at levels above their DWSs (Figure 5.10-15). This well has shown sporadic high chromium and nickel in the past. The FY 1998 values of chromium for well 299-E24-19 were 1,590 and 1,000 $\mu \mathrm{g} / \mathrm{L}$ in the February and June 1998 samples, respectively; nickel ranged from 326 to $303 \mu \mathrm{g} / \mathrm{L}$. Manganese rose to $52 \mu \mathrm{g} / \mathrm{L}$ in June 1998. This is the only well in the network to display high values of these metals. No other contaminants were observed in groundwater samples from this well that correlate with these metal concentrations. It is possible that the elevated metals is related to stress corrosion of the well screen. This possibility is being investigated.

WMA C RCRA Parameters. Critical mean values of the indicator parameters ( $\mathrm{pH}$, specific conductance, total organic carbon, and total organic halides) were not exceeded during FY 1998. As sluicing operations commence at tank C-106, this site has been placed temporarily on monthly monitoring to assist detecting effects of waste-retrieval operations on groundwater quality. 
- For iodine-129, all wells showed activities above the $1-\mathrm{pCi} / \mathrm{L}$ interim $\mathrm{DWS}$ because the iodine-129 plume extends through this region. Although tritium did rise in upgradient well 299-E27-7 from 1,820 (August 1997) to $2,550 \mathrm{pCi} / \mathrm{L}$ (February 1998), values across the site remain well below the $20,000-\mathrm{pCi} / \mathrm{L}$ DWS.

Technetium-99 rose in upgradient well 299-E27-14 from $141 \mathrm{pCi} / \mathrm{L}$ in August 1997 to $672 \mathrm{pCi} / \mathrm{L}$ in September 1998 (Figure 5.10-16). The technetium-99 level in downgradient well 299-E27-13 dropped from $487 \mathrm{pCi} / \mathrm{L}$ in February 1998 to $100 \mathrm{pCi} / \mathrm{L}$ in July 1998. These values are well below the $900-\mathrm{pCi} / \mathrm{L}$ interim DWS. Although historically most wells at this site have undetectable levels of technetium-99, there appears to be slight occurrences or increases in upgradient well 299-E27-7 and downgradient wells 299-E27-12 and 299-E27-15. Small corresponding changes were also observed in nitrate for these wells. Technetium-99 originally rose in a downgradient well (299-E27-13) and then in an upgradient well (299-E27-14) beginning in February 1997. These observations may indicate that the local flow direction is different from that determined from the regional water-table contours.

Total organic carbon levels generally increased in the February 1998 sample. These data are suspect because the entire site experienced this increase at one time and because levels in the June 1998 samples returned to historic trends.

216-A-29 Ditch RCRA Parameters. Critical mean values of the indicator parameters ( $\mathrm{pH}$, specific conductance, total organic carbon, and total organic halides) were not exceeded during FY 1998.

The levels of sulfate (as noted in WHC-SD-EN-EV-032) in the groundwater under this ditch had been declining steadily since the facility stopped receiving sulfate-bearing effluent. This trend did not continue beyond FY 1997. Sample results confirmed that a slight increase was observed in nearly all network wells in FY 1997 and remained elevated in FY 1998. The greatest increase in FY 1997 was at well 299-E25-35 (Figure 5.10-17). In FY 1998, the concentration remained elevated early in the year but rose slightly again in October 1998 to $65 \mathrm{mg} / \mathrm{L}$. The same upward trend can be seen in specific conductance in both upgradient and downgradient wells (Figure 5.10-18). Assessment monitoring performed between 1990 and 1995 confirmed that the elevated specific conductance was related to calcium, sodium, and sulfate, which are nonregulated substances.

The groundwater in the vicinity of this ditch contains iodine-129 at levels above the interim DWS (see Plate 5). In contrast to the area of the $216-\mathrm{A}-10$ and $216-\mathrm{A}-36 \mathrm{~B}$ cribs, this contamination is not associated with high levels of tritium (see Plate 3 ).

216-B-3 Pond RCRA Parameters. The B Pond system was placed into assessment-monitoring status in 1990 because of elevated total organic carbon and total organic halides in two wells (699-43-41E and $699-43-41 F$ ). From that time until mid-1996, comprehensive sampling and analyses were performed to determine the cause of these anomalies. The assessment report concluded that these occurrences were essentially isolated, and that total organic carbon or total organic halides could not be attributed to hazardous waste (PNNL-11604). In October 1997, the site returned to an interim-status indicator evaluation program. Critical mean values of the indicator parameters $(\mathrm{pH}$, specific conductance, total organic carbon, and total organic halides) were not exceeded during FY 1998. 
The only contaminants consistently detected in groundwater that could be ascribed to B Pond operations were tritium (maximum 232,000 pCi/L) and nitrate (maximum $22.5 \mathrm{mg} / \mathrm{L}$ ). Only tritium occurred in activities above the interim DWS. With some recent exceptions, both of these constituents have displayed downward trends in concentrations since monitoring began at the facility. Of seven wells in the B Pond network analyzed for tritium in FY 1998, only two (699-42-42B and 699-43-43) indicated a modest increase of this constituent. The other five wells continued in an historically consistent downward trend in tritium. Nitrate in wells 699-42-39B, 699-43-40, and 699-43-41E, has begun to show a definitive increase in concentration during the last few years. Figure 5.10-19 shows trends for nitrate in these wells.

Filtered chromium, iron, and manganese have historically exceeded their MCLs in several wells. Concentrations of these metals have been attributed to well construction and the effects of dissolved oxygen on aquifer sediments. Arsenic has been detected at extremely low levels (far below its MCL) in wells near the western end of the main B Pond but is described in WHC-EP-0813 as probably having originated from 200-East Area cribs and trenches. Of the seven wells in the network analyzed for iodine-129, two (699-42-42B and 699-43-43) showed increased activity. In well 699-43-43, iodine-129 activity increased from $0.99 \mathrm{pCi} / \mathrm{L}$ in 1997 to $4.36 \mathrm{pCi} / \mathrm{L}$ in FY 1998. These wells have historically produced elevated iodine-129 results, and are thought to be a reflection of the remnant of a larger plume originating from the 200-East Area, before the B Pond hydraulic mound was established.

Groundwater samples were taken once each quarter of FY 1998 for the required indicator parameters (see Appendix A). Concentrations of parameters such as sulfate and specific conductance appear to be recovering slightly from artificially low values. Natural groundwater, normally higher in some anionic species, was temporarily displaced by dilute discharges to the B Pond system.

\subsubsection{Low-Level Waste Management Area 1}

Although there is no evidence of any contribution from LLWMA 1, contaminant plumes are affecting the groundwater quality beneath it. Tritium and nitrate plumes are evident and appear to be the major contaminants in the area of LLWMA 1. Tritium values indicate the presence of two plumes beneath LLWMA 1 with sources to the southeast and east. The data suggest that the maximum concentrations have already passed beneath the southern and western wells at LLWMA 1 , where values continue to decline; wells on the northeastern boundary have increasing tritium values. Iodine-129 is also present beneath LLWMA 1, and technetium-99 is present in well 299-E33-34 above the $900-\mathrm{pCi} / \mathrm{L}$ DWS.

\subsubsection{Low-Level Waste Management Area 2}

There is no evidence of contamination from LLWMA 2. Values of iodine-129 were slightly above the interim DWS in several of the wells along the southern boundary of LLWMA 2. These are related to the widespread iodine- 129 plume beneath the 200-East Area. Nitrate exceeded the DWS in upgradient well 299-W34-7 in FY 1998, and sulfate increased significantly since May 1997 (Figure 5.10-20). The source of this contamination has not been identified, and there have not been similar increases in nearby wells. There are no apparent sources of sulfate in LLWMA 2 near well 299-E34-7. 


\subsubsection{Liquid Effluent-Retention Facility}

Groundwater analyses in FY 1998 indicated a significant increase in concentrations of calcium, magnesium, sodium, and sulfate in several wells. Calcium, magnesium, and sulfate have been progressively increasing in concentration since 1994 (Figures 5.10-21, 5.10-22, and 5.10-23). Sodium also exhibited increasing concentrations over the same time frame but the increase was less exceptional. While the constituents do not exceed RCRA standards, they may be an indication of significant changes in groundwater chemistry.

Groundwater monitoring continues to provide evidence that no dangerous, nonradioactive constituents entered the groundwater from this facility. Included in the analyses list are alkalinity, gamma scan, gross beta, $\mathrm{pH}$, specific conductance, total organic carbon, total organic halides, and turbidity.

\subsubsection{Contamination Within Lower Portion of Ringold Formation (Unit A)}

Contaminants may be moving into the lower portion of the Ringold Formation (the predominantly sandy gravel Unit A) in the 200-East Area. However, the vertical extent of contamination in deeper units is not fully understood. Evidence supporting contamination migration in Unit A is based on an evaluation of eight wells in the 200-East Area. This list of eight wells is not comprehensive, and additional wells across the Hanford Site will be sampled and evaluated in the coming year. Where Unit $A$ is beneath the lower mud unit, it is locally confined. Where the lower mud unit is missing from the sediment column, Unit A is unconfined and sometimes difficult to differentiate from overlying Unit E (also a predominantly sandy gravel of the Ringold Formation).

The eight wells may be separated into three groups based on location and hydrogeology (Figure 5.10-24). The first group is made up of four wells in the northwestern portion of the 200-East Area (299-E28-21 and 299-E28-18) and the eastern side of the 200-East Area (299-E25-28 and 299-E25-32Q). These four wells are located in areas where the lower mud unit is missing from the sediment column. Analytical results show that the levels of contamination (i.e., tritium, nitrate, iodine-129) at these wells are similar to surrounding wells screened in the upper portions of the Ringold Formation (Unit E) or the overlying Hanford formation (see Figure 5.10-24).

The second group includes wells located in the southern (299-E17-21) and southeastern (699-37-47A) portions of the 200-East Area, where the lower mud unit is present and Unit A is locally confined (see Figure 5.10-24). Well 299-E17-21 was drilled and sampled in FY 1998, so the results are comparable with other FY 1998 data. However, data from well 699-37-47A are not as easily compared with FY 1998 data because it was drilled and sampled during FY 1996. Both wells were completed as shallow wells that sampled the aquifer above the lower mud unit. For these two wells, the concentration of nitrate below the lower mud unit was very low ( 35 and $110 \mu \mathrm{g} / \mathrm{L}$, respectively) compared to the same wells screened above the lower mud unit $(7,900$ and $5,500 \mu \mathrm{g} / \mathrm{L}$; see Plate 4$)$. The radioactive contaminants (i.e., tritium, iodine-129) were not detected in these two wells in Unit A. In the same wells screened above the lower mud unit, tritium was 4,500 and $24,000 \mathrm{pCi} / \mathrm{L}$ (see Plate 3 ) and iodine-129 was 0.066 and $2.4 \mathrm{pCi} / \mathrm{L}$ (see Plate 5).

The third group of wells is near B Pond east of the 200-East Area (wells 699-43-41G and 699-41-40; see Figure 5.10-24). At this location, Unit $\mathrm{E}$ of the Ringold Formation is absent, the lower mud unit is 
present, the water table (or the static water level) is within the lower mud unit, and the uppermost aquifer (Unit A) is thought to be locally confined. However, these two wells, and surrounding wells alike, are screened in Unit $A$ and all show similar levels of contamination (see Plates 3, 4, and 5 and Figure 5.10-24). Clearly, contamination at this location is moving within Unit $A$ when it is beneath and locally confined by the lower mud unit.

This information suggests that contamination is moving within Unit A of the Ringold Formation, including at least one area where Unit $A$ is beneath the confining lower mud unit. Near B Pond, tritium, nitrate, and iodine-129 are moving within Unit A. At this former facility, voluminous discharages over a long period of time have provided a pronounced downward head that may have driven contaminants deeper into the aquifer than would have occurred elsewhere in the absence of such large hydraulic forces. However, not enough data have been evaluated to show whether contamination in Unit A is widespread or if contamination in Unit A occurs in other areas at the Hanford Site as well.

\subsection{Area E. C. Thornton}

The 400 Area on the Hanford Site is the location of the Fast Flux Test Facility, a liquid sodiumcooled reactor. The reactor is on standby pending a restart decision for the production of medical isotopes. Assessment efforts associated with the CERCLA 300-FF-2 Operable Unit will extend to include groundwater contamination in the 400 Area.

\subsubsection{Facilities}

\subsubsection{Process Ponds}

The $4608 \mathrm{~B} / \mathrm{C}$ ponds (also called the 400 Area process ponds), located north of the 400 Area perimeter fence, are unlined infiltration ponds that receive wastewater from the 400 Area facilities. The waste stream consists primarily of cooling water and intermittent small contributors (e.g., sinks and drains). The facility is designated as a WAC-173-216 discharge permit site, and the permit was issued on August 1, 1996, and modified on February 10, 1998. One permit condition identified was the addition of another downgradient well to the monitoring network. Well 699-2-6A was installed in August and September 1997. Sampling of this well was initiated during FY 1998.

\subsubsection{Water-Supply Wells}

The water supply for the 400 Area, including the drinking water, is provided by wells completed in the unconfined aquifer system. The original water-supply wells (499-S0-7 and 499-S0-8) were completed near the top of the aquifer. When tritium contamination was detected in the water supply, an additional well (499-S1-8J) was drilled in the lower unconfined aquifer in 1985 to reduce the tritium activity below the 4-mrem/yr effective dose equivalent standard. Well 499-S1-8J is now the primary water-supply well, and wells 499-S0-7 and 499-S0-8 are maintained for backup supply and emergency use. 


\subsubsection{Compliance Issues}

Tritium was detected at levels above the interim DWS in the 400 Area groundwater, and nitrate was detected at levels above the MCL just north of the perimeter fence near the process ponds. Also, tritium was detected at levels above the interim DWS in the backup water-supply wells for this area. Because the backup water-supply wells are seldom used, however, the monthly water-supply sampling indicates that tritium in the drinking water is maintained at a level below $4 \mathrm{mrem} / \mathrm{yr}$. Furthermore, this calculated dosage is based on the dose-conversion factor used in setting the $20,000-\mathrm{pCi} / \mathrm{L}$ interim DWS. As discussed in Section 5.1.6, the dose-conversion factor used in setting the interim DWS is more conservative than that used in more current technology.

\subsubsection{Extent of Contamination}

Nitrate is the only significant contaminant attributable to 400 Area operations and has been detected at elevated levels in one of the wells (699-2-7) downgradient to the process ponds. Elevated nitrate concentrations of up to $95 \mathrm{mg} / \mathrm{L}$ (45-mg/L MCL) found in well 699-2-7 were attributed to the sanitary sewage lagoon immediately west and upgradient of the process ponds (Figures 5.11-1 and 5.11-2). Groundwater samples associated with this well are also frequently elevated with respect to nitrite (Figure 5.11-3), which may have been generated by reduction of nitrate to nitrite as part of denitrification. All nitrite values are below the 3.3-mg/L $\mathrm{MCL}$, however. Disposal to the lagoon has been discontinued and the lagoon backfilled. Thus, groundwater contamination from this source is expected to diminish with time. Nitrate and nitrite concentrations in samples recently obtained from the new downgradient well (699-2-6A) are not significantly elevated relative to the upgradient well (699-8-17):

Slightly elevated manganese concentrations have been noted in the effluent wastewater discharged to the process ponds. A few of the manganese values are in excess of the discharge permit ( $50 \mu \mathrm{g} / \mathrm{L}$, unfiltered) and, thus, are of concern. Groundwater sampling data collected during FY 1998 suggest that the elevated manganese values are unlikely to have been introduced by the water-supply wells and probably represent particulate matter derived from corrosion in tanks or disposal lines. All water-supply well samples that were analyzed for manganese had values below the $50-\mu \mathrm{g} / \mathrm{L} \mathrm{MCL}$.

Elevated levels of tritium (Figure 5.11-4) associated with the groundwater plume from the vicinity of the PUREX Plant in the 200-East Area were identified in 400 Area wells at levels similar to previous years. This source of groundwater contamination is relevant to the water-supply wells. The tritium activities in wells 499-S0-7, 499-S0-8, and 499-S1-8J are compared in Figure 5.11-5 to that of the 400 Area drinking water supply. Tritium was found at levels at or above the $20,000-\mathrm{pCi} / \mathrm{L}$ interim DWS in most samples from well 499-S0-7 during FY 1998. One sample collected from well 499-S0-8 exceeded the interim DWS in FY 1998. All samples collected from well 499-S1-8J in FY 1998 were below the interim DWS. The tritium low north of the 400 Area is probably related to discharge at the process ponds.

Tritium remained below the 20,000-pCi/L interim DWS and the 4-mrem/yr dose equivalent in the drinking water supply (sampled at a tap) for all sampling events in FY 1998 (Figure 5.11-5). Nitrate remained below the MCL in FY 1998 for the water-supply wells, indicating they are not affected by the 400 Area process ponds. FY 1998 and past data from 400 Area and surrounding wells indicates no other constituents are present at levels above their MCLs or interim DWSs. 


\subsection{Area J. W. Lindberg}

The 600 Area consists of all parts of the Hanford Site not specifically included in other operational areas. Most groundwater contamination found in the 600 Area is related to sources in the operational areas discussed previously. However, several other sources or potential sources of contamination exist, including the Central Landfill and Gable Mountain Pond. Chromium was detected in wells in the Central Plateau; its source and extent, however, are uncertain. Also, uranium was detected in a well near the 618-10 burial grounds. Nitrate found in the western part of the 600 Area appears to have an offsite source.

\subsubsection{Facilities}

\subsubsection{Solid Waste Landfill}

The Solid Waste Landfill (SWL) is a 27-ha facility $\sim 5.6 \mathrm{~km}$ southeast of the 200-East Area (see Appendix A and Plate 1). The SWL, along with the adjacent Nonradioactive Dangerous Waste Landfill (NRDWL), are parts of the former Central Landfill; however, the two facilities are now considered separately and under differing regulations. SWL groundwater is monitored in accordance with WAC 173-304. Beginning operation in 1972, SWL received principally solid waste, including paper, construction debris, asbestos, and lunchroom waste. In addition to the solid waste, $3,800,000$ to $5,700,000 \mathrm{~L}$ of sewage were disposed in trenches along the eastern and western sides of the SWL between 1975 and 1987 , and $380,000 \mathrm{~L}$ of Hanford Site bus/garage washwater were disposed in three short trenches along the western side of the site between 1985 and 1987.

\subsubsection{Nonradioactive Dangerous Waste Landfill}

The NRDWL is a 4-ha, inactive, RCRA-regulated landfill $5.5 \mathrm{~km}$ southeast of the 200-East Area (see Appendix A and Plate 1). The NRDWL received waste from 1975 to 1985 that included asbestos, miscellaneous laboratory wastes, solvents, paints, sewerage, sulfamic and other acids, batteries and battery acid, and mercury. The NRDWL continued to receive asbestos waste until 1988 (DOE/RL-90-17).

\subsubsection{Other Facilities}

Gable Mountain Pond. This pond was a liquid waste-disposal area south of Gable Mountain (see Plate 1) that received 200-East Area liquid wastes from 1957 until it was decommissioned in 1987. The surface area of the pond reached at least 28 ha during its operational period (RHO-ST-38). The pond is currently dry and covered with fill. Discharge to the pond included cooling water and condensate from a variety of sources in the 200-East Area. In addition, an unplanned release from a cooling coil in the PUREX Plant contributed 100,000 Ci of fission products to Gable Mountain Pond and B Pond (RHOST-38). The primary radiological constituents discharged to the pond were strontium-90, cesium-137, and ruthenium-106.

618-10 Burial Ground and 316-4 Crib. The burial ground and adjacent crib are southeast of the 400 Area, adjacent to Route 4S. The burial ground operated from 1954 to 1963 and received a variety of 
low- to high-activity radioactive waste, mostly composed of fission products with some plutoniumcontaminated material (DOE/RL-96-42). These wastes were disposed in caissons and trenches and may have included liquid- and solid-waste forms. The crib began receiving uranium-bearing waste solutions in 1948 and continued to periodically receive nitrate, hexone, and organic wastes through at least 1962 (DOE/RL-96-42). This site was investigated as part of a CERCLA limited field investigation for the 300-FF-2 Operable Unit:(DOE/RL-96-42).

\subsubsection{Compliance Issues}

\subsubsection{Solid Waste Landfill}

Activities at the SWL are regulated by WAC 173-304 and are detailed in WHC-SD-EN-AP-043. The SWL is part of the 200-IU-3 Operable Unit. A permit application for operation of the site was submitted to the Benton-Franklin District Health Department in 1991 (DOE/RL-90-38, Rev. 0) and was rejected. Responsibility for the site was assumed by the state, and a revised permit application was submitted in 1993 (DOE/RL-90-38, Rev. 1). As part of the permit review, a corrective action program was requested for the site, and a corrective-action plan was submitted (DOE/RL-94-143). In 1995, because of groundwater contamination at the site, the regulator required that all future trenches be lined. The site was closed, and operations ceased in March 1996. The final closure plan for the site is pending. As part of closure activities for the site, a conceptual model for contamination at the site has been developed (BHI-01063).

The SWL-monitoring network wells are sampled quarterly for constituents specified in WAC 173-304 plus the site-specific constituents of chlorinated hydrocarbons and tritium. Of the 14 groundwater quality constituents of WAC 173-304, only specific conductance and sulfate exceeded tolerance intervals. Four chlorinated hydrocarbons (carbon tetrachloride, 1,1-dichloroethane, tetrachloroethylene, and 1,1,1trichloroethane) exceeded WAC 173-200 groundwater-quality criteria.

Two downgradient wells were installed in December 1993, completing the shallow, compliancepoint, monitoring network. The presence of the two downgradient wells raises the monitoring efficiency from $68 \%$ to $94 \%$ (calculated using the method of Wilson et al. 1992). Additional wells will be needed only if it is shown that significant quantities of contaminants have migrated south of the site boundary (DOE/RL-94-143).

\subsubsection{Nonradioactive Dangerous Waste Landfill}

As part of the federal agreement and consent order (known as the Tri-Party Agreement) (Ecology et al. 1989), it was agreed to close the NRDWL in accordance with RCRA (WAC 173-303) and monitor it under interim-status regulations. A closure/postclosure plan was submitted in 1990 (DOE/RL-90-17). The NRDWL is part of the 200-IU-3 Operable Unit.

Values for RCRA interim-status indicator parameters at the NRDWL did not exceed their critical means in FY 1998.

The uncertainty in groundwater-flow directions beneath the NRDWL (see Section 3.7.2) makes the evaluation of the monitoring network more difficult. If the groundwater flows toward the southeast, as 
indicated by the tritium and nitrate plumes (see Plates 3 and 4), the boundary between the NRDWL and the SWL should be part of the compliance point. If the groundwater flows in an east-northeast direction, as indicated by the water-level data, the northern boundary of the NRDWL should be part of the compliance point. The two monitoring wells along the northern and southern boundaries of the NRDWL, completed in 1992, solve this problem and provide monitoring efficiency between $96 \%$ and $99 \%$ (Wilson et al. 1992), depending on groundwater-flow directions. The current, shallow, monitoring network is adequate.

\subsubsection{Drinking Water Standards and Derived Concentration Guides}

Strontium-90 was detected at levels above the 1,000-pCi/L DCG near the decommissioned Gable Mountain Pond in FY 1998. No other radionuclides exceeded the DCG in the 600 Area. Contamination from other operational areas impacted the 600 Area at levels that exceeded the interim DWSs or MCLs, as discussed in Sections 5.3 through 5.10. Additional contamination at levels greater than the interim DWSs or MCLs in the 600 Area includes strontium-90 near Gable Mountain Pond, uranium in the vicinity of the $618-10$ burial ground and 316-4 crib, and chromium in the southern Central Plateau and south of the 200-East Area. Nitrate concentrations that exceeded the MCL were found upgradient of the operational areas, and probably result from offsite agriculture. 600 Area contamination associated with sources in the 100 and 200 Areas is discussed in previous sections.

\subsubsection{Extent of Contamination}

\subsubsection{Solid Waste Landfill}

The SWL has had little negative impact on Hanford Site groundwater, except minor (below-MCL) contamination with chlorinated hydrocarbons. Downgradient wells show higher specific conductance, alkalinity, total carbon, cation concentrations, and lower $\mathrm{pH}$ than upgradient wells. This is apparently a result of high vadose-zone concentrations of carbon dioxide, resulting from the degradation of sewage material beneath the SWL (Section 5.3 of DOE/RL-93-88).

Chlorinated Hydrocarbons. There was a decline in the concentration of chlorinated hydrocarbons during FY 1998; however, several remained above the groundwater quality criteria set forth in WAC 173-200. The range of reported concentrations of chlorinated hydrocarbons is given in Table 5.12-1. Only tetrachloroethylene, 1,1-dichloroethane, carbon tetrachloride, and 1,1,1-trichloroethane exceeded their respective criteria.

Chlorinated hydrocarbons were detected in all monitoring wells. The concentrations generally increased to the south along the line of downgradient wells, with the exception of tetrachloroethylene. If it is assumed that the principal sources were originally within the landfill boundaries, then this southward increase in concentration demonstrates that the principal sources probably migrated south of the SWL boundary. However, the principal source of tetrachloroethylene is probably still within the boundaries.

The most likely cause of the widespread chlorinated hydrocarbon contamination at the SWL, including upgradient wells and the adjacent NRDWL, is the dissolution of vadose-zone vapors into groundwater. However, the source of the vadose-zone vapors is uncertain. Total inorganic carbon (total carbon 
minus total organic carbon) increases southward along with the chlorinated hydrocarbons. This correspondence suggests a link between the chlorinated hydrocarbon contaminants and the sewage waste, which is the most probable source of the elevated inorganic carbon in groundwater. Thus, the source(s) may be chlorinated hydrocarbons dissolved in sewage liquids that are migrating southward (downdip) along silt layers in the vadose zone.

Carbon tetrachloride was detected in both downgradient and upgradient wells (overall range $<0.06$ to $0.64 \mu \mathrm{g} / \mathrm{L}$ ); however, the most consistent detection and the highest concentrations ( 0.4 to $0.64 \mu \mathrm{g} / \mathrm{L}$ ) occurred in southernmost downgradient well 699-22-35.

Tritium. Tritium, which has a source in the 200-East Area (see Section 5.10.3), is used to help determine groundwater-flow directions and rates. Tritium concentrations in groundwater-monitoring wells ranged from $<130$ to $91,400 \mathrm{pCi} / \mathrm{L}$ and are decreasing. The tritium concentrations in five monitoring wells were above the interim DWS (see Plate 3).

Indicator Parameters. Average values for replicate temperature determinations measured during sampling in downgradient wells ranged from $17.2^{\circ}$ to $19.8^{\circ} \mathrm{C}$. All measurements were below the tolerance limit of $21^{\circ} \mathrm{C}$. There is a tendency for the higher temperatures to occur at the northern end of the site, near the axis of the tritium and nitrate plumes (see Plates 3 and 4).

Average values for replicate specific conductance measurements in downgradient wells ranged from 361 to $790 \mu \mathrm{S} / \mathrm{cm}$. Replicate averages for monitoring wells $699-22-35$ and $699-23-34 \mathrm{~B}$ exceeded the $700-\mu \mathrm{S} / \mathrm{cm}$ standard (WAC 246-290-310) in FY 1998 as they have in previous years. The trends are constant. The $550-\mu \mathrm{S} / \mathrm{cm}$ tolerance limit was exceeded for all samples from downgradient wells.

Average values for replicate $\mathrm{pH}$ measurements in downgradient wells ranged from 6.6 to 7.2. None of the $\mathrm{pH}$ measurements exceeded the tolerance limit of 6.5 to 7.6. As in the past, the lower values occurred in the southernmost downgradient monitoring wells.

The average (of replicates) total organic carbon concentrations in downgradient wells were reported as either less than the method detection level or the practical quantitation limit. All results for the December 1997 samples were reported as $<370 \mu \mathrm{g} / \mathrm{L}$. The reported values did not exceed the $1,250-\mu \mathrm{g} / \mathrm{L}$ tolerance limit.

Reported total organic halides in downgradient wells ranged from $<4.62$ to $70 \mu \mathrm{g} / \mathrm{L}$ (see Table 5.12-1). Unlike the pattern for the chlorinated hydrocarbons, the values do not increase from north to south along the line of compliance-point wells.

Anions. Chloride concentrations in downgradient wells ranged from 5,520 to $7,940 \mu \mathrm{g} / \mathrm{L}$. The $9,045 \mu \mathrm{g} / \mathrm{L}$ tolerance limit was not exceeded. There is a tendency for the higher values to occur in the northernmost wells.

Nitrate concentrations in the downgradient monitoring wells ranged from 11,288 to $22,842 \mu \mathrm{g} / \mathrm{L}$. The $33,800-\mu \mathrm{g} / \mathrm{L}$ tolerance limit and the $45,000-\mu \mathrm{g} / \mathrm{L}$ standard (WAC 173-200) were not exceeded. The highest nitrate concentrations occur in the northernmost wells. 
All nitrite analytical results were nondetections (i.e., below the tolerance limit of $356 \mu \mathrm{g} / \mathrm{L}$ ).

All results for ammonium in downgradient wells were nondetections (reported as $<28$ or $<34 \mu \mathrm{g} / \mathrm{L}$ ). The tolerance limit of $100 \mu \mathrm{g} / \mathrm{L}$ was not exceeded.

Reported sulfate concentrations in downgradient wells ranged from 36,600 to $54,500 \mu \mathrm{g} / \mathrm{L}$. Four samples from well 699-22-35 and two samples from well 699-23-34B exceeded the $51,500-\mu \mathrm{g} / \mathrm{L}$ tolerance limit. None of the samples exceeded the $250,000-\mu \mathrm{g} / \mathrm{L}$ standard (WAC 173-200). There is a strong tendency for the highest sulfate concentrations to occur in the southernmost wells.

Chemical Oxygen Demand. Values for chemical oxygen demand in downgradient wells were reported as $<5,000 \mu \mathrm{g} / \mathrm{L}$, except for the unusual result of 9,000 $\mu \mathrm{g} / \mathrm{L}$ for well 699-22-35 (December 1997 sample) that exceeded the $3,000-\mu \mathrm{g} / \mathrm{L}$ tolerance limit.

Dissolved Metals. Reported values for filtered iron ranged from 28.9 to $88.6 \mu \mathrm{g} / \mathrm{L}$ in downgradient wells. None of the downgradient wells had reported values exceeding the tolerance limit $(102 \mu \mathrm{g} / \mathrm{L})$.

Reported values for filtered manganese in downgradient wells ranged from 2.4 to $7.1 \mu \mathrm{g} / \mathrm{L}$. None of the manganese concentrations exceeded the $11-\mu \mathrm{g} / \mathrm{L}$ tolerance limit or the $50-\mu \mathrm{g} / \mathrm{L}$ standard (WAC 173-200).

Reported values for filtered zinc concentrations in downgradient wells ranged from 4.1 to $28.4 \mu \mathrm{g} / \mathrm{L}$. None of the concentrations exceeded the $34-\mu \mathrm{g} / \mathrm{L}$ tolerance limit or the $5,000-\mu \mathrm{g} / \mathrm{L}$ standard (WAC 173-200).

Total Coliform. With one exception (the February 1998 sampling event), the reported values for total coliform were nondetections (i.e., $0.0 \mathrm{col} / 100 \mathrm{~mL}$ ). In February 1998, a value of $6.0 \mathrm{col} / 100 \mathrm{~mL}$ was reported for well $699-23-34$. The $16 \mathrm{col} / 100-\mathrm{mL}$ tolerance limit was not exceeded.

\subsubsection{Nonradioactive Dangerous Waste Landfill}

Monitoring of the NRDWL concentrates on the RCRA interim-status indicator parameters ( $\mathrm{pH}$, specific conductance, total organic carbon, and total organic halides). Chlorinated hydrocarbons are monitored because they may represent groundwater contamination originating from the NRDWL. Tritium and nitrate are also included in NRDWL monitoring but have a source in the 200-East Area (see Section 5.10.3).

The values for RCRA indicator parameters did not exceed their critical means in FY 1998. Reported total organic halide values for FY 1998-samples ranged from nondetections up to $16.2 \mu \mathrm{g} / \mathrm{L}$ in the shallow downgradient wells and up to $6.5 \mu \mathrm{g} / \mathrm{L}$ in the shallow upgradient wells. The reported values for the deep wells ranged from nondetections up to $9.8 \mu \mathrm{g} / \mathrm{L}$. The total organic halide values are related to the presence of volatile chlorinated hydrocarbons.

Eight chlorinated hydrocarbons were detected; however, none exceeded their MCLs. 1,1,1trichloroethane and trichloroethylene are believed to be present in groundwater at the NRDWL, principally as a result of vadose-zone vapor transport from the adjacent SWL. Tetrachloroethylene is present in 
vadose-zone vapor beneath the $S \bar{W} L$ and is the principal vadose-zone vapor contaminant around the chemical disposal trenches at the NRDWL. Thus, there may be contributions from both sources. 1,1-dichloroethane and 1,4-dichlorobenzene are also found in low concentrations in the groundwater at the SWL. Carbon tetrachloride, chloroform, and methylene chloride may be a result of vadose-zone contamination at the NRDWL.

\subsubsection{Other Facilities}

Gable Mountain Pond. Strontium-90 activities have been rising over the last few years in several wells near Gable Mountain Pond (see Figure 5.10-2). An example of the increase is shown for well 699-53-47B in Figure 5.12-1. The maximum annual average strontium-90 activity (8.0-pCi/L interim DWS) detected in the pond area in FY 1998 was $1,350 \mathrm{pCi} / \mathrm{L}$ in well $699-53-48 \mathrm{~A}$. Strontium-90 in the Gable Mountain Pond area apparently resulted from the discharge of waste to that pond during its early use. The delay (in increasing strontium-90 from the early days of pond use until more recent years) could be due to the retardation in strontium-90 movement from the source to the monitoring wells. Wells completed above the basalt in the vicinity of this pond are becoming difficult to sample because of declining water levels.

618-10 Burial Ground and 316-4 Crib. This burial ground and adjacent crib are southeast of the 400 Area, adjacent to Route 4S. This site was investigated as part of a CERCLA limited field investigation for the 300-FF-2 Operable Unit (DOE/RL-96-42). In FY 1995, high levels of uranium (768 $\mu \mathrm{g} / \mathrm{L}$, unfiltered) and the presence of hydrocarbon contamination (total petroleum hydrocarbon $104 \mathrm{mg} / \mathrm{L}$; alkane and assorted decanes at estimated values ranging from 770 to $1,800 \mu \mathrm{g} / \mathrm{L}$; unknown volatile organics estimated at 3,200 $\mu \mathrm{g} / \mathrm{L}$ ) were detected in well 699-S6-E4A, which is adjacent to both the burial ground and crib. Subsequently, tributyl phosphate was detected in well 699-S6-E4A. The CERCLA investigation included reconfiguration of well 699-S6-E4A and sampling of two cone penetrometer borings near this well. The conclusions in DOE/RL-96-42 were that uranium and hydrocarbon groundwater contamination are probably localized in the area of well 699-S6-E4A, and the source of such contamination is primarily the crib, with possibly some contribution from the burial ground.

In FY 1997, uranium in well 699-S6-E4A increased dramatically to a maximum of $225 \mu \mathrm{g} / \mathrm{L}$ (Figure 5.12-2) but did not reach the level found in FY 1995. In FY 1998, uranium concentration in well 699-S6-E4A ranged from 60.4 to $91.3 \mu \mathrm{g} / \mathrm{L}$.

Tributyl phosphate continued to be detected in well 699-S6-E4A in FY 1997 and FY 1998. The levels reported were 700 and $420 \mu \mathrm{g} / \mathrm{L}$ in the January and June 1997 samples, respectively. In FY 1998, the levels reported were 540 and $310 \mu \mathrm{g} / \mathrm{L}$ in the January and July samples, respectively.

During FY 1996, well 699-S6-E4C (previously completed in multiple zones) was reconfigured to provide two deep, depth-discrete, monitoring intervals within the unconfined aquifer system that, in conjunction with shallow monitoring wells $699-\mathrm{S} 6-\mathrm{E} 4 \mathrm{~B}$ and $699-\mathrm{S} 6-\mathrm{E} 4 \mathrm{D}$, provided information on the vertical distribution of contaminants at this location. The two monitored intervals are piezometers 699-S6-EACT at $26 \mathrm{~m}$ below the water table and 699-S6-EACS at $50 \mathrm{~m}$ below the water table. Tritium activities in piezometer $699-\mathrm{S} 6-\mathrm{E} 4 \mathrm{CT}$ declined from $27,800 \mathrm{pCi} / \mathrm{L}$ shortly after reconfiguration in 
FY 1996 to $6,600 \mathrm{pCi} / \mathrm{L}$ in FY 1997 and further in FY 1998 to $1,500 \mathrm{pCi} / \mathrm{L}$. This suggests that the earlier value resulted from intercommunication down the well bore prior to reconfiguration and that the value at depth is considerably lower. Tritium values for piezometer $699-\mathrm{S} 6-\mathrm{E} 4 \mathrm{CS}$ were still lower, $1,060 \mathrm{pCi} / \mathrm{L}$ in FY 1997 and $122 \mathrm{pCi} / \mathrm{L}$ in FY 1998. Continued monitoring as the well effect dissipates is needed to determine the tritium value at these depths.

Central Plateau. Chromium was detected in filtered samples at levels above the $100-\mu \mathrm{g} / \mathrm{L} \mathrm{MCL}$ in well 699-32-62, south of the 200-East Area where the concentration measured in the single sample for FY 1997 was $227 \mu \mathrm{g} / \mathrm{L}$; for FY 1998, the concentration was $226 \mu \mathrm{g} / \mathrm{L}$ (Figure 5.12-3). Several other wells contained chromium at levels below the MCL. Although one of the wells is near the BC cribs, the other two wells are upgradient, suggesting that the cribs are not the source of chromium. The sources and extent of this contamination are uncertain. Early disposal to the vicinity of the $216-\mathrm{S}-10$ pond and ditch is one possible source. The extent of chromium contamination to the south is particularly poorly defined.

Western 600 Area. Nitrate was detected in wells in the western part of the site, but the levels remained lower than the MCL in FY 1998 (see Plate 4). Nitrate upgradient of the 200-West Area and in well 699-17-70 (54 mg/L) north of the Rattlesnake Hills appears to have an offsite source, possibly related to agricultural activity. An extension of Yakima Ridge, south of the 200-West Area, forms a partial hydraulic barrier for the unconfined aquifer system, and hydraulic head is considerably higher to the south of the ridge (see Plate 2). For this reason and the lack of other Hanford Site contaminants, such as tritium, nitrate south of the ridge is not believed to result from Hanford Site activities.

\subsection{Area J. W. Lindberg}

Activities in the 300 Area have been historically related to various research activities and the processing of uranium into fuel elements for the reactors. In addition to the fuel-fabrication processes, many technical-support, service-support, and research-and-development activities related to fuel fabrication were carried out. Fuel-fabrication activities ended in 1987. During fuel fabrication, uranium was disposed to the process ponds and trenches in dissolved and particulate forms. Facilities known to have received uranium include the 316-1 south process pond, the 316-2 north process pond, and the 316-5 process trenches (see Plate 1). The process ponds were removed from service in the mid-1970s; discharge to the process trenches ceased in December 1994.

\subsubsection{Facilities and Operable Units}

\subsubsection{Facilities}

The facilities in the 300 Area that affected the groundwater include the $316-5$ process trenches, operating until December 1994, which have RCRA requirements for groundwater monitoring. 
316-5 Process Trenches. The two unlined trenches were constructed in 1975. From 1975 until shutdown of fuel-fabrication activities in 1987 and other operations in 1988, the trenches were used for the disposal of most liquid wastes generated in the 300 Area. The liquid waste was known or suspected of including the following (PNL-6716):

$\begin{array}{lll}\text { ammonium } & \text { methyl chloride } & \text { trichloroethylene } \\ \text { barium } & \text { nitrate } & \text { uranium, or other alpha emitters } \\ \text { chloride } & \text { potassium } & \text { vanadium } \\ \text { chloroform } & \text { sodium } & \text { at least one beta emitter. } \\ \text { copper } & \text { sulfate } & \\ \text { iron } & \text { tetrachloroethylene }\end{array}$

The discharge rate reached a maximum of $\sim 7,600 \mathrm{~L} / \mathrm{min}$. After 1988, the wastewater consisted of cooling water with small quantities of nonhazardous maintenance and process water. In July 1991, the trenches were modified as part of an expedited response action. The modification of the trenches involved removing bottom sediment from the inflow end of each trench and placing it at the opposite end of the trenches behind a berm. The trenches were used on an alternating, as-needed basis. The western trench was rendered inoperable on November 20, 1992. Subsequently, the eastern trench received all discharges. The average discharge to the eastern trench was $\sim 850 \mathrm{~L} / \mathrm{min}$ in the latter years of operation. In December 1994, all discharges to the trenches were terminated.

316-1 and 316-2 Process Ponds. These process ponds were the main facility for the disposal of uranium-contaminated wastewater until 1975 when the $316-5$ process trenches were constructed and put into use.

\subsubsection{Operable Units}

The largest volume of waste generated in the 300 Area is from the fuel-fabrication operations associated with two source operable units. The 300-FF-1 Operable Unit contains the 316-1 south and 316-2 north process ponds, the sanitary leaching trenches, and the $316-5$ process trenches. The 300-FF-2 Operable Unit consists primarily of waste-management units that received solid waste and contaminated equipment in the northern and northwestern parts of the area and a variety of miscellaneous wastemanagement units, including solid and liquid wastes in the southern portion of the area.

The 300-FF-5 Operable Unit is the groundwater beneath the two source operable units. The extent of the 300-FF-5 Operable Unit includes all contamination that emanates from the source operable units detected in groundwater and sediments below the water table that exceeds ARARs (applicable or relevant and appropriate federal and state environmental requirements).

Groundwater beneath the 300 Area is potentially affected by contamination flowing in from several source areas in addition to the 300-FF-1 Operable Unit. The other potential sources are the following:

- The 300-FF-2 Operable Unit includes buried waste and contaminated vadose soils in the portion of the 300 Area that is not part of the 300-FF-1 Operable Unit. The 300-FF-2 Operable Unit also 
includes waste and contaminated vadose soils in the 400 Area and in select portions of the 600 Area and addresses groundwater not covered by the 300-FF-5 Operable Unit.

- The southeastern portion of the tritium plume that emanates from the 200 Areas (200-PO-1 Operable Unit).

- The 1100-EM-1 Operable Unit associated with the Horn Rapids Landfill, which contains a plume of trichloroethylene that is migrating in the direction of the 300 Area (discussed in Section 5.14.3.3).

\subsubsection{Compliance Issues}

\subsubsection{316-5 Process Trenches}

A RCRA interim-status quality assessment well network monitored the groundwater near the 300 Area process trenches from June 1985 until December 1996. In December 1996, the interim-status network was changed to a final-status corrective-action network. The schedule for modifying the Hanford Site RCRA Permit (Ecology 1994) required that a closure plan and accompanying revised groundwater-monitoring plan be submitted. The documents were prepared, and the closure plan (DOE/RL-93-73) includes the revised groundwater-monitoring plan (WHC-SD-EN-AP-185). This documentation is referenced in the revised Hanford Site RCRA Permit (Ecology 1994) and became effective December 26, 1996.

As expected, groundwater samples from well 399-1-16B, a downgradient well sampling the base of the unconfined aquifer system, showed that cis-1,2-dichloroethylene and trichloroethylene were in concentrations higher than the required limits (70- and 5- $\mu \mathrm{g} / \mathrm{L}$ MCLs, respectively). Similarly, all three wells monitoring the aquifer at the water table and located downgradient from the $316-5$ process trenches (399-1-10A, 399-1-16A, and 399-1-17A) showed that uranium exceeded the 20- $\mathrm{g} / \mathrm{L}$ proposed MCL. After the first four independent samples were collected in FY 1997, the exceedances were confirmed and the regulator was notified. As required, the monitoring plan was modified for corrective action.

The objective of groundwater monitoring during the corrective-action period is to monitor the trend of the constituents of concern to confirm that they are naturally attenuating, as expected by the CERCLA record of decision for the 300-FF-5 Operable Unit (ROD 1996a). The modified groundwater-monitoring plan for corrective action calls for samples from the same wells that were being sampled in the previous compliance period but at a reduced number of independent samples from each well during each sampling period (i.e., four to one). Also, each well showing an exceedance (four of eight wells) of one of the constituents of concern will be on a quarterly sampling schedule to better follow the trends of contaminant concentration. The other wells in the network will continue to be sampled on a semiannual basis. The modified plan is still being reviewed by the regulator.

Until the modified plan is implemented, the current final-status compliance-monitoring program (WHC-SD-EN-AP-185) will remain in effect. This current plan calls for four independent groundwater samples from each network well (eight) during each semiannual sampling period (2/yr) (i.e., 64 well trips/yr). Efforts are under way to propose an alternate final-status/compliance-monitoring plan that will accomplish the same goals as the original final-status/compliance-monitoring plan but without the requirement of the four independent samples collected during each semiannual sampling event. 
The eight network wells for the 316-5 process trenches are functioning well and are adequate to satisfy the goals of monitoring the groundwater during the current final-status/compliance-monitoring period and the goals of the future corrective-action plan.

\subsubsection{300-FF-1 and 300-FF-5 Operable Units Remedial Actions}

The interim record of decision for the 300-FF-1 and 300-FF-5 Operable Units was approved in July 1996 (ROD 1996b). The selected remedy for the 300-FF-5 Operable Unit is an interim action that involves emplacing security measures to prevent exposures to residual contamination; imposing restrictions on the use of the groundwater until such time as health-based criteria are met for uranium, trichloroethylene, and cis-1,2-dichloroethylene; and allowing contaminants to naturally diminish over time. This is an interim action because there are other constituents (e.g., tritium) migrating into the unit that have not yet been fully addressed and because a portion of the unit is overlaid by uncharacterized waste sites in the 300-FF-2 Operable Unit. A final-action decision for the 300-FF-5 Operable Unit will be made after these issues have been addressed. The selected interim measure includes continued monitoring of groundwater that is contaminated above health-based levels to ensure that concentrations continue to decrease and that institutional controls ensure that groundwater use is restricted to prevent unacceptable exposures to contamination.

An operation and maintenance plan for the 300-FF-5 Operable Unit was released in September 1996 (DOE/RL-95-73). The purpose of that plan is to identify tasks necessary to verify the effectiveness of the selected alternative. The plan describes the monitoring program and administrative tasks that will be used as the selected alternative for the remediation of the groundwater in the operable unit. The routine operation-and-maintenance activities include groundwater and river monitoring.

\subsubsection{Drinking Water Standards and Derived Concentration Guides}

No radiological constituents in 300 Area groundwater were detected at levels above their DCGs in FY 1998. Uranium was detected at levels above the proposed MCL in much of the eastern part of the 300 Area. Trichloroethylene and cis-1,2-dichloroethylene were found at levels above the MCL in the deeper part of the unconfined aquifer system. Trichloroethylene was detected in two wells in the upper portion of the unconfined aquifer of the central and southern parts of the 300 Area. Iron and manganese were found at levels above the secondary MCL in the deeper part of the unconfined aquifer system, but this appears to be the result of naturally occurring material. Tetrachloroethylene was detected above the MCL in six wells in the upper part of the unconfined aquifer east and southeast of the 316-5 process trenches. Nitrate was above the DWS in one well in the southwestern portion of the 300 Area.

\subsubsection{Extent of Contamination}

Uranium is the major contaminant of concern in the 300 Area. Tritium contamination from the 200-East Area impacted the 300 Area at levels less than the interim DWS (Figure 5.13-1). The 2,000-pCi/L isopleth line trends through the 300 Area and shows little change since FY 1997. The tritium contamination is discussed in Sections 5.10.3.2 and 5.14.3.1. Additional constituents detected include strontium-90, nitrate, trichloroethylene, cis-1,2-dichloroethylene, tetrachloroethylene, iron, and manganese. 


\subsubsection{Uranium}

The uranium distribution in the 300 Area is shown in Figure 5.13-2. The highest uranium concentrations are found in the northern part of the 300 Area, downgradient from the 316-5 process trenches and near the 316-1 and 316-2 process ponds. Because the process ponds are downgradient of the trenches, it is difficult to determine the relative contribution of each facility to the contamination. However, the maximum uranium concentrations $(20-\mu \mathrm{g} / \mathrm{L}$ proposed DWS) detected in the 300 Area was $252 \mu \mathrm{g} / \mathrm{L}$ in well 399-2-1 in the August 1998 sample. The line of wells from well 399-1-17A through well 399-1-7 to well 399-2-2 has the highest levels of uranium in the 300 Area and are aligned along the groundwaterflow direction (southeast). This alignment suggests that the major source of the uranium contamination is the $316-5$ process trenches.

Figure 5.13-3 shows the historical trend for uranium in well 399-1-17A (the well closest to the inflow portion of the trenches). Uranium concentrations dropped dramatically in 1991 as a result of the expedited response action but then began to rise sharply again when process trench discharges ceased in December 1994. From FY 1996 through FY 1997, the rise continued, though not at the rapid rate it did in FY 1995. The average uranium levels in FY 1998 were lower than in FY 1997. Uranium (at least one uranium daughter is a beta emitter) is probably responsible for the elevated gross beta at well 399-1-17A; the result was $92.5 \mathrm{pCi} / \mathrm{L}$. The large variability in uranium concentration (see Figure 5.13-1) is caused by river-stage fluctuations.

Presumably, the contribution of uranium to the unconfined aquifer system by the soil column at the process trenches was diluted by the large quantities of process wastewater prior to January 1995. Because wastewater is no longer discharged to the trenches, the increase since January 1995 indicates that uranium continues to be contributed to the groundwater by the soil column at the $316-5$ process trenches. The lack of dilution by large quantities of process wastewater caused the uranium in the groundwater to continue to rise during FY 1996 through FY 1997 and remained elevated during FY 1998. The total uranium contributed by the soil column at the trenches during FY 1998 may actually be the same, or even lower, than it was prior to January 1995.

Another zone of elevated uranium in FY 1996 was near the 324 building (immediately west of well 399-3-11). However, in FY 1997, the zone of higher uranium moved downgradient (southeast) to the area near well 399-4-9 (see Figure 5.13-2). In FY 1996, the uranium in well 399-3-11 (near the 324 building) was $130 \mu \mathrm{g} / \mathrm{L}$; in FY 1997, it dropped to $66 \mu \mathrm{g} / \mathrm{L}$; and in FY 1998, it dropped to $32 \mu \mathrm{g} / \mathrm{L}$. In FY 1996, the average uranium value in well 399-4-9 (southeast of the 324 building near the river) was $74 \mu \mathrm{g} / \mathrm{L}$; in FY 1997, it rose to $130 \mu \mathrm{g} / \mathrm{L}$; and in FY 1998 it continued at the same activity $(130 \mu \mathrm{g} / \mathrm{L})$. Apparently, the uranium high near the 324 building has moved with the groundwater flow to a downgradient position along the Columbia River near well 399-4-9.

\subsubsection{Strontium-90}

Strontium-90 (8-pCi/L interim DWS) continues to be detected at well 399-3-11 near the 324 building. However, the more recently measured activity levels are not as high as the elevated level recorded in the December 1995 sampling event $(8.7 \mathrm{pCi} / \mathrm{L})$. Typical for this well since then is a fluctuation between 3 and $8 \mathrm{pCi} / \mathrm{L}$. Groundwater samples from well 399-3-11 were collected with a bailer and were not filtered, so it is probable that much of the strontium-90 is sorbed to sediment in the samples. Since the high result 
in December 1995, the results have been 3.0 and $3.1 \mathrm{pCi} / \mathrm{L}$ in August 1996 and September 1997, respectively. During FY 1998, the results were 3.2 and $3.4 \mathrm{pCi} / \mathrm{L}$ (February and August 1998). Although there may have been a release of strontium- 90 in the vicinity of the 324 building, the reported $8.7 \mathrm{pCi} / \mathrm{L}$ in . December 1995 was the only result greater than the interim DWS since 1986.

\subsubsection{Trichloroethylene, cis-1,2-Dichloroethylene, and Tetrachloroethylene}

In past years, trichloroethylene was above the 5- $\mu \mathrm{g} / \mathrm{L}$ MCL in wells $399-1-16 \mathrm{~B}$ and $399-1-17 \mathrm{~B}$ that monitor the base of the unconfined aquifer system downgradient of the $316-5$ process trenches. That trend continued during FY 1998 (Figure 5.13-4). Trichloroethylene was above or equal to the 5- $\mu \mathrm{g} / \mathrm{L}$ MCL in six of the eight samples collected from well 399-1-16B during FY 1997 and eight of nine samples collected from well 399-1-16B during FY 1998. The lowest concentration of trichloroethylene in well 399-1-16B was $5.0 \mu \mathrm{g} / \mathrm{L}$ in August 1998; the high was $8.0 \mu \mathrm{g} / \mathrm{L}$ in June 1998 .

There is a narrow plume of trichloroethylene that extends from the Siemens Power Corporation to approximately well 399-5-1 in the 300 Area (Section 5.14.3.3). During FY 1997, the trichloroethylene concentration reached $5.0 \mu \mathrm{g} / \mathrm{L}$ at well 399-5-1, and in August 1998, the concentration was $4.0 \mu \mathrm{g} / \mathrm{L}$ at that well.

The concentration of cis-1,2-dichloroethylene (70- $\mu \mathrm{g} / \mathrm{L} \mathrm{MCL})$ remained elevated in FY 1998 samples from deep well 399-1-16B (Figure 5.13-5). The high for FY 1998 was $180 \mu \mathrm{g} / \mathrm{L}$ in September 1998 and the low was $100 \mu \mathrm{g} / \mathrm{L}$ in May 1998. Average cis-1,2-dichloroethylene for FY 1998 was $156 \mu \mathrm{g} / \mathrm{L}$; the average for FY 1997 was $166 \mu \mathrm{g} / \mathrm{L}$.

A plume of tetrachloroethylene (perchloroethylene or PCE) was discovered in the 300 Area during FY 1998. Groundwater samples taken in December 1997 showed no increase over the laboratory practical quantitation limit. However, the May through September 1998 samples showed a definite increase in concentration. The well having the highest concentration was 399-1-17A near the southern end of the 316-5 process trenches. The concentration at well 399-1-17A ranged from 7 to $10 \mu \mathrm{g} / \mathrm{L}$ in May, rose to $38 \mu \mathrm{g} / \mathrm{L}$ in July, and decreased to $4 \mu \mathrm{g} / \mathrm{L}$ in September (Figure 5.13-6). The plume extended east-west from well 399-1-17A to the Columbia River and from well 399-1-10A on the north to well 399-3-10 on the south during its greatest extent in August 1998 (Figure 5.13-7). The highest concentration of tetrachloroethylene in the plume ( $38 \mu \mathrm{g} / \mathrm{L}$ at well 399-1-17A in July) moved downgradient to well 399-2-2, where it was $18 \mu \mathrm{g} / \mathrm{L}$ in August 1998 (see Figure 5-13-7).

Although tetrachloroethylene was accidentally discharged to the 316-5 process trenches in 1982 and 1984 (530 L total), the trenches have not discharged any fluids to the ground since December 1994 when they were isolated and cutoff from the chemical sewer system. Therefore, the 1998 plume of tetrachloroethylene was not due to a recent discharge. Furthermore, the sudden and wide, lateral extent of the plume indicates that it was not a point source. The most likely source of the tetrachloroethylene is vadose-zone residuals in the vicinity of the 316-5 process trenches that were mobilized by the high-river levels of 1996 and 1997. During the spring and early summer months of both 1996 and 1997, the Columbia River rose to very high levels, which raised the water table in the vicinity of the trenches to levels within the vadose zone that had not been reached since the trenches were put into use. It is likely that some of this vadose zone contained the residual sources of tetrachloroethylene necessary to produce the FY 1998 plume. 


\subsubsection{Iron and Manganese}

Iron and manganese in filtered samples exceeded secondary MCLs $(0.3 \mathrm{mg} / \mathrm{L}$ and $50 \mu \mathrm{g} / \mathrm{L}$, respectively) in wells 399-1-10B, 399-1-16B, 399-1-17B, and 399-1-18B during FY 1998. These wells are deeper and sample groundwater at the bottom of the unconfined aquifer system. In the three downgradient wells (399-1-10B, 399-1-16B, and 399-1-17B), manganese was above the secondary MCL $(117.5,63.2$, and $77.0 \mu \mathrm{g} / \mathrm{L}$, respectively), and iron was above the secondary $\mathrm{MCL}$ in wells 399-1-10B and 399-1-17B ( 0.732 and $0.423 \mathrm{mg} / \mathrm{L}$, respectively). However, iron is also above the secondary MCL in upgradient well $399-1-18 \mathrm{~B}(0.425 \mathrm{mg} / \mathrm{L})$. [Note: The laboratory providing the iron analysis results reported blank contamination at approximately the concentration of the practical quantitation limit.] Manganese is below the secondary MCL in well 399-1-18B ( $45 \mu \mathrm{g} / \mathrm{L}$ ), but this value is generally higher than the concentration of manganese in the downgradient wells that monitor groundwater at the top of the unconfined aquifer system, averaging between 2 and $3 \mu \mathrm{g} / \mathrm{L}$. Therefore, the iron and manganese in these deeper wells are probably not related to waste products discharged to the $316-5$ process trenches. They are due more likely to naturally occurring iron and manganese in the deeper portions of the aquifer that have greater reducing conditions that are more likely to mobilize these metallic ions.

\subsubsection{Other Constituents}

In the southwestern portion of the 300 Area, nitrate concentrations in the groundwater exceeded the 45-mg/L MCL. The highest concentration during FY 1998 was at well 399-5-1 (98.7 $\mathrm{mg} / \mathrm{L})$. The source of the nitrate is probably Siemens Power Corporation, fertilizer applied to the agricultural fields upgradient of Siemens Power Corporation, and potato-processing waste from the Lamb-Weston, Inc. (Section 5.14.3.2).

\subsection{Richland North Area}

\section{D. $R$. Newcomer}

The Richland North Area is located in the southern part of the Hanford Site (see Figure 1.1) and though not formally defined, includes the 1100 and 3000 Areas, that part of the 600 Area adjacent to the 300 Area, and parts of nearby Richland between the Yakima and Columbia Rivers. The 1100 Area was transferred from DOE to Port of Benton ownership in 1998.

\subsubsection{Facilities and Operable Units}

Facilities or activities of interest with respect to groundwater in the Richland North Area include the City of Richland's North Well Field and recharge ponds; Siemens Power Corporation; Richland Landfill; Lamb-Weston, Inc.; Interstate Nuclear Services; Allied Technology Group; and agricultural and residential irrigation. Additionally, one new heavy industry is operational and several are planned $\sim 1$ to $2 \mathrm{~km}$ southwest of Siemens Power Corporation (not shown on Plate 1).

The Richland North Area also contains two operable units: 1100-EM-1 and 1100-EM-2. Of particular concern is the potential for future impacts from these facilities and activities as well as Hanford Site operations (i.e., the tritium plume) at the city's north well field, which serves as the secondary drinking water-supply system for the City of Richland. 


\subsubsection{Compliance Issues}

\subsubsection{Operable Unit Remedial Investigation}

The 1100-EM-1 Operable Unit contains the closed Horn Rapids Landfill. CERCLA investigation results for this operable unit are presented in the final remedial investigation study (DOE/RL-92-67, Draft B) and the record of decision (ROD 1993). The selected remedy for groundwater is monitored natural attenuation, with institutional controls on drilling of new water-supply wells. The 1100-EM-1 Operable Unit was removed from the National Priorities List (Appendix B, 40 CFR 300) in September 1996. Well 699-S41-E12, downgradient of the 1171 building, is sampled annually for the 1100-EM-2 Operable Unit.

A compliance network of 11 groundwater wells is monitored annually for volatile organic constituents adjacent to the Horn Rapids Landfill. Three of these wells establish the downgradient point of compliance for the landfill and extend to the northwest from the George Washington Way diagonal. The point of compliance was established in the record of decision for the 1100-EM-1 Operable Unit (ROD 1993). In FY 1998, a sample from the northwestern point-of-compliance well (699-S27-E12A) had a concentration of $6 \mu \mathrm{g} / \mathrm{L}$ for trichloroethylene $(5-\mu \mathrm{g} / \mathrm{L} \mathrm{MCL})$. Trichloroethylene concentrations in this well have been at or above the MCL for 3 years. Samples from the center and southeastern point-ofcompliance wells (699-S28-E13A and 699-S29-E13A, respectively) showed concentrations less than the MCL. Trichloroethylene concentrations were found in the southwestern part of the $300 \mathrm{Area}(4 \mu \mathrm{g} / \mathrm{L}$ in well 399-5-1) and between the northwestern and center point-of-compliance well ( $6.5 \mu \mathrm{g} / \mathrm{L}$ in well 699-S28-E12). These data, along with data from the northwestern point-of-compliance well, indicate the plume moved downgradient $\sim 300 \mathrm{~m}$ beyond the point of compliance. However, steady or declining concentrations in the majority of wells downgradient of the Horn Rapids Landfill suggest some elements of natural attenuation (e.g., volatilization through passive pumping) may be reducing the plume mass.

Groundwater from well 699-S41-E12 is analyzed specifically for filtered and unfiltered chromium. The filtered chromium concentration for FY 1998 was $10 \mu \mathrm{g} / \mathrm{L}$. An unfiltered concentration of $269 \mu \mathrm{g} / \mathrm{L}$ was reported. The MCL for chromium is $100 \mu \mathrm{g} / \mathrm{L}$.

\subsubsection{Drinking Water Standards and Derived Concentration Guides}

Nitrate, trichloroethylene, and fluoride were detected in groundwater at concentrations above their respective MCLs in the Richland North Area during FY.1998. High levels of gross alpha suggest that uranium may also have been above its MCL during FY 1998. Likely sources of these constituents include offsite industry and agriculture.

\subsubsection{Extent of Contamination}

Forty-two groundwater wells were sampled in the Richland North Area during FY 1998 (38 annually, 3 semiannually, and 1 quarterly). The samples were analyzed predominantly for tritium, nitrate, and trichloroethylene. Selected samples were also analyzed for alkalinity, anions, gamma emitters, gross alpha, gross beta, metals, technetium-99, total petroleum hydrocarbons, and total and isotopic uranium. In addition, Siemens Power Corporation selectively sampled 14 offsite groundwater wells quarterly, 
semiannually, and annually (EMF-1865, Addenda 11 and 14). Analyses for these samples included ammonia, chloride, fluoride, gross alpha, gross beta, nitrate, sulfate, total dissolved solids, and trichloroethylene.

Constituents of concern in groundwater in the Richland North Area include nitrate, trichloroethylene, gross alpha, and uranium. The potential for tritium transport from the Hanford Site south into this area is also addressed here.

\subsubsection{Tritium}

The southward migration of the tritium plume and the increasing concentrations with time in the 300 Area continue to raise concern over potential future impacts at the City of Richland's North Well Field recharge ponds. The average detectable activities ranged between 7 and $74.5 \mathrm{pCi} / \mathrm{L}$ in the Richland North Area (see Plate 3). Several factors are believed to limit significant migration into the Richland North Area: 1) groundwater flow is generally from west to east, being recharged by the Yakima River and discharging to the Columbia River; 2) artificial recharge from agricultural irrigation occurs between the Richland Landfill and the 1100 Area and contributes to the eastward flow; and 3) net recharge at the city's north well field resulted in a groundwater mound that directs flow outward from the well field. These factors produce converging flow lines in the 300 Area and discharge to the Columbia River (see Figure 3.8-2 and Plate 2). The current flow field is based, in part, on the net recharge to the city's north well field; however, recent modeling efforts indicate groundwater flow would still be predominantly west to east without this recharge. Thus, there is still no indication that the well field will be impacted by the tritium plume.

\subsubsection{Nitrate}

Nitrate contamination is found in the Richland North Area likely as a result of offsite industrial and agricultural uses. The FY 1998 distribution in groundwater (see Plate 4) appears similar to FY 1997 at the higher concentrations (e.g., $100 \mathrm{mg} / \mathrm{L}$ or higher). However, the FY 1998 distribution between 45 and $100 \mathrm{mg} / \mathrm{L}$ changed, compared to the distribution in FY 1997. The nitrate plume within these concentrations expanded to encompass larger areas, primarily between the Horn Rapids Landfill and the 300 Area and the area generally east and southeast of the Horn Rapids Landfill.

Concentrations above the 45-mg/L MCL are found both upgradient and downgradient of Siemens Power Corporation (EMF-1865, Addenda 11 and 14). In FY 1998, concentrations in the upgradient and downgradient wells adjacent to the facility generally remained steady or decreased. The maximum concentration in FY 1998 was $174 \mathrm{mg} / \mathrm{L}$ in well GM-16. Potential nitrate sources from industry include Siemens Power Corporation, which is discussed in DOE/RL-92-67, Draft B; and Lamb-Weston, Inc., which process potatoes. Fertilizer applied to the agricultural fields upgradient of Siemens Power Corporation is another probable source.

Nitrate concentrations onsite ranged up to $170 \mathrm{mg} / \mathrm{L}$, with the highest in well 699-S30-E10B just downgradient of the Horn Rapids Landfill. Concentrations exceeding the MCL were found in the southwestern part of the 300 Area and extend as far south as the Horn Rapids Athletic Complex (see 
Plate 4). Nitrate levels in wells at the City of Richland's North Well Field were lower than ambient groundwater, probably as a result of dilution from infiltration of river water at the settling and recharge ponds.

\subsubsection{Trichloroethylene}

The trichloroethylene distribution in groundwater beneath the Richland North Area (Figure 5.14-1) supports the tritium discussion with respect to northeastward flow around the City of Richland's North Well Field recharge ponds. The plume has an elongated configuration similar to previous years and extends $\sim 300$ m northeast of the point of compliance (i.e., the George Washington Way diagonal). Trichloroethylene was found onsite beneath the Horn Rapids Landfill and offsite in Siemens Power Corporation wells. Concentrations in onsite wells ranged from less than detection to $10 \mu \mathrm{g} / \mathrm{L}$, with the highest concentration (well 699-S31-E10A) located immediately downgradient of the Horn Rapids Landfill. Concentrations exceeded the $5-\mu \mathrm{g} / \mathrm{L} \mathrm{MCL}$ in two wells at the point of compliance (wells 699-S27-E12A and 699-S28-E12). Concentrations in the majority of wells downgradient of the Horn Rapids Landfill remained steady or decreased from FY 1997 levels, suggesting some elements of natural attenuation (e.g., volatilization through passive pumping) may be reducing the plume mass.

Trichloroethylene concentrations in the Siemens Power Corporation wells decreased to levels below the 5- $\mu \mathrm{g} / \mathrm{L}$ MCL in FY 1998 (EMF-1865, Addenda 11 and 14). The use of solvent in installing and maintaining process lagoon liners at Siemens Power Corporation is the only potential source of trichloroethylene identified in the Richland North Area (DOE/RL-92-67, Draft B).

\subsubsection{Gross Alpha and Uranium}

Gross alpha levels generally decreased in most of the Siemens Power Corporation wells (EMF-1865, Addenda 11 and 14) in FY 1998. However, gross alpha levels increased in wells GM-11 and GM-12 between Siemens Power Corporation and the Horn Rapids Landfill in FY 1998. Well GM-16 exhibited the highest gross alpha levels, with an average of $\sim 96 \mathrm{pCi} / \mathrm{L}$. All of the downgradient Siemens Power Corporation wells showed average gross alpha levels that were above the $15-\mathrm{pCi} / \mathrm{L} \mathrm{MCL}$. Because Siemens Power Corporation manufactures fuel pellets and assemblies for commercial nuclear power plants, it is probable that the gross alpha levels are largely attributed to uranium. If gross alpha is attributed to uranium with natural isotopic abundances, then $96 \mathrm{pCi} / \mathrm{L}$ gross alpha is equivalent to $139 \mu \mathrm{g} / \mathrm{L}$ uranium, which is above the $20-\mu \mathrm{g} / \mathrm{L}$ proposed MCL for uranium. Samples were not analyzed for uranium in these wells in FY 1998.

Uranium concentrations in wells ranged up to $11.5 \mu \mathrm{g} / \mathrm{L}$, with the highest concentration in well 699-ATH. This well is an irrigation well near the Horn Rapids Athletic Complex. Uranium concentrations have been increasing in wells immediately downgradient of the Horn Rapids Landfill (wells 699-S30-E10A, 699-S30-E10B, and 699-S31-E10B) and in one well (699-S34-E10) southeast of Siemens Power Corporation since $\sim 1995$. The concentrations in these wells in FY 1998 ranged between 9.1 and $11.3 \mu \mathrm{g} / \mathrm{L}$. Gross alpha concentrations, which mimic trends in the uranium concentrations, also increased in these wells since 1995. The gross alpha concentrations in these wells ranged between 7.6 and $14.4 \mathrm{pCi} / \mathrm{L}$. 


\subsubsection{Other Constituents}

Ammonia. Concentrations of ammonia in the Siemens Power Corporation wells generally remained steady or declined in FY 1998 (EMF-1865, Addenda 11 and 14). The highest concentration detected was $16.5 \mathrm{mg} / \mathrm{L}$ (as $\mathrm{N}$ ) in well GM-5. Ammonia is typically absorbed by plants or soil microorganisms or is taken up as an exchangeable ion on soil particles (Hausenbuiller 1972). However, ammonia is usually less stable than nitrate in a biological system like the soil and is rapidly converted to nitrate by nitrification. The fact that ammonia is found in the groundwater suggests that relatively high concentrations reached the soil column.

Fluoride. Three downgradient Siemens Power Corporation wells (GM-5, GM-8, and GM-10) had fluoride concentrations above the 4-mg/L MCL in FY 1998 (EMF-1865, Addenda 11 and 14). The highest concentration was $5.6 \mathrm{mg} / \mathrm{L}$ in well GM-5. Average fluoride concentrations in onsite wells for this area were all below $1 \mathrm{mg} / \mathrm{L}$.

Gross Beta. Measurements of gross beta exhibited similar trends to the gross alpha measurements in most of the Siemens Power Corporation wells (EMF-1865, Addenda 11 and 14). The highest gross beta measurement in FY 1998 was $95 \pm 13 \mathrm{pCi} / \mathrm{L}$ in a downgradient well (GM-12). Low levels of technetium-99, detected near the Horn Rapids Landfill, may be related to the gross beta measurements.

\subsection{Radiological and Chemical Monitoring for the Upper Basalt-Confined Aquifer}

\section{B. Barnett}

The upper basalt-confined aquifer, which lies immediately below the unconfined aquifer system, is affected far less by Hanford Site contamination than the unconfined aquifer system. Minor amounts of contamination reached the upper basalt-confined aquifer through various mechanisms (Section 5.15 in PNNL-11141):

- local erosion of confining basalt layers, allowing intercommunication between aquifers

- disposal of large quantities of water, resulting in groundwater mounding in the unconfined aquifer system and a downward hydraulic gradient to the upper basalt-confined aquifer

- wells penetrating the confined aquifer(s), providing a pathway for downward contaminant migration.

These conditions can allow groundwater and any potentially entrained contaminants to flow from the unconfined aquifer system to the underlying confined aquifer, thus increasing the potential to spread contamination. Because fewer wells are available to monitor the confined aquifer, it is important to consider contamination trends at levels well below the DWS to provide for timely detection of potentially higher levels.

The hydrochemical and hydrogeologic conditions within the upper basalt-confined aquifer and the potential for offsite migration of contaminants through confined-aquifer pathways are documented in PNL-10817. The upper basalt-confined aquifer is monitored to determine the extent of groundwater 
contamination that results from interaction between the unconfined and confined aquifers. Also identified in PNL-10817 were several confined-aquifer wells north and east of the 200-East Area that show evidence of intercommunication with the overlying unconfined aquifer system. Groundwater chemical data from most confined-aquifer wells in other areas of the Hanford Site show no evidence of contamination, with the exception of wells that were previously open to both the unconfined and confined aquifers and, thus, provided routes for the downward transport of contamination.

Intercommunication between the unconfined aquifer and underlying confined aquifer in the vicinity of the northern part of the 200-East Area was identified in RHO-BWI-ST-5 and RHO-RE-ST-12 P. This intercommunication was attributed to erosion of the upper Saddle Mountains Basalt and downward vertical gradients resulting from wastewater disposal that produced groundwater mounding within the unconfined aquifer system.

Results of the 1995 sampling and analyses of groundwater from the upper basalt-confined aquifer indicated only a few areas of concern that warranted continued annual monitoring. Consequently, the number of wells to be sampled has been progressively reduced since 1995. The few, significant analytical results obtained during FY 1998 are discussed below. Figure 5.15-1 shows the locations of wells used for monitoring confined-aquifer groundwater chemistry. Results for tritium are shown in Figure 5.15-2. Undetected values are shown as less than the minimum detectable activity because analytical methods with vastly different detection limits were used. Results selected for other radionuclides are shown in Figure 5.15-3 and for nitrate in Figure 5.15-4. The results shown in Figures 5.15-1 through 5.15-3 represent maximum concentrations measured during FY 1998.

Well 299-E33-12 at the northern border of the 200-East Area produced cyanide results of 30 and $1.33 \mu \mathrm{g} / \mathrm{L}$ (below detection) from replicates of the same sample. The trend for this constituent appears to be slightly downward for the past few years, but several disparate historical results make definitive interpretation difficult. This well produced a technetium-99 result of $1,810 \mathrm{pCi} / \mathrm{L}$ (slightly higher than in the past, but still within the long-term flat trend) and a lower result of $1,220 \mathrm{pCi} / \mathrm{L}$. The maximum tritium result in this well for FY $1998(630 \mathrm{pCi} / \mathrm{L})$ was also up from an average of $409 \mathrm{pCi} / \mathrm{L}$ in FY 1997. Well 299-E33-12 also produced a cobalt-60 result of $21.8 \mathrm{pCi} / \mathrm{L}$, up from the FY 1997 result of $12.9 \mathrm{pCi} / \mathrm{L}$. Despite minor trend departures in concentrations of tritium, technetium-99, and cobalt-60 in this well during FY 1998, long-term records indicate no reversals of unchanging or declining trends for these constituents.

Well 699-42-E9B near the eastern shore of the Columbia River yielded a gross beta result of $11.5 \mathrm{pCi} / \mathrm{L}$ and a typically high $\mathrm{pH}$ of 9.43 . This well also produced a tritium result $(73.9 \mathrm{pCi} / \mathrm{L})$ that is higher than expected for the upper basalt-confined aquifer system. The reason for this level of activity is not known, but interestingly, it fell within the range of tritium activities observed in Columbia River water downstream of the Hanford Site (PNNL-11472). Well 699-32-22B southeast of the 200 Areas produced a tritium result $(9.29 \mathrm{pCi} / \mathrm{L})$ above the low-detection limit for the first time since 1991 . During FY 1995, well 699-49-55B, completed in the confined aquifer northwest of the BY cribs, produced a cobalt-60 result of $154 \mathrm{pCi} / \mathrm{L}$, but the $\mathrm{FY} 1998$ analysis indicated this constituent was below detection. With the exception of the 1995 result, all historical results for cobalt-60 in this well are near or below detection levels, suggesting that the FY 1998 result is more representative. 
Tritium activities in well 699-42-40C have trended downward since 1996 after having reached a high of $\sim 8,000 \mathrm{pCi} / \mathrm{L}$ in 1992 and 1996 . This tritium is believed to have originated from downward migration from the overlying, unconfined aquifer beneath the B Pond system. 
Table 5.1-1. Maximum Contaminant Levels and Interim Drinking Water Standards

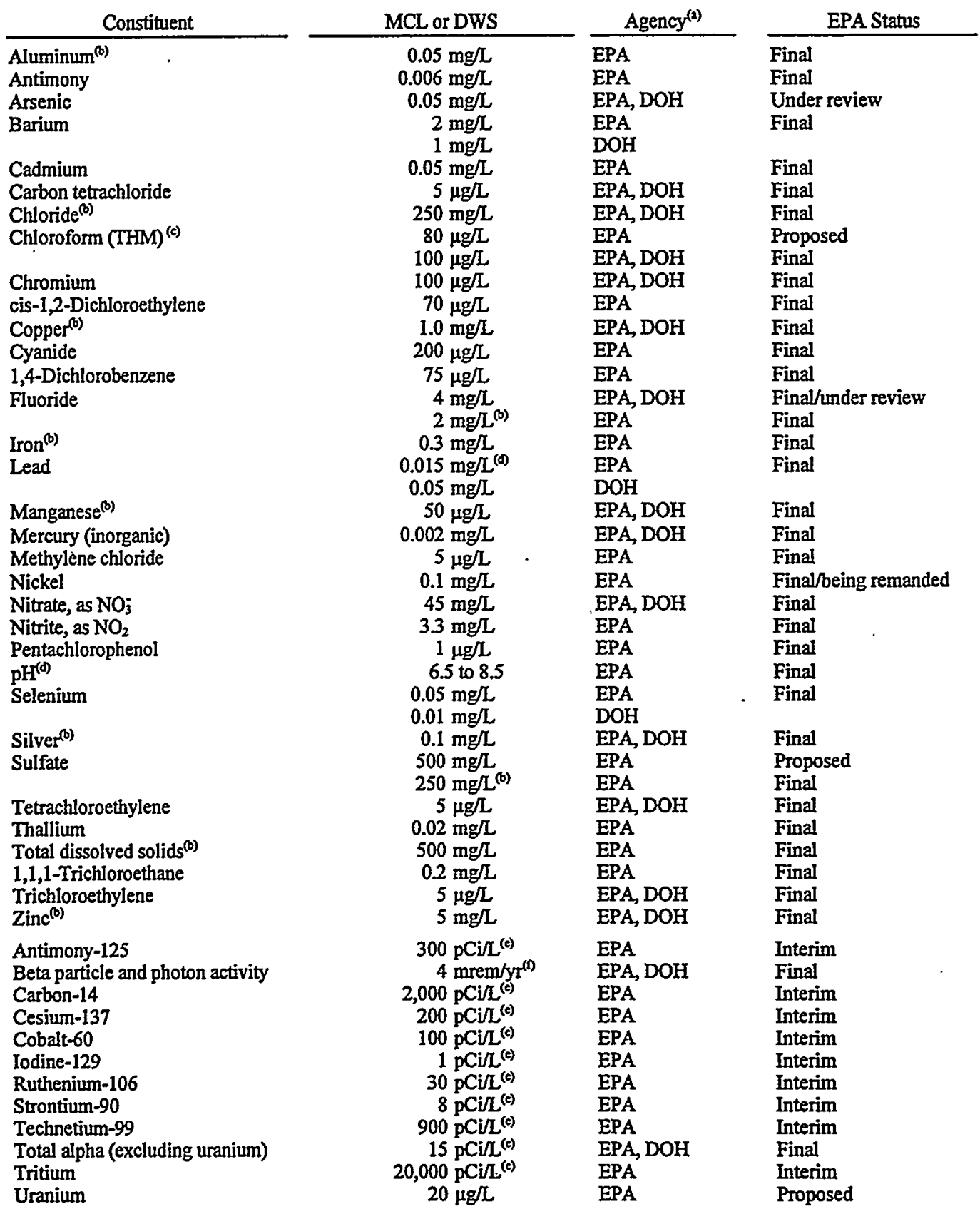

(a) - $\mathrm{DOH}=$ State of Washington Department of Health at WAC 246-290; EPA $=$ U.S. Environmental Protection Agency at 40 CFR 141, 40 CFR 143, and EPA 822-R-96-001.

(b) Secondary maximum contaminant leve!.

(c) Standard is for total trihalomethanes (THM).

(d) Action level.

(e) Concentration assumed to yield an annual dose equivalent of $4 \mathrm{mrem} / \mathrm{yr}$.

(f) Beta and gamma radioactivity from anthropogenic radionuclides. Annual average concentration shall not produce an annual dose from anthropogenic radionuclides equivalent to the total body or any internal organ dose $>4 \mathrm{mrem} / \mathrm{yr}$. If two or more radionuclides are present, the sum of their annual dose equivalents shall not exceed $4 \mathrm{mrem} / \mathrm{yr}$. Compliance may be assumed if annual average concentrations of total beta, tritium, and strontium-90 are $<50,20,000$, and $8 \mathrm{pCi} / \mathrm{L}$, respectively.

DWS $=$ Drinking water standard.

$\mathrm{MCL}=$ Maximum contaminant level. 
Table 5.1-2. Derived Concentration Guides ${ }^{(a, b, c)}$ and 4-mrem Effective Dose Equivalent Concentrations for Drinking Water ${ }^{(d)}$

\begin{tabular}{|c|c|c|}
\hline Radionuclide & $\begin{array}{c}\text { Derived Concentration } \\
\text { Guide, } \mathrm{pCi} / \mathrm{L} \\
\end{array}$ & $\begin{array}{c}\text { 4-mrem Effective Dose } \\
\text { Equivalent, } \mathrm{pCi} / \mathrm{L}\end{array}$ \\
\hline Tritium & $2,000,000$ & 80,000 \\
\hline Carbon-14 & 70,000 & 2,800 \\
\hline Chromium-51 & $1,000,000$ & 40,000 \\
\hline Manganese-54 & 50,000 & 2,000 \\
\hline Cobalt-60 & 5,000 & 200 \\
\hline Zinc-65 & 9,000 & 360 \\
\hline Krypton-85 & NS & NS \\
\hline Strontium-90 & 1,000 & 40 \\
\hline Technetium-99 & 100,000 & 4,000 \\
\hline Ruthenium-103 & 50,000 & 2,000 \\
\hline Ruthenium-106 & 6,000 & 240 \\
\hline Antimony-125 & 60,000 & 2,400 \\
\hline Iodine-129 & 500 & 20 \\
\hline Iodine-131 & 3,000 & 120 \\
\hline Cesium-134 & 2,000 & 80 \\
\hline Cesium-137 & 3,000 & 120 \\
\hline Cerium-144 & 7,000 & 280 \\
\hline Uranium-234 & 500 & 20 \\
\hline Uranium-235 & 600 & 24 \\
\hline Uranium-238 & 600 & 24 \\
\hline Plutonium-238 & 40 & 1.6 \\
\hline Plutonium-239 & 30 & 1.2 \\
\hline Plutonium-240 & 30 & 1.2 \\
\hline Americium-241 & 30 & 1.2 \\
\hline
\end{tabular}

(a) Concentration of a specific radionuclide in water that could be continuously consumed at average annual rates and not exceed an effective dose equivalent of $100 \mathrm{mrem} / \mathrm{yr}$.

(b) Values in this table represent the lowest, most conservative derived concentration guides considered potentially applicable to Hanford Site operations, and may, be adjusted upward (larger) if accurate solubility information is available.

(c) From DOE Order 5400.5 .

(d) Concentration of a specific radionuclide in water that would produce an effective dose equivalent of $4 \mathrm{mrem} / \mathrm{yr}$ if consumed at average annual rates.

NS $=$ No standard . 
Table 5.6-1. Summary of Groundwater Chemistry in Redox Manipulation Technology Demonstration

\begin{tabular}{|c|c|c|c|c|c|c|c|}
\hline \multirow[b]{2}{*}{ Parameter, unit } & \multicolumn{2}{|c|}{ Baseline (September 1997) } & \multicolumn{3}{|c|}{$\begin{array}{l}\text { Treatment Zone }{ }^{(2)} \\
\text { (September 1998) } \\
\end{array}$} & \multicolumn{2}{|c|}{$\begin{array}{l}\text { Downgradient of Treatment } \\
\text { Zone }^{(b)} \text { (September 1998) }\end{array}$} \\
\hline & Range & Average & & Range & Average & Range & Average \\
\hline $\mathrm{pH}$ & 7.44 to 8.22 & 7.69 & 7.93 & to 9.30 & 8.62 & 7.45 to 8.37 & 7.81 \\
\hline $\begin{array}{l}\text { Specific } \\
\text { conductance, } \\
\mu \mathrm{S} / \mathrm{cm}\end{array}$ & 442 to 704 & 602 & 641 & to 4,550 & 1,766 & 520 to 963 & 695 \\
\hline $\begin{array}{l}\text { Dissolved } \\
\text { oxygen, } \mathrm{mg} / \mathrm{L}\end{array}$ & 2.22 to 11.54 & 9.42 & & 0 & 0 & 0.61 to 8.3 & 3.81 \\
\hline Sulfate, $\mathrm{mg} / \mathrm{L}$ & 84.9 to 144 & 120 & 151 & to 1,300 & 521 & 142 to 389 & 277 \\
\hline $\begin{array}{l}\text { Hexavalent } \\
\text { chromium, } \mu \mathrm{g} / \mathrm{L}\end{array}$ & 588 to 1150 & 1,000 & & 0 & 0 & 0 to 550 & 280 \\
\hline
\end{tabular}

(a) Wells 199-D4-1, D4-2, D4-3, D4-7, D4-8, D4-9, D4-10, D4-11, D4-12, D4-16.

(b) Wells 199-D4-4, D4-5, D4-6, D4-17, D4-18.

Table 5.9-1. Quantity of Groundwater Treated and Contaminant Mass Removed Since Startup of 200-UP-1 Operable Unit Pump-and-Treat Operations

\begin{tabular}{|c|c|c|c|c|c|}
\hline Reporting Period & $\begin{array}{l}\text { Groundwater } \\
\text { Treated, L }\end{array}$ & $\begin{array}{c}\text { Mass } \\
\text { Technetium-99 } \\
\text { Removed, } \mathrm{g} \\
\end{array}$ & $\begin{array}{c}\text { Mass Total } \\
\text { Uranium } \\
\text { Removed, } g \\
\end{array}$ & $\begin{array}{l}\text { Mass Carbon } \\
\text { Tetrachloride } \\
\text { Removed, g }\end{array}$ & $\begin{array}{l}\text { Mass Nitrate } \\
\text { Removed, kg }\end{array}$ \\
\hline $\begin{array}{l}\text { March } 1994 \text { - November } \\
1994^{(2)}\end{array}$ & $3,898,550$ & 3.41 & 4,422 & Not reported & N/A \\
\hline December 1994 - August 1995 & $11,391,491$ & 7.79 & 9,831 & 992 & N/A \\
\hline $\begin{array}{l}\text { September } 1995 \text { - November } \\
1995\end{array}$ & $17,198,571$ & 3.95 & 3,895 & 630 & N/A \\
\hline December 1995 - March 1996 & $31,311,340$ & 9.05 & 9,105 & 1,609 & N/A \\
\hline April 1996 - June 1996 & $22,459,108$ & 5.40 & 6,845 & 1,569 & $\mathbf{N} / \mathbf{A}$ \\
\hline July 1996 - September 1996 & $22,370,327$ & 4.01 & 5,134 & 2,790 & $\mathrm{~N} / \mathrm{A}$ \\
\hline October 1996 - December 1996 & $20,300,000$ & 3.33 & 5,607 & 2,980 & N/A \\
\hline $\begin{array}{l}\text { January } 1997-\text { February } \\
1997^{(0)}\end{array}$ & $2,667,600$ & 0.83 & 963 & 73 & N/A \\
\hline February - March 30, 1997 & Shut down & N/A & N/A & N/A & N/A \\
\hline March 31 - September 30, 1997 & $32,414,481$ & 5.6 & 11,000 & 888 & 2,260 \\
\hline October 1 - December 31, 1997 & $20,390,054$ & 3.31 & 6,300 & 572 & 1,530 \\
\hline January 1 - March 31, 1998 & $19,791,765$ & 2.08 & 4,900 & 460 & 1,070 \\
\hline April 1 - June 30, 1998 & $33,538,750$ & 3.58 & 8,680 & 907 & 2,150 \\
\hline July 1 - September 30, 1998 & $26,346,466$ & 1.57 & 3,750 & 296 & 900 \\
\hline Total & $338,413,037$ & 53.91 & 80,432 & 13,766 & 7,910 \\
\hline
\end{tabular}

(a) Data from the treatability test as reported in DOE/RL-95-02.

(b) Estimated values based on $189 \mathrm{~L} / \mathrm{min}$ ( $50 \mathrm{gal} / \mathrm{min})$ flow, running 24 hours $/$ day, at $97.5 \%$ efficiency. N/A $=$ Not applicable. 
Table 5.9-2. Volume of Groundwater Treated and Carbon Tetrachloride Mass Removed Since Startup of 200-ZP-1 Operable Unit Operations

\begin{tabular}{|c|c|c|}
\hline Reporting Period & $\begin{array}{c}\text { Groundwater } \\
\text { Treated, L }\end{array}$ & Mass Removed, kg \\
\hline August 1994 - July 1996 & $26,676,000$ & 75.85 \\
\hline August 1996 - September 1996 & $33,232,327$ & 60.96 \\
\hline October 1996 - December 1996 & $44,583,7.15$ & 143.54 \\
\hline January 1997 - March 199.7 & $69,869,604$ & 237.2 \\
\hline April 1997 - June 1997 & $41,877,094$ & 140.8 \\
\hline July 1997 - September 1997 & $62,469,305$ & 228.8 \\
\hline October 1997 - December 1997 & $81,629,000$ & 245.7 \\
\hline January 1998 - March 1998 & $72,791,000$ & 279.5 \\
\hline April 1998 - June 1998 & $90,842,900$. & 348.9 \\
\hline July 1998 - September 1998 & $90,899,200$ & 338.1 \\
\hline Total & $614,870,100$ & $2,099.2$ \\
\hline
\end{tabular}

Table 5.9-3. Concentrations for Each Phase III Extraction Well and Influent Tank at 200-ZP-1 Operable Unit

\begin{tabular}{|c|c|c|c|c|c|}
\hline Well $^{(\mathrm{a})}$ & $\begin{array}{c}\text { Fiscal Year } \\
1998 \\
\text { Minimum } \\
\text { Value, } \mu \mathrm{g} / \mathrm{L} \\
\end{array}$ & $\begin{array}{c}\text { Fiscal Year } \\
1998 \\
\text { Maximum } \\
\text { Value, } \mu \mathrm{g} / \mathrm{L} \\
\end{array}$ & $\begin{array}{c}\text { Mean } \\
\text { Concentration, } \\
\text { FY } 1998, \mu \mathrm{g} / \mathrm{L} \\
\end{array}$ & $\begin{array}{c}\text { Mean } \\
\text { Concentration, } \\
\text { FY 1997, } \mu \mathrm{g} / \mathrm{L} \\
\end{array}$ & $\begin{array}{c}\text { Mean Flow } \\
\text { Rate, }{ }^{(b)} \mathrm{L} / \mathrm{min} \\
\text { (gal/min) }\end{array}$ \\
\hline 299-W15-33 & 4,700 & 7,200 & 6,000 & 5,058 & $66(18)$ \\
\hline 299-W15-34 & 2,800 & 4,700 & 3,770 & 2,900 & $101(27)$ \\
\hline 299-W15-35 & 2,800 & 4,500 & 3,660 & 3,351 & $310(82)$ \\
\hline 299-W15-32 & 4,800 & 7,800 & 6,560 & 7,120 & $81(22)$ \\
\hline $299-W 15-36$ & 1,600 & 2,600 & 2040 & 2,820 & $112(30)$ \\
\hline $299-W 15-37$ & 140 & 320 & 235 & 280 & $63(17)$ \\
\hline Influent Tank & - & 4,400 & 3,530 & 3,270 & - \\
\hline
\end{tabular}

(a) Wells listed from north to south.

(b) Some discrepancies in discharge rate at the different measurement locations were observed. These are still being resolved. Flow rates may actually be higher by $\sim 15 \%$ to $20 \%$.

FY $=$ Fiscal year. 


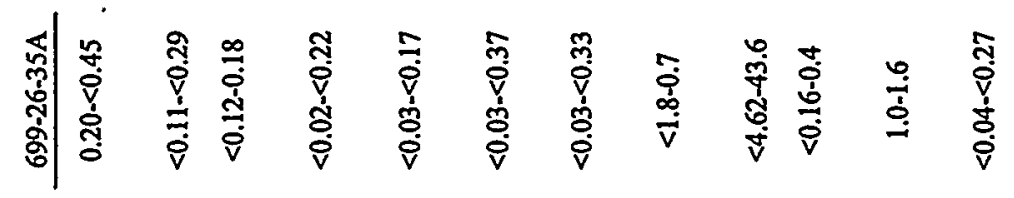

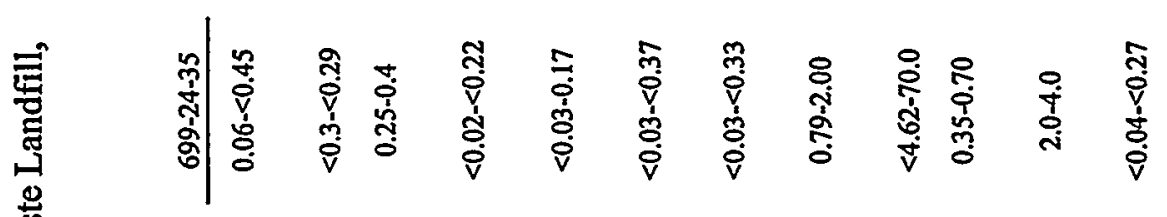

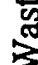

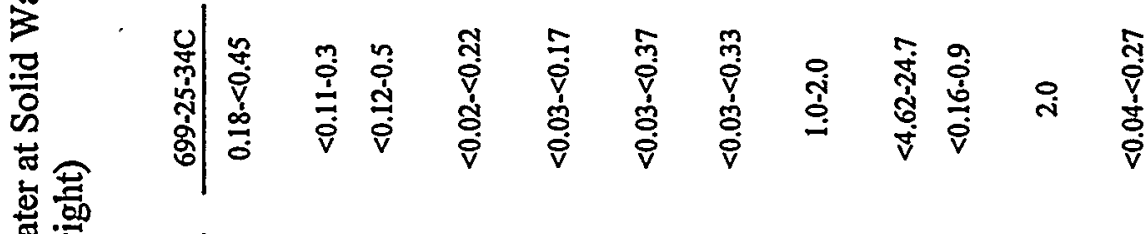

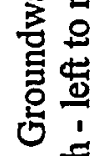

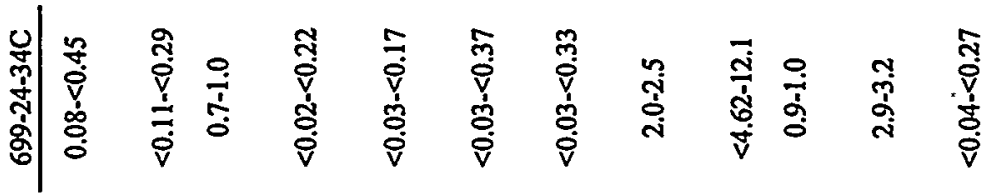

जo

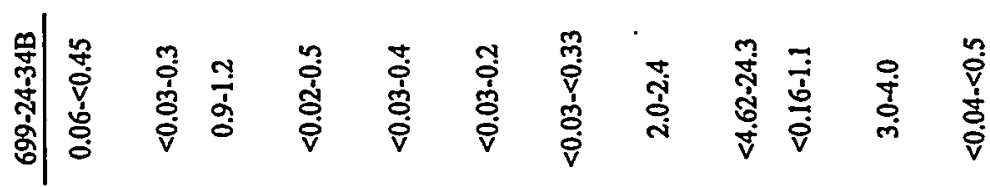

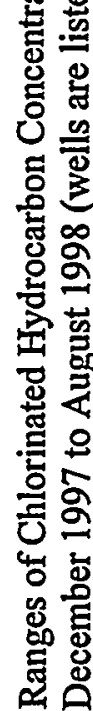

高

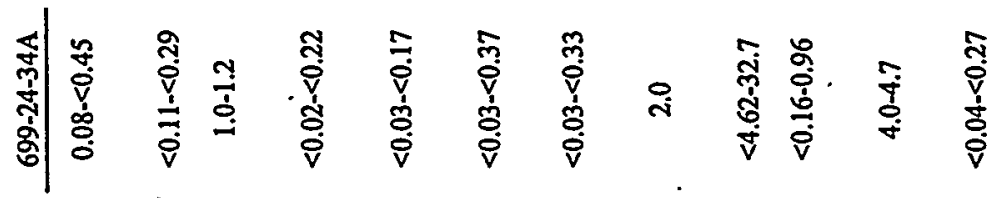

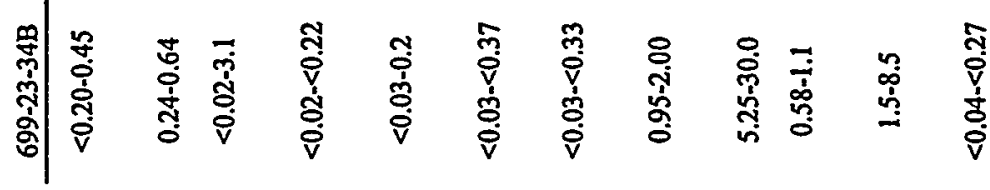

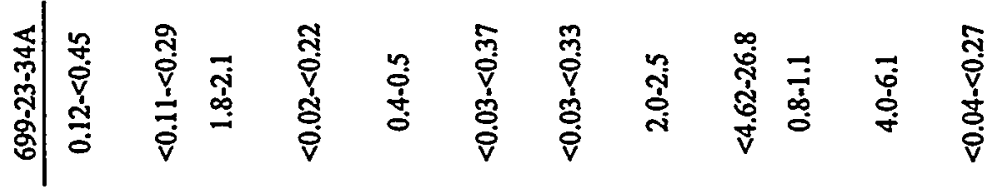

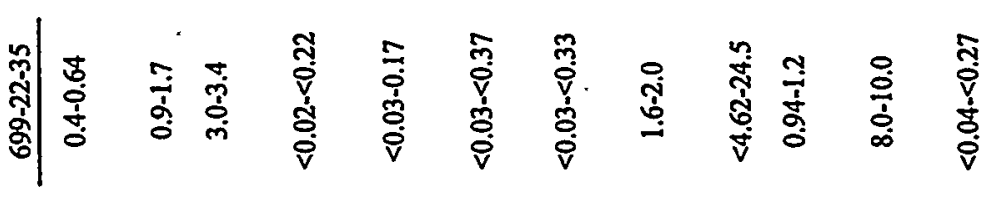

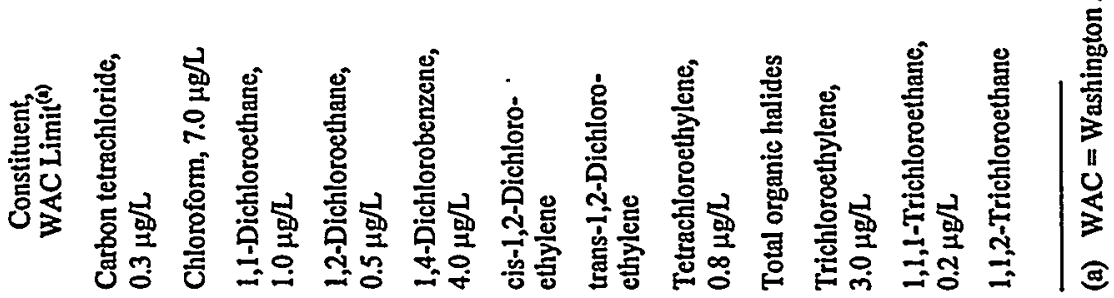




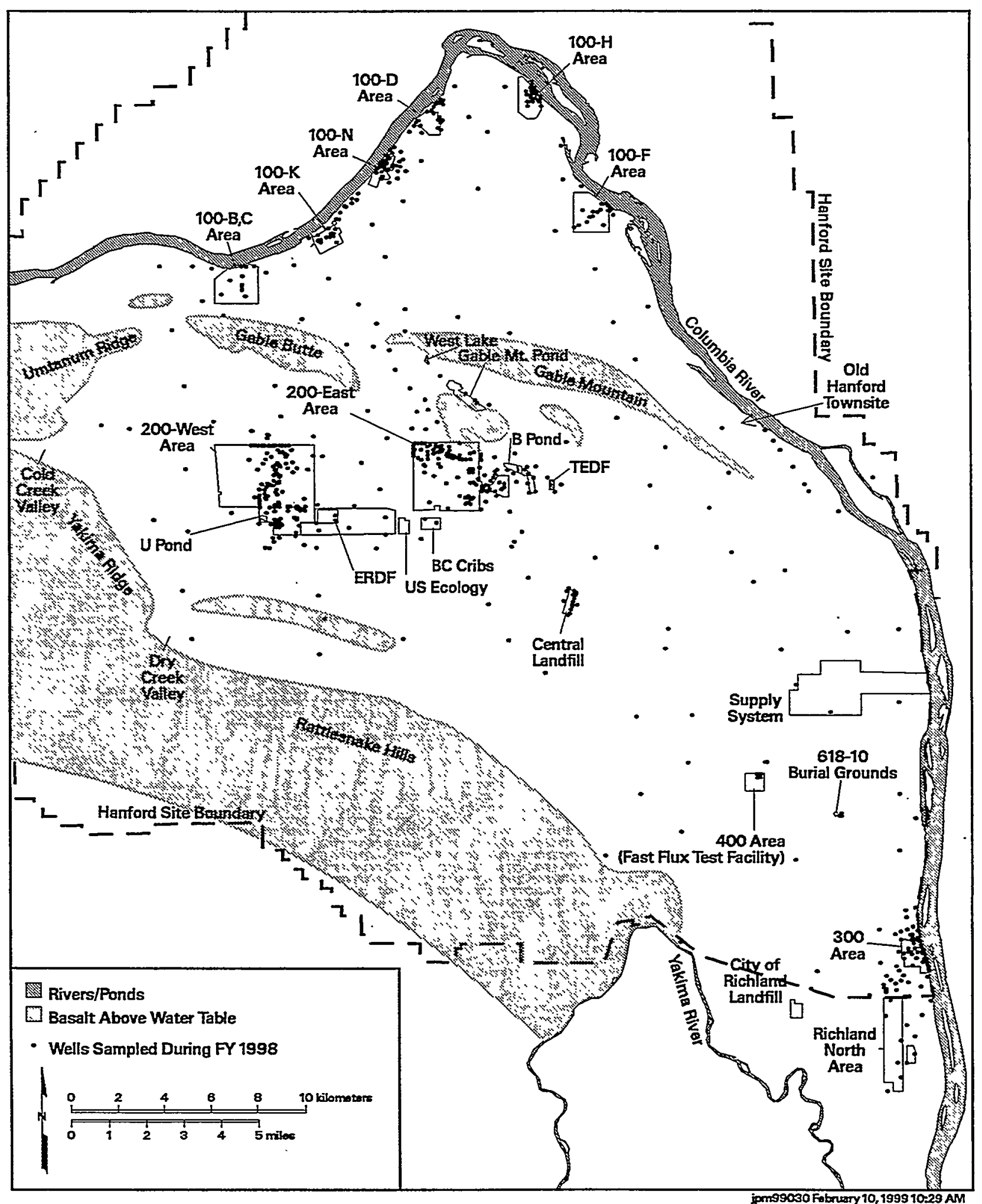

Figure 5.1-1. Wells Sampled During Fiscal Year 1998 


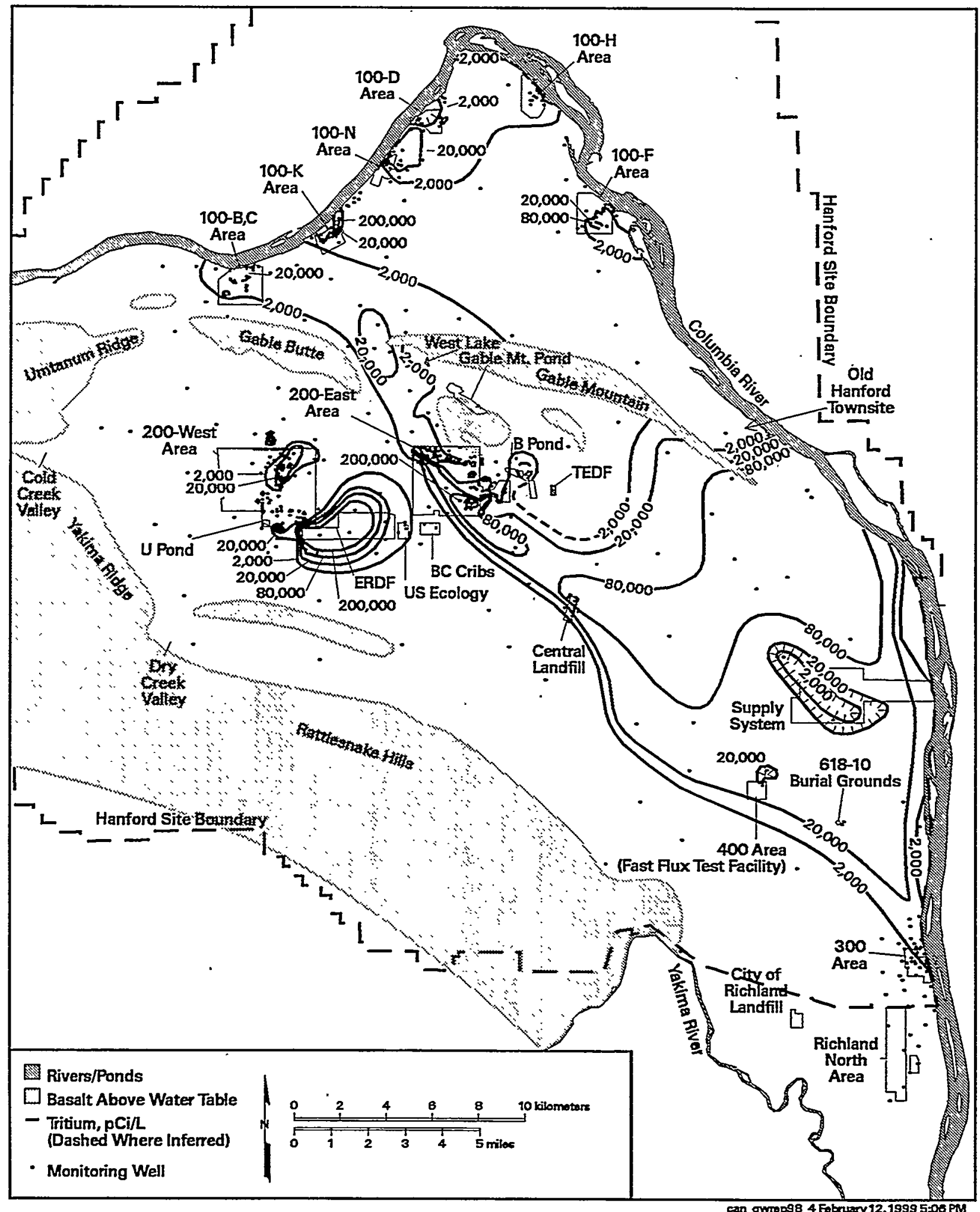

Figure 5.2-1. Average Tritium Activities, Top of Unconfined Aquifer 


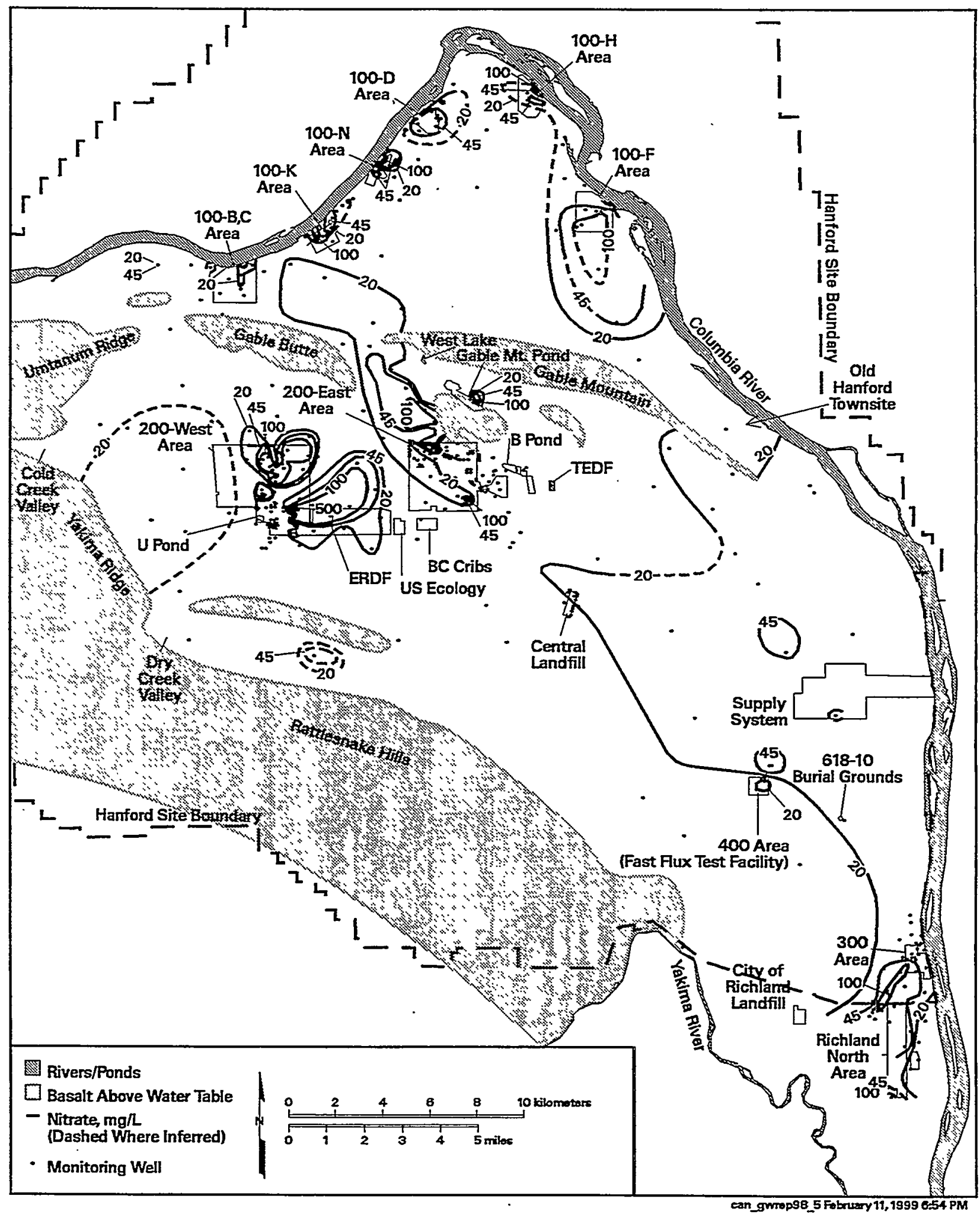

Figure 5.2-2. Average Nitrate Concentrations, Top of Unconfined Aquifer 


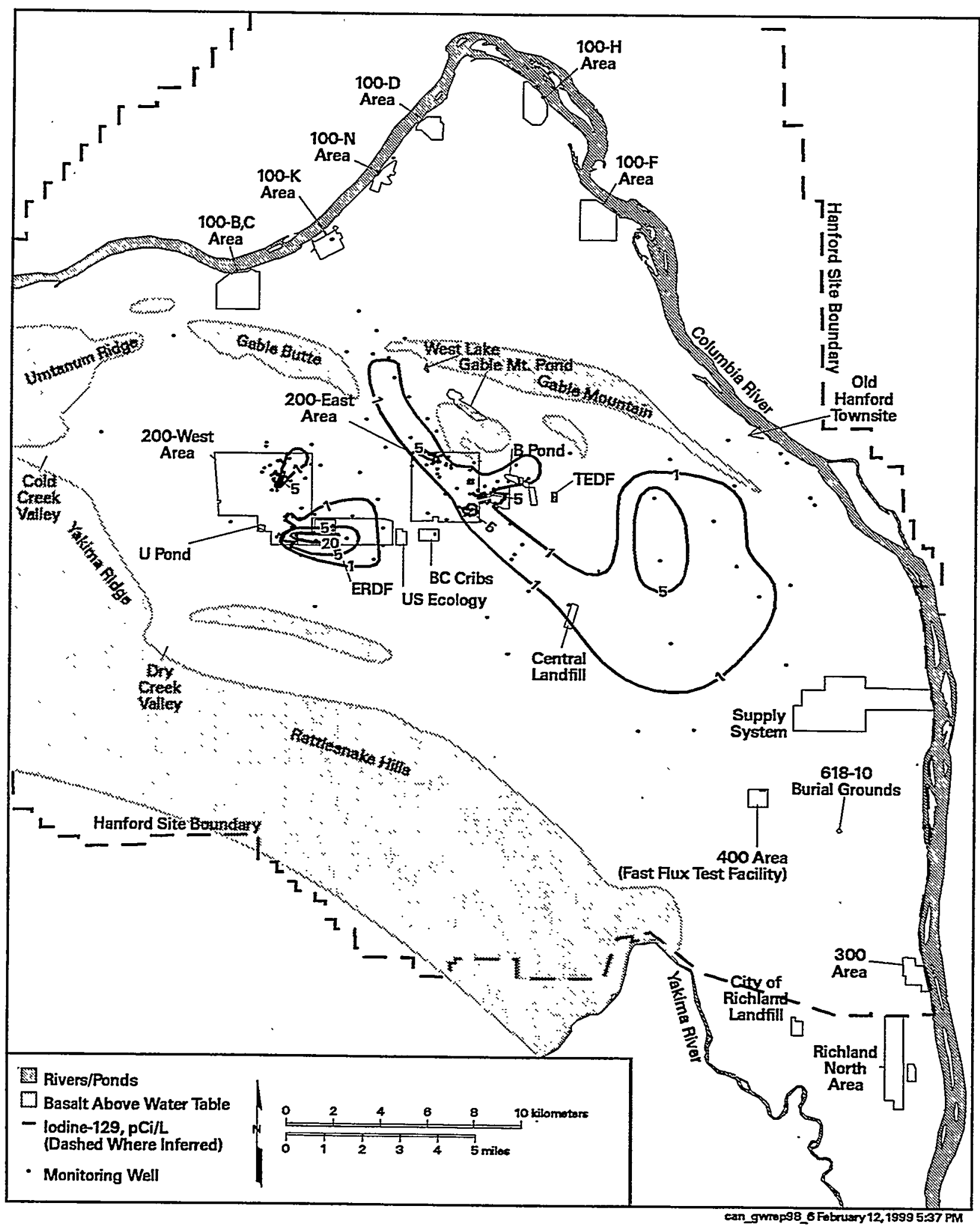

Figure 5.2-3. Average Iodine-129 Activities, Top of Unconfined Aquifer 


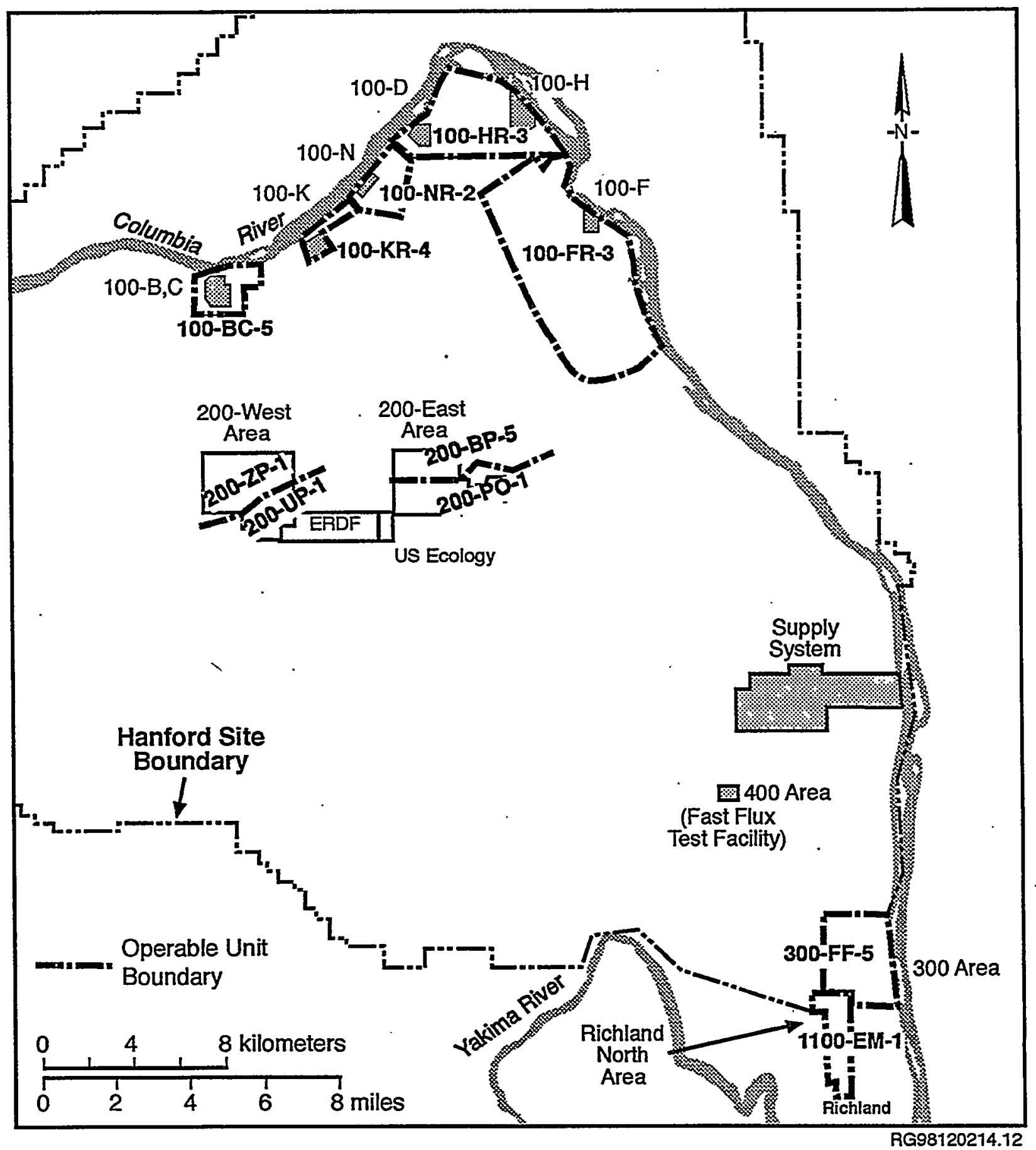

Figure 5.2-4. Groundwater Operable Units 


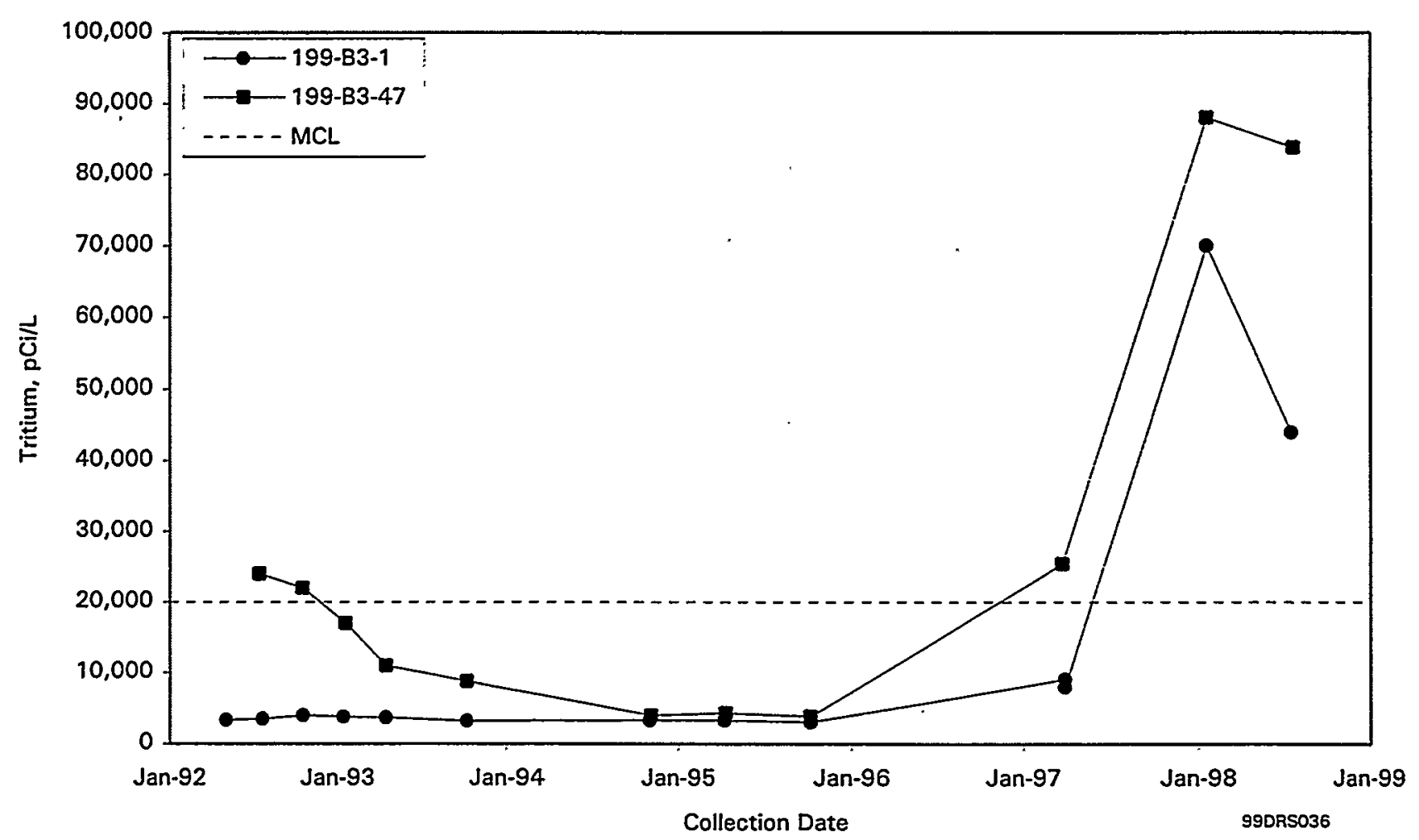

Figure 5.3-1. Tritium Activities in Wells 199-B3-1 and 199-B3-47 


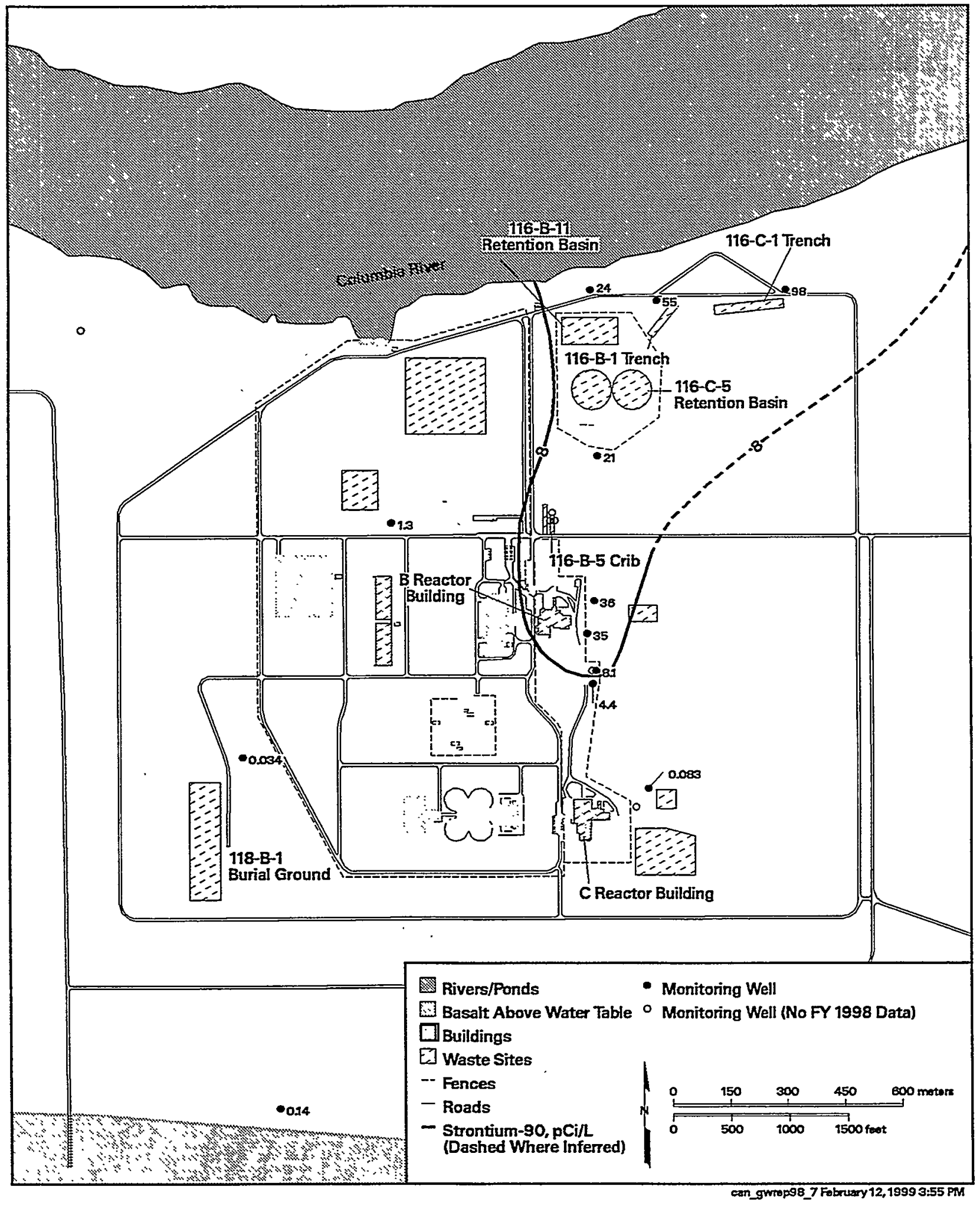

Figure 5.3-2. Average Strontium-90 Activities in 100-B,C Area, Top of Unconfined Aquifer 


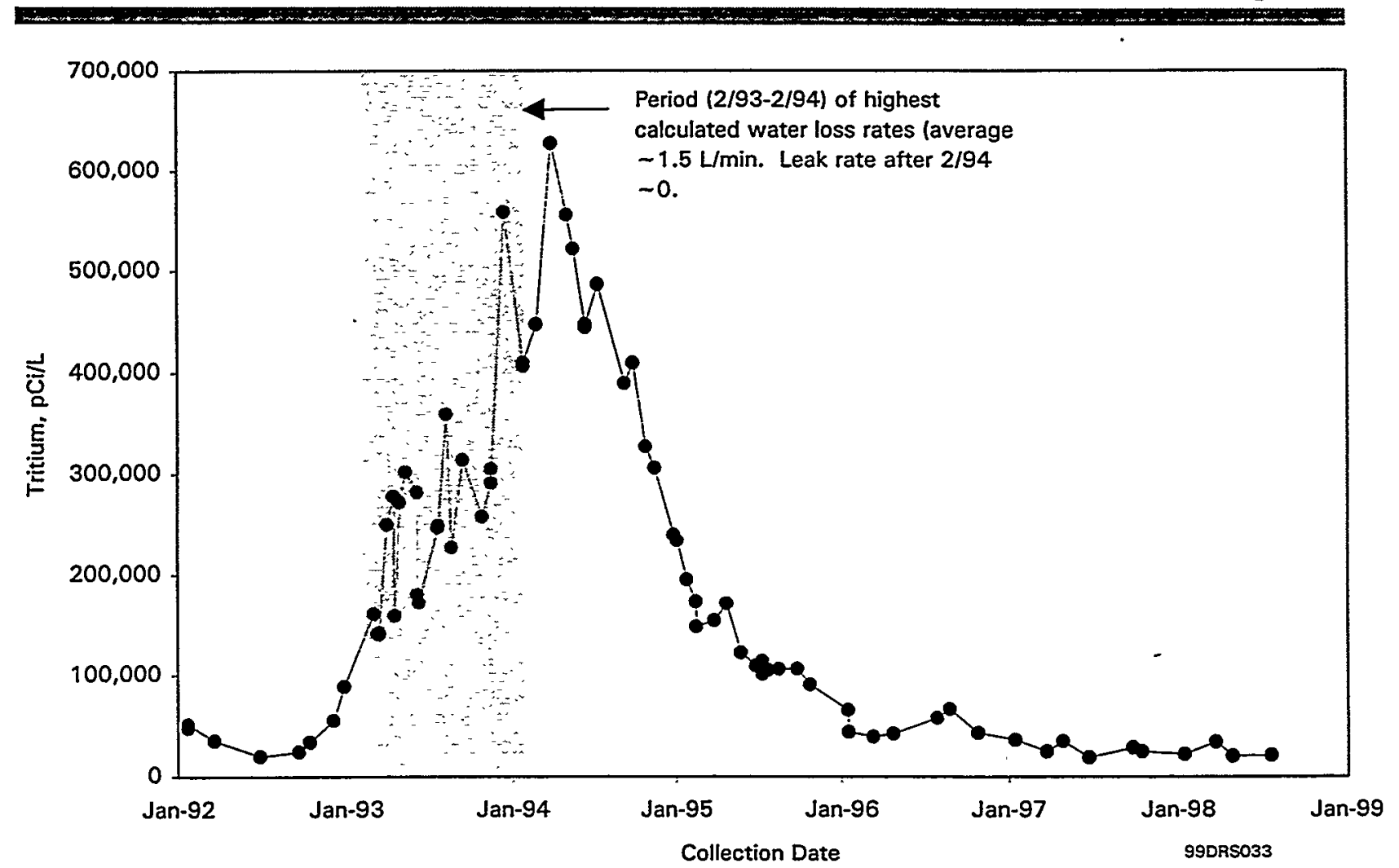

Figure 5.4-1. Tritium Activities in Well 199-K-27 Monitoring K-East Fuel-Storage Basin

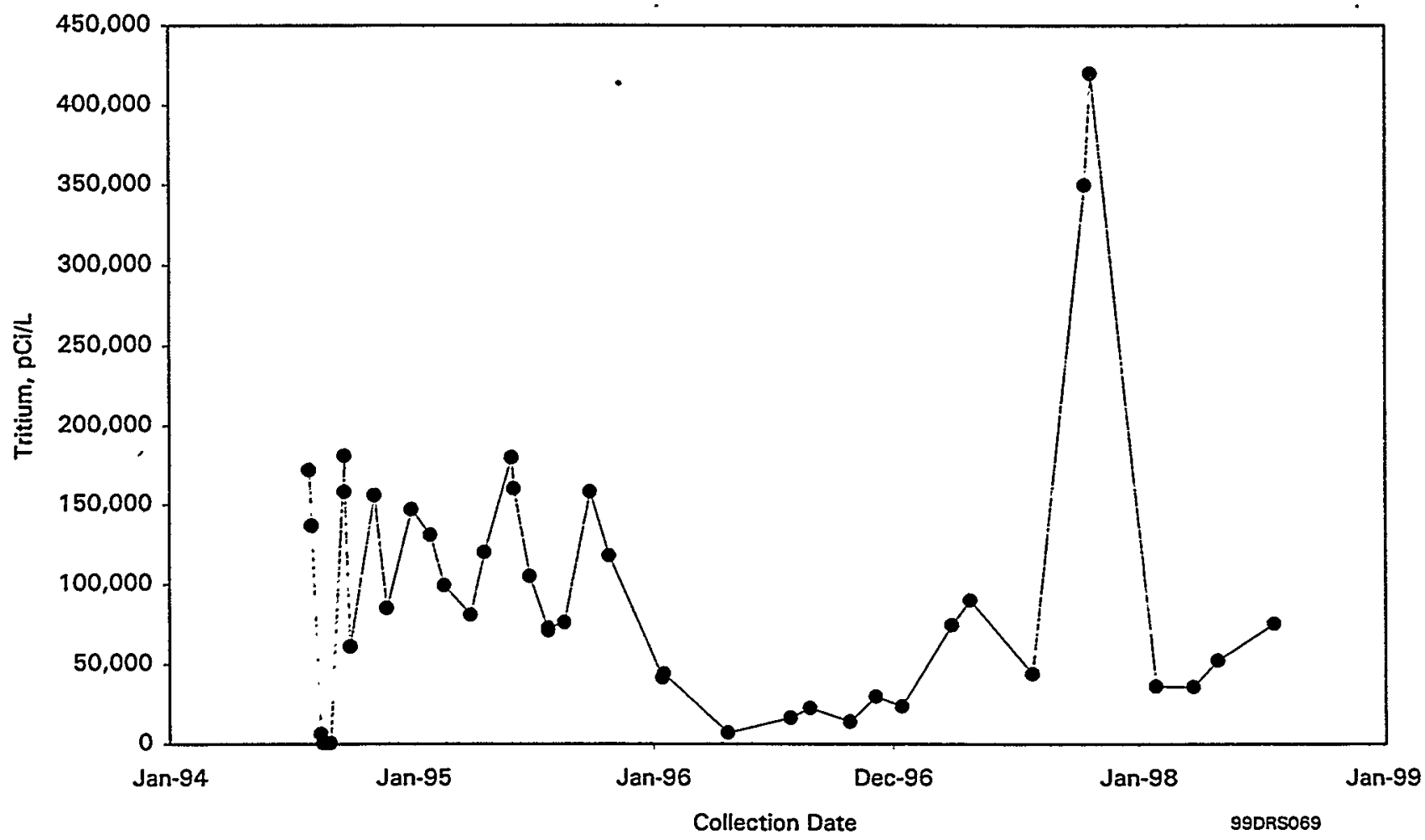

Figure 5.4-2. Tritium Activities in Well 199-K-109A Monitoring K-East Fuel-Storage Basin 


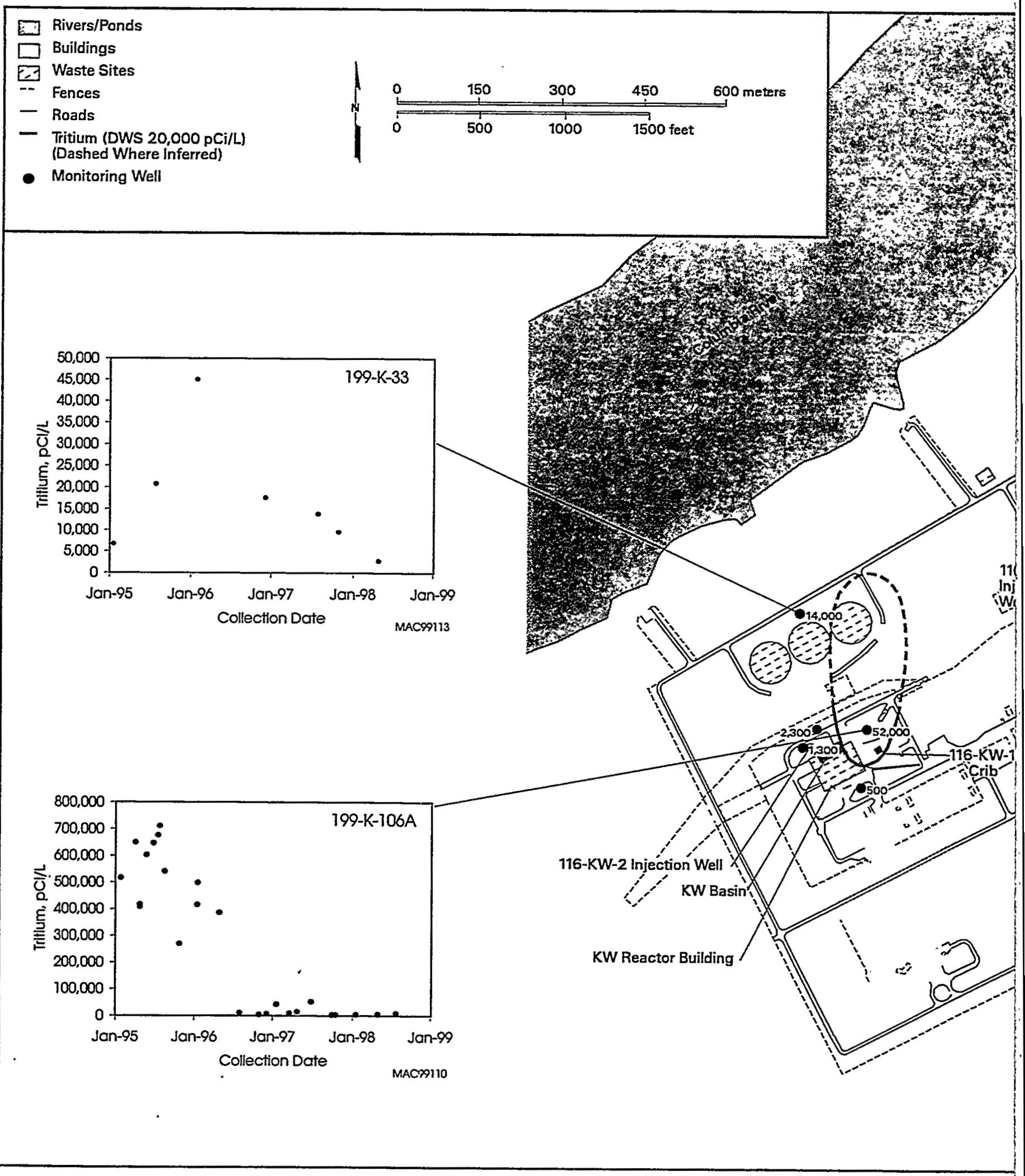

Figure 5.4-3. Effects of Water-Level Changes on Tri 


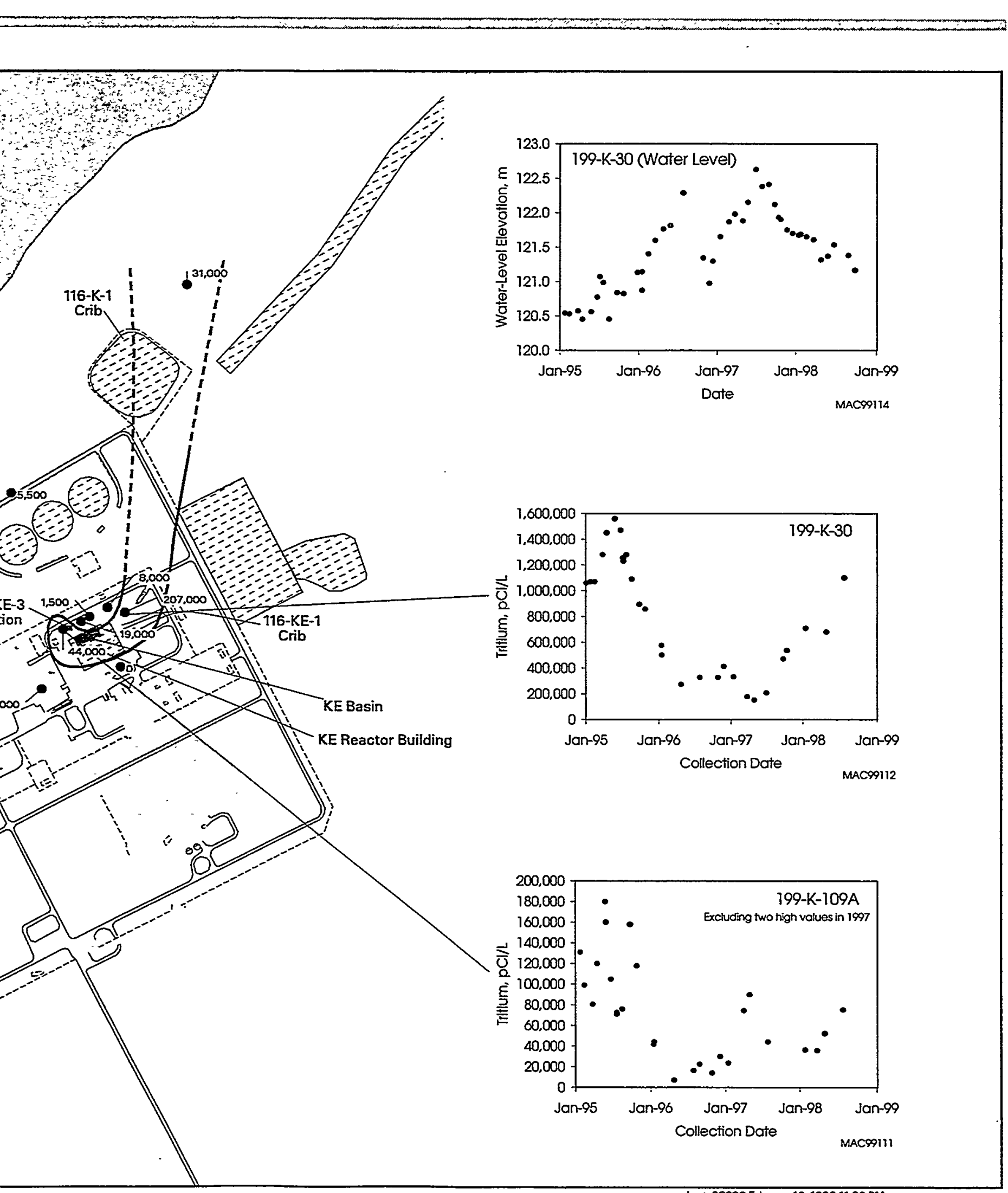

Can_hart_99030 Fobruary 12, 1999 11:32 PM

Im Activity, 100-K Area, Top of Unconfined Aquifer 


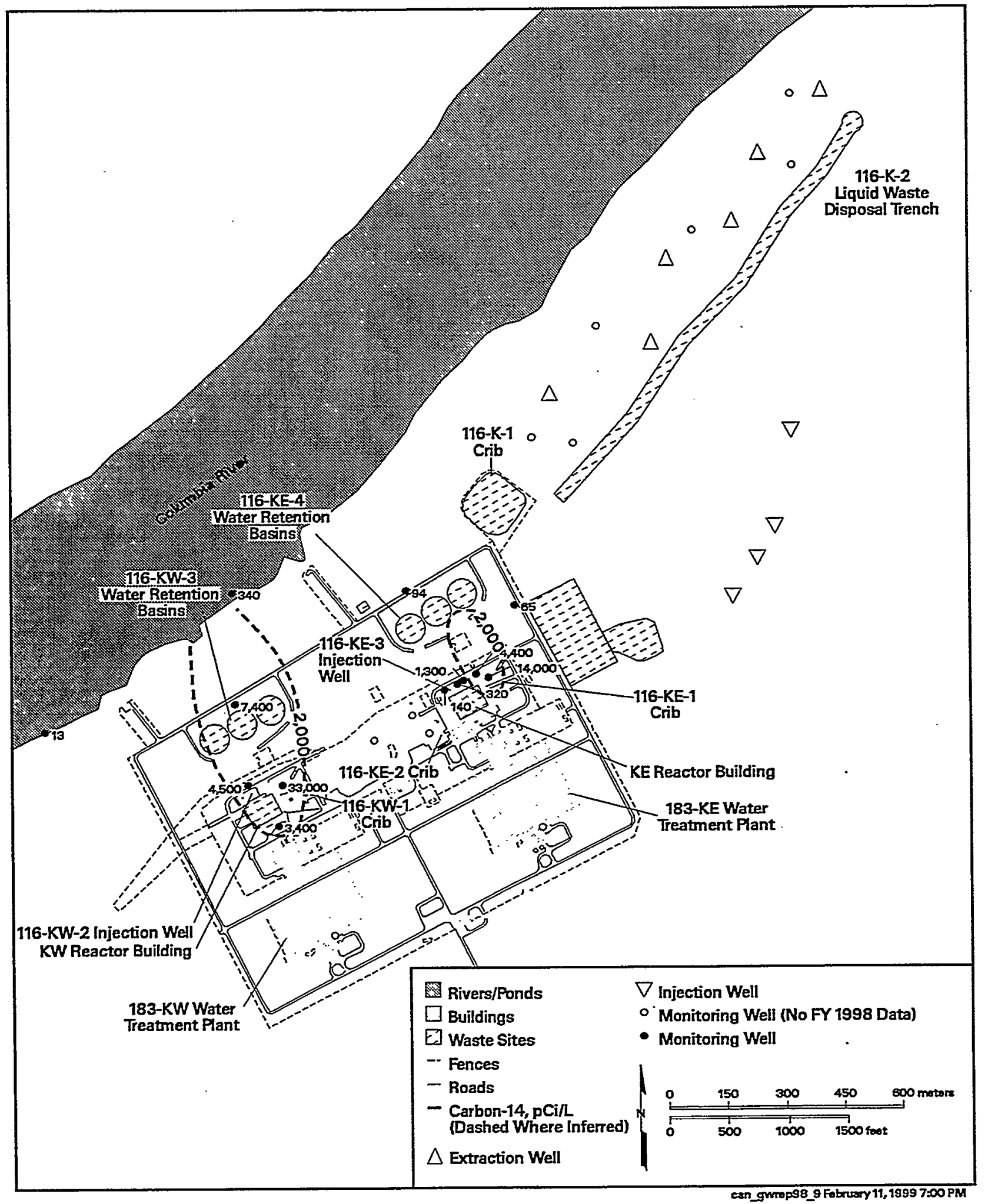

Figure 5.4-4. Average Carbon-14 Activities in 100-K Area, Top of Unconfined Aquifer 


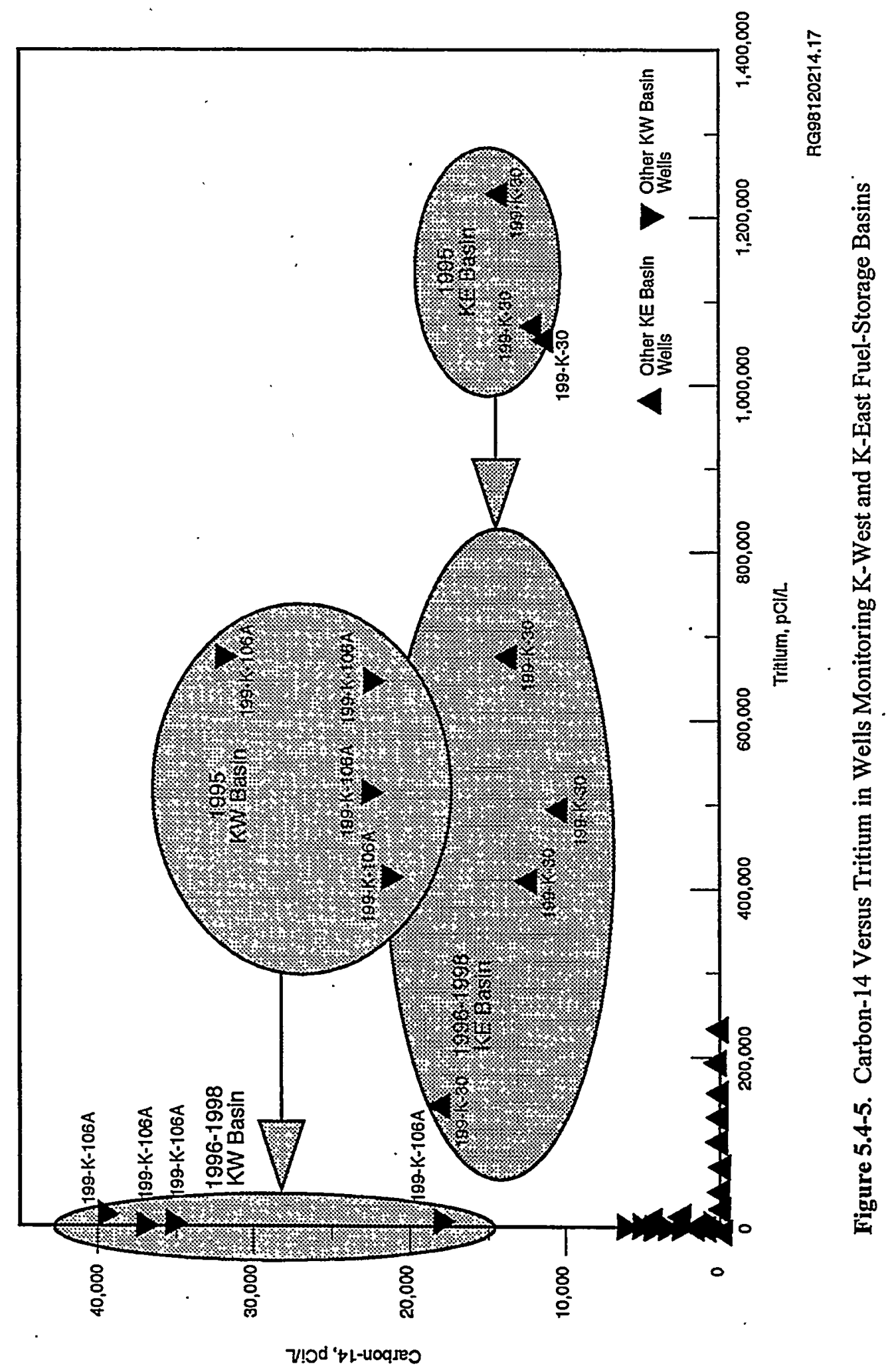




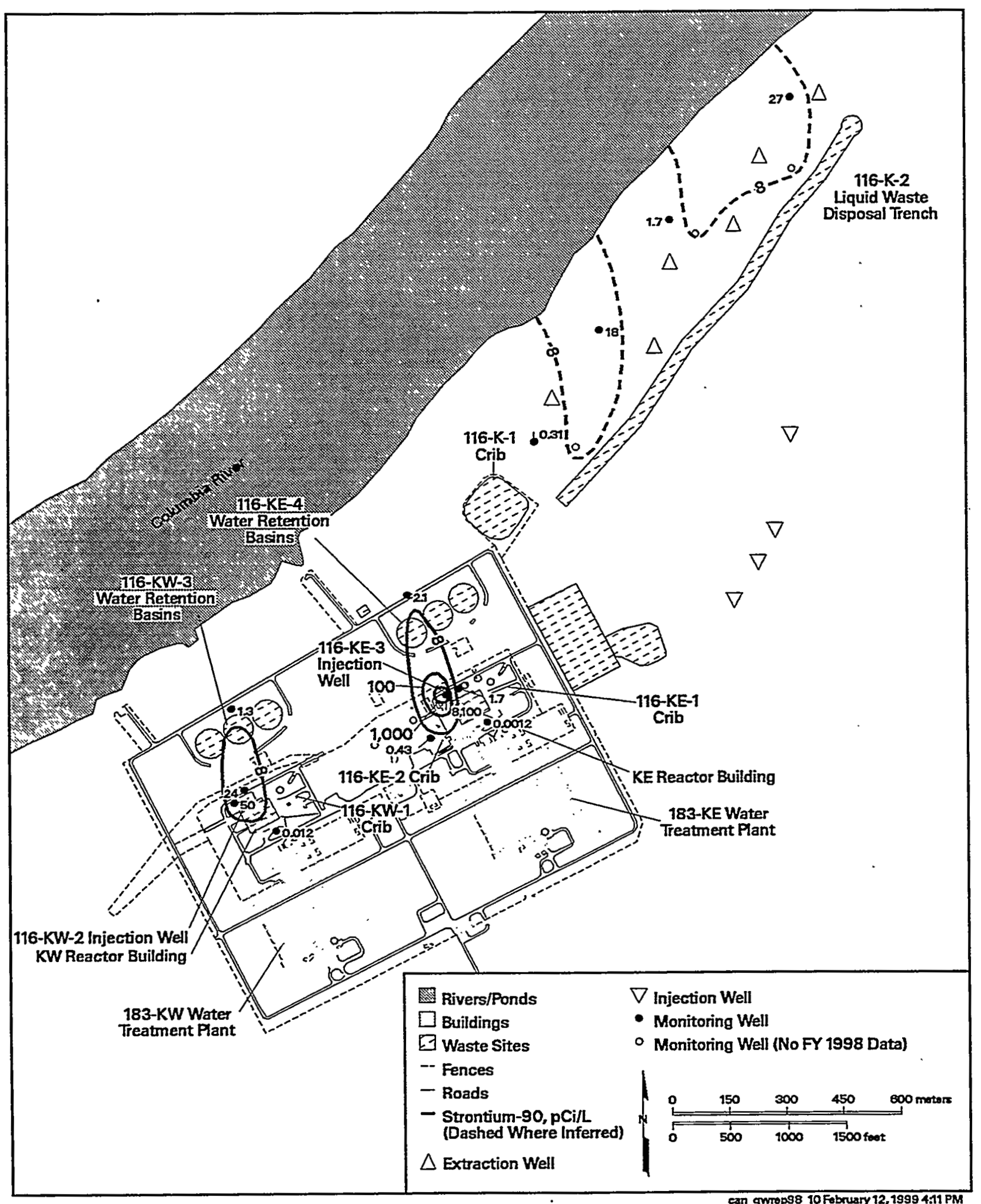

Figure 5.4-6. Average Strontium-90 Activities in 100-K Area, Top of Unconfined Aquifer 


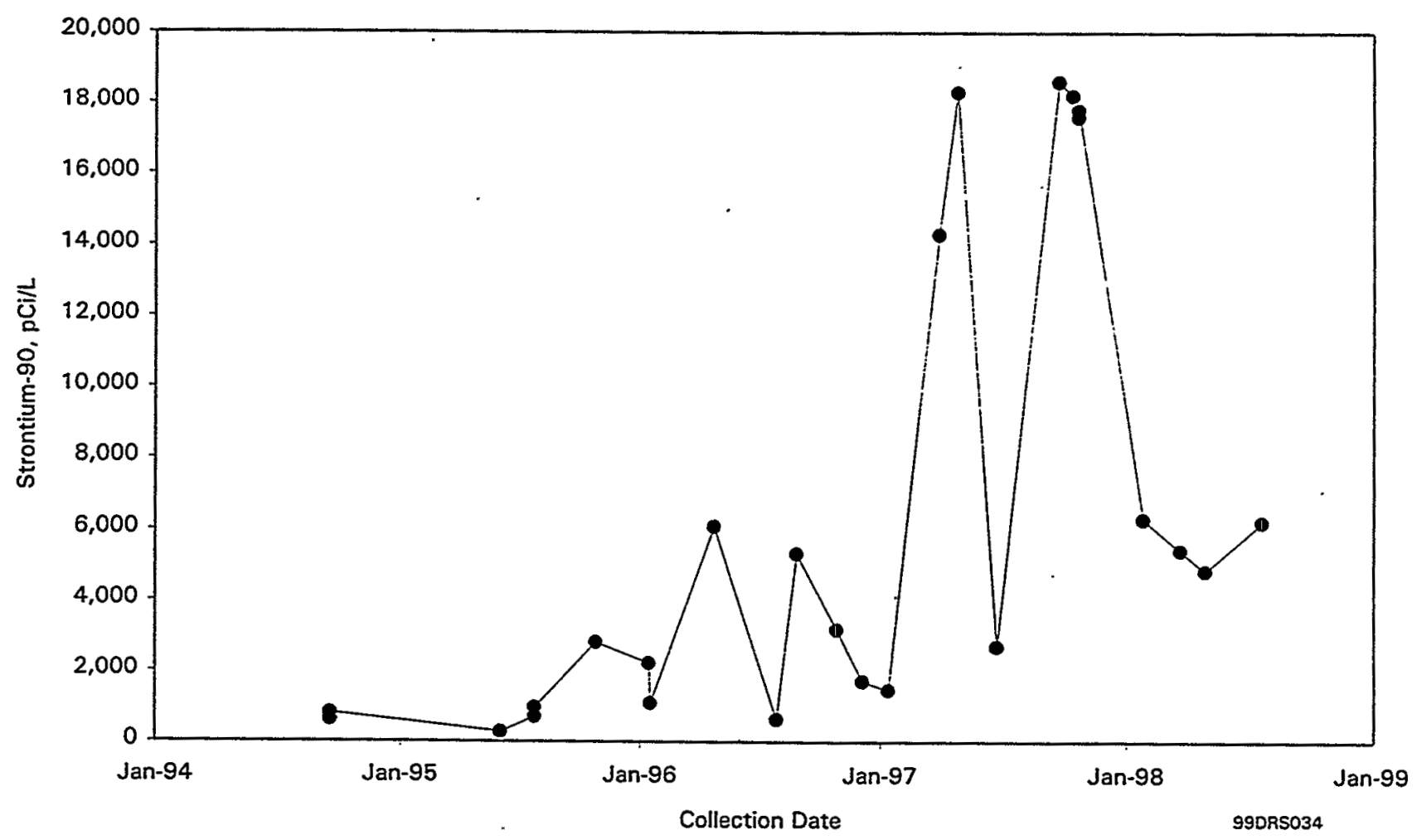

Figure 5.4-7. Strontium-90 Activities in Well 199-K-109A Monitoring K-East Fuel-Storage Basin

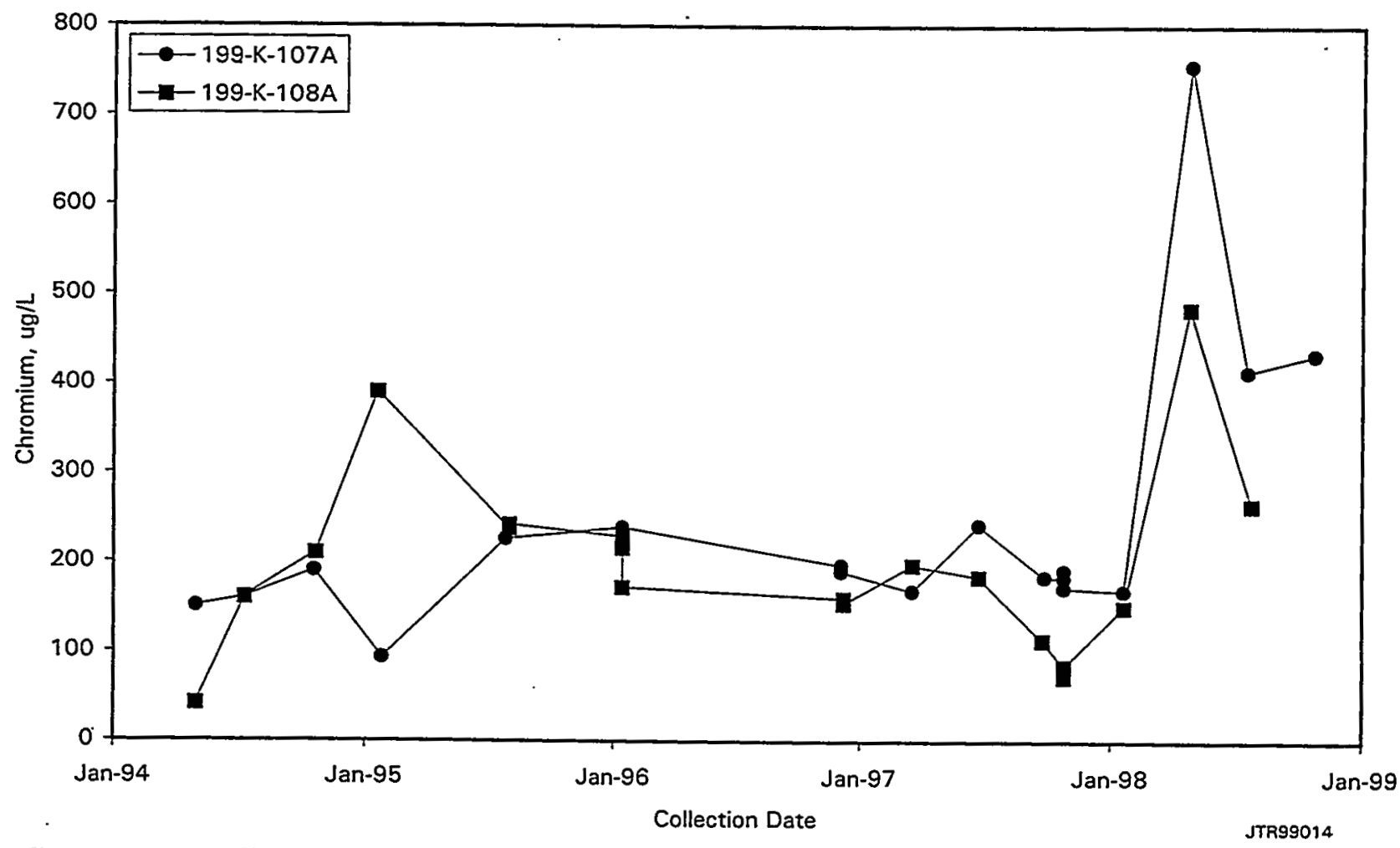

Figure 5.4-8. Filtered Chromium Concentrations in Wells 199-K-107A and 199-K-108A Monitoring $\mathrm{K}$-West Fuel-Storage Basin 


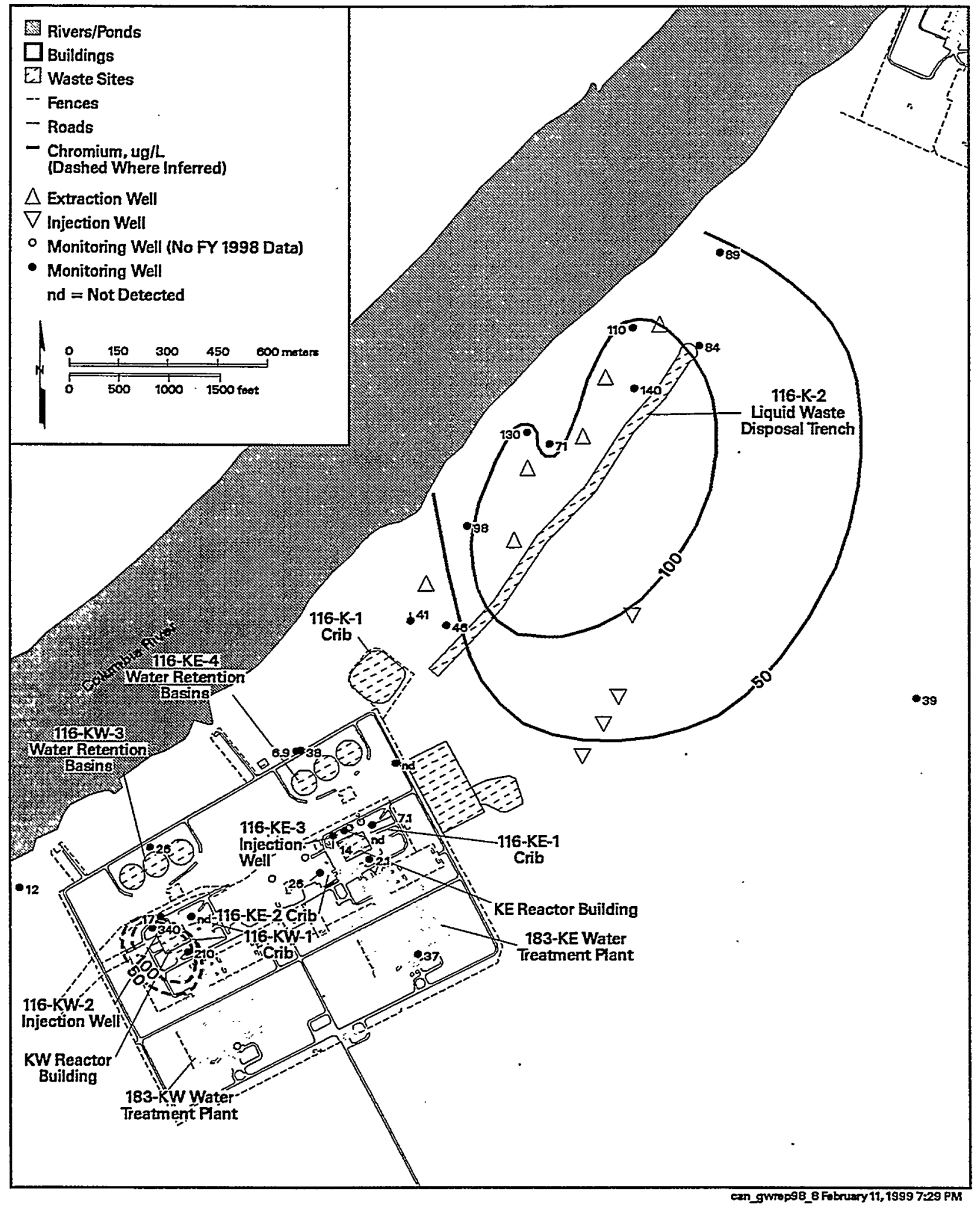

Figure 5.4-9. Average Filtered Chromium Concentrations in 100-K Area, Top of Unconfined Aquifer 
Figure 5.4-10. Filtered Chromium Concentrations in Wells 199-K-20 and 199-K-117A Near 116-K-2 Trench

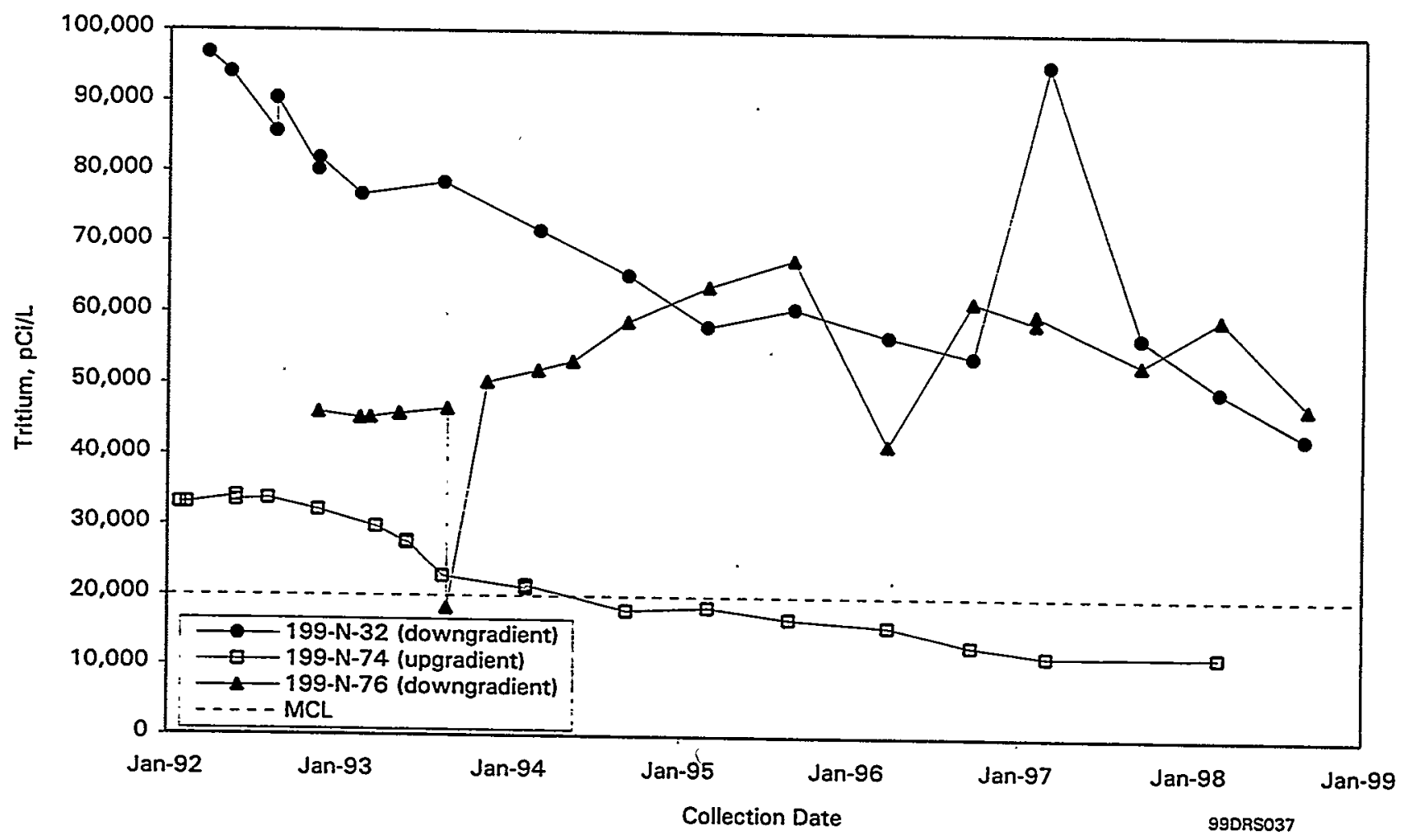

Figure 5.5-1. Tritium Activities in Wells 199-N-32, 199-N-74, and 199-N-76 


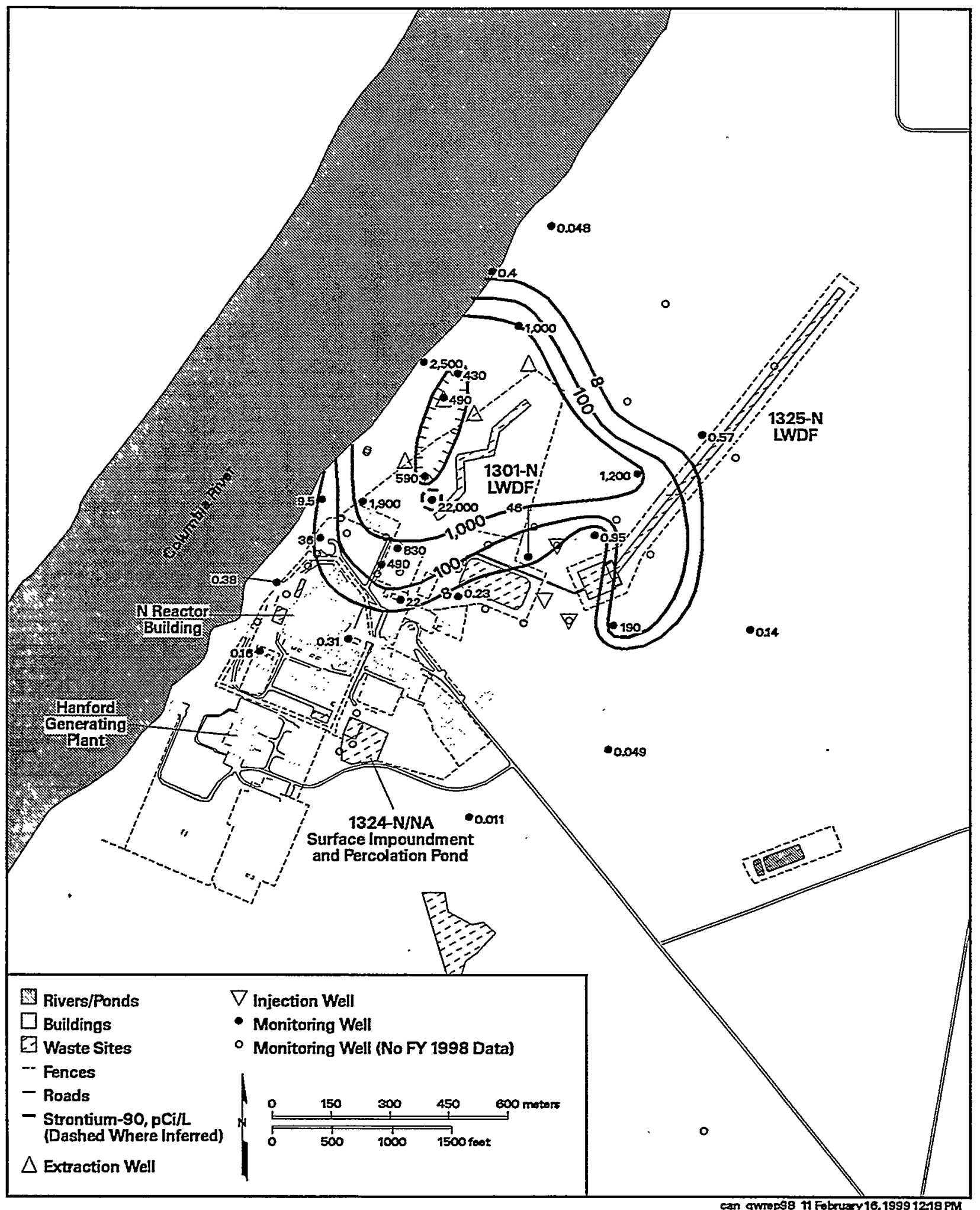

Figure 5.5-2. Average Strontium-90 Activities in 100-N Area, Top of Unconfined Aquifer 

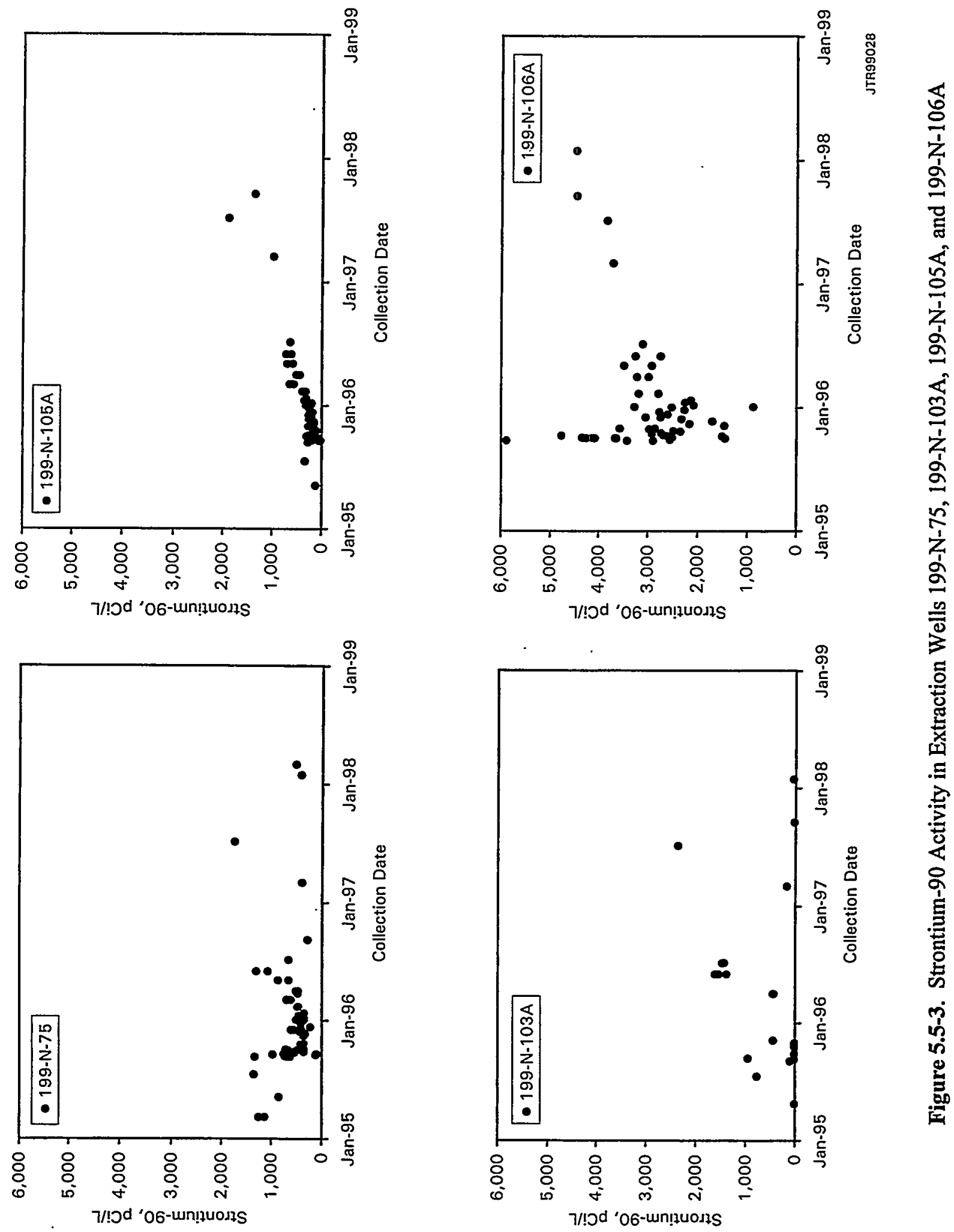


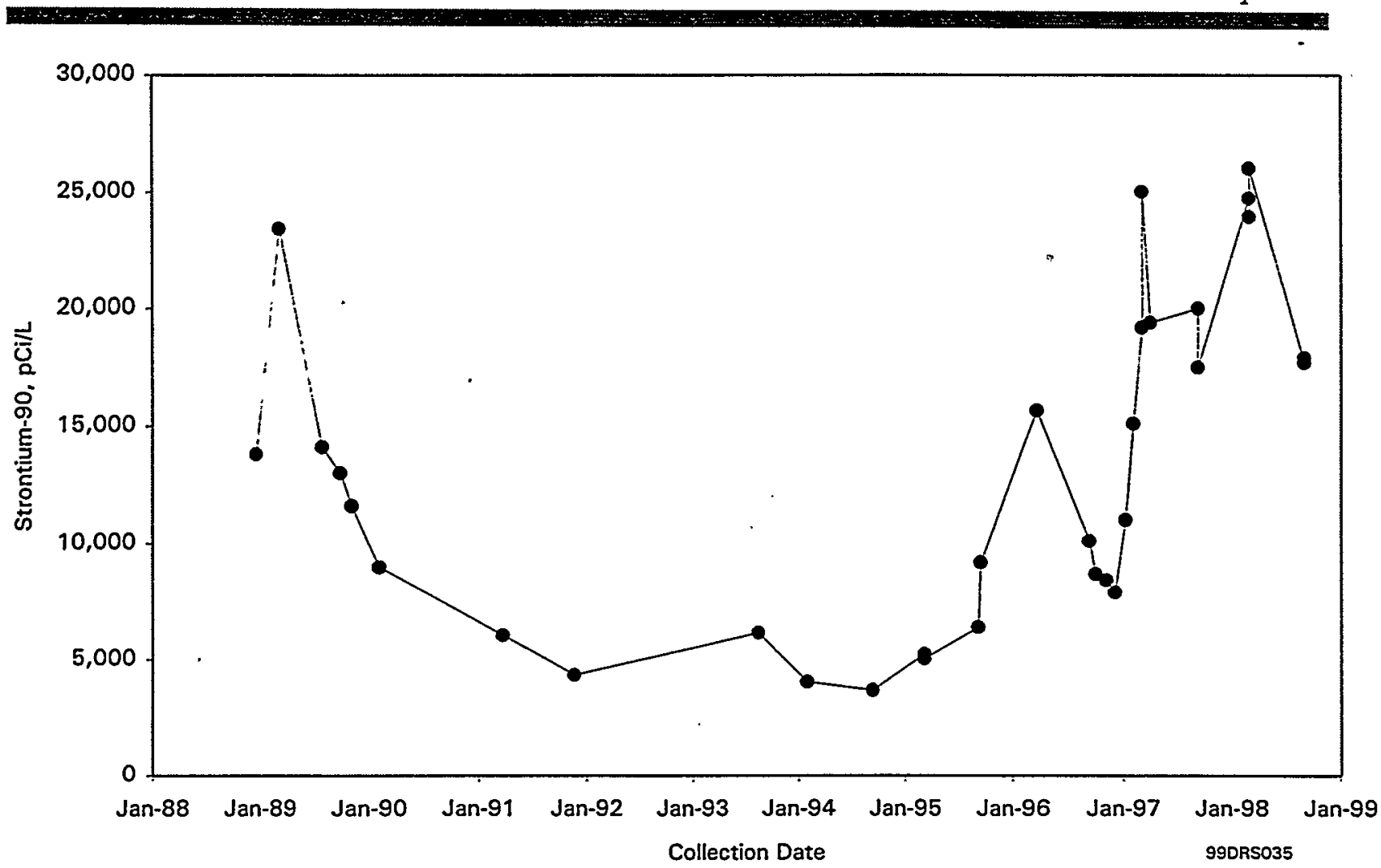

Figure 5.5-4. Strontium-90 Activity in Well 199-N-67 Monitoring 1301-N Liquid Waste-Disposal Facility

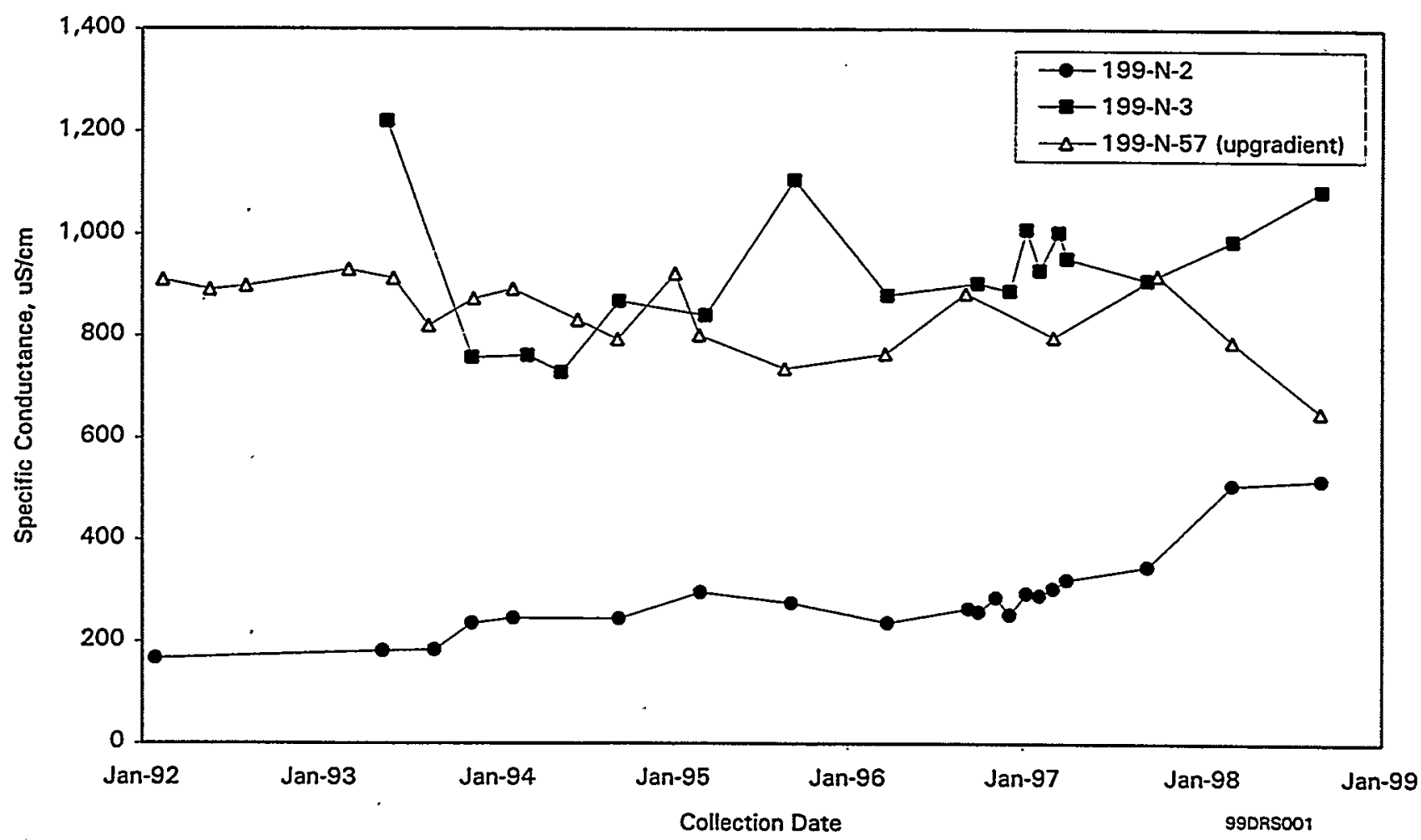

Figure 5.5-5. Specific Conductance in Wells Monitoring 1301-N Liquid Waste-Disposal Facility 


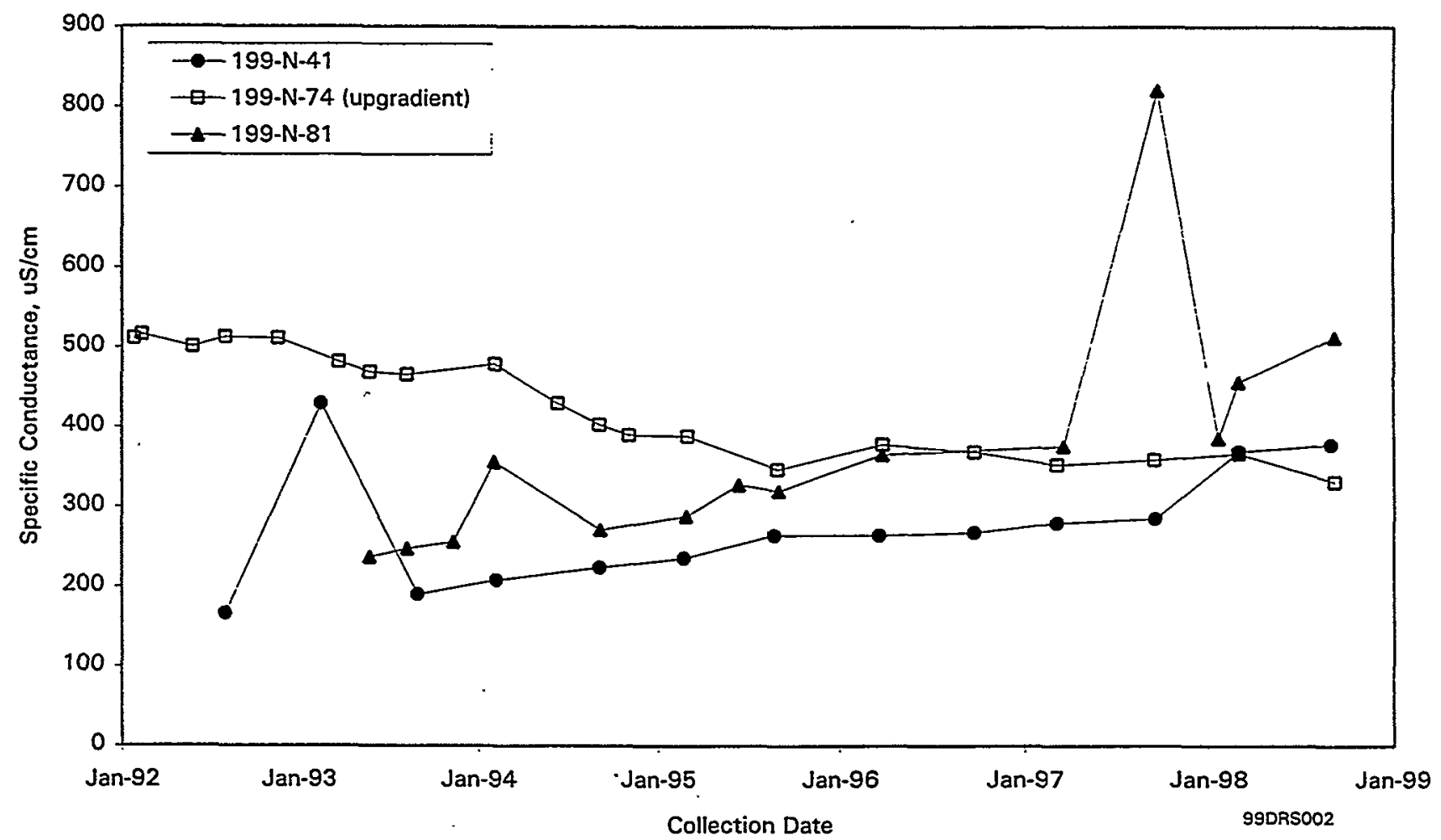

Figure 5.5-6. Specific Conductance in Wells Monitoring 1325-N Liquid Waste-Disposal Facility 


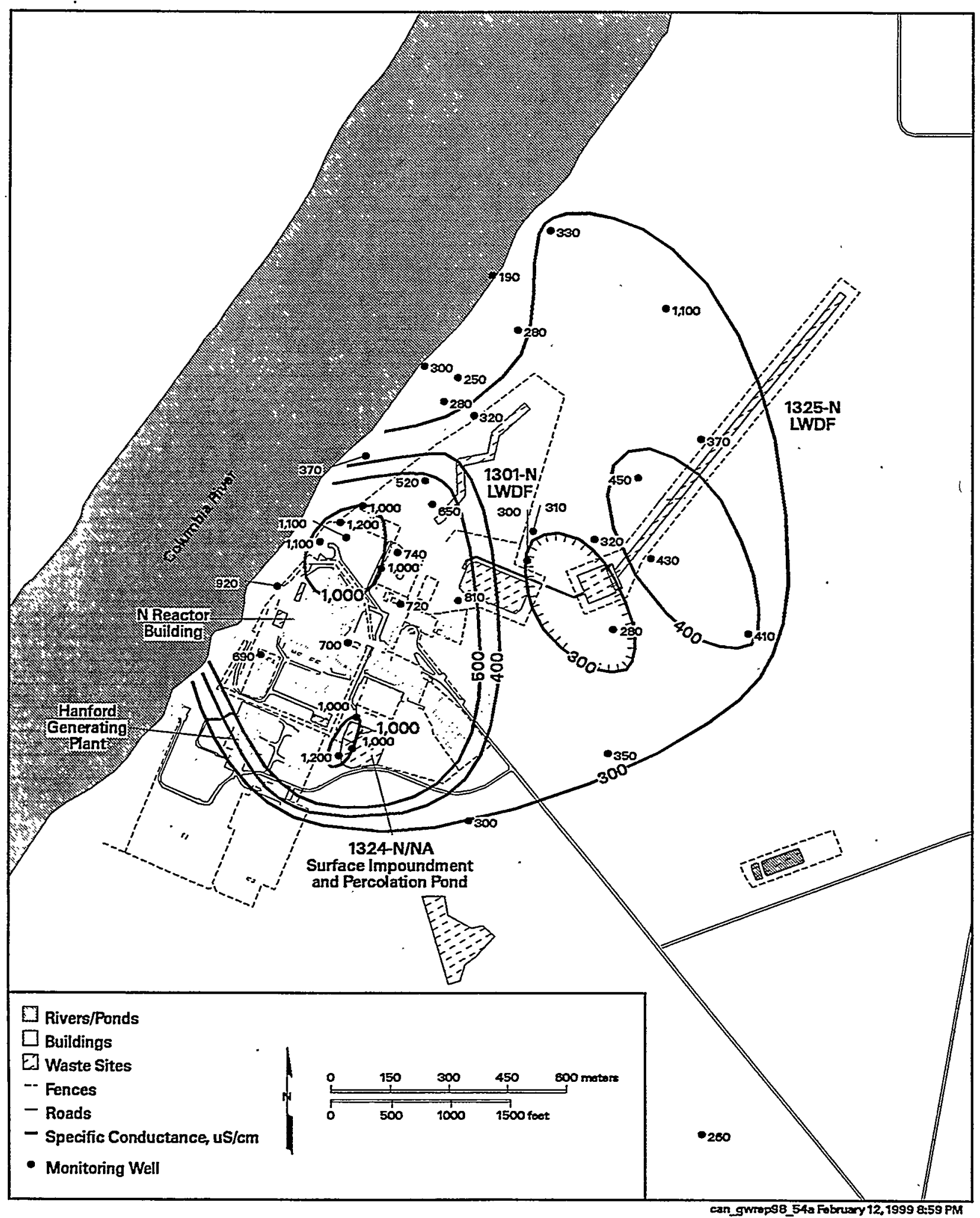

Figure 5.5-7. Specific Conductance in 100-N Area, Top of Unconfined Aquifer 


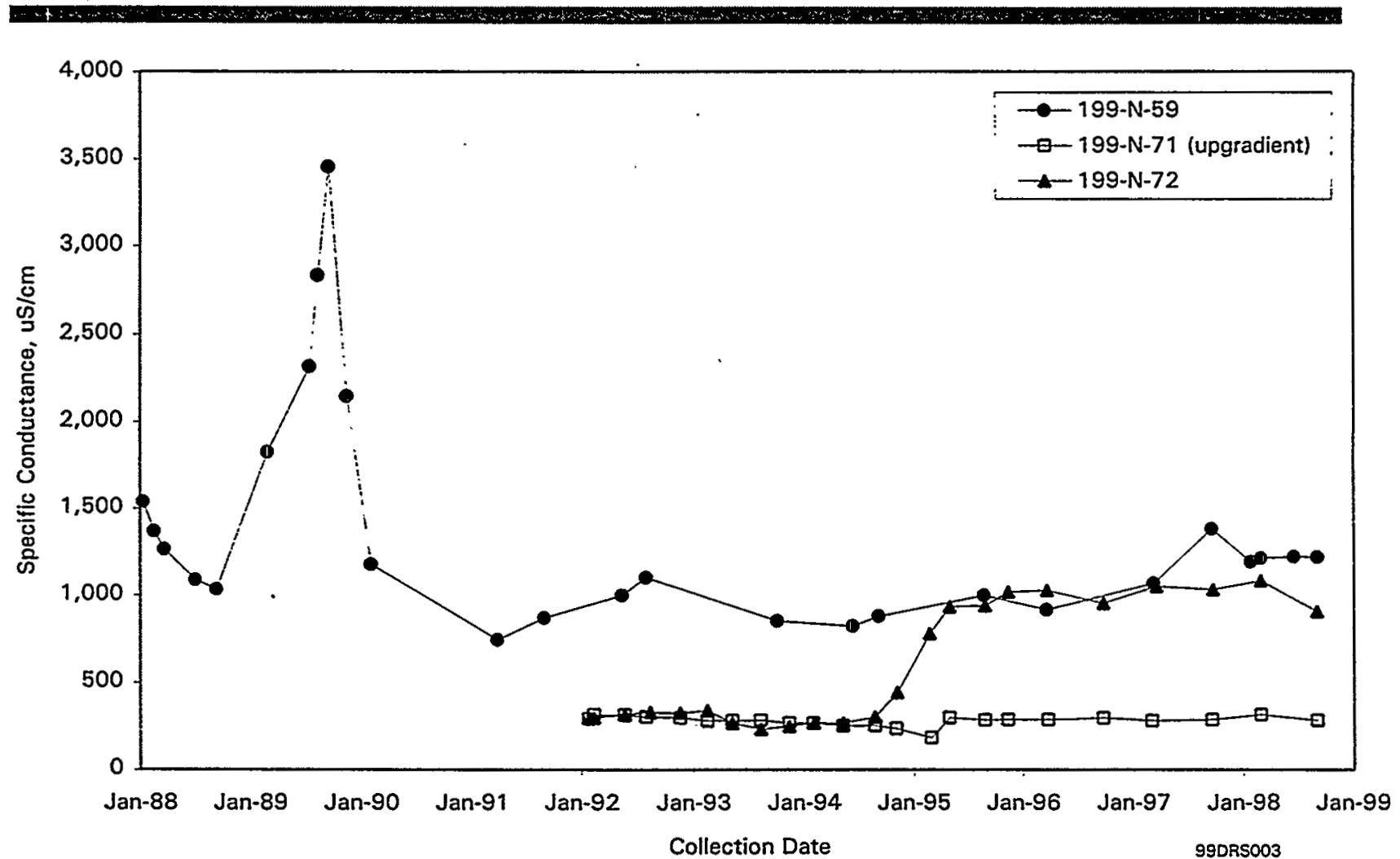

Figure 5.5-8. Specific Conductance in Wells Monitoring 1324-N/NA Facilities

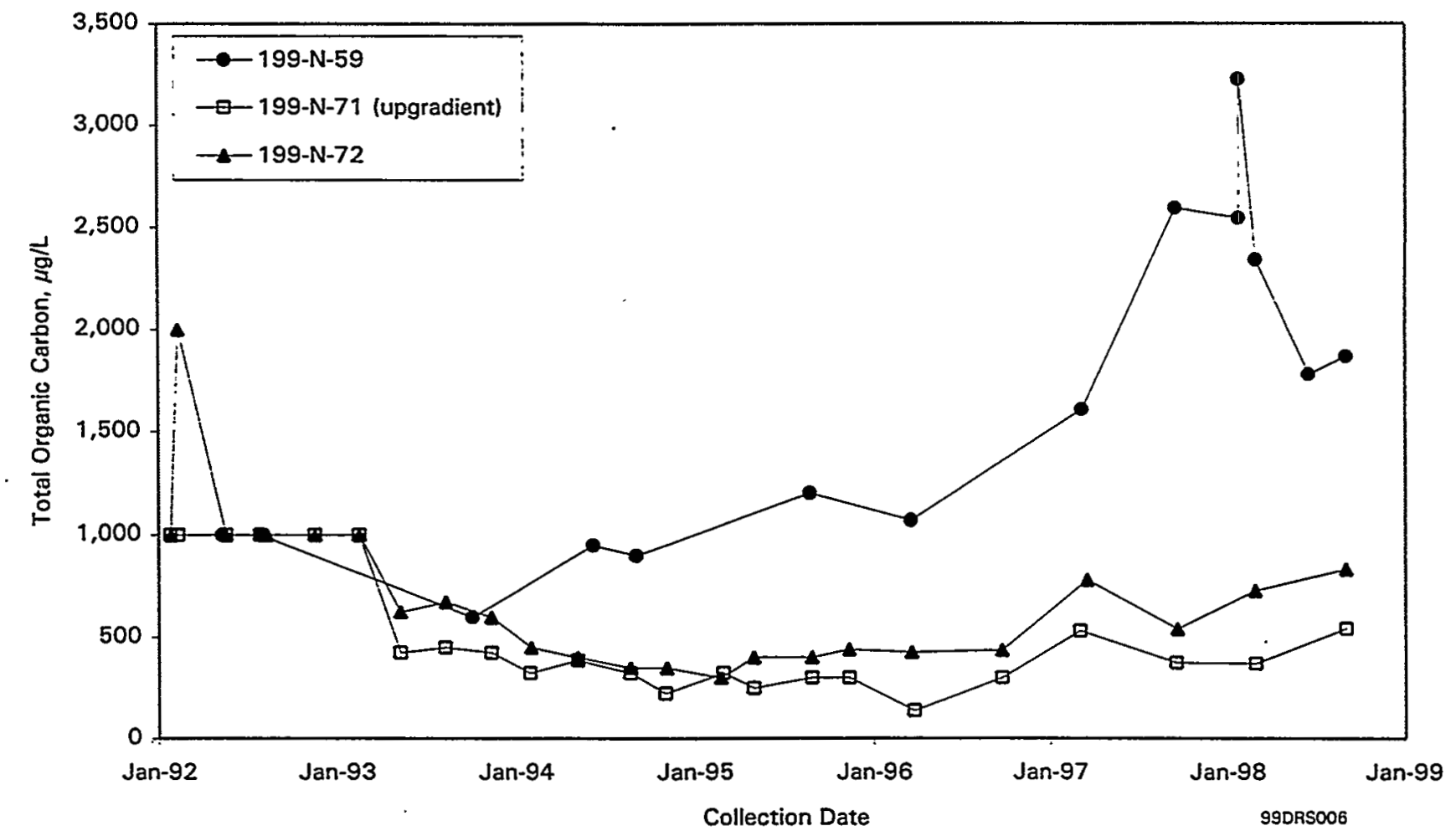

Figure 5.5-9. Total Organic Carbon in Wells Monitoring 1324-N/NA Facilities 


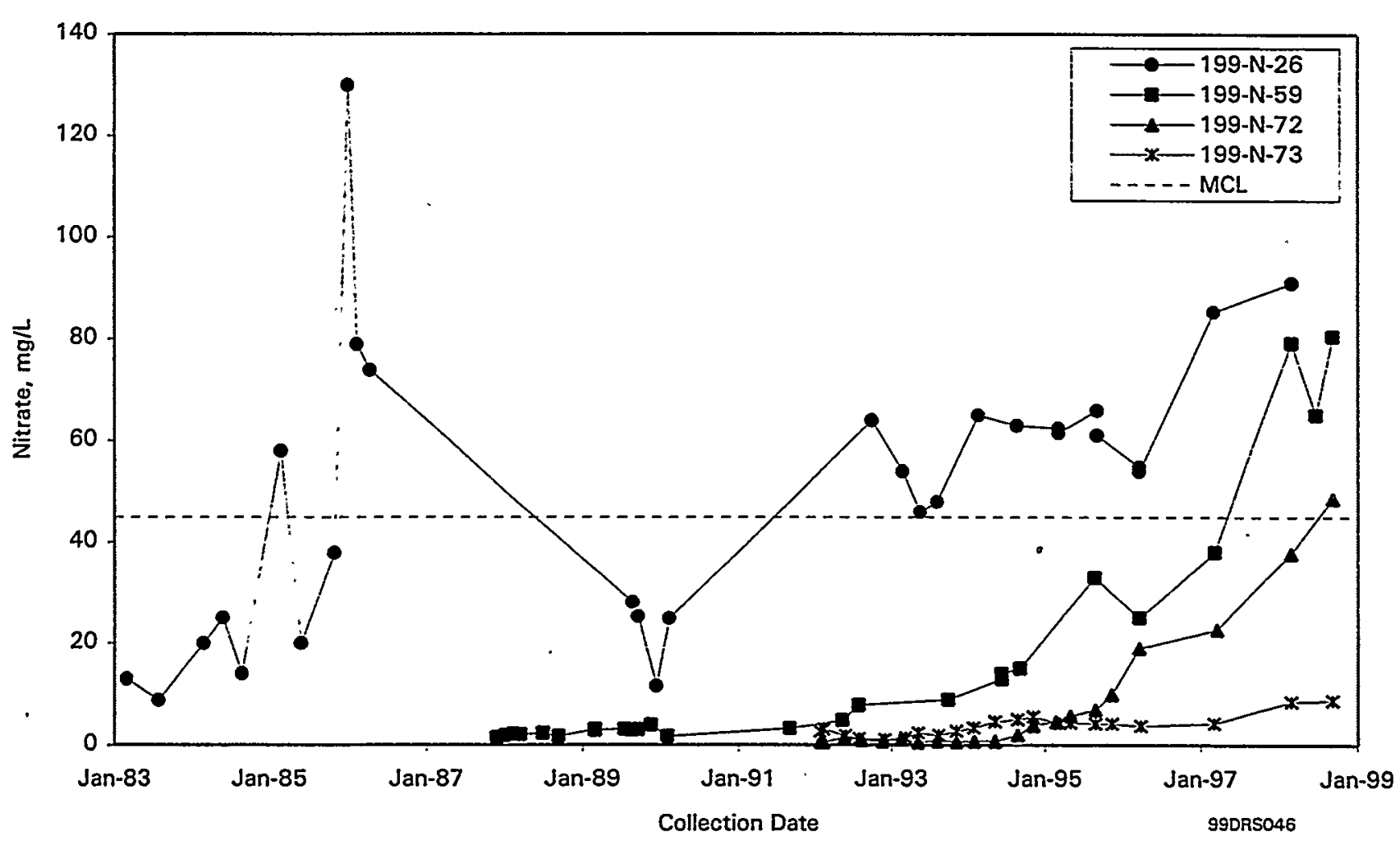

Figure 5.5-10. Nitrate Concentrations in Wells Monitoring 100-N Area

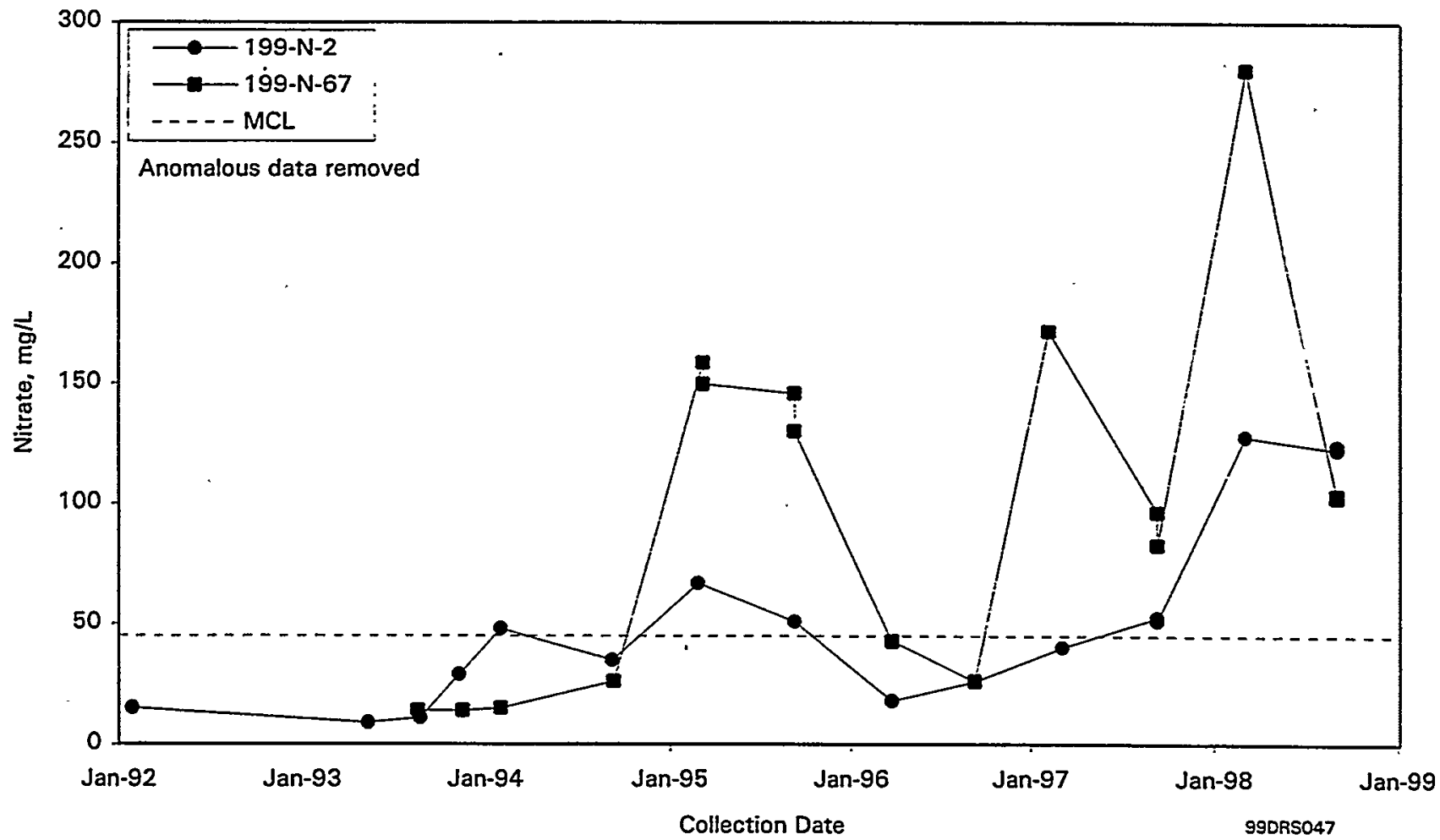

Figure 5.5-11. Nitrate Concentrations in Wells Near 1301-N Facility 


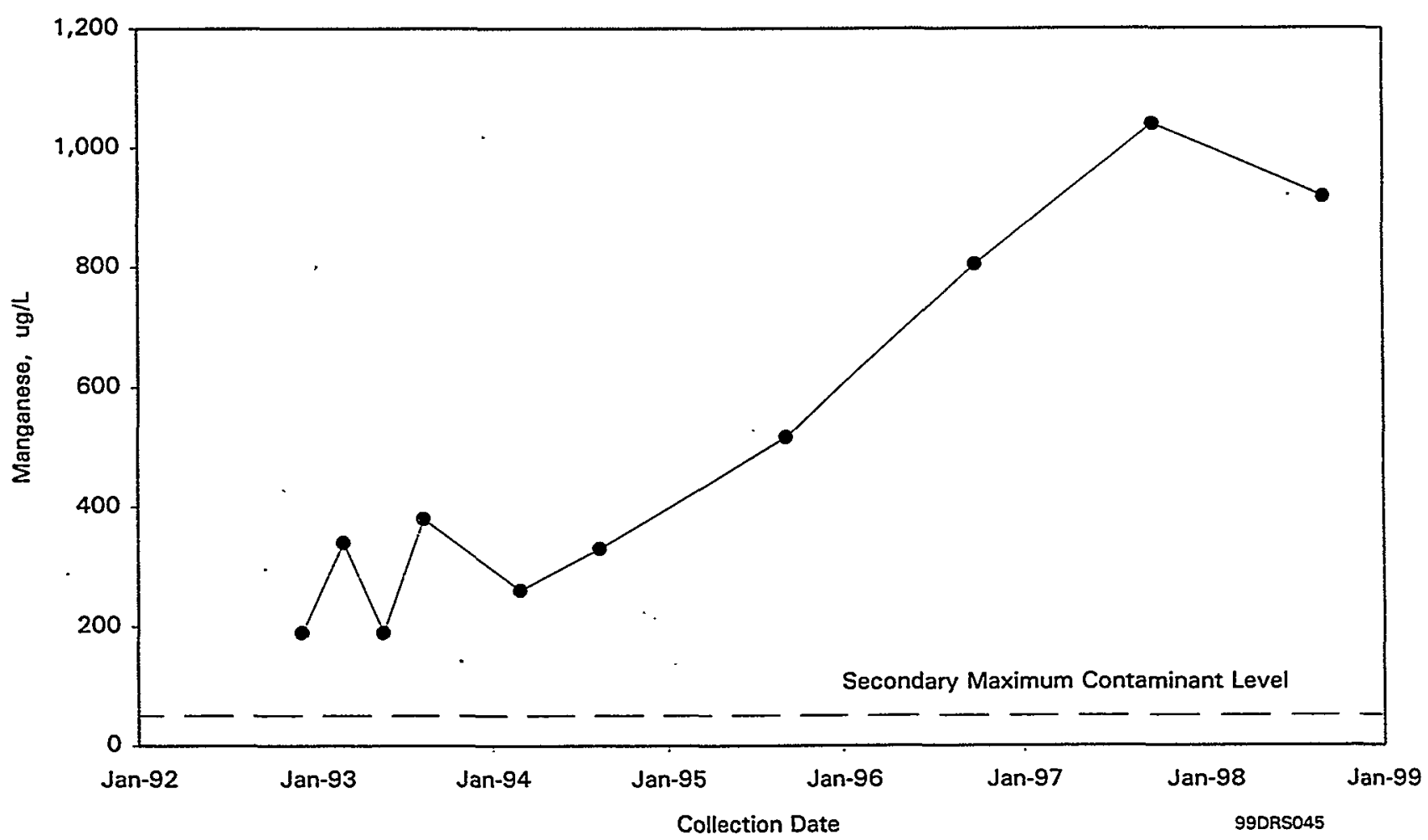

Figure 5.5-12. Manganese Concentrations in Well 199-N-16 


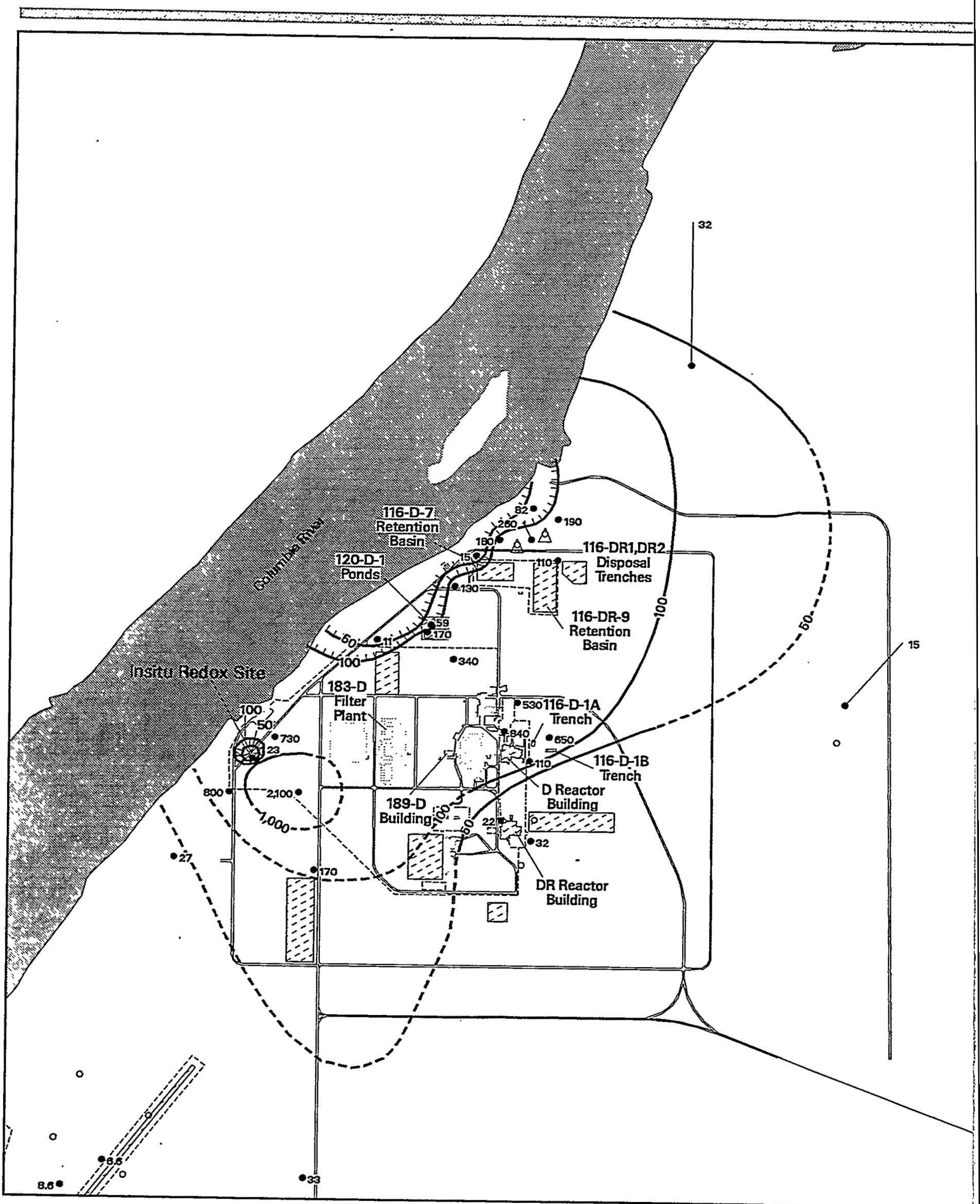

Figure 5.6-1. Average Filtered Chromium Concentration 


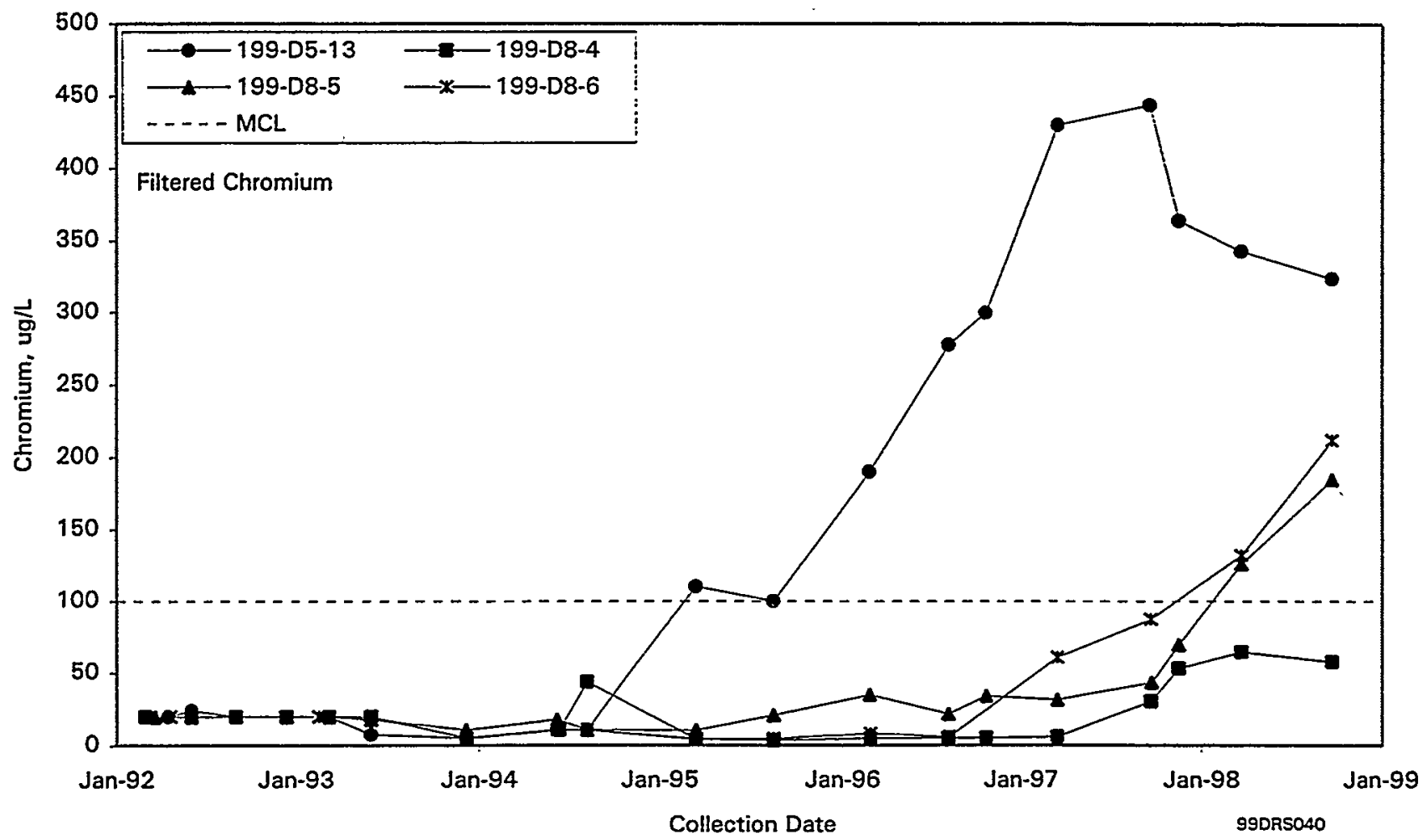

Figure 5.6-2. Chromium Concentrations in Wells Monitoring 120-D-1 Ponds

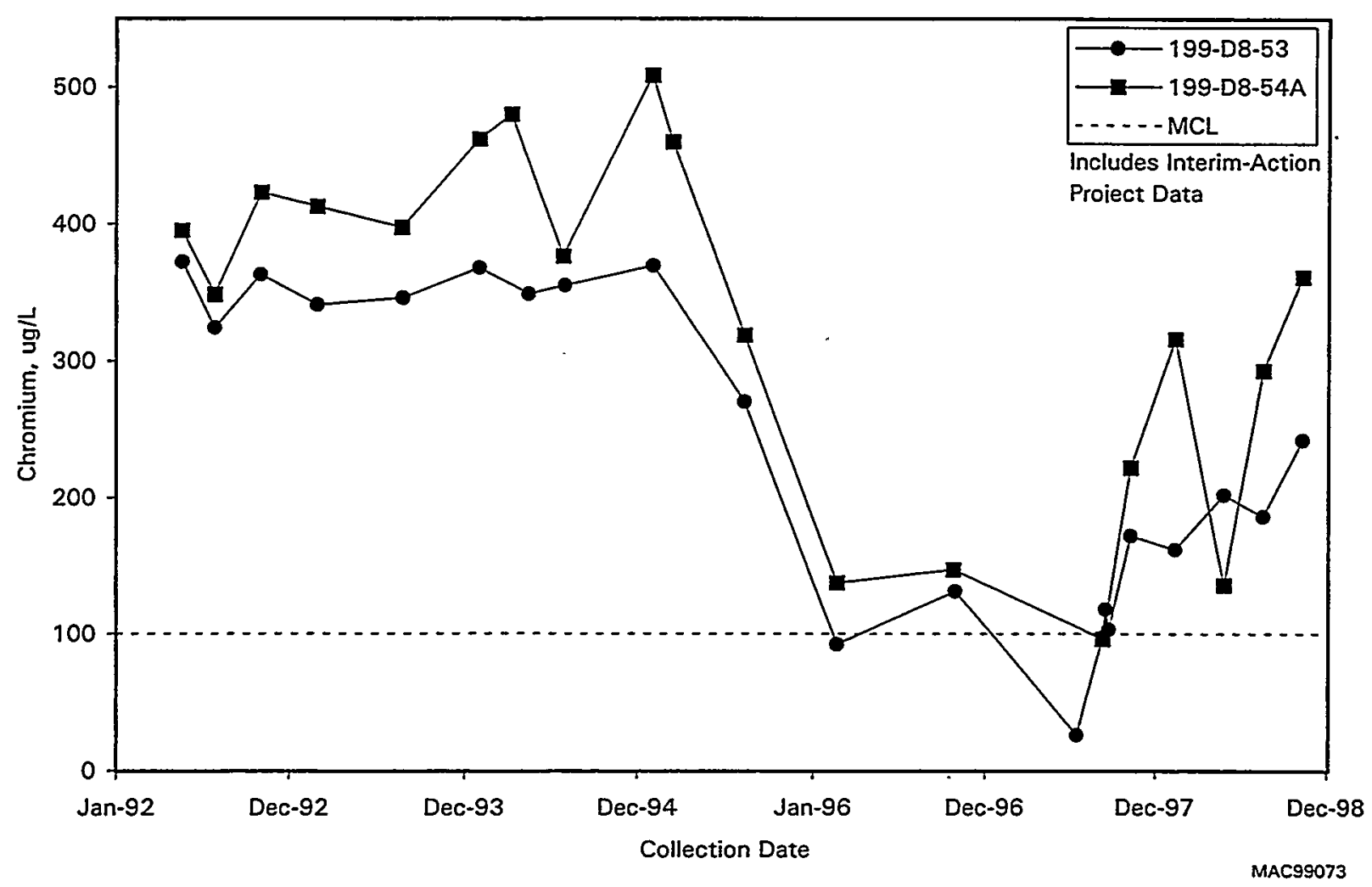

Figure 5.6-3. Chromium Concentrations in Extraction Wells 199-D8-53 and 199-D8-54A 


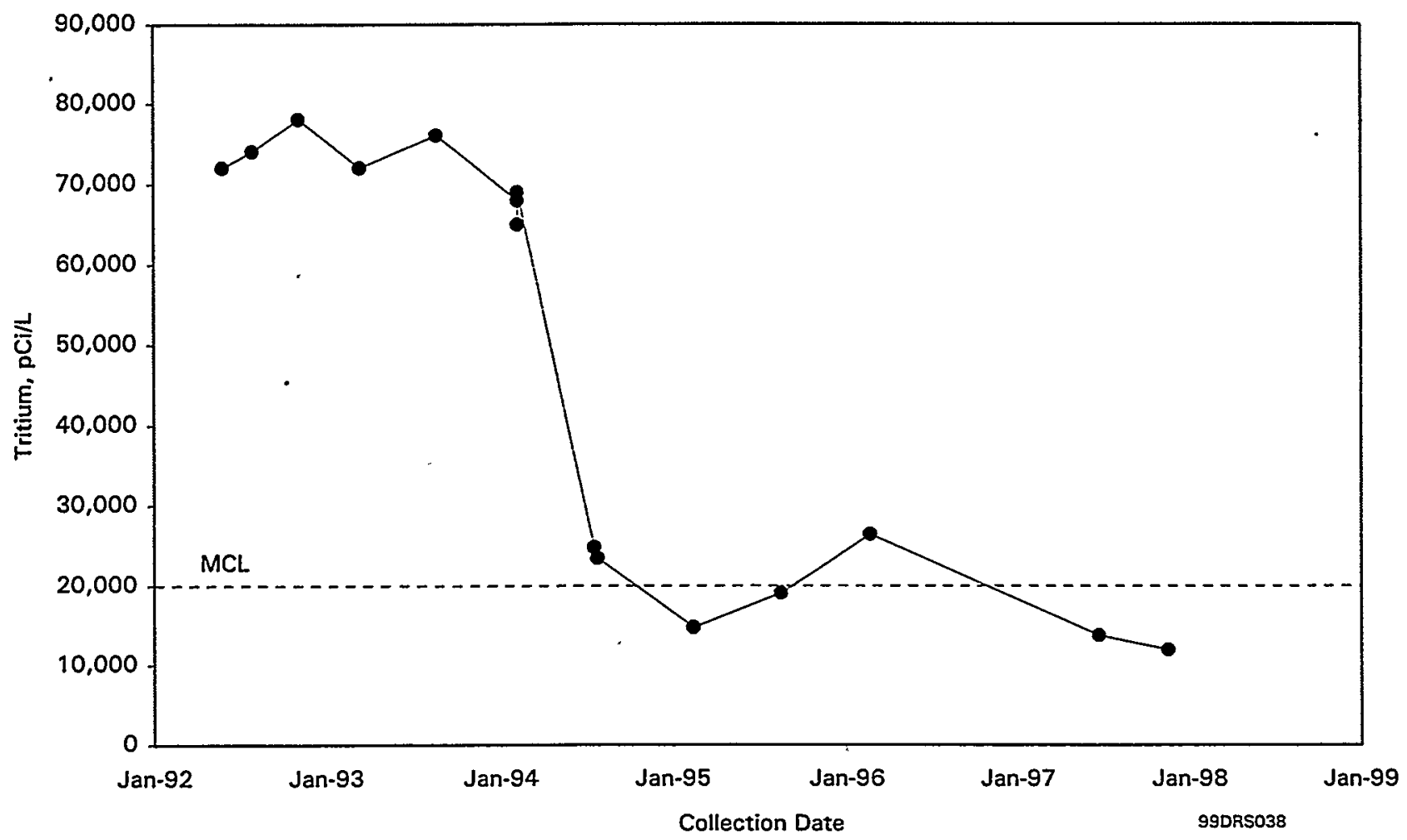

Figure 5.6-4. Tritium Activities in Well 199-D5-17

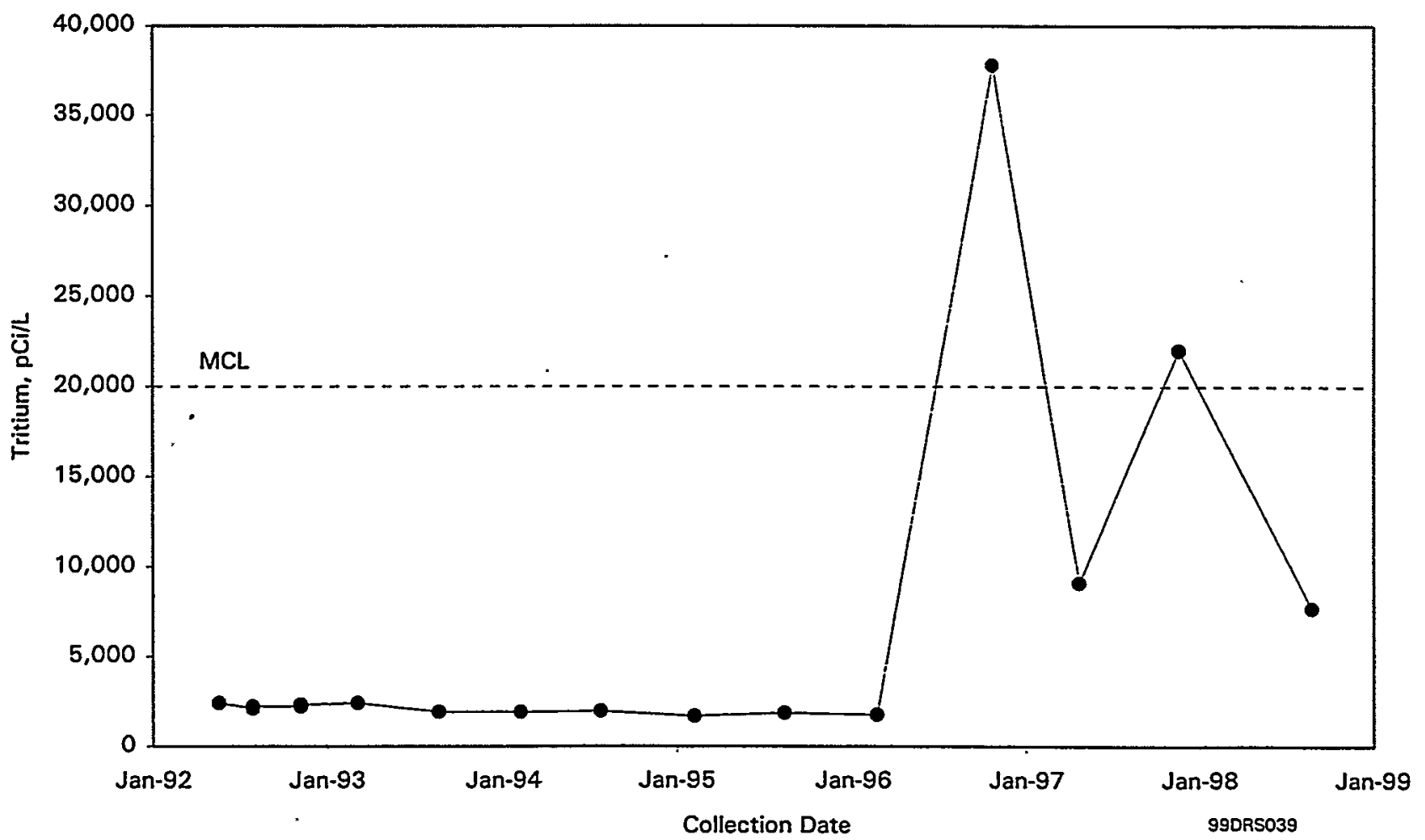

Figure 5.6-5. Tritium Activities in Well 199-D2-6 


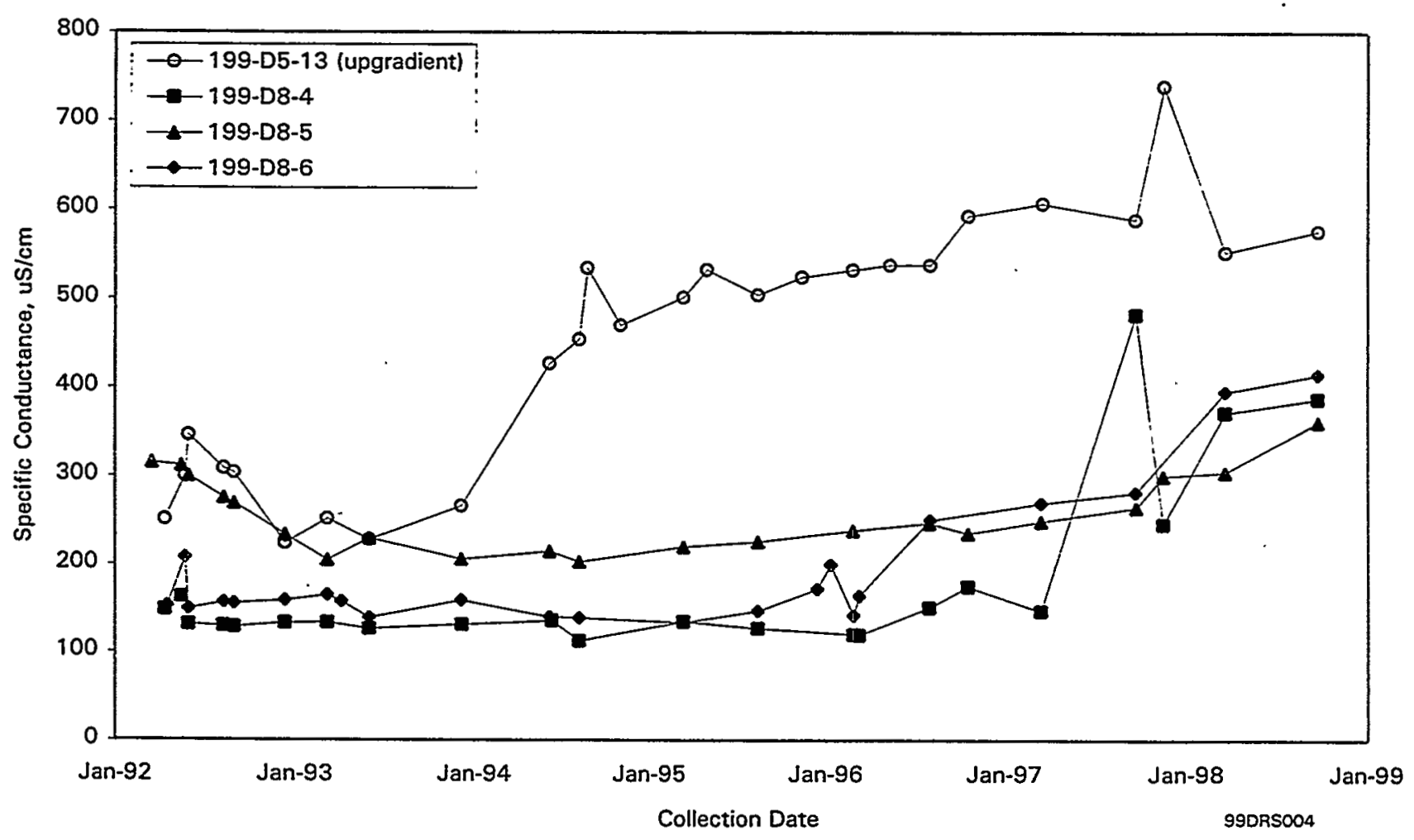

Figure 5.6-6. Specific Conductance in Wells Monitoring 120-D-1 Ponds

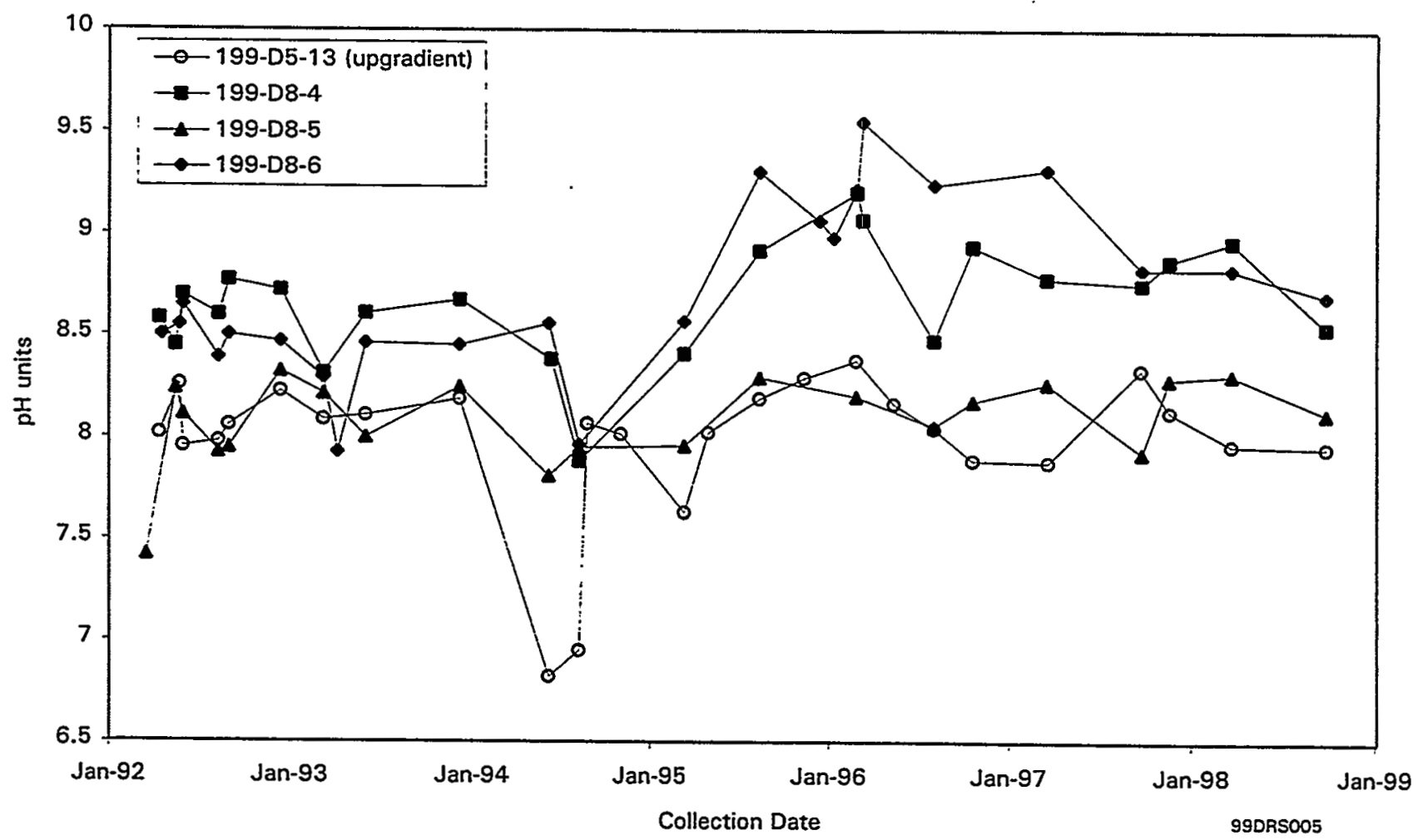

Figure 5.6-7. $\mathrm{pH}$ in Wells Monitoring 120-D-1 Ponds 


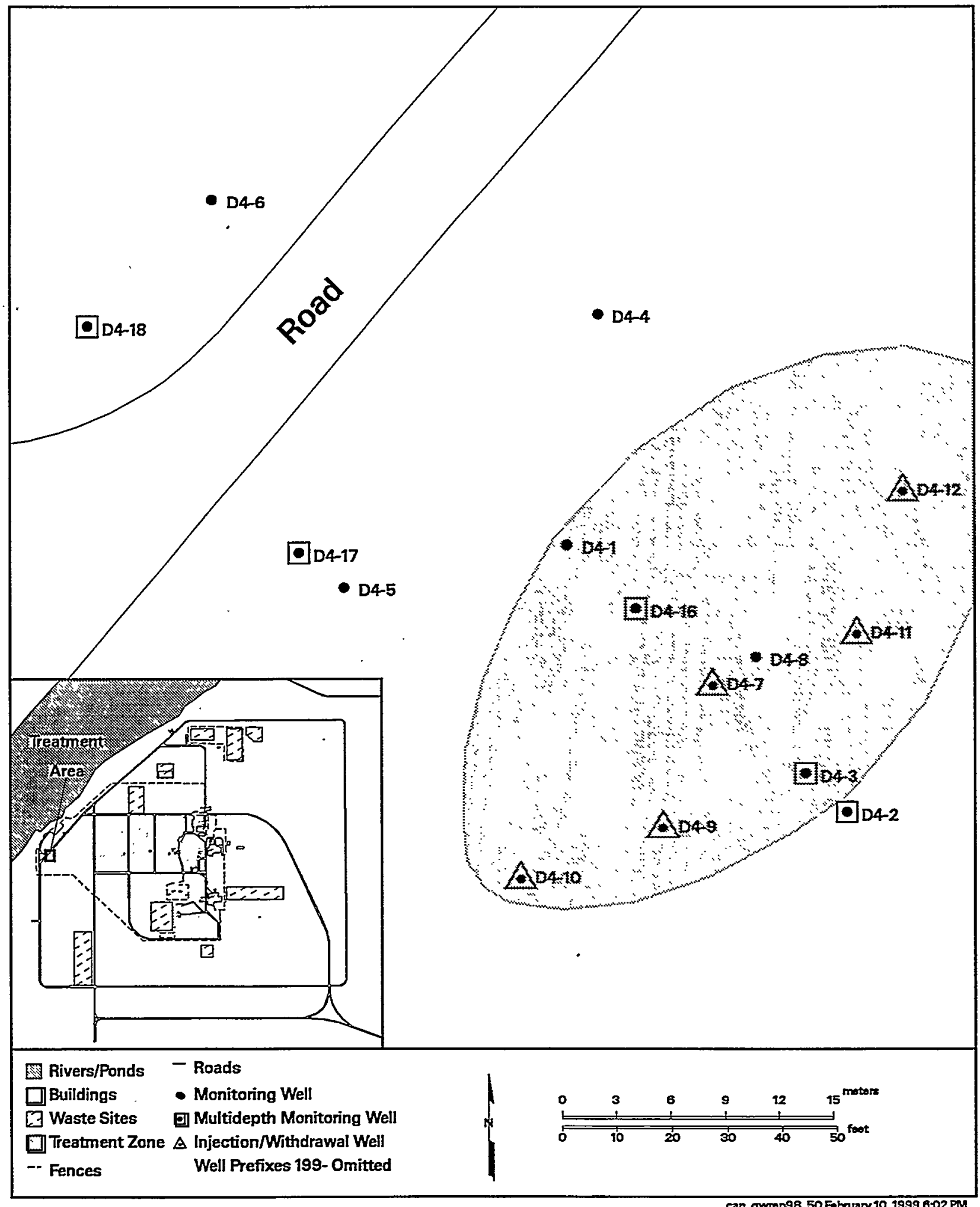

can_gwrop98_50 Fobruary 10, $19996.02 \mathrm{PM}$

Figure 5.6-8. In Situ Redox Manipulation Test Site Well Locations 


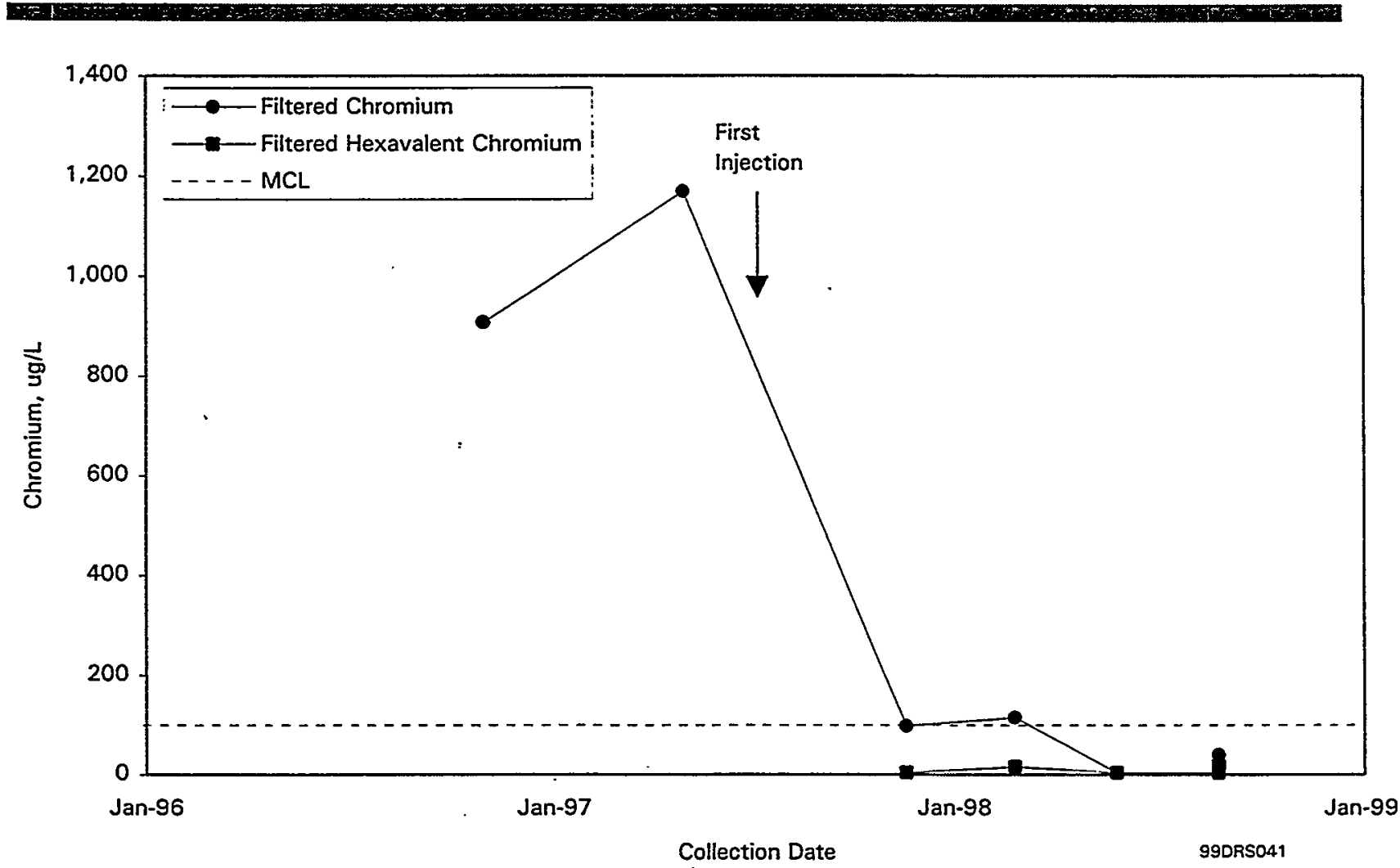

Figure 5.6-9. Chromium Concentrations in Well 199-D4-1 


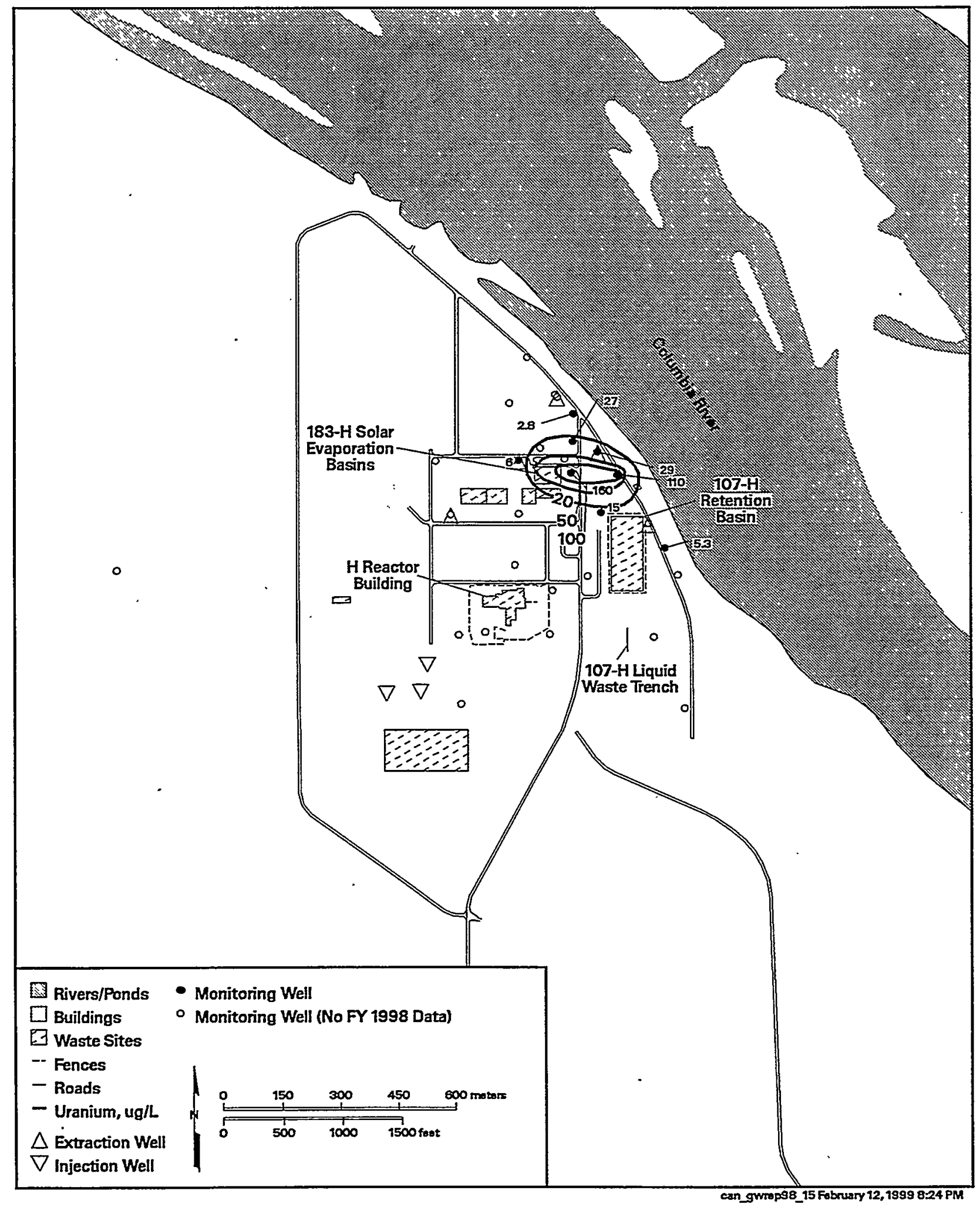

Figure 5.7-1. Average Uranium Concentrations in 100-H Area, Top of Unconfined Aquifer 


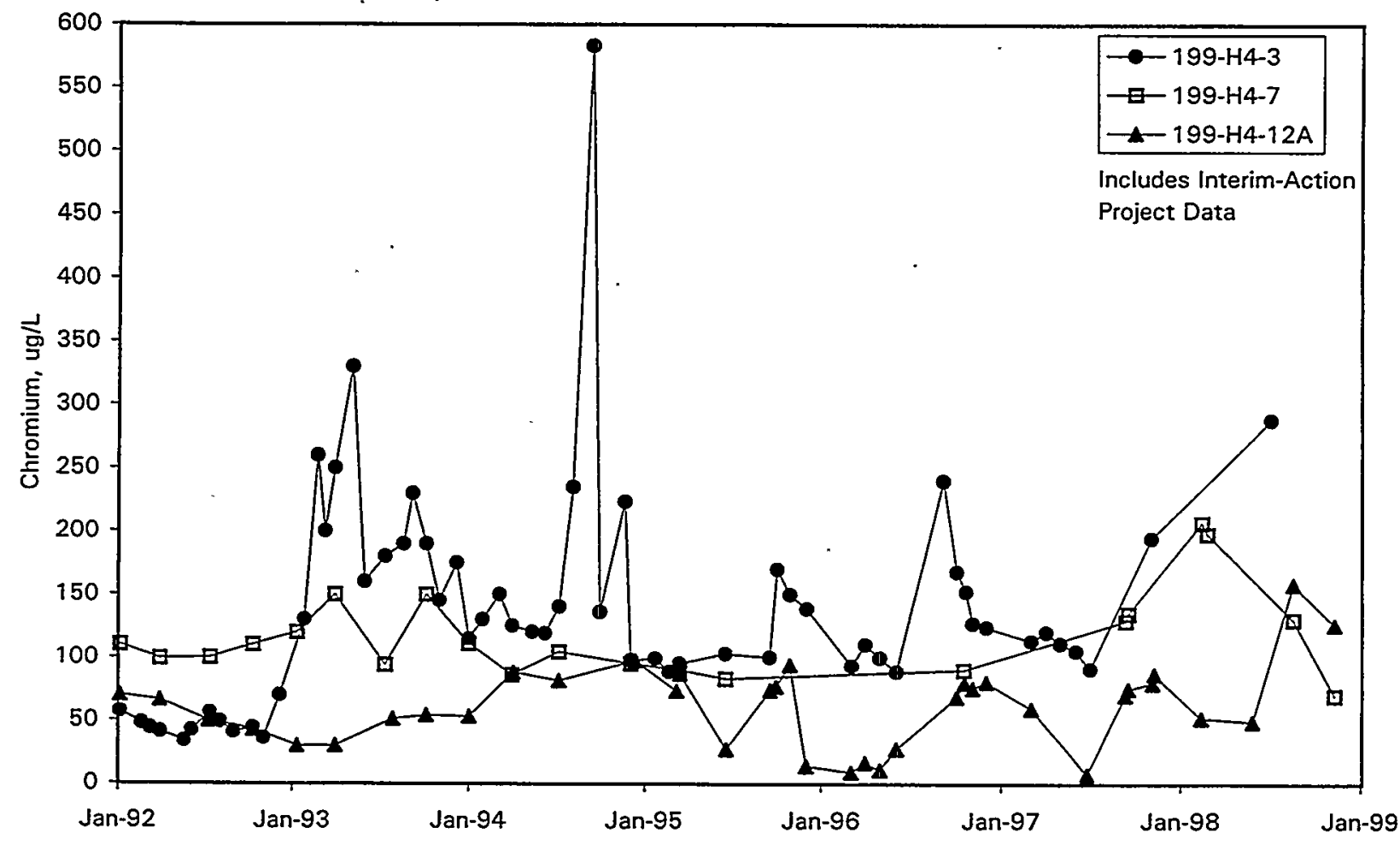

Collection Date

Figure 5.7-2. Filtered Chromium Concentrations in Wells Monitoring 183-H Solar MAC99074 Evaporation Basins

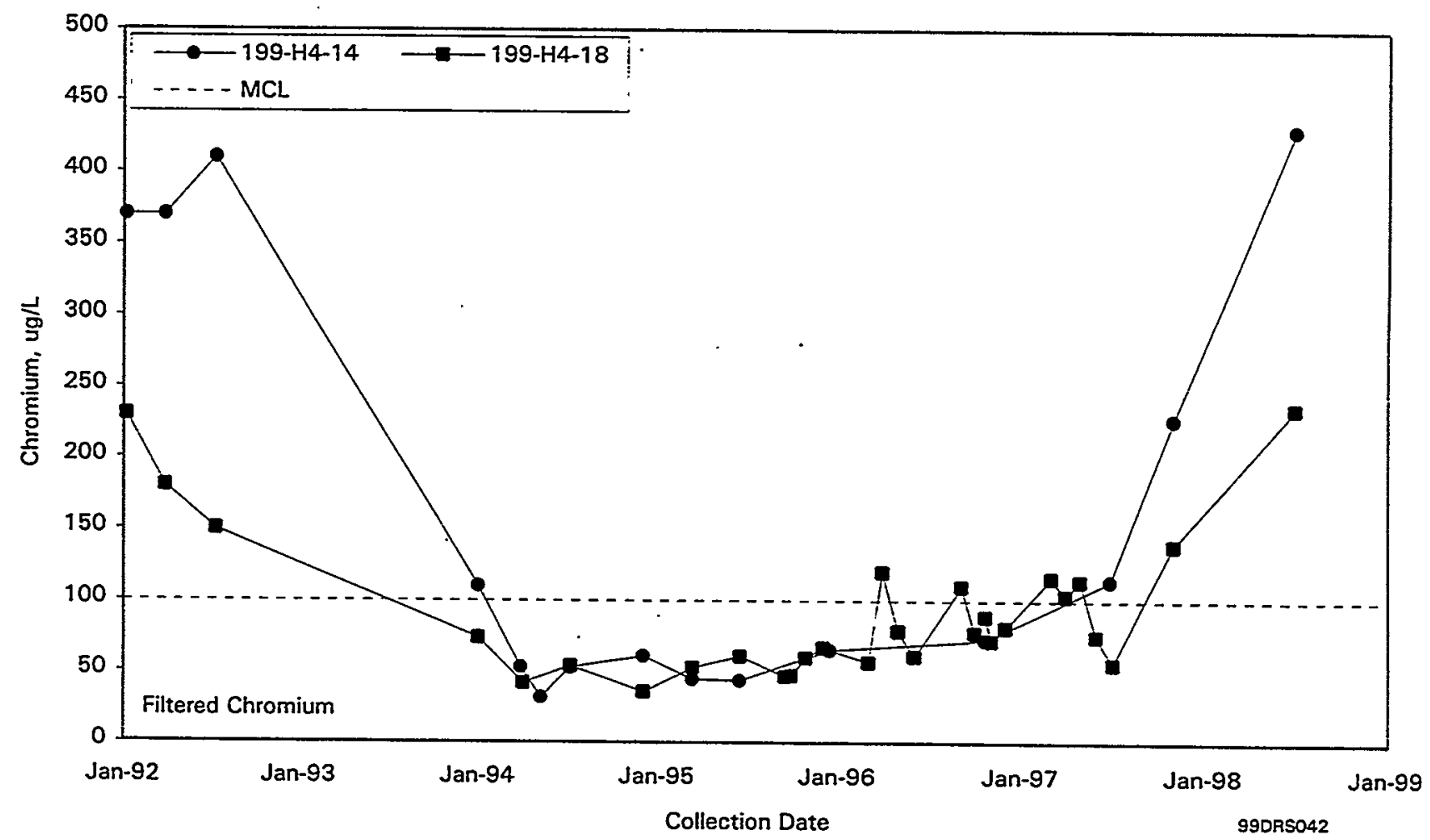

Figure 5.7-3. Chromium Concentrations in Two Wells South of 183-H Solar Evaporation Basins 


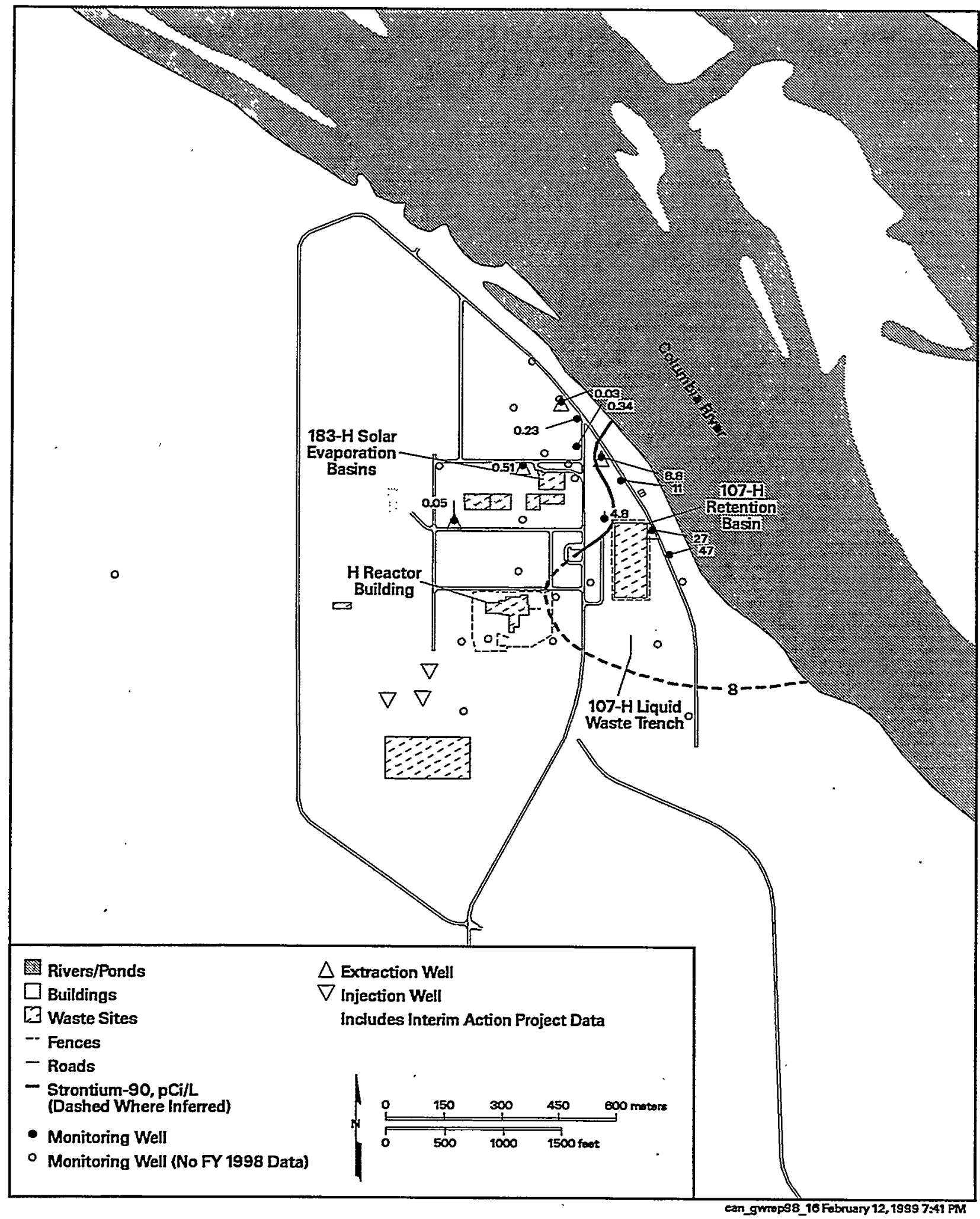

Figure 5.7-4. Average Strontium-90 Activities in 100-H Area, Top of Unconfined Aquifer 


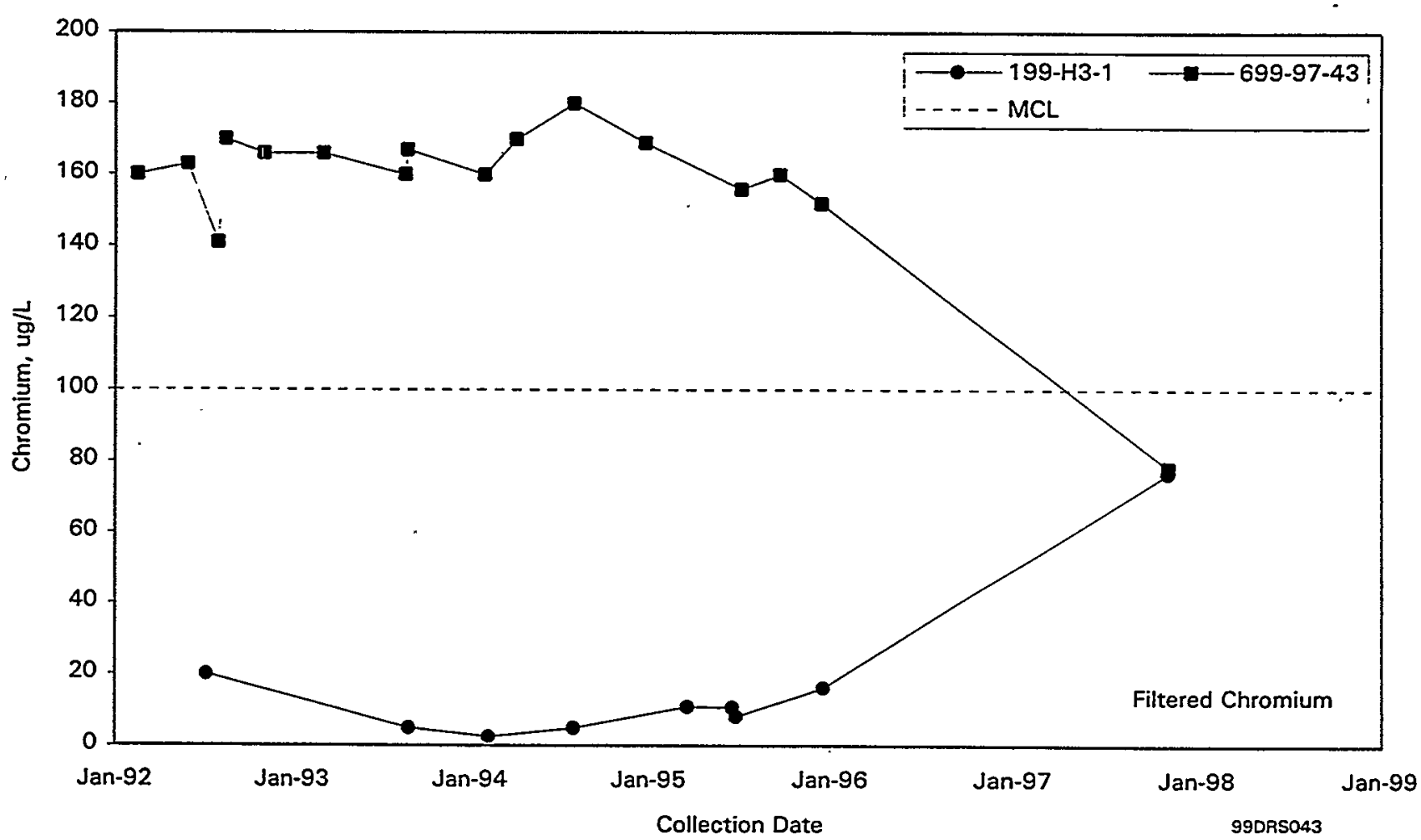

Figure 5.7-5. Chromium Concentrations in Wells 199-H3-1 and 699-97-43

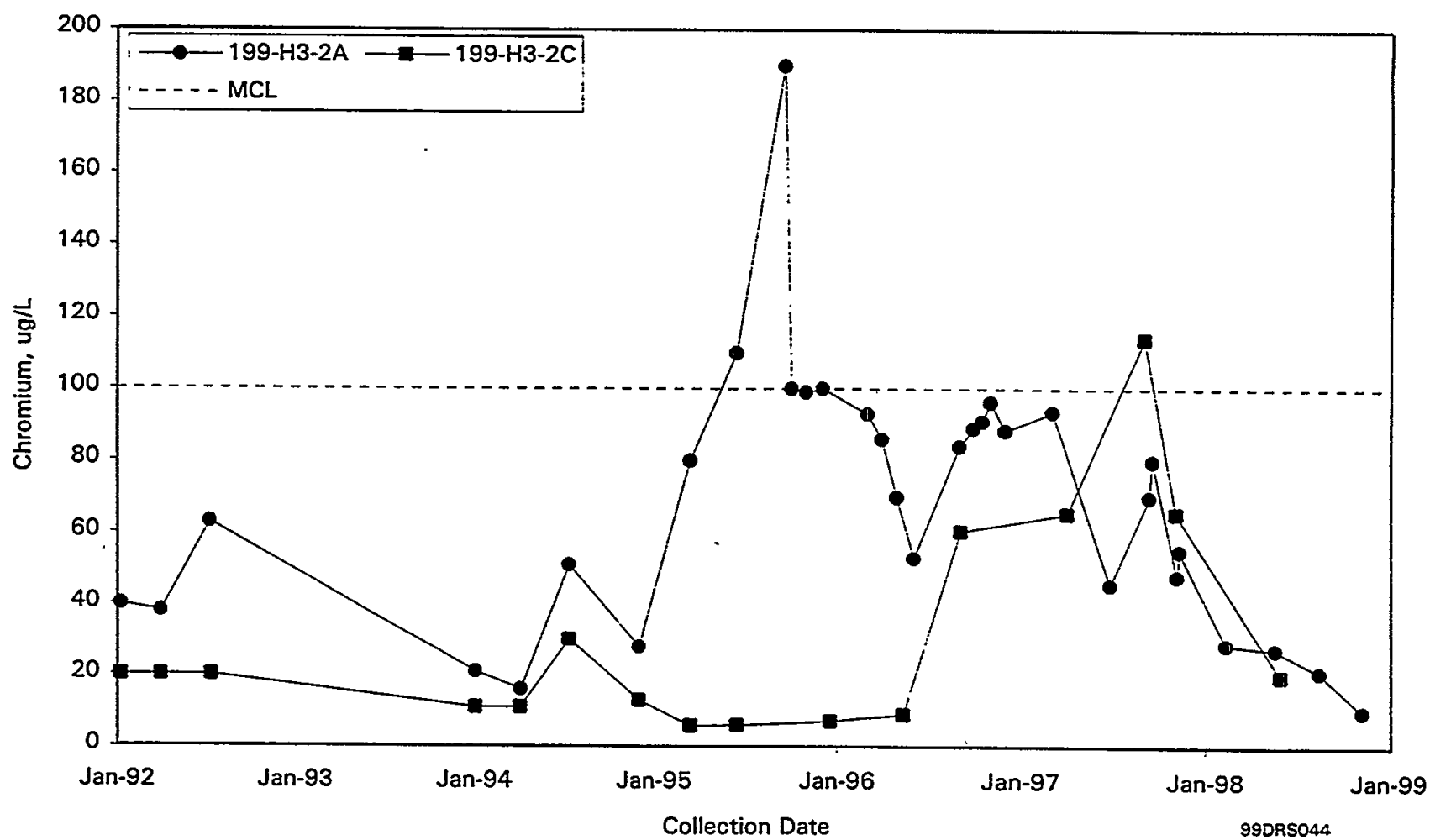

Figure 5.7-6. Chromium Concentrations in Wells 199-H3-2A and 199-H3-2C 


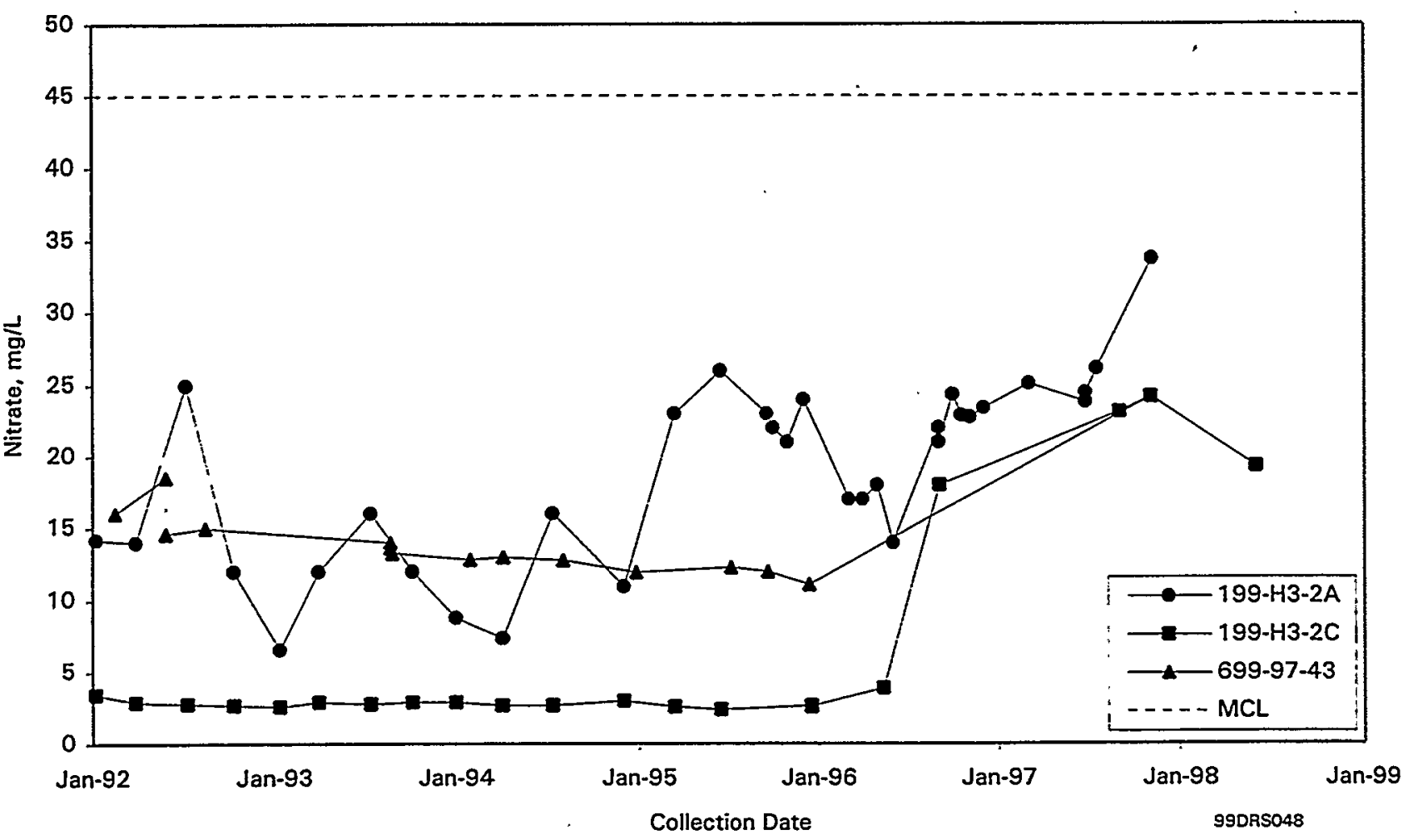

Figure 5.7-7. Nitrate Concentrations in Wells 199-H3-2A, 199-H3-2C, and 699-97-43 


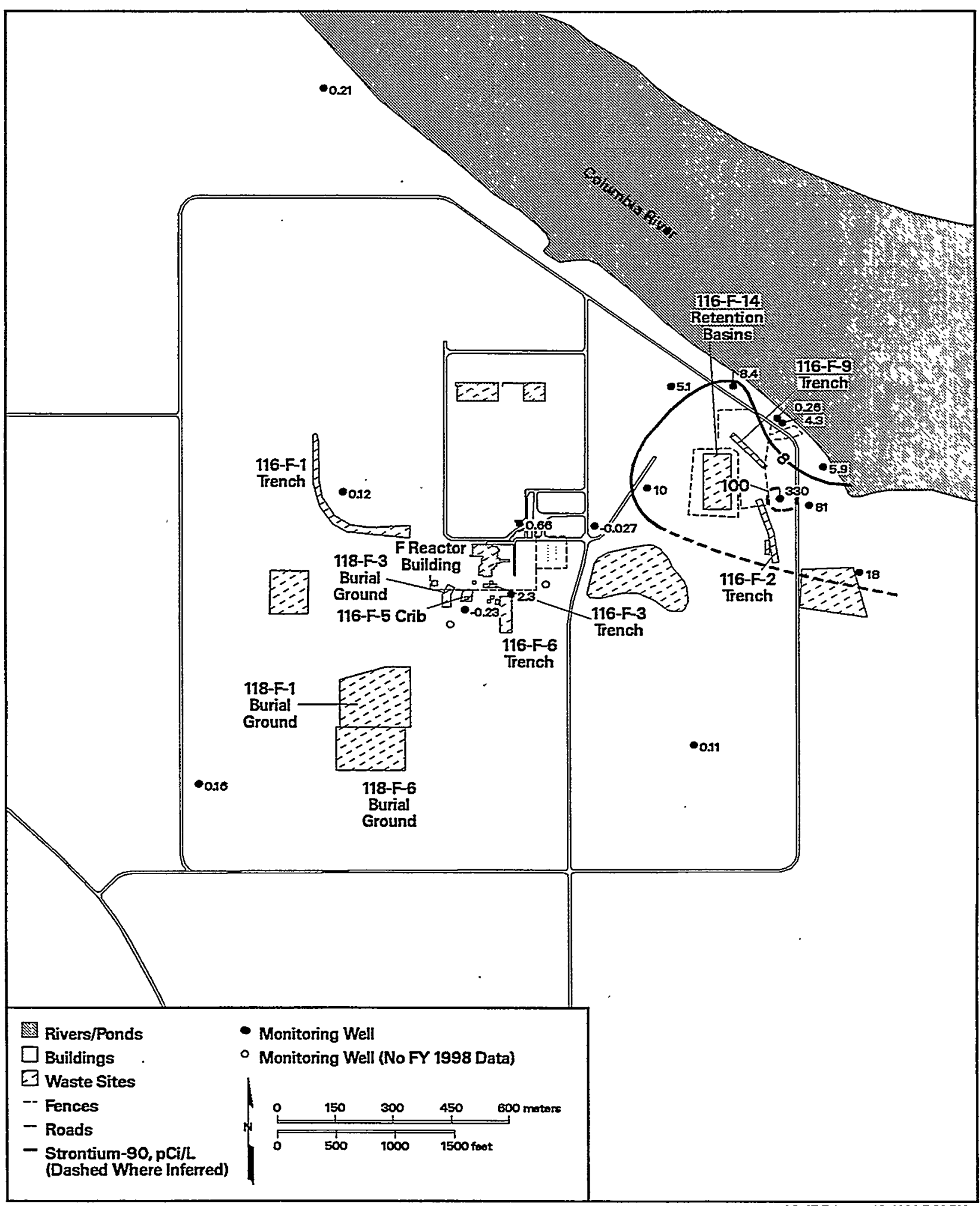

can_gwrop98_17 Fobruary 12, 1999 5æ30 PM

Figure 5.8-1. Average Strontium-90 Activities in 100-F Area, Top of Unconfined Aquifer 


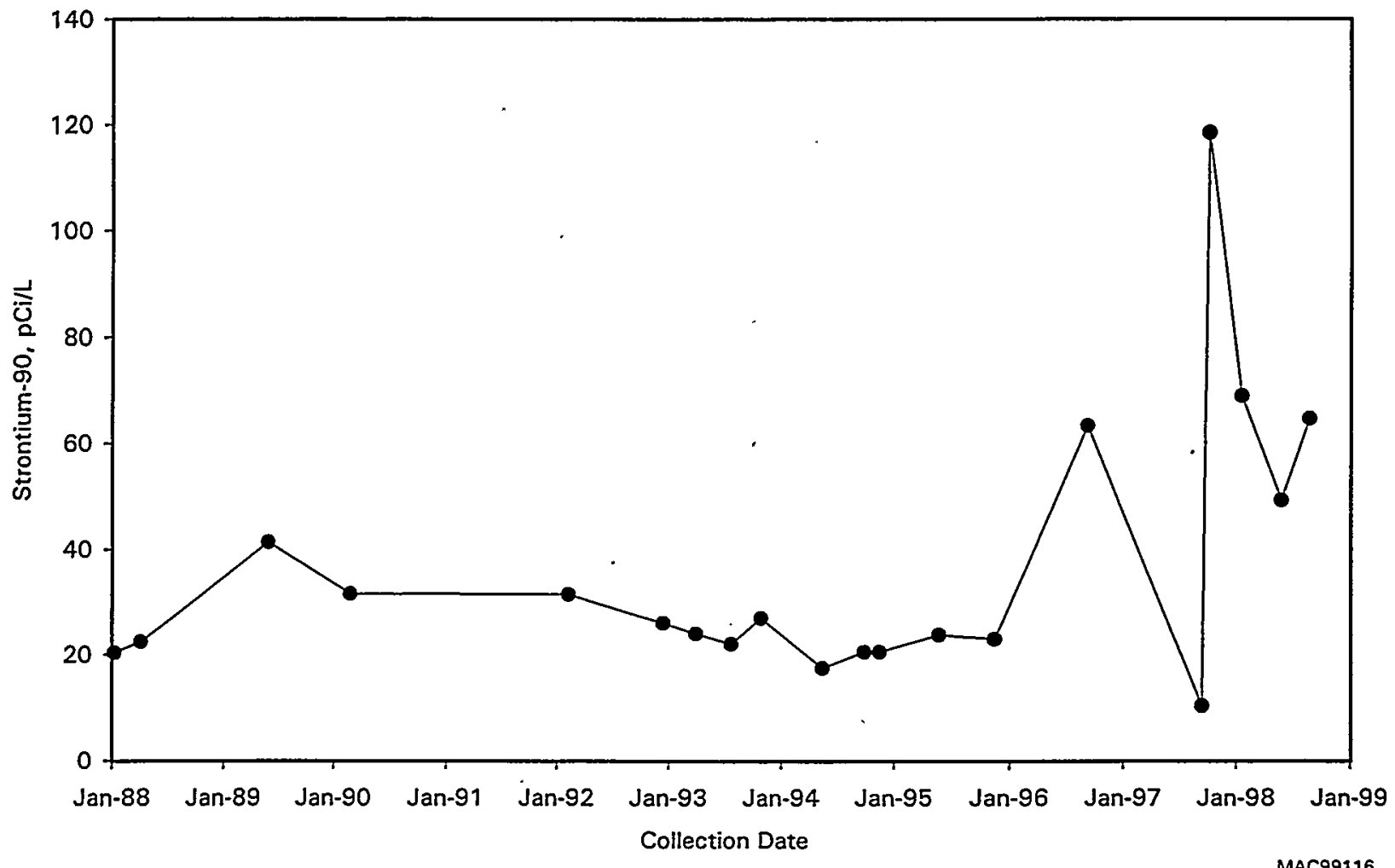

Figure 5.8-2. Strontium-90 Activities in Well 199-F5-1

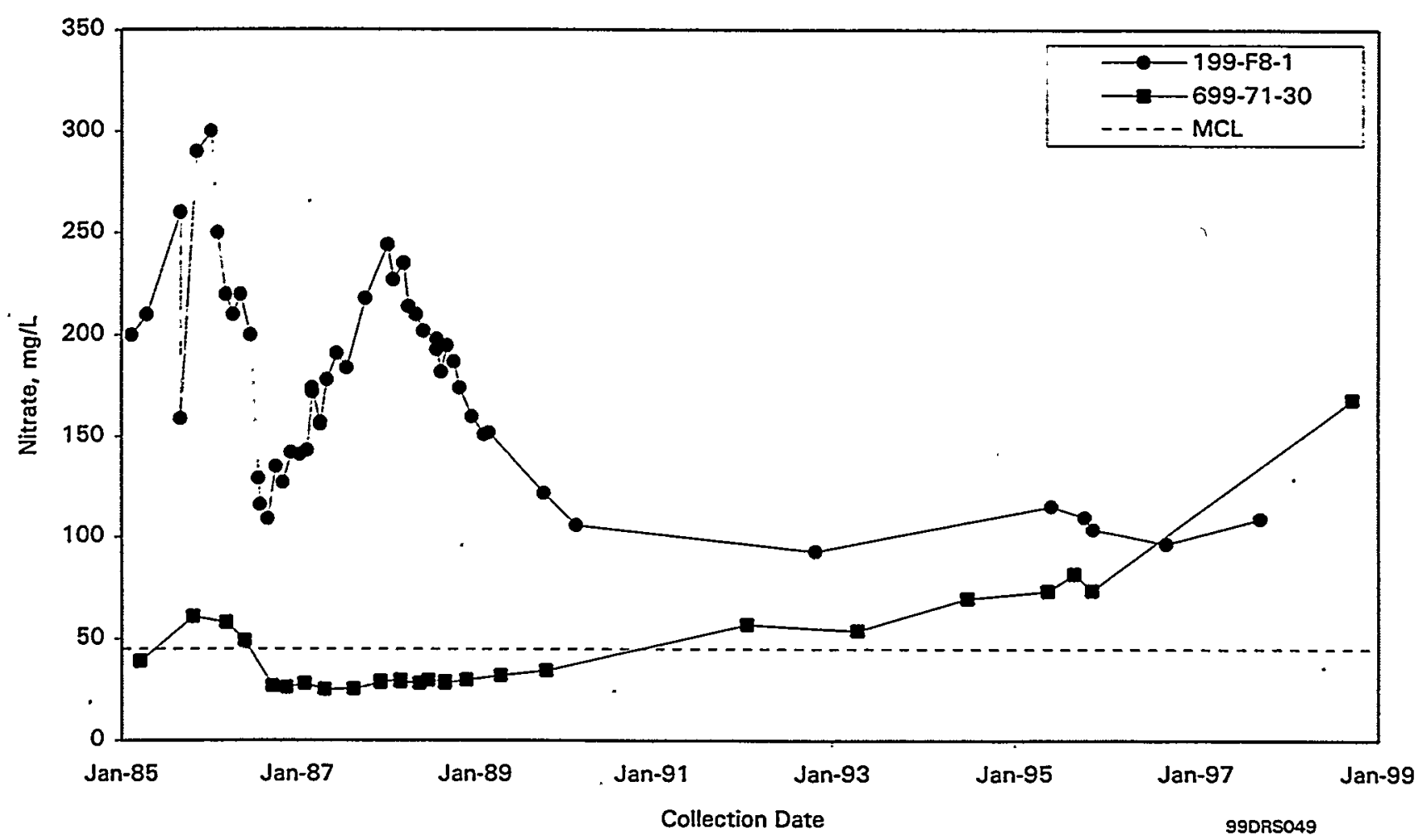

Figure 5.8-3. Nitrate Concentrations in Wells 199-F8-1 and 699-71-30 


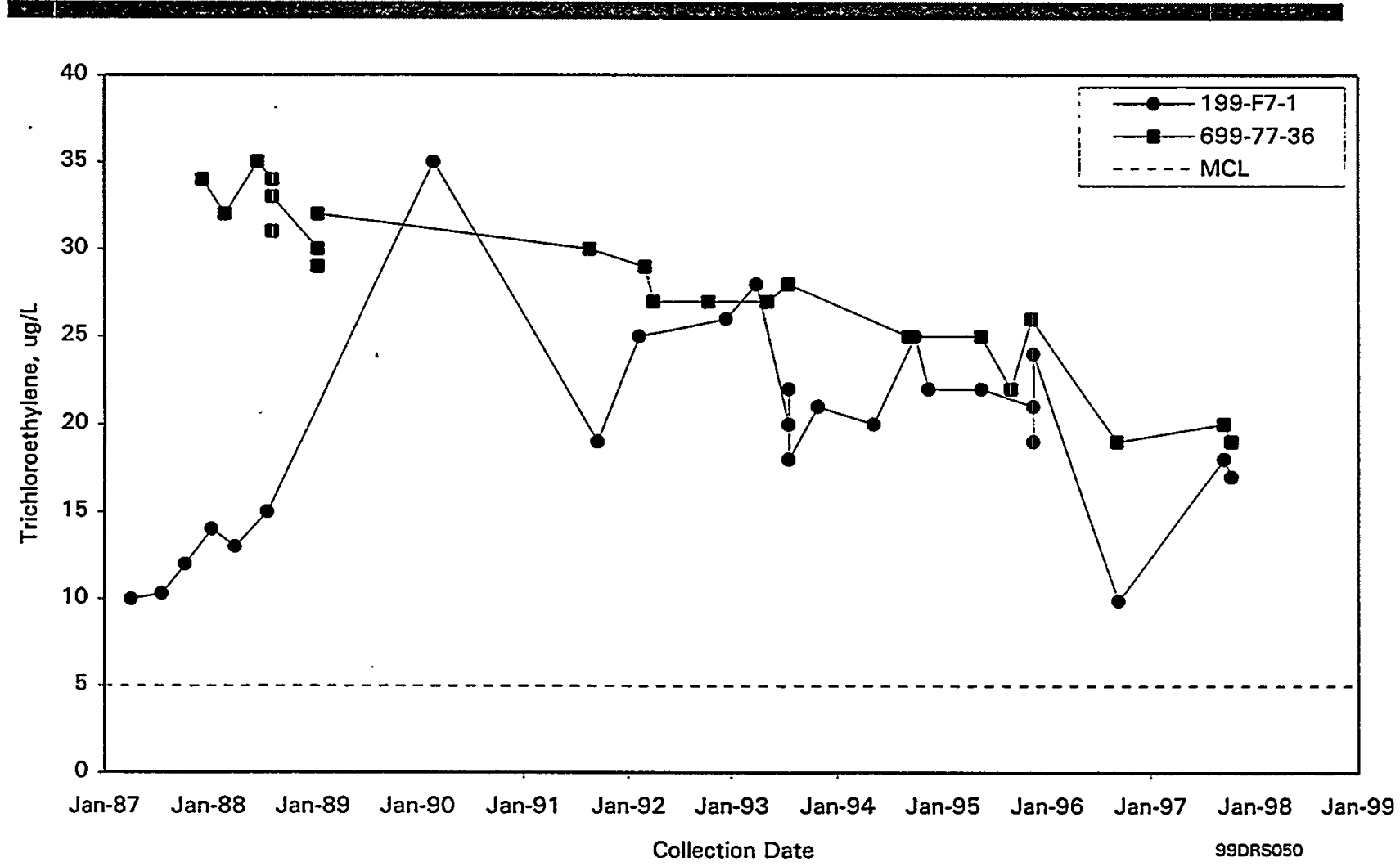

Figure 5.8-4. Trichloroethylene Concentrations in Wells 199-F7-1 and 699-77-36

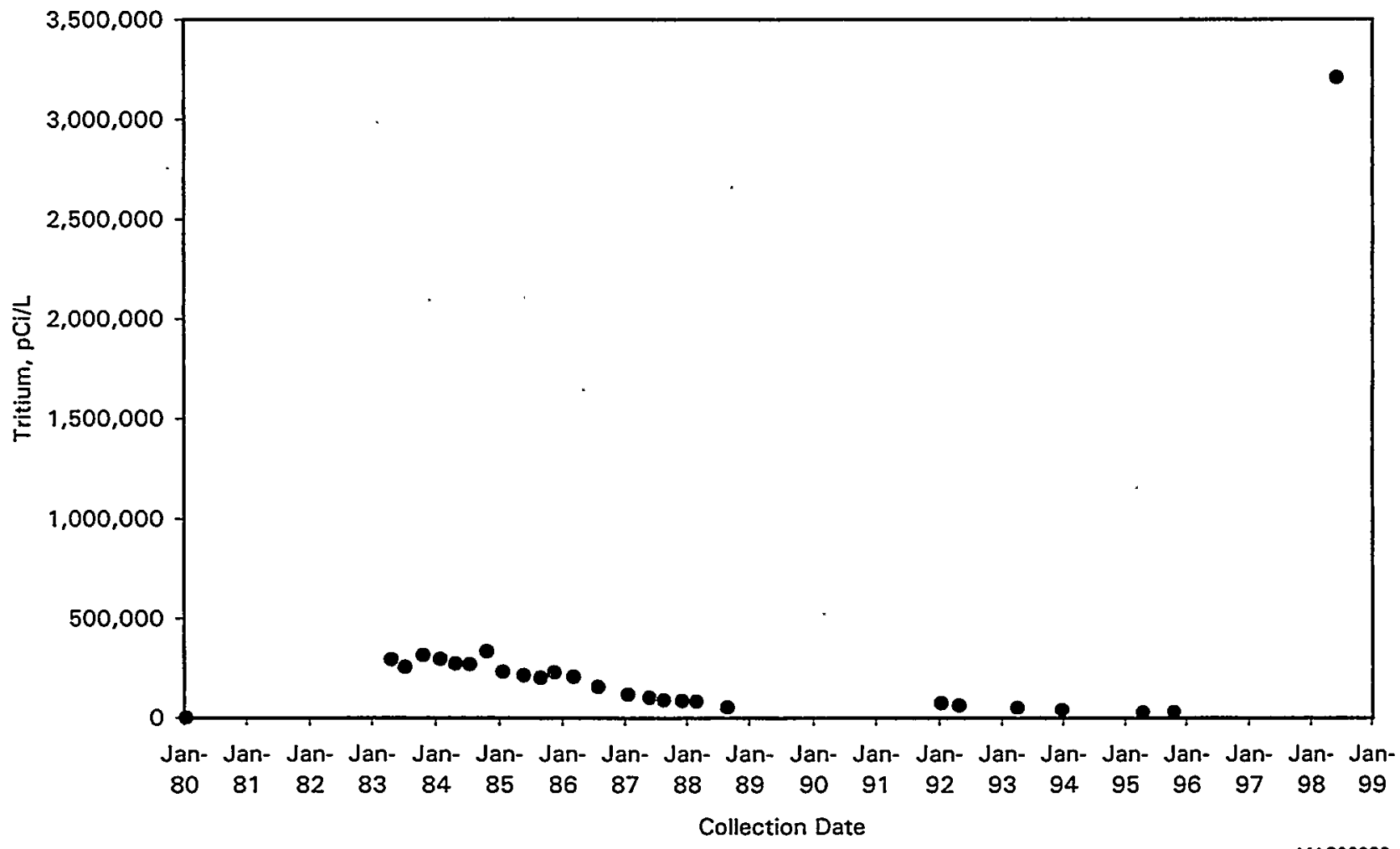

Figure 5.9-1. Tritium Activities in Well 299-W14-2 Monitoring Waste Management Area TX-TY 


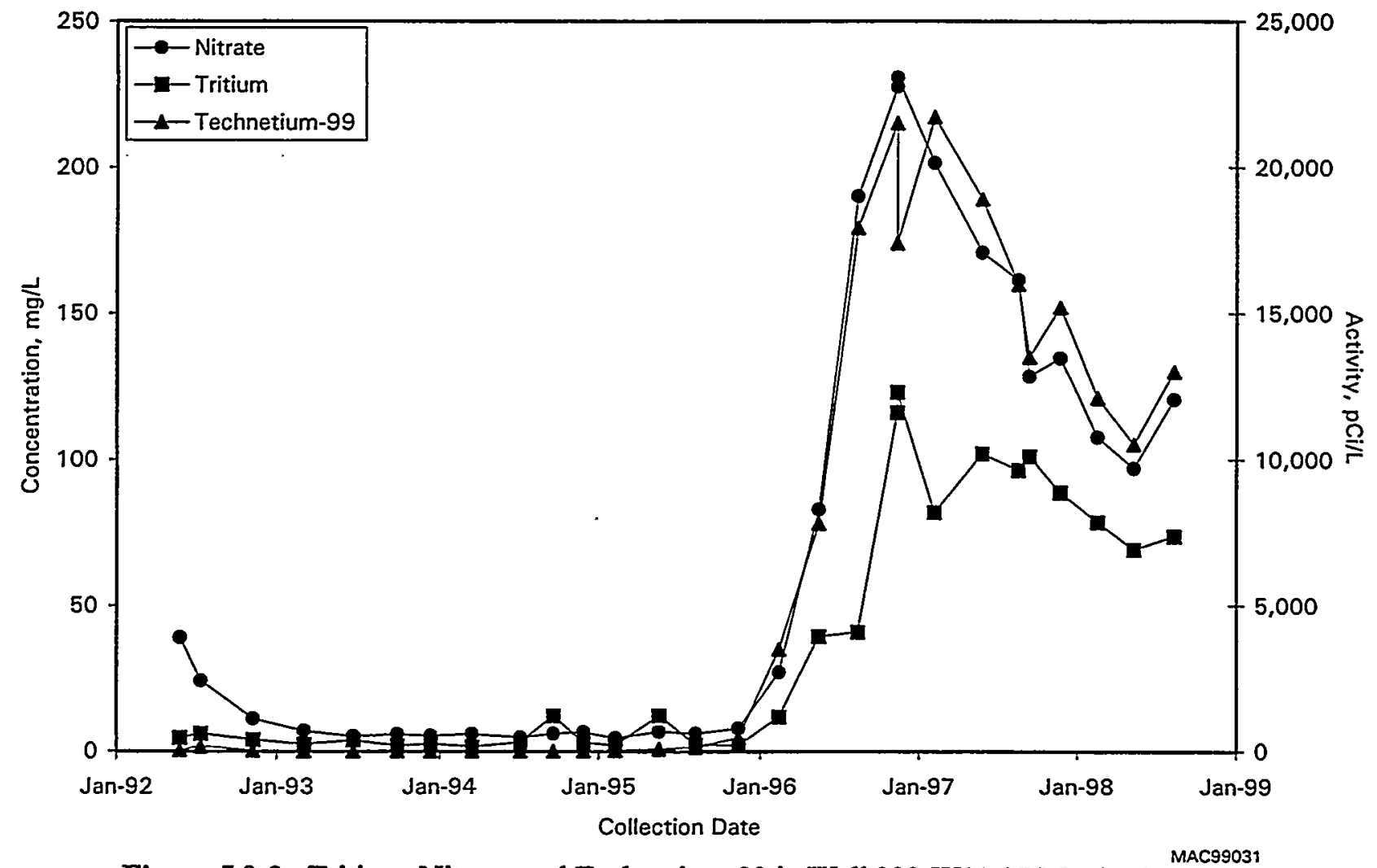

Figure 5.9-2. Tritium, Nitrate, and Technetium-99 in Well 299-W11-27 Monitoring Waste Management Area T 


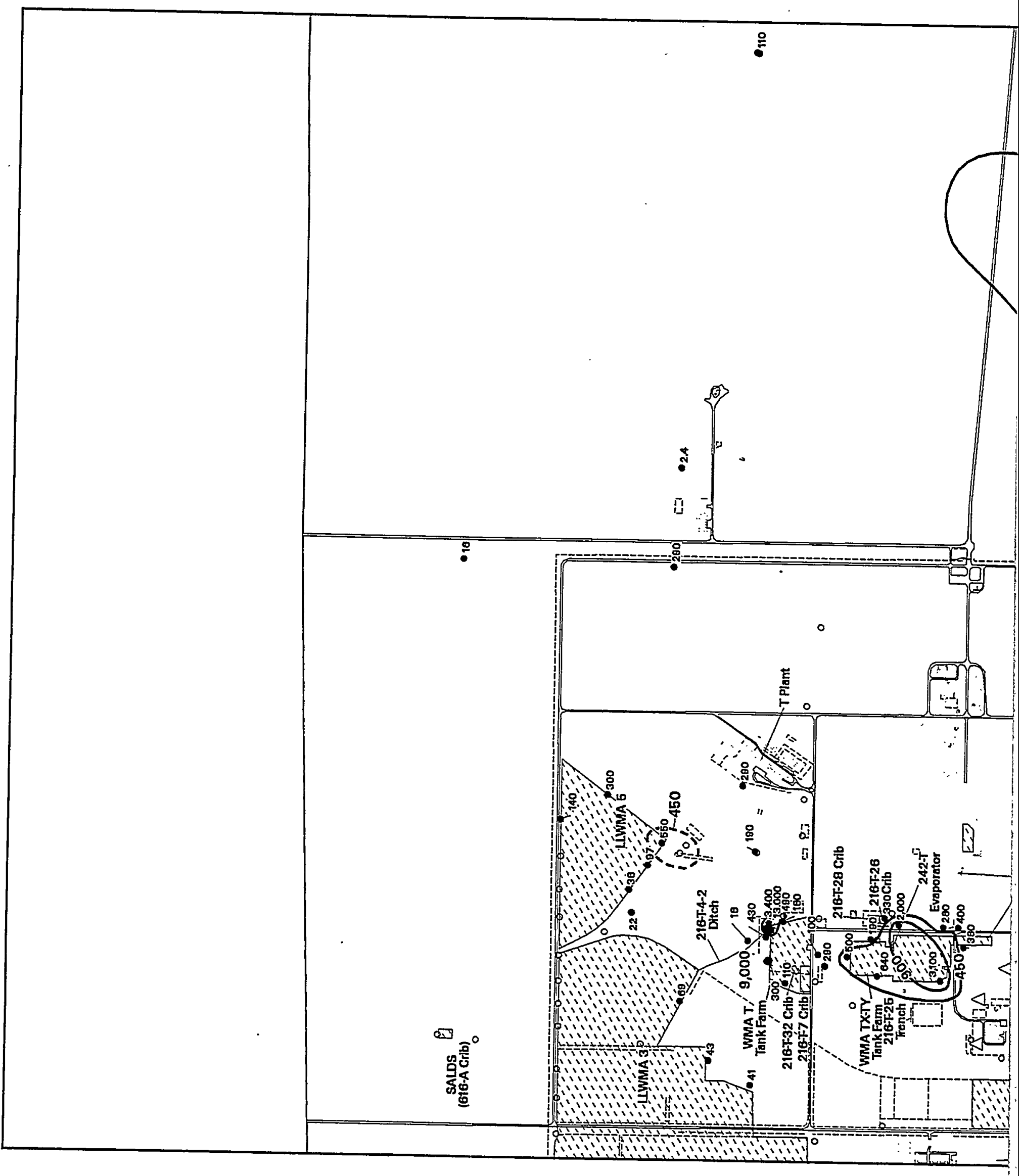




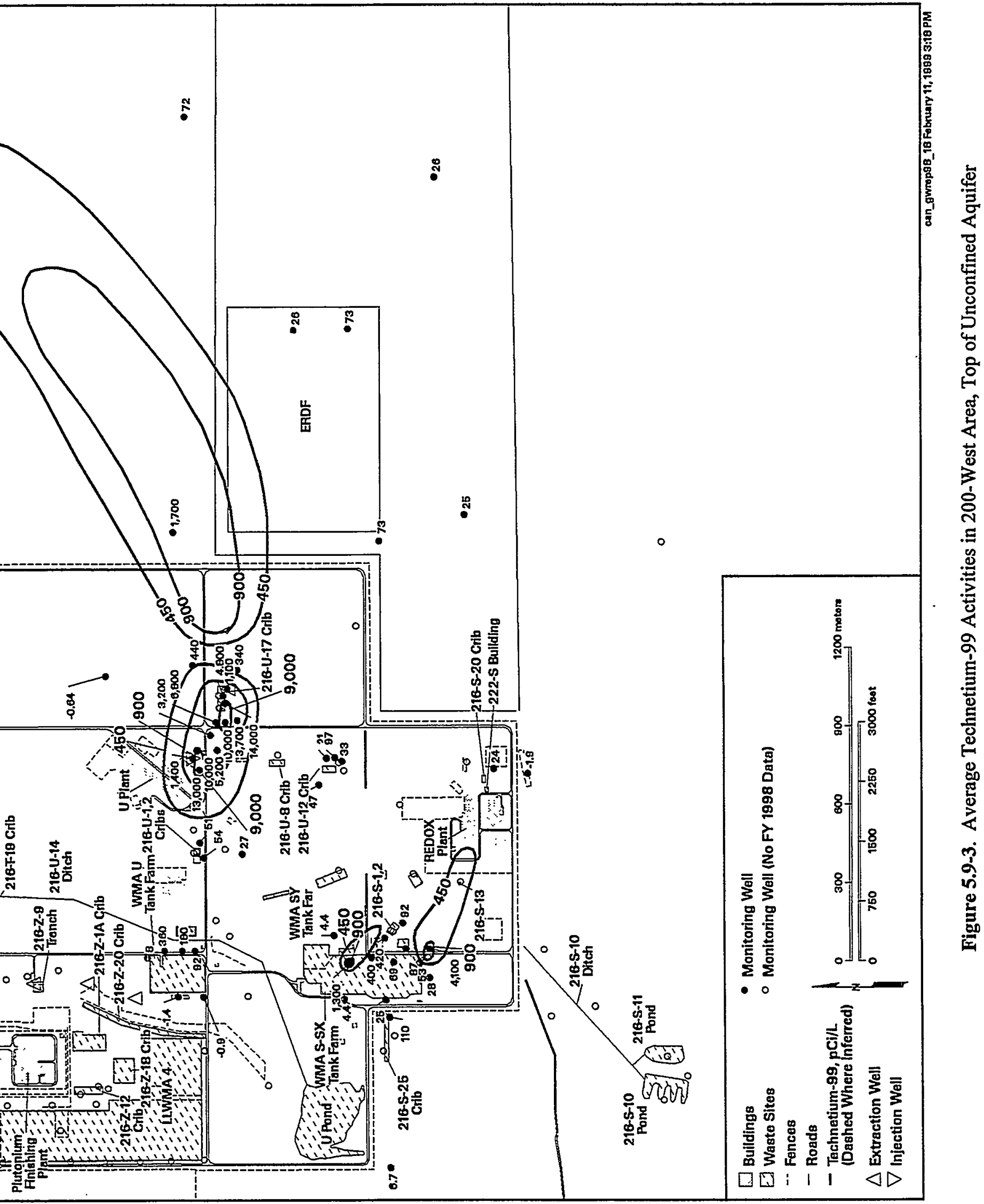




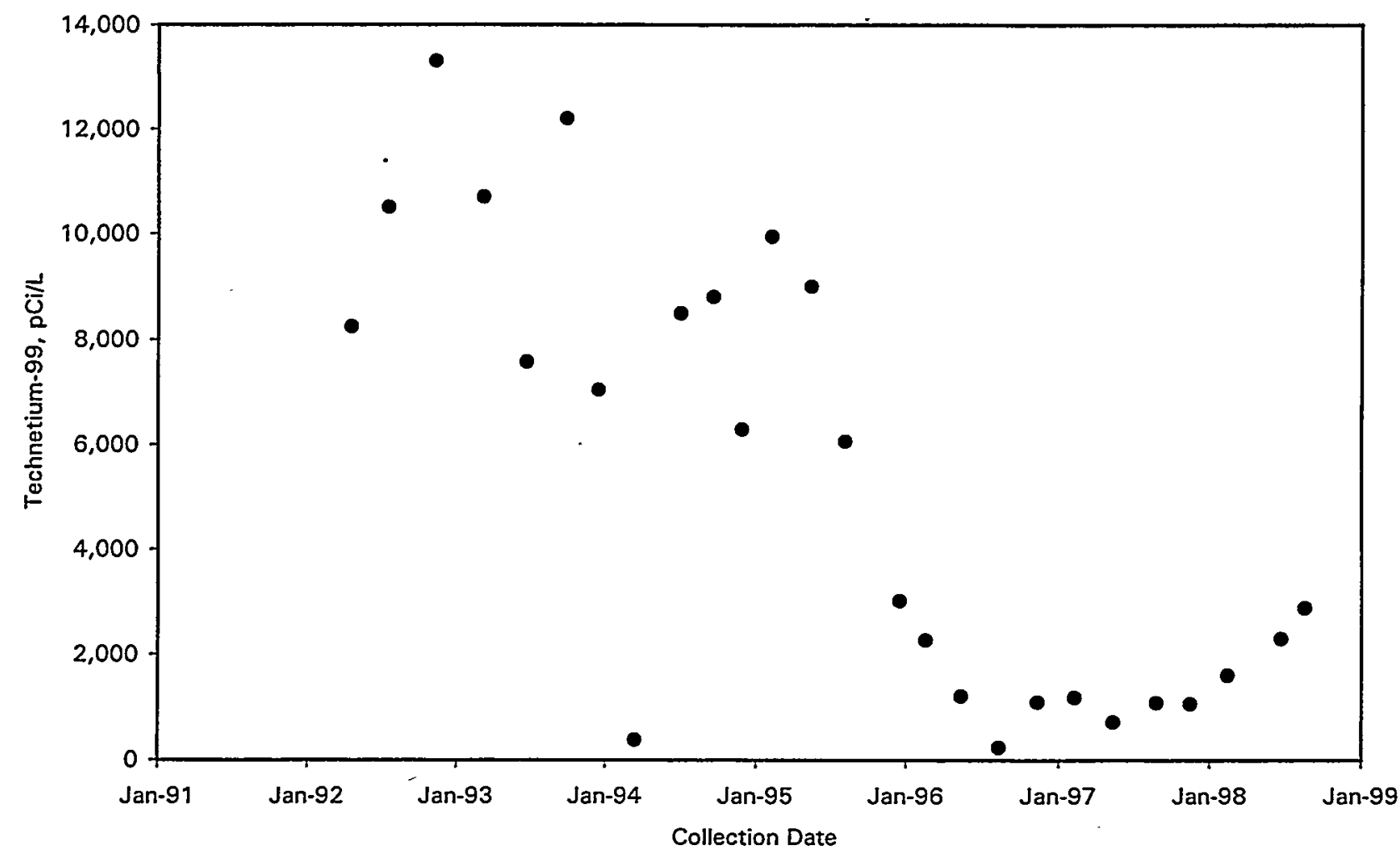

Figure 5.9-4. Technetium-99 Activities in Well 299-W14-12 Monitoring Waste

MAC99029 Management Area TX-TY 


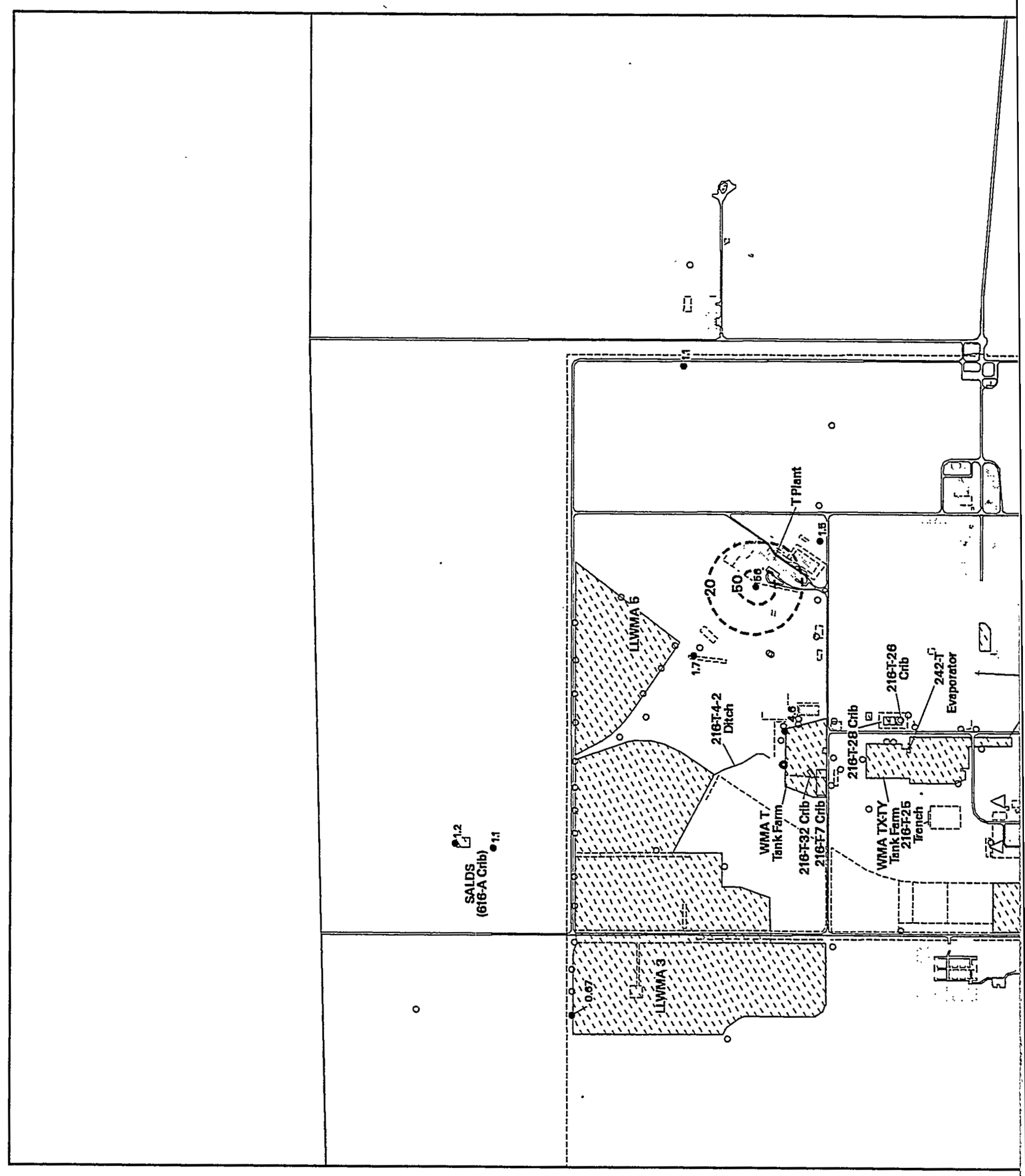




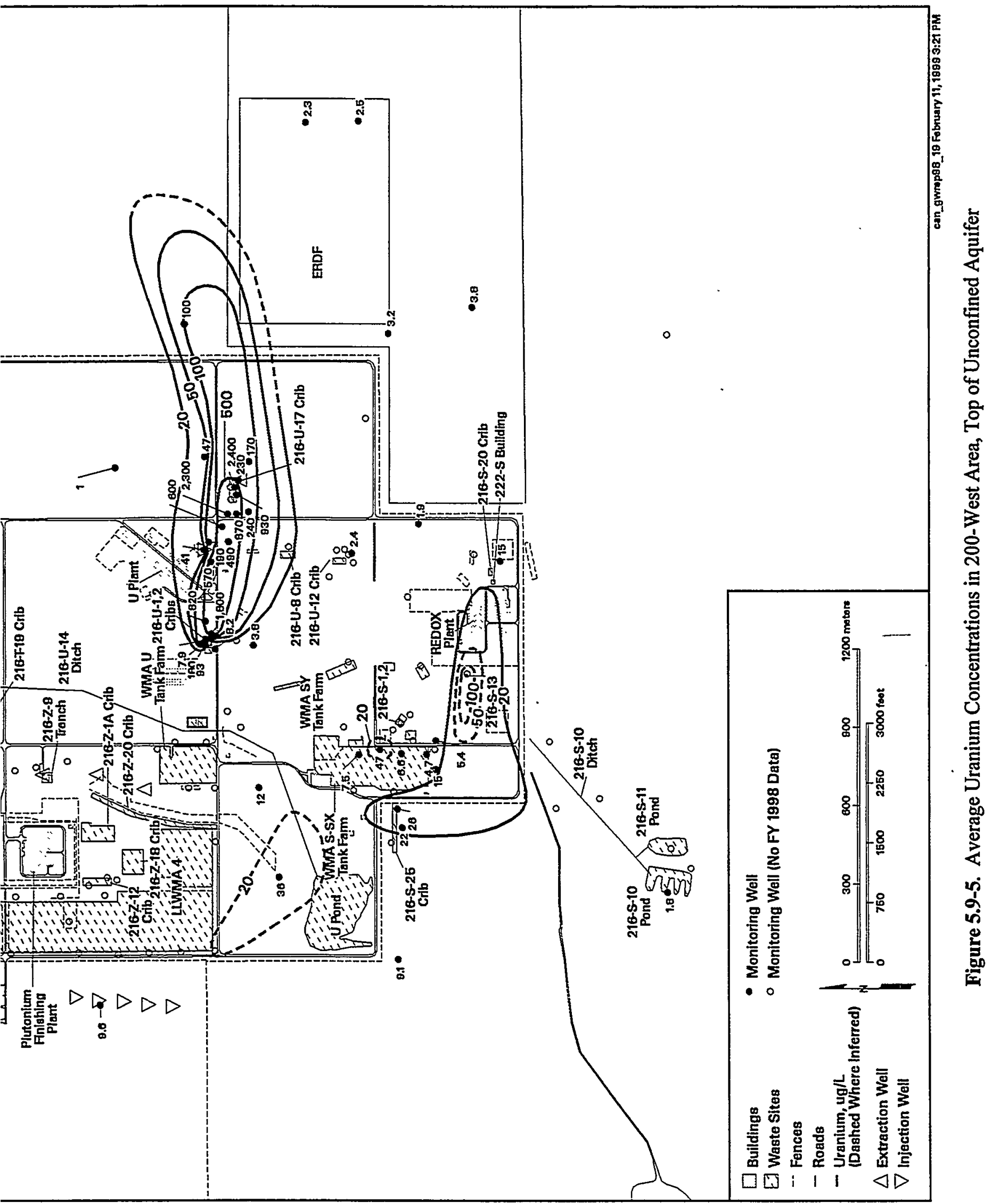




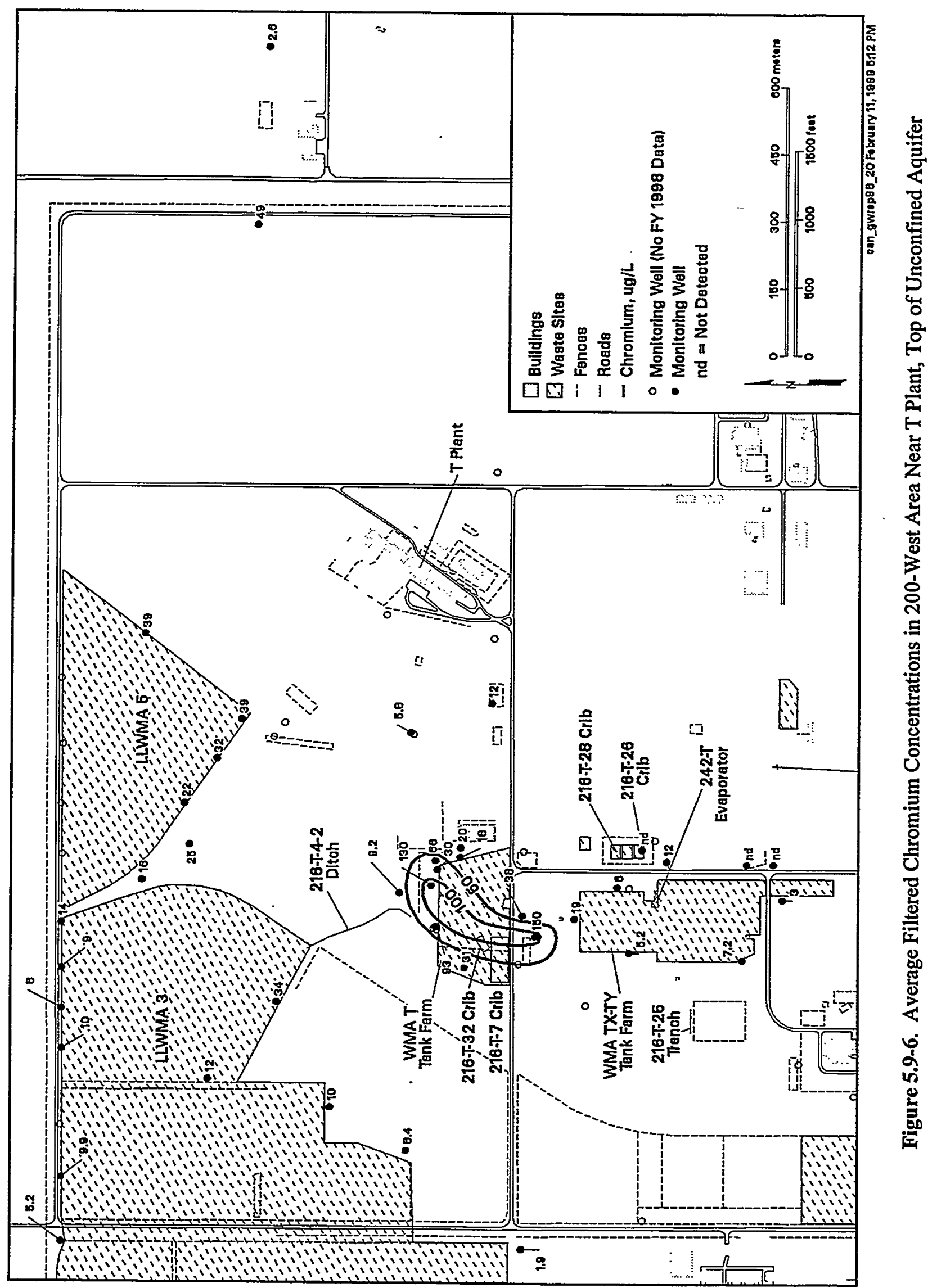




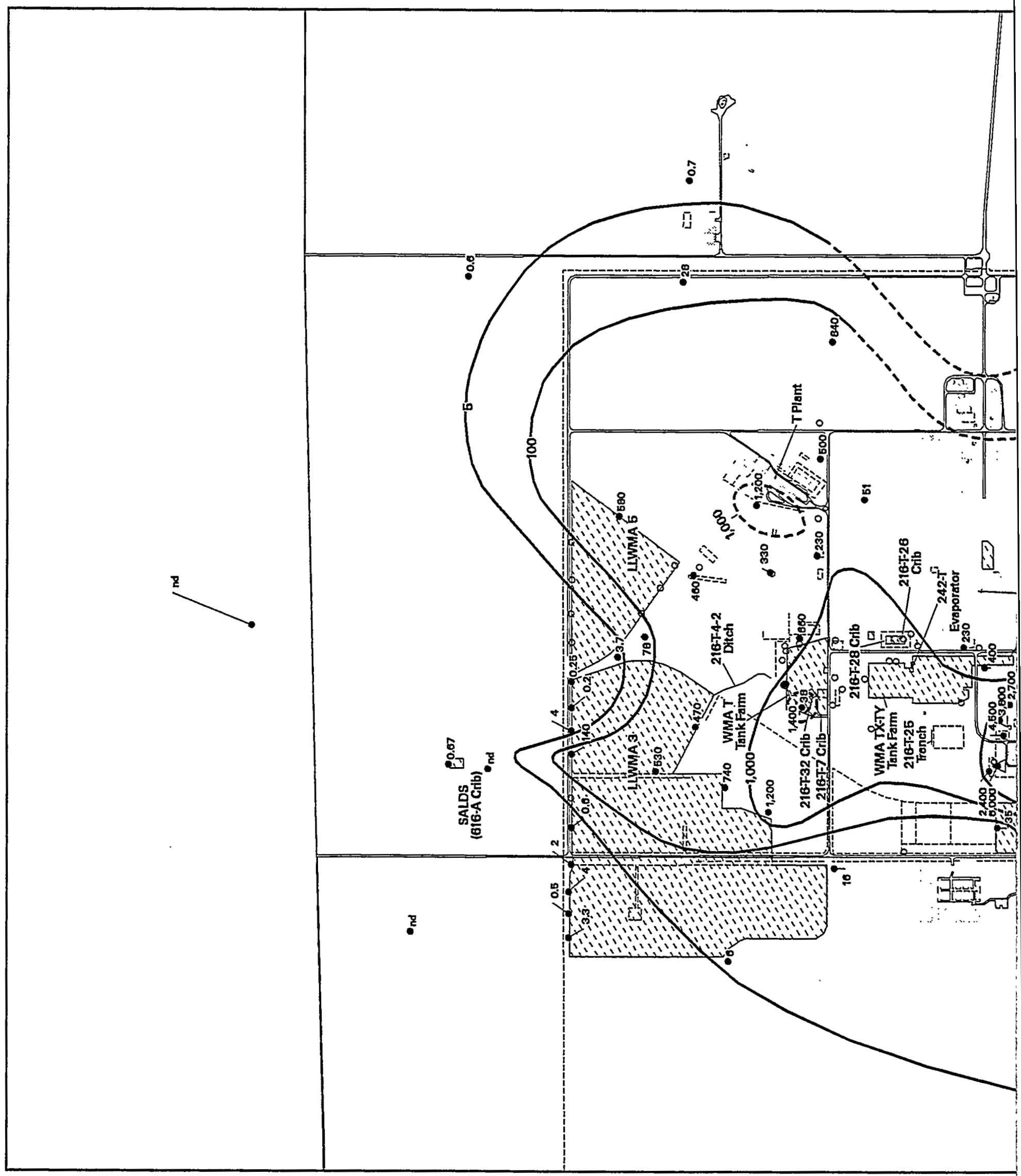




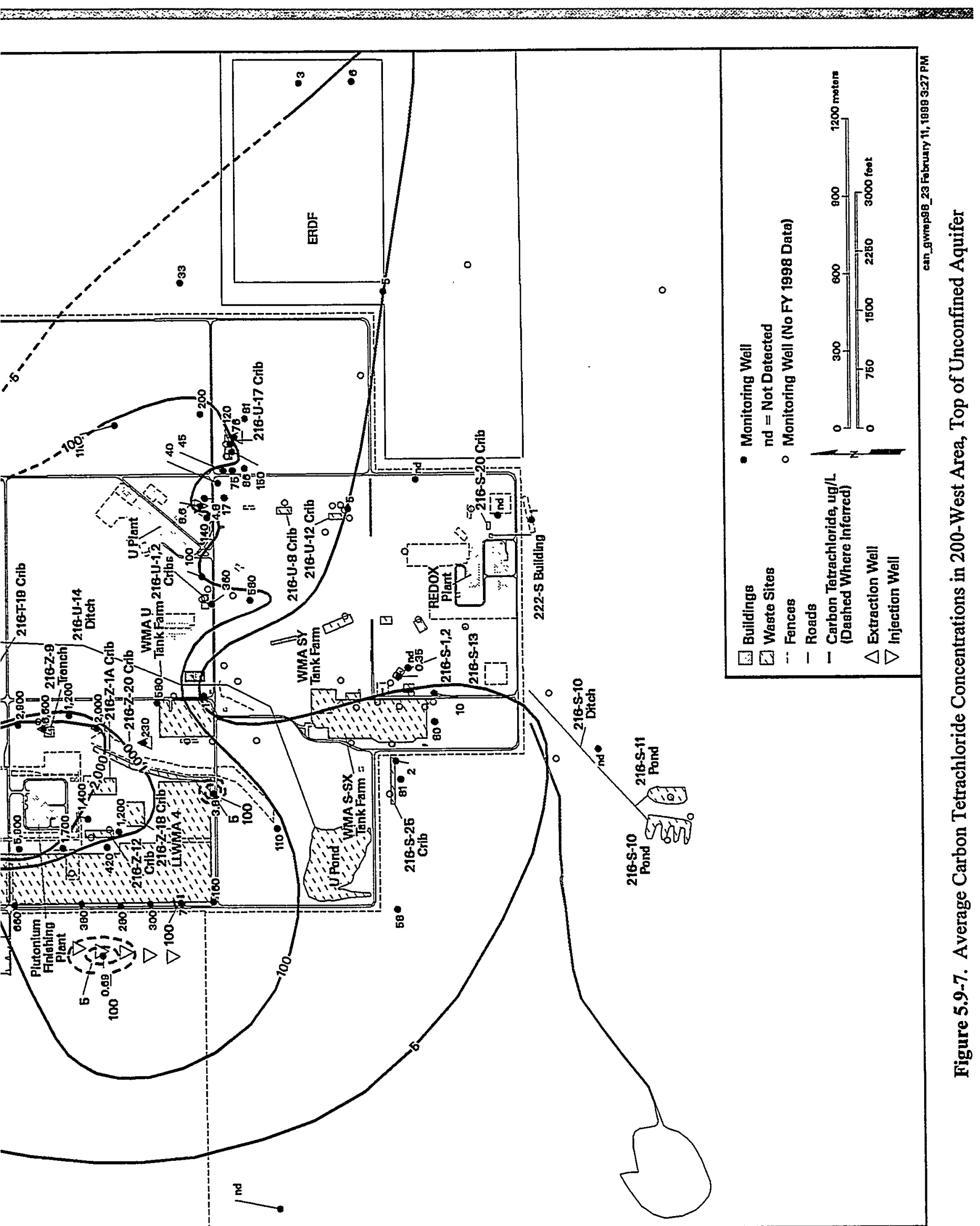




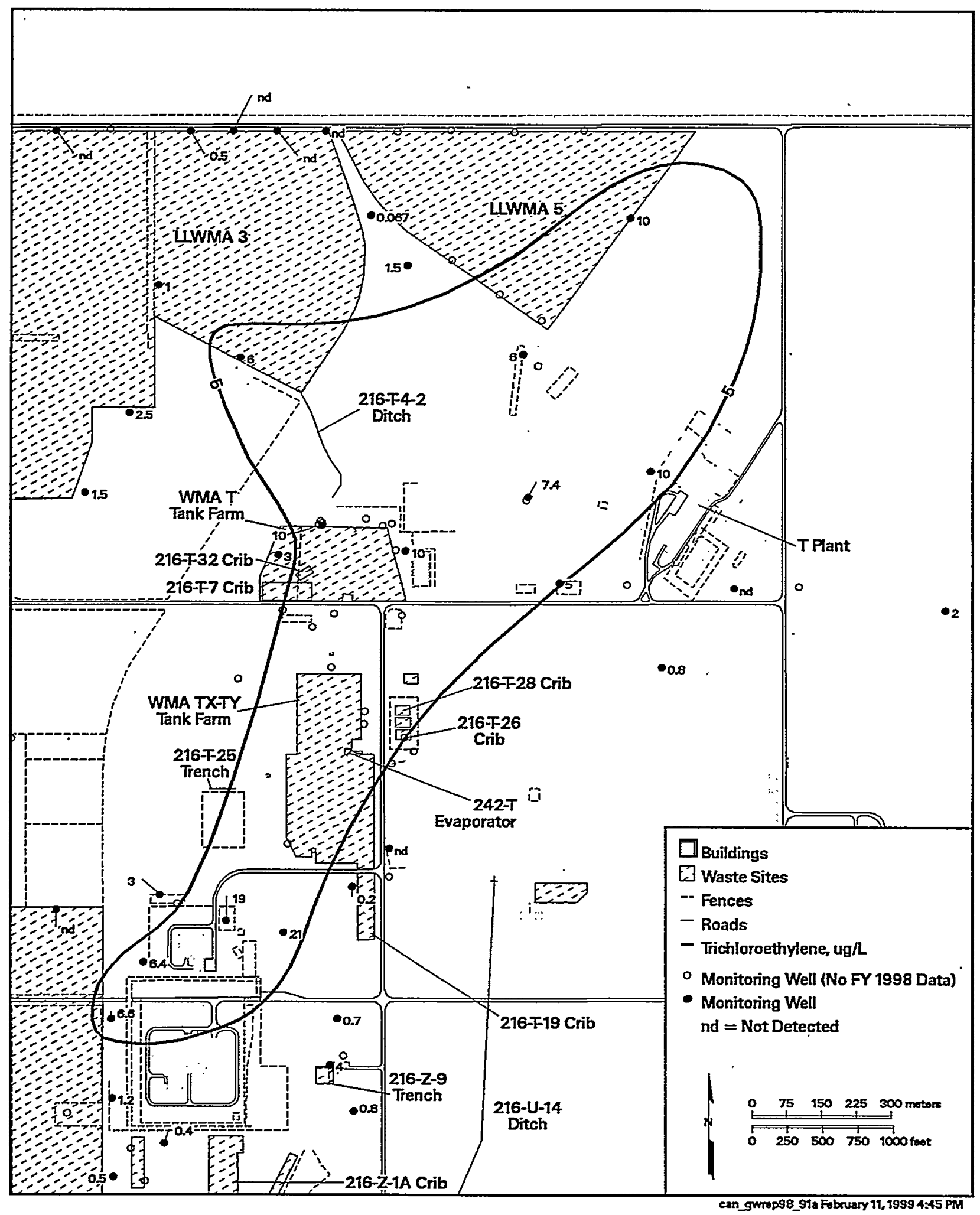

Figure 5.9-8. Average Trichloroethylene Concentrations in Northern 200-West Area 


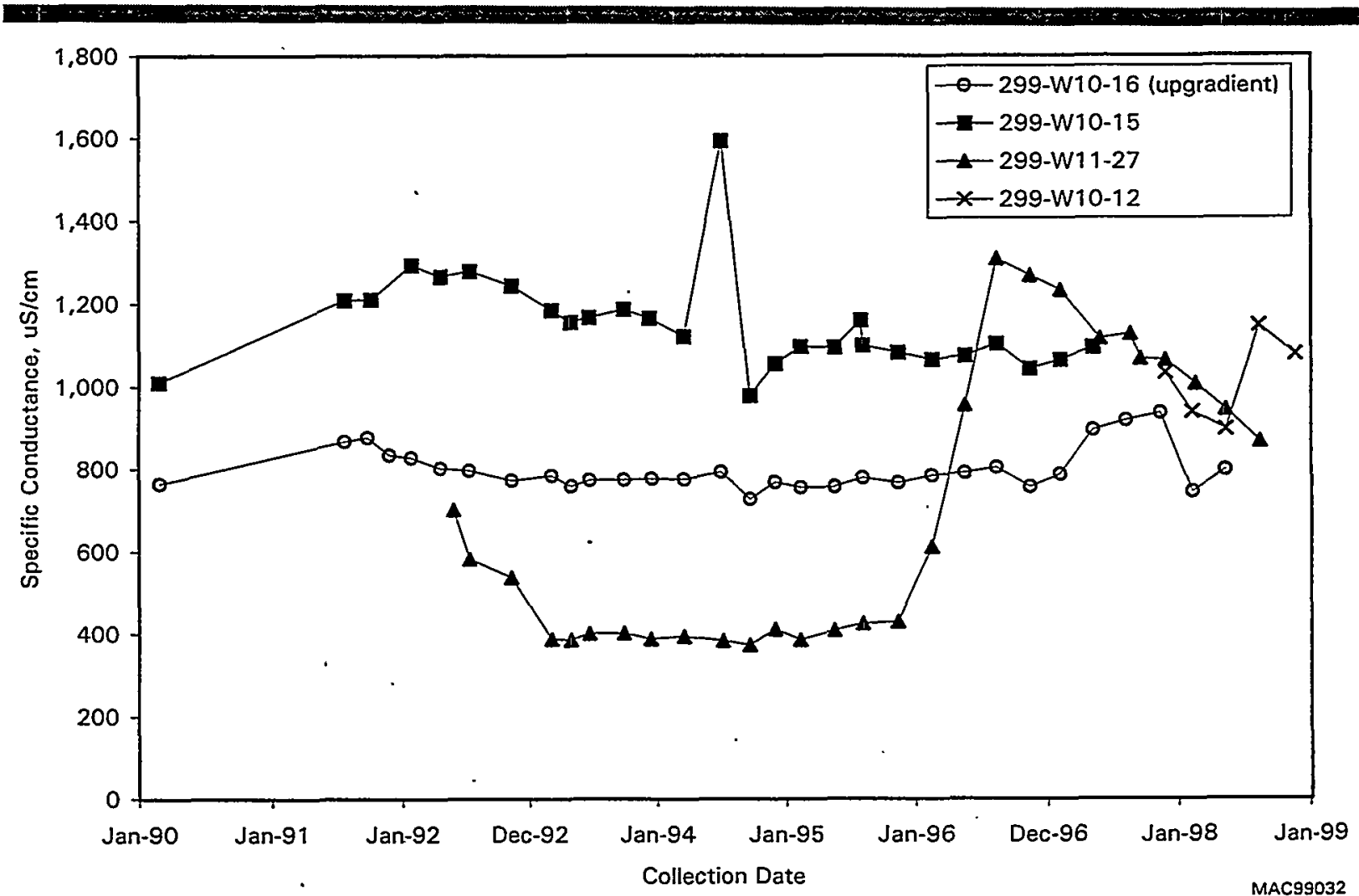

Figure 5.9-9. Specific Conductance in Selected Wells Monitoring Waste Management Area T

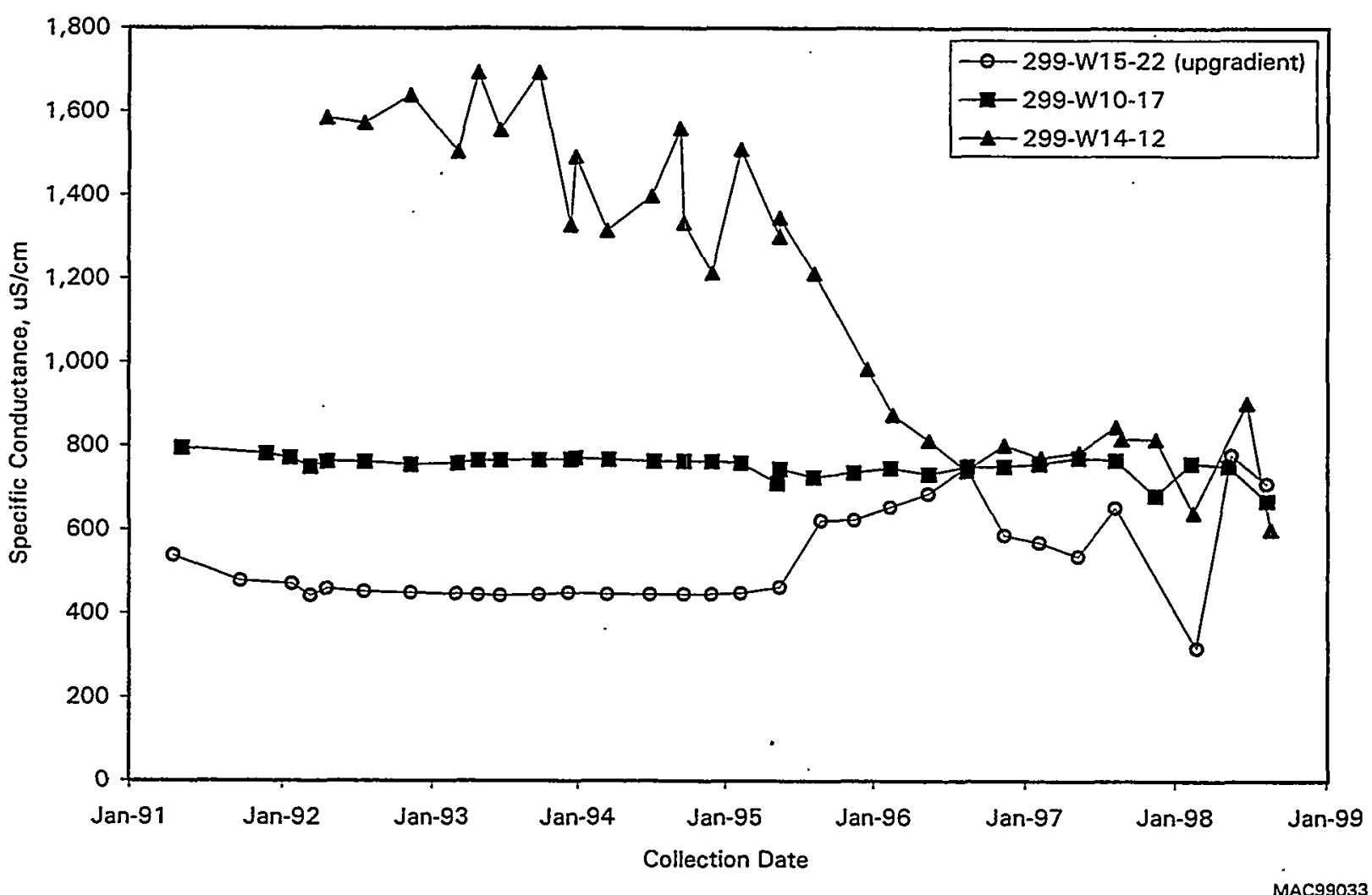

Figure 5.9-10. Specific Conductance in Selected Wells Monitoring Waste Management Area TX-TY 


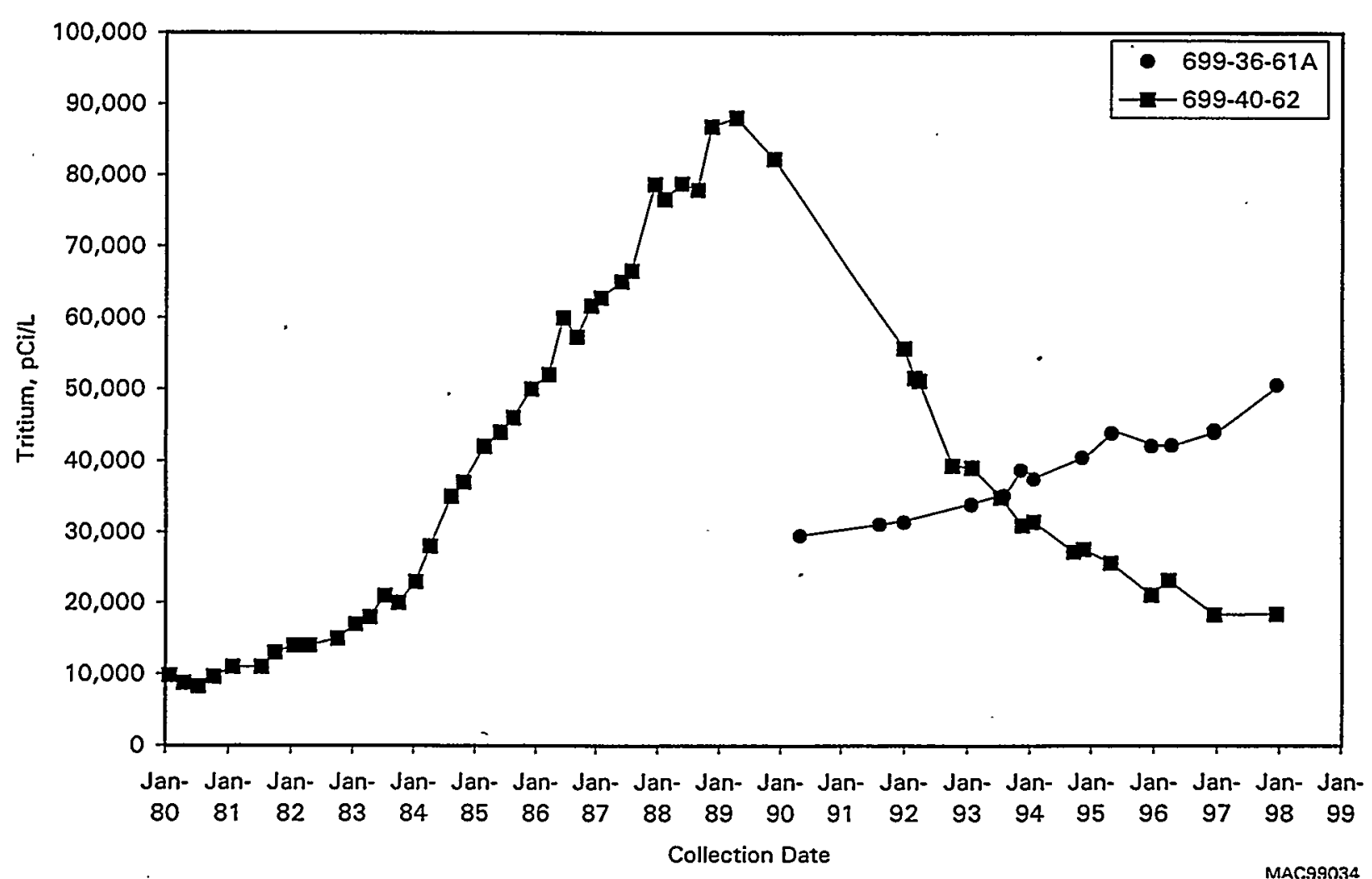

Figure 5.9-11. Tritium Activities in Wells 699-40-62 and 699-36-61A East of 200-West Area 

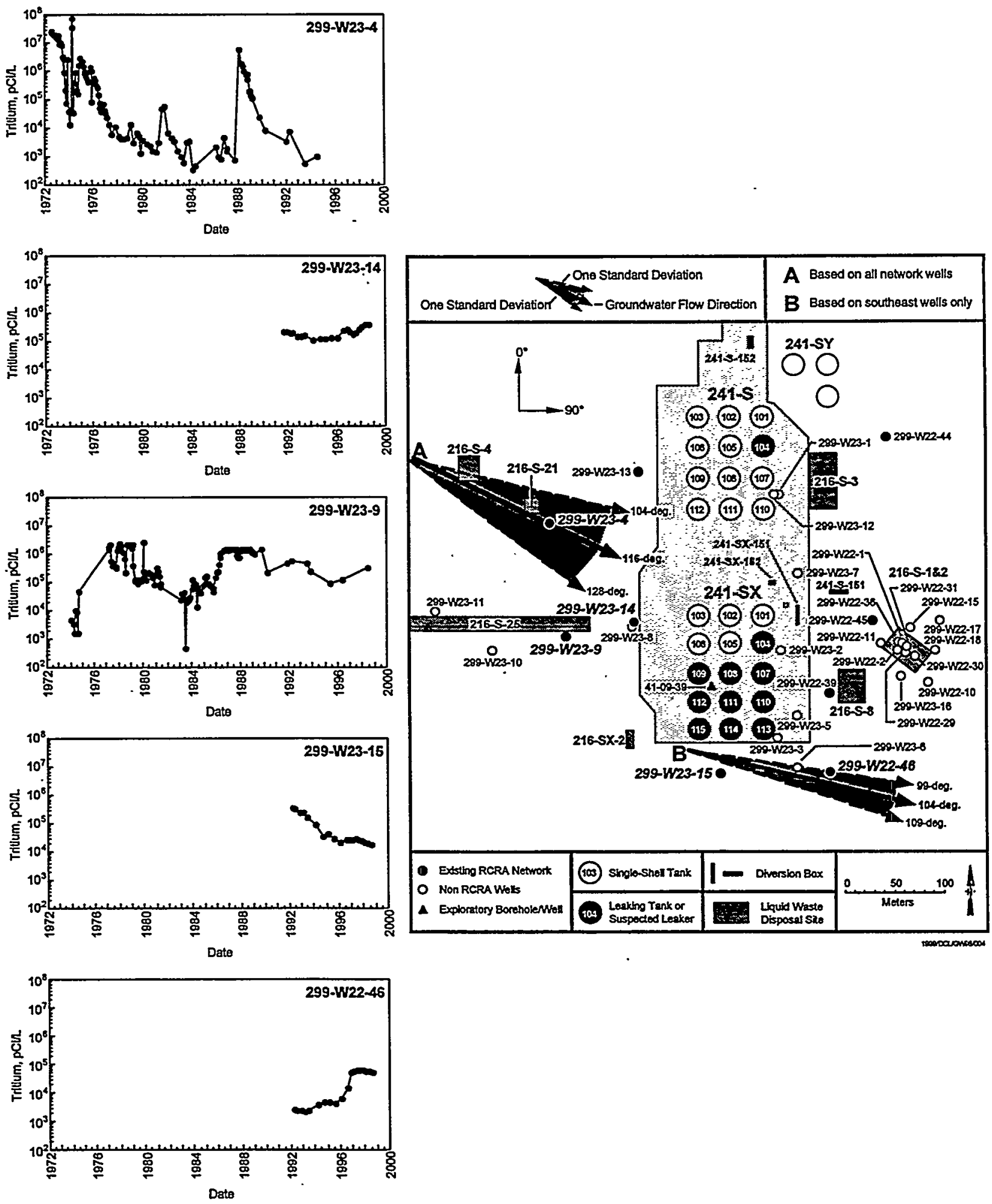

Figure 5.9-12. Tritium Activities in Wells Monitoring Waste Management Area S-SX and Surrounding Areas 


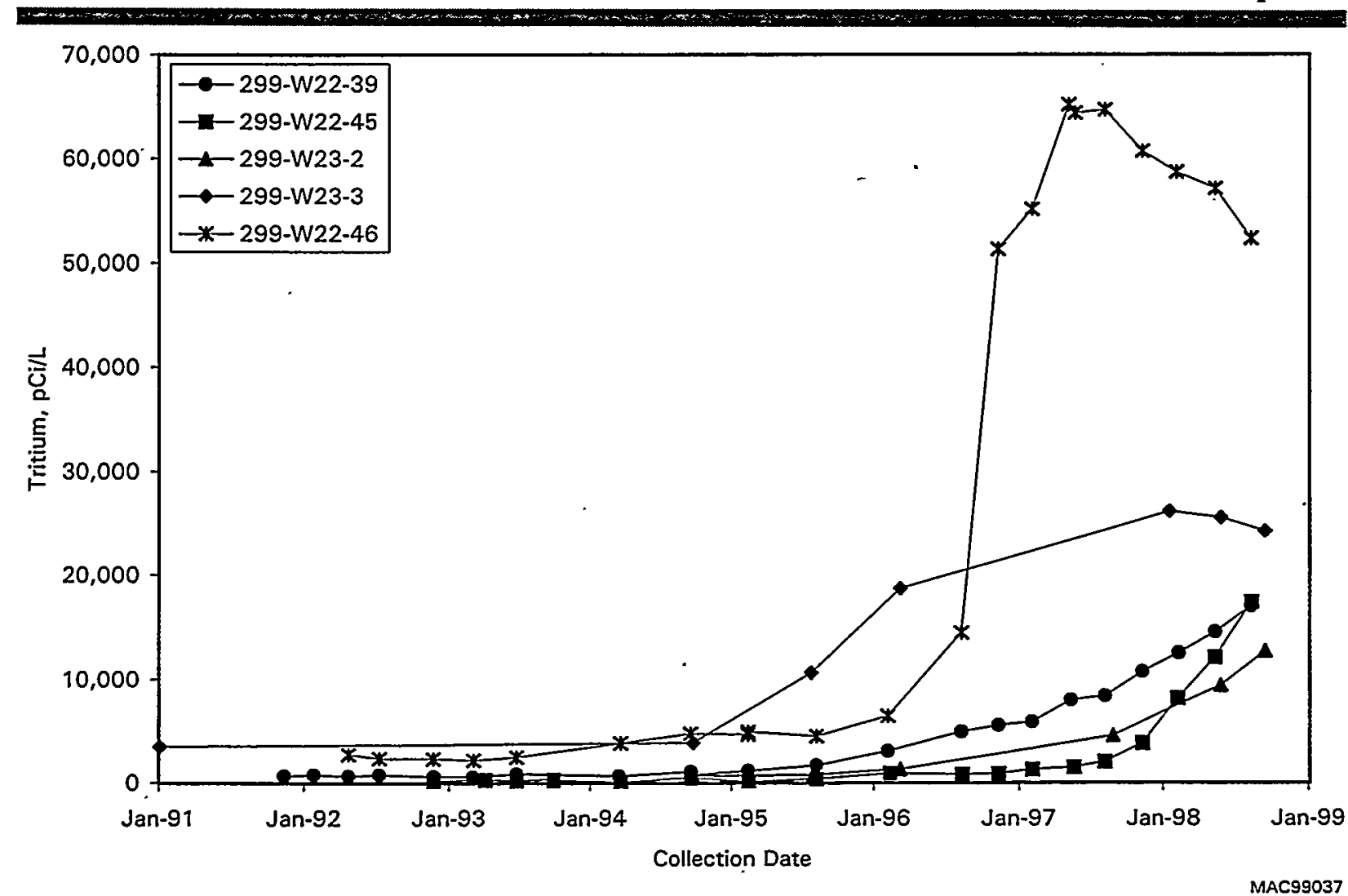

Figure 5.9-13. Tritium Activities in Downgradient Wells Monitoring Waste Management Area S-SX 


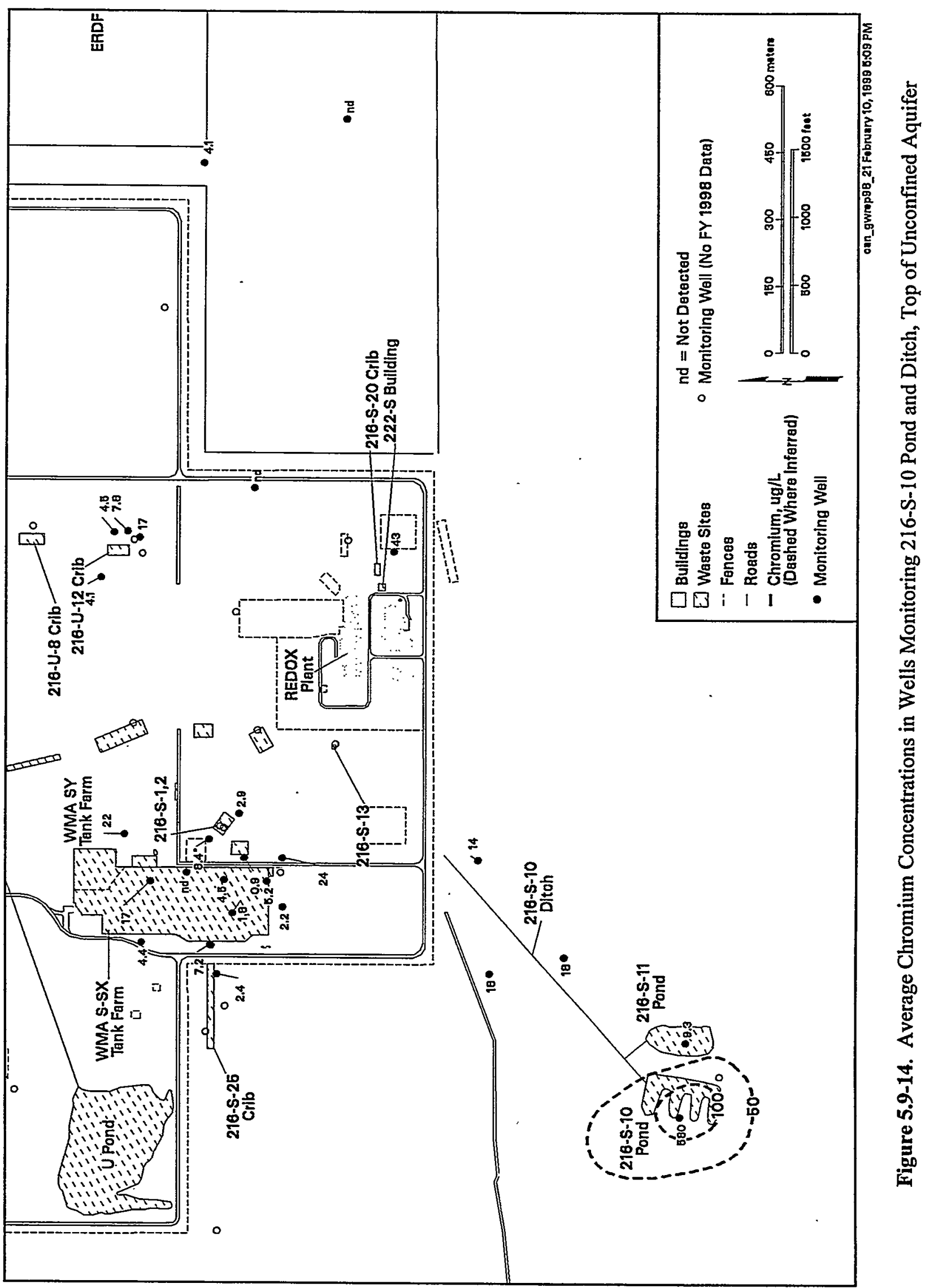



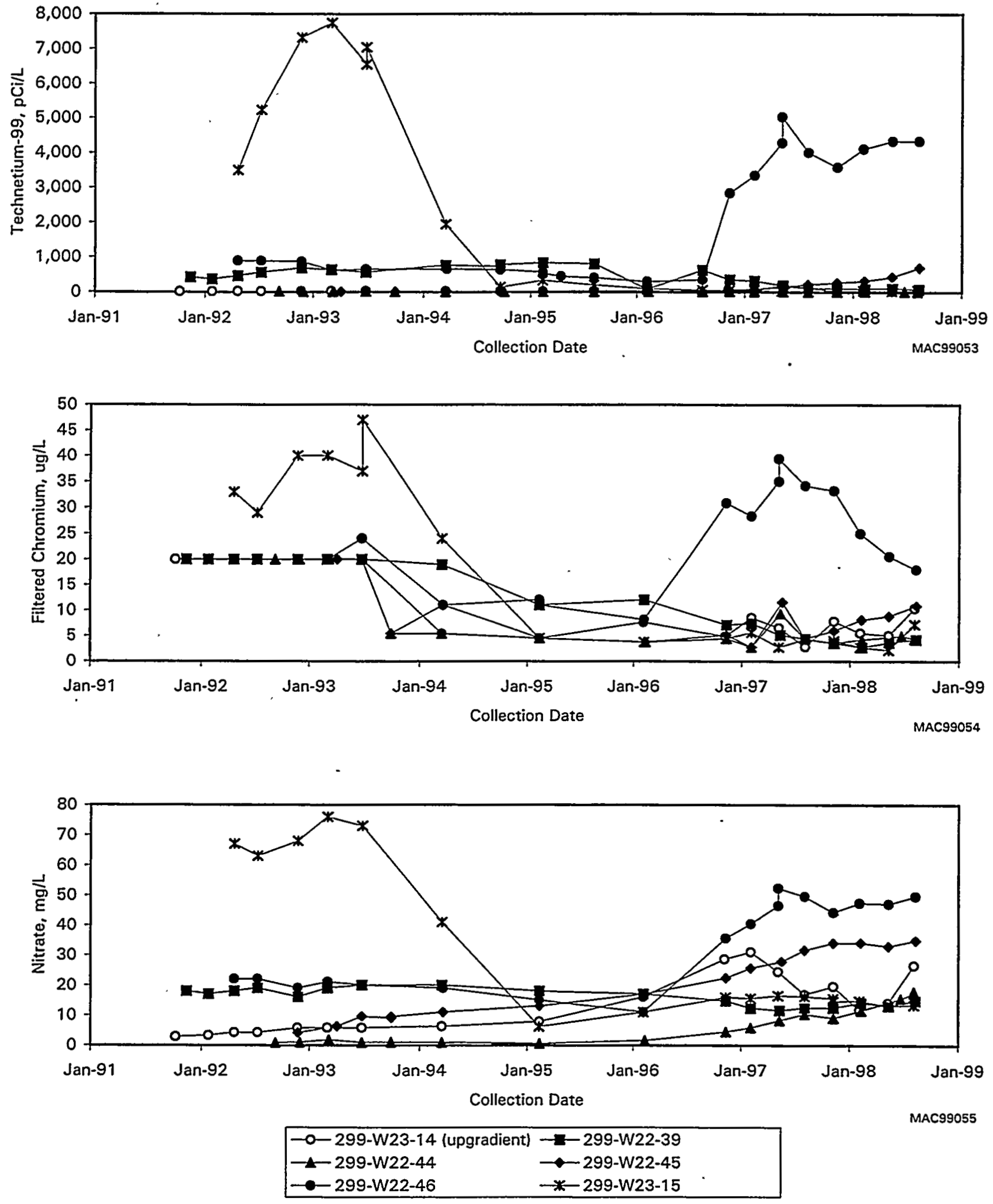

Figure 5.9-15. Time-Series Plot of Technetium-99, Nitrate, and Chromium in Wells Monitoring Waste Management Area S-SX 


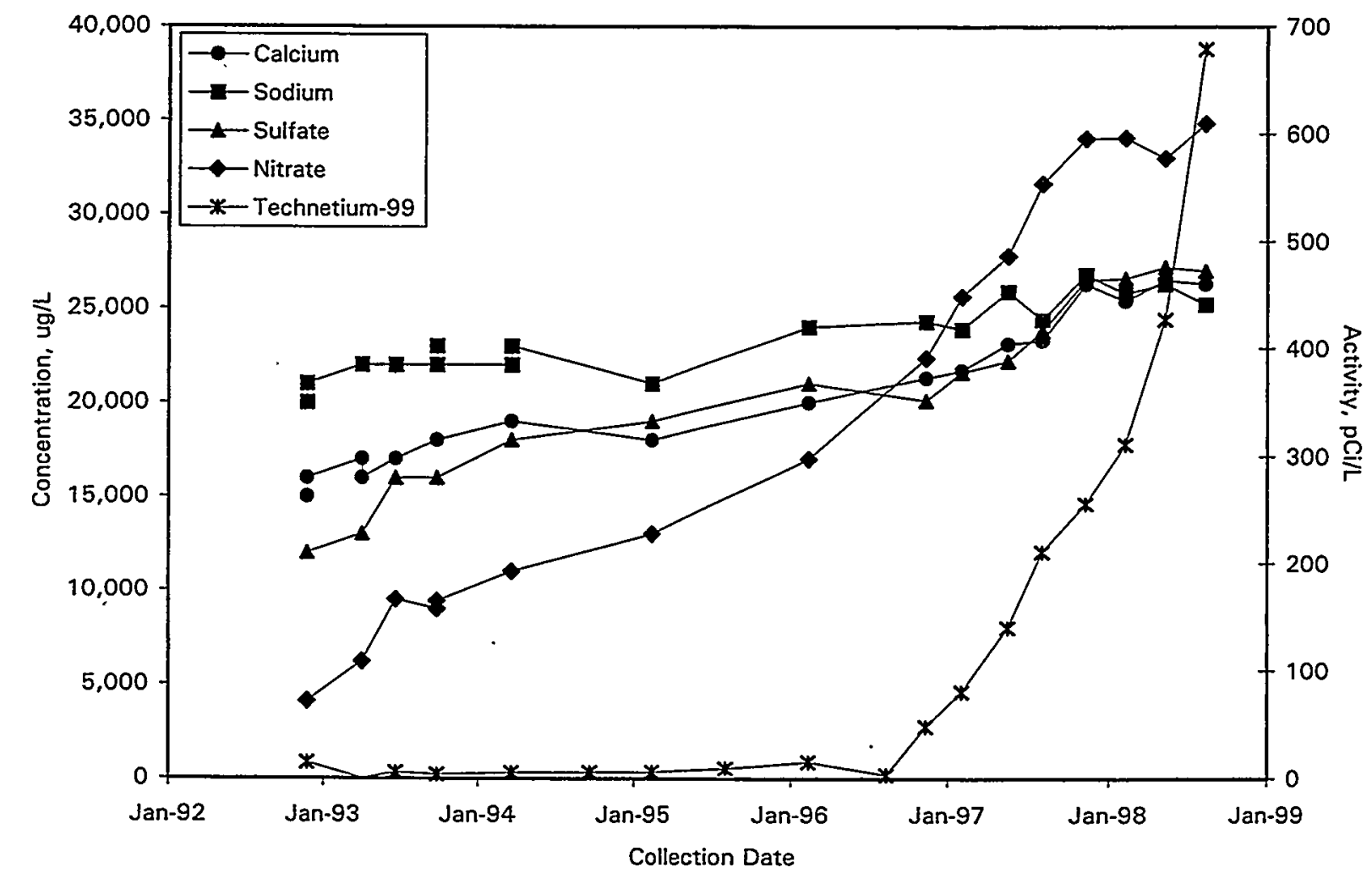

Figure 5.9-16. Technetium-99 Activity and Chemical Concentration Trends in Well 299-W22-45 Monitoring Waste Management Area S-SX

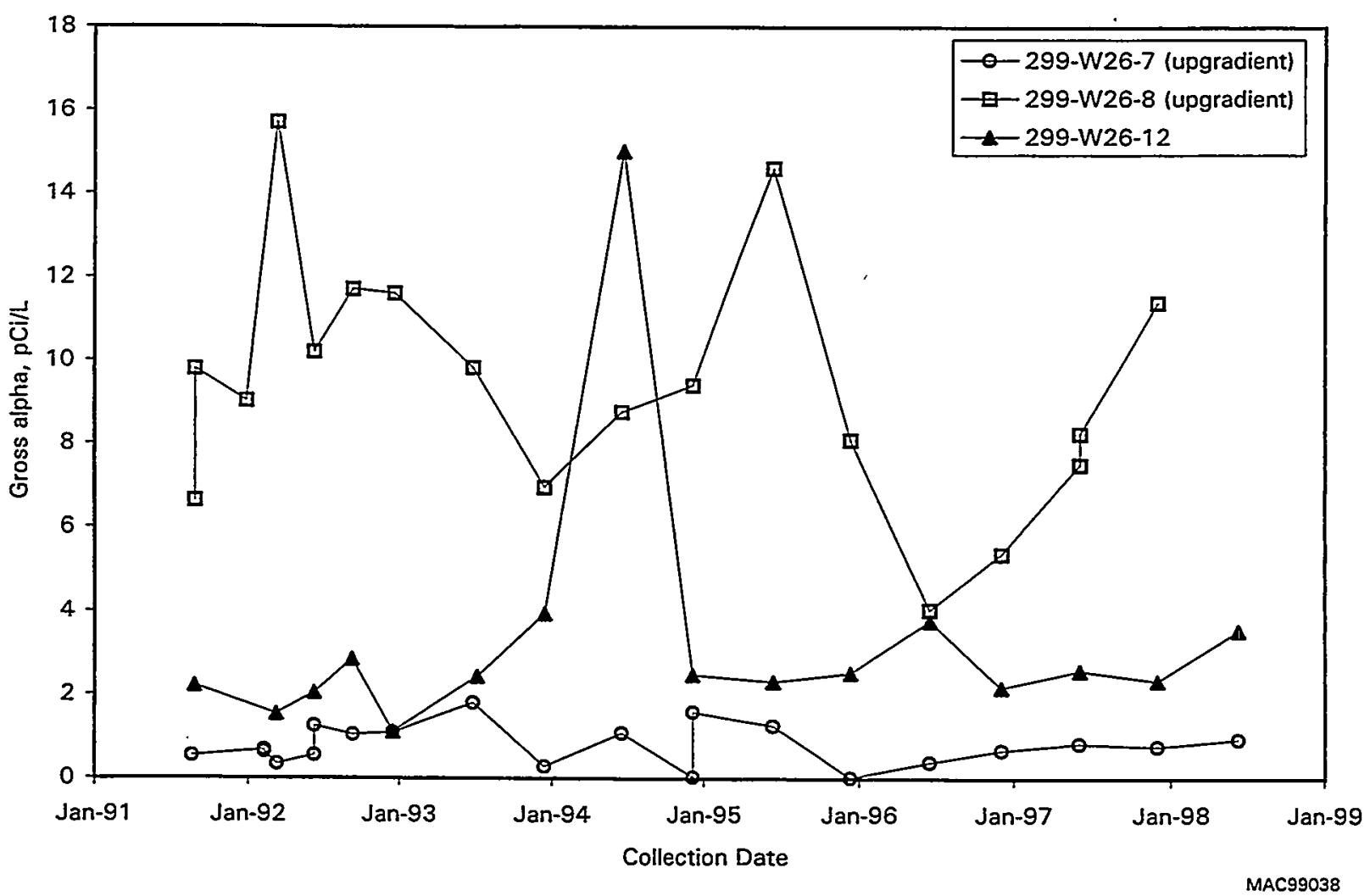

Figure 5.9-17. Gross Alpha Activities in Wells Monitoring 216-S-10 Pond and Ditch 


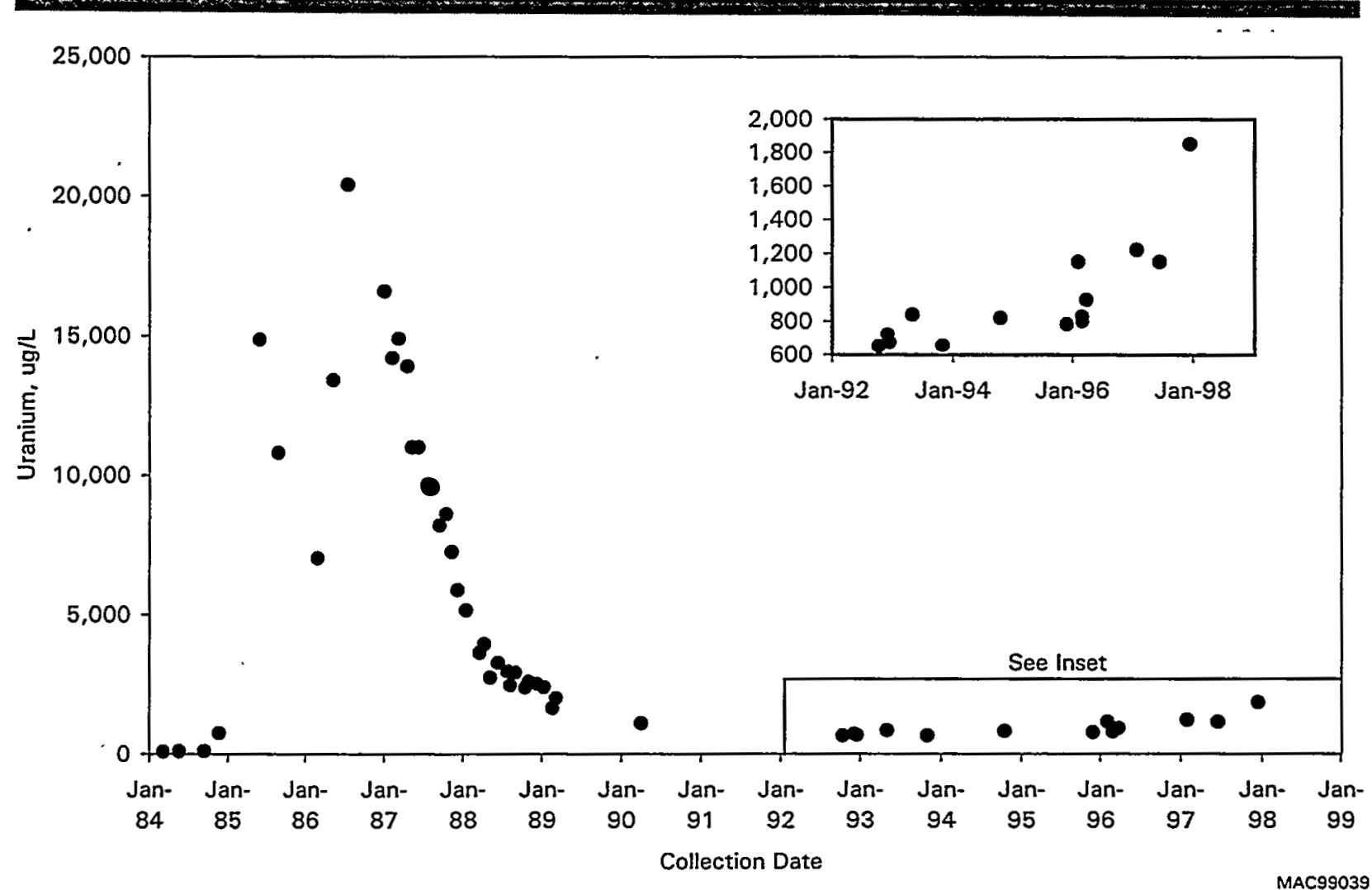

Figure 5.9-18. Uranium Concentrations in Well 299-W19-3 Monitoring 216-U-1 and 216-U-2 Cribs

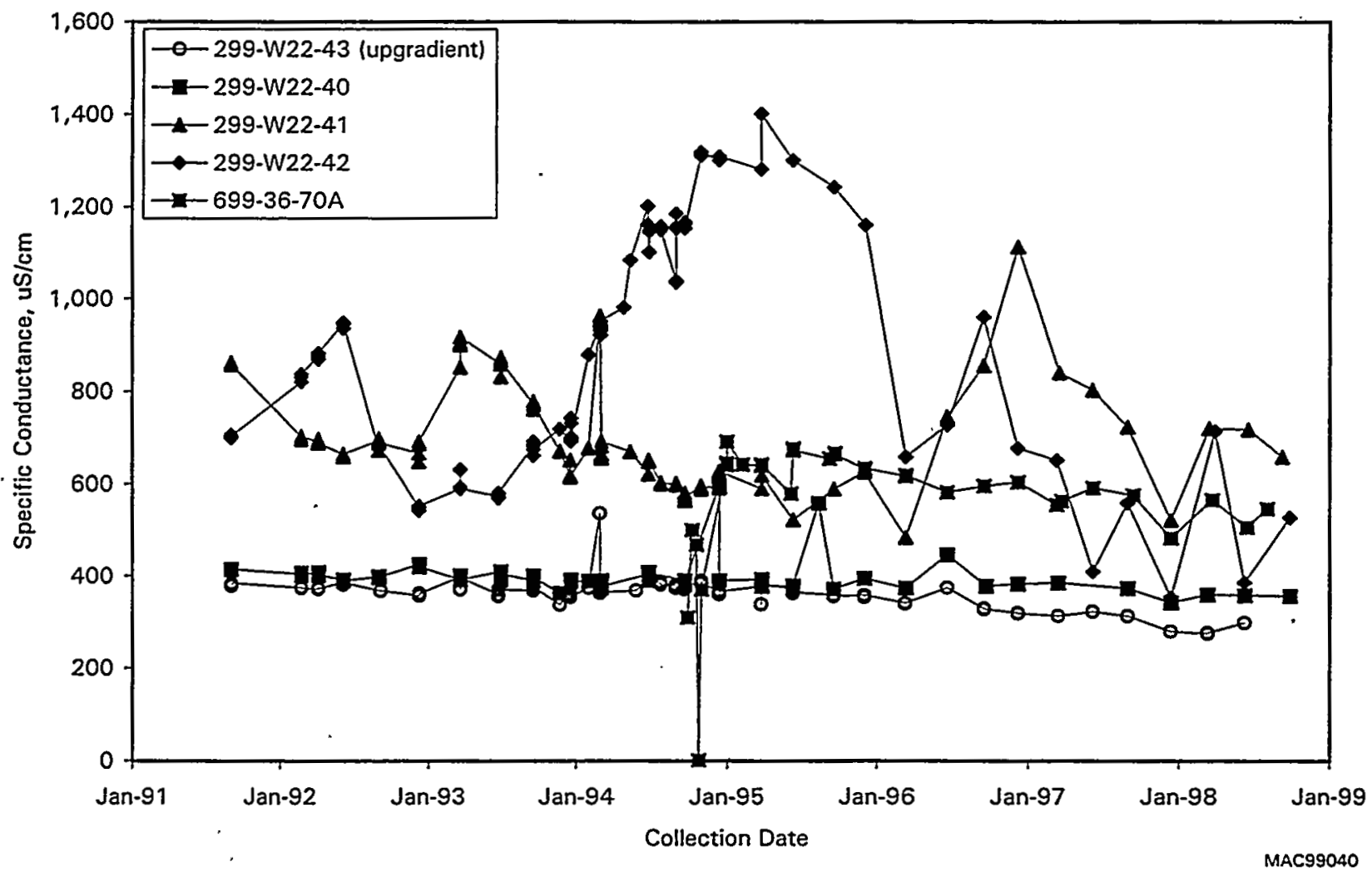

Figure 5.9-19. Specific Conductance in Wells Monitoring 216-U-12 Crib 


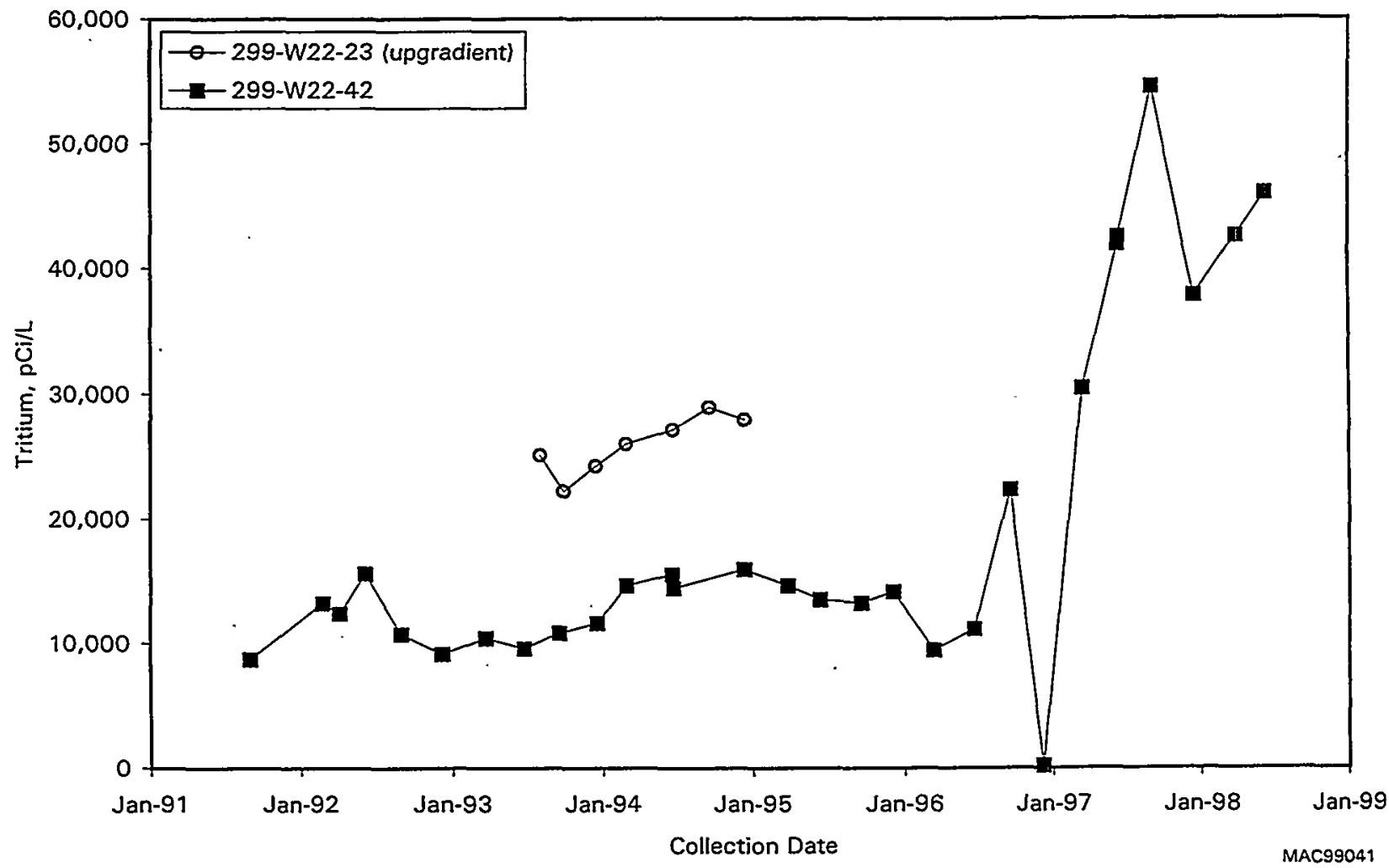

Figure 5.9-20. Tritium Activities in Wells Monitoring 216-U-12 Crib 


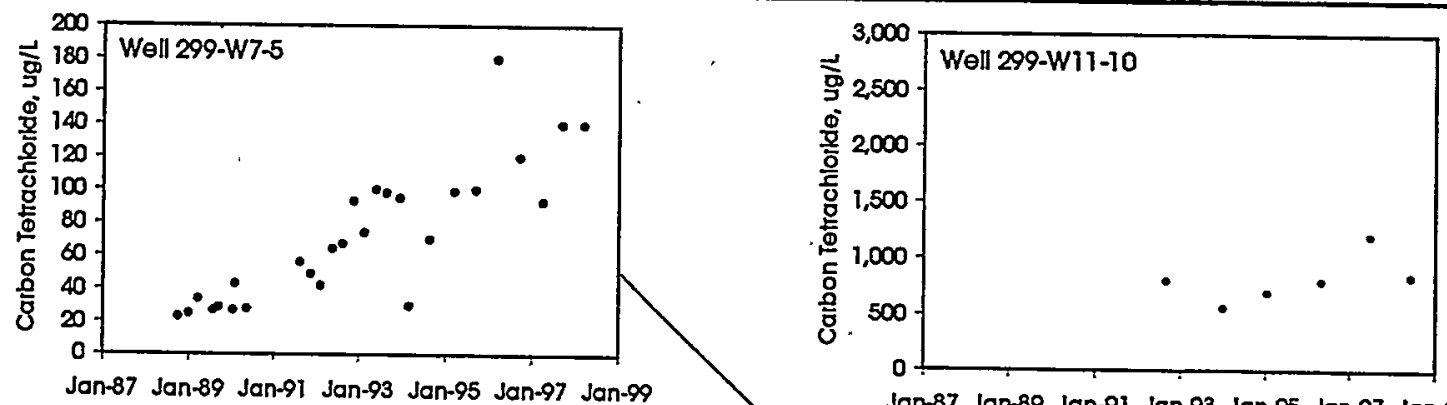

Collection Date Macesoss

Jan-87 Jan-89 Jan-91 Jan-93 Jan-95 Jan-97 Jan-99

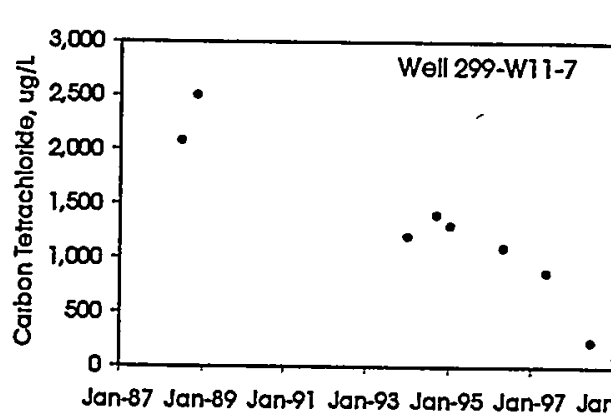

Collection Date Macso47
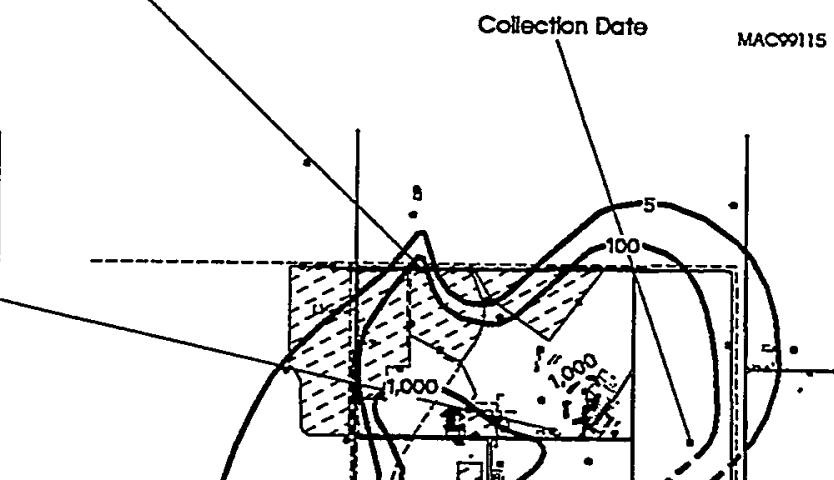


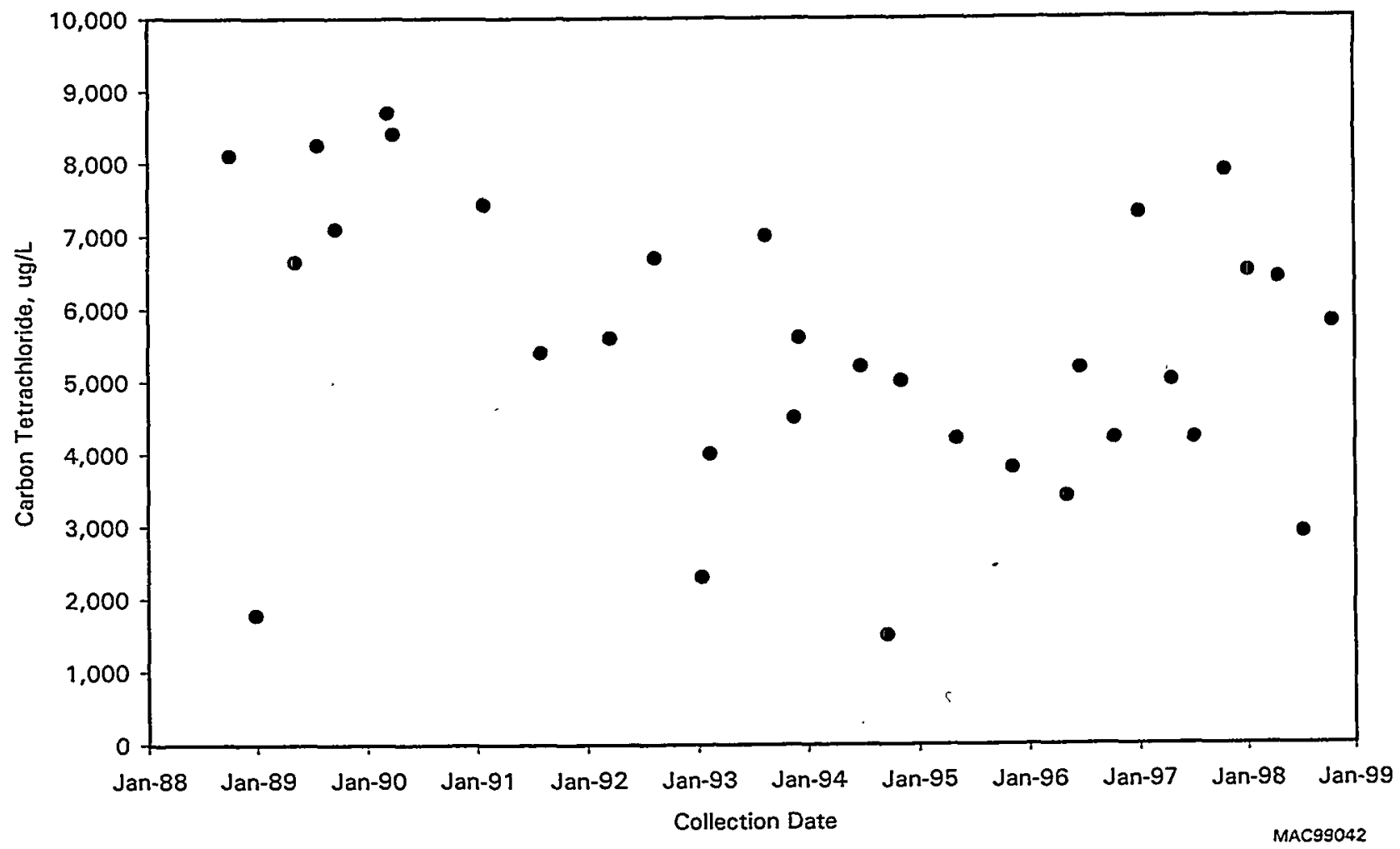

Figure 5.9-22. Carbon Tetrachloride Concentrations in Well 299-W15-16 Near Plutonium Finishing Plant 


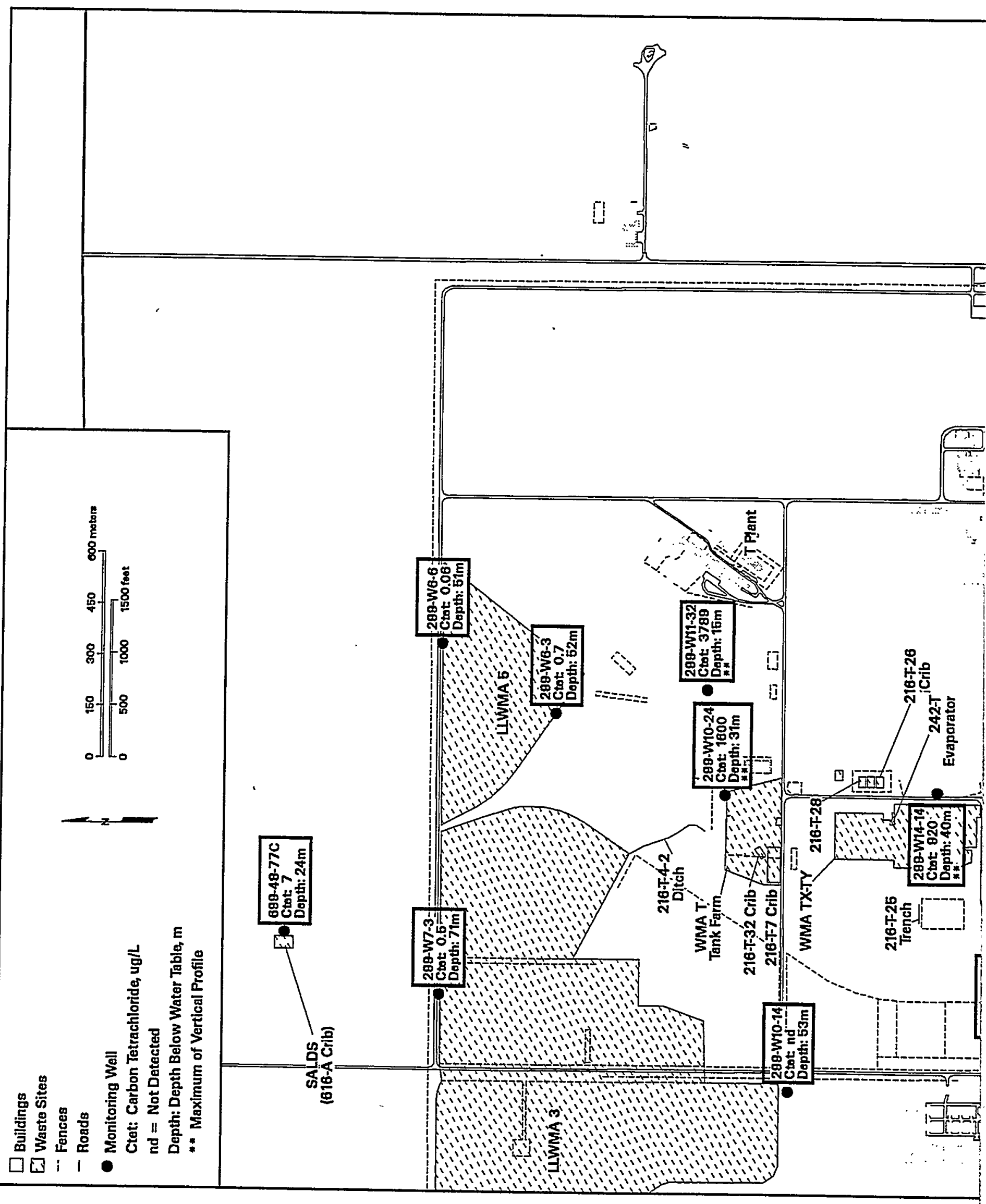




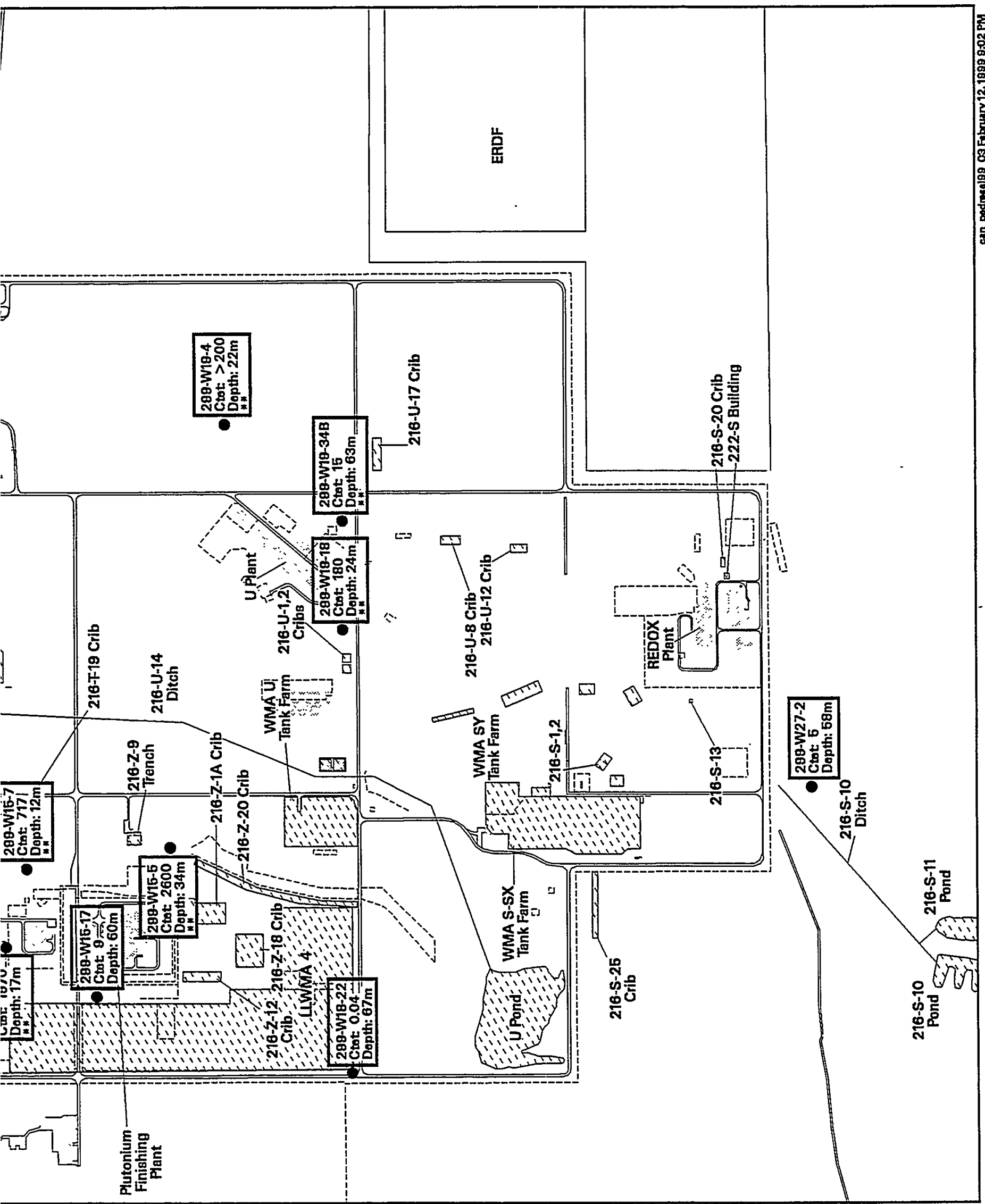




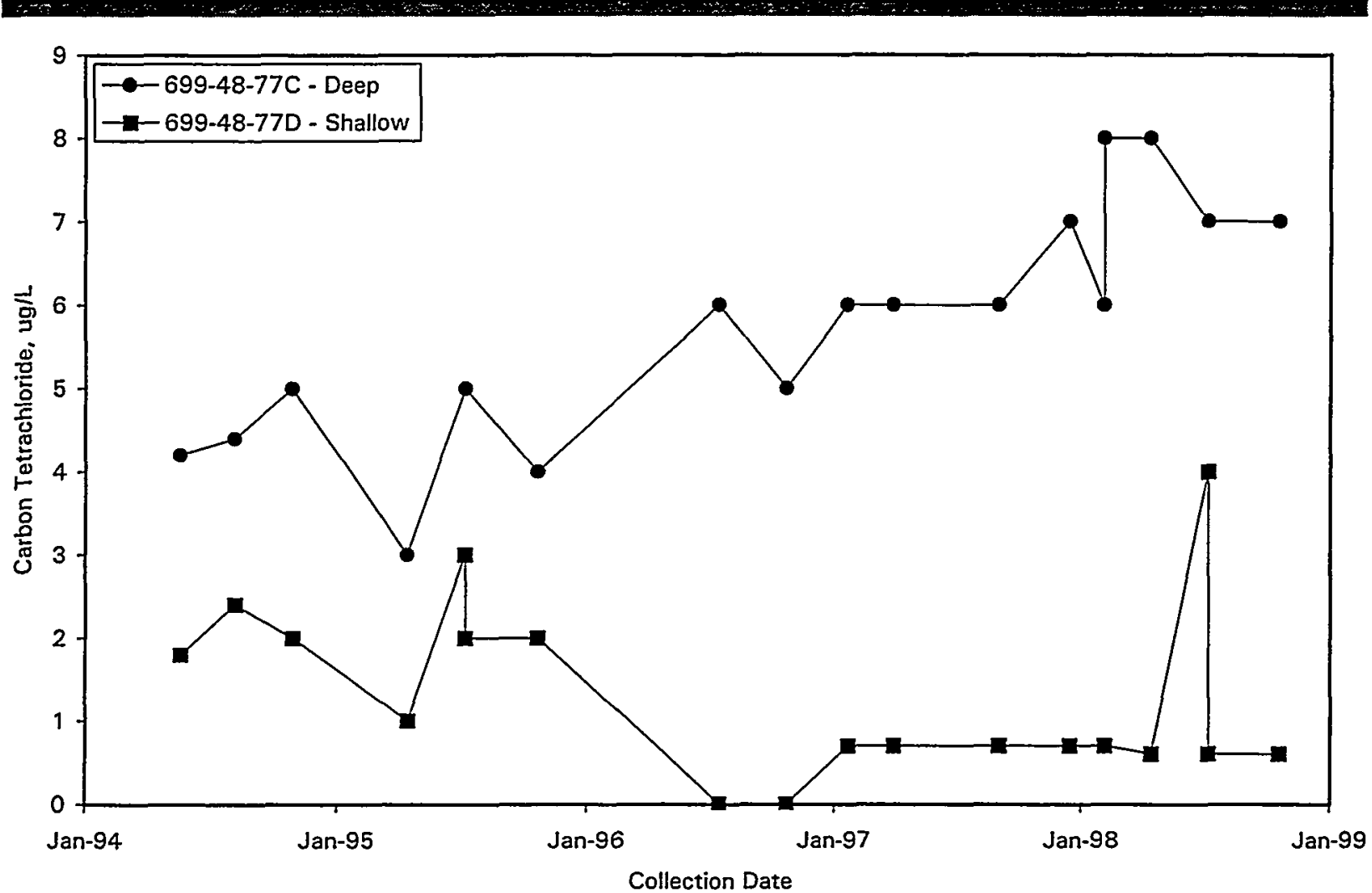

Figure 5.9-24. Carbon Tetrachloride Concentrations in Wells 699-48-77C and 699-48-77D Monitoring State-Approved Land-Disposal Site

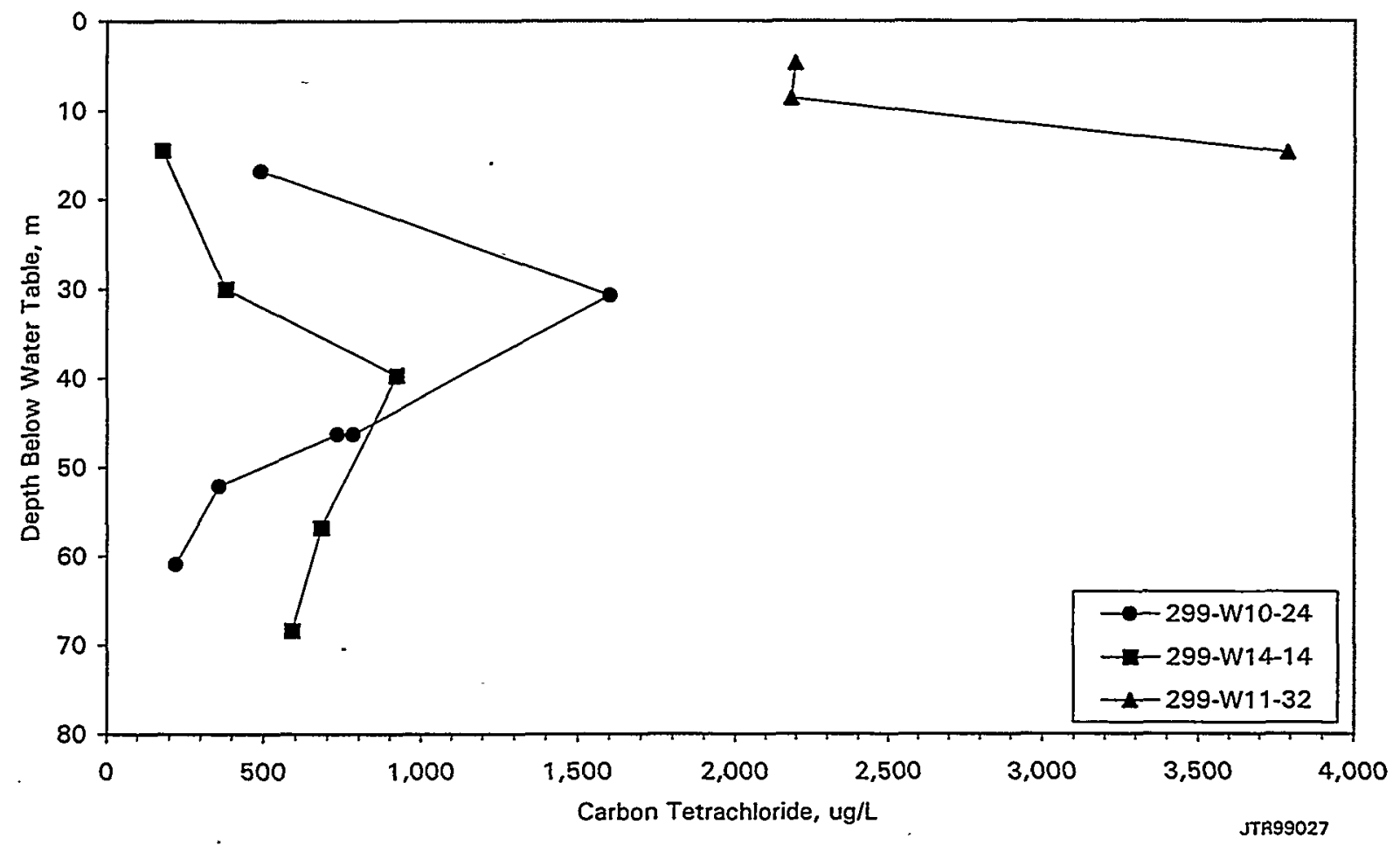

Figure 5.9-25. Vertical Distribution of Carbon Tetrachloride in Wells 299-W10-24, 299-W14-14, and 299-W11-32 


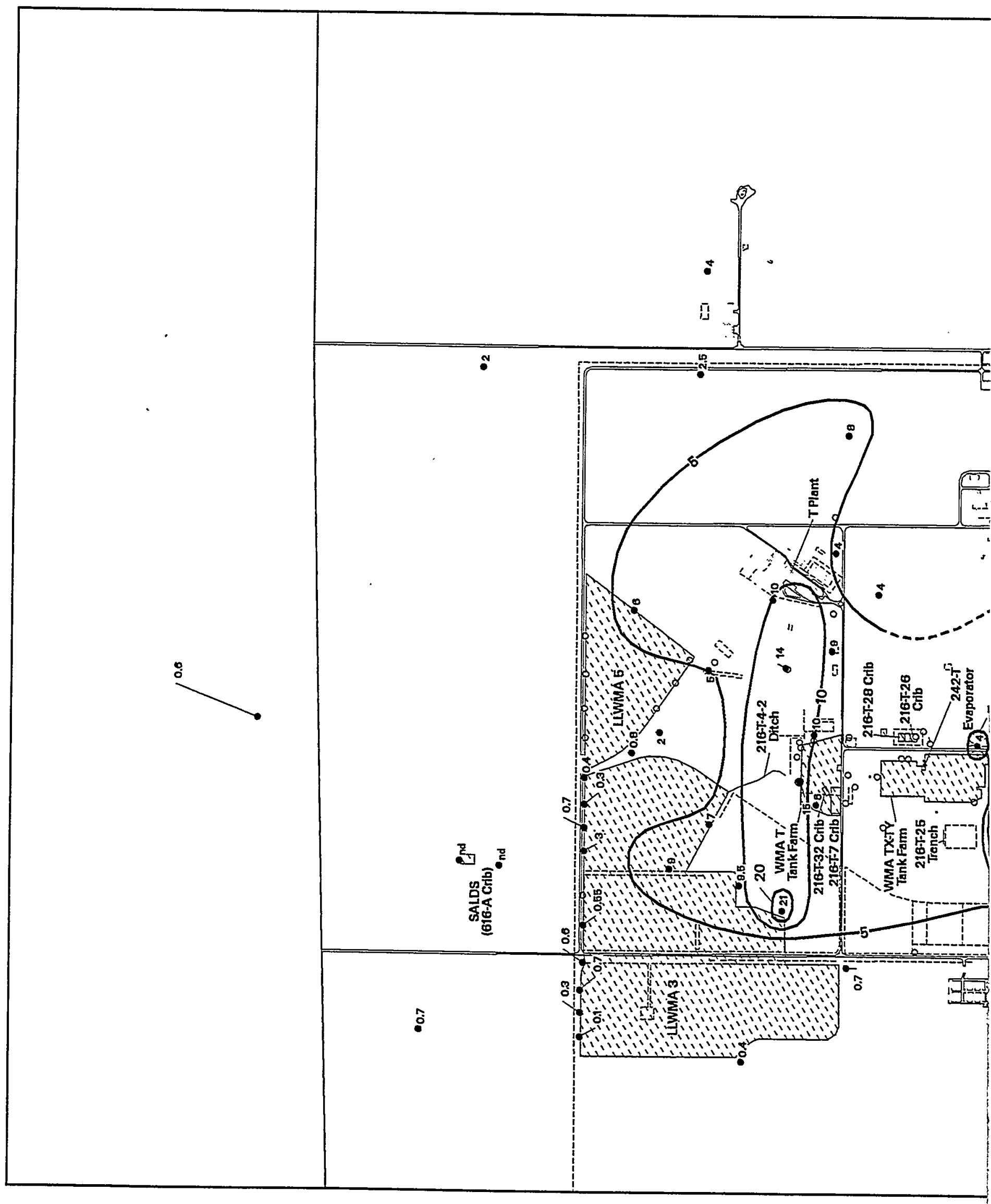




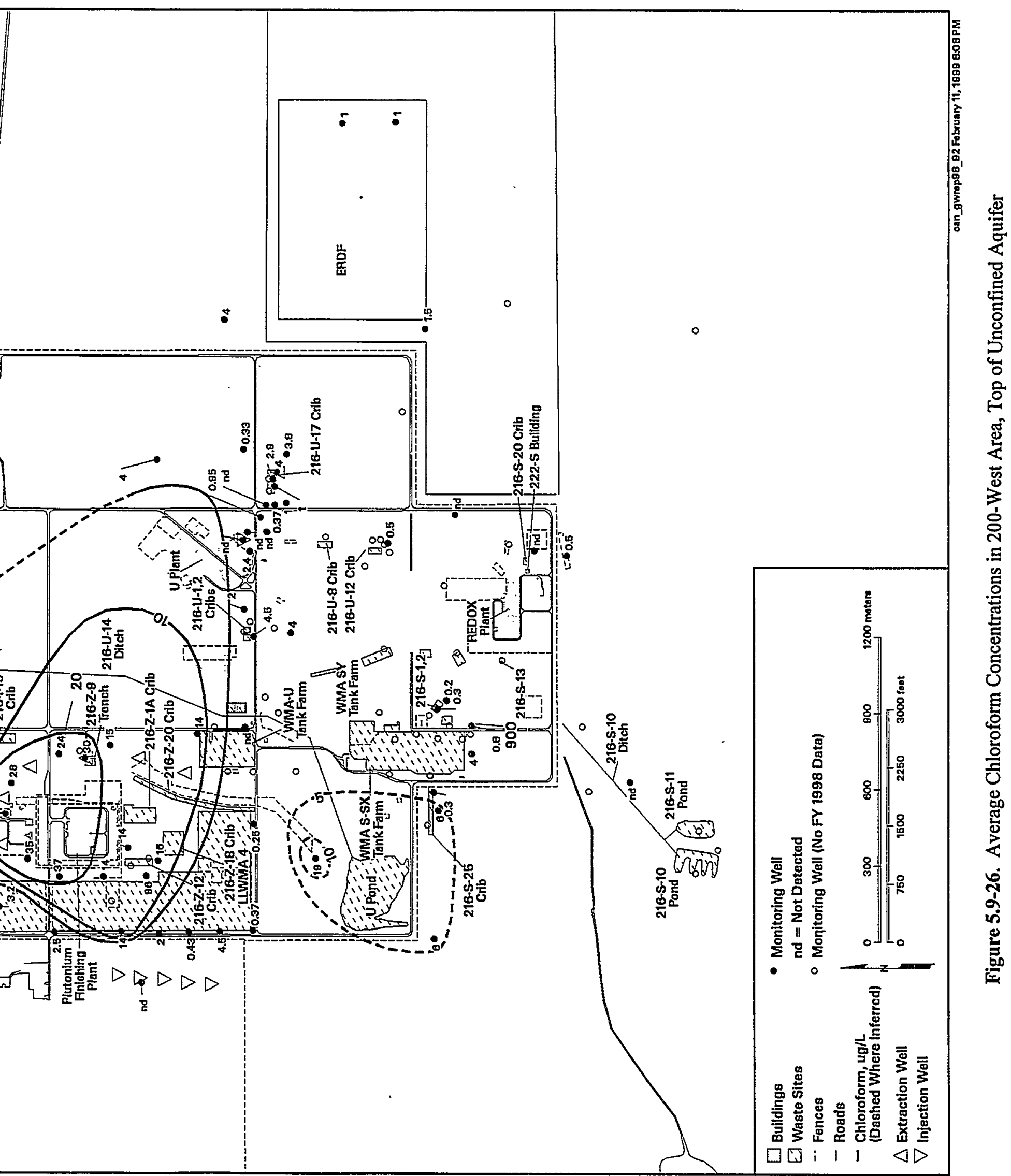



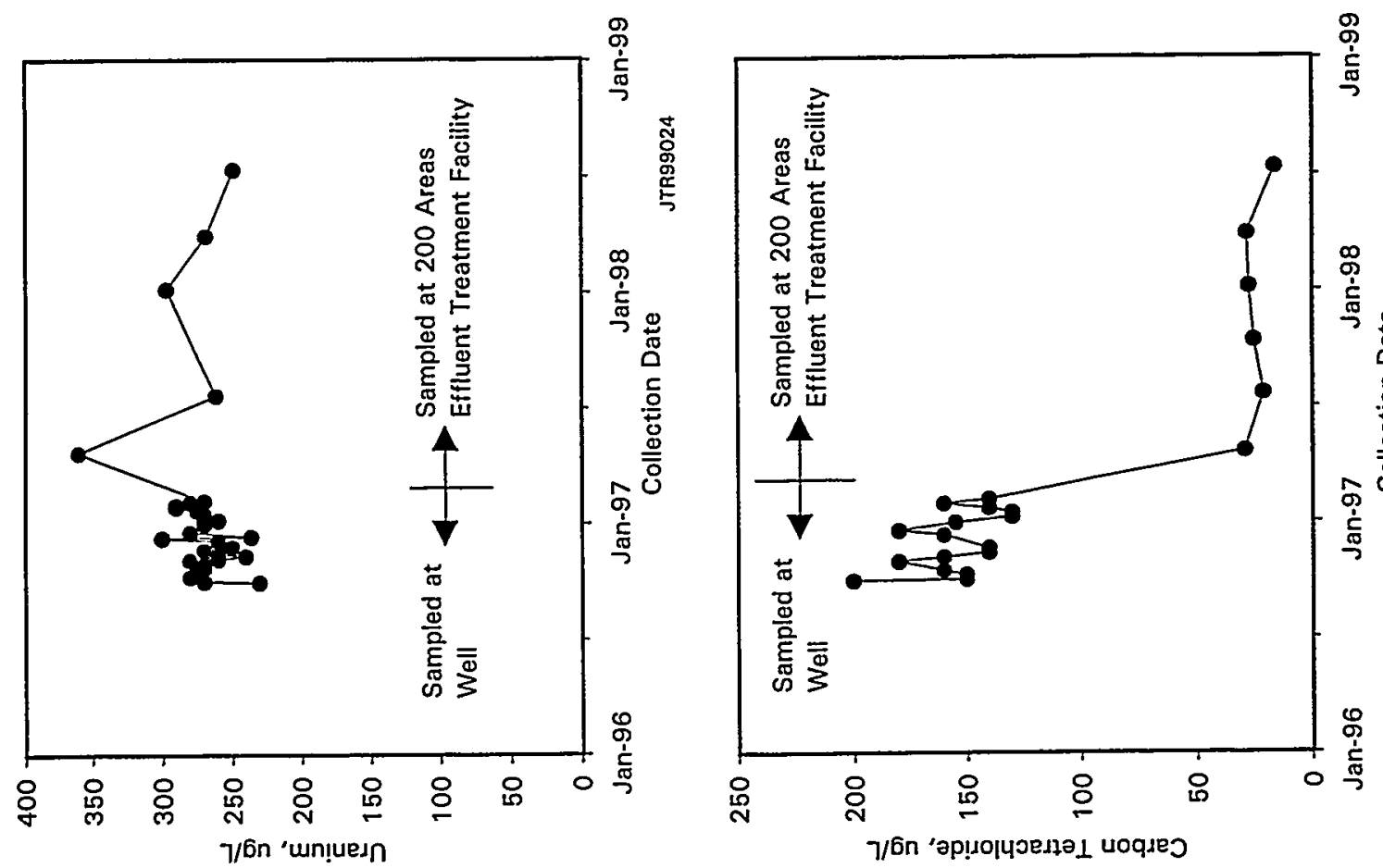


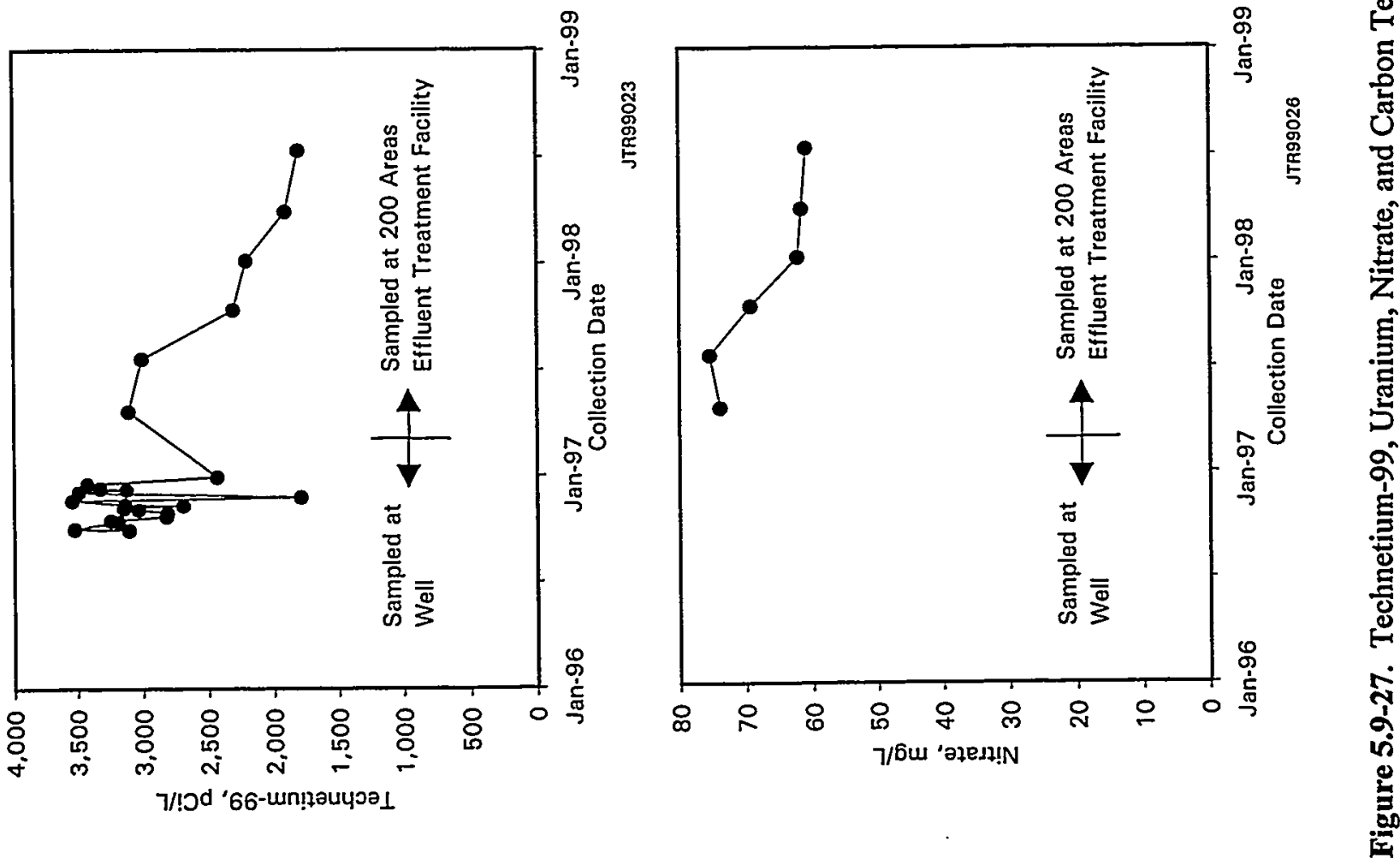


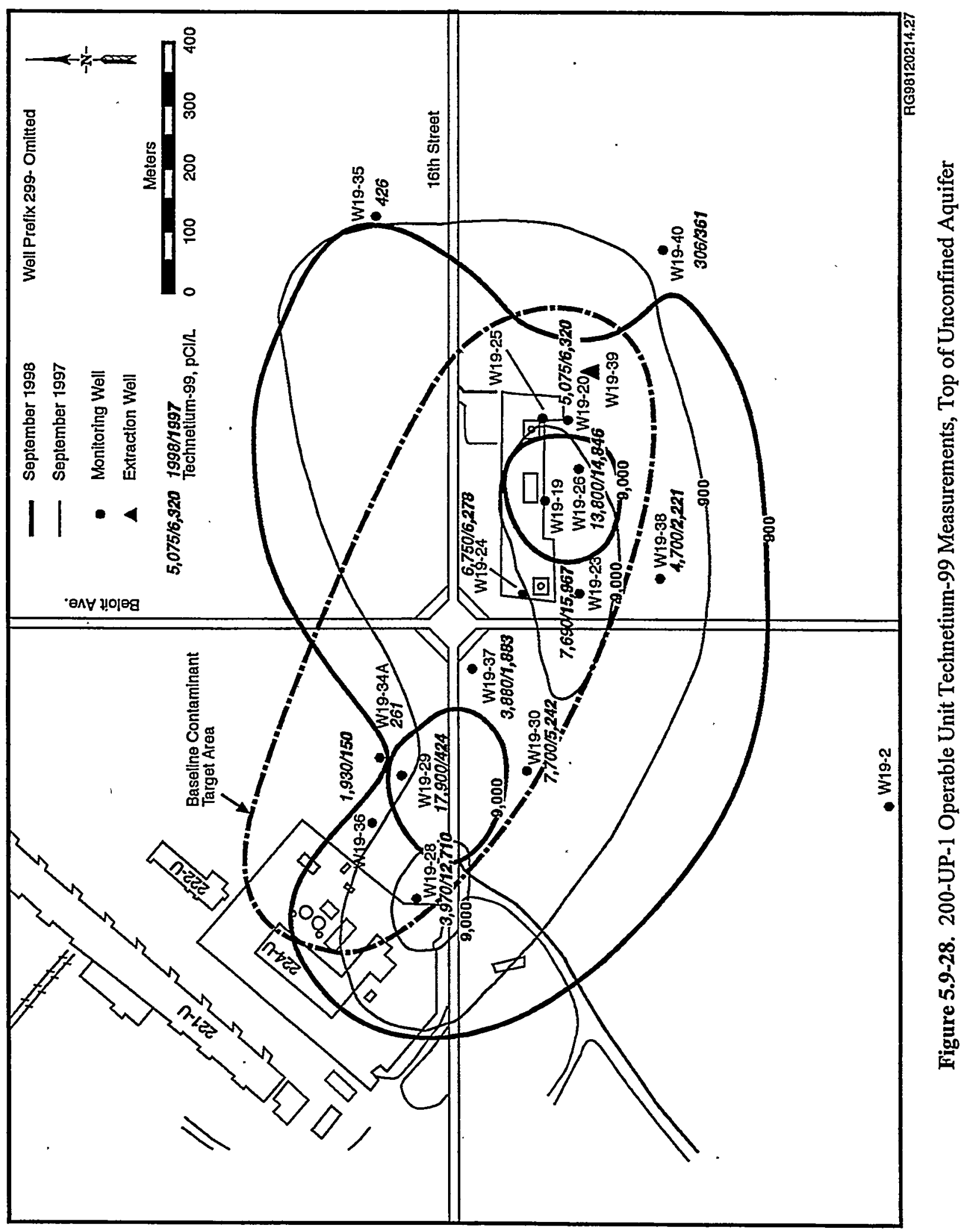




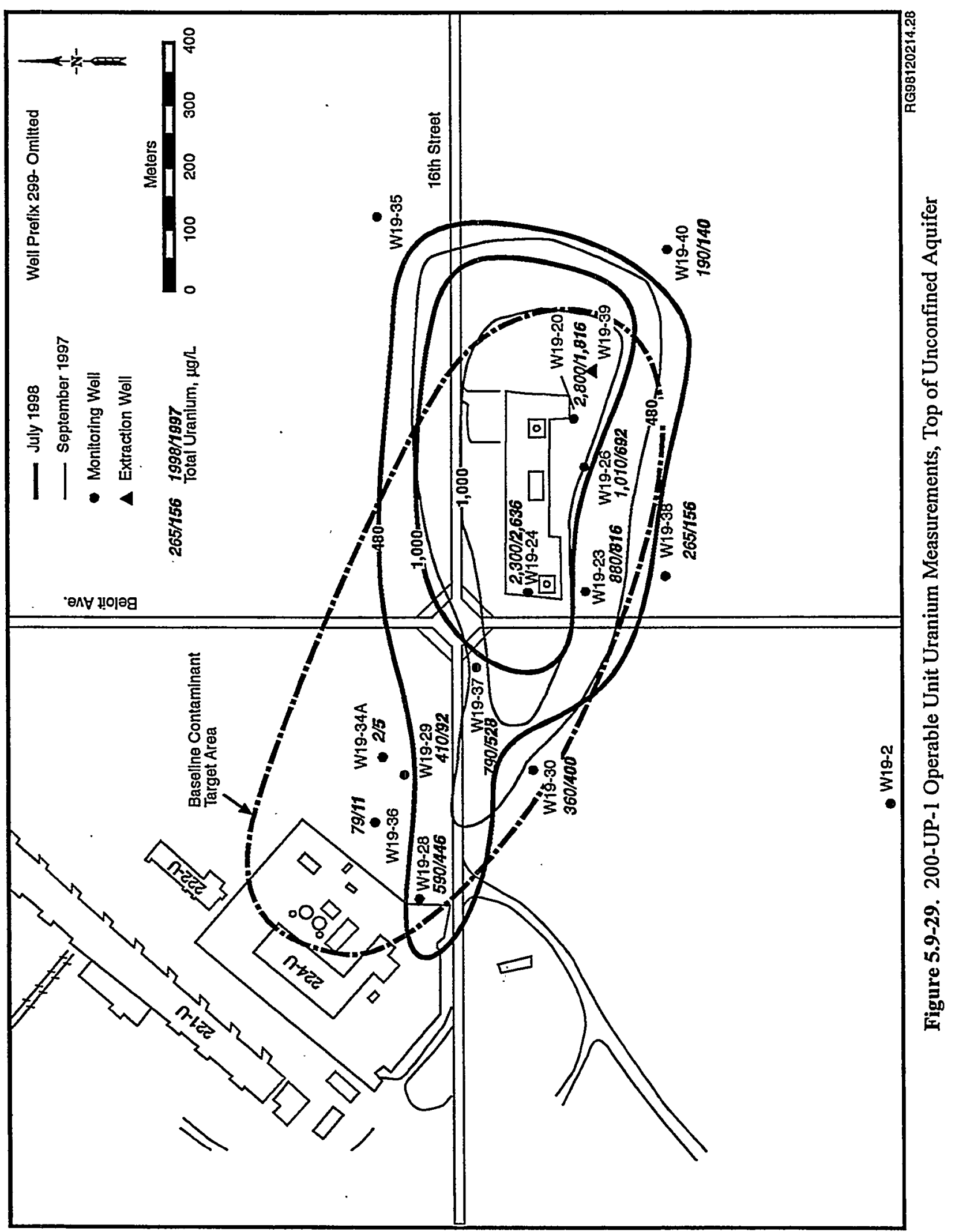




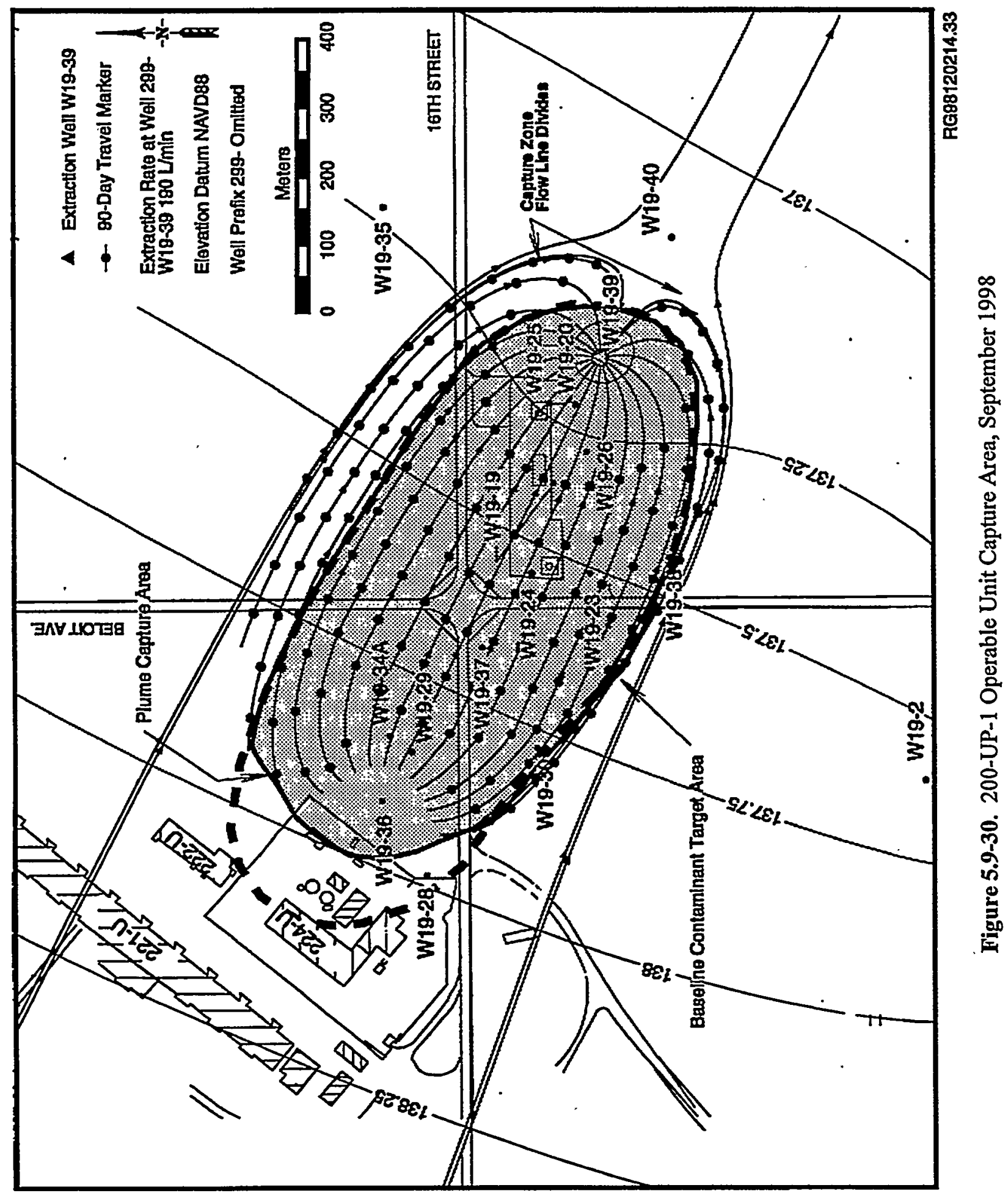




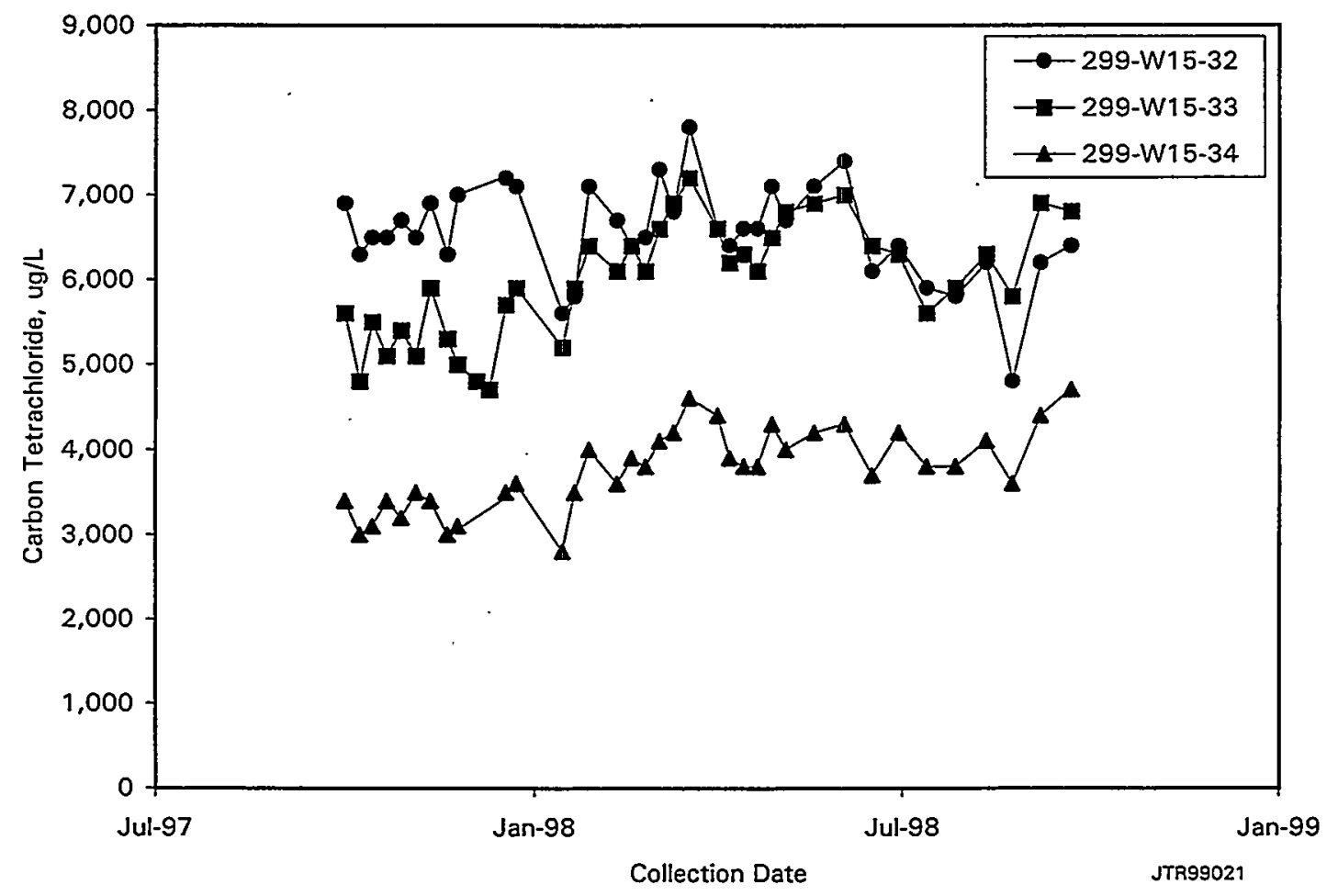

Figure 5.9-31. Carbon Tetrachloride Concentrations at 200-ZP-1 Operable Unit Extraction Wells

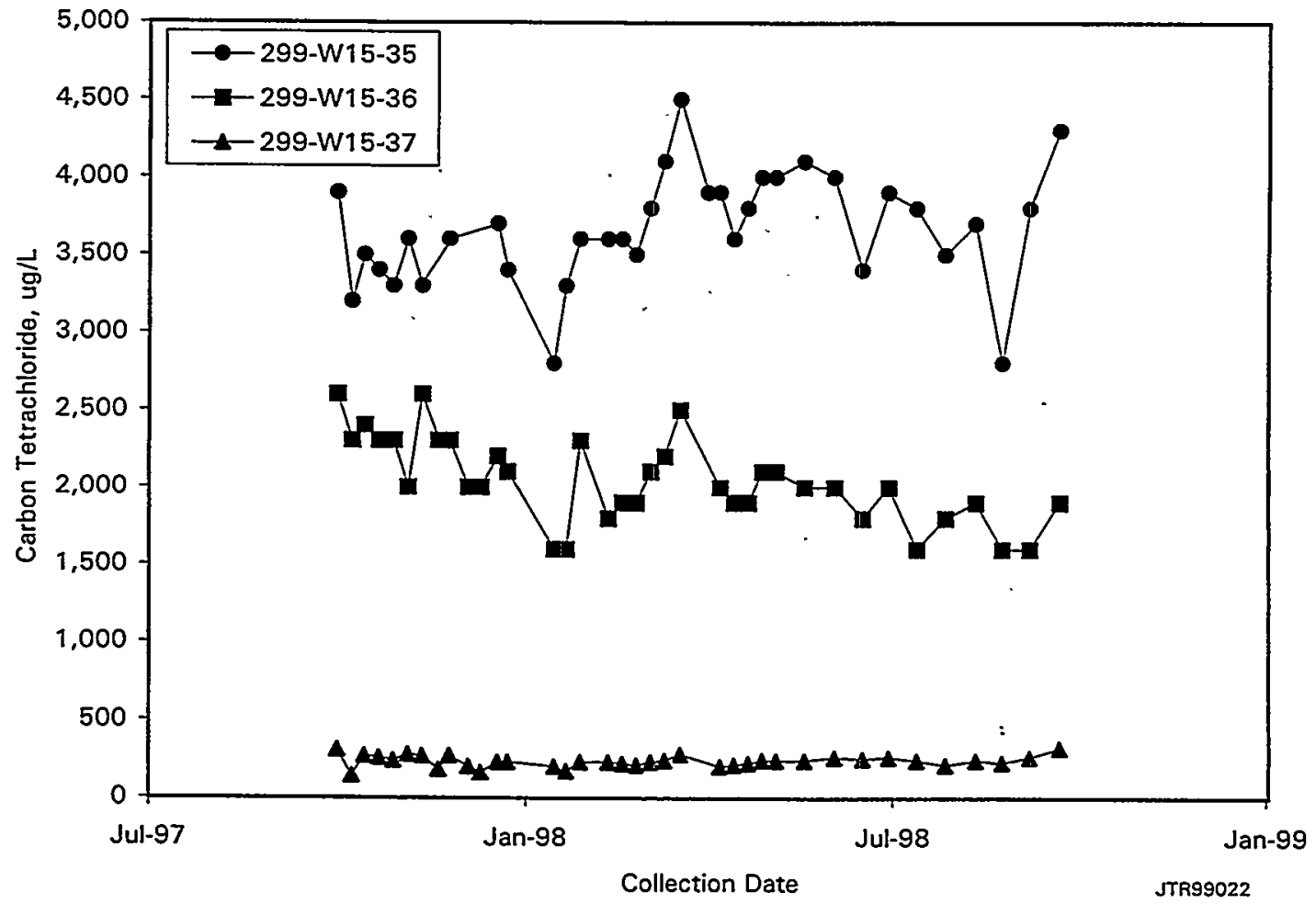

Figure 5.9-32. Carbon Tetrachloride Concentrations at 200-ZP-1 Operable Unit Extraction Wells 


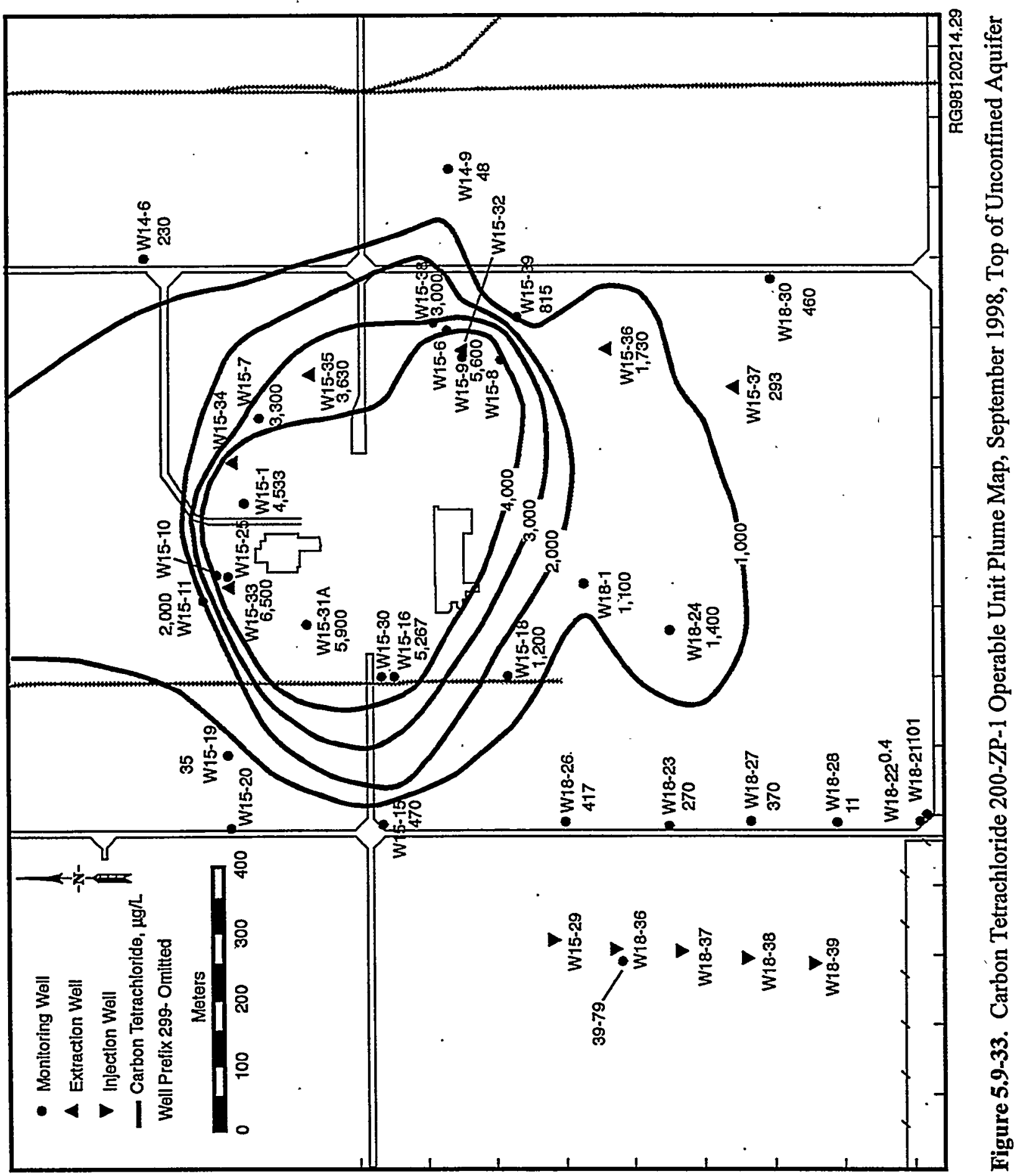




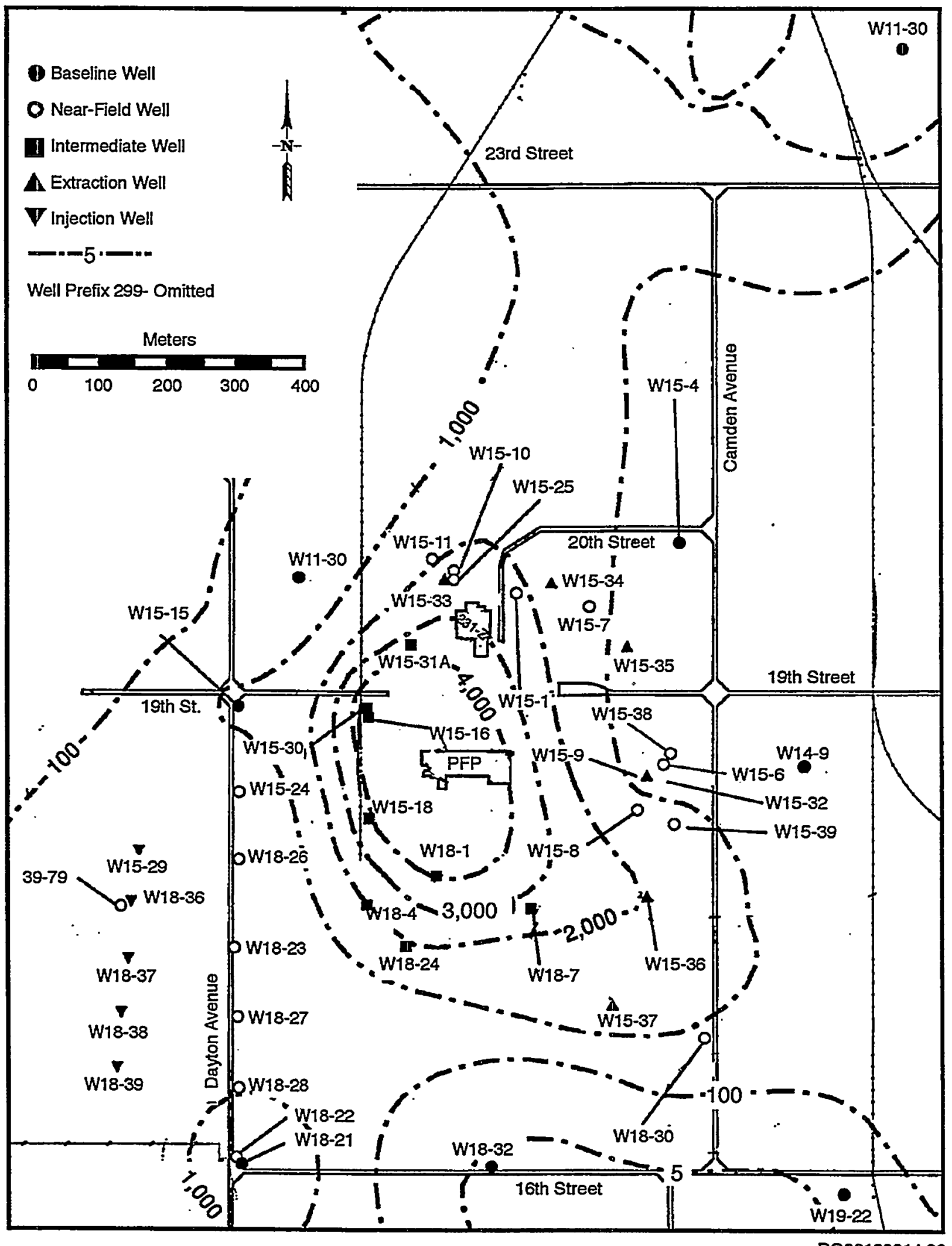

RG98120214.30

Figure 5.9-34. Carbon Tetrachloride 200-ZP-1 Operable Unit Baseline Plume Map, June 1996, Top of Unconfined Aquifer 


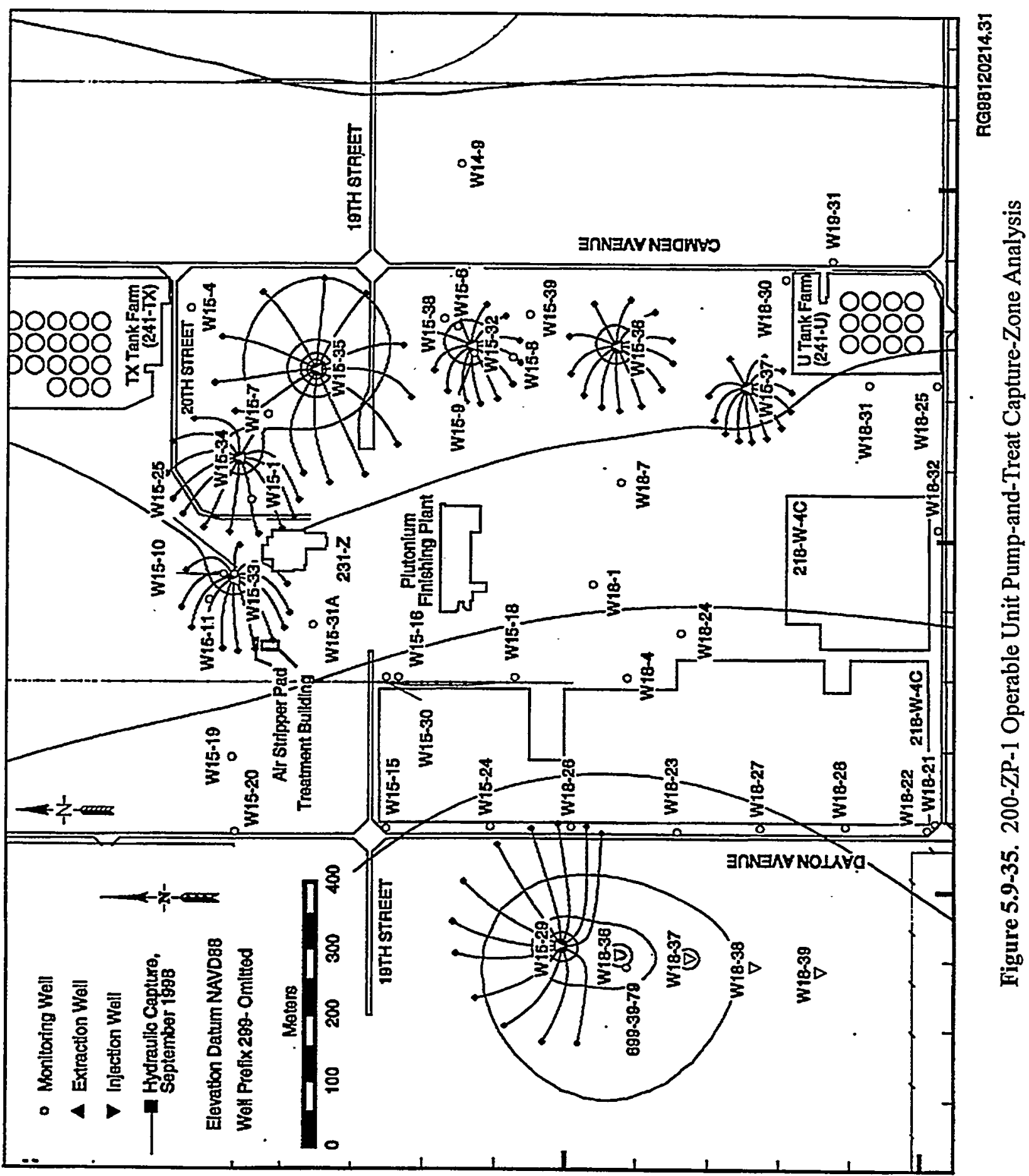




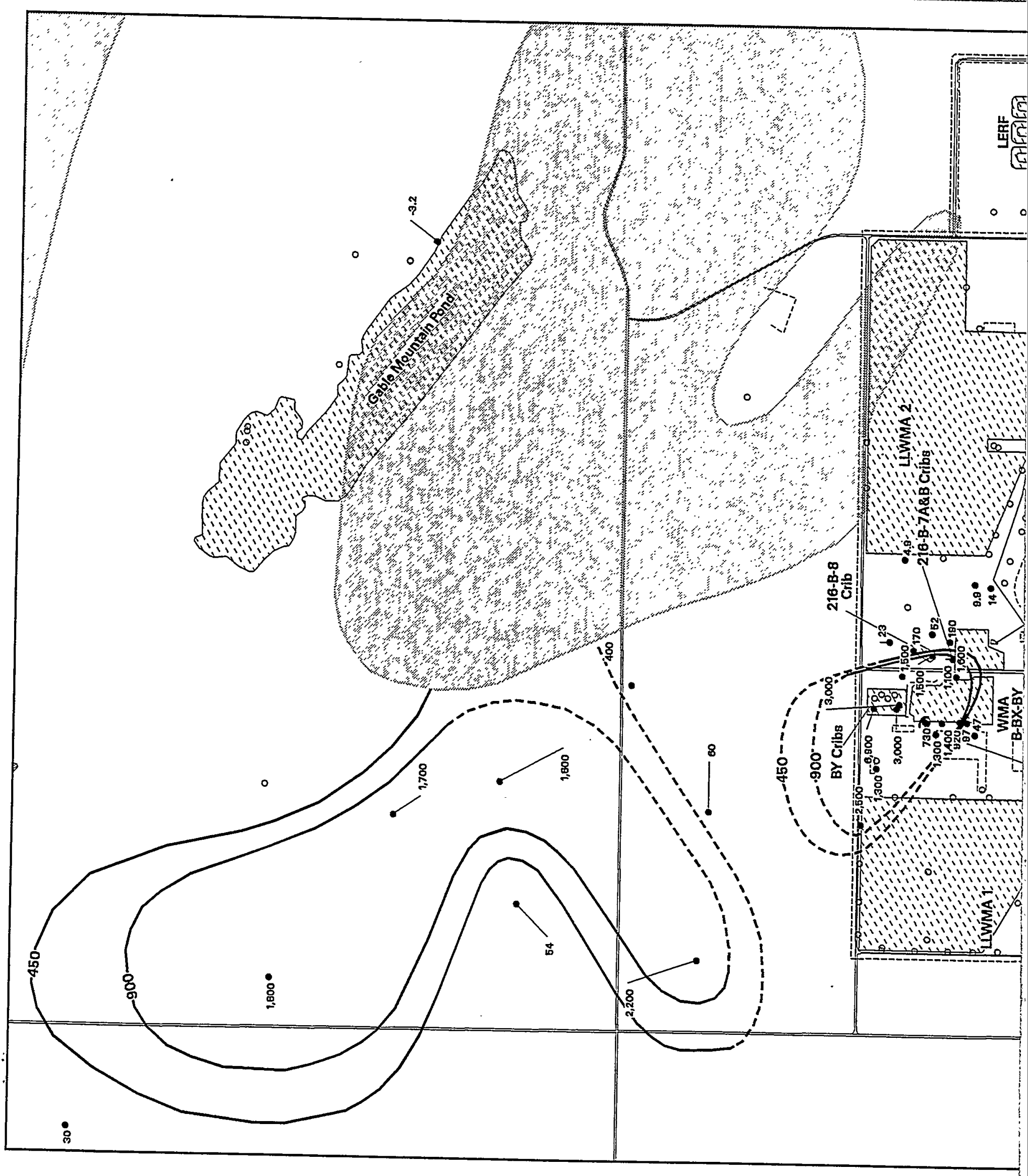




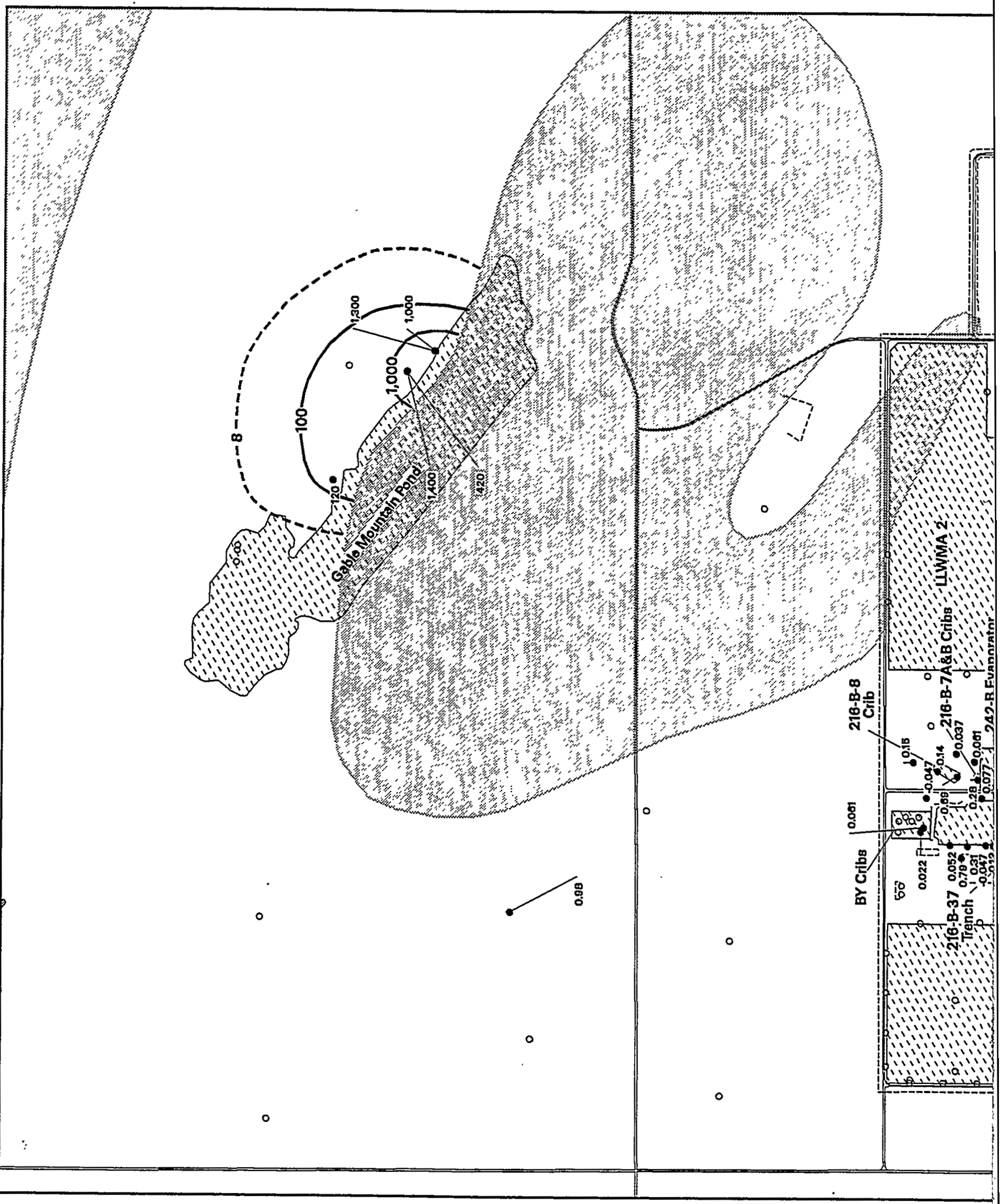




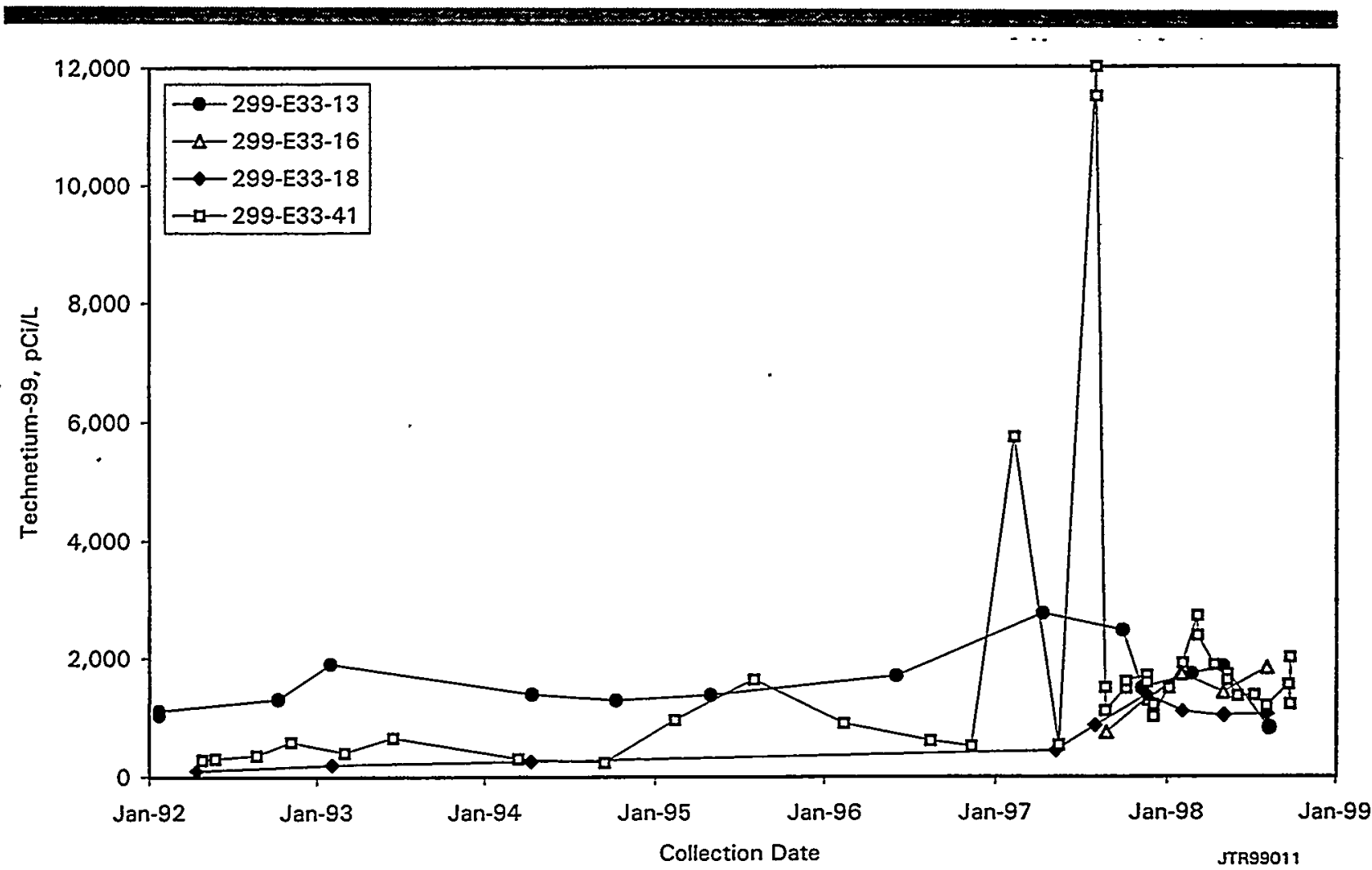

Figure 5.10-3. Technetium-99 Activities in Key Wells on East Side of Waste Management Area B-BX-BY

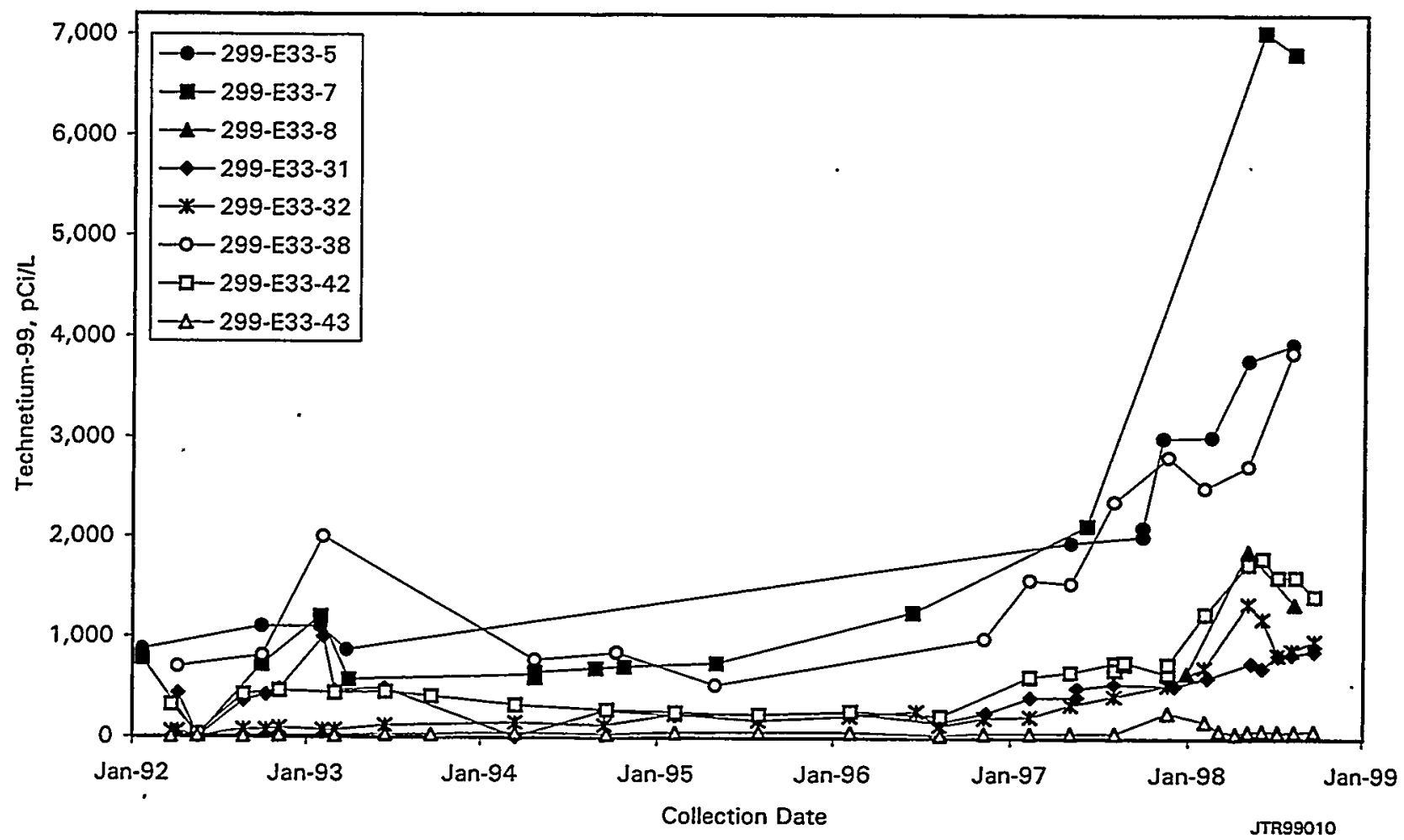

Figure 5.10-4. Technetium-99 Activities in Key Wells North and West of Waste Management Area B-BX-BY 


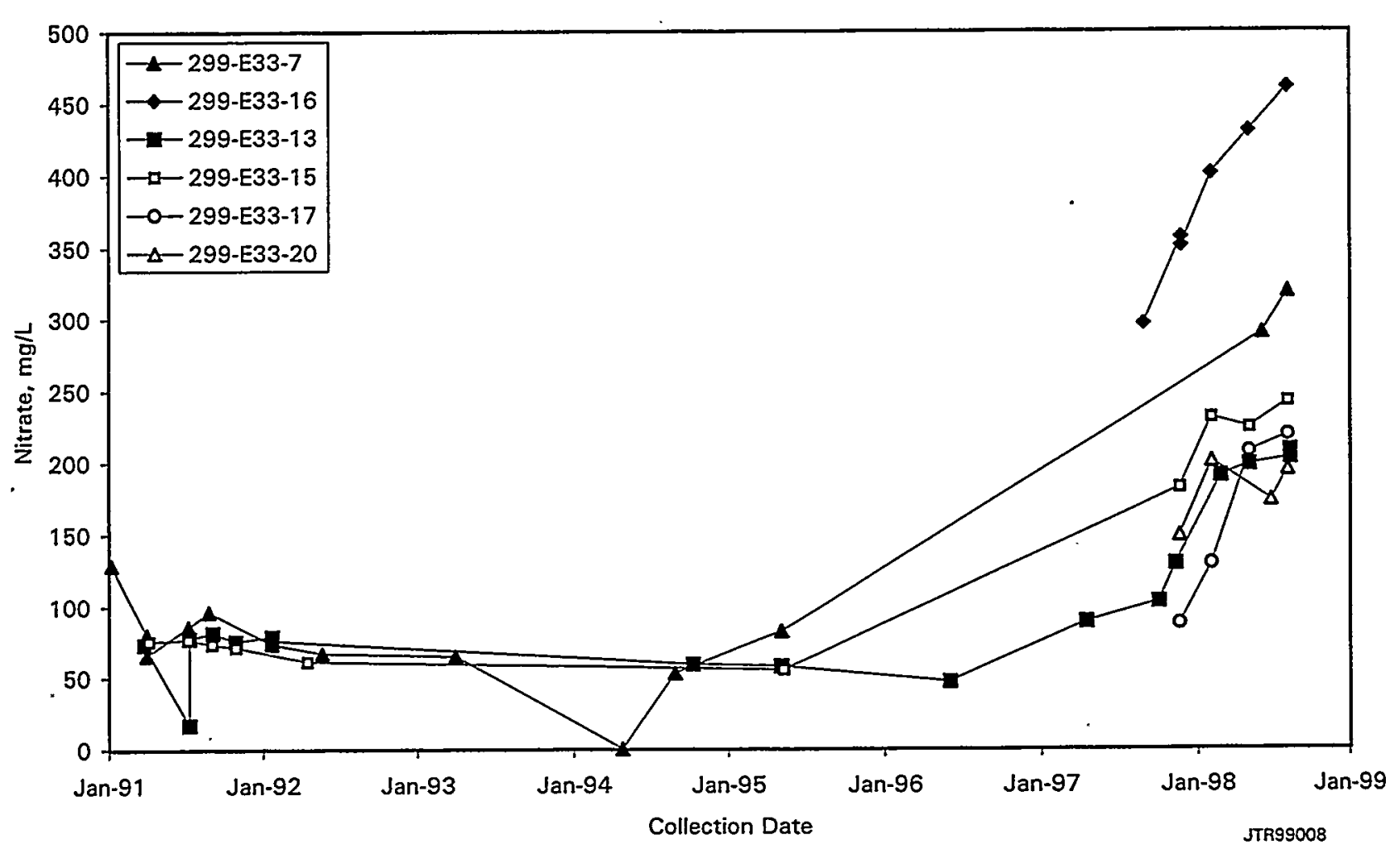

Figure 5.10-5(a). Nitrate Concentrations in Wells East of Waste Management Area B-BX-BY

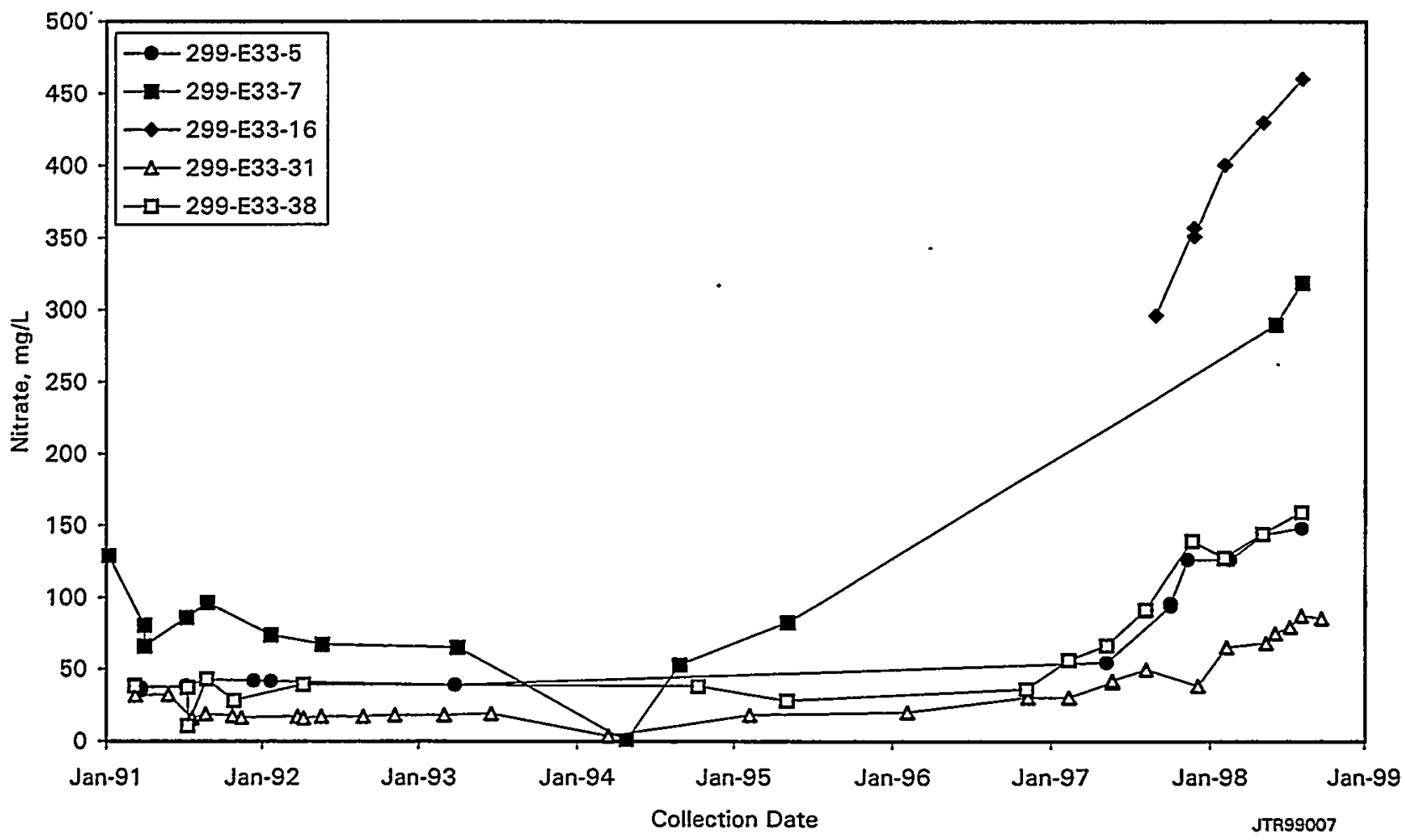

Figure 5.10-5(b). Nitrate Concentrations in Wells North and Along West Side of Waste Management Area B-BX-BY 


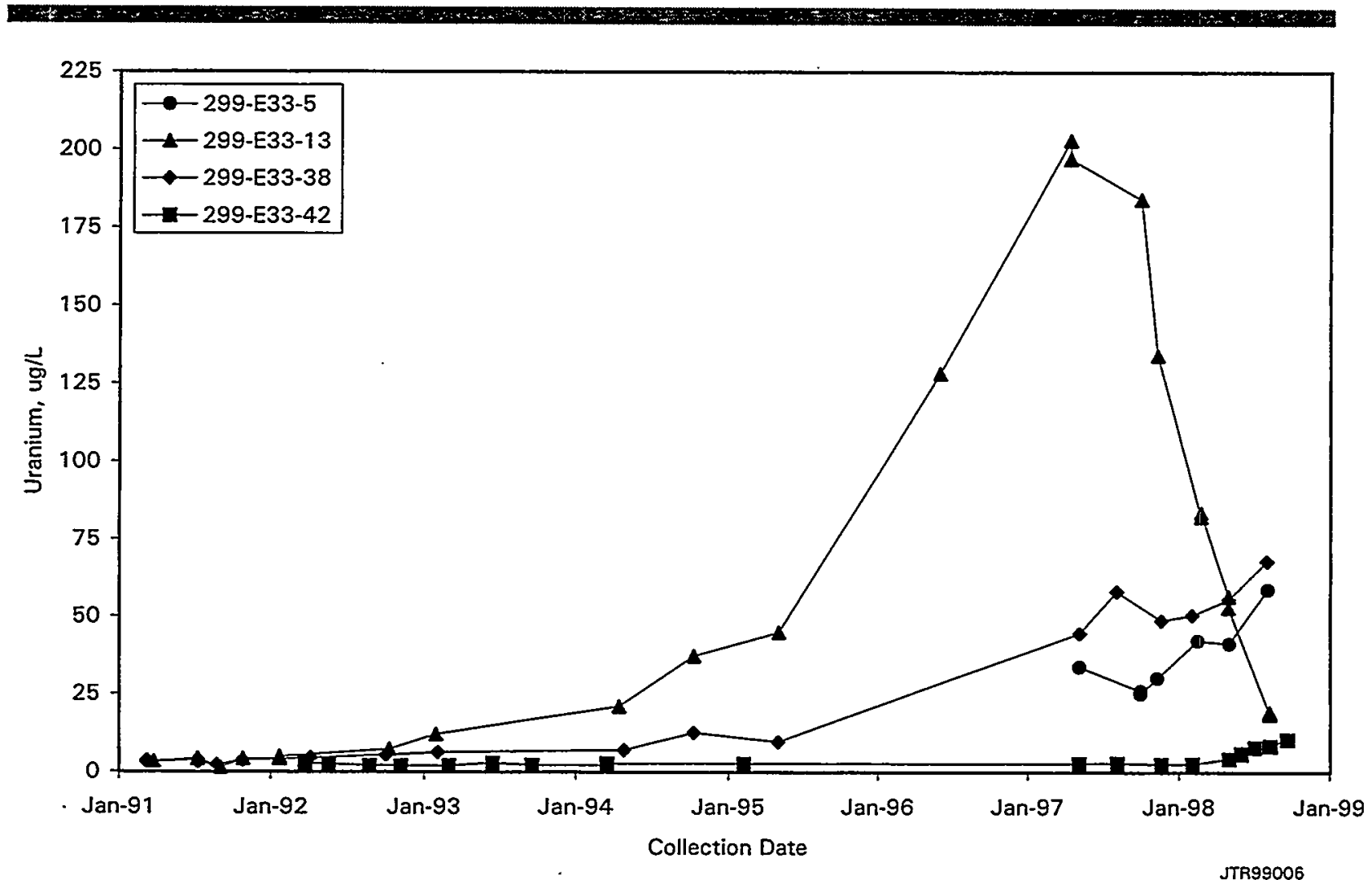

Figure 5.10-6. Uranium Concentration in Wells North and East of Waste Management Area B-BX-BY

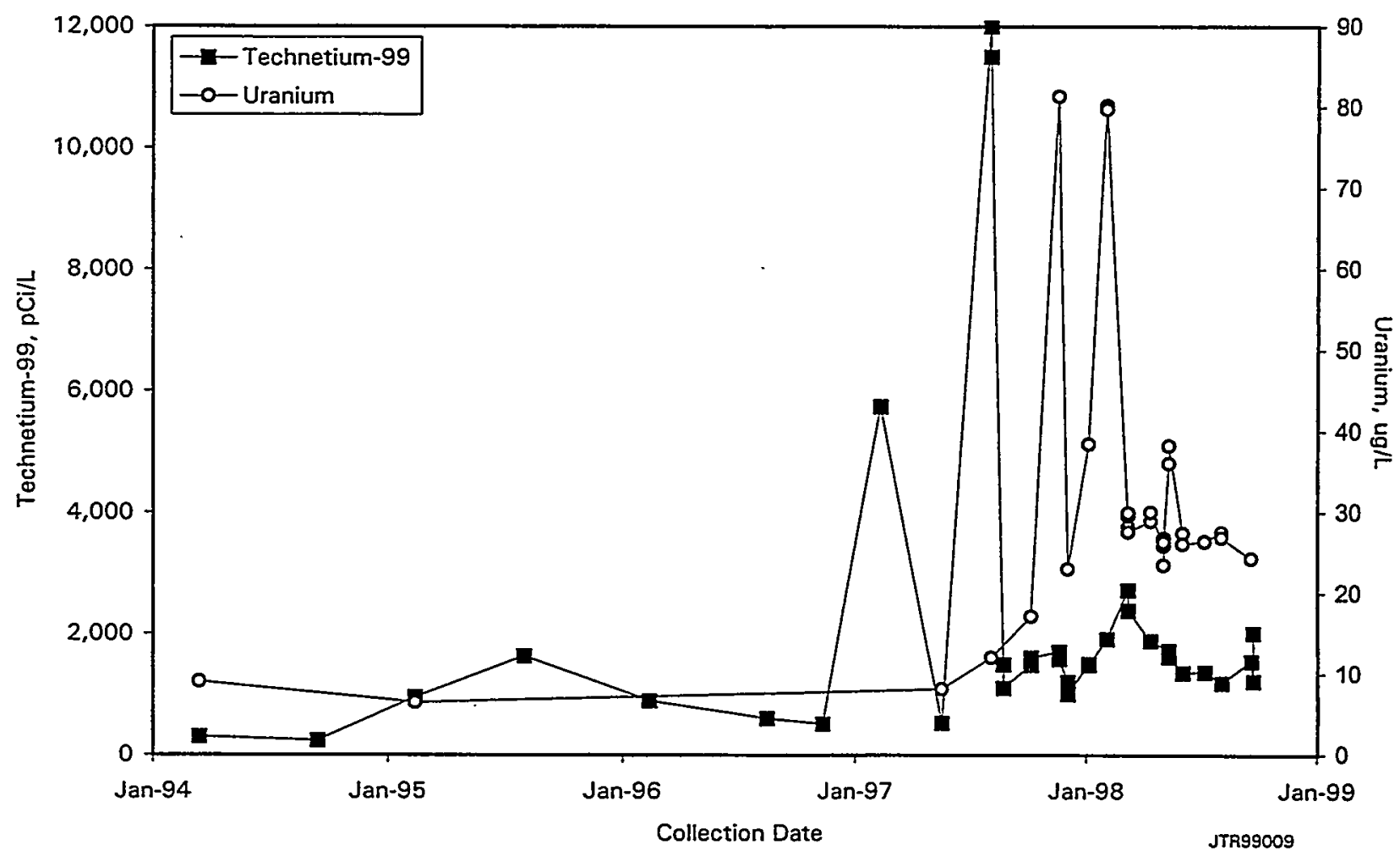

Figure 5.10-7. Comparison of Technetium-99 Versus Uranium in Well 299-E33-41 


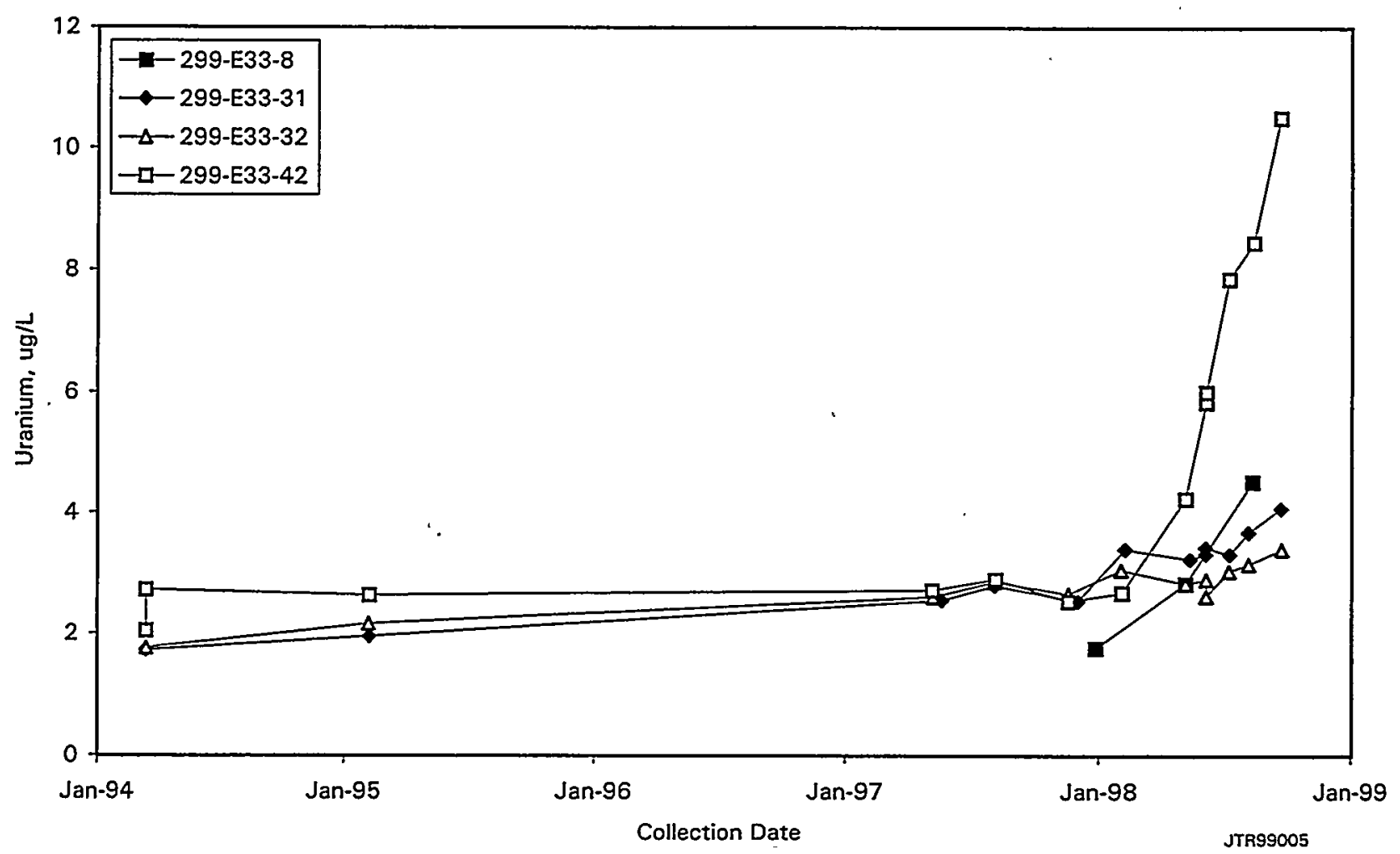

Figure 5.10-8. Uranium Concentration in Wells West of Waste Management Area B-BX-BY

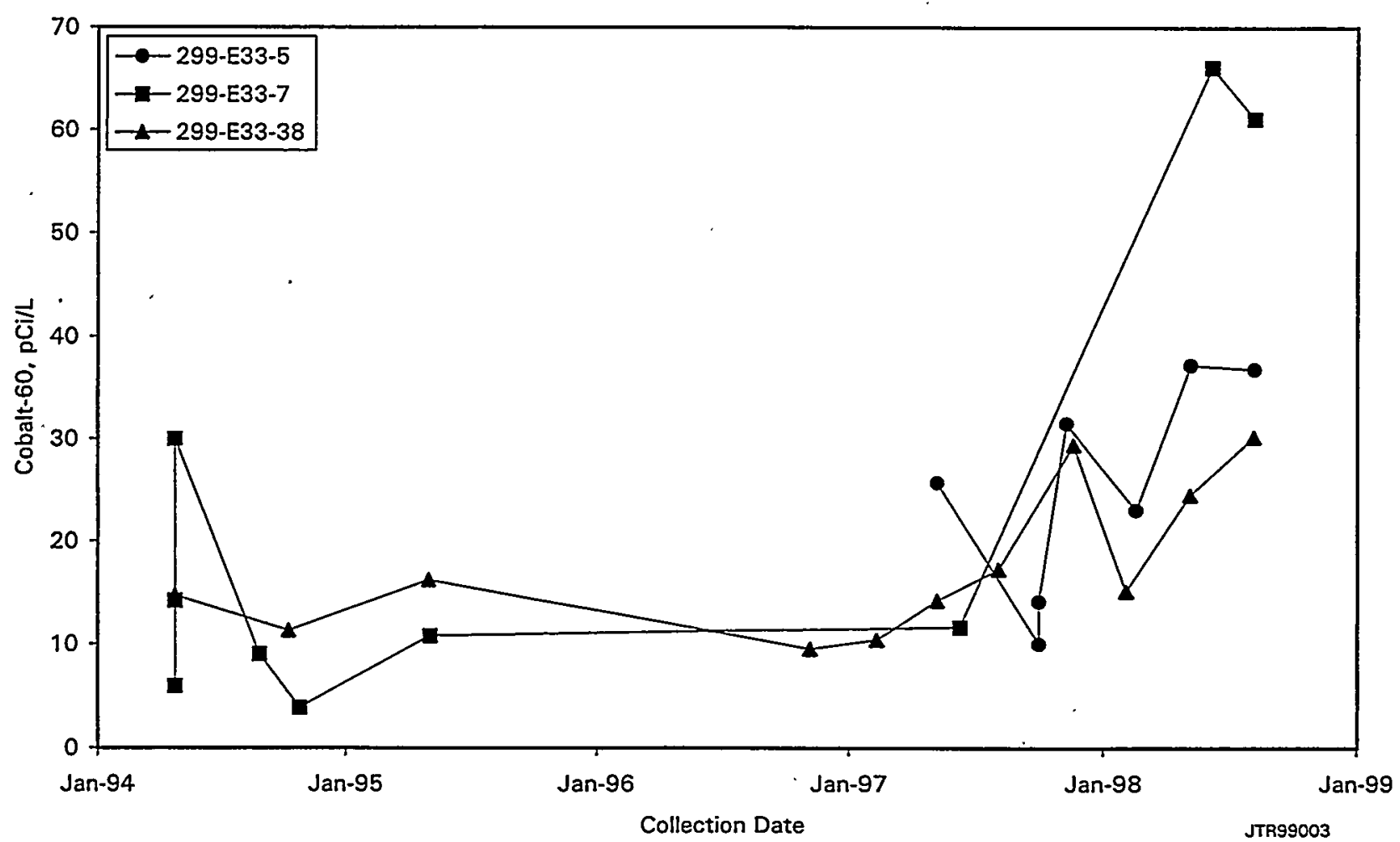

Figure 5.10-9. Cobalt-60 Activities in Wells North of Waste Management Area B-BX-BY 


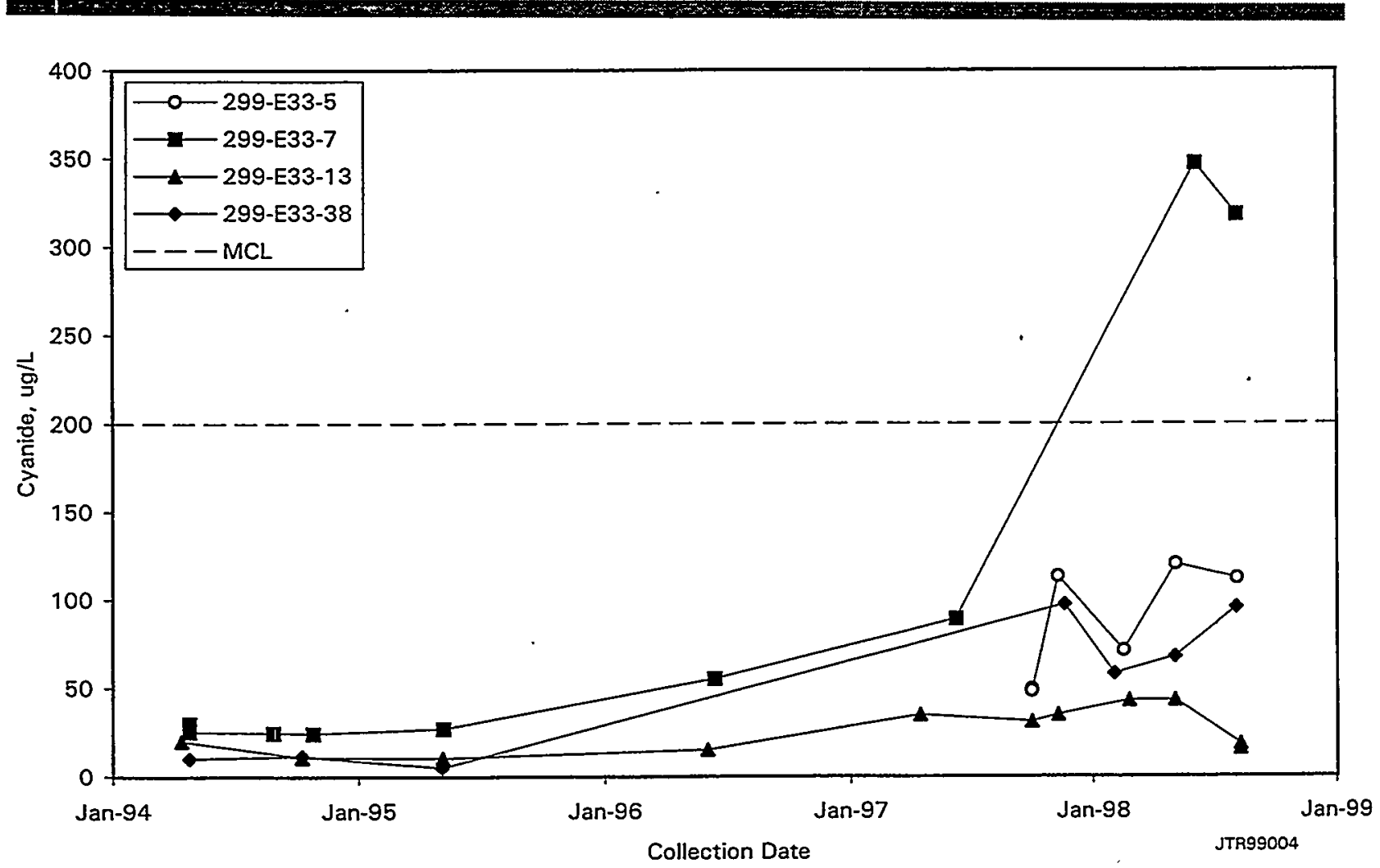

Figure 5.10-10. Cyanide Concentrations in Wells Monitoring Waste Management Area B-BX-BY

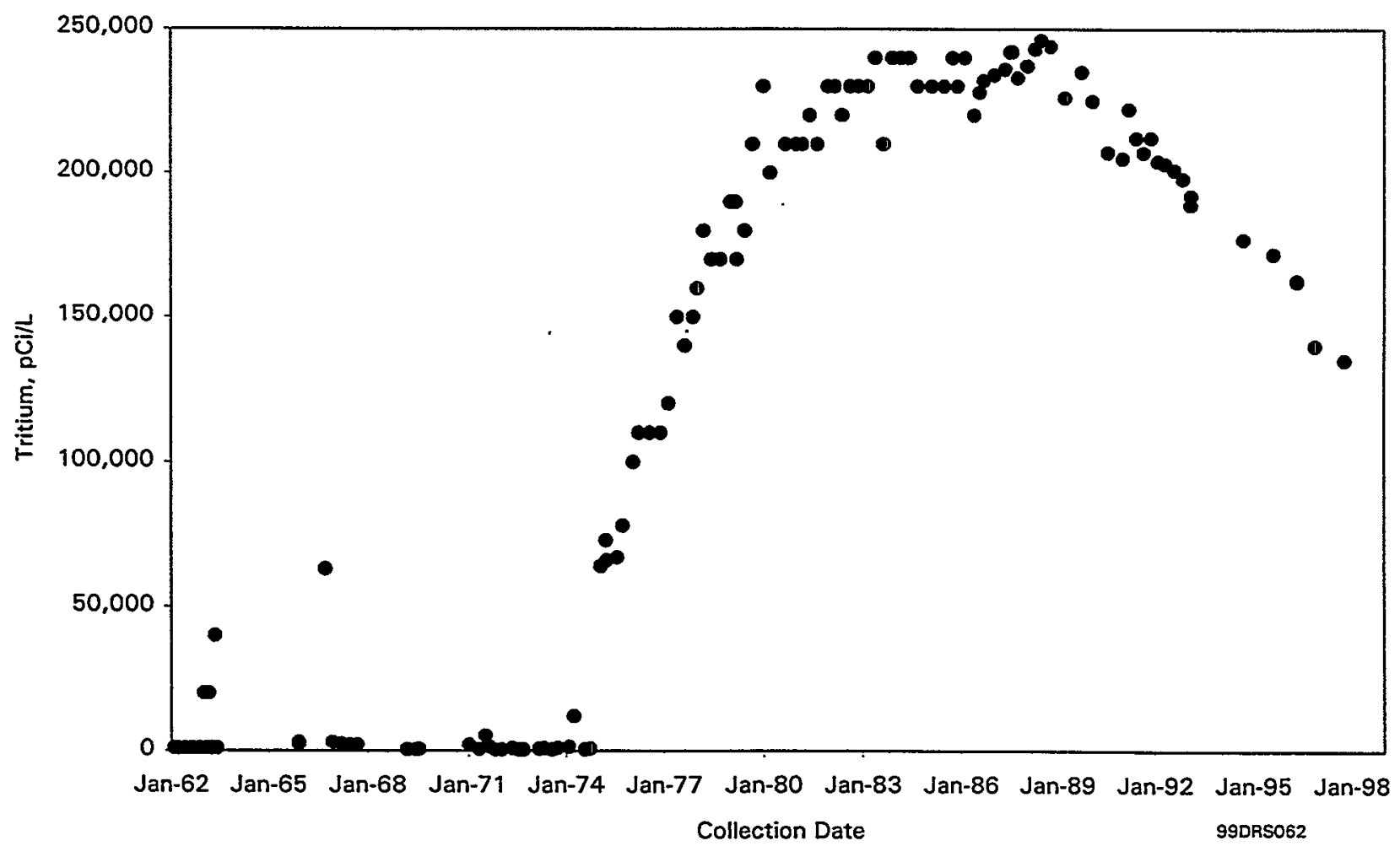

Figure 5.10-11. Tritium Activities in Well 699-40-1 


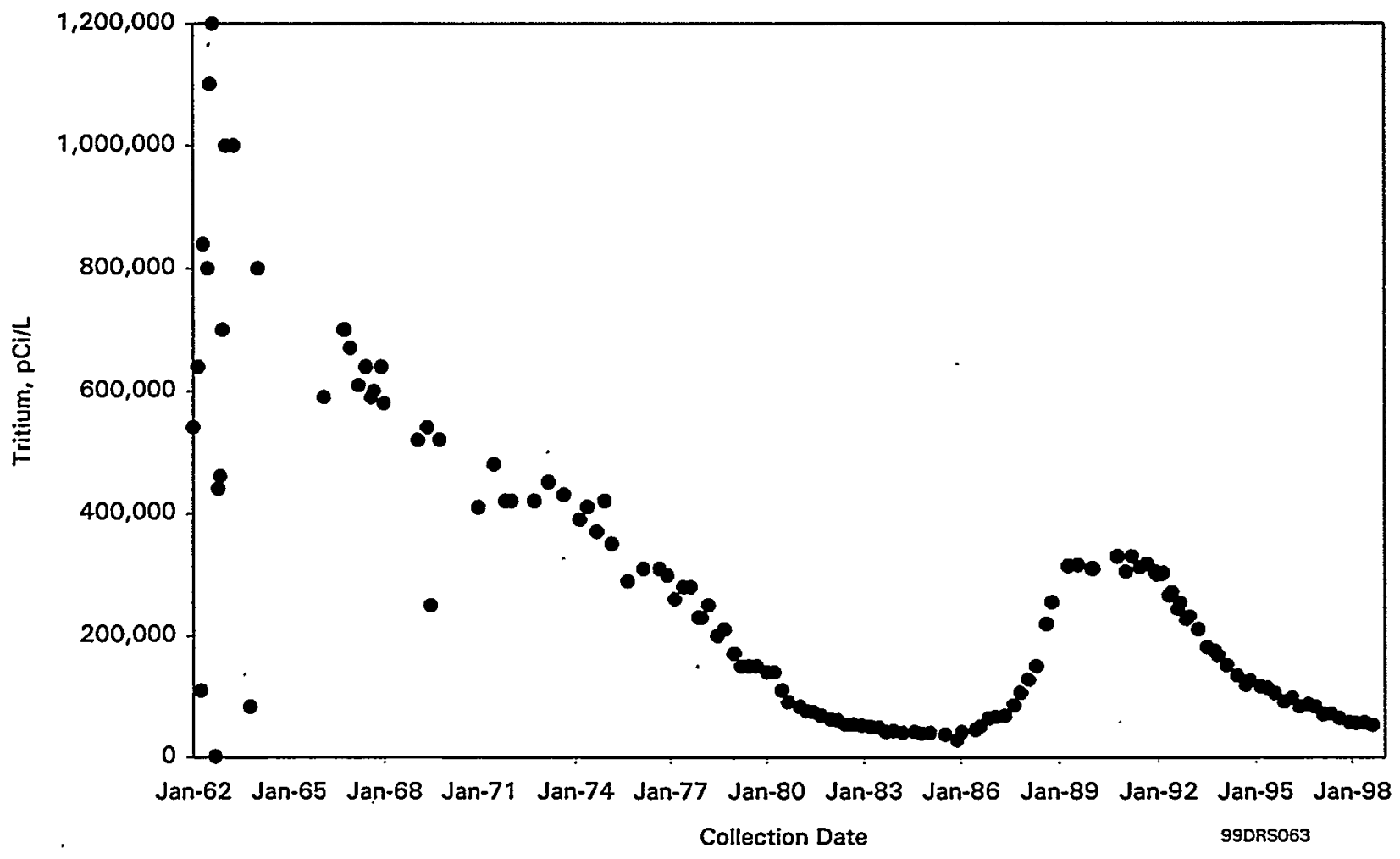

Figure 5.10-12. Tritium Activities in Well 699-24-33

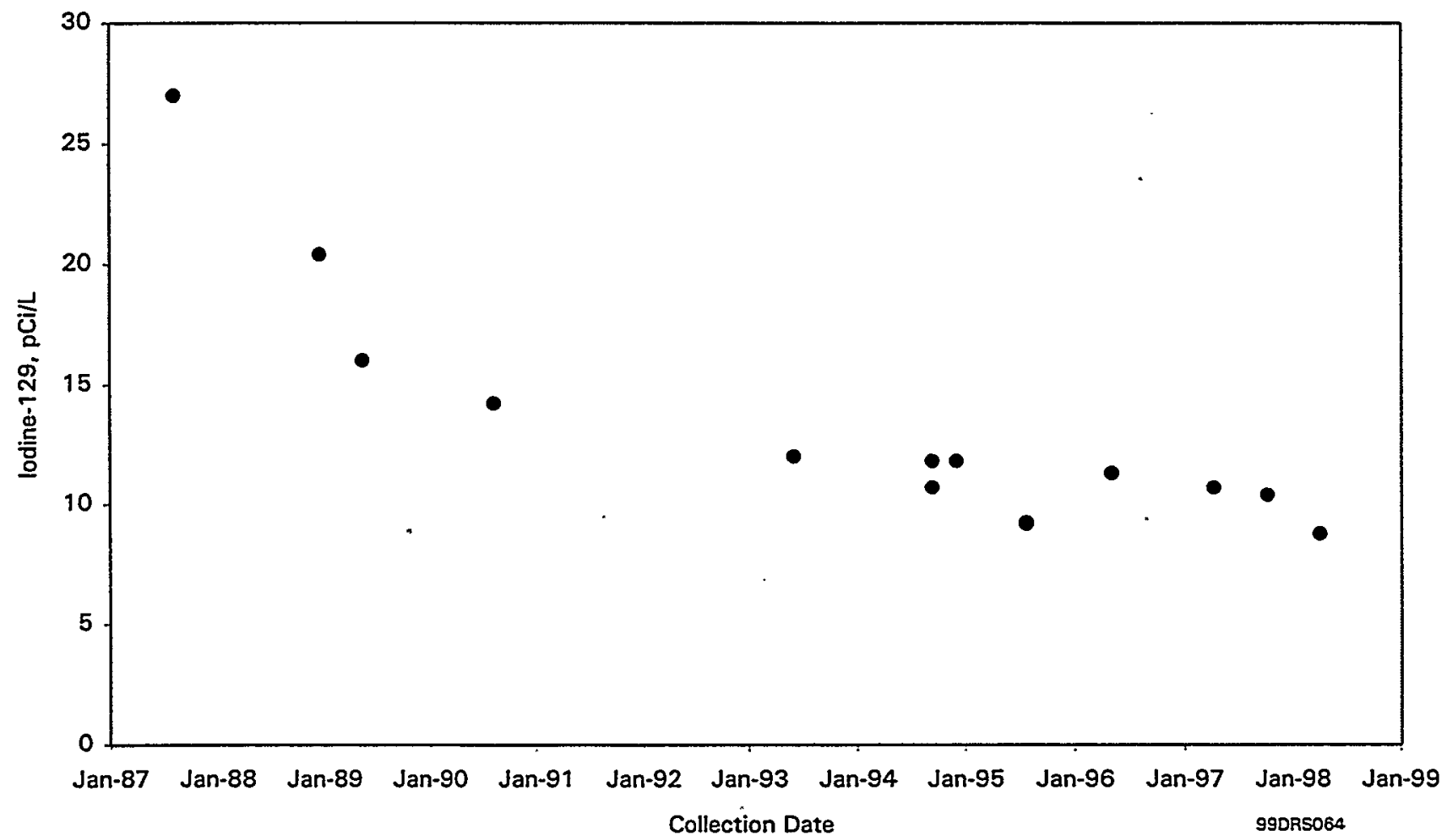

Figure 5.10-13. Iodine-129 Activities in Well 299-E17-9 


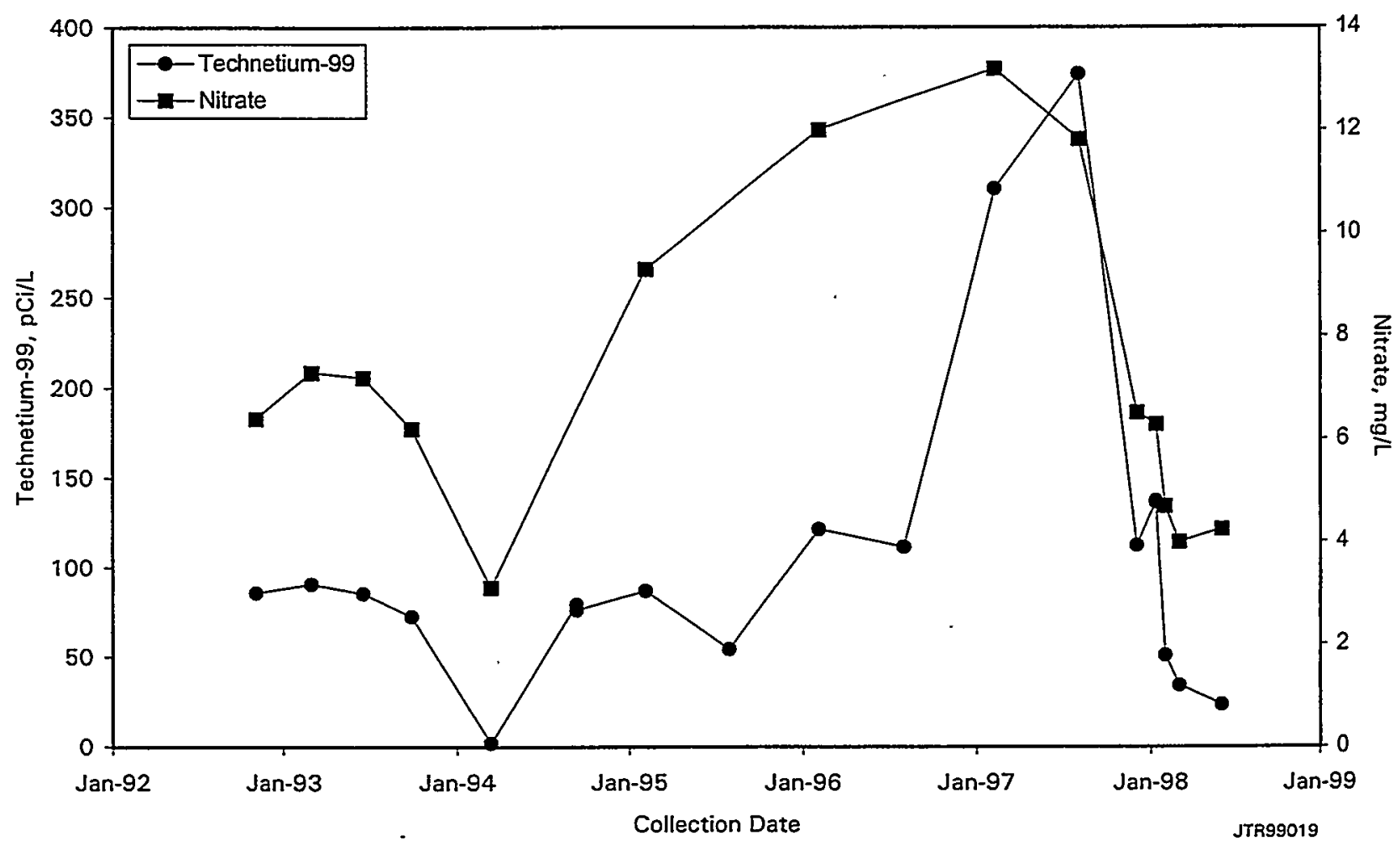

Figure 5.10-14. Comparison of Nitrate Versus Technetium-99 in Well 299-E25-46, Waste Management Area A-AX

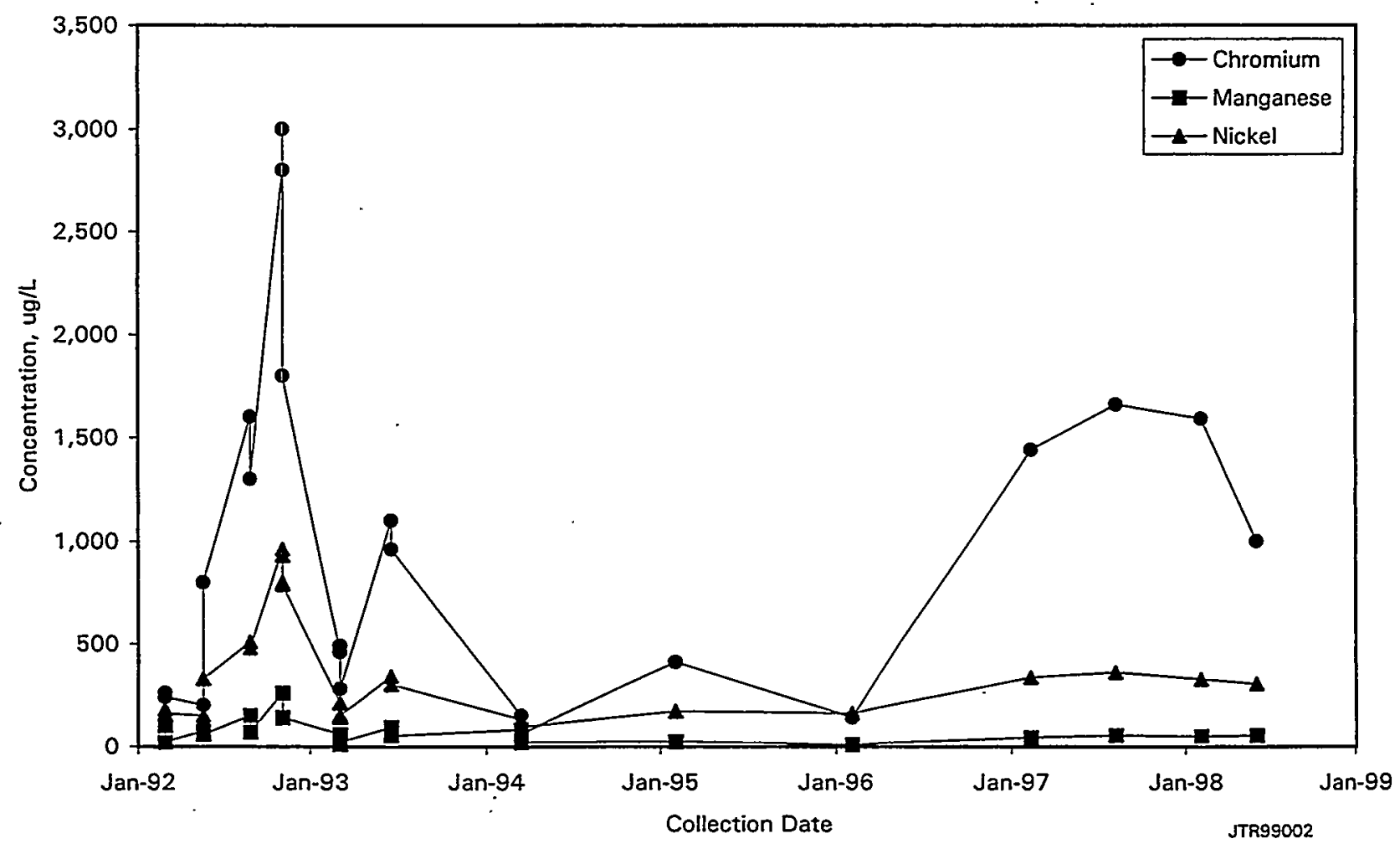

Figure 5.10-15. Comparison of Chromium, Manganese, and Nickel in Well 299-E24-19, Waste Management Area A-AX 


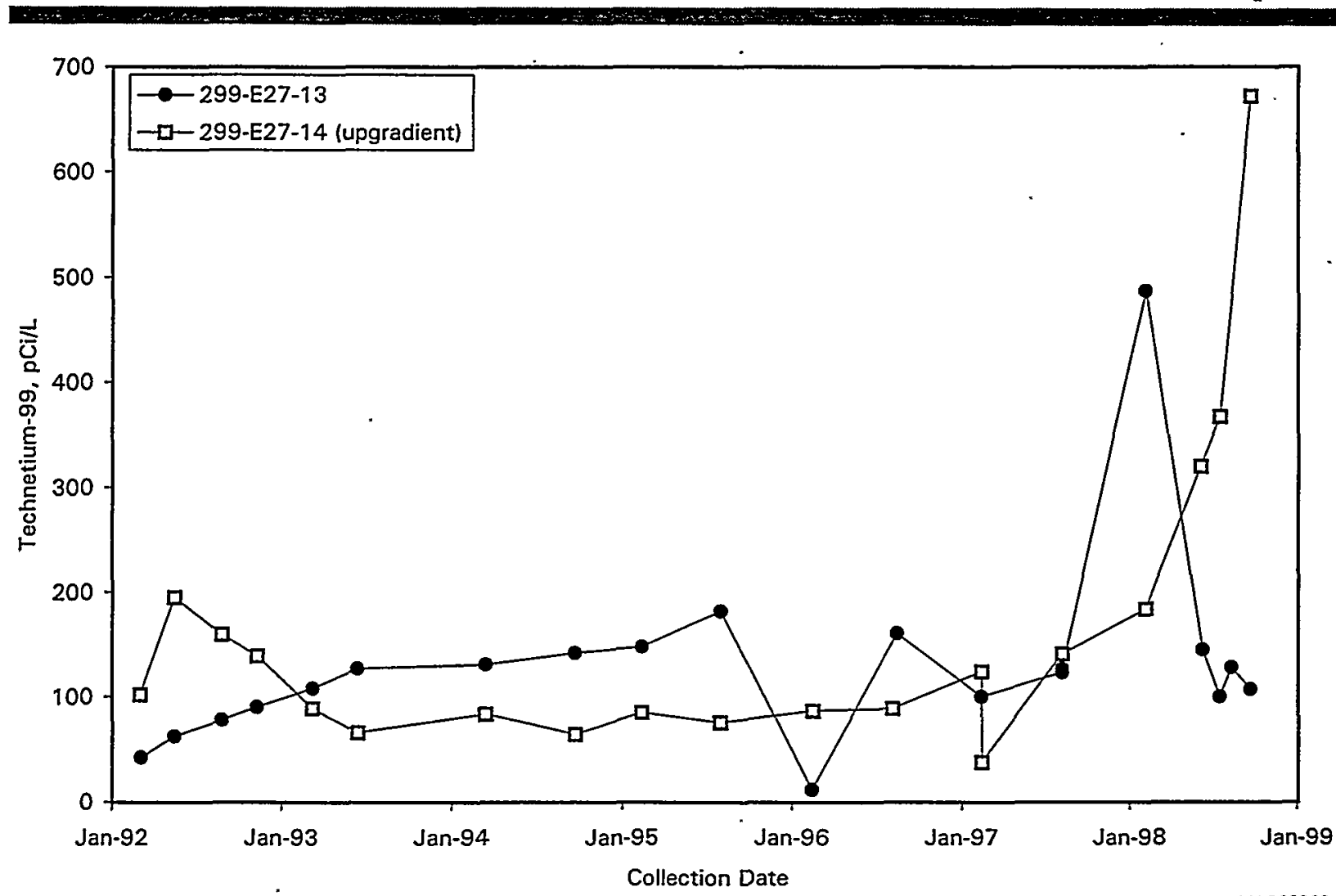

Figure 5.10-16. Technetium-99. Activities in Wells 299-E27-13 and 299-E27-14, Waste Management Area C

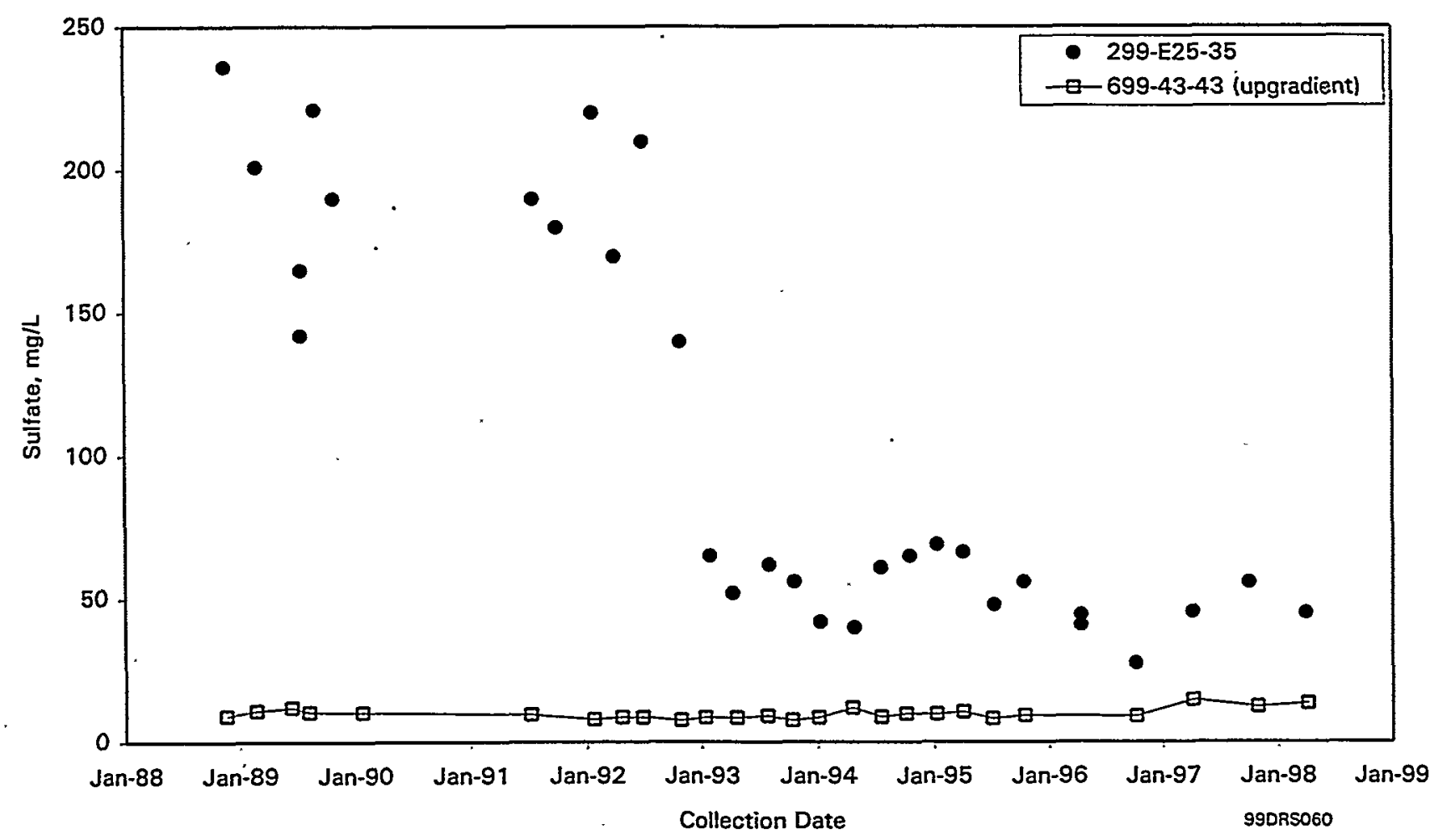

Figure 5.10-17. Sulfate Concentrations in Selected Wells Monitoring 216-A-29 Ditch 


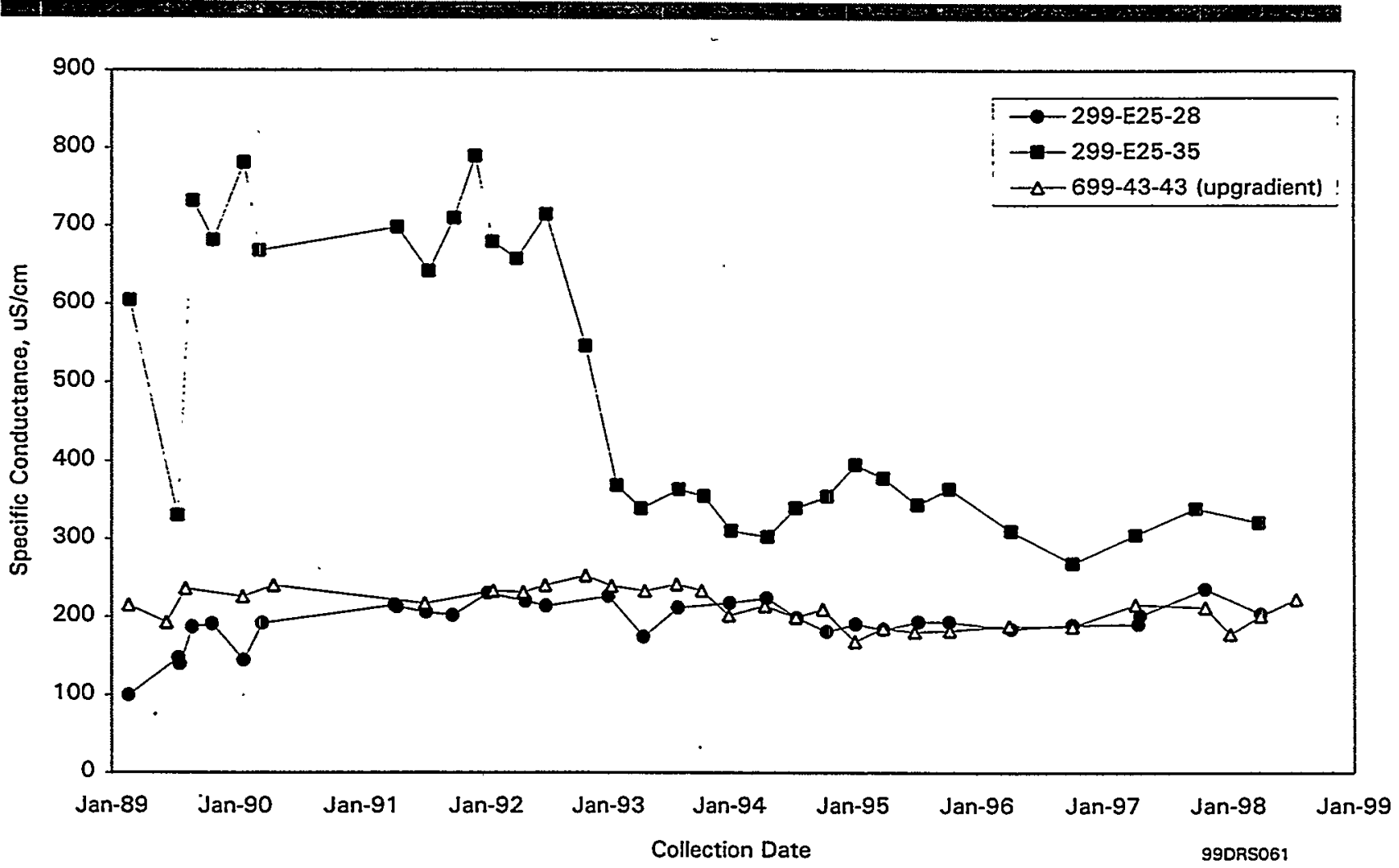

Figure 5.10-18. Specific Conductance in Selected Wells Monitoring 216-A-29 Ditch

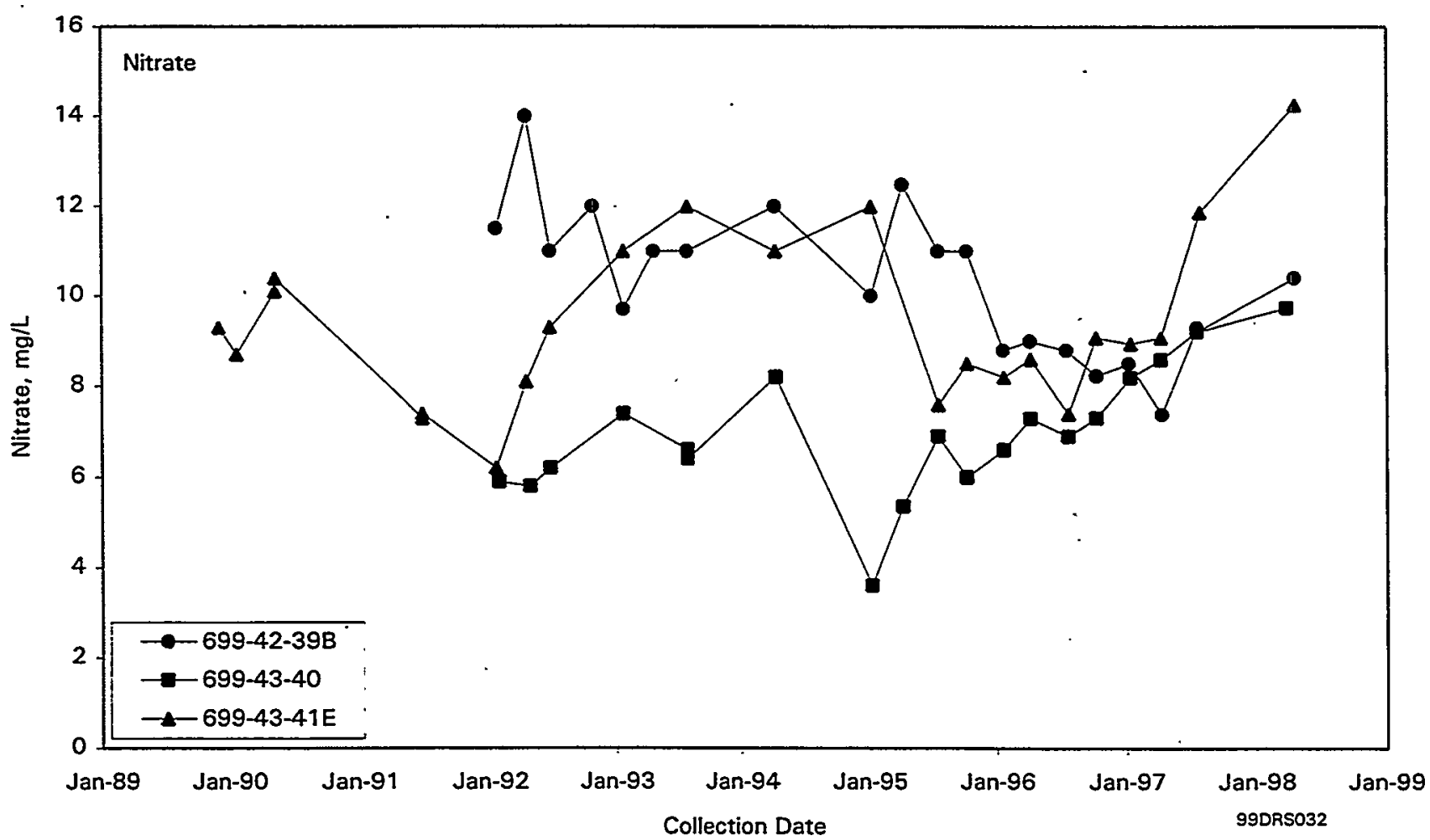

Figure 5.10-19. Nitrate Concentrations in Selected Wells Monitoring 216-B-3 Pond 


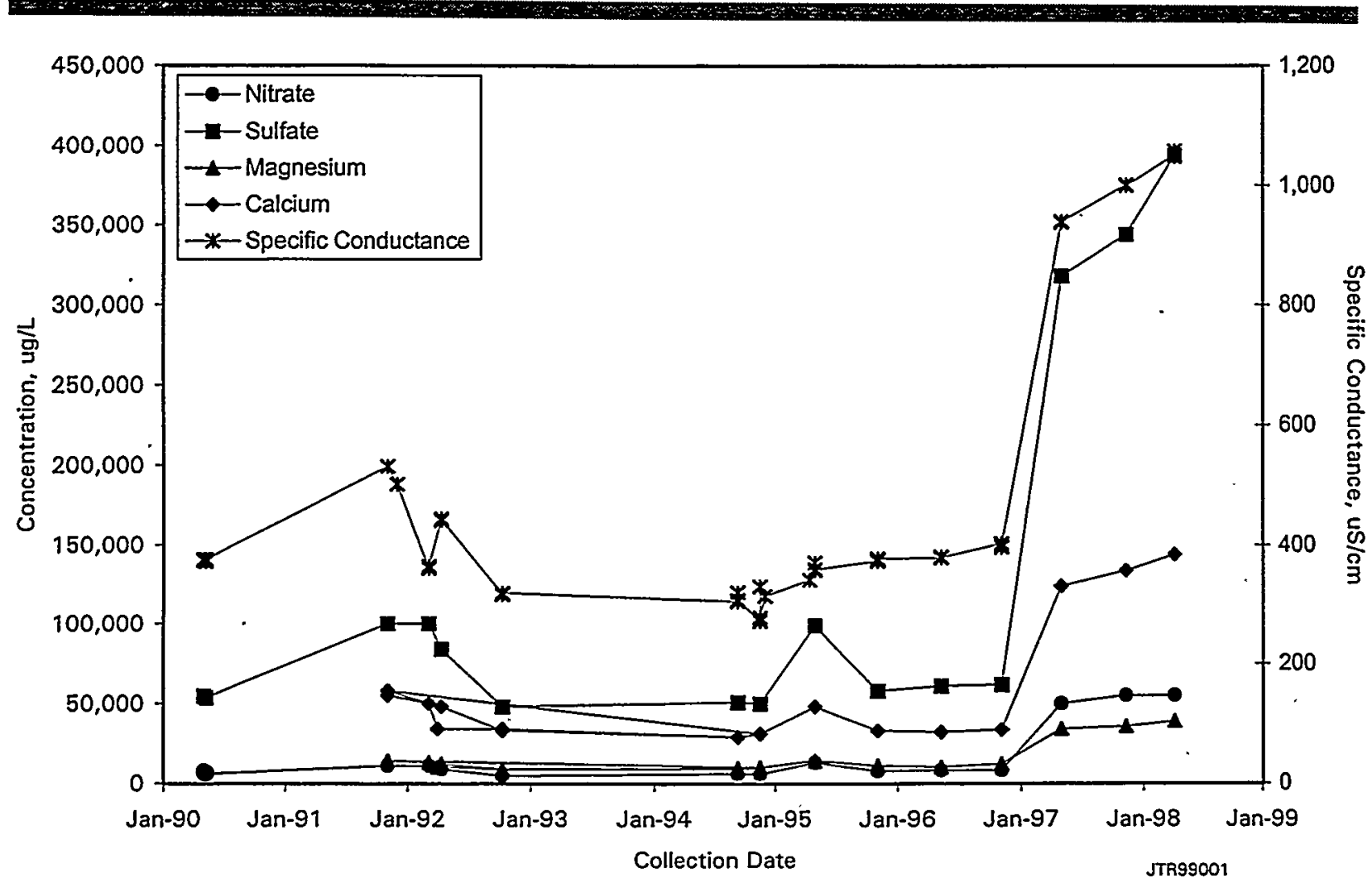

Figure 5.10-20. Contaminant Concentrations in Well 299-E34-7

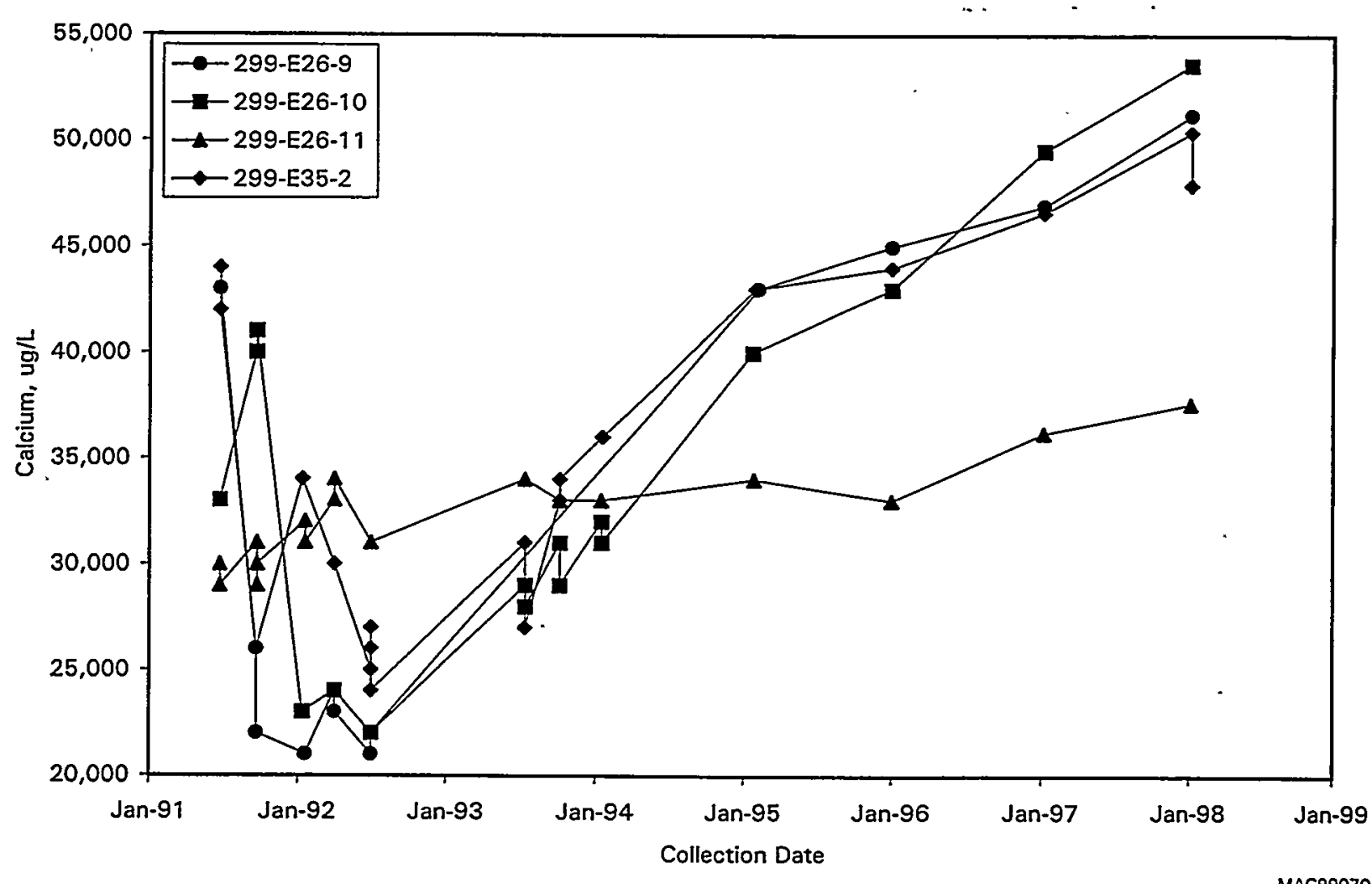

Figure 5.10-21. Calcium Concentrations in Selected Wells Monitoring Liquid EffluentRetention Facility 


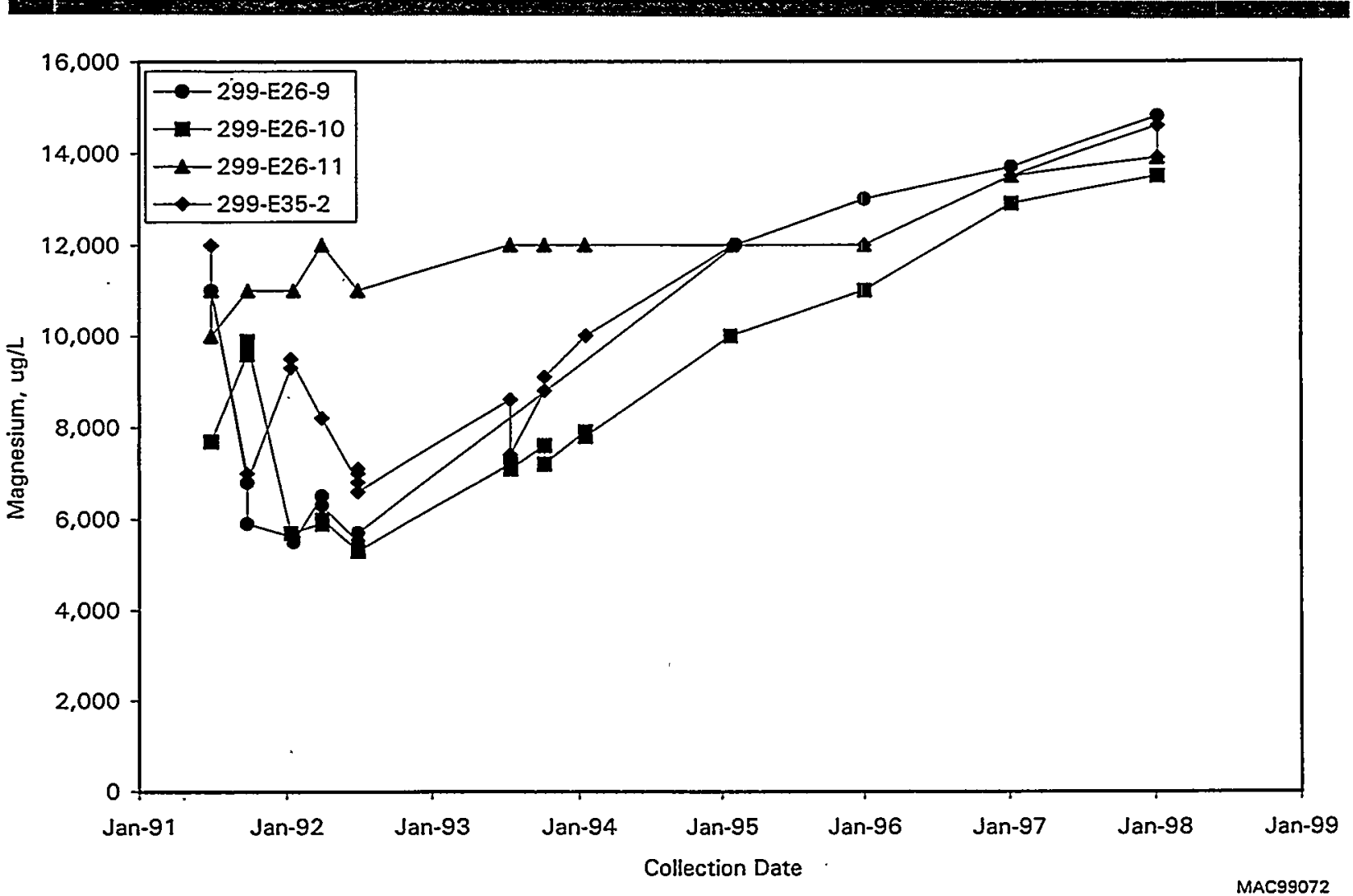

Figure 5.10-22. Magnesium Concentrations in Selected Wells Monitoring Liquid EffluentRetention Facility

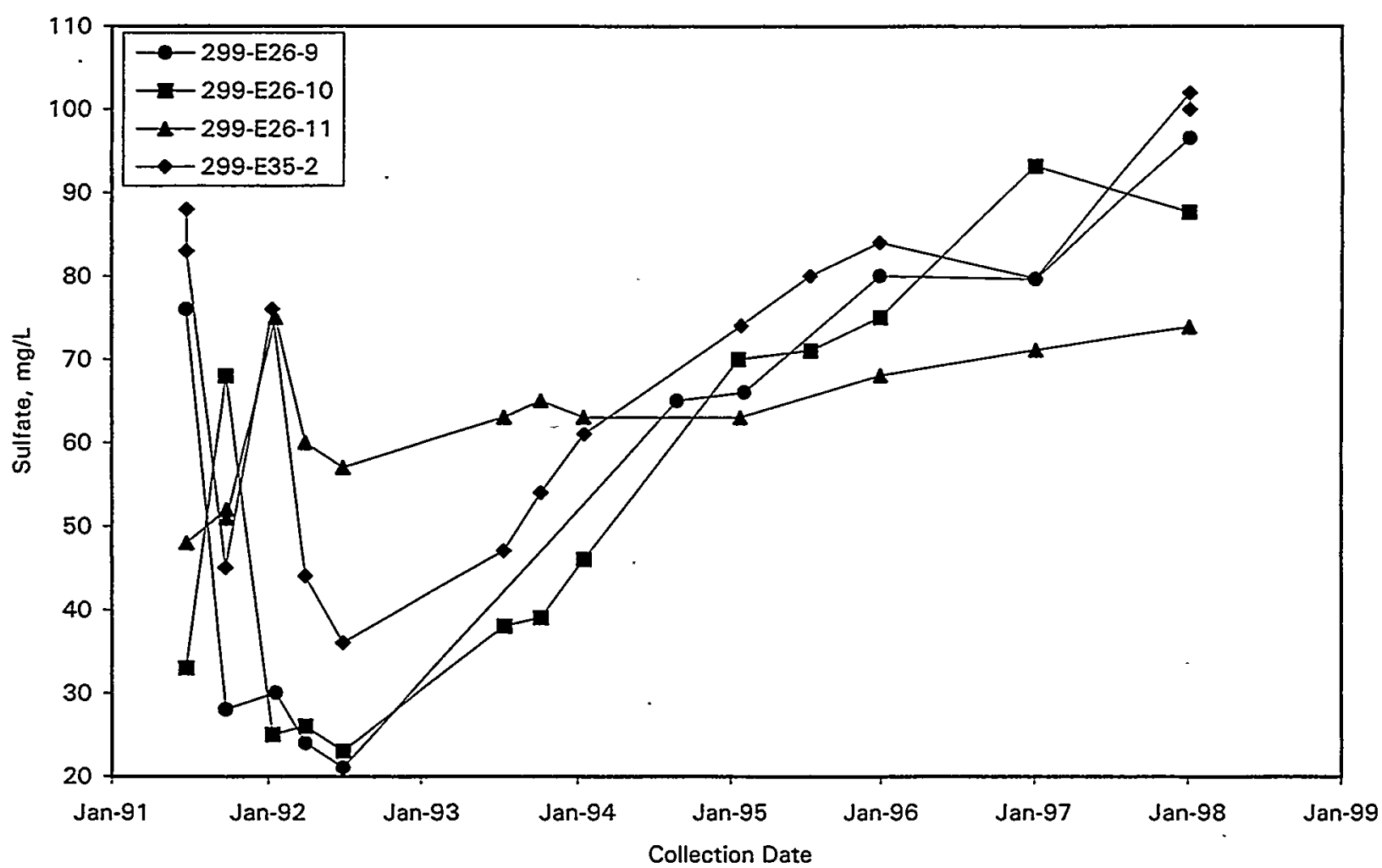

Figure 5.10-23. Sulfate Concentrations in Selected Wells Monitoring Liquid EffluentMAC99071 Retention Facility 


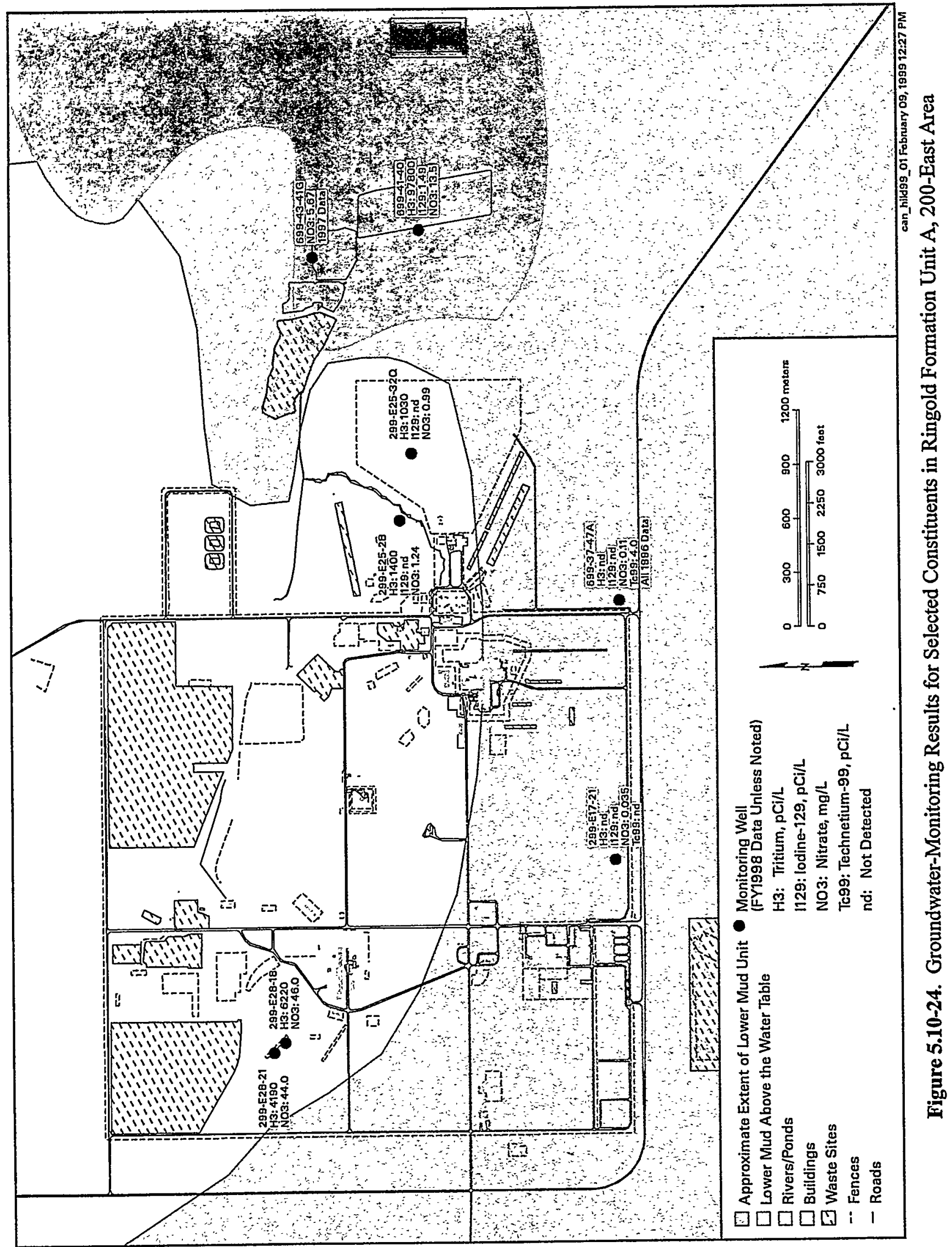




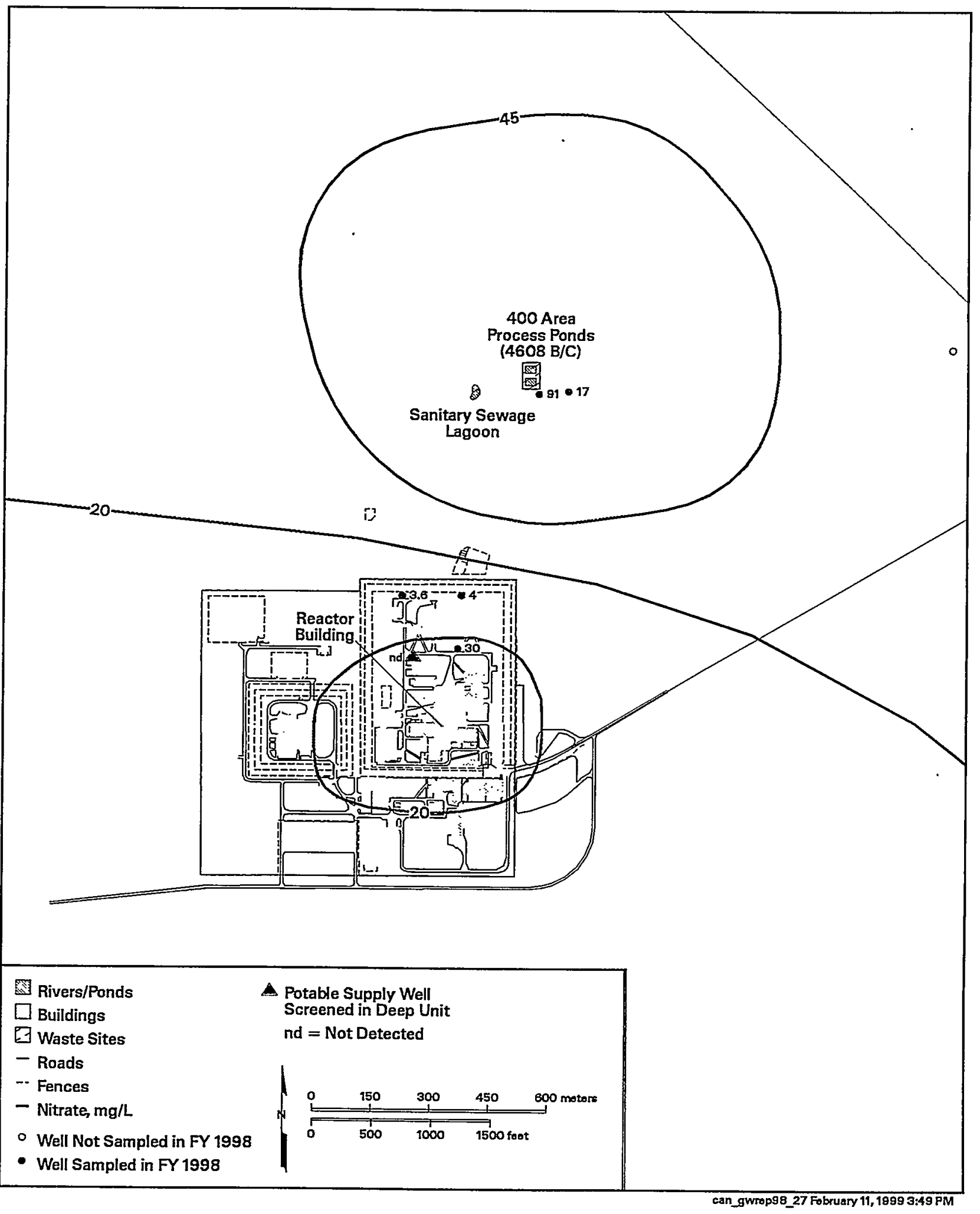

Figure 5.11-1. Average Nitrate Concentrations in 400 Area Wells 


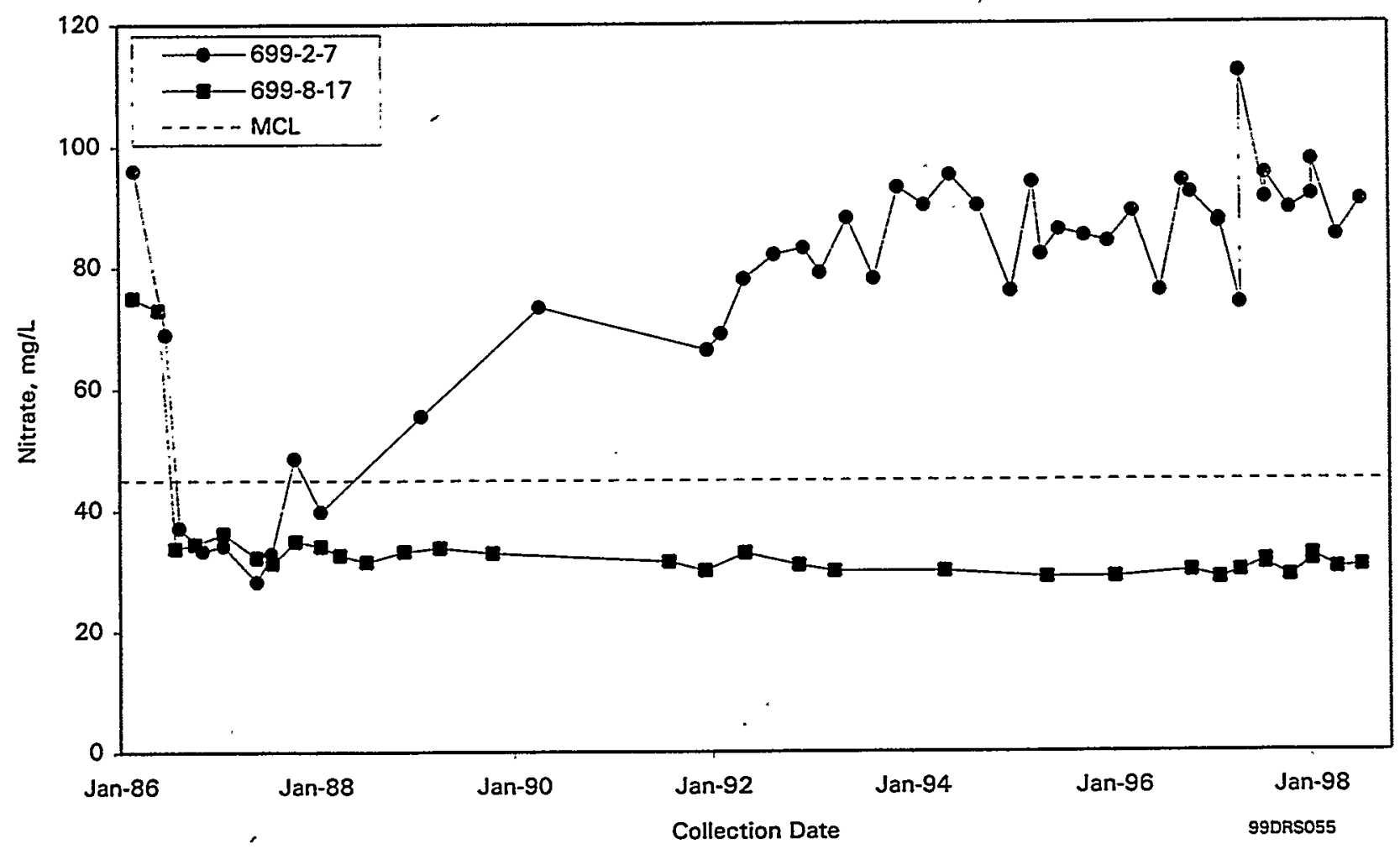

Figure 5.11-2. Nitrate Concentrations in 600 Area Wells Near 400 Area

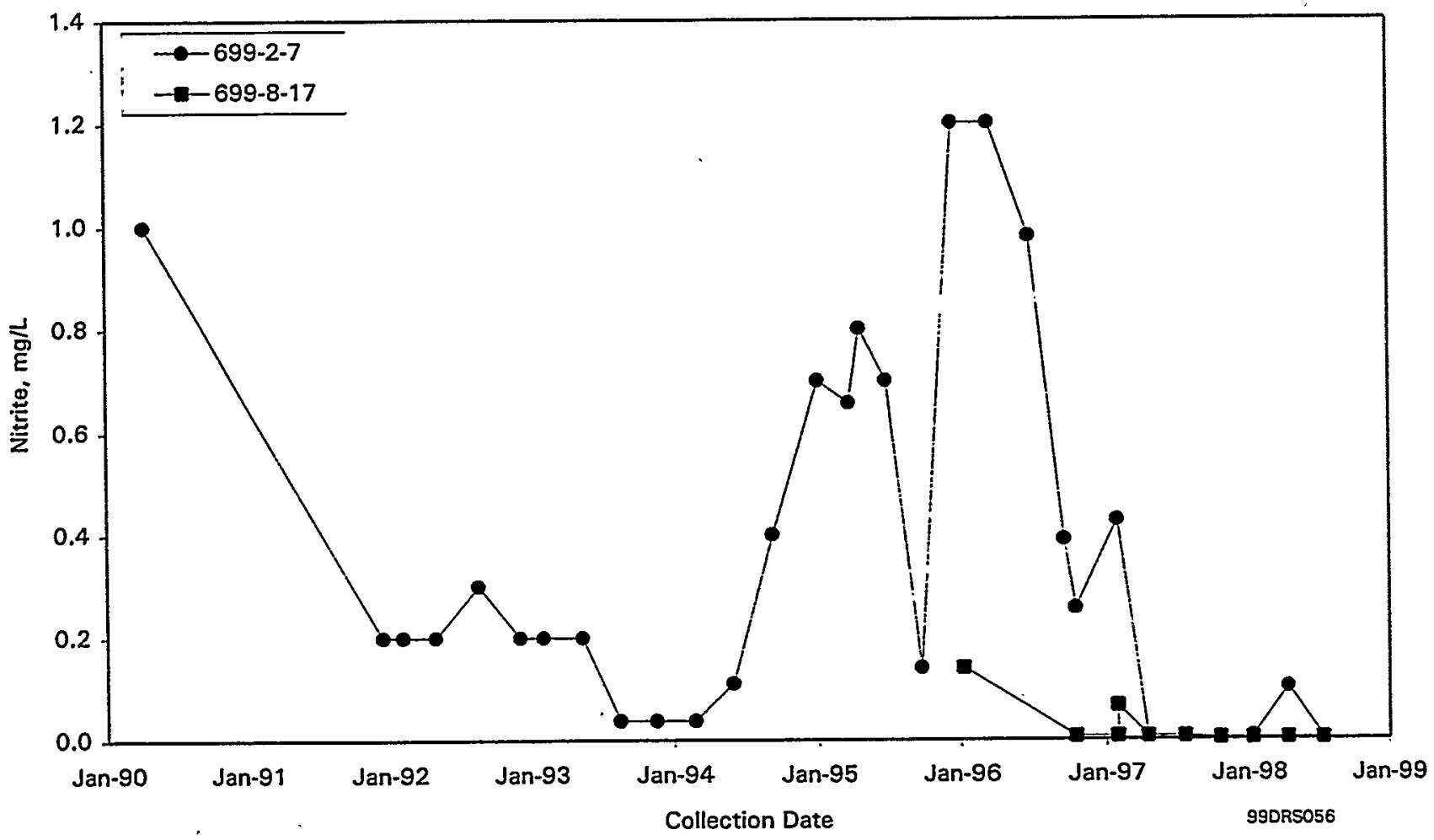

Figure 5.11-3. Nitrite Concentrations in 600 Area Wells Near 400 Area 


\section{- $F$ rom}

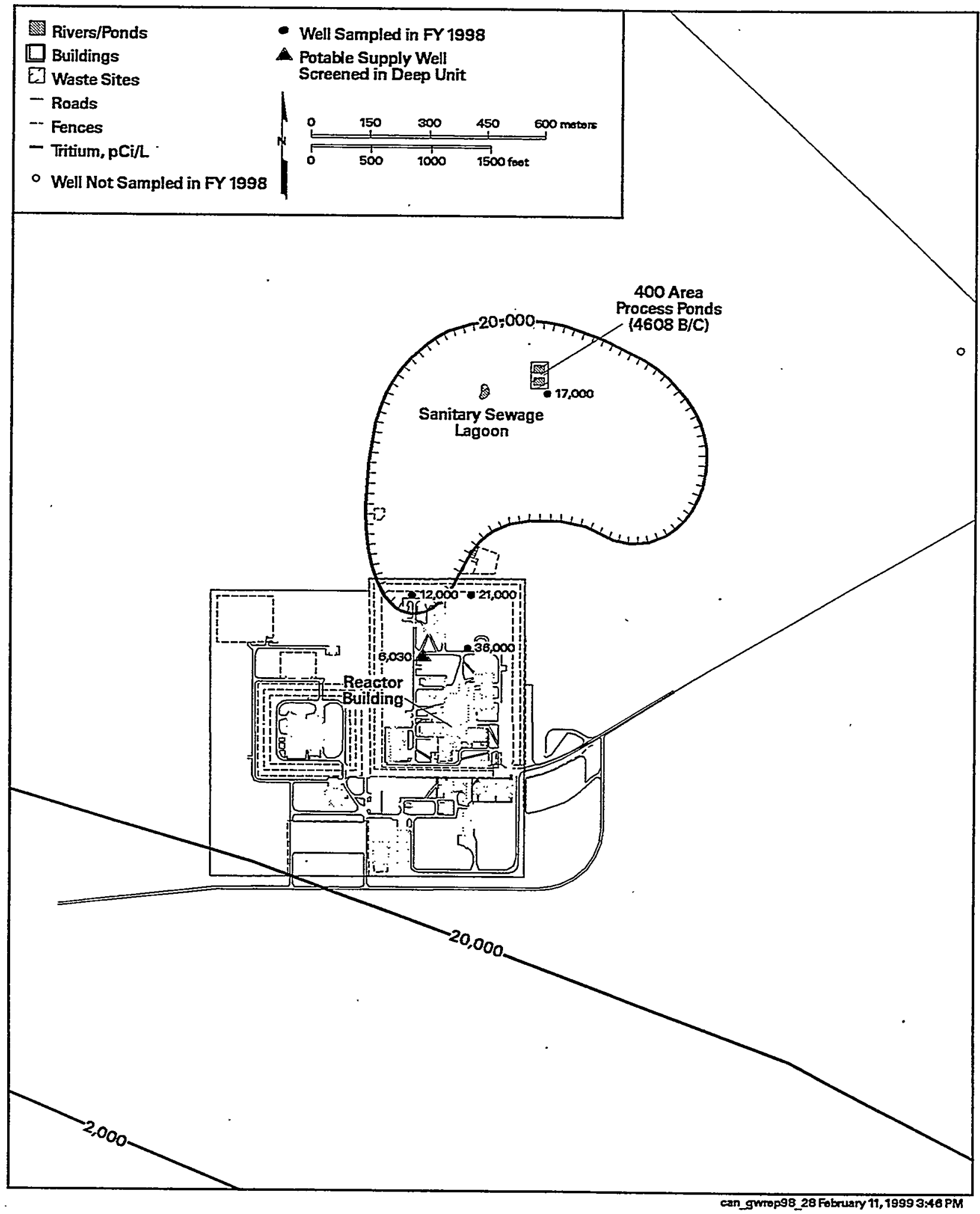

Figure 5.11-4. Average Tritium Activities in 400 Area Wells 

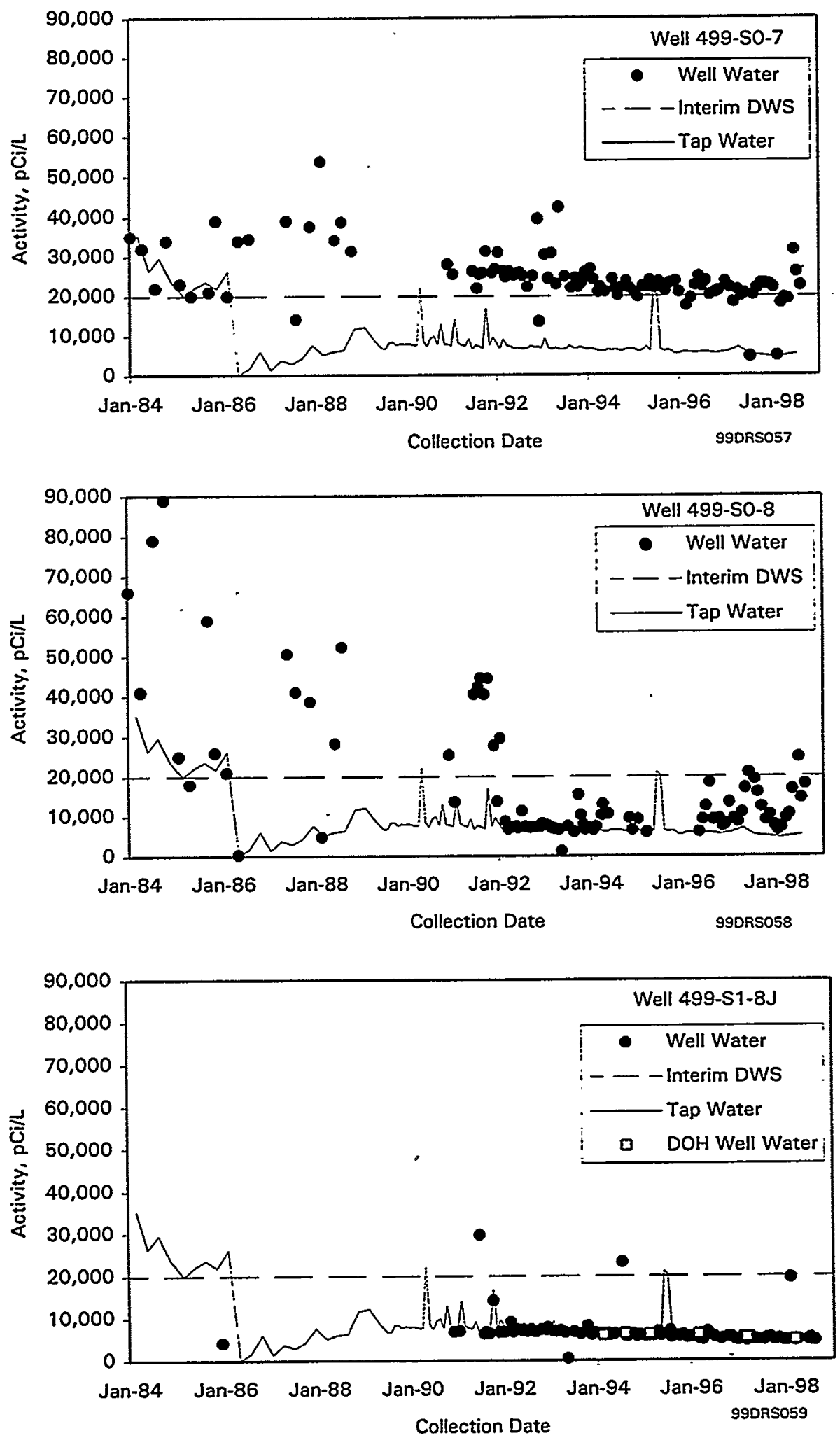

Figure 5.11-5. Comparison of Tritium Activities in 400 Area Drinking Water System 


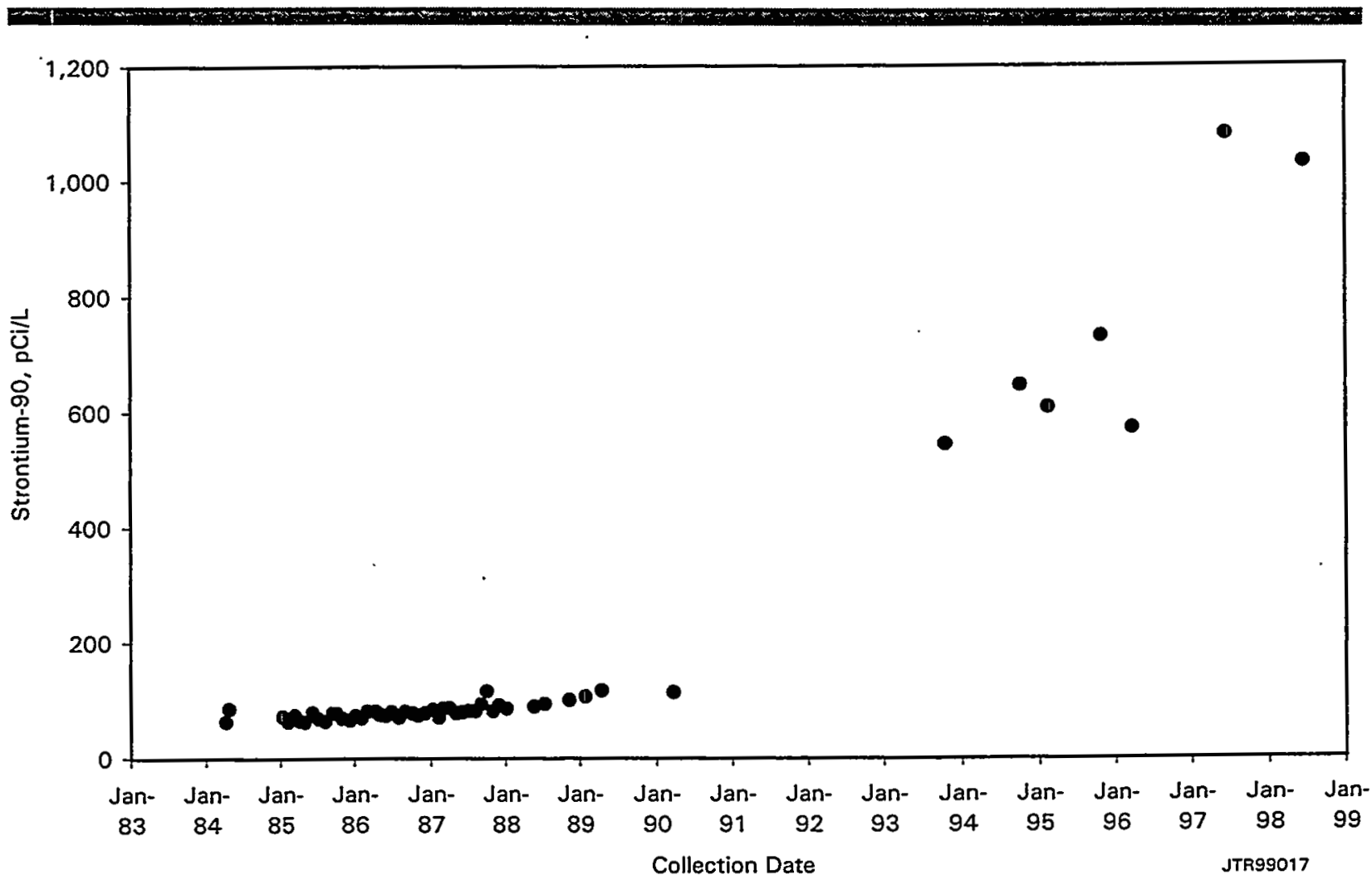

Figure 5.12-1. Strontium-90 Activities in Well 699-53-47B

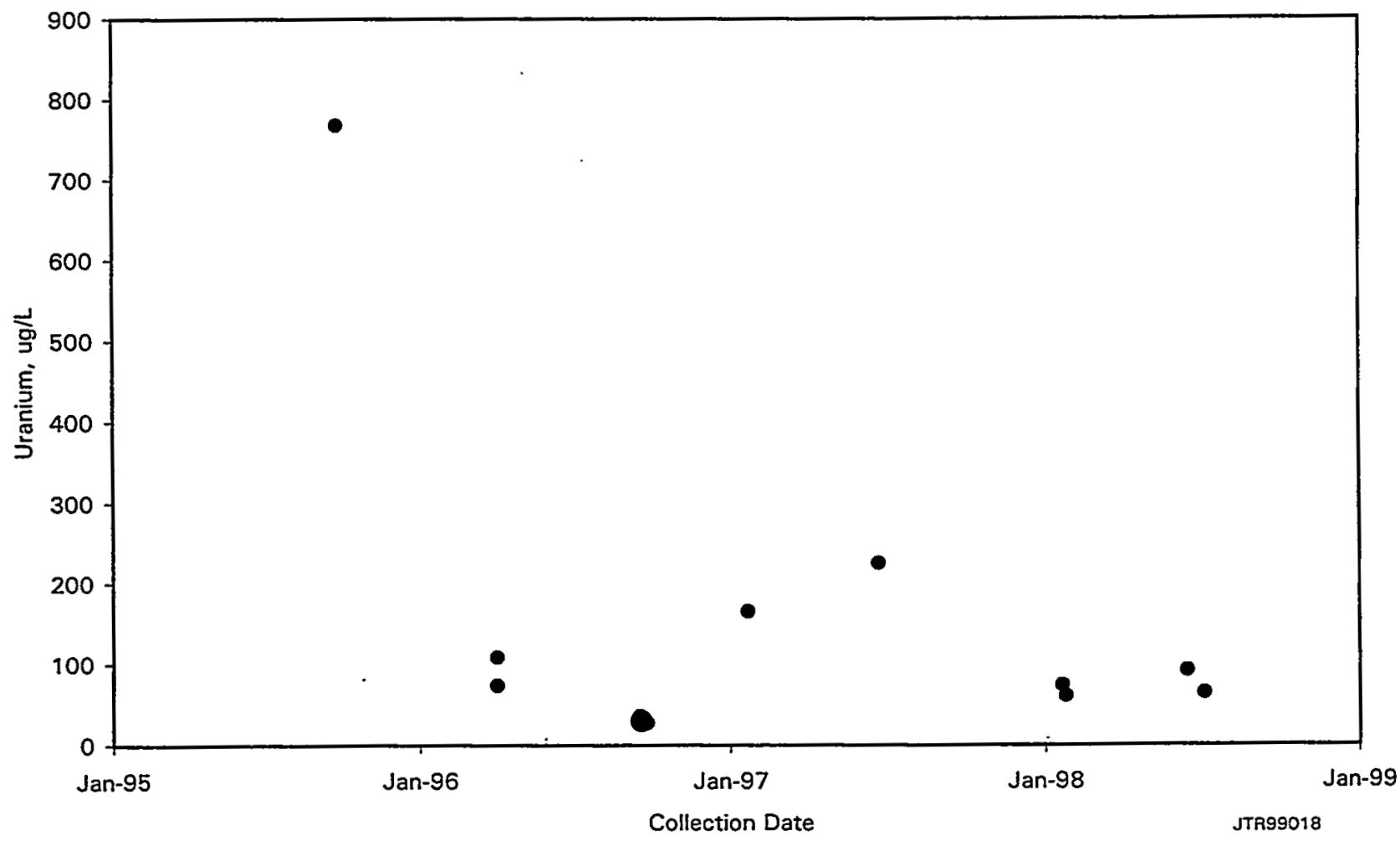

Figure 5.12-2. Uranium Concentrations in Well 699-S6-E4A 


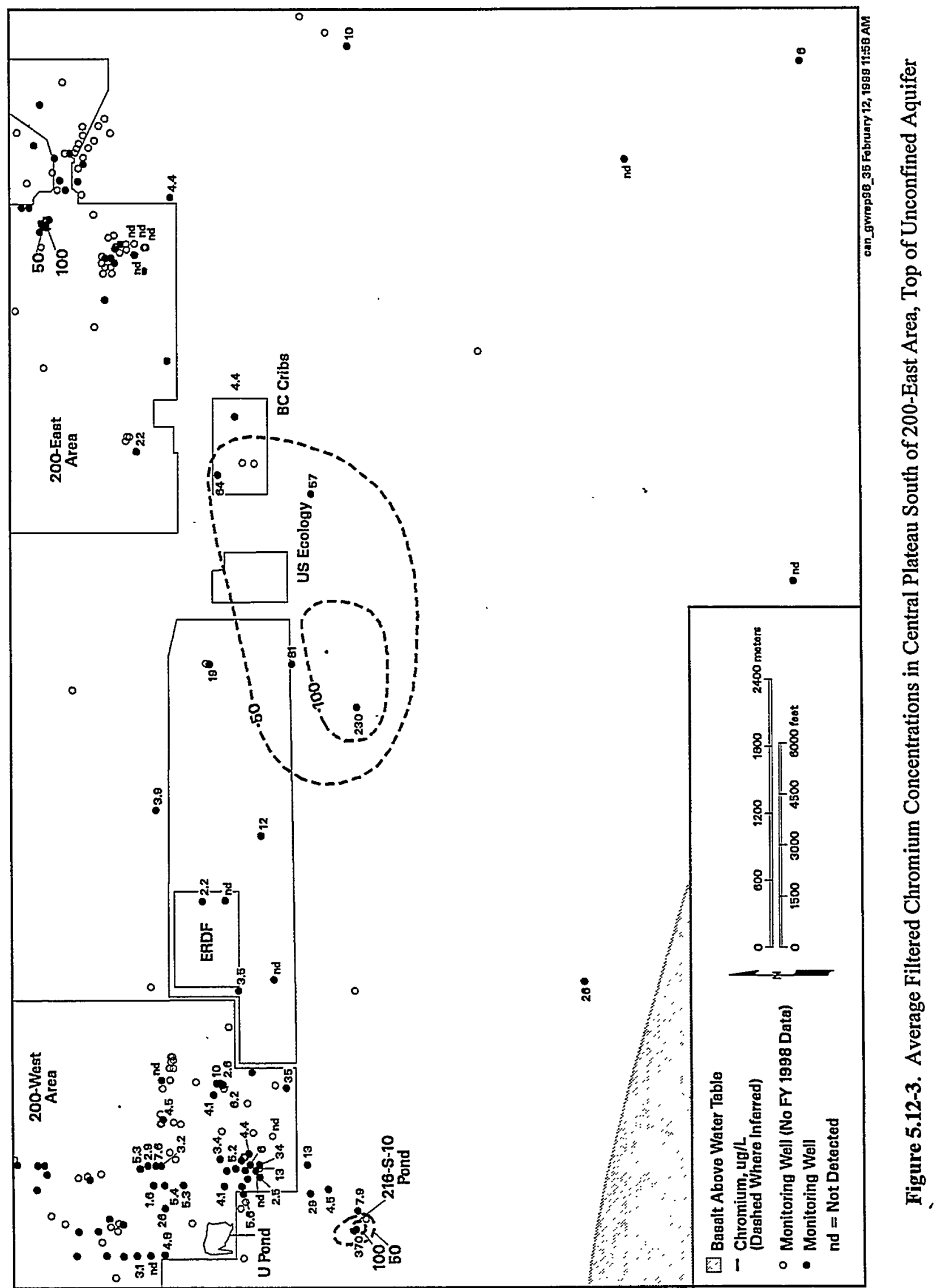




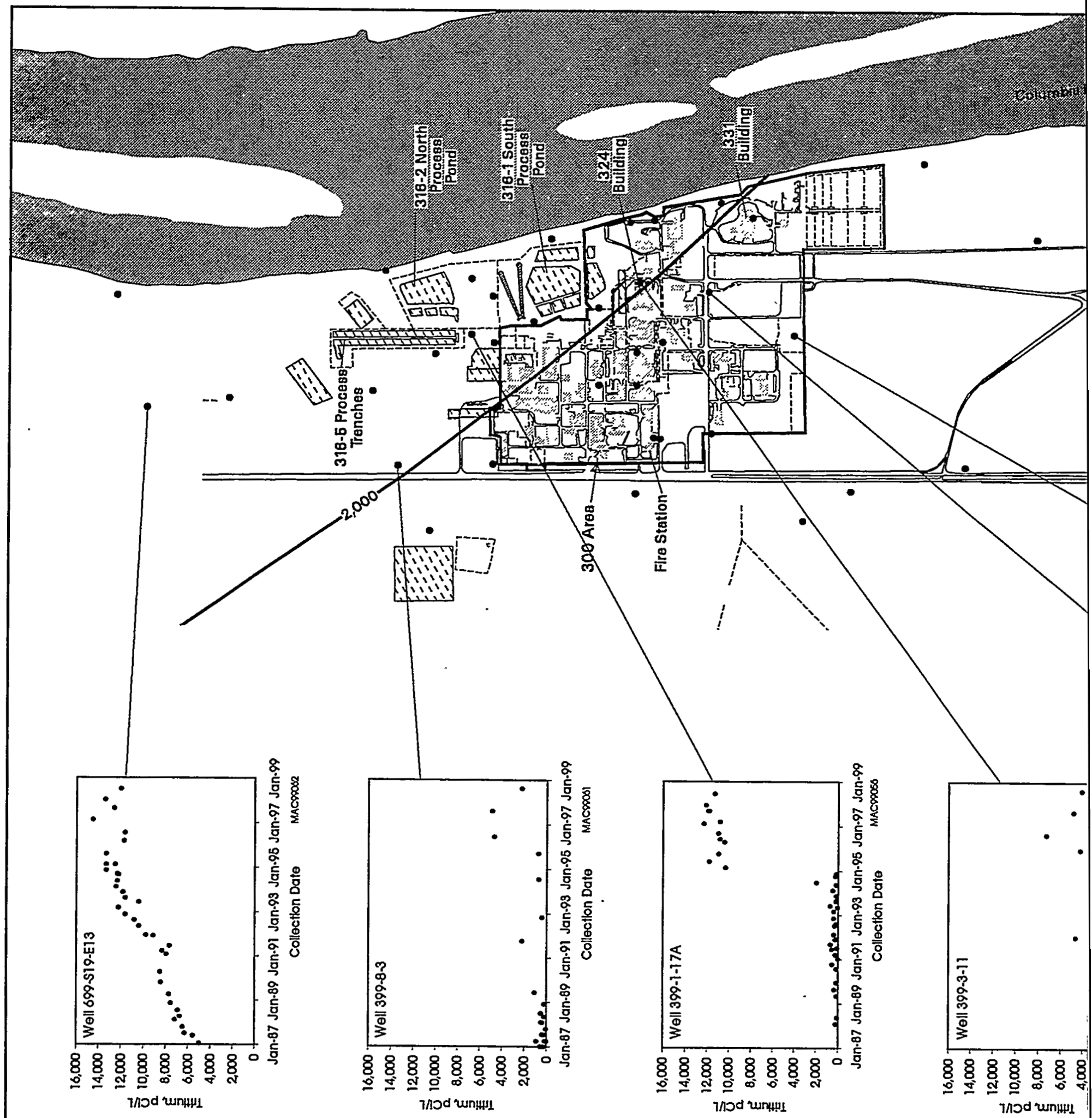




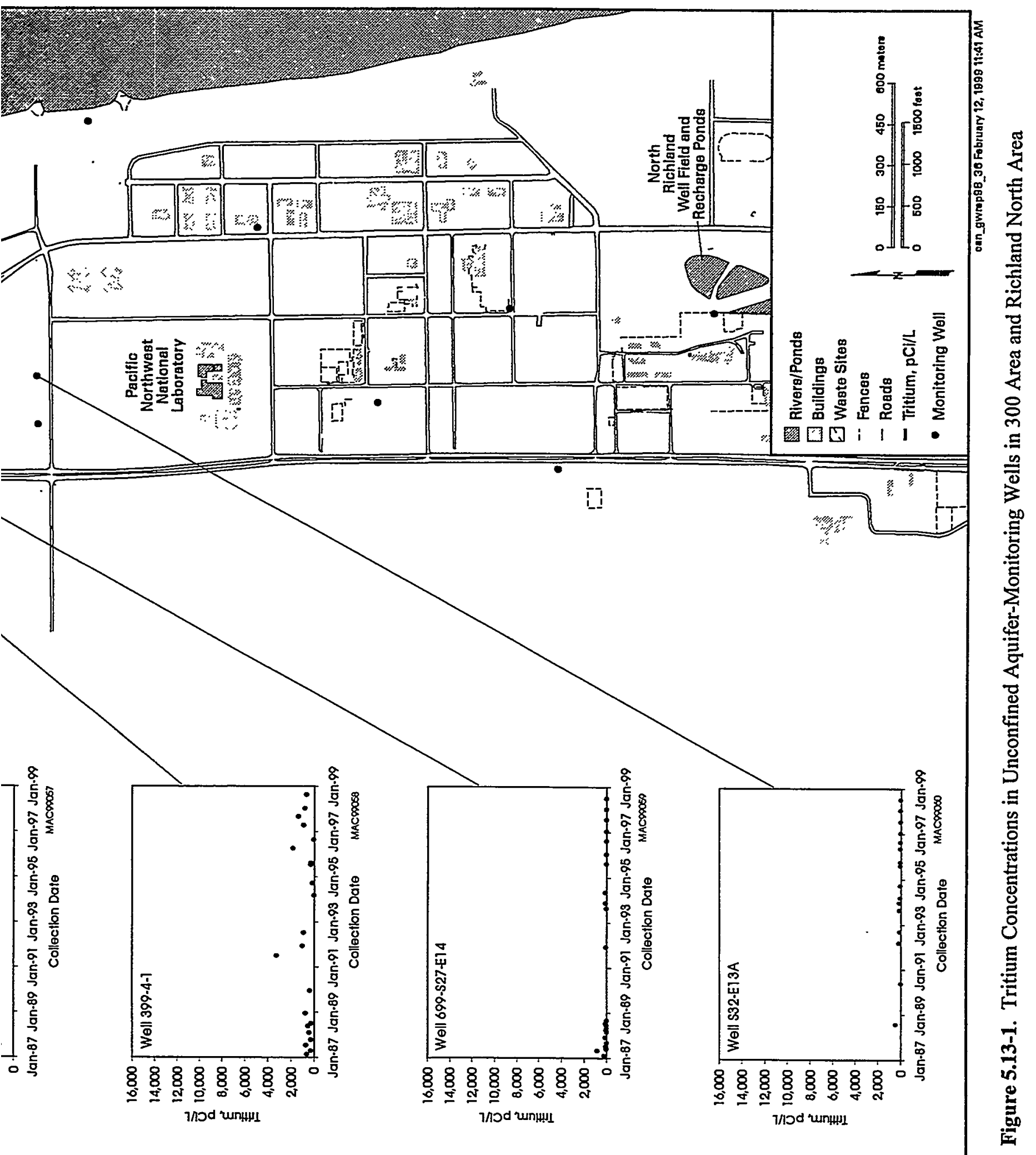




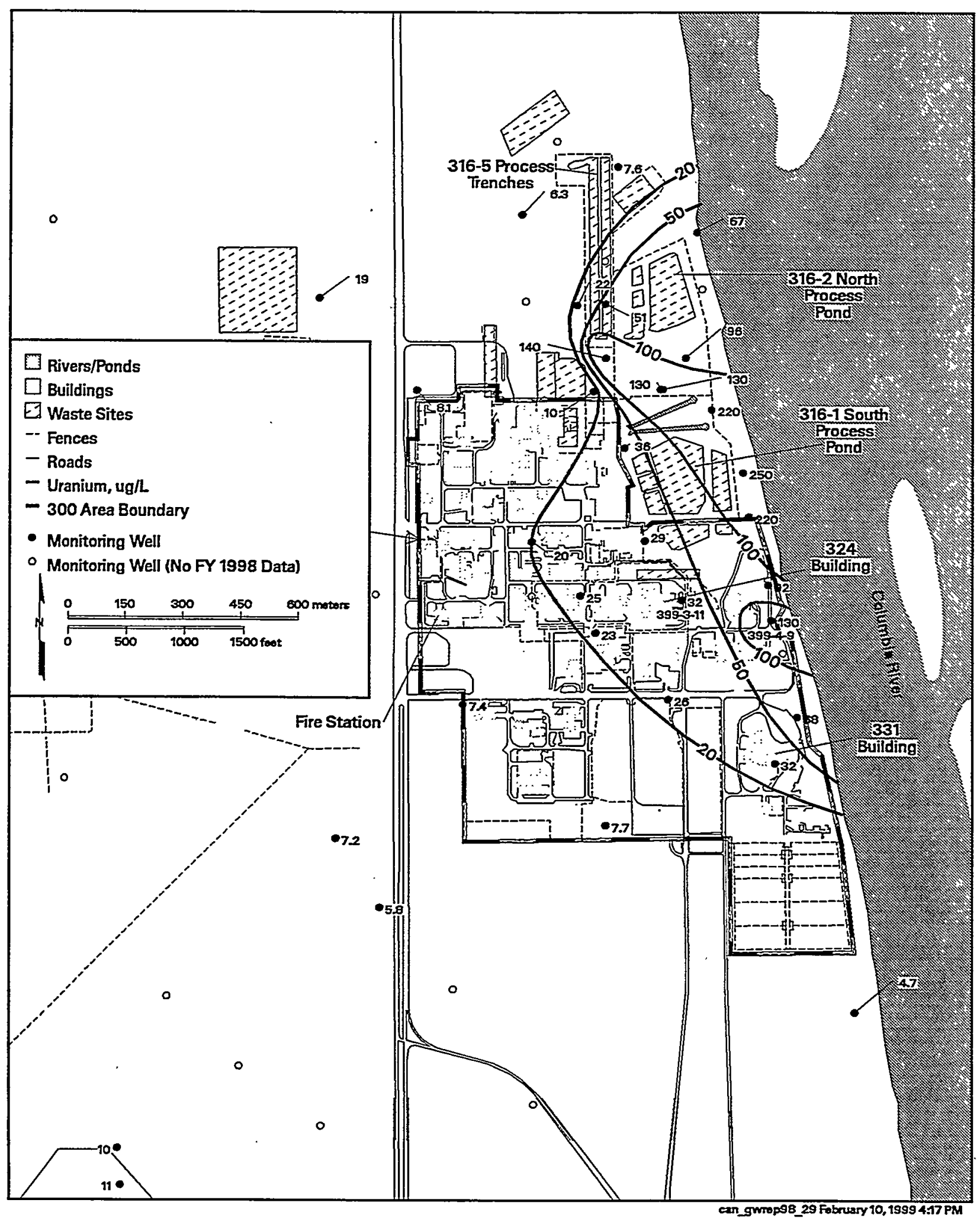

Figure 5.13-2. Average Uranium Concentrations in the 300 Area, Top of Unconfined Aquifer 


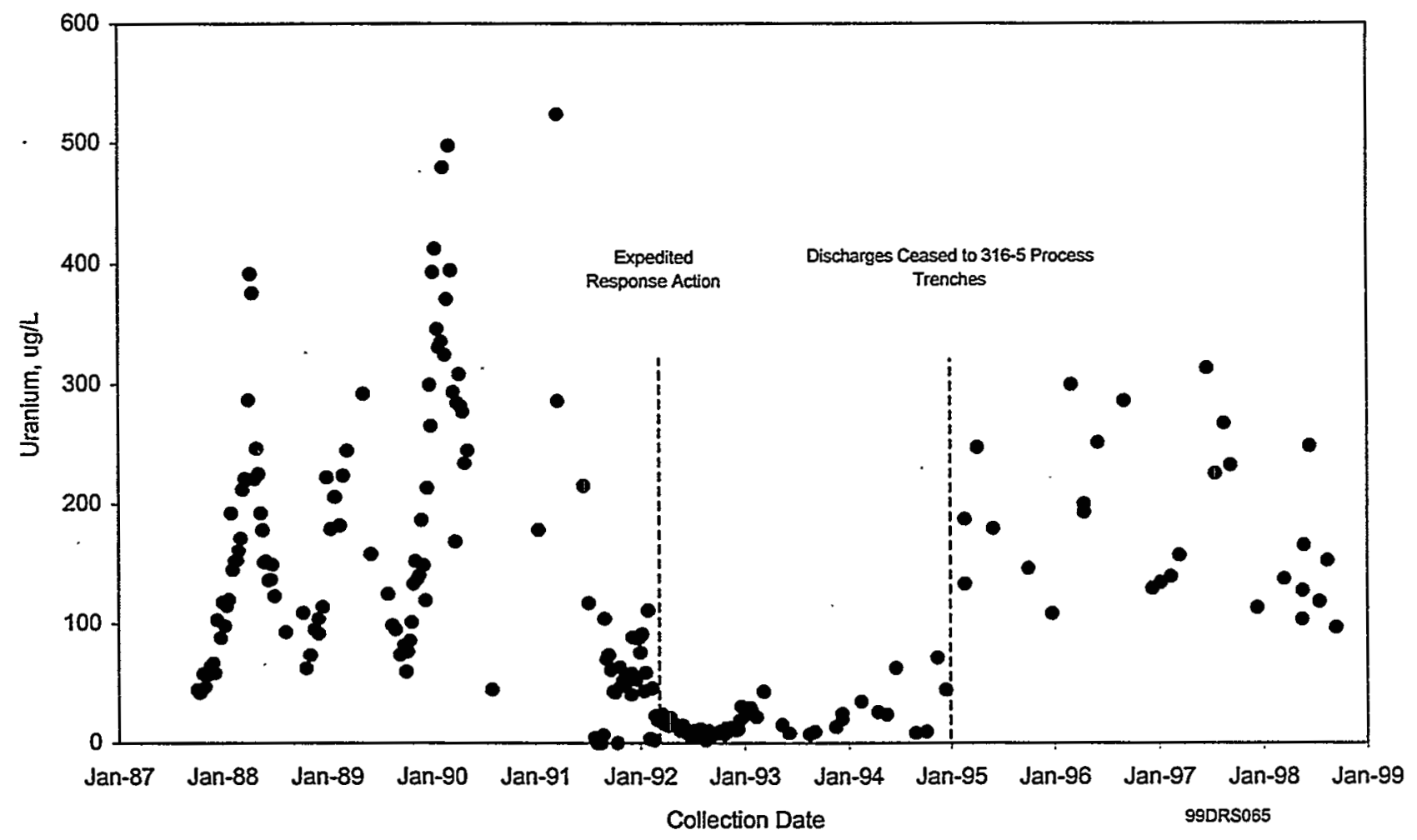

Figure 5.13-3. Uranium Concentrations in Well 399-1-17A

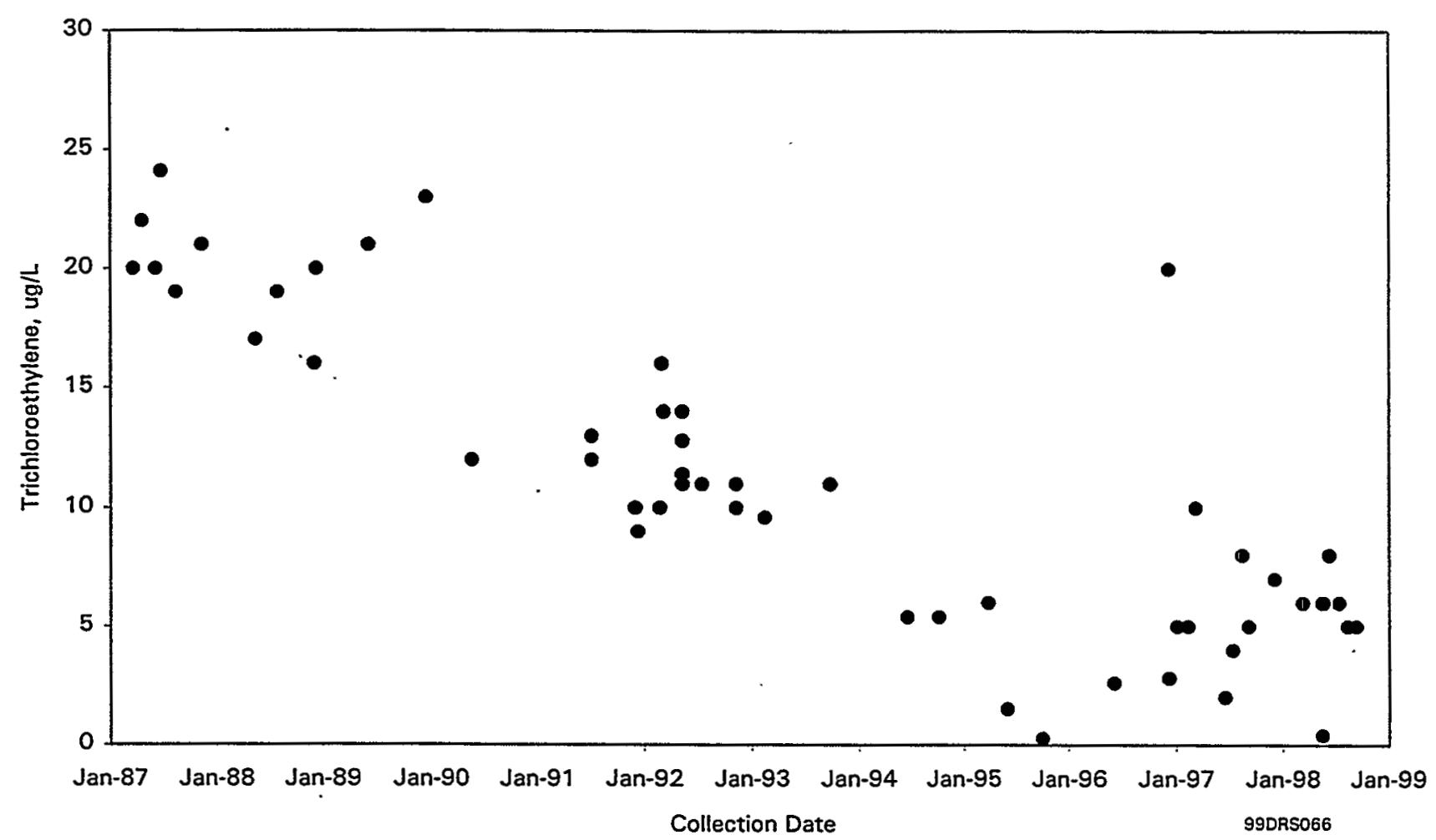

Figure 5.13-4. Trichloroethylene Concentrations in Well 399-1-16B 


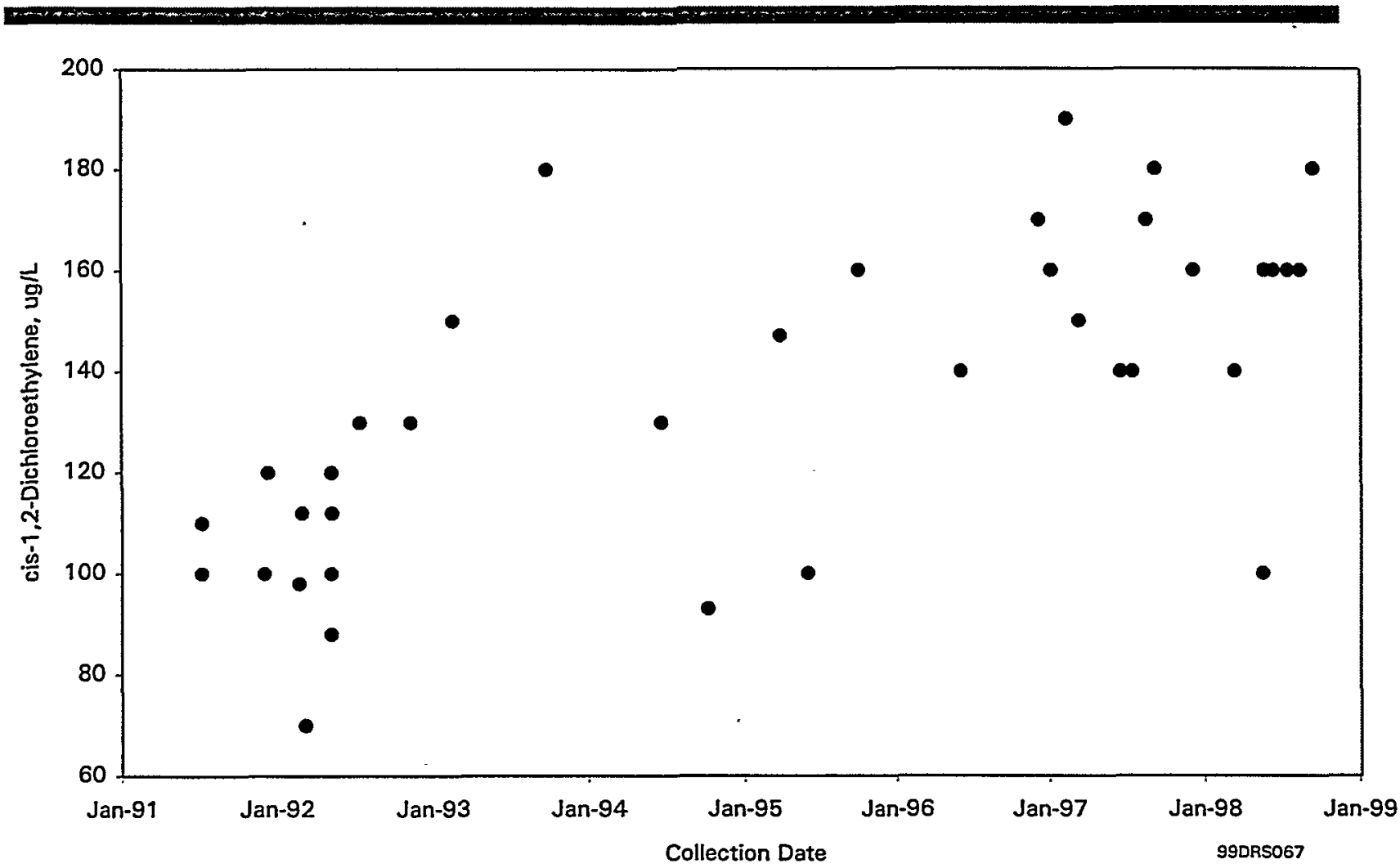

Figure 5.13-5. cis-1,2 Dichloroethylene Concentrations in Well 399-1-16B, 300 Area

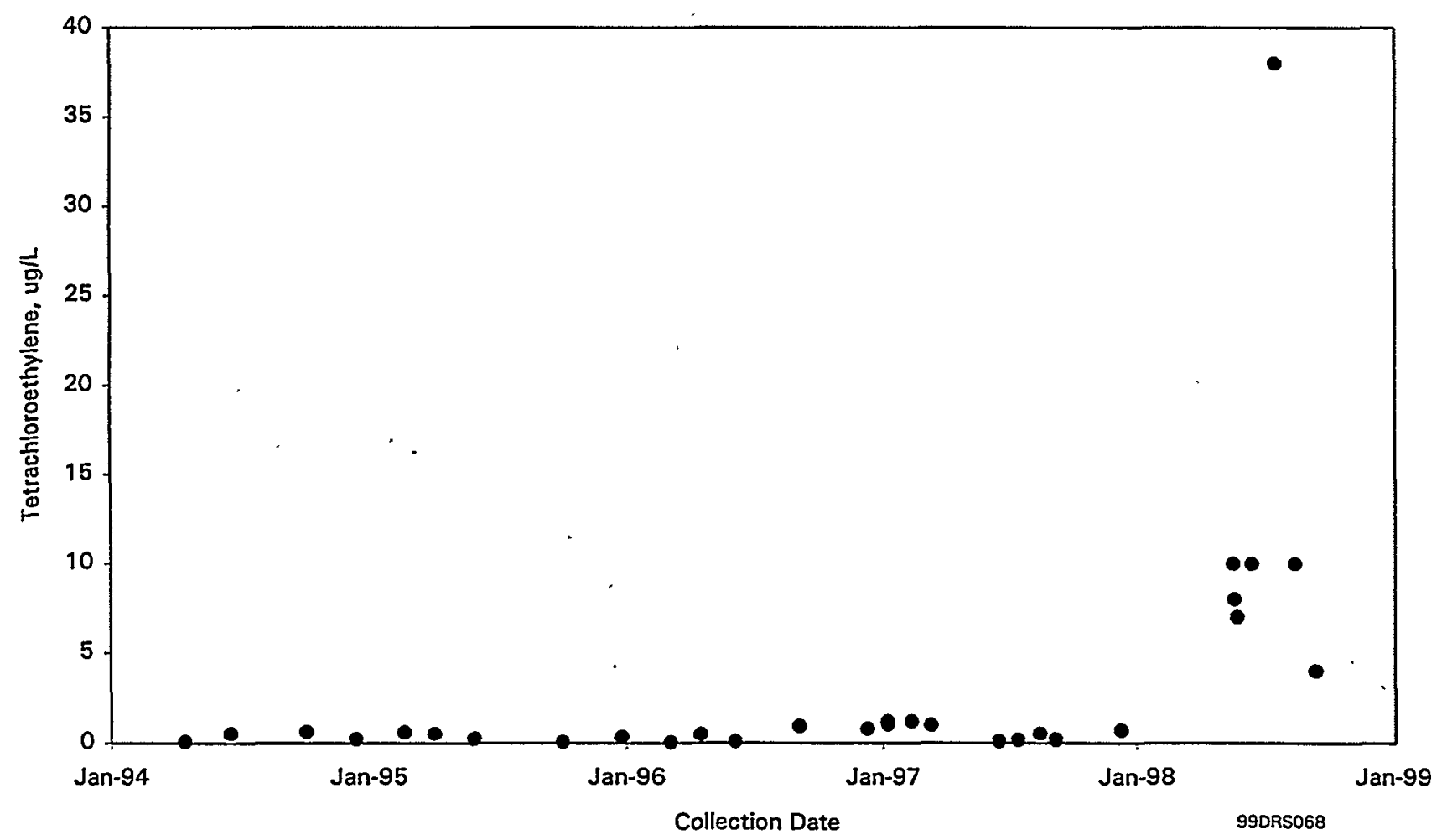

Figure 5.13-6. Tetrachloroethylene Concentrations in Well 399-1-17A, 300 Area 


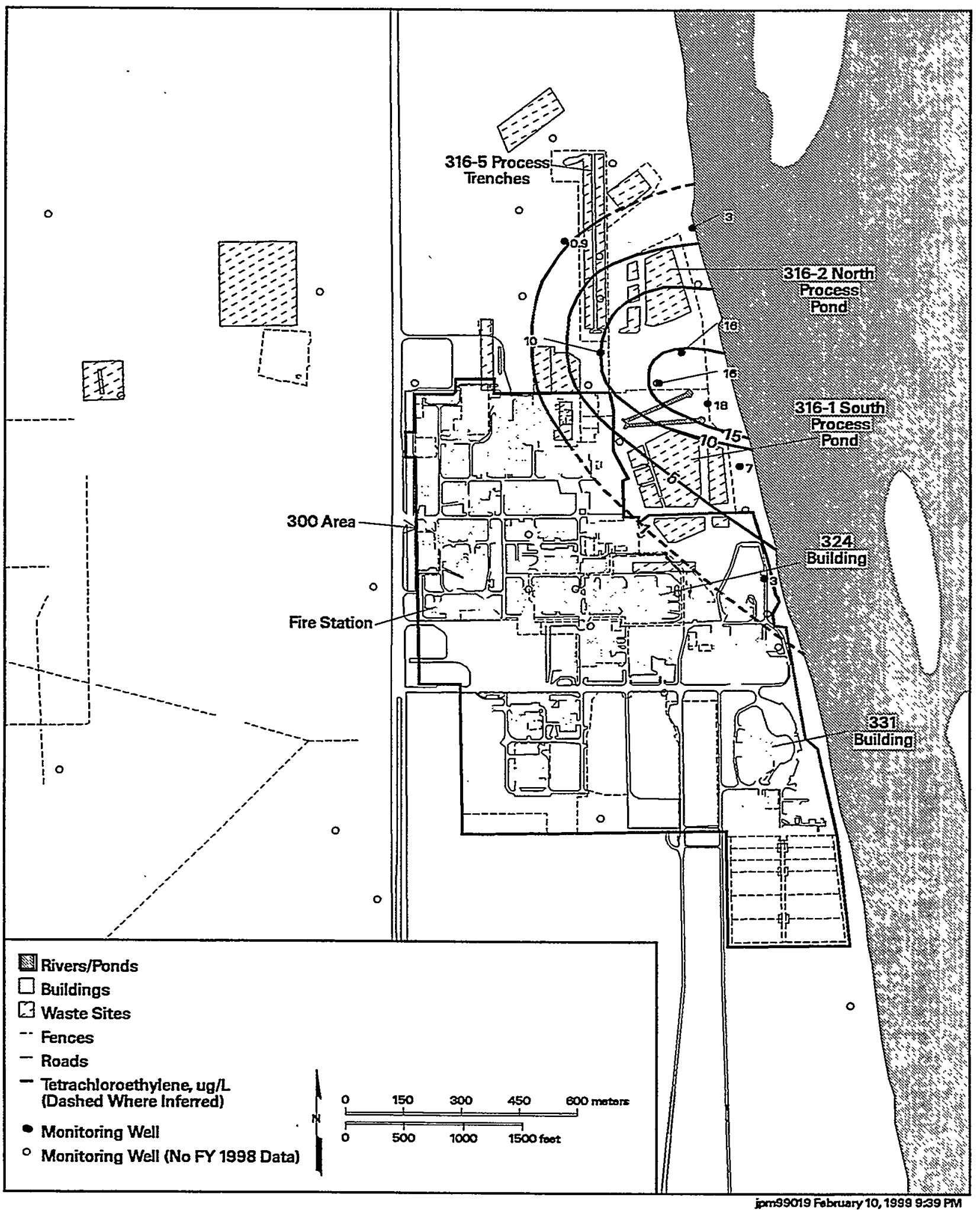

Figure 5.13-7. Tetrachloroethylene Concentrations in 300 Area, August 1998, Top of Unconfined Aquifer 


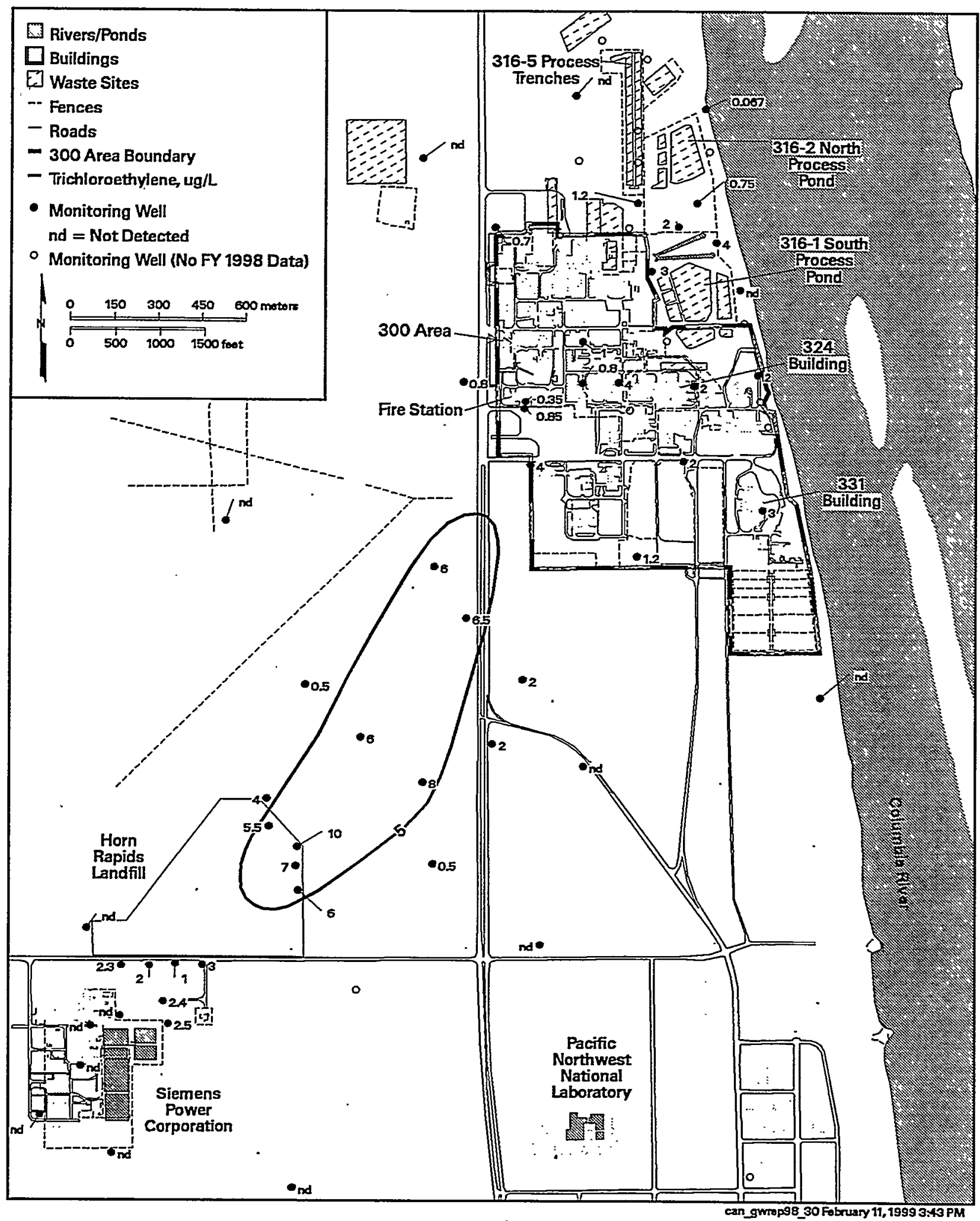

Figure 5.14-1. Average Trichloroethylene Concentrations for the 300 and Richland North Areas, Top of Unconfined Aquifer 


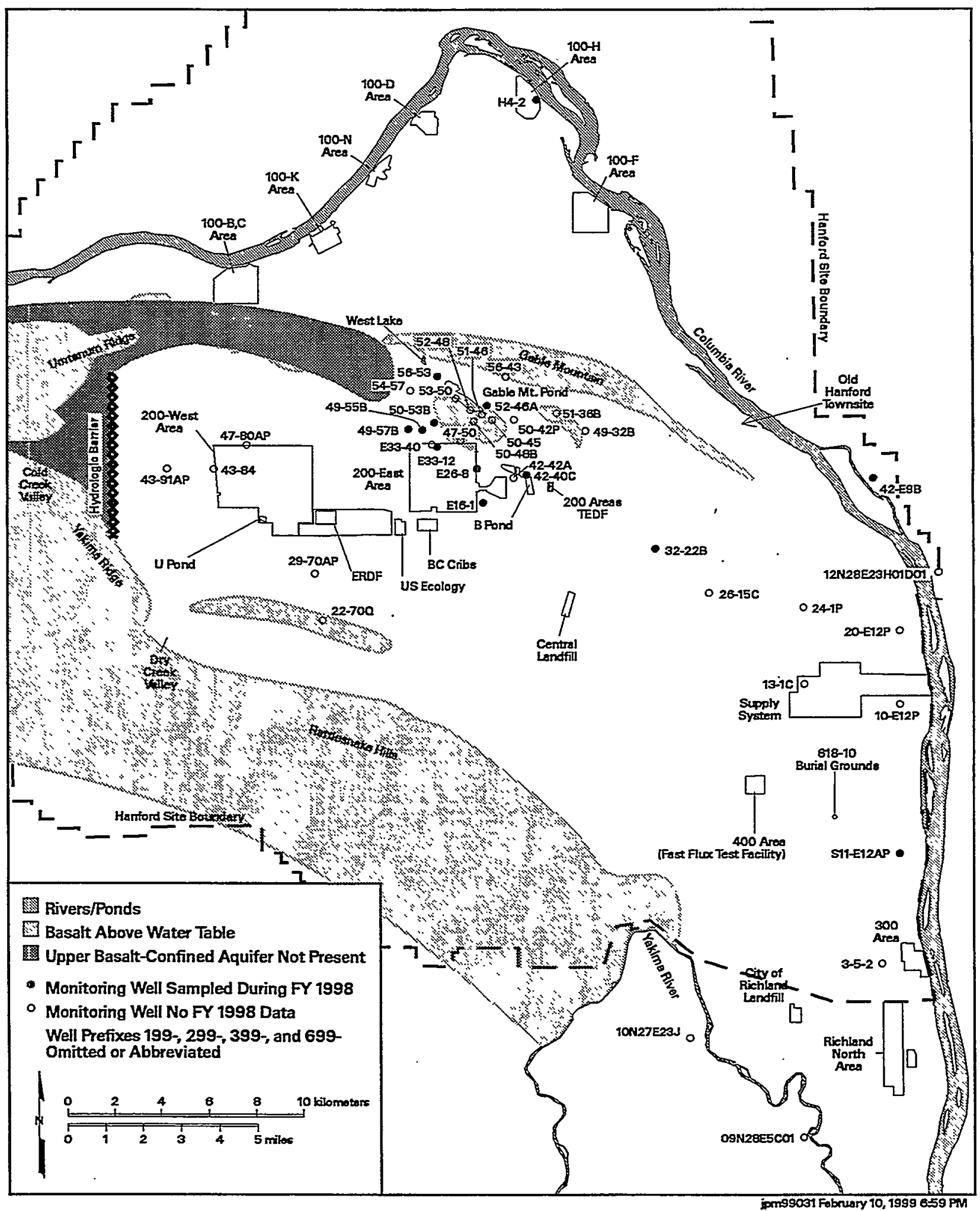

Figure 5.15-1. Hanford Site Map Showing Upper Basalt-Confined Aquifer Wells 


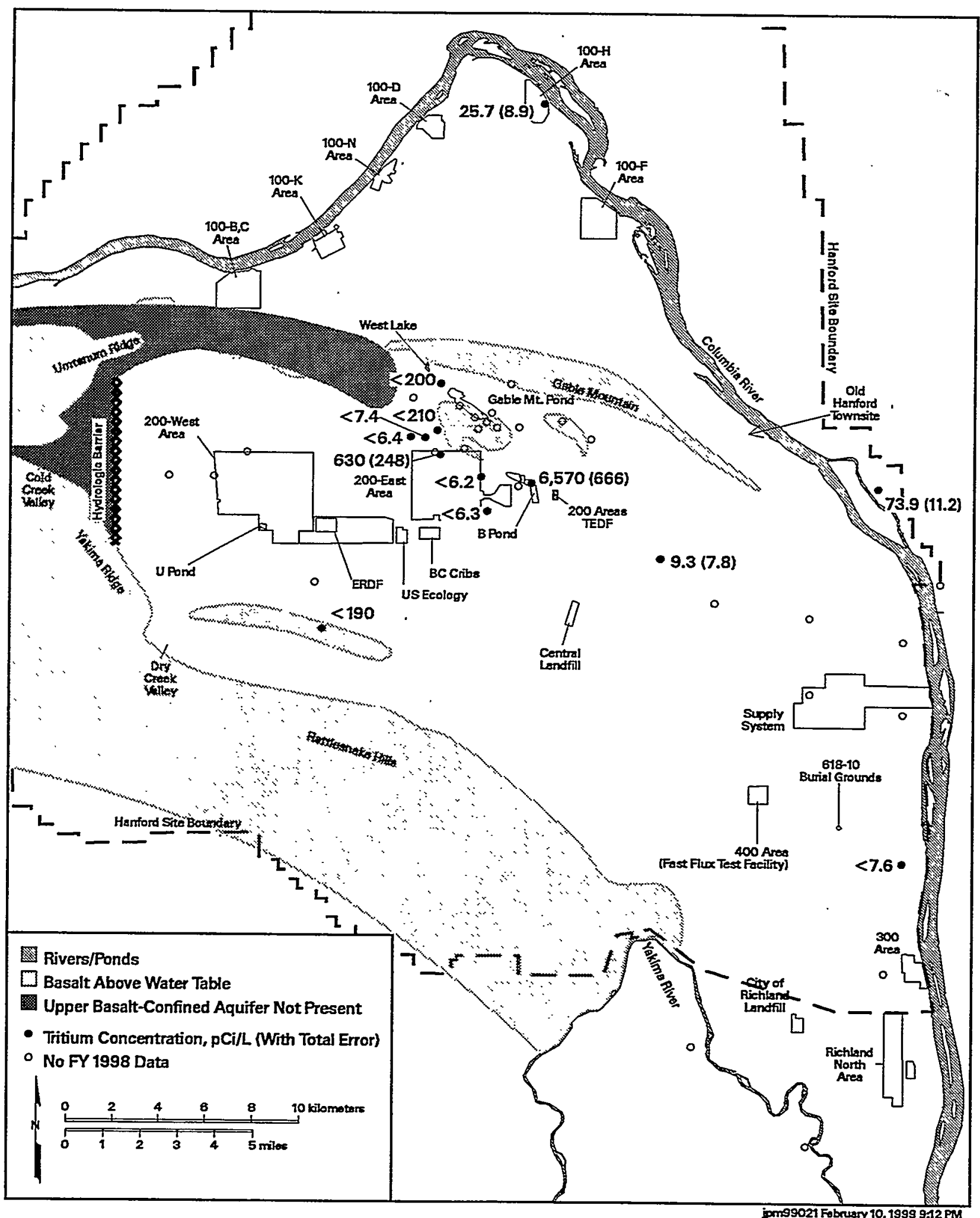

Figure 5.15-2. Highest Results for Tritium Detected in Upper Basalt-Confined AquiferMonitoring Wells 


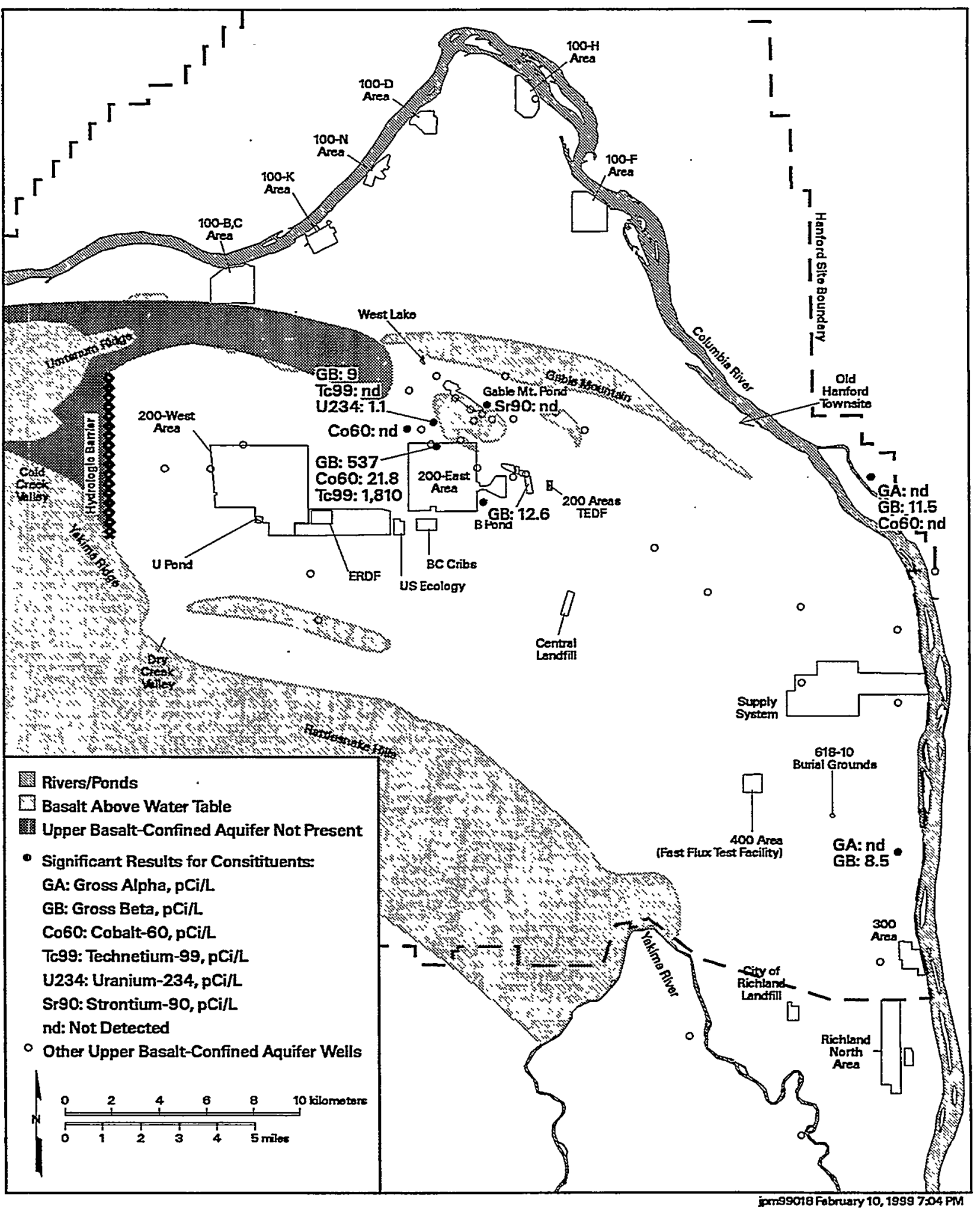

Figure 5.15-3. Highest Results for Selected Radionuclides Detected in Upper Basalt-Confined Aquifer-Monitoring Wells 


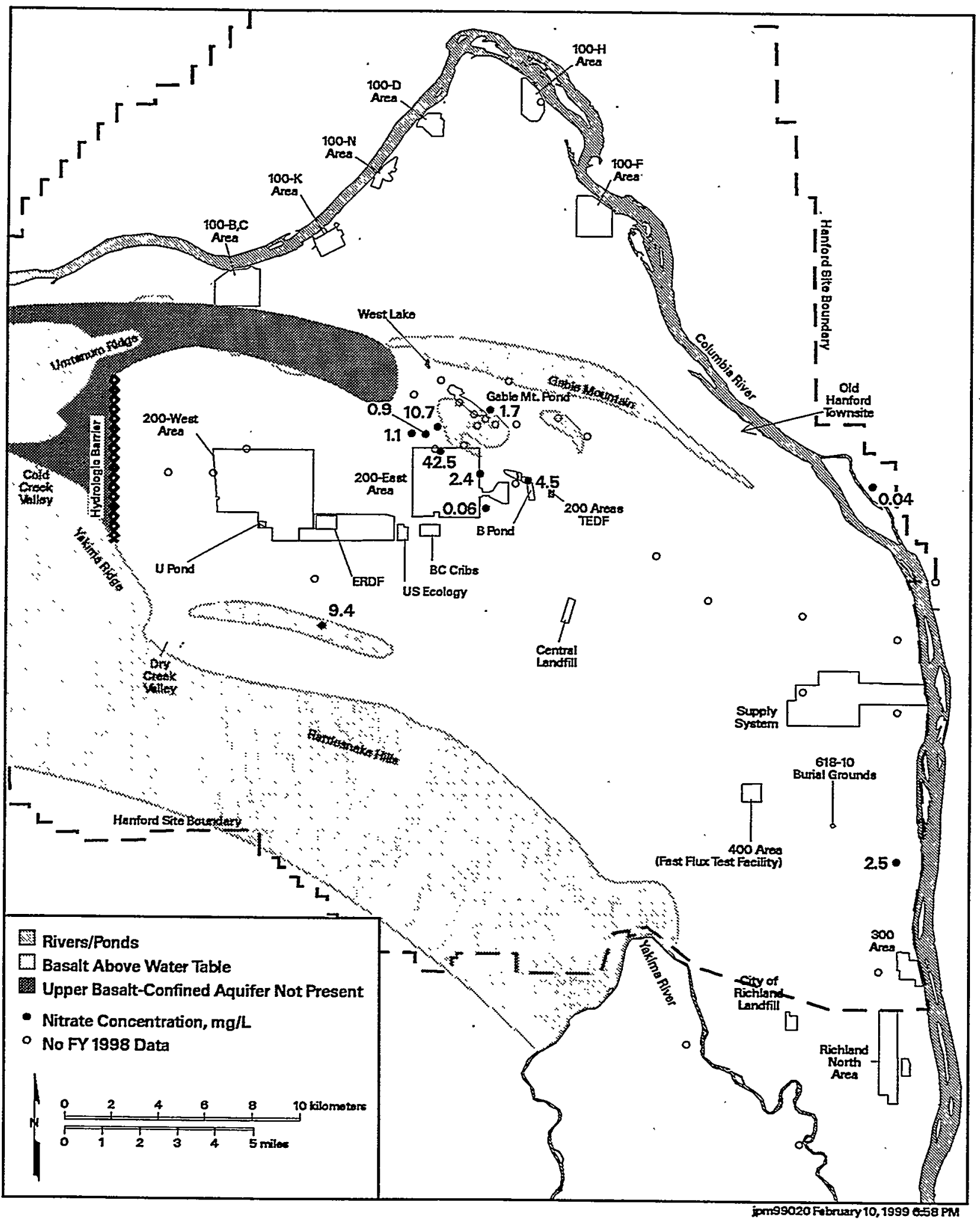

Figure 5.15-4. Highest Results for Nitrate Detected in Upper Basalt-Confined AquiferMonitoring Wells 


\subsection{Groundwater Modeling}

Groundwater-flow and contaminant-transport models are used to simulate future groundwater-flow conditions and predict the migration of contaminants through the groundwater pathway. During the past several years, a sitewide, three-dimensional, flow and transport model has been under development by Pacific Northwest National Laboratory's (PNNL's) Groundwater Monitoring Project.

Two-dimensional flow models have been used extensively at the Hanford Site. These models were generally adequate for predicting aquifer head changes and directions of groundwater flow prior to cessation of large wastewater-disposal operations. This is because groundwater levels were somewhat stable across the Hanford Site. However, in the early 1990s, it was recognized that a three-dimensional model was needed for accurate calculation of future aquifer head changes, directions of groundwater flow, mass transport, and predictions of contaminant concentrations. The three-dimensional model was needed because there is significant vertical heterogeneity in the unconfined aquifer, and the water table is dropping over most of the Hanford Site in response to cessation of large wastewater discharges. The unconfined aquifer system is composed of a series of conductive units that are separated from each other in most places by extensive mud units with relatively low hydraulic conductivities. Accounting for this vertical heterogeneity is particularly important as the water table drops, because the water table is currently near the contact between the Hanford formation and the underlying and much-less-conductive Ringold Formation over a large part of the Hanford Site. Dewatering of the highly permeable Hanford formation sediments in some areas (PNL-10196) may result in aquifer transmissivity changes. These changes would be an order of magnitude or more that would not be properly accounted for by twodimensional flow and transport models.

The sitewide, three-dimensional model was used during fiscal year 1998 to support the composite analysis for low-level waste disposal in the Hanford Site (PNNL 11800). The composite analysis involved simulation of future transport of radioactive contaminants that are expected to exist on the Hanford Site following site closure. Site closure was assumed to occur in the year 2050, followed by a 1,000-year compliance period. Only sources within a designated waste management area on the central plateau were considered because other potential sources are assumed to be remediated before site closure to the level that they will not pose a hazard. During the 1,000-year compliance period, potential exposure to radioactive contaminants outside the waste management area must be within regulatory limits and "as low as reasonably achievable" (PNNL 11800).

Other groundwater models were applied in the design and evaluation of pump-and-treat activities for the remediation of contaminated groundwater. These models were used to describe the capture and injection zones for extraction and injection wells, respectively, and to estimate the area affected by the pump-and-treat operations at different times. 


\subsection{Sitewide, Three-Dimensional, Groundwater-Flow and -Transport Model}

\section{P. D. Thorne, S. K. Wurstner}

This numerical model is based on the Coupled, Fluid, Energy, and Solute Transport (CFEST) code (BMI/ONWI-660). The objectives of the model are to increase the understanding of groundwater flow and contaminant transport at the Hanford Site, to predict future groundwater-flow conditions, and to provide forecasts of the migration of contaminant plumes. Initial development and application of the model are described in PNL-10886 and PNNL-11801.

The sitewide, three-dimensional, conceptual model and resulting CFEST numerical model are described below, followed by a summary of model predictions in support of the composite analysis (PNNL-11801).

\subsubsection{Hydrogeologic Framework}

To support development of the three-dimensional model, the lithofacies described in BHI-00184 (see Section 3.1) were grouped into nine different hydrogeologic model units based on factors such as texture, sorting, and degree of cementation, which generally correlate to flow properties. Other geologic factors such as depositional environment, lithologic composition, and time of deposition were not considered in defining hydrogeologic units for the model. Therefore, the grouping of lithofacies was similar but not identical to that in BH-00184. Hydrogeologic units defined for use in the model were designated by numbers and are briefly described in Table 6.1. More detailed descriptions of the sediments were presented in Section 3.1, and a graphic comparison of the model units against the stratigraphic column defined in BHI-00184 is shown in Figure 3.1-2.

Although nine hydrogeologic units were defined, only seven are found below the water table. Oddnumbered Ringold model units $(5,7$, and 9$)$ are predominantly coarse-grained sediments. Evennumbered Ringold model units $(4,6$, and 8$)$ are predominantly fine-grained sediments with low permeability. The Hanford formation combined with the pre-Missoula gravel deposits were designated model unit 1. Model units 2 and 3 correspond to the early Palouse soil and Plio-Pleistocene deposits, respectively. These units lie above the current water table. The predominantly mud facies of BHI-00184's upper Ringold unit were designated model unit 4 . However, a difference in the definition of model units is that the lower, predominantly sand, portion of the upper Ringold unit described in BHI-00184's was grouped with model unit 5, which also includes Ringold gravel/sand units $\mathrm{E}$ and $\mathrm{C}$. This was done because the predominantly sand portion of the upper Ringold is expected to have hydraulic properties similar to units E and C. BHI-00184's lower mud unit was designated units 6 and 8. Where they exist, the gravel and sand units $B$ and $D$, which are found within the lower Ringold, were designated model unit 7. Gravels of Ringold unit A were designated unit 9 for the model, and the underlying basalt was designated model unit 10 . However, the basalt was assigned a very low hydraulic conductivity and was essentially impermeable in the model.

The lateral extent and thickness distribution of each hydrogeologic unit were defined based on information from well driller's logs, geophysical logs, and an understanding of the geologic environment. These interpreted areal distributions and thicknesses were then integrated into EarthVision ${ }^{\mathrm{TM}}$ (Dynamic Graphics, Inc., Alameda, California), a three-dimensional, visualization, software package that was used to construct a database of the three-dimensional hydrogeologic framework. 


\subsubsection{Recharge and Flow-System Boundaries}

Both natural and artificial recharge to the aquifer were incorporated in the model. Natural recharge to the unconfined aquifer system occurs from infiltration of 1) runoff from elevated regions along the western boundary of the Hanford Site; 2) spring discharges originating from the basalt-confined aquifer system, also along the western boundary; and 3) precipitation falling across the site. Some recharge also occurs along the Yakima River in the southern portion of the site. Natural recharge from runoff and irrigation in the Cold Creek and Dry Creek Valleys, upgradient of the site, also provides a source of groundwater inflow. As discussed in Section 3.2.1, areal recharge from precipitation on the site is highly variable, both spatially and temporally, and depends on local climate, soil type, and vegetation. A recharge distribution based on the map developed in PNL-10285 for 1979 (see Figure 3.2-1) was applied in the model (PNL-10196).

The other source of recharge to the unconfined aquifer is wastewater disposal. As discussed in Section 3.2, the large volume of artificial recharge from wastewater discharged to disposal facilities on the Hanford Site over the past 50 years has significantly impacted groundwater flow and contaminant transport in the unconfined aquifer system. The volume of artificial recharge decreased significantly during the past 10 years, as shown in Figure 3.3-3.

Peripheral boundaries defined for the three-dimensional model are shown in Figure 6.1 together with the three-dimensional flow-model grid. The flow system is bounded by the Columbia River on the north and east and by the Yakima River and basalt ridges on the south and west. The Columbia River represents a point of regional discharge for the unconfined aquifer system. The amount of groundwater discharging to the river is a function of local hydraulic gradient between the groundwater elevation adjacent to the river and the river-stage elevation. This hydraulic gradient is highly variable because the river stage is affected by releases from upstream dams. To approximate the long-term effect of the Columbia River on the unconfined aquifer system in the three-dimensional model, the Columbia River was represented as a constant-head boundary over the entire thickness of the aquifer. The CHARIMA riversimulation model (PNWD-2225 HEDR) was used to generate long-term, average, river-stage elevations for the Columbia River based on 1979 conditions. The previous Columbia River boundary was extended from the left edge of the river to the middle of the river channel to reflect more accurately the hydraulic interaction of the unconfined aquifer and the river. The Yakima River was also represented as a specifiedhead boundary over the entire thickness of the aquifer.

At Cold Creek and Dry Creek Valleys, the unconfined aquifer system extends westward beyond the boundary of the model. To approximate the groundwater flux entering the modeled area from these valleys, both constant-head and constant-flux boundary conditions were defined. A constant-head boundary condition was specified for Cold Creek Valley for the steady-state model calibration runs. Once calibrated, the steady-state model was used to calculate the flux condition that was then used in the transient simulations. The constant-flux boundary was used because it better represents the response of the boundary to a declining water table than a constant-head boundary. Discharges from Dry Creek Valley in the model area, resulting from infiltration of precipitation and spring discharges, are approximated with a prescribed-flux boundary condition.

The basalt underlying the unconfined aquifer sediments represents a lower boundary to the unconfined aquifer system. The potential for interflow (recharge and discharge) between the basalt-confined 
aquifer system and the unconfined aquifer system is largely unquantified but is postulated to be small relative to the other flow components estimated for the unconfined aquifer system. Therefore, interflow with underlying basalt units was not included in the current three-dimensional model. The basalt was defined in the model as an essentially impermeable unit underlying the sediments.

\subsubsection{Hydraulic and Transport Properties}

To model groundwater flow, the distribution of hydraulic properties, including both horizontal and vertical hydraulic conductivity, storativity, and specific yield, were needed for each hydrogeologic unit defined in the model. In addition, to simulate movement of contaminant plumes, transport properties were needed, including contaminant-specific distribution coefficients, bulk density, effective porosity, and longitudinal and transverse dispersivities.

Hydraulic properties of the Hanford Site unconfined aquifer were discussed in Section 3.2.2. For the two-dimensional model, measured values of aquifer transmissivity were used with an inverse modelcalibration procedure to determine the transmissivity distribution. Hydraulic head conditions for 1979 were used in the inverse calibration because measured hydraulic heads were relatively stable at that time. Details concerning the updated calibration of the two-dimensional model are provided in PNNL-11801. The resulting transmissivity distribution for the unconfined aquifer system was shown in Figure 3.2-2.

Hydraulic conductivities were assigned to the three-dimensional model units so that the total aquifer transmissivity from inverse calibration was preserved at every location. The vertical distribution of hydraulic conductivity at each spatial location was determined based on the transmissivity value and other information, including facies descriptions and hydraulic property values measured for similar facies. A complete description of the seven-step process used to vertically distribute the transmissivity among the model hydrogeologic units is described in PNNL-11801.

Information on transport properties used in past modeling studies at the Hanford Site is provided in PNL-10886. Values of distribution coefficient, bulk density, effective porosity, and dispersivity used in aquifer-transport modeling for the composite analysis are given in Table 6.2 and are discussed in detail in PNNL-1 1800. The applied values were the same for all hydrogeologic units, except that a porosity of 0.1 was used for the Ringold Formation (model units 4 through 9) and a porosity of 0.25 was used for the Hanford formation (model unit 1). Distribution coefficients used for aquifer-transport simulations and listed in Table 6.2 were based on low-salt, near-neutral, and low-organic chemical conditions within the aquifer.

\subsubsection{CFEST Flow Model Implementation and Calibration}

The finite-element grid used for the composite analysis (Figure 6.2) was designed to increase the overall effectiveness of the three-dimensional model in simulating transport problems. Most of the interior surface elements are regular ( $375 \mathrm{~m}$ on a side). Surface elements away from the 200 Areas plateau are larger. The total number of surface elements in the three-dimensional model is 2,991 . The three-dimensional model, based on this surface grid, comprises a total of 23,128 elements and 23,668 nodes. 
After a reasonable steady-state solution was generated for the three-dimensional model, the model was calibrated to match past changes in wastewater discharges. A number of calibration simulations were performed to evaluate the specific yield value that results in the best overall match. Specific yield largely controls how well the model responds to changes in flux. Three-dimensional transient simulations were conducted for the 1980 to 1995 time frame and used specific yields ranging from 0.1 and 0.35 . The best fit to the observed data was achieved when a specific yield of 0.1 was used for the Ringold Formation and a specific yield of 0.25 for the Hanford formation. The model was then used to simulate groundwaterflow conditions through the year 4000 to predict the future response of the water table to postulated changes in Hanford Site operations.

\subsubsection{Groundwater-Flow Model Results}

Over an $\sim 300$-year period following site closure and the elimination of wastewater discharges to the ground, the water table is predicted by the model to decline significantly and return to near pre-Hanford Site conditions. Over this period, the water table is predicted to drop as much as $11 \mathrm{~m}$ beneath the 200-West Area near the 216-U-10 pond and 7 to $8 \mathrm{~m}$ beneath the 200-East Area near the 216-B-3 pond (both ponds have been decommissioned and are not in use). The areas where the future water table is predicted to be different from the 1944 water table back-extrapolated in BNWL-B-360 include the area west of the 200-West Area, where higher predicted hydraulic heads reflect the effects of increased irrigation from upgradient regions; and the area of the City of Richland's North Well Field recharge ponds, where net injection of water was assumed to continue. Figure 6.3 shows a comparison of the predicted water table for 2350 and the back-extrapolated water table for 1944.

\subsubsection{Groundwater-Transport Model Implementation}

A groundwater-transport model based on the CFEST-96 code was developed and implemented for the composite analysis (PNNL-11801). The model was used to evaluate the future migration and fate of existing radioactive contaminant plumes as well as the migration of plumes from future sources of radioactive contamination. The simulated, existing, contaminant plumes included tritium, iodine-129, technetium-99, uranium, and strontium-90. Radionuclides evaluated also included future releases of iodine-129, technetium-99, uranium, carbon-14, chlorine-36, selenium-79, and other radionuclides from waste sites and the vadose zone at the Hanford Site. Each of the transport simulations was based on predicted future transient-flow conditions and a high-resolution finite-element grid designed to resolve areas of future plume transport.

Separating the analysis of plumes resulting from future leaching of contaminants from the vadose zone, from the analysis of the migration of existing plumes, facilitated interpretation of results. The existing contaminant plumes superimpose with the plumes generated by future releases of contaminants considered in the composite analysis. Radiological doses resulting from the separate simulations were simply added together in $\mathrm{ARC} / \mathrm{INFO}{ }^{\circ}$ to produce the final results (ARC/NNFO is a registered trademark of Environmental System Research Institute, Inc., Redlands, California). To illustrate the fate and transport of contaminants considered in the composite analysis, the predicted distributions of the contaminant plumes are given in PNNL-11801 at their times of peak concentration in the unconfined aquifer, which are prior to the start of the compliance period.

As discussed in PNNL-11801, simulations for all existing plumes, except tritium, began in 1996. The initial conditions for these simulations were based on the plumes presented in the Hanford Site 
groundwater-monitoring report for fiscal year 1996 (PNNL-11470). The tritium plume simulation was run from 1979 through 2100 , starting with initial conditions interpreted from 1979 monitoring data. The results are presented in PNNL-11801 and compare simulation results for the 1996 tritium plume with interpretations from monitoring observations reported in PNNL-11470.

\subsubsection{Groundwater-Transport Model Results}

Maximum activity-concentration plots were prepared from the three-dimensional model results through a process that determined the maximum concentration vertically at each $x-y$ location. The contour plots of concentration, therefore, represent the areal distribution of the maximum simulated activity concentration at any depth within the aquifer.

The year 2050 was chosen as the beginning of the compliance period, which corresponds to the Hanford Site closure assumed in the composite analysis (PNNL-11801). Figures 6.4 and 6.5 show the predicted distributions of tritium in the unconfined aquifer in 1997 and 2050. Figures 6.6 through 6.12 illustrate the distributions of iodine-129, technetium-99, uranium, strontium-90, carbon-14, chlorine-36, and selenium-79, respectively, for the start of the compliance period (i.e., 2050).

\subsection{Modeling to Support Pump-and-Treat Operations}

\section{C. Swanson}

A groundwater model was used at a local scale in operable units in the 200 Areas to assess the performance of groundwater pump-and-treat systems to remediate contamination within the unconfined aquifer system. This model was used to evaluate system performance and overall progress toward remediation objectives and goals, including evaluating different extraction and injection well configurations, predicting effects of different operational and pumping schedules, assessing extent of hydraulic influence, and evaluating groundwater-travel times and extent of the capture zone.

Modeling was conducted using Micro-FEM ${ }^{\circ}$ (a finite-element code) developed by C. J. Hemker, Amsterdam, The Netherlands. Included in the modeling package are mesh-generating programs, a calculation module, and a postprocessing program. The mesh-generating programs allow the user to construct irregularly shaped and variably spaced triangular finite-element meshes. This feature allows for high resolution of the finite-element mesh near pumping or injection centers. The calculation module supports either a transient or steady-state solution. The postprocessing program enables the user to export the results of the simulations for presentation. The Micro-FEM ${ }^{\circ}$ package was chosen because the finiteelement, mesh-generating, and output capabilities make it easy to change the configuration of pumping and injection wells and quickly examine the results.

The MicroFEM ${ }^{\circ}$ model was used for evaluating the following remedial action sites and contaminants of concern in the 200-West Area:

- 200-UP-1 Operable Unit; technetium-99 and uranium

- 200-ZP-1 Operable Unit; carbon tetrachloride. 


\subsubsection{Model Results for 200-UP-1 Operable Unit}

Numerical modeling for this pump-and-treat operation was performed to evaluate the effects of remedial actions on the aquifer and the contaminants of concern. It was concluded, based on the modeling, that the entire high-concentration area of the technetium-99 and uranium plumes were captured during the fiscal year using the one extraction well (299-W19-39) (DOE/RL-99-02). Through September $1998, \sim 0.90$ pore volume was removed from the targeted plume area. The contaminant-removal efficiency was $\sim 79 \%$, which is a ratio of the amount of water pulled from the target area of the plume to the total amount of water removed from the aquifer. For additional discussion on the 200-UP-1 model, refer to DOE/RL-99-02.

\subsubsection{Model Results for 200-ZP-1 Operable Unit}

Numerical modeling was also performed for this pump-and-treat operation to evaluate the effects of the remedial actions. Based on the modeling, the entire high-concentration area of the carbon tetrachloride plume was captured this fiscal year. The numerical modeling predictions indicate that pump-andtreat operations have resulted in the removal of 1 pore volume from the upper $15 \mathrm{~m}$ of the aquifer at a distance of $\sim 70$ to $80 \mathrm{~m}$ around the three southernmost extraction wells (299-W15-32, 299-W15-36, and 299-W15-37) (see Figure 5.9-33 for well locations). Because the three northernmost extraction wells have operated longer, their area of capture is larger. Operation of these wells resulted in the removal of 1 pore volume at a radius of $130 \mathrm{~m}$ around wells $299-\mathrm{W} 15-33$ and $299-\mathrm{W} 15-34$ and $\sim 170 \mathrm{~m}$ around well 299-W15-35. For a more detailed description of 200-ZP-1 modeling, refer to DOE/RL-99-02. 
Table 6.1. Major Hydrogeologic Units Used in Sitewide Three-Dimensional Model (after PNNL-11801)

Model Unit Number

1

3

4

5

6

7

8

9

10
Corresponding Geologic Unit

Hanford formation and preMissoula gravels

Palouse soil

Plio-Pleistocene unit

Upper Ringold muds

Middle Ringold (Units E and C) and some upper Ringold sands

Lower Ringold mud

Middle Ringold (Units B and D)

Lower Ringold mud

Basal Ringold (Unit A)

Columbia River Basalt Group
Lithologic Description

Glaciofluvial gravels and sands (catastrophic flood deposits)

Fine-grained sediments and eolian silts

Buried soil horizon containing caliche and basaltic gravels

Fine-grained fluvial and lacustrine sediments

Coarse-grained fluvial sediments, semi-indurated, poorly sorted sands and gravels with some silt

Fine-grained fluvial and lacustrine sediments with some interbedded coarse-grained sediments

Coarse-grained fluvial sediments

Fine-grained fluvial and lacustrine sediments

Fluvial sand and gravel

. Basalt 
Table 6.2. Aquifer-Transport Properties Used in Hanford Site Composite Analysis (PNNL-11800)

\begin{tabular}{|c|c|c|c|c|c|}
\hline \multirow[b]{2}{*}{$\begin{array}{c}\text { Plume } \\
\text { Constituent }\end{array}$} & \multirow[b]{2}{*}{$\begin{array}{l}\text { Distribution } \\
\text { Coefficient } \\
\left(\mathrm{K}_{\mathrm{d}}\right), \mathrm{mL} / \mathrm{g} \\
\end{array}$} & \multirow[b]{2}{*}{$\begin{array}{c}\text { Bulk } \\
\text { Density, } \\
\mathrm{g} / \mathrm{mL}\end{array}$} & \multirow{2}{*}{$\begin{array}{l}\text { Effective } \\
\text { Porosity } \\
\text { Ringold/ } \\
\text { Hanford } \\
\end{array}$} & \multicolumn{2}{|c|}{ Dispersivity } \\
\hline & & & & $\begin{array}{c}\text { Longitudinal, } \\
\mathrm{m}\end{array}$ & $\begin{array}{c}\text { Transverse, } \\
\text { m } \\
\end{array}$ \\
\hline Actinium & 300 & 1.9 & $0.1 / 0.25$ & 90 & 9 \\
\hline Americium & 300 & 1.9 & $0.1 / 0.25$ & 90 & 9 \\
\hline Carbon & 5 & 1.9 & $0.1 / 0.25$ & 90 & 9 \\
\hline Cerium & 300 & 1.9 & $0.1 / 0.25$ & 90 & 9 \\
\hline Cesium & 1,500 & 1.9 & $0.1 / 0.25$ & 90 & 9 \\
\hline Chlorine & 0 & 1.9 & $0.1 / 0.25$ & 90 & 9 \\
\hline Cobalt & 1,200 & 1.9 & $0.1 / 0.25$ & 90 & 9 \\
\hline Curium & 300 & 1.9 & $0.1 / 0.25$ & 90 & 9 \\
\hline Europium & 300 & 1.9 & $0.1 / 0.25$ & 90 & 9 \\
\hline Iodine & 0.5 & 1.9 & $0.1 / 0.25$ & 90 & 9 \\
\hline Lead & 6,000 & 1.9 & $0.1 / 0.25$ & 90 & 9 \\
\hline Neptunium & 15 & 1.9 & $0.1 / 0.25$ & 90 & 9 \\
\hline Nickel & 300 & 1.9 & $0.1 / 0.25$ & 90 & 9 \\
\hline Niobium & 300 & 1.9 & $0.1 / 0.25$ & 90 & 9 \\
\hline Plutonium & 200 & 1.9 & $0.1 / 0.25$ & 90 & 9 \\
\hline Protactinium & 15 & 1.9 & $0.1 / 0.25$ & 90 & 9 \\
\hline Radium & 20 & 1.9 & $0.1 / 0.25$ & 90. & 9 \\
\hline Ruthenium & 20 & 1.9 & $0.1 / 0.25$ & 90 & 9 \\
\hline Selenium & 0 & 1.9 & $0.1 / 0.25$ & 90 & 9 \\
\hline Strontium & 20 & 1.9 & $0.1 / 0.25$ & 90 & 9 \\
\hline Technetium & 0 & 1.9 & $0.1 / 0.25$ & 90 & 9 \\
\hline Thorium & 1,000 & 1.9 & $0.1 / 0.25$ & 90 & 9 \\
\hline Tin & 300 & 1.9 & $0.1 / 0.25$ & 90 & 9 \\
\hline Tritium & 0 & 1.9 & $0.1 / 0.25$ & 90 & 9 \\
\hline Uranium & 3 & 1.9 & $0.1 / 0.25$ & 90 & 9 \\
\hline Zirconium & 1,000 & 1.9 & $0.1 / 0.25$ & 90 & 9 \\
\hline
\end{tabular}




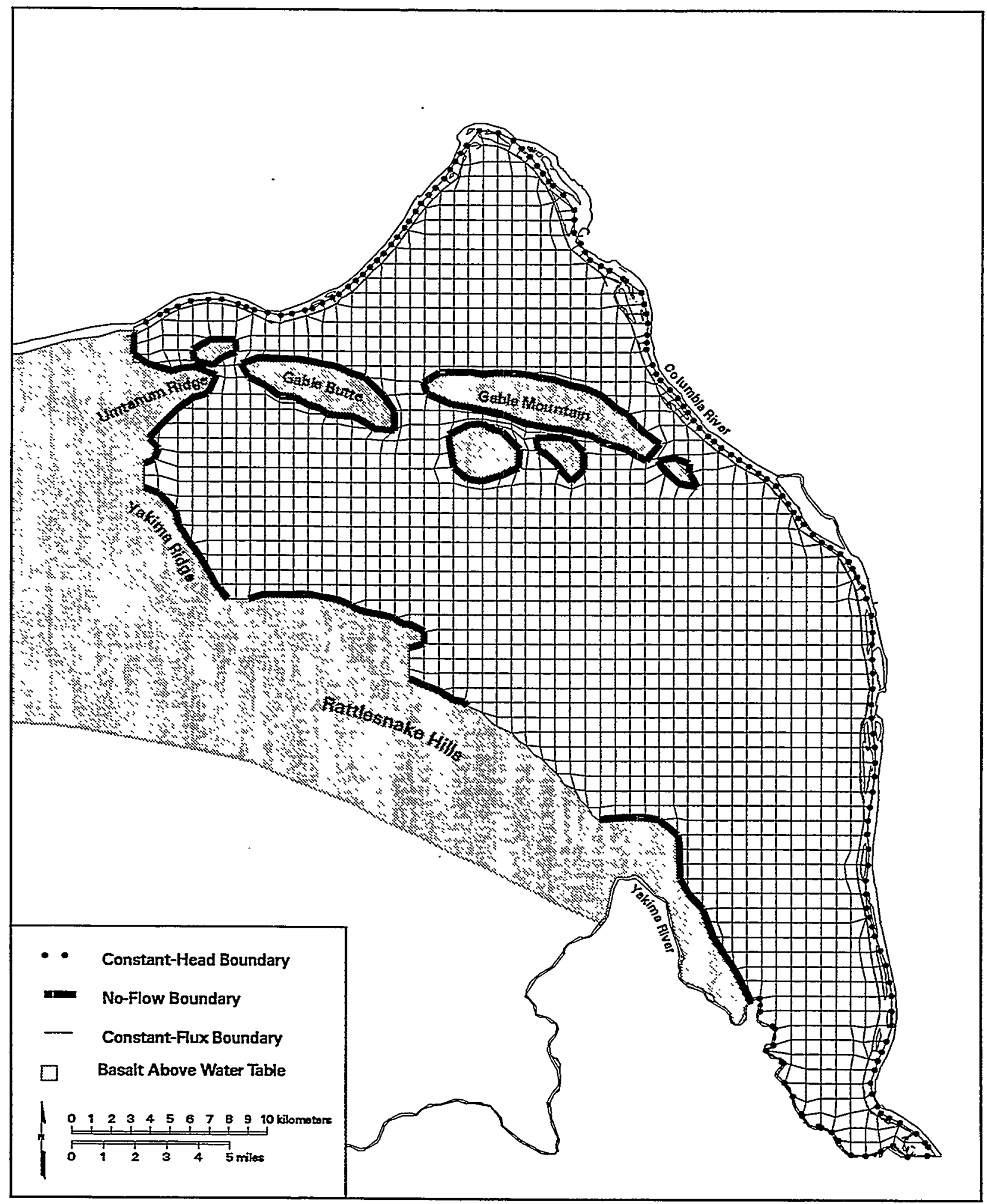

pdt99011eps

Figure 6.1. Surface Grid and Boundary Conditions for Three-Dimensional CFEST Model 


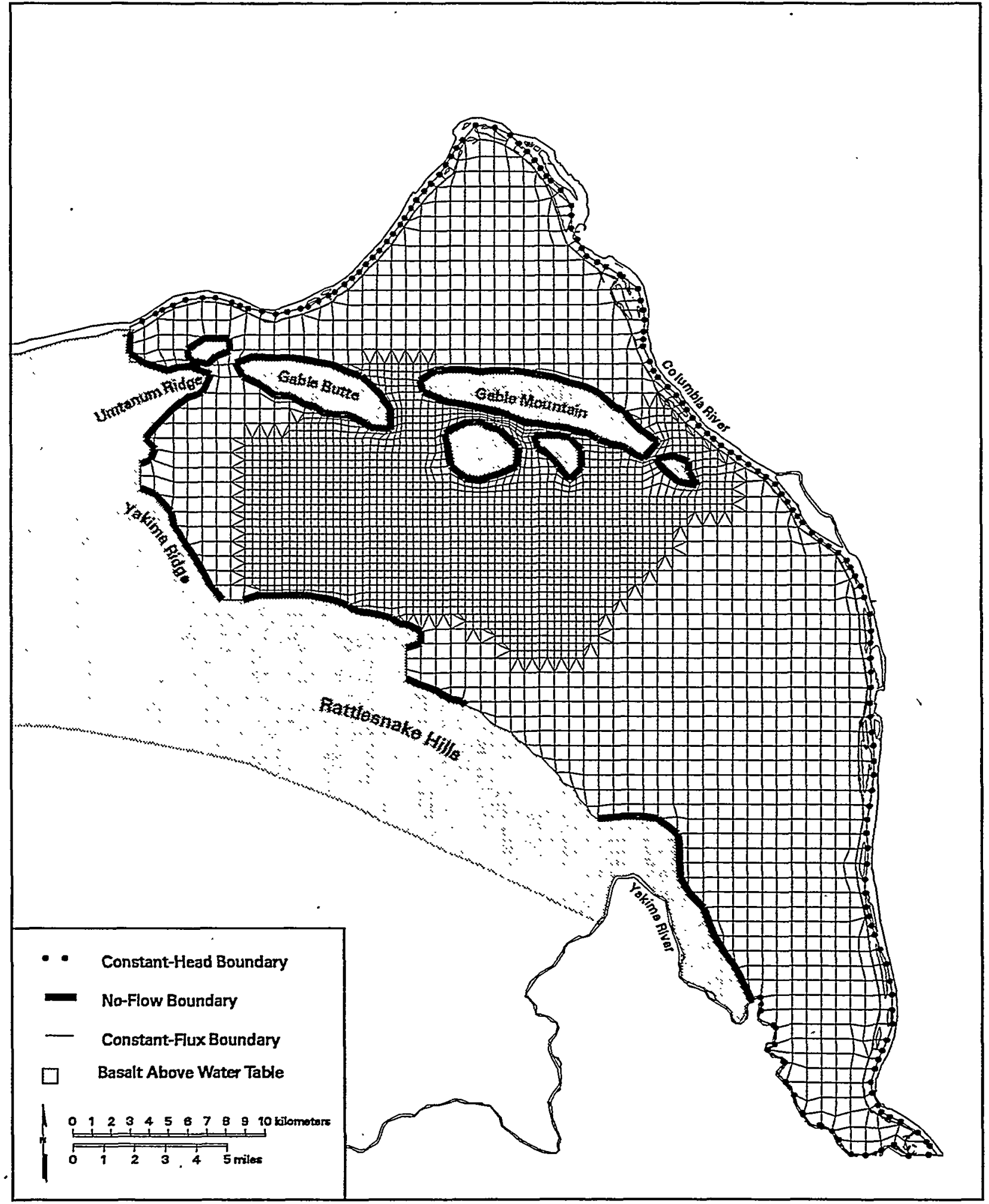

pdt99012.ps

Figure 6.2. Refined CFEST Surface Grid Used for Composite Analysis Transport Modeling 


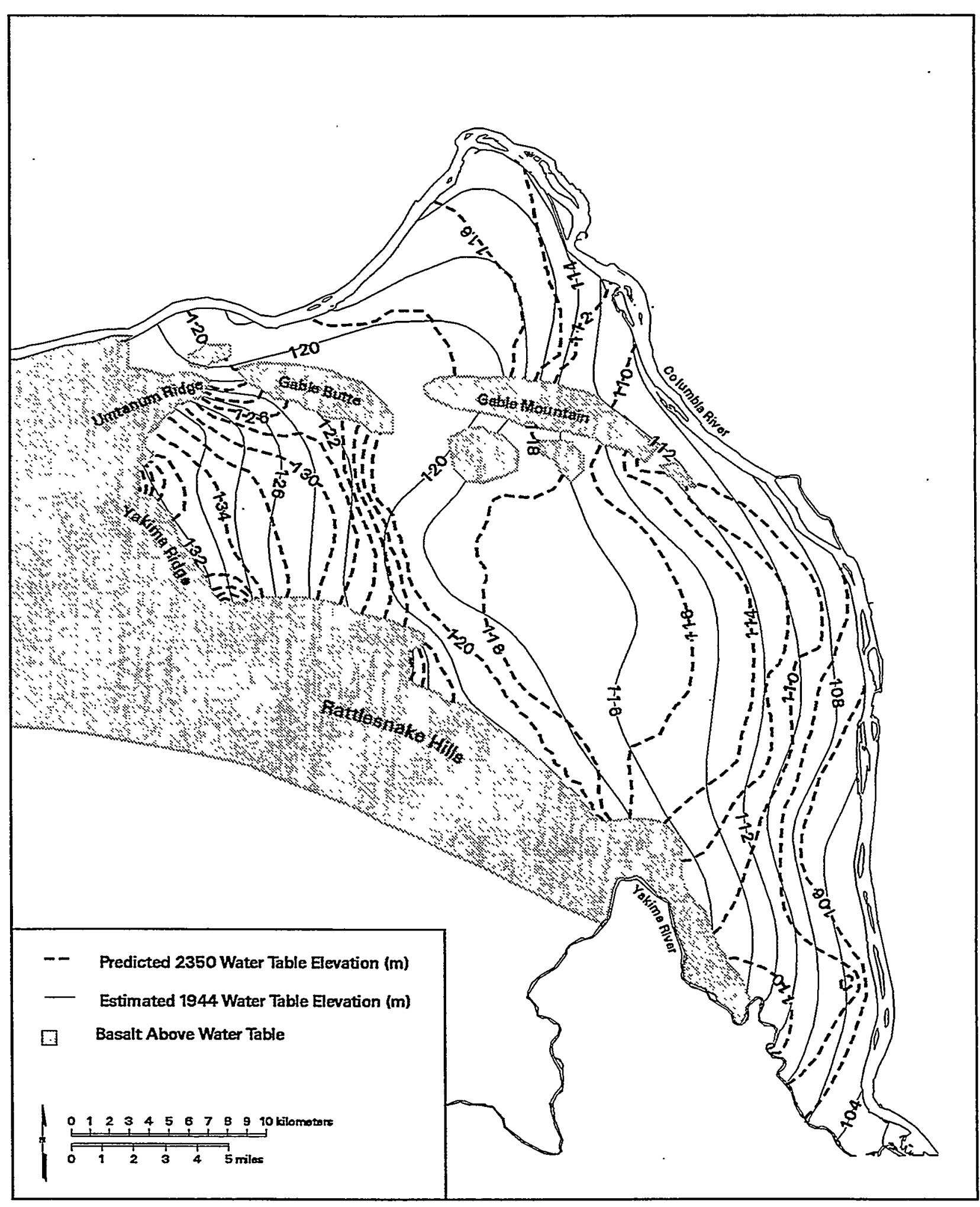

ptt99013eps

Figure 6.3. Water Table Elevations Predicted for 2350 Compared to the Inferred 1944 Water Table 


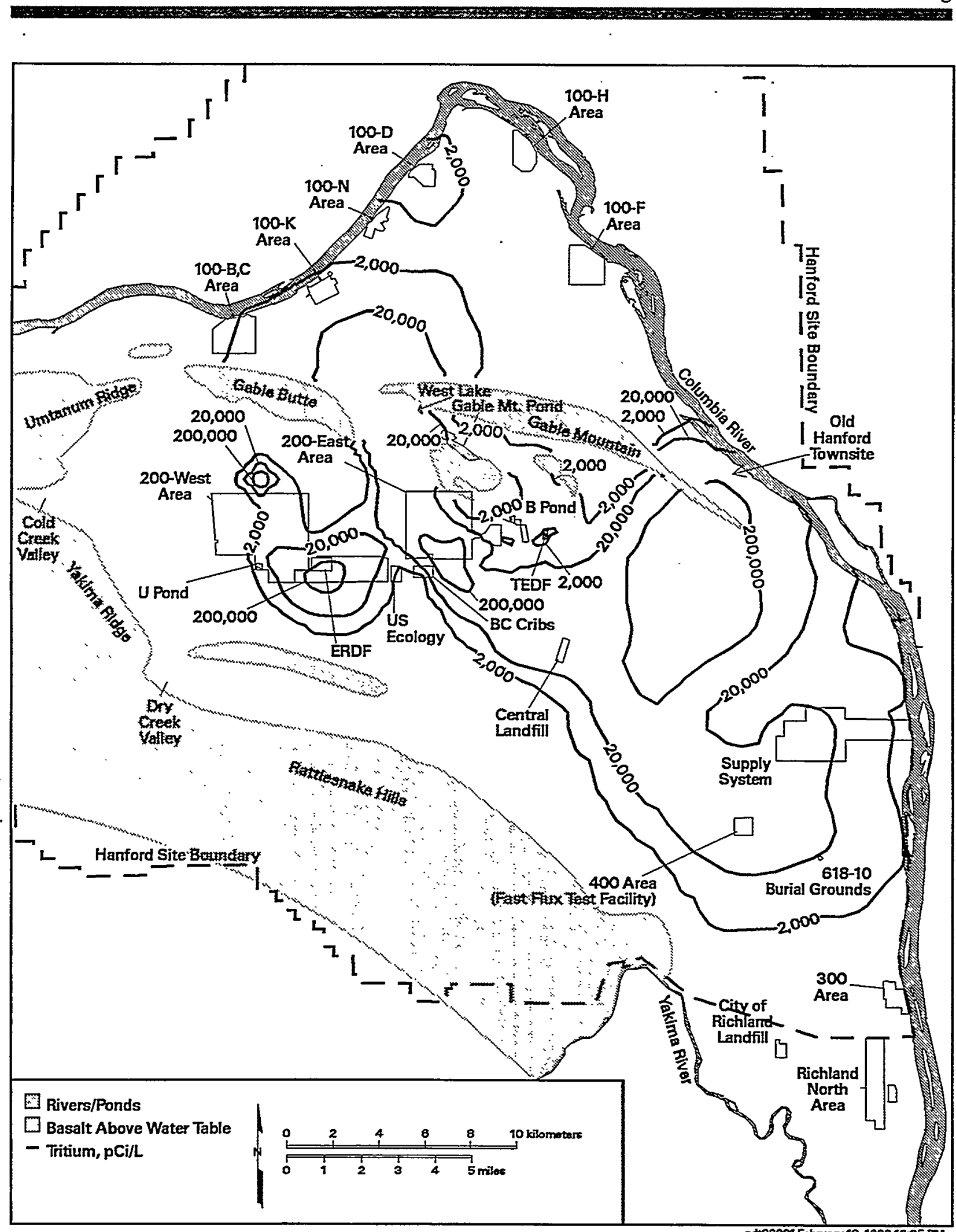

pdt99001 Fabruary 13, 1999 12=05 FM

Figure 6.4. Predicted Tritium Plume from the 200 Areas for 1997 


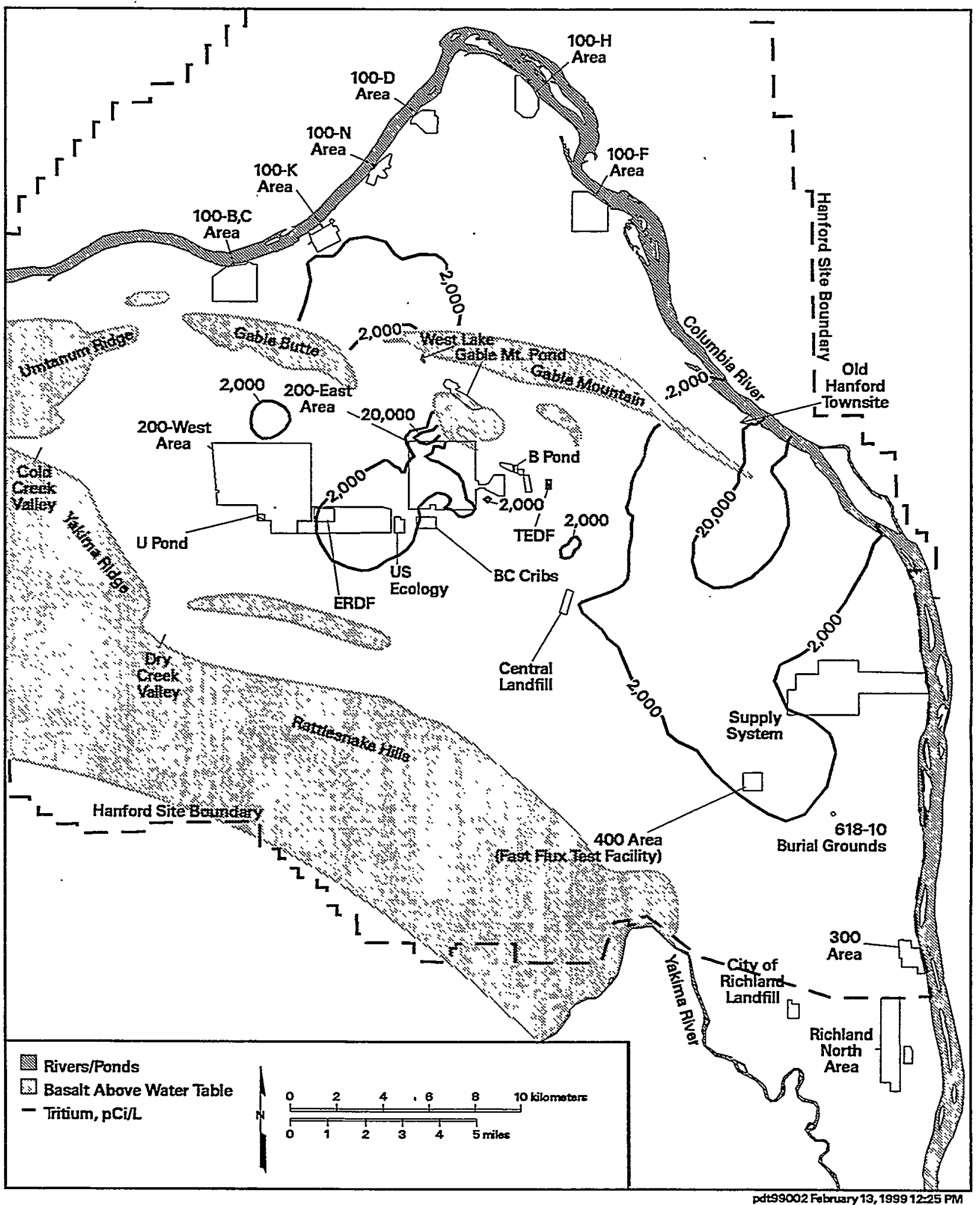

Figure 6.5. Predicted Tritium Plume from the 200 Areas for 2050 (assumed site closure date) 


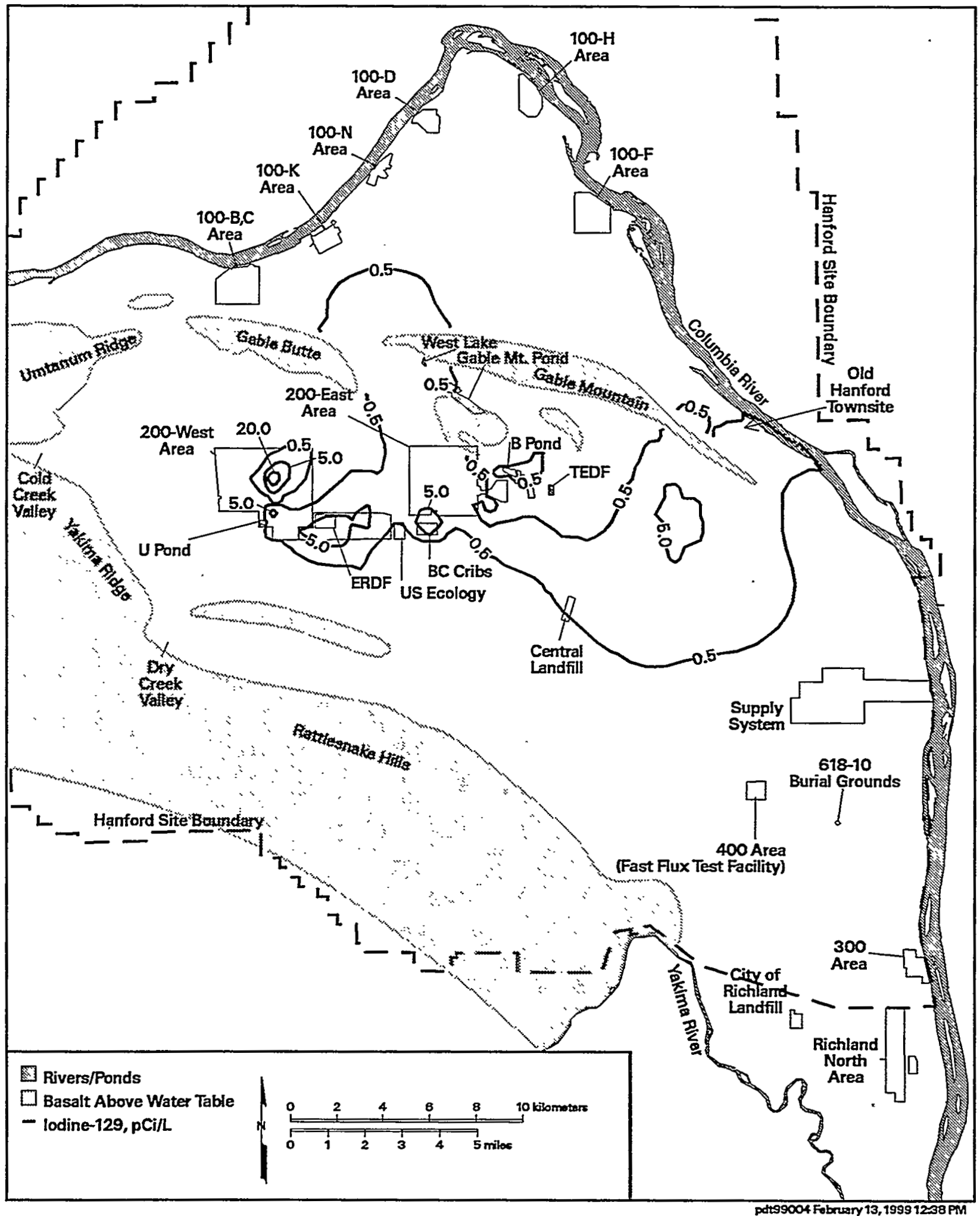

Figure 6.6. Predicted Iodine-129 Plume from the 200 Areas for 2049 (assumed site closure date) 


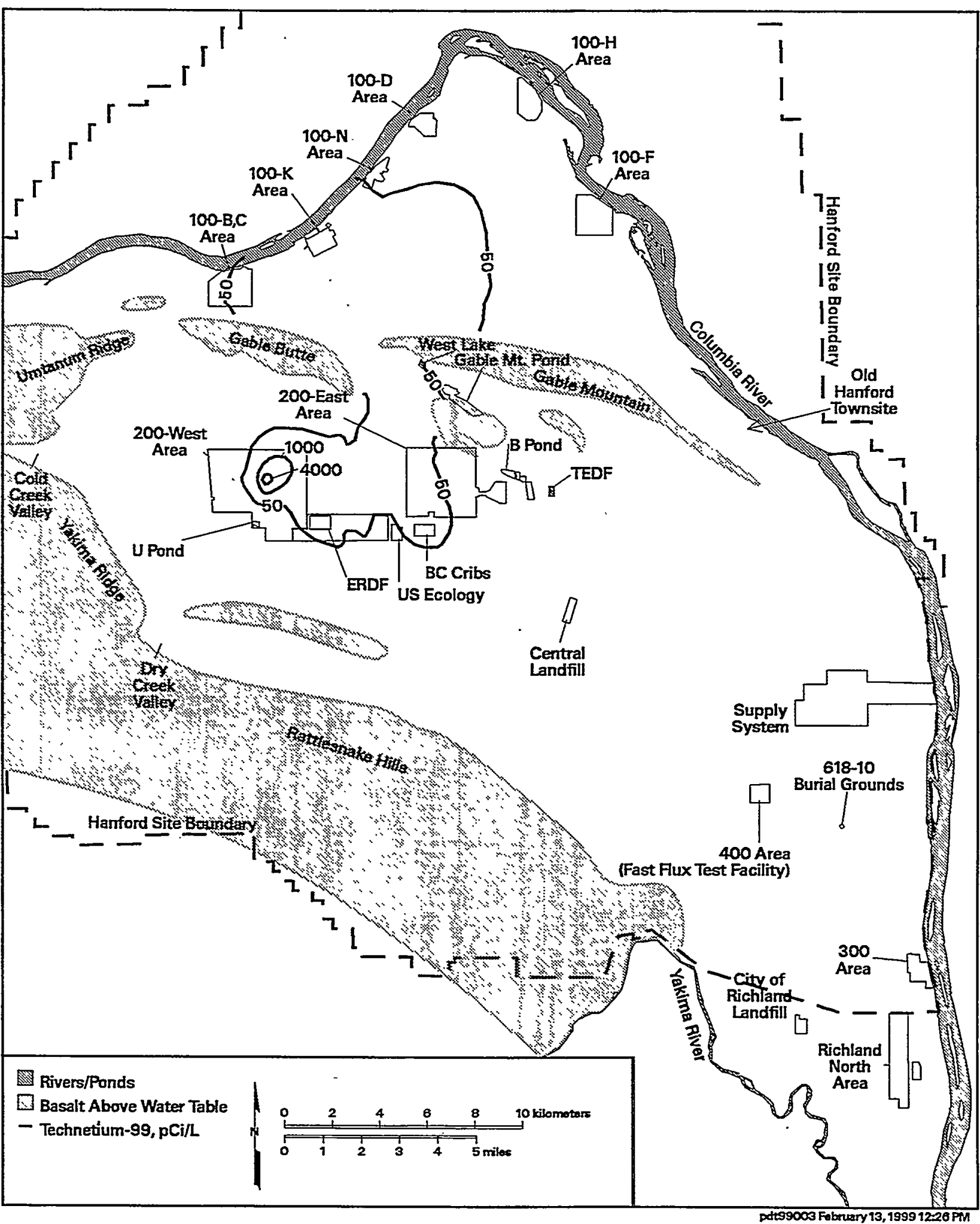

Figure 6.7. Predicted Technetium-99 Plume from the 200 Areas for 2049 (assumed site closure date) 


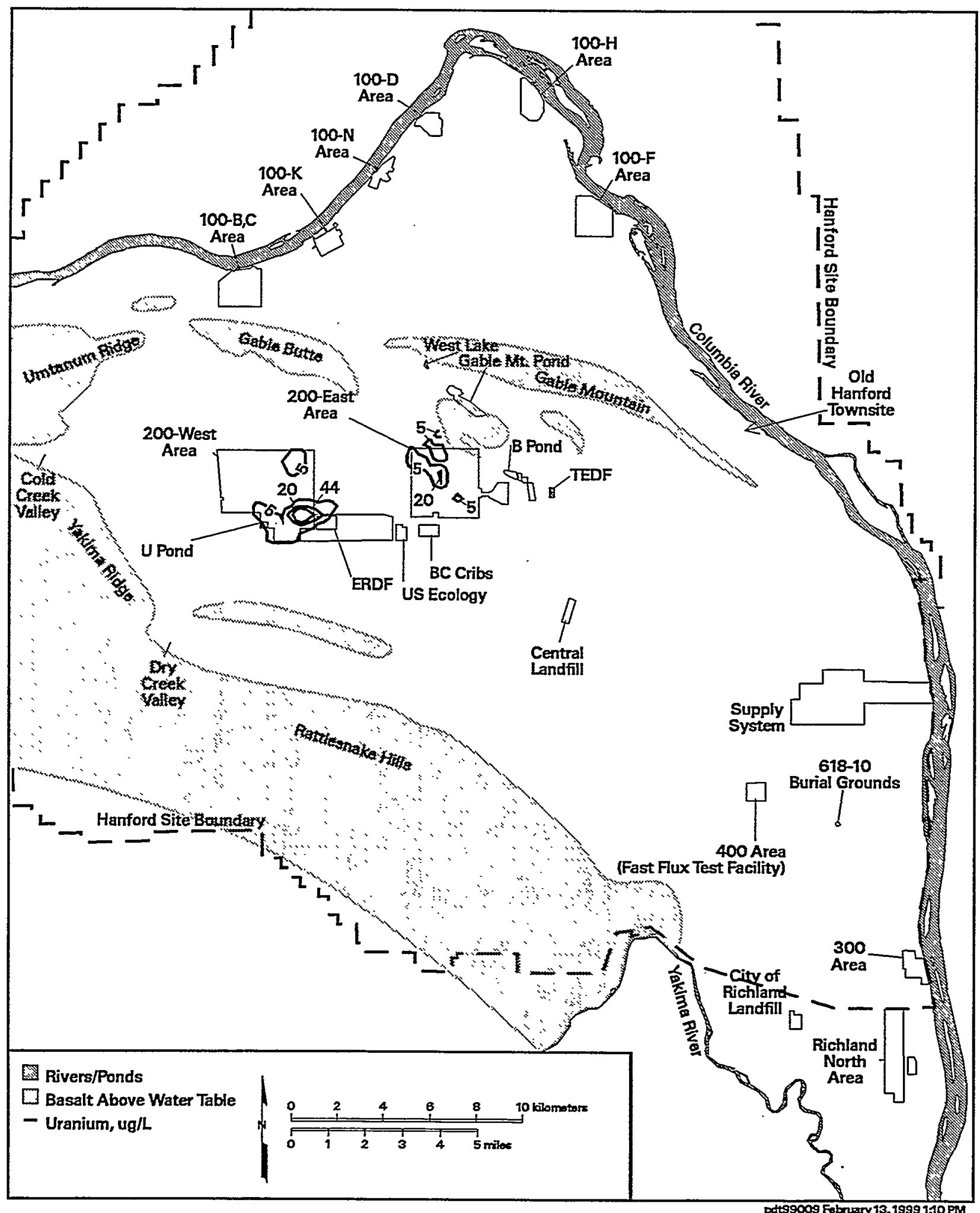

Figure 6.8. Predicted Uranium Plume from the 200 Areas for 2049 (assumed site closure date) 


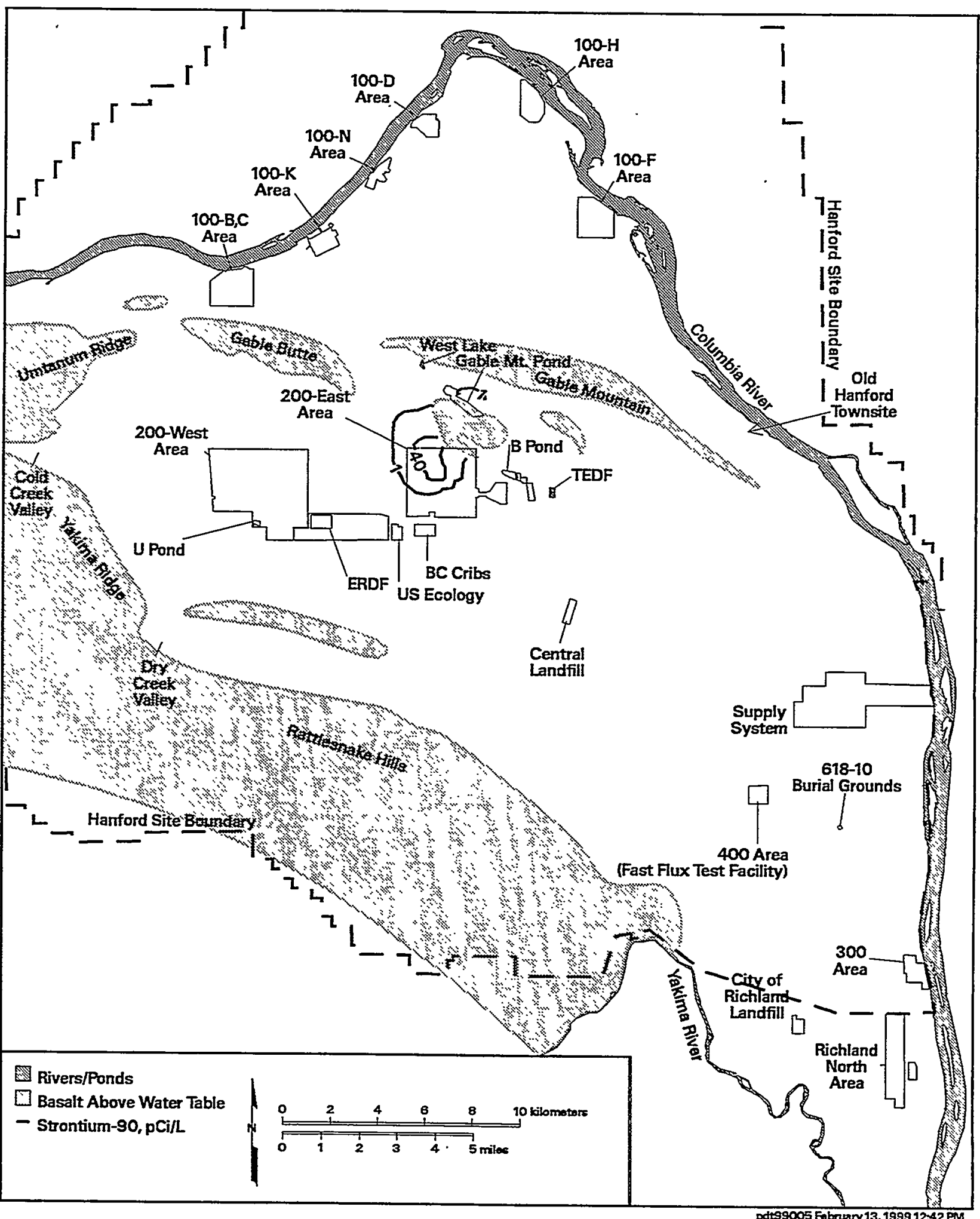

Figure 6.9. Predicted Strontium-90 Plume from the 200 Areas for 2049 (assumed site closure date) 


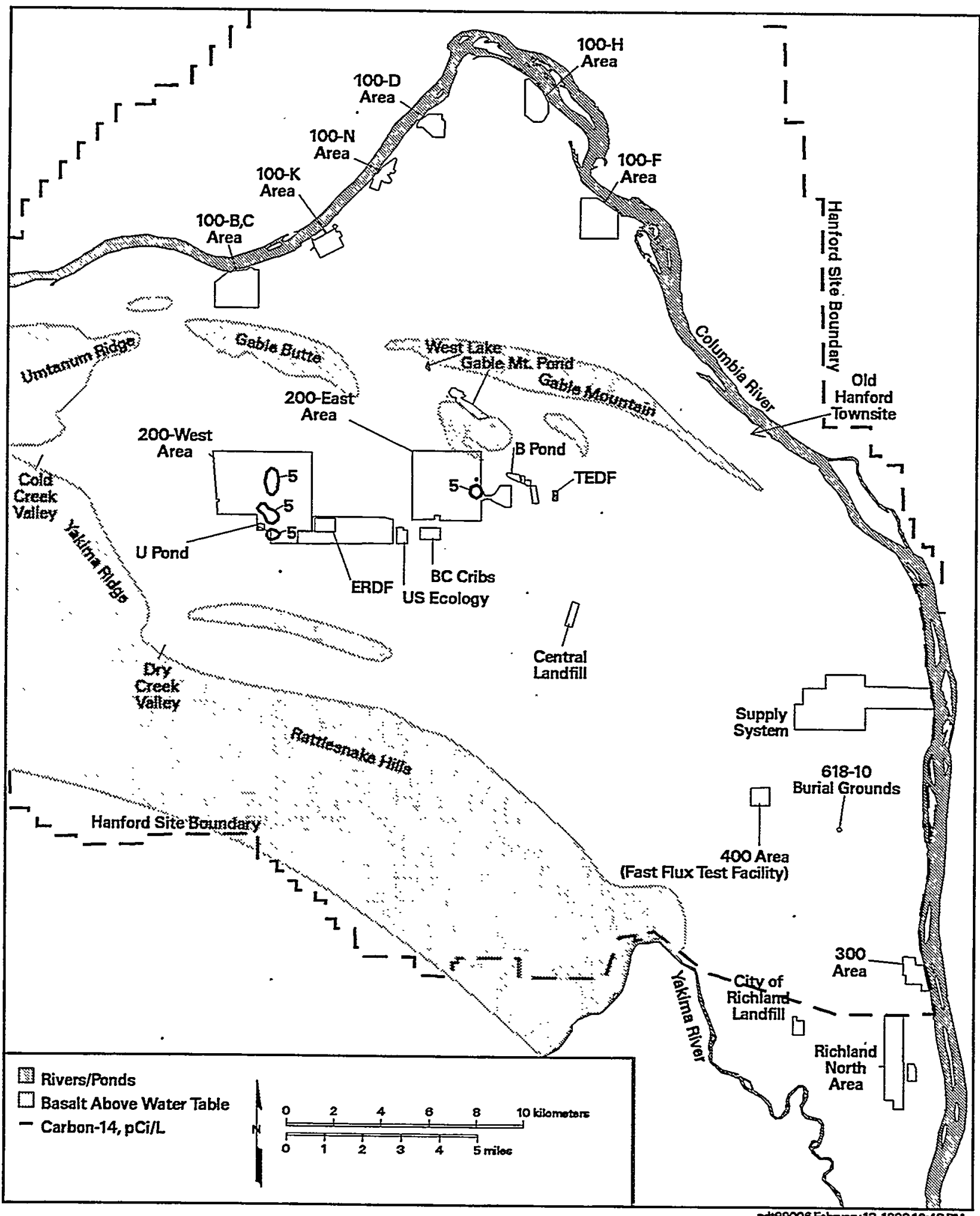

Figure 6.10. Predicted Carbon-14 Plume from the 200 Areas for 2049 (assumed site closure date) 


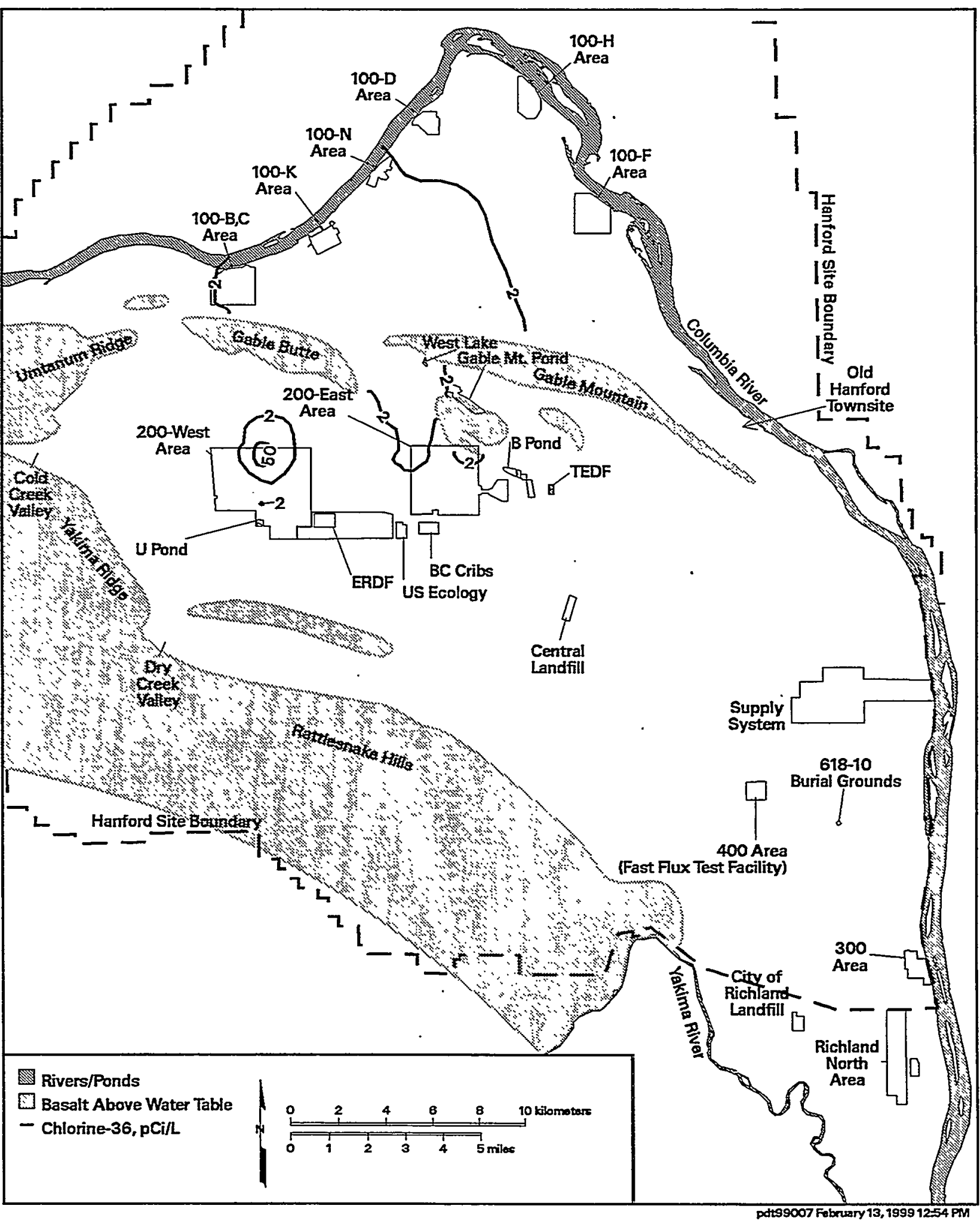

Figure 6.11. Predicted Chlorine-36 Plume from the 200 Areas for 2049 (assumed site closure date) 


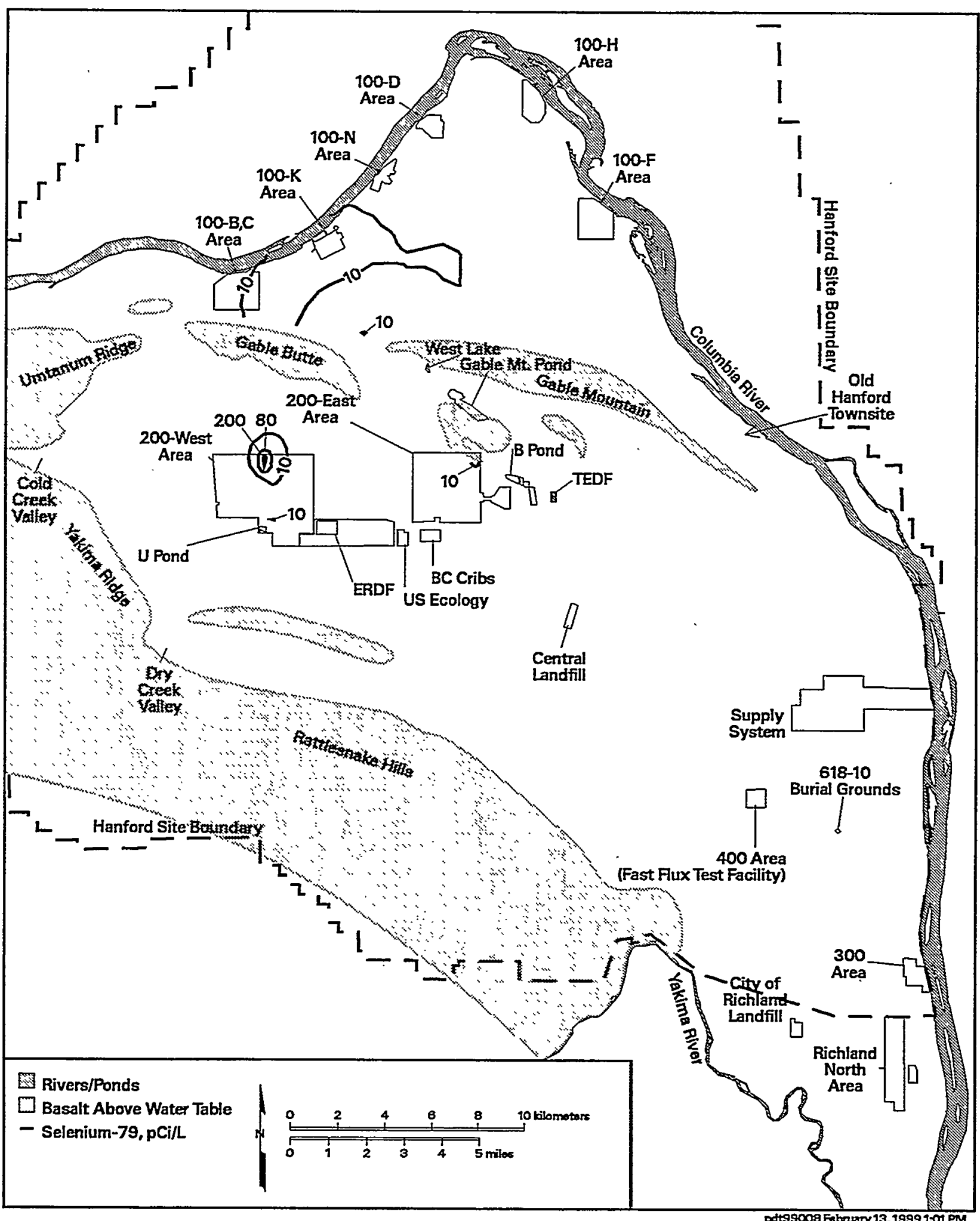

Figure 6.12. Predicted Selenium-79 Plume from the 200 Areas for 2049 (assumed site closure date) 


\title{
7.0 Well Installation, Maintenance, and Decommissioning
}

\author{
R. B. Mercer, B. A. Williams
}

This chapter describes well installation, maintenance, and decommissioning activities conducted on the Hanford Site during fiscal year (FY) 1998.

\subsection{Well Installation}

Planning for new groundwater-monitoring wells is performed as part of a yearly Hanford Groundwater Monitoring Project review to define new well needs. The needs are defined in the description of work between Pacific Northwest National Laboratory and Bechtel Hanford, Inc. Each year, the project installs new wells to maintain network compliance with the Resource Conservation and Recovery Act of 1976 (RCRA) groundwater-monitoring requirements and U.S. Department of Energy orders. These compliance issues include ongoing RCRA facility groundwater assessments, replacement of monitoring wells going dry because of the declining water table, replacement of wells that pose contamination risks to the environment, improvement of spatial coverage of the monitoring networks, and vertical characterization of groundwater contamination.

Each year the U.S. Department of Energy and the State of Washington Department of Ecology approve wells through an integrated data quality objectives process. This process serves to integrate various Hanford Site project data needs in the proposed wells (i.e., Comprehensive Environmental Response, Compensation, and Liability Act of 1980 and Tank Waste Remediation System).

Milestone M-24-00J (Ecology et al. 1989) required the installation of 10 new RCRA groundwatermonitoring wells (Table 7.1). The installation of these 10 wells was successfully completed on November 17, 1998. Of these, seven were installed as new assessment wells to replace those going dry at Waste Management Areas (WMAs) T and TX-TY and at the 216-U-12 crib, located in the 200-West Area. One new assessment well was installed at WMA B-BX-BY, located in the 200-East Area, and two detection groundwater-monitoring wells were installed at WMA U, located in the 200-West Area. All the wells were completed as shallow (top-of-the-aquifer) monitoring wells. The nine new 200-West Area wells have $\sim 11-\mathrm{m}$-long well screens intended to extend their useful life. Two of the 10 wells were drilled deep in the aquifer to characterize the vertical extent of known groundwater contaminants before being completed as shallow wells. Well data packages will be published in FY 1999 with more detailed information about these new wells, including the detailed geologic and geophysical descriptions and a complete set of sampling data results.

Borehole 41-09-39 (WMA S-SX) was extended to groundwater in FY 1998. See Section 4.4.5 for additional information. 


\subsection{Well Maintenance}

Maintenance of groundwater wells is performed to meet regulatory requirements as part of a scheduled preventive maintenance cycle (routine), or in response to problems identified in the field (nonroutine). Maintenance tasks are divided into two general categories:

- surface tasks, which include conducting field inspections, well labeling, maintenance and replacement of locking well caps, casing repairs, diagnosis and repair of surface electrical and pump-discharge deficiencies

- subsurface tasks, which include repairing and replacing sampling pumps; performing camera surveys; brushing casing perforations or screens; developing wells to improve yield, recovery, and sample quality; removing sediment accumulation, etc.

Routine maintenance is performed on a 5-year cycle in support of groundwater sampling and to minimize nonroutine maintenance activities. At a minimum, routine maintenance includes the following tasks:

- removal of groundwater-sampling pump system and/or aquifer-testing instrumentation/equipment

- inspection and repair or replacement, as necessary, of sampling pump system and/or aquifer-testing instrumentation/equipment

- brushing/cleaning of well casing perforations/well screen

- removing debris and fill material

- developing the well

- performing borehole video camera survey

- reinstallation of sampling and/or aquifer-testing instrumentation/equipment

- documenting well conditions and maintenance activities.

Nonroutine tasks are performed in response to a problem identified in the field. Nonroutine maintenance tasks are varied and dependent on the specific problem, or set of problems, encountered at a well.

A summary of the number of maintenance activities by regulatory program, on which routine and nonroutine maintenance tasks were performed in FY 1998, is presented in Table 7.2. 


\subsection{Well Decommissioning}

Decommissioning activities result in the permanent removal of a well from service and from the Hanford Site well inventory. Well decommissioning is performed in accordance with State of Washington Department of Ecology standards (WAC 173-160). A well becomes a candidate for decommissioning if its use has been permanently discontinued; if its condition is so poor that its continued use is impractical; if it fails to meet State of Washington Department of Ecology minimum standards of construction (WAC-173-160); or it poses an environmental, safety, or public health hazard. A sitewide decommissioning program was first implemented in FY 1993. In FY 1997, the sitewide decommissioning strategy was revised to base schedule prioritization on 1) an evaluation of the risk of keeping a well in service (e.g., safety, public health, environmental) and 2) the need to be supportive of environmental cleanup priorities as defined in the Hanford Site long-range environmental restoration schedule (DOE/RL-96-105, Rev. 1).

Wells that present the risk of being immediate hazards to the public health or safety are categorized into basic risk groups (high, medium, and low). These categories identify wells that have the potential to provide preferential pathways that allow movement of contaminants deeper into the subsurface strata. Well classifications are shown in Figure 7.1.

At this time, well decommissioning is generally driven by the long-range environmental restoration schedule (DOE/RL-96-105, Rev. 1). As such, areas adjacent to the Columbia River are being decommissioned before the more inland or central areas of the site.

During FY 1998, 28 Hanford Site wells were decommissioned (Table 7.3). Wells decommissioned to date on the Hanford Site are illustrated in Figure 7.1. 
Table 7.1. Well Installation Summary

\begin{tabular}{|c|c|c|}
\hline Well Number & Well Identification & Location \\
\hline 299-W10-23 & $\mathrm{B} 8545$ & SST T \\
\hline 299-W10-24 & B8546 & SST T \\
\hline 299-W14-14. & B8547 & SST TX-TY \\
\hline 299-W10-26 & B8548 & SST TX-TY \\
\hline 299-W14-13 & B8549 & SST TX-TY \\
\hline 299-W15-40 & $\mathrm{B} 8550$ & SST TX-TY \\
\hline 299-W19-41 & B8551. & SST U \\
\hline 299-W19-42 & $\mathrm{B} 8553$ & SST U \\
\hline 299-W22-79 & B8552 & 216-U-12 CRIB \\
\hline 299-E33-44 & B8554 & SST B-BX-BY \\
\hline
\end{tabular}

Table 7.2. Well Maintenance Summary by Regulatory Program, Fiscal Year 1998

\begin{tabular}{|c|c|c|c|}
\hline \multirow[b]{2}{*}{ Program } & \multirow[b]{2}{*}{ Routine $e^{(a)}$} & \multicolumn{2}{|c|}{ Nonroutine } \\
\hline & & Surface & Subsurface \\
\hline RCRA & 50 & 14 & 41 \\
\hline CERCLA & 0 & 17 & 27 \\
\hline Surveillance & 0 & 11 & 30 \\
\hline Total & 50 & 42 & 98 \\
\hline
\end{tabular}

(a) Routine maintenance activities include both surface and subsurface tasks.

CERCLA = Comprehensive Environmental Response, Compensation, and Liability Act of 1980.

RCRA = Resource Conservation and Recovery Act of 1976. 
Table 7.3. Wells Decommissioned During Fiscal Year 1998

\begin{tabular}{|c|c|c|c|}
\hline Well Name & Well Identification & Location & Date \\
\hline NA & $\mathrm{B} 2857$ & 600 & $11 / 04 / 97$ \\
\hline NA & $\mathrm{B} 2856$ & 600 & $12 / 30 / 97$ \\
\hline 199-F8-1 & A4606 & $100-\mathrm{F}$ & $02 / 03 / 98$ \\
\hline 199-F5-7 & A4601 & $100-\mathrm{F}$ & $02 / 05 / 98$ \\
\hline $\mathrm{NA}$ & B2823 & North Slope & $02 / 10 / 98$ \\
\hline $699-86-64 \mathrm{~A}$ & B2812 & 600 & $02 / 10 / 98$ \\
\hline NA & B2825 & North Slope & $02 / 10 / 98$ \\
\hline NA & B2824 & North Slope & $02 / 10 / 98$ \\
\hline NA & B8539 & North Slope & $02 / 10 / 98$ \\
\hline $\mathrm{NA}$ & B2820 & North Slope & $02 / 10 / 98$ \\
\hline NA & B2819 & North Slope & $02 / 10 / 98$ \\
\hline NA & B2818 & North Slope & $02 / 10 / 98$ \\
\hline $699-86-64 \mathrm{E}$ & B2816 & 600 & $02 / 10 / 98$ \\
\hline 699-86-64D & $\mathrm{B} 2815$ & 600 & $02 / 10 / 98$ \\
\hline $699-86-64 \mathrm{~B}$ & B2813 & 600 & $02 / 10 / 98$ \\
\hline NA & $\mathrm{B} 2821$ & North Slope & $02 / 10 / 98$ \\
\hline $699-86-64 C^{\circ}$ & B2814 & 600 & $02 / 10 / 98$ \\
\hline $699-86-64 \mathrm{~F}$ & B2817 & 600 & $02 / 17 / 98$ \\
\hline $699-86-64$ & A9060 & 600 & $02 / 17 / 98$ \\
\hline 199-H3-1 & A4610 & $100-\mathrm{H}$ & $02 / 25 / 98$ \\
\hline $199-D 2-5$ & A4567 & $100-\mathrm{D}$ & $03 / 02 / 98$ \\
\hline 299-W19-2 & A4948 & 200-West & $03 / 11 / 98$ \\
\hline 199-D8-2 & A5580 & $100-\mathrm{D}$ & $03 / 11 / 98$ \\
\hline 299-E27-1 & A4807 & 200-East & $03 / 23 / 98$ \\
\hline 299-E32-1 & A4829 & 200-East & $03 / 27 / 98$ \\
\hline 199-B3-2 & A9505 & $100-B$ & $12 / 15 / 98$ \\
\hline 199-D8-3 & A4578 & $100-D$ & $09 / 02 / 98$ \\
\hline 299-E25-45 & A5449 & 200-East & $09 / 30 / 98$ \\
\hline
\end{tabular}

North Slope $=$ North of the Columbia River. 


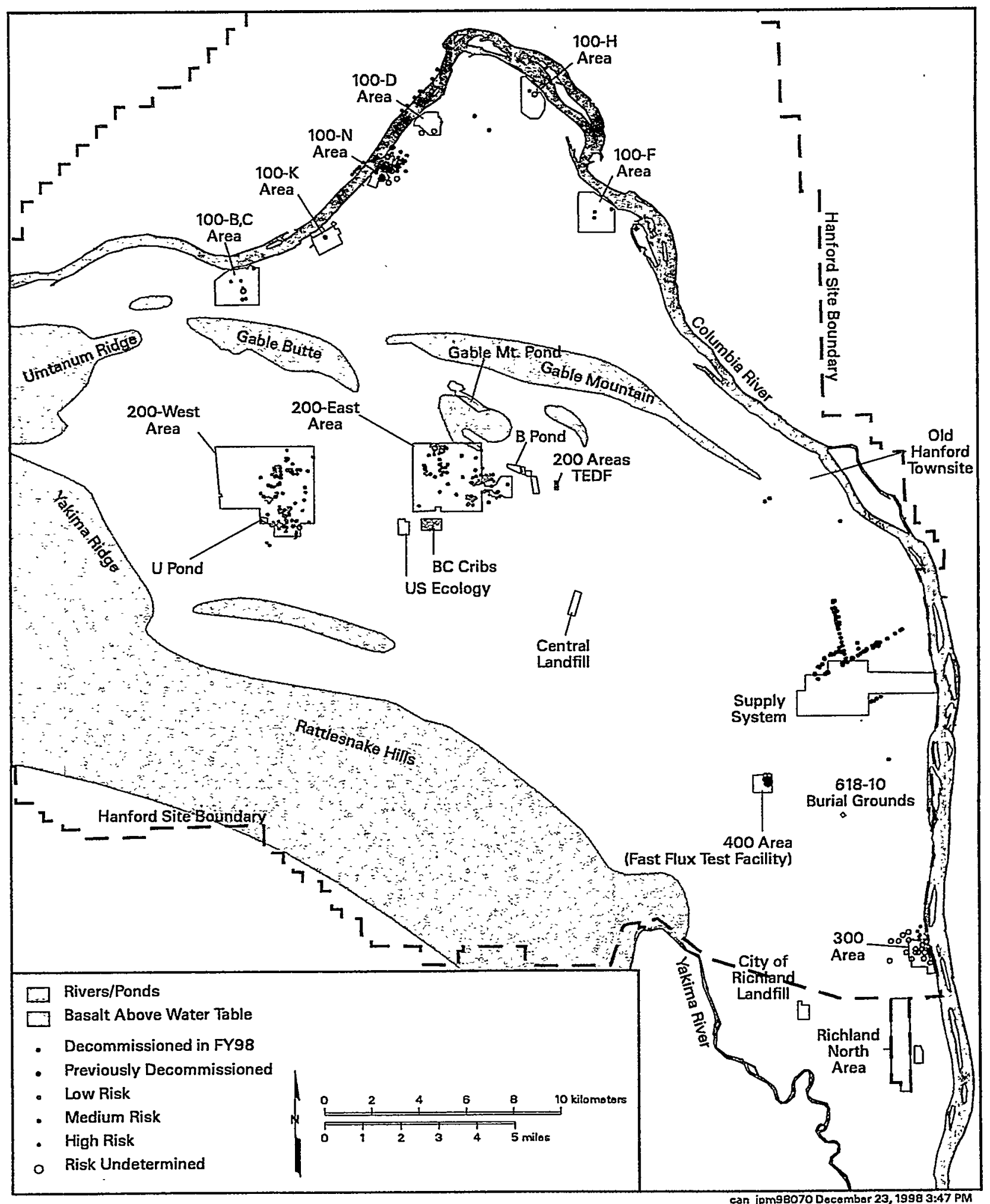

Figure 7.1. Classification of Wells for Decommissioning 


\subsection{References}

\section{Public Laws}

Atomic Energy Act of 1954, as amended, Ch. 1073, 68 Stat. 919, 42 USC 2011 et seq.

Comprehensive Environmental Response, Compensation, and Liability Act of 1980, as amended, Public Law 96-510, 94 Stat. 2767, 42 USC 9601 et seq.

Federal Water Pollution Control Act, as amended, Public Law 96-70, 62 Stat. 1155, 33 USC 1251 et seq.

Hazardous and Solid Waste Amendments of 1984, as amended, Public Law 98-616, 98 Stat. 3221, 42 USC 6901 et seq.

Resource Conservation and Recovery Act of 1976, as amended, Public Law 94-580, 90 Stat. 2795, 42 USC 6901 et seq.

Safe Drinking Water Act of 1974, as amended, Public Law 93-523, 88 Stat. 1660, 42 USC $300 \mathrm{f}$ et seq.

Superfind Amendments and Reauthorization Act of 1986, as amended, Public Law 99-499, 100 Stat. 1613, 42 USC 11001 et seq.

\section{Code of Federal Regulations}

40 CFR 141, Code of Federal Regulations, Title 40, Part 141. National Primary Drinking Water Regulations.

40 CFR 142, Code of Federal Regulations, Title 40, Part 142. National Primary Drinking Water Regulations Implementation.

40 CFR 143, Code of Federal Regulations, Title 40, Part 143. National Secondary Drinking Water Regulations.

40 CFR 257, Code of Federal Regulations, Title 40, Part 257. Criteria for Classification of Solid Waste Disposal Facilities and Practices.

40 CFR 264, Code of Federal Regulations, Title 40, Part 264. Standards for Owners and Operators of Hazardous Waste Treatment, Storage, and Disposal Facilities.

40 CFR 265, Code of Federal Regulations, Title 40, Part 265. Interim Status Standards for Owners and Operators of Hazardous Waste Treatment, Storage, and Disposal Facilities. 
40 CFR 300, Code of Federal Regulations, Title 40, Part 300. National Oil and Hazardous Substances Pollution Contingency Plan.

40 CFR 300, Code of Federal Regulations, Title 40, Part 300, Appendix B. National Priorities List.

\section{U.S. Department of Energy Orders}

DOE Order 5400.1. General Environmental Protection Program. U.S. Department of Energy, Washington, D.C.

DOE Order 5400.5. Radiation Protection of the Public and the Environment. U.S. Department of Energy, Washington, D.C.

DOE Order 5820.2. Radioactive Waste Management. U.S. Department of Energy, Washington, D.C.

Revised Code of Washington

RCW 70.105, Revised Code of Washington, Title 70, Chapter 105. Hazardous Waste Management.

Washington Administrative Code

WAC 173-160, Washington Administrative Code. Minimum Standards for Construction and Maintenance of Wells. Olympia, Washington.

WAC 173-200, Washington Administrative Code. Water Quality Standards for Ground Waters of the State of Washington. Olympia, Washington.

WAC 173-216, Washington Administrative Code. State Waste Discharge Program. Olympia, Washington.

WAC 173-303, Washington Administrative Code. Dangerous Waste Regulations. Olympia, Washington.

WAC 173-303-400, Washington Administrative Code. Interim Status Facility Standards. Olympia, Washington.

WAC 173-303-600, Washington Administrative Code. Final Status Standards. Olympia, Washington.

WAC 173-303-610, Washington Administrative Code. Closure and Postclosure. Olympia, Washington.

WAC 173-303-645, Washington Administrative Code. Releases from Regulated Units. Olympia, Washington. 
WAC 173-304, Washington Administrative Code. Minimum Fumctional Standards for Solid Waste Handling. Olympia, Washington.

WAC 173-304-490, Washington Administrative Code. Ground Water Monitoring Requirements. Olympia, Washington.

WAC 173-340, Washington Administrative Code. Model Toxics Control Act-Cleanup. Olympia, Washington.

WAC 173-340-720, Washington Administrative Code. Ground Water Cleanup Standards. Olympia, Washington.

WAC 246-290, Washington Administrative Code. Public Water Supplies. Olympia, Washington.

WAC 246-290-310, Washington Administrative Code. Maximum Contaminant Levels (MCLs). Olympia, Washington.

Allison, I. S. 1933. "New Version of the Spokane Flood." Geological Society of America Bulletin 44:675-722.

American Society for Testing and Materials. 1986: Annual Book of ASTM Standards. Philadelphia, Pennsylvania.

American Society for Testing and Materials. 1988. "D 4750-87, Standard Method for Determining Subsurface Liquid Levels in a Borehole or Monitoring Well (Observation Well)." Annual Book of ASTM Standards. Philadelphia, Pennsylvania.

ARH-2207. 1971. 216-Z-9 Crib History and Safety Analysis. K. R. Ridgway, M. D. Veatch, and D. T. Crawley, Atlantic Richfield Hanford Company, Richland, Washington.

ARH-2915. 1973. Nuclear Reactivity Evaluations of 216-Z-9 Enclosed Trench. A. E. Smith, Atlantic Richfield Hanford Company, Richland, Washington.

Baker, V., B. N. Bjornstad, A. J. Busacca, K. R. Fecht, E. P. Kiver, U. L. Moody, J. G. Rigby, D. F. Stradling, and A. M. Tallman. 1991. "Quaternary Geology of the Columbia Plateau." In Morrison, R. B. (ed.), Quaternary Nonglacial Geology; Conterminous U.S. The Geological Society of America, v. K-2, p. 215-250.

Bauer, H. H., J. J. Vaccaro, and R. C. Lane. 1985. Maps Showing Ground-Water Levels in the Columbia River Basalt and Overlying Materials, Spring 1983, Southeastern Washington. Water-Resources Investigations Report 84-4360, U.S. Geological Survey, Tacoma, Washington. 
Bear, J. 1979. Hydraulics of Groundwater. McGraw Hill Publishing Company, New York, 569 p.

BHI-00079. 1996. Groundwater Protection Plan for the Environmental Restoration Disposal Facility.

D. C. Weekes, G. K. Jaeger, W. J. McMahon, and B. H. Ford, Bechtel Hanford, Inc., Richland, Washington.

BHI-00127. 1995. 100-H Area Technical Baseline Report. D. Deford and M. W. Einan, Bechtel Hanford, Inc., Richland, Washington.

BHI-00149. 1995. 200-UP-I Vertical Profiling Activity Summary Report. B. H. Ford, Bechtel Hanford, Inc., Richland, Washington.

BHI-00164, Rev. 1. 1995. N Springs Expedited Response Action Performance Monitoring Plan. B. Mukherjee, Bechtel Hanford, Inc., Richland, Washington.

BHI-00184. 1995. Miocene- to Pliocene-Aged Suprabasalt Sediments of the Hanford Site, SouthCentral Washington. K. A. Lindsey, Bechtel Hanford, Inc., Richland, Washington.

BHI-00459. 1996. Numerical Analysis of Carbon Tetrachloride Movement in the Saturated and Unsaturated Zones in the 200 West Area, Hanford Site. M. G. Piepho, Bechtel Hanford Inc., Richland, Washington.

BHI-00720, Rev. 2. 1998. Performance Evaluation Report for Soil Vapor Extraction Operations at the Carbon Tetrachloride Site, February 1992 - September 1997. V. J. Rohay, Bechtel Hanford, Inc., Richland, Washington.

BHI-00725. 1996. 100-N Pilot Project: Proposed Consolidated Groundwater Monitoring Program. J. V. Borghese, M. J. Hartman, S. P. Luttrell, C. J. Perkins, J. P. Zoric, and S. C. Tindall, Bechtel Hanford, Inc., Richland, Washington.

BHI-00778. 1996. Chromium in River Substrate Pore Water and Adjacent Groundwater: 100-D/DR Area, Hanford Site, Washington. S. J. Hope and R. E. Peterson, CH2M Hill Hanford, Inc. for Bechtel Hanford, Inc., Richland, Washington.

BHI-00873. 1996. Description of Work for Routine Groundwater Sampling at the Environmental Restoration Disposal Facility. B. H. Ford, Bechtel Hanford, Inc., Richland, Washington.

BHI-00916. 1996. Groundwater Monitoring Implementation Plan for the 100-BC-5, 100-KR-4, 100-HR-3, and 100-FR-3 Operable Units. R. E. Peterson and R. F. Raidl, prepared by CH2M Hill Hanford, Inc. for Bechtel Hanford, Inc., Richland, Washington.

BHI-00917. 1996. Conceptual Site Models for Groundwater Contamination at 100-BC-5, 100-KR-4, 100-HR-3, and 100-FR-3 Operable Units. R. E. Peterson, R. F. Raidl, and C. W. Denslow, Bechtel Hanford, Inc., Richland, Washington. 
BHI-00952-01. 1996. 200-ZP-1 Phase II Interim Remedial Measure Quarterly Report, August October 1996. J. R. Freeman-Pollard, I. D. Jacques, W. J. McMahon, K. M. Singleton, S. A. Strope, and L. C. Swanson, Bechtel Hanford, Inc., Richland, Washington.

BHI-01052. 1997. Description of Work for a Vadose Zone Characterization Borehole at the 216-B-2-2 Ditch. J. M. Faurote and C. D. Wittreich, Bechtel Hanford, Inc., Richland, Washington.

BHI-01063. 1997. Conceptual Model for the Solid Waste Landfill. V. J. Rohay, Bechtel Hanford, Inc., Richland, Washington.

BHI-01090. 1997. Description of Work for Installing Aquifer Sampling Tubes Along the 100 Area and Hanford Townsite Shorelines. R. E. Peterson, K. L. Singleton, and J. V. Borghese, CH2M Hill Hanford, Inc. for Bechtel Hanford, Inc., Richland, Washington.

BHI-01105. 1997. Rebound Study Report for the Carbon Tetrachloride Soil Vapor Extraction Site, Fiscal Year 1997. V. J. Rohay, Bechtel Hanford, Inc., Richland, Washington.

BHI-01121. 1997 Decommissioning Report for Well 299-W-15-5. J. E. Auten, CH2M Hill Hanford, Inc. and K. D. Reynolds, Waste Management Federal Services Inc., Northwest Operations for Bechtel Hanford, Inc., Richland, Washington.

BHI-01131. 1997. Chromium Plume West of the 100-D/DR Reactors--Data Supplement. M. P. Connelly, CH2M Hill Hanford, Inc. for Bechtel Hanford, Inc., Richland, Washington.

BHI-01153. 1998. Aquifer Sampling Tube Completion Report: 100 Area and Hanford Townsite Shorelines. R. E. Peterson, J. V. Borghese, and D. B. Erb, CH2M Hill Hanford, Inc. for Bechtel Hanford, Inc., Richland, Washington.

BHI-01165. 1998. N-Springs Expedited Response Action Performance Monitoring Plan: Update. R. E. Peterson, CH2M Hill Hanford, Inc. for Bechtel Hanford, Inc., Richland, Washington.

BHI-01177. 1998. Borehole Summary Report for the 216-B-2-2 Ditch. V. J. Rohay and D. C. Weekes, Bechtel Hanford, Inc., Richland, Washington.

BMI/ONWI-660. 1987. Coupled Fluid, Energy, and Solute Transport (CFEST) Model: Formulation and User's Manual. S. K. Gupta, C. R. Cole, C. T. Kincaid, and A. M. Monti, Battelle Memorial Institute, Columbus, Ohio.

BNWL-B-360. 1974. Selected Water Table Contour Maps and Hydrographs for the Hanford Reservation, 1944-1973. K. L. Kipp and R. D. Mudd, Battelle, Pacific Northwest Laboratory, Richland, Washington.

BNWL-1709. 1973. Collection and Analysis of Pump Test Data for Transmissivity Values. K. L. Kipp and R. D. Mudd, Battelle, Pacific Northwest Laboratory, Richland, Washington. 
DOE/EH-0173T. 1991. Environmental Regulatory Guide for Radiological Effluent Monitoring and Environmental Surveillance. Assistant Secretary for the Environment, Safety, and Health, U.S. Department of Energy, Washington, D.C.

DOE/EIS-0189. 1996. . Tank Waste Remediation System, Hanford Site, Final Environmental Impact Statement. U.S. Department of Energy, Washington, D.C.

DOE/ID/12584-268, GJPO-HAN-4. 1996. Vadose Zone Characterization Project at the Hanford Tank Farms, SX Tank Farm Report. U.S. Department of Energy, Albuquerque Operations Office and Grand Junction Office for Richland Operations Office, Richland, Washington.

DOE/RL-89-12, Rev. 2. 1995. Hanford Site Ground-Water Protection Management Plan. D. B. Barnett, J. S. Schmid, S. S. Lowe, W. L. Allen, N. A. Ballantyne, C. H. Dohrer, M. J. Hartman, F. N. Hodges, D. G. Horton, V. G. Johnson, K. J. Lueck, D. J. Ortiz, A. J. Knepp, B. H. Ford, S. P. Hope, D. K. Tyler, R. D. Hildebrand, D. E. Olson, R. E. Peterson, G. L. Kasza, D. A. Myers, S. P. Luttrell, P. D. Thorne, and K. R. Moser. U.S. Department of Energy, Richland Operations Office, Richland, Washington.

DOE/RL-89-14. 1990. RU/FS Work Plan for the 300-FF-5 Operable Unit, Hanford Site, Richland, Washington. U.S. Department of Energy, Richland Operations Office, Richland, Washington.

DOE/RL-89-28, Rev. 2. 1994. 216-B-3 Expansion Ponds Closure Plan. U.S. Department of Energy, Richland Operations Office, Richland, Washington.

DOE/RL-90-08. 1992. Remedial Investigation/Feasibility Study Work Plan for the 100-BC-5 Operable Unit, Hanford Site, Richland, Washington. U.S. Department of Energy, Richland Operations Office, Richland, Washington.

DOE/RL-90-17. 1990. Nonradioactive Dangerous Waste Landfill Closure/Postclosure Plan. U.S. Department of Energy, Richland Operations Office, Richland, Washington.

DOE/RL-90-18. 1990. Phase 1 Remedial Investigation Report for the Hanford Site 1100-EM-1 Operable Unit. U.S. Department of Energy, Richland Operations Office, Richland, Washington.

DOE/RL-90-38, Rev. 0. 1991. Hanford Site Solid Waste Landfill Permit Application. U.S. Department of Energy, Richland Operations Office, Richland, Washington.

DOE/RL-90-38, Rev. 1. 1996. Hanford Site Solid Waste Landfill Interim Closure Plan. U.S. Department of Energy, Richland Operations Office, Richland, Washington.

DOE/RL-91-03. 1991. Annual Report for RCRA Groundwater Monitoring Projects at Hanford Site Facilities for 1990. Prepared by Geosciences Group, Westinghouse Hanford Company, Environmental Division for U.S. Department of Energy, Richland Operations Office, Richland, Washington. 
DOE/RL-91-28, Rev. 3. 1995. Environmental Restoration Project Quality System Requirements for the Hanford Site. U.S. Department of Energy, Richland Operations Office, Richland, Washington.

DOE/RL-91-31, Rev. 1. 1991. Hanford Site Waste Minimization and Pollution Awareness Program Plan. U.S. Department of Energy, Richland Operations Office, Richland, Washington.

DOE/RL-91-32, Draft B. 1991. Expedited Response Action Proposal (EE/CA \& EA) for 200 West Area Carbon Tetrachloride Plume, Appendix B. V. J. Rohay and V. G. Johnson for U.S. Department of Energy, Richland Field Office, Richland, Washington.

DOE/RL-91-40. 1991. Hanford Past-Practices Strategy. K. M. Thompson, U.S. Department of Energy, Richland Operations Office, Richland, Washington.

DOE/RL-91-45, Rev. 3. 1995. Hanford Site Risk Assessment Methodology. U.S.Department of Energy, Richland Operations Office, Richland, Washington.

DOE/RL-91-50, Rev. 2. 1997. Environmental Monitoring Plan, United States Department of Energy, Richland Operations Office. Prepared by personnel from Pacific Northwest National Laboratory, Fluor Daniel Hanford, Inc. and its subcontractor Waste Management Federal Services of Hanford, Inc., and Bechtel Hanford, Inc. for U.S. Department of Energy, Richland Operations Office, Richland, Washington.

DOE/RL-91-58. 1992. Z Plant Source Aggregate Area Management Study Report. U.S. Department of Energy, Richland Operations Office, Richland, Washington.

DOE/RL-92-03. 1992. Annual Report for RCRA Groundwater Monitoring Projects at Hanford Site Facilities for 1991. Prepared by Geosciences Group, Westinghouse Hanford Company, Environmental Division for U.S. Department of Energy, Richland Operations Office, Richland, Washington.

DOE/RL-92-67, Draft B. 1992. Final Remedial Investigation Study-Environmental Assessment Report for the 1100-EM-1 Operable Unit, Hanford. U.S. Department of Energy, Richland Operations Office, Richland, Washington.

DOE/RL-92-71, Rev. 2. 1998. 100-D Ponds Closure Plan. U.S. Department of Energy, Richland Operations Office, Richland, Washington.

DOE/RL-93-09. 1993. Annual Report for RCRA Groundwater Monitoring Projects at Hanford Site Facilities for 1992. Prepared by Geosciences Group, Westinghouse Hanford Company, Environmental Division for U.S. Department of Energy, Richland Operations Office, Richland, Washington.

DOE/RL-93-73. 1994. 300 Area Process Trenches Closure Plan. U.S. Department of Energy, Richland Operations Office, Richland, Washington. 
DOE/RL-93-88. 1994. Annual Report for RCRA Groundwater Monitoring Projects at Hanford Site Facilities for 1993. Prepared by Geosciences Group, Westinghouse Hanford Company, Environmental Division for U.S. Department of Energy, Richland Operations Office, Richland, Washington.

DOE/RL-93-99, Rev. 1. 1994. Remedial Investigation and Feasibility Study Report for the Environmental Restoration Disposal Facility. U.S. Department of Energy, Richland Operations Office, Richland, Washington.

DOE/RL-94-95, Rev. 1. 1995. Hanford Site Groundwater Remediation Strategy. U.S. Department of Energy, Richland Operations Office, Richland, Washington.

DOE/RL-94-99. 1995. Proposed Plan for Interim Remedial Measures at the 100-BC-1 Operable Unit. U.S. Department of Energy, Richland Operations Office, Richland, Washington.

DOE/RL-94-111. 1994. Tri-Party Agreement Strategic Data Management Plan. U.S. Department of Energy, Richland Operations Office, Richland, Washington.

DOE/RL-94-136. 1995. Annual Report for RCRA Groundwater Monitoring Projects at Hanford Site Facilities for 1994. Prepared by Earth and Environmental Technical Services, Westinghouse Hanford Company for U.S. Department of Energy, Richland Operations Office, Richland, Washington.

DOE/RL-94-143. 1994. Corrective Action Plan for the Hanford Site Solid Waste Landfill. U.S. Department of Energy, Richland Operations Office, Richland, Washington.

DOE/RL-95-02. 1995. Treatability Report for the 200-UP-1 Operable Unit-Hanford Site.

U.S. Department of Energy, Richland Operations Office, Richland, Washington.

DOE/RL-95-30. 1995. 200-ZP-1 Operable Unit Treatability Test Report. U.S. Department of Energy, Richland Operations Office, Richland, Washington.

DOE/RL-95-54, Draft B. 1995. Proposed Plan for Interim Remedial Measures at the 100-FR-1 Operable Unit. U.S. Department of Energy, Richland Operations Office, Richland, Washington.

DOE/RL-95-66, Draft A. 1995. Proposed Plan for Interim Remedial Measures at the 100-BC-2 Operable Unit. U.S. Department of Energy, Richland Operations Office, Richland, Washington.

DOE/RL-95-73. 1996. Operation and Maintenance Plan for the 300-FF-5 Operable Unit. U.S. Department of Energy, Richland Operations Office, Richland, Washington.

DOE/RL-95-83. 1995. The Pilot-Scale Treatability Test Simmary for the 100-HR-3 Operable Unit. U.S. Department of Energy, Richland Operations Office, Richland, Washington.

DOE/RL-95-92, Decisional Draft. 1995. Proposed Plan for Interim Remedial Measures at the 100-FR-2 Operable Unit. U.S. Department of Energy, Richland Operations Office, Richland, Washington. 
DOE/RL-95-99. 1996. 100-FR-3 Groundwater/Soil Gas Supplemental Limited Field Investigation Report. U.S. Department of Energy, Richland Operations Office, Richland, Washington.

DOE/RL-95-100, Rev. 1. 1995. RCRA Facility Investigation Report for the 200-PO-1 Operable Unit. U.S. Department of Energy, Richland Operations Office, Richland, Washington.

DOE/RL-95-110. 1996. The N-Springs Expedited Response Action Performance Evaluation Report. U.S. Department of Energy, Richland Operations Office, Richland, Washington.

DOE/RL-95-111. 1998. Corrective Measures Study for the 100-NR-1 and 100-NR-2 Operable Units. U.S. Department of Energy, Richland Operations Office, Richland, Washington.

DOE/RL-96-01. 1996. Annual Report for RCRA Groundwater Monitoring Projects at Hanford Site Facilities for 1995. Prepared by Earth and Environmental Technical Services, Westinghouse Hanford Company for U.S. Department of Energy, Richland Operations Office, Richland, Washington.

DOE/RL-96-39. 1998. 100-NR-1 Treatment, Storage, and Disposal Units Corrective Measure Study/ Closure Plan. U.S. Department of Energy, Richland Operations Office, Richland, Washington.

DOE/RL-96-42. 1996. Limited Field Investigation Report for the 300-FF-2 Operable Unit. U.S. Department of Energy, Richland Operations Office, Richland, Washington.

DOE/RL-96-61. 1996. Hanford Site Background: Part 3, Groundwater Background. U.S. Department of Energy, Richland Operations Office, Richland, Washington.

DOE/RL-96-66. 1996. RCRA Corrective Measure Study for the 200-PO-1 Operable Unit. U.S. Department of Energy, Richland Operations Office, Richland, Washington.

DOE/RL-96-81. 1997. Waste Site Grouping for 200 Areas Soil Investigations. U.S. Department of Energy, Richland Operations Office, Richland, Washington.

DOE/RL-96-84. 1996. Remedial Design Report and Remedial Action Work Plan for the 100-HR-3 and 100-KR-4 Groundwater Operable Units' Interim Action. U.S. Department of Energy, Richland Operations Office, Richland, Washington.

DOE/RL-96-102. 1998. Proposed Plan for Interim Action at the 100-NR-1 Source Sites Operable Unit and the 100-NR-2 Groundwater Operable Unit. Prepared by Bechtel Hanford, Inc. for the U.S. Department of Energy, Richland Operations Office, Richland, Washington.

DOE/RL-96-105, Rev. 1. 1997. Richland Environmental Restoration Project Baseline, Multi-Year Work Plan. U.S. Department of Energy, Richland Operations Office, Richland, Washington.

DOE/RL-97-34. 1997. N-Springs Pump and Treat System Optimization Study. U.S. Department of Energy, Richland Operations Office, Richland, Washington. 
DOE/RL-97-48, Draft A. 1997. 183-H Postclosure Plon. J. W. Baden and R. E. Peterson, CH2M Hill Hanford, Inc. for Bechtel Hanford, Inc. for U.S. Department of Energy, Richland Operations Office, Richland, Washington.

DOE/RL-97-49. 1997. TWRS Vadose Zone Contamination Issue Expert Panel Status Report. U.S. Department of Energy, Richland Operations Office, Richland, Washington.

DOE/RL-97-69. 1998. Hanford Immobilized Low-Activity Tank Waste Performance Assessment. F. M. Mann, R. J. Puigh, II, P. D. Rittmann, N. W. Kline, J. A. Voogd, Y. Chen, C. R. Eiholzer, C. T. Kincaid, B. P. McGrail, A. H. Lu, G. F. Williamson, N. R. Grown, and P. E. LaMont, U.S. Department of Energy, Richland Operations, Richland, Washington.

DOE/RL-97-96. 1998. 100-KR-4 and 100-HR-3 Operable Units Interim Action Performance Evaluation Report. Prepared by CH2M Hill Hanford, Inc. for Bechtel Hanford, Inc., U.S. Department of Energy, Richland Operations Office, Richland, Washington.

DOE/RL-98-48, Draft C. 1998. Groundwater/Vadose Zone Integration Project Specification. Prepared by Bechtel Hanford, Inc. for the U.S. Department of Energy, Richland Operations Office, Richland, Washington.

DOE/RL-99-02. 1999. Fiscal Year 1998 Annual Summary Report for the 200-UP-1, 200-ZP-1, and 100-NR-2 Pump-and-Treat Operations and Operable Units. U.S. Department of Energy, Richland Operations Office, Richland, Washington.

DOE/RW-0164. 1988. Consultation Draft, Site Characterization Plan, Reference Repository Location, Hanford Site, Washington. U.S. Department of Energy, Richland Operations Office, Richland, Washington.

Drost, B. W., K. M. Schurr, and W. E. Lum II. 1989. Selected Ground-Water Information for the Pasco Basin and Adjacent Areas, Washington, 1986-1989. Open-File Report 89-228, U.S. Geological Survey, Tacoma, Washington.

Drost, B. W., J. C. Ebbert, and S. E. Cox. 1993. Long-Term Effects of Irrigation With Imported Water on Water Levels and Water Quality. Water-Resources Investigations Report 93-4060, U.S. Geological Survey, Tacoma, Washington.

Drost, B. W., S. E. Cox, and K. M. Schurr. 1997. Changes in Ground-Water Levels and Ground-Water Budgets, from Predevelopment to 1986, in Parts of the Pasco Basin, Washington. Water-Resources Investigations Report 96-4086, U.S. Geological Survey, Tacoma, Washington.

Drummond, M. E. 1992. The Future for Hanford: Uses and Cleanup. A Final Report of the Hanford Future Site Uses Working Group. Eastern Washington University, Cheney, Washington. 
Ebbert, J. C., S. E. Cox, and B. W. Drost. 1991. "The Effects of Lining Irrigation Canals on Nitrate Concentrations in Ground Water." In Proceedings of the Conference on Nonpoint Source Pollution: The Unfinished Agenda for the Protection of Our Water Quality. U.S. Geological Survey, Tacoma, Washington.

Ebbert, J. C., S. E. Cox, B. W. Drost, and K. M. Shurr. 1995. Distribution and Sources of Nitrate and Presence of Fluoride and Pesticides in Parts of the Pasco Basin, Washington, 1986-19.88. WaterResources Investigations Report 93-4197, U.S. Geological Survey, Washington, D.C., p. 173.

Ecology (see State of Washington Department of Ecology)

EMF-1865, Addendum 11. 1998. Quarterly Groundwater Monitoring Summary - Fourth Quarter 1997. Siemens Power Corporation, Richland, Washington.

EMF-1865, Addendum 14. 1998. Quarterly Groundwater Monitoring Summary - Third Quarter 1998. Siemens Power Corporation, Richland, Washington.

EPA 510-R-93-001. 1993. HyperVentilate Users Manual (v1.01 and v2.0), A Software Guidance System Created For Vapor Extraction Applications. P. C. Johnson, Shell Development Westhollow Research Center for Solid Waste and Emergency Response, U.S. Environmental Protection Agency, Washington, D.C.

EPA-600/4-79-020. 1979. Methods for Chemical Analysis of Water and Wastes. U.S. Environmental Protection Agency, Washington, D.C.

EPA/600/R-96/055. 1994. Guidance for the Data Quality Objectives Process, EPA QA/G-4. Office of Research and Development, U.S. Environmental Protection Agency, Washington, D.C.

EPA 822-R-96-001. 1996. Drinking Water Regulations and Health Advisories. Office of Water, U.S. Environmental Protection Agency, Washington, D.C.

Fecht, K. R., S. P. Reidel, and A. M. Tallman. 1987. "Paleodrainage of the Columbia River System on the Columbia Plateau of Washington State - A Summary." In Schuster, J. E. (ed.), Selected Papers on the Geology of Washington. Bulletin 77, Washington State Division of Geology and Earth Resources, Olympia, Washington, p. 219-248.

Garber, M. S. and F. C. Koopman. 1968. Methods of Measuring Water Levels in Deep Wells: U.S. Geological Survey. TRWI, Book 8, Chapter A-1. U.S. Government Printing Office, Washington, D.C.

Gee, G. W., M. J. Fayer, M. L. Rockhold, and M. D. Campbell. 1992. "Variations in Recharge at the Hanford Site." Northwest Science 66:237-250. 
GJO-97-30-TAR, GJO-HAN-16. 1998. Hanford Tank Farms Vadose Zone, TY Tank Farm Report. U.S. Department of Energy, Albuquerque Operations Office and Grand Junction Office for Richland Operations Office, Richland, Washington.

GJO-97-31-TAR, GJO-HAN-17. 1998. Hanford Tank Farms Vadose Zone, S Tank Farm Report. U.S. Department of Energy, Albuquerque Operations Office and Grand Junction Office for Richland Operations Office, Richland, Washington.

GJO-98-39-TAR, GJO-HAN-18: 1998. Hanford Tank Farms Vadose Zone, C Tank Farm Report. U.S. Department of Energy, Albuquerque Operations Office and Grand Junction Office for Richland Operations Office, Richland, Washington.

GJO-98-40-TAR, GJO-HAN-19. 1998. Hanford Tank Farms Vadose Zone, BX Tank Farm Report. U.S. Department of Energy, Albuquerque Operations Office and Grand Junction Office for Richland Operations Office, Richland, Washington.

GJPO-HAN-1. 1995. Vadose Zone Characterization Project at the Hanford Tank Farms, Calibration of Two Spectral Gamma-Ray Logging Systems for Baseline Characterization Measurements in the Hanford Tank Farms. Prepared by Rust Geotech for U.S. Department of Energy, Grand Junction Projects Office, Grand Junction, Colorado.

GJPO-HAN-3. 1996. Vadose Zone Characterization Project at the Hanford Tank Farms, Biannual Recalibration of Two Spectral Gamma-Ray Logging Systems Used for Baseline Characterization Measurements in the Hanford Tank Farms. Prepared by Rust Geotech for U.S. Department of Energy, Grand Junction Projects Office, Grand Junction, Colorado.

Hausenbuiller, R. L. 1972. Soil Science: Principles and Practices. Wm. C. Brown Company Publishers, Dubuque, Iowa.

HNF-2067. 1998. TWRS Phase 1 Privatization Site Preconstruction Characterization Report. R. M. Mitchell (ed.), D. L. Edwards, B. M. Markes, R. K. Price, and K. D. Reynolds, Waste Management Federal Services, Inc., Northwest Operations; W. R. Thackaberry, Waste Management Federal Services of Hanford, Inc.; C. J. Chou, V. G. Johnson, D. G. Horton, and S. P. Reidel, Pacific Northwest National Laboratory; and K. A. Bergstrom and T. H. Mitchell, CH2M Hill Hanford, Inc. for Fluor Daniel Hanford, Inc., Richland, Washington.

HNF-2855. 1998. Findings of the Extension of Borehole 41-09-39, 241-SX Tank Farm. D. A. Myers, Lockheed Martin Hanford Corporation; D. L. Parker, MACTEC-ERS; G. W. Gee, V. G. Johnson, G. V. Last, and R. J. Serne, Pacific Northwest National Laboratory; and D. J. Moak, Waste Management Northwest for Lockheed Martin Hanford Corporation, Richland, Washington.

HNF-EP-0527-6. 1997. Environmental Releases for Calendar Year 1996. B. P. Gleckler, Waste Management Federal Services of Hanford Inc. for Fluor Daniel Hanford, Inc., Richland, Washington. 
HNF-EP-0573-6. 1998. Hanford Site Near-Facility Environmental Monitoring Annual Report, Calendar Year 1997. C. J. Perkins, A. R. Johnson, B. M. Markes, S. M. McKinney, and R. M. Mitchell, Waste Management Federal Services, Inc. for Fluor Daniel Hanford, Inc., Richland, Washington.

HW-48862. 1957. Disposal of High Cobalt-60 Scavenged Wastes. W. A. Haney, Hanford Atomic Products Operations, Richland, Washington.

HW-60601. 1959. Aquifer Characteristics and Groundwater Movement at Hanford. W. H. Bierschenk, Hanford Atomic Products Operations, Richland, Washington.

IRIS. 1997. IRIS: Integrated Risk Information System. Office of Research and Development, National Center for Environmental Assessment, U.S. Environmental Protection Agency, Washington, D.C.

Online manual; available at http://www.epa.gov/ngispgm 3/iris/index.html (last updated December 30, 1997).

Jenkins, O.P. 1922. Undergroundwater Supply of the Region About White Bluffs and Hanford. Bulletin No. 26, State of Washington Department of Conservation and Development, Division of Geology, Olympia, Washington.

Johnson, V. G., and F. N. Hodges. 1997. "Mobile Transuranics: A Hanford Site Case History." Presented at The 2nd Symposium on the Hydrogeology of Washington State. Abstracts, August 25, 26, \& 27th, 1997, The Evergreen State College. State of Washington Department of Ecology, Olympia, Washington.

Johnson, V. G., and C. J. Chou. 1998. "Implications of RCRA Groundwater Quality Assessment Results for Hanford's Single Shell Tank Waste Management Areas." In Proceedings of the 39th Annual Meeting of the Institute of Nuclear Materials Management, Florida, July 1998. Institute of Nuclear Materials Management, Northbrook, Illinois.

Koizumi, C. J., J. R. Brodeur, R. K. Price, J. E. Meisner, and D. C. Stromswold. 1994. "HighResolution Gamma-Ray Spectrometry Logging for Contamination Assessment." Nuclear Geophysics 8:149-164.

LA-UR-94-2657, Rev. 2. 1995. Hanford Defined Wastes: Chemical and Radionuclide Compositions. S. F. Agnew, Chemical Science and Technology Division, Los Alamos National Laboratory, Los Alamos, New Mexico.

LA-UR-96-858. 1996. Hanford Tank Chemical and Radionuclide Inventories: HDW Model, Rev. 3. S. F. Agnew, J. Boyer, R. A. Corbin, T. B. Duran, J. R. FitzPatrick, K. A. Jurgensen, T. P. Ortiz, and B. L. Young, Los Alamos National Laboratory, Los Alamos, New Mexico.

LA-UR-96-3860. 1997. Hanford Tank Chemical and Radionuclide Inventories: HDW Model Rev. 4. S. F. Agnew, Los Alamos National Laboratory, Los Alamos, New Mexico. 
MAC-VZCP-1.7.2, Rev. 1. 1997. Hanford Tank Farms Vadose Zone, Project Management Plan. Prepared by MACTEC-ERS for U.S. Department of Energy, Grand Junction Projects Office, Grand Junction, Colorado.

MAC-VZCP-1.7.3, Rev. 1. 1997. Hanford Tank Farms Vadose Zone, Calibration Plan for Spectral Gamma-Ray Logging Systems. Prepared by MACTEC-ERS for U.S. Department of Energy, Grand Junction Projects Office, Grand Junction, Colorado.

MAC-VZCP-1.7.4, Rev 1. 1997. Hanford Tank Farms Vadose Zone, Health and Safety Plan. Prepared by MACTEC-ERS for U.S. Department of Energy, Grand Junction Projects Office, Grand Junction, Colorado.

MAC-VZCP 1.7.9, Rev. 1. 1997. Hanford Tank Farms Vadose Zone, Data Analysis Manual. Prepared by MACTEC-ERS for U.S. Department of Energy, Grand Junction Projects Office, Grand Junction, Colorado.

MAC-VZCP-1.7.10-1, Rev. 2. 1997. Hanford Tank Farms Vadose Zone, High Resolution Passive Spectral Gamma-Ray Logging Procedures. Prepared by MACTEC-ERS for U.S. Department of Energy, Grand Junction Projects Office, Grand Junction, Colorado.

MAC-VZCP-1.7.10.-2, Rev. 1. 1997. Hanford Tank Farms Vadose Zone, Preventative Maintenance Procedures for the Spectral Gamma Logging System. Prepared by MACTEC-ERS for U.S. Department of Energy, Grand Junction Projects Office, Grand Junction, Colorado.

Newcomb, R. C. 1958. "Ringold Formation of the Pleistocene Age in the Type Locality, The White Bluffs, Washington." American Journal of Science 256:328-340.

Newcomb, R. C., J. R. Strand, and F. J. Frank. 1972. Geology and Ground-Water Characteristics of the Hanford Reservation of the U.S. Atomic Energy Commission, Washington. Professional Paper 717, U.S. Geological Survey, Washington, D.C.

NUREG/CR-6124. 1996. Characterization of Radionuclide-Chelating Agent Complexes Found in LowLevel Radioactive Decontamination Waste. R. J. Serne, A. R. Felmy, K. J. Cantrell, K. M. Krupka, J. A. Campbell, H. Bolton, Jr., and J. K. Fredrickson, U.S. Nuclear Regulatory Commission, Washington, D.C.

OSWER-9950.1. 1986. Resource Conservation and Recovery Act (RCRA) Groundwater Monitoring Technical Enforcement Guidance Document (TEGD). U.S. Environmental Protection Agency, Washington, D.C.

Peterson, R. E., and M. P. Connelly. 1992. "Characterization of a Chromium Plume in Groundwater Along the Columbia River Shoreline, Hanford Site, Washington.” Presented at 1992 Fall Meeting, American Geophysical Union, San Francisco, California, December 7-11, 1992. EOS Transactions, American Geophysical Union 73:43; also WHC-SA-1674-VA, Westinghouse Hanford Company, Richland, Washington. 
P-GJPO-1783, Rev. 1. 1995. Vadose Zone Characterization at the Hanford Tank Farms, HighResolution Passive Spectral Gamma-Ray Logging Procedures. Prepared by Rust Geotech for U.S. Department of Energy, Grand Junction Projects Office, Grand Junction, Colorado.

P-GJPO-1786. 1995. Vadose Zone Characterization Project at the Hanford Tank Farms, Spectral Gamma-Ray Borehole Geophysical Logging Characterization and Baseline Monitoring Plan for the Hanford Single-Shell Tanks. Prepared by Rust Geotech for U.S. Department of Energy, Grand Junction Projects Office, Grand Junction, Colorado.

PNL-2949. 1979. Geohydrology and Ground-Water Quality Beneath the 300 Area, Hanford Site, Washington. J. W. Lindberg and F. W. Bond, Pacific Northwest Laboratory, Richland, Washington.

PNL-5506. 1986. Hanford Site Water Table Changes 1950 Through 1980-Data Observations and Evaluation. D. A. Zimmerman, A. E. Reisenauer, G. D. Black, and M. A. Young, Pacific Northwest Laboratory, Richland, Washington.

PNL-6313. 1987. An Evaluation of Aquifer Intercommunication Between the Unconfined and Rattlesnake Ridge Aquifers on the Hanford Site. E. J. Jensen, Pacific Northwest Laboratory, Richland, Washington.

PNL-6328. 1988. Estimation of Ground-Water Travel Time at the Hanford Site: Description, Past Work, and Future Needs. M. D. Freshley and M. J. Graham, Pacific Northwest Laboratory, Richland, Washington.

PNL-6456. 1988. Hazard Ranking System Evaluation of CERCLA Inactive Waste Sites at Hanford. Volume I, Evaluation Method and Results. R. D. Stenner, K. H. Cramer, K. A. Higley, S. J. Jette, D. A. Lamar, T. J. McLaughlin, D. R. Sherwood, and N. C. VanHouten, Pacific Northwest Laboratory, Richland, Washington.

PNL-6463. 1988. The Predicted Impacts to the Ground Water and Columbia River from Ammoniated Water Discharged to the 216-A-36B Crib. J. L. Buelt, W. Conbere, M. D. Freshley, R. J. Hicks, W. L. Kuhn, D. A. Lamar, R. J. Serne, and J. L. Smoot, Pacific Northwest Laboratory, Richland, Washington.

PNL-6716. 1988. Interim Characterization Report for the 300 Area Process Trenches. R. Schalla, R. W. Wallace, R. L. Aaberg, S. P. Airhart, D. J. Bates, J.V.M. Carlile, C. S. Cline, D. I. Dennison, M. D. Freshley, P. R. Heller, E. J. Jensen, K. B. Olsen, R. G. Parkhurst, J. T. Rieger, and E. J. Westergard, Pacific Northwest Laboratory, Richland, Washington.

PNL-6728. 1988. Geohydrologic Characterization of the Area Surrounding the 183-H Solar Evaporation Basins. T. L. Liikala, R. L. Aaberg, N. J. Aimo, D. J. Bates, T. J Gilmore, E. J. Jensen, G. V. Last, P. L. Oberlander, K. B. Olsen, K. R. Oster, L. R. Roome, J. C. Simpson, S. S. Teel, and E. J. Westergard, Pacific Northwest Laboratory, Richland, Washington. 
PNL-6820. 1989. Hydrogeology for the 200 Areas Low-Level Burial Grounds - An Interim Report. G. V. Last, B. N. Bjornstad, M. P. Bergeron, D. W. Wallace, D. R. Newcomer, J. A. Schramke, M. A. Chamness, C. S. Cline, S. P. Airhart, and J. S. Wilber, Pacific Northwest Laboratory, Richland, Washington.

PNL-6852. 1989. RCRA Ground-Water Monitoring Projects for Hanford Facilities: Annual Progress Report for 1988. R. M. Fruland and R. E. Lundgren (eds.), Pacific Northwest Laboratory, Richland, Washington.

PNL-7498. 1990. Evaluation of Hanford Site Water-Table Changes-1980 to 1990. D. R. Newcomer, Pacific Northwest Laboratory, Richland, Washington.

PNL-8122. 1992. Water-Table Elevations on the Hanford Site and Outlying Areas, 1991. D. R. Newcomer, K. D. Pohlod, and J. P. McDonald, Pacific Northwest Laboratory, Richland, Washington.

PNL-8332. 1992. Status Report on the Development of a Three-Dimensional Conceptual Model for the Hanford Site Unconfined Aquifer System. P. D. Thorne and M. A. Chamness, Pacific Northwest Laboratory, Richland, Washington.

PNL-8335. 1992. Applications of Three Aquifer Test Methods for Estimating Hydraulic Properties Within the 100-N Area. T. J Gilmore, F. A. Spane, Jr., D. R. Newcomer, and C. R. Sherwood, Pacific Northwest Laboratory, Richland, Washington.

PNL-8337. 1992. Summary and Evaluation of Available Hydraulic Property Data for the Hanford Site Unconfined Aquifer System. P. D. Thorne and D. R. Newcomer, Pacific Northwest Laboratory, Richland, Washington.

PNL-8539. 1993. Selected Hydraulic Test Analysis Techniques for Constant-Rate Discharge Tests. F. A. Spane, Jr., Pacific Northwest Laboratory, Richland, Washington.

PNL-8580. 1993. Water Level Measurements for Modeling Hydraulic Properties in the 300-FF-5 and 100 Aggregate Area Operable Units. M. D. Campbell, W. J. McMahon, and K. R. Simpson, Pacific Northwest Laboratory, Richland, Washington.

PNL-8597. 1993. Refined Conceptual Model for the Volatile Organic Compounds - Arid Integrated Demonstration and 200 West Area Carbon Tetrachloride Expedited Response Action. G. V. Last and V. J. Rohay, Pacific Northwest Laboratory, Richland, Washington.

PNL-8869. 1993. Preliminary Potentiometric Map and Flow Dynamic Characteristics for the UpperBasalt Confined Aquifer System. F. A. Spane, Jr. and R. G. Raymond, Pacific Northwest Laboratory, Richland, Washington. 
PNL-8971. 1993. Three-Dimensional Conceptual Model for the Hanford Site Unconfined Aquifer System, FY 93 Status Report. P. D. Thorne, M. A. Chamness, F. A. Spane, Jr., V. R. Vermeul, and W. D. Webber, Pacific Northwest Laboratory, Richland, Washington.

PNL-9958. 1994. Calibration Facilities at Hanford for Gamma-Ray and Fission-Neutron Well Logging. D. C. Stromswold, Pacific Northwest Laboratory, Richland, Washington.

PNL-10082. 1994. Hanford Site Ground-Water Monitoring for 1993. P. E. Dresel, S. P. Luttrell, J. C. Evans, W. D. Webber, P. D. Thorne, M. A. Chamness, B. M. Gillespie, B. E. Opitz, J. T. Rieger, and J. K. Merz, Pacific Northwest Laboratory, Richland, Washington.

PNL-10094. 1994. Hydrogeology Along the Southern Boundary of the Hanford Site Between the Yakima and Columbia Rivers, Washington. T. L. Liikala, Pacific Northwest Laboratory, Richland, Washington.

PNL-10158. 1994. Summary and Evaluation of Hydraulic Property Data Available for the Hanford Site Upper Basalt Confined Aquifer System. F. A. Spane, Jr. and V. R. Vermeul, Pacific Northwest Laboratory, Richland, Washington.

PNL-10195. 1994. Three-Dimensional Conceptual Model for the Hanford Site Unconfined Aquifer System: FY 1994 Status Report. P. D. Thorne, M. A. Chamness, V. R. Vermeul, Q. C. MacDonald, and S. E. Schubert, Pacific Northwest Laboratory, Richland, Washington.

PNL-10196. 1994. Predicted Impacts of Future Water Level Decline on Monitoring Wells Using a Ground-Water Model of the Hanford Site. S. K. Wurstner and M. D. Freshley, Pacific Northwest Laboratory, Richland, Washington.

PNL-10285. 1995. Estimated Recharge Rates at the Hanford Site. M. J. Fayer and T. B. Walters, Pacific Northwest Laboratory, Richland, Washington.

PNL-10379, SUP. 1. 1995. Distribution Coefficient Values Describing Iodine, Neptunium, Selenium, Technetium, and Uranium Sorption to Hanford Sediments. D. I. Kaplan and R. J. Serne, Pacific Northwest Laboratory, Richland, Washington.

PNL-10422. 1995. Geology, Hydrology, Chemistry, and Microbiology of the In Situ Bioremediation Demonstration Site. D. R. Newcomer, L. A. Doremus, S. H. Hall, M. J. Truex, V. R. Vermeul, and R. E. Engelman, Pacific Northwest Laboratory, Richland, Washington.

PNL-10633. 1995. Geologic, Geochemical, Microbiologic, and Hydrologic Characterization at the In Situ Redox Manipulation Test Site. V. R. Vermeul, S. S. Teel, J. E. Amonette, C. R. Cole, J. S. Fruchter, Y. A. Gorby, F. A. Spane, Jr., J. E. Szecsody, M. D. Williams, and S. B. Yabusaki, Pacific Northwest Laboratory, Richland, Washington. 
PNL-10801. 1995. Calibration Models for Measuring Moisture in Unsaturated Formations by Neutron Logging. R. E. Engelman, R. E. Lewis, and D. C. Stromswold, Pacific Northwest Laboratory, Richland, Washington.

PNL-10817. 1995. Hydrochemistry and Hydrogeologic Conditions Within the Hanford Upper Basalt Confined Aquifer System. F. A. Spane, Jr. and W. D. Webber, Pacific Northwest Laboratory, Richland, Washington.

PNL-10835. 1995. Comparison of Constant-Rate Pumping Test and Slug Interference Test Results at the B-Pond Multi-Level Test Facility, Hanford Site. F. A. Spane, Jr. and P. D. Thorne, Pacific Northwest Laboratory, Richland, Washington.

PNL-10886. 1995. Development of a Three-Dimensional Ground-Water Model of the Hanford Site Unconfined Aquifer System: FY 1995 Status Report. S. K. Wurstner, P. D. Thorne, M. A. Chamness, M. D. Freshley, and M. D. Williams, Pacific Northwest Laboratory, Richland, Washington.

PNL-10899. 1996. Strontium-90 Adsorption-Desorption Properties and Sediment Characterization at the 100-N Area. R. J. Serne and V. L. LeGore, Pacific Northwest Laboratory, Richland, Washington.

PNNL-11141. 1996. Hanford Site Ground-Water Monitoring for 1995. P. E. Dresel, J. T. Rieger, W. D. Webber, P. D. Thorne, B. M. Gillespie, S. P. Luttrell, S. K. Wurstner, and T. L. Liikala, Pacific Northwest National Laboratory, Richland, Washington.

PNNL-11372. 1996. In Situ Redox Manipulation Field Injection Test Report - Hanford 100-H Area. J. S. Fruchter, J. E. Amonette, C. R. Cole, Y. A. Gorby, M. D. Humphrey, J. D. Isok, F. A. Spane, J. E. Szecsody, S. S. Teel, V. R. Vermeul, M. D. Williams, and S. B. Yabusaki, Pacific Northwest National Laboratory, Richland, Washington.

PNNL-11470. 1997. Hanford Site Groundwater Monitoring for Fiscal Year 1996. M. J. Hartman and P. E. Dresel (eds.), Pacific Northwest National Laboratory, Richland, Washington.

PNNL-11472. 1997. Hanford Site Environmental Report for Calendar Year 1996. R. L. Dirkes and R. W. Hanf (eds.), Pacific Northwest National Laboratory, Richland, Washington.

PNNL-11515. 1997. Borehole Data Package for Well 699-37-47A, PUREX Plant Cribs, CY 1996. J. W. Lindberg, B. A. Williams, and F. A. Spane, Pacific Northwest National Laboratory, Richland, Washington.

PNNL-11523. 1997. Combination RCRA Goundwater Monitoring Plan for the 216-A-10, 216-A-36B, and 216-A-37-1 PUREX Cribs. J. W. Lindberg, Pacific Northwest National Laboratory, Richland, Washington.

PNNL-11573. 1997. Groundwater Monitoring Plan for the 183-H Solar Evaporation Basins. M. J. Hartman, Pacific Northwest National Laboratory, Richland, Washington. 
PNNL-11574. 1997. Results of RCRA Groundwater Quality Assessment Program at the 216-U-12 Crib. B. A. Williams and C. J. Chou, Pacific Northwest National Laboratory, Richland, Washington.

PNNL-11604. 1997. Results of RCRA Groundwater Quality Assessment at the 216-B-3 Pond Facility. D. B. Barnett and S. S. Teel, Pacific Northwest National Laboratory, Richland, Washington.

PNNL-11620. 1997. Liquid Effluent Retention Facility Final-Status Groundwater Monitoring Plan. M. D. Sweeney, C. J. Chou, and B. N. Bjornstad, Pacific Northwest National Laboratory, Richland, Washington.

PNNL-11633. 1997. Origin of Increased Sulfate in Groundwater at the ETF Disposal Site. E. C. Thornton, Pacific Northwest National Laboratory, Richland, Washington.

PNNL-11665. 1997. Tritium Monitoring in Groundwater and Evaluation of Model Predictions for the Hanford Site 200 Area Effluent Treatment Facility. D. B. Barnett, M. P. Bergeron, C. R. Cole, M. D. Freshley, and S. K. Wurstner, Pacific Northwest National Laboratory, Richland, Washington.

PNNL-11793. 1998. Hanford Site Groundwater Monitoring for Fiscal Year 1997. M. J. Hartman and P. E. Dresel (eds.), Pacific Northwest National Laboratory, Richland, Washington.

PNNL-11795. 1998. Hanford Site Environmental Report for Calendar Year 1997. R. L. Dirkes, and R. W. Hanf (eds.), Pacific Northwest National Laboratory, Richland, Washington.

PNNL-11800. 1998. Composite Analysis for Low-Level Waste Disposal in the 200 Areas Plateau of the Hanford Site. C. T. Kincaid, M. P. Bergeron, C. R. Cole, M. D. Freshley, N. L. Hassig, V. G. Johnson, D. I. Kaplan, R. J. Serne, G. P. Streile, D. L. Strenge, P. D. Thorne, L. W. Vail, G. A. Whyatt, and S. K. Wurstner, Pacific Northwest National Laboratory, Richland, Washington.

PNNL-11801. 1998. Three-Dimensional Analysis of Future Groundwater Flow Conditions and Contaminant Plume Transport in the Hanford Site Unconfined Aquifer System: FY 1996 and 1997 Status Report. C. R. Cole, S. K. Wurstner, M. P. Bergeron, M. D. Williams, and P. D. Thorne, Pacific Noithwest National Laboratory, Richland, Washington.

PNNL-11809. 1998. Results of Phase I Groundwater Quality Assessment for Single-Shell Tank Waste Management Areas T and TX-TY at the Hanford Site. F. N. Hodges, Pacific Northwest National Laboratory, Richland, Washington.

PNNL-11810. 1998. Results of Phase I Groundwater Quality Assessment for Single-Shell Tank Waste Management Areas S-SX at the Hanford Site. V. G. Johnson and C. J. Chou, Pacific Northwest National Laboratory, Richland, Washington.

PNNL-11826. 1998. Results of Phase I Groundwater Quality Assessment for Single-Shell Tank Waste Management Areas $B-B X-B Y$ at the Hanford Site. S. M. Narbutovskih, Pacific Northwest National Laboratory, Richland, Washington. 
PNNL-11885. 1998. Groundwater Quality Assessment Plan for the 1324-N/NA Site - Phase I (First Determination). M. J. Hartman, Pacific Northwest National Laboratory, Richland, Washington.

PNNL-11957. 1998. Immobilized Low-Activity Waste Site Borehole 299-E17-21. S. P. Reidel, K. D. Reynolds, and D. G. Horton, Pacific Northwest National Laboratory, Richland, Washington.

PNNL-11966. 1998. Radionuclide Distribution Coefficients for Sediments Collected from Borehole 299-E17-21: Final Report for Subtask Ia. D. I. Kaplan, K. E. Parker, and I. V. Kutynakov, Pacific Northwest National Laboratory, Richland, Washington.

PNNL-11975. 1998. Uranium (VI) Sorption and Transport in Unsaturated, Subsurface Hanford Sediments: Effect of Moisture Content and Sediment Texture. A. P. Gamerdinger, D. I. Kaplan, and C. T. Resch, Pacific Northwest National Laboratory, Richland, Washington.

PNNL-11978. 1998. Results of 1998 Spectral Gamma-Ray Monitoring of Boreholes at the 216-Z-1A Tile Field, 216-Z-9 Trench, and 216-Z-12 Crib. D. G. Horton and R. R. Randall, Pacific Northwest National Laboratory, Richland, Washington.

PNNL-11986. 1998. Evaluation of Groundwater Monitoring Results at the Hanford Site 200 Area Treated Effluent Disposal Facility. D. B. Barnett, Pacific Northwest National Laboratory, Richland, Washington.

PNNL-11989. 1998. Integrated Monitoring Plan for the Hanford Groundwater Monitoring Project. M. J. Hartman, P. E. Dresel, J. P. McDonald, R. B. Mercer, D. R. Newcomer, and E. C. Thornton, Pacific Northwest National Laboratory, Richland, Washington.

PNNL-12023. 1998. Groundwater Monitoring for the 100-K Area Fuel-Storage Basins: July 1996 through April 1998. V. G. Johnson, C. J. Chou, M. J. Hartman, and W. D. Webber, Pacific Northwest National Laboratory, Richland, Washington.

PNNL-12067. 1998. Upper Basalt-Confined Aquifer System in the Southern Hanford Site. P. Thome, Pacific Northwest National Laboratory, Richland, Washington.

PNWD-1974 HEDR. 1992. Ground-Water Contribution to Dose from Past Hanford Operations. M. D. Freshley and P. D. Thorne, Pacific Northwest Laboratory, Richland, Washington.

PNWD-2225 HEDR. 1994. Reconstruction of Radionuclide Concentrations in the Columbia River from Hanford, Washington to Portland, Oregon January 1950-January 1971. W. H. Walters, M. C. Richmond, and B. G. Gilmore, Pacific Northwest Laboratory, Richland, Washington.

Price, S. M., and L. L. Ames. 1976. "Characterization of Actinide-Bearing Sediments Underlying Liquid Waste Disposal Facilities at Hanford." In Transuranium Nuclides in the Environment, International Atomic Energy Agency, Vienna, Austria. Also known as ARH-SA-232, Atlantic Richfield Hanford Company, Richland, Washington. 
Puget Sound Power and Light Company. 1982. Skagit/Hanford Nuclear Project, Preliminary Safety Analysis Report. Appendix 20, Amendment 23, Bellevue, Washington.

Record of Decision (ROD). 1993. Record of Decision, USDOE Hanford 1100 Area, Hanford Site, Richland Washington (1100-EM-1, 1100-EM-2, 1100-EM-3, and 1100-IU-1 Operable Units). State of Washington Department of Ecology, U.S. Environmental Protection Agency, and U.S. Department of Energy, Richland Operations Office, Richland, Washington.

Record of Decision (ROD). 1995. Declaration of the Record of Decision, USDOE Hanford 200 Area, Hanford Site, Benton County, Washington (200-ZP-1). State of Washington Department of Ecology, U.S. Environmental Protection Agency, and U.S. Department of Energy, Richland Operations Office, Richland, Washington.

Record of Decision (ROD). 1996a. Declaration of the Record of Decision for the 300-FF-1 and 300-FF-5 Operable Units. State of Washington Department of Ecology, U.S. Environmental Protection Agency, and U.S. Department of Energy, Richland Operations Office, Richland, Washington.

Record of Decision (ROD). 1996b. Declaration of the Record of Decision, USDOE Hanford 100 Area, 100-HR-3 and 100-KR-4 Operable Units, Hanford Site, Benton County, Washington, April 1996. State of Washington Department of Ecology, U.S. Environmental Protection Agency, and U.S. Department of Energy, Richland Operations Office, Richland, Washington.

Record of Decision (ROD). 1997. Declaration of the Record of Decision, U.S. DOE Hanford 200 Area, Hanford Site, Benton County, Washington (200-UP-1). State of Washington Department of Ecology, U.S. Environmental Protection Agency, and U.S. Department of Energy, Richland Operations Office, Richland, Washington.

Reidel, S. P. and K. R. Fecht. 1994a. Geologic Map of the Richland 1:100,000 Quadrangle, Washington. Open File Report 94-8, Washington Division of Geology and Earth Resources, Washington State Department of Natural Resources, Olympia, Washington.

Reidel, S. P. and K. R. Fecht. 1994b. Geologic Map of the Priest Rapids 1:100,000 Quadrangle, Washington. Open File Report 94-13, Washington Division of Geology and Earth Resources, Washington State Department of Natural Resources, Olympia, Washington.

Reidel, S. P., K. R. Fecht, K. A. Lindsey, and N. P. Campbell. 1994. "Late Cenozoic Structure and Stratigraphy of South-Central Washington." In Lasmanis, R. and E. S. Cheney (eds.), Washington Division of Geology and Earth Resources Bulletin 80, Olympia, Washington, p. 159-180.

RHO-BWI-C-56. 1979. A Review of Water-Well Data From the Unconfined Aquifer in the Eastern and Southern Parts of the Pasco Basin. R. E. Brown, Rockwell Hanford Operations, Richland, Washington. 
RHO-BWI-ST-4. 1979. Geologic Studies of the Columbia Plateau: A Status Report. C. W. Myers/ S. M. Price, J. A. Caggiano, M. P. Cochran, W. J. Czimer, N. J. Davidson, R. C. Edwards, K. R. Fecht, G. E. Holmes, M. G. Jones, J. R. Kunk, R. D. Landon, R. K. Ledgerwood, J. T. Lillie, P. E. Long, T. H. Mitchell, E. H. Price, S. M. Reidel, and A. M. Tallman, Rockwell Hanford Operations, Richland, Washington.

RHO-BWI-ST-5. 1979. Hydrologic Studies Within the Columbia Plateau, Washington: An Integration of Current Knowledge. R. E. Gephart, R. C. Arnett, R. G. Baca, L. S. Leonhart, and F. A. Spane, Jr., Rockwell Hanford Operations, Richland, Washington.

RHO-BWI-ST-14. 1981. Subsurface Geology of the Cold Creek Syncline. C. W. Myers and S. M. Price (eds.), Rockwell Hanford Operations, Richland, Washington.

RHO-HS-EV-18. 1983. Serviceability of Cribs Affected by PUREX Startup. R. M. Smith and R. B. Kasper, Rockwell Hanford Operations, Richland, Washington.

RHO-HS-SR-86-3-4Q LIQ P. 1987. Radioactive Liquid Wastes Discharged to Ground in the 200 Areas During 1986. R. C. Aldrich, Rockwell Hanford Operations, Richland, Washington.

RHO-RE-ST-12 P. 1984. An Assessment of Aquifer Intercommunication in the B Pond, Gable Mountain Pond Area. M. J. Graham, G. V. Last, and K. R. Fecht, Rockwell Hanford Operations, Richland, Washington.

RHO-ST-17. 1979. Distribution of Plutonium and Americium Beneath the 216-Z-1A Crib: Status Report. S. M. Price, R. B. Kasper, M. K. Additon, R. M. Smith, and G. V. Last, Rockwell Hanford Operations, Richland, Washington.

RHO-ST-21. 1978. Report on Plutonium Mining Activities at 216-Z-9 Enclosed Trench. J. D. Ludowise, Rockwell Hanford Operations, Richland, Washington.

RHO-ST-23. 1979. Geology of the Separations Areas, Hanford Site, South-Central Washington. A. M. Tallman, K. R. Fecht, M. C. Marratt, and G. V. Last, Rockwell Hanford Operations, Richland, Washington.

RHO-ST-37. 1980. 216-B-5 Reverse Well Characterization Study. R. M. Smith, Rockwell Hanford Operations, Richland, Washington.

RHO-ST-38. 1982. Geohydrology of the Rattlesnake Ridge Interbed in the Gable Mountain Pond Area. S. R. Strait and B. A. Moore, Rockwell Hanford Operations, Richland, Washington.

RHO-ST-42. 1981. Hydrology of the Separations Area. M. J. Graham, M. D. Hall, S. R. Strait, and W. R. Brown, Rockwell Hanford Operations, Richland, Washington. 
RHO-ST-44. 1982. 216-Z-12 Transuranic Crib Characterization: Operational History and Distribution of Plutonium and Americium. R. B. Kasper, Rockwell Hanford Operations, Richland, Washington.

ROD - See Record of Decision

SD-BWI-DP-039. 1984. Suprabasalt Stratigraphy Within and Adjacent to the Reference Repository Location. B. N. Bjornstad, Rockwell Hanford Operations, Richland, Washington.

Slate, J. L. 1996. "Buried Carbonate Paleosols Developed in Pliocene-Pleistocene Deposits of the Pasco Basin, South Central Washington, USA.” In Quaternary International 34-36:191-196.

Spane, F. A. Jr. 1996. "Applicability of Slug Interference Tests for Hydraulic Characterization of Unconfined Aquifers: (1) Analytical Assessment." Ground Water 34(1):66-74.

State of Washington Department of Ecology. 1994. Dangerous Waste Portion of the Resource Conservation and Recovery Act Permit for the Treatment, Storage, and Disposal of Dangerous Waste, as amended. Permit Number WA7890008967, Effective September 28, 1994. Olympia, Washington.

State of Washington Department of Ecology. 1995a. State Waste Discharge Permit (216 Permit) for the 200 Area Treated Effluent Disposal Facility (TEDF). Permit No. ST 4502, issued in compliance with the provisions of Chapter $90.48 \mathrm{RCW}$, as amended, and Chapter 173-216 WAC, as amended, Olympia, Washington.

State of Washington Department of Ecology. 1995b. State Waste Discharge Permit (216 Permit) for the 200 Area Effluent Treatment Facility (ETF). Permit No. ST 4500, issued in compliance with the provisions of Chapter 90.48 RCW, as amended, and Chapter 173-216 WAC, as amended, Olympia, Washington.

State of Washington Department of Ecology. 1996. State Waste Discharge Permit No. ST 4501 (400 Area Pond). Olympia, Washington.

State of Washington Department of Ecology and U.S. Environmental Protection Agency. 1994. Action Memorandum: N-Springs Expedited Response Action Cleanup Plan, U.S. Department of Energy, Hanford Site, Washington. Olympia, Washington.

State of Washington Department of Ecology, U.S. Environmental Protection Agency, and U.S. Department of Energy. 1989. Hanford Federal Facility Agreement and Consent Order Between the U.S. Environmental Protection Agency, the U.S. Department of Energy, and the State of Washington Department of Ecology, May 15, 1989, as amended. Olympia, Seattle, and Richland, Washington.

SW-846. 1986. Test Methods for Evaluating Solid Wastes: Physical/Chemical Methods, 3rd ed. Office of Solid Waste and Emergency Response, U.S. Environmental Protection Agency, Washington, D.C. 
Swanson, D. A., J. L. Anderson, R. D. Bentley, V. E. Camp, J. N. Gardner, and T. L. Wright. 1979. Reconnaissance Geologic Map of the Columbia River Basalt Group in Washington and Adjacent Idaho. Open-File Report 79-1363, U.S. Geological Survey, Washington, D.C.

U.S. Army Corps of Engineers. 1997. Corpscon, Version 5.x, Technical Documentation and Operating Instructions. Geodetic Applications Division, Topographic Applications Laboratory, U.S. Army Topographic Engineering Center, Alexandria, Virginia.

U.S. Geological Survey. 1977. National Handbook of Recommended Methods for Water Data Acquisition. Office of Water Data Coordination, Reston, Virginia.

van Genuchten, M. Th. 1981. Non-E்quilibrium Transport Parameters from Miscible Displacement Experiments. Research Report 119, Salinity Laboratory, U.S. Department of Agriculture, Washington D.C.

van Genuchten, M. Th., and J. C. Parker. 1984. Determining Transport Parameters from Laboratory and Field Tracer Experiments. Bulletin 84-3, Virginia Agriculture Experiment Station, Blacksburg, Virginia.

WHC-EP-0021. 1987. Interim Hydrogeologic Characterization Report and Groundwater Monitoring System for the Nonradioactive Dangerous Waste Landfill, Hanford Site, Washington. D. C. Weekes, S. P. Luttrell, and M. R. Fuchs, Westinghouse Hanford Company, Richland, Washington.

WHC-EP-0133. 1988. U1/U2 Uranium Plume Characterization, Remedial Action Review and Recommendation for Future Action. S. M. Baker, J. L. Devary, R. P. Elmore, R. L. Lorang, A. J. Rossi, and M. D. Freshley, Westinghouse Hanford Company, Richland, Washington.

WHC-EP-0142-3. 1989. Groundwater Maps of the Hanford Site Separations Area, June 1989.

G. L. Kasza, S. P. Reidel, and A. L. Schatz, Westinghouse Hanford Company, Richland, Washington.

WHC-EP-0142-4. 1990. Ground Water Maps of Hanford Site Separations Area, December 1989. G. L. Kasza, Westinghouse Hanford Company, Richland, Washington.

WHC-EP-0367. 1990. Liquid Effluent Study Final Project Report. V. J. Rohay, Westinghouse Hanford Company, Richland, Washington.

WHC-EP-0394-3. 1991. Ground Water Maps of the Hanford Site, June 1991. G. L. Kasza, M. J. Hartman, F. N. Hodges, and D. C. Weekes, Westinghouse Hanford Company, Richland, Washington.

WHC-EP-0573-4. 1996. Westinghouse Hanford Company Operational Environmental Monitoring Annual Report, Calendar Year 1995. J. W. Schmidt, J. W. Fasset, V. G. Johnson, R. M. Mitchell, B. M. Markes, S. M. McKinney, K. J. Moss, and C. J. Perkins, Westinghouse Hanford Company, Richland, Washington. 
WHC-EP-0587. 1992. Groundwater Impact Assessment Report for the 400 Area Ponds. D. K. Tyler, Westinghouse Hanford Company, Richland, Washington.

WHC-EP-0666. 1993. Groundwater Impact Assessment Report for the 100-D Ponds. D. J. Alexander, Westinghouse Hanford Company, Richland, Washington.

WHC-EP-0674. 1993. Groundwater Impact Assessment Report for 216-Z-20 Crib, 200 West Area. V. G. Johnson, Westinghouse Hanford Company, Richland, Washington.

WHC-EP-0813. 1995. Ground Water Impact Assessment Report for the 216-B-3 Pond System. V. G. Johnson, A. G. Law, S. P. Reidel, S. D. Evelo, D. B. Barnett, and M. D. Sweeney, Westinghouse Hanford Company, Richland, Washington.

WHC-EP-0815. 1995. Groundwater Impact Assessment Report for the 216-T-4-2 Ditch. D. J. Alexander, S. D. Evelo, V. G. Johnson, and M. D. Sweeney, Westinghouse Hanford Company, Richland, Washington.

WHC-EP-0883. 1995. Variability and Scaling of Hydraulic Properties for 200 Area Soils, Hanford Site. R. Khaleel and E. J. Freeman, Westinghouse Hanford Company, Richland, Wașhington.

WHC-MR-0132. 1990. A History of the 200 Area Tank Farms. J. D. Anderson, Westinghouse Hanford Company, Richland, Washington.

WHC-MR-0206. 1990. Borehole Completion Data Package for the 216-S-10 Ditch and Pond. S. P. Airhart, Westinghouse Hanford Company, Richland, Washington.

WHC-MR-0208. 1990. Borehole Completion Data Package for the 216-U-12 Crib. S. M. Goodwin, Westinghouse Hanford Company, Richland, Washington.

WHC-MR-0227. 1991. Tank Wastes Discharged Directly to the Soil at the Hanford Site. J. L. Waite, Westinghouse Hanford Company, Richland, Washington.

WHC-MR-0391. 1992. Field Trip Guide to the Hanford Site. S. P. Reidel, K. A. Lindsey, and K. R. Fecht, Westinghouse Hanford Company, Richland, Washington.

WHC-MR-0425. 1993. Manhattan Project Buildings and Facilities at the Hanford Site: A Construction History. M. S. Gerber, Westinghouse Hanford Company, Richland, Washington.

WHC-SD-C018H-RPT-003. 1994. 1994 Characterization Report for the State Approved Land Disposal Site. L. C. Swanson, Westinghouse Hanford Company, Richland, Washington.

WHC-SD-C018H-PLN-004, Rev. 1. 1996. Ground-Water Screening Evaluation/Monitoring Plan 200 Area Effluent Treatment Facility (Project C-018H). J. D. Davis, D. B. Barnett, C. J. Chou, and P. B. Freeman, Westinghouse Hanford Company, Richland, Washington. 
WHC-SD-EN-AP-012, Rev. 0. 1989. 40 CFR 265 Interim-Status Ground-Water Monitoring Plan for the Single-Shell Tanks. E. J. Jensen, S. P. Airhart, M. A. Chamness, T. J Gilmore, D. R. Newcomer, and K. R. Oster, Pacific Northwest Laboratory for Westinghouse Hanford Company, Richland, Washington.

WHC-SD-EN-AP-012, Rev. 1. 1991. Interim-Status Groundwater Monitoring Plan for the Single-Shell Tanks. J. A. Caggiano and S. M. Goodwin, Westinghouse Hanford Company, Richland, Washington.

WHC-SD-EN-AP-013. 1995. Interim-Status Groundwater Monitoring Plan for the 216-B-3 Pond. M. D. Sweeney, Westinghouse Hanford Company, Richland, Washington.

WHC-SD-EN-AP-015. 1998. Revised Ground-Water Monitoring Plan for the 200 Areas Low-Level Burial Grounds. G. V. Last and B. N. Bjornstad, Pacific Northwest National Laboratory, Richland, Washington.

WHC-SD-EN-AP-024. 1990. Interim Status Groundwater Monitoring Plan for the 200 East Area Liquid Effluent Retention Facility. J. S. Schmid, Westinghouse Hanford Company, Richland, Washington.

WHC-SD-EN-AP-038, Rev. 2. 1996. Groundwater Monitoring Plan for the 1301-N, 1325-N, and 1324-N/NA Sites. M. J. Hartman, Westinghouse Hanford Company, Richland, Washington.

WHC-SD-EN-AP-043. 1993. Groundwater Monitoring Plan for the Solid Waste Landfill, Hanford, Washington. F. N. Hodges, Westinghouse Hanford Company, Richland, Washington.

WHC-SD-EN-AP-048. 1991. Groundwater Monitoring Plan for the 100-D Ponds. M. J. Hartman, Westinghouse Hanford Company, Richland, Washington.

WHC-SD-EN-AP-108. 1993. Interim-Status Groundwater Quality Assessment Plan for the 216-U-12 Crib. C. J. Chou and B. A. Williams, Westinghouse Hanford Company, Richland, Washington.

WHC-SD-EN-AP-170, Rev. 0-A. 1994. Interim-Status Groundwater Monitoring Plan for the 216-A-10 and 216-A-36B Cribs. G. L. Kasza, Westinghouse Hanford Company, Richland, Washington.

WHC-SD-EN-AP-174. 1995. Groundwater Monitoring and Assessment Plan for the 100-K Area Fuel Storage Basins. V. G. Johnson, C. J. Chou, and J. W. Lindberg, Westinghouse Hanford Company, Richland, Washington.

WHC-SD-EN-AP-185. 1995. Groundwater Monitoring Plan for the 300 Area Process Trenches. J. W. Lindberg, C. J. Chou, and V. G. Johnson, Westinghouse Hanford Company, Richland, Washington.

WHC-SD-EN-AP-191. 1996. Assessment Groundwater Monitoring Plan for Single-Shell Tank Waste Management Area S-SX. J. A. Caggiano, Westinghouse Hanford Company, Richland, Washington. 
WHC-SD-EN-DP-042. 1993. Borehole Completion Data Package for CY 1991 and CY 1992 RCRA Wells at Single-Shell Tanks. J. A. Caggiano, Westinghouse Hanford Company, Richland, Washington.

WHC-SD-EN-DP-043. 1992. Borehole Completion Data Package, 100-D Ponds Wells: CY 1992. M. J. Hartman, Westinghouse Hanford Company, Richland, Washington.

WHC-SD-EN-DP-047. 1992. Borehole Completion Data Package for the 216-A-29 RCRA Facility Monitoring Wells: Calendar Year 1991. G. L. Kasza, Westinghouse Hanford Company, Richland, Washington.

WHC-SD-EN-SP-049. 1993. 1992 Borehole Completion Data Package for the Low-Level Burial Grounds. R. B. Mercer, Westinghouse Hanford Company, Richland, Washington.

WHC-SD-EN-DP-052. 1993. Borehole Completion Data Package for the 216-S-10 Facility, CY-1992. B. A. Williams and D. B. Barnett, Westinghouse Hanford Company, Richland, Washington.

WHC-SD-EN-EE-004. 1991. Revised Stratigraphy for the Ringold Formation, Hanford Site, SouthCentral Washington. K. A. Lindsey, Westinghouse Hanford Company, Richland, Washington.

WHC-SD-EN-EV-002. 1990. Interim Hydrogeologic Characterization Report for the 216-B-3 Pond. Westinghouse Hanford Company, Richland, Washington.

WHC-SD-EN-EV-003, Rev. 1. 1992. Results of Groundwater Quality Assessment Monitoring at the 1301-N and 1324-N/NA Facilities. M. J. Hartman, Westinghouse Hanford Company, Richland, Washington.

WHC-SD-EN-EV-027. 1993. Hydrogeology of the 100-N Area, Hanford Site, Washington. M. J. Hartman and K. A. Lindsey, Westinghouse Hanford Company, Richland, Washington.

WHC-SD-EN-EV-032. 1995. Results of Groundwater Quality Assessment Program at the 216-A-29 Ditch RCRA Facility. J. M. Votava, Westinghouse Hanford Company, Richland, Washington.

WHC-SD-EN-EV-033. 1996. 100-D Ponds Groundwater Quality Assessment. M. J. Hartman, Westinghouse Hanford Company, Richland, Washington.

WHC-SD-EN-TA-004. 1996. Feasibility of CPT-Deployed Vertical Electrode Array in Single Shell Tank Farms. S. M. Narbutovskih, D. F. Iwatate, M. D. Sweeney, A. L. Ramirez, W. Daily, R. M. Morey, and L. Christensen, Westinghouse Hanford Company, Richland, Washington.

WHC-SD-EN-TI-008. 1991. Geologic Setting of the 200 West Area: An Update. K. A. Lindsey, M. P. Connelly, and B. N. Bjornstad, Westinghouse Hanford Company, Richland, Washington. 
WHC-SD-EN-TI-012. 1992. Geologic Setting of the 200 East Area: An Update. K. A. Lindsey, B. N: Bjornstad, J. W. Lindberg, and K. M. Hoffman, Westinghouse Hanford Company, Richland, Washington.

WHC-SD-EN-TI-014. 1992. Hydrogeologic Model for the 200 West Groundwater Aggregate Area. M. P. Connelly, B. H. Ford, and J. V. Borghese, Westinghouse Hanford Company, Richland, Washington.

WHC-SD-EN-TI-019. 1992. Hydrogeologic Model for the 200 East Groundwater Aggregate Area. M. P. Connelly, B. H. Ford, J. W. Lindberg, S. J. Trent, C. D. Delaney, and J. V. Borghese, Westinghouse Hanford Company, Richland, Washington.

WHC-SD-EN-TI-023. 1992. Hydrologic Information Summary for the Northern Portion of the Hanford Site. M. J. Hartman and R. E. Peterson, Westinghouse Hanford Company, Richland, Washington.

WHC-SD-EN-TI-052. 1992. Phase I Hydrogeologic Summary of the 300-FF-5 Operable Unit, 300 Area. L. C. Swanson, Westinghouse Hanford Company, Richland, Washington.

WHC-SD-EN-TI-071. 1993. Geology and Aquifer Characteristics of the Grout Treatment Facility. J. W. Lindberg, J. V. Borghese, B. N. Bjornstad, and M. P. Connelly, Westinghouse Hanford Company, Richland, Washington.

WHC-SD-EN-TI-101. 1993. Carbon Tetrachloride Evaporative Losses and Residual Inventory Beneath 200 West Area at the Hanford Site. Westinghouse Hanford Company, Richland, Washington.

WHC-SD-EN-TI-132. 1993. Geologic Setting of the 100-HR-3 Operable Unit, Hanford Site, SouthCentral Washington. K. A. Lindsey and G. K. Jaeger, Westinghouse Hanford Company, Richland, Washington.

WHC-SD-EN-TI-133. 1993. Geology of the 100-B/C Area, Hanford Site, South-Central Washington. J. W. Lindberg, Westinghouse Hanford Company, Richland, Washington.

WHC-SD-EN-TI-147. 1990. Hydrologic Testing at the Single-Shelled Tanks, 1989. D. R. Newcomer, J. V. Borghese, and W. E. Cronin, Westinghouse Hanford Company, Richland, Washington.

WHC-SD-EN-TI-155. 1993. Geology of the 100-K Area, Hanford Site, South-Central Washington. J. W. Lindberg, Westinghouse Hanford Company, Richland, Washington.

WHC-SD-EN-TI-169. 1993. 100-F Reactor Site Technical Baseline Report Including Operable Units 100-FR-1 and 100-FR-2. D. H. Deford, Westinghouse Hanford Company, Richland, Washington.

WHC-SD-EN-TI-181. 1993. 100-D Technical Baseline Report. R. W. Carpenter, Westinghouse Hanford Company, Richland, Washington. 
WHC-SD-EN-TI-220. 1994. 100-B/C Area Technical Baseline Report. R. W. Carpenter, S. L. Cotè, D. H. Deford, and M. W. Einan, Westinghouse Hanford Company, Richland, Washington.

WHC-SD-EN-TI-239. 1994. 100-K Area Technical Baseline Report. R. W. Carpenter and S. L. Cotè, Westinghouse Hanford Company, Richland, Washington.

WHC-SD-EN-TI-248. 1994. 1994 Conceptual Model of the Carbon Tetrachloride Contamination in the 200 West Area at the Hanford Site. V. J. Rohay, K. J. Swett, and G. V. Last, Westinghouse Hanford Company, Richland, Washingtọn.

WHC-SD-EN-TI-251. 1994. 100-N Technical Baseline Report. S. L. Cotè, Westinghouse Hanford Company, Richland, Washington.

WHC-SD-EN-TI-290. 1994. Geologic Setting of the Low-Level Burial Grounds. K. A. Lindsay, J. L. Slate, G. K. Jaeger, K. J. Swett, and R. B. Mercer, Westinghouse Hanford Company, Richland, Washington.

WHC-SD-EN-TI-292. 1994. Calibration of the Radionuclide Logging System Germanium Detector. R. R. Randall, Westinghouse Hanford Company, Richland, Washington.

WHC-SD-EN-TI-294. 1995. Hydrogeology of the 100-K Area, Hanford Site, South-Central Washington. J. W. Lindberg, Westinghouse Hanford Company, Richland, Washington.

WHC-SD-EN-TI-306. 1996. Radionuclide Logging System In Situ Vadose Zone Moisture Measurement Calibration. R. K. Price, J. E. Meisner, and R. R. Randall, Westinghouse Hanford Company, Richland, Washington.

WHC-SD-ER-TI-003. 1991. Geology and Hydrology of the Hanford Site: A Standardized Text for Use in Westinghouse Hanford Company Documents and Reports. C. D. Delaney, K. A. Lindsey, and S. P. Reidel, Westinghouse Hanford Company, Richland, Washington.

WHC-SD-LEF-EV-001. 1996. Effluent Variability Study Results for the 200 Area Effluent Disposal Facility (W-049H). C. J. Chou and V. G. Johnson, Westinghouse Hanford Company, Richland, Washington.

WHC-SD-WM-TI-565, Rev. 1. 1993. Radionuclide and Chemical Inventories for the Single-Shell Tanks. R. J. Van Vleet, WASTREN, Inc. for Westinghouse Hanford Company, Richland, Washington.

Wilson, C. R., C. M. Einberger, R. L. Jackson, and R. B. Mercer. 1992. "Design of Ground-Water Monitoring Networks using the Monitoring Efficiency Model (MEMO)." Groundwater 30(6):965-970.

WMNW-CM-004. 1998. Operational Environmental Monitoring. Waste Management Federal Services, Northwest Operations, Inc., Richland, Washington. 
WMNW/TRS-ES-VZMA-002. 1998. Monitoring Results for the SX Single Shell Tank Farm Dry Well Gamma Ray Surveillance Log Surveys. R. R. Randall and R. K. Price, Waste Management Federal Services Inc., Northwest Operations, Richland, Washington. 


\section{Appendix A}

Supporting Information for Regulated Units 



\section{Contents}

A.1 References

\section{Tables}

A.1 Organizational Matrix for Regulated Units ................................................................... A.5

A.2 Monitoring Wells and Constituents for 100-N Area Units................................................ A.8

A.3 Monitoring Wells and Constituents for 120-D-1 Ponds .................................................... A.10

A.4 Monitoring Wells and Constituents for 183-H Solar Evaporation Basins .............................. A.12

A.5 Monitoring Wells and Constituents for 216-S-10 Pond and Ditch ........................................ A.14

A.6 Monitoring Wells and Constituents for 216-U-12 Crib..................................................... A.16

A.7 Monitoring Wells and Constituents for 216-B-3 Pond..................................................... A.18

A.8 Monitoring Wells and Constituents for 216-A-29 Ditch....................................................... A.20

A.9 Monitoring Wells and Constituents for PUREX Cribs .................................................... A.22

A.10 Monitoring Wells and Constituents for 216-B-63 Trench................................................ A.24

A.11 Monitoring Wells and Constituents for Liquid Effluent-Retention Facility ........................... A.26

A.12 Monitoring Wells and Constituents for Low-Level Waste Management Area 1 .................... A.28

A.13 Monitoring Wells and Constituents for Low-Level Waste Management Area 2 .................... A.30

A.14 Monitoring Wells and Constituents for Low-Level Waste Management Area 3 ..................... A.32

A.15 Monitoring Wells and Constituents for Low-Level Waste Management Area 4 .................... A. A.34

A.16 Monitoring Wells and Constituents for Waste Management Areas A-AX and C.................... A.36

A.17 Monitoring Wells and Constituents for Waste Management Area B-BX-BY ........................ A.. A

A.18 Monitoring Wells and Constituents for Waste Management Areas S-SX and U................... A.40

A.19a Monitoring Wells and Constituents for Waste Management Area T .................................... A.42 
A.19b Monitoring Wells and Constituents for Waste Management Area TX-TY ........................... A.43

A.20a Monitoring Wells and Constituents for Solid Waste Landfill ............................................ A.47

A.20b Monitoring Wells and Constituents for Nonradioactive Dangerous Waste Landfill ............... A.48

A.21 Monitoring Wells and Constituents for 316-5 Process Trenches ......................................... A.50

A.22 Tritium Tracking Network for State-Approved Land-Disposal Site.................................. A.52

A.23 Monitoring Wells and Constituents for 200 Areas Treated Effluent-Disposal Facility ........... A.54

A.24 Monitoring Wells and Constituents for 400 Area Process Ponds ....................................... A.56

A.25 RCRA Monitoring Results Exceeding Maximum Contaminant Levels ................................. A.60

A.26 Monitoring Wells and Constituents for Environmental Restoration Disposal Facility ............ A.72

\section{Figures}

A.1 Regulated Units on the Hanford Site Requiring Groundwater Monitoring........................... A.7

A.2 Monitoring Well Locations for 100-N Area..................................................................... A.9

A.3 Monitoring Well Locations for 120-D-1 Ponds ..................................................................... A.11

A.4 Monitoring Well Locations for 183-H Solar Evaporation Basins ....................................... A.13

A.5 Monitoring Well Locations for 216-S-10 Pond and Ditch ................................................... A.15

A.6 Monitoring Well Locations for 216-U-12 Crib ................................................................ A.17

A.7 Monitoring Well Locations for 216-B-3 Pond ......................................................................... A.19

A.8 Monitoring Well Locations for 216-A-29 Ditch ................................................................ A.21

A.9 Near-Field Monitoring Well Locations for PUREX Cribs................................................... A.23

A.10 Monitoring Well Locations for 216-B-63 Trench ............................................................ A.25

A.11 Monitoring Well Locations for Liquid Effluent-Retention Facility .................................... A.27

A.12 Monitoring Well Locations for Low-Level Waste Management Area 1 ............................... A.29

A.13 Monitoring Well Locations for Low-Level Waste Management Area 2 .............................. A.31

A.14 Monitoring Well Locations for Low-Level Waste Management Area 3 ............................... A.33 
A.15 Monitoring Well Locations for Low-Level Waste Management Area 4

A.16 Monitoring Well Locations for Waste Management Areas A-AX and C

A.17 Monitoring Well Locations for Waste Management Area B-BX-BY

A.18 Monitoring Well Locations for Waste Management Areas S-SX and U.

A.19 Monitoring Well Locations for Waste Management Areas T and TX-TY

A.20 Monitoring Well Locations for Solid Waste Landfill and Nonradioactive Dangerous Waste Landfill

A.21 Monitoring Well Locations for 316-5 Process Trenches.

A.22 Tritium Tracking Network for State-Approved Land-Disposal Site.

A.23 Monitoring Wells for 200 Areas Treated Effluent-Disposal Facility.

A.24 Monitoring Wells for 400 Area Process Ponds

A.25 Well Locations for 200-UP-1 Groundwater Operable Unit

A.26 Well Locations for 200-ZP-1 Groundwater Operable Unit 


\section{Appendix A}

\section{Supporting Information for Regulated Units}

\section{J. Hartman}

This appendix lists supplemental information for waste-disposal facilities on the Hanford Site requiring groundwater monitoring and regulated under the Washington Administrative Code (WAC). Most of these are Resource Conservation and Recovery Act of 1976 (RCRA) facilities (WAC 173-303), on which this appendix is focused. Three treated effluent-disposal facilities (WAC 173-216), one solid waste landfill (WAC 173-304), and two operable units (Comprehensive Environmental Response, Compensation, and Liability Act of 1980) are also included.

Figure A.1 shows the locations of the WAC-regulated units on the Hanford Site. Figures A.2 through A.24 show well locations for each facility. Table A.1 is a matrix showing where in this report more information on regulated units may be found. Tables A.2 through A.24 are well and constituent lists for each WAC-regulated facility. The tables include references to the current monitoring plans or assessment plans. Wells that are cosampled with other RCRA units or to meet the requirements of other regulations or U.S. Department of Energy (DOE) orders are noted in the "other networks" column. Wells sampled for DOE Order 5400.1 are designated "surveillance." Designations of "CERCLA" or operable unit number (e.g., 100-HR-3) denote monitoring under the Comprehensive Environmental Response, Compensation, and Liability Act of 1980. Well-location figures are interspersed with well lists in this appendix for the reader's convenience. Figures A.25 and A.26 show monitoring networks for assessing the performance of remedial actions in the 200-UP-1 and 200-ZP-1 groundwater operable units, respectively.

Table A.25 lists RCRA monitoring results for fiscal year 1998 that exceeded primary or secondary maximum contaminant levels or interim drinking water standards (see Table 5.1-1 in the main text for references to standards). Federal standards from 40 CFR 141 and 40 CFR 143 were applied for all constituents, except two organic constituents for which there are no federal maximum contaminant levels. For those constituents, bis(2-ethylhexyl)phthalate and 1,1-dichloroethane, the standards of WAC 173-200 were applied. The groundwater database was queried for all wells sampled for RCRA with results greater than each constituent's drinking water standard between October 1, 1997 and September 30, 1998. Results were excluded from this table if the analyte was undetected and the drinking water standard was smaller than the detection limit (i.e., result was flagged with a $U$ in the database). Results that are suspected to be erroneous are also excluded (results flagged with $F, Y$, or $R$ in the database).

This table may be used to determine where constituents are consistently greater than the drinking water standards, as reflected by a high number of exceedances and/or exceedances in multiple wells. Results of upgradient wells are included, reflecting possible upgradient sources of contaminants. Interpretation of the most significant contaminants for each RCRA unit are included in Chapter 5.0 of the main text.

Table A.26 lists the wells and constituents for the Environmental Restoration Disposal Facility. 


\section{A.1 References}

40 CFR 141, Code of Federal Regulations, Title 40, Part 141. National Primary Drinking Water Regulations.

40 CFR 143, Code of Federal Regulations, Title 40, Part 143. National Secondary Drinking Water Regulations.

BHI-00873. Description of Work for Routine Groundwater Sampling at the Environmental Restoration Disposal Facility. B. H. Ford, Bechtel Hanford, Inc., Richland, Washington.

Comprehensive Environmental Response, Compensation, and Liability Act of 1980, as amended, Public Law 96-510, 94 Stat. 2767, 42 USC 9601 et seq.

DOE Order 5400.1. General Environmental Protection Program. U.S. Department of Energy, Washington, D.C.

PNNL-11523. 1997. Combination RCRA Groundwater Monitoring Plan for the 216-A-10, 216-A-36B, and 216-A-37-1 PUREX Cribs. J. W. Lindberg, Pacific Northwest National Laboratory, Richland, Washington.

PNNL-11573. 1997. Groundwater Monitoring Plan for the 183-H Solar Evaporation Basins. M. J. Hartman, Pacific Northwest National Laboratory, Richland, Washington.

Resource Conservation and Recovery Act of 1976, as amended, Public Law 94-580, 90 Stat. 2795, 42 USC 6901 et seq.

WAC 173-200, Washington Administrative Code. Water Quality Standards for Ground Waters of the State of Washington. Olympia, Washington.

WAC 173-216, Washington Administrative Code. State Waste Discharge Program. Olympia, Washington.

WAC 173-303, Washington Administrative Code. Dangerous Waste Regulations. Olympia, Washington.

WAC 173-304, Washington Administrative Code. Minimum Functional Standards for Solid Waste Handling. Olympia, Washington.

WAC-173-304-490, Washington Administrative Code. Ground Water Monitoring Requirements. Olympia, Washington.

WHC-SD-C018H-PLN-004, Rev. 1. 1996. Ground-Water Screening Evaluation/Monitoring Plan200 Area Effluent Treatment Facility (Project C-018H). J. D. Davis, D. B. Barnett, C. J. Chou, and P. B. Freeman, Westinghouse Hanford Company, Richland, Washington. 
WHC-SD-EN-AP-012, Rev. 1. 1991. Interim-Status Groundwater Monitoring Plan for the Single-Shell Tanks. J. A. Caggiano and S. M. Goodwin, Westinghouse Hanford Company, Richland, Washington.

WHC-SD-EN-AP-013, Rev. 1. 1995. Interim Status Groundwater Monitoring Plan for the 216-B-3 Pond. Westinghouse Hanford Company, Richland, Washington.

WHC-SD-EN-AP-015. 1989. Revised Ground-Water Monitoring Plan for the 200 Areas Low-Level Burial Grounds. G. V. Last and B. N. Bjornstad, prepared by Pacific Northwest Laboratory for Westinghouse Hanford Company, Richland, Washington.

WHC-SD-EN-AP-018. 1990. Interim-Status Ground Water Monitoring Plan for the 216-S-10 Pond and Ditch. S. P. Airhart, J. V. Borghese, and S. Dudziak, prepared by Pacific Northwest Laboratory for Westinghouse Hanford Company, Richland, Washington.

WHC-SD-EN-AP-019. 1990. Interim-Status Ground-Water Monitoring Plan for the 216-U-12 Crib. E. J. Jensen, M. A. Chamness, S. M. Goodwin, S. H. Hall, and D. R. Newcomer, prepared by Pacific Northwest Laboratory for Westinghouse Hanford Company, Richland, Washington.

WHC-SD-EN-AP-024. 1990. Interim Status Groundwater Monitoring Plan for the 200 East Area Liquid Effluent Retention Facility. J. S. Schmid, Westinghouse Hanford Company, Richland, Washington.

WHC-SD-EN-AP-026. 1992. Interim Status Groundwater Monitoring Plan for the Nonradioactive Dangerous Waste Landfill, Hanford, Washington. F. N. Hodges, Westinghouse Hanford Company, Richland, Washington.

WHC-SD-EN-AP-038, Rev. 2. 1996. Groundwater Monitoring Plan for the 1301-N, 1325-N; and 1324-N/NA Sites. M. J. Hartman, Westinghouse Hanford Company, Richland, Washington.

WHC-SD-EN-AP-043. 1993. Groundwater Monitoring Plan for the Solid Waste Landfill, Hanford, Washington. F. N. Hodges, Westinghouse Hanford Company, Richland, Washington.

WHC-SD-EN-AP-045, Rev. 0-A. 1991. Groundwater Monitoring Plan for the 216-A-29 Ditch. G. L. Kasza and S. M. Goodwin, Westinghouse Hanford Company, Richland, Washington.

WHC-SD-EN-AP-048. 1991. Groundwater Monitoring Plan for the 100-D Ponds. M. J. Hartman, Westinghouse Hanford Company, Richland, Washington.

WHC-SD-EN-AP-103. 1993. Interim-Status Groundwater Quality Assessment Plan for the 216-U-12 Crib. B. A. Williams and C. J. Chou, Westinghouse Hanford Company, Richland, Washington.

WHC-SD-EN-AP-132. 1993. Interim-Status Groundwater Quality Assessment Plan for the Single-Shell Tank Waste Management Areas T and TX-TY. J. A. Caggiano and C. J. Chou, Westinghouse Hanford Company, Richland, Washington.

WHC-SD-EN-AP-165. 1995. Interim Status Groundwater Monitoring Plan for the 216-B-63 Trench. M. D. Sweeney, Westinghouse Hanford Company, Richland, Washington. 
WHC-SD-EN-AP-185. 1995. Groundwater Monitoring Plan for the 300 Area Process Trenches.

J. W. Lindberg, C. J. Chou, and V. G. Johnson, Westinghouse Hanford Company, Richland, Washington.

WHC-SD-EN-AP-191. 1996. Assessment Groundwater Monitoring Plan for Single-Shell Tank Waste Management Area S-SX. J. A. Caggiano, Westinghouse Hanford Company, Richland, Washington.

WHC-SD-EN-WP-012, Rev. 1. 1995. Groundwater Screening Evaluation/Monitoring Plan -- 200 Area Treated Effluent Disposal Facility (Project W-049H). D. B. Barnett, J. D. Davis, L. B. Collard, P. B. Freeman, and C. J. Chou, Westinghouse Hanford Company, Richland, Washington.

WHC-SD-ENV-AP-002. 1996. Assessment Groundwater Monitoring Plan for SST Waste Management Area $B-B X-B Y$. J. A. Caggiano, Westinghouse Hanford Company, Richland, Washington. 


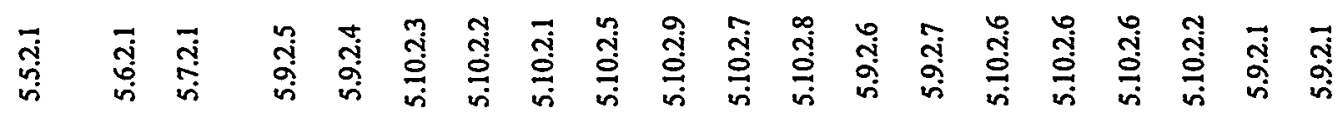

$\stackrel{0}{2}$

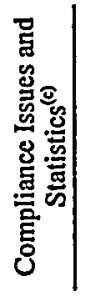

in is $i$

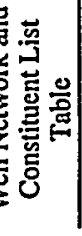

謤总|

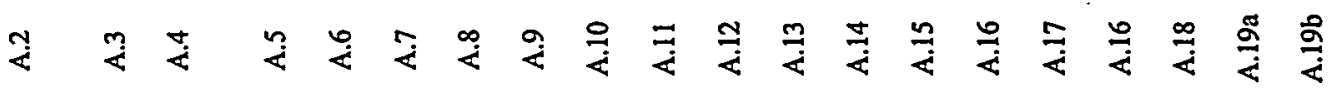

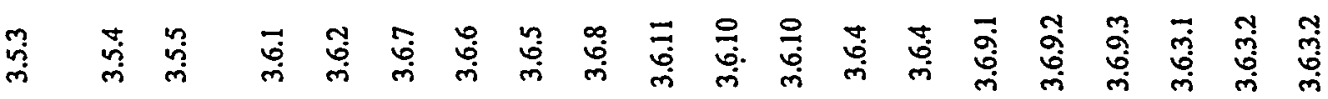

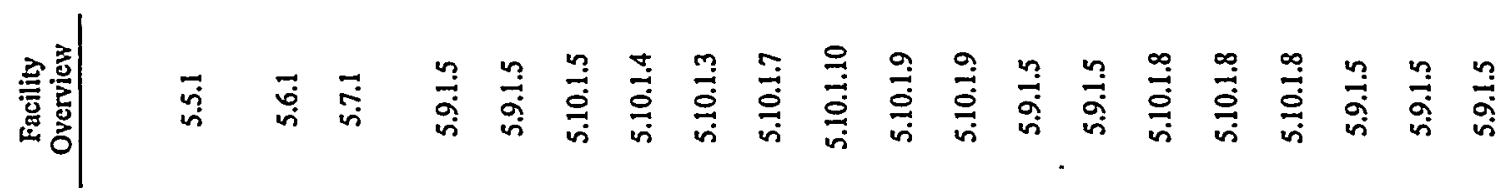
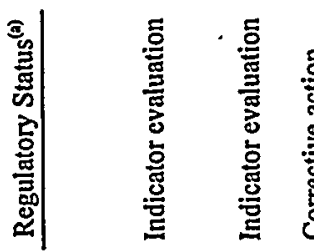

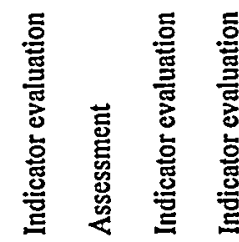

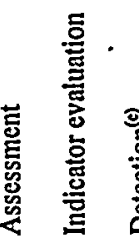

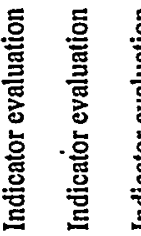
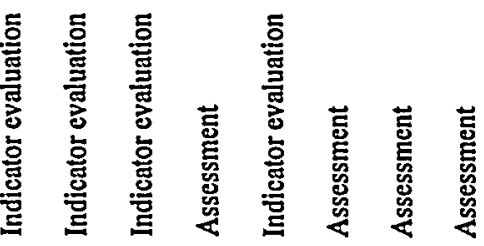

| 


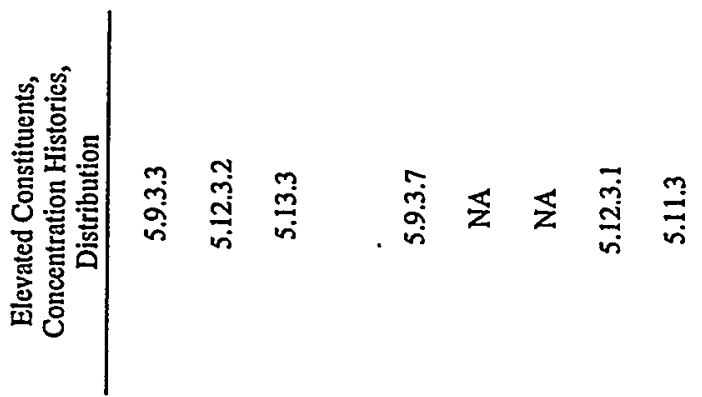

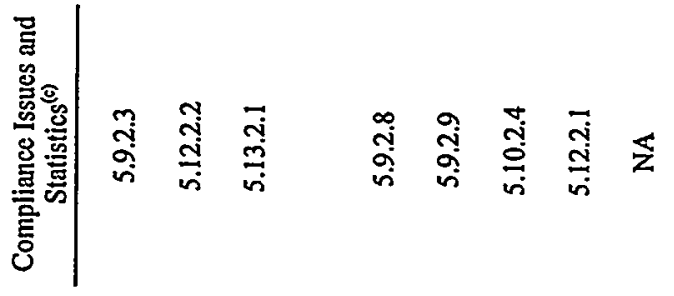

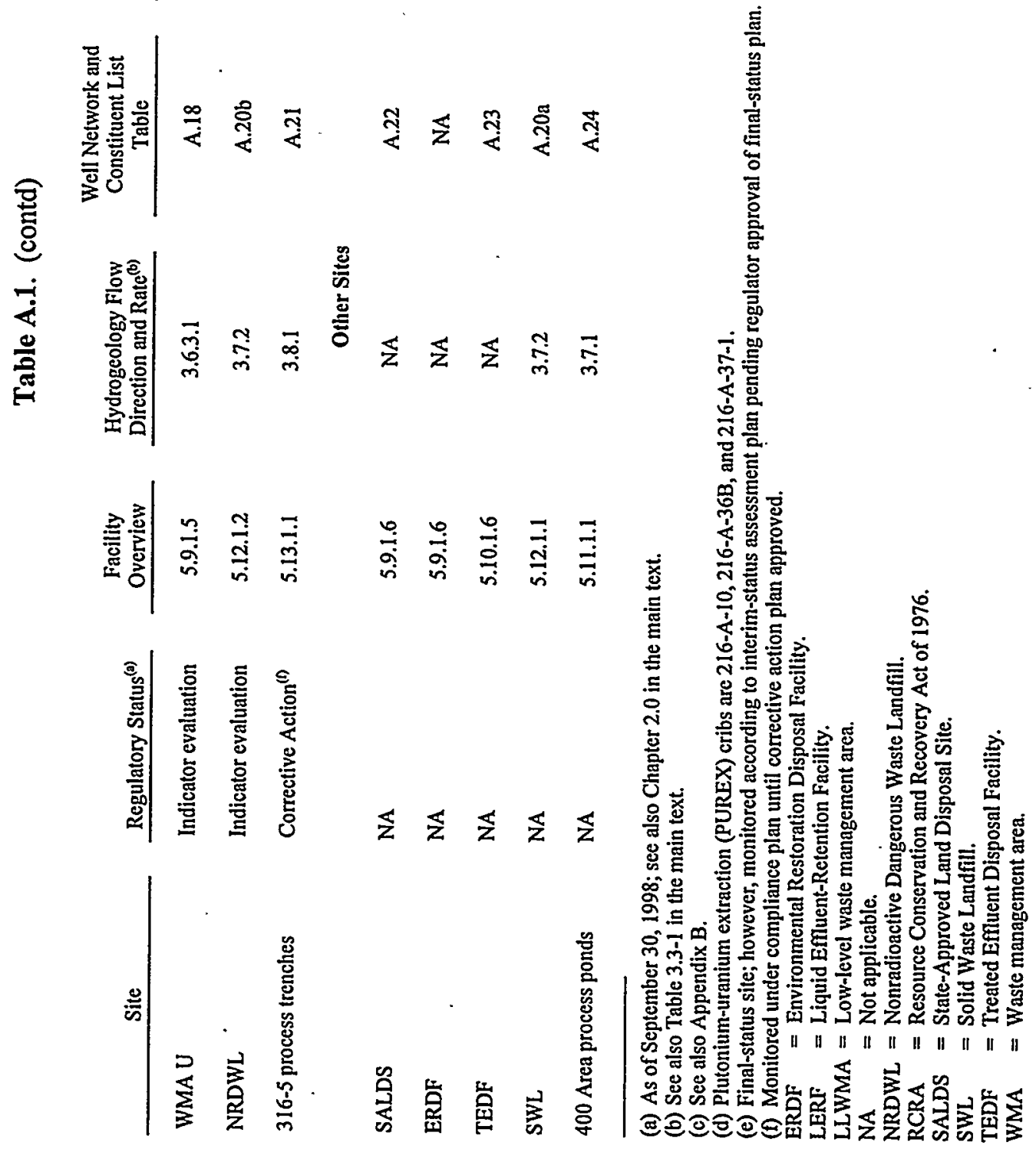




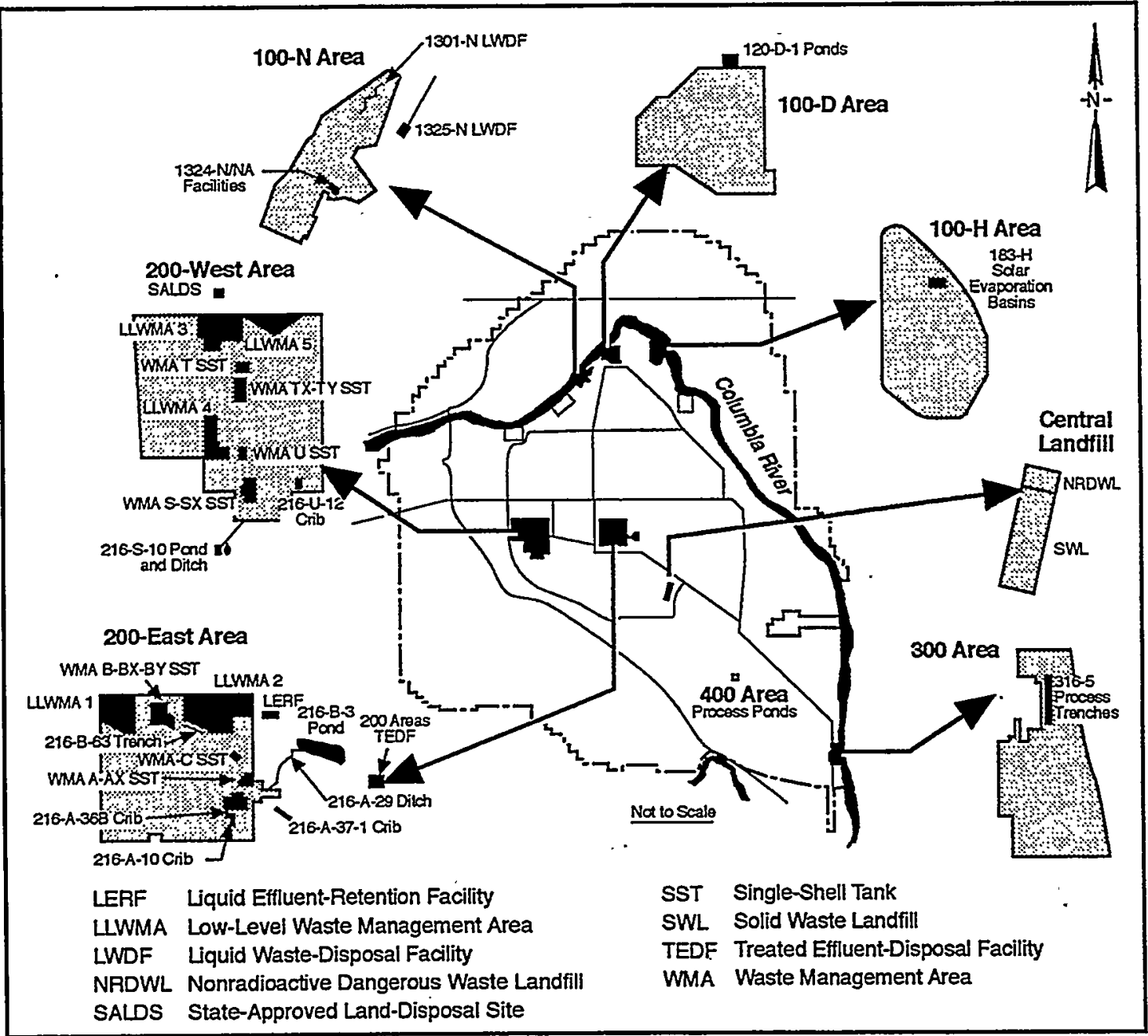

RG98120214.13

Figure A.1. Regulated Units on the Hanford Site Requiring Groundwater Monitoring 
Table A.2. Monitoring Wells and Constituents for 100-N Area Units (adapted from WHC-SD-EN-AP-038, Rev. 2)

\begin{tabular}{|c|c|c|c|c|c|}
\hline Well & $\begin{array}{c}\text { Hydrogeologic Unit } \\
\text { Monitored }\end{array}$ & $\begin{array}{l}\text { Sampling } \\
\text { Frequency }\end{array}$ & $\begin{array}{l}\text { Water-Level } \\
\text { Measurement }\end{array}$ & $\begin{array}{c}\text { Well } \\
\text { Standard }\end{array}$ & Other Networks \\
\hline \multicolumn{6}{|c|}{ 1301-N Liquid Waste-Disposal Facility } \\
\hline $199-\mathrm{N}-2^{64}$ & Top of unconfined & Semiannual & Semiannual & PRE & 100-NR-2, ERA \\
\hline $199-N-3^{64}$ & Top of unconfined & Semiannual & Semiannual & PRE & $\begin{array}{c}\text { 100-NR-2, ERA, } \\
\text { Surveillance }\end{array}$ \\
\hline $199-N-34^{83}$ & Top of unconfined & Semiannual & Semiannual & PRE & Surveillance \\
\hline $199-\mathrm{N}-57^{87}$ & Top of unconfined & Semiannual & Semiannual & RCRA & Surveillance \\
\hline $199-N-105 A^{95}$ & Unconfined & Semiannual & - & $\operatorname{RCRA}^{(a)}$ & ERA \\
\hline \multicolumn{6}{|c|}{ 1324-N/NA Liquid Waste-Disposal Facilities } \\
\hline $199-\mathrm{N}-59^{87}$ & Top of unconfined & Semiannual & Semiannual & RCRA & - \\
\hline $199-\mathrm{N}-71^{91}$ & Top of unconfined & Semiannual & Semiannual & RCRA & Surveillance \\
\hline $199-\mathrm{N}-72^{91}$ & Top of unconfined & Semiannual & Semiannual & RCRA & -- \\
\hline $199-\mathrm{N}-73^{91}$ & Top of unconfined & Semiannual & Semiannual & RCRA & - \\
\hline $199-\mathrm{N}-77^{92}$ & Bottom of unconfined & Semiannual & Semiannual & RCRA & - \\
\hline \multicolumn{6}{|c|}{ 1325-N Liquid Waste-Disposal Facility } \\
\hline $199-N-28^{83(b)}$ & Top of unconfined & Semiannual & Semiannual & . PRE & Surveillance \\
\hline $199-N-32^{83}$ & Top of unconfined & Semiannual & Semiannual & PRE & $100-N R-2$ \\
\hline $199-\mathrm{N}-41^{84}$ & Top of unconfined & Semiannual & Semiannual & PRE & Surveillance \\
\hline $199-\mathrm{N}=74^{91}$ & Top of unconfined & Semiannual & Semiannual & RCRA & $100-N R-2$ \\
\hline $199-\mathrm{N}-81^{93}$ & Top of unconfined & Semiannual & Semiannual & RCRA & $\begin{array}{l}\text { 100-NR-2, } \\
\text { Surveillance }\end{array}$ \\
\hline \multicolumn{2}{|c|}{ Contamination Indicator Parameters } & & \multicolumn{3}{|c|}{ Site-Specific Parameters } \\
\hline $\mathrm{pH}$ (field) & & & Alkalinity & \multicolumn{2}{|c|}{ ICP metals (filtered) } \\
\hline Specific condu & (field) & & Anions & \multicolumn{2}{|c|}{ Turbidity } \\
\hline
\end{tabular}

Total organic carbon

Total organic halides

(a) Extraction well; screened over entire thickness of aquifer.

(b) Used for supplemental information; no statistical evaluations.

Shading = Upgradient well.

Superscript $=$ Year of installation.

ERA $\quad=$ Expedited response action.

PRE = Well not constructed to RCRA standards.

RCRA = Well constructed to RCRA standards. 


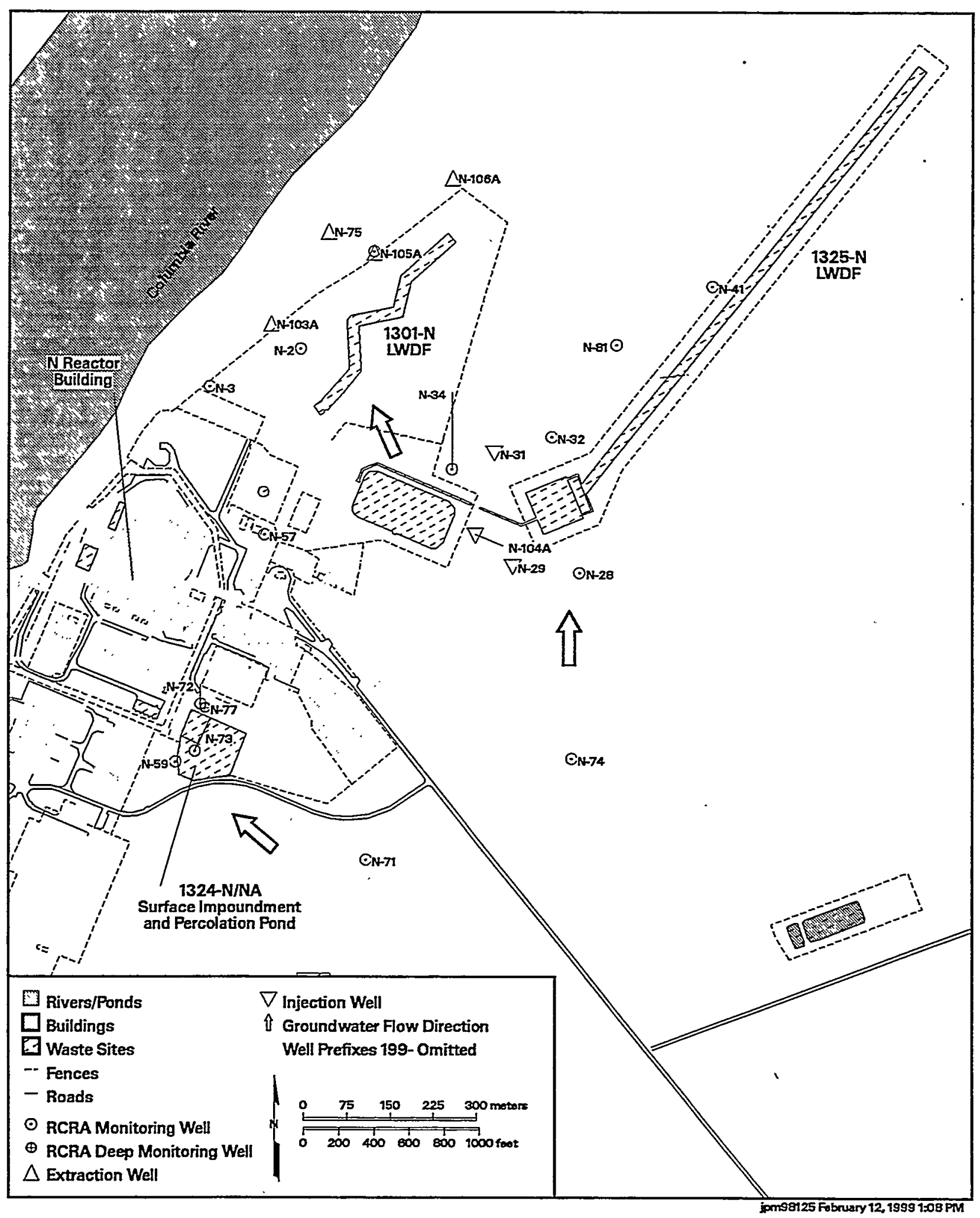

Figure A.2. Monitoring Well Locations for $100-\mathrm{N}$ Area 
Table A.3. Monitoring Wells and Constituents for 120-D-1 Ponds

(adapted from WHC-SD-EN-AP-048)

\begin{tabular}{|c|c|c|c|c|c|}
\hline Well & $\begin{array}{l}\text { Hydrogeologic Unit } \\
\text { Monitored } \\
\end{array}$ & $\begin{array}{l}\text { Sampling } \\
\text { Frequency }\end{array}$ & $\begin{array}{l}\text { Water-Level } \\
\text { Measurement }\end{array}$ & $\begin{array}{c}\text { Well } \\
\text { Standard }\end{array}$ & $\begin{array}{c}\text { Other } \\
\text { Network }\end{array}$ \\
\hline $199-D 5-13^{91}$ & Top of unconfined & Semiannual & Semiannual & RCRA & $100-\mathrm{HR}-3$ \\
\hline $199-\mathrm{D} 8-4^{91}$ & Top of unconfined & Semiannual & Semiannual & RCRA & $100-\mathrm{HR}-3$ \\
\hline $199-D 8-5^{91}$ & Top of unconfined & Semiannual & Semiannual & RCRA & 100-HR-3 \\
\hline $199-\mathrm{D} 8-6^{91}$ & Top of unconfined & Semiannual & Semiannual & RCRA & $100-\mathrm{HR}-3$ \\
\hline
\end{tabular}

Contamination Indicator Parameters

Site-Specific Parameters

$\mathrm{pH}$ (field)

Specific conductance (field)

Total organic carbon

Total organic halides

\begin{tabular}{ll}
\multicolumn{2}{c}{ Site-Specific Parameters } \\
\hline Alkalinity & ICP metals (filtered) \\
Anions & Mercury (filtered) \\
Gross alpha & Tritium \\
Gross beta & Turbidity (field)
\end{tabular}

Shading = Upgradient well.

Superscript $=$ Year of installation.

RCRA = Well constructed to RCRA standards. 


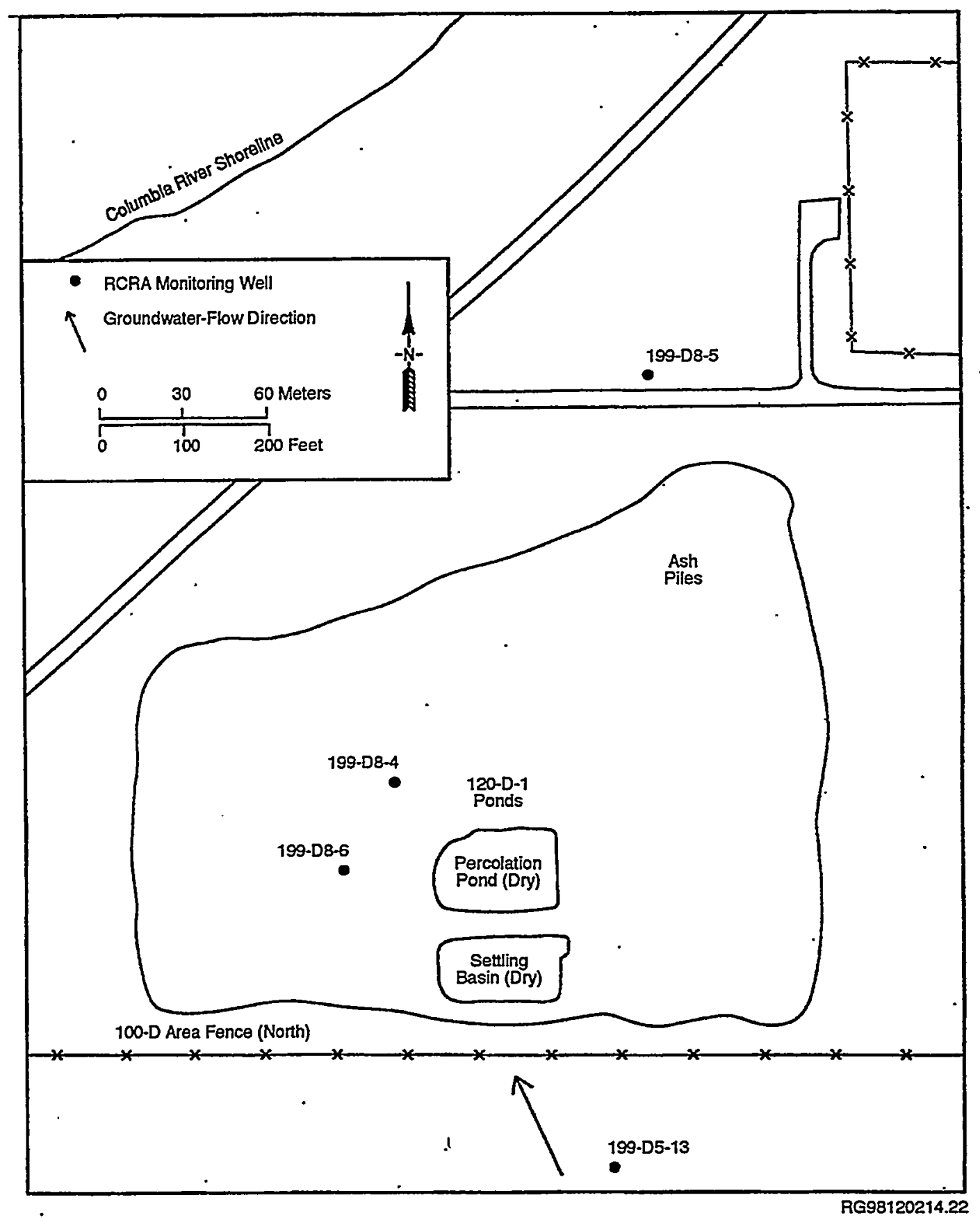

Figure A.3. Monitoring Well Locations for 120-D-1 Ponds 
Table A.4. Monitoring Wells and Constituents for 183-H Solar Evaporation Basins (adapted from PNNL-11573)

\begin{tabular}{|c|c|}
\hline Well & $\begin{array}{l}\text { Hydrogeologic Unit } \\
\text { Monitored }\end{array}$ \\
\hline $199-\mathrm{H}_{4}-3^{74}$ & Top of unconfined \\
\hline $199-\mathrm{H} 4-7^{86(2)}$ & Top of unconfined \\
\hline $199-H 4-12 A^{86(a)}$ & Top of unconfined \\
\hline $199-H 4-12 C^{86}$ & Mid-depth unconfined \\
\hline \multicolumn{2}{|c|}{ Dangerous Constituents } \\
\hline
\end{tabular}

Chromium (filtered)

Nitrate

Fluoride

\begin{tabular}{|c|c|c|c|}
\hline $\begin{array}{l}\text { Sampling } \\
\text { Frequency }\end{array}$ & $\begin{array}{l}\text { Water-Level } \\
\text { Measurement }\end{array}$ & $\begin{array}{c}\text { Well } \\
\text { Standard }\end{array}$ & Other Networks \\
\hline Annual & Semiannual & PRE & IRA \\
\hline Annual & Semiannual & $\mathrm{RCRA}$ & IRA \\
\hline Annual & Semiannual & RCRA & IRA \\
\hline Annual & Semiannual & RCRA & IRA \\
\hline
\end{tabular}

Site-Specific Parameters

Technetium-99

Uranium

(a) Former extraction well.

Superscript $=$ Year of installation.

IRA $\quad=$ Interim response action.

PRE = Well not constructed to RCRA standards.

RCRA = Well constructed to RCRA standards.

Alkalinity

Anions

ICP metals (filtered)
$\mathrm{pH}$

Specific conductance

Turbidity 


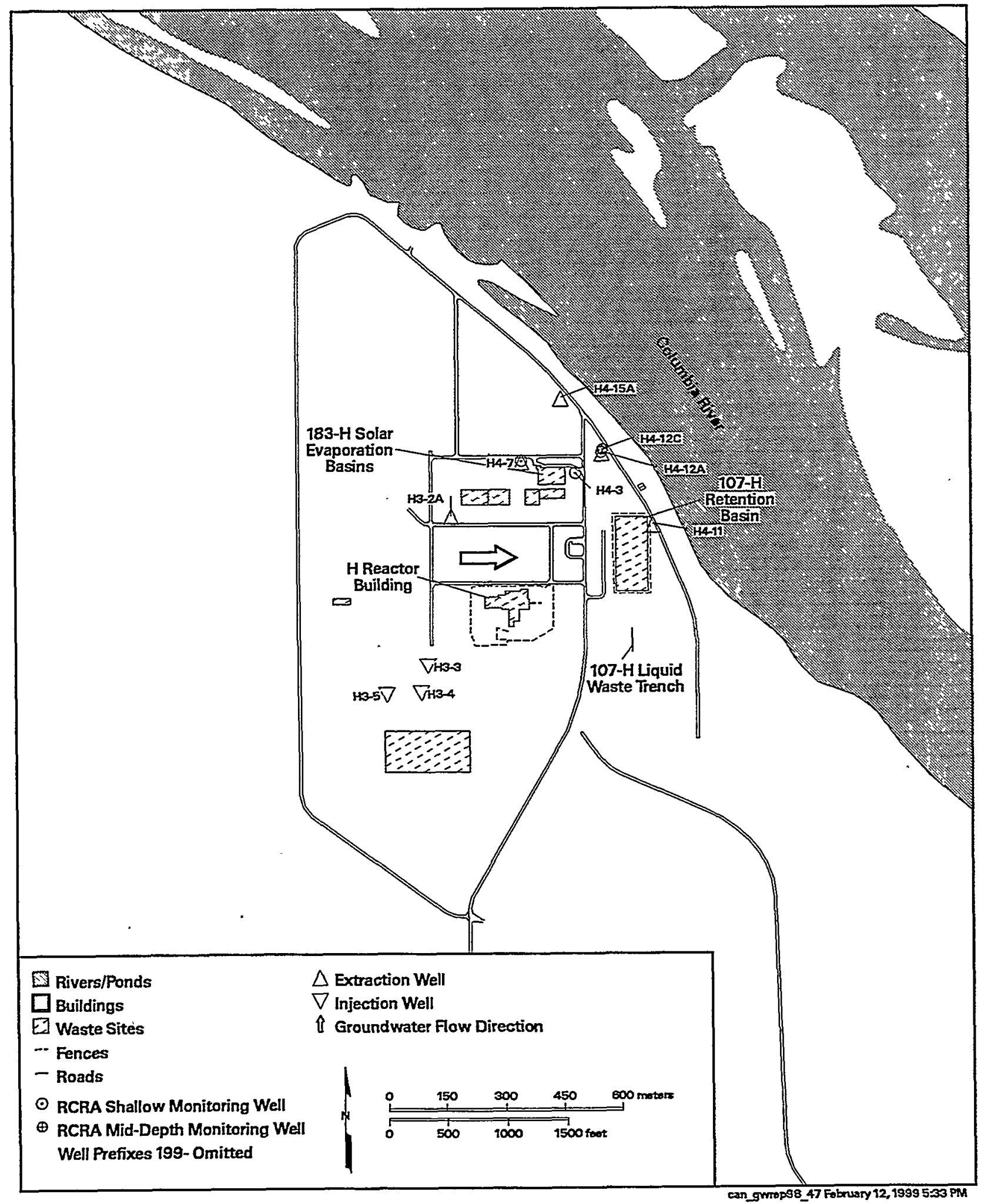

Figure A.4. Monitoring Well Locations for 183-H Solar Evaporation Basins 
Table A.5. Monitoring Wells and Constituents for 216-S-10 Pond and Ditch (adapted from WHC-SD-EN-AP-018)

\begin{tabular}{|c|c|c|c|c|c|}
\hline Well & $\begin{array}{l}\text { Hydrogeologic Unit } \\
\text { Monitored } \\
\end{array}$ & $\begin{array}{c}\text { Sampling } \\
\text { Frequencies }\end{array}$ & $\begin{array}{l}\text { Water-Level } \\
\text { Measurements }\end{array}$ & $\begin{array}{c}\text { Well } \\
\text { Standard }\end{array}$ & Other Network \\
\hline $299-\mathrm{W} 26-7^{91}$ & Top of unconfined & Quarterly $^{(a)}$ & Quarterly & RCRA & Surveillance \\
\hline $299-W 26-8^{90}$ & Top of unconfined & Dry ${ }^{(b)}$ & - & RCRA & Surveillance \\
\hline $299-W 26-9^{90}$ & Top of unconfined & Semiannual & Semiannual & RCRA & - \\
\hline $299-W 26-10^{91}$ & Top of unconfined & Semiannual & Semiannual & RCRA & Surveillance \\
\hline 299-W26-12 & Top of unconfined & Semiannual & Semiannual & RCRA & - \\
\hline $299-W 27-2^{92}$ & Base of unconfined & Semiannual & Semiannual & RCRA & Surveillance \\
\hline \multicolumn{2}{|c|}{ Contamination Indicator Parameters } & & \multicolumn{3}{|c|}{ Site-Specific Parameters } \\
\hline \multicolumn{2}{|l|}{$\mathrm{pH}$} & & Alkalinity & \multicolumn{2}{|c|}{ ICP metals (filtered) } \\
\hline \multicolumn{2}{|c|}{ Specific conductance } & & Anions & \multicolumn{2}{|c|}{ Phenols } \\
\hline \multicolumn{2}{|c|}{ Total organic carbon } & & Gross alpha & \multicolumn{2}{|c|}{ Turbidity } \\
\hline \multicolumn{2}{|c|}{ Total organic halides } & & Gross beta & & \\
\hline
\end{tabular}

(a) Upgradient wells sampled in December 1997 and March, June, and September 1998 for total organic halides.

(b) Well dry; last sampled March 1998.

Shading = Upgradient well.

Superscript $=$ Year of installation.

RCRA = Well constructed to RCRA standards. 


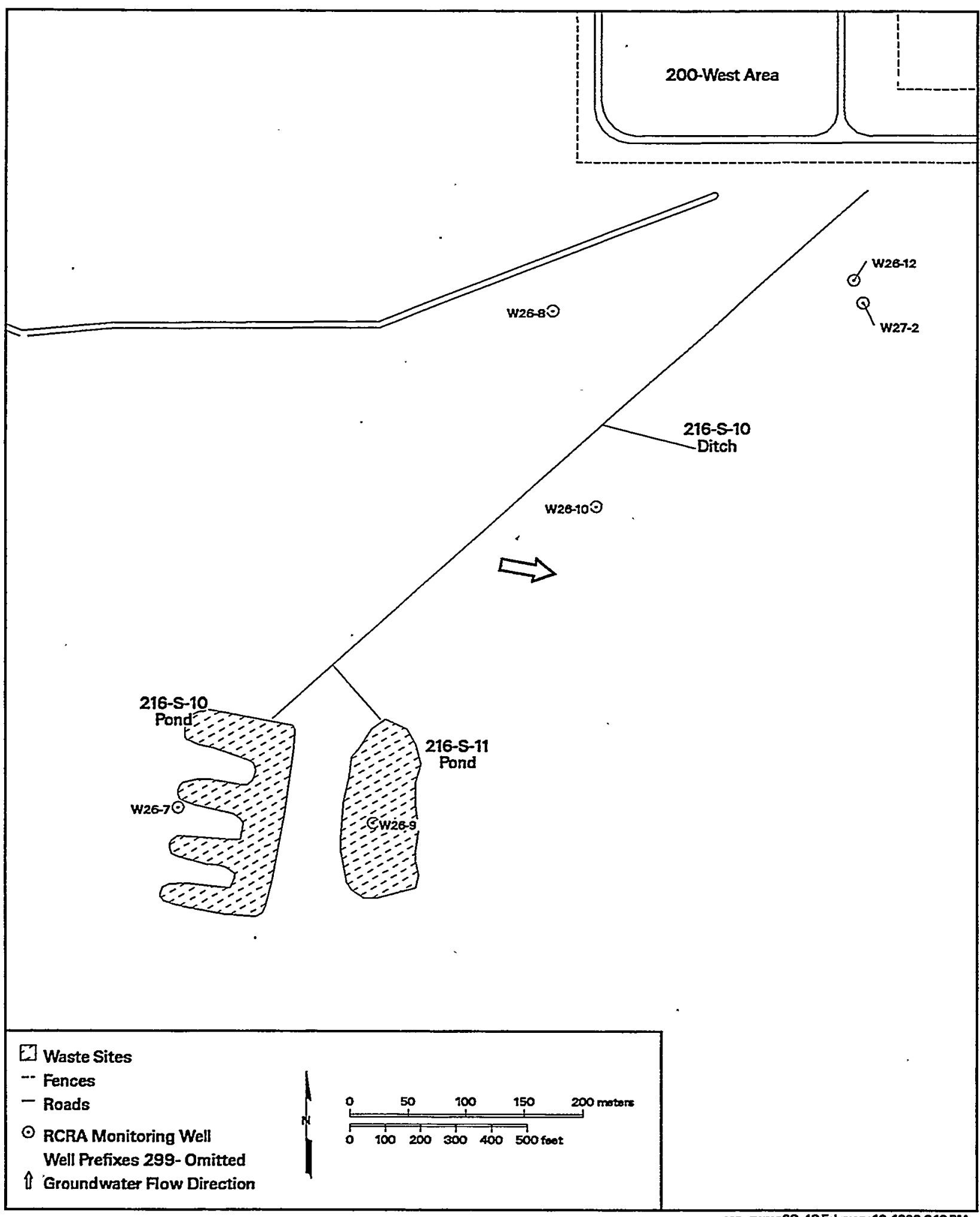

can_gwrop98_48 Fobruary 12, 1999 E.13 PM

Figure A.5. Monitoring Well Locations for 216-S-10 Pond and Ditch 
Table A.6. Monitoring Wells and Constituents for 216-U-12 Crib (adapted from WHC-SD-EN-AP-019 and WHC-SD-EN-AP-103)

\begin{tabular}{|c|c|c|c|c|c|}
\hline Well & $\begin{array}{c}\text { Hydrogeologic Unit } \\
\text { Monitored } \\
\end{array}$ & $\begin{array}{l}\text { Sampling } \\
\text { Frequency }\end{array}$ & $\begin{array}{l}\text { Water-Level } \\
\text { Measurement }\end{array}$ & $\begin{array}{c}\text { Well } \\
\text { Standard } \\
\end{array}$ & Other Networks \\
\hline $299-\mathrm{W} 22-40^{90}$ & Top of unconfined & Quarterly & Quarterly & RCRA & Surveillance \\
\hline $299-W 22-41^{90}$ & Top of unconfined & Quarterly & Quarterly & RCRA & - \\
\hline $299-W 22-42^{90}$ & Top of unconfined & Quarterly & Quarterly & RCRA & Surveillance \\
\hline $299-W 22-43^{90}$ & Top of unconfined & Quarterly & Quarterly & RCRA & - \\
\hline $699-36-70 A^{94}$ & Top of unconfined & Quarterly & Quarterly & RCRA & $\begin{array}{l}\text { ERDF, } \\
\text { Surveillance }\end{array}$ \\
\hline
\end{tabular}

Contamination Indicator Parameters .

$\mathrm{pH}$

Specific conductance

Total organic carbon

Total organic halides
Site-Specific Parameters

$\begin{array}{ll}\text { Alkalinity(a) } & \text { Iodine-129 } \\ \text { Anions } & \text { Technetium-99 } \\ \text { Gross alpha } & \text { Total dissolved solids } \\ \text { Gross beta } & \text { Tritium } \\ \text { ICP metals (filtered) } & \text { Turbidity }\end{array}$

(a) Analyzed annually.

Shading = Upgradient well.

Superscript $=$ Year of installation.

ERDF = Environmental Restoration Disposal Facility.

RCRA = Well constructed to RCRA standards. 
- 299-W19-7

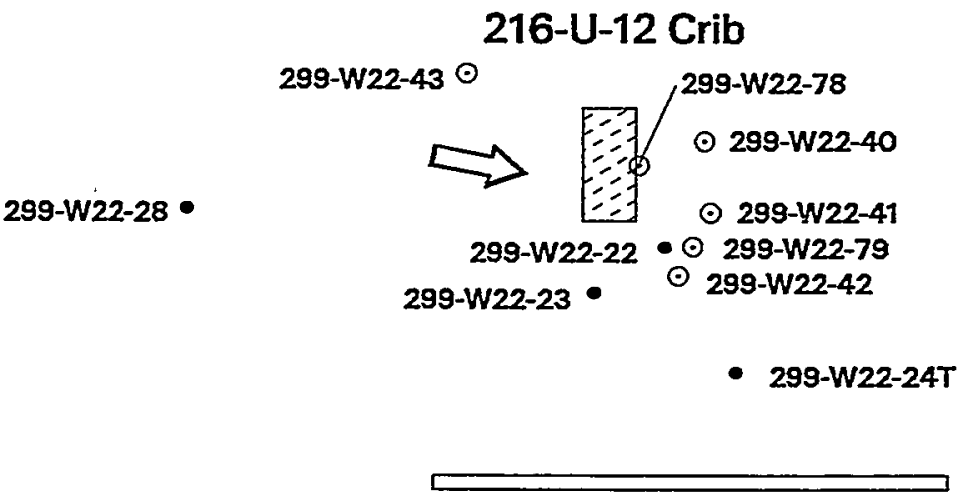

- 299-W22-6

299-W22-7 -

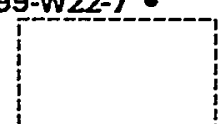

Waste Sites

-- Fences

- Roads

- RCRA Monitoring Well

- Other Monitoring Well

1) Groundwater Flow Direction See Plate 1 for Well 699-36-70A

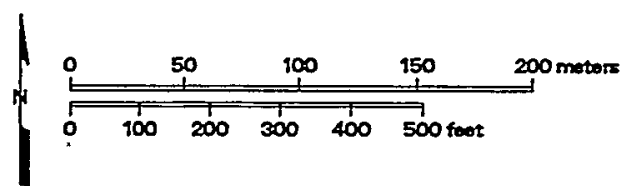

216-U-8 Crib

$E==7$

299-W19-2

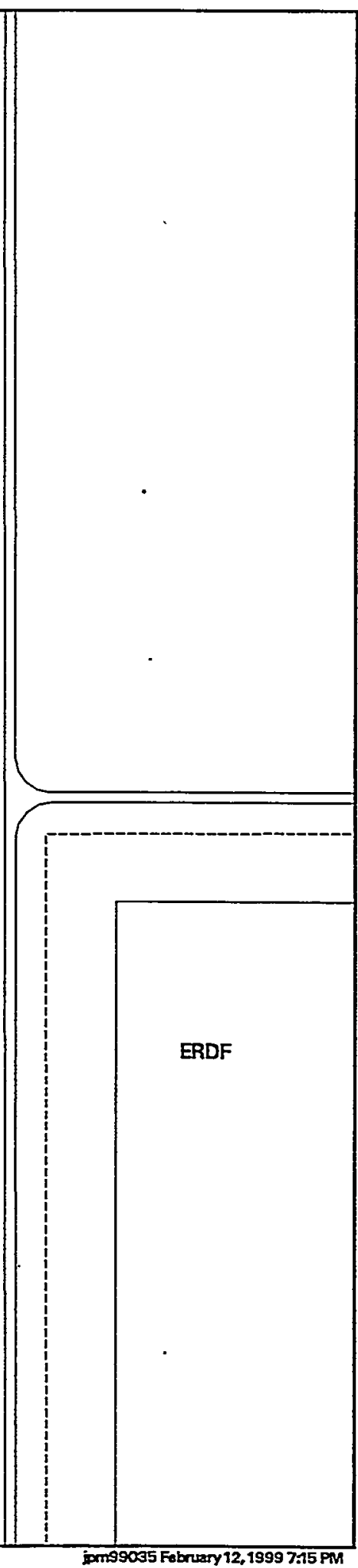

Figure A.6. Monitoring Well Locations for 216-U-12 Crib 
Table A.7. Monitoring Wells and Constituents for 216-B-3 Pond (adapted from WHC-SD-EN-AP-013, Rev. 1)

\begin{tabular}{|c|c|c|c|c|c|}
\hline Well & $\begin{array}{l}\text { Hydrogeologic Unit } \\
\text { Monitored }\end{array}$ & $\begin{array}{l}\text { Sampling } \\
\text { Frequency }\end{array}$ & $\begin{array}{l}\text { Water-Level } \\
\text { Measurement }\end{array}$ & $\begin{array}{c}\text { Well } \\
\text { Standard }\end{array}$ & Other Networks \\
\hline 299-E26-11 ${ }^{89}$ & Bottom of uppermost & Semiannual & Quarterly & RCRA & $\begin{array}{c}\text { LERF, } \\
\text { Surveillance }\end{array}$ \\
\hline $299-\mathrm{E} 32-4^{87}$ & Top of uppermost & Quarterly & Quarterly & RCRA & $\begin{array}{l}\text { LLWMA 1, } \\
\text { Surveillance }\end{array}$ \\
\hline $699-40-36^{92}$ & Top of uppermost & Quarterly & Quarterly & RCRA & TEDF \\
\hline $699-40-40 A^{91}$ & Lower uppermost & Quarterly & Quarterly & $\mathrm{RCRA}$ & - \\
\hline $699-41-40^{89}$ & Top of uppermost & Quarterly & Quarterly & $\mathrm{RCRA}$ & -- \\
\hline $699-41-42^{92}$ & Top of uppermost & Quarterly & Quarterly & $\mathrm{RCRA}$ & - \\
\hline $699-42-39 \mathrm{~B}^{91}$ & Lower uppermost & Quarterly & Quarterly & $\mathrm{RCRA}$ & - \\
\hline $699-42-37^{92}$ & Top of uppermost & Quarterly & Quarterly & RCRA & TEDF \\
\hline $699-42-41^{91}$ & Top of uppermost & Quarterly & Quarterly & RCRA & - \\
\hline $699-42-42 B^{88}$ & Top of uppermost & Quarterly & Quarterly & RCRA & -- \\
\hline $699-43-40^{91}$ & Top of uppermost & Quarterly & Quarterly & RCRA & - \\
\hline $699-43-41 E^{89}$ & Top of uppermost & Quarterly & Quarterly & RCRA & - \\
\hline $699-43-41 G^{91}$ & Top of uppermost & Quarterly & Quarterly & RCRA & - \\
\hline $699-43-43^{88}$ & Top of uppermost & Semiannual & Semiannual & RCRA & $\begin{array}{l}\text { 216-A-29 ditch, } \\
\text { Surveillance }\end{array}$ \\
\hline $699-43-45^{89}$ & Top of uppermost. & Quarteriy & Quarteriy & $\mathrm{RCRA}$ & $\begin{array}{l}\text { 216-A-29 ditch, } \\
\text { Surveillance }\end{array}$ \\
\hline $699-44-39 B^{92}$ & Top of uppermost & Quarterly & Quarterly & RCRA & - \\
\hline $699-44-43 B^{89}$ & Top of uppermost & Quarterly & Quarterly & RCRA & - \\
\hline \multicolumn{2}{|c|}{ Contamination Indicator Parameters } & & \multicolumn{3}{|c|}{ Site-Specific Parameters } \\
\hline \multicolumn{2}{|c|}{$\mathrm{pH}$} & & Alkalinity & \multicolumn{2}{|c|}{ Gross beta } \\
\hline \multicolumn{2}{|c|}{ Specific conductance } & & Anions & \multicolumn{2}{|c|}{ Turbidity } \\
\hline \multicolumn{3}{|c|}{ Total organic carbon } & Gross alpha & & \\
\hline
\end{tabular}

Total organic halides

Note: Not all wells were sampled during each sampling event during fiscal year 1998.

Shading = Upgradient wells.

Superscript $=$ Year of installation.

LERF $\quad=$ Liquid Effluent-Retention Facility.

LLWMA = Low-level waste management area.

RCRA = Well constructed to RCRA standards.

TEDF $\quad=200$ Areas Treated Effluent-Disposal Facility. 


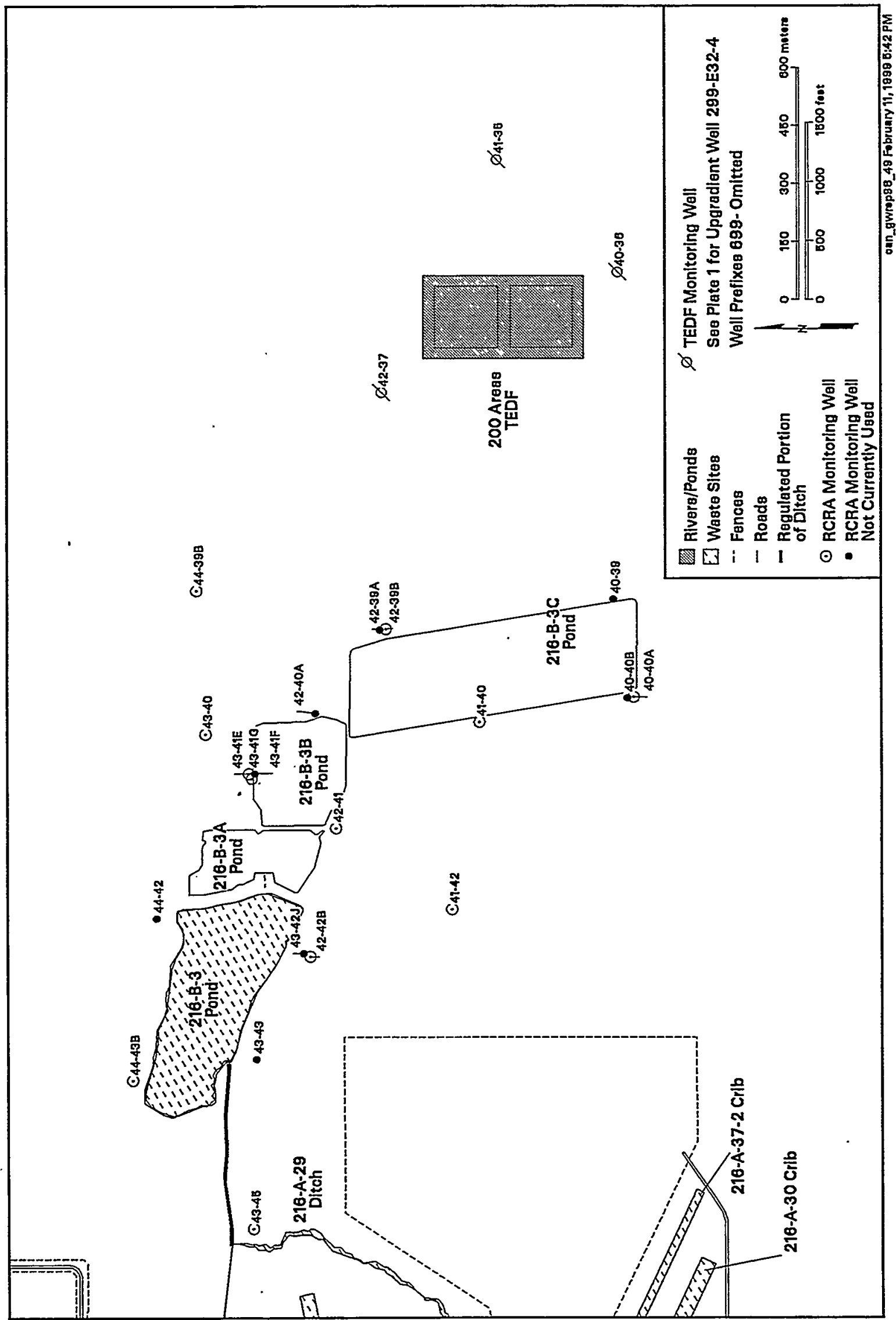

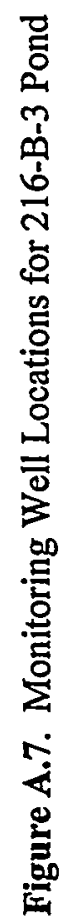


Table A.8. Monitoring Wells and Constituents for 216-A-29 Ditch (adapted from WHC-SD-EN-AP-045, Rev. 0-A)

\begin{tabular}{|c|c|c|c|c|c|}
\hline Well & $\begin{array}{c}\text { Hydrogeologic Unit } \\
\text { Monitored }\end{array}$ & $\begin{array}{l}\text { Sampling } \\
\text { Frequency } \\
\end{array}$ & $\begin{array}{l}\text { Water-Level } \\
\text { Measurement }\end{array}$ & $\begin{array}{c}\text { Well } \\
\text { Standard }\end{array}$ & $\begin{array}{c}\text { Other } \\
\text { Networks } \\
\end{array}$ \\
\hline $299-E 25-26^{85}$ & Upper unconfined & Semiannual & Quarterly & RCRA & - \\
\hline $299-E 25-28^{86}$ & Deep unconfined & Semiannual & Quarterly & RCRA & Surveillance \\
\hline 299-E25-32P ${ }^{88}$ & Top of unconfined & Semiannual & Quarterly & RCRA & - \\
\hline $299-E 25-34^{88}$ & Top of unconfined & Semiannual & Quarterly & RCRA & Surveillance \\
\hline $299-E 25-35^{88}$ & Top of unconfined & Semiannual & Quarterly & RCRA & - \\
\hline $299-E 25-48^{92}$ & Top of unconfined & Semiannual & Quarterly & RCRA & - \\
\hline $299-E 26-12^{91}$ & Top of unconfined & Semiannual & Quarterly & RCRA & - \\
\hline $299-\mathrm{E} 26-13^{91}$ & Top of unconfined & Semiannual & Quarterly & RCRA & - \\
\hline $699-43-43^{88}$ & Top of unconfined & Semiarnual & Quarterly & RCRA & $\begin{array}{l}\text { 216-B-3 pond, } \\
\text { Surveillance }\end{array}$ \\
\hline $699-43-45^{89}$ & Top of unconfined & Semiannual & Quarterly & RCRA & $\begin{array}{l}\text { 216-B-3 pond, } \\
\text { Surveillance }\end{array}$ \\
\hline
\end{tabular}

Contamination Indicator Parameters

$\begin{array}{ll}\mathrm{pH} & \text { Total organic carbon } \\ \text { Specific conductance } & \text { Total organic halides }\end{array}$

Shading $=$ Upgradient wells.

Superscript $=$ Year of installation.

RCRA = Well constructed to RCRA standards.
Site-Specific Parameters

$\begin{array}{ll}\text { Alkalinity } & \text { ICP metals (filtered) } \\ \text { Anions } & \text { Turbidity }\end{array}$




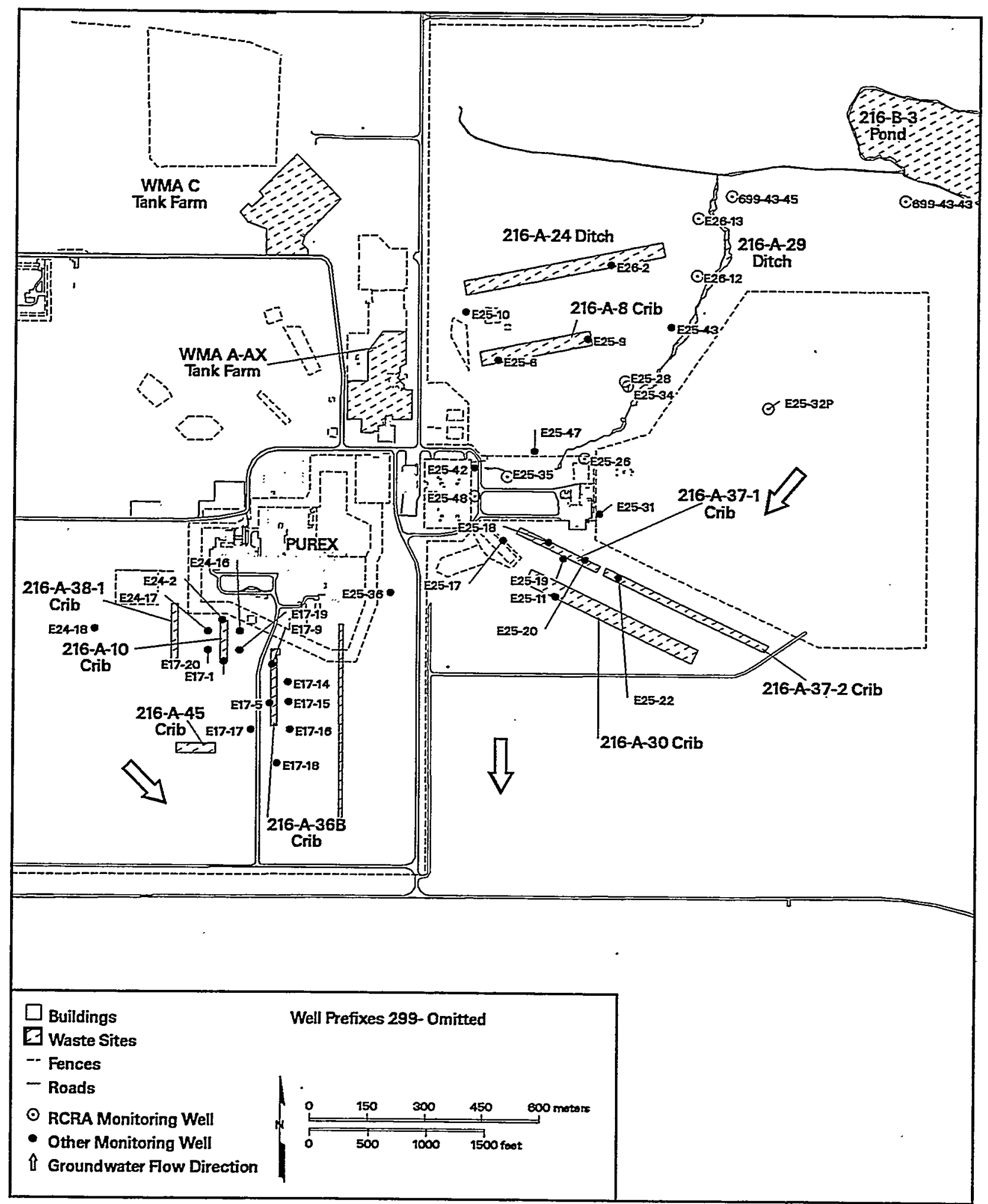

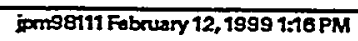

Figure A.8. Monitoring Well Locations for 216-A-29 Ditch 
Table A.9. Monitoring Wells and Constituents for PUREX Cribs (216-A-10, 216-A-36B, and 216-A-37-1) (adapted from PNNL-11523)

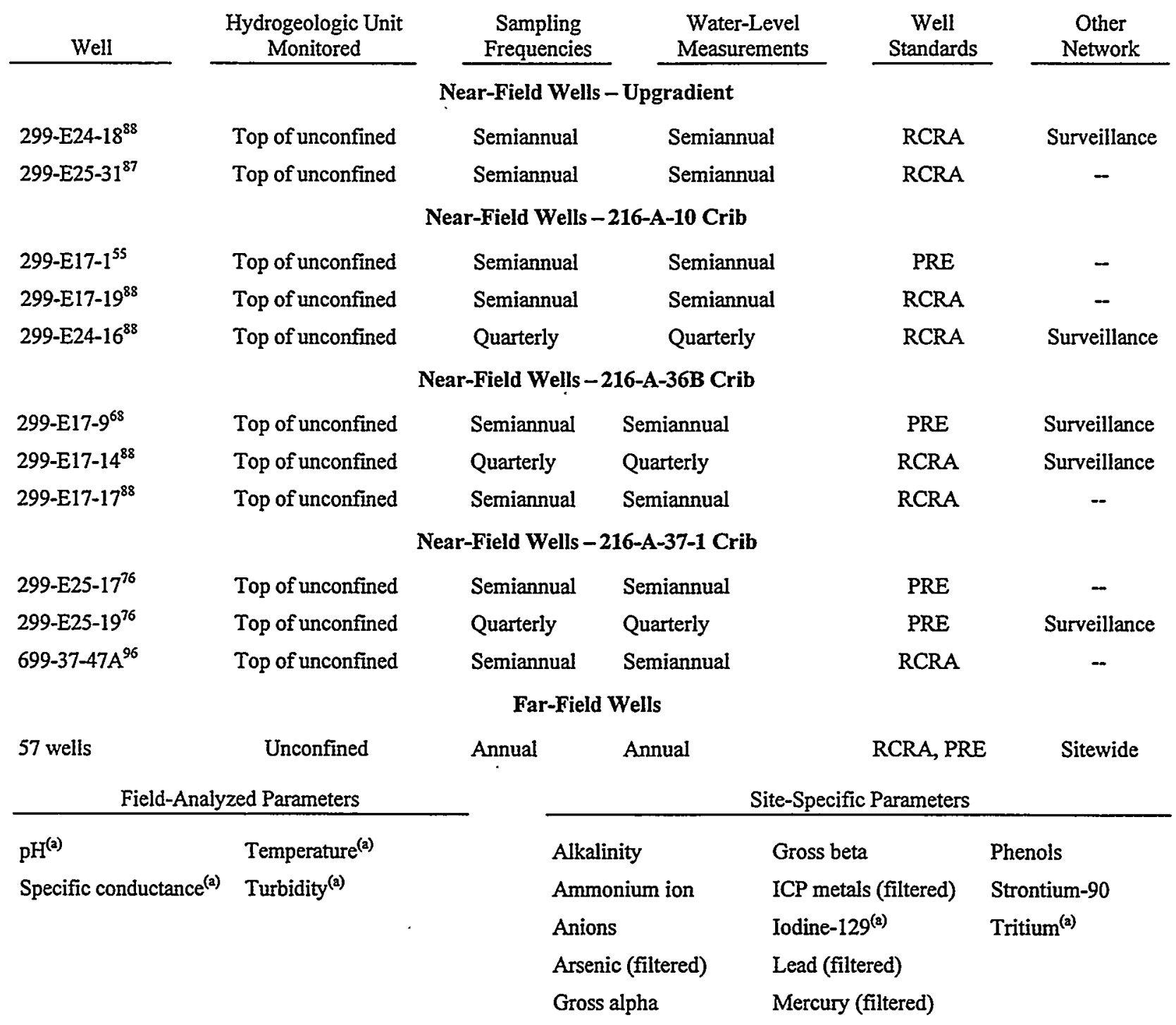

(a) Far-field wells analyzed for these constituents only.

Shading = Upgradient wells.

Superscript $=$ Year of installation.

PRE = Well not constructed to RCRA standards.

PUREX = Plutonium-uranium extraction (plant).

RCRA = Well constructed to RCRA standards. 


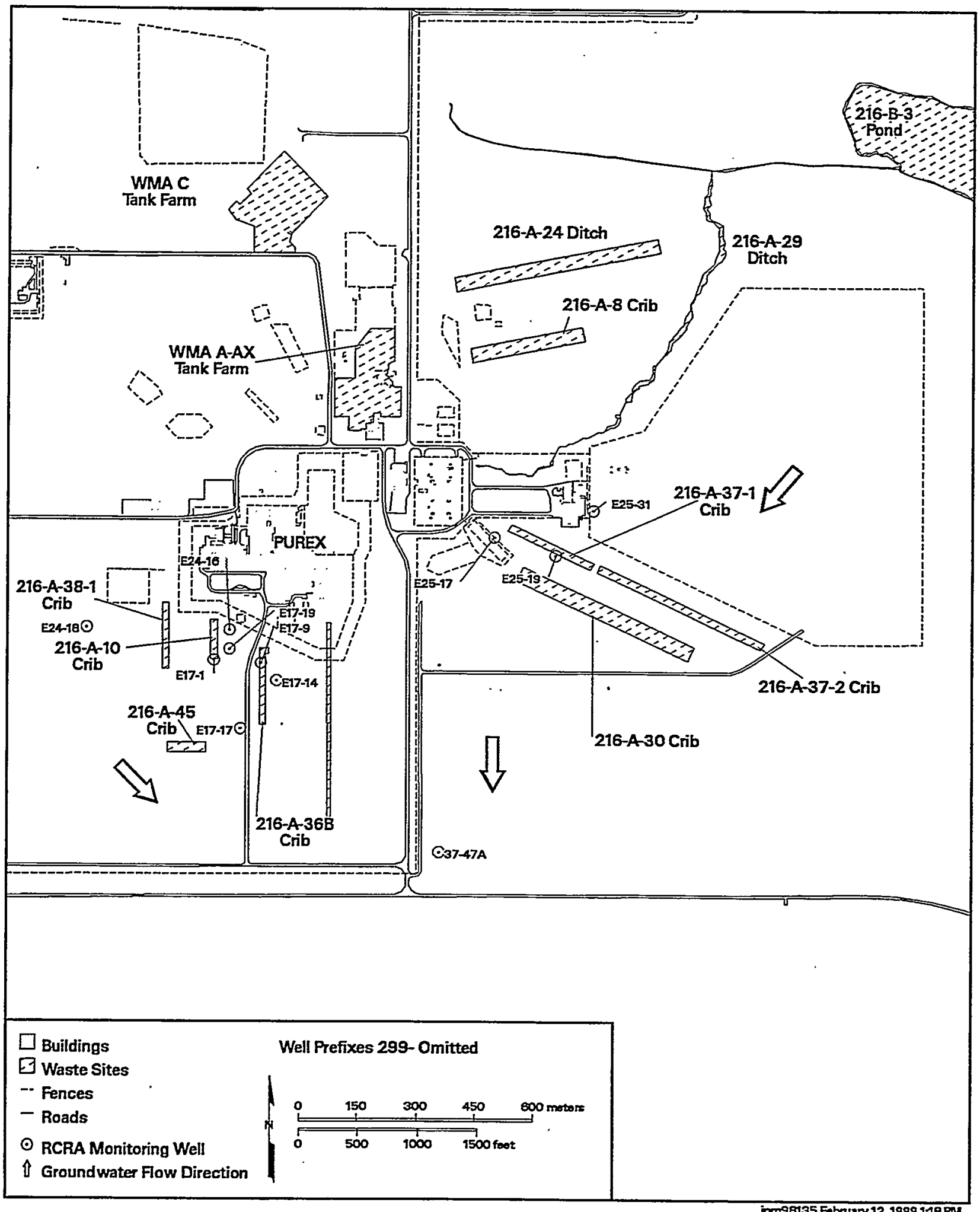

Figure A.9. Near-Field Monitoring Well Locations for PUREX Cribs (216-A-10, 216-A-36B, and 216-A-37-1) 
Table A.10. Monitoring Wells and Constituents for 216-B-63 Trench (adapted from WHC-SD-EN-AP-165)

\begin{tabular}{|c|c|c|c|c|c|}
\hline Well & $\begin{array}{c}\text { Hydrogeologic Unit } \\
\text { Monitored }\end{array}$ & $\begin{array}{l}\text { Sampling } \\
\text { Frequency }\end{array}$ & $\begin{array}{l}\text { Water-Level } \\
\text { Measurement }\end{array}$ & $\begin{array}{c}\text { Well } \\
\text { Standard } \\
\end{array}$ & Other Networks \\
\hline $299-E 27-8^{87}$ & Top of unconfined & Semiannual & Quarterly & RCRA & LLWMA 2 \\
\hline $299-E 27-9^{87}$ & Top of unconfined & Semiannual & Quarterly & $\mathrm{RCRA}$ & LLWMA 2 \\
\hline 299-E27-11 ${ }^{89}$ & Top of unçonfined & Semiannual & Quarterly & RCRA & LLWMA 2 \\
\hline 299-E27-1690 & Top of unconfined & Semiannual & Quarterly & RCRA & - \\
\hline 299-E27-17 ${ }^{91}$ & Top of unconfined & Semiannual & Quarterly & RCRA & LLWMA 2 \\
\hline 299-E27-18 & Top of unconfined. & Semiannual & Quarterly & RCRA & Surveillance \\
\hline 299-E27-1992 & Top of unconfined & Semiannual & Quarterly & RCRA & - \\
\hline $299-\mathrm{E} 33-33^{90}$ & Top of unconfined & Semiannual & Quarterly & RCRA & WMA B-BX-BY \\
\hline 299-E33-36 & Top of unconfined & Semiannual & Quarterly & $\mathrm{RCRA}$ & WMA B-BX-BY \\
\hline 299-E33-3790 & Top of unconfined & Semiannual & Quarterly & RCRA & Surveillance \\
\hline $299-\mathrm{E} 34-8^{90}$ & Top of unconfined & Semiannual & Quarterly & $\mathrm{RCRA}$ & Surveillance \\
\hline 299-E34-1091 & Top of unconfined & Semiannual & Quarterly & RCRA & $\begin{array}{l}\text { LLWMA 2, } \\
\text { Surveillance }\end{array}$ \\
\hline
\end{tabular}

\begin{tabular}{ll}
\multicolumn{2}{c}{ Contamination Indicator Parameters } \\
\hline $\mathrm{pH}$ & Total organic carbon \\
Specific conductance & Total organic halides
\end{tabular}

Shading = Upgradient wells.

Superscript $=$ Year of installation.

LLWMA = Low-level waste management area.

RCRA = Well constructed to RCRA standards.

WMA $=$ Waste management area.
Site-Specific Parameters

$\begin{array}{ll}\text { Alkalinity } & \text { ICP metals (filtered) } \\ \text { Anions } & \text { Phenols } \\ \text { Gross alpha } & \text { Turbidity } \\ \text { Gross beta } & \end{array}$




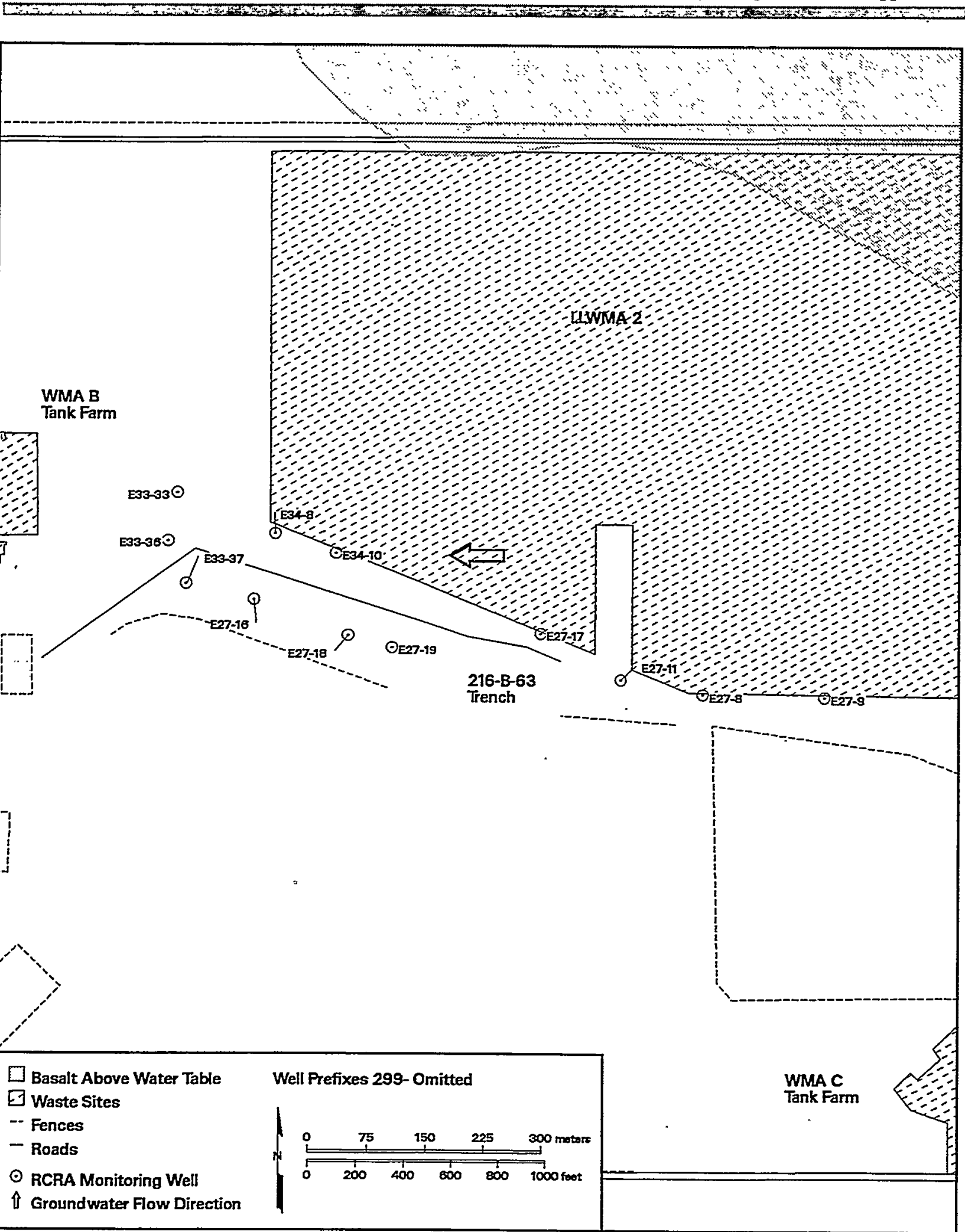

ipme8t36 Fobruary 12, 1999 2:02 PM

Figure A.10. Monitoring Well Locations for 216-B-63 Trench 
Table A.11. Monitoring Wells and Constituents for Liquid Effluent-Retention Facility (adapted from WHC-SD-EN-AP-024).

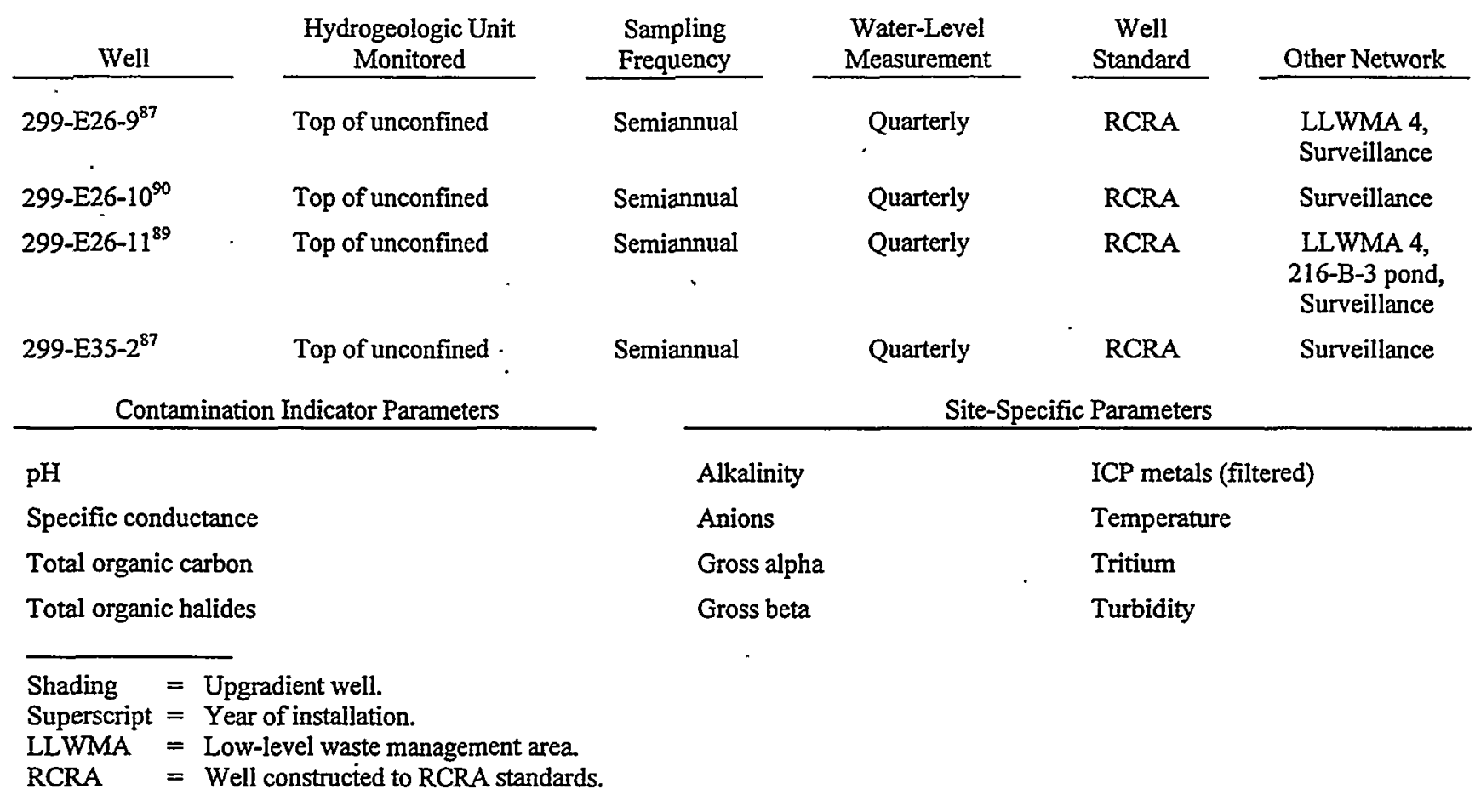




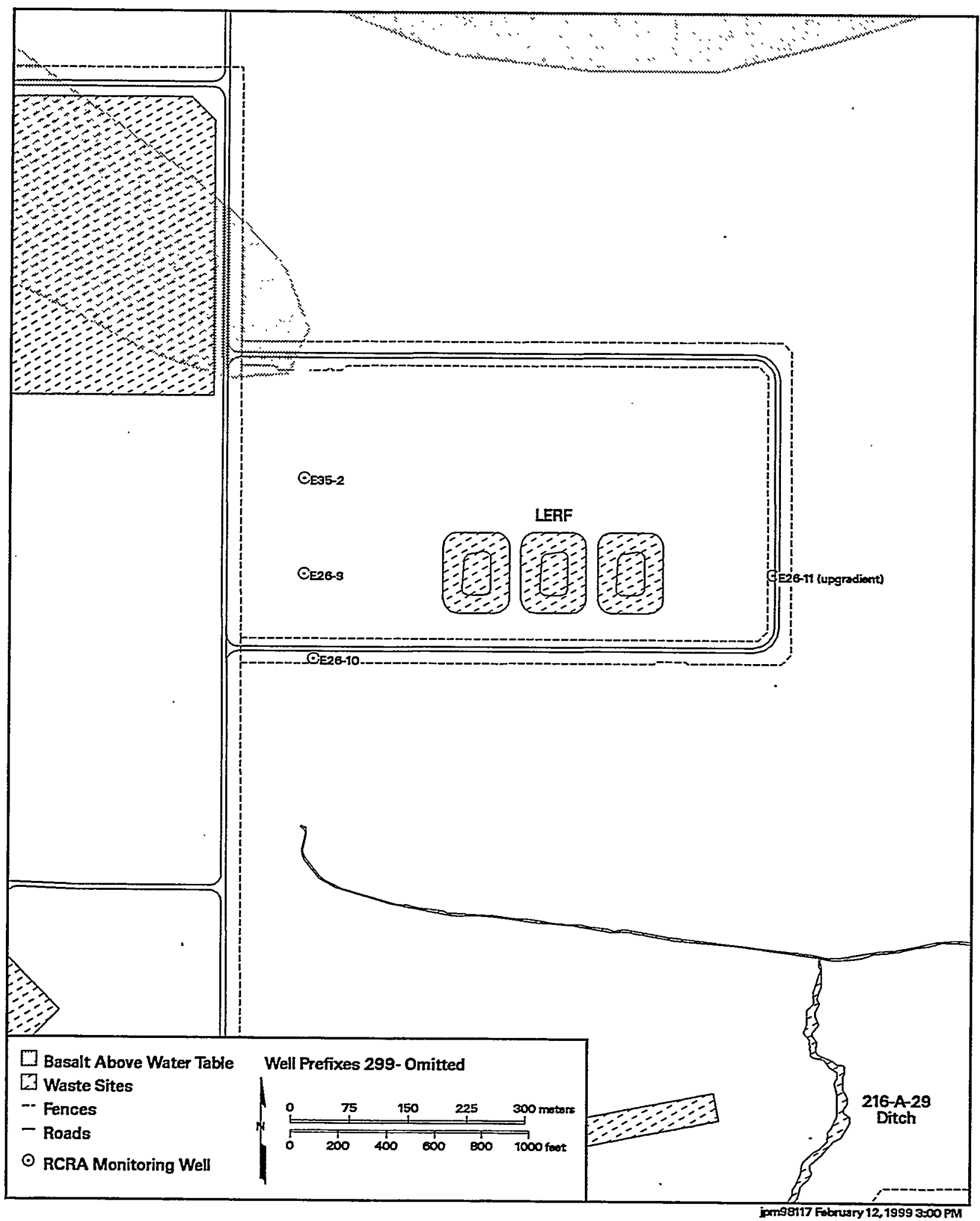

Figure A.11. Monitoring Well Locations for Liquid Effluent-Retention Facility 
Table A.12. Monitoring Wells and Constituents for Low-Level Waste Management Area 1 (adapted from WHC-SD-EN-AP-015)

\begin{tabular}{|c|c|c|c|c|c|}
\hline Well & $\begin{array}{c}\text { Hydrogeologic Unit } \\
\text { Monitored }\end{array}$ & $\begin{array}{l}\text { Sampling } \\
\text { Frequency }\end{array}$ & $\begin{array}{c}\text { Water-Level } \\
\text { Measurement }\end{array}$ & $\begin{array}{c}\text { Well } \\
\text { Standard }\end{array}$ & Other Network \\
\hline $299-E 28-26^{87}$ & Top of unconfined & Semiannual & Semiannual & RCRA & . - - \\
\hline 299-E28-27 & Top of unconfined & Semiannual & Semiannual & RCRA & - \\
\hline $299-E 28-28^{90}$ & Top of unconfined & Semiannual & Semiannual & $\mathrm{RCRA}$ & - \\
\hline $299-E 32-2^{87}$ & Top of unconfined & Semiannual & Semiannual & RCRA & Surveillance \\
\hline $299-E 32-3^{87}$ & Top of unconfined & Semiannual & Semiannual & RCRA & - \\
\hline $299-E 32-4^{87}$ & Top of unconfined & Semiannual & Semiannual & RCRA & $\begin{array}{c}216-\mathrm{B}-3 \text { pond, } \\
\text { Surveillance }\end{array}$ \\
\hline $299-E 32-5^{89}$ & Top of unconfined & Semiannual & Semiannual & RCRA & Surveillance \\
\hline $299-E 32-6^{91}$ & Top of unconfined & Semiannual & Semiannual & RCRA & - \\
\hline $299-\mathrm{E} 32-7^{91}$ & Top of unconfined & Semiannual & Semiannual & RCRA & - \\
\hline $299-\mathrm{E} 32-8^{91}$ & Top of unconfined & Semiannual & Semiannual & RCRA & Surveillance \\
\hline $299-E 32-9^{91}$ & Top of unconfined & Semiannual & Semiannual & RCRA & - \\
\hline $299-E 32-10^{92}$ & Top of unconfined & Semiannual & Semiannual & $\mathrm{RCRA}$ & - \\
\hline $299-E 33-28^{87}$ & Top of unconfined & Semiannual & Semiannual & RCRA & - \\
\hline $299-E 33-29^{87}$ & Top of unconfined & Semiannual & Semiannual & RCRA & Surveillance \\
\hline $299-E 33-30^{87}$ & Top of unconfined & Semiannuà & Semiannual & RCRA & -- \\
\hline $299-E 33-34^{90}$ & Top of unconfined & Semiannual & Semiannual & RCRA & Surveillance \\
\hline $299-\mathrm{E} 33-35^{90}$ & Top of unconfined & Semiannual & Semiannual & $\mathrm{RCRA}$ & - \\
\hline
\end{tabular}

Contamination Indicator Parameters

Site-Specific Parameters

$\mathrm{pH}$

Specific conductance

Total organic carbon

Total organic halides

\begin{tabular}{ll}
\hline Alkalinity & Mercury (filtered) \\
Gross alpha & Phenols \\
Gross beta & Tritium \\
ICP metals (filtered) & Turbidity \\
Lead (filtered) &
\end{tabular}

Shading $=$ Upgradient wells.

Superscript $=$ Year of installation.

RCRA = Well constructed to RCRA standards. 


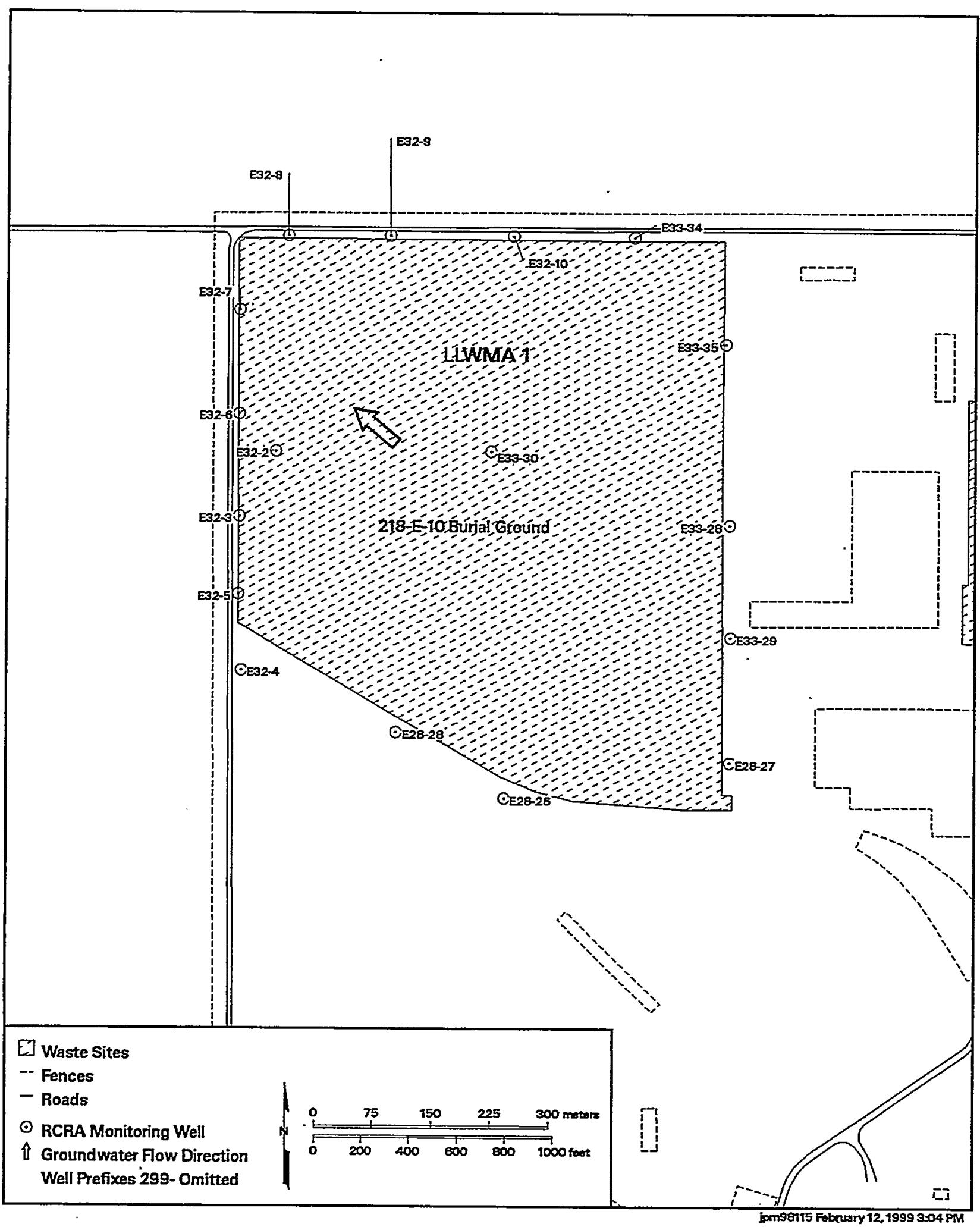

Figure A.12. Monitoring Well Locations for Low-Level Waste Management Area 1 
Table A.13. Monitoring Wells and Constituents for Low-Level Waste Management Area 2 (adapted from WHC-SD-EN-AP-015)

\begin{tabular}{|c|c|c|c|c|c|}
\hline Well & $\begin{array}{l}\text { Hydrogeologic Unit } \\
\text { Monitored } \\
\end{array}$ & $\begin{array}{l}\text { Sampling } \\
\text { Frequency } \\
\end{array}$ & $\begin{array}{l}\text { Water-Level } \\
\text { Measurement } \\
\end{array}$ & $\begin{array}{c}\text { Well } \\
\text { Standard }\end{array}$ & Other Networks \\
\hline $299-E 27-8^{87}$ & Top of unconfined & Semiannual & Semiannual & RCRA & 216-B-63 trench \\
\hline $299-\mathrm{E} 27-9^{87}$ & Top of unconfined & Semiannual & Semiannual & RCRA & 216-B-63 trench \\
\hline $299-\mathrm{E} 27-10^{90}$ & Top of unconfined & Semiannual & Semiannual & RCRA & Surveillance \\
\hline 299-E27-11 $1^{89}$ & Top of unconfined & Semiannual & Semiannual & RCRA & 216-B-63 trench \\
\hline $299-\mathrm{E} 27-17^{91}$ & Top of unconfined & Semiannual & Semiannual & - RCRA & 216-B-63 trench \\
\hline $299-E 34-2^{87}$ & Top of unconfined & Semiannual & Semiannual & $\mathrm{RCRA}$ & Surveillance \\
\hline $299-E 34-3^{87}$ & Top of unconfined & Semiannual & Semiannual & RCRA & - \\
\hline $299-E 34-4^{87}$ & Top of unconfined & Dry & Dry & RCRA & - \\
\hline $299-E 34-5^{87}$ & Top of unconfined & Semiannual & Semiannual & RCRA & - \\
\hline $299-E 34-6^{87}$ & Top of unconfined & Dry & Dry & RCRA & - \\
\hline $299-\mathrm{E} 34-7^{89}$ & Top of unconfined & Semiannual & Semiannual & RCRA & Surveillance \\
\hline 299-E34-991 & Top of unconfined & Semiannual & Semiannual & RCRA & - \\
\hline 299-E34-10 $0^{91}$ & Top of unconfined & Semiannual & Semiannual & RCRA & $\begin{array}{l}\text { 216-B-63 trench, } \\
\text { Surveillance }\end{array}$ \\
\hline $299-E 34-11^{92}$ & Top of unconfined & Semiannual & Semiannual & RCRA & Surveillance \\
\hline $299-\mathrm{E} 34-12^{92}$ & Top of unconfined & Semiannual & Semiannual & RCRA & - \\
\hline 299-E35-1 ${ }^{89}$ & Top of unconfined & Dry & Dry & RCRA & - \\
\hline
\end{tabular}

Contamination Indicator Parameters

$\mathrm{pH}$

Specific conductance

Total organic carbon

Total organic halides

Site-Specific Parameters

$\begin{array}{ll}\text { Alkalinity } & \text { Mercury (filtered) } \\ \text { Gross alpha } & \text { Phenols } \\ \text { Gross beta } & \text { Polychlorinated biphenyls } \\ \text { ICP metals (filtered) } & \text { Tritium } \\ \text { Lead (filtered) } & \text { Turbidity }\end{array}$

Shading = Upgradient wells.

Superscript $=$ Year of installation.

RCRA = Well constructed to RCRA standards. 


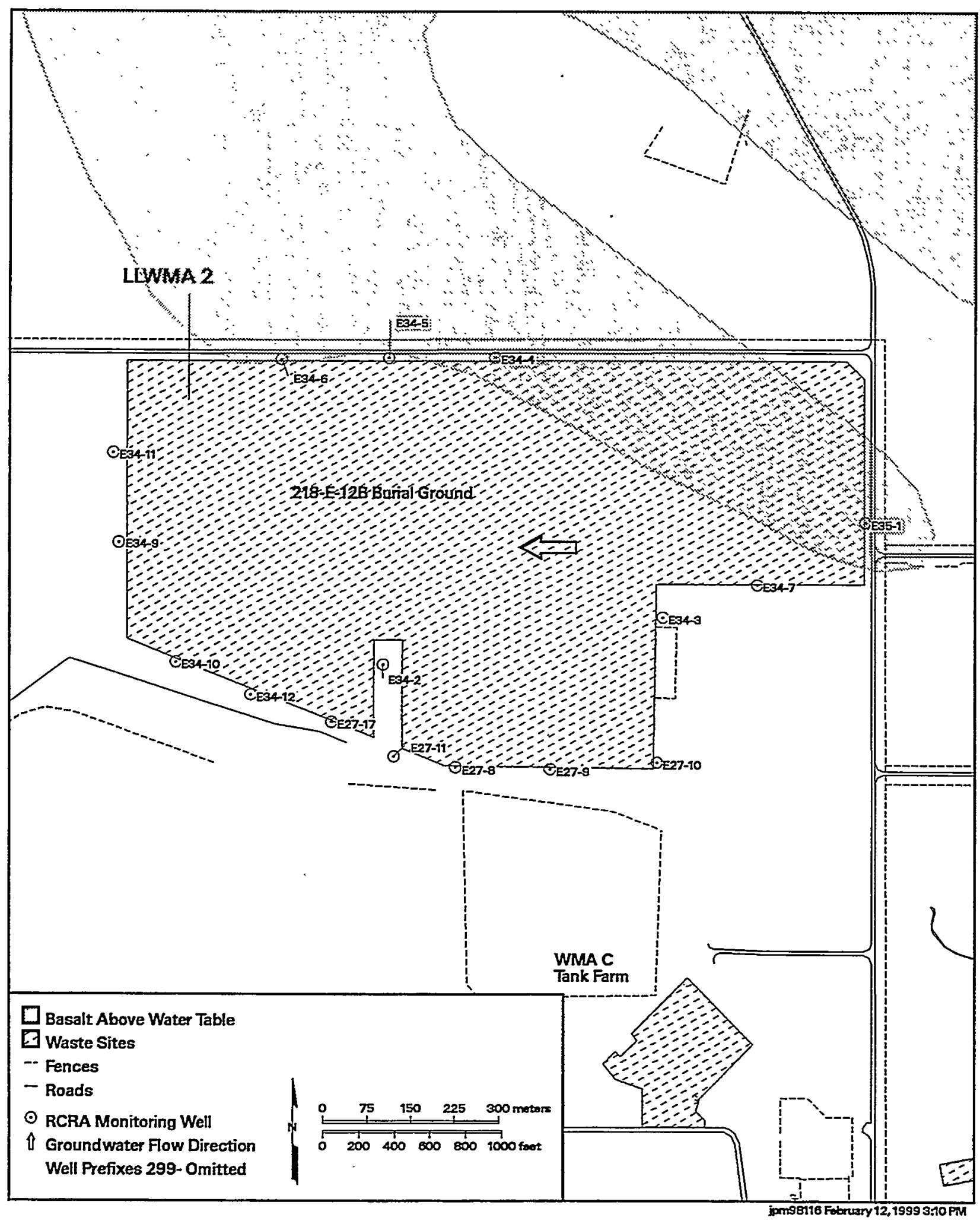

Figure A.13. Monitoring Well Locations for Low-Level Waste Management Area 2 
Table A.14. Monitoring Wells and Constituents for Low-Level Waste Management Area 3 (adapted from WHC-SD-EN-AP-015)

\begin{tabular}{|c|c|c|c|c|c|}
\hline Well & $\begin{array}{c}\text { Hydrogeologic Unit } \\
\text { Monitored }\end{array}$ & $\begin{array}{l}\text { Sampling } \\
\text { Frequency }\end{array}$ & $\begin{array}{l}\text { Water-Level } \\
\text { Measurement }\end{array}$ & $\begin{array}{c}\text { Well } \\
\text { Standard }\end{array}$ & $\begin{array}{c}\text { Other } \\
\text { Networks }\end{array}$ \\
\hline 299-W6-2 ${ }^{87}$ & Top of unconfined & Semiannual & Semiannual & RCRA & $\begin{array}{l}\text { SSTF, } \\
\text { Surveillance }\end{array}$ \\
\hline $299-W 7-1^{87}$ & Top of unconfined & Semiannual & Semiannual & $\mathrm{RCRA}$ & - \\
\hline $299-W 7-2^{87}$ & Top of unconfined & Dry & Dry & RCRA & - \\
\hline $299-W 7-3^{87}$ & Deep unconfined & Semiannual & Semiannual & RCRA & - \\
\hline $299-W 7-4^{87}$ & Top of unconfined & Semiannual & Semiannual & $\mathrm{RCRA}$ & -- \\
\hline $299-W 7-5^{87}$ & Top of unconfined & Semiannual & Semiannual & RCRA & - \\
\hline $299-W 7-6^{87}$ & Top of unconfined & Semiannual & Semiannual & $\mathrm{RCRA}$ & Surveillance \\
\hline $299-W 7-7^{89}$ & Top of unconfined & Semiannual & Semiannual & RCRA & -- \\
\hline $299-W 7-8^{89}$ & Top of unconfined & Semiannual & Semiannual & RCRA & -- \\
\hline $299-W 7-9^{90}$ & Top of unconfined & Semiannual & Semiannual & RCRA & - \\
\hline 299-W7-1090 & Top of unconfined & Semiannual & Semiannual & RCRA & - \\
\hline $299-W 7-11^{91}$ & Top of unconfined & Semiannual & Semiannual & RCRA & - \\
\hline $299-W 7-12^{91}$ & Top of unconfined & Semiannual & Semiannual & RCRA & - \\
\hline $299-W 8-1^{87}$ & Top of unconfined & Semiannual & Semiannual & RCRA & SALDS \\
\hline $299-W 9-1^{87}$ & Top of unconfined & Semiannual & Semiannual & RCRA & - \\
\hline $299-W 10-13^{87}$ & Top of unconfined & Semiannual & Semiannual & $\mathrm{RCRA}$ & - \\
\hline $299-W 10-14^{87}$ & Deep unconfined & Semiannual & Semiannual & RCRA & - \\
\hline $299-W 10-19^{92}$ & Top of unconfined & Semiannual & Semiannual & RCRA & SSTF \\
\hline $299-W 10-20^{93}$ & Top of unconfined & Semiannual & Semiannual & $\mathrm{RCRA}$ & SSTF \\
\hline $299-W 10-21^{93}$ & Top of unconfined & Semiannual & Semiannual & RCRA & SSTF \\
\hline
\end{tabular}

Contamination Indicator Parameters

Site-Specific Parameters

$\mathrm{pH}$

Specific conductance

Total organic carbon

Total organic halides

$\begin{array}{ll}\text { Alkalinity } & \text { Mercury (filtered) } \\ \text { Gross alpha } & \text { Phenols } \\ \text { Gross beta } & \text { Tritium } \\ \text { ICP metals (filtered) } & \text { Turbidity } \\ \text { Lead (filtered) } & \text { Volatile organic compounds }\end{array}$

Shading = Upgradient wells.

Superscript $=$ Year of installation.

RCRA = Well constructed to RCRA standards.

SALDS = State-Approved Land-Disposal Site.

SSTF $\quad=$ Single-shell tank farm. 


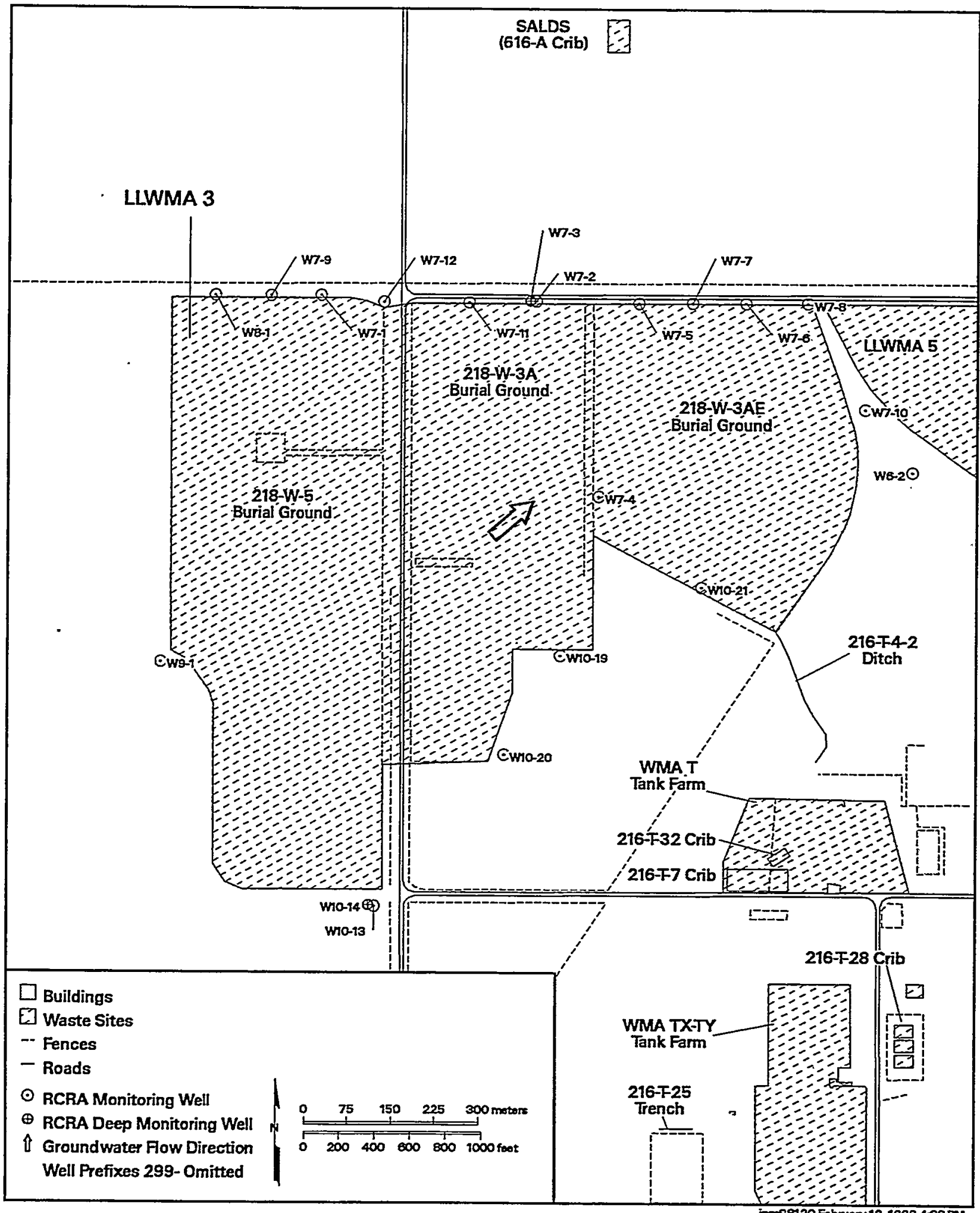

Figure A.14. Monitoring Well Locations for Low-Level Waste Management Area 3 
Table A.15. Monitoring Wells and Constituents for Low-Level Waste Management Area 4 (adapted from WHC-SD-EN-AP-015)

\begin{tabular}{|c|c|c|c|c|c|}
\hline Well & $\begin{array}{c}\text { Hydrogeologic Unit } \\
\text { Monitored } \\
\end{array}$ & $\begin{array}{l}\text { Sampling } \\
\text { Frequency }\end{array}$ & $\begin{array}{l}\text { Water-Level } \\
\text { Measurement }\end{array}$ & $\begin{array}{c}\text { Well } \\
\text { Standard }\end{array}$ & $\begin{array}{c}\text { Other } \\
\text { Networks }\end{array}$ \\
\hline $299-W 15-15^{87}$ & Top of unconfined & Semiannual & Semiannual & RCRA & $200-Z P-1$ \\
\hline $299-W 15-16^{87}$ & Top of unconfined & Semiannual & Semiannual & RCRA & \\
\hline $299-W 15-17^{87}$ & Deep unconfined & Semiannual & Semiannual & RCRA & - \\
\hline $299-W 15-18^{87}$ & Top of unconfined & Semiannual & Semiannual & RCRA & \\
\hline $299-W 15-19^{89}$ & Top of unconfined & Dry & Semiannual & RCRA & $\begin{array}{l}200-Z P-1 \\
\text { Surveillance }\end{array}$ \\
\hline $299-W 15-20^{89}$ & Top of unconfined & Dry & Semiannual & RCRA & -- \\
\hline $299-W 15-23^{90}$ & Top of unconfined & Dry & Dry & $\mathrm{RCRA}$ & -- \\
\hline $299-W 15-24^{89}$ & Top of unconfined & Dry & Dry & $\mathrm{RCRA}$ & -- \\
\hline $299-W 18-21^{87}$ & Top of unconfined & Semiannual & Semiannual & RCRA & $200-Z P-1$ \\
\hline $299-W 18-22^{87}$ & Deep unconfined & Semiannual & Semiannual & RCRA & Surveillance \\
\hline $299-W 18-23^{87}$ & Top of unconfined & Semiannual & Semiannual & RCRA & $200-Z P-1$ \\
\hline $299-W 18-24^{87}$ & Top of unconfined & Semiannual & Semiannual & RCRA & \\
\hline $299-W 18-26^{89}$ & Top of unconfined & Semiannual & Semiannuai & RCRA & $200-Z \mathrm{P}-1$ \\
\hline $299-W 18=27^{91}$. & Top of unconfined & Semiannual & Semiannual & RCRA & 200-ZP-1 \\
\hline $299-W 18-28^{91}$ & Top of unconfined & Semiannual & Semiannual & RCRA & \\
\hline $299-W 18-29^{91}$ & Perched zone & Dry & Dry & $\mathrm{RCRA}$ & - \\
\hline $299-W 18-32^{92}$ & Top of unconfined & Dry & Semiannual & RCRA & $200-Z P-1$ \\
\hline
\end{tabular}

Contamination Indicator Parameters

$\mathrm{pH}$

Specific conductance

Total organic carbon

Total organic halides
Site-Specific Parameters

$\begin{array}{ll}\text { Alkalinity } & \text { Mercury (filtered) } \\ \text { Gross alpha } & \text { Phenols } \\ \text { Gross beta } & \text { Tritium } \\ \text { ICP metals (filtered) } & \text { Turbidity } \\ \text { Lead (filtered) } & \text { Volatile organic compounds }\end{array}$

Shading $=$ Upgradient wells.

Superscript $=$ Year of installation.

RCRA = Well constructed to RCRA standards. 


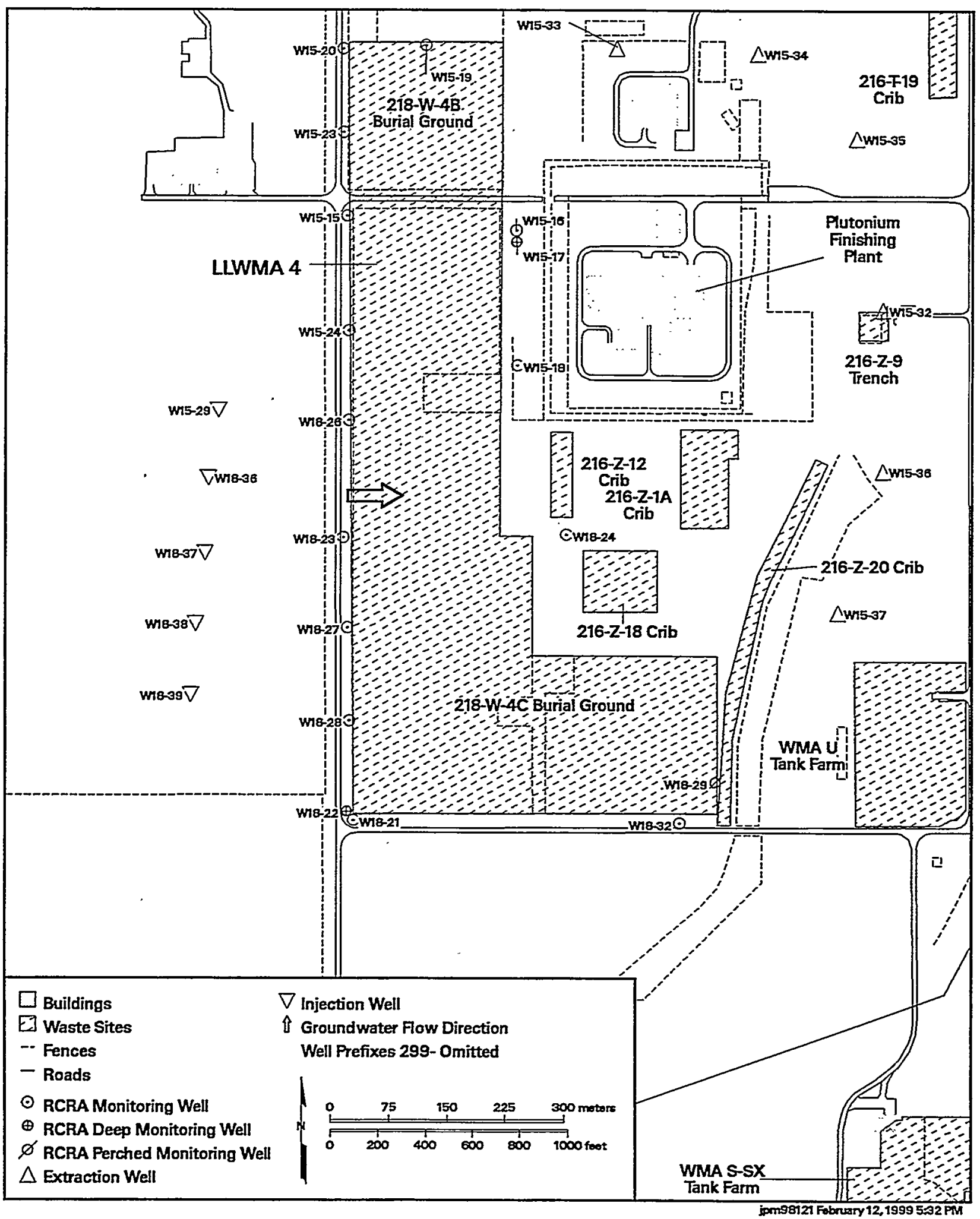

Figure A.15. Monitoring Well Locations for Low-Level Waste Management Area 4 
Table A.16. Monitoring Wells and Constituents for Waste Management Areas A-AX and C (adapted from WHC-SD-EN-AP-012, Rev. 1)

\begin{tabular}{|c|c|c|c|c|c|}
\hline Well & $\begin{array}{c}\text { Hydrogeologic Unit } \\
\text { Monitored } \\
\end{array}$ & $\begin{array}{l}\text { Sampling } \\
\text { Frequency }\end{array}$ & $\begin{array}{l}\text { Water-Level } \\
\text { Measurement }\end{array}$ & $\begin{array}{c}\text { Well } \\
\text { Standard } \\
\end{array}$ & $\begin{array}{c}\text { Other } \\
\text { Network }\end{array}$ \\
\hline \multicolumn{6}{|c|}{ A-AX Single-Shell Tank Farms } \\
\hline $299-\mathrm{E} 24-19^{89}$ & Top of unconfined & Semiannual & Quarterly & RCRA & Surveillance \\
\hline $299-\mathrm{E} 24-20^{91}$ & Top of unconfined & Semiannual & Quarterly & RCRA & - \\
\hline $299-E 25-2^{55}$ & Top of unconfined & - & Quarterly & PRE & -. \\
\hline $299-E 25-40^{89}$ & Top of unconfined & Semiannual & Quarterly & RCRA & $\because$ \\
\hline $299-\mathrm{E} 25-41^{89}$ & Top of unconfined & Semiannual & Quarterly & $\mathrm{RCRA}$ & Surveillance \\
\hline $299-\mathrm{E} 25-46^{92}$ & Top of unconfined & Semiannual & Quarterly & RCRA & - \\
\hline \multicolumn{6}{|c|}{ C Single-Shell Tank Farm } \\
\hline $299-\mathrm{E} 27-7^{82}$ & Top of unconfined & Semiannual & Quarterly & PRE & -- \\
\hline $299-E 27-12^{89}$ & Top of unconfined & Semiannual & Quarterly & RCRA & - \\
\hline $299-E 27-13^{89}$ & Top of unconfined & Semiannual & Quarterly & $\mathrm{RCRA}$ & - \\
\hline $299-E 27-14^{89}$ & Top of unconfined & Semiannual & Quarterly & RCRA & Surveillance \\
\hline $299-E 27-15^{89}$ & Top of unconfined & Semiannual & Quarterly & RCRA & Surveillance \\
\hline
\end{tabular}

Contamination Indicator Parameters

Site-Specific Parameters

$\mathrm{pH}$

Specific conductance

Total organic carbon

Total organic halides

Shading = Upgradient wells.

Superscript $=$ Year of installation.

PRE = Well not constructed to RCRA standards.

RCRA = Well constructed to RCRA standards.
Low-level gamma

Phenols

Technetium-99

Tritium

Turbidity

$\begin{array}{ll}\text { Anions } & \text { Low-level gamma } \\ \text { Gross alpha } & \text { Phenols } \\ \text { Gross beta } & \text { Technetium-99 } \\ \text { ICP metals (filtered) } & \text { Tritium } \\ \text { Iodine-129 } & \text { Turbidity }\end{array}$




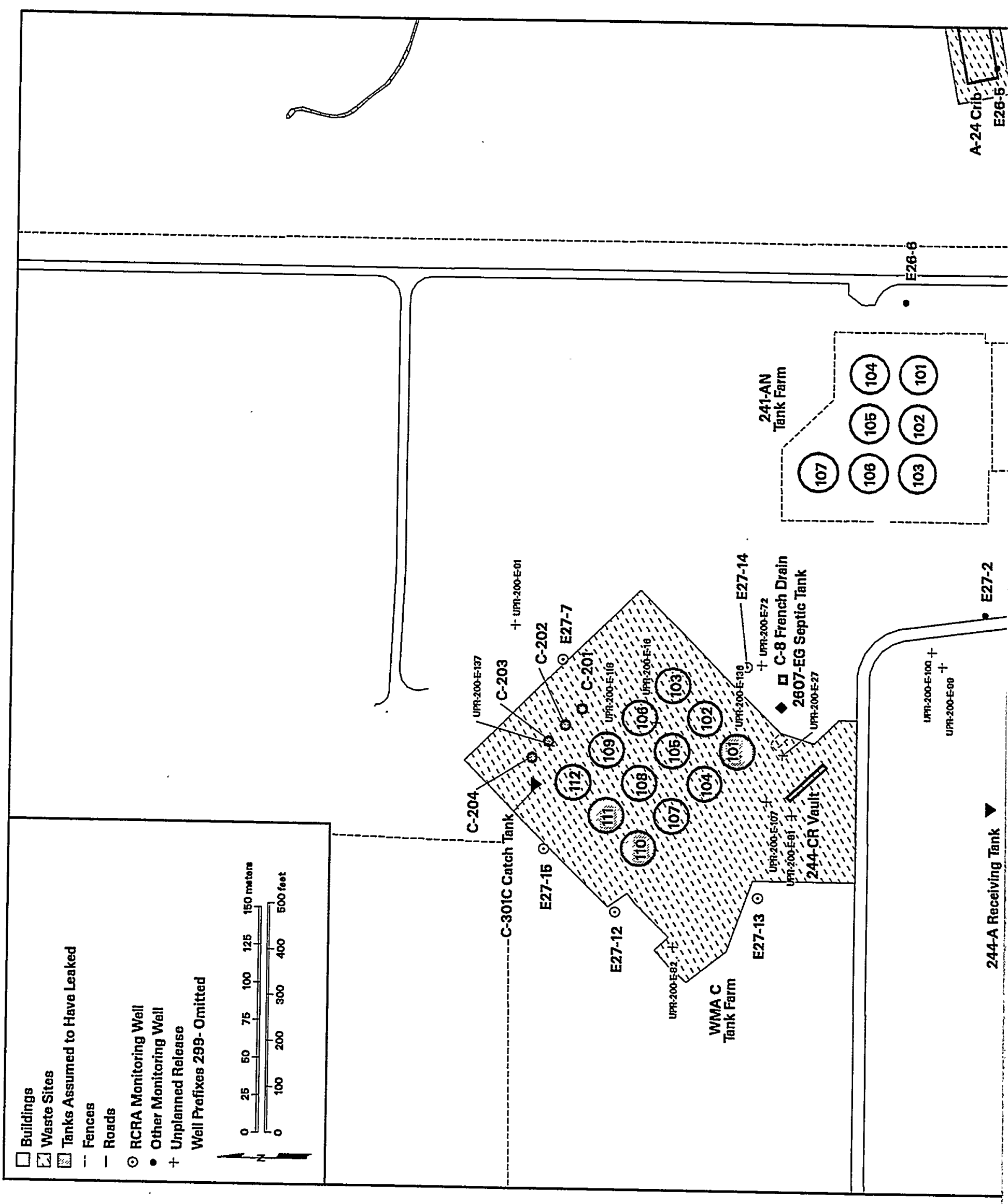




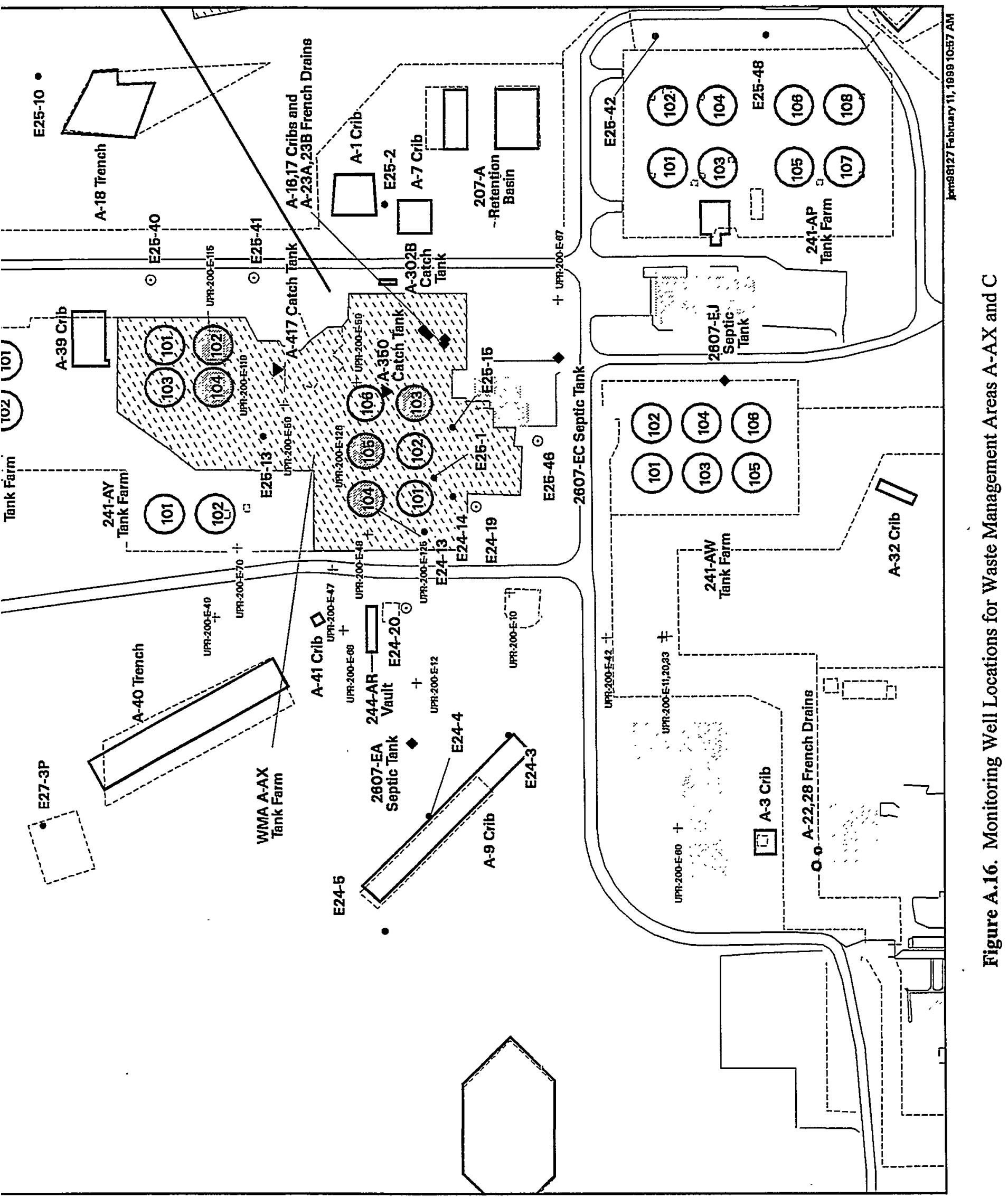


Table A.17. Monitoring Wells and Constituents for Waste Management Area B-BX-BY(a) (adapted from WHC-SD-EN-AP-012, Rev. 1 and WHC-SD-ENV-AP-002)

\begin{tabular}{|c|c|c|c|c|c|}
\hline Well & $\begin{array}{l}\text { Hydrogeologic Unit } \\
\text { Monitored }\end{array}$ & $\begin{array}{l}\text { Sampling } \\
\text { Frequency }\end{array}$ & $\begin{array}{l}\text { Water-Level } \\
\text { Measurement }\end{array}$ & $\begin{array}{c}\text { Well } \\
\text { Standard }\end{array}$ & Other Network \\
\hline $299-\mathrm{E} 28-8^{57}$ & Top of unconfined & Quarterly & Quarterly & PRE & - \\
\hline 299-E33-5 & Top of unconfined & Quarterly & Quarterly & PRE & - \\
\hline 299-E33-7 55 & Top of unconfined & Quarterly & Quarterly & PRE & Surveillance \\
\hline $299-\mathrm{E} 33-8^{53}$ & Top of unconfined & Quarterly & Quarterly & PRE & - \\
\hline $299-E 33-13^{53}$ & Top of unconfined & Quarterly & Quarterly & PRE & Surveillance \\
\hline 299-E33-15 $5^{53}$ & Top of unconfined & Quarterly & Quarterly & PRE & - \\
\hline 299-E33-16 $6^{53}$ & Top of unconfined & Quarterly & Quarterly & PRE & - \\
\hline $299-E 33-17^{53}$ & Top of unconfined & Quarterly & Quarterly & PRE & - \\
\hline $299-E 33-18^{50}$ & Top of unconfined & - & Quarterly & PRE & - \\
\hline $299-E 33-21^{57}$ & Top of unconfined & Quarterly & Quarterly & PRE & - \\
\hline 299-E33-31 ${ }^{89}$ & Top of unconfined & Quarterly ${ }^{(b)}$ & Quarterly & RCRA & - \\
\hline 299-E33-32 ${ }^{89}$ & Top of unconfined & Quarterly ${ }^{(b)}$ & Quarterly & RCRA & - \\
\hline 299-E33-33 & Top of unconfined & Quarterly & Quarterly & RCRA & 216-B-63 trench \\
\hline 299-E33-36 & Top of unconfined & Quarterly & Quarterly & RCRA & $216-\mathrm{B}-63$ trench \\
\hline 299-E33-3891 & Top of unconfined & Quarterly & Quarterly & $\mathrm{RCRA}$ & - \\
\hline 299-E33-3991 & Top of unconfined & Quarterly & Quarterly & RCRA & Surveillance \\
\hline $299-\mathrm{E} 33-41^{91}$ & Top of unconfined & Quarterly ${ }^{(b)}$ & Quarterly & RCRA & - \\
\hline $299-\mathrm{E} 33-42^{91}$ & Top of unconfined & Quarterly ${ }^{(b)}$ & Quarterly & RCRA & - \\
\hline $299-E 33-43^{91}$ & Top of unconfined & Quarterly(b) & Quarterly & RCRA & - \\
\hline
\end{tabular}

Contamination Indicator Parameters

Site-Specific Parameters

$\mathrm{pH}$

Specific conductance

Total organic carbon

Total organic halides

$\begin{array}{ll}\text { Anions } & \text { Low-level gamma } \\ \text { Gross alpha } & \text { Technetium-99 } \\ \text { Gross beta } & \text { Tritium } \\ \text { ICP metals (filtered) } & \text { Turbidity } \\ \text { Iodine-129 } & \text { Uranium }\end{array}$

(a) Well list varies, depending on assessment requirements and changes in contaminant or flow conditions.

(b) Sampled monthly for selected constituents only. Subject to monthly revision.

Shading = Upgradient wells.

Superscript $=$ Year of installation.

PRE = Well not constructed to RCRA standards.

RCRA = Well constructed to RCRA standards. 


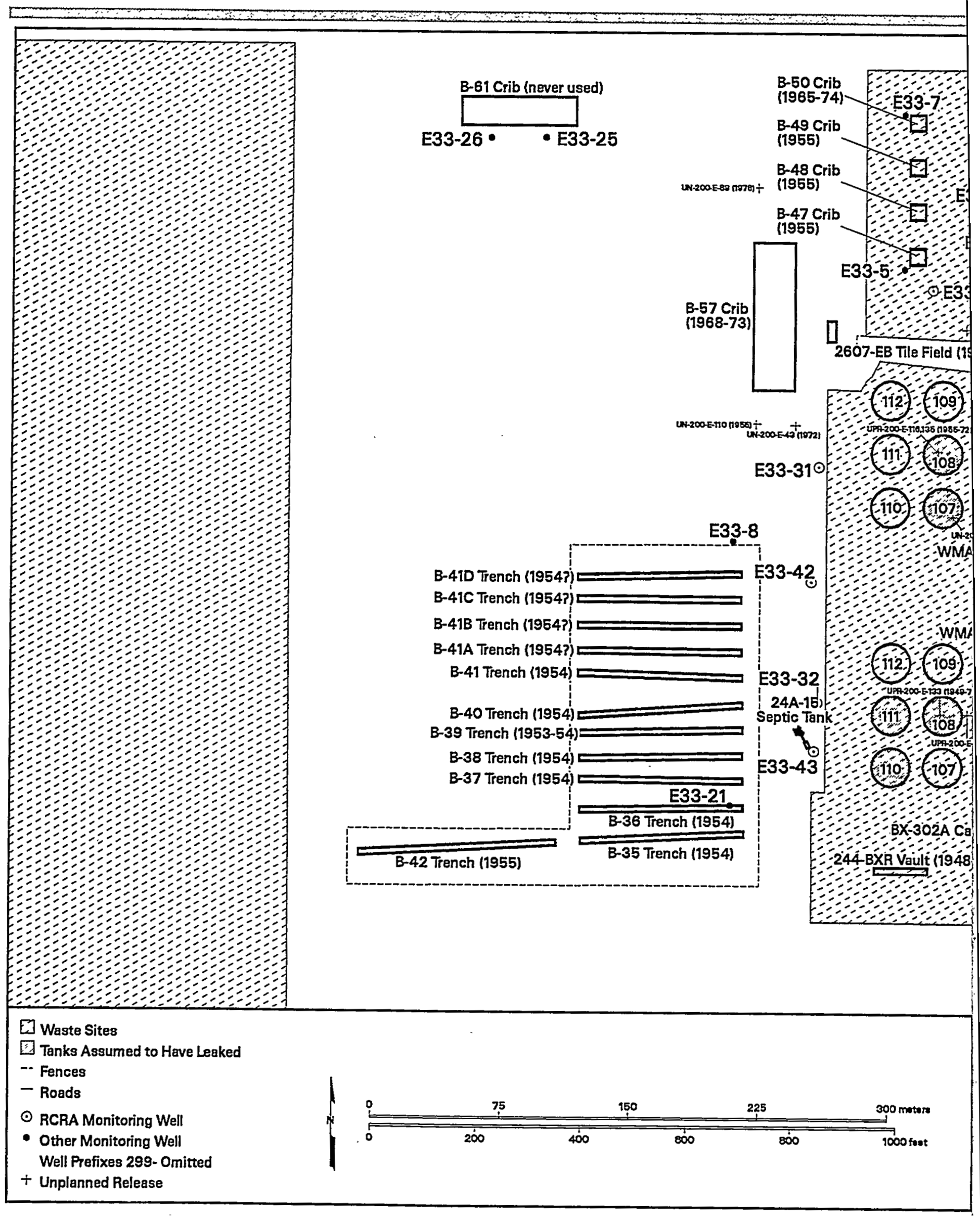

Figure A.17. Monitoring Well Locatio 


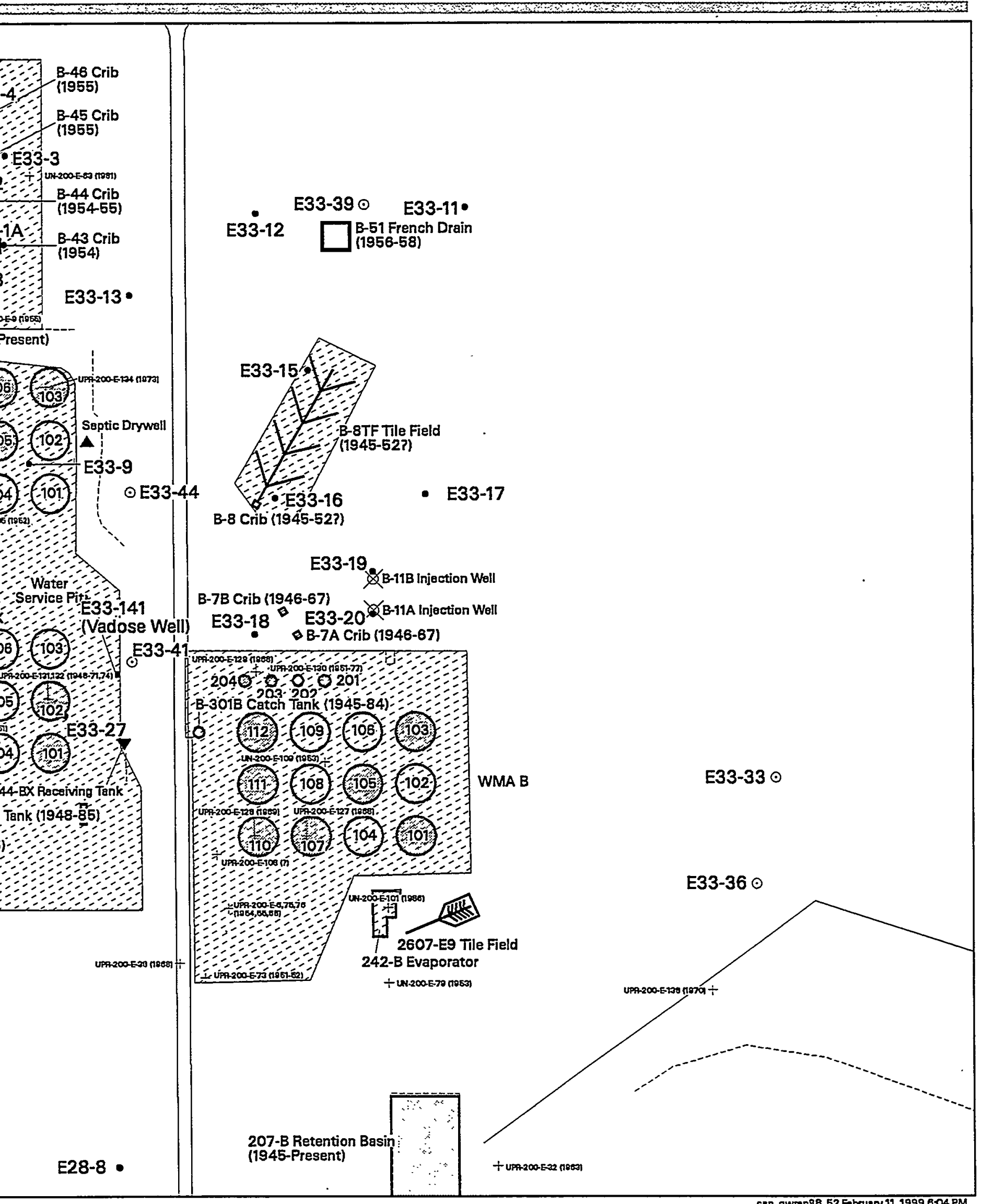

cen_gwrop98_52 Fobruary 91, 1999 6.04 PM

; for Waste Management Area B-BX-BY 
Table A.18. Monitoring Wells and Constituents for Waste Management Areas S-SX and U (adapted from WHC-SD-EN-AP-012, Rev. 1 and WHC-SD-EN-AP-191)

Well

\begin{tabular}{c} 
Well \\
\hline \\
$299-W 22-39^{91}$ \\
$299-W 22-44^{91}$ \\
$299-W 22-45^{92}$ \\
$299-W 22-46^{91}$ \\
$299-W 23-7^{69}$ \\
$299-W 23-13^{90}$ \\
$299-W 23-14^{91}$ \\
$299-W 23-15^{91}$ \\
\\
$299-W 18-25^{90}$ \\
$299-W 18-30^{91}$ \\
$299-W 18-31^{91}$ \\
$299-W 19-12^{12}$ \\
$299-W 19-31^{90}$ \\
$299-W 19-32^{91}$
\end{tabular}

Hydrogeologic Unit
Monitored

Top of unconfined

Top of unconfined

Top of unconfined

Top of unconfined

Top of unconfined

Top of unconfined

Top of unconfined

- Top of unconfined

Top of unconfined

Top of unconfined

Top of unconfined

Top of unconfined

Top of unconfined

Top of unconfined
Sampling
Frequencies

\section{S-SX Single-Shell Tank Farms}

$\begin{array}{ll}\text { Semiannual } & \text { Semiannual } \\ \text { Semiannual } & \text { Semiannual } \\ \text { Semiannual } & \text { Semiannual } \\ \text { Semiannual } & \text { Semiannual } \\ \text { Semiannual } & \text { Semiannual } \\ \text { Semiannual } & \text { Semiannual } \\ \text { Semiannual } & \text { Semiannual } \\ \text { Semiannual } & \text { Semiannual }\end{array}$

U Single-Shell Tank Farm

Quarterly
Semiannual(a)
Quarterly
Quarterly
Quarterly $^{(a)}$
Quarterly $^{(\mathfrak{)})}$

Quarterly
Semiannual
Quarterly
Quarterly
Quarterly
Quarterly(b)

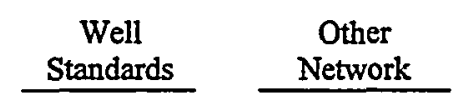

RCRA

RCRA

RCRA

RCRA Surveillance

PRE

RCRA

RCRA

RCRA

$\begin{array}{cc}\text { RCRA } & \text { Surveillance } \\ \text { RCRA } & 200-Z P-1 \\ \text { RCRA } & - \\ \text { PRE } & -\end{array}$

RCRA

Surveillance

RCRA

Surveillance

Contamination Indicator Parameters

Site-Specific Parameters

$\mathrm{pH}$

Specific conductance

Total organic carbon

Total organic halides

\begin{tabular}{ll}
\hline Anions & Phenols \\
Gross alpha $^{(c)}$ & Technetium-99 \\
Gross beta $^{(c)}$ & Tritium \\
ICP metals (filtered) & Turbidity
\end{tabular}

(a) Sampling suspended first half of fiscal year 1998; will be sampled quarterly in fiscal year 1999.

(b) Dry September 1998. Will be replaced by well 299-W19-41 in fiscal year 1999. Well 299-W19-42 also will be added to network in fiscal year 1999.

(c) For WMA U.

Shading = Upgradient wells.

Superscript $=$ Year of installation.

PRE = Well not constructed to RCRA standards.

RCRA = Well constructed to RCRA standards. 


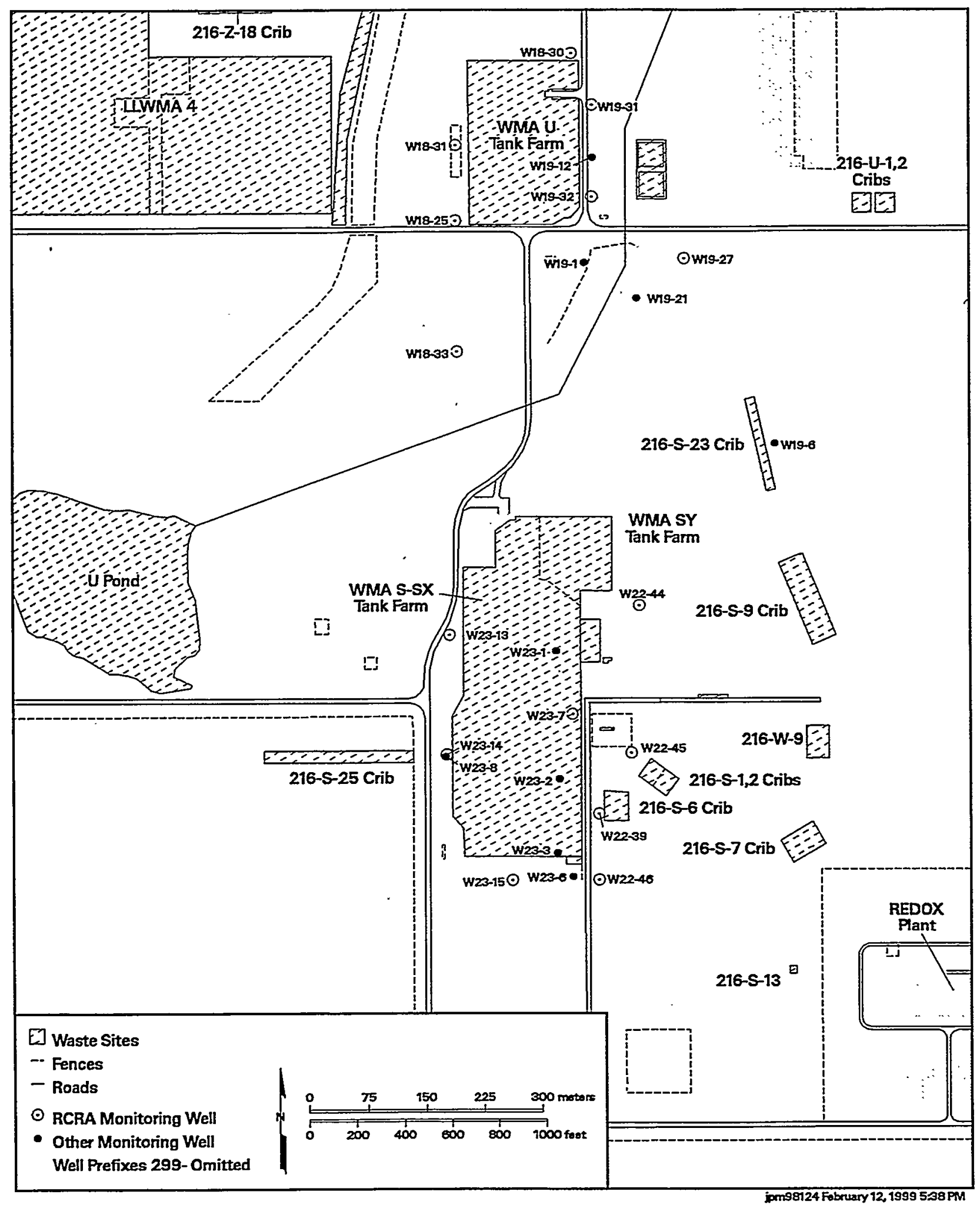

Figure A.18. Monitoring Well Locations for Waste Management Areas S-SX and U 
Table A.19a. Monitoring Wells and Constituents for Waste Management Area T (adapted from WHC-SD-EN-AP-012, Rev. 1 and WHC-SD-EN-AP-132)

\begin{tabular}{|c|c|c|c|c|c|}
\hline Well & $\begin{array}{l}\text { Hydrogeologic Unit } \\
\text { Monitored }\end{array}$ & $\begin{array}{l}\text { Sampling } \\
\text { Frequency }\end{array}$ & $\begin{array}{l}\text { Water-Level } \\
\text { Measurement }\end{array}$ & $\begin{array}{c}\text { Well } \\
\text { Standards }\end{array}$ & $\begin{array}{c}\text { Other } \\
\text { Networks }\end{array}$ \\
\hline $299-W 6-2^{87(2)}$ & Top of unconfined & Quarterly $^{(b)}$ & - & RCRA & $\begin{array}{l}\text { LLWMA 3, } \\
\text { Surveillance }\end{array}$ \\
\hline $299-W 6-4^{91(a)}$ & Top of unconfined & Quarterly ${ }^{(b)}$ & - & $\mathrm{RCRA}$ & - \\
\hline $299-W 6-9^{92(a)}$ & Top of unconfined & Quarterly ${ }^{(b)}$ & - & RCRA & -- \\
\hline $299-W 10-8^{73}$ & Top of unconfined & Quarterly & Quarterly & PRE & -- \\
\hline $299-W 10-9^{73}$ & Top of unconfined & - & Quarterly & PRE & - \\
\hline $299-W 10-11^{74}$ & Top of unconfined & - & Quarterly & PRE & - \\
\hline $299-W 10-12^{74}$ & Top of unconfined & Quarterly $^{(b)}$ & Quarterly & PRE & Surveillance \\
\hline $299-W 10-16^{89}$ & Top of unconfined & Quarterly $^{(\mathfrak{c})}$ & Quarterly & RCRA & Surveillance \\
\hline $299-W 10-19^{92(a)}$ & Top of unconfined & Quarterly $^{(b)}$ & - & RCRA & LLWMA 3 \\
\hline $299-W 10-20^{93(a)}$ & Top of unconfined & Quarterly $^{(b)}$. & - & RCRA & LLWMA 3 \\
\hline $299-W 10-21^{93(a)}$ & Top of unconfined & Quarterly $^{(b)}$ & -- & $\mathrm{RCRA}$ & LLWMA 3 \\
\hline $299-W 11-23^{73}$ & Top of unconfined & Quarterly & Quarterly & PRE & - \\
\hline $299-W 11-24^{73}$ & Top of unconfined & Quarterly & Quarterly & PRE & - \\
\hline $299-W 11-27^{91}$ & Top of unconfined & Quarterly & Quarterly & RCRA & - \\
\hline $299-W 11-28^{91}$ & Top of unconfined & Quarterly & Quarterly & $\mathrm{RCRA}$ & Surveillance \\
\hline $299-W 11-31^{92(a)}$ & Top of unconfined & Quarterly ${ }^{(b)}$ & - & RCRA & - \\
\hline \multicolumn{2}{|c|}{ Contamination Indicator Parameters } & \multicolumn{4}{|c|}{ Site-Specific Parameters } \\
\hline \multicolumn{2}{|l|}{$\mathrm{pH}$} & \multicolumn{2}{|c|}{ Ammonium } & \multicolumn{2}{|c|}{ ICP metals (filtered) } \\
\hline \multicolumn{2}{|c|}{ Specific conductance } & \multicolumn{2}{|l|}{ Anions } & \multicolumn{2}{|c|}{ Iodine-129 } \\
\hline \multicolumn{2}{|c|}{ Total organic carbon } & \multicolumn{2}{|c|}{ Cesium-137 } & \multicolumn{2}{|l|}{ Phenols } \\
\hline \multicolumn{2}{|c|}{ Total organic halides } & \multicolumn{2}{|c|}{ Cobalt- 60} & \multicolumn{2}{|c|}{ Technetium-99 } \\
\hline & & \multicolumn{2}{|c|}{ Gamma scan } & \multicolumn{2}{|l|}{ Tritium } \\
\hline & & \multicolumn{2}{|c|}{ Gross alpha } & \multicolumn{2}{|c|}{ Turbidity } \\
\hline \multicolumn{6}{|c|}{ Gross beta } \\
\hline
\end{tabular}

(a) Wells used for expanded assessment monitoring.

(b) Will be sampled semiannually in fiscal year 1999.

(c) Will not be sampled for RCRA in fiscal year 1999.

Shading = Upgradient well.

Superscript $=$ Year of installation.

LLWMA = Low-level waste management area.

PRE = Well not constructed to RCRA standards.

RCRA = Well constructed to RCRA standards. 
Table A.19b: Monitoring Wells and Constituents for Waste Management Area TX-TY (adapted from WHC-SD-EN-AP-012, Rev. 1 and WHC-SD-EN-AP-132)

\begin{tabular}{|c|c|c|c|c|c|}
\hline Well & $\begin{array}{l}\text { Hydrogeologic Unit } \\
\text { Monitored }\end{array}$ & $\begin{array}{l}\text { Sampling } \\
\text { Frequency }\end{array}$ & $\begin{array}{l}\text { Water-Level } \\
\text { Measurement }\end{array}$ & $\begin{array}{c}\text { Well } \\
\text { Standards } \\
\end{array}$ & $\begin{array}{c}\text { Other } \\
\text { Networks }\end{array}$ \\
\hline $299-W 6-2^{87(a)}$ & Top of unconfined & Quarterly ${ }^{(b)}$ & - & RCRA & $\begin{array}{l}\text { LLWMA } 3 \text {, } \\
\text { WMA T, } \\
\text { Surveillance }\end{array}$ \\
\hline $299-W 6-4^{91(a)}$ & Top of unconfined & Quarterly ${ }^{(0)}$ & - & RCRA & WMA T \\
\hline $299-W 6-9^{92(a)}$ & Top of unconfined & Quarterly ${ }^{(b)}$ & - & $\mathrm{RCRA}$ & WMA T \\
\hline $299-W 10-17^{91}$ & Top of unconfined & Quarterly & Quarterly & RCRA & - \\
\hline $299-\mathrm{W} 10-18^{90}$ & Top of unconfined & Quarterly & Quarterly & RCRA & - \\
\hline 299-W10-1922(a) & Top of unconfined & Quarterly ${ }^{(b)}$ & - & RCRA & $\begin{array}{l}\text { LLWMA 3, } \\
\text { WMA T }\end{array}$ \\
\hline $299-W 10-20^{93(a)}$ & Top of unconfined & Quarterly ${ }^{(6)}$ & - & RCRA & $\begin{array}{l}\text { LLWMA } 3 \\
\text { WMA T }\end{array}$ \\
\hline $299-W 10-21^{93(a)}$ & Top of unconfined & Quarterly ${ }^{(\mathfrak{)})}$ & - & RCRA & $\begin{array}{l}\text { LLWMA } 3 \text {, } \\
\text { WMA T }\end{array}$ \\
\hline $299-W 11-31^{92(a)}$ & Top of unconfined & Quarterly ${ }^{(b)}$ & - & RCRA & WMA T \\
\hline $299-W 14-12^{91}$ & Top of unconfined & Quarterly & Quarteriy & RCRA & - \\
\hline $299-W 15-12^{73}$ & Top of unconfined & - & Quarterly & PRE & Surveillance \\
\hline $299-W 15-13^{73}$ & Top of unconfined & - & Quarterly & PRE & - \\
\hline $299-W 15-22^{91}$ & Top of unconfined & Quarterly & Quarterly & $\mathrm{RCRA}$ & - \\
\hline \multicolumn{2}{|c|}{ Contamination Indicator Parameters } & & \multicolumn{3}{|c|}{ Site-Specific Parameters } \\
\hline $\mathrm{pH}$ & & & Ammonium & $\mathrm{ICP} \mathrm{m}$ & (filtered) \\
\hline Specific conductance & & & Anions & Iodine & \\
\hline Total organic carbon & & & Cesium-137 & Phenol & \\
\hline \multirow[t]{4}{*}{ Total organic halides } & & & Cobalt-60 & Techn & $n-99$ \\
\hline & & & Gamma scan & Tritiun & \\
\hline & & & Gross alpha & Turbid & \\
\hline & & & Gross beta & & \\
\hline
\end{tabular}

(a) Wells used for expanded assessment monitoring.

(b) Will be sampled semiannually in fiscal year 1999.

Shading = Upgradient well.

Superscript $=$ Year of installation.

LLWMA = Low-level waste management area.

PRE = Well not constructed to RCRA standards.

RCRA = Well constructed to RCRA standards.

WMA = Waste management area. 
This page intentionally left blank. 


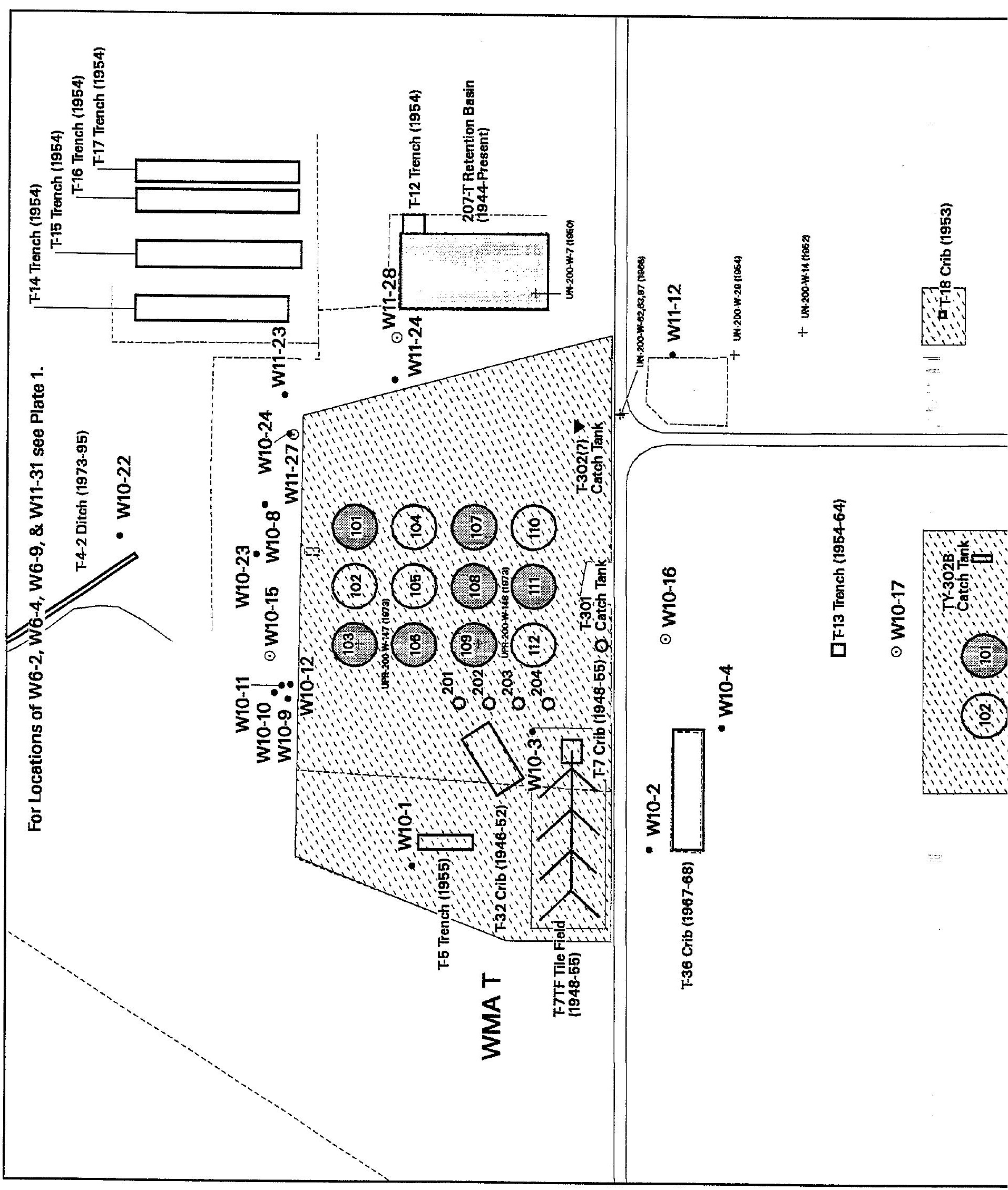


This page intentionally left blank. 
Table A.20a. Monitoring Wells and Constituents for Solid Waste Landfill (adapted from WHC-SD-EN-AP-043)

\begin{tabular}{|c|c|c|c|c|c|}
\hline Well & $\begin{array}{l}\text { Hydrogeologic Unit } \\
\text { Monitored }\end{array}$ & $\begin{array}{l}\text { Sampling } \\
\text { Frequency }\end{array}$ & $\begin{array}{l}\text { Water-Level } \\
\text { Measurement }\end{array}$ & $\begin{array}{c}\text { Well } \\
\text { Standards }\end{array}$ & $\begin{array}{c}\text { Other } \\
\text { Networks }\end{array}$ \\
\hline $699-22-35^{93}$ & Top of unconfined & Quarterly & Quarterly & $\mathrm{RCRA}$ & - \\
\hline $699-23-34 A^{87}$ & Top of unconfined & Quarterly & Quarterly & RCRA & - \\
\hline $699-23-34 \mathrm{~B}^{93}$ & Top of unconfined & Quarterly & Quarterly & RCRA & - \\
\hline $699-24-33^{48}$ & Top of unconfined & Quarterly ${ }^{(a)}$ & Quarterly & PRE & - \\
\hline $699-24-34 A^{87}$ & Top of unconfined & Quarterly & Quarterly & $\mathrm{RCRA}$ & - \\
\hline $699-24-34 \mathrm{~B}^{87}$ & Top of unconfined & Quarterly & Quarterly & $\mathrm{RCRA}$ & - \\
\hline $699-24-34 C^{87}$ & Top of unconfined & Quarterly & Quarterly & RCRA & - \\
\hline $699-24-35^{87}$ & Top of unconfined & Quarterly & Quarterly & RCRA & - \\
\hline $699-25-34 C^{87}$ & Top of unconfined & Quarterly. & Quarterly & $\mathrm{RCRA}$ & - \\
\hline $699-26-35 A^{86}$ & Top of unconfined & Quarterly & Quarterly & RCRA & $\begin{array}{l}\text { NRDWL, } \\
\text { Surveillance }\end{array}$ \\
\hline
\end{tabular}

Parameters/Constituents Required by WAC 173-304-490

Site-Specific Constituents

$\begin{array}{llll}\text { Ammonia as nitrogen } & \text { Nitrate } & \text { Total organic halides } & \text { Trichloroethylene } \\ \text { Chemical oxygen demand } & \text { Nitrite } & 1,1,1-\text { Trichloroethane } & \text { Tritium } \\ \text { Chloride } & \mathrm{pH} & & \\ \text { Specific conductance } & \text { Sulfate } & & . \\ \text { Dissolved iron } & \text { Temperature } & & \\ \text { Dissolved zinc } & \text { Total coliform } & & \\ \text { Manganese } & \text { Total organic carbon } & \end{array}$

(a) Well sampled for supporting data.

Shading = Upgradient wells.

Superscript $=$ Year of installation.

NRDWL = Nonradioactive Dangerous Waste Landfill.

PRE = Well not constructed to RCRA standards.

RCRA = Well constructed to RCRA standards. 
Table A.20b. Monitoring Wells and Constituents for Nonradioactive Dangerous Waste Landfill (adapted from WHC-SD-EN-AP-026)

\begin{tabular}{|c|c|c|c|c|c|}
\hline Well & $\begin{array}{l}\text { Hydrogeologic Unit } \\
\text { Monitored } \\
\end{array}$ & $\begin{array}{c}\text { Sampling } \\
\text { Frequencies }\end{array}$ & $\begin{array}{l}\text { Water-Level } \\
\text { Measurement }\end{array}$ & $\begin{array}{c}\text { Well } \\
\text { Standard } \\
\end{array}$ & $\begin{array}{c}\text { Other } \\
\text { Network }\end{array}$ \\
\hline $699-25-33 A^{87}$ & Top of $L P U^{(a)}$ & Semiannual & Semiannual & RCRA & -- \\
\hline $699-25-34 A^{85}$ & Top of unconfined & Semiannual & Quarterly & RCRA & - \\
\hline $699-25-34 \mathrm{~B}^{86}$ & Top of unconfined & Semiannual & Semiannual & RCRA & - \\
\hline $699-25-34 D^{92}$ & Top of unconfined & Quarterly & Semiannual & RCRA & - \\
\hline $699-26-33^{86}$ & Top of unconfined & Semiannual & Semiannual & RCRA & -- \\
\hline $699-26-34 A^{92}$ & Top of unconfined & Semiannual & Quarterly & RCRA & - \\
\hline $699-26-34 \mathrm{~B}^{92}$ & Top of unconfined & Quarterly & Quarterly & RCRA & - \\
\hline $699-26-35 A^{86}$ & Top of unconfined & Semiannual & Quarterly & RCRA & $\begin{array}{l}\text { SWL, } \\
\text { Surveillance }\end{array}$ \\
\hline $699-26-35 C^{87}$ & Top of $L P U^{(a)}$ & Semiannual & Semiannual & RCRA & - \\
\hline
\end{tabular}

Contamination Indicator Parameters

$\mathrm{pH}$

Specific conductance

Total organic carbon

Total organic halides
Site-Specific Parameters

$\begin{array}{ll}\text { Anions } & \text { Phenols } \\ \text { Coliform bacteria } & \text { Tritium } \\ \text { Gross alpha } & \text { Turbidity } \\ \text { Gross beta } & \text { Volatile chlorinated hydrocarbons } \\ \text { ICP metals (filtered) } & \end{array}$

(a) Low-permeability unit in upper Ringold Formation.

Shading = Upgradient wells.

Superscript $=$ Year of installation.

RCRA = Well constructed to RCRA standards.

SWL $\quad=$ Solid Waste Landfill. 


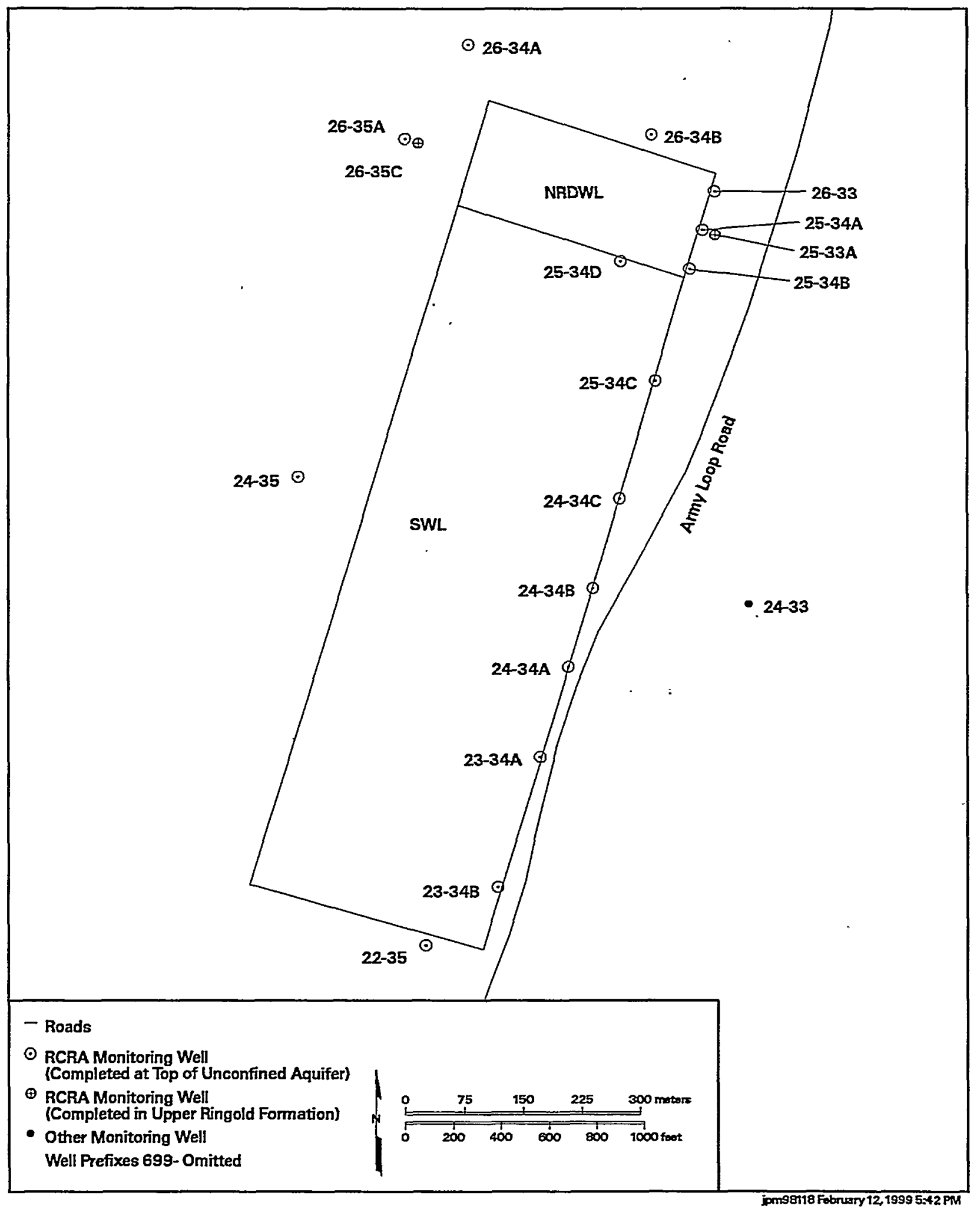

Figure A.20. Monitoring Well Locations for Solid Waste Landfill and Nonradioactive Dangerous Waste Landfill 
Table A.21. Monitoring Wells and Constituents for 316-5 Process Trenches (adapted from WHC-SD-EN-AP-185)

\begin{tabular}{|c|c|c|c|c|c|}
\hline Well & $\begin{array}{l}\text { Hydrogeologic Unit } \\
\text { Monitored }\end{array}$ & $\begin{array}{l}\text { Sampling } \\
\text { Frequency }\end{array}$ & $\begin{array}{l}\text { Water-Level } \\
\text { Measurement }{ }^{\left({ }^{2}\right)}\end{array}$ & $\begin{array}{c}\text { Well } \\
\text { Standard } \\
\end{array}$ & $\begin{array}{c}\text { Other } \\
\text { Networks }\end{array}$ \\
\hline $399-1-10 A^{86}$ & Top of unconfined & Semiannual & Semiannually & RCRA & Surveillance \\
\hline $399-1-10 \mathrm{~B}^{91}$ & Bottom of unconfined & Semiannual & Semiannually & RCRA & Surveillance \\
\hline $399-1-16 A^{86}$ & Top of unconfined & Semiannual & Semiannually & RCRA & Surveillance \\
\hline $399-1-16 B^{87}$ & Bottom of unconfined & Semiannual & Semiannually & RCRA & Surveillance \\
\hline $399-1-17 A^{86}$ & Top of unconfined & Semiannual & Semiannually & RCRA & $\begin{array}{l}\text { Surveillance, } \\
\text { DOH }\end{array}$ \\
\hline $399-1-17 B^{86}$ & Bottom of unconfined & Semiannual & Semiannually & RCRA & Surveillance \\
\hline $399-1-18 A^{86}$ & Top of unconfined & Semiannual & Semiannually & RCRA & Surveillance \\
\hline $399-1-18 \mathrm{~B}^{87}$ & Bottom of unconfined & Semiannual & Semiannually & RCRA & - \\
\hline \multicolumn{2}{|c|}{ Field-Measured Parameters } & \multicolumn{4}{|c|}{ Site-Specific Parameters } \\
\hline \multicolumn{2}{|l|}{$\mathrm{pH}$} & \multicolumn{2}{|c|}{ Benzo(a)pyrene ${ }^{(b)}$} & \multicolumn{2}{|c|}{ Manganese $^{(\mathrm{c}, \mathrm{d})}$} \\
\hline \multicolumn{2}{|c|}{ Specific conductance } & \multicolumn{2}{|c|}{ Chrysene $^{(\text {b) }}$} & \multicolumn{2}{|c|}{ Polychlorinated biphenyls ${ }^{(b)}$} \\
\hline \multicolumn{2}{|l|}{ Temperature } & \multicolumn{2}{|c|}{ cis-Dichloroethylene } & \multicolumn{2}{|c|}{ Thallium $^{(b)}$} \\
\hline \multirow[t]{3}{*}{ Turbidity } & & \multicolumn{2}{|c|}{ Dissolved oxygen $^{(c)}$} & \multicolumn{2}{|c|}{ Trichloroethylene } \\
\hline & & \multicolumn{2}{|c|}{$E^{(c)}$} & \multicolumn{2}{|l|}{ Uranium } \\
\hline & & \multicolumn{2}{|c|}{$\operatorname{Iron}^{(c d)}$} & & \\
\hline
\end{tabular}

(a) Sampled.and measured monthly for 4 months for each semiannual sampling period.

(b) Analyzed first 2 years. Completed during second quarter 1998.

(c) Deep wells only for 2 years. Completed during second quarter 1998.

(d) Filtered samples.

Shading = Upgradient wells.

Superscript $=$ Year of installation.

$\mathrm{DOH}=$ State of Washington Department of Health.

RCRA = Well constructed to RCRA standards. 


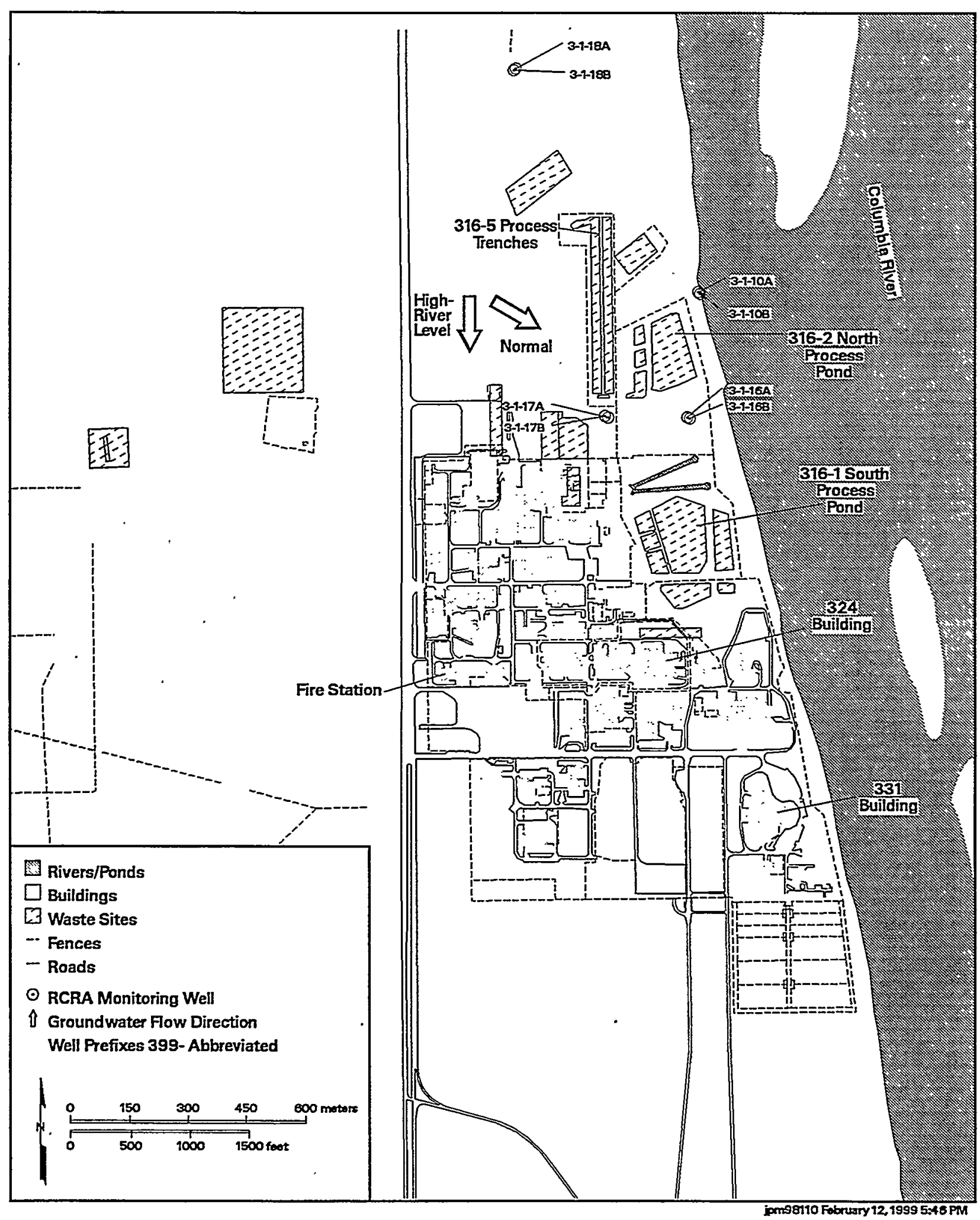

Figure A.21. Monitoring Well Locations for 316-5 Process Trenches 
Table A.22. Tritium Tracking Network for State-Approved Land-Disposal System (adapted from WHC-SDD-C018H-PLN-004, Rev. 1)

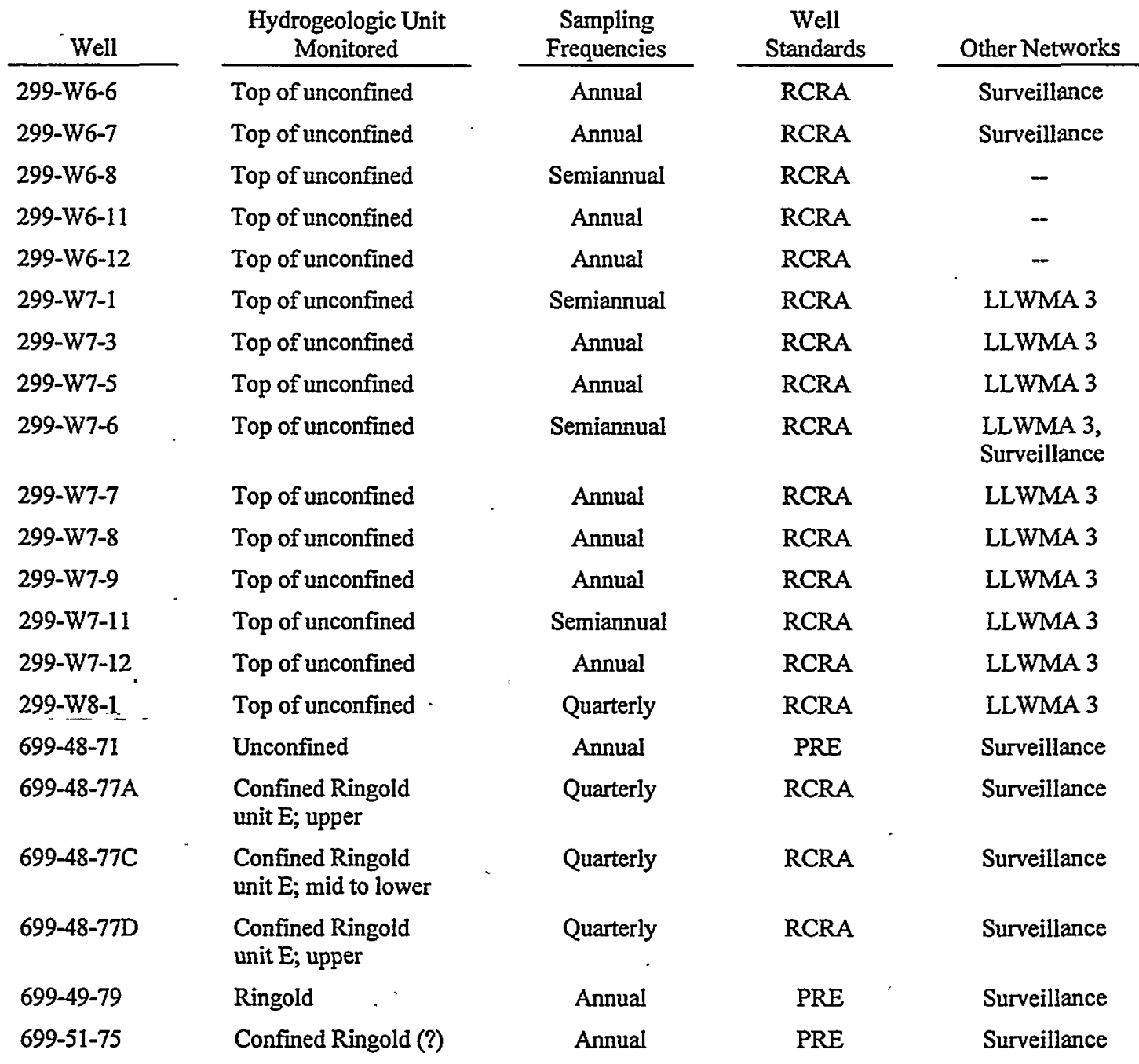

Shading $=$ Upgradient well.

LLWMA = Low-level waste management area.

PRE = Well not constructed to RCRA standards.

RCRA = Well constructed to RCRA standards. 


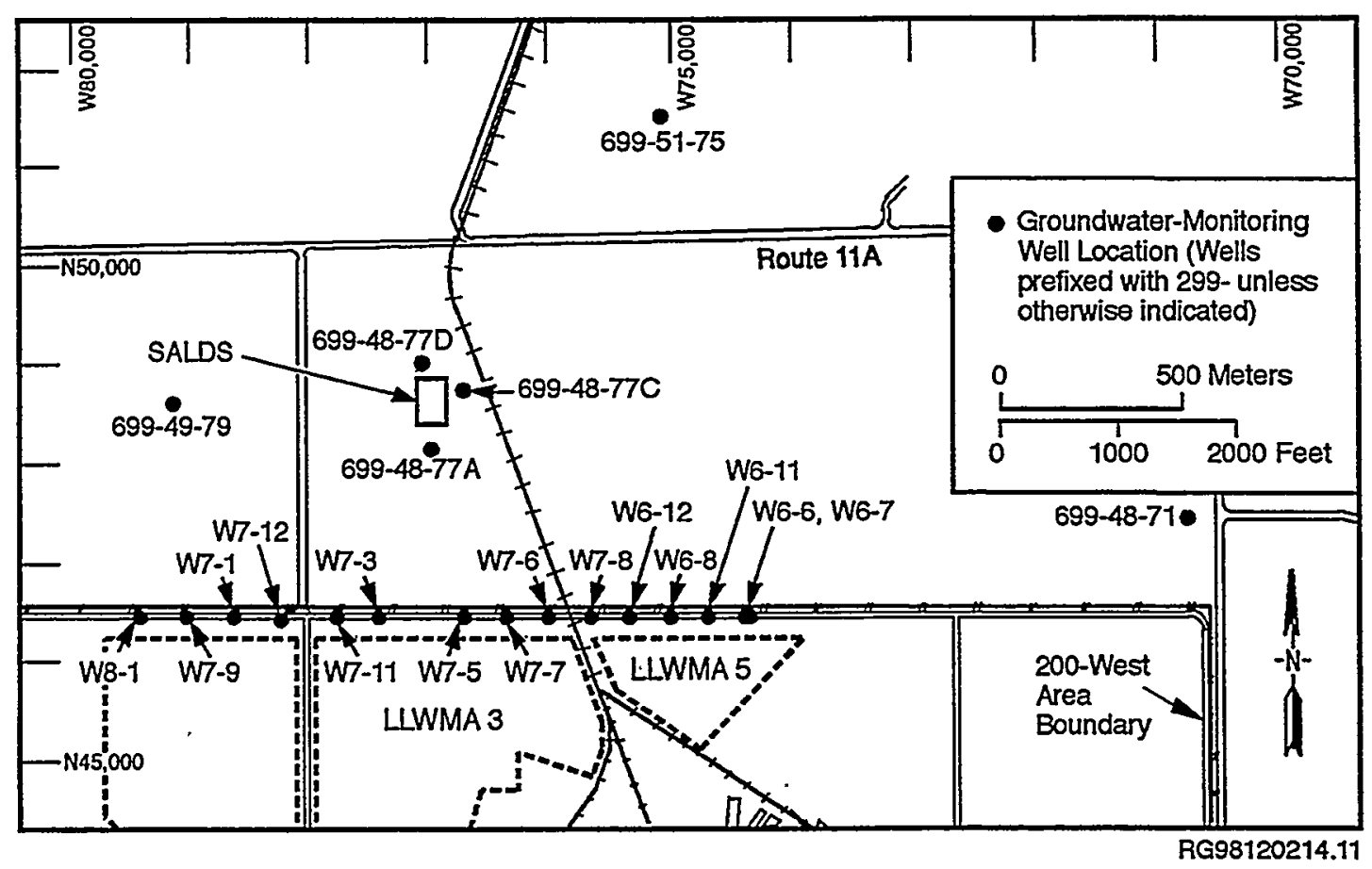

Figure A.22. Tritium Tracking Network for State-Approved Land-Disposal Site 
Table A.23. Monitoring Wells for 200 Areas Treated Effluent-Disposal Facility (adapted from WHC-SD-EN-WP-012, Rev. 1)

\begin{tabular}{|c|c|c|c|c|}
\hline Well & $\begin{array}{l}\text { Hydrogeologic Unit } \\
\text { Monitored }\end{array}$ & $\begin{array}{l}\text { Sampling } \\
\text { Frequency }\end{array}$ & Well Standard & Other Network \\
\hline $699-40-36$ & Confined Ringold & Quarterly & RCRA & 216-B-3 pond \\
\hline $699-41-35$ & Confined Ringold & Quarterly & $\mathrm{RCRA}$ & - \\
\hline $699-42-37$ & Confined Ringold & Quarterly & RCRA & .216-B-3 pond \\
\hline
\end{tabular}

Shading = Upgradient well.

RCRA = Well constructed to RCRA standards. 


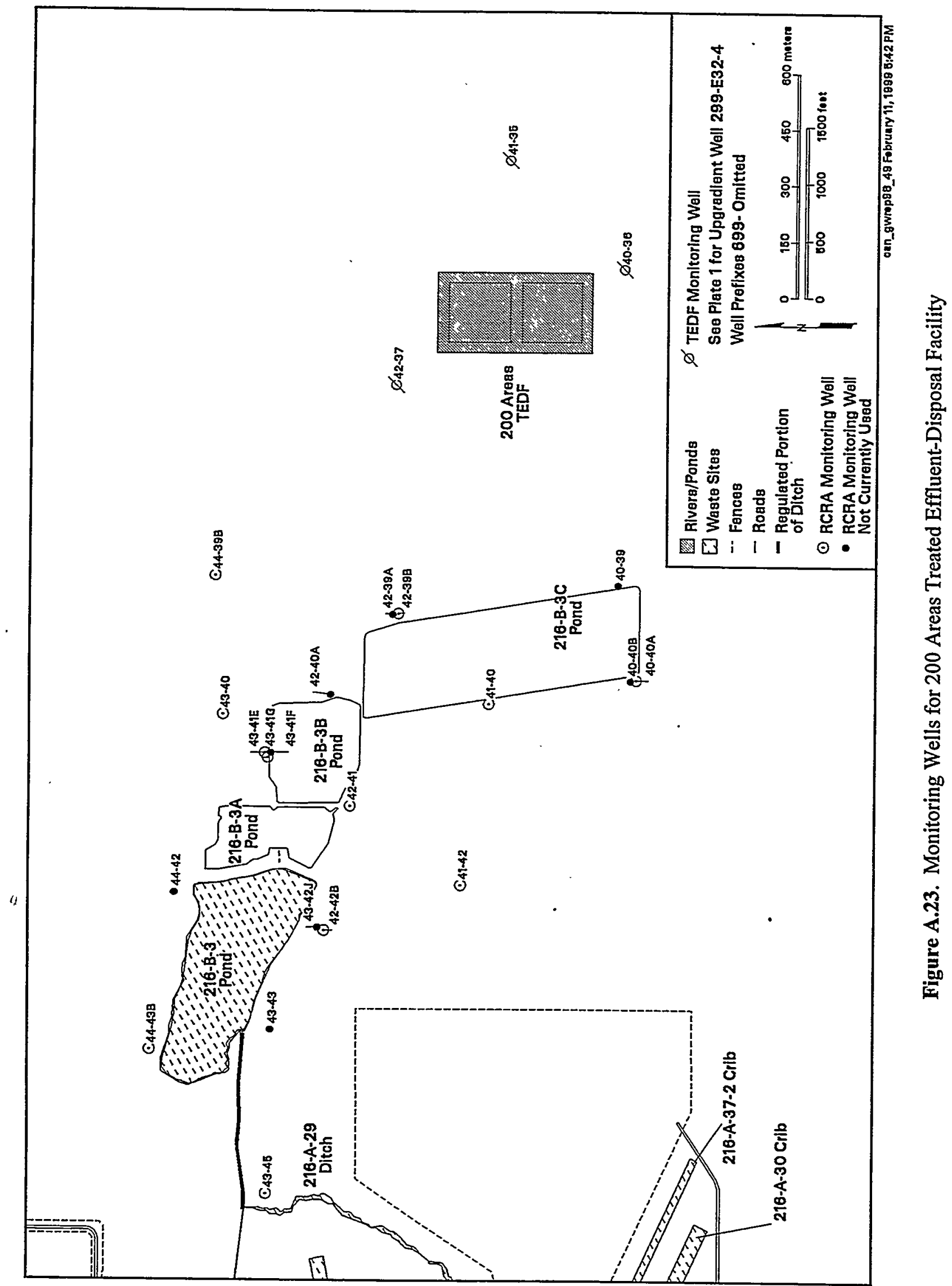


Table A.24. Monitoring Wells and Constituents for 400 Area Process Ponds

\begin{tabular}{|c|c|c|c|c|c|}
\hline Well & $\begin{array}{c}\text { Hydrogeologic Unit } \\
\text { Monitored }\end{array}$ & $\begin{array}{l}\text { Sampling } \\
\text { Frequency } \\
\end{array}$ & $\begin{array}{c}\text { Water-Level } \\
\text { Measurements }\end{array}$ & $\begin{array}{c}\text { Well } \\
\text { Standards } \\
\end{array}$ & $\begin{array}{c}\text { Other } \\
\text { Network } \\
\end{array}$ \\
\hline $699-2-6 A^{97}$ & Unconfined aquifer & Quarterly & Annual & RCRA & Surveillance \\
\hline $699-2-7^{78}$ & Unconfined aquifer & Quarterly & Annual & PRE & Surveillance \\
\hline $699-8-17^{50}$ & Unconfined aquifer & Quarterly & Semiannual & PRE & Surveillance \\
\hline \multicolumn{2}{|c|}{ Field-Measured Parameters } & & \multicolumn{3}{|c|}{ Site-Specific Parameters } \\
\hline \multicolumn{3}{|l|}{$\mathrm{pH}$} & \multirow[b]{2}{*}{ Cadmium (unfiltered) } & \multicolumn{2}{|c|}{ Mercury (unfiltered) } \\
\hline \multicolumn{2}{|c|}{ Specific conductance } & & & \multicolumn{2}{|l|}{$\mathrm{pH}$} \\
\hline \multicolumn{2}{|l|}{ Temperature } & & Chromium (unfiltered) & \multicolumn{2}{|c|}{ Sulfate } \\
\hline \multirow[t]{2}{*}{ Turbidity } & & & \multirow{2}{*}{$\begin{array}{l}\text { Lead (unfiltered) } \\
\text { Manganese (unfiltered) }\end{array}$} & \multicolumn{2}{|c|}{ Total Dissolved Solids } \\
\hline & & & & \multicolumn{2}{|c|}{ Total organic carbon } \\
\hline
\end{tabular}

Shading = Upgradient wells.

Superscript $=$ Year of installation.

PRE = Well not constructed to RCRA standards.

RCRA = Well constructed to RCRA standards. 


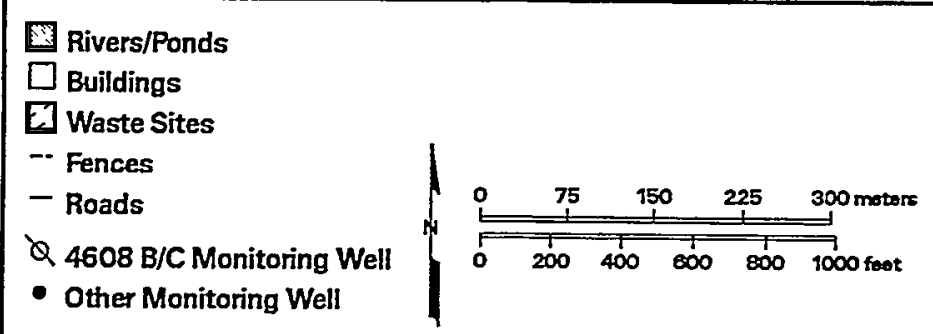

Rivers/Ponds

$\square$ Buildings

E] Waste Sites

-- Fences

Q 4608 B/C Monitoring Well

- Other Monitoring Well

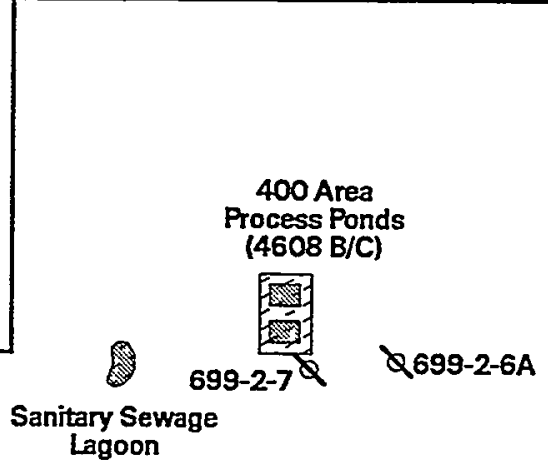

[

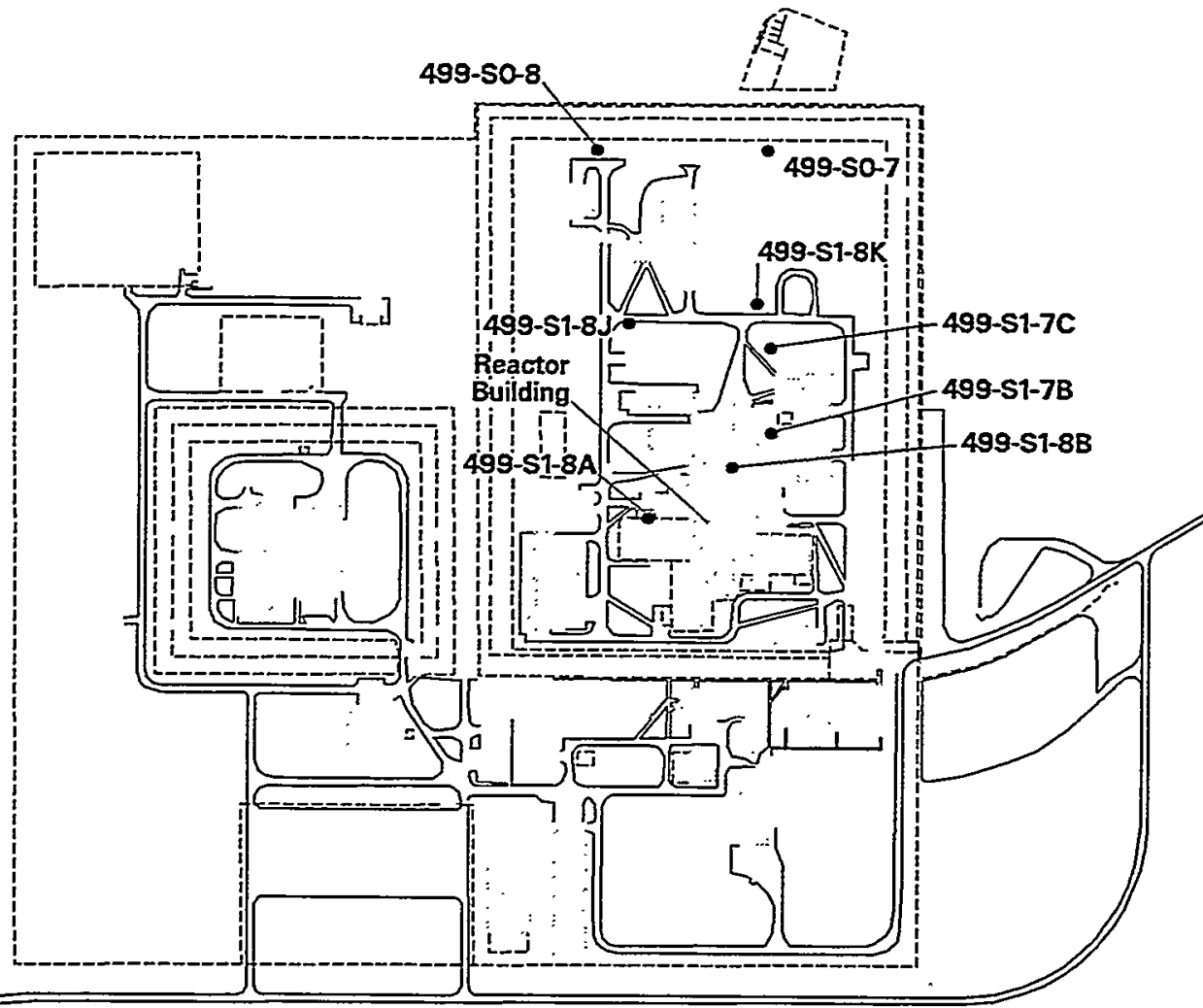

ipro8052 Fabruary 12, $19995: 49$ PM

Figure A.24. Monitoring Wells for 400 Area Process Ponds 


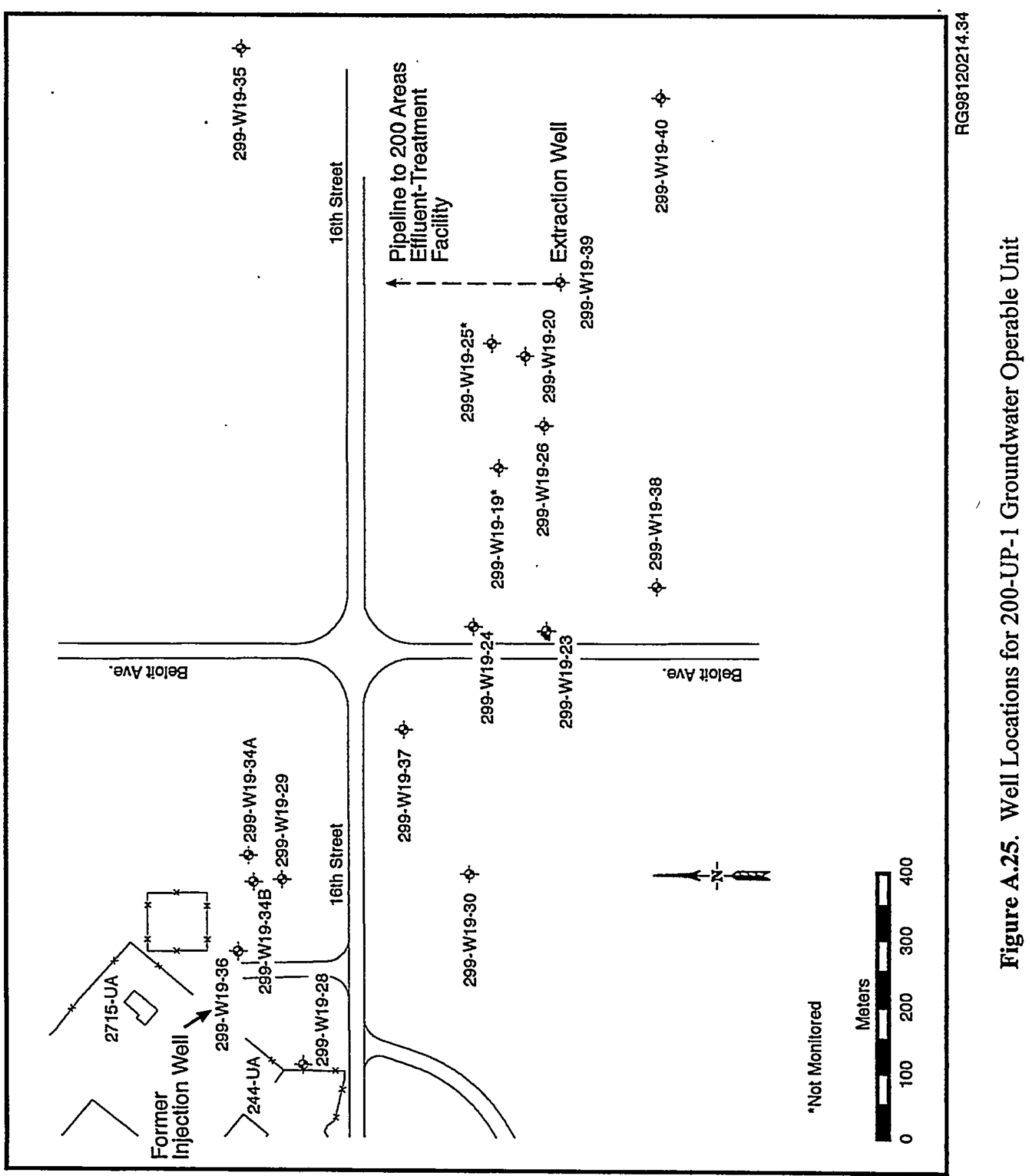




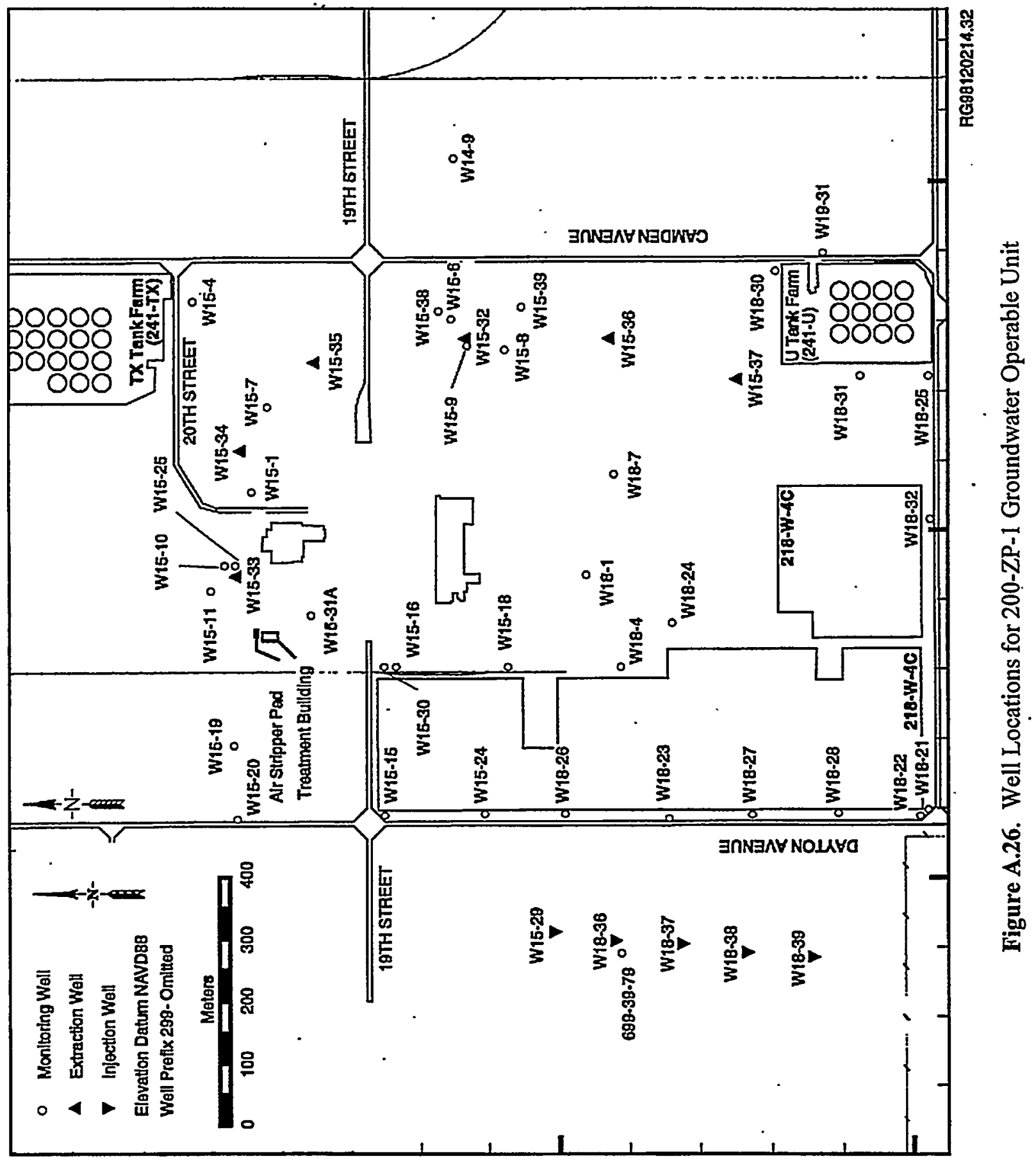


Table A.25. RCRA-Monitoring Results Exceeding Maximum Contaminant Levels

\begin{tabular}{|c|c|c|c|c|c|c|}
\hline Constituent, unit ${ }^{(a)}$ & Filter $^{(\text {) })}$ & Well Name & $\begin{array}{c}\text { Upgradient/ } \\
\text { Downgradient }\end{array}$ & $\begin{array}{c}\text { Number of } \\
\text { Exceedances }\end{array}$ & $\begin{array}{c}\text { Maximum } \\
\text { Result }\end{array}$ & $\begin{array}{l}\text { Drinking } \\
\text { Water } \\
\text { Standard }\end{array}$ \\
\hline \multicolumn{7}{|c|}{ 100-N Area } \\
\hline Aluminum, $\mu \mathrm{g} / \mathrm{L}$ & $\mathbf{Y}$ & $199-\mathrm{N}-81$ & Down & 1 & 160 & 50 \\
\hline Antimony, $\mu \mathrm{g} / \mathrm{L}$ & $\mathrm{Y}$ & $199-N-59$ & Down & 1 & 44.8 & 6 \\
\hline Gross beta, $\mathrm{pCi} / \mathrm{L}$ & $\begin{array}{l}N \\
N \\
N\end{array}$ & $\begin{array}{l}199-N-2 \\
199-N-3 \\
199-N-81\end{array}$ & $\begin{array}{l}\text { Down } \\
\text { Down } \\
\text { Down }\end{array}$ & $\begin{array}{l}2 \\
2 \\
2\end{array}$ & $\begin{array}{l}1,150 \\
5,310 \\
2,740\end{array}$ & $\begin{array}{l}50 \\
50 \\
50\end{array}$ \\
\hline Nitrogen in nitrate, $\mu \mathrm{g} / \mathrm{L}$ & $\begin{array}{l}\mathrm{N} \\
\mathrm{N} \\
\mathrm{N} \\
\mathrm{N} \\
\mathrm{N} \\
\mathrm{N} \\
\mathrm{N}\end{array}$ & $\begin{array}{l}199-N-105 A \\
199-N-2 \\
199-N-3 \\
199-N-32 \\
199-N-59 \\
199-N-72 \\
199-N-81\end{array}$ & $\begin{array}{l}\text { Down } \\
\text { Down } \\
\text { Down } \\
\text { Down } \\
\text { Down } \\
\text { Down } \\
\text { Down }\end{array}$ & $\begin{array}{l}1 \\
4 \\
1 \\
2 \\
3 \\
1 \\
3\end{array}$ & $\begin{array}{l}15,800 \\
28,900 \\
10,900 \\
10,700 \\
18,200 \\
11,000 \\
14,500\end{array}$ & $\begin{array}{l}10,000 \\
10,000 \\
10,000 \\
10,000 \\
10,000 \\
10,000 \\
10,000\end{array}$ \\
\hline Strontium-90, $\mathrm{pCi} / \mathrm{L}$ & $\begin{array}{l}\mathrm{N} \\
\mathrm{N} \\
\mathrm{N} \\
\mathrm{N} \\
\mathrm{N} \\
\mathrm{N}\end{array}$ & $\begin{array}{l}199-N-2 \\
199-N-28 \\
199-N-3 \\
199-N-34 \\
199-N-57 \\
199-N-81\end{array}$ & $\begin{array}{l}\text { Down } \\
\text { Up } \\
\text { Down } \\
\text { Up } \\
\text { Up } \\
\text { Down }\end{array}$ & $\begin{array}{l}2 \\
1 \\
2 \\
1 \\
1 \\
3\end{array}$ & $\begin{array}{r}606 \\
189 \\
2,500 \\
46.2 \\
22 \\
1,300\end{array}$ & $\begin{array}{l}8 \\
8 \\
8 \\
8 \\
8 \\
8\end{array}$ \\
\hline Sulfate, $\mu g / L$ & $\begin{array}{l}N \\
N \\
N \\
N\end{array}$ & $\begin{array}{l}199-\mathrm{N}-3 \\
199-\mathrm{N}-59 \\
199-\mathrm{N}-72 \\
199-\mathrm{N}-73\end{array}$ & $\begin{array}{l}\text { Down } \\
\text { Down } \\
\text { Down } \\
\text { Down }\end{array}$ & $\begin{array}{l}1 \\
3 \\
1 \\
2\end{array}$ & $\begin{array}{l}260,000 \\
366,000 \\
269,000 \\
372,000\end{array}$ & $\begin{array}{l}250,000 \\
250,000 \\
250,000 \\
250,000\end{array}$ \\
\hline Tritium, $\mathrm{pCi} / \mathrm{L}$ & $\begin{array}{l}N \\
N \\
N\end{array}$ & $\begin{array}{l}199-N-2 \\
199-N-32 \\
199-N-81\end{array}$ & $\begin{array}{l}\text { Down } \\
\text { Down } \\
\text { Down }\end{array}$ & $\begin{array}{l}2 \\
2 \\
2\end{array}$ & $\begin{array}{l}38,300 \\
49,500 \\
25,100\end{array}$ & $\begin{array}{l}20,000 \\
20,000 \\
20,000\end{array}$ \\
\hline \multicolumn{7}{|c|}{ 120-D-1 Ponds } \\
\hline Aluminum, $\mu \mathrm{g} / \mathrm{L}$ & $\mathbf{N}$ & 199-D5-13 & Up & 1 & 253 & 50 \\
\hline Chromium, $\mu \mathrm{g} / \mathrm{L}$ & $\begin{array}{l}\mathrm{Y} \\
\mathrm{N} \\
\mathrm{Y} \\
\mathrm{Y}\end{array}$ & $\begin{array}{l}\text { 199-D5-13 } \\
\text { 199-D5-13 } \\
\text { 199-D8-5 } \\
199-D 8-6\end{array}$ & $\begin{array}{c}\text { Up } \\
\text { Up } \\
\text { Down } \\
\text { Down }\end{array}$ & $\begin{array}{l}2 \\
1 \\
2 \\
1\end{array}$ & $\begin{array}{l}364 \\
353 \\
126 \\
132\end{array}$ & $\begin{array}{l}100 \\
100 \\
100 \\
100\end{array}$ \\
\hline Iron, $\mu \mathrm{g} / \mathrm{L}$ & $\mathrm{N}$ & 199-D5-13 & Up & 1 & 477 & 300 \\
\hline Nitrogen in nitrate, $\mu g / L$ & $\mathrm{~N}$ & 199-D5-13 & Up & 2 & 15,900 & 10,000 \\
\hline $\mathrm{pH}$ & $\begin{array}{l}\mathrm{N} \\
\mathrm{N}\end{array}$ & $\begin{array}{l}199-D 8-4 \\
199-D 8-6\end{array}$ & $\begin{array}{l}\text { Down } \\
\text { Down }\end{array}$ & $\begin{array}{l}9 \\
8\end{array}$ & $\begin{array}{r}9 \\
8.84\end{array}$ & $\begin{array}{l}8.5 \\
8.5\end{array}$ \\
\hline \multicolumn{7}{|c|}{ 183-H Solar Evaporation Basins } \\
\hline Aluminum, $\mu g / L$ & $\mathbf{N}$ & 199-H4-3 & Down & 1 & 65.2 & 50 \\
\hline Chromium, $\mu \mathrm{g} / \mathrm{L}$ & $\begin{array}{l}\mathrm{N} \\
\mathrm{Y} \\
\mathrm{N} \\
\mathrm{Y} \\
\mathrm{Y}\end{array}$ & $\begin{array}{l}199-\mathrm{H} 4-12 \mathrm{C} \\
199-\mathrm{H} 4-12 \mathrm{C} \\
199-\mathrm{H} 4-3 \\
199-\mathrm{H} 4-3 \\
199-\mathrm{H} 4-7\end{array}$ & $\begin{array}{l}\text { Down } \\
\text { Down } \\
\text { Down } \\
\text { Down } \\
\text { Up }\end{array}$ & $\begin{array}{l}1 \\
2 \\
1 \\
2 \\
1\end{array}$ & $\begin{array}{l}254 \\
236 \\
201 \\
196 \\
198\end{array}$ & $\begin{array}{l}100 \\
100 \\
100 \\
100 \\
100\end{array}$ \\
\hline Gross alpha, $\mathrm{pCi} / \mathrm{L}$ & $\mathbf{N}$ & 199-H4-3 & Down & 1 & 109 & 15 \\
\hline Gross beta, $\mathrm{pCi} / \mathrm{L}$ & $\mathrm{N}$ & 199-H4-3 & Down & 1 & 543 & 50 \\
\hline
\end{tabular}


Table A.25. (contd)

\begin{tabular}{|c|c|c|c|c|c|c|}
\hline Constituent, unit ${ }^{(a)}$ & Filter ${ }^{(b)}$ & Well Name & $\begin{array}{c}\text { Upgradient/ } \\
\text { Downgradient }\end{array}$ & $\begin{array}{c}\text { Number of } \\
\text { Exceedances }\end{array}$ & $\begin{array}{c}\text { Maximum } \\
\text { Result }\end{array}$ & $\begin{array}{c}\text { Drinking } \\
\text { Water } \\
\text { Standard } \\
\end{array}$ \\
\hline Hexavalent chromium, $\mu g / L$ & $\begin{array}{l}\mathrm{Y} \\
\mathrm{Y} \\
\mathrm{N}\end{array}$ & $\begin{array}{l}199-\mathrm{H} 4-12 \mathrm{C} \\
199-\mathrm{H} 4-3 \\
199-\mathrm{H} 4-7\end{array}$ & $\begin{array}{c}\text { Down } \\
\text { Down } \\
\text { Up }\end{array}$ & $\begin{array}{l}2 \\
3 \\
1\end{array}$ & $\begin{array}{l}232 \\
288 \\
207\end{array}$ & $\begin{array}{l}100 \\
100 \\
100\end{array}$ \\
\hline Iron, $\mu g / L$ & $\mathrm{~N}$ & 199-H4-3 & Down & 1 & 988 & 300 \\
\hline Nitrogen in nitrate, $\mu \mathrm{g} / \mathrm{L}$ & $\begin{array}{l}\mathrm{N} \\
\mathrm{N}\end{array}$ & $\begin{array}{l}199-\mathrm{H} 4-12 \mathrm{~A} \\
199-\mathrm{H} 4-3\end{array}$ & $\begin{array}{l}\text { Down } \\
\text { Down }\end{array}$ & $\begin{array}{l}1 \\
1\end{array}$ & $\begin{array}{r}42,300 \\
100,000\end{array}$ & $\begin{array}{l}10,000 \\
10,000\end{array}$ \\
\hline Technetium-99, pCi/L & $\mathrm{N}$ & 199-H4-3 & Down & 1 & 1,190 & 900 \\
\hline Uranium, $\mu \mathrm{g} / \mathrm{L}$ & $\begin{array}{l}\mathrm{N} \\
\mathrm{N}\end{array}$ & $\begin{array}{l}\text { 199-H4-12A } \\
199-\mathrm{H} 4-3\end{array}$ & $\begin{array}{l}\text { Down } \\
\text { Down }\end{array}$ & $\begin{array}{l}1 \\
1\end{array}$ & $\begin{array}{r}29.1 \\
159\end{array}$ & $\begin{array}{l}20 \\
20\end{array}$ \\
\hline \multicolumn{7}{|c|}{ 216-A-29 Ditch } \\
\hline Aluminum, $\mu \mathrm{g} / \mathrm{L}$ & $\mathrm{Y}$ & 299-E25-32P & Down & 1 & 179 & 50 \\
\hline Iodine-129, pCi/L & $\begin{array}{l}\mathrm{N} \\
\mathrm{N}\end{array}$ & $\begin{array}{l}699-43-43 \\
699-43-45\end{array}$ & $\begin{array}{l}\mathrm{Up}_{\mathrm{p}} \\
\mathrm{Up}\end{array}$ & $\begin{array}{l}1 \\
1\end{array}$ & $\begin{array}{l}4.36 \\
4.27\end{array}$ & $\begin{array}{l}1 \\
1\end{array}$ \\
\hline $\mathrm{pH}$ & $\begin{array}{l}\mathrm{N} \\
\mathrm{N} \\
\mathrm{N} \\
\mathrm{N}\end{array}$ & $\begin{array}{l}299-E 25-26 \\
299-E 25-35 \\
699-43-43 \\
699-43-45\end{array}$ & $\begin{array}{l}\text { Down } \\
\text { Down } \\
\text { Up } \\
\text { Up }\end{array}$ & $\begin{array}{l}8 \\
8 \\
4 \\
4\end{array}$ & $\begin{array}{r}8.77 \\
8.67 \\
8.75 \\
8.6\end{array}$ & $\begin{array}{l}8.5 \\
8.5 \\
8.5 \\
8.5\end{array}$ \\
\hline \multicolumn{7}{|c|}{ 216-B-3 Pond } \\
\hline Iodine-129, pCi/L & $\begin{array}{l}N \\
N \\
N\end{array}$ & $\begin{array}{l}699-42-42 B \\
699-43-40 \\
699-43-45\end{array}$ & $\begin{array}{l}\text { Down } \\
\text { Down } \\
\text { Down }\end{array}$ & $\begin{array}{l}1 \\
1 \\
1\end{array}$ & $\begin{array}{l}5.33 \\
2.79 \\
4.27\end{array}$ & $\begin{array}{l}1 \\
1 \\
1\end{array}$ \\
\hline $\mathrm{pH}$ & $\begin{array}{l}\mathrm{N} \\
\mathrm{N} \\
\mathrm{N}\end{array}$ & $\begin{array}{l}699-41-42 \\
699-42-40 \mathrm{C} \\
699-43-45\end{array}$ & $\begin{array}{l}\text { Down } \\
\text { Down } \\
\text { Down }\end{array}$ & $\begin{array}{l}4 \\
1 \\
4\end{array}$ & $\begin{array}{r}8.62 \\
8.52 \\
8.6\end{array}$ & $\begin{array}{l}8.5 \\
8.5 \\
8.5\end{array}$ \\
\hline Tritium, $\mathrm{pCi} / \mathrm{L}$ & $\begin{array}{l}N \\
N \\
N \\
N \\
N \\
N\end{array}$ & $\begin{array}{l}699-41-40 \\
699-42-39 A \\
699-42-39 B \\
699-42-42 B \\
699-43-40 \\
699-43-41 E\end{array}$ & $\begin{array}{l}\text { Down } \\
\text { Down } \\
\text { Down } \\
\text { Down } \\
\text { Down } \\
\text { Down }\end{array}$ & $\begin{array}{l}1 \\
1 \\
1 \\
1 \\
1 \\
1\end{array}$ & $\begin{array}{l}97,800 \\
42,200 \\
60,500 \\
38,900 \\
39,400 \\
49,000\end{array}$ & $\begin{array}{l}20,000 \\
20,000 \\
20,000 \\
20,000 \\
20,000 \\
20,000\end{array}$ \\
\hline \multicolumn{7}{|c|}{ 216-B-63 Ditch } \\
\hline Aluminum, $\mu \mathrm{g} / \mathrm{L}$ & $\begin{array}{l}\mathrm{Y} \\
\mathrm{Y}\end{array}$ & $\begin{array}{l}299-E 27-18 \\
299-E 27-9\end{array}$ & $\begin{array}{l}\text { Down } \\
\text { Up }\end{array}$ & $\begin{array}{l}1 \\
1\end{array}$ & $\begin{array}{l}224 \\
142\end{array}$ & $\begin{array}{l}50 \\
50\end{array}$ \\
\hline Iodine-129, $\mathrm{pCi} / \mathrm{L}$ & $\begin{array}{l}\mathrm{N} \\
\mathrm{N} \\
\mathrm{N}\end{array}$ & $\begin{array}{l}299-E 27-18 \\
299-E 33-33 \\
299-E 33-36\end{array}$ & $\begin{array}{l}\text { Down } \\
\text { Down } \\
\text { Down }\end{array}$ & $\begin{array}{l}1 \\
2 \\
3\end{array}$ & $\begin{array}{l}2.86 \\
6.49 \\
5.77\end{array}$ & $\begin{array}{l}1 \\
1 \\
1\end{array}$ \\
\hline Pentachlorophenol, $\mu \mathrm{g} / \mathrm{L}$ & $\mathbf{N}$ & 299-E33-36 & Down & 1 & 2.3 & 1 \\
\hline $\mathrm{pH}$ & $\mathrm{N}$ & 299-E33-36 & Down & 1 & 8.6 & 8.5 \\
\hline Total dissolved solids, $\mu g / \mathcal{L}$ & $N$ & 299-E33-36 & Down & 1 & 503,000 & 500,000 \\
\hline \multicolumn{6}{|c|}{ 216-S-10 Pond } & \\
\hline Carbon tetrachloride, $\mu \mathrm{g} / \mathrm{L}$ & $\mathrm{N}$ & $299-W 27-2$ & Down & 1 & 5 & 5 \\
\hline Chromium, $\mu \mathrm{g} / \mathrm{L}$ & $Y$ & 299-W26-7 & Up & 1 & 576 & 100 \\
\hline
\end{tabular}


Table A.25. (contd)

\begin{tabular}{|c|c|c|c|c|c|c|}
\hline Constituent, unit ${ }^{(2)}$ & Filter $^{(b)}$ & Well Name & $\begin{array}{c}\text { Upgradient/ } \\
\text { Downgradient }\end{array}$ & $\begin{array}{c}\text { Number of } \\
\text { Exceedances }\end{array}$ & $\begin{array}{l}\text { Maximum } \\
\text { Result }\end{array}$ & $\begin{array}{c}\text { Drinking } \\
\text { Water } \\
\text { Standard }\end{array}$ \\
\hline \multicolumn{7}{|c|}{ 216-U-12 Crib } \\
\hline Carbon tetrachloride, $\mu g / L$ & $\begin{array}{l}\mathrm{N} \\
\mathrm{N}\end{array}$ & $\begin{array}{l}299-W 22-42 \\
699-36-70 A\end{array}$ & $\begin{array}{l}\text { Down } \\
\text { Down }\end{array}$ & 1 . & $\begin{array}{r}5 \\
10\end{array}$ & $\begin{array}{l}5 \\
5\end{array}$ \\
\hline Chromium, $\mu \mathrm{g} / \mathrm{L}$ & $\mathbf{N}$ & $699-36-70 A$ & Down & 1 & 107 & 100 \\
\hline Iodine-129, $\mathrm{pCi} / \mathrm{L}$ & $\stackrel{N}{N}$ & $\begin{array}{l}299-W 22-42 \\
699-36-70 A\end{array}$ & $\begin{array}{l}\text { Down } \\
\text { Down }\end{array}$ & $\begin{array}{l}1 \\
3\end{array}$ & $\begin{array}{l}7.64 \\
15.2\end{array}$ & $\begin{array}{l}1 \\
1\end{array}$ \\
\hline Nitrogen in nitrate, $\mu \mathrm{g} / \mathrm{L}$ & $\begin{array}{l}\mathrm{N} \\
\mathrm{N} \\
\mathrm{N}\end{array}$ & $\begin{array}{l}299-W 22-41 \\
299-W 22-42 \\
699-36-70 A\end{array}$ & $\begin{array}{l}\text { Down } \\
\text { Down } \\
\text { Down }\end{array}$ & $\begin{array}{l}4 \\
2 \\
2\end{array}$ & $\begin{array}{l}53,800 \\
42,600 \\
25,300\end{array}$ & $\begin{array}{l}10,000 \\
10,000 \\
10,000\end{array}$ \\
\hline $\begin{array}{l}\text { Nitrogen in nitrite and } \\
\text { nitrate, } \mu \mathrm{g} / \mathrm{L}\end{array}$ & $\mathbf{N}$ & $699-36-70 \mathrm{~A}$ & Down & 2 & 26,300 & 10,000 \\
\hline Total dissolved solids, $\mu \mathrm{g} / \mathrm{L}$ & $\begin{array}{l}\mathbf{N} \\
\mathbf{N}\end{array}$ & $\begin{array}{l}299-W 22-41 \\
299-W 22-42\end{array}$ & $\begin{array}{l}\text { Down } \\
\text { Down }\end{array}$ & $\begin{array}{l}2 \\
1\end{array}$ & $\begin{array}{l}577,000 \\
529,000\end{array}$ & $\begin{array}{l}500,000 \\
500,000\end{array}$ \\
\hline Tritium, pCi/L & $\begin{array}{l}\mathrm{N} \\
\mathrm{N}\end{array}$ & $\begin{array}{l}299-W 22-42 \\
699-36-70 A\end{array}$ & $\begin{array}{l}\text { Down } \\
\text { Down }\end{array}$ & $\begin{array}{l}3 \\
4\end{array}$ & $\begin{array}{r}46,000 \\
106,000\end{array}$ & $\begin{array}{l}20,000 \\
20,000\end{array}$ \\
\hline \multicolumn{7}{|c|}{ 316-5 Trenches } \\
\hline $\begin{array}{l}\text { cis-1,2-Dichloroethylene, } \\
\mu \mathrm{g} / \mathrm{L}\end{array}$ & $\mathbf{N}$ & $399-1-16 \mathrm{~B}$ & Down & 8 & 180 & 70 \\
\hline Gross alpha, $\mathrm{pCi} / \mathrm{L}$ & $\mathbf{N}$ & $399-1-17 A$ & Down & 2 & 154 & 15 \\
\hline Gross beta, $\mathrm{pCi} / \mathrm{L}$ & $\mathrm{N}$ & $399-1-17 A$ & Down & 1 & 92.5 & 50 \\
\hline Iron, $\mu \mathrm{g} / \mathrm{L}$ & $\begin{array}{l}\mathrm{Y} \\
\mathrm{Y} \\
\mathrm{Y}\end{array}$ & $\begin{array}{l}399-1-10 \mathrm{~B} \\
399-1-17 \mathrm{~B} \\
399-1-18 \mathrm{~B}\end{array}$ & $\begin{array}{c}\text { Down } \\
\text { Down } \\
\text { Up }\end{array}$ & $\begin{array}{l}2 \\
2 \\
2\end{array}$ & $\begin{array}{l}740 \\
426 \\
466\end{array}$ & $\begin{array}{l}300 \\
300 \\
300\end{array}$ \\
\hline Manganese, $\mu \mathrm{g} / \mathrm{L}$ & $\begin{array}{l}Y \\
Y \\
Y\end{array}$ & $\begin{array}{l}399-1-10 B \\
399-1-16 B \\
399-1-17 B\end{array}$ & $\begin{array}{l}\text { Down } \\
\text { Down } \\
\text { Down }\end{array}$ & $\begin{array}{l}2 \\
2 \\
2\end{array}$ & $\begin{array}{r}119 \\
65.6 \\
78\end{array}$ & $\begin{array}{l}50 \\
50 \\
50\end{array}$ \\
\hline Methylenechloride, $\mu \mathrm{g} / \mathrm{L}$ & $\mathbf{N}$ & $399-1-10 A$ & Down & 1 & 5 & 5 \\
\hline Tetrachloroethene, $\mu \mathrm{g} / \mathrm{L}$ & $\begin{array}{l}\mathrm{N} \\
\mathrm{N} \\
\mathrm{N}\end{array}$ & $\begin{array}{l}399-1-10 A \\
399-1-16 A \\
399-1-17 A\end{array}$ & $\begin{array}{l}\text { Down } \\
\text { Down } \\
\text { Down }\end{array}$ & $\begin{array}{l}1 \\
4 \\
6\end{array}$ & $\begin{array}{r}8 \\
17 \\
38\end{array}$ & $\begin{array}{l}5 \\
5 \\
5\end{array}$ \\
\hline Thallium, $\mu \mathrm{g} / \mathrm{L}$ & $\begin{array}{l}Y \\
Y\end{array}$ & $\begin{array}{l}399-1-10 A \\
399-1-10 \mathrm{~B}\end{array}$ & $\begin{array}{l}\text { Down } \\
\text { Down }\end{array}$ & $\begin{array}{l}1 \\
1\end{array}$ & $\begin{array}{l}2.4 \\
2.4\end{array}$ & $\begin{array}{l}2 \\
2\end{array}$ \\
\hline Trichloroethene, $\mu \mathrm{g} / \mathrm{L}$ & $\mathbf{N}$ & $399-1-16 \mathrm{~B}$ & Down & 8 & 8 & 5 \\
\hline Uranium, $\mu \mathrm{g} / \mathrm{L}$ & $\begin{array}{l}\mathrm{N} \\
\mathrm{N} \\
\mathrm{N}\end{array}$ & $\begin{array}{l}399-1-10 A \\
399-1-16 A \\
399-1-17 A\end{array}$ & $\begin{array}{l}\text { Down } \\
\text { Down } \\
\text { Down }\end{array}$ & $\begin{array}{c}10 \\
9 \\
9\end{array}$ & $\begin{array}{r}96 \\
124 \\
248\end{array}$ & $\begin{array}{l}20 \\
20 \\
20\end{array}$ \\
\hline \multicolumn{7}{|c|}{ Liquid Effluent-Retention Facility } \\
\hline Pentachlorophenol, $\mu \mathrm{g} / \mathrm{L}$ & $\mathbf{N}$ & 299-E35-2 & Down & 1 & 2.4 & 1 \\
\hline \multicolumn{7}{|c|}{ Low-Level Waste Management Area 1} \\
\hline Aluminum, $\mu g / L$ & $\mathrm{Y}$ & 299-E32-5 & Down & 1 & 108 & 50 \\
\hline
\end{tabular}


Table A.25. (contd)

\begin{tabular}{|c|c|c|c|c|c|c|}
\hline Constituent, unit & Filter $r^{(b)}$ & Well Name & $\begin{array}{c}\text { Upgradient } \\
\text { Downgradient }\end{array}$ & $\begin{array}{c}\text { Number of } \\
\text { Exceedances }\end{array}$ & $\begin{array}{c}\text { Maximum } \\
\text { Result }\end{array}$ & $\begin{array}{c}\text { Drinking } \\
\text { Water } \\
\text { Standard }\end{array}$ \\
\hline \multirow[t]{3}{*}{ Gross beta, $\mathrm{pCi} / \mathrm{L}$} & $\mathrm{N}$ & 299-E32-10 & Down & 1 & 130 & 50 \\
\hline & $\mathrm{N}$ & 299-E33-34 & Down & 2 & $565^{\circ}$ & 50 \\
\hline & $\mathrm{N}$ & 299-E33-35 & Up & 2 & 139 & 50 \\
\hline \multirow[t]{3}{*}{ Iodine-129, pCi/L } & $\mathbf{N}$ & 299-E32-8 & Down & 1 & 3.98 & 1 \\
\hline & $\mathbf{N}$ & 299-E33-29 & Up & 1 & 3.96 & 1 \\
\hline & $N$ & 299-E33-34 & Down & 1 & 6.57 & 1 \\
\hline \multirow[t]{2}{*}{ Nitrogen in nitrate, $\mu \mathrm{g} / \mathrm{L}$} & $N$ & 299-E28-26 & Up & 1 & 10,200 & 10,000 \\
\hline & N & 299-E33-34 & Down & 2 & $30,700^{\circ}$ & 10,000 \\
\hline \multirow[t]{5}{*}{ Pentachlorophenol, $\mu \mathrm{g} / \mathrm{L}$} & $\mathrm{N}$ & 299-E28-26 & Up & 1 & 2.3 & 1 \\
\hline & $\mathrm{N}$ & 299-E28-28 & Up & 1 & 2.3 & 1 \\
\hline & $\mathrm{N}$ & 299-E32-3 & Down & $i$ & 2.3 & 1 \\
\hline & $\mathrm{N}$ & 299-E32-5 & Down & 1 & 3.7 & 1 \\
\hline & $\mathrm{N}$ & 299-E33-28 & $\mathrm{Up}$ & 1 & 2.3 & 1 \\
\hline $\mathrm{pH}$ & N & 299-E33-35 & Up & 2 & 8.75 & 8.5 \\
\hline Technetium-99, pCi/L & $\mathrm{N}$ & 299-E33-34 & Down & 1 & 2,470 & 900 \\
\hline \multirow[t]{5}{*}{ Tritium, pCi/L } & $\mathrm{N}$ & 299-E28-27 & $\mathrm{Up}_{\mathrm{p}}$ & 2 & 28,600 & 20,000 \\
\hline & $\mathrm{N}$ & 299-E32-2 & Down & 1 & 21,400 & 20,000 \\
\hline & $\mathrm{N}$ & 299-E32-3 & Down & 1 & 21,200 & 20,000 \\
\hline & $\mathrm{N}$ & 299-E32-6 & Down & 1 & 26,400 & 20,000 \\
\hline & $\mathrm{N}$ & 299-E32-7 & Down & 1 & 20,700 & 20,000 \\
\hline \multicolumn{7}{|c|}{ Low-Level Waste Management Area 2} \\
\hline Aluminum, $\mu g / L$ & $\mathrm{Y}$ & 299-E27-9 & Down & 1 & 142 & 50 \\
\hline Nitrogen in nitrate, $\mu \mathrm{g} / \mathrm{L}$ & $N$ & 299-E34-7 & Up & 2 & 12,500 & 10,000 \\
\hline \multirow[t]{2}{*}{ Sulfate, $\mu g / L$} & $\mathrm{~N}$ & 299-E34-7 & Up & 2 & 394,000 & 250,000 \\
\hline & & Low-Level & Management & & & \\
\hline \multirow[t]{3}{*}{ Aluminum, $\mu \mathrm{g} / \mathrm{L}$} & $\dot{Y}$ & 299-W10-14 & Up & 1 & 74.6 & 50 \\
\hline & $\mathrm{Y}$ & 299-W7-8 & Down & 1 & 61.4 & 50 \\
\hline & & 299-W8-1 & Down & 1 & 78 & 50 \\
\hline \multirow[t]{10}{*}{ Carbon tetrachloride, $\mu \mathrm{g} / \mathrm{L}$} & $\mathrm{N}$ & 299-W10-13 & $\mathrm{Up}_{\mathrm{p}}$ & 2 & 17 & 5 \\
\hline & $\mathrm{N}$ & 299-W10-19 & Up & 2 & 900 & 5 \\
\hline & $\mathbf{N}$ & 299-W10-20 & Up & 2 & 1,200 & 5 \\
\hline & $\mathrm{N}$ & 299-W10-21 & $U_{p}$ & 2 & 610 & 5 \\
\hline & $\mathrm{N}$ & 299-W6-2 & Down & 2 & 97 & 5 \\
\hline & $\mathbf{N}$ & $299-W 7-4$ & Down & 2 & 550 & 5 \\
\hline & $\mathrm{N}$ & 299-W7-5 & Down & 1 & 140 & 5 \\
\hline & $\mathrm{N}$ & 299-W7-7 & Down & 1 & 5 & 5 \\
\hline & $\mathbf{N}$ & 299-W8-1 & Down & 3 & 5 & 5 \\
\hline & $\mathrm{N}$ & 299-W9-1 & Up & 1 & 6 & 5 \\
\hline \multirow[t]{3}{*}{ Methylenechloride, $\mu \mathrm{g} / \mathrm{L}$} & $\mathrm{N}$ & 299-W10-20 & Up & 1 & 26 & 5 \\
\hline & $\mathrm{N}$ & 299-W7-4 & Down & 1 & 42 & 5 \\
\hline & N & 299-W7-5 & Down & 1 & 7 & 5 \\
\hline Nickel, $\mu \mathrm{g} / \mathrm{L}$ & $\mathbf{Y}$ & 299-W7-4 & Down & 1 & 134 & 100 \\
\hline \multirow[t]{6}{*}{ Nitrogen in nitrate, $\mu \mathrm{g} / \mathrm{L}$} & $\mathrm{N}$ & 299-W10-19 & Up & 3 & 31,100 & 10,000 \\
\hline & $\mathrm{N}$ & 299-W10-20 & Up & 3 & 29,800 & 10,000 \\
\hline & $\mathbf{N}$ & 299-W10-21 & Up & 3 & 45,200 & 10,000 \\
\hline & $\mathrm{N}$ & 299-W6-2 & Down & 3 & 11,500 & 10,000 \\
\hline & $\mathrm{N}$ & $299-w 7-4$ & Down & 2 & 22,900 & 10,000 \\
\hline & $\mathbf{N}$ & 299-W7-5 & Down & 2 & 13,600 & 10,000 \\
\hline
\end{tabular}


Table A.25. (contd)

\begin{tabular}{|c|c|c|c|c|c|c|}
\hline Constituent, unif ${ }^{(a)}$ & Filter & Well Name & $\begin{array}{c}\text { Upgradient } \\
\text { Downgradient }\end{array}$ & $\begin{array}{c}\text { Number of } \\
\text { Exceedances }\end{array}$ & $\begin{array}{c}\text { Maximum } \\
\text { Result }\end{array}$ & $\begin{array}{c}\text { Drinking } \\
\text { Water } \\
\text { Standard }\end{array}$ \\
\hline Pentachlorophenol, $\mu \mathrm{g} / \mathrm{L}$ & $\mathrm{N}$ & 299-W10-13 & Up & 1 & 2.2 & \\
\hline $\mathrm{pH}$ & $\begin{array}{l}N \\
N \\
N \\
N \\
N\end{array}$ & $\begin{array}{l}299-W 10-19 \\
299-W 7-1 \\
299-W 7-10 \\
299-W 7-3 \\
299-W 7-7\end{array}$ & $\begin{array}{c}\text { Up } \\
\text { Down } \\
\text { Down } \\
\text { Down } \\
\text { Down }\end{array}$ & $\begin{array}{l}5 \\
4 \\
2 \\
4 \\
4\end{array}$ & $\begin{array}{r}8.96 \\
8.63 \\
8.5 \\
8.61 \\
8.76\end{array}$ & $\begin{array}{l}8.5 \\
8.5 \\
8.5 \\
8.5 \\
8.5\end{array}$ \\
\hline Total dissolved solids, $\mu g / L$ & $\mathrm{~N}$ & 299-W10-21 & Up & 1 & 609,000 & 500,000 \\
\hline Trichloroethene, $\mu \mathrm{g} / \mathrm{L}$ & $\mathrm{N}$ & 299-W10-21 & Up & 2 & 7 & . \\
\hline Tritium, $\mathrm{pCi} / \mathrm{L}$ & $\mathrm{N}$ & $299-W 7-6$ & Down & 1 & 150,000 & 20,00 \\
\hline \multicolumn{7}{|c|}{ Low-Level Waste Management Area 4} \\
\hline Antimony, $\mu \mathrm{g} / \mathrm{L}$ & $\mathrm{Y}$ & 299-W18-32 & Up & 1 & 32.7 & \\
\hline Carbon tetrachloride, $\mu \mathrm{g} / \mathrm{L}$ & $\begin{array}{l}N \\
N \\
N \\
N \\
N \\
N \\
N \\
N \\
N \\
N \\
N \\
N\end{array}$ & $\begin{array}{l}299-W 15-15 \\
299-W 15-16 \\
299-W 15-17 \\
299-W 15-18 \\
299-W 15-19 \\
299-W 18-21 \\
299-W 18-23 \\
299-W 18-24 \\
299-W 18-26 \\
299-W 18-27 \\
299-W 18-28 \\
299-W 18-32\end{array}$ & $\begin{array}{c}\text { Down } \\
\text { Up } \\
\text { Up } \\
\text { Up } \\
\text { Down } \\
\text { Down } \\
\text { Down } \\
\text { Up } \\
\text { Down } \\
\text { Down } \\
\text { Down } \\
\text { Up }\end{array}$ & $\begin{array}{c}8 \\
4 \\
2 \\
6 \\
1 \\
7 \\
2 \\
3 \\
13 \\
7 \\
1 \\
1\end{array}$ & $\begin{array}{r}974 \\
7,871 \\
12 \\
2,146 \\
35 \\
260 \\
290 \\
1,880 \\
800 \\
370 \\
11 \\
12\end{array}$ & \\
\hline Gross alpha, $\mathrm{pCi} / \mathrm{L}$ & $\begin{array}{l}\mathrm{N} \\
\mathrm{N}\end{array}$ & $\begin{array}{l}299-W 18-21 \\
299-W 18-32\end{array}$ & $\begin{array}{l}\text { Down } \\
\text { Up }\end{array}$ & $\begin{array}{l}1 \\
1\end{array}$ & $\begin{array}{l}16.2 \\
23.8\end{array}$ & $\begin{array}{l}15 \\
15\end{array}$ \\
\hline Methylenechloride, $\mu \mathrm{g} / \mathrm{L}$ & $\begin{array}{l}\mathbf{N} \\
\mathbf{N} \\
\mathrm{N} \\
\mathrm{N}\end{array}$ & $\begin{array}{l}299-W 15-15 \\
299-W 15-18 \\
299-W 18-26 \\
299-W 18-28\end{array}$ & $\begin{array}{l}\text { Down } \\
\text { Up } \\
\text { Down } \\
\text { Down }\end{array}$ & $\begin{array}{l}2 \\
1 \\
1 \\
1\end{array}$ & $\begin{array}{r}11 \\
10 \\
52 \\
7\end{array}$ & \\
\hline Nitrogen in nitrate, $\mu \mathrm{g} / \mathrm{L}$ & $\begin{array}{l}\mathrm{N} \\
\mathrm{N} \\
\mathrm{N} \\
\mathrm{N} \\
\mathrm{N} \\
\mathrm{N} \\
\mathrm{N}\end{array}$ & $\begin{array}{l}299-W 15-15 \\
299-W 15-16 \\
299-W 15-18 \\
299-W 18-21 \\
299-W 18-23 \\
299-W 18-24 \\
299-W 18-26\end{array}$ & $\begin{array}{l}\text { Down } \\
\text { Up } \\
\text { Up } \\
\text { Down } \\
\text { Down } \\
\text { Up } \\
\text { Down }\end{array}$ & $\begin{array}{l}2 \\
2 \\
2 \\
2 \\
1 \\
2 \\
1\end{array}$ & $\begin{array}{l}15,600 \\
16,600 \\
23,200 \\
20,600 \\
13,600 \\
19,300 \\
13,400\end{array}$ & $\begin{array}{l}10,000 \\
10,000 \\
10,000 \\
10,000 \\
10,000 \\
10,000 \\
10,000\end{array}$ \\
\hline Trichloroethene, $\mu \mathrm{g} / \mathrm{L}$ & $\mathrm{N}$ & 299-W15-16 & Up & 4 & 9.8 & \\
\hline \multicolumn{7}{|c|}{ Plutonium-Uranium Extraction (PUREX) Cribs } \\
\hline Aluminum, $\mu \mathrm{g} / \mathrm{L}$ & $\mathrm{Y}$ & 299-E24-18 & Up & 1 & 121 & 5 \\
\hline Antimony, $\mu \mathrm{g} / \mathrm{L}$ & $\mathrm{Y}$ & 299-E25-19 & Down & 1 & 30.5 & \\
\hline Gross beta, $\mathrm{pCi} / \mathrm{L}$ & $\mathrm{N}$ & 299-E17-14 & Down & 4 & 68.3 & \\
\hline
\end{tabular}


Table A.25. (contd)

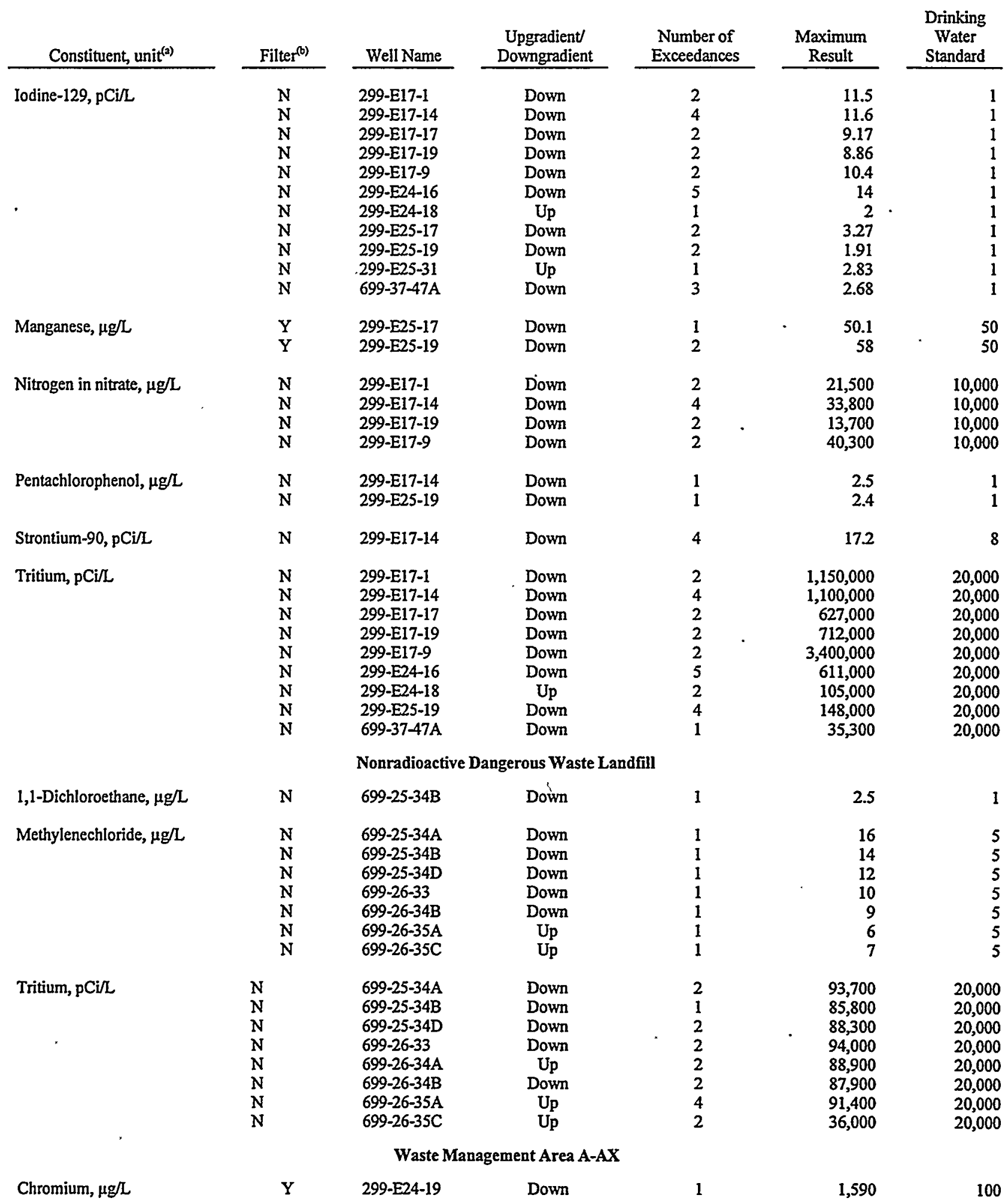


Table A.25. (contd)

\begin{tabular}{|c|c|c|c|c|c|c|}
\hline Constituent, unit ${ }^{(a)}$ & Filter ${ }^{(b)}$ & Well Name & $\begin{array}{c}\text { Upgradient/ } \\
\text { Downgradient }\end{array}$ & $\begin{array}{c}\text { Number of } \\
\text { Exceedances }\end{array}$ & $\begin{array}{c}\text { Maximum } \\
\text { Result }\end{array}$ & $\begin{array}{c}\text { Drinking } \\
\text { Water } \\
\text { Standard } \\
\end{array}$ \\
\hline \multirow{5}{*}{ Iodine-129, $\mathrm{pCi} / \mathrm{L}$} & $\mathrm{N}$ & 299-E24-19 & Down & 1 & 5.44 & 1 \\
\hline & N & 299-E24-20 & Down & 2 & 4.81 & $i$ \\
\hline & $\mathrm{N}$ & 299-E25-40 & $U_{p}$ & 1 & 3.57 & 1 \\
\hline & $\mathrm{N}$ & 299-E25-41 & Up & 2 & 3.45 & 1 \\
\hline & $\mathrm{N}$ & $299-\mathrm{E} 25-46$ & Down & 2 & 4.77 & 1 \\
\hline Nickel, $\mu \mathrm{g} / \mathrm{L}$ & $\mathbf{Y}$ & 299-E24-19 & Down & 1 & 326 & 100 \\
\hline \multicolumn{7}{|c|}{ Waste Management Area B-BX-BY } \\
\hline Aluminum, $\mu \mathrm{g} / \mathrm{L}$ & $\mathrm{Y}$ & 299-E33-5 & $\mathrm{NA}$ & 1 & 149 & 50 \\
\hline Cadmium, $\mu \mathrm{g} / \mathrm{L}$ & $\begin{array}{l}\mathrm{Y} \\
\mathrm{Y}\end{array}$ & $\begin{array}{l}299-E 33-17 \\
299-E 33-38\end{array}$ & $\begin{array}{l}\text { NA } \\
\text { NA }\end{array}$ & $\begin{array}{l}1 \\
1\end{array}$ & $\begin{array}{l}6.8 \\
5.2\end{array}$ & $\begin{array}{l}5 \\
5\end{array}$ \\
\hline Cyanide, $\mu \mathrm{g} / \mathrm{L}$ & $\mathrm{N}$ & 299-E33-7 & NA & 2 & 347 & 200 \\
\hline \multirow[t]{5}{*}{ Gross alpha, $\mathrm{pCi} / \mathrm{L}$} & $\mathrm{N}$ & 299-E33-13 & $\mathrm{NA}$ & 4 & 79.5 & 15 \\
\hline & $\mathbf{N}$ & 299-E33-18 & $\mathrm{NA}$ & 5 & 84.8 & 15 \\
\hline & $\mathrm{N}$ & 299-E33-38 & NA & 3 & 28.3 & 15 \\
\hline & $N$ & 299-E33-41 & NA & 5 & 37.5 & 15 \\
\hline & $\mathrm{N}$ & 299-E33-5 & NA & 4 & 27.8 & 15 \\
\hline \multirow[t]{14}{*}{ Gross beta, $\mathrm{pCi} / \mathrm{L}$} & $\mathrm{N}$ & 299-E33-13 & NA & 6 & 602 & 50 \\
\hline & $\mathrm{N}$ & 299-E33-15 & NA & 1 & 65.5 & 50 \\
\hline & $\mathrm{N}$ & 299-E33-16 & NA & 5 & 490 & 50 \\
\hline & $\mathrm{N}$ & 299-E33-18 & $\mathrm{NA}$ & 5 & 557 & 50 \\
\hline & $\mathrm{N}$ & 299-E33-20 & NA & 3 & 73 & 50 \\
\hline & $\mathrm{N}$ & 299-E33-31 & NA & 7 & 336 & 50 \\
\hline & $\mathrm{N}$ & 299-E33-32 & NA & 7 & 342 & 50 \\
\hline & $\mathrm{N}$ & 299-E33-38 & NA & 4 & 1,330 & 50 \\
\hline & $\mathrm{N}$ & 299-E33-41 & NA & 17 & 1,190 & 50 \\
\hline & $\mathrm{N}$ & 299-E33-42 & NA & 8 & 628 & 50 \\
\hline & $\mathrm{N}$ & 299-E33-43 & NA & 1 & 70.2 & 50 \\
\hline & $\mathrm{N}$ & 299-E33-5 & NA & 6 & 1,220 & 50 \\
\hline & $\mathbf{N}$ & 299-E33-7 & NA & 3 & 1,700 & 50 \\
\hline & $\mathrm{N}$ & 299-E33-8 & NA & 3 & 492 & 50 \\
\hline \multirow[t]{15}{*}{ Iodine-129, $\mathrm{pCi} / \mathrm{L}$} & $\mathrm{N}$ & 299-E28-8 & NA & 1 & 3.26 & 1 \\
\hline & $\mathrm{N}$ & 299-E33-13 & $\mathrm{NA}$ & 4 & 5.46 & 1 \\
\hline & $\mathbf{N}$ & 299-E33-18 & $\mathrm{NA}$ & 2 & 3.93 & $i$ \\
\hline & $\mathrm{N}$ & 299-E33-21 & $\mathrm{NA}$ & 2 & 4.36 & 1 \\
\hline & $\mathrm{N}$ & 299-E33-26 & $\mathrm{NA}$ & 1 & 5.52 & I \\
\hline & $\mathrm{N}$ & 299-E33-31 & $\mathrm{NA}$ & 3 & 5.81 & i \\
\hline & $\mathbf{N}$ & 299-E33-32 & NA & 2 & 4.69 & 1 \\
\hline & $\mathrm{N}$ & $299-\mathrm{E} 33-33$ & NA & 2 & 6.49 & 1 \\
\hline & $\mathbf{N}$ & 299-E33-36 & NA & 3 & 5.77 & 1 \\
\hline & $\mathrm{N}$ & 299-E33-38 & NA & 3 & 6.27 & $i$ \\
\hline & $\mathrm{N}$ & 299-E33-39 & $\mathrm{NA}$ & 1 & 1.66 & 1 \\
\hline & $\mathbf{N}$ & 299-E33-41 & $\mathrm{NA}$ & 3 & 6.01 & 1 \\
\hline & $\mathrm{N}$ & 299-E33-42 & NA & 2 & 6.42 & 1 \\
\hline & N & 299-E33-43 & $\mathrm{NA}$ & 3 & 4.99 & $i$ \\
\hline & $\mathrm{N}$ & $299-$ E33-5 & $\mathrm{NA}$ & 3 & 5.35 & 1 \\
\hline Manganese, $\mu \mathrm{g} / \mathrm{L}$ & $\mathrm{Y}$ & 299-E33-8 & NA & 1 & 73 & 50 \\
\hline Nickel, $\mu g / L$ & 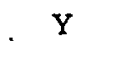 & 299-E33-39 & NA & 1 & 194 & 100 \\
\hline Nitrate, $\mu g / L$ & $\mathbf{N}$ & 299-E33-31 & NA & 1 & 68,000 & 45,000 \\
\hline
\end{tabular}


Table A.25. (contd)

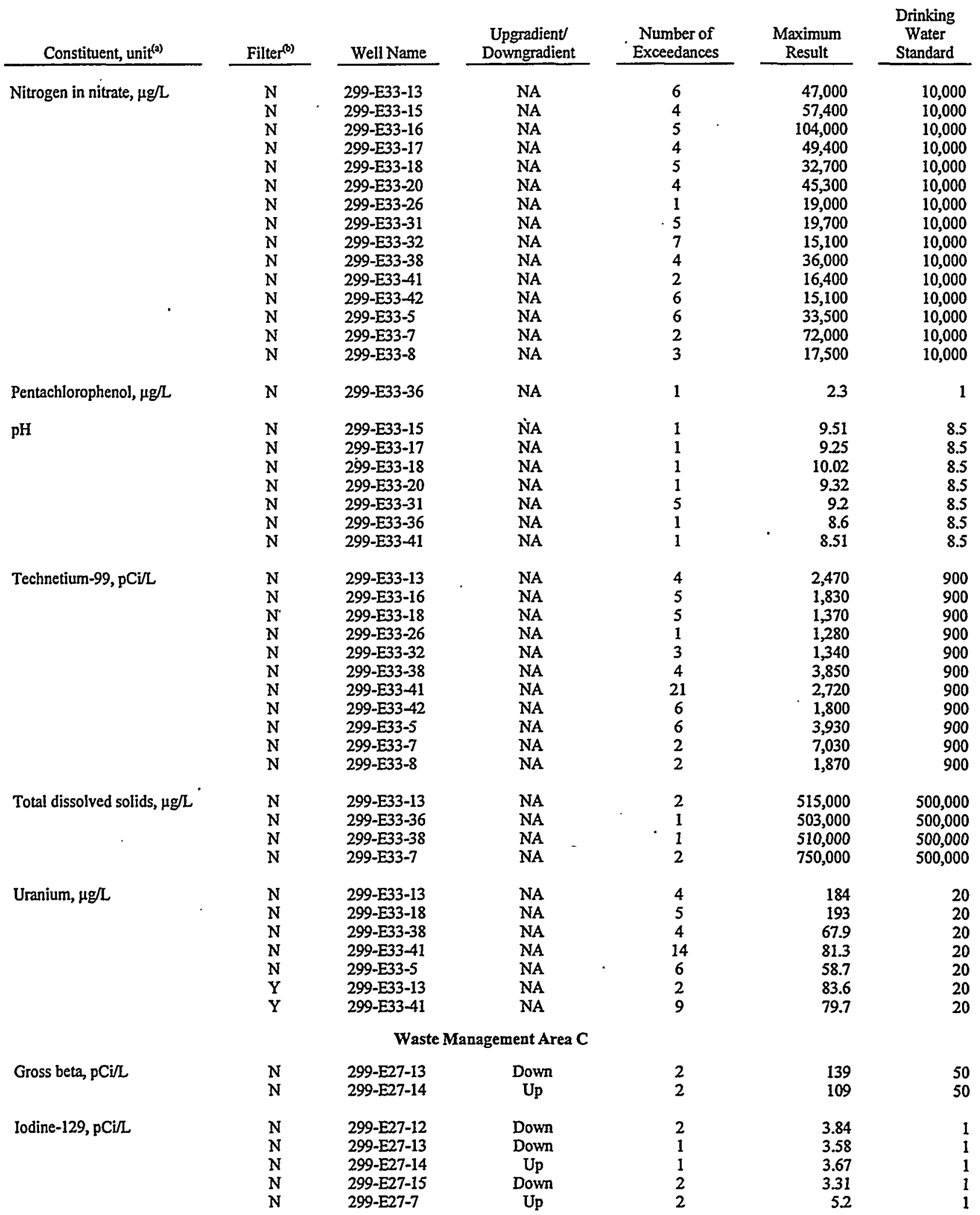


Table A.25. (contd)

\begin{tabular}{|c|c|c|c|c|c|c|}
\hline Constituent, unit ${ }^{(\mathfrak{)})}$ & Filter ${ }^{(b)}$ & Well Name & $\begin{array}{c}\text { Upgradient/ } \\
\text { Downgradient }\end{array}$ & $\begin{array}{c}\text { Number of } \\
\text { Exceedances }\end{array}$ & $\begin{array}{c}\text { Maximum } \\
\text { Result }\end{array}$ & $\begin{array}{c}\text { Drinking } \\
\text { Water } \\
\text { Standard } \\
\end{array}$ \\
\hline $\mathrm{pH}$ & $\begin{array}{l}\mathrm{N} \\
\mathrm{N}\end{array}$ & $\begin{array}{l}299-E 27-13 \\
299-E 27-15\end{array}$ & $\begin{array}{l}\text { Down } \\
\text { Down }\end{array}$ & $\begin{array}{c}3 \\
10\end{array}$ & $\begin{array}{r}8.7 \\
8.59\end{array}$ & $\begin{array}{l}8.5 \\
8.5\end{array}$ \\
\hline \multicolumn{7}{|c|}{ Waste Management Area S-SX } \\
\hline Aluminum, $\mu \mathrm{g} / \mathrm{L}$ & $\mathrm{Y}$ & $299-W 22-44$ & Down & 1 & 184 & 50 \\
\hline Carbon tetrachloride, $\mu \mathrm{g} / \mathrm{L}$ & $\begin{array}{l}\mathrm{N} \\
\mathrm{N}\end{array}$ & $\begin{array}{l}299-W 22-46 \\
299-W 23-15\end{array}$ & $\begin{array}{l}\text { Down } \\
\text { Down }\end{array}$ & $\begin{array}{l}1 \\
1\end{array}$ & $\begin{array}{l}10 \\
80\end{array}$ & $\begin{array}{l}5 \\
5\end{array}$ \\
\hline Chromium, $\mu \mathrm{g} / \mathrm{L}$ & $\mathrm{Y}$ & $299-W 22-44$ & Down & 1 & 103 & 100 \\
\hline Gross beta, $\mathrm{pCi} / \mathrm{L}$ & $\begin{array}{l}\mathrm{N} \\
\mathrm{N}\end{array}$ & $\begin{array}{l}\text { 299-W22-45 } \\
299-W 22-46\end{array}$ & $\begin{array}{l}\text { Down } \\
\text { Down }\end{array}$ & $\begin{array}{l}4 \\
4\end{array}$ & $\begin{array}{r}165 \\
1700\end{array}$ & $\begin{array}{l}50 \\
50\end{array}$ \\
\hline Iron, $\mu g / L$ & $\mathrm{Y}$ & $299-W 22-44$ & Down & 1 & 766 & 300 \\
\hline Nitrate, $\mu \mathrm{g} / \mathrm{L}$ & $\mathbf{N}$ & $299-W 22-46$ & Down & 1 & 47,000 & 45,000 \\
\hline Nitrogen in nitrate, $\mu \mathrm{g} / \mathrm{L}$ & $\mathbf{N}$ & $299-W 22-46$ & Down & 3 & 11,200 & 10,000 \\
\hline $\mathrm{pH}$ & $N$ & $299-W 23-14$ & Up & 1 & 8.52 & 8.5 \\
\hline Technetium-99, $\mathrm{pCi} / \mathrm{L}$ & $\mathrm{N}$ & $299-W 22-46$ & Down & 4 & 4,330 & 900 \\
\hline Tritium, $\mathrm{pCi} / \mathrm{L}$ & $\begin{array}{l}\mathrm{N} \\
\mathrm{N} \\
\mathrm{N}\end{array}$ & $\begin{array}{l}299-W 22-46 \\
299-W 23-14 \\
299-W 23-15\end{array}$ & $\begin{array}{l}\text { Down } \\
\text { Up } \\
\text { Down }\end{array}$ & $\begin{array}{l}4 \\
4 \\
4 .\end{array}$ & $\begin{array}{r}60,700 \\
382,000 \\
24,700\end{array}$ & $\begin{array}{l}20,000 \\
20,000 \\
20,000\end{array}$ \\
\hline \multicolumn{7}{|c|}{ Waste Management Area T } \\
\hline Cadmium, $\mu \mathrm{g} / \mathrm{L}$ & $\mathrm{Y}$ & 299-W11-27 & Down & 2 & 127 & 5 \\
\hline Carbon tetrachloride, $\mu \mathrm{g} / \mathrm{L}$ & $\begin{array}{l}N \\
N \\
N\end{array}$ & $\begin{array}{l}299-W 10-1 \\
299-W 10-12 \\
299-W 11-28\end{array}$ & $\begin{array}{l}\text { Up } \\
\text { Down } \\
\text { Down }\end{array}$ & $\begin{array}{l}1 \\
1 \\
2\end{array}$ & $\begin{array}{r}38 \\
1,400 \\
880\end{array}$ & $\begin{array}{l}5 \\
5 \\
5\end{array}$ \\
\hline Chromium, $\mu \mathrm{g} / \mathrm{L}$ & $\begin{array}{l}\mathrm{Y} \\
\mathrm{Y} \\
\mathrm{Y}\end{array}$ & $\begin{array}{l}299-W 10-12 \\
299-W 10-4 \\
299-W 10-8\end{array}$ & $\begin{array}{l}\text { Down } \\
\text { Up } \\
\text { Down }\end{array}$ & $\begin{array}{l}1 \\
4 \\
4\end{array}$ & $\begin{array}{l}104 \\
172 \\
143\end{array}$ & $\begin{array}{l}100 \\
100 \\
100\end{array}$ \\
\hline Fluoride, $\mu \mathrm{g} / \mathrm{L}$ & $\begin{array}{l}\mathrm{N} \\
\mathrm{N}\end{array}$ & $\begin{array}{l}299-W 10-12 \\
299-W 10-4\end{array}$ & $\begin{array}{l}\text { Down } \\
\text { Up }\end{array}$ & $\begin{array}{l}1 \\
2\end{array}$ & $\begin{array}{l}4,600 \\
4,270\end{array}$ & $\begin{array}{l}4,000 \\
4,000\end{array}$ \\
\hline Gross alpha, pCill & $\mathbf{N}$ & 299-W11-27 & Down & 3 & 97.9 & 15 \\
\hline Gross beta, $\mathrm{pCi} / \mathrm{L}$ & $\begin{array}{l}\mathbf{N} \\
N \\
N \\
N \\
N \\
N \\
N\end{array}$ & $\begin{array}{l}299-W 10-12 \\
299-W 10-4 \\
299-W 10-8 \\
299-W 11-23 \\
299-W 11-24 \\
299-W 11-27 \\
299-W 11-28\end{array}$ & $\begin{array}{l}\text { Down } \\
\text { Up } \\
\text { Down } \\
\text { Down } \\
\text { Down } \\
\text { Down } \\
\text { Down }\end{array}$ & $\begin{array}{l}4 \\
4 \\
4 \\
4 \\
2 \\
4 \\
5\end{array}$ & $\begin{array}{r}79.9 \\
81.1 \\
114 \\
2640 \\
67.3 \\
5710 \\
146\end{array}$ & $\begin{array}{l}50 \\
50 \\
50 \\
50 \\
50 \\
50 \\
50\end{array}$ \\
\hline Iron, $\mu \mathrm{g} / \mathrm{L}$ & $\begin{array}{l}\mathrm{Y} \\
\mathrm{Y}\end{array}$ & $\begin{array}{l}299-W 11-24 \\
299-W 11-28\end{array}$ & $\begin{array}{l}\text { Down } \\
\text { Down }\end{array}$ & $\begin{array}{l}1 \\
1\end{array}$ & $\begin{array}{l}401 \\
360\end{array}$ & $\begin{array}{l}300 \\
300\end{array}$ \\
\hline Manganese, $\mu g / L$ & $\begin{array}{l}\mathrm{Y} \\
\mathrm{Y} \\
\mathrm{Y}\end{array}$ & $\begin{array}{l}299-W 11-24 \\
299-W 11-27 \\
299-W 11-28\end{array}$ & $\begin{array}{l}\text { Down } \\
\text { Down } \\
\text { Down }\end{array}$ & $\begin{array}{l}2 \\
1 \\
5\end{array}$ & $\begin{array}{r}135 \\
55.6 \\
193\end{array}$ & $\begin{array}{l}50 \\
50 \\
50\end{array}$ \\
\hline
\end{tabular}


Table A.25. (contd)

\begin{tabular}{|c|c|c|c|c|c|c|}
\hline Constituent, unit ${ }^{(a)}$ & Filter ${ }^{(0)}$ & Well Name & $\begin{array}{c}\text { Upgradient/ } \\
\text { Downgradient }\end{array}$ & $\begin{array}{l}\text { Number of } \\
\text { Exceedances }\end{array}$ & $\begin{array}{c}\text { Maximum } \\
\text { Result }\end{array}$ & $\begin{array}{c}\text { Drinking } \\
\text { Water } \\
\text { Standard }\end{array}$ \\
\hline Nitrate, $\mu \mathrm{g} / \mathrm{L}$ & $\begin{array}{l}N \\
N \\
N \\
N \\
N \\
N\end{array}$ & $\begin{array}{l}299-W 10-12 \\
299-W 10-16 \\
299-W 10-4 \\
299-W 10-8 \\
299-W 11-27 \\
299-W 11-28\end{array}$ & $\begin{array}{l}\text { Down } \\
\text { Up } \\
\text { Up } \\
\text { Down } \\
\text { Down } \\
\text { Down }\end{array}$ & $\begin{array}{l}1 \\
1 \\
1 \\
1 \\
1 \\
2\end{array}$ & $\begin{array}{r}350,000 \\
190,000 \\
650,000 \\
450,000 \\
97,000 \\
150,000\end{array}$ & $\begin{array}{l}45,000 \\
45,000 \\
45,000 \\
45,000 \\
45,000 \\
45,000\end{array}$ \\
\hline Nitrogen in nitrate, $\mu \mathrm{g} / \mathrm{L}$ & $\begin{array}{l}N \\
N \\
N \\
N \\
N \\
N \\
N \\
N \\
N \\
N\end{array}$ & $\begin{array}{l}299-W 10-1 \\
299-W 10-12 \\
299-W 10-16 \\
299-W 10-22 \\
299-W 10-4 \\
299-W 10-8 \\
299-W 11-23 \\
299-W 11-24 \\
299-W 11-27 \\
299-W 11-28\end{array}$ & $\begin{array}{l}\text { Up } \\
\text { Down } \\
\text { Up } \\
\text { Down } \\
\text { Up } \\
\text { Down } \\
\text { Down } \\
\text { Down } \\
\text { Down } \\
\text { Down }\end{array}$ & $\begin{array}{l}1 \\
3 \\
2 \\
1 \\
3 \\
3 \\
2 \\
3 \\
3 \\
3\end{array}$ & $\begin{array}{r}42,600 \\
85,800 \\
45,700 \\
10,400 \\
153,000 \\
108,000 \\
14,500 \\
31,200 \\
30,400 \\
36,300\end{array}$ & $\begin{array}{l}10,000 \\
10,000 \\
10,000 \\
10,000 \\
10,000 \\
10,000 \\
10,000 \\
10,000 \\
10,000 \\
10,000\end{array}$ \\
\hline Nitrogen in nitrite, $\mu g / L$ & $\mathrm{~N}$ & $299-W 11-24$ & Down & 1 & 1,130 & 1,000 \\
\hline $\mathrm{pH}$ & $\begin{array}{l}\mathrm{N} \\
\mathrm{N}\end{array}$ & $\begin{array}{l}299-W 11-24 \\
299-W 11-28\end{array}$ & $\begin{array}{l}\text { Down } \\
\text { Down }\end{array}$ & $\begin{array}{l}1 \\
1\end{array}$ & $\begin{array}{r}9.29 \\
10.25\end{array}$ & $\begin{array}{l}8.5 \\
8.5\end{array}$ \\
\hline Sulfate, $\mu \mathrm{g} / \mathrm{L}$ & $\mathbf{N}$ & 299-W11-27 & Down & 1 & 266,000 & 250,000 \\
\hline Technetium-99, $\mathrm{pCi} / \mathrm{L}$ & $\begin{array}{l}N \\
N\end{array}$ & $\begin{array}{l}299-W 11-23 \\
299-W 11-27\end{array}$ & $\begin{array}{l}\text { Down } \\
\text { Down }\end{array}$ & $\begin{array}{l}4 \\
4\end{array}$ & $\begin{array}{r}5,950 \\
15,200\end{array}$ & $\begin{array}{l}900 \\
900\end{array}$ \\
\hline Total dissolved solids, $\mu \mathrm{g} / \mathrm{L}$ & $\begin{array}{l}\mathrm{N} \\
\mathrm{N} \\
\mathrm{N} \\
\mathrm{N} \\
\mathrm{N} \\
\mathrm{N} \\
\mathrm{N} \\
\mathrm{N}\end{array}$ & $\begin{array}{l}299-W 10-1 \\
299-W 10-12 \\
299-W 10-16 \\
299-W 10-4 \\
299-W 10-8 \\
299-W 11-24 \\
299-W 11-27 \\
299-W 11-28\end{array}$ & $\begin{array}{l}\text { Up } \\
\text { Down } \\
\text { Up } \\
\text { Up } \\
\text { Down } \\
\text { Down } \\
\text { Down } \\
\text { Down }\end{array}$ & $\begin{array}{l}1 \\
4 \\
3 \\
4 \\
4 \\
1 \\
4 \\
5\end{array}$ & $\begin{array}{r}537,000 \\
859,000 \\
620,000 \\
1,273,000 \\
962,000 \\
550,000 \\
781,000 \\
640,000\end{array}$ & $\begin{array}{l}500,000 \\
500,000 \\
500,000 \\
500,000 \\
500,000 \\
500,000 \\
500,000 \\
500,000\end{array}$ \\
\hline Trichloroethene, $\mu \mathrm{g} / \mathrm{L}$ & $\begin{array}{l}\mathrm{N} \\
\mathrm{N}\end{array}$ & $\begin{array}{l}299-W 10-12 \\
299-W 11-28\end{array}$ & $\begin{array}{l}\text { Down } \\
\text { Down }\end{array}$ & $\begin{array}{l}1 \\
2\end{array}$ & $\begin{array}{l}10 \\
11\end{array}$ & $\begin{array}{l}5 \\
5\end{array}$ \\
\hline Tritium, $\mathrm{pCi} / \mathrm{L}$ & $\begin{array}{l}\mathbf{N} \\
\mathbf{N} \\
\mathbf{N} \\
\mathbf{N} \\
\mathbf{N} \\
\mathbf{N}\end{array}$ & $\begin{array}{l}299-W 10-12 \\
299-W 10-16 \\
299-W 10-4 \\
299-W 10-8 \\
299-W 11-24 \\
299-W 11-28\end{array}$ & $\begin{array}{l}\text { Down } \\
\text { Up } \\
\text { Up } \\
\text { Down } \\
\text { Down } \\
\text { Down }\end{array}$ & $\begin{array}{l}4 \\
3 \\
4 \\
4 \\
3 \\
5\end{array}$ & $\begin{array}{l}27,000 \\
36,700 \\
32,800 \\
27,500 \\
27,000 \\
47,100\end{array}$ & $\begin{array}{l}20,000 \\
20,000 \\
20,000 \\
20,000 \\
20,000 \\
20,000\end{array}$ \\
\hline \multicolumn{7}{|c|}{ Waste Management Area T Assessment Wells } \\
\hline Aluminum, $\mu \mathrm{g} / \mathrm{L}$ & $\mathbf{Y}$ & 299-W11-31 & Down & 2 & 265 & 50 \\
\hline Carbon tetrachloride, $\mu g / L$ & $\begin{array}{l}\mathbf{N} \\
\mathbf{N} \\
\mathbf{N} \\
\mathrm{N} \\
\mathrm{N}\end{array}$ & $\begin{array}{l}299-W 10-19 \\
299-W 10-20 \\
299-W 10-21 \\
299-W 6-10 \\
299-W 6-2\end{array}$ & $\begin{array}{l}\text { Down } \\
\text { Down } \\
\text { Down } \\
\text { Up } \\
\text { Down }\end{array}$ & $\begin{array}{l}2 \\
2 \\
2 \\
1 \\
2\end{array}$ & $\begin{array}{r}900 \\
1,200 \\
610 \\
580 \\
97\end{array}$ & $\begin{array}{l}5 \\
5 \\
5 \\
5 \\
5\end{array}$ \\
\hline Gross beta, $\mathrm{pCi} / \mathrm{L}$ & $\stackrel{N}{N}$ & $\begin{array}{l}\text { 299-W11-31 } \\
299-W 6-10\end{array}$ & $\begin{array}{l}\text { Down } \\
\text { Up }\end{array}$ & $\begin{array}{l}3 \\
3\end{array}$ & $\begin{array}{l}138 \\
111\end{array}$ & $\begin{array}{l}50 \\
50\end{array}$ \\
\hline Iodine-129, $\mathrm{pCi} / \mathrm{L}$ & $\begin{array}{l}\mathrm{N} \\
\mathrm{N}\end{array}$ & $\begin{array}{l}\text { 299-W11-31 } \\
299-W 6-10\end{array}$ & $\begin{array}{c}\text { Down } \\
\text { Up }\end{array}$ & $\begin{array}{l}1 \\
1\end{array}$ & $\begin{array}{l}2.07 \\
2.02\end{array}$ & \\
\hline
\end{tabular}


Table A.25. (contd)

\begin{tabular}{|c|c|c|c|c|c|c|}
\hline Constituent, unit ${ }^{(a)}$ & Filter $r^{(b)}$ & Well Name & $\begin{array}{l}\text { Upgradient/ } \\
\text { Downgradient }\end{array}$ & $\begin{array}{l}\text { Number of } \\
\text { Exceedances }\end{array}$ & $\begin{array}{c}\text { Maximum } \\
\text { Result }\end{array}$ & $\begin{array}{c}\text { Drinking } \\
\text { Water } \\
\text { Standard }\end{array}$ \\
\hline Iron, $\mu g / L$ & $\begin{array}{l}Y \\
Y\end{array}$ & $\begin{array}{l}\text { 299-W11-31 } \\
299-W 6-9\end{array}$ & $\begin{array}{l}\text { Down } \\
\text { Down }\end{array}$ & $\begin{array}{l}1 \\
1\end{array}$ & $\begin{array}{l}375 \\
641\end{array}$ & $\begin{array}{l}300 \\
300\end{array}$ \\
\hline Methylenechloride, $\mu \mathrm{g} / \mathrm{L}$ & $\mathrm{N}$ & 299-W10-20 & Down & 1 & 26 & 5 \\
\hline Nitrogen in nitrate, $\mu \mathrm{g} / \mathrm{L}$ & $\begin{array}{l}N \\
N \\
N \\
N \\
N \\
N \\
N \\
N\end{array}$ & $\begin{array}{l}299-W 10-19 \\
299-W 10-20 \\
299-W 10-21 \\
299-W 11-31 \\
299-W 6-10 \\
299-W 6-2 \\
299-W 6-4 \\
299-W 6-9\end{array}$ & $\begin{array}{l}\text { Down } \\
\text { Down } \\
\text { Down } \\
\text { Down } \\
\text { Up } \\
\text { Down } \\
\text { Down } \\
\text { Down }\end{array}$ & $\begin{array}{l}3 \\
3 \\
3 \\
3 \\
3 \\
3 \\
3 \\
3 \\
3 \\
3\end{array}$ & $\begin{array}{l}31,100 \\
29,800 \\
45,200 \\
28,600 \\
25,800 \\
11,500 \\
18,500 \\
13,100\end{array}$ & $\begin{array}{l}10,000 \\
10,000 \\
10,000 \\
10,000 \\
10,000 \\
10,000 \\
10,000 \\
10,000\end{array}$ \\
\hline $\mathrm{pH}$ & $\stackrel{N}{N}$ & $\begin{array}{l}\text { 299-W10-19 } \\
299-W 6-4\end{array}$ & $\begin{array}{l}\text { Down } \\
\text { Down }\end{array}$ & $\begin{array}{l}5 \\
1\end{array}$ & $\begin{array}{l}8.96 \\
8.79\end{array}$ & $\begin{array}{l}8.5 \\
8.5\end{array}$ \\
\hline Total dissolved solids, $\mu \mathrm{g} / \mathrm{L}$ & $\begin{array}{l}\mathrm{N} \\
\mathrm{N} \\
\mathrm{N}\end{array}$ & $\begin{array}{l}299-W 10-21 \\
299-W 11-31 \\
299-W 6-10\end{array}$ & $\begin{array}{l}\text { Down } \\
\text { Down } \\
\text { Up }\end{array}$ & $\begin{array}{l}1 \\
1 \\
1\end{array}$ & $\begin{array}{l}609,000 \\
545,000 \\
506,000\end{array}$ & $\begin{array}{l}500,000 \\
500,000 \\
500,000\end{array}$ \\
\hline Trichloroethene, $\mu g / L$ & $\begin{array}{l}N \\
N\end{array}$ & $\begin{array}{l}299-W 10-21 \\
299-W 6-10\end{array}$ & Down & $\begin{array}{l}2 \\
1\end{array}$ & $\begin{array}{r}7 \\
10\end{array}$ & $\begin{array}{l}5 \\
5\end{array}$ \\
\hline Tritium, $\mathrm{pCi} / \mathrm{L}$ & $\begin{array}{l}\mathrm{N} \\
\mathrm{N} \\
\mathrm{N}\end{array}$ & $\begin{array}{l}299-W 11-31 \\
299-W 6-10 \\
299-W 6-4\end{array}$ & $\begin{array}{l}\text { Down } \\
\text { Up } \\
\text { Down }\end{array}$ & $\begin{array}{l}3 \\
3 \\
3\end{array}$ & $\begin{array}{l}59,300 \\
57,400 \\
24,200\end{array}$ & $\begin{array}{l}20,000 \\
20,000 \\
20,000\end{array}$ \\
\hline \multicolumn{7}{|c|}{ Waste Mạagement Area TX-TY } \\
\hline Aluminum, $\mu \mathrm{g} / \mathrm{L}$ & $\mathbf{Y}$ & 299-W10-17 & Down & 1 & 86.1 & 50 \\
\hline Cadmium, $\mu g / L$ & $\begin{array}{l}\mathrm{Y} \\
\mathrm{Y} \\
\mathrm{Y}\end{array}$ & $\begin{array}{l}299-W 10-18 \\
299-W 14-12 \\
299-W 15-22\end{array}$ & $\begin{array}{l}\text { Down } \\
\text { Down } \\
\text { Up }\end{array}$ & $\begin{array}{l}2 \\
1 \\
1\end{array}$ & $\begin{array}{l}45.7 \\
24.8 \\
39.8\end{array}$ & $\begin{array}{l}5 \\
5 \\
5\end{array}$ \\
\hline Carbon tetrachloride, $\mu \mathrm{g} / \mathrm{L}$ & $\stackrel{N}{N}$ & $\begin{array}{l}\text { 299-W14-6 } \\
299-W 15-4\end{array}$ & $\begin{array}{l}\text { Down } \\
\text { Down }\end{array}$ & $\begin{array}{l}1 \\
5\end{array}$ & $\begin{array}{l}230 \\
510\end{array}$ & $\begin{array}{l}5 \\
5\end{array}$ \\
\hline Gross alpha, pCi/L & $\stackrel{N}{N}$ & $\begin{array}{l}\text { 299-W10-18 } \\
\text { 299-W15-22 }\end{array}$ & $\begin{array}{c}\text { Down } \\
\text { Up }\end{array}$ & $\begin{array}{l}1 \\
2\end{array}$ & $\begin{array}{r}27.6 \\
157\end{array}$ & $\begin{array}{l}15 \\
15\end{array}$ \\
\hline Gross beta, $\mathrm{pCi} / \mathrm{L}$ & $\begin{array}{l}N \\
N \\
N \\
N \\
N \\
N \\
N \\
N \\
N\end{array}$ & $\begin{array}{l}299-W 10-17 \\
299-W 10-18 \\
299-W 14-12 \\
299-W 14-2 \\
299-W 14-5 \\
299-W 14-6 \\
299-W 15-12 \\
299-W 15-22 \\
299-W 15-4\end{array}$ & $\begin{array}{l}\text { Down } \\
\text { Down } \\
\text { Down } \\
\text { Down } \\
\text { Down } \\
\text { Down } \\
\text { Down } \\
\text { Up } \\
\text { Down }\end{array}$ & $\begin{array}{l}4 \\
2 \\
4 \\
1 \\
1 \\
1 \\
1 \\
3 \\
1 \\
1\end{array}$ & $\begin{array}{l}139 \\
103 \\
756 \\
193 \\
97.2 \\
72.6 \\
144 \\
942 \\
113\end{array}$ & $\begin{array}{l}50 \\
50 \\
50 \\
50 \\
50 \\
50 \\
50 \\
50 \\
50\end{array}$ \\
\hline Iodine-129, $\mathrm{pCi} / \mathrm{L}$ & $\begin{array}{l}\mathrm{N} \\
\mathrm{N}\end{array}$ & $\begin{array}{l}299-W 14-12 \\
299-W 14-2\end{array}$ & $\begin{array}{l}\text { Down } \\
\text { Down }\end{array}$ & $\begin{array}{l}4 \\
1\end{array}$ & $\begin{array}{l}22.1 \\
81.4\end{array}$ & $\begin{array}{l}1 \\
1\end{array}$ \\
\hline Iron, $\mu \mathrm{g} / \mathrm{L}$ & $\mathrm{Y}$ & 299-W14-2 & Down & 1 & 1,050 & 300 \\
\hline Manganese, $\mu \mathrm{g} / \mathrm{L}$ & $\begin{array}{l}Y \\
Y \\
Y \\
Y\end{array}$ & $\begin{array}{l}299-W 14-12 \\
299-W 14-2 \\
299-W 14-5 \\
299-W 15-22\end{array}$ & $\begin{array}{l}\text { Down } \\
\text { Down } \\
\text { Down } \\
\text { Up }\end{array}$ & $\begin{array}{l}1 \\
1 \\
1 \\
1\end{array}$ & $\begin{array}{r}93.6 \\
444 \\
108 \\
75.5\end{array}$ & $\begin{array}{l}50 \\
50 \\
50 \\
50\end{array}$ \\
\hline Nickel, $\mu g / L$ & $\mathbf{Y}$ & 299-W15-22 & Up & 1 & 118 & 100 \\
\hline
\end{tabular}


Table A.25. (contd)

\begin{tabular}{|c|c|c|c|c|c|c|}
\hline Constituent, unit $\mathrm{t}^{(\mathrm{)})}$ & Filter ${ }^{(b)}$ & Well Name & $\begin{array}{l}\text { Upgradient } \\
\text { Downgradient }\end{array}$ & $\begin{array}{l}\text { Number of } \\
\text { Exceedances }\end{array}$ & $\begin{array}{c}\text { Maximum } \\
\text { Result }\end{array}$ & $\begin{array}{l}\text { Drinking } \\
\text { Water } \\
\text { Standard }\end{array}$ \\
\hline Nitrate, $\mu \mathrm{g} / \mathrm{L}$ & $\mathbf{N}$ & 299-W10-17 & Down & 1 & 150,000 & 45,000 \\
\hline Nitrogen in nitrate, $\mu \mathrm{g} / \mathrm{L}$ & $\begin{array}{l}N \\
N \\
N \\
N \\
N \\
N \\
N \\
N\end{array}$ & $\begin{array}{l}299-W 10-17 \\
299-W 10-18 \\
299-W 14-12 \\
299-W 14-2 \\
299-W 14-5 \\
299-W 14-6 \\
299-W 15-22 \\
299-W 15-4\end{array}$ & $\begin{array}{l}\text { Down } \\
\text { Down } \\
\text { Down } \\
\text { Down } \\
\text { Down } \\
\text { Down } \\
\text { Up } \\
\text { Down }\end{array}$ & $\begin{array}{l}3 \\
3 \\
4 \\
1 \\
1 \\
1 \\
1 \\
3 \\
1\end{array}$ & $\begin{array}{l}37,700 \\
19,300 \\
92,500 \\
11,900 \\
37,600 \\
24,600 \\
43,000 \\
29,700\end{array}$ & $\begin{array}{l}10,000 \\
10,000 \\
10,000 \\
10,000 \\
10,000 \\
10,000 \\
10,000 \\
10,000\end{array}$ \\
\hline $\mathrm{pH}$ & $\mathrm{N}$ & 299-W14-2 & Down & 1 & 8.93 & 8.5 \\
\hline Technetium-99, $\mathrm{pCi} / \mathrm{L}$ & $\begin{array}{l}\mathrm{N} \\
\mathrm{N}\end{array}$ & $\begin{array}{l}299-W 14-12 \\
299-W 15-22\end{array}$ & $\begin{array}{l}\text { Down } \\
\text { Up }\end{array}$ & $\begin{array}{l}4 \\
3\end{array}$ & $\begin{array}{l}2,880 \\
3,680\end{array}$ & $\begin{array}{l}900 \\
900\end{array}$ \\
\hline Total dissolved solids, $\mu \mathrm{g} / \mathrm{L}$ & $\begin{array}{l}\mathrm{N} \\
\mathrm{N} \\
\mathrm{N}\end{array}$ & $\begin{array}{l}299-W 10-17 \\
299-W 14-12 \\
299-W 14-5\end{array}$ & $\begin{array}{l}\text { Down } \\
\text { Down } \\
\text { Down }\end{array}$ & $\begin{array}{l}2 \\
4 \\
1\end{array}$ & $\begin{array}{r}525,000 \\
1,180,000 \\
596,000\end{array}$ & $\begin{array}{r}500,000 \\
500,000 \\
500,000\end{array}$ \\
\hline Tritium, $\mathrm{pCi} / \mathrm{L}$ & $\begin{array}{l}N \\
N \\
N \\
N \\
N\end{array}$ & $\begin{array}{l}299-W 10-17 \\
299-W 14-12 \\
299-W 14-2 \\
299-W 15-12 \\
299-W 15-22\end{array}$ & $\begin{array}{c}\text { Down } \\
\text { Down } \\
\text { Down } \\
\text { Down } \\
\text { Up }\end{array}$ & $\begin{array}{l}4 \\
4 \\
1 \\
1 \\
2\end{array}$ & $\begin{array}{r}33,400 \\
415,000 \\
3,210,000 \\
33,700 \\
20,100\end{array}$ & $\begin{array}{l}20,000 \\
20,000 \\
20,000 \\
20,000 \\
20,000\end{array}$ \\
\hline \multicolumn{7}{|c|}{ Waste Management Area U } \\
\hline Aluminum, $\mu \mathrm{g} \Omega$ & $\mathbf{Y}$ & 299-W19-32 & Down & 1 & 336 & 50 \\
\hline Carbon tetrachloride, $\mu \mathrm{g} / \mathrm{L}$ & $\mathbf{N}$ & $299-W 18-30$ & Down & 6 & 760 & 5 \\
\hline Gross alpha, $\mathrm{pCi} / \mathrm{L}$ & $\mathrm{N}$ & 299-W19-32 & Down & 1 & 19.6 & 15 \\
\hline Gross beta, $\mathrm{pCi} / \mathrm{L}$ & $\begin{array}{l}\mathbf{N} \\
\mathbf{N} \\
\mathrm{N}\end{array}$ & $\begin{array}{l}299-W 19-12 \\
299-W 19-31 \\
299-W 19-32\end{array}$ & $\begin{array}{l}\text { Down } \\
\text { Down } \\
\text { Down }\end{array}$ & $\begin{array}{l}3 \\
4 \\
2\end{array}$ & $\begin{array}{r}75 \\
114 \\
59.9\end{array}$ & $\begin{array}{l}50 \\
50 \\
50\end{array}$ \\
\hline Iron, $\mu \mathrm{g} / \mathrm{L}$ & $\mathrm{Y}$ & 299-W19-32 & Down & 1 & 1,060 & 300 \\
\hline Manganese, $\mu \mathrm{g} / \mathrm{L}$ & $\mathrm{Y}$ & 299-W19-32 & Down & 1 & 160 & 50 \\
\hline Nickel, $\mu g / \mathrm{L}$ & $\mathrm{Y}$ & 299-W19-32 & Down & 1 & 227 & 100 \\
\hline $\mathrm{pH}$ & $\mathbf{N}$ & 299-W19-31 & Down & 1 & 8.59 & 8.5 \\
\hline
\end{tabular}

(a) See Table 5.1-1 for references to standards. Aluminum, iron, manganese, silver, sulfate, total dissolved solids are secondary maximum contaminant levels. Standard for hexavalent chromium is assumed to be the same as total chromium.

(b) Sampled filtered in the field. 
Table A.26. Monitoring Wells and Constituents for Environmental Restoration Disposal Facility - (adapted from BHI-00873).

\begin{tabular}{|c|c|c|c|c|c|}
\hline Well & $\begin{array}{l}\text { Hydrogeologic } \\
\text { Unit Monitored }\end{array}$ & $\begin{array}{l}\text { Sampling } \\
\text { Frequency }\end{array}$ & $\begin{array}{l}\text { Water-Level } \\
\text { Measurement }\end{array}$ & $\begin{array}{c}\text { Well } \\
\text { Standard }\end{array}$ & $\begin{array}{c}\text { Other } \\
\text { Network }\end{array}$ \\
\hline $699-35-66 A^{57}$ & Top of unconfined & Semiannual & Semiannual & PRE & Surveillance \\
\hline $699-36-67^{96}$ & Top of unconfined & Semiannual & Semiannual & RCRA & - \\
\hline $699-36-70 \mathrm{~A}^{94}$ & Top of unconfined & Semiannual & Semiannual & RCRA & $\begin{array}{l}\text { 216-U-12, } \\
\text { Surveillance }\end{array}$ \\
\hline $699-37-68^{96}$ & Top of unconfined & Semiannual & Semiannual & RCRA & - \\
\hline \multicolumn{2}{|c|}{ Field Parameters } & & \multicolumn{3}{|c|}{ Site Specific Parameters } \\
\hline \multicolumn{2}{|l|}{$\mathrm{pH}$} & \multicolumn{2}{|r|}{ Alkalinity } & \multicolumn{2}{|c|}{ ICP metals (filtered) } \\
\hline \multicolumn{2}{|c|}{ Specific conductance } & \multicolumn{2}{|r|}{ Anions } & \multicolumn{2}{|c|}{ Iodine-129 } \\
\hline \multirow[t]{5}{*}{ Turbidity } & & \multicolumn{2}{|r|}{ Arsenic (filtered) } & \multicolumn{2}{|l|}{ Radium } \\
\hline & & \multicolumn{2}{|r|}{ Carbon-14 } & \multicolumn{2}{|c|}{ Technetium-99 } \\
\hline & & \multicolumn{2}{|r|}{ Carbon tetrachloride } & \multicolumn{2}{|c|}{ Total dissolved solids } \\
\hline & & \multicolumn{2}{|r|}{ Gross alpha } & \multicolumn{2}{|c|}{ Total organic halides } \\
\hline & & \multicolumn{2}{|r|}{ Gross beta } & \multicolumn{2}{|l|}{ Uranium } \\
\hline
\end{tabular}

Shading = Upgradient well.

Superscript $=$ Year of installation.

RCRA = Well constructed to RCRA standards. 


\title{
Appendix B
}

\author{
Statistics
}





\section{Contents}

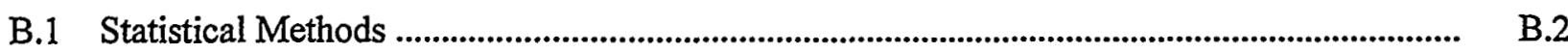

B.1.1 RCRA Interim-Status Facilities ..................................................................... B.

B.1.2 RCRA Final-Status Facilities ............................................................................ B.4

B.1.2.1 Detection-Level Monitoring.................................................................... B.4

B.1.2.2 Compliance-Level Monitoring ................................................................ B. B

B.1.2.3 Corrective Action ............................................................................... B. B

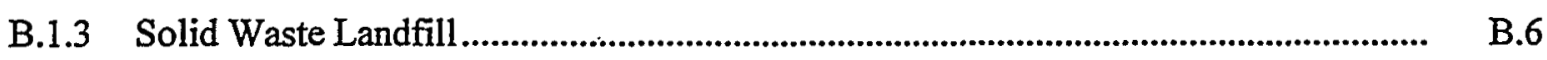

B.1.3.1 Calculating Background Summary Statistics .............................................. B. 6

B.1.3.2 Testing Assumption of Normality of Data ................................................ B. B.

B.1.3.3 Establishing Background Levels ................................................................ B.7

B.1.3.4 Comparisons with Background Levels......................................................... B. B

B.1.4 Liquid Effluent-Receiving Facilities ................................................................ B. B.

B.1.4.1 Preoperational Monitoring ................................................................... B. B.

B.1.4.2 Operational Monitoring........................................................................... B. B

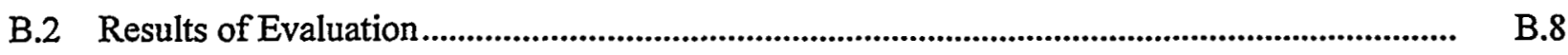

B.2.1 RCRA Interim-Status Facilities ....................................................................... B.8

B.2.1.1 Waste Management Area U ................................................................ B. B

B.2.1.2 216-A-29 Ditch ............................................................................... B. B

B.2.1.3 1301-N Liquid Waste-Disposal Facility.................................................... B. B

B.2.1.4 1324-N/NA Liquid Waste-Disposal Facility ........................................... B.9

B.2.1.5 1325-N Liquid Waste-Disposal Facility.................................................... B. B

B.2.1.6 Liquid Effluent-Retention Facility ....................................................... B.10

B.2.1.7 120-D-1 Ponds..................................................................................... B. B

B.2.1.8 216-S-10 Pond and Ditch ................................................................ B.11

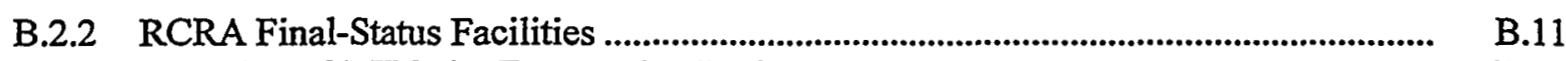

B.2.2.1 183-H Solar Evaporation Basins ............................................................... B.11

B.2.2.2 316-5 Process Trenches........................................................................ B.11

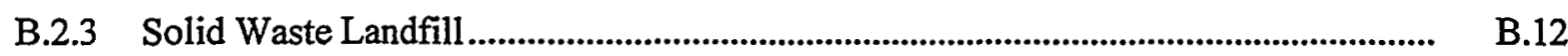

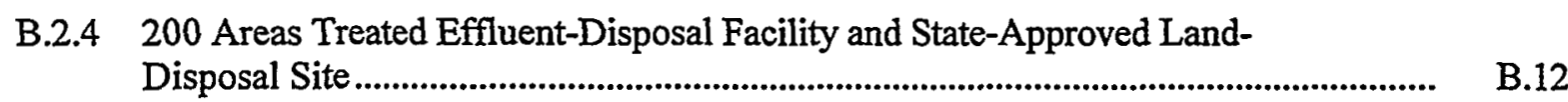

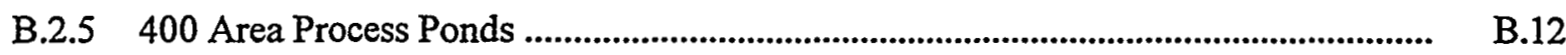

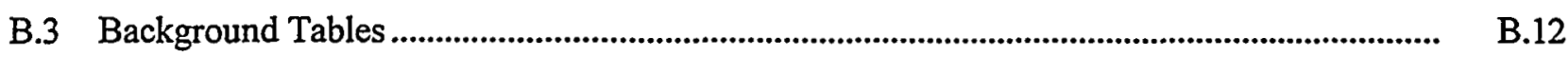

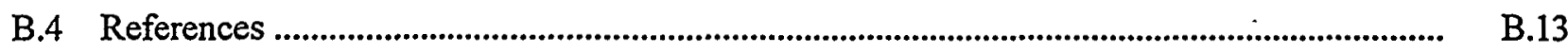




\section{Tables}

B.1 Results of Lilliefors Test for Normality and Background Threshold Values for Solid Waste Landfill

B.2 Summary of Groundwater-Sampling Results for 316-5 Process Trenches

B.3 Sampling Results for Required Constituents at Solid Waste Landfill

B.18

B.4 Critical Means for 20 Comparisons--Background Contamination Indicator Parameter Data for 1301-N Liquid Waste-Disposal Facility

B.5 Critical Means for 16 Comparisons--Background Contamination Indicator Parameter Data for 1324-N/NA Liquid Waste-Disposal Facilities

B.6 Critical Means for 16 Comparisons--Background Contamination Indicator Parameter Data for 1325-N Liquid Waste-Disposal Facility

B.7 Critical Means for 16 Comparisons--Background Contamination Indicator Parameter Data for 120-D-1 Ponds.

B.8 Critical Means for 20 Comparisons--Background Contamination Indicator Parameter Data for 216-S-10 Pond and Ditch

B.9 Critical Means for 36 Comparisons--Background Contamination Indicator Parameter Data for 216-B-3 Pond

B.10 Critical Means for 36 Comparisons--Background Contamination Indicator Parameter Data for 2160-A-29 Ditch

B.11 Critical Means for 48 Comparisons--Background Contamination Indicator Parameter Data for 216-B-63 Trench

B.12 Critical Means for 16 Comparisons--Background Contamination Indicator Parameter Data for Liquid Effluent-Retention Facility

B.13 Critical Means for 68 Comparisons--Background Contamination Indicator Parameter Data for Low-Level Waste Management Area 1

B.14 Critical Means for 48 Comparisons--Background Contamination Indicator Parameter Data for Low-Level Waste Management Area 2

B.15 Critical Means for 28 Comparisons--Background Contamination Indicator Parameter Data for Low-Level Waste Management Area 3

B.16 Critical Means for 40 Comparisons--Background Contamination Indicator Parameter Data for Low-Level Waste Management Area 3 
B.17 Critical Means for 40 Comparisons--Background Contamination Indicator Parameter Data for Low-Level Waste Management Area 4

B.18 Critical Means for 20 Comparisons--Background Contamination Indicator Parameter Data for Waste Management Area A-AX.

B.19 Critical Means for 16 Comparisons--Background Contamination Indicator Parameter Data for Waste Management Area C.

B.20 Critical Means for 20 Comparisons--Background Contamination Indicator Parameter Data for Waste Management Area U.

B.21 Critical Means for 28 Comparisons--Background Contamination Indicator Parameter Data for Nonradioactive Dangerous Waste Landfill 


\section{Appendix B}

\section{Statistics}

\section{J. Chou}

Data gathered in support of groundwater monitoring at the Hanford Site are used to evaluate the changes noted in groundwater quality from baseline conditions of the various operations facilities. The methods used for the statistical evaluations are described in this appendix. The facilities included in this evaluation are the 1) Resource Conservation and Recovery Act of 1976 (RCRA) liquid and solid waste treatment, storage, and/or disposal units; 2) Solid Waste Landfill; and 3) some liquid effluent-receiving facilities where statistical comparisons of groundwater samples were specified in the groundwatermonitoring plans.

The RCRA units with a potential to contaminate groundwater require monitoring as prescribed in 40 CFR 265, WAC 173-303-400 (interim status), and 40 CFR 264 Subpart F and WAC 173-303-645 (final status). During fiscal year (FY) 1998, groundwater-monitoring activities at most of the RCRA units were governed by interim-status regulations, except for the $183-\mathrm{H}$ solar evaporation basins and the 316-5 process trenches that were subject to corrective-action-level programs in accordance with finalstatus regulations. The Solid Waste Landfill, though not a RCRA hazardous waste site, is statistically evaluated according to requirements of WAC 173-304. A permit application for the Solid Waste Landfill was prepared (DOE/RL-90-38).

Operations at the 200 Areas Treated Effluent-Disposal Facility and the State-Approved LandDisposal Site began during 1995. Another facility, the $4608 \mathrm{~B} / \mathrm{C}$ ponds (also called the 400 Area process. ponds), consists of unlined infiltration ponds that receive wastewater from the 400 Area facilities. These sites are regulated by WAC 173-216. Because these are discharge permit disposal facilities, they require effluent and groundwater monitoring. Upgradient and downgradient comparisons for constituents of concern were performed at these sites in accordance with groundwater-monitoring plans.

During FY 1997, the Hanford Groundwater Monitoring Project developed a data quality objectivesbased process that integrates various groundwater-monitoring projects for the Hanford Site. This process has been used to justify why data are being collected, how the data will be used to make decisions, and the amount of data needed to meet criteria specified by the stakeholders. Efforts are under way to work with the stakeholders in developing a groundwater-monitoring strategy that will allow the use of technically improved statistical evaluation procedures (e.g., methods allowed by final status) rather than strict adherence to interim-status requirements. The State of Washington Department of Ecology's approval is needed to implement the proposed sampling and analysis procedures. Although they have not granted a waiver for applying final-status methods at interim-status sites, discussions will continue to resolve many issues regarding groundwater monitoring (e.g., allowable statistical method, constituents of concern; network, control limits). 


\section{B.1 Statistical Methods}

\section{B.1.1 RCRA Interim-Status Facilities}

The primary objectives of RCRA groundwater monitoring are to comply with regulatory requirements and agreements; to assess potential impacts on groundwater quality; and to identify near-term corrective measures, if feasible, to mitigate the impacts. In accordance with 40 CFR 265 Subpart F (which was incorporated, by reference, into WAC 173-303-400), RCRA projects are monitored according to one of three levels of effort: 1) background monitoring, 2) indicator parameter evaluation, or 3) groundwater quality assessment. All of the RCRA facilities at the Hanford Site have completed their initial background monitoring programs.

Statistical evaluations for interim status RCRA facilities during FY 1998 consisted of reestablishing background levels to reflect changing conditions and evaluating the facility's impact on groundwater quality. A general description of the applicable statistical methods that are appropriate for these interimstatus facilities is provided in this section.

The statistical method used to summarize background data is the averaged replicate $t$-test method as described in Appendix B of OSWER-9950.1 and Chou (1991). The averaged replicate t-test method for each contamination indicator parameter during each evaluation period is calculated as

$$
t=\left(\bar{x}_{i}-\bar{x}_{b}\right) / S_{b} * \sqrt{1+1 / n_{b}}
$$

where $\quad t=$ test statistic

$\bar{x}_{i}=$ average of replicates from the $i^{\text {th }}$ monitoring well

$\bar{x}_{\mathrm{b}}=$ background average

$S_{b}=$ background standard deviation

$\mathrm{n}_{\mathrm{b}}=$ number of background replicate averages.

The guiding documentation (OSWER-9950.1) states that a test statistic larger than the Bonferroni critical value, $t_{c}$, (i.e., $t>t_{c}$ ) indicates a statistically significant probability of contamination. These Bonferroni critical values depend on the overall false-positive rate required for each sampling period (i.e., $1 \%$ for interim status), the total number of wells in the monitoring network, and the number of degrees of freedom $\left(n_{b}-1\right)$ associated with the background standard deviation. Because of the nature of the test statistic in Equation (B.1), sampling results to be compared to background do not contribute to the estimate of the variance, $\mathrm{S}_{\mathrm{b}}{ }^{2}$. The test can be reformulated, without prior knowledge of the results of the sample to be compared to background, in such a way that a critical mean, CM, can be obtained

$$
\begin{aligned}
& C M=\bar{x}_{b}+t_{c} * S_{b} * \sqrt{\left(1+1 / n_{b}\right)} \text { (one tailed) } \\
& C M=\bar{x}_{b} \pm t_{c} * S_{b} * \sqrt{\left(1+1 / n_{b}\right)} \text { (two tailed). }
\end{aligned}
$$


For $\mathrm{pH}$, a two-tailed $\mathrm{CM}$ (or critical range) is calculated and a one-tailed $\mathrm{CM}$ is calculated for specific conductance, total organic carbon, and total organic halides. The $\mathrm{CM}$ (or range for $\mathrm{pH}$ ) is the value above which (or above/below in the case of $\mathrm{pH}$ ) a compared value is determined to be statistically different from background.

The measured values for total organic carbon from upgradient (background) wells during the initial background periods for most of the RCRA facilities were less than the contractually required quantitation limit of $1,000 \mu \mathrm{g} / \mathrm{L}$ for DataChem Laboratories, Inc., Salt Lake City, Utah. These values were reported with the contractually required quantitation limit value followed by a $U$ qualifier. Estimates of the background standard deviations cannot be obtained. The lack of estimates of background variability precludes the determination of total organic carbon critical means for various RCRA facilities. In this case, a limit of quantitation is to be used as the threshold value for upgradient/downgradient comparisons. For FY 1998, a limit of quantitation of $1,179 \mu \mathrm{g} / \mathrm{L}$, calculated using FY 1997 field blanks data, was used for total organic carbon (see Table D.10 in PNNL-11793). For comparisons to be conducted in FY 1999, limits of quantitation for total organic carbon and total organic halides were calculated to be 1,140 and $25.2 \mu \mathrm{g} / \mathrm{L}$, respectively, using FY 1998 field blanks data (given in Appendix D of this report). In FY 1998, many total organic carbon blank results were higher than groundwater sample results, and the suspected high values were removed from the limit of quantitation determination. Of the 270 laboratory method blanks run in FY 1998, only $19(\sim 7 \%)$ were above the method detection limit. In contrast, $\sim 50 \%$ of the field blank results were above the method detection limit. These observations suggest some problems may have occurred in preparation of the field blanks. Investigations are under way to identify and correct the cause(s). The removal of unrepresentative total organic carbon blank data resulted in a lower limit of quantitation and a more-sensitive triggering (upgradient/downgradient comparison) value for some of the RCRA facilities where total organic carbon has been essentially not detected in the upgradient wells. In FY 1999, limit of detection/limit of quantitation determinations will be updated more frequently (e.g., quarterly), and the most recent updated values for total organic carbon and total organic halides will be used in the statistical evaluations.

Because of concerns over the laboratory's procedure for total organic halides, samples were analyzed by another laboratory from November 1993 to May 1995. The lack of four consecutive quarters of consistent data did not provide the needed background values from which critical means could be derived. However, the data were evaluated using the following steps: 1) screening total organic halide values from upgradient wells; 2) if results from upgradient wells indicated a history of nondetections, a limit of quantitation was used as the upgradient/downgradient comparison value; and 3) if total organic halides were historically detected, a limit of quantitation could not be used as a surrogate background value. In this case, the background value must be derived based on four quarters of monitoring data and used in the statistical evaluation (e.g., 216-S-10 pond and ditch).

Finally, if the calculated critical ranges for $\mathrm{pH}$ were too large to be meaningful because of the requirement to use four quarters of data to establish background (e.g., 120-D-1 ponds, Liquid Effluent-Retention Facility), the upgradient/downgradient comparison value would be revised to the critical range by using all available data. The expansion of the background dataset to include more than 1 year's data provides a better estimate of background mean and background standard deviation. More important, it increases the number of degrees of freedom associated with the background standard deviation. Other things being equal, a smaller $t_{c}$ value and a narrower critical range for $\mathrm{pH}$ would result. This approach is preferred because it complies with both the requirements and the spirit of the regulations. 


\section{B.1.2 RCRA Final-Status Facilities}

Three levels of groundwater-monitoring programs are required by the final-status regulations (40 CFR 264 Subpart F and WAC 173-303-645): detection monitoring, compliance monitoring, and corrective action. During FY 1998, the 183-H solar evaporation basins and the $316-5$ process trenches were monitored in accordance with the RCRA final-status requirements.

Statistical methods appropriate for a final-status groundwater-monitoring program include analysis of variance, tolerance intervals, prediction intervals, control charts, test of proportions, or other statistical methods approved by the regulator. The important factors to consider when selecting appropriate statistical methods are the distribution(s) of monitoring parameters; the nature of the data; and the proportions of nondetections, seasonal, temporal, and spatial variations. The statistical evaluation procedures chosen for final-status facilities will be based on guidance given in PB89-151047, EPA/530-R-93-003, and American Society for Testing and Materials (1996). Specific statistical methods are to be addressed in the unit-specific permit applications and/or in the groundwater-monitoring plans.

\section{B.1.2.1 Detection-Level Monitoring}

In a detection-level groundwater-monitoring program, the objective is to detect a potential impact from a regulated unit by testing for statistically significant changes in geochemistry in a downgradient monitoring well relative to baseline levels. These baseline levels could be obtained from upgradient (or background) wells, and the comparisons are referred to as interwell (or between-well) comparisons. Alternatively, if baseline values are obtained from historical measurements from that same well, the comparisons are referred to as intrawell (or within-well) comparisons. Groundwater parameter data (e.g., $\mathrm{pH}$, specific conductance, total organic carbon, total organic halides, heavy metals, waste constituents, reaction products) from downgradient, compliance-point wells will be compared semiannually with baseline data to determine whether there is a statistically significant increase (or decrease for $\mathrm{pH}$ ) over baseline concentrations. Final-status, detection-level, groundwater-monitoring plans for the Liquid Effluent-Retention Facility and low-level burial grounds were proposed and presented to the State of Washington Department of Ecology. However, a decision was made to not incorporate the low-level burial grounds into the permit, so these sites continue to be monitored in accordance with interim-status requirements. Although the Liquid Effluent-Retention Facility was included in the Hanford Site RCRA Permit, groundwater monitoring will continue in interim status until regulators approve the final-status plan.

During FY 1998, an attempt was made to design a sampling and analysis plan for an interim-status site (i.e., the 216-B-3 pond) in accordance with final-status requirements using the data quality objectives process. In a data quality objectives meeting, the State of Washington Department of Ecology assigned staff to work with the U.S. Department of Energy, the U.S. Environmental Protection Agency, and stakeholders to address modifications in groundwater monitoring to enhance effectiveness and efficiency within a technically defensible framework. The groundwater-monitoring plan for the 216-B-3 pond (PNNL-11903) was such a proposal. Specific conductance, gross alpha, and gross beta were proposed as constituents of concern, on the basis of the conceptual model, for evaluating possible impacts on groundwater quality from the B Pond system. Additionally, the combined Shewhart-CUSUM (cumulative sum) control-chart approach (Gibbons 1994) was further proposed. Rather than collecting four samples per sampling event, a single sample from wells in the network would be collected and analyzed at least 
semiannually. A change in groundwater concentrations at the compliance well would be declared if any sample result were above a specified upper Shewhart control limit or if the CUSUM statistic were above a specified limit. If one or both of the Shewhart-CUSUM control limits were exceeded, then a resample from the triggering well would be obtained and analyzed for the constituent in question. A statistically significant result would be declared if the resample were larger than the trigger value. In that case, assessment-level monitoring would be conducted to determine if the regulated unit were the source of the contamination. If so, additional monitoring would be initiated to determine the rate and extent of contaminant migration and concentration in the groundwater.

At the time of publication of this report, the proposed groundwater-monitoring plan for the B Pond system had not been approved. One problem appears to be the concern that the B Pond system is still an interim-status facility and the proposed plan does not comply with the interim-status regulations. Continued discussions will be held to resolve the issues regarding groundwater monitoring (e.g., allowable statistical method, constituents of concern, network, control limits).

\section{B.1.2.2 Compliance-Level Monitoring}

A compliance-level, groundwater-monitoring program will be established for a unit if groundwater sampling during detection-level monitoring reveals statistically significant evidence of contamination for constituents of concern at any monitoring well at the compliance point. In compliance-level monitoring, the objective is to determine whether specified concentration limits (e.g., groundwater-protection standards) have been exceeded. This is accomplished by comparing the concentration of a constituent of concern to a concentration limit, such as a risk-based maximum concentration limit; alternative concentration limit; area or natural background; or applicable, relevant, and appropriate requirements. These concentration limits would be applied during compliance monitoring to determine whether corrective action might be necessary.

Maximum concentration limits will be identified for each groundwater-monitoring constituent of concern. Alternative concentration limits will be proposed after considering the observed concentrations of chemical constituents in the groundwater that might have originated from the regulated unit in question. The area background, natural background, and other standards that are applicable, relevant, and . appropriate will be evaluated when proposing an alternative concentration limit. The parameters monitored, the concentration limits, and the statistical methods were specified in the unit-specific groundwatermonitoring plan (e.g., WHC-SD-EN-AP-180).

Groundwater monitoring at the 316-5 process trenches showed a confirmed exceedance of concentration limits for trichloroethylene, cis-1,2-dichloroethylene, and uranium in some of the downgradient compliance wells in FY 1998. The State of Washington Department of Ecology was notified and the site RCRA permit was revised, putting the $316-5$ process trenches into corrective action. However, the compliance-level plan is still in effect because approval of the corrective-action monitoring plan has not been given. In FY 1999, discussions will be held to resolve the issues concerning the proposed sampling and analysis method (i.e., the combined Shewhart-CUSUM control-chart approach). 


\section{B.1.2.3 Corrective Action}

A corrective-action program is initiated if a concentration limit at the point of compliance is exceeded. Exceedance is defined as statistically significant evidence of increased contamination. Details for the corrective-action program will be specified in the unit-specific permit application. In addition, a groundwater-monitoring plan, which will be used to assess the effectiveness of the corrective-action measures, will be submitted for approval. That monitoring plan may be similar in scope to the compliance-level, groundwater-monitoring program and may include all relevant information pertaining to the location and description of monitoring wells, monitoring network, well construction and development, sampling and analysis plans, statistical methods, and quality assurance and quality control procedures.

\section{B.1.3 Solid Waste Landfill}

Groundwater-monitoring activities at the Solid Waste Landfill are regulated in accordance with WAC 173-304-490, requiring no replicate analyses. Thus, the tolerance-interval approach, suitable for individual sample comparisons, was used for performing the required comparisons between upgradient and downgradient wells for determining whether a significant change over background occurred for constituents specified in WAC 173-304-490. The statistical evaluations are described as follows.

\section{B.1.3.1 Calculating Background Summary Statistics}

Summary statistics were calculated using background samples for the site (Table B-11 in DOE/RL-91-03). The results were presented in Table B.1 of PNNL-11793. Some of the background data are below the contractual detection limits required of the contracting laboratory or below the contractually required quantitation limit. In cases where measured values are available (e.g., most of the total organic carbon values), they were used in calculating the summary statistics. In cases where the proportion of nondetections is between $15 \%$ and $50 \%$, less-than values were replaced by half of their contractual detection limits and/or contractually required quantitation limits, and the usual calculations were performed (e.g., filtered iron). In cases where the proportion of nondetections is $>50 \%$, summary statistics are not calculated (e.g., ammonium, chemical oxygen demand, coliform, filtered manganese, filtered zinc, nitrite).

\section{B.1.3.2 Testing Assumption of Normality of Data}

The tolerance interval defines a concentration range (from background or upgradient well data) that contains at least a specified proportion (coverage) of the population with a specified probability (confidence level). There are two types of tolerance intervals: parametric and nonparametric. Parametric tolerance-interval techniques are sensitive to the assumption that the data are drawn from a normal population. The statistical tests used for evaluating whether the data follow a specified distribution are called goodness-of-fit tests. The Lilliefors test is used to evaluate the fit of a hypothesized normal or lognormal

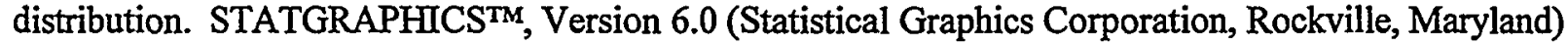
was used to calculate the Lilliefors test statistics. Test procedures are described by Conover (1980). If the data are not normal, the Lilliefors test was applied to the natural logarithm of the data to see if the transformed data are approximately normal. This is equivalent to testing the hypothesis that the 
concentration measurements follow a lognormal distribution. If the proportion of nondetections is $>15 \%$, a goodness-of-fit test is not performed and a nonparametric tolerance interval will be calculated to the extent possible.

Results of the Lilliefors tests are presented in Table B.1. Chloride, field pH, and temperature measurements from background wells are approximately normally distributed. Nitrate, specific conductance, sulfate, and total organic carbon concentrations are neither normal nor lognormal.

\section{B.1.3.3 Establishing Background Levels}

Tolerance intervals are constructed from the data on upgradient wells. Both the upper and lower bounds of the interval (two sided) were calculated for field $\mathrm{pH}$. For other constituents of concern, only the upper bounds of the intervals (one sided) were calculated.

If a normal (or a lognormal) distribution is a reasonable approximation of the background concentrations, a parametric tolerance interval, $\mathrm{TI}$, of the following form is calculated

$$
\mathrm{TI}=\overline{\mathrm{x}}_{\mathrm{b}} \pm \mathrm{k}^{*} \mathrm{~S}_{\mathrm{b}} \text { (two sided) or } \mathrm{TI}=\overline{\mathrm{x}}_{\mathrm{b}}+\mathrm{k}^{*} \mathrm{~S}_{\mathrm{b}} \text { (one sided) }
$$

where $\mathrm{k}=$ a normal tolerance factor, which depends on the number of background samples ( $\mathrm{n}$ ), coverage (P\%), and confidence level ( $\mathrm{Y}$ ). A coverage of $95 \%$ and a confidence level of $95 \%$ are recommended (PB89-151047). With $\mathrm{n}=16, \mathrm{P}=95 \%$, and $\mathrm{Y}=95 \%, \mathrm{k}$ is $2.523(\mathrm{k}$ is 2.566 if $n=15$ ) for a one-sided normal tolerance interval (Natrella 1966).

If background concentrations do not follow a normal or lognormal distribution, a nonparametric tolerance interval can be constructed (Conover 1980). A two-sided nonparametric tolerance interval is just the range of the observed data. An upper, one-sided, nonparametric tolerance limit is the largest observation. The number of background samples determines the coverage (P\%) and the confidence level (Y) associated with that proportion. For a one-sided $95 \%(\mathrm{P}=95 \%)$ nonparametric tolerance interval with $95 \%(Y=95 \%)$ probability, the number of background samples required is 59 (Conover 1980). With only 15 background samples (filtered iron, filtered zinc, and nitrate), the coverage is $85 \%$ and the confidence level is $90 \%$ (i.e., the upper one-sided tolerance limit defined by the largest background concentration contains at least $85 \%$ of the background population with $90 \%$ confidence). More background samples are needed if a larger coverage and/or a larger confidence level are desired.

In cases where all of the background values are below the contractually established detection limits or where the proportion of nondetections is $>15 \%$, a limit of quantitation was used (e.g., total organic carbon). In cases where a limit of quantitation is not available (e.g., chemical oxygen demand, coliform), the contractually required quantitation limits were used as the background threshold values. The resulting tolerance limits, limits of quantitation, and background threshold values are also presented in Table B.1.

\section{B.1.3.4 Comparisons with Background Levels}

Once the background threshold values are established, data from point-of-compliance wells were compared individually with these background concentration levels. If the background levels are . exceeded, it is interpreted as providing evidence of statistically significant contamination. 


\section{B.1.4 Liquid Effluent-Receiving Facilities}

Operation of the 200 Areas Treated Effluent-Disposal Facility and the State-Approved Land-Disposal Site began during 1995. These facilities are regulated by WAC 173-216; both require effluent and groundwater monitoring. Another facility, the 400 Area process ponds, is also designated as a WAC 173-216 discharge permit site, and the permit was issued on August 1, 1996 and modified on February 10, 1998. The principal groundwater quality regulations (WAC 173-200) emphasize the nondegradation of current groundwater quality. These regulations require "Establishment of an enforcement limit as near the natural ground water quality as practical," and establishment of the point of compliance in the groundwater "...as near the source as technically, hydrogeologically, and geographically feasible."

\section{B.1.4.1 Preoperational Monitoring}

Groundwater quality data from the preoperational phases of the 200 Areas Treated Effluent-Disposal Facility and the State-Approved Land-Disposal Site were used to establish the background (baseline) values for the potential constituents of concern. In essence, background values were calculated using the parametric tolerance-interval approach discussed above because background water quality is statistically defined as the $95 \%$ upper tolerance interval with a $95 \%$ confidence (Ecology 1996, p. 65). The baseline values were provided to the regulator to allow the determination of enforcement limits for specific constituents in groundwater.

\section{B.1.4.2 Operational Monitoring}

The objectives of collecting and evaluating the groundwater quality data from operational monitoring are 1) to determine if groundwater quality has changed from the baseline, preoperational conditions; 2) to evaluate the impacts, if any, that operation of the facility have on the quality of groundwater in the uppermost aquifer; and 3) to demonstrate compliance with the groundwater-enforcement limits set forth in the permit.

Statistical approaches used for preoperational and operational monitoring were described in detail in the groundwater-monitoring plans for the 200 Areas Treated Effluent-Disposal Facility (WHC-SD-ENWP-012, Rev. 1) and State-Approved Land-Disposal Site (WHC-SD-C018H-PLN-004, Rev. 1).

\section{B.2 Results of Evaluation}

\section{B.2.1 RCRA Interim-Status Facilities}

During FY 1998, a problem was identified with some of the meters and/or probes used to measure specific conductance in the field (discussion provided in Section D.2.1.1 of Appendix D). The results obtained from these meters/probes tended to be biased low (20\% to $40 \%)$. The faulty equipment was in use between October 1997 and July 1998. Specific conductance measurements obtained with this equipment has been flagged as suspect in the Hanford Environmental Information System (HEIS) database. The equipment was taken out of use, and the flagged specific conductance data were not used in the statistical evaluation during the second and third quarters of calendar year (CY) 1998. As a measure to validate the accuracy of future reported field specific conductance values, measurements of laboratory 
specific conductance were requested for groundwater samples collected in November and December 1998. Until good correlation between laboratory and field measurements is obtained, additional laboratory analyses may continue. In addition, if field specific conductance measurements were not in line with previous established trends, verification resampling was requested (e.g., well 299-E26-10, discussed in Section B.2.1.6), even though the critical mean was not exceeded.

The results of statistical evaluations are summarized in the following sections.

\section{B.2.1.1 Waste Management Area U}

Groundwater samples from downgradient well 299-W19-31 continued to exceed the total organic halide upgradient/downgradient comparison value (critical mean) for the site $(241 \mu \mathrm{g} / \mathrm{L})$ during the first, second, and third quarters of CY 1998. The exceedances are caused by the same encroaching carbon tetrachloride plume from an upgradient source that caused an earlier exceedance (August 1996) in another downgradient well (299-W18-30). Two letters of notification were transmitted to the regulators, one in April 1997 and one in August 1998, indicating the reported exceedance is clearly the result of an encroachment of a carbon tetrachloride plume from the northwest and is not related to the tank farm. Therefore, because there is clearly an upgradient source for the detected contamination, an assessment plan is not necessary.

\section{B.2.1.2 216-A-29 Ditch}

The average total organic carbon concentration of $1,382.5 \mu \mathrm{g} / \mathrm{L}$, collected on October 2,1997 from downgradient well 299-E25-48, exceeded the upgradient/downgradient comparison value of $1,179 \mu \mathrm{g} / \mathrm{L}$. Subsequent routine sampling conducted on April 17, 1998 yielded an average concentration of $552 \mu \mathrm{g} / \mathrm{L}$, and confirmed that the initial exceedance was an error in analysis.

\section{B.2.1.3 1301-N Liquid Waste-Disposal Facility}

Total organic carbon in downgradient well 199-N-3 exceeded the critical mean $(1,405.2 \mu \mathrm{g} / \mathrm{L})$ in September 1998. Verification sampling was performed in January 1999, but the results were not available when this report was compiled.

\section{B.2.1.4 1324-N/NA Liquid Waste-Disposal Facility}

Total organic carbon in downgradient well 199-N-59 exceeded the critical mean $(1,373.2 \mu \mathrm{g} / \mathrm{L})$ in September 1997. Verification sampling was performed on January 27, 1998). Results from two laboratories (Quanterra Environmental Services, St Louis, Missouri and Thermo Analytical, Richmond, California) confirmed the initial exceedance was real. An assessment plan was prepared and submitted in accordance with 40 CFR 265.93(d)(2). However, the State of Washington Department of Ecology subsequently agreed that the contamination is from another source so that assessment monitoring was not required. In accordance with the State of Washington Department of Ecology's instruction, a detectionmonitoring program was assumed at this site. The total organic carbon critical mean continued to be exceeded in this well during the routine sampling that occurred in the first and third quarters of CY 1998. 
In addition, concentrations of specific conductance in three downgradient wells (199-N-59, 199-N-72, and 199-N-73) continued to exceed the $618.7-\mu \mathrm{S} / \mathrm{cm}$ critical mean in the first and third quarters of CY 1998. The exceedances were expected because the data trend with previous conductivity measurements. A previous groundwater quality assessment conducted at this site (WHC-SD-EN-EV-003, Rev. 1) indicated that sodium and sulfate (nonhazardous constituents) caused the high conductance. Because an assessment has already been completed and the high conductance was caused by nonhazardous constituents, verification sampling and additional assessment monitoring were not initiated.

\section{B.2.1.5 1325-N Liquid Waste-Disposal Facility}

Groundwater concentration in downgradient well $199-\mathrm{N}-81$ exceeded the $1,179-\mu \mathrm{g} / \mathrm{L}$ critical mean for total organic carbon in September 1997. Verification sampling was performed on January 22, 1998. The results from two laboratories confirmed that the initial exceedance was a laboratory analysis error (Quanterra Environmental Services average value was 1,132.5 $\mu \mathrm{g} / \mathrm{L}$; Thermo Analytical average value was $485 \mu \mathrm{g} / \mathrm{L})$.

\section{B.2.1.6 Liquid Effluent-Retention Facility}

The quadruplicate total organic halide average from upgradient well 299-E26-11 was $22.8 \mu \mathrm{g} / \mathrm{L}$, slightly above the $21.3-\mu \mathrm{g} / \mathrm{L}$ critical mean in January 1998 . Verification sampling conducted in July and August 1998 confirmed that the initial exceedance was a laboratory analysis error.

The quadruplicate specific conductance average ( $479 \mu \mathrm{S} / \mathrm{cm})$ approached the critical mean (489.4 $\mu \mathrm{S} / \mathrm{cm}$ ) in downgradient well 299-E26-10 during routine sampling conducted on January 7, 1998. This well has shown an upward trend since May 1993. Calcium, chloride, magnesium, nitrate, and sulfate are all increasing in this well. Tritium, which is present in the effluent discharged to this facility, is not elevated, indicating that a contaminant plume from other facilities in the 200 Areas causes the increase in specific conductance. Specific conductance measured on July 6, 1998 in this well was low (quadruplicate average was $409.5 \mu \mathrm{S} / \mathrm{cm}$ ) in relation to historical trends and anion and cation analysis results. The reported values were flagged as suspect because of the use of faulty meters/probes. Although the critical mean was not exceeded in well 299-E26-10, resampling was conducted on November 19, 1998. Specific conductance (field) averaged $\sim 48 \mu \mathrm{S} / \mathrm{cm}$, slightly below the critical mean. Laboratory specific conductance results averaged $475 \mu \mathrm{S} / \mathrm{cm}$, in agreement with the field measurements.

\section{B.2.1.7 120-D-1 Ponds}

The quadruplicate total organic carbon average $(1,610 \mu \mathrm{g} / \mathrm{L})$ obtained from upgradient well 199-D5-13 on September 24, 1998 exceeded the critical mean of $1,483.1 \mu \mathrm{g} / \mathrm{L}$. Verification resampling was deemed unnecessary because the exceeding well is upgradient of the site and the exceedance does not indicate possible impact from the facility. Further, the closure plan for the ponds (DOE/RL-92-71, Rev. 2) has been revised, and the site was incorporated in 1998 into the Hanford Site RCRA Permit. All dangerous wastes, waste constituents, or residues associated with the operation of the ponds were removed. The facility will be closed (modified clean closure) in FY 1999, and groundwater monitoring will not be required. 


\section{B.2.1.8 216-S-10 Pond and Ditch}

The background values for this site were reestablished during FY 1998 because one of the two upgradient wells (299-W26-8) went dry. Also, the practice of analyzing quadruplicate measurements of the general contamination indicator parameters in well 299-W27-2 was discontinued. Instead, only one measurement was obtained, starting in the second quarter of CY 1998. This well monitors the deeper portion of the unconfined aquifer. Results are used for providing supplementary information not for required statistical evaluation.

\section{B.2.2 RCRA Final-Status Facilities}

\section{B.2.2.1 183-H Solar Evaporation Basins}

In February 1998, this RCRA facility began to be monitored in accordance with a final-status corrective-action program when the Hanford Site RCRA Permit modification $\mathrm{C}$ became effective. Groundwater remediation is integrated with the 100-HR-3 Operable Unit, where remediation for chromium is under way. RCRA monitoring consists of annual sampling of four wells for chromium, fluoride, nitrate, technetium-99, and uranium (PNNL-11573; see Appendix A of this report) while the pump-andtreat system is operating to remediate chromium-contaminated groundwater. The objective of monitoring during this period is to determine whether concentrations of the contaminants of concern are decreasing.

\section{B.2.2.2 316-5 Process Trenches}

In December 1996, these process trenches began final-status compliance-level monitoring (WAC 173-303-645). Four independent samples were collected from December 1997, March and May 1998, and again from June through September 1998. Exceedances were noted for cis-1,2-dichloroethylene, trichloroethylene, and uranium in some of the downgradient compliance wells. Confirmation sampling was not conducted because these exceedances were expected. A summary of groundwater-sampling results for the constituents of concern is presented in Table B.2.

In FY 1998, groundwater monitoring at these trenches was elevated to a corrective-action program as a result of exceedances of cis-1,2-dichloroethylene, trichloroethylene, and uranium concentration limits in some of the downgradient compliance wells (see Table B.2). Groundwater monitoring is continuing according to the compliance-level monitoring plan; however, approval of the final-status, correctiveaction, groundwater-monitoring plan is pending. In FY 1999, discussions will be held to resolve issues concerning the proposed sampling and analysis method (i.e., the combined Shewhart-CUSUM controlchart approach).

It should be noted that tetrachloroethylene (also called perchloroethylene or PCE) has been detected at or has exceeded the 5- $\mu \mathrm{g} / \mathrm{L}$ maximum contaminant level in samples collected from wells 399-1-10A, 399-1-16A, and 399-1-17A during FY 1998 (May, June, July, and August). The highest observed concentration was $38 \mu \mathrm{g} / \mathrm{L}$ in well 399-1-17A in July 1998; the concentration decreased to 10 and $4 \mu \mathrm{g} / \mathrm{L}$ in August and September, respectively. Tetrachloroethylene was also detected above the maximum contaminant level in wells 399-1-3, 399-2-1, and 399-2-2 that monitor the 300-FF-5 Operable Unit or are sampled for sitewide environmental surveillance. A letter of notification was submitted in November 1998. 


\section{B.2.3 Solid Waste Landfill}

The sampling results from FY 1998 were compared to the background levels (see Table B.1). The sampling and comparison results are given in Table B.3. Values for specific conductance exceeded the background level in downgradient wells 699-22-35, 699-23-34A, 699-23-34B, 699-24-34A, 699-24-34B, 699-24-34C, and 699-25-34C for at least one sampling event during this reporting period. In the past, exceedances were noted in these wells during most if not all of the sampling events. The lower-thanexpected specific conductance values were artifacts from the use of faulty equipment. The pattern of exceedances is similar to that observed from 1990 through 1996. Detailed discussions are presented in Section 5.12.3.1 of the main text.

\section{B.2.4 200 Areas Treated Effluent-Disposal Facility and State-Approved Land-Disposal Site}

Groundwater samples are collected quarterly and analyzed for the permit constituents. Groundwater monitoring at the 200 Areas Treated Effluent-Disposal Facility has not detected any changes in groundwater quality caused by its operation and no permit criteria for constituents in groundwater were exceeded during FY 1998. Results of groundwater data analyzed for the State-Approved Land-Disposal Site indicated that tritium-rich effluent began affecting groundwater in July 1996. Analyses also indicate that calcium, specific conductance, sulfate, and a few other parameters have been elevated by the leaching of natural soil constituents by the effluent.

\section{B.2.5 400 Area Process Ponds}

Groundwater samples are collected quarterly and analyzed for the permit constituents. One of the permit conditions was the addition of another downgradient well to the monitoring network. Well 699-2-6A was installed in August 1997. Groundwater-monitoring results indicated that tritium and nitrate were detected above their interim drinking water standard and maximum contaminant level, respectively. Elevated levels of tritium are attributed to the plume originating from the vicinity of the Plutonium-Uranium Extraction (PUREX) Plant in the 200-East Area. Elevated nitrate concentrations were attributed to the sanitary sewage lagoon located immediately west and upgradient of the process ponds. Disposal to the lagoon has been discontinued and the lagoon backfilled. Therefore, groundwater contamination from this source is expected to diminish with time.

\section{B.3 Background Tables}

This section provides critical means tables (Tables B.4 through B.21) for RCRA facilities that are/ have been in indicator-parameter evaluation-monitoring status during FY 1998. Some revisions were made in FY 1998 to reflect the change in monitoring network (e.g., 216-S-10 pond and ditch) because many wells went dry and/or groundwater-flow direction changed (e.g., Low-Level Waste Management Area 4). Note that the number of digits presented in these tables do not reflect the precision of the analytical methods. These digits are for formatting purposes only. 


\section{B.4 References}

American Society for Testing and Materials. 1996. "PS 64-96, Provisional Standard Guide for Developing Appropriate Statistical Approaches for Ground-Water Detection Monitoring Programs.” Annual Book of ASTM Standards. West Conshohocken, Pennsylvania.

40 CFR 264, Code of Federal Regulations, Title 40, Part 264. Standards for Owners and Operators of Hazardous Waste Treatment, Storage, and Disposal Facilities.

40 CFR 265, Code of Federal Regulations, Title 40, Part 265. Interim Status Standards for Owners and Operators of Hazardous Waste Treatment, Storage, and Disposal Facilities.

Chou, C. J. 1991. "Statistical Approach on RCRA Groundwater Monitoring Projects at the Hanford Site." In American Statistical Association 1991 Proceedings of the Section on Statistics and the Environment. Alexandria, Virginia, pp. 326-241; also, WHC-SA-1124-FP, Westinghouse Hanford Company, Richland, Washington.

Conover, W. J. 1980. Practical Nonparametric Statistics, Second Edition. John Wiley and Sons, Inc., New York, pp. 118-121, 346-363.

DOE/RL-90-38. 1991. Hanford Site Solid Waste Landfill Permit Application. U.S. Department of Energy, Richland Operations Office, Richland, Washington.

DOE/RL-91-03. 1991. Annual Report for RCRA Groundwater Monitoring Projects at Hanford Site Facilities for 1990. Prepared by Geosciences Group, Westinghouse Hanford Company, Environmental Division for U.S. Department of Energy, Richland Operations Office, Richland, Washington.

DOE/RL-92-71, Rev. 2. 1998. 100-D Ponds Closure Plan. U.S. Department of Energy, Richland Operations Office, Richland, Washington.

Ecology (see State of Washington Department of Ecology).

EPA/530-R-93-003. 1992. Statistical Analysis of Ground-Water Monitoring Data at RCRA Facilities, Draft Addendum to Interim Final Guidance. U.S. Environmental Protection Agency, Washington, D.C.

Gibbons, R. D. 1994. Statistical Methods for Groundwater Monitoring. John Wiley \& Sons, Inc., New York.

Natrella, M. G. 1966. Experimental Statistics. National Bureau of Standards Handbook 91, John Wiley \& Sons, New York, Table A-7.

OSWER-9950.1. 1986. Resource Conservation and Recovery Act (RCRA) Groundwater Monitoring Technical Enforcement Guidance Document (TEGD). U.S. Environmental Protection Agency, Washington, D.C. 
PB89-151047. 1989. Statistical Analysis of Ground-Water Monitoring Data at RCRA Facilities--Interim Final Guidance. U.S. Environmental Protection Agency, Washington, D.C.

PNNL-11573. 1997. Groundwater Monitoring Plan for the 183-H Solar Evaporation Basins. M. J. Hartman, Pacific Northwest National Laboratory, Richland, Washington.

PNNL-11793. 1998. Hanford Site Groundwater Monitoring for Fiscal Year 1997. M. J. Hartman and P. E. Dresel (eds.), Pacific Northwest National Laboratory, Richland, Washington.

PNNL-11903. 1998. Groundwater Monitoring Plan for the Hanford Site 216-B-3 Pond RCRA Facility. D. B. Barnett and C. J. Chou, Pacific Northwest National Laboratory, Richland, Washington.

Resource Conservation and Recovery Act of 1976, as amended, Public Law 94-580, 90 Stat. 2795, 42 USC 6901 et seq.

State of Washington Department of Ecology (Ecology). 1996. Implementation Guidance for the Ground Water Quality Standards. Olympia, Washington.

WAC 173-200, Washington Administrative Code. Water Quality Standards for Ground Waters of the State of Washington. Olympia, Washington.

WAC 173-216, Washington Administrative Code. State Waste Discharge Program. Olympia, Washington.

WAC 173-303-400, Washington Administrative Code. Interim Status Facility Standards. Olympia, Washington.

WAC 173-303-645, Washington Administrative Code. Releases from Regulated Units. Olympia, Washington.

WAC-173-304, Washington Administrative Code. Minimum Functional Standards for Solid Waste Handling. Olympia, Washington.

WAC 173-304-490, Washington Administrative Code. Ground Water Monitoring Requirements. Olympia, Washington.

WHC-SD-C018H-PLN-004, Rev. 1. 1996. Ground-Water Screening Evaluation/Monitoring Plan -200 Area Effluent Treatment Facility (Project C-018H). J. D. Davis, D. B. Barnett, C. J. Chou, and P. B. Freeman, Westinghouse Hanford Company, Richland, Washington.

WHC-SD-EN-AP-180. 1995. Groundwater Monitoring Plan for the 183-H Solar Evaporation Basins. M. J. Hartman and C. J. Chou. Westinghouse Hanford Company, Richland, Washington.

WHC-SD-EN-EV-003, Rev. 1. 1992. Results of Groundwater Quality Assessment Monitoring at the 1301-N and 1324-N/NA Facilities. M. J. Hartman, Westinghouse Hanford Company, Richland, Washington. 


\section{Fo -}

WHC-SD-EN-WP-012, Rev. 1. 1995. Groundwater Screening Evaluation/Monitoring Plan -- 200 Area Treated Effluent Disposal Facility (Project W-049H). D. B. Barnett, J. D. Davis, L. B. Collard, P. B. Freeman, and C. J. Chou, Westinghouse Hanford Company, Richland, Washington. 
Table B.1. Results of Lilliefors Test for Normality and Background Threshold Values for Solid Waste Landfill

\begin{tabular}{|c|c|c|c|c|}
\hline Constituent, unit & $\begin{array}{c}\text { Test } \\
\text { Statistic, } \\
\text { Raw Data }\end{array}$ & $\begin{array}{c}\text { Test } \\
\text { Statistic, } \\
\text { Log Value }\end{array}$ & $\begin{array}{c}\text { Upper } \\
\text { Tolerance } \\
\text { Limit } \\
\end{array}$ & $\begin{array}{c}\text { Background } \\
\text { Threshold } \\
\text { Value }^{(a)}\end{array}$ \\
\hline Temperature, ${ }^{\circ} \mathrm{C}$ & $0.115 \mathrm{~ns}$ & NA & $21.0^{(b)}$ & 21.0 \\
\hline $\begin{array}{l}\text { Specific conductance, } \\
\mu \mathrm{S} / \mathrm{cm}\end{array}$ & $0.162 \mathrm{~s}$ & $0.207 \mathrm{~s}$ & $550^{(c)}$ & 550 \\
\hline $\begin{array}{l}\text { Field } \mathrm{pH}^{(\mathrm{d})} \\
\text { Field } \mathrm{pH}^{(\mathrm{s}}\end{array}$ & $\begin{array}{l}0.140 \mathrm{~ns} \\
0.089 \mathrm{~ns}\end{array}$ & $\begin{array}{l}\text { NA } \\
\text { NA }\end{array}$ & $\begin{array}{l}{[5.7,8.75]^{(b)}} \\
{[6.2,8.46]^{(b)}}\end{array}$ & {$[6.2,8.46]$} \\
\hline $\begin{array}{l}\text { Total organic carbon, } \\
\mu \mathrm{g} / \mathrm{L}\end{array}$ & $0.191 \mathrm{~s}$ & $0.181 \mathrm{~s}$ & $\begin{array}{r}750^{(\mathrm{c})} \\
1,179^{(\mathrm{c})}\end{array}$ & 1,179 \\
\hline Chloride, $\mu \mathrm{g} / \mathrm{L}$ & $0.104 \mathrm{~ns}$ & NA & $9,045^{(b)}$ & 9,045 \\
\hline Nitrate, $\mu \mathrm{g} / \mathrm{L}$ & $0.168 \mathrm{~s}$ & $0.195 \mathrm{~s}$ & $33,800^{(c)}$ & 33,800 \\
\hline Nitrite, $\mu \mathrm{g} / \mathrm{L}$ & $\mathrm{NC}$ & $\mathrm{NC}$ & $250^{(e)}$ & 250 \\
\hline Ammonium, $\mu \mathrm{g} / \mathrm{L}$ & $\mathrm{NC}$ & $\mathrm{NC}$ & $\begin{array}{r}100^{(c)} \\
50^{(e)}\end{array}$ & 100 \\
\hline Sulfate, $\mu g / L$ & $0.179 \mathrm{~s}$ & $0.190 \mathrm{~s}$ & $51,500^{(c)}$ & 51,500 \\
\hline Iron, filtered, $\mu \mathrm{g} / \mathrm{L}$ & NC & NC & $\begin{array}{r}78^{(\mathrm{c})} \\
160^{(\mathrm{e})}\end{array}$ & 160 \\
\hline Zinc, filtered, $\mu \mathrm{g} / \mathrm{L}$ & NC & NC & $\begin{array}{l}34^{(\mathrm{c})} \\
18^{(\mathrm{e})}\end{array}$ & 18 \\
\hline Manganese, filtered, $\mu \mathrm{g} / \mathrm{L}$ & NC & $\mathrm{NC}$ & $\begin{array}{l}11^{(\mathrm{c})} \\
3.2^{(\mathrm{c})}\end{array}$ & 11 \\
\hline $\begin{array}{l}\text { Coliform, most probable } \\
\text { number }\end{array}$ & NC & NC & $\begin{array}{l}16^{(\mathfrak{c})} \\
3.7^{(\mathfrak{k})}\end{array}$ & 16 \\
\hline $\begin{array}{l}\text { Chemical oxygen } \\
\text { demand, } \mu \mathrm{g} / \mathrm{L}\end{array}$ & $\mathrm{NC}$ & $\mathrm{NC}$ & $5,000^{(g)}$ & 5,000 \\
\hline
\end{tabular}

(a) Background threshold value for each constituent is the larger of the upper tolerance limit or the applicable limit of quantitation.

(b) Based on normal distribution.

(c) Maximum value reported.

(d) Outliers removed.

(e) Based on limit of quantitation (discussed in Appendix D).

(f) Based on method detection limit.

(g) Based on laboratory practical quantitation limit.

NA $=$ Not applicable.

$\mathrm{NC}=$ Not calculated; insufficient measured values.

ns $=$ Not significant at 0.05 level of significance.

$s \quad=$ Significant at 0.05 level of significance. 
Table B.2. Summary of Groundwater-Sampling Results for 316-5 Process Trenches

\begin{tabular}{|c|c|c|c|}
\hline Sampling Time & $\begin{array}{l}\text { Constituent of } \\
\text { Concern }\end{array}$ & $\begin{array}{l}\text { Concentration } \\
\text { Level, } \mu \mathrm{g} / \mathrm{L}\end{array}$ & $\begin{array}{l}\text { Well Exceeding Concentration Limit } \\
\quad(\text { Range, } \mu \mathrm{g} / \mathrm{L})\end{array}$ \\
\hline \multirow{3}{*}{$\begin{array}{l}\text { December 1997, March, } \\
\text { May, June, July, August, } \\
\text { September } 1998\end{array}$} & Trichloroethylene & 5 & $399-1-16 B(5-7)$ \\
\hline & $\begin{array}{l}\text { cis-1,2-Dichloro- } \\
\text { ethylene }\end{array}$ & 70 & $399-1-16 \mathrm{~B}(100-180)$ \\
\hline & Uranium & 20 & $\begin{array}{l}399-1-10 A(38.2-96) \\
399-1-16 A(52.9-124) \\
399-1-17 A(96.2-248)\end{array}$ \\
\hline
\end{tabular}


Table B.3. Sampling Results for Required Constituents ${ }^{(a)}$ at Solid Waste Landfill

\begin{tabular}{|c|c|c|c|c|c|c|}
\hline Constituent, unit & $\begin{array}{l}\text { Tolerance } \\
\text { Interval }^{(b)} \\
\end{array}$ & Date & $\begin{array}{c}\text { Well } \\
699-22-35 \\
\end{array}$ & $\begin{array}{c}\text { Well } \\
699-23-34 \mathrm{~A} \\
\end{array}$ & $\begin{array}{c}\text { Well } \\
699-23-34 \mathrm{~B} \\
\end{array}$ & $\begin{array}{c}\text { Well } \\
699-24-34 \mathrm{~A} \\
\end{array}$ \\
\hline Temperature, ${ }^{\circ} \mathrm{C}$ & 21.0 & $\begin{array}{c}\text { Dec } 1997 \\
\text { Feb } 1998 \\
\text { May } 1998 \\
\text { August } 1998\end{array}$ & $\begin{array}{l}17.4 \\
17.7 \\
17.9 \\
18.6\end{array}$ & $\begin{array}{l}17.6 \\
18.0 \\
18.3 \\
18.8\end{array}$ & $\begin{array}{l}17.2 \\
18.8 \\
18.3 \\
18.6\end{array}$ & $\begin{array}{l}17.8 \\
18.1 \\
18.1 \\
18.9\end{array}$ \\
\hline $\begin{array}{l}\text { Specific } \\
\text { conductance, } \\
\mu \mathrm{S} / \mathrm{cm}\end{array}$ & 550 & $\begin{array}{c}\text { Dec } 1997 \\
\text { Feb } 1998 \\
\text { May } 1998 \\
\text { August } 1998\end{array}$ & $\begin{array}{c}790^{(c)} \\
571^{(\mathrm{c} d)} \\
484^{(\mathrm{c})} \\
776^{(\mathrm{c})}\end{array}$ & $\begin{array}{l}647^{(())} \\
487^{(\mathrm{d})} \\
427^{(\mathrm{d})} \\
643^{(\mathrm{c})}\end{array}$ & $\begin{array}{l}773^{(c)} \\
442^{(\mathrm{d})} \\
453^{(\mathrm{c})} \\
728^{(\mathrm{c})}\end{array}$ & $\begin{array}{c}531^{(c)} \\
469^{(\delta)} \\
612^{(c d)} \\
631^{(c)}\end{array}$ \\
\hline Field pH & {$[6.2,8.46]$} & $\begin{array}{c}\text { Dec } 1997 \\
\text { Feb } 1998 \\
\text { May } 1998 \\
\text { August } 1998\end{array}$ & $\begin{array}{l}7.0 \\
6.8 \\
6.9 \\
6.7\end{array}$ & $\begin{array}{l}7.6 \\
6.5 \\
6.6 \\
6.7\end{array}$ & $\begin{array}{l}6.7 \\
7.3 \\
6.7 \\
6.8\end{array}$ & $\begin{array}{l}6.8 \\
6.6 \\
6.8 \\
6.7\end{array}$ \\
\hline $\begin{array}{l}\text { Total organic } \\
\text { carbon, } \mu g / L\end{array}$ & 1,140 & $\begin{array}{c}\text { Dec } 1997 \\
\text { Feb } 1998 \\
\text { May } 1998 \\
\text { August } 1998\end{array}$ & $\begin{array}{l}<370 \\
653 \\
706 \\
<256\end{array}$ & $\begin{array}{l}<370 \\
663 \\
575 \\
636\end{array}$ & $\begin{array}{c}<370 \\
<370 \\
520 \\
276\end{array}$ & $\begin{array}{l}<370 \\
677 \\
706 \\
<256\end{array}$ \\
\hline Chloride, $\mu \mathrm{g} / \mathrm{L}$ & 9.045 & $\begin{array}{c}\text { Dec } 1997 \\
\text { Feb } 1998 \\
\text { May } 1998 \\
\text { August } 1998\end{array}$ & $\begin{array}{l}6,210 \\
6,530 \\
5,810 \\
6,710\end{array}$ & $\begin{array}{l}5,700 \\
6,400 \\
5,580 \\
6,320\end{array}$ & $\begin{array}{l}5,690 \\
7,700 \\
5,700 \\
6,750\end{array}$ & $\begin{array}{l}5,910 \\
6,220 \\
5,520 \\
6,520\end{array}$ \\
\hline Nitrate, $\mu \mathrm{g} / \mathrm{L}$ & 33,800 & $\begin{array}{c}\text { Dec } 1997 \\
\text { Feb } 1998 \\
\text { May } 1998 \\
\text { August } 1998\end{array}$ & $\begin{array}{l}15,000 \\
14,800 \\
14,000 \\
15,000\end{array}$ & $\begin{array}{l}11,600 \\
12,400 \\
11,300 \\
12,000\end{array}$ & $\begin{array}{l}13,000 \\
26,600 \\
12,900 \\
13,900\end{array}$ & $\begin{array}{l}12,000 \\
13,500 \\
12,700 \\
12,600\end{array}$ \\
\hline Nitrite, $\mu g / L$ & 250 & $\begin{array}{c}\text { Dec } 1997 \\
\text { Feb } 1998 \\
\text { May } 1998 \\
\text { August } 1998\end{array}$ & $\begin{array}{l}<70 \\
<70 \\
<70 \\
<70\end{array}$ & $\begin{array}{l}<70 \\
<70 \\
<70 \\
<70\end{array}$ & $\begin{array}{l}<70 \\
<70 \\
<70 \\
<70\end{array}$ & $\begin{array}{l}<70 \\
<70 \\
<70 \\
<70\end{array}$ \\
\hline Ammonium, $\mu \mathrm{g} / \mathrm{L}$ & 100 & $\begin{array}{c}\text { Dec } 1997 \\
\text { Feb } 1998 \\
\text { May } 1998 \\
\text { August } 1998\end{array}$ & $\begin{array}{l}<11 \\
<11 \\
<11 \\
<11\end{array}$ & $\begin{array}{l}<11 \\
<11 \\
<11 \\
<11\end{array}$ & $\begin{array}{l}<11 \\
<11 \\
<11 \\
<11\end{array}$ & $\begin{array}{l}<11 \\
<11 \\
<11 \\
<11\end{array}$ \\
\hline Sulfate, $\mu \mathrm{g} / \mathrm{L}$ & 51,500 & $\begin{array}{c}\text { Dec } 1997 \\
\text { Feb } 1998 \\
\text { May } 1998 \\
\text { August } 1998\end{array}$ & $\begin{array}{l}54,000^{(c)} \\
54,200^{(s)} \\
52,800^{(\varepsilon)} \\
54,500^{(s)}\end{array}$ & $\begin{array}{l}42,000 \\
42,500 \\
41,300 \\
42,500\end{array}$ & $\begin{array}{c}51,200 \\
39,300 \\
51,700^{(c)} \\
52,700\end{array}$ & $\begin{array}{l}41,500 \\
40,900 \\
41,100 \\
41,700\end{array}$ \\
\hline Iron, filtered, $\mu \mathrm{g} / \mathrm{L}$ & 160 & $\begin{array}{c}\text { Dec } 1997 \\
\text { Feb } 1998 \\
\text { May } 1998 \\
\text { August } 1998\end{array}$ & $\begin{array}{l}50.3 \\
44.8 \\
28.9 \\
44.4\end{array}$ & $\begin{array}{l}50.0 \\
35.9 \\
33.2 \\
44.6\end{array}$ & $\begin{array}{l}60.4 \\
35.7 \\
40.4 \\
63.7\end{array}$ & $\begin{array}{l}50.8 \\
52.4 \\
49.5 \\
43.5\end{array}$ \\
\hline $\begin{array}{l}\text { Zinc, filtered, } \\
\mu \mathrm{g} / \mathrm{L}\end{array}$ & 34 & $\begin{array}{c}\text { Dec } 1997 \\
\text { Feb } 1998 \\
\text { May } 1998 \\
\text { August } 1998\end{array}$ & $\begin{array}{c}5.8 \\
12.9 \\
27.6 \\
10.3\end{array}$ & $\begin{array}{c}4.4 \\
4.7 \\
9.0 \\
21.0\end{array}$ & $\begin{array}{c}5.5 \\
10.8 \\
10.0 \\
8.8\end{array}$ & $\begin{array}{l}5.2 \\
5.8 \\
4.1 \\
8.2\end{array}$ \\
\hline $\begin{array}{l}\text { Manganese, } \\
\text { filtered, } \mu g / L\end{array}$ & 11 & $\begin{array}{c}\text { Dec } 1997 \\
\text { Feb } 1998 \\
\text { May } 1998 \\
\text { August } 1998\end{array}$ & $\begin{array}{l}5.0 \\
5.3 \\
3.1 \\
4.7\end{array}$ & $\begin{array}{l}5.6 \\
4.4 \\
2.8 \\
3.9\end{array}$ & $\begin{array}{l}6.5 \\
3.4 \\
3.5 \\
4.3\end{array}$ & $\begin{array}{l}5.9 \\
4.2 \\
2.4 \\
3.8\end{array}$ \\
\hline $\begin{array}{l}\text { Chemical oxygen } \\
\text { demand, } \mu \mathrm{g} / \mathrm{L}\end{array}$ & 5,000 & $\begin{array}{c}\text { Dec } 1997 \\
\text { Feb } 1998 \\
\text { May } 1998 \\
\text { August } 1998\end{array}$ & $\begin{array}{l}9,000^{(e)} \\
<3,070 \\
<3,070 \\
<3,820\end{array}$ & $\begin{array}{l}<3,070 \\
<3,070 \\
<3,070 \\
<3,820\end{array}$ & $\begin{array}{l}<, 070 \\
<3.070 \\
<3,070 \\
<3,820\end{array}$ & $\begin{array}{l}<, 070 \\
\beta, 070 \\
<3,070 \\
<3,820\end{array}$ \\
\hline $\begin{array}{l}\text { Coliform bacteria, } \\
\text { most probable } \\
\text { number }\end{array}$ & 16 & $\begin{array}{c}\text { Dec } 1997 \\
\text { Feb } 1998 \\
\text { August } 1998\end{array}$ & $\begin{array}{l}0.0^{(e)} \\
0.0 \\
0.0\end{array}$ & $\begin{array}{l}0.0^{(\mathrm{c})} \\
0.0 \\
0.0\end{array}$ & $\begin{array}{c}0.0 \\
6.0^{(s)} \\
0.0\end{array}$ & $\begin{array}{c}0.0^{(e)} \\
0.0 \\
0.0\end{array}$ \\
\hline
\end{tabular}


Table B.3. (contd)

\begin{tabular}{|c|c|c|c|c|c|c|c|}
\hline Constituent, unit & $\begin{array}{l}\text { Tolerance } \\
\text { Interval }^{\left({ }^{()}\right)} \\
\end{array}$ & Date & $\begin{array}{c}\text { Well } \\
\text { 699-24-34B } \\
\end{array}$ & $\begin{array}{c}\text { Well } \\
699-24-34 \mathrm{C} \\
\end{array}$ & $\begin{array}{c}\text { Well } \\
699-24-35 \\
\end{array}$ & $\begin{array}{c}\text { Well } \\
699-25-34 \mathrm{C} \\
\end{array}$ & $\begin{array}{c}\text { Well } \\
699-26-35 \mathrm{~A}\end{array}$ \\
\hline Temperature, ${ }^{\circ} \mathrm{C}$ & 21.0 & $\begin{array}{c}\text { Dec } 1997 \\
\text { Feb } 1998 \\
\text { May } 1998 \\
\text { August } 1998\end{array}$ & $\begin{array}{l}18.2 \\
18.4 \\
18.4 \\
19.0\end{array}$ & $\begin{array}{r}18.1 \\
18.3 \\
-18.6 \\
19.3\end{array}$ & $\begin{array}{l}17.0 \\
17.0 \\
19.3 \\
18.2\end{array}$ & $\begin{array}{l}18.1 \\
18.5 \\
18.7 \\
19.3\end{array}$ & $\begin{array}{l}19.0 \\
19.5 \\
19.4 \\
19.8\end{array}$ \\
\hline $\begin{array}{l}\text { Specific } \\
\text { conductance, } \\
\mu \mathrm{S} / \mathrm{cm}\end{array}$ & 550 & $\begin{array}{c}\text { Dec } 1997 \\
\text { Feb } 1998 \\
\text { May } 1998 \\
\text { August } 1998\end{array}$ & $\begin{array}{l}539^{(d)} \\
476^{(\triangleleft)} \\
622^{(\varsigma, d)} \\
635^{(\odot)}\end{array}$ & $\begin{array}{l}572^{(\mathrm{dc})} \\
489^{(d)} \\
421^{(d)} \\
677^{(c)}\end{array}$ & 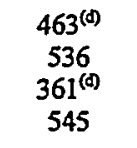 & $\begin{array}{l}488^{(\mathrm{d})} \\
575^{(\mathrm{c})} \\
394^{(\mathrm{d})} \\
597^{(\mathrm{c})}\end{array}$ & $\begin{array}{c}460 \\
461 \\
365^{(d)} \\
464\end{array}$ \\
\hline Field pH & {$[6.2,8.46]$} & $\begin{array}{c}\text { Dec } 1997 \\
\text { Feb } 1998 \\
\text { May } 1998 \\
\text { August } 1998\end{array}$ & $\begin{array}{l}6.5 \\
6.6 \\
6.7 \\
6.7\end{array}$ & $\begin{array}{l}6.8 \\
7.2 \\
7.1 \\
7.0\end{array}$ & $\begin{array}{l}7.0 \\
6.8 \\
6.8 \\
7.0\end{array}$ & $\begin{array}{l}7.0 \\
7.2 \\
7.4 \\
7.1\end{array}$ & $\begin{array}{l}7.2 \\
7.6 \\
7.5 \\
7.3\end{array}$ \\
\hline $\begin{array}{l}\text { Total organic } \\
\text { carbon, } \mu \mathrm{g} / \mathrm{L}\end{array}$ & 1,140 & $\begin{array}{c}\text { Dec } 1997 \\
\text { Feb } 1998 \\
\text { May } 1998 \\
\text { August } 1998\end{array}$ & $\begin{array}{c}<370 \\
718 \\
823 \\
<256\end{array}$ & $\begin{array}{l}<370 \\
714 \\
576 \\
412\end{array}$ & $\begin{array}{l}<370 \\
842 \\
579 \\
297\end{array}$ & $\begin{array}{l}870 \\
770 \\
849 \\
306\end{array}$ & $\begin{array}{l}<70 \\
<370 \\
725 \\
<256\end{array}$ \\
\hline Chloride, $\mu g / L$ & 9.045 & $\begin{array}{c}\text { Dec } 1997 \\
\text { Feb } 1998 \\
\text { May } 1998 \\
\text { August } 1998\end{array}$ & $\begin{array}{l}6,540 \\
6,700 \\
5,890 \\
6,490\end{array}$ & $\begin{array}{l}6,860 \\
7,725 \\
6,755 \\
7,530\end{array}$ & $\begin{array}{l}5,920 \\
6,150 \\
5,400 \\
6,070\end{array}$ & $\begin{array}{l}7,150 \\
8,110 \\
6,880 \\
7,940\end{array}$ & $\begin{array}{l}7,730 \\
7,820 \\
7,300 \\
7,690\end{array}$ \\
\hline Nitrate, $\mu \mathrm{g} / \mathrm{L}$ & 33,800 & $\begin{array}{c}\text { Dec } 1997 \\
\text { Feb } 1998 \\
\text { May } 1998 \\
\text { August } 1998\end{array}$ & $\begin{array}{l}14,800 \\
14,900 \\
13,800 \\
13,500\end{array}$ & $\begin{array}{r}19,200 \\
\cdot 19,600 \\
18,400 \\
19,100\end{array}$ & $\begin{array}{l}12,000 \\
12,000 \\
11,300 \\
11,300\end{array}$ & $\begin{array}{l}21,800 \\
22,500 \\
21,600 \\
21,500\end{array}$ & $\begin{array}{l}22,200 \\
22,400 \\
21,200 \\
22,300\end{array}$ \\
\hline Nitrite, $\mu \mathrm{g} / \mathrm{L}$ & 250 & $\begin{array}{c}\text { Dec } 1997 \\
\text { Feb } 1998 \\
\text { May } 1998 \\
\text { August } 1998\end{array}$ & $\begin{array}{l}<70 \\
<70 \\
<70 \\
<70\end{array}$ & $\begin{array}{l}<70 \\
<70 \\
<70 \\
<70\end{array}$ & $\begin{array}{l}<70 \\
<70 \\
<70 \\
<70\end{array}$ & $\begin{array}{l}<70 \\
<70 \\
<70 \\
<70\end{array}$ & $\begin{array}{l}<70 \\
<70 \\
<70 \\
<70\end{array}$ \\
\hline Ammonium, $\mu \mathrm{g} / \mathrm{L}$ & 100 & $\begin{array}{c}\text { Dec } 1997 \\
\text { Feb } 1998 \\
\text { May } 1998 \\
\text { August } 1998\end{array}$ & $\begin{array}{l}<11 \\
<11 \\
<11 \\
<11\end{array}$ & $\begin{array}{l}<11 \\
<11 \\
<11 \\
<11\end{array}$ & $\begin{array}{l}<11 \\
<11 \\
<11 \\
<11\end{array}$ & $\begin{array}{l}<11 \\
<11 \\
<11 \\
<11\end{array}$ & $\begin{array}{l}<11 \\
<11 \\
<11 \\
<11\end{array}$ \\
\hline Sulfate, $\mu g / L$ & 51,500 & $\begin{array}{c}\text { Dec } 1997 \\
\text { Feb } 1998 \\
\text { May } 1998 \\
\text { August } 1998\end{array}$ & $\begin{array}{l}41,500 \\
40,800 \\
41,700 \\
41,800\end{array}$ & $\begin{array}{l}41,300 \\
41,300 \\
39,850 \\
41,300\end{array}$ & $\begin{array}{l}41,650 \\
41,600 \\
41,100 \\
42,200\end{array}$ & $\begin{array}{l}37,300 \\
39,300 \\
40,200 \\
41,600\end{array}$ & $\begin{array}{l}36,600 \\
38,700 \\
37,900 \\
39,900\end{array}$ \\
\hline Iron, filtered, $\mu \mathrm{g} / \mathrm{L}$ & 160 & $\begin{array}{c}\text { Dec } 1997 \\
\text { Feb } 1998 \\
\text { May } 1998 \\
\text { August } 1998\end{array}$ & $\begin{array}{l}43.5 \\
39.6 \\
47.6 \\
51.2\end{array}$ & $\begin{array}{l}56.0 \\
84.0 \\
29.3 \\
47.4\end{array}$ & $\begin{array}{l}47.5 \\
49.9 \\
23.9 \\
30.0\end{array}$ & $\begin{array}{l}57.5 \\
30.0 \\
88.6 \\
32.9\end{array}$ & $\begin{array}{l}39.8 \\
21.7 \\
44.3 \\
24.1\end{array}$ \\
\hline $\begin{array}{l}\text { Zinc, filtered, } \\
\mu \mathrm{g} / \mathrm{L}\end{array}$ & 34 & $\begin{array}{c}\text { Dec } 1997 \\
\text { Feb } 1998 \\
\text { May } 1998 \\
\text { August } 1998\end{array}$ & $\begin{array}{l}4.1 \\
8.1 \\
6.1 \\
9.0\end{array}$ & $\begin{array}{c}9.2 \\
12.2 \\
10.5 \\
19.8\end{array}$ & $\begin{array}{c}6.5 \\
11.0 \\
14.0 \\
8.7\end{array}$ & $\begin{array}{c}7.9 \\
7.8 \\
12.8 \\
28.4\end{array}$ & $\begin{array}{c}9.2 \\
9.1 \\
9.2 \\
10.0\end{array}$ \\
\hline $\begin{array}{l}\text { Manganese, } \\
\text { filtered, } \mu \mathrm{g} / \mathrm{L}\end{array}$ & 11 & $\begin{array}{c}\text { Dec } 1997 \\
\text { Feb } 1998 \\
\text { May } 1998 \\
\text { August } 1998\end{array}$ & $\begin{array}{l}4.9 \\
4.2 \\
2.9 \\
4.7\end{array}$ & $\begin{array}{l}7.1 \\
4.8 \\
3.1 \\
7.4\end{array}$ & $\begin{array}{l}5.5 \\
4.4 \\
2.3 \\
4.5\end{array}$ & $\begin{array}{c}5.5 \\
3.1 \\
2.4 \\
12.6\end{array}$ & $\begin{array}{l}4.3 \\
2.0 \\
1.5 \\
2.4\end{array}$ \\
\hline $\begin{array}{l}\text { Chemical oxygen } \\
\text { demand, } \mu \mathrm{g} / \mathcal{L}\end{array}$ & 5,000 & $\begin{array}{c}\text { Dec } 1997 \\
\text { Feb } 1998 \\
\text { May } 1998 \\
\text { August } 1998\end{array}$ & $\begin{array}{l}<3,070 \\
<, 070 \\
<3,070 \\
<, 820\end{array}$ & $\begin{array}{l}<, 070 \\
<3,070 \\
<3,070 \\
<3,820\end{array}$ & $\begin{array}{l}<, 070 \\
<, 070 \\
<, 070 \\
<3,820\end{array}$ & $\begin{array}{l}<, 070 \\
<3,070 \\
<, 070 \\
<, 820\end{array}$ & $\begin{array}{l}<3,070 \\
<3,070 \\
<, 070 \\
<3,820\end{array}$ \\
\hline
\end{tabular}


Table B.3. (contd)

\begin{tabular}{|c|c|c|c|c|c|c|c|}
\hline Constituent, unit & $\begin{array}{l}\text { Tolerance } \\
\text { Interval }^{(b)}\end{array}$ & Date & $\begin{array}{c}\text { Well } \\
699-24-34 B\end{array}$ & $\begin{array}{c}\text { Well } \\
699-24-34 C\end{array}$ & $\begin{array}{c}\text { Well } \\
699-24-35\end{array}$ & $\begin{array}{c}\text { Well } \\
699-25-34 \mathrm{C}\end{array}$ & $\begin{array}{c}\text { Well } \\
699-26-35 \mathrm{~A} \\
\end{array}$ \\
\hline $\begin{array}{l}\text { Coliform bacteria, } \\
\text { most probable } \\
\text { number }\end{array}$ & 16 & $\begin{array}{c}\text { Dec } 1997 \\
\text { Feb } 1998 \\
\text { May } 1998 \\
\text { August } 1998\end{array}$ & $\begin{array}{c}0.0^{(e)} \\
0.0 \\
-\overline{0.0}\end{array}$ & $\begin{array}{c}0.0^{(\epsilon)} \\
0.0 \\
0.0 \\
0.0\end{array}$ & $\begin{array}{c}0.0 \\
0.0^{(e)} \\
\overline{0.0}\end{array}$ & $\begin{array}{c}0.0 \\
0.0^{(e)} \\
\overline{0.0}\end{array}$ & $\begin{array}{l}0.0 \\
0.0^{(e)} \\
\overline{0.0}\end{array}$ \\
\hline
\end{tabular}

(a) WAC 173-304.

(b) Numbers obtained from Table B.1 (background threshold value column).

(c) Exceeding background threshold values.

(d) Suspect data (measured by faulty meters and probes).

(e) Exceeded holding time.

$<=$ Data values less than the method detection limit; number given is the respective limit.

Table B.4. Critical Means for 20 Comparisons--Background Contamination Indicator Parameter.Data for 1301-N Liquid Waste-Disposal Facility ${ }^{(a)}$

\begin{tabular}{|c|c|c|c|c|c|c|c|}
\hline Constituent, unit & $\mathbf{n}$ & df & $t_{c}$ & $\begin{array}{c}\text { Average } \\
\text { Background }\end{array}$ & $\begin{array}{l}\text { Standard } \\
\text { Deviation }\end{array}$ & $\begin{array}{l}\text { Critical } \\
\text { Mean }\end{array}$ & $\begin{array}{c}\text { Upgradient/ } \\
\text { Downgradient } \\
\text { Comparison Value } \\
\end{array}$ \\
\hline $\begin{array}{l}\text { Specific } \\
\text { conductance, } \mu \mathrm{S} / \mathrm{cm}\end{array}$ & 10 & 9 & 4.7815 & 592.70 & 272.527 & $1,959.4$ & $1,959.4$ \\
\hline Field $\mathrm{pH}^{(\mathrm{b})}$ & 9 & 8 & 5.6180 & 7.855 & 0.248 & {$[6.38,9.33]$} & {$[6.38,9.33]$} \\
\hline $\begin{array}{l}\text { Total organic carbon, } \\
\mu \mathrm{g} / \mathrm{L}\end{array}$ & 10 & 9 & 4.7815 & 377 & 205.037 & $1,405.2$ & $1,405.2$ \\
\hline Total organic halides, & 10 & 9 & 4.7815 & 10.742 & 5.087 & 36.2 & 36.2 \\
\hline
\end{tabular}

(a) Data collected from February 1994 to February 1995 for upgradient wells 199-N-57 and 199-N-34.

(b) Excluding suspect pH data collected on September 6, 1994 from well 199-N-57.

df $=$ Degrees of freedom (n-1).

$\mathrm{n}=$ Number of background replicate averages.

$\mathrm{t}_{\varepsilon}=$ Bonferroni critical $\mathrm{t}$-value for appropriate df and 20 comparisons. 
Table B.5. Critical Means for 16 Comparisons--Background Contamination Indicator Parameter Data for 1324-N/NA Liquid Waste-Disposal Facilities ${ }^{(a)}$

\begin{tabular}{|c|c|c|c|c|c|c|c|}
\hline Constituent, unit & $\mathbf{n}$ & df & $t_{c}$ & $\begin{array}{c}\text { Average } \\
\text { Background } \\
\end{array}$ & $\begin{array}{c}\text { Standard } \\
\text { Deviation } \\
\end{array}$ & Critical Mean & $\begin{array}{c}\text { Upgradient/ } \\
\text { Downgradient } \\
\text { Comparison Value }\end{array}$ \\
\hline $\begin{array}{l}\text { Specific } \\
\text { conductance, } \\
\mu \mathrm{S} / \mathrm{cm}\end{array}$ & $4^{(b)}$ & 3 & 11.984 & 260.812 & 26.709 & 618.7 & 618.7 \\
\hline Field pH & $4^{(b)}$ & 3 & 15.145 & 8.198 & 0.115 & {$[6.26,10.14]$} & {$[7.59,8.87]^{(c)}$} \\
\hline $\begin{array}{l}\text { Total organic } \\
\text { carbon, } \mu g / L\end{array}$ & $4^{(d)}$ & 3 & 11.984 & 291.875 & 80.710 & $1,373.2$ & 1,3732 \\
\hline $\begin{array}{l}\text { Total organic } \\
\text { halides, } \mu g / L\end{array}$ & 5 & 4 & 8.122 & 6.470 & 2.385 & 27.7 & 27.7 \\
\hline
\end{tabular}

(a) Data collected from May 1994 to May 1995 for upgradient well 199-N-71.

(b) Excluding outliers for specific conductance and pH collected on March 1, 1995 and August 26, 1994, respectively.

(c) Values calculated using data collected from May 1994 to September 1996 because the critical range calculated using only four quarters of data is too large to be meaningful.

(d) Excluding invalid data collected on November 4, 1994; blank contamination.

df $=$ Degrees of freedom $(n-1)$.

$\mathrm{n}=$ Number of background replicate averages.

$t_{c}=$ Bonferroni critical t-value for appropriate df and 16 comparisons.

Table B.6. Critical Means for 16 Comparisons--Background Contamination Indicator Parameter Data for 1325-N Liquid Waste-Disposal Facility ${ }^{(a)}$

\begin{tabular}{|c|c|c|c|c|c|c|c|}
\hline Constituent, unit & $N$ & df & $t_{e}$ & $\begin{array}{c}\text { Average } \\
\text { Background }\end{array}$ & $\begin{array}{l}\text { Standard } \\
\text { Deviation } \\
\end{array}$ & Critical Mean & $\begin{array}{c}\text { Upgradient/ } \\
\text { Downgradient } \\
\text { Comparison Value }\end{array}$ \\
\hline $\begin{array}{l}\text { Specific } \\
\text { conductance, } \\
\mu \mathrm{S} / \mathrm{cm}\end{array}$ & 4 & 3 & 11.984 & 501.75 & 14.046 & 689.9 & 689.9 \\
\hline Field pH & 4 & 3 & 15.145 & 7.991 & 0.129 & {$[5.81,10.18]$} & {$[6.57,9.05]^{(b)}$} \\
\hline $\begin{array}{l}\text { Total organic } \\
\text { carbon, }{ }^{(\Theta)} \mu \mathrm{g} / \mathrm{L}\end{array}$ & 4 & 3 & 11.984 & 500 & $\mathrm{NC}$ & NC & 1,140 \\
\hline $\begin{array}{l}\text { Total organic } \\
\text { halides, } \mu \mathrm{g} / \mathrm{L}\end{array}$ & 4 & 3 & 11.984 & 11.185 & 2.952 & 50.7 & 50.7 \\
\hline
\end{tabular}

(a) Data collected from May 1992 to March 1993 for upgradient well 199-N-74, except for total organic halide that was collected from June 1994 to March 1995.

(b) Values calculated using data collected from May 1992 to November 1994 because the critical range calculated using only four quarters of data is too large to be meaningful.

(c) Critical means not calculated because of lack of background standard deviation estimate. The upgradient/downgradient comparison value is the limit of quantitation (discussed in Appendix $D$ ).

df $=$ Degrees of freedom $(n-1)$.

$\mathrm{n}=$ Number of background replicate averages.

$\mathrm{NC}=$ Not calculated.

$t_{c}=$ Bonferroni critical $t$-value for appropriate df and 16 comparisons. 
Table B.7. Critical Means for 16 Comparisons--Background Contamination Indicator Parameter Data for 120-D-1 Ponds ${ }^{(a)}$

\begin{tabular}{|c|c|c|c|c|c|c|c|}
\hline Constituent, unit & $n$ & df & $t_{e}$ & $\begin{array}{c}\text { Average } \\
\text { Background }\end{array}$ & $\begin{array}{l}\text { Standard } \\
\text { Deviation }\end{array}$ & Critical Mean & $\begin{array}{c}\text { Upgradient/ } \\
\text { Downgradient } \\
\text { Comparison Value }\end{array}$ \\
\hline $\begin{array}{l}\text { Specific } \\
\text { conductance, } \\
\mu \mathrm{S} / \mathrm{cm}\end{array}$ & 5 & 4 & 8.122 & 519.40 & 15.265 & 655.2 & 655.2 \\
\hline Field $\mathrm{pH}$ & $4^{(b)}$ & 3 & 15.145 & 8.223 & 0.151 & {$[5.66,10.78]$} & {$[7.06,9.31]^{(c)}$} \\
\hline $\begin{array}{l}\text { Total organic } \\
\text { carbon, } \mu g / L\end{array}$ & 5 & 4 & 8.122 & 853.65 . & 70.751 & $1,483.1$ & $1,483.1$ \\
\hline $\begin{array}{l}\text { Total organic } \\
\text { halides, } \mu \mathrm{g} / \mathrm{L}\end{array}$ & 5 & 4 & 8.122 & 8.752 & 3.239 & 37.6 & 37.6 \\
\hline
\end{tabular}

(a) Data collected from March 1995 to February 1996 for upgradient well 199-D5-13.

(b) Excluding invalid pH data collected on March 14, 1995.

(c) Values calculated using data collected from May 1995 to August 1996 because the critical range calculated using only four quarters of data is too large to be meaningful.

$\mathrm{df}=$ Degrees of freedom $(\mathrm{n}-1)$.

$\mathrm{n}=$ Number of background replicate averages.

$t_{c}=$ Bonferroni critical $t-v a l u e$ for appropriate df and 16 comparisons.

Table B.8. Critical Means for 20 Comparisons--Background Contamination Indicator Parameter Data for 216-S-10 Pond and Ditch ${ }^{(\mathrm{a})}$

\begin{tabular}{|c|c|c|c|c|c|c|c|}
\hline Constituent, unit & $\mathbf{n}$ & df & $t_{c}$ & $\begin{array}{c}\text { Average } \\
\text { Background }\end{array}$ & $\begin{array}{l}\text { Standard } \\
\text { Deviation } \\
\end{array}$ & Critical Mean & $\begin{array}{c}\text { Upgradient/ } \\
\text { Downgradient } \\
\text { Comparison Value }\end{array}$ \\
\hline $\begin{array}{l}\text { Specific } \\
\text { conductance, } \\
\mu \mathrm{S} / \mathrm{cm}\end{array}$ & 5 & 4 & 8.1216 & 276.6 & 5.504 & 325.6 & 325.6 \\
\hline Field pH & 5 & 4 & 9.7291 & 8.101 & 0.089 & {$[7.15,9.05]$} & {$[7.15 ; 9.05]$} \\
\hline $\begin{array}{l}\text { Total organic } \\
\text { carbon, }{ }^{(0)} \mu g / L\end{array}$ & 4 & 3 & 11.984 & 291.25 & NC & . NC & 1,140 \\
\hline $\begin{array}{l}\text { Total organic } \\
\text { halides, } \mu \mathrm{g} / \mathrm{L}\end{array}$ & 5 & 4 & 8.1216 & 6.490 & 3.683 & 39.3 & 39.3 \\
\hline
\end{tabular}

(a) Data collected from December 1996 to December 1997 for upgradient well 299-W26-7.

(b) Critical means not calculated because of lack of background standard deviation estimate. The upgradient/downgradient comparison value is the limit of quantitation (discussed in Appendix D).

df $=$ Degrees of freedom $(n-1)$.

$\mathrm{n}=$ Number of background replicate averages.

$\mathrm{NC}=$ Not calculated.

- $t_{c}=$ Bonferroni critical t-value for appropriate df and 20 comparisons. 
Table B.9. Critical Means for 36 Comparisons--Background Contamination Indicator Parameter Data for 216-B-3 Pond ${ }^{(a)}$

\begin{tabular}{|c|c|c|c|c|c|c|c|}
\hline Constituent, unit & $\mathbf{n}$ & df & $t_{c}$ & $\begin{array}{c}\text { Average } \\
\text { Background }\end{array}$ & $\begin{array}{l}\text { Standard } \\
\text { Deviation }\end{array}$ & Critical Mean & $\begin{array}{c}\text { Upgradient/ } \\
\text { Downgradient } \\
\text { Comparison Value }\end{array}$ \\
\hline $\begin{array}{l}\text { Specific } \\
\text { conductance, } \\
\mu \mathrm{S} / \mathrm{cm}\end{array}$ & 15 & 14 & 4.4445 & 41.7 .667 & 7.215 & 450.8 & 450.8 \\
\hline Field pH & 15 & 14 & 4.8903 & 7.704 & 0.262 & {$[6.40,9.01]$} & {$[6.40,9.01]$} \\
\hline $\begin{array}{l}\text { Total organic } \\
\text { carbon, }{ }^{(6,6)} \mu \mathrm{g} / \mathrm{L}\end{array}$ & 15 & 14 & 4.4445 & 174.150 & 123.011 & 738.8 & 1,140 \\
\hline $\begin{array}{l}\text { Total organic } \\
\text { halides, }{ }^{(6, c)} \mu \mathrm{g} / \mathrm{L}\end{array}$ & 14 & 13 & 4.5400 & 3.980 & 2.242 & 14.5 & 25.2 \\
\hline
\end{tabular}

(a) Data collected from January 1994 to January 1997 for upgradient well 299-E32-4.

(b) Critical means calculated from values reported below the contractually required detection limit.

(c) Upgradient/downgradient comparison value is the limit of quantitation (discussed in Appendix D).

df $=$ Degrees of freedom $(n-1)$.

$\mathrm{n}=$ Number of background replicate averages.

$t_{c}=$ Bonferroni critical t-value for appropriate df and 36 comparisons.

Table B.10. Critical Means for 36 Comparisons--Background Contamination Indicator Parameter Data for 216-A-29 Ditch $^{(\text {a) }}$

\begin{tabular}{|c|c|c|c|c|c|c|c|}
\hline Constituent, unit & $\mathbf{n}$ & $\mathrm{df}$ & $t_{\varepsilon}$ & $\begin{array}{c}\text { Average } \\
\text { Background }\end{array}$ & $\begin{array}{l}\text { Standard } \\
\text { Deviation }\end{array}$ & Critical Mean & $\begin{array}{c}\text { Upgradient' } \\
\text { Downgradient } \\
\text { Comparison Value }\end{array}$ \\
\hline $\begin{array}{l}\text { Specific conductance, } \\
\mu \mathrm{S} / \mathrm{cm}\end{array}$ & 8 & 7 & 5.976 & 217.75 & 28.382 & 397.6 & 397.6 \\
\hline Field pH & 8 & 7 & 6.699 & 7.792 & 0.308 & {$[5.60,9.98]$} & {$[6.16,9.71]^{(b)}$} \\
\hline $\begin{array}{l}\text { Total organic } \\
\text { carbon, }{ }^{(c)} \mu g / L\end{array}$ & 8 & 7 & 5.976 & 499.375 & 98.758 & $1,125.3$ & 1,140 \\
\hline $\begin{array}{l}\text { Total organic } \\
\text { halides, }{ }^{(c)} \mu g / L\end{array}$ & 8 & 7 & 5.976 & 5.964 & 2.509 & 21.9 & 25.2 \\
\hline
\end{tabular}

(a) Data collected from April 1994 to January 1995 for upgradient wells 699-43-43 and 699-43-45.

(b) Values calculated using data collected from April 1994 to July 1995 (wells 699-43-43 and 699-43-45) because the critical range calculated using only four quarters of data is too large to be meaningful.

(c) Upgradient/downgradient comparison value is the limit of quantitation (discussed in Appendix D).

df $=$ Degrees of freedom $(n-1)$.

$\mathfrak{n}=$ Number of background replicate averages.

$t_{c}=$ Bonferroni critical t-value for appropriate df and 36 comparisons. 


\section{Table B.11. Critical Means for 48 Comparisons--Background Contamination Indicator} Parameter Data for 216-B-63 Trench $^{(a)}$

\begin{tabular}{|c|c|c|c|c|c|c|c|}
\hline Constituent, unit & $\mathbf{n}$ & df & $t_{c}$ & $\begin{array}{c}\text { Average } \\
\text { Background }\end{array}$ & $\begin{array}{l}\text { Standard } \\
\text { Deviation }\end{array}$ & Critical Mean & $\begin{array}{c}\text { Upgradient/ } \\
\text { Downgradient } \\
\text { Comparison Value } \\
\end{array}$ \\
\hline $\begin{array}{l}\text { Specific } \\
\text { conductance, } \\
\mu \mathrm{S} / \mathrm{cm}\end{array}$ & 21 & 20 & 4.224 & 369.393 & 60.192 & 629.6 & 629.6 \\
\hline Field pH & 20 & 19 & 4.572 & 7.975 & 0.190 & {$[7.08,8.87]$} & {$[7.08,8.87]$} \\
\hline $\begin{array}{l}\text { Total organic } \\
\text { carbon, }{ }^{(0)} \mu \mathrm{g} / \mathrm{L}\end{array}$ & 20 & 19 & $4.267^{\circ}$ & 500 & NC & NC & 1,140 \\
\hline $\begin{array}{l}\text { Total organic } \\
\text { halides, }{ }^{(\mathrm{C})} \mu \mathrm{g} / \mathrm{L}\end{array}$ & $\mathrm{NC}$ & NC & NC & NC & NC & NC & 25.2 \\
\hline
\end{tabular}

(a) Data collected from July 1992 to April 1993 for upgradient wells 299-E27-8, 299-E27-9, 299-E27-17, and 299-E34-10. Data collected from July 1992 to July 1993 for upgradient well 299-E27-11.

(b) Critical means not calculated because of lack of background standard deviation estimate. The upgradient/downgradient comparison value is the limit of quantitation (discussed in Appendix D).

(c) Critical means not calculated because of problems associated with data quality for samples analyzed by DataChem Laboratories, Inc., Salt Lake City, Utah. The upgradient/downgradient comparison value is the limit of quantitation (discussed in Appendix $D$ ).

df $=$ Degrees of freedom $(n-1)$

$\mathrm{n}=$ Number of background replicate averages.

$\mathrm{NC}=$ Not calculated.

$t_{\varepsilon}=$ Bonferroni critical $t-v a l u e$ for appropriate df and 48 comparisons.

Table B.12. Critical Means for 16 Comparisons--Background Contamination Indicator Parameter Data for Liquid Effluent-Retention Facility ${ }^{(a)}$

\begin{tabular}{|c|c|c|c|c|c|c|c|}
\hline Constituent, unit & $\mathbf{n}$ & df & $t_{c}$ & $\begin{array}{c}\text { Average } \\
\text { Background }\end{array}$ & $\begin{array}{c}\text { Standard } \\
\text { Deviation }\end{array}$ & Critical Mean & $\begin{array}{c}\text { Upgradient/ } \\
\text { Downgradient } \\
\text { Comparison Value } \\
\end{array}$ \\
\hline $\begin{array}{l}\text { Specific } \\
\text { conductance, } \\
\mu \mathrm{S} / \mathrm{cm}\end{array}$ & 4 & 3 & 11.984 & 332.125 & 11.736 & 489.4 & 489.4 \\
\hline Field pH & 4 & 3 & 15.145 & 7.742 & 0.311 & {$[2.48,13.01]$} & {$[6.25,9.42]^{(b)}$} \\
\hline $\begin{array}{l}\text { Total organic } \\
\text { carbon, }{ }^{(9)} \mu \mathrm{g} / \mathrm{L}\end{array}$ & 4 & 3 & 11.984 & 718.75 & 295.364 & 4,676 & 4,676 \\
\hline $\begin{array}{l}\text { Total organic } \\
\text { halides, }{ }^{(\oplus)} \mu g / L\end{array}$ & $\mathrm{NC}$ & NC & NC & $\mathrm{NC}$ & NC & NC & 25.2 \\
\hline
\end{tabular}

(a) Data collected from June 1991 to April 1992 for upgradient well 299-E26-11.

(b) Values calculated using data from June 1991 to October 1993 (well 299-E26-11) because the critical range calculated using four quarters of data is too large to be meaningful.

(c) Critical means calculated from values reported below the contractually required quantitation limit.

(d) Critical means not calculated because of problems associated with data quality for samples analyzed by DataChem Laboratories, Inc., Salt Lake City, Utah. The upgradient/downgradient comparison value is the limit of quantitation (discussed in Appendix D).

$\mathrm{df}=$ Degrees of freedom $(\mathrm{n}-1)$.

$\mathrm{n}=$. Number of background replicate averages.

$\mathrm{NC}=$ Not calculated.

$t_{e}=$ Bonferroni critical t-value for appropriate df and 16 comparisons. 
Table B.13. Critical Means for 68 Comparisons--Background Contamination Indicator Parameter Data for Low-Level Waste Management Area $1^{(a)}$

\begin{tabular}{|c|c|c|c|c|c|c|c|}
\hline Constituent, unit & $\mathbf{n}$ & df & $\mathfrak{t}_{\mathbf{c}}$ & $\begin{array}{c}\text { Average } \\
\text { Background }\end{array}$ & $\begin{array}{c}\text { Standard } \\
\text { Deviation }\end{array}$ & Critical Mean & $\begin{array}{c}\text { Upgradient } \\
\text { Downgradient } \\
\text { Comparison Value } \\
\end{array}$ \\
\hline $\begin{array}{l}\text { Specific } \\
\text { conductance, } \\
\mu \mathrm{S} / \mathrm{cm}\end{array}$ & $26^{(0)}$ & 25 & 4.2027 & 373.721 & 74.637 & 693.4 & 693.4 \\
\hline Field pH & 27 & 26 & 4.4409 & 7.896 & 0.330 & {$[6.40,9.39]$} & {$[6.40,9.39]$} \\
\hline $\begin{array}{l}\text { Total organic } \\
\text { carbon, }{ }^{(G)} \mu \mathrm{g} / \mathrm{L}\end{array}$ & 26 & 25 & 4.2027 & 500 & $\mathrm{NC}$ & $\mathrm{NC}$ & 1,140 \\
\hline $\begin{array}{l}\text { Total organic } \\
\text { halides, }{ }^{(\oplus)} \mu / L\end{array}$ & NC & NC & $\mathrm{NC}$ & $\mathrm{NC}$ & $\mathrm{NC}$ & NC & 25.2 \\
\hline
\end{tabular}

(a) Data collected from July 1992 to April 1993 for upgradient wells 299-E28-26, 299-E28-27, 299-E28-28, 299-E33-28, 299-E33-29; from July 1992 to January 1993 for 299-E33-35; and from September 1991 to July 1992 for 299-E32-4.

(b) Excluding outlier collected on July 2, 1992 from well 299-E33-28.

(c) Critical means not calculated because of lack of background standard deviation estimate. The upgradient/downgradient comparison value is the limit of quantitation (discussed in Appendix D).

(d) Critical means not calculated because of problems associated with data quality for samples analyzed by DataChem Laboratories, Inc., Salt Lake City, Utah. The upgradient/downgradient comparison value is the limit of quantitation (discussed in Appendix D).

df $=$ Degrees of freedom (n-1).

$\mathrm{n}=$ Number of background replicate averages.

NC $=$ Not calculated.

$t_{c}=$ Bonferroni critical t-value for appropriate df and 68 comparisons.

Table B.14. Critical Means for 48 Comparisons--Background Contamination Indicator Parameter Data for Low-Level Waste Management Area $2^{\text {(a) }}$

\begin{tabular}{|c|c|c|c|c|c|c|c|}
\hline Constituent, unit & $\mathbf{n}$ & $\mathrm{df}$ & $\mathbf{t}_{e_{e}}$ & $\begin{array}{c}\text { Average } \\
\text { Background }\end{array}$ & $\begin{array}{c}\text { Standard } \\
\text { Deviation }\end{array}$ & Critical Mean & $\begin{array}{c}\text { Upgradient/ } \\
\text { Downgradient } \\
\text { Comparison Value } \\
\end{array}$ \\
\hline $\begin{array}{l}\text { Specific } \\
\text { conductance, } \\
\mu \mathrm{S} / \mathrm{cm}\end{array}$ & 12 & 11 & 4.9786 & 404.104 & 41.359 & 618.4 & 618.4 \\
\hline Field pH & 12 & 11 & 5.4261 & 8.206 & 0.225 & {$[6.94,9.48]$} & {$[6.94,9.48]$} \\
\hline $\begin{array}{l}\text { Total organic } \\
\text { carbon, }{ }^{(0)} \mu g / L\end{array}$ & 12 & 11 & 4.9786 & 272.667 & 71.404 & 642.7 & 1,140 \\
\hline $\begin{array}{l}\text { Total organic } \\
\text { halides, }{ }^{(0)} \mu g / L\end{array}$ & 12 & 11 & 4.9786 & 2.992 & 1.289 & 9.7 & 25.2 \\
\hline
\end{tabular}

(a) Data collected from May 1995 to November 1996 for upgradient wells 299-E27-10, 299-E34-3, and 299-E34-7.

(b) Upgradient/downgradient comparison value is the limit of quantitation (discussed in Appendix D).

df $=$ Degrees of freedom $(n-1)$.

$n=$ Number of background replicate averages.

$t_{c}=$ Bonferroni critical t-value for appropriate df and 48 comparisons. 
Table B.15. Critical Means for 28 Comparisons--Background Contamination Indicator Parameter Data for Low-Level Waste Management Area $3^{(\mathrm{a})}$

\begin{tabular}{|c|c|c|c|c|c|c|c|}
\hline Constituent, unit & $\mathbf{n}$ & df & $t_{c}$ & $\begin{array}{c}\text { Average } \\
\text { Background }\end{array}$ & $\begin{array}{c}\text { Standard } \\
\text { Deviation } \\
\end{array}$ & Critical Mean & $\begin{array}{c}\text { Upgradient/ } \\
\text { Downgradient } \\
\text { Comparison Value }\end{array}$ \\
\hline $\begin{array}{l}\text { Specific } \\
\text { conductance, } \\
\mu \mathrm{S} / \mathrm{cm}\end{array}$ & 12 & 11 & $4.6425^{\circ}$ & 439.812 & 26.865 & 569.6 & 569.6 \\
\hline Field pH & 12 & 11 & 5.0765 & 8.120 & 0.294 & {$[6.57,9.67]$} & {$[6.57,9.67]$} \\
\hline $\begin{array}{l}\text { Total organic } \\
\text { carbon, }{ }^{(b)} \mu \mathrm{g} / \mathrm{L}\end{array}$ & 10 & 9 & 5.0255 & 195.75 & 42.296 & 418.7 & 1,140 \\
\hline $\begin{array}{l}\text { Total organic } \\
\text { halides, } \mu \mathrm{g} / \mathrm{L}\end{array}$ & 9 & 8 & 5.3168 & 8.731 & 7.183 & 49.0 & 49.0 \\
\hline
\end{tabular}

(a) Data collected from February 1994 to March 1995 for upgradient wells 299-W9-1 and 299-W10-13. Critical means calculated for area not impacted by upgradient source of contamination.

(b) Critical means calculated from values reported below contractually required detection limit. The upgradient/downgradient comparison value is the limit of quantitation (discussed in Appendix D).

$\mathrm{df}=$ Degrees of freedom $(\mathrm{n}-1)$.

$\mathbf{n}=$ Number of background replicate averages.

$\mathrm{t}_{\mathrm{c}}=$ Bonferroni critical $\mathrm{t}$-value for appropriate df and 28 comparisons.

Table B.16. Critical Means for 40 Comparisons--Background Contamination Indicator Parameter Data for Low-Level Waste Management Area $3^{(a)}$

\begin{tabular}{|c|c|c|c|c|c|c|c|}
\hline Constituent, unit & $\mathbf{n}$ & $\mathrm{de}$ & $t_{c}$ & $\begin{array}{c}\text { Average } \\
\text { Background }\end{array}$ & $\begin{array}{l}\text { Standard } \\
\text { Deviation }\end{array}$ & Critical Mean & $\begin{array}{c}\text { Upgradient/ } \\
\text { Downgradient } \\
\text { Comparison Value }\end{array}$ \\
\hline $\begin{array}{l}\text { Specific } \\
\text { conductance, } \mu \mathrm{S} / \mathrm{cm}\end{array}$ & 17 & 16 & 4.3467 & 580.941 & 32.230 & 725.1 & 725.1 \\
\hline Field pH & 17 & 16 & 4.6820 & 7.838 & 0.3867 & {$[5.97,9.70]$} & {$[5.97,9.70]$} \\
\hline $\begin{array}{l}\text { Total organic } \\
\text { carbon, }^{(0, c)} \mu g / L\end{array}$ & 15 & 14 & 4.4995 & 367.833 . & 107.483 & 867.3 & 1,140 \\
\hline $\begin{array}{l}\text { Total organic } \\
\text { halides, } \mu g / L\end{array}$ & 14 & 13 & 4.5978 & 797.923 & 319.605 & $2,319.0$ & 2.319 .0 \\
\hline
\end{tabular}

(a) Data collected from February 1994 to March 1995 for upgradient wells 299-W10-19, 299-W10-20, and 299-W10-21. Critical means calculated for area impacted by upgradient source of contamination.

(b) Critical means calculated from values reported below contractually required detection limit.

(c) Upgradient/downgradient comparison value is the limit of quantitation (discussed in Appendix D).

df $=$ Degrees of freedom $(n-1)$.

$\mathrm{n}=$ Number of background replicate averages.

$t_{c}=$ Bonferroni critical t-value for appropriate df and 40 comparisons. 
Table B.17. Critical Means for 40 Comparisons--Background Contamination Indicator Parameter Data for Low-Level Waste Management Area $4^{(\text {a) }}$

\begin{tabular}{|c|c|c|c|c|c|c|c|}
\hline Constituent, unit & $\mathrm{n}$ & df & $t_{c}$ & $\begin{array}{c}\text { Average } \\
\text { Background }\end{array}$ & $\begin{array}{c}\text { Standard } \\
\text { Deviation }\end{array}$ & Critical Mean & $\begin{array}{c}\text { Upgradient/ } \\
\text { Downgradient } \\
\text { Comparison Value }\end{array}$ \\
\hline $\begin{array}{l}\text { Specific } \\
\text { conductance, } \\
\mu \mathrm{S} / \mathrm{cm}\end{array}$ & 16 & 15 & 4.4169 & 328.594 & 133.345 & 935.7 & 935.7 \\
\hline Field $\mathrm{pH}$ & 16 & 15 & 4.7663 & 7.779 & 0.261 & {$[6.50,9.06]$} & {$[6.50,9.06]$} \\
\hline $\begin{array}{l}\text { Total organic } \\
\text { carbon, }^{(0, n)} \mu \mathrm{g} / \mathrm{L}\end{array}$ & 15 & 14 & 4.4995 & 470.0 & 142.428 & $1,131.9$ & 1,140 \\
\hline $\begin{array}{l}\text { Total organic } \\
\text { halides }{ }_{2}^{(b)} \mu g / L\end{array}$ & 11 & 10 & 5.0494 & $2,029.796$ & $2,002.864$ & 12,593 & 12,593 \\
\hline
\end{tabular}

(a) Data collected from October 1988 to July 1989 for upgradient wells 299-W15-16, 299-W15-18, and 299-W18-24 and from October 1992 to August 1993 for the newly installed upgradient well 299-W18-32.

(b) Critical means calculated using data analyzed by United States Testing Company, Inc., Richland, Washington.

(c) Upgradient/downgradient comparison value is the limit of quantitation (discussed in Appendix D).

df $=$ Degrees of freedom $(n-1)$.

$\mathrm{n}=$ Number of background replicate averages.

$t_{c}=$ Bonferroni critical $t$-value for appropriate df and 40 comparisons.

Table B.18. Critical Means for 20 Comparisons--Background Contamination Indicator Parameter Data for Waste Management Area A-AX ${ }^{(a)}$

\begin{tabular}{|c|c|c|c|c|c|c|c|}
\hline Constituent, unit & $\mathbf{n}$ & df & $t_{c}$ & $\begin{array}{c}\text { Average } \\
\text { Background }\end{array}$ & $\begin{array}{c}\text { Standard } \\
\text { Deviation } \\
\end{array}$ & Critical Mean & $\begin{array}{c}\text { Upgradient } \\
\text { Downgradient } \\
\text { Comparison Value }\end{array}$ \\
\hline $\begin{array}{l}\text { Specific } \\
\text { conductance, } \\
\mu \mathrm{S} / \mathrm{cm}\end{array}$ & 8 & 7 & 5.4079 & 396.563 & 59.671 & 738.8 & 738.8 \\
\hline Field $\mathrm{pH}$ & 8 & 7 & 6.0818 & 7.798 & 0.194 & {$[6.55,9.05]$} & {$[6.55,9.05]$} \\
\hline $\begin{array}{l}\text { Total organic } \\
\text { carbon, }{ }^{(0)} \mu \mathrm{g} / \mathrm{L}\end{array}$ & $6^{(-)}$ & 5 & 5.4079 & 500 & NC & NC & 1,140 \\
\hline $\begin{array}{l}\text { Total organic } \\
\text { halides, }{ }^{(1)} \mu \mathrm{g} / \mathrm{L}\end{array}$ & NC & NC & $\mathrm{NC}$ & $\mathrm{NC}$ & NC & NC & 25.2 \\
\hline
\end{tabular}

(a) Data collected from July 1991 to May 1992 for upgradient wells 299-E25-40 and 299-E25-41.

(b) Critical means not calculated because of lack of background standard deviation estimate. The upgradient/downgradient comparison value is the limit of quantitation (discussed in Appendix D).

(c) Excluding values collected on February 28, 1992 from wells 299-E25-40 and 299-E25-41 because of nonconformance report.

(d) Critical means not calculated because of problems associated with data quality for samples analyzed by DataChem Laboratories, Inc., Salt Lake City, Utah. The upgradient/downgradient comparison value is the limit of quantitation (discussed in Appendix D).

df $=$ Degrees of freedom (n-1).

$\mathrm{n}=$ Number of background replicate averages.

$\mathrm{NC}=$ Not calculated.

$t_{c}=$ Bonferroni critical t-value for appropriate df and 20 comparisons. 
Table B.19. Critical Means for 16 Comparisons--Background Contamination Indicator Parameter Data for Waste Management Area $C^{(a)}$

\begin{tabular}{|c|c|c|c|c|c|c|c|}
\hline Constituent, unit & $\mathrm{n}$ & df & $t_{c}$ & $\begin{array}{c}\text { Average } \\
\text { Background }\end{array}$ & $\begin{array}{l}\text { Standard } \\
\text { Deviation } \\
\end{array}$ & Critical Mean & $\begin{array}{c}\text { Upgradient } \\
\text { Downgradient } \\
\text { Comparison Value }\end{array}$ \\
\hline $\begin{array}{l}\text { Specific } \\
\text { conductance, } \\
\mu \mathrm{S} / \mathrm{cm}\end{array}$ & 4 & 3 & 11.9838 & 353.063 & $\begin{array}{c}14.244 \\
.\end{array}$ & 543.9 & 543.9 \\
\hline Field pH & 4 & 3 & 15.1451 & 8.038 & 0.109 & {$[6.19,9.88]$} & {$[6.19,9.88]$} \\
\hline $\begin{array}{l}\text { Total organic } \\
\text { carbon, }{ }^{(f)} \mu g / L\end{array}$ & 4 & 3 & 11.9838 & 500 & $\mathrm{NC}$ & NC & 1,140 \\
\hline $\begin{array}{l}\text { Total organic } \\
\text { halides, }{ }^{\left({ }^{\prime}\right)} \mu \mathrm{g} / \mathrm{L}\end{array}$ & $\mathrm{NC}$ & NC & NC & NC & NC & NC & 25.2 \\
\hline
\end{tabular}

(a) Data collected from July 1991 to August 1992 for upgradient well 299-E27-14.

(b) Critical means not calculated because of lack of background standard deviation estimate. The upgradient/downgradient comparison value is the limit of quantitation (discussed in Appendix D).

(c) Critical means not calculated because of problems associated with data quality for samples analyzed by DataChem Laboratories, Inc., Salt Lake City, Utah. The upgradient/downgradient comparison value is the limit of quantitation (discussed in Appendix D).

df $=$ Degrees of freedom (n-1).

$\mathbf{n}=$ Number of background replicate averages.

$\mathrm{NC}=$ Not calculated.

$t_{c}=$ Bonferroni critical t-value for appropriate df and 16 comparisons.

Table B.20. Critical Means for 20 Comparisons--Background Contamination Indicator Parameter Data for Waste Management Area $U^{(a)}$

\begin{tabular}{|c|c|c|c|c|c|c|c|}
\hline Constituent, unit & $\mathbf{n}$ & $\mathrm{df}$ & $t_{c}$ & $\begin{array}{c}\text { Average } \\
\text { Background }\end{array}$ & $\begin{array}{l}\text { Standard } \\
\text { Deviation }\end{array}$ & Critical Mean & $\begin{array}{c}\text { Upgradient/ } \\
\text { Downgradient } \\
\text { Comparison Value }\end{array}$ \\
\hline $\begin{array}{l}\text { Specific } \\
\text { conductance, . } \\
\mu S / \mathrm{cm}\end{array}$ & 8 & 7 & 5.4079 & 308.875 & 39.032 & 532.8 & 532.8 \\
\hline Field pH & 8 & 7 & 6.0818 & 8.008 & 0.091 & {$[7.42,8.59]$} & {$[7.42,8.59]$} \\
\hline $\begin{array}{l}\text { Total organic } \\
\text { carbon, }{ }^{(b)} \mu g / L\end{array}$ & 8 & 7 & 5.4079 & 275.031 & 82.580 & 748.7 & 1,140 \\
\hline $\begin{array}{l}\text { Total organic } \\
\text { halides, } \mu \mathrm{g} / \mathrm{L}\end{array}$ & 8 & 7 & 5.4079 & 102.994 & 24.120 & 241.3 & 241.3 \\
\hline
\end{tabular}

(a) Data collected based on semiannual sampling events from February 1995 to August 1996 for upgradient wells 299-W18-25 and 299-W18-31.

(b) Upgradient/downgradient comparison value is the limit of quantitation (discussed in Appendix D).

df $=$ Degrees of freedom $(n-1)$.

$n=$ Number of background replicate averages.

$\mathrm{t}_{\mathrm{c}}=$ Bonferroni critical $\mathrm{t}$-value for appropriate $\mathrm{df}$ and 20 comparisons. 
Table B.21. Critical Means for 28 Comparisons--Background Contamination Indicator Parameter Data for Nonradioactive Dangerous Waste Landfill ${ }^{(\mathrm{a})}$

\begin{tabular}{|c|c|c|c|c|c|c|c|}
\hline Constituent, unit & $\mathrm{n}$ & df & $t_{c}$ & $\begin{array}{c}\text { Average } \\
\text { Background }\end{array}$ & $\begin{array}{c}\text { Standard } \\
\text { Deviation }\end{array}$ & Critical Mean & $\begin{array}{c}\text { Upgradient/ } \\
\text { Downgradient } \\
\text { Comparison Value }\end{array}$ \\
\hline $\begin{array}{l}\text { Specific } \\
\text { conductance, } \\
\mu \mathrm{S} / \mathrm{cm}\end{array}$ & 8 & 7 & 5.7282 & 335.31 & 80.088 & 821.9 & 821.9 \\
\hline Field pH & 7 & 6 & 7.2227 & 7.546 & 0.685 & {$[2.26,12.84]$} & {$[5.16,9.87]^{(b)}$} \\
\hline $\begin{array}{l}\text { Total organic } \\
\text { carbon, }{ }^{(, q, a, c)} \mu \mathrm{g} / \mathrm{L}\end{array}$ & 8 & 7 & 5.7282 & 424.65 & 89.98 & 971.3 & 1,140 \\
\hline $\begin{array}{l}\text { Total organic } \\
\text { halides, }{ }^{(d e)} \mu \mathrm{g} / \mathrm{L}\end{array}$ & 8 & 7 & 5.7282 & 5.15 & 1.83 & 16.3 & 25.2 \\
\hline
\end{tabular}

(a) Data collected from November 1987 to July 1988 for upgradient wells 699-26-34A and 699-26-35A.

(b) Values calculated using data collected from November 1987 to June 1992 (wells 699-26-34A and 699-25-35A) because the critical range calculated using four quarters of data is too large to be meaningful.

(c) Critical means calculated from values reported below the contractually required detection limit.

(d) Critical means calculated using data analyzed by United States Testing Company, Inc., Richland, Washington.

(e) Upgradient/downgradient comparison value is the limit of quantitation (discussed in Appendix D).

df $=$ Degrees of freedom $(n-1)$.

$\mathrm{n}=$ Number of background replicate averages.

$t_{c}=$ Bonferroni critical t-value for appropriate df and 28 comparisons. 
Appendix C

Analytical Methods 



\section{Contents}

C.1 General Chemical Analyses ................................................................................................... C.1

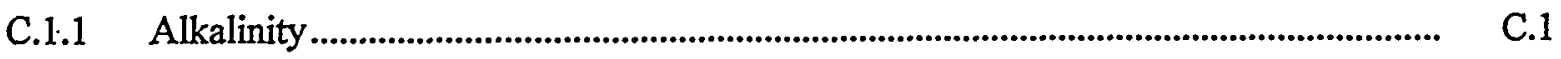

C.1.2 Chemical Oxygen Demand......................................................................................... C.1

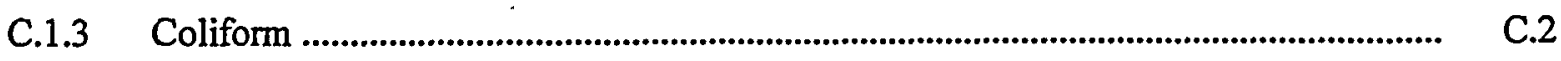

C.1.4 Oil and Grease ......................................................................................................... C.2

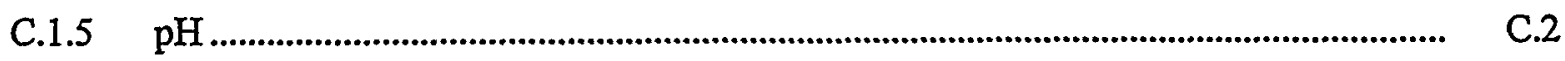

C.1.6 Specific Conductance ........................................................................................ C.2

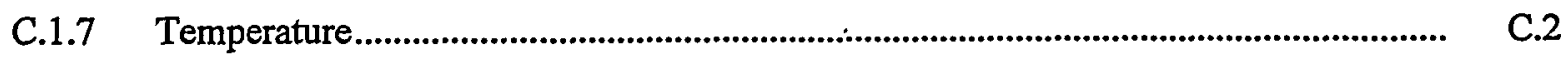

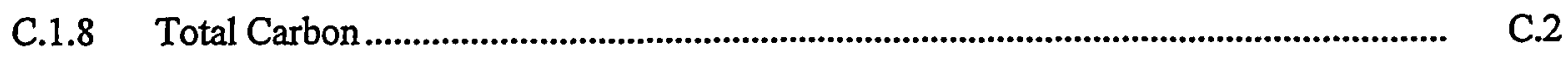

C.1.9 Total Dissolved Solids........................................................................................... C.3

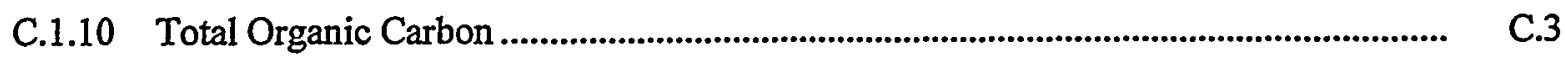

C.1.11 Total Organic Halides................................................................................................... C.3

C.1.12 Total Petroleum Hydrocarbons................................................................................... C.3

C.1.13 Turbidity ....................................................................................................................... C.3

C.2 Ammonia, Anions, and Cyanide ........................................................................................... C.4

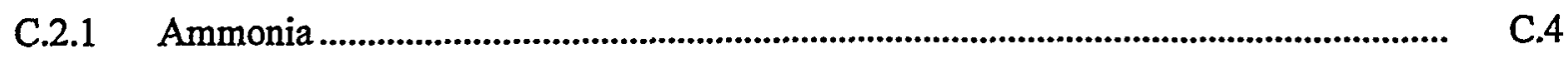

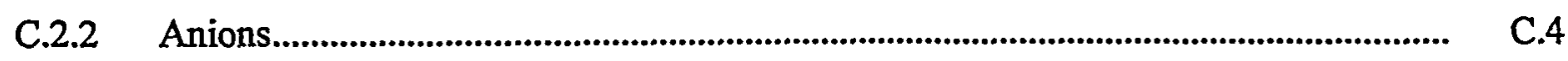

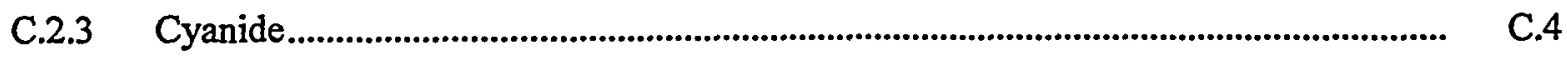

C.3 Volatile Organic Compound Analyses........................................................................... C.4

C.4 Semivolatile Organic.Compound Analyses................................................................................ C.5

C.5 Metals Analyses ........................................................................................................................ C.5

C.5.1 Atomic Absorption ....................................................................................................... C.5

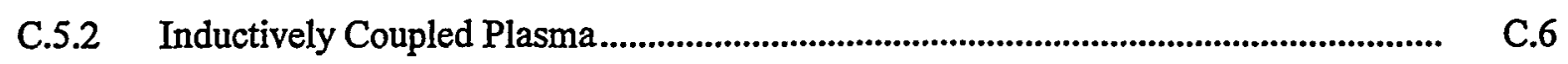


C.5.3 Hexavalent Chromium ....................................................................................... C.6

C.6 Radiological Parameters................................................................................................. C.6

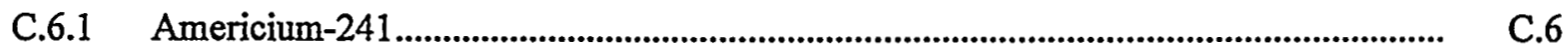

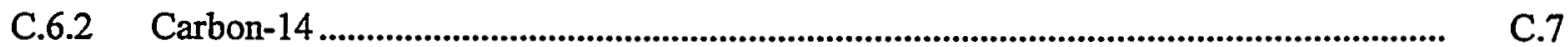

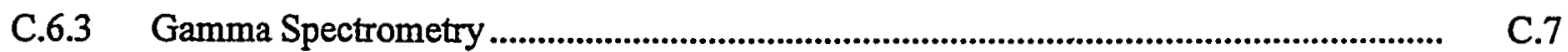

C.6.4 Gross Alpha and Gross Beta................................................................................ C.7

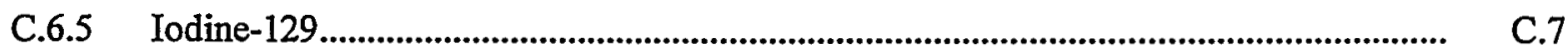

C.6.6 Low-Level Tritium

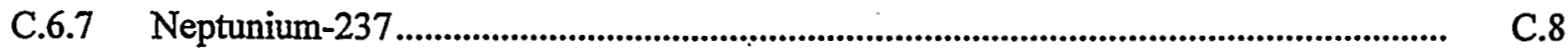

C.6.8 Nickel-63

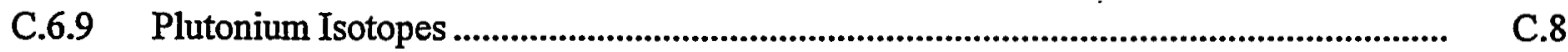

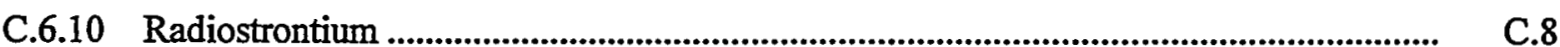

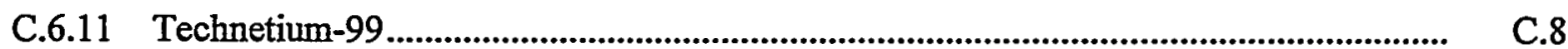

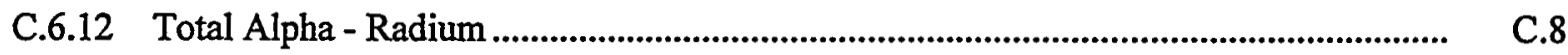

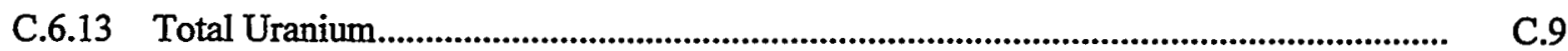

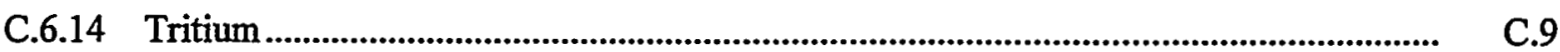

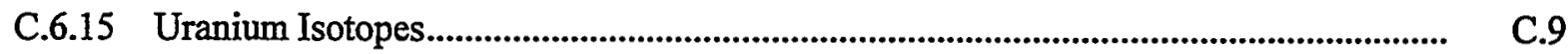

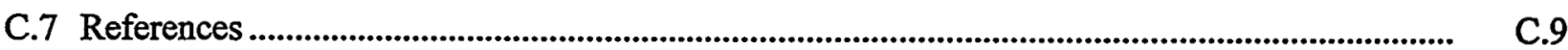

\section{Table}

C.1 Methodologies Used to Obtain Routine Data Results for Project Samples 


\title{
Appendix C
}

\section{Analytical Methods}

\author{
B. M. Gillespie
}

The methodology for analysis of chemical constituents in groundwater at the Hanford Site for fiscal year 1998 conforms to the U.S. Environmental Protection Agency's (EPA's) Test Methods for Evaluating Solid Wastes: Physical/Chemical Methods, 3rd Ed. (SW-846); Methods for Chemical Analysis of Water . and Wastes (EPA-600/4-79-020) or other EPA methods; and the Annual Book of ASTM Standards (American Society for Testing and Materials 1986). During fiscal year 1998, samples were analyzed for chemical constituents by four laboratories and for radiochemical analytes by three primary. The methods used for analysis of radiochemical constituents were developed by the analyzing laboratory and are recognized as acceptable within the technical radiochemical industry. The methods used to obtain routine data results are presented in Table C.1 and are organized into several categories: general chemicals, ammonia and anions, volatile organic compounds, semivolatile organic compounds, metals, and radionuclides. Brief descriptions of the methods for each test ordered are given in the following sections. Some tests were performed by slightly different methods, depending on the laboratory. Also, those tests performed in the field are noted in the applicable sections.

\section{C.1 General Chemical Analyses}

\section{C.1.1 Alkalinity}

Method 310.1 (EPA-600/4-79-020) was used to determine alkalinity. The sample was titrated electrometrically with hydrochloric acid or sulfuric acid to an end point of $\mathrm{pH} 4.5$.

\section{C.1.2 Chemical Oxygen Demand}

Method 410.4 (EPA-600/4-79-020) was used to determine chemical oxygen demand. Organic and oxidizable inorganic substances in the sample were oxidized by potassium dichromate in $50 \%$ sulfuric acid solution at reflux temperature. Silver sulfate was used as a catalyst, and mercuric sulfate was added to remove chloride interference. Intensity was measured spectrophotometrically at $600 \mathrm{~nm}$.

In the field, measurements for dissolved oxygen were based on the membrane electrode Method 360.1 (EPA-600/4-79-020). 


\section{C.1.3 Coliform}

Method 9131 (SW-846) was used to determine coliform by the tube fermentation technique. This method consisted of a three-stage procedure in which the results were statistically expressed in terms of the most probable number. The three stages were used to determine the probability of coliform growth based on gas production and culture growth.

\section{C.1.4 Oil and Grease}

Method 413.1 (EPA-600/4-79-020) was used to determine oil and grease in groundwater samples. In this method, the sample was acidified to a low $\mathrm{pH}(<2)$ and serially extracted with fluorocarbon-113 in a separatory funnel. The solvent was evaporated from the extract and the residue weighed. The definition of oil and grease was based on the procedure used. The nature of the oil and/or grease and the presence of extractable nonoily matter influenced the material measured and interpretation of results. Oil and grease were measures of biodegradable animal greases and vegetable oils along with the relative nonbiodegradable mineral oils.

\section{C.1.5 pH}

In the field, $\mathrm{pH}$ was determined by potentiometric measurement using Method 9040 (SW-846) or company-specific procedures based on EPA methodology and instrument manuals.

\section{C.1.6 Specific Conductance}

Method 120.1 (EPA-600/4-79-020) or Method 9050 (SW-846) was used to determine the specific conductance of a sample. The conductance was measured by use of a self-contained conductivity meter, Wheatstone bridge-type, or equivalent.

In the field, specific conductance was measured using company-specific procedures based on Method 9050 (SW-846).

\section{C.1.7 Temperature}

In the field, the temperature of samples was based on company-specific and instrument manual methodology using electronic digital thermometers.

\section{C.1.8 Total Carbon}

Total carbon measurements were based on instrument manufacturer parameters and Method 415.1 (EPA-600/4-79-020). Carbon in a sample was converted to carbon dioxide by catalytic combustion or wet chemical oxidation. The carbon dioxide formed was measured directly by an infrared detector or converted to methane and measured by a flame ionization detector. The amount of carbon dioxide or methane was directly proportional to the concentration of carbonaceous material in the sample. 


\section{C.1.9 Total Dissolved Solids}

Method 160.1 (EPA-600/4-79-020) was used to determine total dissolved solids. The sample was dried to $180^{\circ} \mathrm{C}$, and the total dissolved solids content determined by the gravimetric technique.

\section{C.1.10 Total Organic Carbon}

Method 9060 (SW-846) or Method 415.1 (EPA-600/4-79-020) was used to determine total organic carbon. This method used a carbonaceous analyzer to convert the organic carbon in the sample to carbon dioxide by either catalytic combustion or wet chemical oxidation. The carbon dioxide was then directly measured by an infrared detector or converted to methane and measured by a flame ionization detector. The amount of carbon dioxide or methane measured was directly proportional to the concentration of carbonaceous material in the sample.

\section{C.1.11 Total Organic Halides}

Method 9020 (SW-846) was used to determine total organic halides. The sample was passed through an activated carbon column. The column was washed to remove any trapped inorganic halides. The sample was then combusted to convert the adsorbed organohalides to hydrogen halide, which was trapped and titrated electrolytically using a microcoulometric detector.

\section{C.1.12 Total Petroleum Hydrocarbons}

Three methods were used to determine total petroleum hydrocarbons, the first of which was Method 418.1 (EPA-600/4-79-020). This method determined the mineral oils by acidifying the sample to $\mathrm{pH}<2$ and serially extracting with fluorocarbon-113 in a separatory funnel. Interferences were removed with silica gel absorbent. Infrared analysis of the extract was performed by direct comparison with standards.

Gasoline range total petroleum hydrocarbons were determined using the method in State of Washington Department of Ecology (1992), which adapted Methods 5030 and/or 8020 (SW-846) to perform the analysis. The method involved purging an aliquot of sample via a purge-and-trap concentrator and analyzing the purged components using a gas chromatograph equipped with a flame ionization detector.

Diesel range total petroleum hydrocarbons were determined using the method in State of Washington Department of Ecology (1992), which adapted Methods 3510 and 8000 (SW-846). The method involved extracting the samples with methylene chloride and injecting a portion of the extract into a gas chromatograph equipped with a flame ionization detector. ' Quantitation was accomplished by integrating to baseline, as a group, the area of components between do'decane through tetracosane.

\section{C.1.13 Turbidity}

In the field, turbidity values were given as nephelometric measurements based on Method 180.1 (EPA-600/4-79-020) or Standard Method 214A (American Public Health Association 1985). 


\section{C.2 Ammonia, Anions, and Cyanide}

\section{C.2.1 Ammonia}

Ammonia was determined by one of the methods listed below.

A colorimeter was used to determine ammonia by Method 350.1 (EPA-600/R-93-100). The method used alkaline phenol and hypochlorite to react with ammonia to form indenophenol blue in an amount proportional to the ammonia concentration. The blue color formed was intensified with sodium nitroprusside. The concentration was measured using a calibrated colorimeter.

Poteniometric determination of ammonia by ion-selective ammonia electrode was performed by Method 350.3 (EPA-600/4-79-020).

Using Method 300.7 (EPA-600/4-86-024), a small volume of sample was introduced into an ion chromatograph. The cations of interest were separated and measured, using a system comprised of a guard column, separator column, suppressor device, and conductivity detector. The analysis yielded accurate quantitative results for ammonium, calcium, lithium, magnesium, potassium, and sodium.

\section{C.2.2 Anions}

Method 300.0 (EPA-600/R-93-100) was used to determine nitrate, nitrite, bromide, chloride, fluoride, phosphate, and sulfate. The sample was introduced into an ion chromatograph, where the anions of interest were separated and measured with a conductivity detector. The specific method for the detection of individual anions used in some instances is given below.

Method 353.1 (EPA-600/4-79-020) was used to determine total nitrate plus nitrite. This method is a colorimetric method that first reduced the nitrate to nitrite with either hydrazine or cadmium. Total nitrite was determined colorimetrically by using sulfanilamide and $\mathrm{N}$-(1-naphthyl)-ethylenediamine dihydrochloride to form a highly colored azo dye. The results were expressed as nitrogen in nitrate plus nitrite.

\section{C.2.3 Cyanide}

Method 9012 (SW-846) or Method 335.3 (EPA-600/4-79-020) were used to determine cyanide. The sample was acidified, converting any cyanide to hydrocyanic acid. The sample was then distilled, and the hydrocyanic acid trapped in an absorber scrubber of sodium hydroxide solution. The cyanide ion was converted to cyanogen chloride with Chloramine- $T$, and color formation achieved through the addition of pyridine barbituric acid. The cyanide concentration was then determined by volumetric titration, colorimetry, or automated ultraviolet colorimetry.

\section{C.3 Volatile Organic Compound Analyses}

Methods $8010 / 8020,8240,8260$ (SW-846) or Method 524.2 (EPA-600/R-95-131) were used to analyze volatile organic compounds by gas chromatography. Volatile organic compounds were extracted 
from the water sample using a purge-and-trap system (e.g., Method 5030 [SW-846]). Purged sample components were trapped in a tube containing suitable sorbent materials. When purging was complete, the sorbent tube was heated and backflushed with helium to desorb trapped sample components onto a gas chromatography column. The column separated the analytes, which were then detected with either a photoionization detector or a halogen-specific detector placed in series for Methods 8010/8020. For Methods 524.2, 8240, and 8260, the compounds were identified and quantified using a mass spectrometer.

Nonhalogenated volatile organic compounds were determined by Method 8015 (SW-846). Samples were introduced into the gas chromatograph using the purge-and-trap system (Method 5030 [SW-846]). Detection was achieved by a flame ionization detector.

Field-screening methods for volatile organic compounds by gas chromatography were based on Method 8010 (SW-846).

\section{C.4 Semivolatile Organic Compound Analyses}

Method 8270 (SW-846) was used to analyze semivolatile organic compounds after extraction into methylene chloride, using a fused-silica capillary column. Polynuclear aromatic hydrocarbons, chlorinated hydrocarbons and pesticides, phthalate esters, organophosphate esters, nitrosamines, haloethers, aldehydes, ethers, ketones, anilines, pyridines, quinolines, aromatic nitro compounds, and phenols (including nitrophenols) could be analyzed using this method.

Method 8040 (SW-846), which specified gas chromatographic conditions, was used to determine phenolic compounds. A sample was extracted, using methylene chloride, and then injected into the gas chromatograph, using the solvent-flush technique. The compounds in the gas chromatograph effluent were detected by a flame ionization detector. This method also provided for the preparation of pentafluorobenzyl-bromide derivatives, with additional cleanup procedures for electron-capture gas chromatography.

Method 8080 (SW-846) was used to determine polychlorinated biphenyl compounds and organochloride pesticides. This method specified gas chromatographic conditions for detection. Prior to analysis, appropriate sample-extraction techniques were used. Both neat and diluted organic liquids may be analyzed by direct injection. A 2- to 5-mL sample was injected into a gas chromatograph, using the solvent-flush technique, and separated compounds were detected by an electron-capture detector or an electrolytic conductivity detector.

\section{C.5 Metals Analyses}

\section{C.5.1 Atomic Absorption}

The following SW-846 methods were used to analyze samples for arsenic (7060), cadmium (7131), chromium (7191), lead (7421), selenium (7740), and thallium (7841) after acid digestion. Method 236.2 
(EPA-600/4-79-020) was used for iron analysis. Samples were introduced into the pyrolitic graphite chamber and atomized. Background-subtraction techniques were used to correct for absorbance or scatter of light.

Method 218.2 (EPA-600/4-79-020) was used to analyze chromium by flame atomic absorption analysis after digestion. The sample was atomized by direct aspiration into the flame.

Method 7470 (SW-846), a cold-vapor atomic absorption technique, is based on the absorption of radiation at $253.7-\mathrm{nm}$ by mercury vapor. The mercury was reduced to the elemental state and aerated from solution in a closed system. The mercury vapor passed through a cell positioned in the light path of an atomic absorption spectrophotometer. Absorbance (peak height) was measured as a function of mercury concentration.

\section{C.5.2 Inductively Coupled Plasma}

Before analysis by Methods 3010 or 3015 (SW-846), samples were acid digested and then injected into a plasma following Method 6010 (SW-846) or Methods 200.7 or 200.8 (EPA-600/R-94-111). Metal concentrations were determined by inductively coupled atomic emission spectrometry (Methods 6010 and 200.7) and by inductively coupled atomic emission spectrometry/mass spectrometry for Method 200.8.

\section{C.5.3 Hexavalent Chromium}

Method 7196 (SW-846) was used in the laboratory and in the field to determine hexavalent chromium by colorimetry. An excess of diphenylcarbazide yielded the red-violet product, and its absorbance was measured photometrically at $540 \mathrm{~nm}$.

\section{C.6 Radiological Parameters}

The methods described below were typical for most analyses, but each laboratory may have used a slightly different, or modified, process.

\section{C.6.1 Americium-241}

Americium and curium were concentrated in the sample by coprecipitation on ferric hydroxide. Thorium and plutonium were separated from the americium and curium as the sample passed through an anion-exchange resin column conditioned with dilute nitric acid. The iron was then separated from the americium and curium by coprecipitation on calcium oxalate. The americium and curium were then extracted into a bidentate organophosphorus solvent (DDCP; dibutyl N,N-diethylcarbamylphosphonate) from a nitric acid solution and then backextracted with weak nitric acid. Traces of iron, thorium, and any organic residue were removed by passing the solution through a cation-exchange resin column. The americium and curium were eluted from the cation-exchange resin column with dilute hydrochloric acid, electrodeposited or precipitated on a counting disk, and counted by alpha spectrometry. 


\section{C.6.2 Carbon-14}

The carbon in a sample was converted to carbon dioxide through oxidizing and distillation. The carbon dioxide was converted to salts of carbonic acid. The carbonates were then precipitated as barium carbonate and counted by liquid scintillation.

\section{C.6.3 Gamma Spectrometry}

Gamma scans provided a quantitative assay for a large number of gamma-emitting isotopes with a range of half-lives. Because these assays were performed by high-resolution counting techniques, it was possible to identify isotopes of interest with a high degree of confidence. In addition, a software library search was conducted to identify unknowns. The routinely reported isotopes included cobalt-60, ruthenium-106, antimony-125, and cesium-137; numerous other isotopes were reported when detected. Laboratory-specific methods were used.

Samples were counted directly, using an intrinsic (hyperpure) germanium or lithium-drifted germanium detector. Isotopes with gamma-ray energies from 60 to $2,000 \mathrm{KeV}$ were detected. Activity concentrations were determined using a laboratory computer system-supplied isotope library.

\section{C.6.4 Gross Alpha and Gross Beta}

Methods 9310 (SW-846) or 900.0 (EPA-600/4-80-032) were used to determine gross alpha and gross beta. An aliquot of water was evaporated onto a stainless steel counting planchet. The residue was dried to constant weight and counted for alpha and beta radioactivity. Activity was determined using a standardized counting efficiency versus sample solids curve for the detector system. Efficiencies were determined using strontium/yttrium-90 and americium-241 certified standards.

\section{C.6.5 Iodine-129}

Iodine-129 analyses presented a particular challenge because of the need for especially sensitive measurements. The iodine-129 interim drinking water standard is $1 \mathrm{pCi} / \mathrm{L}$ - the lowest for any radionuclide (40 CFR 141). The contractual detection limit is $1 \mathrm{pCi} / \mathrm{L}$ for the most-sensitive method used by the primary radiological laboratory.

Iodine isotopes were first separated from interfering radioactive isotopes by oxidation to iodine $\left(\mathrm{I}_{2}\right)$ with sodium nitrite and then extracted into carbon tetrachloride from dilute acid media. The iodine was next reduced to iodide with sodium bisulfite. The iodide was then backextracted into water, precipitated as silver iodide, and counted on a low-energy photon detector. Chemical yield was determined gravimetrically.

\section{C.6.6 Low-Level Tritium}

The sample was distilled in the presence of potassium permanganate to eliminate solids and organic material that may cause quenching. The sample was then enriched in a basic medium by electrolysis to a small volume. The enriched volume was transferred to a liquid-scintillation vial with scintillation 
cocktail and allowed to sit for $24 \mathrm{~h}$ while the chemiluminescence decays and temperature equilibrium is reached. The sample was then counted by liquid-scintillation instrumentation.

\section{C.6.7 Neptunium-237}

First, neptunium was coprecipitated on lanthanum fluoride. The neptunium was then extracted in 2-thenoyltrifluoroacetone (TTA) in xylene, electrodeposited, and counted through alpha energy analysis.

\section{C.6.8 Nickel-63}

A nickel carrier was added to the sample. Separation of iron from the sample was performed using extraction chromatography or ion exchange. The sample was finally purified through extraction chromatography and counted by liquid scintillation.

\section{C.6.9 Plutonium Isotopes}

The sample was acidified with nitric acid, the plutonium oxidation state was adjusted to +4 with sodium nitrite, and the solution was loaded onto an anion-exchange resin column. The plutonium was eluted with hydrochloric acid and ammonium iodide. The sample was electrodeposited or coprecipitated on a counting disk, and the activity counted by alpha spectrometry.

\section{C.6.10 Radiostrontium}

Samples for radiostrontium analysis were precipitated first as a nitrate and then as a carbonate. Calcium, barium, lead, and radium were removed by coprecipitation on barium chromate. Iron and other fission products were removed through hydroxide scavenging. The gravimetric yield of carrier (or strontium- 85 tracer yield) was determined along with the total radiostrontium activity by beta counting, following final carbonate precipitation. For strontium- 90 and/or strontium-89 determination, yttrium-90 was separated from the strontium by hydroxide and oxalate precipitations. The yttrium oxalate was converted to yttrium oxide, weighed for chemical recovery, and counted by beta-proportional counting for activity.

\section{C.6.11 Technetium-99}

The technetium-99 samples were wet ashed with nitric acid and hydrogen peroxide to destroy organic material in the sample. Actinides, lanthinides, alkaline earths, transition metals, and lead were removed through precipitation as hydroxides and carbonates. Technetium, as the pertechnetate ion, was adsorbed from a weak nitric acid solution on a strongly basic anion-exchange resin column. The technetium was then eluted with a stronger nitric acid solution and determined by liquid-scintillation beta counting.

\section{C.6.12 Total Alpha - Radium}

Method 9315 (SW-846) was used to determine the total radium alpha activity. Radium was coprecipitated in water samples with mixed barium and lead sulfates. The carriers were added to an alkaline solution containing citrate, which prevented precipitation during carrier exchange with radium isotopes in 
the sample. Ammonium sulfate was then used to precipitate the sulfates, which were purified by nitric acid washes. The precipitate was dissolved in an alkaline solution containing EDTA (disodium ethylenedinitriloacetate dihydrate), and the barium and radium sulfates were precipitated by addition of acetic acid, thus separating radium from lead and other radionuclides. The precipitate was dried on a plate, weighed to determine chemical yield, and alpha counted to determine the activity concentration of the radium isotopes.

\section{C.6.13 Total Uranium}

Total uranium analyses were generally performed by laser kinetic phosphorimetry but could also have been performed by alpha-counting determinations of individual isotopes for activity.

In the laser kinetic phosphorimetry method, the water samples were pretreated for organic and halidequenching interferents (if necessary) and the particulates filtered out. The uranium is complexed with a substance such as phosphoric acid for it to phosphoresce. The concentration was calculated based on the phosphorescence of the sample in a laser phosphorimeter.

In the field, laser kinetic phosphorimetry, using instrument manufacturer's and company-specific methods, was used for total uranium determination.

\section{C.6.14 Tritium}

Laboratory-specific methods or Method 906.0 (EPA-600/4-80-032) were used. Sodium hydroxide was added to the tritium sample. The alkaline sample was then distilled, and a fraction $(5 \mathrm{~mL})$ mixed with scintillation cocktail, allowed to sit while the chemiluminescence decayed, and then counted by liquid-scintillation instrumentation.

\section{C.6.15 Uranium Isotopes}

Uranium was separated from lead, radium, and thorium on a hydrochloric acid anion-exchange resin column; iron was removed by passing the sample through a nitric acid anion-exchange resin column. The uranium fraction was eluted and electrodeposited on a disk for alpha spectrometry counting.

\section{C.7 References}

American Public Health Association (APHA). 1985. Standard Methods for the Examination of Water and Wastewater, 16th Edition. New York.

American Society for Testing and Materials. 1986. Annual Book of ASTM Standards. Philadelphia, Pennsylvania.

40 CFR 141, Code of Federal Regulations, Title 40, Part 141. National Primary Drinking Water Regulations. 
EPA-600/4-79-020. 1979. Methods for Chemical Analysis of Water and Wastes. U.S. Environmental Protection Agency, Washington, D.C.

EPA-600/4-80-032. 1980. Prescribed Procedures for Measurement of Radioactivity in Drinking Water. U.S. Environmental Protection Agency, Cincinnati, Ohio.

EPA-600/4-86-024. 1986. Development of Standard Methods for the Collection and Analysis of Precipitation. U.S. Environmental Protection Agency, Washington, D.C.

EPA-600/R-93-100. 1998. Methods for the Determination of Inorganic Substances in Environmental Samples. U.S. Environmental Protection Agency, Washington, D.C.

EPA-600/R-94-111. 1994. Methods for the Determination of Metals in Environmental Samples, Supplement 1 to EPA-600/4-91-010. U.S. Environmental Protection Agency, Washington, D.C.

EPA-600/R-95-131. August 1995. Methods for the Determination of Organic Compounds in Drinking Water, Supplement III. (EMSL) Supplement to EPA 600-4-88-039. U.S. Environmental Protection Agency, Washington, D.C.

State of Washington Department of Ecology (Ecology). 1992. Total Petroleum Hydrocarbons Analytical Methods. Prepared by J. Barreca, April 8, 1992, Olympia, Washington.

SW-846. 1986. Test Methods for Evaluating Solid Wastes: Physical/Chemical Methods, 3rd ed. Office of Solid Waste and Emergency Response, U.S. Environmental Protection Agency, Washington, D.C. 
Table C.1. Methodologies Used to Obtain Routine Data Results for Project Samples

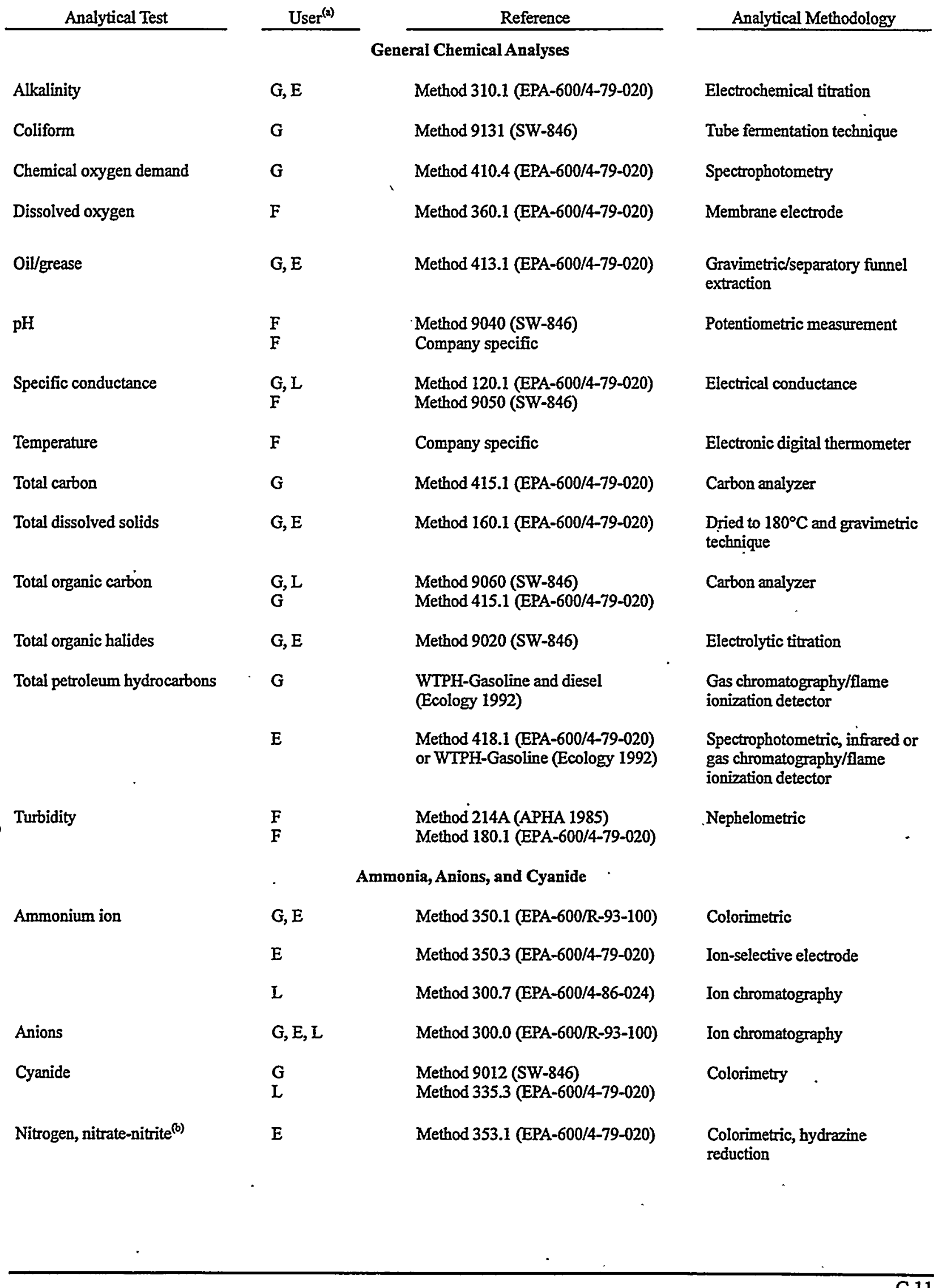


Table C.1. (contd)

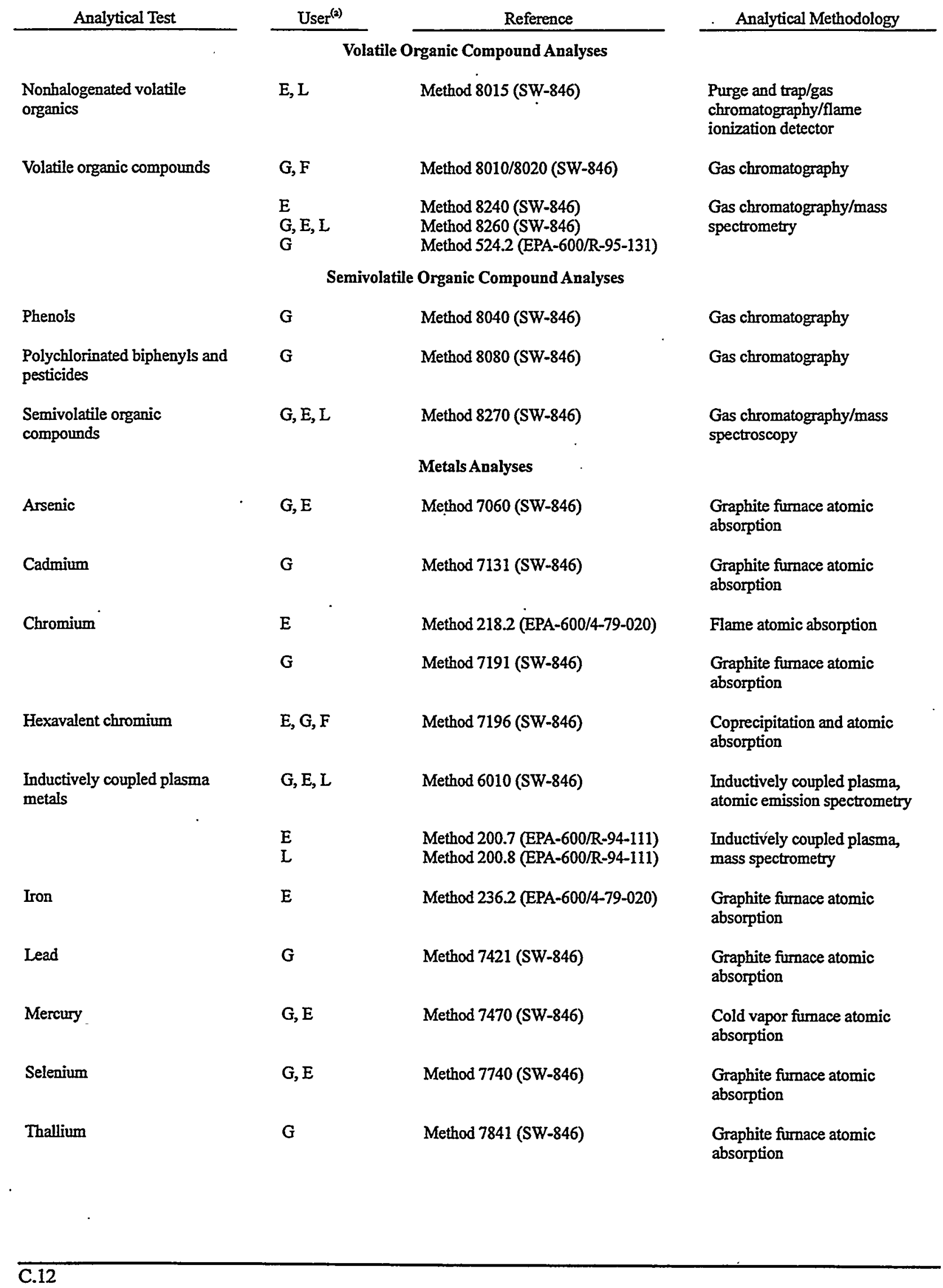


Table C.1. (contd)

\begin{tabular}{|c|c|c|c|}
\hline Analytical Test & User ${ }^{(2)}$ & Reference & Analytical Methodology \\
\hline & \multicolumn{2}{|r|}{ Radiological Analyses } & \\
\hline Americium-241 & G & Laboratory specific & $\begin{array}{l}\text { Anion- and cation-exchange } \\
\text { resin separation with alpha } \\
\text { energy analysis }\end{array}$ \\
\hline Carbon-14 & G, E & Laboratory specific & $\begin{array}{l}\text { Separation and liquid } \\
\text { scintillation counting }\end{array}$ \\
\hline Gamma spectrometry & G & Laboratory specific & Intrinsic germanium counting \\
\hline Gross alpha and gross beta & $\begin{array}{l}G, L \\
E\end{array}$ & $\begin{array}{l}\text { Method } 9310 \text { (SW-846) } \\
\text { Method } 900.0 \text { (EPA-600/4-80-032) }\end{array}$ & Gas-flow proportional counting \\
\hline Iodine-129 & G & Laboratory specific" & $\begin{array}{l}\text { Chemical separation, } \\
\text { coprecipitated, and counted on } \\
\text { low-energy photon detector }\end{array}$ \\
\hline Isotopic plutonium & G & Laboratory specific & $\begin{array}{l}\text { Anion-exchange resin } \\
\text { separation with alpha energy } \\
\text { analysis }\end{array}$ \\
\hline Isotopic uranium & $G$ & Laboratory specific & $\begin{array}{l}\text { Anion-exchange resin } \\
\text { separation with alpha energy } \\
\text { analysis }\end{array}$ \\
\hline Low-level tritium & $\mathrm{G}, \mathrm{E}, \mathrm{L}$ & Laboratory specific & $\begin{array}{l}\text { Electrolysis to enriched volume } \\
\text { and liquid scintillation counting }\end{array}$ \\
\hline Neptunium-237 & G & Laboratory specific. & $\begin{array}{l}\text { Liquid-liquid separation and } \\
\text { alpha energy analysis }\end{array}$ \\
\hline Nickel-63 & $\mathbf{E}$ & Laboratory specific & $\begin{array}{l}\text { Separation and liquid } \\
\text { scintillation counting }\end{array}$ \\
\hline Strontium-90 & $\mathrm{G}, \mathrm{E}$ & Laboratory specific & $\begin{array}{l}\text { Nitrate and carbonate } \\
\text { coprecipitation, gravimetric } \\
\text { yield, and beta gas-flow- } \\
\text { proportional counting }\end{array}$ \\
\hline Technetium-99 & $\mathrm{G}, \mathrm{E}$ & Laboratory specific & $\begin{array}{l}\text { Anion-exchange resin column } \\
\text { separation with liquid } \\
\text { scintillation counting }\end{array}$ \\
\hline Total alpha radium & G, E, L & 9315 (SW-846) & $\begin{array}{l}\text { Coprecipitation and alpha } \\
\text { counting }\end{array}$ \\
\hline \multirow[t]{2}{*}{ Total uranium } & $\mathrm{G}, \mathrm{E}$ & Laboratory specific & $\begin{array}{l}\text { Laser kinetic phosphorimetry or } \\
\text { fluorophotometry }\end{array}$ \\
\hline & $F$ & Company specific & Laser kinetic phosphorimetry \\
\hline Tritium & $\begin{array}{l}\mathrm{G}, \mathrm{E} \\
\mathrm{G}, \mathrm{E}\end{array}$ & $\begin{array}{l}\text { Laboratory specific } \\
\text { Method } 906.0 \text { (EPA-600/4-80-032) }\end{array}$ & $\begin{array}{l}\text { Distillation and liquid } \\
\text { scintillation counting }\end{array}$ \\
\hline \multicolumn{4}{|c|}{$\begin{array}{l}\text { (a) } E \text { = Environmental Restoration Contractor, Bechtel Hanford, Inc. } \\
F=\text { Field (all contractors). } \\
G=\text { Groundwater Monitoring Project, Pacific Northwest National Laboratory. } \\
\mathrm{L}=\text { Liquid Waste-Processing Facilities, Waste Management Federal Services of Hanford, Inc. } \\
\text { (b) Also analyzed by anion methods. } \\
\text { WTPH = Washington total petroleum hydrocarbons. }\end{array}$} \\
\hline
\end{tabular}




\section{Appendix D}

Quality Assurance and Quality Control 



\section{Contents}

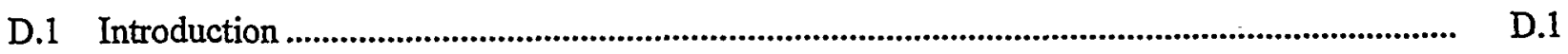

D.2 Sample Collection and Analysis....................................................................................... D.1

D.2.1 Sample Collection ................................................................................................ D.1

D.2.1.1 Field Measurements of Specific Conductance ............................................ D. D

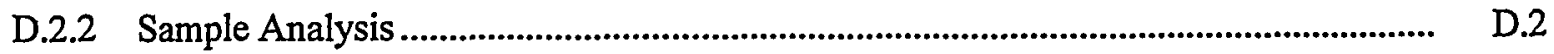

D.3 Field Quality Control Samples ............................................................................................. D.2

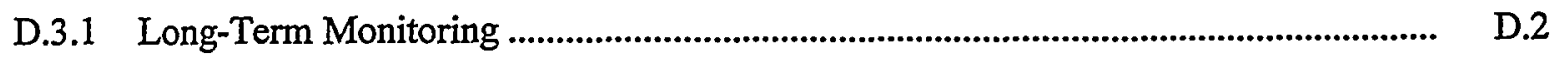

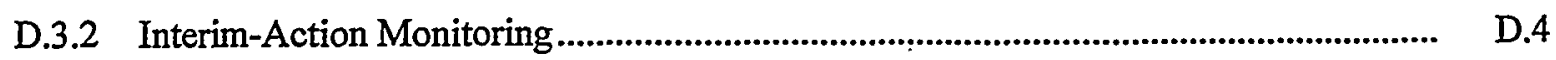

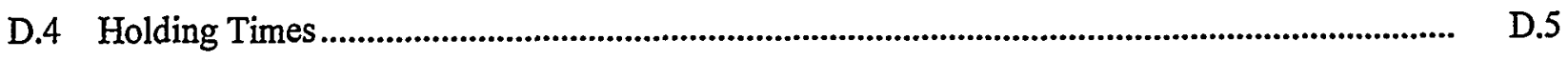

D.5 Laboratory Performance ...................................................................................................... D.6

D.5.1 EPA and DOE Performance-Evaluation Studies.................................................... D.7

D.5.1.1 EPA Water Pollution and Water Supply Studies for Quanterra................... D.7

D.5.1.2 EPA and DOE Quality Assessment and Performance-Evaluation
Results for Quanterra .................................................................................... D. D

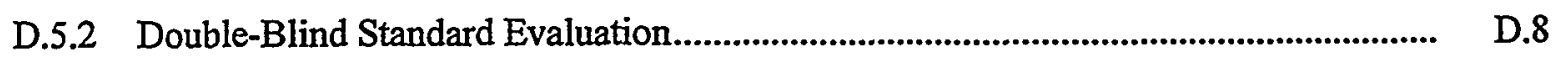

D.5.3 Laboratory Internal QC Programs ........................................................................ D.9

D.5.3.1 Issue Resolution ........................................................................................... D. 11

D.5.3.2 Laboratory Audits/Assessments ................................................................. D.11

D.5.4 Data Completeness and Comparability ................................................................ D.12

D.6 Limit of Detection, Limit of Quantitation, and Method Detection Limit................................ D.13

D.7 Glossary of QA/QC Terms ................................................................................................... D.15

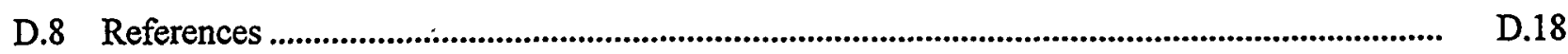

\section{Tables}

D.1 Full Trip Blanks Exceeding Quality Control Limits ............................................................ D.21

D.2 Field Trip Blanks Exceeding Quality Control Limits......................................................... D.22 
D.3 Equipment Blanks Exceeding Quality Control Limits ......................................................... D.23

D.4 Field Duplicates Exceeding Quality Control Limits .............................................................. D.24

D.5 Hanford Groundwater Monitoring Project Holding Times ..................................................... D... D

D.6 Results of U.S. Environmental Protection Agency Water Pollution and Water Supply Performance Evaluation Studies............................................................................................. D.26

D.7 Summary of Quanterra Environmental Services Interlaboratory Performance ......................... D. D.26

D.8 Summary of Quanterra Environmental Services Quarterly Double-Blind Spike Determinations

D.9 Quanterra Environmental Services Blind Standard Results

D.10 Method Blank Results .

D.11 Laboratory Control Samples.

D.12 Matrix Spikes and Matrix Spike Duplicates.

D.13 Matrix Duplicates

D.14 Surrogates

D.15 Split Sample Results Exceeding Quality Control Limits

D.16 Summary of Quanterra Environmental Services Detection/Quantitation Limits Determined from Field Blank Data .

D.17 Summary of Quanterra Environmental Services Detection/Quantitation Limits Determined from Method Detection Limit Studies

\section{Figures}

D.1 Method Blank Frequency of Detection

D.2 Levels of Detection and Quantitation 


\section{Appendix D}

\section{Quality Assurance and Quality Control}

\section{D.1 Introduction H. Hampt, C. J. Thompson}

The groundwater chemistry quality assurance/quality control (QA/QC) information for fiscal year (FY) 1998 for long-term and interim-action groundwater monitoring is presented in this appendix. The long-term monitoring is conducted by the Hanford Groundwater Monitoring Project and includes monitoring for Resource Conservation and Recovery Act of 1976 (RCRA), Atomic Energy Act of 1954, and Comprehensive Environmental Response, Compensation, and Liability Act of 1980 (CERCLA) sites with no groundwater remediation. The Hanford Groundwater Monitoring Project is managed by Pacific Northwest National Laboratory. Interim-action groundwater monitoring is managed by Bechtel Hanford, - Inc. and encompasses monitoring for sites with active groundwater remediation under CERCLA.

The QAVQC practices used by the Hanford Groundwater Monitoring Project assess and enhance the reliability and validity of field and laboratory measurements conducted to support these programs. The primary parameters used to assess data quality are accuracy, precision, and detection (Mitchell et al. 1985). Representativeness, completeness, and comparability may also be used. These parameters are evaluated through laboratory QC checks (e.g., matrix spikes, laboratory blanks), replicate sampling and analysis, analysis of blind standards and blanks, and interlaboratory comparisons. Acceptance criteria have been established for each of these parameters. When a parameter is outside the criteria, corrective actions are taken to prevent a future occurrence.

The QC practices for RCRA samples are based on guidance from the U.S. Environmental Protection Agency (EPA) (OSWER-9950.1, SW-846). U.S. Department of Energy (DOE) orders and internal requirements provide the guidance for the collection and analysis of samples for long-term monitoring. The QC practices for the Hanford Groundwater Monitoring Project are described in the project-specific QA plan. Guidance for the interim-action monitoring QC practices is provided in project-specific documents (e.g., DOE/RL-88-36; DOE/RL-90-08; DOE/RL-90-21; DOE/RL-91-46; DOE/RL-91-53;

Section 1.5 in DOE/RL-92-03; DOE/RL-96-07; DOE/RL-96-90, Draft A).

A. glossary of QA/QC terms is provided in Section D.7.

\section{D.2 Sample Collection and Analysis H. Hampt, M. J. Hartman, C. J. Thompson}

\section{D.2.1 Sample Collection}

Groundwater sampling for FY 1998 was conducted by Waste Management Federal Services, Inc., Northwest Operations. Their tasks included bottle preparation, sample set coordination, field 
measurements, sample collection, sample shipping, well pumping, and coordination of purgewater containment and disposal. Quality requirements for sampling activities are defined in their statement of work, and approved sampling procedures are followed.

\section{D.2.1.1 Field Measurements of Specific Conductance}

During FY 1998, several new meters and probes that had been in dry storage for approximately 2 years were put into use. In July 1998, it became evident that data collected with these meters/probes were erratic and generally biased low. After the problem was identified, the meters/probes were taken out of use. The meters are uniquely numbered, and their numbers are recorded on sampling records. The meter number is traceable to suspect results, which were then flagged in the database. Flagged data were not used in statistical comparisons for RCRA (see discussion in Appendix B).

Several improvements are being made to avoid this type of problem in the future. The faulty probes are being replaced. Field comparisons will be performed to ensure consistent results. Probes (conductance, as well as other instruments) will be uniquely numbered and tracked on the field records. Requirements for weekly cleanings shall be written into the specific conductance measurement procedure. Improvements to the calibration procedure are also being made. Finally, laboratory measurements of specific conductance will be made on a percentage of wells to compare to field measurements.

\section{D.2.2 Sample Analysis}

Routine analyses of hazardous and nonhazardous chemicals for the Hanford Groundwater Monitoring Project were performed by Quanterra Enivironmental Services, St. Louis, Missouri (Quanterra, St. Louis). Chemical analyses for interim-action monitoring were performed by Quanterra (St. Louis) and Recra Environmental, Inc., Lionville, Pennsylvania.

Most routine radiochemical analyses for long-term and interim-action groundwater monitoring were performed by Quanterra, Richland, Washington (Quanterra, Richland). Thermo NUtech, Richmond, California, also performed routine radiochemical analyses for interim-action groundwater monitoring.

\section{D.3 Field Quality Control Samples}

\section{H. Hampt, C. J. Thompson, R. L. Weiss}

\section{D.3.1 Long-Term Monitoring (Hanford Groundwater Monitoring Project)}

Field quality control samples include field duplicates and three types of field blanks. Field duplicates are used to assess sampling and measurement precision, while field blanks provide an overall measure of contamination introduced during the sampling and analysis process. 
The analytical results of field QC samples are considered acceptable if the following evaluation criteria are met:

- field duplicates - Results of field duplicates must have precision within $20 \%$, as measured by the relative percent difference. Only results that were above five times the method detection limit or minimum detectable activity were evaluated.

- blanks - Three kinds of blanks are used to check for contamination that may result from field activities and/or bottle preparation: full trip, field trip, and equipment blanks. For most chemical constituents, results above two times the method detection limit are identified as suspected contamination. However, for common laboratory contaminants such as acetone, methylene chloride, 2-butanone, toluene, and phthalate esters, the limit is set at five times the method detection limit. For radiochemistry data, blank results are flagged if they are greater than two times the total propagated analytical uncertainty.

If a field blank does not meet the established criteria, it is assumed that there are potential problems with the data for all associated samples (i.e., samples collected or analyzed on the same day as the field blank). Those data are flagged with a $\mathrm{Q}$ in the database, indicating the samples were associated with a field blank sample that was out of limits. $A$ Q is also applied to both duplicate results when their precision exceeds the QC limits.

The percentages of acceptable field blank (93\%) and duplicate (95\%) results evaluated in FY 1998 were very high, indicating little problem with contamination and good precision overall. In most cases, the out-of-limit field blank results were below the maximum contaminant levels. Therefore, the results from field blanks that exceeded the QC limits did not have a significant impact on the usefulness of the data. Little difference in the overall percentage of flagged results was observed between the different types of field blanks (e.g., full trip, equipment). Because equipment blanks are only collected at wells in which nondedicated sampling equipment is used, this suggests that the source of contamination at these wells is not the use of nondedicated equipment. However, it should be noted that the equipment blanks had higher detection frequencies that full trip blanks for alkalinity, total organic halides, nitrate, sulfate, tritium, and zinc.

Tables D.1 through D.4 summarize field blank and field duplicate results that exceeded QC limits. To assist with their evaluation, the tables are divided into the following categories, where applicable: general chemical parameters, ammonia and anions, volatile organic compounds, semivolatile organic compounds, metals, and radiological parameters. Constituents not listed in the tables had $100 \%$ acceptable field blanks and/or field duplicates.

All six classes of constituents had blank results that were flagged as potentially contaminated. In most cases, the flagged blank results were less than five times the method detection limit, or below quantifiable limits for all types of blanks. Three full trip blanks had unusually high alkalinity results $(54,800,152,000$, and $217,000 \mu \mathrm{g} / \mathrm{L})$ believed to be the result of switched samples at the laboratory. An inadvertent sample swap may also explain the $672,000-\mu \mathrm{g} / \mathrm{L}$ total dissolved solids result associated with one of the equipment blanks. The majority of the flagged blank results for volatile organics were over five times greater than the method detection limit, resulting in quantifiable contamination of acetone, carbon tetrachloride, chloroform, methylene chloride, 1,2-dichlorethane, trichlorethene, and xylenes. The 
frequency of detection of these contaminants was generally. $<25 \%$, but the relatively high concentrations warrant an investigation of their sources during the next fiscal year. Several total organic carbon blanks also had results above the method detection limit. These will be investigated during the next fiscal year.

The number of flagged inductively coupled-plasma metal field blank results decreased in FY 1998. Because of the high numbers of flagged results in FY 1997, the laboratory added an additional blank (i.e., a rinse blank) to the inductively coupled-plasma metal procedure. The purpose of the rinse blank was to prevent possible carryover of a high-level standard that is routinely analyzed before the method blank. It is unclear whether the additional blank is the cause of the reduction in inductively coupled-plasma metal blank flags. Another explanation is that the laboratory's instrument detection limits were slightly higher in FY 1998 than in FY 1997, resulting in fewer false-positive results. This latter explanation is consistent with the similar concentrations and frequencies of detection observed between the field and method blanks (see Tables D.1 and D.3 and the discussion in Section D.4.3).

Duplicate results were flagged for total dissolved solids, four anions, five volatile organics, six metals, and three radiological parameters. Overall, the total number of flagged duplicate results was very low, but the percentages of unacceptable results were high (i.e., $>40 \%$ ) for ammonia, 1,1,1-trichloroethane, 1,1-dichloroethane, carbon tetrachloride, chloroform, and tetrachloroethene. Most of the out-of-limit duplicate results appear to be anomalous instances of poor precision based on other QC indicators such as the results from the blind standards and laboratory duplicates (discussed in Sections D.4.2 and D.4.3). In a few cases, the laboratory was asked to reanalyze or investigate duplicate results with a very high relative percent difference, but the checks did not reveal the source of the problem. Especially poor agreement was observed between one pair of results for the following: nitrate (185 and $768 \mu \mathrm{g} / \mathrm{L})$, carbon tetrachloride (430 and $880 \mu \mathrm{g} / \mathrm{L})$, iron $(2,560$ and $1,430 \mu \mathrm{g} / \mathrm{L})$, manganese $(22.8$ and $4.3 \mu \mathrm{g} / \mathrm{L})$, gross beta (537 and $312 \mathrm{pCi} / \mathrm{L}$ ), and technetium-99 (2,890 and $513 \mathrm{pCi} / \mathrm{L})$. Mislabeled samples or procedural errors at the laboratory may have caused the unmatched results.

\section{D.3.2 Interim-Action Monitoring}

Samples were collected by trained staff in accordance with approved procedures. Field QC samples were collected and evaluated according to site-specific requirements (e.g., BHI-00038, Rev. 2; DOE/RI90-08; DOE/RL-91-03; DOE/RL-91-46; DOE/RL-92-76; DOE/RL-96-07; DOE/RL-96-90, Draft A; DOE/RL-97-36, Rev. 2). In general, field QC samples consisted of field duplicates, splits, equipment blanks, and trip blanks. Field QC data are evaluated as necessary to make decisions that may modify or terminate a remedial action. In FY 1998, no evaluations were necessary for decision-making purposes.

Field QC data were examined to monitor laboratory operations and to identify potential problem areas where improvements were necessary. Evaluation criteria were essentially the same as those used for the Hanford Groundwater Monitoring Project, with the following exceptions.

- The $20 \%$ relative percent difference criterion for field duplicate and split sample results was relaxed for sample analytical results near (i.e., typically within five times) the method detection limits. 
- Bechtel Hanford, Inc. sent no blind standards as part of interim-action monitoring to the commercial laboratories in FY 1998. The great similarity of matrices between the long-term and interim-action monitoring samples and common use of the same laboratories make additional analysis of blind standards redundant.

For field blank samples, approximately $84 \%$ of all results were returned as nondetected. Greater than $80 \%$ of the reported detected blank results were common metals (e.g., calcium, iron, manganese, sodium) measured by the inductively coupled-plasma method at levels close to analysis procedure detection limits. All detected organic constituents ( $14 \%$ of all reported detections) were common laboratory contaminants seen at very. low levels ( 1 to $13 \mu \mathrm{g} / \mathrm{L}$ ). Minimal radioactive contamination was reported, but all were very near analysis detection limits. The number reported is consistent with statistical possibilities for falsepositive results in radiochemistry analysis. Evaluation of field blank samples shows no evidence of unexpected or excessive contamination of blanks in the field or by the laboratory. The constituents and levels of contamination found should have no impacts on decision making for interim-action monitoring.

Field duplicate and split results show $\sim 6.5 \%(30)$ exceeding the criteria used for evaluation. It should be noted that the criteria used are likely more restrictive than necessary because they are based on similar criteria for laboratory replicate evaluation (i.e., analysis of multiple aliquots from the same sample container by the same laboratory in the same analytical batch). Over one-third of the high relative percent differencè results were between field analyses and fixed laboratories. Greater differences would be more typical between field and fixed laboratory analyses. The differences between the laboratories appear to be essentially random (i.e., the high or low laboratories often switch places for the same analysis on different samples), with the following exceptions.

- There are six pairs of duplicate/split results where it appears likely that one of the samples was switched (i.e., sample B0XXX analyzed by the laboratory as B0YYY and BOYYY analyzed as B0XXX) with an unmatched sample within the analytical batch. It is also possible that the samples were either switched in the field or misidentified in the sample database.

- The only radionuclide analysis showing a potential problem was for technetium-99. Two out of four analyses exceeded the $20 \%$ relative percent difference (maximum $26.1 \%$ ). However, all four split pairs show results reported by Quanterra (Richland) to be less that those reported by the split laboratory. This analysis should be further investigated with additional samples measured at both laboratories.

Overall evaluation indicates no significant issues between procedures and analyses performed by the laboratories providing services to Bechtel Hanford, Inc.

\section{D.4 Holding Times H. Hampt}

Chemical constituent concentrations in groundwater samples are required to be determined within a specified time frame, or holding time, from the time of collection to the time of analysis or preparation. Samples must be analyzed within this time frame or the concentration of the constituents of concern may, 
in some instances, be compromised by volatilization, decomposition, or other chemical changes. Samples are also refrigerated to slow potential chemical reactions within the sample matrix. Holding times for constituents frequently analyzed for by the Hanford Groundwater Monitoring Project are listed in Table D.5. There is no designated holding time for radiochemical constituents because they do not change chemically or decompose under ambient temperatures. Results of radionuclide analysis are corrected for decay between sampling and analysis dates.

Of the 8,154 nonradiochemical samples analyzed in FY 1998 for the Hanford Groundwater Monitoring Project, holding times were exceeded for 346 samples (4\%). The percentage of holding time exceed ances is higher than in FY 1997 and earlier years. Throughout FY 1998, 13\% of holding times were missed for anions; however, that percentage peaked at $27 \%$ during the third quarter of FY 1998 . Also during the third quarter, high percentages of phenol; semivolatile organics, volatile organics, and pesticide/polychlorinated biphenyl holding times were exceeded. According to the analytical laboratory, a number of personnel changes took place during this period, which may have slowed down sample processing. Quanterra (St. Louis) was reminded that holding times must not be violated. During the fourth quarter of FY 1998, high percentages of total organic halide holding times were exceeded because of instrument failure at the laboratory. Quanterra (St. Louis) has acquired an additional instrument for total organic halide analysis, so high percentages of holding-time exceedances for this analysis should not occur in the future. Data for which holding times were exceeded were flagged with an $\mathrm{H}$. Although the impact of missed holding times is unclear in many cases, the affected data may still be used for general trending purposes.

Specific evaluation of adherence to analytical holding times for interim-action monitoring was not performed for this report. Analytical holding times are monitored as part of ongoing sample and data management activities throughout the year. Laboratory issues (primarily at those facilities providing chemical analyses) resulted in more holding time exceedances in FY 1998. These issues have been identified with the affected laboratories and will continue to be monitored closely in future years. No remediation decisions were affected by missed holding times in FY 1998.

\section{D.5 Laboratory Performance H. Hampt, D. S. Sklarew, D. L. Stewart, C. J. Thompson}

Laboratory performance is measured using several indicators, including the results from DOE and EPA performance-evaluation studies, double-blind standard analyses, laboratory audits, and data collected from internal laboratory QA/QC programs. Quanterra (St. Louis) and Recra Environmental participate in the EPA's Water Pollution and Water Supply Performance Evaluation Studies. Quanterra (Richland) and Thermo NUtech participate in DOE's Quality Assessment Program and Mixed Analyte Performance Evaluation Program and EPA's National Exposure Research Laboratory Performance Evaluation Studies. Performance indicators for the primary analytical laboratories (Quanterra St. Louis and Richland) are discussed in this section. Performance-evaluation and laboratory QC data for Recra Environmental and Thermo NUtech are not included in this appendix. 


\section{D.5.1 EPA and DOE Performance-Evaluation Studies}

\section{D.5.1.1 EPA Water Pollution and Water Supply Studies for Quanterra}

Every quarter the EPA distributes standard water samples as blind standards to participating laboratories. These samples contain specific organic and inorganic analytes at concentrations unknown to the participating laboratories. After analysis, results are submitted to the EPA. Regression equations are used to determine acceptance and warning limits. The results of these studies independently verify the level of laboratory performance and are expressed as a percentage of EPA-acceptable results. Results from these studies for Quanterra are summarized in Table D.6. For FY 1998, the percentage of EPAacceptable results ranged from $89 \%$ to $95 \%$, indicating excellent overall performance for the samples analyzed. Of the 19 constituents with unacceptable results, only 2 were out of limits more than once. Methylene chloride was above the acceptance limits in both water supply studies. This was attributed to low-level laboratory contamination. Orthophosphate results were unacceptable in two water pollution studies and one water supply study; however, in the first water pollution study, a corrected calculation brought the result within acceptable limits. Because orthophosphate also gave poor results for three water pollution/supply studies in FY 1997, it has been scrutinized more carefully by the laboratory. The EPA sample for the latest water supply study (WS041) was analyzed for orthophosphate by the ion chromatography method used for Hanford Site groundwater samples as well as by the certifiable drinking water method required by the EPA (i.e., Method 365.1, EPA-600/4-79-020). While the drinking water method gave an unacceptable result, the ion chromatography method gave a result in the acceptable range. Method 365.1 is not routinely used for analysis of Hanford Site groundwater samples.

\section{D.5.1.2 EPA and DOE Quality Assessment and Performance-Evaluation Results for Quanterra}

Quanterra participates in DOE's Quality Assessment Program at the Environmental Measurements Laboratory, New York; in DOE's Mixed Analyte Performance Evaluation Program at the Radiological and Environmental Sciences Laboratory, Idaho Falls, Idaho; and in EPA's Laboratory Performance Evaluation Studies at the National Exposure Research Laboratory, Las Vegas, Nevada.

These programs provide blind standards that contain specific amounts of one or more radionuclides. After sample analysis, the results are forwarded to DOE or EPA for comparison with known values and with results from other laboratories. Both DOE and EPA evaluate the accuracy of the results by determining if they fall within \pm 3 standard deviations of the mean of all results reported in the intercomparison study (EML-594, EML-596, EPA-600/4-81-004). DOE also evaluates the accuracy of Mixed Analyte Performance Evaluation Program results for radiological and inorganic samples by determining if they fall within a $30 \%$ bias of the reference value. Summaries of FY 1998 results for water samples for the various radiological programs are provided in Table D.7.

All of the results from DOE's quality assessment and EPA's performance-evaluation analyses conducted during FY 1998 were within the \pm 3 standard deviations of the mean. The December 1997 DOE mixed analyte program water sample had one result for strontium-90 that was not acceptable. It was determined that the cause was a reporting error, not an analytical error. After correction, the result met the acceptance criteria. Thus, Quanterra's performance on the samples that were analyzed for DOE and EPA was acceptable. 


\section{D.5.2 Double-Blind Standard Evaluation}

The Hanford Groundwater Monitoring Project forwarded blind QC standards to Quanterra (Richland and St. Louis) during FY 1998. Blind spiked standards were usually prepared in triplicate and submitted to check the accuracy and precision of analyses. The number and types of blind standards along with the control limits used in FY 1998 are listed in Table D.8. Overall, 80\% of the blind spike determinations were within control limits, which represents a slight improvement over FY 1997 (i.e., 75\% were within limits in FY 1997). In general, total organic carbon and total organic halide samples were spiked at higher concentrations in FY 1998 than in FY 1997, which may account for some of the improvement in FY 1998. A detailed listing of the blind standard results is shown in Table D.9. One or more laboratory results were biased high for total organic carbon, total organic halides, fluoride, chloroform, gross beta, and plutonium-239. Similarly, one or more results were biased low for total organic halides, cyanide, carbon tetrachloride, trichloroethene, gross alpha, and gross beta. The most significant problems were associated with total organic carbon, total organic halides, and gross beta. The results are discussed in more detail below.

Seven of the 15 total organic carbon results were biased high, with individual out-of-limit recoveries ranging from $152 \%$ to $244 \%$. All seven of the notable results were submitted for analysis during the second and third quarters of FY 1998. The laboratory performed data rechecks on the results and reanalyses on the samples but was unable to identify a reason for the discrepancies. The Hanford Groundwater Monitoring Project is currently investigating this problem by sending split double-blind standards to both Quanterra and Thermo Analytical and performing in-house verification analyses of the standards.

The total organic halide results from the second quarter of FY 1998 were high for both the trichlorophenol-spiked samples and the samples spiked with carbon tetrachloride, chloroform, and trichloroethene. Laboratory investigations failed to provide an explanation for the high bias observed for those samples, but all subsequent results have been within acceptance limits. It is suspected that the second quarter total organic halide standards were contaminated with methylene chloride at the laboratory. The other FY 1998 total organic halide standards that were spiked with 2,4,6-trichlorophenol had results that were within the QC limits. In the first quarter, the three samples spiked with the volatile organic mixture were biased low by $\sim 50 \%$. Although it is recognized that the results from samples spiked with a volatile organic mixture could be biased low (because of volatilization during the analysis), a $50 \%$ recovery is indicative of a significant problem with either the preparation of the samples or the laboratory analysis. Unfortunately, subsequent reanalyses of the first quarter samples were inconclusive as a result of the introduction of headspace in the sample bottles. Low-biased total organic halide results are of concern because of the potential for not detecting halogenated organics at RCRA sites. However, even with a $50 \%$ negative bias, detection should occur at concentrations well below the limit of quantitation (discussed in Section D.5). Beginning in the fourth quarter, the Hanford Groundwater Monitoring Project performed in-house verification analyses on the total organic halide standards prepared with the volatile organic mixture. During FY 1999, several of these samples will also be split and sent to an alternate laboratory.

Gross beta standards prepared with strontium-90 had 4 out of 13 results that were outside QC limits. The samples in question were submitted for analysis during the second and third quarters of FY 1998. Three of the results were biased high by up to $106 \%$, and one of the results was biased low by $33 \%$. The 
reasons for these discrepancies are still unknown. Reanalyses of the third quarter standards were consistent with the original results, suggesting either a systematic analytical problem or a problem with the concentration of the standards. As with the total organic carbon and total organic halide standards, gross beta blind standards will be split and sent to an alternate laboratory during FY 1999. Additional gross . beta standards, prepared at different spike concentrations and with different isotopes, may also be used in the future to help investigate recurring gross beta problems.

Cyanide results have consistently been biased low by $30 \%$ to $40 \%$, while fluoride results have been biased high by $\sim 20 \%$. The Hanford Groundwater Monitoring Project is investigating these problems by performing in-house analyses of standards with alternative methods (e.g., electrochemical and colorimetric methods). Beginning with the first quarter of FY 1999, in-house verification analyses will also be conducted on carbon tetrachloride, chloroform, and trichloroethene blind standards in an effort to reduce uncertainties in their concentration and improve the double-blind standard program.

\section{D.5.3 Laboratory Internal QC Programs}

Quanterra (Richland and St. Louis) maintains internal QA/QC programs and generates data on analytical performance by analyzing method blanks, laboratory control samples, matrix spikes and matrix spike duplicates, matrix duplicates, and surrogates. Depending on the laboratory (i.e., Richland or St. Louis), the results of these $\mathrm{QC}$ checks are reported to the Hanford Groundwater Monitoring Project on either a monthly basis (i.e., in the form of monthly QC reports) or more frequently by including the $\mathrm{QC}$ data in the standard data deliverables provided for regular groundwater sample results. An assessment of the laboratory QC data for FY 1998 is summarized in this section.

Results for method blanks were evaluated by the frequency of detection above the blank $\mathrm{QC}$ limits. In general, these limits are two times the method detection limit or instrument detection limit for chemical constituents and two times the total propagated error for radiological parameters. For common laboratory contaminants such as acetone, 2-butanone, methylene chloride, phthalate esters, and toluene, the.QC limit is five times the method detection limit. Table D.10 lists the frequency of detection as well as the concentration range of the individual constituents detected. Figure D.1 is a bar graph of the frequency of detection above the $\mathrm{QC}$ limits. The metals category had the greatest percentage of data points exceeding the QC limits, with $17.5 \%$ exceeding twice the instrument detection limit. For all other categories, QC limits were exceeded by $<5 \%$ of the samples. Thus, it is apparent that the method blank results were excellent for all general categories, except metals. For individual parameters, the QC limits were exceeded by $>5 \%$ of the following: specific conductance, chloride, cyanide, 1,4-dichlorobenzene, acetone, methylene chloride, styrene, 2,4-dinitrophenol, 4,6-dinitro-2-sec-butylphenol, 4,6-dinitro-2-methylphenol, the aroclors, tributyl phosphate, aluminum, calcium, iron, magnesium, sodium, vanadium, zinc, and total uranium. It should be noted that only two of five method blanks were analyzed for specific conductance, styrene, and tributyl phosphate. Acetone and methylene chloride show frequent blank problems because of low-level background contamination in the laboratories. The laboratory's instrument detection limits for the metals are believed to be unrealistically low for Method 6010 (the inductively coupled-plasma method [SW-846]), which resulted in the large number of method blanks that exceeded the limits for this method. If the $\mathrm{QC}$ limits were taken to be five times the instrument detection limit for Method 6010, then $7.4 \%$ of the metals exceeded the limit, and only aluminum (8.5\%), calcium (56\%), and iron (68\%) had $>5 \%$ detected. 
To assess the laboratory control samples, QC limits for general chemical parameters, ammonia, anions, and metals were between $80 \%$ and $120 \%$; those for radiological parameters were between $70 \%$ and $130 \%$. These limits were based on values provided by Quanterra for the first quarter of FY 1998. The percentages of results that were outside this range were $0 \%$ for the general chemical parameters, ammonia, and anions; $2.2 \%$ for the metals; and $1.8 \%$ for the radiological parameters. Only $4.3 \%$ of the general chemical parameters and $2.8 \%$ of the anions fell outside the $90 \%$ to $110 \%$ range. Silver was the only metal that had a significant number $(40 \%)$ of results outside the limits; however, silver recoveries are expected to be low as a result of precipitation during the sample-digestion process used for analysis of groundwater samples (Method 3010, SW-846).

For the organics, laboratory control sample QC limits were not available electronically for all compounds. In the absence of these limits, $70 \%$ to $130 \%$ were chosen in accordance with Method 8000 (SW-846), "In the absence of recommended acceptance criteria for the initial demonstration of proficiency, the laboratory should use recoveries of $70-130 \%$ as guidance in evaluating the results." Analyses outside $70 \%$ to $130 \%$ included $4.1 \%$ of the volatile organics and $25.7 \%$ of the semivolatile organics. The semivolatile organic problem occurred mainly with the phenols, but polycyclic aromatic hydrocarbons were also affected. Recoveries for the phenols are typically poor. In fact, laboratory QC limits ranged as low as $12 \%$ for certain phenols. Using the laboratory's QC limits when available, only $1.8 \%$ of the semivolatile organic data fell outside these QC limits. Table D.11 gives more details for the constituents that exceeded the laboratory control limits.

Matrix spike and matrix spike duplicate QC limits were the same as for the laboratory control samples noted above. Analyses outside this range included $6.4 \%$ of the general chemical parameters, $7.4 \%$ of the ammonia and anions, $6.8 \%$ of the volatile organics, $28.1 \%$ of the semivolatile organics, $2.1 \%$ of the metals, and 3.0\% of the radiological parameters (Table D.12). When the laboratory's QC limits were used for the volatile and semivolatile organics, the analyses outside the QC limits were $1.1 \%$ and 5.4\%, respectively. Individual constituents with $>10 \%$ of analyses outside the laboratory's $Q C$ limits included total carbon; total organic halides; nitrogen in nitrate; 1,1-dichloroethane; 1,1-dichloroethene; 1,4-dichlorobenzene; chloroform; tetrachloroethene; vinyl chloride; silver; and a number of semivolatile organics, especially the phenols and polycyclic aromatic hydrocarbons. As with the laboratory control samples, the poor recoveries of phenols and to a lesser extent the polycyclic aromatic hydrocarbons and some chlorinated compounds may indicate a difficulty in recovery of these types of analytes from groundwater samples.

Matrix duplicates were evaluated by comparing the relative percent difference to the QC limit for results that were greater than the method detection limit for general chemical parameters, ammonia, and anions and greater than five times the minimum detectable activity for radiological parameters. The QC limit was typically $20 \%$ for the general chemical parameters, ammonia, anions, and radiological parameters. In all three categories, $<2 \%$ of the constituents exceeded the QC limits, indicating excellent precision. Matrix duplicates were not analyzed for volatile and semivolatile organic compounds or metals. Table D.13 details the constituents that exceeded the relative percent difference limits.

Surrogate data included two compounds for volatile organics and four for semivolatile organics. Using the QC limits electronically available from Quanterra for the first quarter of FY 1998, 2.2\% of the volatile organics and $11.7 \%$ of the semivolatile organics exceeded the limits. Based on the default limits of $70 \%$ to $130 \%$ (see laboratory control samples above), however, $0.3 \%$ of the volatile organics and $49 \%$ 
of the semivolatile organics exceeded the limits. Again, as with the matrix spikes and laboratory control samples, the phenol surrogates showed low recoveries, suggesting that some of the target analyte results could be biased low. Table D.14 gives more detailed results.

\section{D.5.3.1 Issue Resolution}

Issue-resolution forms are documents for recording and resolving problems encountered with sample receipt, sample analysis, and data reporting. The forms are generated by the laboratory and forwarded to the Hanford Groundwater Monitoring Project as soon as possible after a potential problem is identified. The forms indicate if direction on the part of the project is required. The documentation is intended to identify occurrences, deficiencies, and/or issues that may potentially have an adverse effect on data integrity. These issues include, but are not limited to, the following:

- lost sample

- broken bottles

- instrument malfunctions

- calibration standards out of acceptable range

- laboratory control standards out of acceptable range

- matrix spike recovery out of acceptable range

- blank contamination

- procedural noncompliance

- chain-of-custody discrepancies

- shipping temperatures out of acceptable range

- misreported data.

\section{D.5.3.2 Laboratory Audits/Assessments}

Laboratory activities are regularly assessed by surveillance and auditing processes to ensure that quality problems are prevented and/or detected. Regular assessment supports continuous process improvement.

An assessment of Quanterra (St. Louis) was conducted from May 6 through 8, 1998 by the Hanford Site's Integrated Contractor Assessment Team, consisting of representatives from Bechtel Hanford, Inc., Pacific Northwest National Laboratory, and Waste Management Federal Services of Hanford, Inc. The purpose of the assessment was to evaluate the continued capability of Quanterra (St. Louis) to analyze and process samples for the Hanford Site as specified in the statement of work between Waste Management Federal Services of Hanford, Inc. and Quanterra.

The assessment scope was based on the analytical and QA requirements for groundwater samples. The primary area of focus was the implementation of the Quanterra (St. Louis) QA program; compliance to their technical operating procedures; and verification of the corrective actions initiated in response to the previous audit. The specific assessment areas for the Hanford Groundwater Monitoring Project were implementation of the QA/QC procedure related to method detection limit determinations, review of data packages prior to delivery to the client, and resolution of reporting issues. 
Thirteen findings and three observations were identified during the assessment. These findings and observations related to deficiencies in four specific programmatic areas: document control, quality improvement, work process, and calibration. Corrective-action responses to the assessment findings and observations have been evaluated. Eleven findings and all observations have been closed. Closure of the remaining two findings is pending.

Assessments of Thermo NUtech and its subcontractor laboratory, Recra Environmental, were conducted by the integrated contractor assessment team on March 24-26, and June 22-24, 1998. The scope of these audits focused on the analytical and QA requirements for sample analyses as specified in the contract with the laboratories.

Nine findings and one observation were identified during the audit conducted at Thermo NUtech. All corrective-action responses, with the exception of three have been accepted, and the findings have been closed. On receipt of revised procedures, the remaining three findings will also be closed.

Eight findings and seven observations were noted for Recra Environmental. All findings, with the exception of two, have been closed. The remaining findings will be closed on receipt of revised procedures.

Continued assessments of the laboratories are planned for the upcoming year to further evaluate performance and to ensure those corrective actions for the past findings and observations have been implemented.

\section{D.5.4 Data Completeness and Comparability}

For FY 1998, 88\% of the Hanford Groundwater Monitoring Project data were considered complete. Potentially invalid data had flags assigned for QC problems such as field blank contamination and poor agreement between field duplicate results ( $4.6 \%$ of all results), holding time exceedances $(2.6 \%)$, rejected data $(0.01 \%)$, suspect data $(1 \%)$, and laboratory blank contamination $(4.6 \%)$.

Samples are split in the field and forwarded to two or more laboratories when problems arise that require confirmation of analytical results. During FY 1998, 12 samples were split for one or more analyses of general chemical parameters, anions, volatile organic compounds, metals, and radiological parameters. Samples were analyzed for hazardous and nonhazardous chemicals by Quanterra (St. Louis ) and Recra Environmental. Radiological analyses were performed by Quanterra (Richland) and Thermo NUtech. Table D. 15 lists the split sample results that had a relative percent difference $>20 \%$ and in which at least one of the results was greater than five times the detection limit. The acetone and methylene chloride results appear to be a result of laboratory contamination, but the discrepancies between total organic carbon, nitrate, iron, and zinc results are difficult to explain. All of the total organic carbon results are reasonable based on past trends at the wells from which the samples were collected. However, the lower results obtained by Quanterra appear more consistent with previous data generated by Quanterra and other laboratories. Both the filtered and unfiltered iron samples were collected from the same well on the same day. The higher iron result in the unfiltered Recra Environmental sample may have resulted from a greater amount of suspended iron in that sample. In spite of these discrepancies, most of the split sample results showed good agreement ( 42 constituents had acceptable results) and were useful for confirming out-of-trend well data. 
Specific evaluation of completeness and comparability issues for interim-action groundwater monitoring was not performed for this report. Completeness and comparability issues are primarily assessed as part of site-specific validation activities. No validation activities were performed on interim-action groundwater monitoring data in FY 1998.

\section{D.6 Limit of Detection, Limit of Quantitation, and Method Detection Limit C. J. Chou, H. Hampt}

Detection and quantitation limits are essential in evaluating data quality and usefulness because they provide the limits of a method's measurement. The detection limit is the lower limit at which a measurement can be differentiated from background. The quantitation limit is the lower limit where a measurement becomes quantifiably meaningful. The limit of detection (LOD), limit of quantitation (LOQ), and method detection limit (MDL) are useful for evaluating groundwater data.

The LOD is defined as the lowest concentration level statistically different from a blank (Currie 1988). The concentration at which an analyte can be detected depends on the variability of the blank response. For the purpose of this discussion, the blank is taken to be a method blank.

In general, the LOD is calculated as the mean concentration in the blank plus three standard deviations of that concentration (EPA/540/P-87/001, OSWER 9355.0-14). The blank-corrected LOD is simply three times the blank standard deviation. At three standard deviations from the blank mean, the falsepositive and the false-negative error rates are each 7\% (Miller and Miller 1988). A false-positive error is an instance when an analyte is declared to be present but is, in fact, absent. A false-negative error is an instance when an analyte is declared to be absent but is, in fact, present.

The LOD for a radionuclide is typically computed from the counting error associated with each reported result (e.g., EPA 520/1-80-012) and represents instrumental or background conditions at the time of analysis. In contrast, the LOD and LOQ for the radionuclides shown in Table D.16 are based on variabilities that result from both counting errors and uncertainties introduced by sample handling. In the latter case, distilled water (submitted as a sample) is processed as if it were an actual sample. Thus, any random cross-contamination of the blank during sample processing will be included in the overall error, and the values shown in Table D.16 are most useful for assessing long-term variability in the overall process.

The LOQ is defined as the level above which quantitative results may be obtained with a specified degree of confidence (Keith 1991). The LOQ is calculated as the blank mean plus 10 standard deviations of the blank (EPA/540/P-87/001, OSWER 9355.014). The blank-corrected LOQ is simply 10 times the blank standard deviation. The LOQ is most useful for defining the lower limit of the useful range of concentration measurement technology. When the analyte signal is 10 times larger than the standard deviation of the blank measurements, there is a $95 \%$ probability that the true concentration of the analyte is $\pm 25 \%$ of the measured concentration. The LOD and LOQ are shown graphically in Figure D.2. For purposes of illustration, the numbers appearing in this figure are the respective blank mean, LOD, and LOQ for total organic carbon and total organic halides (see Table D.16). 
The MDL is defined as the minimum concentration of a substance that can be measured and reported with a $99 \%$ confidence that the analyte concentration is greater than zero. The MDL is determined from analysis of a sample in a given matrix containing the analyte (Currie 1988). The MDL is 3.14 times the standard deviation of the results of 7 replicates of a low-level standard. Note that the MDL, as defined above, is based on the variability of the response of low-level standards rather than on the variability of the blank response.

For this report, total organic carbon, total organic halides, and radionuclide field blank data are available for LOD and LOQ determinations. The field blanks are QC samples that are introduced into a process to monitor the performance of the system. The use of field blanks to calculate LOD and LOQ is preferred over the use of laboratory blanks because field blanks include error contributions from sample preparation and handling, in addition to analytical uncertainties. Methods to calculate LOD and LOQ are described in detail in Appendix A of DOE/RL-91-03. The results of the LOD and LOQ determinations are listed in Table D.16.

Because of the lack of blank data for other constituents of concern, it was necessary to calculate approximate LOD and LOQ values by using variability information obtained from low-level standards. The data from the low-level standards are obtained from laboratory MDL studies. As shown in Figure D.2, the values along the horizontal axis are measured in units of standard deviation of the measurement process (i.e., based on a well-known blank). If low-level standards are used, the variability of the difference between the sample and blank response is increased by a factor of $\sqrt{2}$ (Currie 1988, p. 84). The formulas are summarized below:

$$
\begin{aligned}
\mathrm{MDL} & =3.14 \times \mathrm{s} \\
\mathrm{LOD} & =3 \times(\sqrt{2} \times \mathrm{s}) \\
& =4.24 \times \mathrm{s} \\
\mathrm{LOQ} & =10 \times(\sqrt{2} \times \mathrm{s}) \\
& =14.14 \times \mathrm{s}
\end{aligned}
$$

where $s=$ standard deviation from the seven replicates of the low-level standard.

The results of MDL, LOD, and LOQ calculations for other constituents of concern are listed in Table D.17.

Specific evaluation of detection-limit issues for the interim-action groundwater-monitoring program was not performed for this report. Detection-limit issues are primarily assessed as part of site-specific validation activities. No validation activities were performed on interim-action groundwater-monitoring data in FY 1998. 


\section{D.7 Glossary of QA/QC Terms}

- accuracy - closeness of agreement between an observed value and a true value. Accuracy is assessed by means of reference samples and percent recoveries. Laboratory matrix spikes; laboratory control samples; EPA water pollution, water supply, and interlaboratory comparison programs; and blind standards are all used to assess accuracy.

- blind standard - sample that contains a concentration of analyte known to the supplier but unknown to the analyzing laboratory. The analyzing laboratory is informed that the sample is a QC sample and not a field sample. Blind, double blind, and matrix-matched double-blind standards are used to evaluate analytical accuracy and precision as a measure of laboratory performance.

- comparability - degree to which one set of data can be compared to another. For example, the results from samples analyzed by more than one laboratory may or not be comparable. Ideally, comparability should be evaluated using identical samples to ensure that valid comparisons can be made.

- completeness - amount of acceptable data divided by the total number of data points. The Hanford Groundwater Monitoring Project determines completeness by calculating the number of unflagged data resulting from the validation process, dividing the total number of data evaluated, and multiplying by 100 . The calculated percentages used in reporting completeness are conservative because all data flagged with $\mathrm{B}, \mathrm{H}, \mathrm{Q}, \mathrm{R}$, and $\mathrm{Y}$ (see flags) are used in calculating the percentage complete; however, flagged data may still be valid.

- contractually required quantitation limit - value that represents the lowest analyte concentration in a given matrix that the laboratory must be able to achieve consistently. This value is agreed on in the contract statement of work.

- double-blind standard - sample that contains a concentration of analyte known to the supplier but unknown to the analyzing laboratory. The analyzing laboratory is not informed that the sample is a QC sample. All attempts are made to make this sample appear like a field sample. For example, the double-blind standard should be submitted to the laboratory within the same time period and with a sample identification number similar to that of the field samples. The double-blind standard may or may not include matrix matching. Blind, double-blind, and matrix-matched double-blind standards are used to assess accuracy and precision as a measure of laboratory performance.

- equipment blank - sample that contains Type II reagent water and any required preservative(s). An equipment blank is filled by pumping or washing Type II reagent water through a nondedicated pump or manifold. The equipment blank is analyzed for all constituents scheduled for the sampling event:

- field duplicate sample - replicate sample to determine the repeatability of the sampling and analytical measurement process by comparing results with an identical sample collected at the same time and location. Matching field duplicate samples are stored in separate containers and are analyzed independently by the same laboratory. 
- field trip blank - sample that contains Type II reagent water and any required preservative(s). At the time of sample collection, the field trip blank is filled at the sampling site by pouring Type II reagent water from a cleaned container into vials. After collection, the field trip blank is treated in the same manner as the other samples collected during the sampling event. Field trip blanks are collected only on days when other samples are collected for volatile organics analysis and are analyzed only for volatile organic constituents.

- flag(s) - codes that alert data users to limitations on reported data values. In general, data flags are assigned by onsite data management personnel. An exception is the B flag that is assigned by the analytical laboratory. The flags that are used include the following:

- B - data associated with contamination in the laboratory method blank

- F - suspect data currently under review

- $\mathrm{H}$ - laboratory holding time exceeded

- G - reviewed data considered valid

- P - potential problem (with the sample or well that may have affected the data)

- Q - result associated with suspect field QC data

- $\mathrm{R}$ - reviewed data are unusable

- Y - reviewed data continue to be suspect.

- full trip blank - sample that contains only Type II reagent water and preservative, as required. A full trip blank is used to check for contamination in sample bottles and sample preparation. The full trip blank is analyzed for all constituents of interest and is collected in all types of sample bottles used during that sampling period. The frequency of collection for a full trip blank is 1 per 20 samples, or 1 per sampling batch. A full trip blank is filled in the field sampling laboratory using the same sample-preparation procedures as for regular well samples. The full trip blank is not opened in the field.

- laboratory control sample - sample of Type II reagent water spiked with known amounts of the target analyte(s). The sample is extracted (if appropriate) and analyzed to monitor the performance of the analytical method.

- limit of detection - lowest concentration level statistically different from a blank. The limit of detection is calculated from the average blank signal plus three standard deviations for the blank analyses.

- limit of quantitation - level above which quantitative results may be obtained with a $95 \%$ probability that the true concentration of the analyte is within $\pm 25 \%$ of the measured concentration. The limit of quantitation is calculated from the blank mean plus 10 standard deviations of the blank.

- matrix duplicate - replicate analysis of a regular (i.e., groundwater) sample. Matrix duplicates and matrix spike duplicates are used to evaluate the precision of an analysis.

- matrix-matched double-blind standard - sample prepared to contain a concentration of analyte known to the supplier but unknown to the analyzing laboratory. The sample matrix is selected to closely 
match that of the field samples. Matrix-matched double-blind standards are disguised to appear as regular well samples to help ensure that any analyses performed are representative of those for routine well samples.

- matrix spikes/matrix spike duplicates - sample(s) prepared by adding known quantities of one or more target analytes to a sample prior to extraction and analysis. Comparison of the original (i.e., unspiked) sample and matrix spike results provides information about the suitability of an analysis for the sample matrix. For example, unusually high or low recoveries of spiked compounds may indicate that components in the matrix interfere with the analysis. Matrix spike duplicates are replicate matrix spike samples that are used to assess the precision of an analysis.

- method blank - sample of Type II reagent water prepared in the laboratory, extracted (if appropriate), and analyzed as if it were a regular sample. Method blanks are used to monitor the possible introduction of contaminants during sample preparation and analysis.

- method detection limit - minimum concentration of a substance measurable with $99 \%$ confidence that the analyte concentration is greater than zero. The method detection limit is determined from replicate analyses of a low-level standard containing the analyte in a given matrix type.

- minimum detectable activity - lowest level of activity practically achievable by a radiochemistry counting measurement system.

- precision - agreement among individual measurements of the same property, usually under prescribed similar conditions. For a set of duplicate measurements, precision is calculated by the relative percent difference of the duplicate results. For Hanford Groundwater Monitoring Project samples, results from laboratory duplicates, matrix spike duplicates, blind standards, and field duplicates are used to evaluate precision.

- relative percent difference (RPD) - calculated as follows:

$$
R P D=\frac{\left|D_{1}-D_{2}\right|}{\left(D_{1}+D_{2}\right) \div 2} \times 100
$$

where $D_{1}=$ original sample value

$\mathrm{D}_{2}=$ duplicate sample value.

- reliable detection level - limit set at two times the method detection limit so the risk of both falsepositives and false-negatives falls below $1 \%$.

- representativeness - expression of the degree to which samples represent the actual composition of the groundwater in the aquifer. Representativeness is addressed qualitatively by the specification of well construction, sampling locations, sampling intervals, and sampling and analysis techniques addressed in monitoring plans. 
- split samples - replicate samples sequentially collected from the same location and analyzed by different laboratories. To help ensure split samples are identical in composition, the samples are only collected after adequate well purging has occurred (i.e., field measurements of specific conductance and turbidity indicate the composition of pumped well water has stabilized).

- surrogates - organic compounds similar to analytes of interest in chemical composition, extraction, and analytical properties, but which are not normally found in environmental samples. Surrogates are spiked into method blanks, samples, and matrix spikes and are then extracted and analyzed to monitor the effectiveness of sample preparation and analysis on individual samples.

- Type II reagent water - distilled or deionized water free of contaminants that may interfere with the analytical test.

\section{D.8 References}

Atomic Energy Act of 1954, as amended, Ch. 1073, 68 Stat. 919, 42 USC 2011 et seq.

BHI-00038, Rev. 2. 1995. 200-ZP-1 Groundwater Sampling and Analysis Plan/Quality Assurance Plan. K. M. Singleton, Bechtel Hanford, Inc., Richland, Washington.

Comprehensive Environmental Response, Compensation, and Liability Act of 1980, as amended, Public Law 96-510, 94 Stat. 2767, 42 USC 9601 et seq.

Currie, L. A. (ed.). 1988. Detection in Analytical Chemistry: Importance, Theory, and Practice. ACS Symposium Series 361, American Chemical Society, Washington, D.C., pp. 17, 79-92.

DOE/RL-88-36. 1992. RCRA Facility Investigation/Corrective Measures Study Work Plan for the 100-HR-3 Operable Unit, Hanford Site, Richland, Washington. U.S. Department of Energy, Richland Operations Office, Richland, Washington.

DOE/RL-90-08. 1992. Remedial Investigation/Feasibility Study Work Plan for the 100-BC-5 Operable Unit, Hanford Site, Richland, Washington. U.S. Department of Energy, Richland Operations Office, Richland, Washington.

DOE/RL-90-21. 1992. Remedial Investigation/Feasibility Study Work Plan for 100-KR-4 Operable Unit, Hanford Site, Richland, Washington. U.S. Department of Energy, Richland Operations Office, Richland, Washington.

DOE/RL-91-03. 1991. Annual Report for RCRA Groundwater Monitoring Projects at Hanford Site Facilities for 1990. Prepared by Geosciences Group, Westinghouse Hanford Company, Environmental Division for U.S. Department of Energy, Richland Operations Office, Richland, Washington.

DOE/RL-91-46. 1996. RCRA Facility Investigation/Corrective Measures Study Work Plan for the 100-NR-2 Operable Unit Hanford Site, Richland, Washington, U.S. Department of Energy, Richland Operations Office, Richland, Washington. 
DOE/RL-91-53. 1992. Remedial Investigation/Feasibility Study Work Plan for 100-FR-3 Operable Unit, Hanford Site, Richland, Washington. U.S. Department of Energy, Richland Operations Office, Richland, Washington.

DOE/RL-92-03. 1992. Annual Report for RCRA Groundwater Monitoring Projects at Hanford Site Facilities for 1991. Prepared by Geosciences Group, Westinghouse Hanford Company, Environmental Division for U.S. Department of Energy, Richland Operations Office, Richland, Washington.

DOE/RL-92-76. 1994. Remedial Investigation/Feasibility Study Work Plan for the 200-UP-1 Groundwater Operable Unit, Hanford Site, Richland, Washington. U.S. Department of Energy, Richland Operations Office, Richland, Washington.

DOE/RL-96-07. 1996. 200-ZP-I IRM Phase II and III Remedial Design Report. U.S. Department of Energy, Richland Operations Office, Richland, Washington.

DOE/RL-96-90, Draft A. 1996. Interim Action Monitoring Plan for the 100-HR-3 and 100-KR-4 Operable Units. Prepared by CH2M Hill Hanford, Inc. for U.S. Department of Energy, Richland Operations Office, Richland, Washington.

DOE/RL-97-36, Rev. 2. 1997. 200-UP-1 Groundwater Remedial Design/Remedial Action Work Plan. U.S. Department of Energy, Richland Operations Office, Richland, Washington.

EML-594. 1998. Semi-Annual Report of the Department of Energy, Office of Environmental Management, Quality Assessment Program. P. Greenlaw, Environmental Measurements Laboratory, U.S. Department of Energy, New York.

EML-596. 1998. Semi-Annual Report of the Department of Energy, Office of Environmental Management, Quality Assessment Program. P. Greenlaw and S. Minick, Environmental Measurements Laboratory, U.S. Department of Energy, New York.

EPA 520/1-80-012. 1980. Upgrading Environmental Radiation Data. Health Physics Report HPSR-1 (1980). J. E. Watson, Office of Radiation Programs, U.S. Environmental Protection Agency, Washington, D.C.

EPA/540/P-87/001, OSWER 9355.0-14. 1987. A Compendium of Superfind Field Operations Methods. U.S. Environmental Protection Agency, Washington, D.C., pp. 16-3 to 16-5.

EPA-600/4-79-020. 1979. Methods for Chemical Analysis of Water and Wastes. U.S. Environmental Protection Agency, Washington, D.C.

EPA-600/4-81-004. 1981. Environmental Radioactivity Laboratory Intercomparison Studies Program: Fiscal Year 1980-81. A. B. Jarvis and L. Siu, U.S. Environmental Protection Agency, Las Vegas, Nevada.

Keith, L. H. 1991. Environmental Sampling and Analysis: A Practical Guide. Lewis Publishers, CRC Press, Inc., Boca Raton, Florida, pp. 93-115. 
Miller, J. C., and J. N. Miller. 1988. Statistics for Analytical Chemistry, Second Edition. Ellis Horwood Limited, Chichester, England, pp. 115-116.

Mitchell, W. J., R. C. Rhodes, and F. F. McElroy. 1985. "Determination of Measurement Data Quality and Establishment of Achievable Goals for Environmental Measurements." Quality Assurance for Environmental Measurements, ASTM STP 867. J: K. Taylor and T. W. Stanley (eds.), American Society for Testing and Materials, Philadelphia, Pennsylvania, pp. 41-52.

OSWER-9950.1. 1986. Resource Conservation and Recovery Act (RCRA) Groundwater Monitoring Technical Enforcement Guidance Document (TEGD). U.S. Environmental Protection Agency, Washington, D.C.

Resource Conservation and Recovery Act of 1976, as amended, Public Law 94-580, 90 Stat 2795, 42 USC 6901 et seq.

SW-846. 1986. Test Methods for Evaluating Solid Wastes: Physical/Chemical Methods, 3rd ed. Office of Solid Waste and Emergency Response, U.S. Environmental Protection Agency, Washington, D.C. 
Table D.1. Full Trip Blanks Exceeding Quality Control Limits

\begin{tabular}{|c|c|c|c|c|c|}
\hline Constituent & $\begin{array}{l}\text { Number } \\
\text { Out of } \\
\text { Limits }\end{array}$ & $\begin{array}{l}\text { Number } \\
\text { of } \\
\text { Analyses }\end{array}$ & $\begin{array}{l}\text { Percent Out } \\
\text { of Limits }\end{array}$ & Range of QC Limits ${ }^{(2)}$ & $\begin{array}{l}\text { Range of Out-of-Limit } \\
\text { Results } \\
\end{array}$ \\
\hline & \multicolumn{5}{|c|}{ General Chemical Parameters } \\
\hline Alkalinity & 3 & 37 & 8.1 & $598-1,840 \mu \mathrm{g} / \mathrm{L}$ & $54,800-217,000 \mu \mathrm{g} / \mathrm{L}$ \\
\hline Total dissolved solids & 10 & 20 & 50.0 & $5,980-8,456 \mu \mathrm{g} / \mathrm{L}$ & $6,000-50,000 \mu \mathrm{g} / \mathrm{L}$ \\
\hline Total organic carbon & 15 & 72 & 20.8 & $512-736 \mu \mathrm{g} / \mathrm{L}$ & $534-1,030 \mu \mathrm{g} / \mathrm{L}$ \\
\hline Total organic halides & 5 & 71 & 7.0 & $4.76-9.24 \mu \mathrm{g} / \mathrm{L}$ & $6.95-18.9 \mu \mathrm{g} / \mathrm{L}$ \\
\hline \multicolumn{6}{|c|}{ Ammonia and Anions } \\
\hline Chloride & 12 & 49 & 24.5 & $44-70 \mu \mathrm{g} / \mathrm{L}$ & $55-147 \mu \mathrm{g} / \mathrm{L}$ \\
\hline Fluoride & 1 & 49 & 2.0 & $24-26 \mu \mathrm{g} / \mathrm{L}$ & $96 \mu \mathrm{g} / \mathrm{L}$ \\
\hline Nitrogen in nitrate & 7 & 49 & 14.3 & $4 \mu \mathrm{g} / \mathrm{L}$ & $6-23 \mu g / L$ \\
\hline Sulfate & 3 & 49 & 6.1 & $46-194 \mu \mathrm{g} / \mathrm{L}$ & $257-276 \mu \mathrm{g} / \mathrm{L}$ \\
\hline \multicolumn{6}{|c|}{ Volatile Organic Compounds } \\
\hline Acetone & 1 & 13 & 7.7 & $9.7 \mu \mathrm{g} / \mathrm{L}$ & $10 \mu \mathrm{g} / \mathrm{L}$. \\
\hline Bromodichloromethane & 1 & 1 & 100.0 & $0.1996 \mu \mathrm{g} / \mathrm{L}$ & $0.3 \mu g / L$ \\
\hline Carbon tetrachloride & 1 & 17 & 5.9 & $0.05-0.904 \mu \mathrm{g} / \mathrm{L}$ & $0.5 \mu \mathrm{g} / \mathrm{L}$ \\
\hline Chloroform & 5 & 17 & 29.4 & $0.056-0.572 \mu \mathrm{g} / \mathrm{L}$ & $0.4-3 \mu \mathrm{g} / \mathrm{L}$ \\
\hline Methylene chloride & 4 & 17 & 23.5 & $1.035-3.8 \mu \mathrm{g} / \mathrm{L}$ & $4.0-67 \mu g / L$ \\
\hline \multicolumn{6}{|c|}{ Semivolatile Organic Compounds } \\
\hline 2,4-Dinitrophenol & 3 & 9 & 33.3 & $1.06 \mu \mathrm{g} / \mathrm{L}$ & $1.1-2.5 \mu \mathrm{g} / \mathrm{L}$ \\
\hline $\begin{array}{l}\text { 2-sec-Butyl-4,6- } \\
\text { dinitrophenol }\end{array}$ & 1 & 9 & 11.1 & $1.044 \mu \mathrm{g} / \mathrm{L}$ & $1.3 \mu \mathrm{g} / \mathrm{L}$ \\
\hline $\begin{array}{l}\text { 4,6-Dinitro-2-methyl } \\
\text { phenol }\end{array}$ & 2 & 9 & 22.2 & $0.928 \mu \mathrm{g} / \mathrm{L}$ & $1.3 \mu \mathrm{g} / \mathrm{L}$ \\
\hline \multicolumn{6}{|c|}{ Metals } \\
\hline Aluminum & 1 & 46 & 2.2 & $53.04-76 \mu \mathrm{g} / \mathrm{L}$ & $177 \mu \mathrm{g} / \mathrm{L}$ \\
\hline Antimony & 1 & 46 & 2.2 & $31.4-54.6 \mu \mathrm{g} / \mathrm{L}$ & $47.7 \mu \mathrm{g} / \mathrm{L}$ \\
\hline Barium, & 4 & 46 & 8.7 & $1.2-2.2 \mu \mathrm{g} / \mathrm{L}$ & $1.4-3.8 \mu \mathrm{g} / \mathrm{L}$ \\
\hline Calcium & 17 & 46 & 37.0 & $140.94-249 \mu \mathrm{g} / \mathrm{L}$ & $144-362 \mu \mathrm{g} / \mathrm{L}$ \\
\hline Copper & 5 & 46 & 10.9 & $4.6-8 \mu \mathrm{g} / \mathrm{L}$ & $9.9-19.3 \mu \mathrm{g} / \mathrm{L}$ \\
\hline Iron & 6 & 46 & 13.0 & $45.4-71.2 \mu \mathrm{g} / \mathrm{L}$ & $46.4-202 \mu \mathrm{g} / \mathrm{L}$ \\
\hline Magnesium & 13 & 46 & 28.3 & $33-68.2 \mu \mathrm{g} / \mathrm{L}$ & $58.4-629 \mu \mathrm{g} / \mathrm{L}$ \\
\hline Manganese & 9 & 46 & 19.6 & $1.4 \mu \mathrm{g} / \mathrm{L}$ & $1.4-8.3 \mu \mathrm{g} / \mathrm{L}$ \\
\hline Silver & 1 & 46 & 2.2 & $5.2-7.6 \mu \mathrm{g} / \mathrm{L}$ & $6.8 \mu \mathrm{g} / \mathrm{L}$ \\
\hline Sodium & 35 & 46 & 76.1 & $61-239.6 \mu \mathrm{g} / \mathrm{L}$ & $82.2-860 \mu \mathrm{g} / \mathrm{L}$ \\
\hline Strontium (elemental) & 2 & 46 & 4.4 & $0.8-1.4 \mu \mathrm{g} / \mathrm{L}$ & $2.9-3.2 \mu \mathrm{g} / \mathrm{L}$ \\
\hline Vanadium & 8 & 46 & 17.4 & $4-7.4 \mu \mathrm{g} / \mathrm{L}$ & $6.2-30.4 \mu \mathrm{g} / \mathrm{L}$ \\
\hline Zinc & 4 & 46 & 8.7 & $8.2-16.8 \mu \mathrm{g} / \mathrm{L}$ & $8.4-9 \mu \mathrm{g} / \mathrm{L}$ \\
\hline \multicolumn{6}{|c|}{ Radiological Parameters } \\
\hline Gross beta & 4 & 42 & 9.5 & $2.06-3.18 \mathrm{pCi} / \mathrm{L}^{(\mathrm{l})}$ & $2.83-3.4 \mathrm{pCi} / \mathrm{L}$ \\
\hline Tritium & 1 & 48 & 2.1 & $31.4-452 \mathrm{pCi} / /^{(b)}$ & $117 \mathrm{pCi} / \mathrm{L}$ \\
\hline Uranium & 1 & 15 & 6.7 & $0.0729 \mu \mathrm{g} / \mathrm{L}$ & $0.0875 \mu g / \mathrm{L}$ \\
\hline
\end{tabular}

(a) Because method detection limits may change throughout the year, the limits are presented as a range. However, each result was evaluated according to the method detection limit in effect at the time the sample was analyzed.

(b) The limit for radiological samples is determined by the sample-specific total propagated uncertainty. 
Table D.2. Field Trip Blanks Exceeding Quality Control Limits

\begin{tabular}{|c|c|c|c|c|c|}
\hline Constituent & $\begin{array}{l}\text { Number } \\
\text { Out of } \\
\text { Limits }\end{array}$ & $\begin{array}{c}\text { Number } \\
\text { of } \\
\text { Analyses }\end{array}$ & $\begin{array}{l}\text { Percent } \\
\text { Out of } \\
\text { Limits }\end{array}$ & $\begin{array}{l}\text { Range of QC } \\
\text { Limits, } \mu g / L^{(a)}\end{array}$ & $\begin{array}{c}\text { Range of Out-of- } \\
\text { Limit Results, } \\
\mu \mathrm{g} / \mathrm{L}\end{array}$ \\
\hline \multicolumn{6}{|c|}{ Volatile Organic Compounds } \\
\hline 1,1,1-Trichloroethane & 1 & 86 & 1.2 & $0.056-0.684$ & 0.06 \\
\hline 1,2-Dichloroethane & 1 & 86 & 1.2 & $0.036-0.444$ & 2 \\
\hline 1,4-Dichlorobenzene & 3 & 92 & 3.3 & $0.052-0.368$ & $0.5-0.6$ \\
\hline 2-Butanone & 1 & 74 & 1.4 & 0.84 & 4 \\
\hline 4-Methyl-2-pentanone & 1 & 74 & 1.4 & 0.38 & 0.7 \\
\hline Bromodichloromethane & 1 & 2 & 50.0 & 0.1996 & 0.3 \\
\hline Carbon disulfide & 2 & 74 & 2.7 & 0.296 & $0.5-0.7$ \\
\hline Carbon tetrachloride & 6 & 86 & 7.0 & $0.05-0.904$ & $0.3-8$ \\
\hline Chloroform & 37 & 86 & 43.0 & $0.056-0.572$ & $0.17-7$ \\
\hline Methylene chloride & 21 & 86 & 24.4 & $1.035-3.8$ & $1.5-16$ \\
\hline Toluene & 1 & 86 & 1.2 & $0.024-1.105$ & 1 \\
\hline Trichloroethene & 2 & 86 & 2.3 & $0.056-0.8$ & $5-8$ \\
\hline Xylenes (total) & 1 & 80 & 1.3 & $0.13-0.284$ & 6 \\
\hline
\end{tabular}

(a) Because method detection limits may change throughout the year, the limits are presented as a range. However, each result was evaluated according to the method detection limit in effect at the time the sample was analyzed. 
Table D.3. Equipment Blanks Exceeding Quality Control Limits

\begin{tabular}{|c|c|c|c|c|c|}
\hline Constituent & $\begin{array}{l}\text { Number } \\
\text { Out of } \\
\text { Limits }\end{array}$ & $\begin{array}{l}\text { Number of } \\
\text { Analyses }\end{array}$ & $\begin{array}{l}\text { Percent Out of } \\
\text { Limits }\end{array}$ & $\begin{array}{c}\text { Range of } Q C \\
\text { Limits }^{(2)}\end{array}$ & $\begin{array}{l}\text { Range of Out-of-Limit } \\
\text { Results }\end{array}$ \\
\hline & \multicolumn{4}{|c|}{ General Chemical Parameters } & \\
\hline Alkalinity & 5 & 14 & 35.7 & $598 \mu g / L$ & $5,530-30,300 \mu \mathrm{g} / \mathrm{L}$ \\
\hline Total dissolved solids & 4 & 8 & 50.0 & $5,980-8,456 \mu \mathrm{g} / \mathrm{L}$ & $11,000-672,000 \mu \mathrm{g} / \mathrm{L}$ \\
\hline Total organic carbon & 4 & 29 & 13.8 & $512-736 \mu \mathrm{g} / \mathrm{L}$ & $614-1,020 \mu \mathrm{g} / \mathrm{L}$ \\
\hline Total organic halides & 5 & 28 & 17.9 & $4.76-9.24 \mu \mathrm{g} / \mathrm{L}$ & $6.05-47.4 \mu \mathrm{g} / \mathrm{L}$ \\
\hline \multicolumn{6}{|c|}{ Ammonia and Anions } \\
\hline Chloride & 9 & 24 & 37.5 & $44-70 \mu \mathrm{g} / \mathrm{L}$ & $46-291 \mu \mathrm{g} / \mathrm{L}$ \\
\hline Fluoride & 1 & 22 & 4.5 & $24-26 \mu \mathrm{g} / \mathrm{L}$ & $72 \mu \mathrm{g} / \mathrm{L}$ \\
\hline Nitrogen in nitrate & 14 & 24 & 58.3 & $4 \mu \mathrm{g} / \mathrm{L}$ & $8-45 \mu \mathrm{g} / \mathrm{L}$ \\
\hline Sulfate & 5 & 22 & 22.7 & $46-194 \mu g / L$ & $249-865 \mu \mathrm{g} / \mathrm{L}$ \\
\hline \multicolumn{6}{|c|}{ Volatile Organic Compounds } \\
\hline 1,4-Dichlorobenzene & 1 & 5 & 20.0 & $0.368 \mu \mathrm{g} / \mathrm{L}$ & $0.7 \mu \mathrm{g} / \mathrm{L}$ \\
\hline Carbon disulfide & 1 & 5 & 20.0 & $0.296 \mu \mathrm{g} / \mathrm{L}$ & $0.9 \mu \mathrm{g} / \mathrm{L}$ \\
\hline Carbon tetrachloride & 1 & 5 & 20.0 & $0.284 \mu \mathrm{g} / \mathrm{L}$ & $0.3 \mu \mathrm{g} / \mathrm{L}$ \\
\hline Chloroform & 1 & 5 & 20.0 & $0.344 \mu \mathrm{g} / \mathrm{L}$ & $0.6 \mu \mathrm{g} / \mathrm{L}$ \\
\hline Methylenechloride & 1 & 5 & 20.0 & $3.8 \mu \mathrm{g} / \mathrm{L}$ & $4 \mu \mathrm{g} / \mathrm{L}$ \\
\hline \multicolumn{6}{|c|}{ Semivolatile Organic Compounds } \\
\hline 2,4-Dinitrophenol & 1 & 1 & 100.0 & $1.06 \mu \mathrm{g} / \mathrm{L}$ & $2.4 \mu \mathrm{g} / \mathrm{L}$ \\
\hline \multicolumn{6}{|c|}{ Metals } \\
\hline Aluminum & 1 & 23 & 4.3 & $53.04-76 \mu g / L$ & $100 \mu g / L$ \\
\hline Barium & 1 & 23 & 4.3 & $1.2-2.2 \mu \mathrm{g} / \mathrm{L}$ & $1.5 \mu \mathrm{g} / \mathrm{L}$ \\
\hline Calcium & 5 & 23 & 21.7 & $140.94-249 \mu \mathrm{g} / \mathrm{L}$ & $177-289 \mu \mathrm{g} / \mathrm{L}$ \\
\hline Chromium & 1 & 25 & 4.0 & $4.8-5.4 \mu \mathrm{g} / \mathrm{L}$ & $6.7 \mu \mathrm{g} / \mathrm{L}$ \\
\hline Copper & 3 & 23 & 13.0 & $4.6-8 \mu \mathrm{g} / \mathrm{L}$ & $6.4-21.5 \mu \mathrm{g} / \mathrm{L}$ \\
\hline Iron & 2 & 23 & 8.7 & $45.4-71.2 \mu \mathrm{g} / \mathrm{L}$ & $163-335 \mu \mathrm{g} / \mathrm{L}$ \\
\hline Magnesium & 9 & 23 & 39.1 & $33-68.2 \mu \mathrm{g} / \mathrm{L}$ & $102-200 \mu \mathrm{g} / \mathrm{L}$ \\
\hline Manganese & 7 & 23 & 30.4 & $1.4 \mu \mathrm{g} / \mathrm{L}$ & $1.6-5.1 \mu \mathrm{g} / \mathrm{L}$ \\
\hline Sodium & 13 & 23 & 56.5 & $61-239.6 \mu \mathrm{g} / \mathrm{L}$ & $134-572 \mu \mathrm{g} / \mathrm{L}$ \\
\hline Vanadium & 4 & 23 & 17.4 & $4-7.4 \mu \mathrm{g} / \mathrm{L}$ & $7-10 \mu \mathrm{g} / \mathrm{L}$ \\
\hline Zinc & 9 & 23 & 39.1 & $8.2-16.8 \mu \mathrm{g} / \mathrm{L}$ & $8.3-24 \mu \mathrm{g} / \mathrm{L}$ \\
\hline \multicolumn{6}{|c|}{ Radiological Parameters } \\
\hline Tritium & 2 & 24 & 8.3 & $26.8-474 \mathrm{pCi} / \mathrm{L}$ & $92.2-93.3 \mathrm{pCi} / L^{(f)}$ \\
\hline
\end{tabular}

(a) Because method detection limits may change throughout the year, the limits are presented as a range. However, each result was evaluated according to the method detection limit in effect at the time the sample was analyzed.

(b) The limit for radiological samples is determined by the sample-specific total propagated uncertainty. 
Table D.4. Field Duplicates Exceeding Quality Control Limits

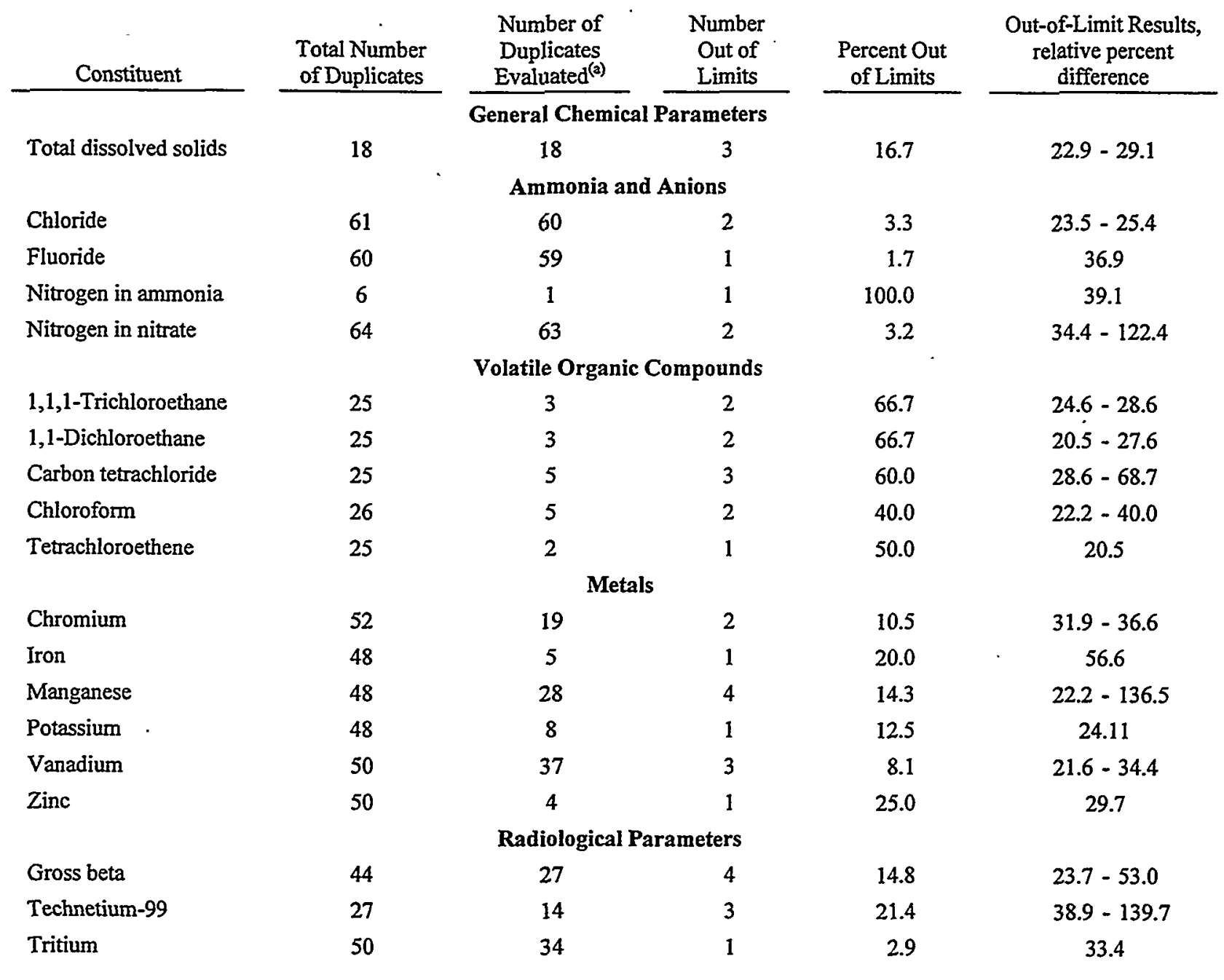

(a) Results less than five times the method detection limit or minimum detectable activity were excluded from the evaluation. 
Table D.5. Hanford Groundwater Monitoring Project Holding Times

\begin{tabular}{|c|c|c|}
\hline Methods & Constituents & Holding Times \\
\hline $8010 / 8020 / 8260$ (SW-846) & Volatile organics & 14 days \\
\hline 8270 (SW-846) & Semivolatile organics & $\begin{array}{l}7 \text { days before extraction; } \\
40 \text { days after extraction }\end{array}$ \\
\hline 8080 (SW-846) & Pesticides & $\begin{array}{l}7 \text { days before extraction; } \\
40 \text { days after extraction }\end{array}$ \\
\hline 8080 (SW-846) & Polychlorinated biphenyls & $\begin{array}{l}7 \text { days before extraction; } \\
40 \text { days after extraction }\end{array}$ \\
\hline 8040 (SW-846) & Phenols & $\begin{array}{l}7 \text { days before extraction; } \\
40 \text { days after extraction }\end{array}$ \\
\hline $6010(\mathrm{SW}-846)$ & Inductively coupled-plasma metals & 6 months \\
\hline 7060 (SW-846) & Arsenic & 6 months \\
\hline 7421 (SW-846) & Lead & 6 months \\
\hline 7470 (SW-846) & Mercury & 28 days \\
\hline 7740 (SW-846) & Selenium & 6 months \\
\hline 7841 (SW-846) & Thallium & 6 months \\
\hline $9012(\mathrm{SW}-846)$ & Cyanide & 14 days \\
\hline 9020 (SW-846) & Total organic halides & 28 days \\
\hline 9060 (SW-846) & Total organic carbon & 28 days \\
\hline 300.0 (EPA-600/4-81-004) & Bromide & 28 days \\
\hline 300.0 (EPA-600/4-81-004) & Chloride & 28 days \\
\hline 300.0 (EPA-600/4-81-004) & Fluoride & 28 days \\
\hline 300.0 (EPA-600/4-81-004) & Nitrate & 72 hours \\
\hline 300.0 (EPA-600/4-81-004) & Nitrite & 72 hours \\
\hline 300.0 (EPA-600/4-81-004) & Phosphate & 72 hours \\
\hline 300.0 (EPA-600/4-81-004) & Sulfate & 28 days \\
\hline 310.1 (EPA-600/4-81-004) & Alkalinity & 14 days \\
\hline 410.4 (EPA-600/4-81-004) & Chemical oxygen demand & 28 days \\
\hline
\end{tabular}


Table D.6. Results of U.S. Environmental Protection Agency Water Pollution (WP) and Water Supply (WS) Performance Evaluation Studies

\begin{tabular}{|c|c|c|c|c|}
\hline Laboratory & $\begin{array}{c}\text { WP038 } \\
\text { November } 1997 \\
\text { Percent } \\
\text { Acceptable }\end{array}$ & $\begin{array}{c}\text { WS040 } \\
\text { March } 1998 \\
\text { Percent } \\
\text { Acceptable }\end{array}$ & $\begin{array}{c}\text { WP039 } \\
\text { May } 1998 \\
\text { Percent } \\
\text { Acceptable }\end{array}$ & $\begin{array}{c}\text { WS041 } \\
\text { September } 1998 \\
\text { Percent } \\
\text { Acceptable }\end{array}$ \\
\hline $\begin{array}{l}\text { Quanterra Environmental } \\
\text { Services, St. Louis, Missouri }\end{array}$ & $89^{(a)}$ & $94^{(b)}$ & $95^{(\mathrm{c})}$ & $91^{(d)}$ \\
\hline
\end{tabular}

(a) Unacceptable results were for magnesium, alkalinity, orthophosphate, kjeldahl-nitrogen, aroclor 1232, aroclor 1248 , ethylbenzene, and nonfilterable residue.

(b) Unacceptable results were for vinyl chloride, 1,1-dichloroethylene, dichloromethane, and $\mathrm{pH}$.

(c) Unacceptable results were total hardness, nitrate-nitrogen, orthophosphate, and oil and grease.

(d) Unacceptable results were for orthophosphate, bromoform, chlorodibromomethane, total trihalomethane, dichloromethane, and total cyanide.

Table D.7. Summary of Quanterra Environmental Services Interlaboratory Performance

\begin{tabular}{|c|c|c|}
\hline Radionuclides & $\begin{array}{l}\text { Number of Results } \\
\text { Reported for Each }\end{array}$ & $\begin{array}{l}\text { Number Within } \\
\text { Acceptable Control Limits }\end{array}$ \\
\hline \multicolumn{3}{|c|}{$\begin{array}{l}\text { DOE Quality Assessment Program } \\
\text { Environmental Measurements Laboratory }\end{array}$} \\
\hline $\begin{array}{l}\text { Gross alpha, gross beta, tritium, manganese- } 54 \text {, } \\
\text { cobalt- } 60 \text {, strontium- } 90 \text {, cesium-137, uranium- } 234 \text {, } \\
\text { uranium- } 235 \text {, plutonium-238, plutonium-239, } \\
\text { americium-241, uranium }\end{array}$ & 2 & $2^{(2, b)}$ \\
\hline \multicolumn{3}{|c|}{$\begin{array}{l}\text { DOE Mixed Analyte Performance Evaluation Program } \\
\text { Radiological and Environmental Sciences Laboratory }\end{array}$} \\
\hline $\begin{array}{l}\text { Americium-241, cesium-137, cobalt- } 57 \text {, cobalt- } 60 \text {, } \\
\text { manganese-54, plutonium- } 238 \text {, plutonium- } 239 / 240 \text {, } \\
\text { strontium-90, uranium-234/233, uranium-235, } \\
\text { uranium-238, zinc- } 65\end{array}$ & 1 & $1^{(\mathrm{d})}$ \\
\hline \multicolumn{3}{|c|}{$\begin{array}{l}\text { EPA Laboratory Intercomparison Studies } \\
\text { National Exposure Research Laboratory }\end{array}$} \\
\hline $\begin{array}{l}\text { Gross alpha, gross beta, radium- } 225 \text {, radium- } 228 \text {, } \\
\text { uranium, cobalt- } 60 \text {, cesium- } 134 \text {, cesium- } 137\end{array}$ & 4 & $4^{(\mathrm{c})}$ \\
\hline Strontium-89, strontium-90 & 3 & $3^{(\mathrm{c})}$ \\
\hline Zinc- 65 , barium- 133 & 2 & $2^{(\mathrm{c})}$ \\
\hline Iodine-131, tritium & 1 & $1^{(\mathrm{c})}$ \\
\hline
\end{tabular}

(a) Control limits from EML-594 and EML-596.

(b) One result for cobalt-60 was acceptable but outside warning limits.

(c) Control limits from EPA-600/4-81-004.

(d) Strontium-90 result was initially reported incorrectly; the corrected result was within the acceptable range. 


\section{Table D.8. Summary of Quanterra Environmental Services Quarterly Double-Blind Spike} Determinations

\begin{tabular}{|c|c|c|c|c|}
\hline \multirow[t]{2}{*}{ Constituent } & $\begin{array}{c}\text { Number of Results } \\
\text { Reported }^{(2)}\end{array}$ & \multicolumn{2}{|c|}{$\begin{array}{l}\text { Number of Results } \\
\text { Outside Quality } \\
\text { Control Limits } \\
\end{array}$} & \multirow[t]{2}{*}{ Control Limits, \% } \\
\hline & \multicolumn{3}{|c|}{ General Chemical Parameters } & \\
\hline $\begin{array}{l}\text { Total organic carbon spiked with } \\
\text { potassium phthalate }\end{array}$ & 15 & \multicolumn{2}{|l|}{7} & \pm 25 \\
\hline $\begin{array}{l}\text { Total organic halides spiked with } 2,4,6- \\
\text { trichlorophenol }\end{array}$ & 14 & \multicolumn{2}{|l|}{3} & \pm 25 \\
\hline $\begin{array}{l}\text { Total organic halides spiked with carbon } \\
\text { tetrachloride, chloroform, and } \\
\text { trichloroethene }\end{array}$ & 14 & \multicolumn{2}{|l|}{7} & $\begin{array}{l}\text { Determined each } \\
\text { quarter }\end{array}$ \\
\hline \multicolumn{5}{|c|}{ Ammonia and Anions } \\
\hline Cyanide & 12 & 9 & & \pm 25 \\
\hline Fluoride & 12 & 3 & & \pm 25 \\
\hline Nitrate & 12 & 0 & & \pm 25 \\
\hline \multicolumn{5}{|c|}{ Volatile Organic Compounds } \\
\hline Carbon tetrachloride & 12 & 2 & & $\begin{array}{l}\text { Determined each } \\
\text { quarter }\end{array}$ \\
\hline Chloroform & 12 & 4 & , & $\begin{array}{l}\text { Determined each } \\
\text { quarter }\end{array}$ \\
\hline \multirow[t]{2}{*}{ Trichloroethene } & 12 & 1 & & $\begin{array}{l}\text { Determined each } \\
\text { quarter }\end{array}$ \\
\hline & \multicolumn{2}{|l|}{ Metals } & & · \\
\hline \multirow[t]{2}{*}{ Chromium } & 12 & 0 & & \pm 20 \\
\hline & \multicolumn{3}{|c|}{ Radiological Parameters } & \\
\hline Gross alpha spiked with plutonium-239 & 12 & 2 & & \pm 25 \\
\hline Gross beta spiked with strontium-90 & 13 & 4 & & \pm 25 \\
\hline Iodine-129 & 12 & $\mathbf{0}$ & & \pm 30 \\
\hline Cesium-137 & 12 & 0 & & \pm 30 \\
\hline Plutonium-239,240 & 12 & 2 & & \pm 30 \\
\hline Cobalt- 60 & 12 & $\mathbf{0}$ & & \pm 30 \\
\hline Strontium-90 & 12 & 0 & & \pm 30 \\
\hline Technetium-99 & 12 & 0 . & & \pm 30 \\
\hline Tritium & 12 & 0 & & \pm 30 \\
\hline Uranium & 12 & $\mathbf{0}$ & & \pm 30 \\
\hline
\end{tabular}

(a) Blind standards were submitted in triplicate or quadruplicate each quarter and compared to actual spike values.

(b) Quality control limits are given in the Hanford Groundwater Monitoring Project's quality assurance plan. 
Table D.9. Quanterra Environmental Services Blind Standard Results

\begin{tabular}{|c|c|c|c|c|c|}
\hline Constituent & $\begin{array}{c}\text { Fiscal Year } \\
\text { Quarter }\end{array}$ & Spike Amount & Average Result & $\begin{array}{c}\text { Percent Average } \\
\text { Recovery }\end{array}$ & $\begin{array}{c}\text { Percent } \\
\text { Precision }\end{array}$ \\
\hline \multicolumn{6}{|c|}{ General Chemical Parameters } \\
\hline \multirow[t]{4}{*}{ Total organic carbon } & First & $1,550 \mu \mathrm{g} / \mathrm{L}$ & $1,740 \mu \mathrm{g} / \mathrm{L}$ & 112 & 6 \\
\hline & Second & $1,004 \mu \mathrm{g} / \mathrm{L}$ & $2,367 \mu \mathrm{g} / \mathrm{L}$ & 236 & 3 \\
\hline & Third & $1,503 \mu \mathrm{g} / \mathrm{L}$ & $2,613 \mu \mathrm{g} / \mathrm{L}$ & 174 & 11 \\
\hline & Fourth & $2,005 \mu \mathrm{g} / \mathrm{L}$ & $2,205 \mu \mathrm{g} / \mathrm{L}$ & 110 & 5 \\
\hline \multirow{4}{*}{$\begin{array}{l}\text { Total organic halides } \\
\text { (phenol) }\end{array}$} & First & $1,510 \mu \mathrm{g} / \mathrm{L}$ & $1,275 \mu \mathrm{g} / \mathrm{L}$ & 85 & 13 \\
\hline & Second & $25 \mu g / L$ & $60 \mu \mathrm{g} / \mathrm{L}$ & 239 & 6 \\
\hline & Third & $102 \mu \mathrm{g} / \mathrm{L}$ & $85 \mu \mathrm{g} / \mathrm{L}$ & 84 & 5 \\
\hline & Fourth & $131 \mu \mathrm{g} / \mathrm{L}$ & $116 \mu \mathrm{g} / \mathrm{L}$ & 88 & 5 \\
\hline \multirow{5}{*}{$\begin{array}{l}\text { Total organic halides } \\
\text { (volatile organic analyte) }\end{array}$} & First & $1,545 \mu \mathrm{g} / \mathrm{L}$ & $763 \mu \mathrm{g} / \mathrm{L}$ & 49 & 7 \\
\hline & Second & $25 \mu g / \mathrm{L}$ & $302 \mu \mathrm{g} / \mathrm{L}$ & 1,209 & 19 \\
\hline & Third & $101 \mu \mathrm{g} / \mathrm{L}$ & $85 \mu g / L$ & 84 & 5 \\
\hline & Fourth & $131 \mu \mathrm{g} / \mathrm{L}$ & $88 \mu \mathrm{g} / \mathrm{L}$ & 67 & 4. \\
\hline & & Anion & & & \\
\hline \multirow[t]{4}{*}{ Cyanide } & First & $100 \mu \mathrm{g} / \mathrm{L}$ & $59 \mu \mathrm{g} / \mathrm{L}$ & 60 & 3 \\
\hline & Second & $100 \mu \mathrm{g} / \mathrm{L}$ & $61 \mu \mathrm{g} / \mathrm{L}$ & 61 & 1 \\
\hline & Third & $100 \mu \mathrm{g} / \mathrm{L}$ & $76 \mu g / L$ & 76 & 0 \\
\hline & Fourth & $100 \mu \mathrm{g} / \mathrm{L}$ & $68 \mu \mathrm{g} / \mathrm{L}$ & 68 & 1 \\
\hline \multirow[t]{4}{*}{ Fluoride } & First & $1 \mathrm{mg} / \mathrm{L}$ & $1.13 \mathrm{mg} / \mathrm{L}$ & 113 & 2 \\
\hline & Second & $1 \mathrm{mg} / \mathrm{L}$ & $1.27 \mathrm{mg} / \mathrm{L}$ & 127 & 4 \\
\hline & Third & $1 \mathrm{mg} / \mathrm{L}$ & $1.24 \mathrm{mg} / \mathrm{L}$ & 124 & 4 \\
\hline & Fourth & $1 \mathrm{mg} / \mathrm{L}$ & $1.22 \mathrm{mg} / \mathrm{L}$ & 122 & 2 \\
\hline \multirow[t]{4}{*}{ Nitrate } & First & $10.17 \mathrm{mg} / \mathrm{L}$ & $10.4 \mathrm{mg} / \mathrm{L}$ & 102 & 1 \\
\hline & Second & $10.2 \mathrm{mg} / \mathrm{L}$ & $10.3 \mathrm{mg} / \mathrm{L}$ & 101 & 1 \\
\hline & Third & $10.2 \mathrm{mg} / \mathrm{L}$ & $9.9 \mathrm{mg} / \mathrm{L}$ & 97 & 1 \\
\hline & Fourth & $10.6 \mathrm{mg} / \mathrm{L}$ & $10.5 \mathrm{mg} / \mathrm{L}$ & 99 & 1 \\
\hline \multicolumn{6}{|c|}{ Volatile Organic Compounds } \\
\hline \multirow[t]{4}{*}{ Carbon tetrachloride } & First & $6 \mu \mathrm{g} / \mathrm{L}$ & $6 \mu \mathrm{g} / \mathrm{L}$ & 100 & 0 \\
\hline & Second & $420 \mu \mathrm{g} / \mathrm{L}$ & $376.7 \mu \mathrm{g} / \mathrm{L}$ & 90 & 30 \\
\hline & Third & $5 \mu \mathrm{g} / \mathrm{L}$ & $5 \mu \mathrm{g} / \mathrm{L}$ & 100 & 0 \\
\hline & Fourth & $49 \mu \mathrm{g} / \mathrm{L}$ & $38.7 \mu \mathrm{g} / \mathrm{L}$ & 79 & 18 \\
\hline \multirow[t]{4}{*}{ Chloroform } & First & $100 \mu \mathrm{g} / \mathrm{L}$ & $110 \mu \mathrm{g} / \mathrm{L}$ & 110 & 0 \\
\hline & Second & $430 \mu \mathrm{g} / \mathrm{L}$ & $480 \mu \mathrm{g} / \mathrm{L}$ & 112 & 9 \\
\hline & Third & $5.1 \mu \mathrm{g} / \mathrm{L}$ & $7 \mu \mathrm{g} / \mathrm{L}$ & 144 & 8 \\
\hline & Fourth & $50 \mu \mathrm{g} / \mathrm{L}$ & $42 \mu \mathrm{g} / \mathrm{L}$ & 83 & 16 \\
\hline \multirow[t]{4}{*}{ Trichloroethene } & First & $51 \mu g / L$ & $53 \mu \mathrm{g} / \mathrm{L}$ & 103 & 3 \\
\hline & Second & $410 \mu \mathrm{g} / \mathrm{L}$ & $403 \mu \mathrm{g} / \mathrm{L}$ & 98 & 14 \\
\hline & Third & $5 \mu \mathrm{g} / \mathrm{L}$ & $5 \mu \mathrm{g} / \mathrm{L}$ & 93 & 12 \\
\hline & Fourth & $50 \mu g / L$ & $42 \mu \mathrm{g} / \mathrm{L}$. & 84 & 19 \\
\hline & & Metal & & & \\
\hline \multirow[t]{4}{*}{ Chromium } & First & $300 \mu \mathrm{g} / \mathrm{L}$ & $299.7 \mu \mathrm{g} / \mathrm{L}$ & 100 & 1 \\
\hline & Second & $300 \mu \mathrm{g} / \mathrm{L}$ & $292.3 \mu \mathrm{g} / \mathrm{L}$ & 97 & 1 \\
\hline & Third & $300 \mu \mathrm{g} / \mathrm{L}$ & $300.3 \mu \mathrm{g} / \mathrm{L}$ & 100 & 2 \\
\hline & Fourth & $300 \mu \mathrm{g} / \mathrm{L}$ & $277.3 \mu \mathrm{g} / \mathrm{L}$ & 92 & 0 \\
\hline
\end{tabular}


Table D.9. (contd)

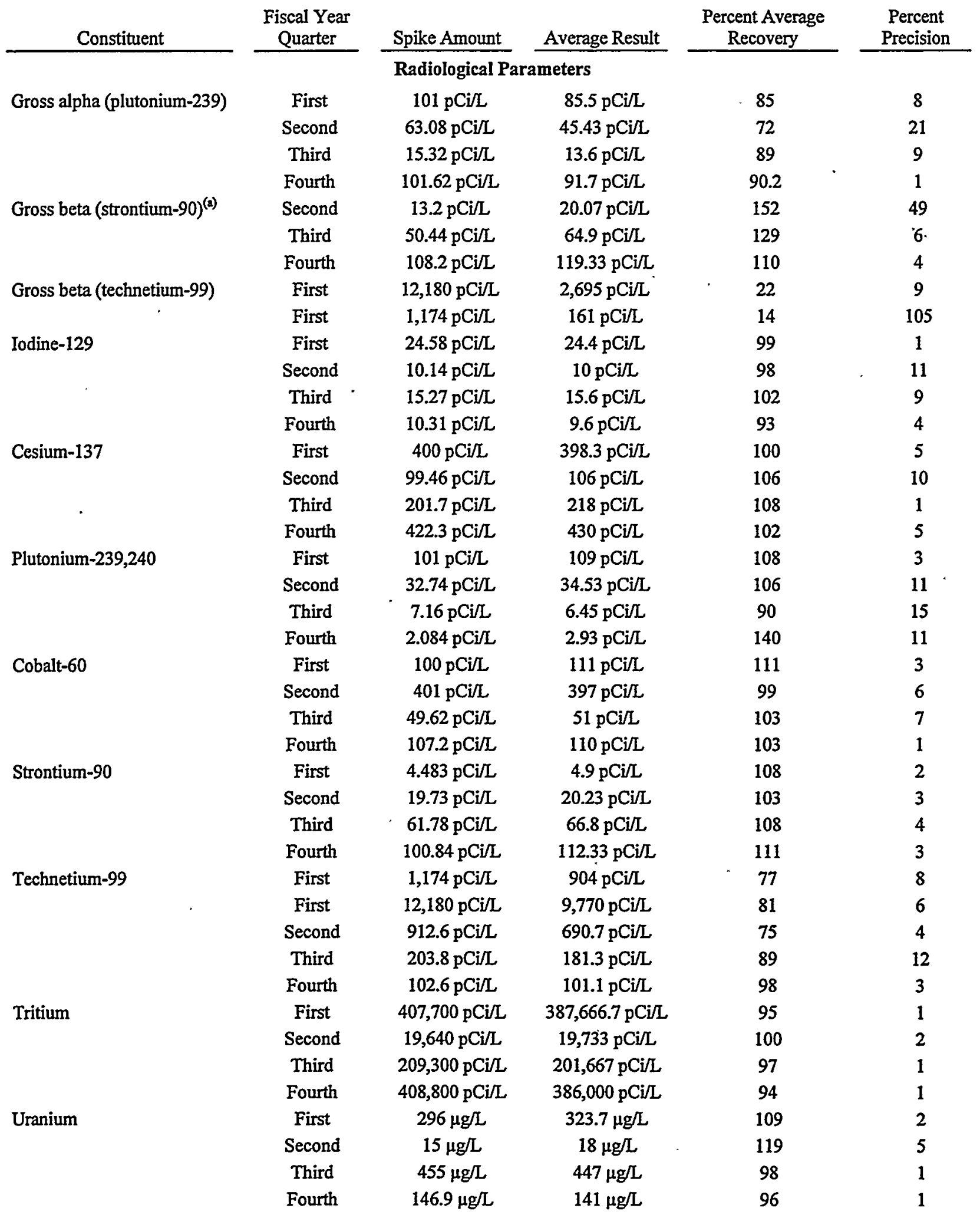

(a) Assuming strontium-90 and yttrium-90 are in equilibrium, spike amount is strontium-90 + yttrium-90. 
Table D.10. Method Blank Results

Constituent

Total General Chemical Parameters

Specific conductance

Total organic carbon

Total organic halides

Total Ammonia and Anions

Chloride

Cyanide

Nitrogen in nitrate

Sulfate

Total Volatile Organic Compounds

1,1,1-Trichloroethane

1,1,2-Trichloroethane

1,1-Dichloroethane

1,2-Dichloroethane

1,4-Dichlorobenzene

1-Butanol

2-Butanone

4-Methyl-2-pentanone

Acetone

Benzene

Carbon disulfide

Carbon tetrachloride

Chloroform

cis-1,2-Dichloroethylene

Ethyl cyanide

Ethylbenzene

Dichloromethane

Styrene

Tetrachloroethene

Toluene

trans-1,2-Dichloroethylene

Trichloroethene

Vinyl chloride

Xylenes (total)

Total Semivolatile Organic

Compounds

2,4-Dinitrophenol
Detection Frequency, number of detections/number of analyses $^{(2)}$

General Chemical Parameters

$9 / 808$
$5 / 5$
$2 / 268$
$1 / 258$

Ammonia and Anions

$68 / 1,605$

$54 / 305$

$4 / 44$

$4 / 272$

$6 / 305$

Volatile Organic Compounds

$93 / 4,009$

$1 / 183$

$1 / 183$

$1 / 182$

$1 / 182$

$26 / 195$

$1 / 165$

$8 / 166^{(a)}$

$1 / 165$

$18 / 166^{(a)}$

$1 / 183$

2/166

$2 / 183$

$2 / 183$

$1 / 182$

$1 / 166$

$1 / 21$

$14 / 183^{(a)}$

$1 / 3$

$1 / 183$

$1 / 183^{(2)}$

$1 / 183$

2/183

$1 / 183$

4/177

Semivolatile Organic Compounds

$51 / 1,210$

$19 / 53$

\begin{tabular}{|c|c|}
\hline $\begin{array}{l}\text { Percent Out } \\
\text { of Limit }\end{array}$ & $\begin{array}{c}\text { Concentration Range } \\
\text { Detections } \\
\end{array}$ \\
\hline 1.1 & $\omega$ \\
\hline 100.0 & $0.681-0.94 \mu \mathrm{S} / \mathrm{cm}$ \\
\hline 0.7 & $868-1,320 \mu \mathrm{g} / \mathrm{L}$ \\
\hline 0.4 & $17.1 \mu \mathrm{g} / \mathrm{L}$ \\
\hline
\end{tabular}

4.2

17.7

9.1

1.5

2.0

47-107 $\mu \mathrm{g} / \mathrm{L}$

$3.05 \mu \mathrm{g} / \mathrm{L}$

7-9 $\mu \mathrm{g} / \mathrm{L}$

273-500 $\mu \mathrm{g} / \mathrm{L}$

2.3

0.5

0.5

0.5

0.5

13.3

0.6

4.8

0.6

10.8

0.5

1.2

1.1

1.1

0.5

0.6

4.8

7.7

33.3

0.5

0.5

0.5

1.1

0.5

2.3

4.2

35.8

$$
\begin{gathered}
0.89 \mu \mathrm{g} / \mathrm{L} \\
0.5 \mu \mathrm{g} / \mathrm{L} \\
1 \mu \mathrm{g} / \mathrm{L} \\
0.72 \mu \mathrm{g} / \mathrm{L} \\
0.4-0.92 \mu \mathrm{g} / \mathrm{L} \\
13 \mu \mathrm{g} / \mathrm{L} \\
3-7 \mu \mathrm{g} / \mathrm{L} \\
1 \mu \mathrm{g} / \mathrm{L} \\
10-28 \mu \mathrm{g} / \mathrm{L} \\
0.84 \mu \mathrm{g} / \mathrm{L} \\
0.4-0.74 \mu \mathrm{g} / \mathrm{L} \\
0.4-0.71 \mu \mathrm{g} / \mathrm{L} \\
0.86-1 \mu \mathrm{g} / \mathrm{L} \\
0.51 \mu \mathrm{g} / \mathrm{L} \\
4.8 \mu \mathrm{g} / \mathrm{L} \\
1.3 \mu \mathrm{g} / \mathrm{L} \\
2-18 \mu \mathrm{g} / \mathrm{L} \\
0.3 \mu \mathrm{g} / \mathrm{L} \\
0.184 \mu \mathrm{g} / \mathrm{L} \\
0.24 \mu \mathrm{g} / \mathrm{L} \\
0.63 \mu \mathrm{g} / \mathrm{L} \\
0.11-2 \mu \mathrm{g} / \mathrm{L} \\
3.4 \mu \mathrm{g} / \mathrm{L} \\
0.71-0.78 \mu \mathrm{g} / \mathrm{L}
\end{gathered}
$$


Table D.10. (contd)

\begin{tabular}{|c|c|c|c|c|}
\hline \multicolumn{2}{|l|}{ Constituent } & $\begin{array}{c}\text { Detection Frequency, number } \\
\text { of detections/number of } \\
\text { analyses }^{(a)}\end{array}$ & $\begin{array}{c}\text { Percent Out } \\
\text { of Limit }\end{array}$ & $\begin{array}{c}\text { Concentration Range of } \\
\text { Detections }\end{array}$ \\
\hline \multicolumn{5}{|c|}{ Semivolatile Organic Compounds (contd) } \\
\hline 2-sec-Butyl-4,6-dinitrophenol & & $7 / 53$ & 13.2 & $1.2-5 \mu \mathrm{g} / \mathrm{L}$ \\
\hline 4,6-Dinitro-2-methyl phenol & & $16 / 53$ & 30.2 & $1.1-3.8 \mu \mathrm{g} / \mathrm{L}$ \\
\hline Aroclor 1016 & & $1 / 23$ & 4.3 & $0.2 \mu \mathrm{g} / \mathrm{L}$ \\
\hline Aroclor 1221 & & $1 / 17$ & 5.9 & $0.2 \mu \mathrm{g} / \mathrm{L}$ \\
\hline Aroclor 1232 & & $1 / 17$ & 5.9 & $0.2 \mu \mathrm{g} / \mathrm{L}$ \\
\hline Aroclor 1242 & & $1 / 17$ & 5.9 & $0.2 \mu \mathrm{g} / \mathrm{L}$ \\
\hline Aroclor 1248 & & $1 / 17$ & 5.9 & $0.2 \mu \mathrm{g} / \mathrm{L}$ \\
\hline Aroclor 1254 & & $1 / 17$ & 5.9 & $0.19 \mu \mathrm{g} / \mathrm{L}$ \\
\hline Aroclor 1260 & & $1 / 18$ & 5.6 & $0.19 \mu \mathrm{g} / \mathrm{L}$ \\
\hline Pentachlorophenol & & $1 / 54$ & 1.9 & $78.7 \mu \mathrm{g} / \mathrm{L}$ \\
\hline \multirow[t]{2}{*}{ Tributyl phosphate } & & $1 / 2$ & 50.0 & $50 \mu \mathrm{g} / \mathrm{L}$ \\
\hline & & Metals & & • \\
\hline Total Metals & & $607 / 3,477$ & 17.5 & - \\
\hline Aluminum & & $90 / 176$ & 51.1 & $44.9-271 \mu \mathrm{g} / \mathrm{L}$ \\
\hline Barium & & $7 / 176$ & 4.0 & $1.5-2.2 \mu \mathrm{g} / \mathrm{L}$ \\
\hline Calcium & & $167 / 176$ & 94.9 & $20.9-28.8 \mu \mathrm{g} / \mathrm{L}$ \\
\hline Chromium & & $5 / 180$ & 2.8 & $4.3-6.8 \mu \mathrm{g} / \mathrm{L}$ \\
\hline Copper & & $8 / 176$ & 4.5 & $8.1-15 \mu \mathrm{g} / \mathrm{L}$ \\
\hline Iron & & $161 / 175$ & 92.0 & $20.8-128 \mu \mathrm{g} / \mathrm{L}$ \\
\hline Magnesium & & $51 / 176$ & 29.0 & $91.4-320 \mu \mathrm{g} / \mathrm{L}$ \\
\hline Manganese & & $8 / 177$ & 4.5 & $1.7-2.4 \mu \mathrm{g} / \mathrm{L}$ \\
\hline Silver & & $2 / 176$ & 1.1 & $10.7-138 \mu \mathrm{g} / \mathrm{L}$ \\
\hline Sodium & & $59 / 176$ & 33.5 & $60.4-468 \mu \mathrm{g} / \mathrm{L}$ \\
\hline Vanadium & & $28 / 176$ & 15.9 & $4.2-14.6 \mu \mathrm{g} / \mathrm{L}$ \\
\hline Zinc & & $21 / 176$ & 11.9 & $5.1-72.3 \mu \mathrm{g} / \mathrm{L}$ \\
\hline . & & Radiological Parameters & & \\
\hline Total Radiological Parameters & & $9 / 1,358^{(b)}$ & 0.7 & - \\
\hline Strontium-90 & & $2 / 68$ & 2.9 & $1.39 \mathrm{pCi} / \mathrm{L}$ \\
\hline Tritium & . & $3 / 108$ & 2.8 & $8.86-13.5 \mathrm{pCi} / \mathrm{L}$ \\
\hline Total uranium & & $4 / 77$ & 5.2 & $0.151-0.327 \mu \mathrm{g} / \mathrm{L}$ \\
\hline
\end{tabular}

(a) Quality control limits for footnoted compounds are five times the method detection limit.

(b) Minimum detectable activities of zero were calculated on occasion for potassium-40 and technetium-99; only nonzero, positive minimum detectable activities were used in the evaluation. 
Table D.11. Laboratory Control Samples

\begin{tabular}{|c|c|c|c|c|}
\hline Constituent & $\begin{array}{l}\text { Out-of-Limit Results } \\
\text { (Range } 1)^{(\mathrm{a})} \text { number } \\
\text { out/number of analyses }\end{array}$ & $\begin{array}{c}\text { Percent Out } \\
\text { of Limit } \\
\text { (Range 1) }^{(2)}\end{array}$ & $\begin{array}{c}\text { Out-of-Limit } \\
\text { Results (Range 2), } \\
\text { number out/number } \\
\text { of analyses }\end{array}$ & $\begin{array}{c}\text { Percent Ou } \\
\text { of Limit } \\
\text { (Range 2) }^{(b)}\end{array}$ \\
\hline \multicolumn{5}{|c|}{ General Chemical Parameters } \\
\hline & Range: $80-120 \%$ & & Range: $90-110 \%$ & \\
\hline $\begin{array}{l}\text { Total General Chemical } \\
\text { Parameters }\end{array}$ & $0 / 816$ & 0 & $35 / 816$ & 4.3 \\
\hline Alkalinity & - & -- & $12 / 167$ & 7.2 \\
\hline Chemical oxygen demand & - & -- & $4 / 12$ & 33.3 \\
\hline Total dissolved solids & - & -- & $3 / 68$ & 4.4 \\
\hline Total organic carbon & - & - & $11 / 276$ & 4.0 \\
\hline Total organic halides & - & - & $5 / 257$ & 1.9 \\
\hline \multicolumn{5}{|c|}{ Ammonia and Anions } \\
\hline & Range: $80-120 \%$ & & Range: $90-110 \%$ & \\
\hline Total Ammonia and Anions & $0 / 1655$ & 0 & $47 / 1655$ & 2.8 \\
\hline Chloride & - & - & $1 / 304$ & 0.3 \\
\hline Cyanide & - & - & $8 / 46$ & 17.4 \\
\hline Fluoride & - & - & $14 / 292$ & 4.8 \\
\hline Nitrogen in Nitrate & - & - & $4 / 322$ & 1.2 \\
\hline Nitrogen in Nitrite & - & - & $17 / 346$ & 4.9 . \\
\hline Sulfate & - & - & $3 / 304$ & $1.0^{\circ}$ \\
\hline \multicolumn{5}{|c|}{ Volatile Organic Compounds } \\
\hline & Range: varies & & Range: $70-130 \%$ & \\
\hline $\begin{array}{l}\text { Total Volatile Organic } \\
\text { Compounds }\end{array}$ & - & -- & $37 / 903$ & 4.1 \\
\hline 1,1-Dichloroethene & - & - & $17 / 114$ & 14.9 \\
\hline 1,4-Dichlorobenzene & - & - & $11 / 29$ & 37.9 \\
\hline Benzene & - & - & $2 / 126$ & 1.6 \\
\hline Carbon tetrachloride & - & - & $1 / 12$ & 8.3 \\
\hline Chloroform & - & - & $1 / 12$ & 8.3 \\
\hline Toluene & - & - & $1 / 126$ & 0.8 \\
\hline Trichloroethene & - & - & $1 / 125$ & 0.8 \\
\hline Vinyl chloride & - & - & $2 / 12$ & 16.7 \\
\hline \multicolumn{5}{|c|}{ Semivolatile Organic Compounds } \\
\hline & Range: varies & & Range: $70-130 \%$ & . \\
\hline $\begin{array}{l}\text { Total Semivolatile Organic } \\
\text { Compounds }\end{array}$ & $5 / 284$ & 1.8 & $295 / 1,149$ & 25.7 \\
\hline 1,2,4-Trichlorobenzene & - & - & $5 / 5$ & 100 \\
\hline 2,3,4,6-Tetrachlorophenol & $0 / 16$ & 0 & $6 / 57$ & 10.5 \\
\hline 2,4,5-Trichlorophenol & $0 / 16$ & 0 & $4 / 57$ & 7.0 \\
\hline 2,4,6-Trichlorophenol & $1 / 16$ & 6.3 & $4 / 57$ & 7.0 \\
\hline 2,4-Dichlorophenol & $1 / 16$ & 6.3 & $4 / 57$ & 7.0 \\
\hline 2,4-Dimethylphenol & $0 / 16$ & 0 & $4 / 57$ & 7.0 \\
\hline 2,4-Dinitrophenol & $0 / 16$ & 0 & $13 / 57$ & 22.8 \\
\hline 2,4-Dinitrotoluene & - & - & $1 / 5$ & 20.0 \\
\hline 2,6-Dichlorophenol & - & -- & $4 / 57$ & 7.0 \\
\hline 2-Chlorophenol & $0 / 16$ & 0 & $9 / 62$ & 14.5 \\
\hline
\end{tabular}


Table D.11. (contd)

\begin{tabular}{|c|c|c|c|c|}
\hline Constituent & $\begin{array}{l}\text { Out-of-Limit Results } \\
\text { (Range 1), })^{(2)} \text { number } \\
\text { out/number of analyses }\end{array}$ & $\begin{array}{l}\text { Percent Out } \\
\text { of Limit } \\
\text { (Range 1) }\end{array}$ & $\begin{array}{c}\text { Out-of-Limit } \\
\text { Results (Range } 2)^{(b)} \\
\text { number out/number } \\
\text { of analyses }\end{array}$ & $\begin{array}{l}\text { Percent Out } \\
\text { of Limit } \\
\text { (Range 2) }^{(b)}\end{array}$ \\
\hline \multicolumn{5}{|c|}{ Semivolatile Organic Compounds (contd) } \\
\hline 2-Methylphenol & - & - & $7 / 57$ & 12.3 \\
\hline 2-Nitrophenol & $2 / 16$ & 12.5 & $4 / 57$ & 7.0 \\
\hline Dinitrophenol & - & - & $18 / 57$ & 31.6 \\
\hline 3,4-Dimethylphenol & $0 / 16$ & 0 & $20 / 57$ & 35.1 \\
\hline 4,6-Dinitro-2-methylphenol & $0 / 16$ & 0 & $16 / 57$ & 28.1 \\
\hline 4-Chloro-3-methylphenol & $1 / 16$ & 6.3 & $8 / 62$ & 12.9 \\
\hline 4-Nitrophenol & $0 / 16$ & 0 & $60 / 62$ & 96.8 \\
\hline Acenaphthene & - & - & $3 / 8$ & 37.5 \\
\hline Aldrin & - & - & $1 / 4$ & 25.0 \\
\hline Anthracene & - & - & $1 / 3$ & 33.3 \\
\hline Aroclor 1016 & $0 / 6$ & 0 & $7 / 22$ & 31.8 \\
\hline Benzo(a)pyrene & - & - & $3 / 3$ & 100 \\
\hline Benzo(ghi)perylene & - & - & $2 / 3$ & 66.7 \\
\hline Benzo(k)fluoranthene & - & - & $3 / 3$ & 100 \\
\hline Dibenz $[a, h] a n t h r a c e n e$ & - & - & $3 / 3$ & 100 \\
\hline Dieldrin & - & - & $1 / 4$ & 25.0 \\
\hline Diesel oil & - & - & $3 / 7$ & 42.9 \\
\hline Endrin & - & - & $1 / 4$ & 25.0 \\
\hline Gamma-BHC & - & - & $1 / 4$ & 25.0 \\
\hline Indeno(1,2,3-cd)pyrene & - & - & $2 / 3$ & 66.7 \\
\hline Pentachlorophenol & $0 / 16$ & 0 & $10 / 62$ & 16.1 \\
\hline Phenol & $0 / 16$ & 0 & $46 / 47$ & 97.9 \\
\hline \multirow[t]{3}{*}{ Pyrene } & - & - & $4 / 8$ & 50.0 \\
\hline & \multicolumn{2}{|c|}{ Metals } & & \\
\hline & Range: $80-120 \%$ & & Range: $70-130 \%$ & \\
\hline Total Metals & $77 / 3517$ & 2.2 & $10 / 3517$ & 0.3 \\
\hline Antimony & $2 / 178$ & 1.1 & $2 / 178$ & 1.1 \\
\hline Iron & $2 / 178$ & 1.1 & $0 / 178$ & 0 \\
\hline Silver & $72 / 178$ & 40.4 & $7 / 178$ & 3.9 \\
\hline \multirow[t]{3}{*}{ Zinc } & $1 / 178$ & 0.6 & $1 / 178$ & 0.6 \\
\hline & \multicolumn{2}{|c|}{ Radiological Parameters } & & \\
\hline & Range: $70-130 \%$ & & & \\
\hline Total Radiological Parameters & $16 / 913$ & 1.8 & - & - \\
\hline Americium-241 & $1 / 3$ & 33.3 & - & - \\
\hline Cesium-137 & $3 / 65$ & 4.6 & - & - \\
\hline Cobalt -60 & $2 / 66$ & 3.0 & - & - \\
\hline Europium-152 & $2 / 66$ & 3.0 & - & - \\
\hline Technetium-99 & $1 / 75$ & 1.3 & - & - \\
\hline Uranium-235 & $7 / 31$ & 22.6 & - & - \\
\hline
\end{tabular}

(a) Range 1 corresponds to the laboratory $\mathrm{QC}$ limits.

(b) For organic compounds, range 2 is based on guidance in Method 8000 (SW-846). For other constituent classes, range 2 consists of arbitrarily chosen limits that make it easier to evaluate laboratory performance. 
Table D.12. Matrix Spikes and Matrix Spike Duplicates

\begin{tabular}{|c|c|c|c|c|}
\hline Constituent & $\begin{array}{l}\text { Out-of-Limit Results } \\
\text { (Range } 1),{ }^{(a)} \text { number } \\
\text { out/number of analyses }\end{array}$ & $\begin{array}{l}\text { Percent Out } \\
\text { of Limit } \\
\text { (Range 1) }\end{array}$ & $\begin{array}{c}\text { Out-of-Limit } \\
\text { Results (Range } 2),{ }^{(b)} \\
\text { number out/number } \\
\text { of analyses }\end{array}$ & $\begin{array}{c}\text { Percent Out } \\
\text { of Limit } \\
\text { (Range 2) }^{(b)}\end{array}$ \\
\hline \multicolumn{5}{|c|}{ General Chemical Parameters } \\
\hline \multicolumn{5}{|c|}{ Range: $80-120 \%$} \\
\hline $\begin{array}{l}\text { Total General Chemical } \\
\text { Parameters }\end{array}$ & $17 / 267$ & 6.4 & - & - \\
\hline Total organic carbon & $3 / 11$ & 27.3 & -- & - \\
\hline Total organic halides & $14 / 127$ & 11.0 & - & - \\
\hline \multicolumn{5}{|c|}{ Ammonia and Anions } \\
\hline \multicolumn{5}{|c|}{ Range: $80-120 \%$} \\
\hline Total Ammonia and Anions & $55 / 745$ & 7.4 & - & - \\
\hline Chloride & $.1 / 107$ & 0.9 & - & - \\
\hline Cyanide & $3 / 32$ & 9.4 & - & - \\
\hline Nitrogen in Nitrate & $2 / 21$ & 9.5 & - & - \\
\hline Nitrogen in Nitrate & $35 / 137$ & 25.5 & - & - \\
\hline Nitrogen in Nitrite & $4 / 156$ & 2.6 & - & - \\
\hline Sulfate & $10 / 131$ & 7.6 & - & - \\
\hline \multicolumn{5}{|c|}{ Volatile Organic Compounds } \\
\hline & $\begin{array}{l}\text { Range: Laboratory QC } \\
\text { Limits }\end{array}$ & & Range: $70-130 \%$ & \\
\hline $\begin{array}{l}\text { Total Volatile Organic } \\
\text { Compounds }\end{array}$ & $1 / 95$ & 1.1 & $73 / 1,070$ & 6.8 \\
\hline 1,1-Dichloroethane & - & - & $5 / 23$ & 21.7 \\
\hline 1,1-Dichloroethene & - & - & $39 / 150$ & 26.0 \\
\hline 1,4-Dichlorobenzene & - & - & $11 / 33$ & 33.3 \\
\hline Benzene & - & - & $3 / 173$ & 1.7 \\
\hline Chloroform & - & - & $3 / 12$ & 25.0 \\
\hline Tetrachloroethene & - & - & $3 / 12$ & 25.0 \\
\hline Toluene & - & -- & $2 / 173$ & 1.2 \\
\hline Trichloroethene & $1 / 9$ & 11.1 & $5 / 173$ & 2.9 \\
\hline Vinyl chloride & & & $3 / 12$ & 25.0 \\
\hline \multicolumn{5}{|c|}{ Semivolatile Organic Compounds } \\
\hline & $\begin{array}{l}\text { Range: Laboratory QC } \\
\text { Limits }\end{array}$ & & Range: $70-130 \%$ & \\
\hline $\begin{array}{l}\text { Total Semivolatile Organic } \\
\text { Compounds }\end{array}$ & $16 / 296$ & 5.4 & $406 / 1,444$ & 28.1 \\
\hline 1,2,4-Trichlorobenzene & $3 / 10$ & 30.0 & $6 / 8$ & 75.0 \\
\hline 2,3,4,6-Tetrachlorophenol & - & - & $5 / 74$ & 6.8 \\
\hline 2,4,5-Trichlorophenol & $2 / 10$ & 20.0 & $6 / 74$ & 8.1 \\
\hline 2,4,6-Trichlorophenol & $2 / 20$ & 10.0 & $5 / 74$ & 6.8 \\
\hline 2,4-Dichlorophenol & $2 / 20$ & 10.0 & $7 / 74$ & $9.5^{\circ}$ \\
\hline 2,4-Dimethylphenol & $1 / 20$ & 5.0 & $13 / 74$ & 17.6 \\
\hline 2,4-Dinitrophenol & $0 / 20$ & 0.0 & $11 / 74$ & 14.9 \\
\hline 2,4-Dinitrotoluene & - & - & $3 / 8$ & 37.5 \\
\hline
\end{tabular}


Table D.12. (contd)

\begin{tabular}{|c|c|c|c|c|}
\hline Constituent & $\begin{array}{l}\text { Out of Limit Results } \\
\text { (Range } 1)^{(a)} \text { number } \\
\text { out/number of analyses }\end{array}$ & $\begin{array}{c}\text { Percent Out } \\
\text { of Limit } \\
\text { (Range 1) }\end{array}$ & $\begin{array}{l}\text { Out of Limit Results } \\
\text { (Range } 2)^{(b)} \text { number } \\
\text { out } / \text { number of } \\
\text { analyses }\end{array}$ & $\begin{array}{c}\text { Percent Out } \\
\text { of Limit } \\
\text { (Range 2) } \\
\text { (o) }\end{array}$ \\
\hline & \multicolumn{3}{|c|}{ Semivolatile Organic Compounds (contd) } & \\
\hline 2,6-Dichlorophenol & $2 / 10$ & 20.0 & $5 / 74$ & 6.8 \\
\hline 2-Chlorophenol & $0 / 20$ & 0.0 & $15 / 82$ & 18.3 \\
\hline 2-Dimethylphenol & $0 / 10$ & 0.0 & $22 / 74$ & 29.7 \\
\hline 2-Nitrophenol & $2 / 20$ & 10.0 & $7 / 74$ & 9.5 \\
\hline Dinitrophenol & $0 / 10$ & 0.0 & $26 / 74$ & 35.1 \\
\hline 3,4-Dimethylphenol & $0 / 10$ & 0.0 & $40 / 74$ & 54.1 \\
\hline 4.4'-DDT & - & - & $1 / 4$ & 25.0 \\
\hline 4,6-Dinitro-2-methylphenol & $0 / 20$ & 0.0 & $15 / 74$ & 20.3 \\
\hline 4-Chloro-3-methylphenol & $2 / 20$ & 10.0 & $9 / 82$ & 11.0 \\
\hline 4-Nitrophenol & $0 / 20$ & 0.0 & $81 / 82$ & 98.8 \\
\hline Acenaphthene & -- & - & $6 / 10$ & 60.0 \\
\hline Acenaphthylene & - & - & $2 / 2$ & 100.0 \\
\hline Aldrin & - & - & $1 / 4$ & 25.0 \\
\hline Anthracene & - & - & $2 / 2$ & 100.0 \\
\hline Aroclor 1016 & $0 / 8$ & 0.0 & $8 / 22$ & 36.4 \\
\hline Aroclor 1260 & $0 / 8$ & 0.0 & $5 / 22$ & 22.7 \\
\hline Benzo(a)anthracene & $\cdots$ & -- & $1 / 2$ & 50.0 \\
\hline Benzo(a)pyrene & - & - & $1 / 2$ & 50.0 \\
\hline Benzo(b)fluoranthene & - & - & $1 / 2$ & 50.0 \\
\hline Benzo(ghi)perylene & - & - & $2 / 2$ & 100.0 \\
\hline Benzo(k)fluoranthene & - & - & $2 / 2$ & 100.0 \\
\hline Chrysene & - & - & $2 / 2$ & 100.0 \\
\hline Dibenz $(\mathrm{a}, \mathrm{h})$ anthracene & - & - & $2 / 2$ & 100.0 \\
\hline Dieldrin & - & - & $3 / 4$ & 75.0 \\
\hline Diesel oil & - & - & $3 / 6$ & 50.0 \\
\hline Endrin & - & - & $0 / 4$ & 0.0 \\
\hline Fluoranthene & - & - & $2 / 2$ & 100.0 \\
\hline Fluorene & - & - & $1 / 2$ & 50.0 \\
\hline Heptachlor & - & - & $3 / 4$ & 75.0 \\
\hline Indeno(1,2,3-d)pyrene & - & - & $2 / 2$ & 100.0 \\
\hline N-nitroso-di-n-propylamine & - & - & $4 / 8$ & 50.0 \\
\hline Naphthalene & - & - & $1 / 2$ & 50.0 \\
\hline Pentachlorophenol & $0 / 20$ & 0.0 & $13 / 82$ & 15.9 \\
\hline Phenanthrene & - & - & $1 / 2$ & 50.0 \\
\hline Phenol & $0 / 20$ & 0.0 & $82 / 82$ & 100.0 \\
\hline Pyrene & $0 / 20$ & 0.0 & $6 / 10$ & 60.0 \\
\hline
\end{tabular}

Total Metals

Aluminum

Antimony
Range: $80-120 \%$

$116 / 5,444$
$7 / 242$
$6 / 111$

2.1

2.9

5.4

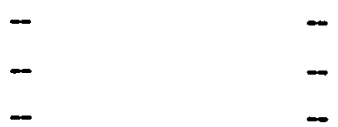


Table D.12. (contd)

\begin{tabular}{|c|c|c|c|c|}
\hline Constituent & $\begin{array}{l}\text { Out-of-Limit Results } \\
\text { (Range 1), }{ }^{(2)} \text { number } \\
\text { out/number of analyses }\end{array}$ & $\begin{array}{l}\text { Percent Out } \\
\text { of Limit } \\
\text { (Range 1) }\end{array}$ & $\begin{array}{c}\text { Out-of-Limit } \\
\text { Results (Range 2), } \\
\text { number out/number } \\
\text { of analyses }\end{array}$ & $\begin{array}{l}\text { Percent Out } \\
\text { of Limit } \\
\text { (Range 2) }^{(\text {b) }}\end{array}$ \\
\hline \multicolumn{5}{|c|}{ Metals (contd) } \\
\hline Barium & $1 / 215$ & 0.5 & - & - \\
\hline Cadmium & $17 / 277$ & 6.1 & - & - \\
\hline Calcium & $4 / 211$ & 1.9 & - & - \\
\hline Chromium & $6 / 281$ & 2.1 & - & - \\
\hline Copper & $2 / 211$ & 0.9 & - & - \\
\hline Iron & $15 / 273$ & 5.5 & - & - \\
\hline Lead & $3 / 84$ & 3.6 & - & -- \\
\hline Magnesium & $2 / 211$ & 0.9 & - & - \\
\hline Manganese & $6 / 213$ & 2.8 & - & - \\
\hline Silver & $43 / 273$ & 15.8 & - & - \\
\hline Vanadium & $2 / 215$ & 0.9 & - & - \\
\hline Zinc & $2 / 209$ & 1.0 & - & - \\
\hline \multicolumn{5}{|c|}{ Radiological Parameters } \\
\hline \multicolumn{5}{|c|}{ Range: $70-130 \%$} \\
\hline Total Radiological Parameters & $8 / 266$ & 3.0 & -- & - \\
\hline Technetium-99 & $4 / 76$ & 5.3 & - & - \\
\hline Tritium & $1 / 107$ & 0.9 & - & - \\
\hline Uranium & $3 / 76$ & 3.9 & - & - \\
\hline
\end{tabular}

(a) Range 1 corresponds to the laboratory QC limits.

(b) For organic compounds, range 2 is based on guidance in Method 8000 (SW-846). For other constituent classes, range 2 consists of arbitrarily chosen limits that make it easier to evaluate laboratory performance. 
Table D.13. Matrix Duplicates

\begin{tabular}{|c|c|c|}
\hline Constituent & $\begin{array}{c}\text { Out-of-Limit Results, } \\
\text { number out/number of } \\
\text { analyses }\end{array}$ & $\begin{array}{l}\text { Percent Out of } \\
\text { Limit }\end{array}$ \\
\hline \multicolumn{3}{|c|}{ General Chemical Parameters ${ }^{(a)}$} \\
\hline Total General Chemical Parameters & $9 / 366$ & 2.5 \\
\hline Total dissolved solids & $4 / 46$ & 8.7 \\
\hline Total organic carbon & $1 / 107$ & 0.9 \\
\hline Total organic halides & $3 / 104$ & 2.9 \\
\hline Oil/grease & $1 / 1$ & 100.0 \\
\hline \multicolumn{3}{|c|}{ Ammonia and Anions ${ }^{(a)}$} \\
\hline Total Ammonia and Anions & $3 / 663$ & 0.5 \\
\hline Bromide & $1 / 2$ & 50.0 \\
\hline Chloride & $1 / 21$ & 4.8 \\
\hline Fluoride & $1 / 21$ & 4.8 \\
\hline \multicolumn{3}{|c|}{ Radiological Parameters $^{(\mathfrak{b})}$} \\
\hline Total Radiological Parameters & $24 / 1,358$ & 1.8 \\
\hline Carbon-14 & $1 / 13$ & 7.7 \\
\hline Cobalt-60 & $1 / 63$ & 1.6 \\
\hline Gross alpha & $3 / 104$ & 2.9 \\
\hline Gross beta & $2 / 103$ & 1.9 \\
\hline Iodine-129 & $4 / 71$ & 5.6 \\
\hline Plutonium-239/240 & $1 / 10$ & 10.0 \\
\hline Potassium -40 & $6 / 52$ & 11.5 \\
\hline Tritium & $1 / 166$ & 0.6 \\
\hline Uranium & $3 / 75$ & 4.0 \\
\hline Uranium-235 & $1 / 18$ & 5.6 \\
\hline Uranium-238 & $1 / 18$ & 5.6 \\
\hline
\end{tabular}

(a) Quality control limits are greater than the method detection limit.

(b) Quality control limits are greater than five times the method detection limit. 
Table D.14. Surrogates

\begin{tabular}{|c|c|c|c|c|}
\hline Constituent & $\begin{array}{l}\text { Out of Limit Results } \\
\text { (Range } 1)^{(a)} \text { number } \\
\text { out/number of analyses }\end{array}$ & $\begin{array}{l}\text { Percent Out } \\
\text { of Limit } \\
\text { (Range 1) }^{(a)}\end{array}$ & $\begin{array}{c}\text { Out of Limit Results } \\
\text { (Range 2), } \\
\text { number out/number } \\
\text { of analyses }\end{array}$ & $\begin{array}{c}\text { Percent Out } \\
\text { of Limit } \\
\text { (Range 2) } \\
\end{array}$ \\
\hline \multicolumn{5}{|c|}{ Volatile Organic Compounds } \\
\hline & Range: $80-120 \%$ & & Range: $70-130 \%$ & \\
\hline $\begin{array}{l}\text { Total Volatile Organic } \\
\text { Compounds }\end{array}$ & $30 / 1,347$ & 2.2 & $4 / 1347$ & 0.3 \\
\hline 4-Bromofluorobenzene & $15 / 740$ & 2.0 & $1 / 740$ & 0.1 \\
\hline Toluene-d8 & $15 / 607$ & 2.5 & $3 / 607$ & 0.5 \\
\hline \multicolumn{5}{|c|}{ Semivolatile Organic Compounds } \\
\hline & Range: varies & & Range: $70-130 \%$ & \\
\hline $\begin{array}{l}\text { Total Semivolatile Organic } \\
\text { Compounds }\end{array}$ & $44 / 377$ & 11.7 & $203 / 417$ & 48.7 \\
\hline 2,4,6-Tribromophenol & $13 / 224$ & 5.8 & $53 / 224$ & 23.7 \\
\hline 2-Fiuorobiphenyl & - & - & $10 / 20$ & 50.0 \\
\hline 2-Fluorophenol & $31 / 153$ & 20.3 & $134 / 153$ & 87.6 \\
\hline Nitrobenzene-d5 & - & - & $6 / 20$ & 30.0 \\
\hline
\end{tabular}

(a) Range 1 corresponds to the laboratory QC limits.

(b) Range 2 is based on guidance in Method 8000 (SW-846).

Table D.15. Split Sample Results Exceeding Quality Control Limits

\begin{tabular}{|c|c|c|c|}
\hline Constituent & $\begin{array}{c}\text { Quanterra Result, } \\
\mu \mathrm{g} / \mathrm{L}\end{array}$ & $\begin{array}{c}\text { Recra Environmental, Inc. } \\
\text { Result, } \mu \mathrm{g} / \mathrm{L}\end{array}$ & $\begin{array}{c}\text { Relative Percent } \\
\text { Difference }\end{array}$ \\
\hline \multicolumn{4}{|c|}{ Indicator Parameters } \\
\hline Total organic carbon & 2,545 & 3,228 & 23.7 \\
\hline Total organic carbon & 548 & 1,133 & 69.5 \\
\hline \multicolumn{4}{|c|}{ Ammonia and Anions } \\
\hline Nitrogen in nitrate & 9,060 & 33,700 & 115.2 \\
\hline \multicolumn{4}{|c|}{ Metals } \\
\hline Iron (filtered) & 100 & 59.5 & 50.8 \\
\hline Iron & 192 & 602 & 103.3 \\
\hline Zinc & 43.9 & 7.5 & 141.6 \\
\hline \multicolumn{4}{|c|}{ Volatile Organic Compounds } \\
\hline Acetone & $<1.9$ & 17.0 & 159.8 \\
\hline Methylene chloride & $<0.8$ & 15.7 & 181.6 \\
\hline
\end{tabular}


Table D.16. Summary of Quanterra Environmental Services Detection/Quantitation Limits Determined from Field Blank Data

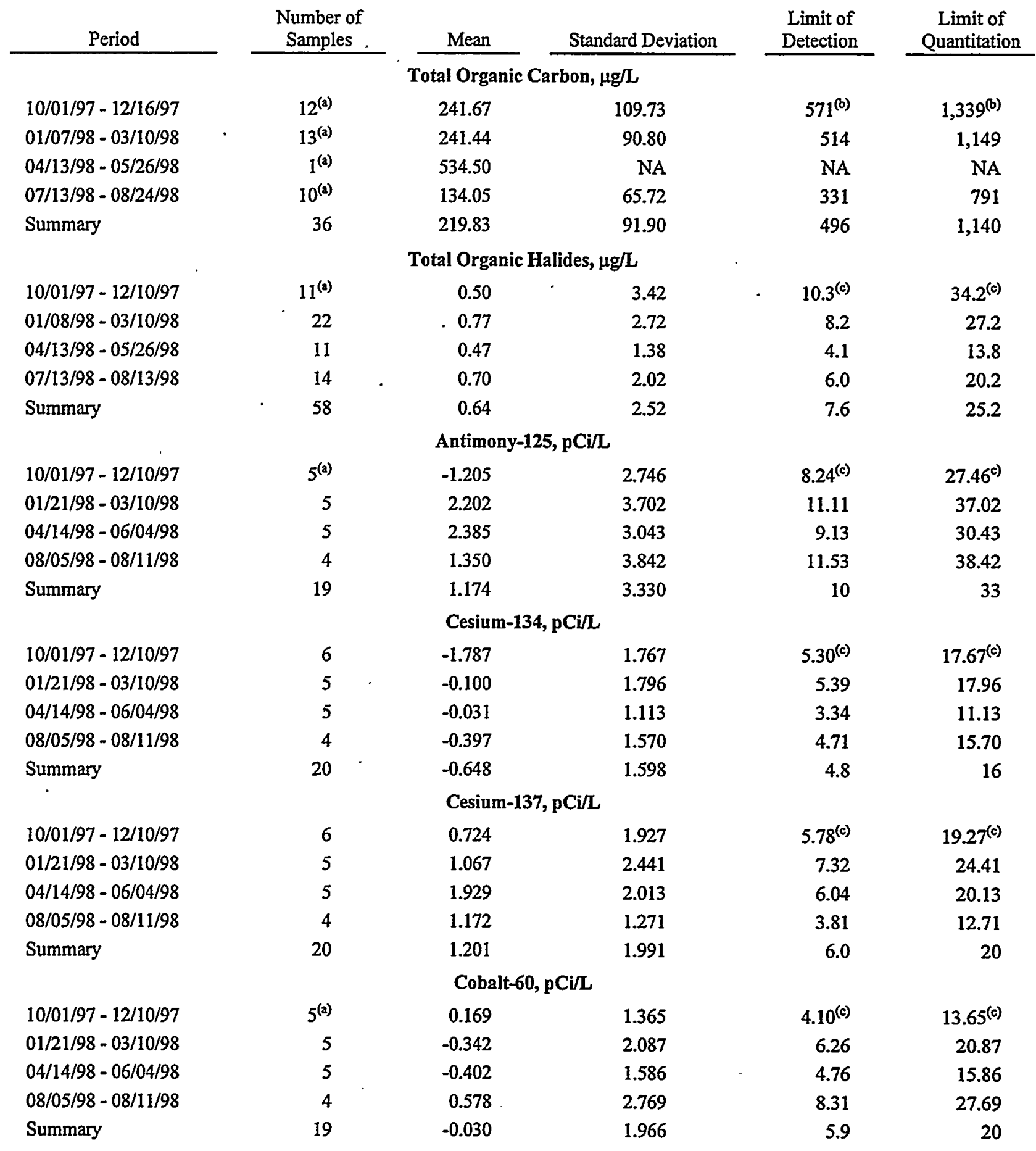


Table D.16. (contd)

\begin{tabular}{|c|c|c|c|c|c|}
\hline Period & $\begin{array}{c}\text { Number of } \\
\text { Samples }\end{array}$ & Mean & Standard Deviation & $\begin{array}{l}\text { Limit of } \\
\text { Detection }\end{array}$ & $\begin{array}{c}\text { Limit of } \\
\text { Quantitation }\end{array}$ \\
\hline \multicolumn{6}{|c|}{ Europium-154, pCi/L } \\
\hline $10 / 01 / 97-12 / 10 / 97$ & $5^{(2)}$ & 0.242 & 4.748 & $14.25^{(\mathrm{c})}$ & $47.48^{(\mathrm{c})}$ \\
\hline $01 / 21 / 98-03 / 10 / 98$ & 5 & 1.170 & 2.404 & 7.21 & 24.04 \\
\hline $04 / 14 / 98-06 / 04 / 98$ & 5 & -0.408 & 7.015 & 21.05 & 70.15 \\
\hline $08 / 05 / 98-08 / 11 / 98$ & 4 & -1.465 & 5.598 & 16.79 & 55.98 \\
\hline Summary & 19 & -0.044 & 5.191 & 16 & 52 \\
\hline \multicolumn{6}{|c|}{ Gross Alpha, pCi/L } \\
\hline $10 / 01 / 97-12 / 16 / 97$ & 7 & 0.212 & 0.181 & $0.54^{(\mathrm{c})}$ & $1.81^{(\mathrm{c})}$ \\
\hline 01/07/98 - 03/31/98 & 13 & 0.065 & 0.135 & 0.41 & 1.35 \\
\hline 04/07/98 - 06/18/98 & 11 & 0.034 & 0.119 & 0.36 & 1.19 \\
\hline 07/08/98 - 08/24/98 & 8 & 0.030 & 0.127 & 0.38 & 1.27 \\
\hline Summary & 39 & 0.075 & 0.138 & 0.42 & 1.4 \\
\hline \multicolumn{6}{|c|}{ Gross Beta, pCi/L } \\
\hline $10 / 01 / 97-12 / 16 / 97$ & 7 & 0.890 & 1.203 & $3.61^{(c)}$ & $12.03^{(c)}$ \\
\hline 01/07/98 - 03/31/98 & 13 & 0.618 & 0.892 & 2.68 & 8.92 \\
\hline 04/07/98 - 06/18/98 & 11 & 1.318 & 1.111 & 3.33 & 11.11 \\
\hline 07/08/98 - 08/24/98 & 8 & 0.518 & 0.514 & 1.54 & 5.14 \\
\hline Summary & 39 & 0.844 & 0.962 & 2.9 & 9.6 \\
\hline \multicolumn{6}{|c|}{ Iodine-129, pCi/L } \\
\hline $10 / 01 / 97-12 / 17 / 97$ & 5 & 0.322 & 0.135 & $0.40^{c)}$ & $1.35^{(\mathrm{c})}$ \\
\hline $01 / 07 / 98-03 / 31 / 98$ & 6 & 0.040 & 0.098 & 0.29 & 0.98 \\
\hline 04/07/98 - 06/17/98 & 5 & -0.128 & 0.267 & 0.80 & 2.67 \\
\hline 07/08/98 - 08/24/98 & 4 & 0.004 & 0.103 & 0.31 & 1.03 \\
\hline Summary & 20 & 0.061 & 0.165 & 0.50 & 1.7 \\
\hline \multicolumn{6}{|c|}{ Strontium-90, pCi/L } \\
\hline $10 / 01 / 97-12 / 04 / 97$ & 5 & 0.203 & 0.150 & $0.45^{(c)}$ & $1.50^{(\mathrm{c})}$ \\
\hline $01 / 07 / 98-03 / 04 / 98$ & 7 & 0.067 & 0.053 & 0.16 & 0.53 \\
\hline $04 / 07 / 98-05 / 21 / 98$ & 4 & 0.042 & 0.130 & 0.39 & 1.30 \\
\hline 07/08/98 - 08/1 1/98 & 3 & 0.090 & 0.078 & 0.24 & 0.78 \\
\hline Summary & 19 & 0.101 & 0.106 & 0.32 & 1.1 \\
\hline \multicolumn{6}{|c|}{ Technetium-99, pCi/L } \\
\hline $10 / 01 / 97-12 / 16 / 97$ & 5 & -0.301 & 5.475 & $16.43^{\mathrm{c})}$ & $54.75^{(c)}$ \\
\hline 02/09/98 - 03/12/98 & 4 & 0.360 & 4.532 & 13.60 & 45.32 \\
\hline 04/14/98 - 06/18/98 & 9 & -0.358 & 3.284 & 9.85 & 32.84 \\
\hline 08/05/98 - 08/13/98 & 4 & 2.453 & 3.298 . & 9.89 & 32.98 \\
\hline Summary & 22 & 0.296 & 4.086 & 12 & 41 \\
\hline
\end{tabular}


Table D.16. (contd)

\begin{tabular}{|c|c|c|c|c|c|}
\hline Period & $\begin{array}{l}\text { Number of } \\
\text { Samples }\end{array}$ & Mean & Standard Deviation & $\begin{array}{l}\text { Limit of } \\
\text { Detection }\end{array}$ & $\begin{array}{c}\text { Limit of } \\
\text { Quantitation }\end{array}$ \\
\hline \multicolumn{6}{|c|}{ Tritium, pCi/L } \\
\hline $10 / 01 / 97$ - 12/18/97 & 11 & 128.3 & 99.1 & $297.4^{(\mathrm{c})}$ & $991.4^{(\mathrm{c})}$ \\
\hline $01 / 07 / 98-03 / 31 / 98$ & 14 & 122.9 & 85.8 & 257.3 & 857.7 \\
\hline $04 / 07 / 98-06 / 18 / 98$ & 12 & 129.8 & 101.9 & 305.7 & $1,019.1$ \\
\hline $07 / 08 / 98-08 / 24 / 98$ & 8 & 115.6 & 79.0 & 237.0 & 790.1 \\
\hline Summary & 45 & 124.8 & 92.6 & 278 & 926 \\
\hline \multicolumn{6}{|c|}{ Uranium, $\mu \mathrm{g} / \mathrm{L}$} \\
\hline $10 / 01 / 97-12 / 04 / 97$ & 4 & 0.0148 & 0.0156 & $0.062^{(b)}$ & $0.171^{(\mathfrak{b})}$ \\
\hline $02 / 09 / 98-02 / 20 / 98$ & 2 & 0.0041 & 0.0022 & 0.011 & 0.026 \\
\hline $04 / 14 / 98-08 / 05 / 98$ & 7 & 0.0203 & 0.0299 & 0.110 & 0.319 \\
\hline Surmmary & 13 & 0.0161 & 0.0260 & 0.094 & 0.277 \\
\hline
\end{tabular}

(a) Excluded outlier.

(b) Limit of detection equals the mean blank concentration plus 3 standard deviations; limit of quantitation equals the mean blank concentration plus 10 standard deviations.

(c) Limit of detection (blank corrected) equals 3 times the blank standard deviation; limit of quantitation (blank corrected) equals 10 times the blank standard deviation. 


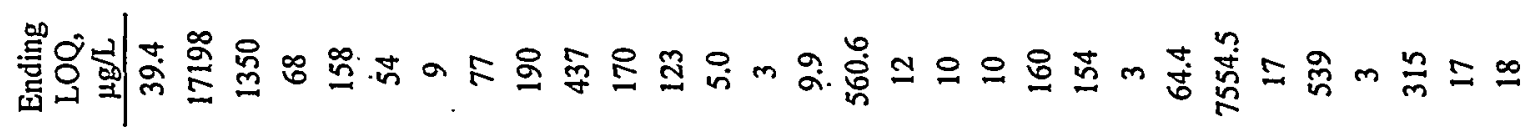

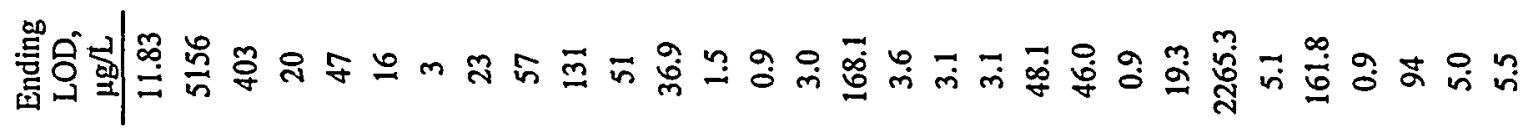

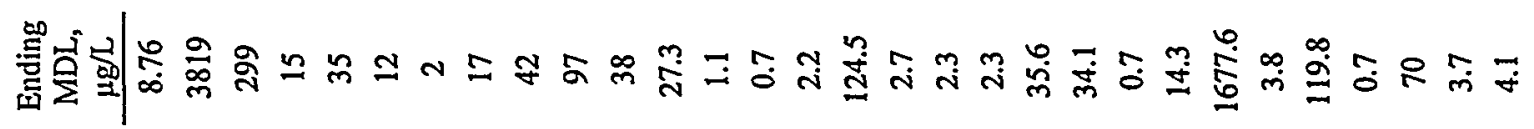
总:

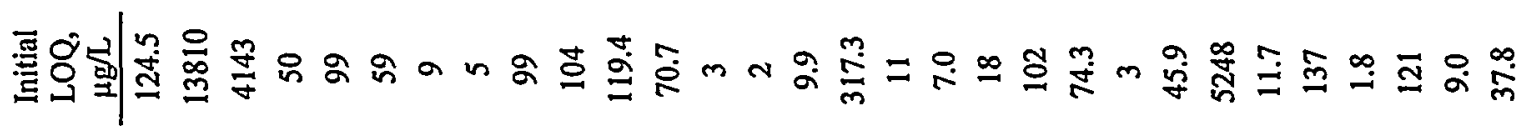

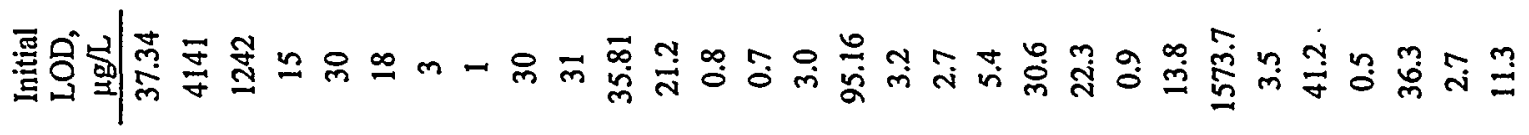

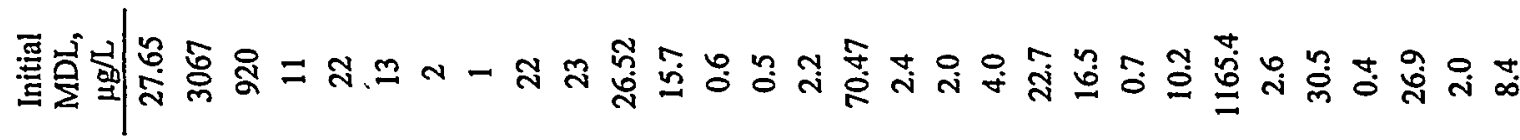

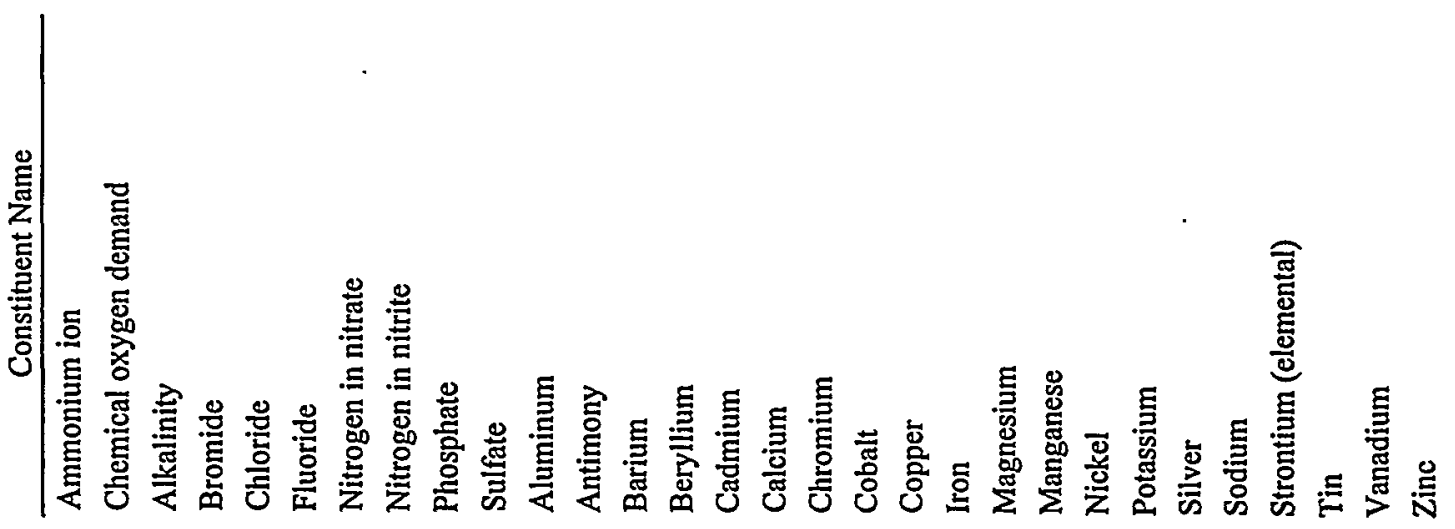

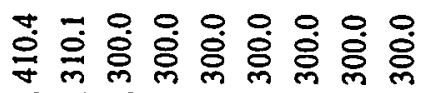

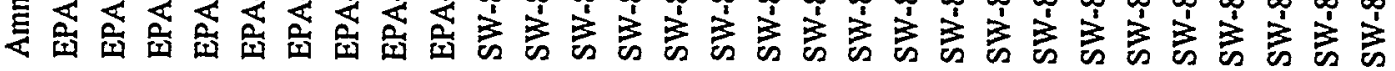




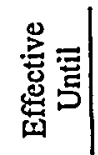

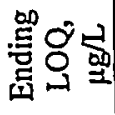

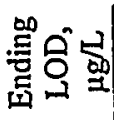

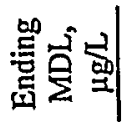

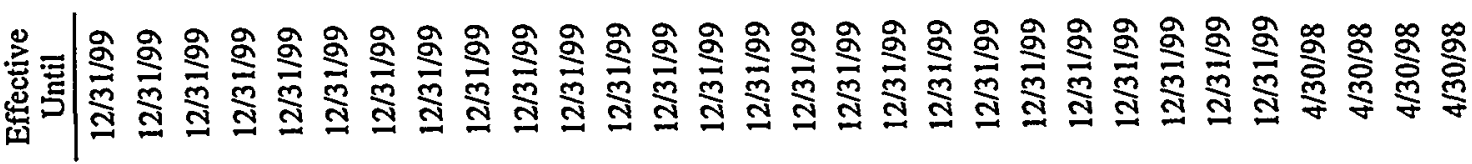

高

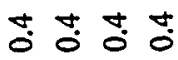

वें०்

$\stackrel{\infty}{\circ} \stackrel{\circ}{\circ} \stackrel{\circ}{\circ} \stackrel{\circ}{0}$

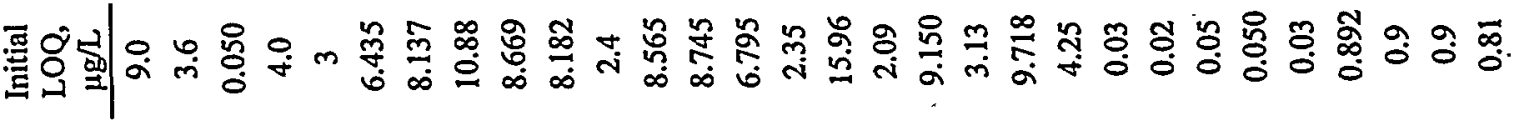

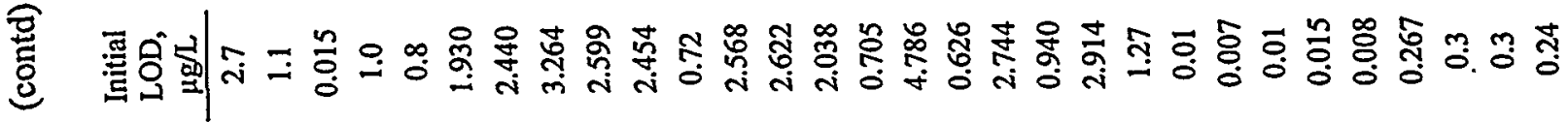
点

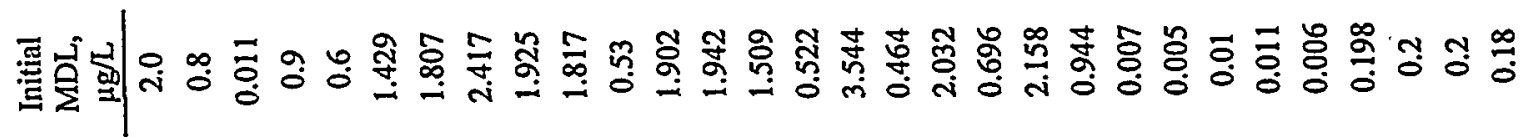

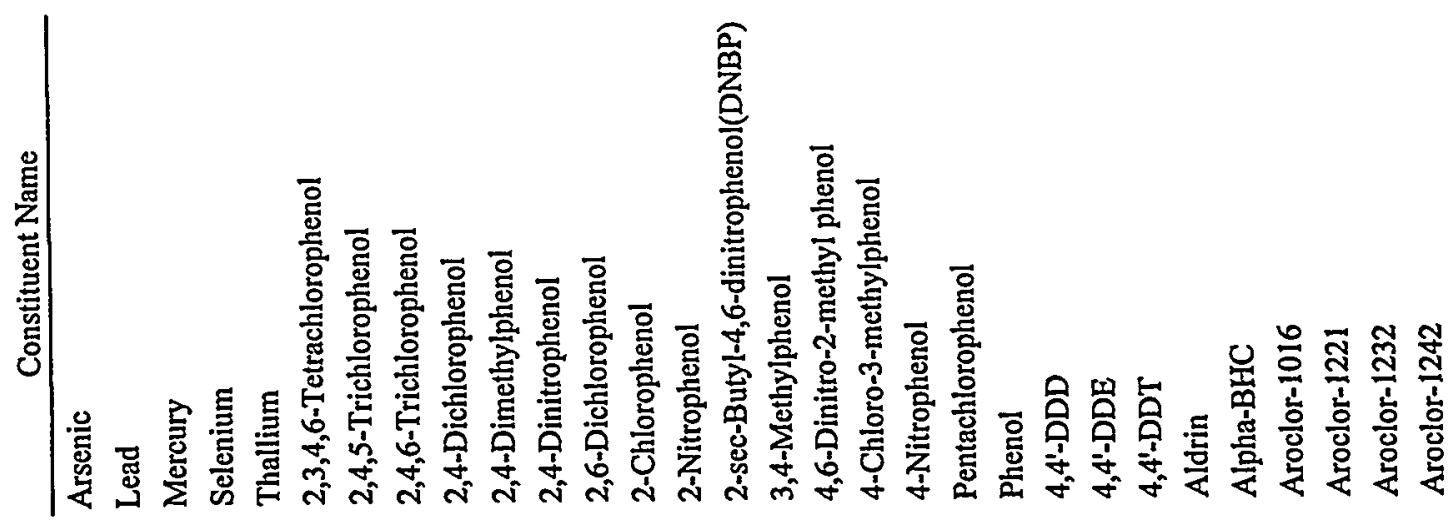

密

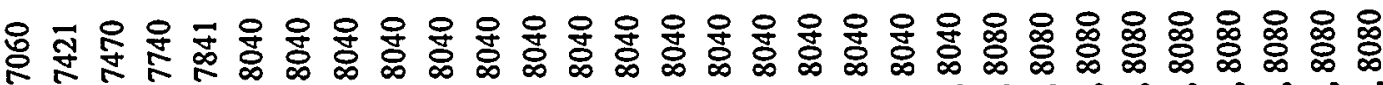

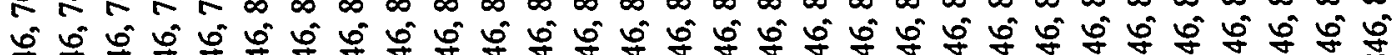

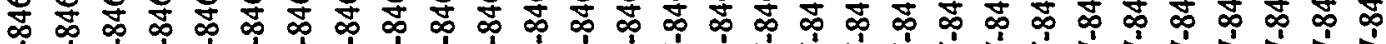

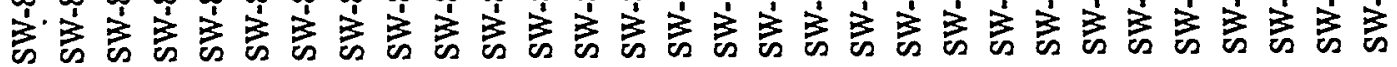




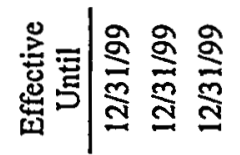

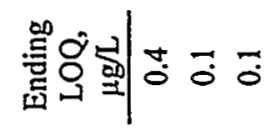

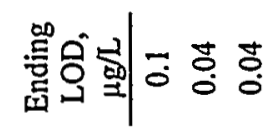

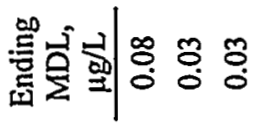

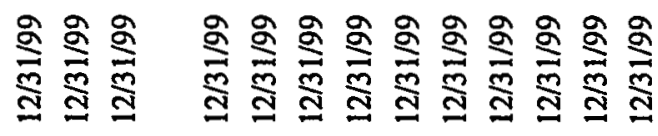

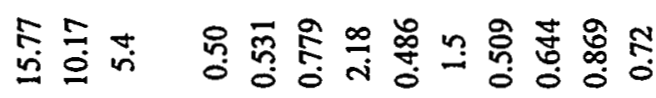

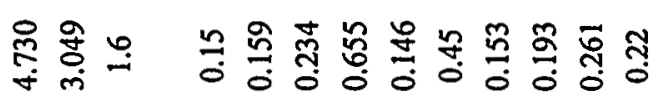

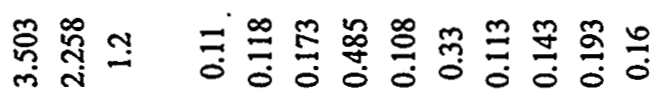

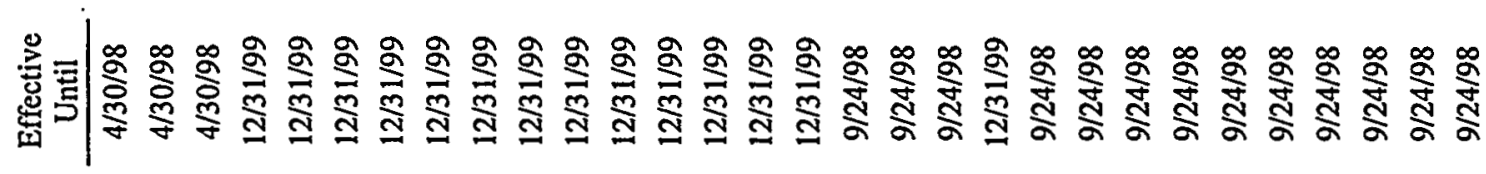

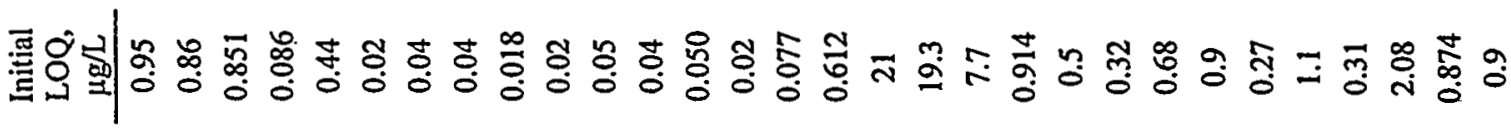

总

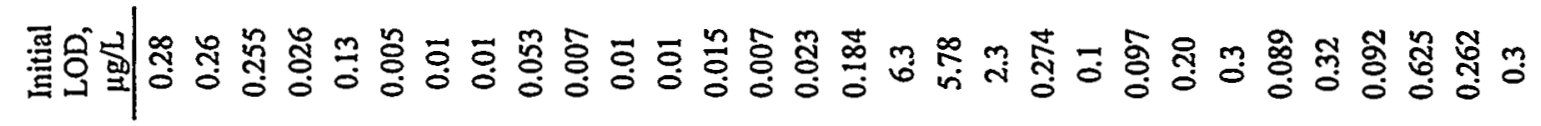

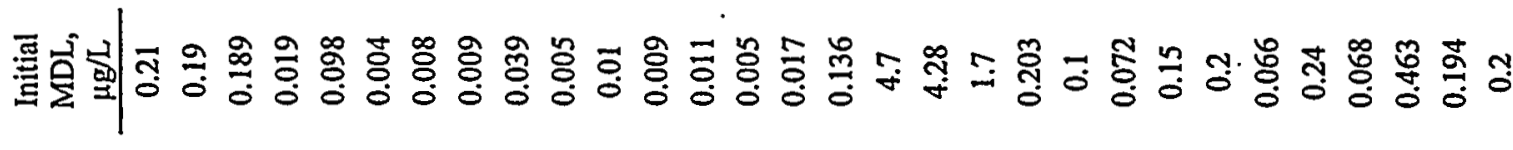
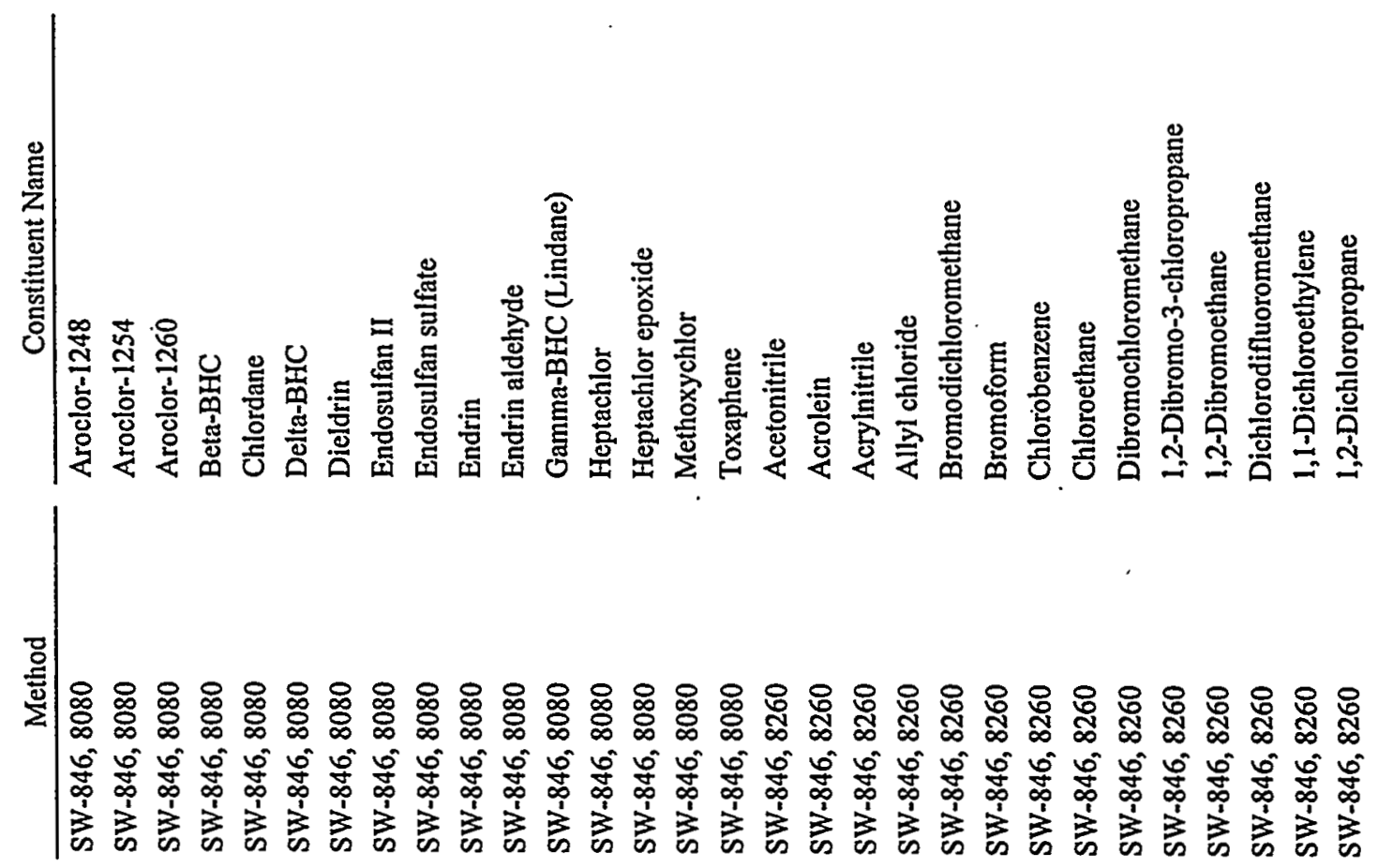


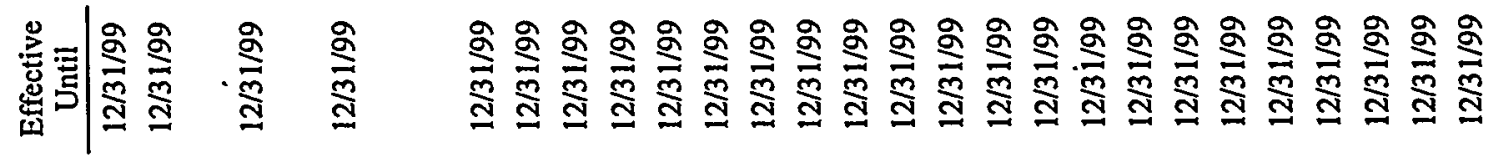

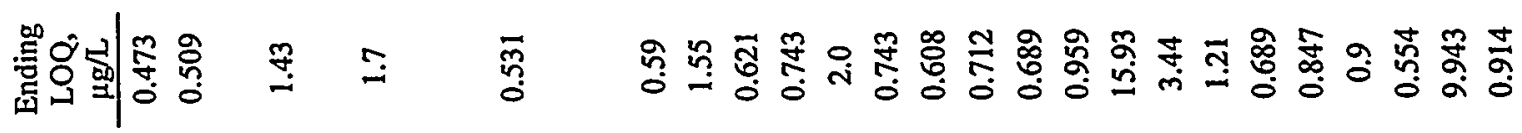

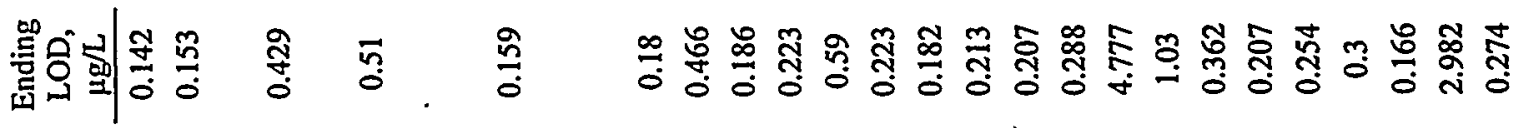

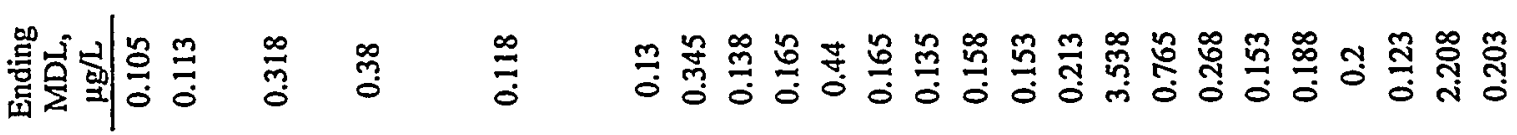

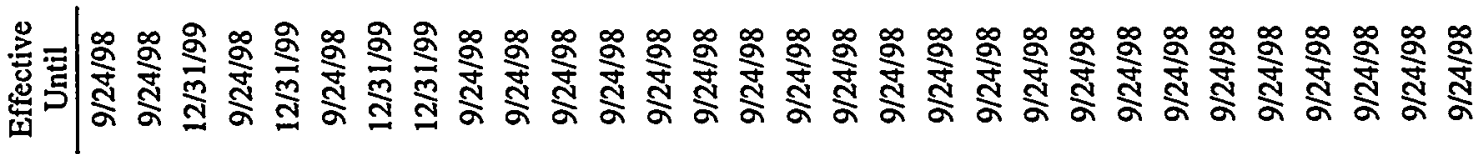

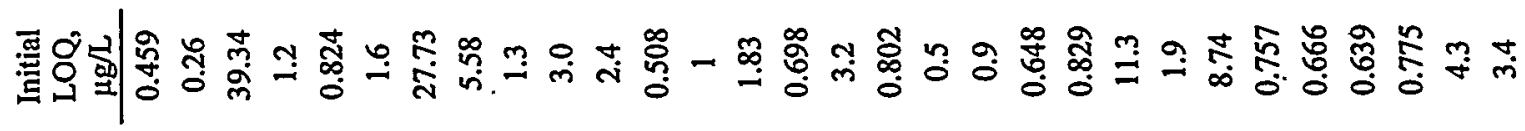

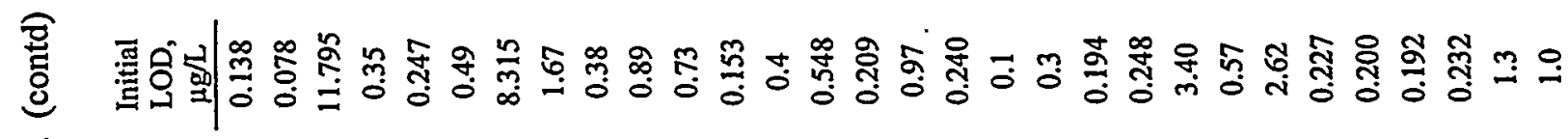

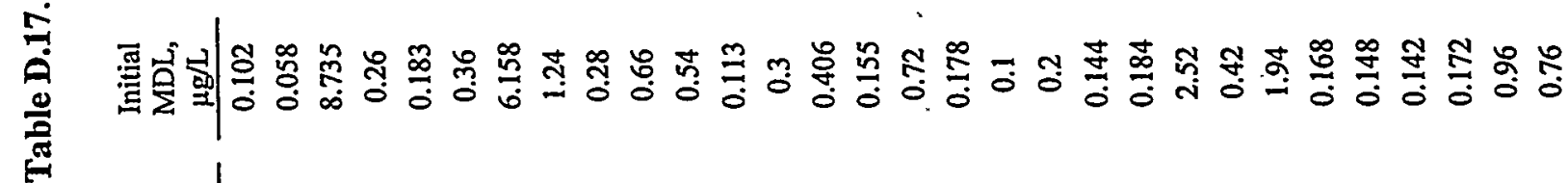

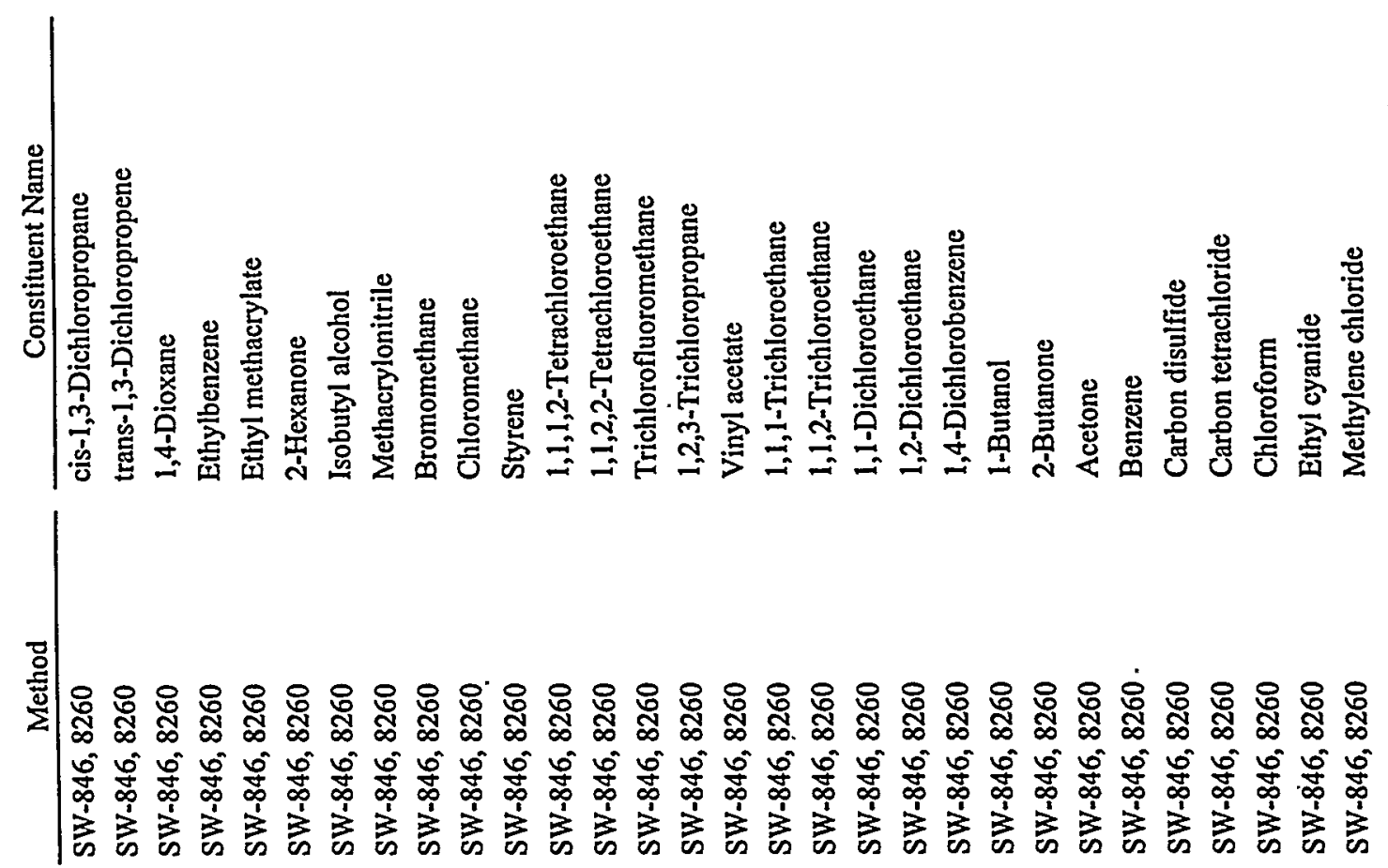




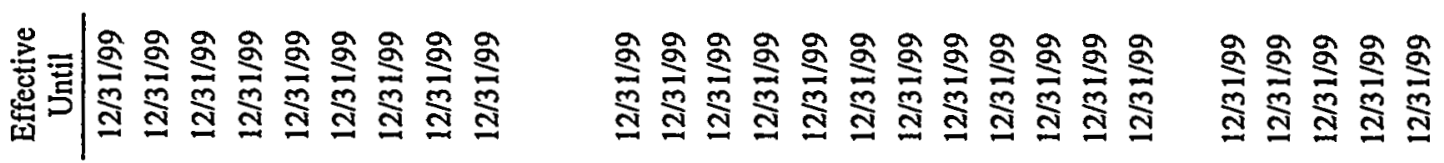

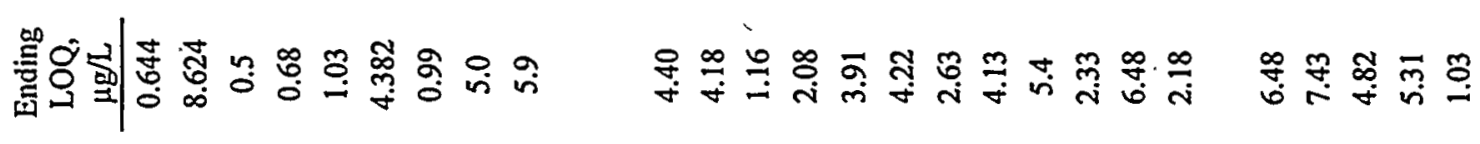

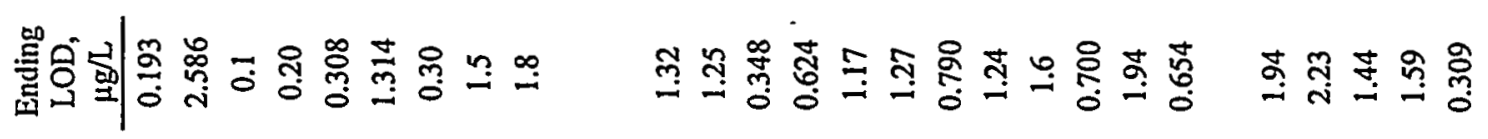

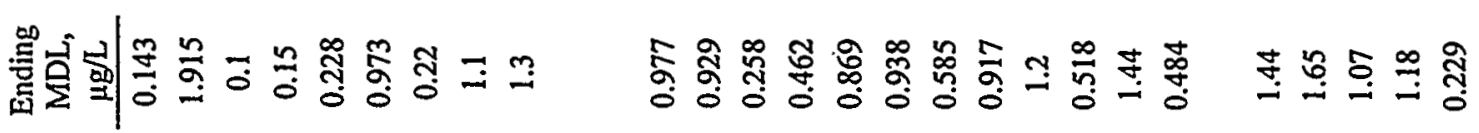

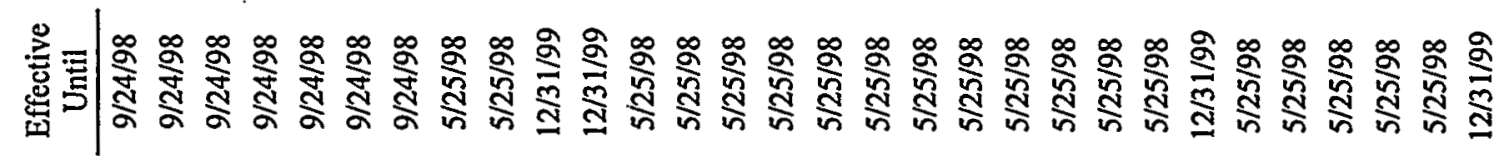

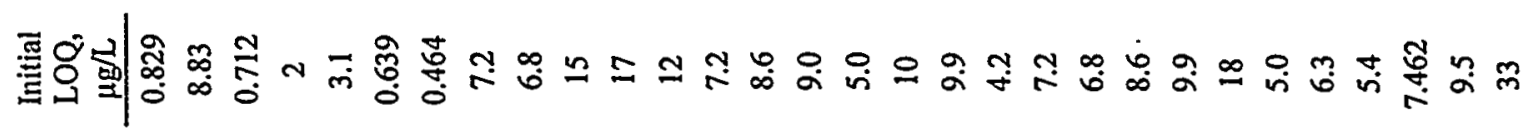

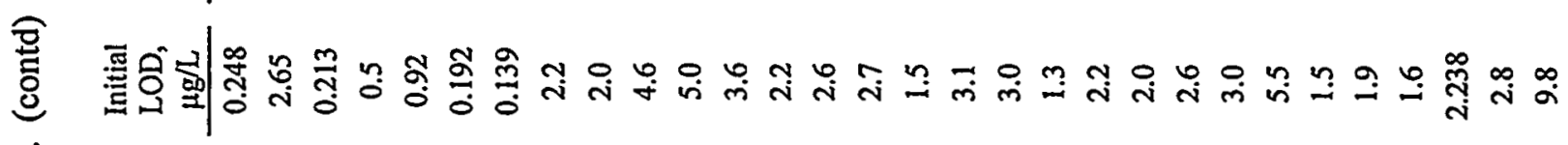

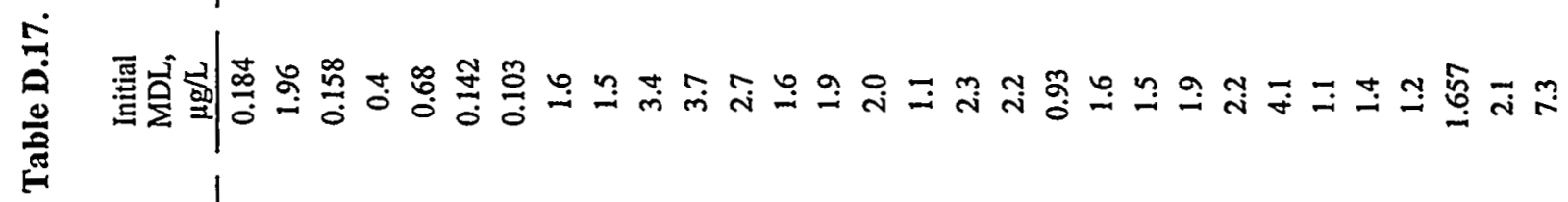

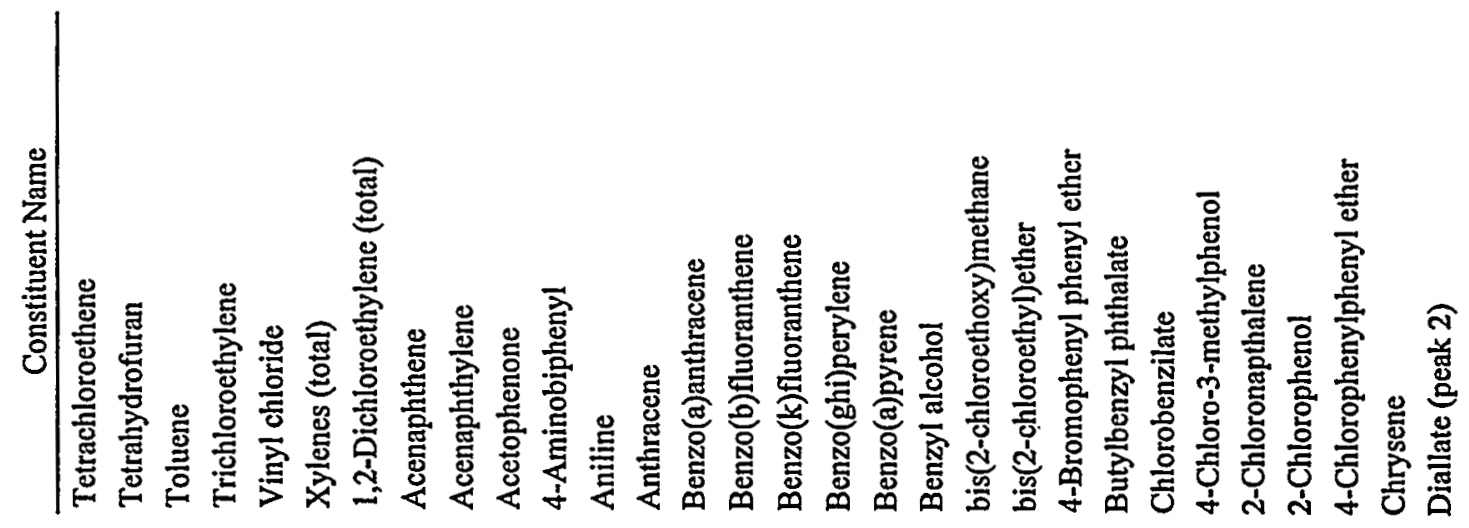

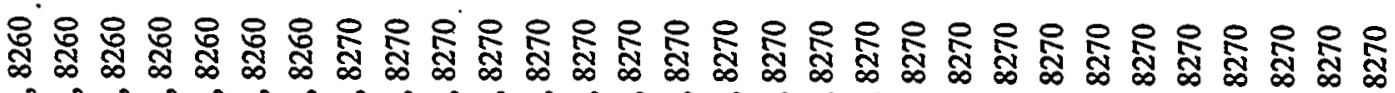

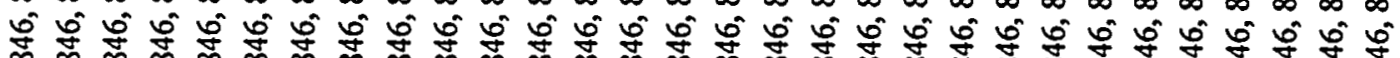

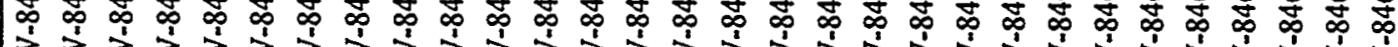

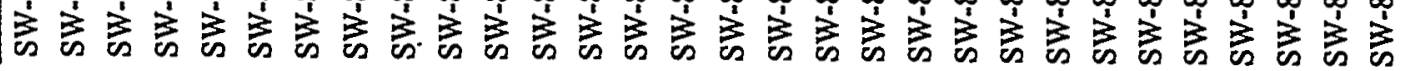




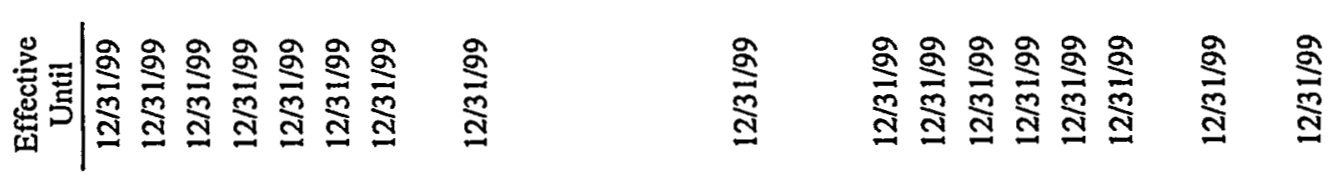

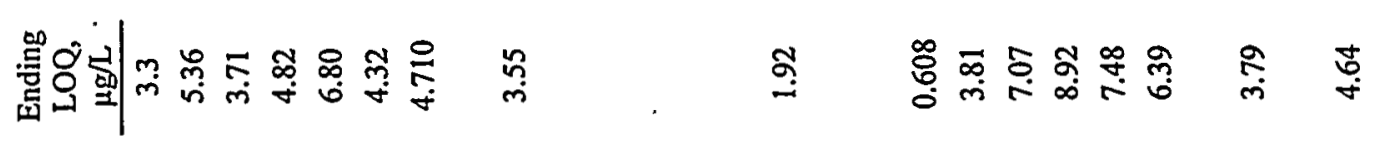

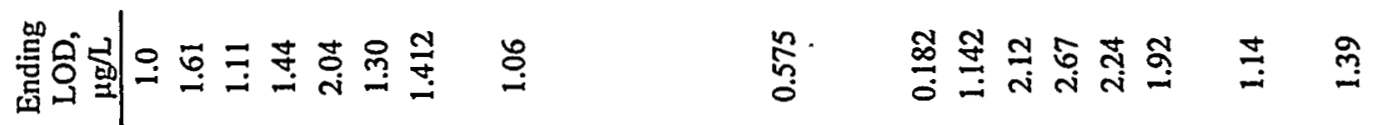

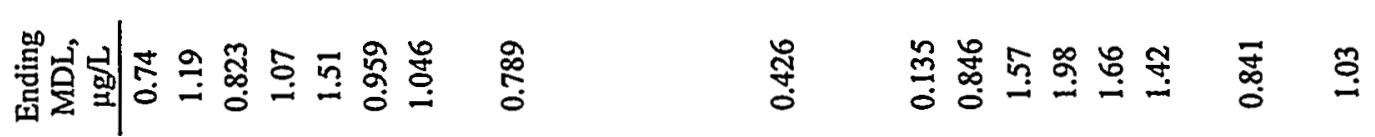

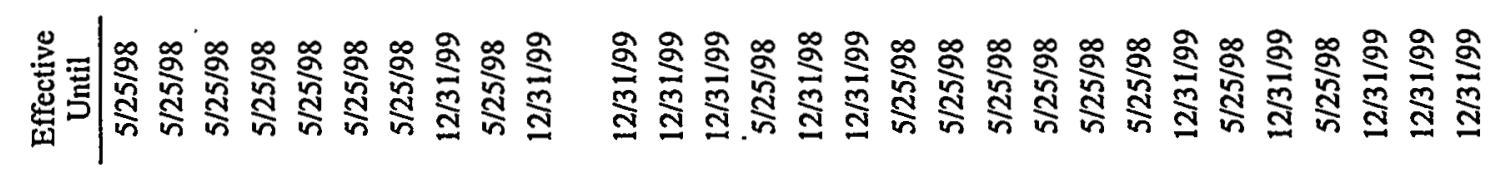

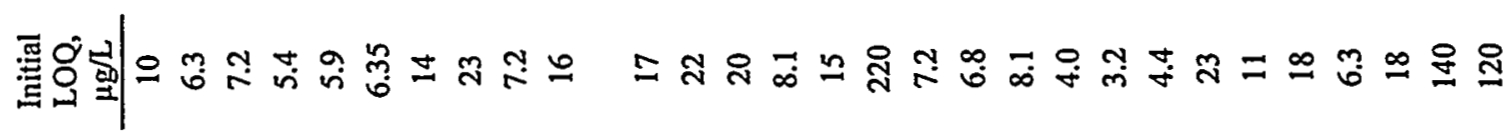

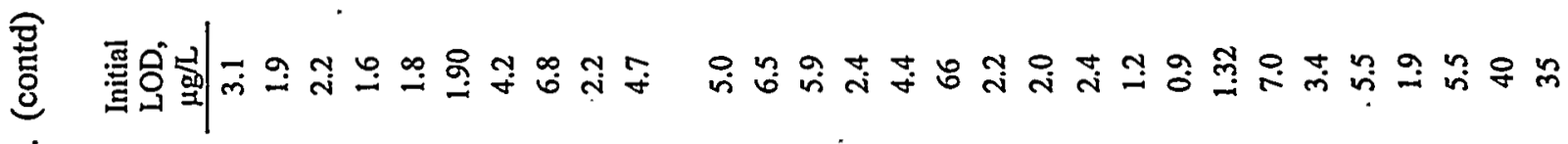

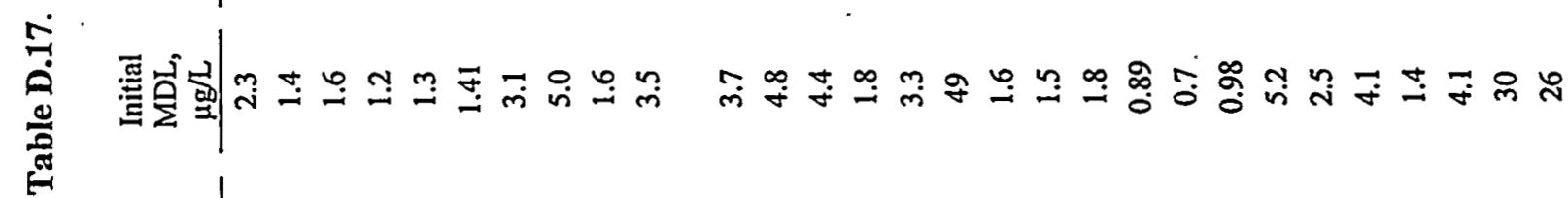
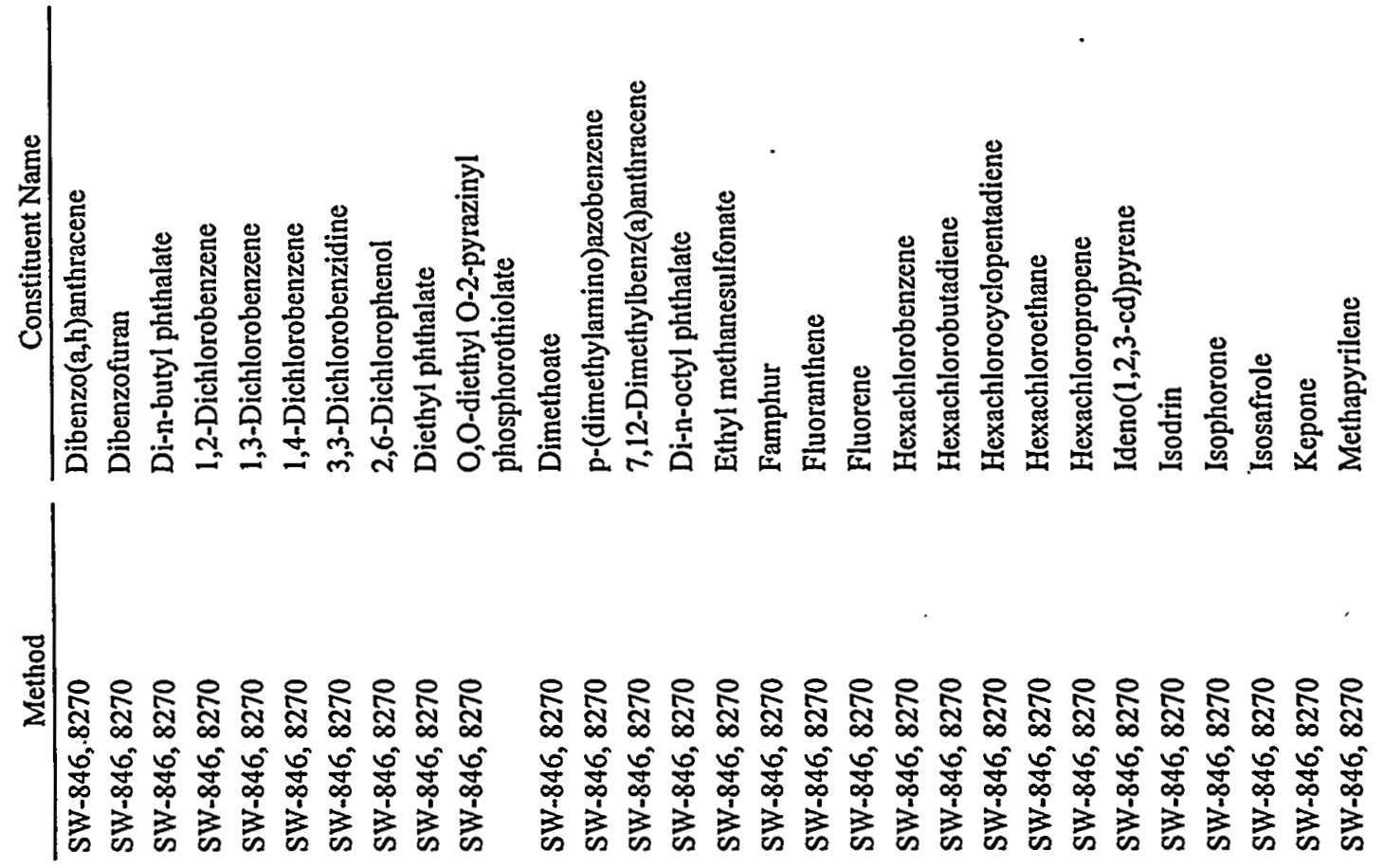


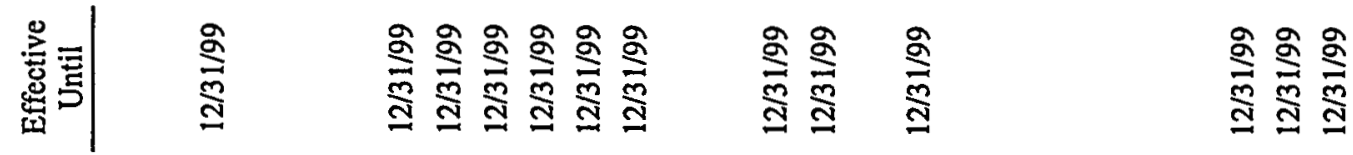

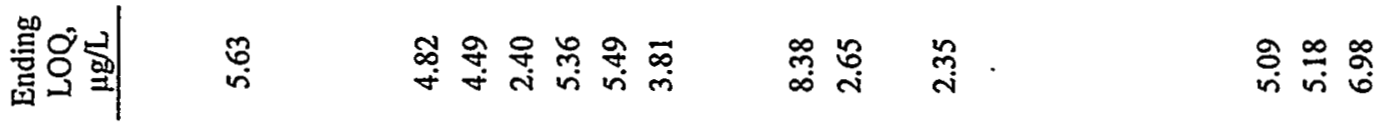

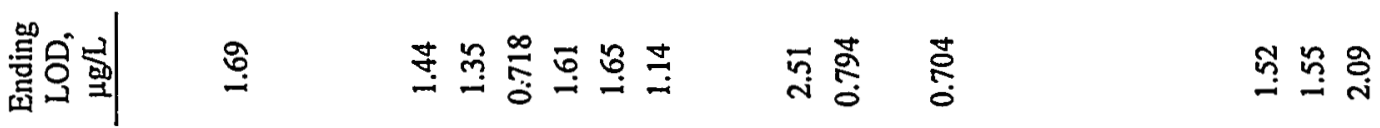

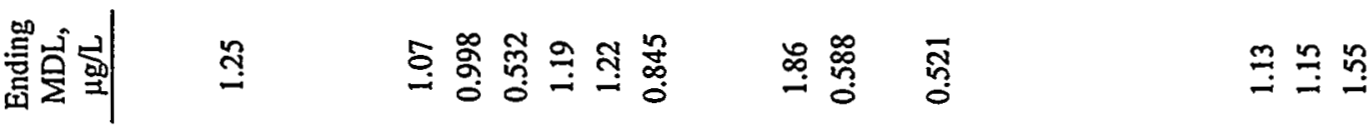

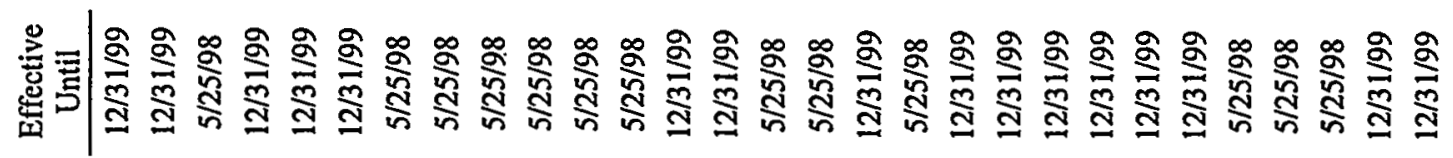

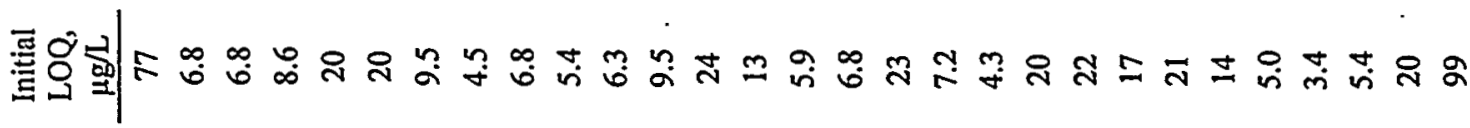

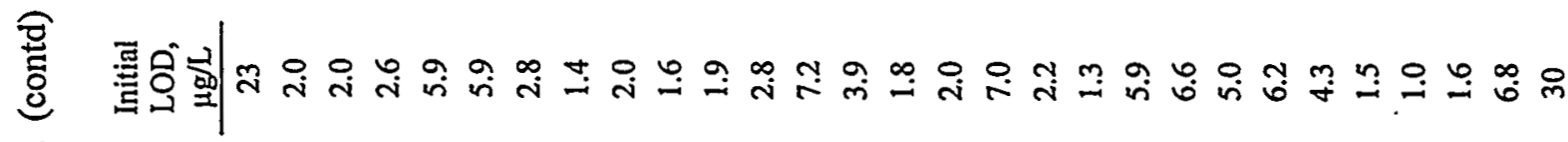

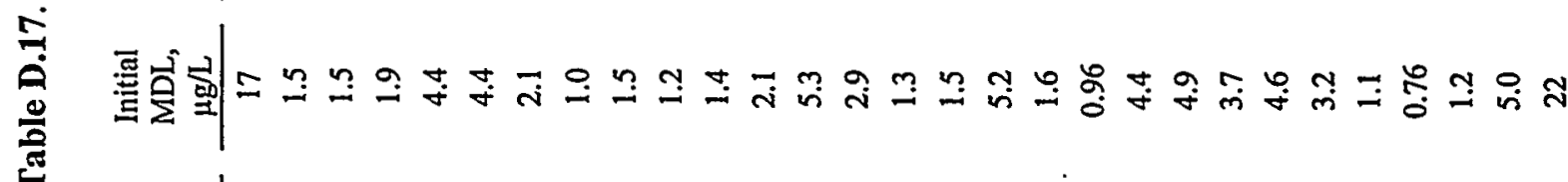

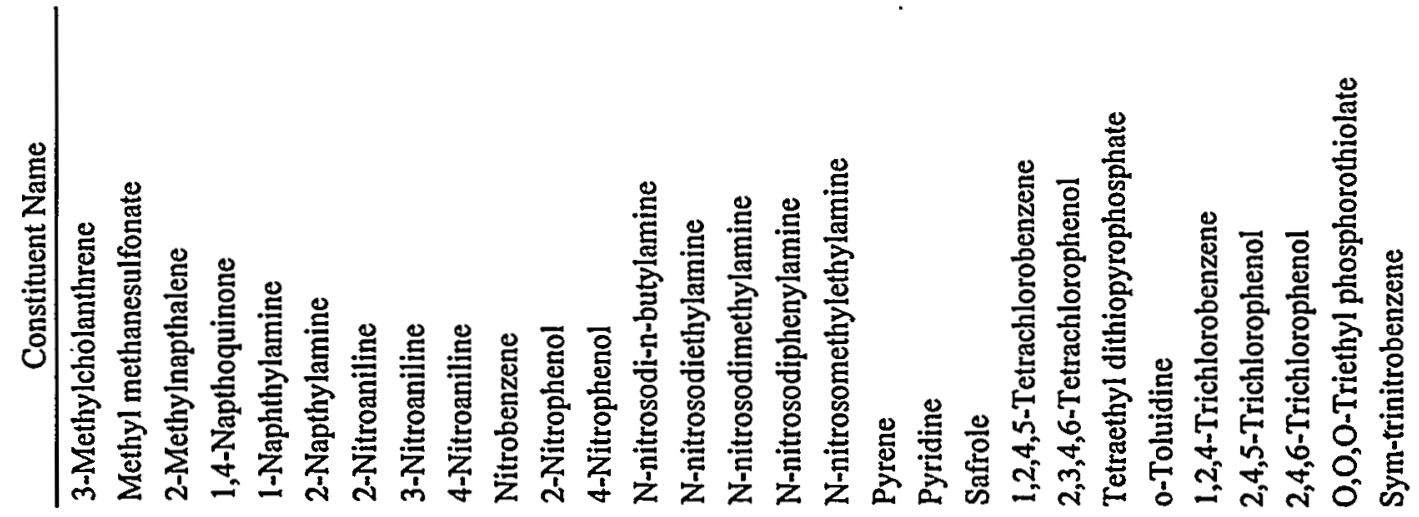

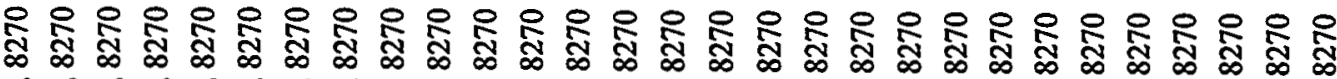
फी की

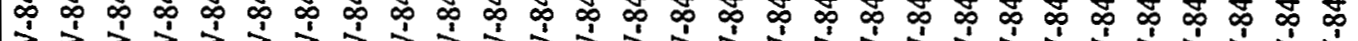

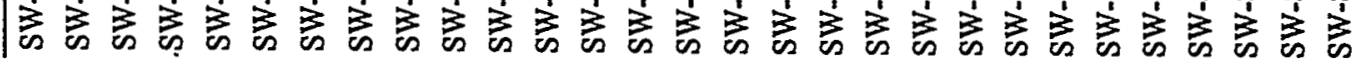




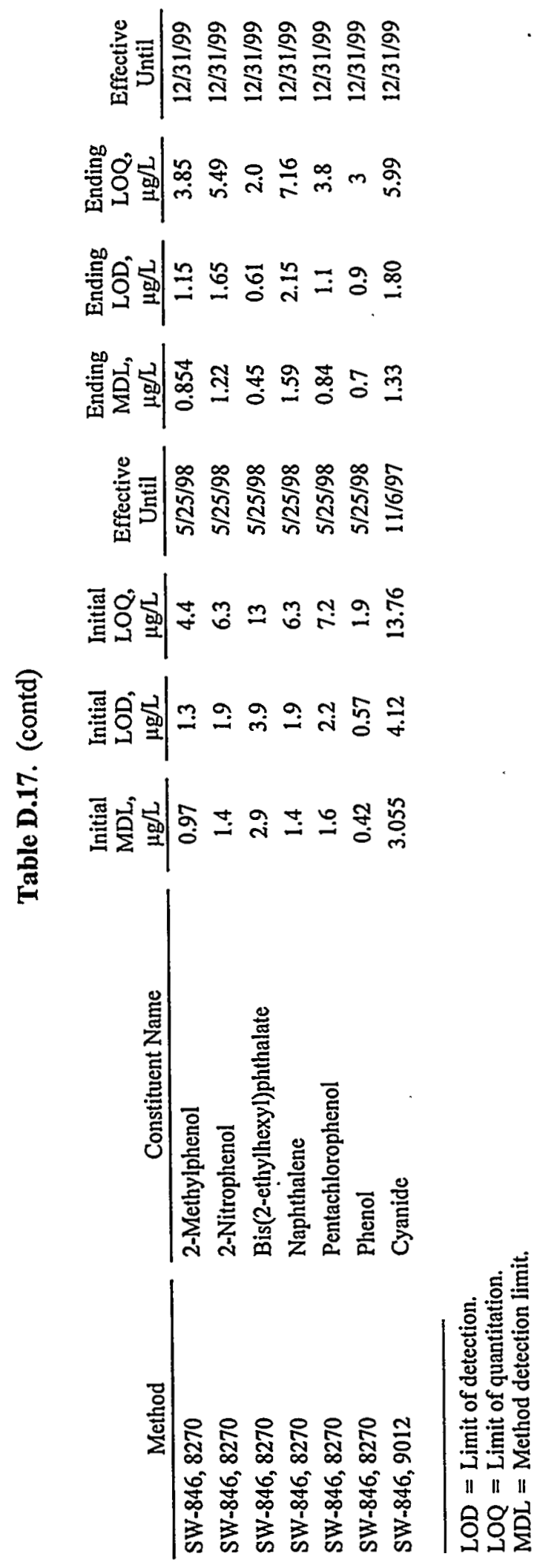




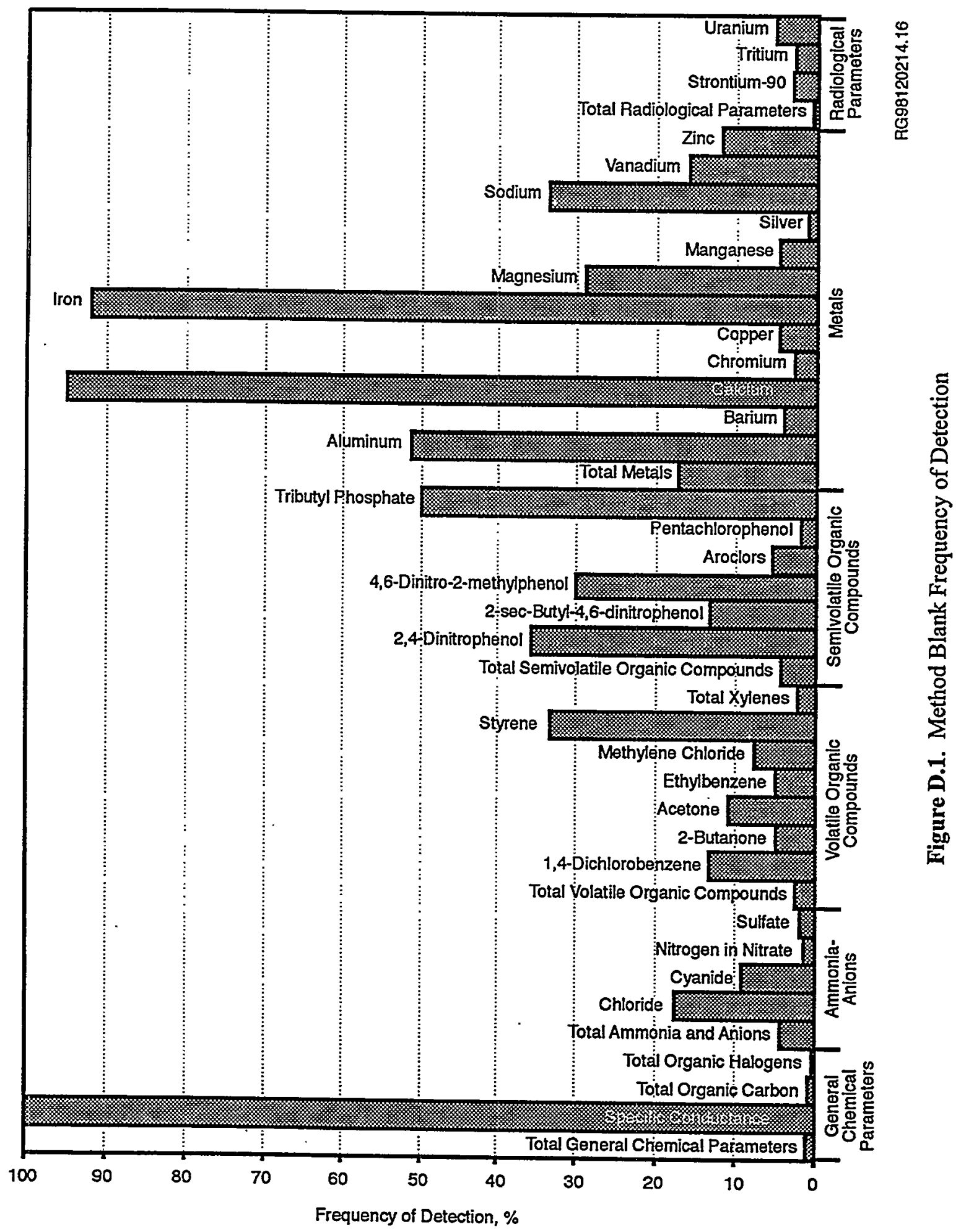



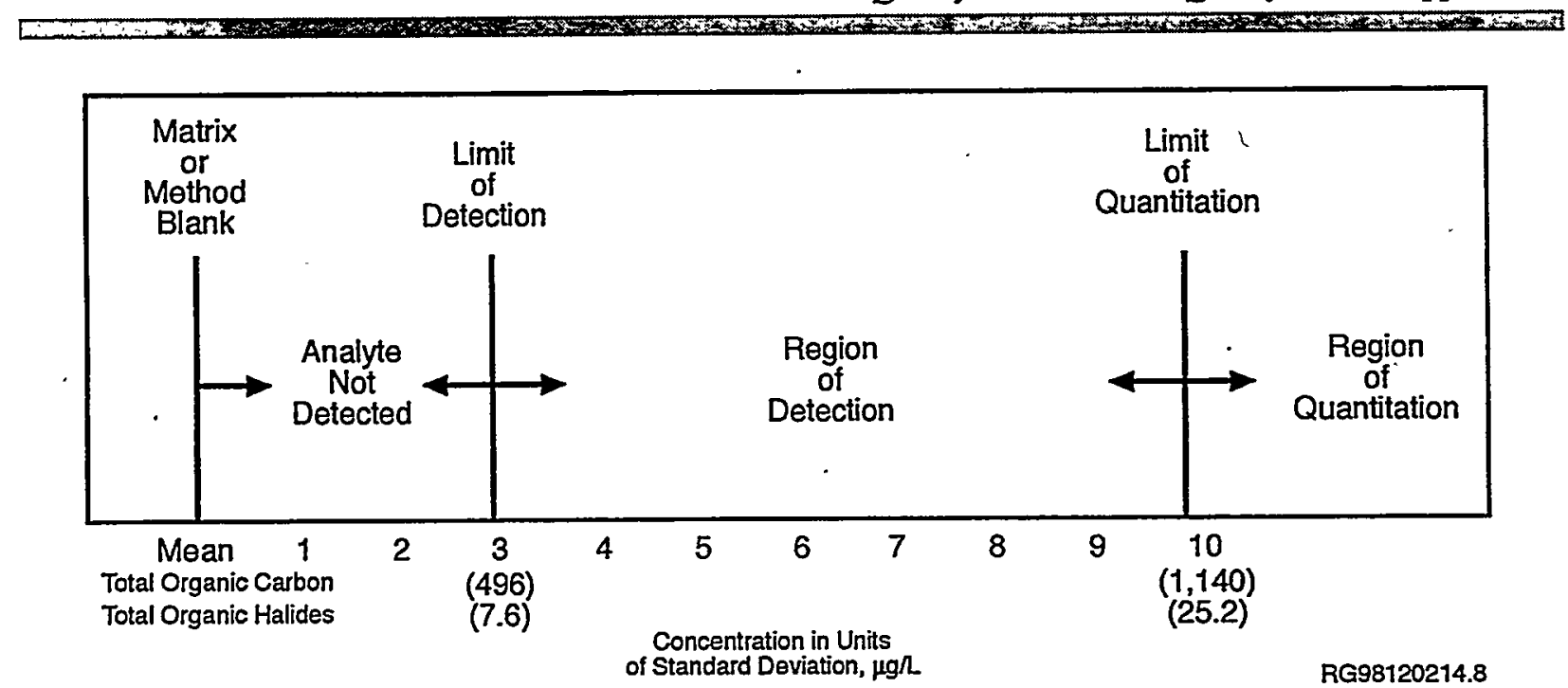

- Figure D.2. Levels of Detection and Quantitation 


\section{Distribution}

No. of

Copies

Offsite

* A. Aldrich

Bureau of Land Management

U.S. Department of the Interior

Spokane District Office

1103 North Fancher

Spokane, WA 99212-1275

R. Alvarez

U.S. Department of Energy

Forrestal Building, PO-5

1000 Independence Avenue, S.W.

Washington, D.C. 20585

* M. Ault

US Ecology, Inc:

P.O. Box 638

Richland, WA 99352

J. S. Bachmaier

U.S. Department of Energy

Forrestal Building, EH-412

1000 Independence Avenue, S.W.

Washington, D.C. 20585

* J. R. Beaver

Kennewick City Council

210 West Sixth Avenue

Kennewick, WA 99336

* M. E. Benitz, Jr.

Benton County Commissioner

P.O. Box 190

Prosser, WA 99350

* J. Blanchard

Bureau of Reclamation

U.S. Department of the Interior

P.O. Box 815

Ephrata, WA 98823
No. of

Copies

* J. O. Boda

U.S. Department of Energy

Cloverleaf Building, EM-34

19901 Germantown Road

Germantown, MD 20874-1290

R. Buck, Jr.

Wanapum Indian Band

P.O. Box 878

Ephrata, WA 98823

* J. A. Caggiano

330 Snyder

Richland, WA 99352

T. E. Carpenter

Government Accountability Project

West Coast Office, Suite 1215

1402 3rd Avenue

Seattle, WA 98101

* K. Campbell

Fish and Wildlife Service

U.S. Department of the Interior

P.O. Box 1157

Moses Lake, WA 98837

* C. M. Caprio

Jason Associates

3250 Port of Benton Boulevard

Richland, WA 99352

* J. Chasse

Washington Public Power Supply System

P.O. Box 968

Richland, WA 99352

* J. Conaway

Los Alamos National Laboratory

P.O. Box 1663, MS J561

Los Alamos, NM 87545 
No. of

Copies

2 Confederated Tribes of the Umatilla Indian Reservation

Environmental Planning/Rights Protection P.O. Box 638

Pendleton, OR 97801

ATTN: T. Gilmore

J. R. Wilkerson

R. A. Danielson

State of Washington Department of Health 2 South 45th Avenue

Yakima, WA 98908

* G. De Bruler

Columbia River United

P.O. Box 912

Bingen, WA 98605

* B. W. Drost

Geological Survey

U.S. Department of the Interior

1201 Pacific Avenue, Suite 600

Tacoma, WA 98402

D. Dunning

State of Oregon Department of Energy 625 Marion Street N.E.

Salem, OR 97310

* S. Foss

State of Washington Department of Agriculture

P.O. Box 42589

Olympia, WA 98504

\section{A.J.K. Fyall}

Benton County Planning Department P.O. Box 910

Prosser, WA 99350

* M. W. Grainey

Assistant to the Director

State of Oregon Department of Energy 625 Marion Street N.E.

Salem, OR 97310
No. of

Copies

* H. Gucinski, Chair

Pacific Northwest Natural Area Committee 3200 Jefferson Way

Corvallis, OR 97331

L. E. Haler

City of Richland

505 Swift Boulevard

Richland, WA 99352

M. K. Harmon

U.S. Department of Energy

Cloverleaf Building, EM-44

19901 Germantown Road

Germantown, MD 20874-1290

* A. Haymaker

1721 Cottonwood Drive

Pasco, WA 99301

* R. E. Isaacson

2106 Lee Boulevard

Richland, Washington 99352

* R. E. Jaquish

State of Washington Department of Health 1906 Peachtree Lane

Richland, WA 99352

P. Knight

Northwest Environmental Advocates/

Hanford Watch

133 Southwest Second Avenue, Suite 302

Portland, OR 97204-3526

K. T. Lang

U.S. Department of Energy

Cloverleaf Building, EM-38

19901 Germantown Road

Germantown, MD 20874-1290

* R. J. Leaumont

Lower Columbia Basin Audubon Society

9016 Sunset Terrace

Pasco, WA 99301 
No. of

Copies

* J. Leier

Walla Walla District

U.S. Army Corps of Engineers

Building 602, City-County Airport

Walla Walla, WA 99632-9265

* R. Luxmoore

Oak Ridge National Laboratory

P.O. Box 2008, MS 6038

Oak Ridge, TN 37831-6038

* L. Maas

Siemens Power Corporation

2101 Horn Rapids Road

Richland, WA 99352

* J. Matuszek

JMM Consulting Services

82 McGuffy Lane

Delmar, NY 12054-4206

* M. Nelson

Jacobs Engineering Group, Inc.

507 Knight Street, Suite B

Richland, WA 99352-4219

3 Nez Perce Tribe

Environmental Restoration/Waste Management

P.O. Box 365

Lapwai, ID 83540-0365

ATTN: P.Danielson

D. Pawaukee

S. Sobczyk

* C. O'Neale

9106 Boulder Lane S.E., Apt. D

Olympia, WA 98501

* R. Patt

1655 S. Elm \#405

Canby, OR 97013
No. of

Copies

G. M. Pollet

Executive Director

Heart of America, NW

Cobb Building, Suite 208

1305 Fourth Avenue

Seattle, WA 98101

* R. K. Price

4200 W. 19th

Kennewick, WA 99338

* . P. Rodgers

Jacobs Engineering Group, Inc.

3250 W. Clearwater

Kennewick, WA 99336

* South Columbia Basin Irrigation District

1135 S. Hillsboro Road

Pasco, WA 99301

State of Washington Department of

Ecology, MS 7600

P.O. Box 47600

Olympia, WA $98504-7600$

2 State of Washington Department of Health

Division of Radiation Protection

P.O. Box 47827

Olympia, WA 98504-7827

ATTN: M. Dunkleman

D. McBaugh

L. Stembridge

Executive Director

Hanford Education Action League (HEAL)

1718 W. Broadway Avenue \#203

Spokane, WA 99201-1818

* L. C. Treichel

U.S. Department of Energy

Cloverleaf Building 2114, EM-44

19901 Germantown Road

Germantown, MD 20874-1290 
No. of

Copies

2 Yakama Indian Nation

Environmental Restoration/Waste Management

P.O. Box 151

Toppenish, WA 98948

ATTN: R. Jim

W. Rigsby

* P. Zielinski

U.S. Department of Energy

Cloverleaf Building

19901 Germantown Road

Germantown, MD 20874-1290

Onsite

32

DOE Richland Operations Office

M. P. Blancq

D. H. Chapin

T. W. Ferns

B. L. Foley

M. J. Furman (10)

J. B. Hall

R. D. Hildebrand (10)

J. E. Kinzer

P. E. Lamont

R. W. Lober

J. K. McClusky

R. G. McLeod

D. E. Olson

J. C. Peschong

G. L. Sinton

K. M. Thompson (5)

A. C. Tortoso

D. C. Ward

C. D. West

D. D. Wodrich

Public Reading Room (2)
No. of

Copies

Bechtel Hanford, Inc.

K. R. Fecht

B. H. Ford

M. J. Graham

G. C. Henckel

A. J. Knepp

R. P. Prosser

S. J. Trent

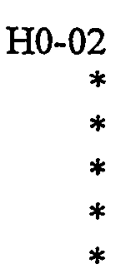

B\&W Hanford Company

S. J. Gray

N2-13

4 CH2M Hill Hanford, Inc.

J. V. Borghese

H9-03

R. L. Jackson

M. A. Mihalic

R. F. Raidl

V. J. Rohay

L. C. Swanson

H9-11

R. L. Weiss

J. P. Zoric

H9-11

X5-57

COGEMA Engineering Corporation

J. D. Davis

H6-34

2 DynCorp Tri-Cities Services, Inc.

$\mathrm{H} 0-12$

S7-55

$\mathrm{H} 0-12$

$\mathrm{HO}-12$

*

$\mathrm{H} 2-53$
H. B. Hathaway

K. D. Johnson

L. M. Kelly

G3-07

S2-21

Fluor Daniel Hanford, Inc.

M. C. Brown

S. M. Price

F. A. Ruck

W. E. Toebe

J. D. Williams
H6-23

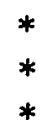


No. of

Copies

Fluor Daniel Northwest, Inc.

F. M. Mann

H0-31

2 Lockheed Martin Hanford Corporation

H. L. Boston

E. A. Fredenburg

C. M. Lewis

D. A. Myers

H6-12

G3-21

\section{MACTEC-ERS}

S. E. Kos

*

8 State of Washington Department of

Ecology

J. W. Donnelly

B5-18

S. M. Alexander

B5-18

D. Goswami

B5-18

S. Leja

B5-18

C. O. Ruud

B5-18

P. R. Staats

B5-18

M. A. Wilson (2)

B5-18

Waste Management Federal Services, Inc., Northwest Operations

J. J. Dorian

M. G. Gardner

K. M. McDonald

D. J. Moak

C. J. Perkins

S. H. Worley

Waste Management Federal Services of Hanford, Inc.

B. M. Barnes

L. P. Diediker

P. C. Mohondro

M. I. Wood
No. of

Copies

2 U.S. Environmental Protection Agency

L. E. Gadbois

B5-01

D. R. Sherwood

B5-01

91 Pacific Northwest National Laboratory

D. H: Bacon

D. B. Barnett

D. J. Bates

M. P. Bergeron

C. A. Brandt

R. W. Bryce

J. W. Buck

C. J. Chou

C. R. Cole

S. F. Conley

R. L. Dirkes

P. E. Dresel (20)

M. J. Fayer

M. D. Freshley

J. S. Fruchter

D. R. Geist

R. E. Gephart

B. M. Gillespie

T. J Gilmore

S. M. Goodwin

H. Hampt

R. W. Hanf

M. J. Hartman (10)

J. O. Heaberlin

P. S. Henry

F. N. Hodges

D. G. Horton

V. G. Johnson

C. T. Kincaid

G. V. Last

E. A. Lepel

T. L. Liikala

J. W. Lindberg

P. E. Long

S. P. Luttrell (10)

J. P. McDonald

R. B. Mercer

L. F. Morasch
K6-81

K9-36

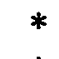

K6-80

K6-81

K9-36

K6-75

K6-75

K6-96

K9-96

K9-76

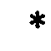

K6-81

K6-96

K6-81

K6-81

K6-96

K9-33

P8-08

K6-81

K9-48

K6-96

K6-96

K6-96

K6-86 
No. of

Copies

S. M. Narbutovskih

D. R. Newcomer

K. B. Olsen

B. E. Opitz

M. S. Peffers

R. E. Peterson

S. P. Reidel

J. T. Rieger

R. G. Riley

D. R. Sauer

J. Á. Serkowski

R. J. Serne

D. S. Sklarew

R. M. Smith (10)
No. of

Copies
K6-81

K6-75

K6-96

K6-96

K6-96

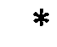

K6-81

K6-96

K6-96
F. A. Spane, Jr.

D. L. Stewart

G. P. Streile

M. D. Sweeney

C. J. Thompson

P. D. Thorne

E. C. Thornton

V. R. Vermeul

W. D. Webber

R. S. Weeks

B. A. Williams

M. D. Williams

S. K. Wurstner

Information Release Office (7)
K6-96

K6-96

K9-33

K6-96

$\mathrm{K} 6-81$

K9-36

K9-36

K1-06

*Will receive letter informing of the availability of the report on the Internet and CD and providing the Internet address. Recipient may contact PNNL to receive paper or CD copies if desired. 


\section{Notice}

Page(s) size did not permit electronic reproduction. Information may be purchased by the general public from the National Technical Information Service, U.S. Department of Commerce, Springfield, VA 22161 (1800-553-6847). DOE and DOE contractors may purchase information by contacting DOE's Office of Scientific and Technical Information, P.O. Box 62, Oak Ridge, TN 37831-0062, Attn: Information Services (1865-576-8401). 